\title{
مركز البحوث الجغرافية والكارتوجرافية
}

قسم الجغرافيا - كلية الآداب - جامعة المنوفية

المؤثمر الجغرافي الدولي الثاني

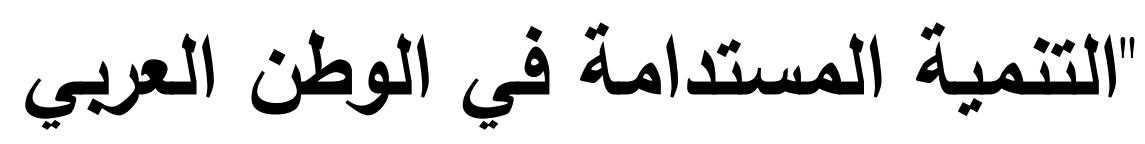

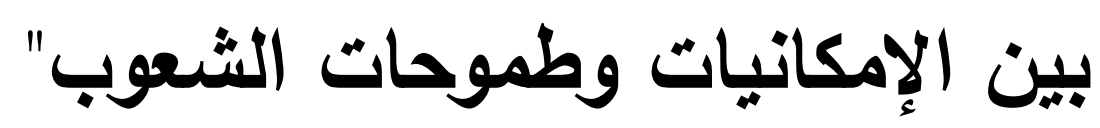

2019 - 5 - 20

$$
\text { تحت رعاية }
$$

رئيس جامعة المنوفية

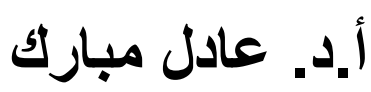

رئيس المؤتمر وعميد كلية الآداب

أ.د. أسامة مدني أمرئ

$$
\text { مقرر المؤتمر }
$$

أ.د. إيملي حمادة

مدير مركز البحوث الجغرافية والكارتوجرافية

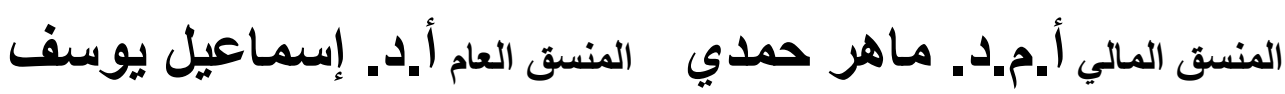




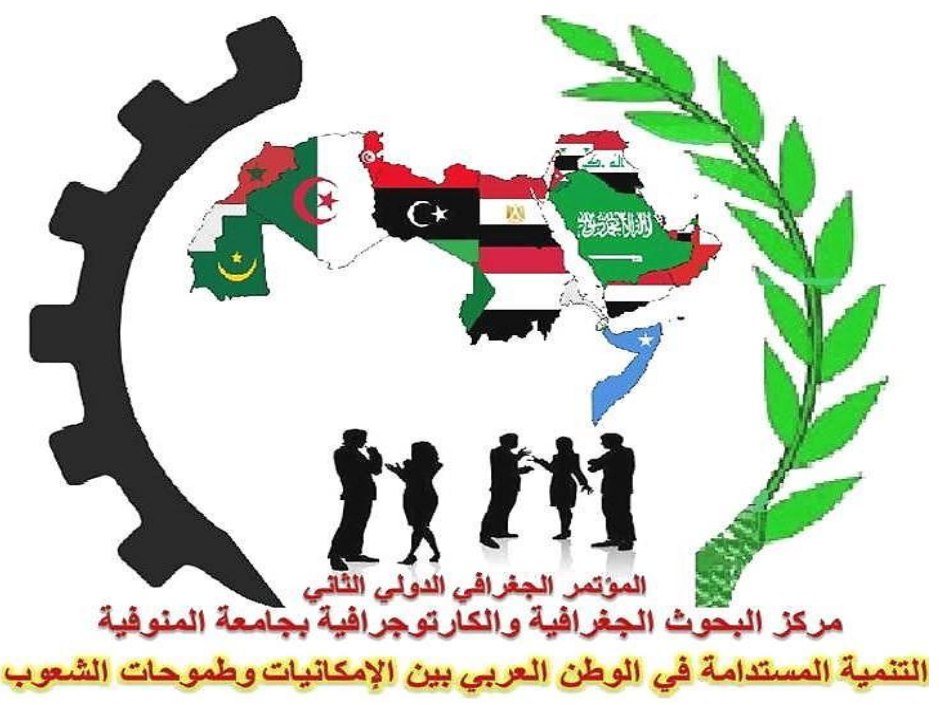

بسم الله وعلى بركة الله

نبأ فعاليات المؤتمر الجغرافي الدولي الثياني

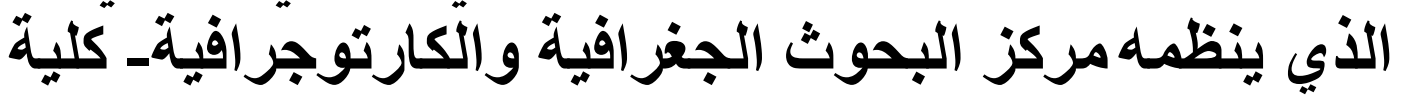

الآداب جامعة المنوفية

$$
\text { التنمية المستدامة في الوطن العربى الإمكاتيات وطموحات الشعوب } 5 \text { الثبر اير } 2019 \text { - } 2019
$$




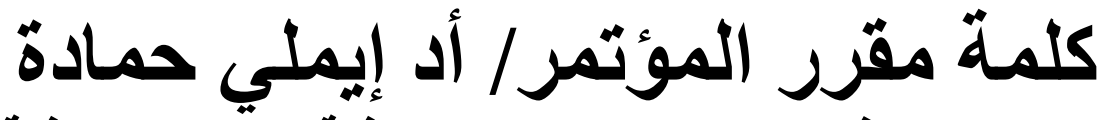

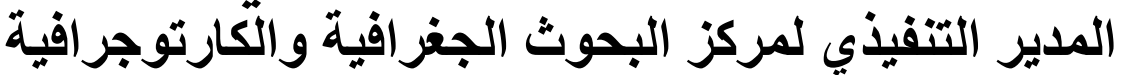

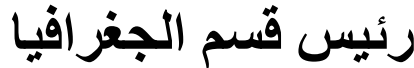

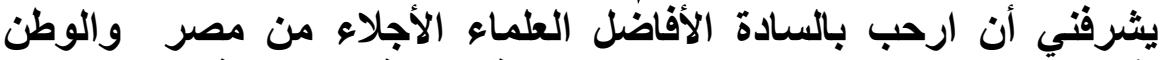

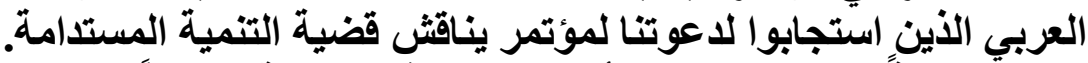
بداية، يجدر التنويه بأن اختيار هذه القضية تحديداً جاء ضمن فئن توصيات

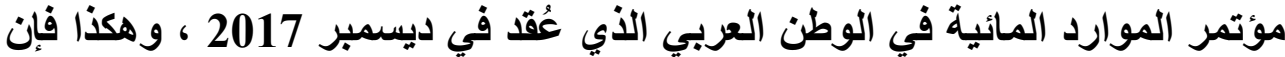

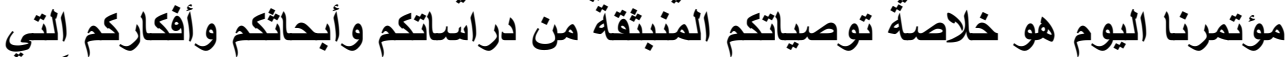

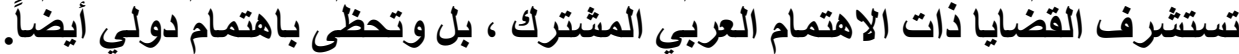

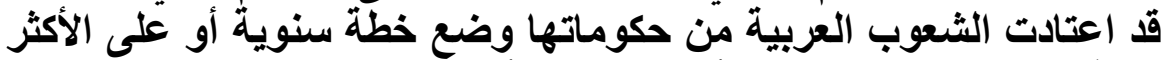

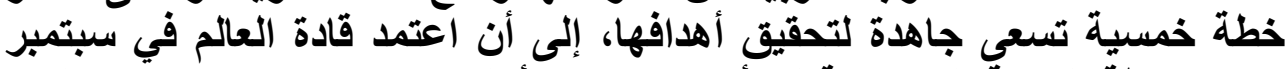

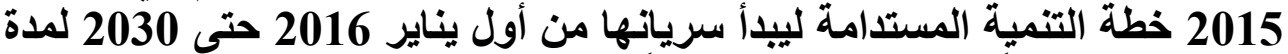

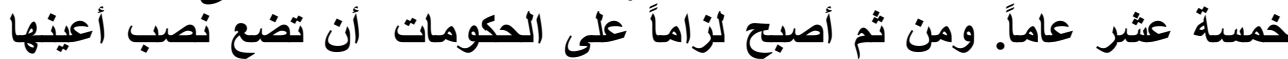

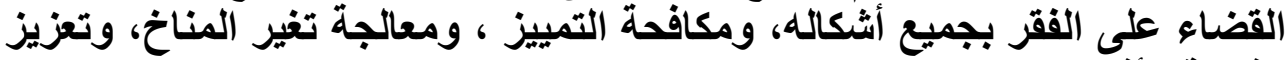
رفاهية الأفراد مع تحسين جودة الحيع الفياة.

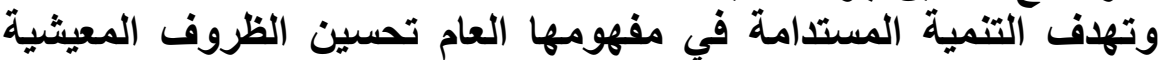

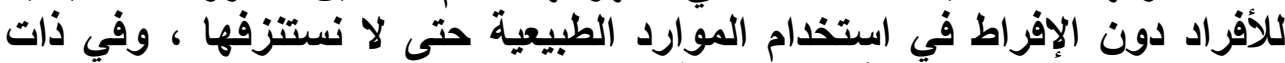
الوقت نحافظ على نصيب الأجيال القادمة منها.

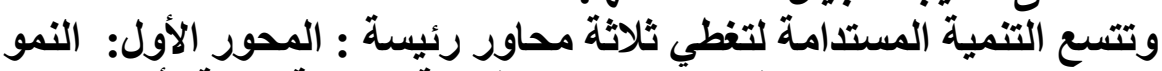

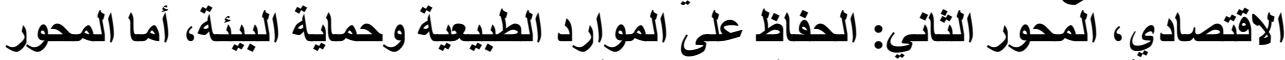
الثالث والأخير فهو خاص بالتئمية الاجتماعية.

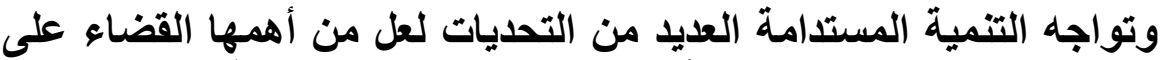

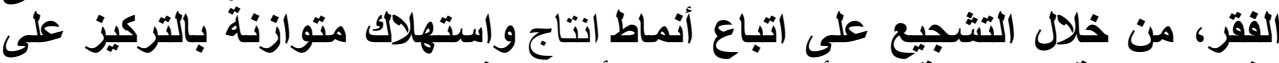

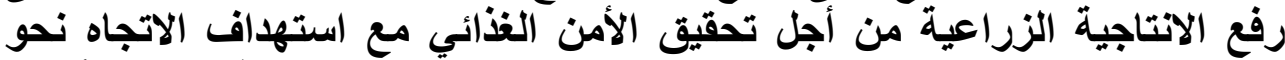

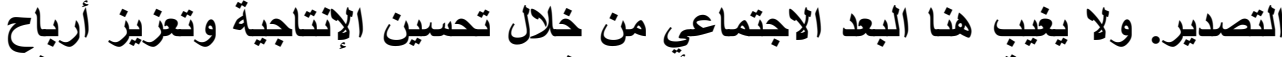

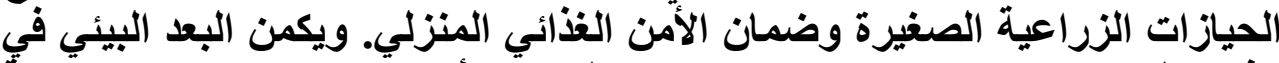

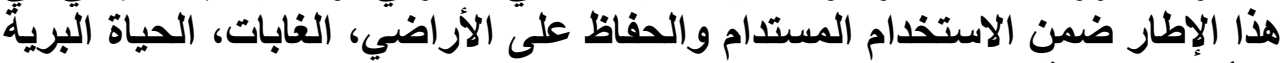
والأحياء المائية، وموارد المين الإناه

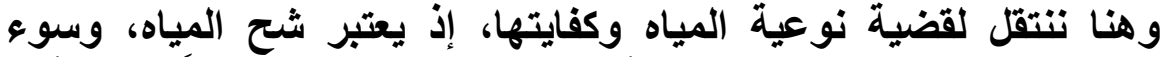

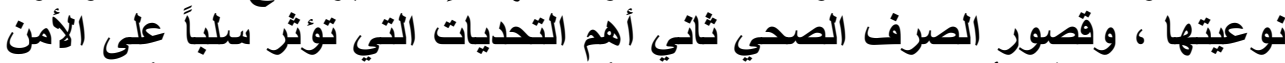

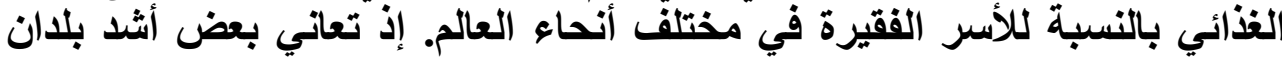


العالم فقراً من نوبات الجفاف المتكررة والمجدبة، مما يؤدي إلى اتساع دائرة

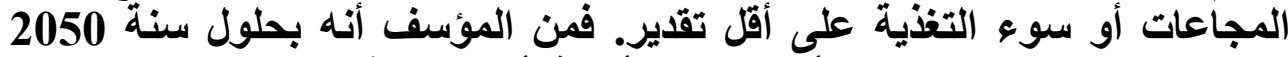

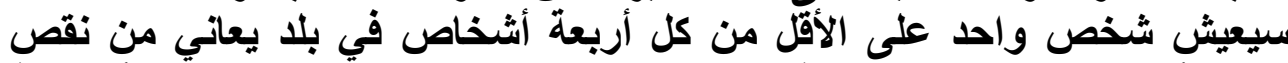

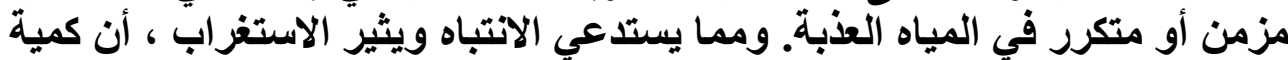

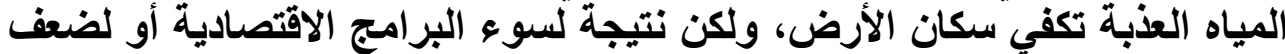

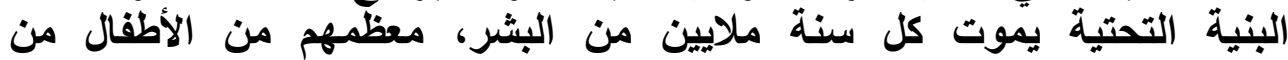

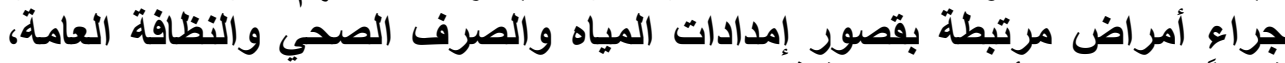
فضلاً عن الجوع أو سوء التظذية.

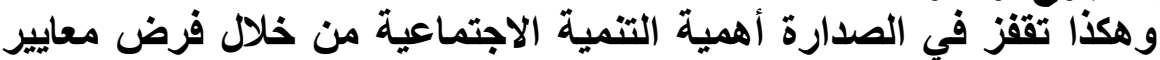

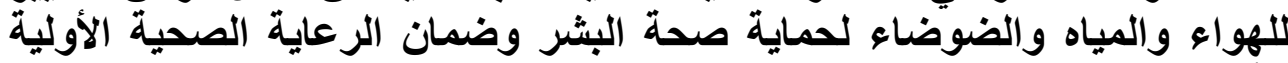

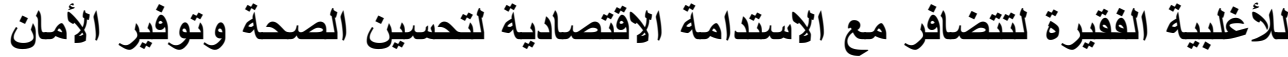

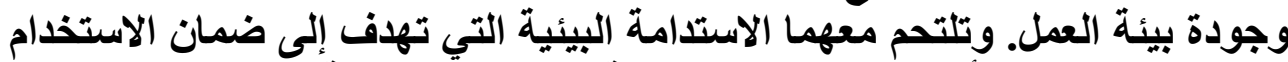

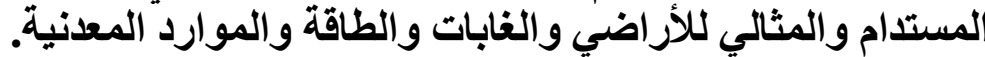

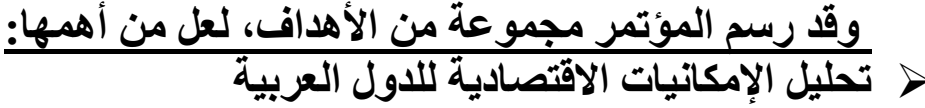

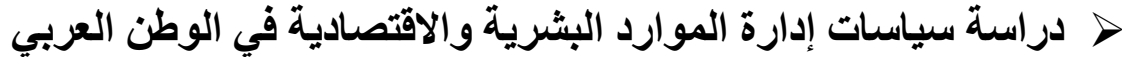

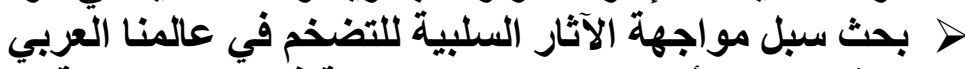

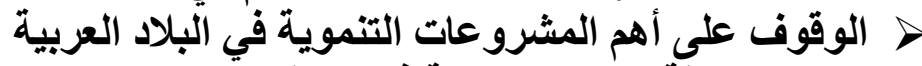

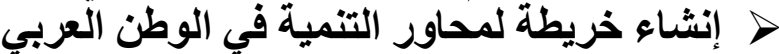

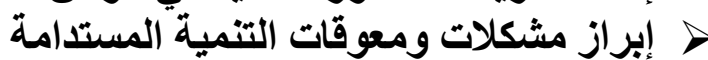

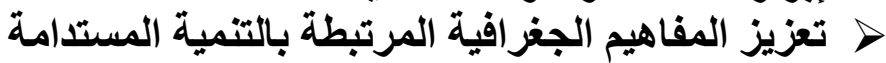

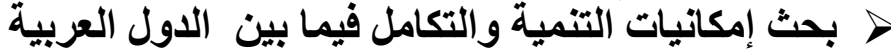

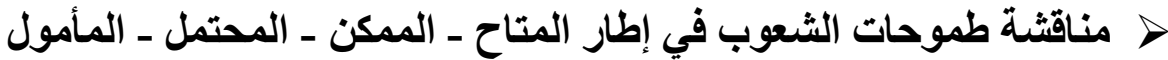

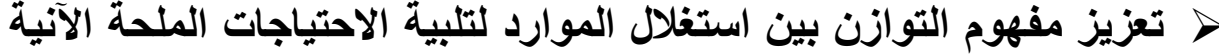

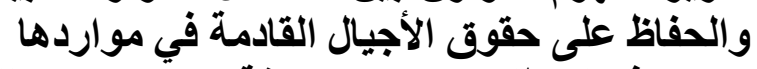

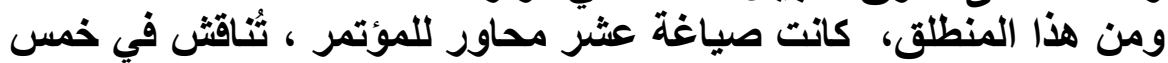
عشرة جلسة على النحو التالي: المني: > المحور الأول : خريطة الموارد الاقتصادية في البلاد العربية

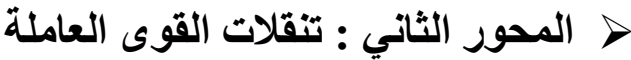

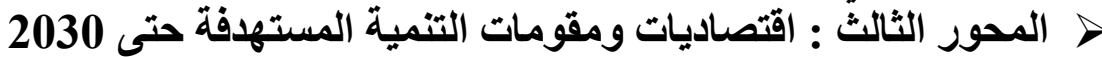
> المحور الرابع : التنمية الصناعية والتوطن الصناعي المتخصص التصنية والمتكامل

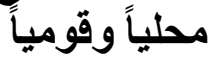

> > المحور الخامس : الزيادة السكانية واتجاهاتها وتنمية القدرات البشرية > المحور السادس: استخلام تقتيات الجيوماتكس في مجابهة مخاطر المشكلات البيئية 


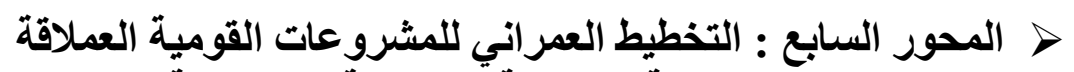

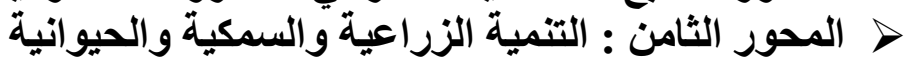

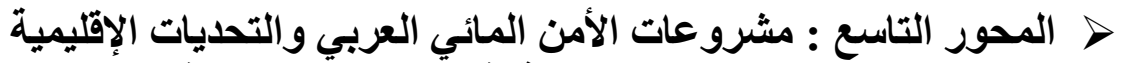

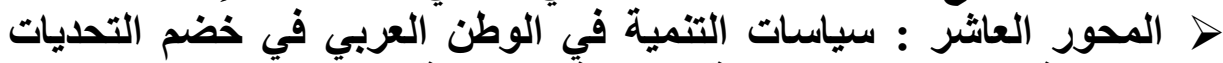

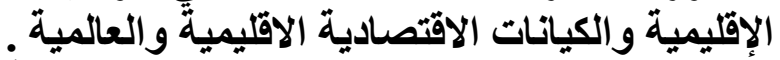

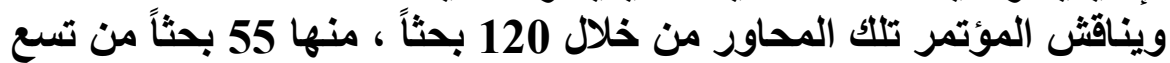

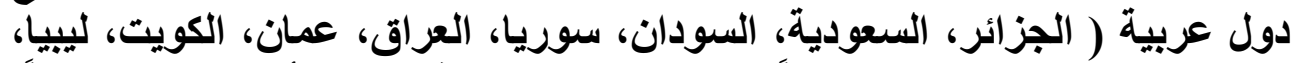

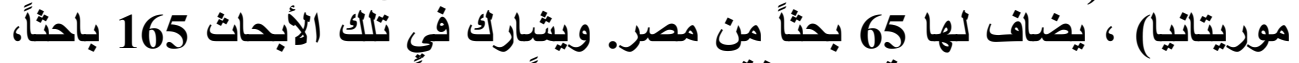

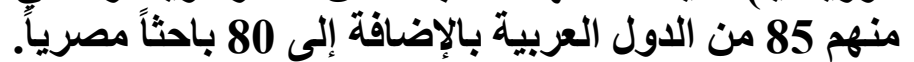

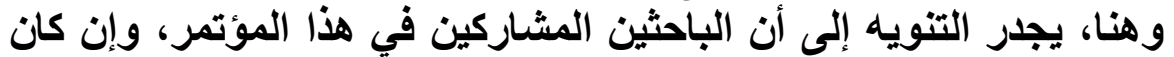

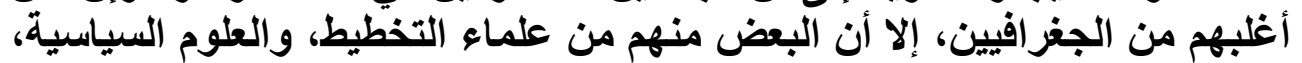

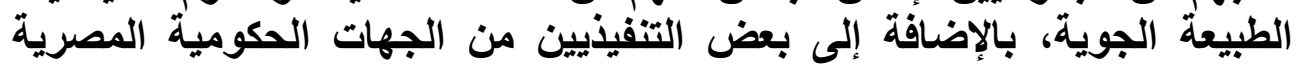

ويحدو بنا الأمل والرجاء أن يصل المؤتمر إلى توصيات قابلة للتفعيل والمؤسسات الدولية.

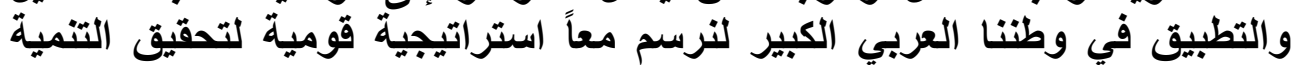

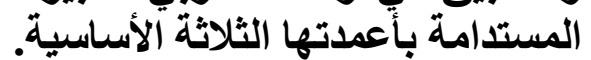

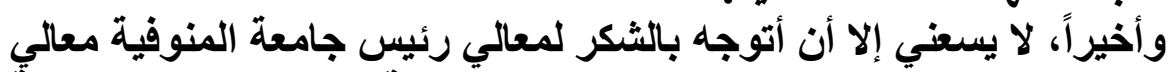

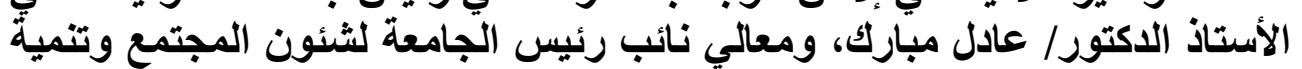

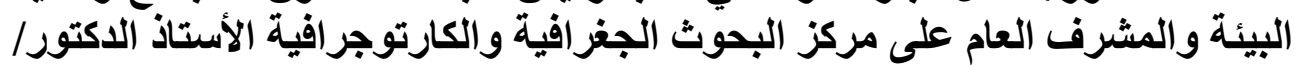

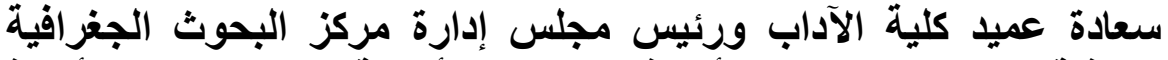
عبا الرحمن قرمان.

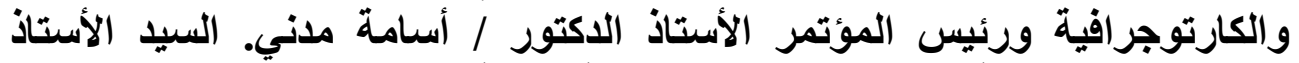

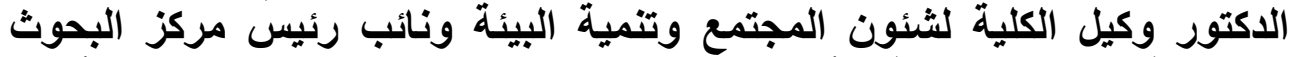

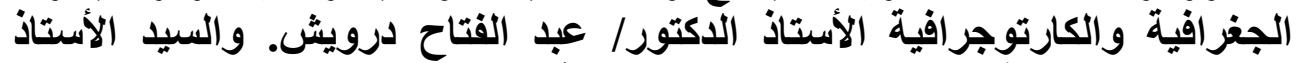

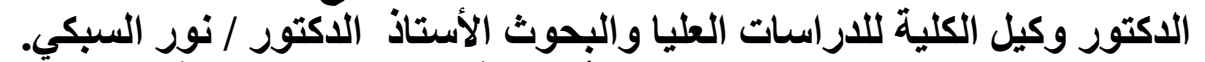

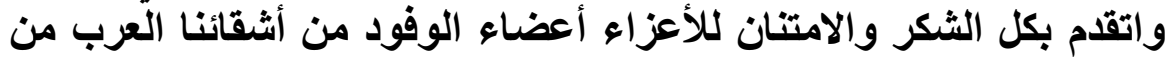

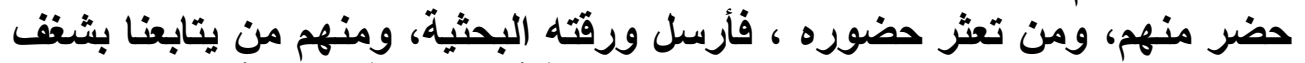

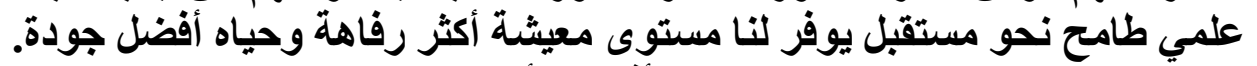

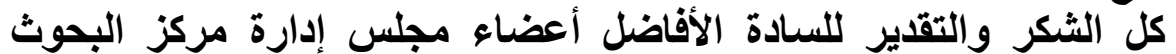

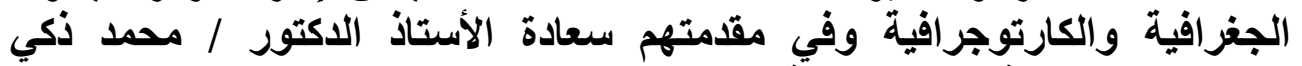
السديمي عميد كلية الآداب جامعة والية طنطا السابق.

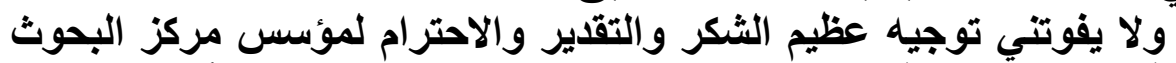

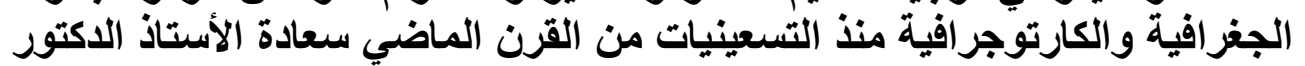

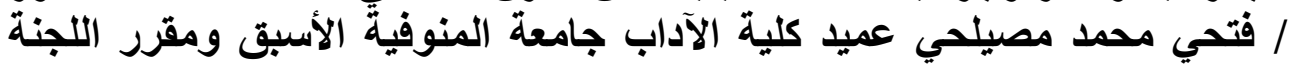


العلمية الدائمة لترقية الأساتذة والأساتذة المساعدين بأقسام الجغرافيا في الجامعات

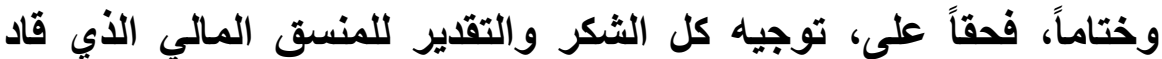

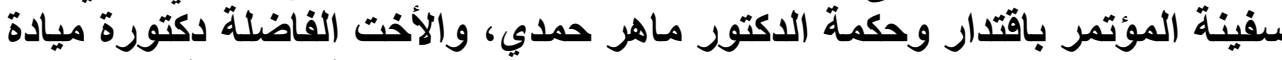

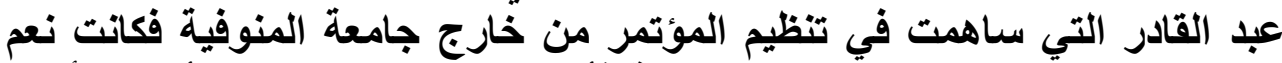

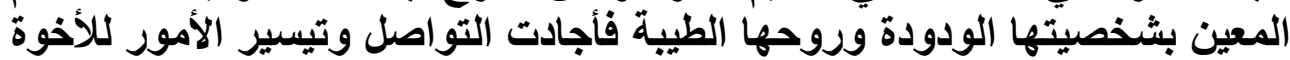

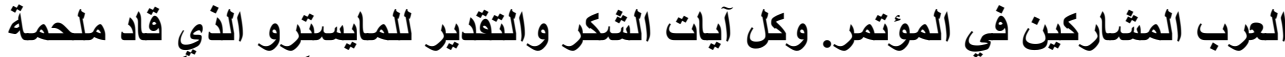

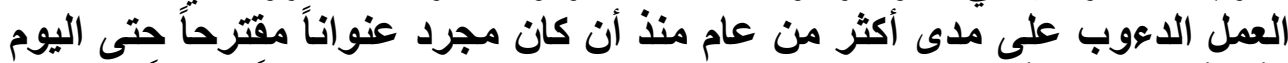

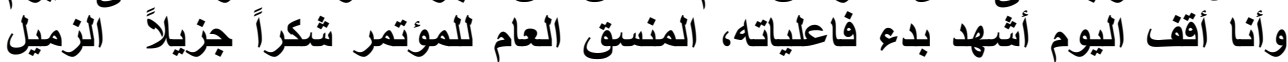

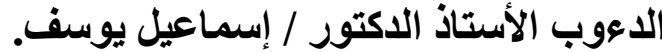

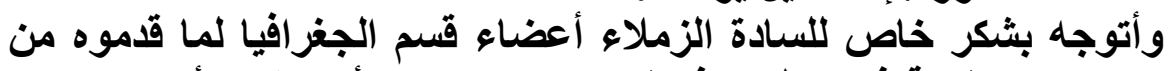
تعاون ومساعدة مخلصة في تنظيم هذا المؤتمر. ويسعدني أن اتقدم بأسمى وباسم أتماء

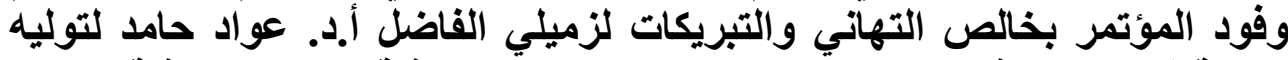

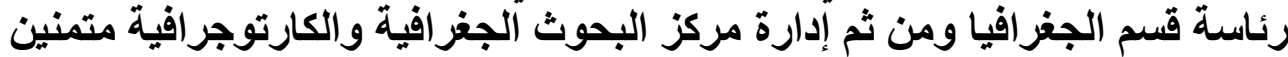

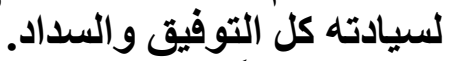

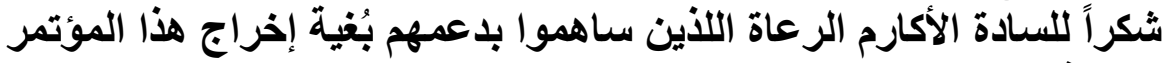

$$
\text { بشكل يليق بهذا الحضور الكريم الأرم الرعاة }
$$

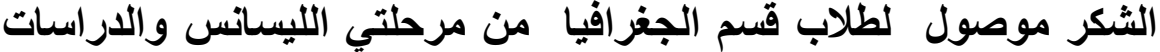

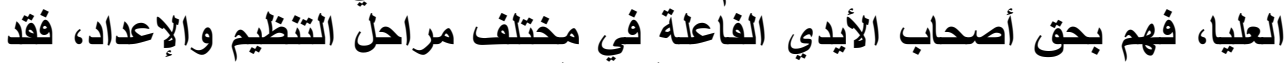

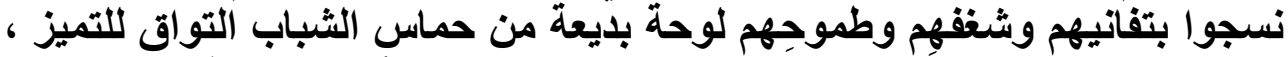

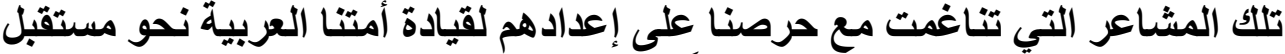

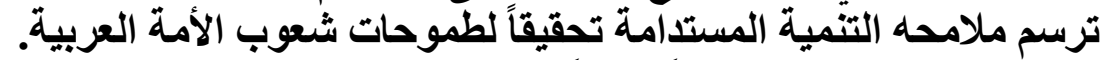
شكراً جزيلاً للسيدات والسادة الحضور الكريم مقرر المؤتمر المريم
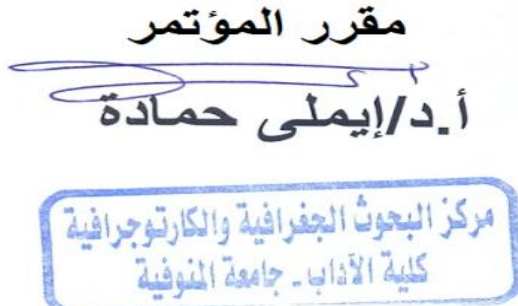


\section{كلمة المنسق العام للمؤتمر أ.د. إسماعيل يوسف إسنى إسماعيل الموليز}

الأساتذة الأكارم السيدات والسادة الأفاضل ضيوف "مؤتمر التنمية

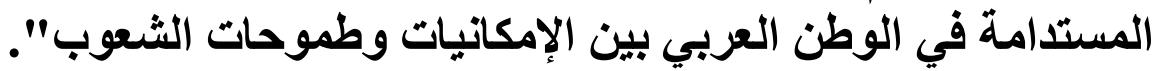

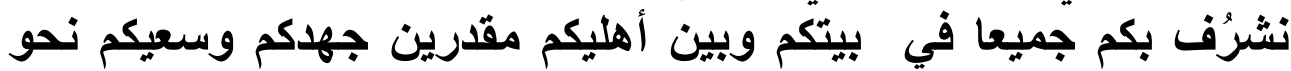

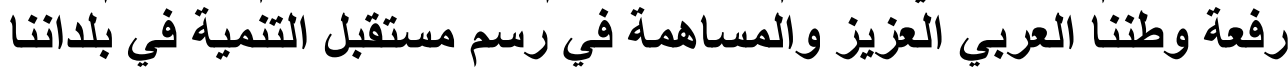

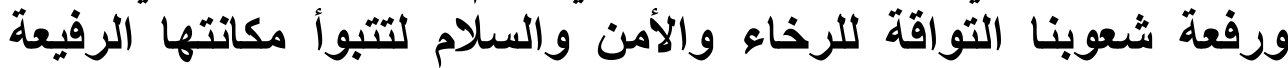

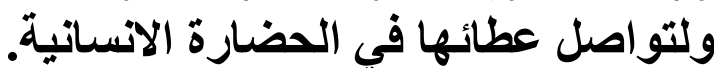

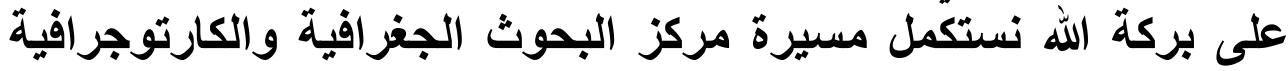

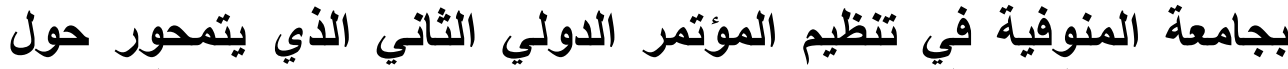

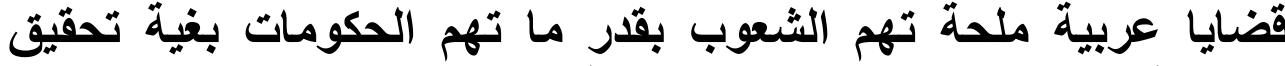
الرفاهية التي تستحقها وتسعى إليها كافة الثعوب.

واتوجه بالشكر والتقدير لكل فريق العمل الذي بذل جهوداً مخلصة من أجل نجاح فعاليات هذا المؤتمر.

والله الموفق والمستعان.

أ.د. ـ إسماعيل يوسف إسماعيل

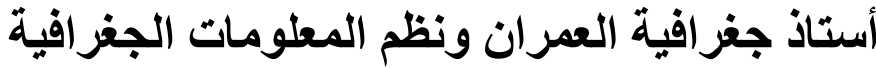

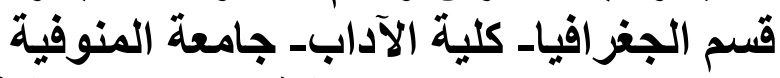

عضو مركز البحوث الجغرافية والكارتوجرافية جالية 


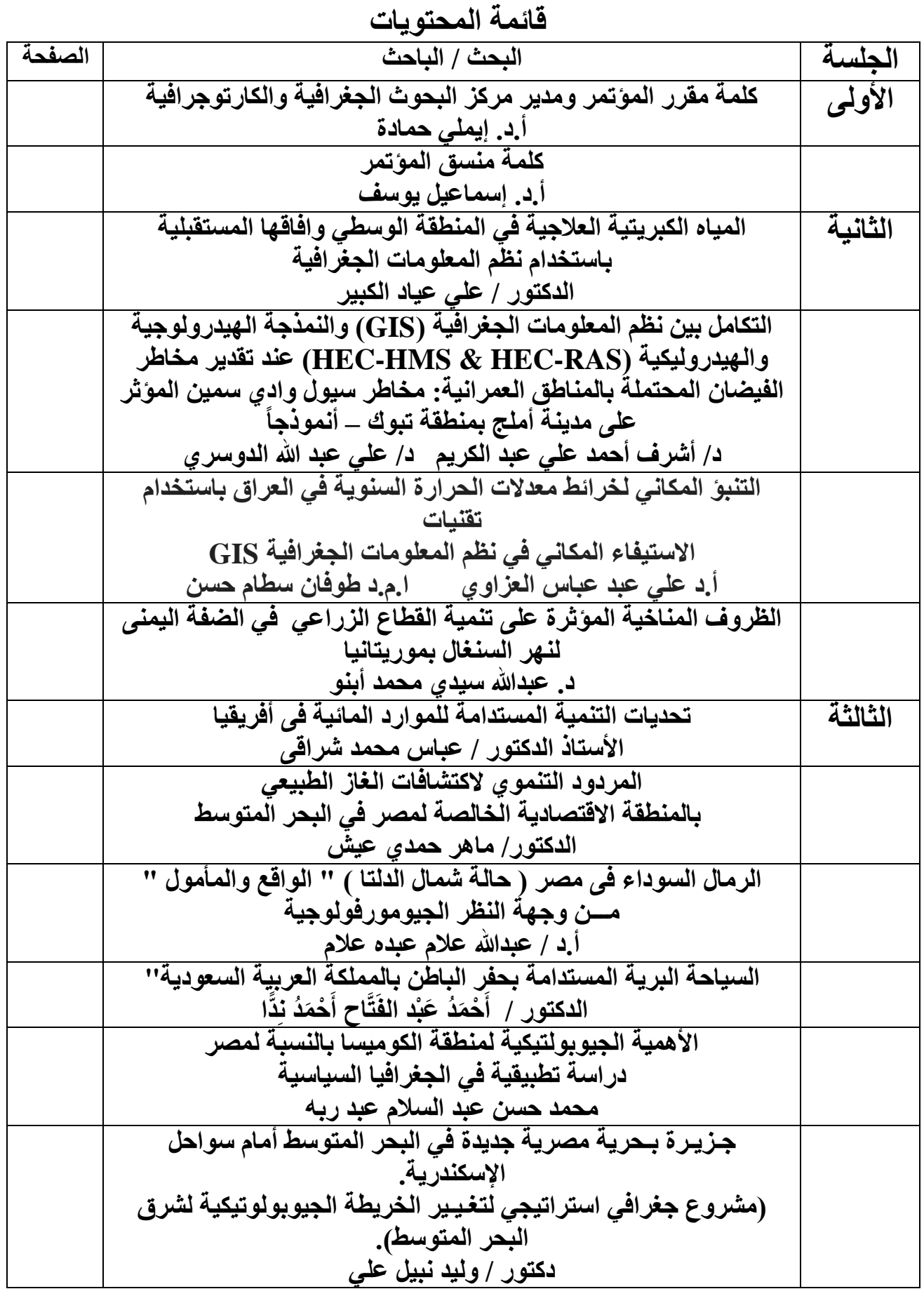




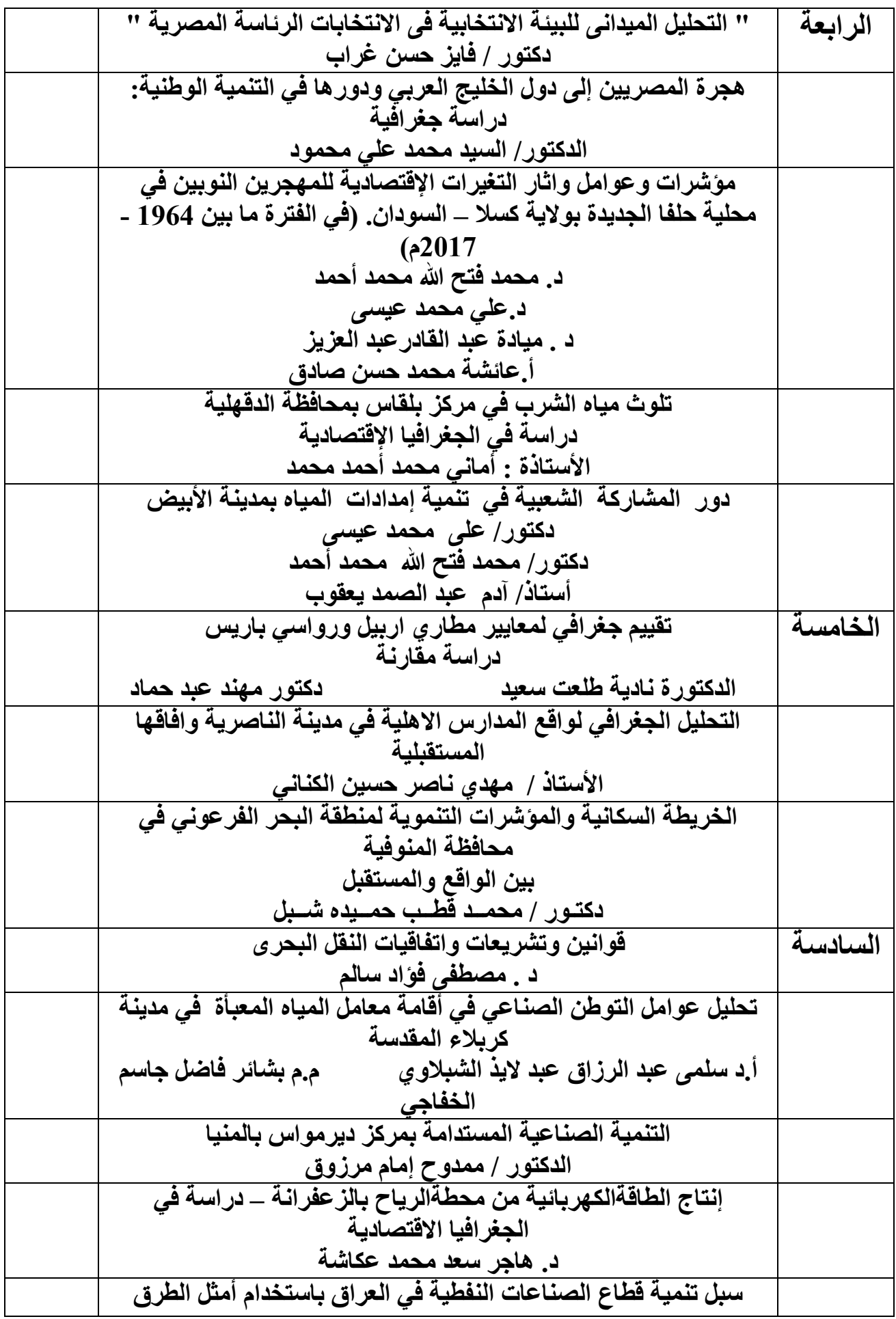




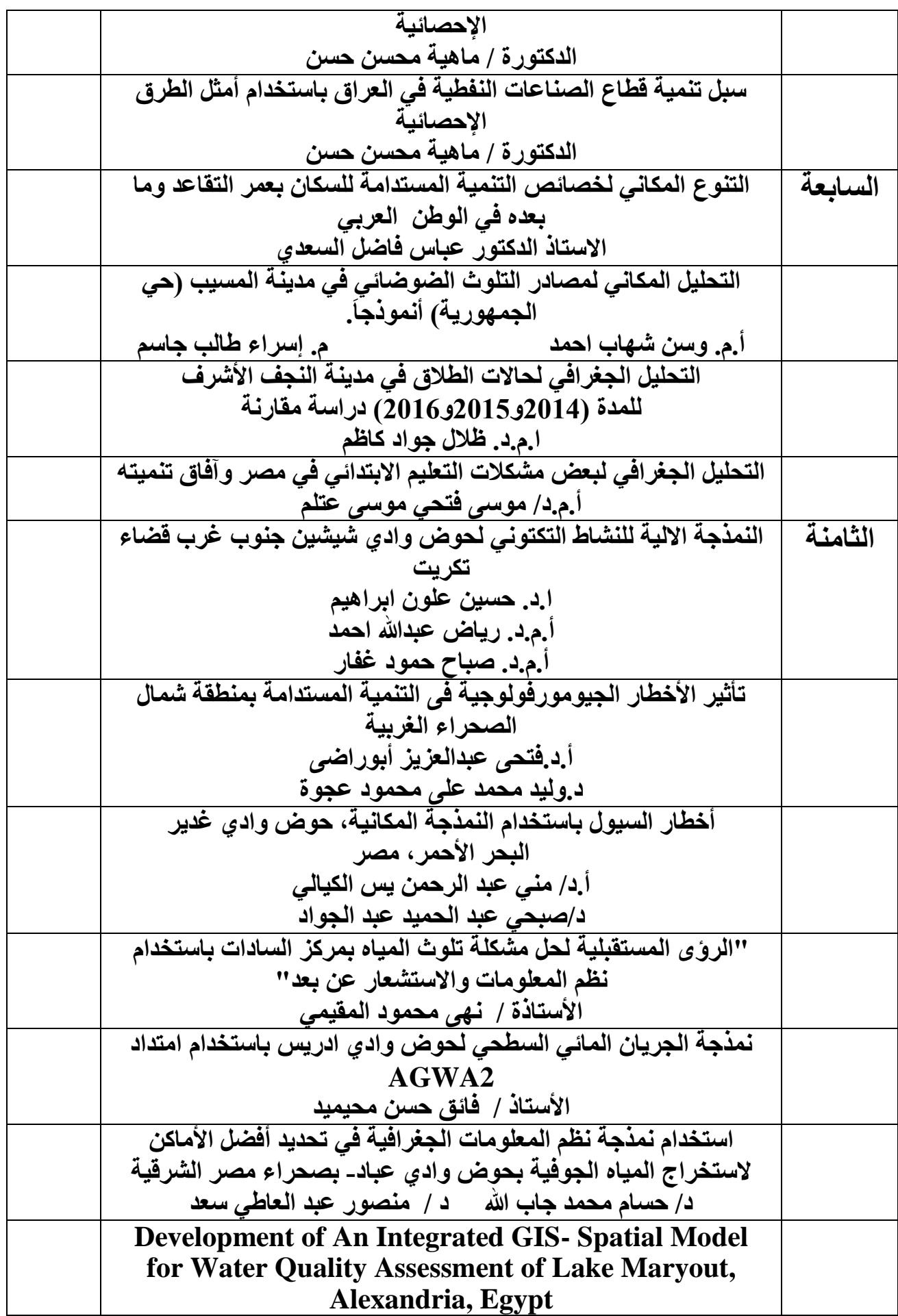




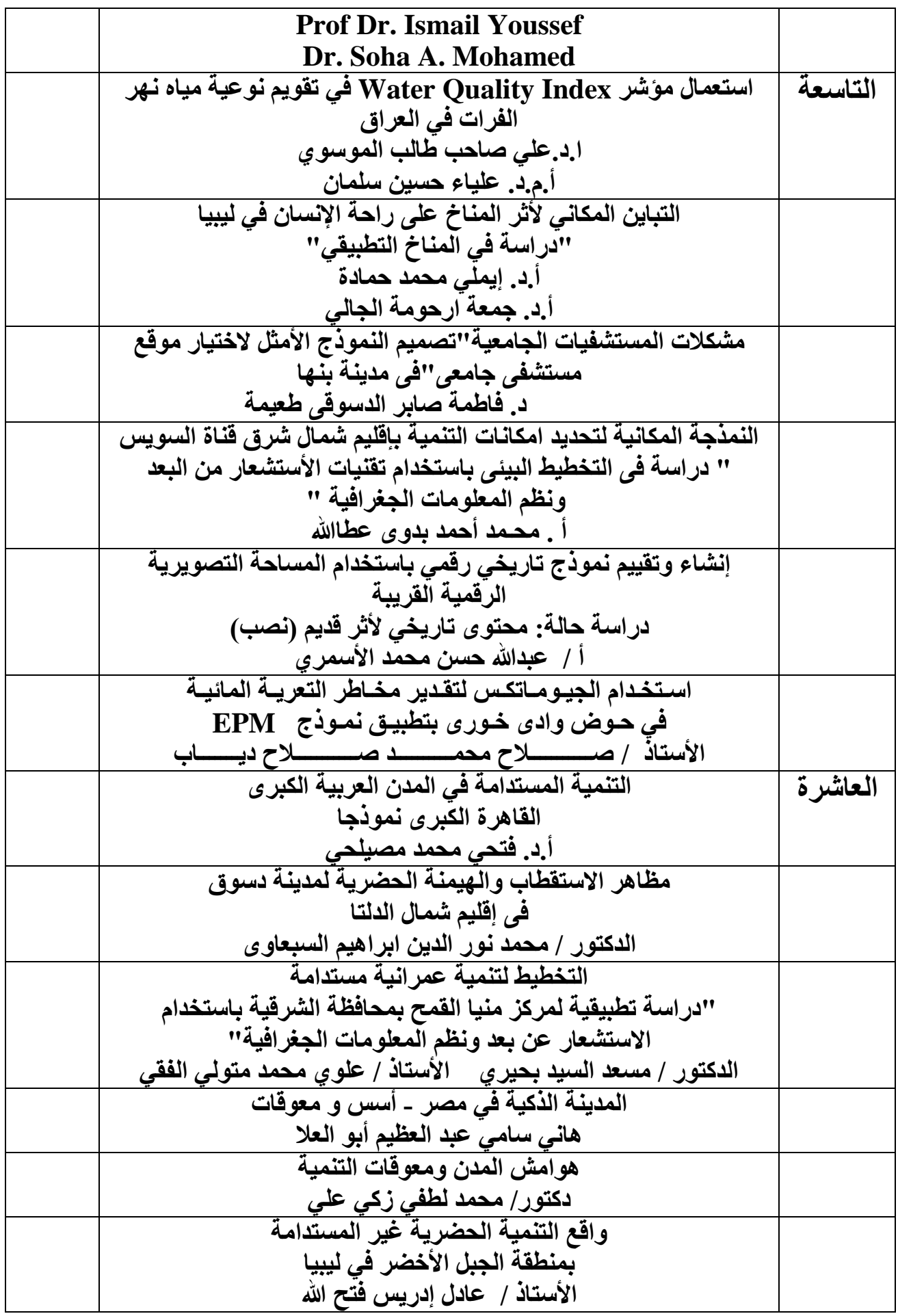




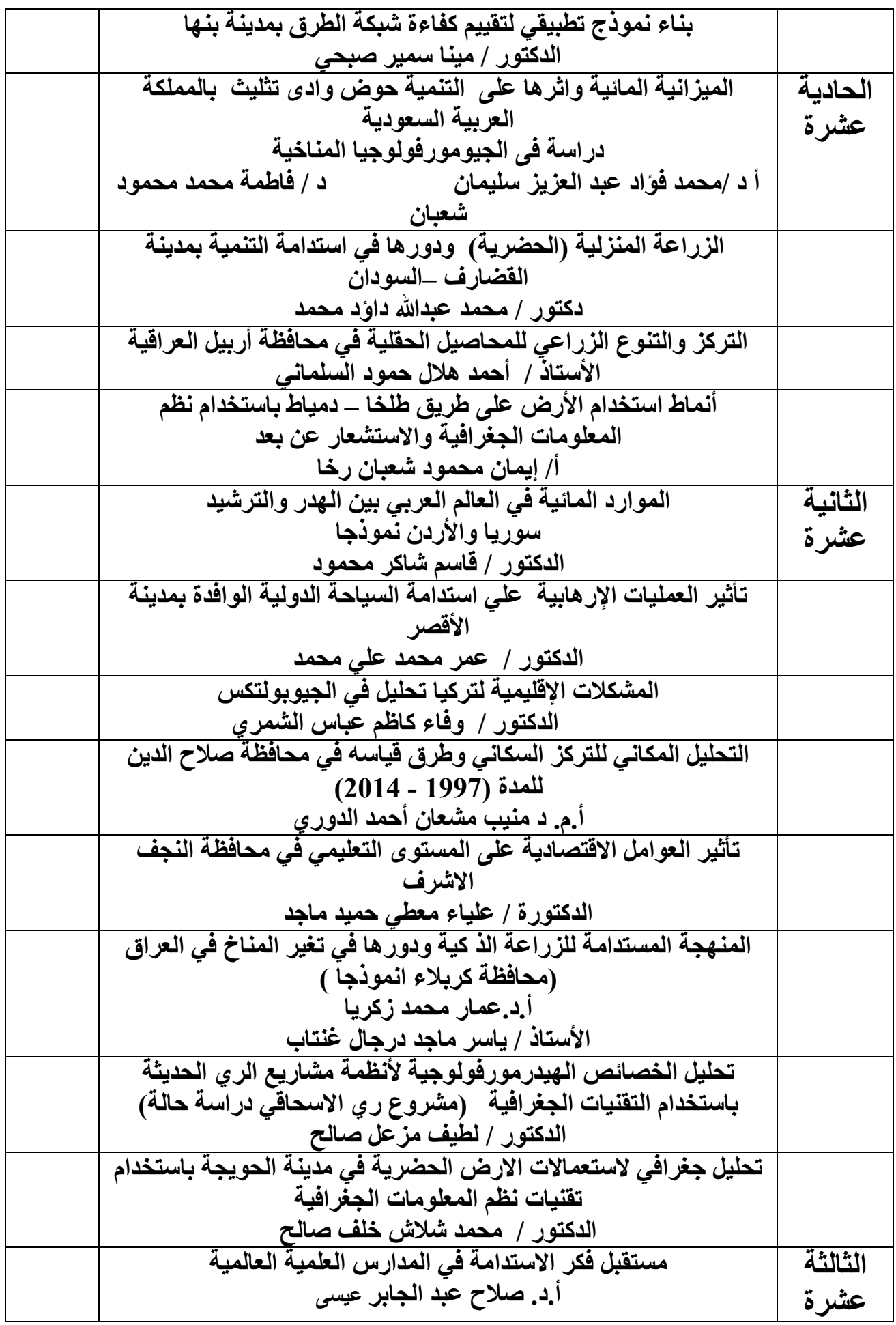




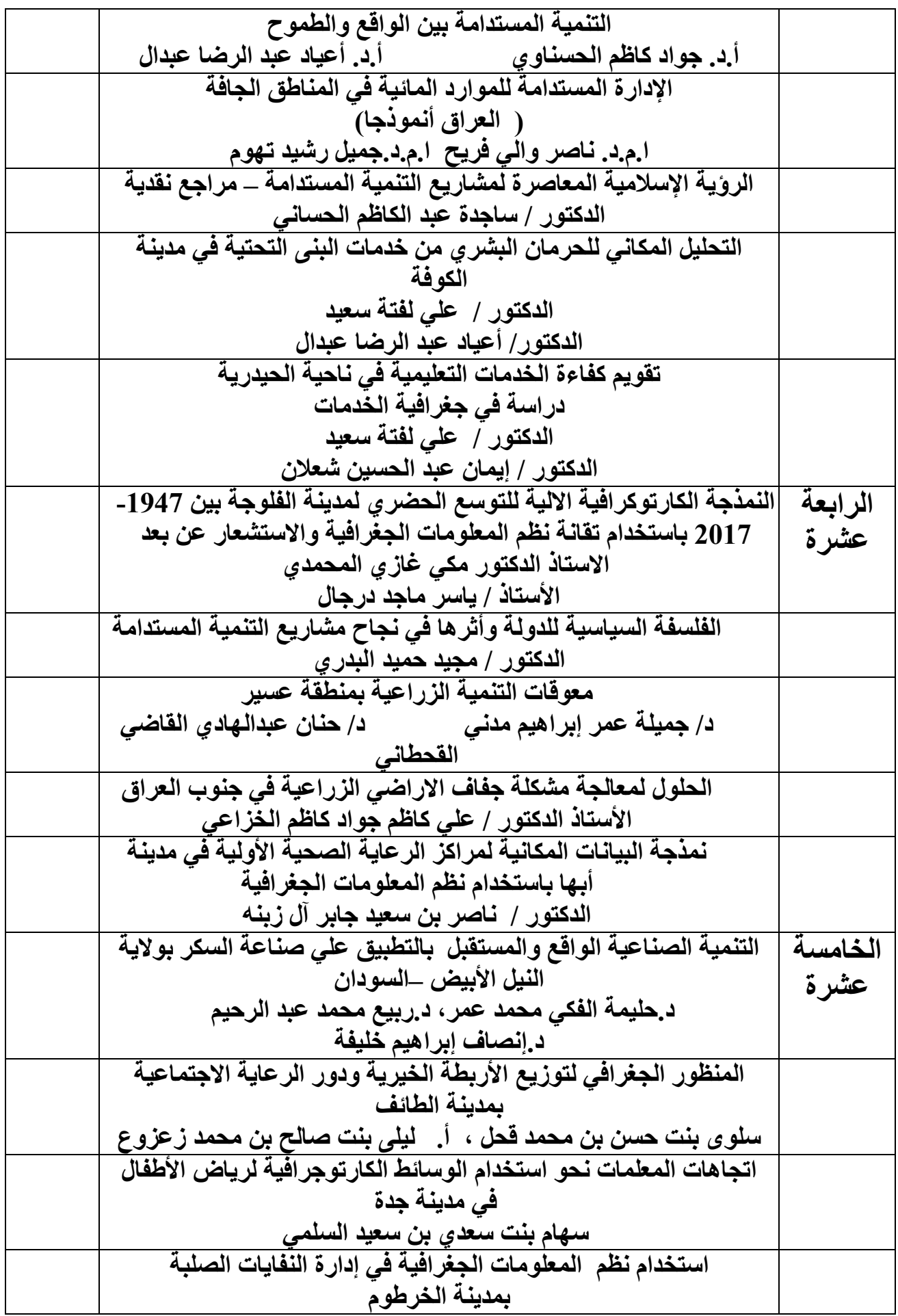




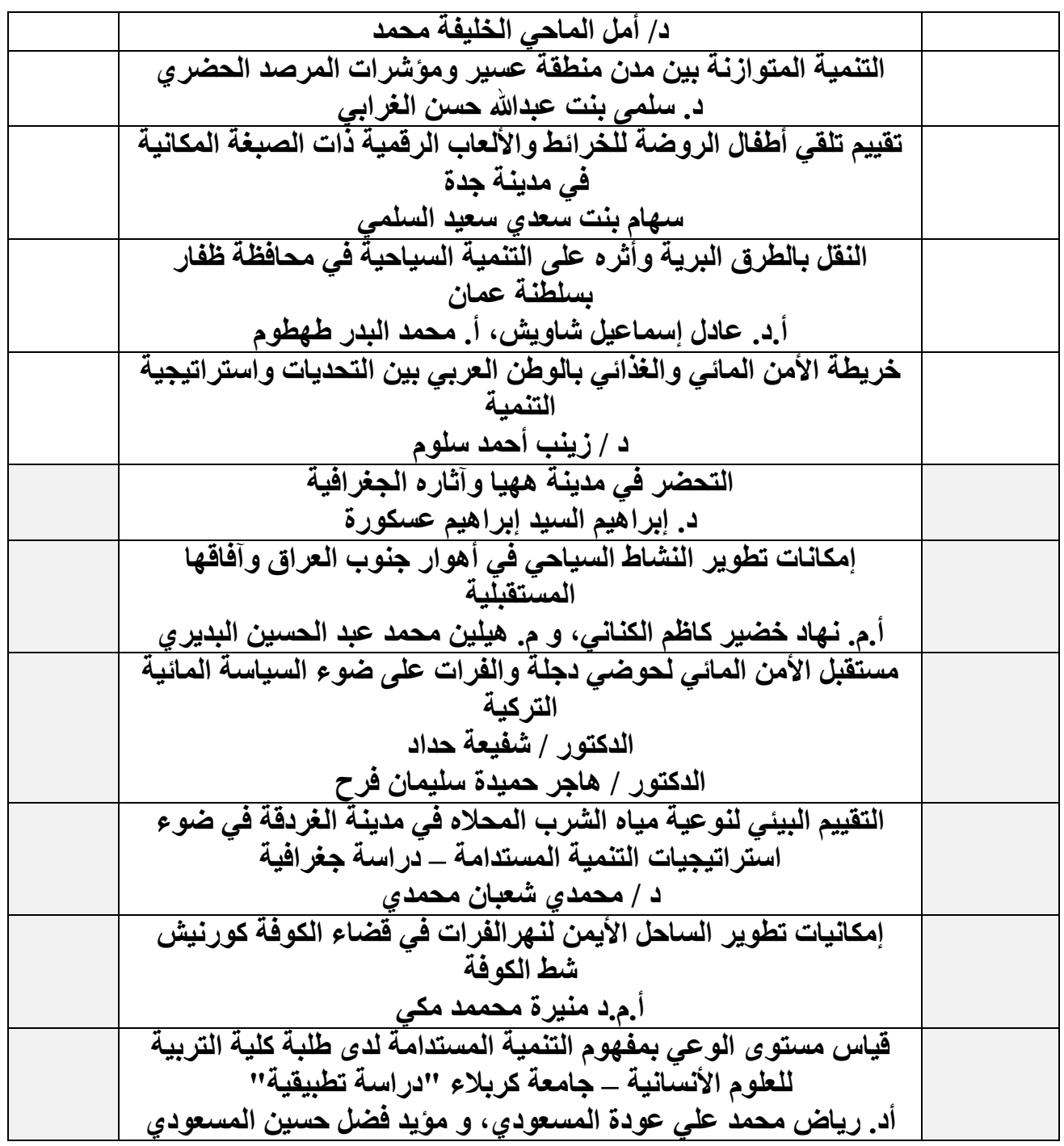


مركز البحوث الجغرافية والكارتوجرافية - قسم الجغرافيا - كلية الآداب - جامعة الدنوفية المؤتمر الجغرافي الدولي الثاني " التمية المستدامة في الوطن العربي بين الإمكانيات وطموحات الثعوب" فبراير 2019 


\section{الجلسة الخامسة عشرة}

التنمية الصناعية الواقع والمستقبل بالتطبيق

$$
\begin{aligned}
& \text { علي صناعة السكر بولاية النيل الأبيض - السودان } \\
& \text { د.حليمة الفكي محمد عمر }
\end{aligned}
$$

أستاذ الجغرافيا المشارك - كلية الآداب - جامعة بخت الرضا

$$
\text { د.ربيع محمد عبد الرحيم }
$$

أستاذ الجغرافيا المشارك - عميد كلية التربية أساس ( مبروكة ) - جامعة بخت الرضا

$$
\text { د.إنصاف إبراهيم خليفة }
$$

أستاذ الجغر افيا المساعد - كلية الآداب و العلوم الإسانية - جامعة بحري

$$
\text { مستخلص الاراسة }
$$

تناولت هذه الدراسة التتمية الصناعية بولاية النيل الأبيض -السودان الواقع والمستقبل بالتطبيق

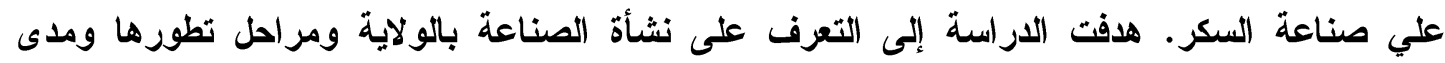

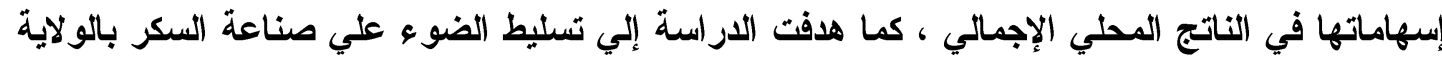

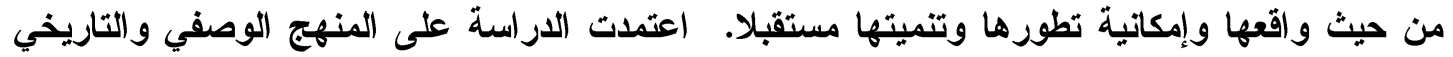

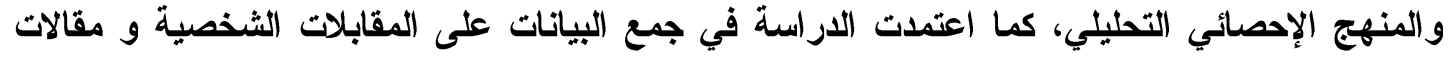

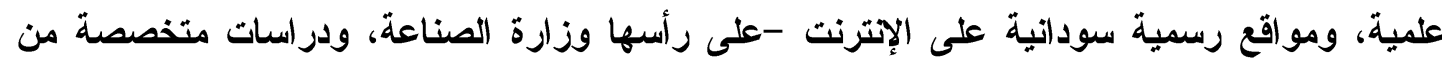

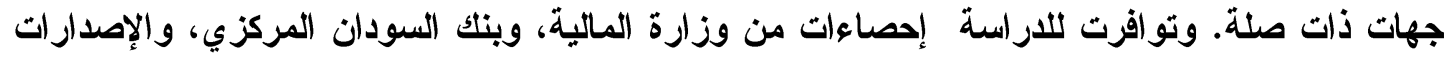

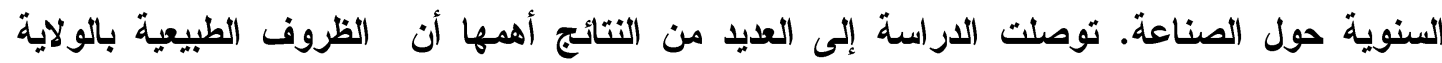

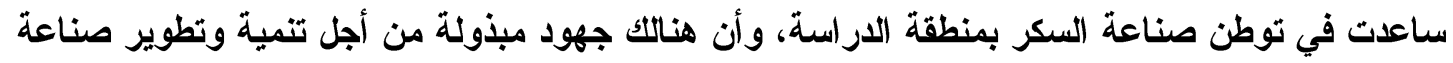

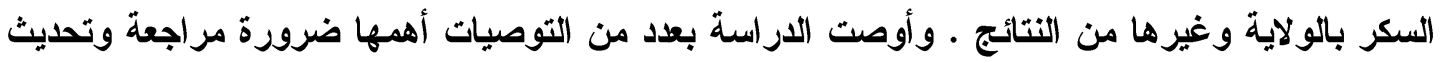

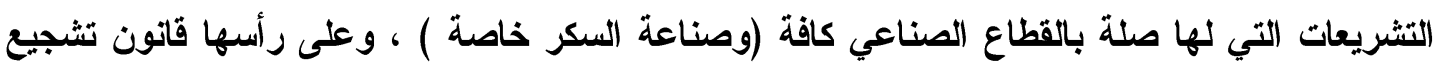

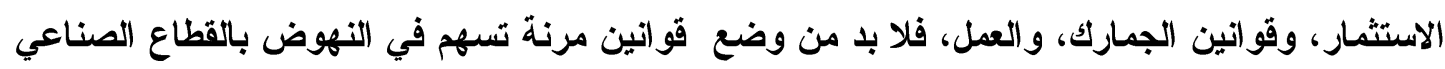

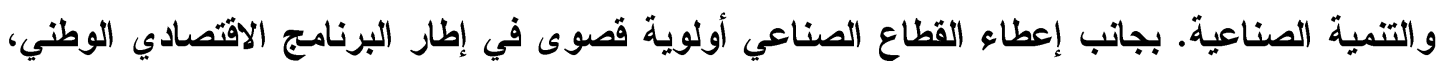

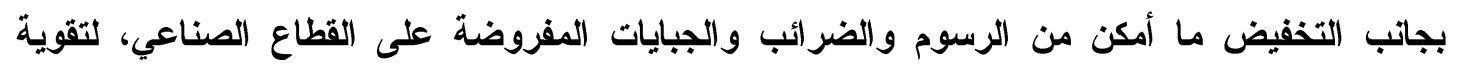

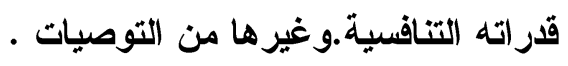




\section{Abstract}

This study dealt with industrial development in the state of White Nile Sudan, the reality and the future by applying to the sugar industry. The study aimed to identify the origin of the industry in the state and the strategies of development and the extent of its contribution to GDP. The study also aimed to shed light on the sugar industry in the state in terms of its reality and the possibility of its development and future development. The study was based on the descriptive and historical methodology and analytical statistical method. The study relied on collecting data on personal interviews, scientific articles, and official Sudanese websites, headed by the Ministry of Industry, and specialized studies from related parties. Statistics from the Ministry of Finance, the Central Bank of Sudan, and annual publications on the industry were available. The study concluded that the natural conditions in the state helped to settle the sugar industry in the study area and that efforts are being made to develop the sugar industry in the state and other results. The study recommended, there are necessity to review and update legislation related to the industrial sector (especially the sugar industry), foremost of which is investment promotion law, customs and labor laws. In addition to giving the industrial sector a high priority within the framework of the national economic program, as well as reducing the fees, taxes and levies imposed on the industrial sector to strengthen its competitiveness and other recommendations.

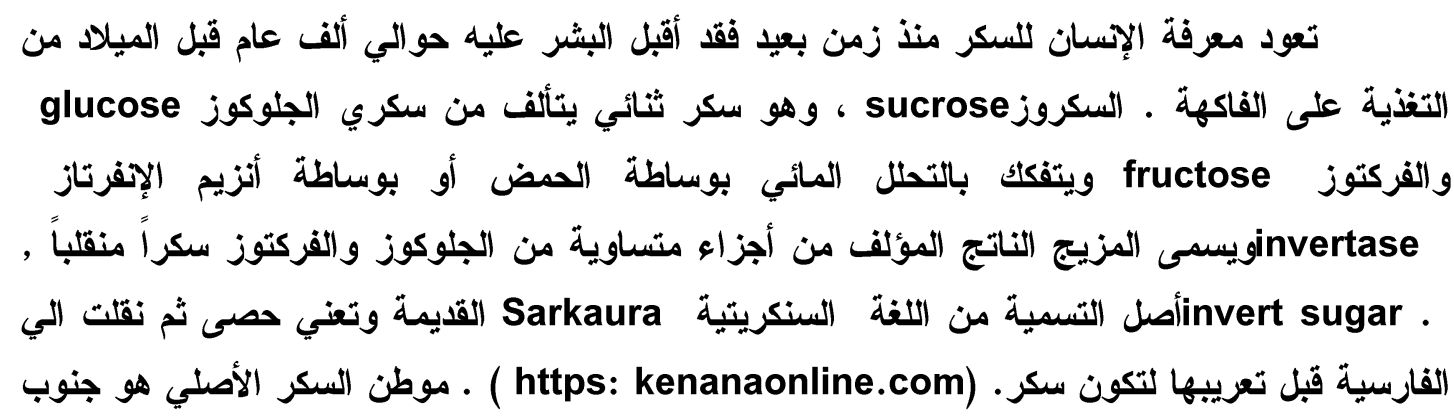


قارة آسيا ويرجح أن تكون الهند هي أول مكان ينمو فيه نبات قصب السكر وقد نقله الإسكندر الأكبر إلى ألى

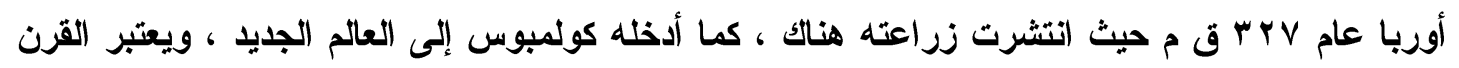

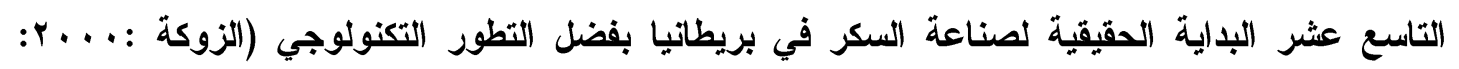

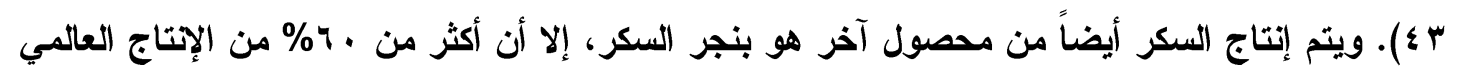

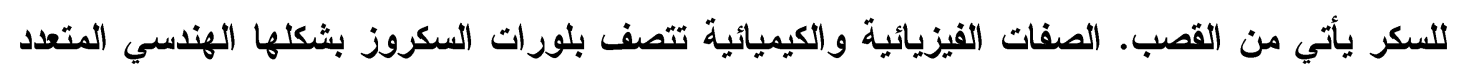

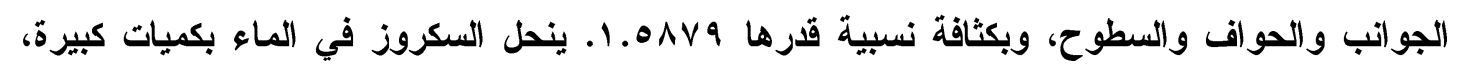

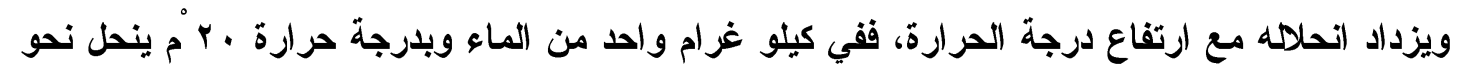

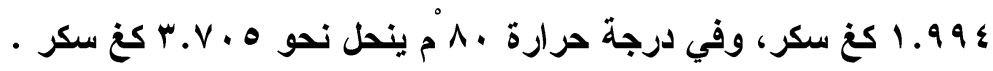
ويتم الحصول على مادة السكر من عصارة محصول قصب السكر بعد عصر عيدانه وذلتك

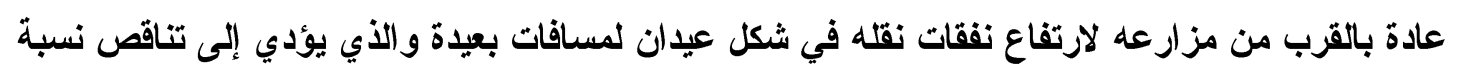

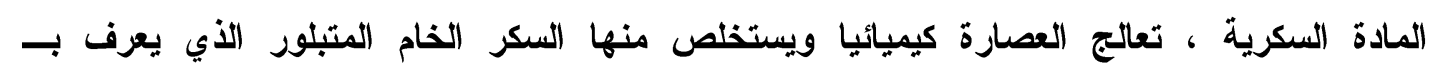
Crystalline

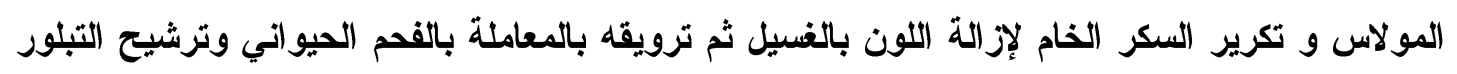
السكر

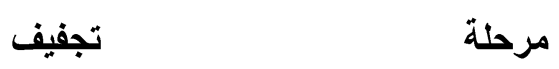
وأخيرا .http://www.tpsudan.gov.sd/index.php/ar/home/show_export/80

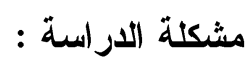
ما هو واقع صناعة السكر في ولاية النيل الأبيض ؟

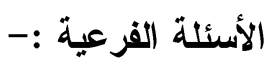

1/هل للتخطيط التنموي أثر في واقع صناعة السكر بولاية النيل الأبيض .

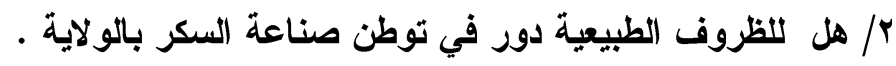

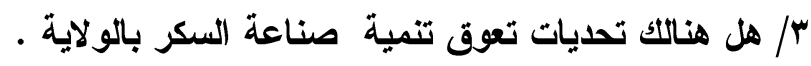

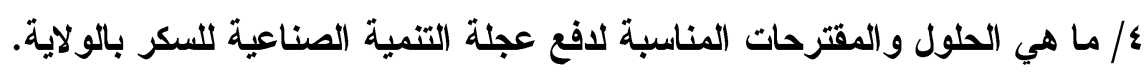

$$
\text { فتروض الاراسة : }
$$

اللتخطبط التنموي أثر في واقع صناعة السكر بمنطقة الاتئ الدار اسة. / / الظروف الطبيعية ساهمت في توطن صناعة السكر بمنطقة الار اسة. / / / هنالك بعض التحديات تعوق تنمية قطاع صناعة السكر بالمنطقة.

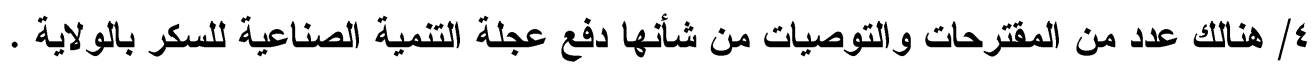

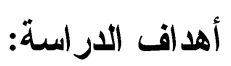
تهرف الار اسة إلى الآتي: //الوقوف على التطور التاريخي لصناعة السكر في السودان. 
r/إبراز أهمية قطاع صناعة السكر في الاقتصاد السوداني.

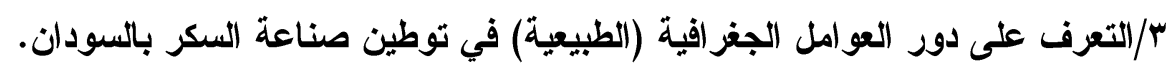

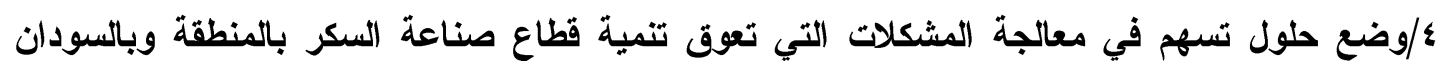

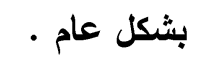
أهمية الدراسة :

تأتي أهية هذه الار اسة بأن السودان بمتلك عوامل طبيعية وبشرية عديدة تساهم في نجاح وتطور

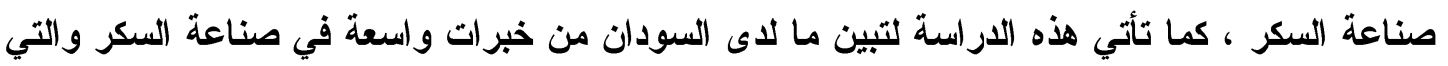

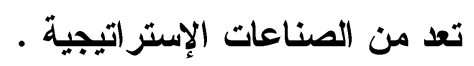
منهجية الار اسة : العناعة الاسن

اتبعت الاراسة العديد من المناهج العلمية منها : 1-المنهج التاريخي لتوضيح التغيرات التي حدثت في المنطقة خلال مراحلها المختلفة الأمر الذي يساعد

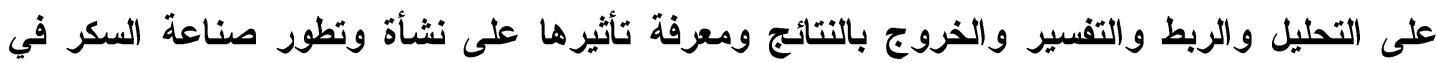

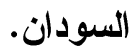
r- المنهج الوصفي يعتد المنهج الوصفي على وصف الواقع أو الظاهرة كما توجد في الواقع ويهتم

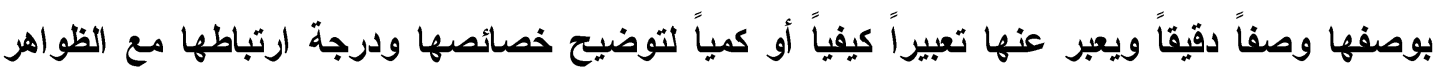
المختلفة الأخرى ـ وهو أسلوب مختص بدراسة المشكلات المتعلقة بالمجال الإساني والطبيعي .وقا

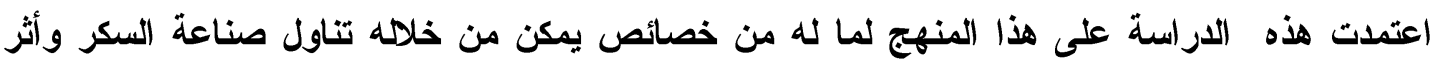

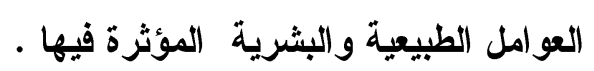

ب-المنهج الإحصائي التحليلي تعل عملية جمع المعلومات والبيانات وعرضها وترتيبها وتحليلها واستخلاص نتائجها ذات أهمية، لذا تم استخام المنهج الإحصائي لترجمة البيانات التي تم الحصول عليها

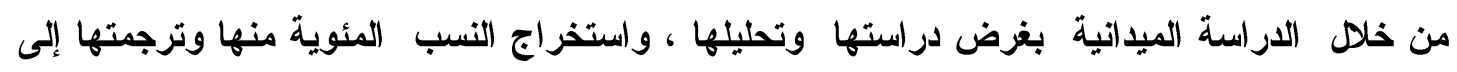
جاول وأثكال بيانية بغرض استخلاص وتحديد النتائج منها. مصادر جمع البيانات : تم الاعتماد في جمع المطومات على مصادر أولية التي تحقى أغراض الدراسة

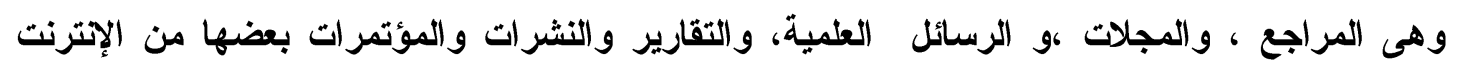
و البعض الآخر من المكتبات لبعض المعلومات المرتبطة بمجال الدراسة. حود الاراسة:

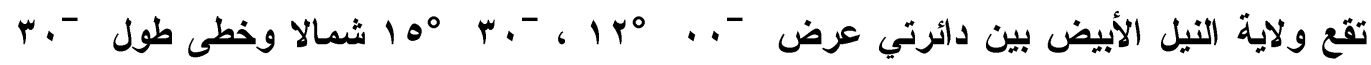

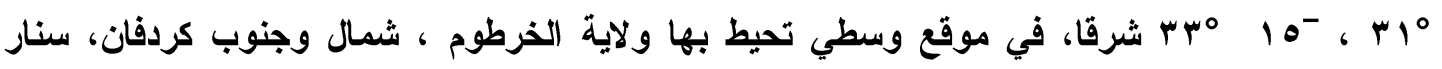


و الجزيرة . وتحدها من الجنوب دولة جنوب السودان. وتبلغ مساحتها . . 19 اء كلم مربع لاحظ خريطة

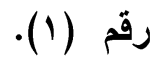

تعريف السكر

أجمع الباحثون في هذا المجال علي أن السكر المبلور المعروف تجاريا والمتداول في المنطقة العربية والأفريقية علي وجه الخصوص يقصد به : مادة بلورية متجانسة حلوة الطعم وذات لون أبيض

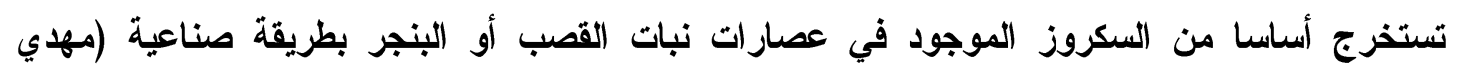
$\cdot(191 \cdot:$

\section{خريطة (1) :موقع منطقة الار اسة}

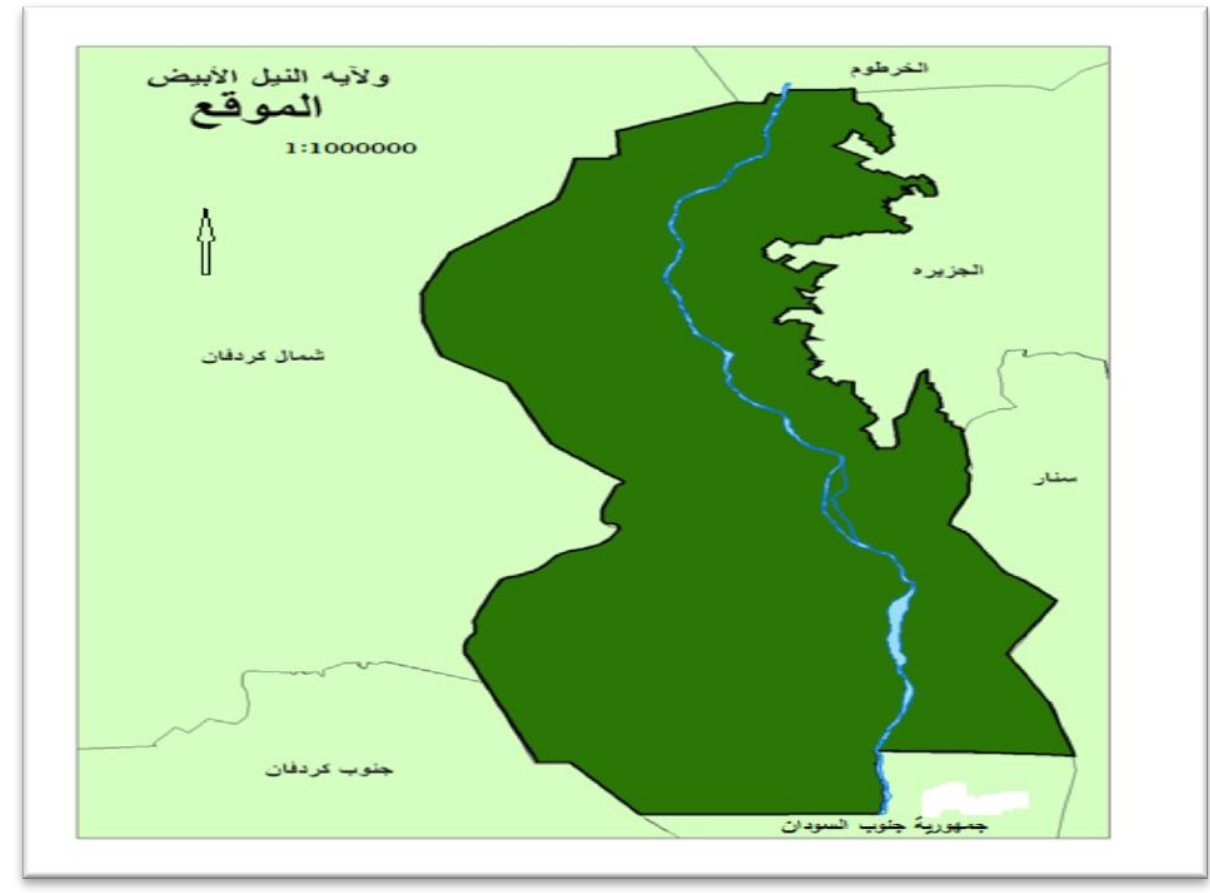

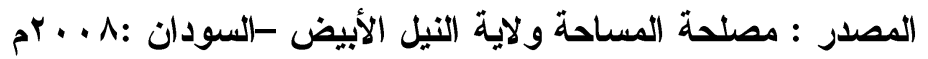

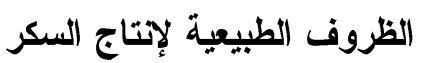

تتركز مناطق زراعة قصب السكر في المناطق المدارية وشبه المدارية ،وبذلك تقع مناطق زراعته بين دائرتي عرض Vr درجة شمالاً و ـ ب درجة جنوباً . ووفقاً لذلك يكون هذا النبات من محاصيل 
المناطق الحارة. وفيما يلي نتناول بالتفصيل العو امل الطبيعة (حرارة- أمطار-تربة) المؤثرة في إنتاج هذا

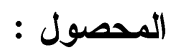

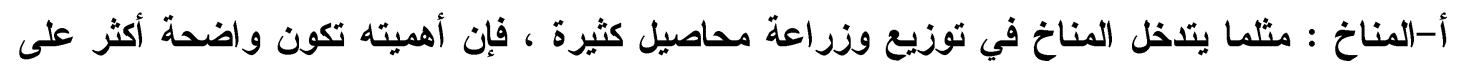

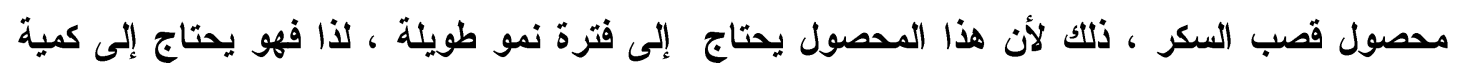

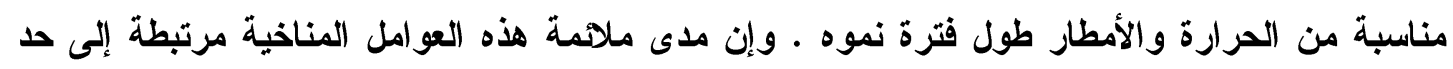
كبير في إنتاجية هذا المحصول

و واستناداً على تقسيم كوين 9 19 ام للأقاليم المناخية، فان منطقة الداسة تقع في الإقليم الثاني

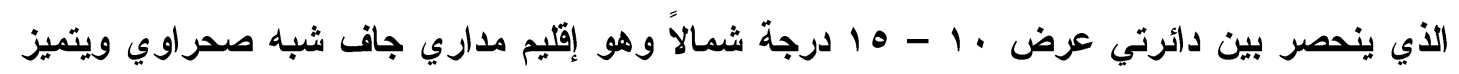

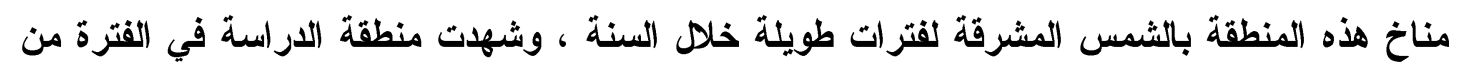

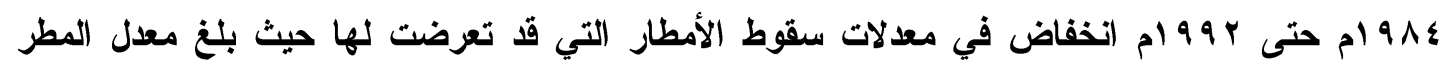

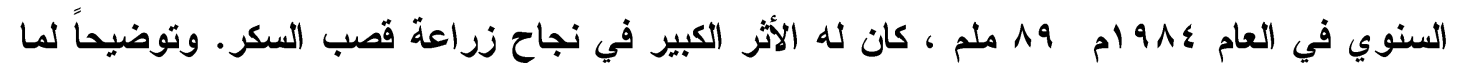

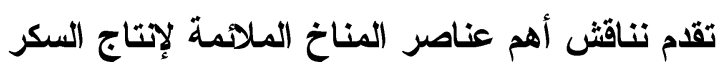

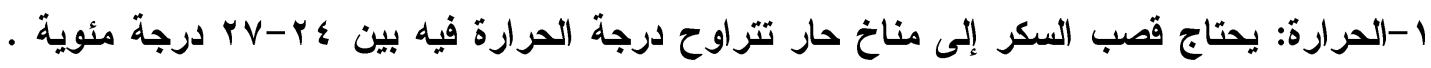

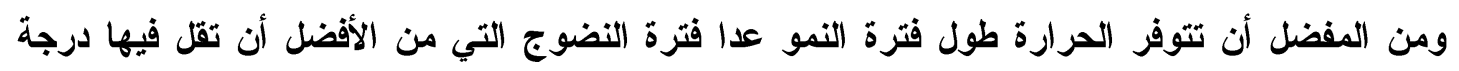

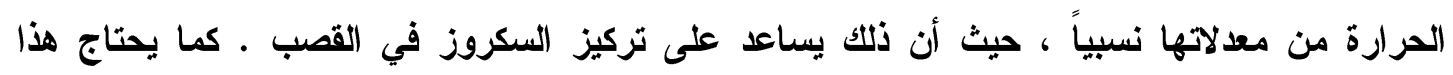

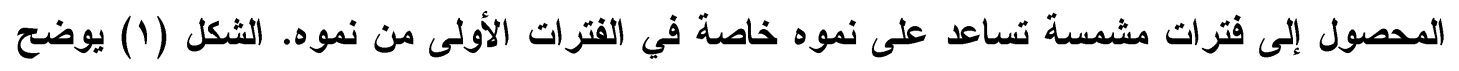
درجات الحرارة بمنطقة الدراسة.

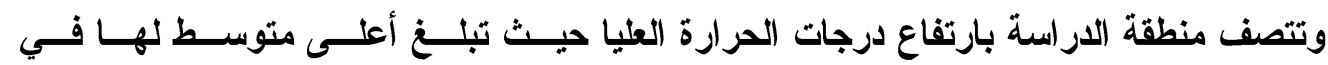

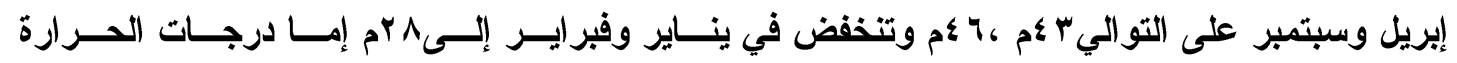

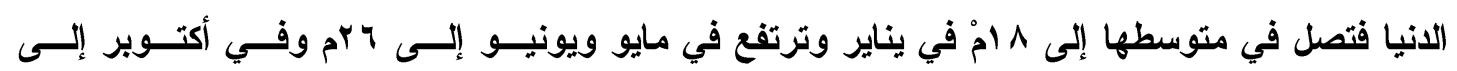

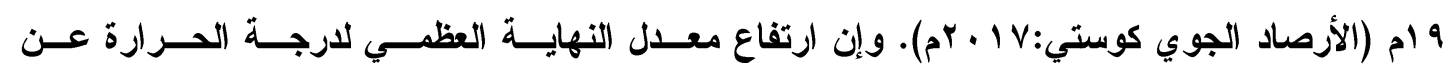

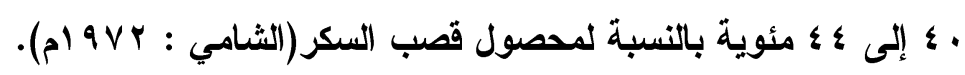


شكل (1) المتوسطات الشهرية للحرارة والرطوبة والتبخر بمنطقة الدراسة

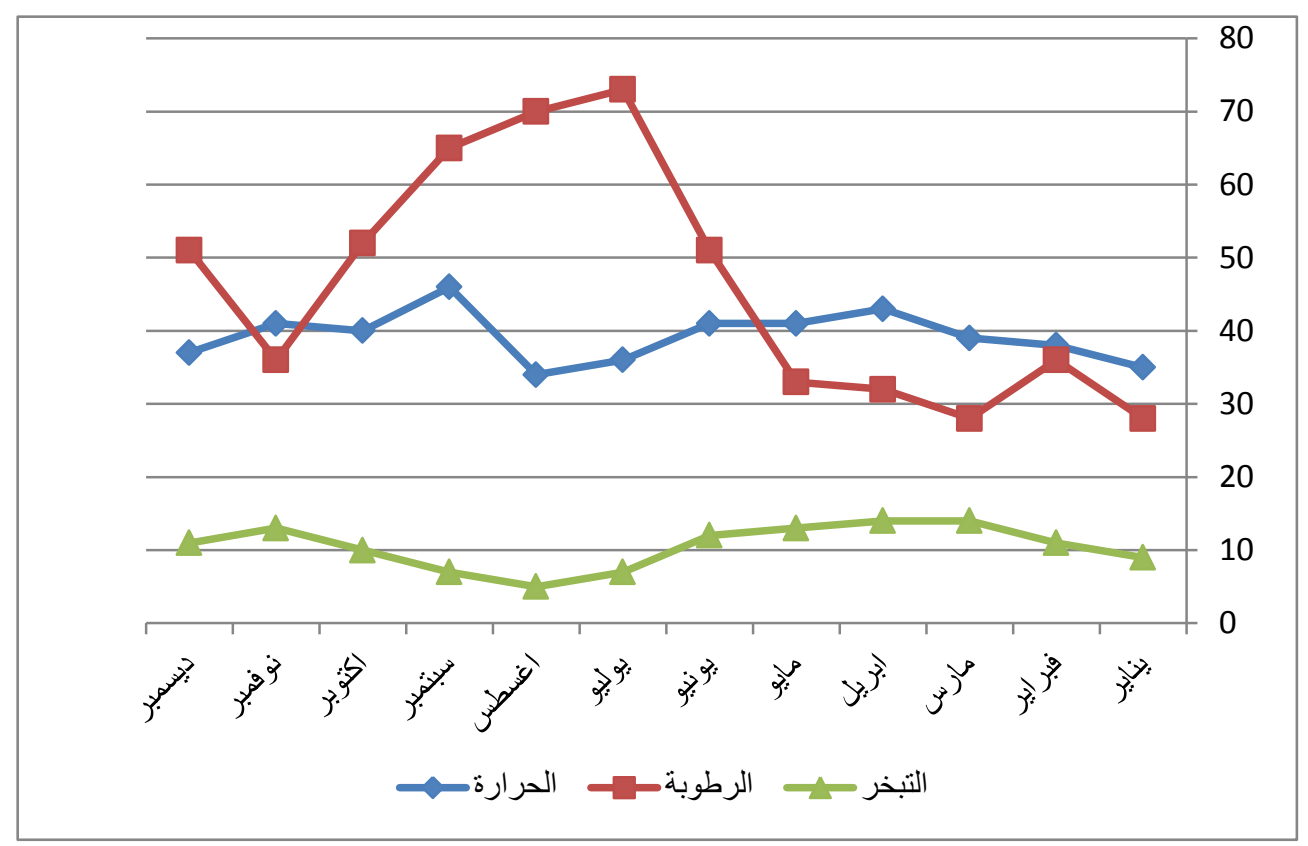

المصدر:الأرصاد الجوي كوستي: V l r ام

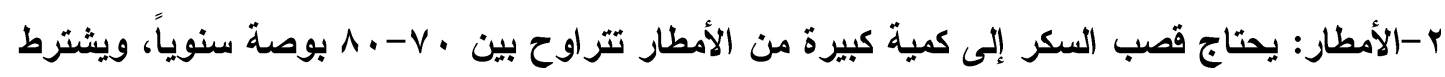

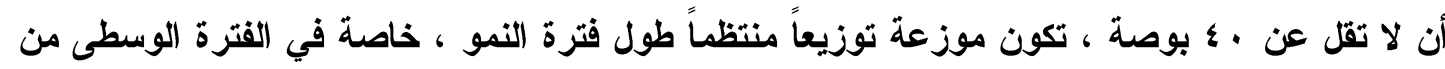

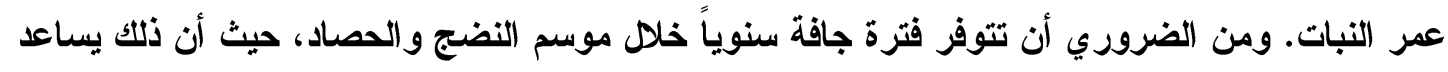

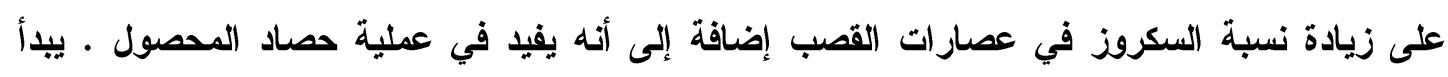

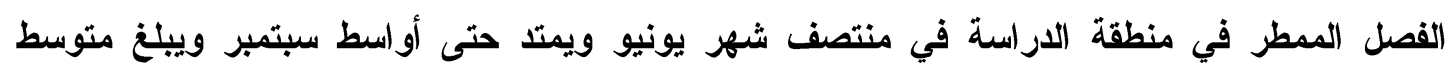

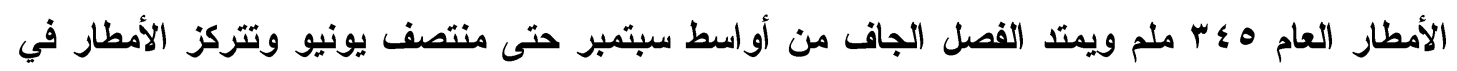

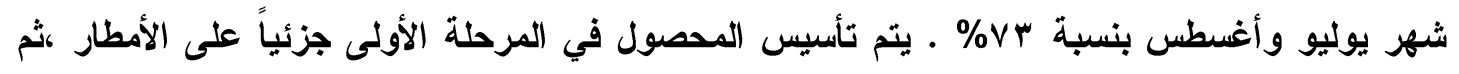

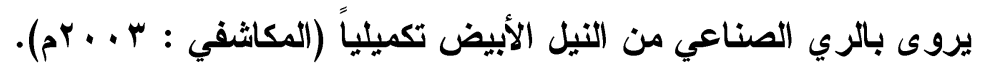




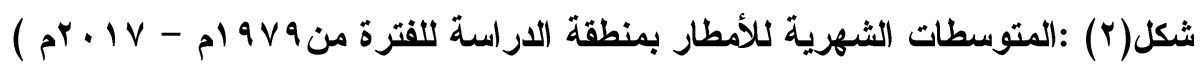

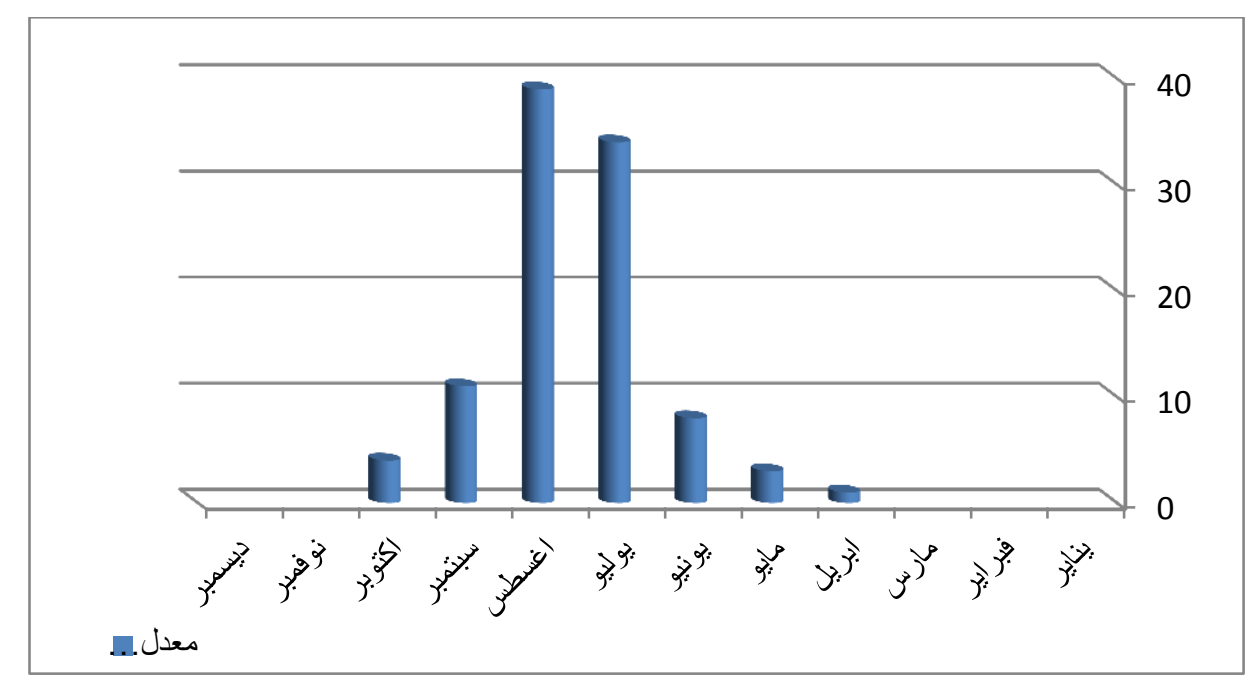

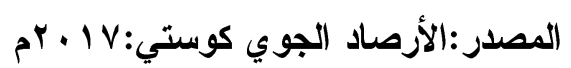

شكل (r) متوسطات الأمطار السنوية لمنطقة الدراسة للأعوام 9 ام ام - V ا ب م.

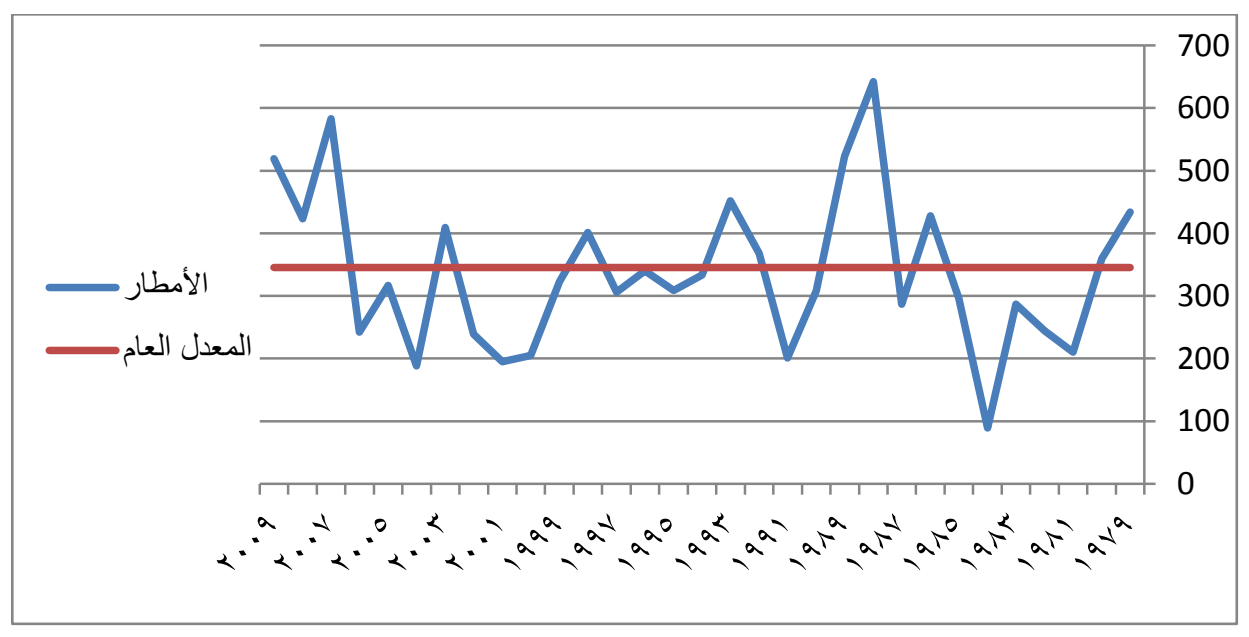

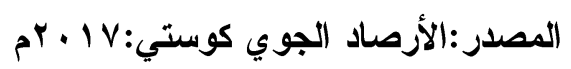

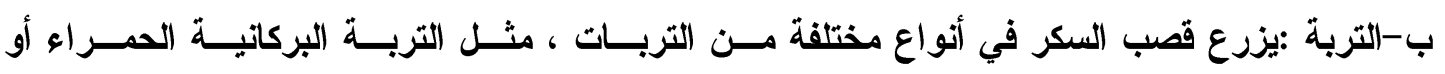

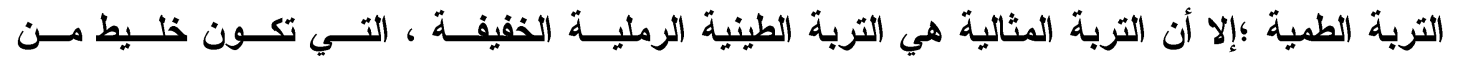

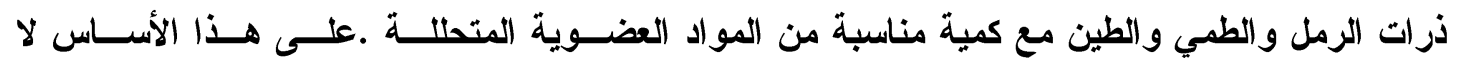




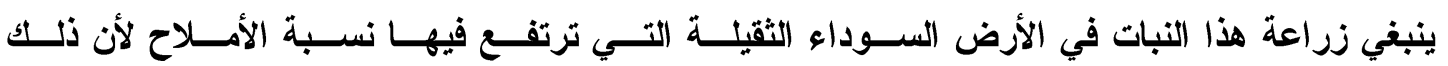
يؤدي إلى اتحادها مع السكروز فيكون غير قابل للتبلور عند عملية التصنيع.

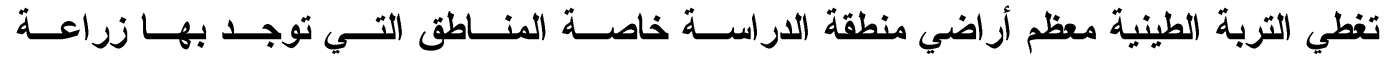

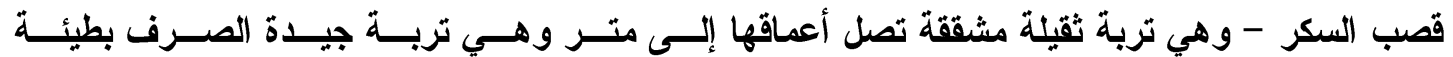

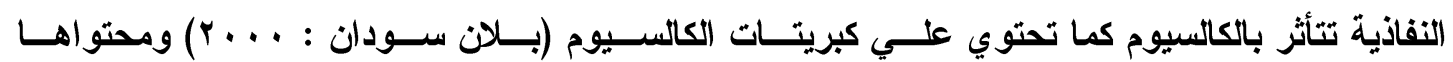

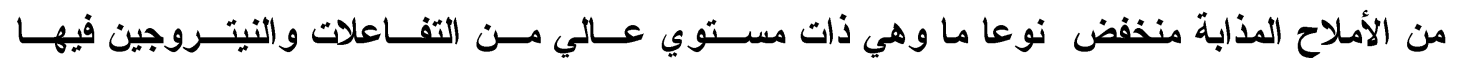

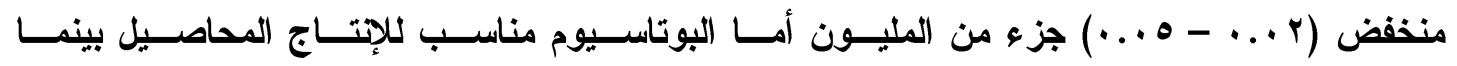

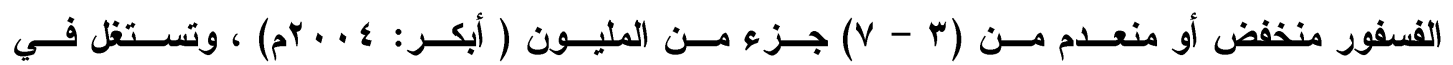

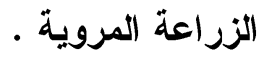

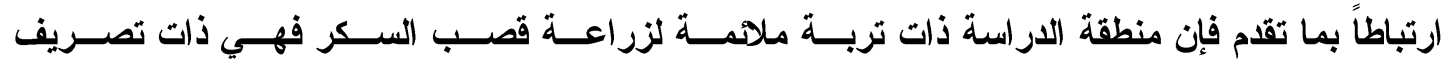

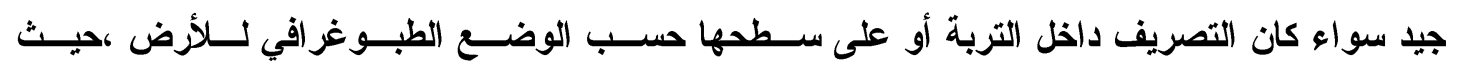

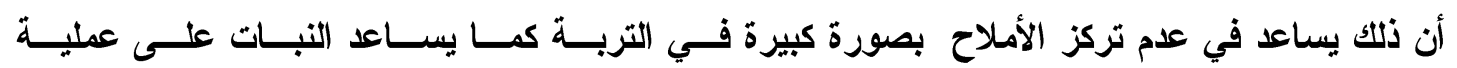

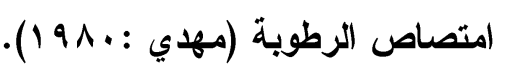
تطور إنتاج السكر في السودان :

يعتبر قطاع الصناعة من أحدث قطاعات الاقتصاد في الدول النامية ولطبيعة الصناعة والتصنيع التي تميزها عن بقية القطاعات الاقتصادية في هذه الدول ولكن يواجه بعض المشاكل والمعوقات التي تعيق تقدمه ولا شكك فإن لظروف الدول النامية أثر كبير في تعميق جذور هذه فئه المشاكل والمعوقات

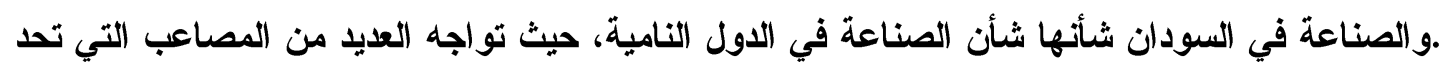
تقدمها، (نطلاق

من

وتعتبر صناعة السكر من الصناعات الإستراتيجية المهمة يعول عليها في الإصلاح الاقتصادي فيجب أن تكون لها أسبقية عالية في مشاريع الصناعة المحلية ليصل إنتاجها إلى حد الاكتفاء الأاتي والاتجاه

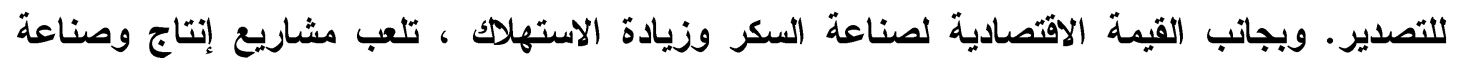

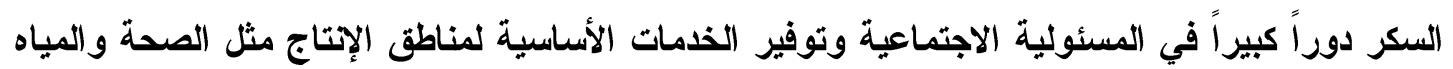

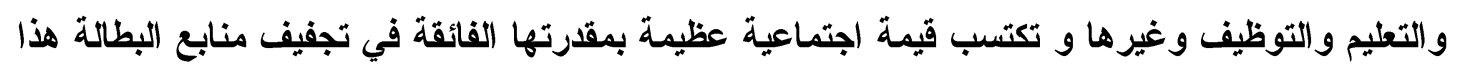

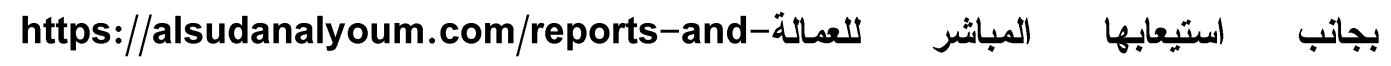
investigations

بدأ التفكىر في إنثاء مصانع السكر في السودان في الثلاذىنات دىث أوفلت شركة بوكسل

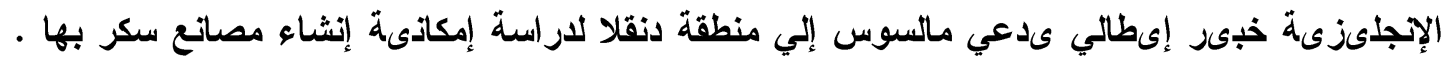


وكان في ذلك الوقت السودان تحت سدىطرة الحكم الثنائي وكاتت زراعة قصب السكر موجودة في كل من

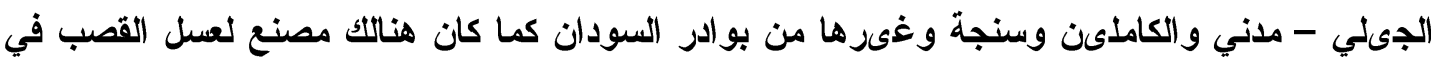

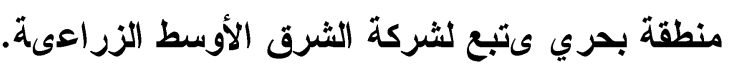
في أوائل الخمدىنات تمت تجارب لزراعة قصب السكر في منطقة منقلة بمواردها الطبىعىىة التي تتمثل

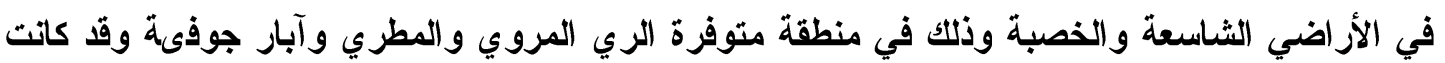

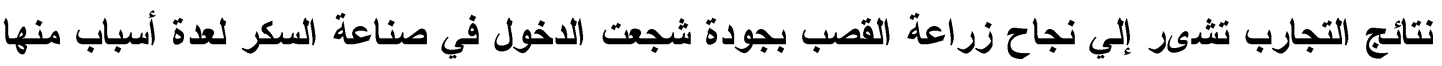

1- نتىجة لزىادة عدد السكان في السودان فقد ارتفع معدل استهلاك السكر في السودان مما جعل

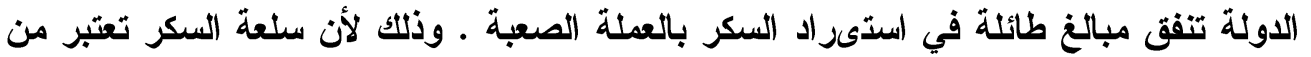

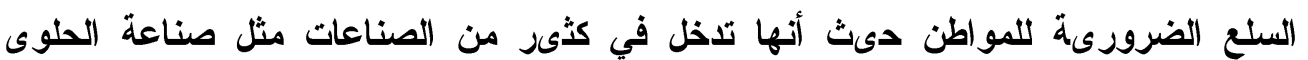
و البسكوىت وصناعة المشرويات الغازىة بالإضافة إلي الاستعمالات المنزلىة الأخرى ونتى هنئة لذلك الأسباب قررت الدولة الاخول في صناعة السكر محدىاً وذلك لتوفىر العملة الصعبة. ץ- إن استخلاص السكر ىنتج منه صناعات أخرى مثل استخلاص المولاص ىصنع منه الكحول بالإضافة إلي الخشب المضغوط وصناعة الورق وصناعة عسل القصب والأعلاف وكل هذه الصناعات قابلة للتصدىر خارج السودان مما ىمود على البلاد بعملة صعبة .

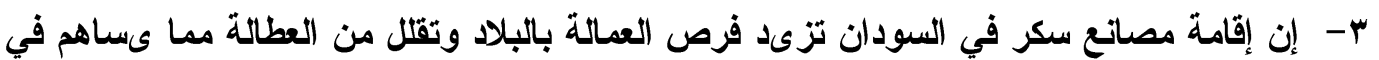
حل القضاىا الاجتماءىة أضف إلي ذلك قيىام مصانع للسكر في السودان. وىتدىز السودان بتوفر مصادر الري فنهر الذىل ىسقي الأراضي السوداذىة وله الأمطار

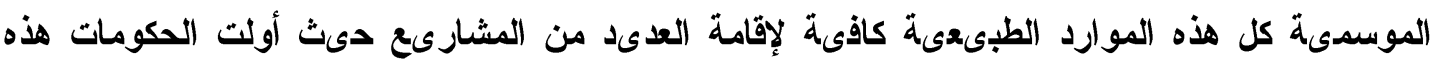

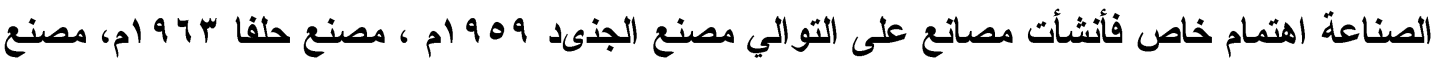

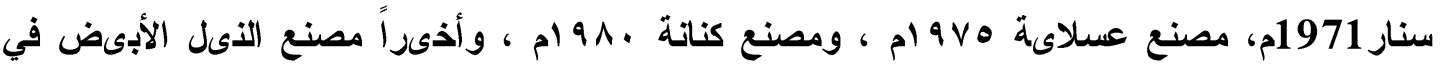
عام 11 • rم ،وتضم منطقة الار اسة الثلاثة مصاتع الأخيرة وهي تعد مركز ثقل صناعة السكر بالسودان.

تتجه كل الاول العربية للتوسع أفقياً ورأسياً في إنتــاج وتصــنيع الســكر بغـرض تحقيـق قـــر

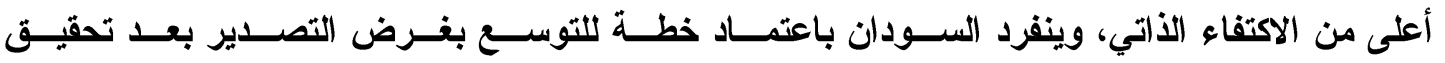

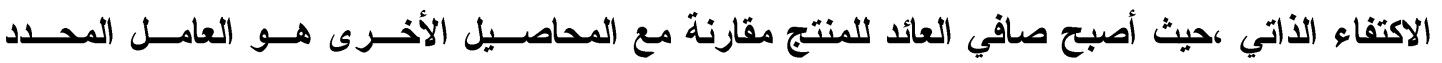

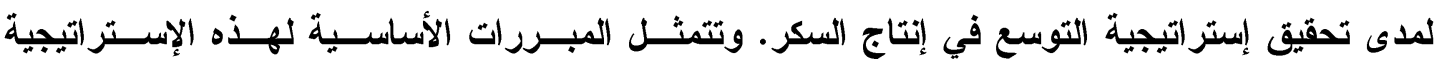

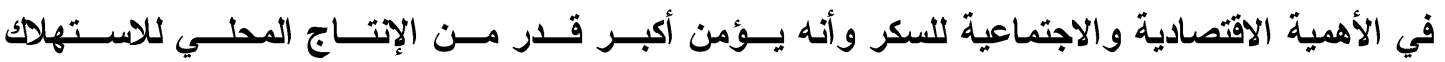

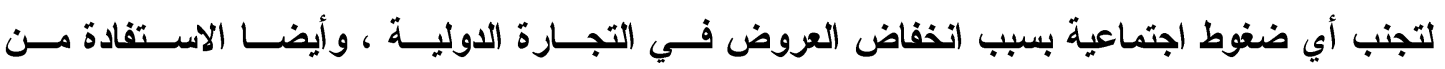


الموارد الزراعية من أراضي ومياه للتوسع في إنتــاج محصــول الســكر .وعليــهـ فـإن الخطــة تقــوم

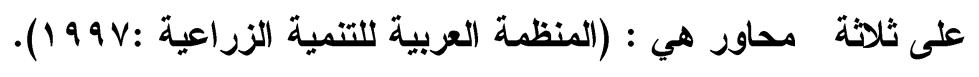
ا-تنفيذ المشاريع الإتتاجية الجديدة.

r-تطوير الخدمات الزراعية لمحصول السكر. r-تنمية وزيادة الطاقة الإتتاجية.

وقد اتبع السودان عبر الحقب الزمنية المختلفـة عــد مــن السياســات والخطـط مــن أجـل تنمية صناعة السكر تتمثل في الآتي :

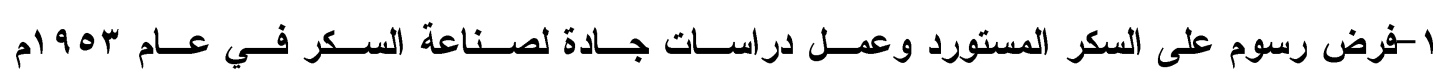

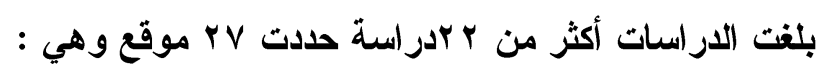
-بمنطقة بحر الجبل : منقلا ،وبنكو ،وجونقلي. -بمنطقة النيل الأبيض : كوستي ،وملوط ،والرنكل ،وكنانة ،وعسلاية. - بالنيل الأزرق :سنار ،ود النيل ،أبو نعامة . -بمنطقة نهر عطبرة : البرقيق ،الغابة ، العلياب ،و الزايداب.

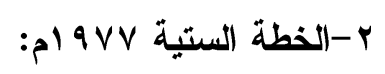

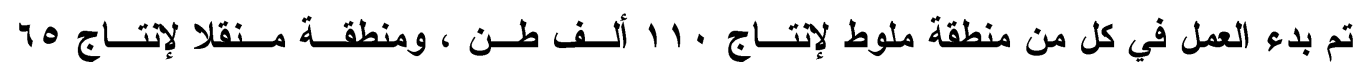

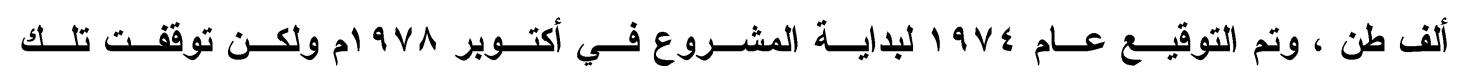

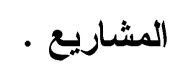

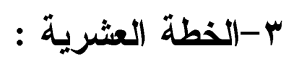

- استهرفت إنتاج السكر في المناطق التالية : r- - الجبلين لإنتاج • 11 ألف طن

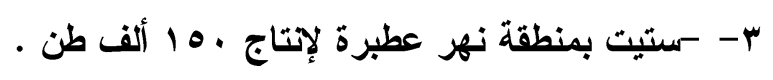

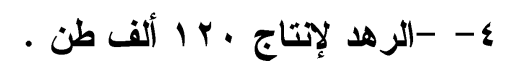

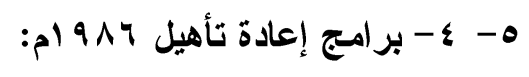

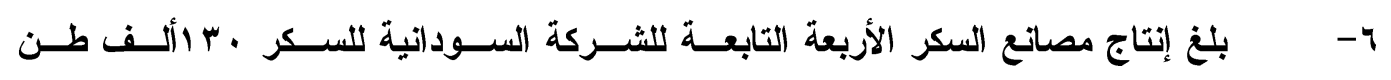

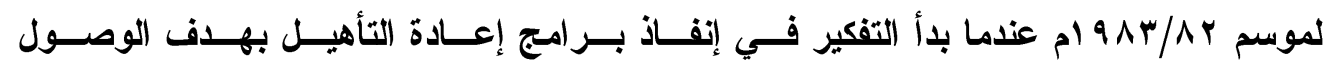

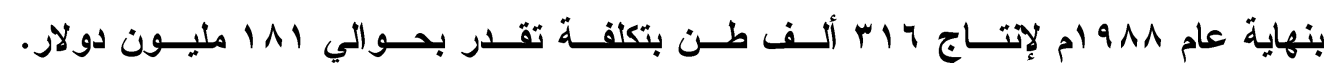




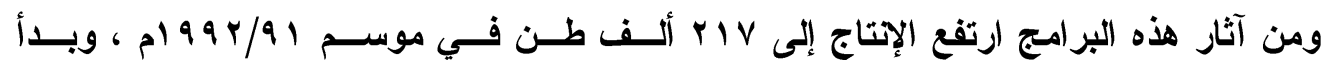

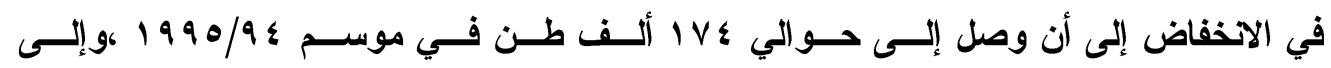

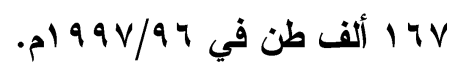

- V - ه-سياسة ترشيد الاستهلاكك ووقف استير اد السكر في ســبيل الارتقــاء بقطــاع الســكر للعــام • $99 \varepsilon / 9 r$

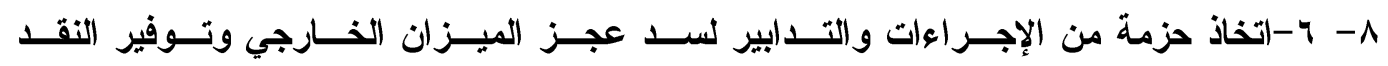

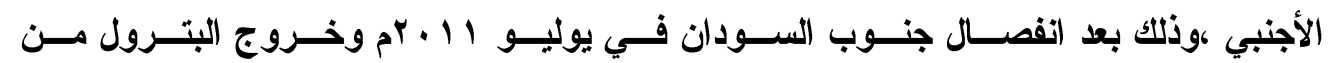

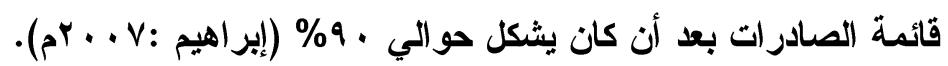

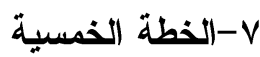

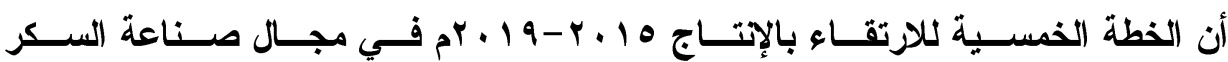

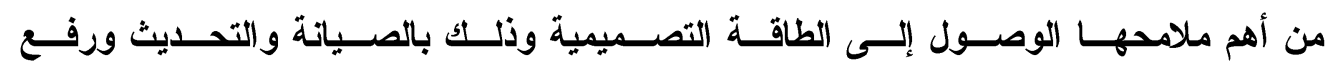

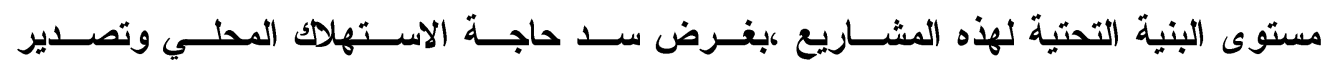

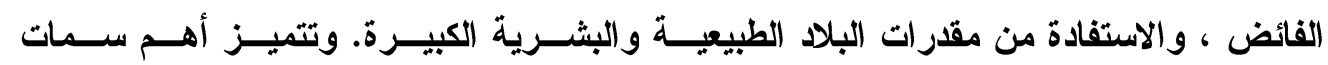

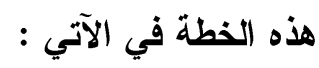

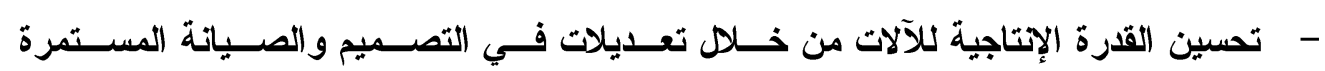
و المحسنة.

- - تحسين تكنولوجيا الإتتاج بإجر اء التوسع المناسب اقتصادياً .

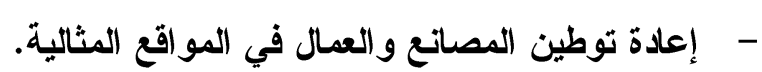

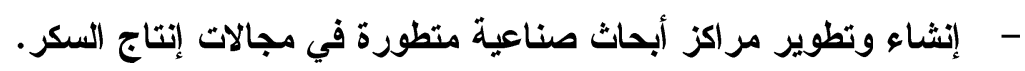
- - تحديد الأدوار النسبية التي يمكن أن تلعبها الصناعات من المخلفات الصناعية.

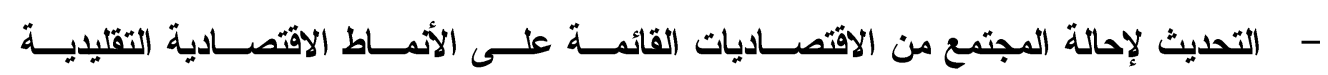

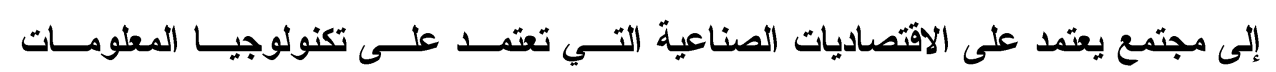

$$
\text { والمعرفة }
$$

- - ربط البحوث العلمية بالجوانب التطبيقية .

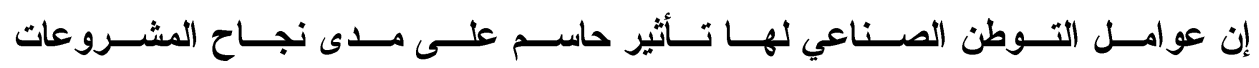

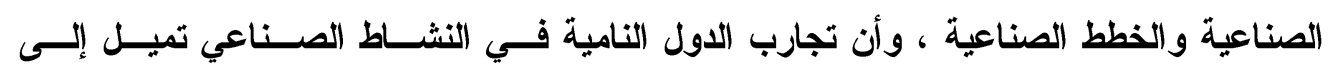

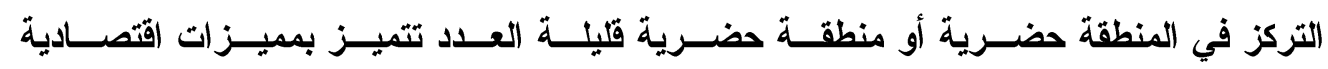

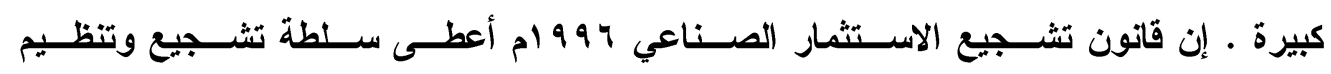




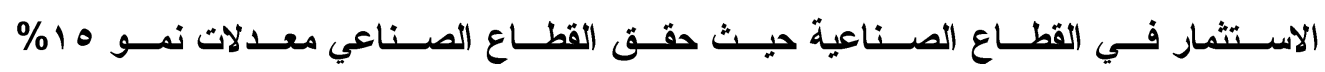

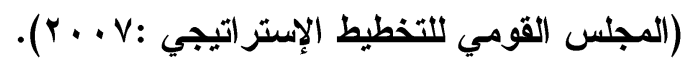

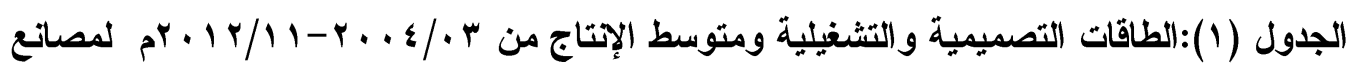
السكر في السودان

\begin{tabular}{|c|c|c|c|c|c|c|c|}
\hline الكلي & النيل الأبيض & كناتة & عسلاية & سنار & حلفا & الجنيد & البيان \\
\hline & re trot & . 9 ام & مlqva & 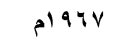 & مام & ratr & بداية الإنتاج \\
\hline $.90 \ldots$ & $i v \ldots$ & iv... & $10 .$. & $10 .$. & 00. & $\varepsilon \ldots$ & قالطبة التصميمية طن \\
\hline $11 r \ldots$. & $\{0 \ldots$ & $r \ldots .$. & $11 \ldots$ & $11 \ldots$ & $9 \ldots$. & r.... & إنتاج السكر بالطن /العام \\
\hline \multirow[t]{3}{*}{$90 \ldots$} & $\{0, \ldots$ & rrt... & rr... & r.... & or... & 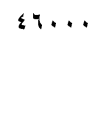 & طالطاقة الفطية للإنتاج \\
\hline & & $111 \ldots$ & $\mu \ldots$ & rY.VT & OV.vA & iv.iv & لمبة النع السكر \\
\hline & - & rsl... & A.... & A.... & A.... & s.... & متوسط الإتتاج \\
\hline
\end{tabular}

المصدر : منظومة السكر السودانية ،10 بrم 


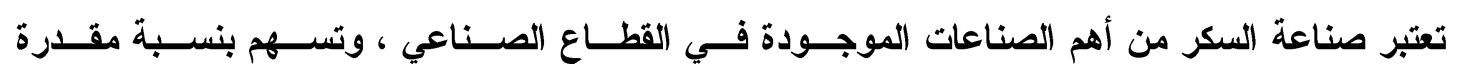
في الصادرات الصناعية ـ وتكمن أهمية صناعة السكر في الآتي :

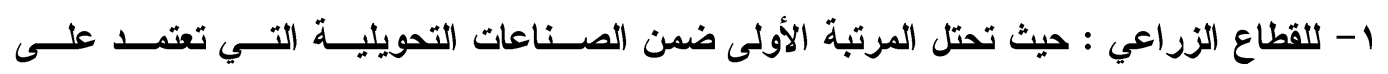

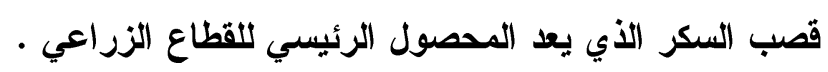

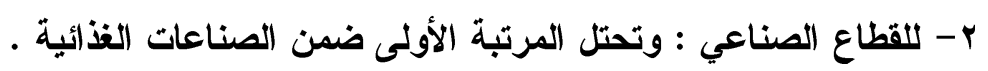

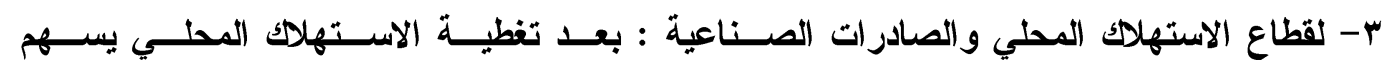
في تنمية الصادرات الصناعية.

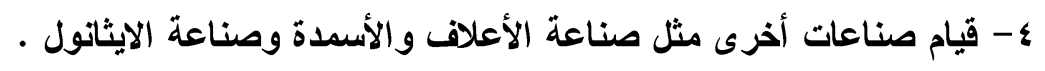

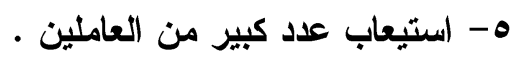

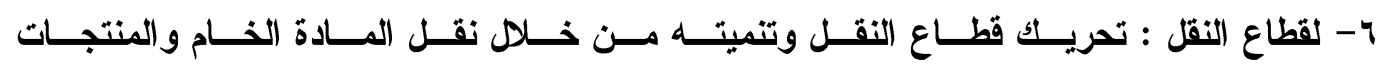
الصناعية .

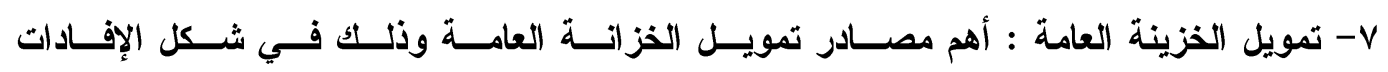
المحصلة والضر ائب على المبيعات ورسوم دعم سلع إستر اتيجية ورسوم جمركية. 1- ضخامة رأس المال المستثر في صناعة السكر مقارنة بالصناعات الأخرى. مشاريع إنتاج السكر بمنطقة الدراسة : تضم منطقة الدراسة كما أسلفتا ثلاذة مشاريع لإتاج السكر سيتم استعر اضها فيما يلي :

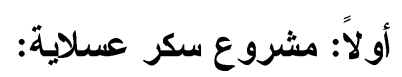

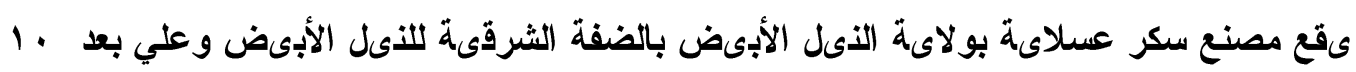

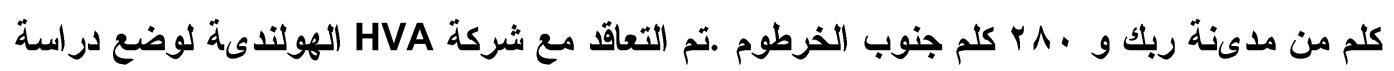

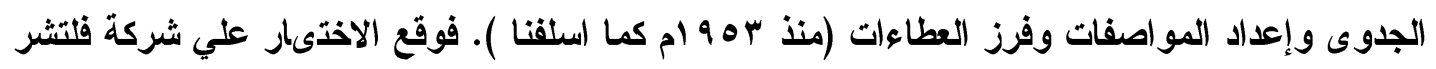

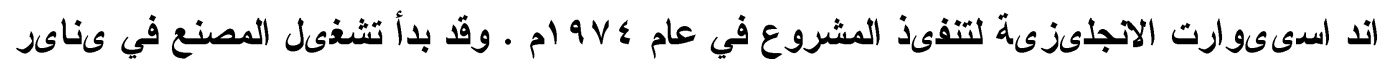

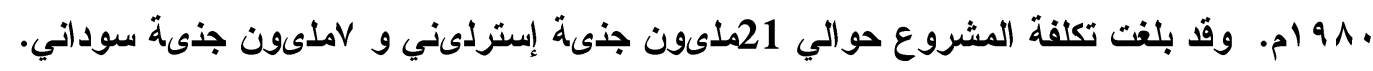

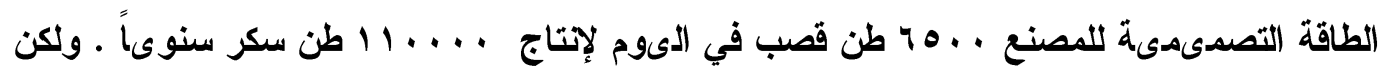

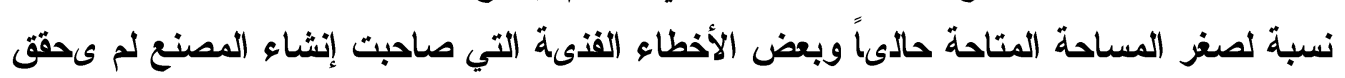

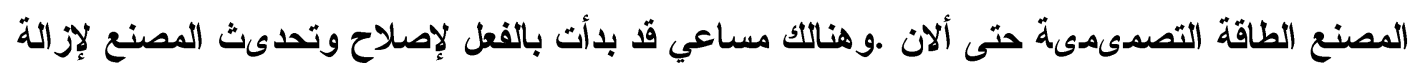

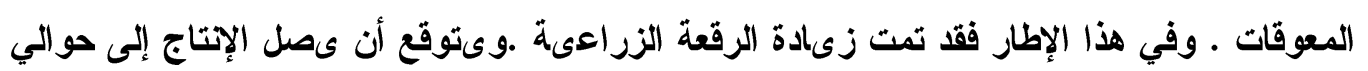

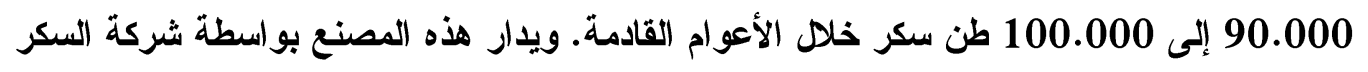




$$
\text { السوداتية المحدودة التي تعد من احدي أهم }
$$

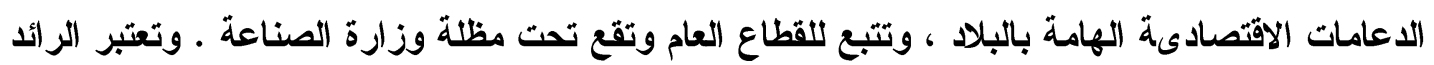

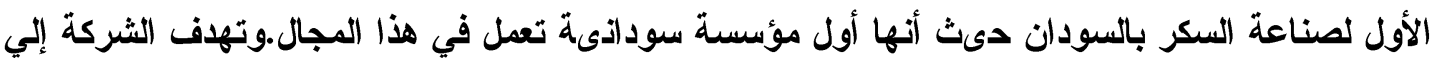

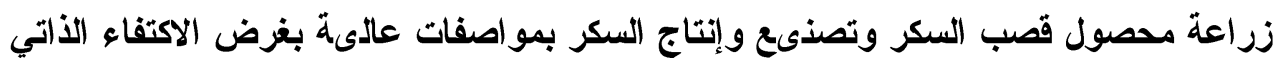

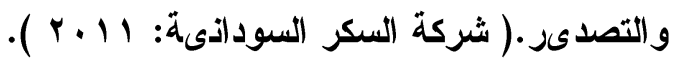

$$
\begin{aligned}
& \text { أهداف مشروع سكر عسلاية : } \\
& \text { - إنتاج محصول قصب السكر. }
\end{aligned}
$$

-انتاج سكر ابيض بمواصفات عالية للأسواق العالمية والمحلية.

-الاستثمار في مجال الصناعات التكاملية مع سناعة السكر.

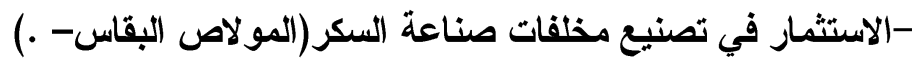
-تصنيع مدخلات الانتاج محلياً مثل الجوالات للتعبئة وقطع الغيار و الجير),.

- تطوير ورفع القدرات و المهارت للعامل السوداني مهنياً وفنياً.

- تطوير وتنمية المناطق الريفية .

ساهم مصنع سكر عسلاية في تقديم بعض الخدمات الاجتماعية والإقتصادية لإنسان المنطقة وذلك بإنشأ

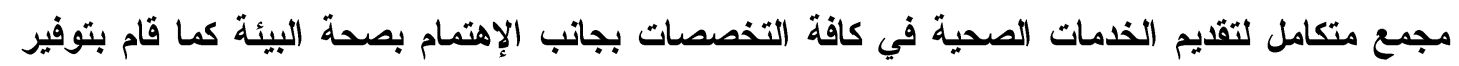

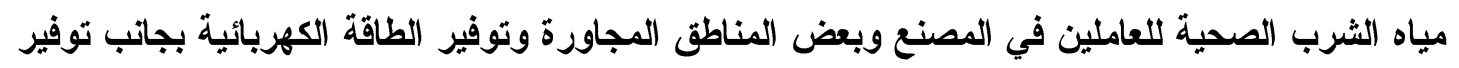
الالبان والخضروات والدواجن وبعض الفواكه.أما في مجال التعليم قام المصنع بتشييلعدد من المدارس الثانوية والاساسية للبنات والبنين كل علي حدة وعلد من الخلاوي والرياض والاندية والرياضية بجانب

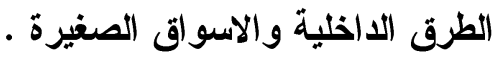
ثانياً: مشروع سكر كنانة

في عام •919 ام كان السكان ىستورد كمىات كبىرة من السكر كما أن المصاتع المتمثلة في الثركة السوداذىة للسكر لم تستطىع تغطىة الفجوة على طلب ، لذلك برزت فكرة تنفيذ ما تم تخطيطه ضمن خطة ror ام كما أسلفنا ) وذللك بإنشاء مشروع عملاق لإنتاج السكر في العام الV أم واستقر

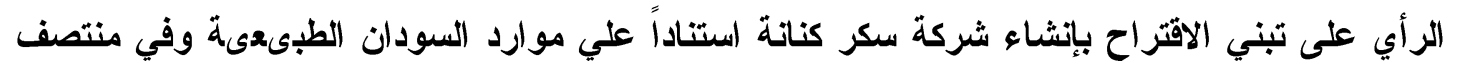

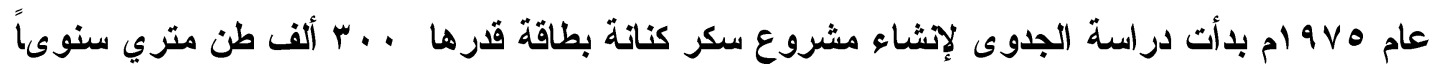

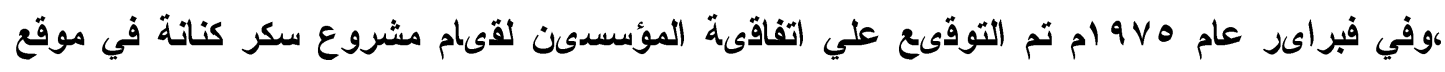

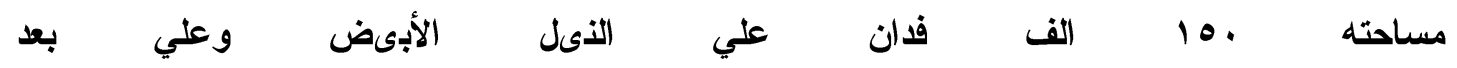
250كلم جنوب الخرطوم. وقد تم إنشاوها برأس مال سوداني عربي أجنبي بنسب المساهمة المبىنة في

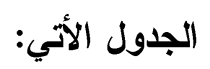


الجدول (r): نسب المساهدىن في شركة سكر كنانة

\begin{tabular}{|c|c|}
\hline 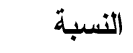 & 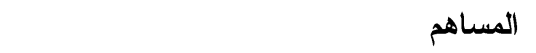 \\
\hline$\% 35.33$ & حكومة السودان \\
\hline$\% 36.64$ & الهئة العامة للاستثمار الكوىذىة \\
\hline$\% 10.96$ & حكومة المملكة العربىة السعودىة \\
\hline$\% 6.99$ & الثركة العربىة للاستثمار \\
\hline$\% 5.69$ & مصرف التندىة الصناءىة \\
\hline$\% 5.9$ & الهىئة العربىة للاستثمار و الإنماء الزراعي \\
\hline$\% 4.47$ & مجموعة بنوك التجارىة السوداذىة \\
\hline$\% 0.16$ & شركة الظاىج للأسماك \\
\hline$\% 0.16$ & شركة ذيشو ایىوان \\
\hline
\end{tabular}

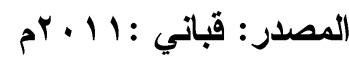

أهداف مشروع سكر كنانة

-

- تقديم الخدمات التقنية و الهندسية.

-جعل السودان من البلان الرئيسية المصدرة للسكر النقي . 
- خلق فرص عمل ومحاربة البطالة لأكبر قطاع من السكان .

$$
\begin{aligned}
& \text { وتتمثل الطاقات الاتتاجية للشركة في الاتي: } \\
& \text { - - السكر الأبيض: . . - ألف طن/سنة }
\end{aligned}
$$

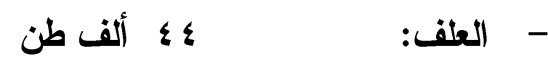

$$
\begin{aligned}
& \text { - } \\
& \text { - } \\
& \text { - ل لحوم دواجن: مليون كيلو }
\end{aligned}
$$

وبالتأكيد لثركة سكر كناتة اسهامات وانجازات إجتماعية وإقتصادية واضحة جدا في تنمية إنسان

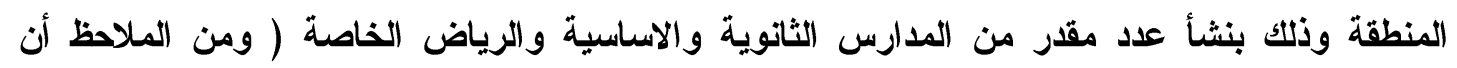

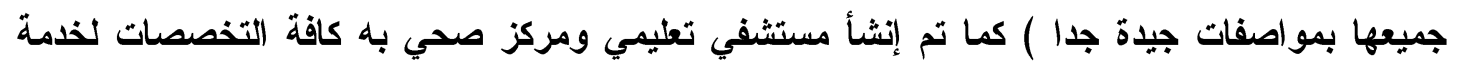

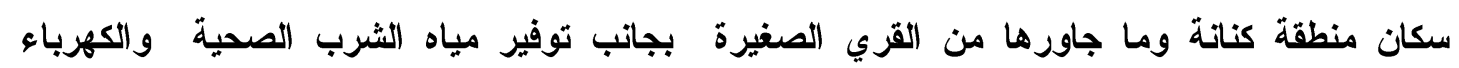

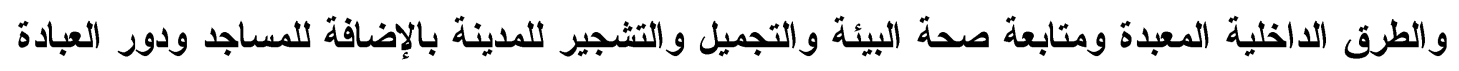

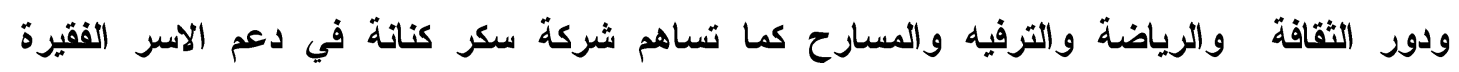

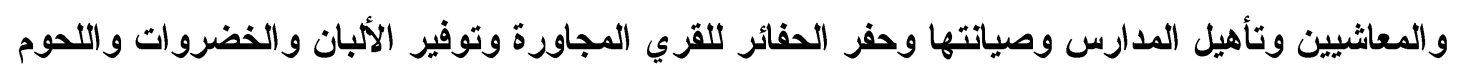

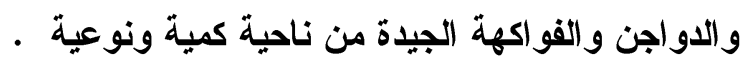

ثالثاً: مشروع سكر النيل الأبيض

ققع المصنع في ولاىة الذىل الأبىض في وسط السودان على الضفة الثرقىة للأىل

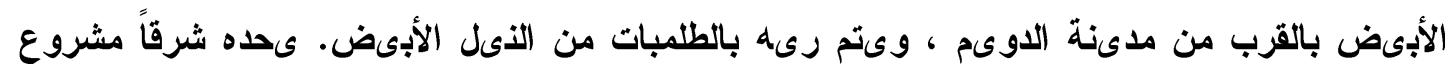

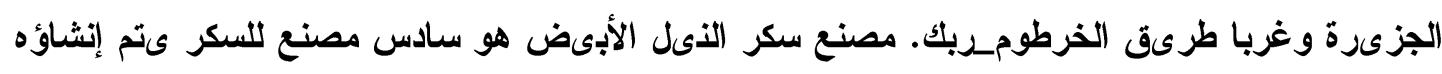

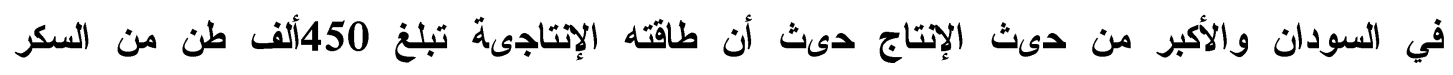

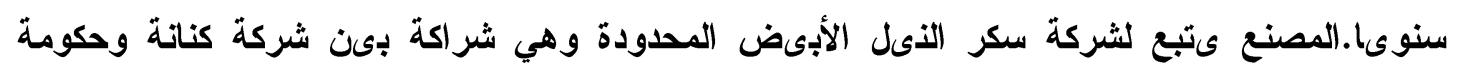

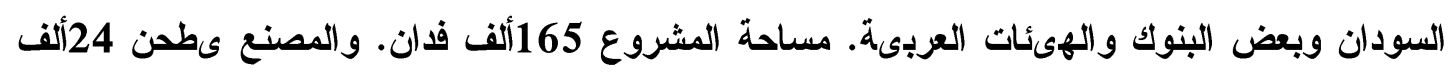

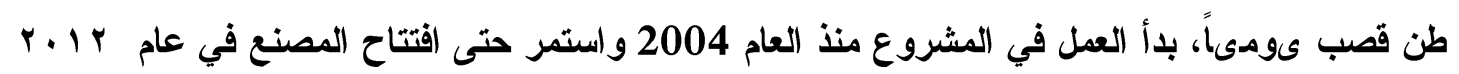

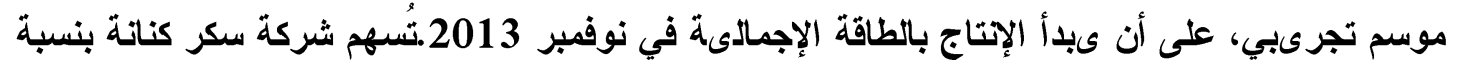

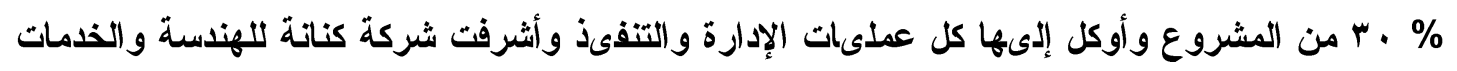

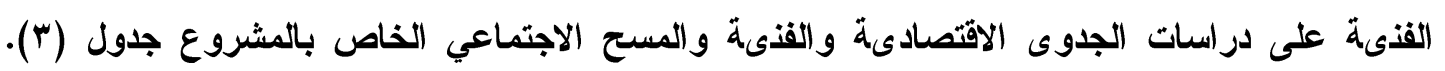


وتبلغ المساحة الكلىة للرقعة المزروعة ه ألف فدان منها همألف فدان، ستتم زراعتها بقصب السكر تعادل

مساحة الأراضي البور ه ألف فدان، بجانب زراعة هبألف فدان بالمحاصىل النقاىة، إضافة إلى

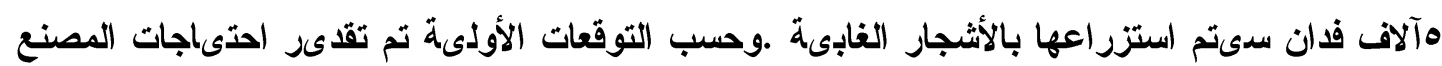

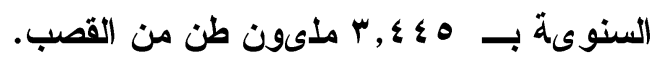

جدول (r): نسب المساهمون في مشروع سكر النيل الأبيض

\begin{tabular}{|c|c|}
\hline تسبة المساهمة & الجهة المساهمة \\
\hline 31.08 & شركة سكر كنانة \\
\hline 14.38 & الهيئة العربية \\
\hline 9.84 & صندوق المعاثـات \\
\hline 9.14 & حكومة السودان \\
\hline 35.56 & الآخرون (بنوك محلية ومستثمرون أجاتب)( \\
\hline
\end{tabular}

https://www.aaaid.org/ar/white-nile-sugar-company-wnsc-:مصدر

أهداف مشروع سكر النيل الأبيض:

ا. إنتاج . ؛ ؛ ألف طن من السكر الأبيض عالي الجودة وذلك للاستهلاك المحلى والتصدير. r. إنتاج ع . إن ميغاو اط من الكهرباء.

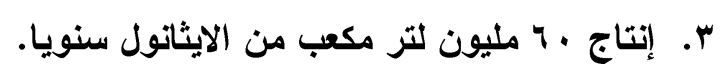
ع. إنتاج . . 1 ألف طن من الأعلاف سنويا.

ه. إنتاج • ؛ ألف طن من المحاصيل النقلية من السمس وزهرة الثمس والأرة الصفراء. ד. توفير فرص عمل في كافة المهن لمواطني منطقة المشروع V. . - تقوية موقف السودان في مجال صناعة السكر كي يحتل موقعا متقدما في مجال تجارة وصناعة السكر في الأسواق العالمية. 


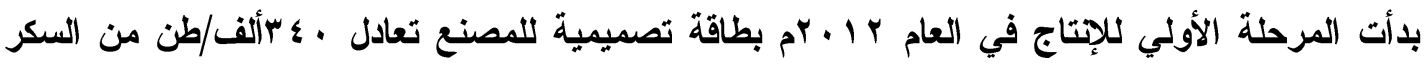

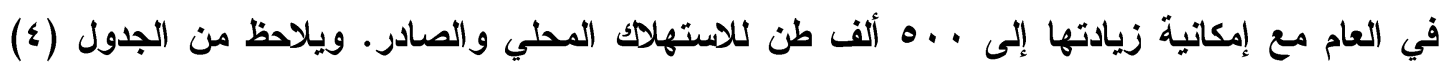

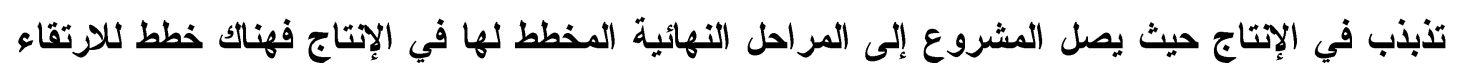

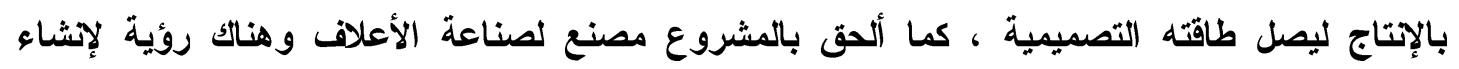

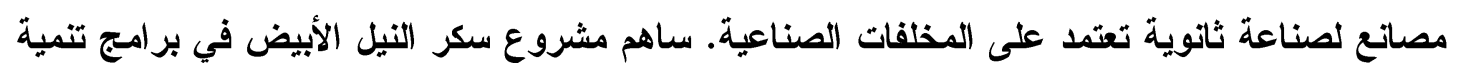

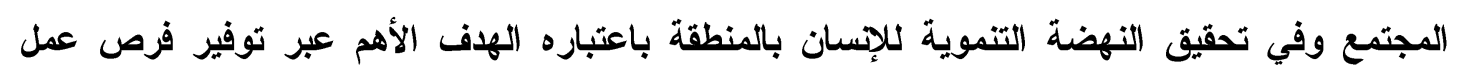

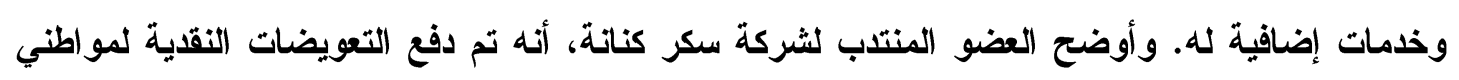

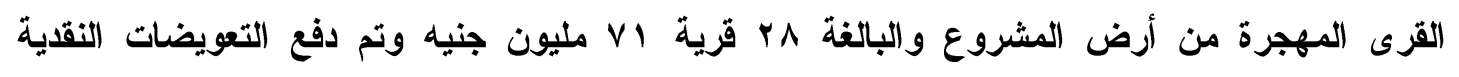

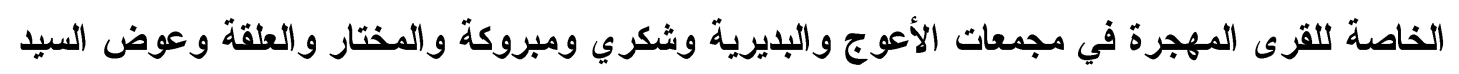

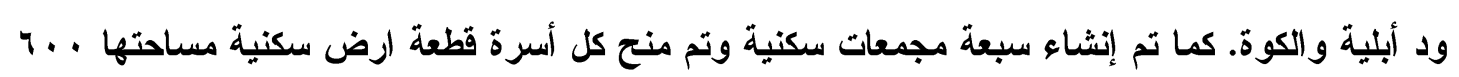

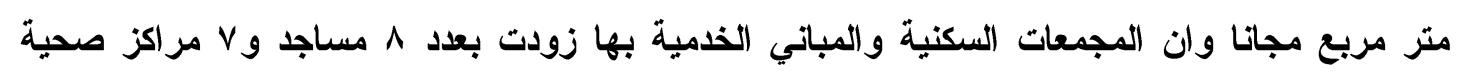

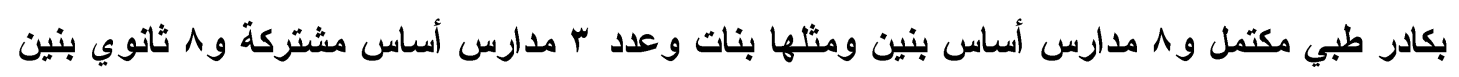

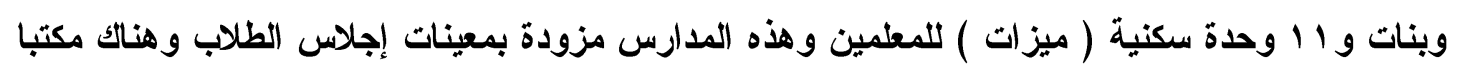

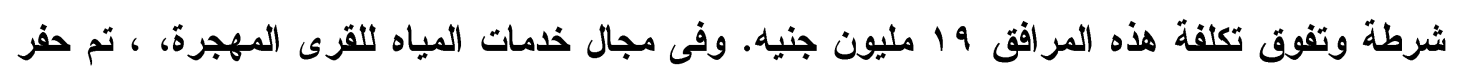

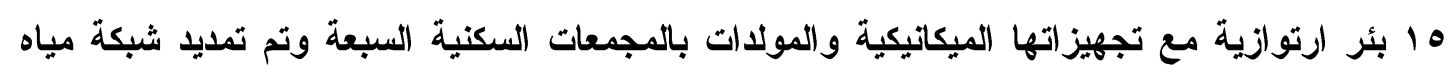

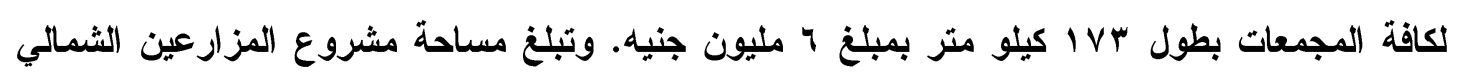

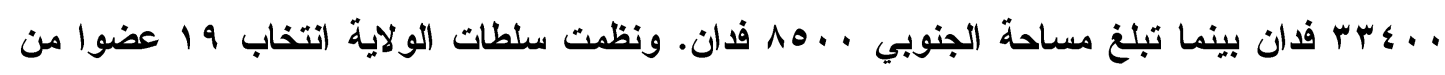

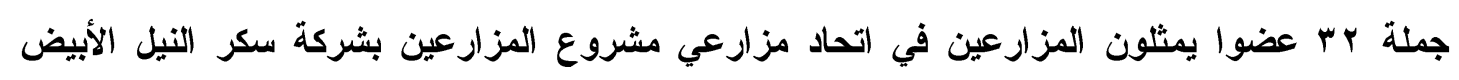

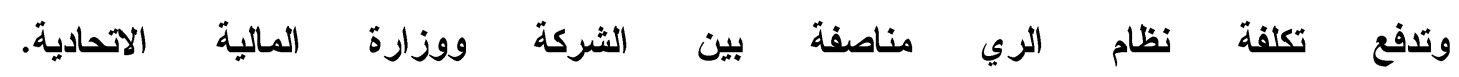

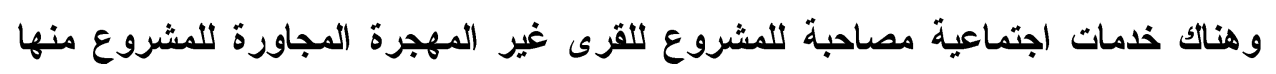

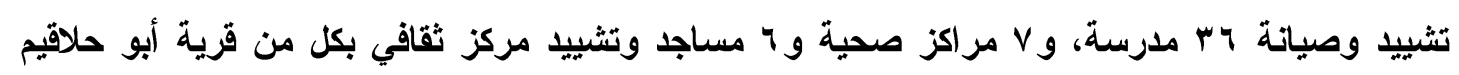

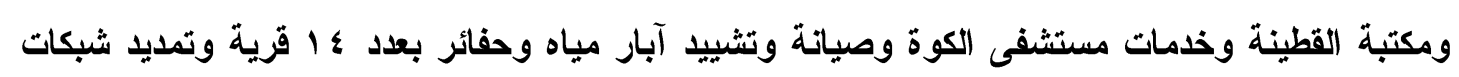

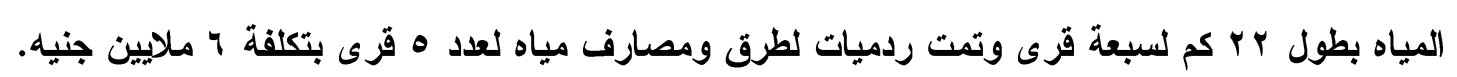

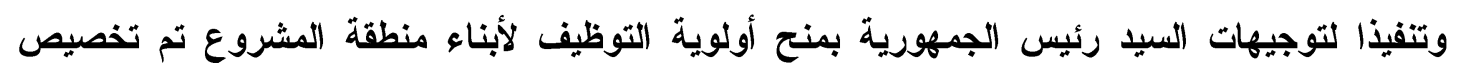

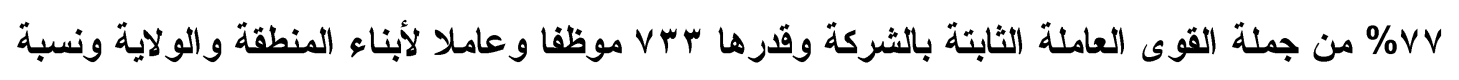

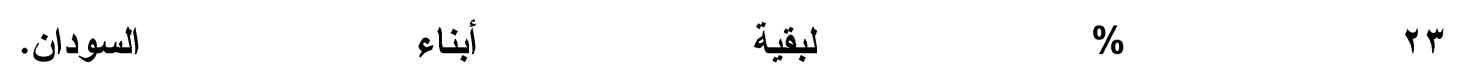
وفقا للاتفاق إجارة الأراضي الموقع بين الثركة وولاية النيل الأبيض يمنح صاحب كل حيازة مزرعة 


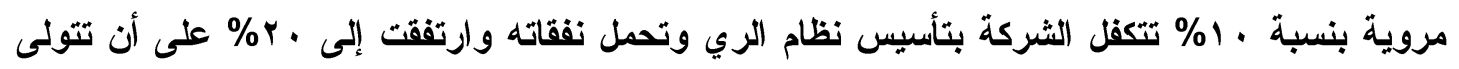

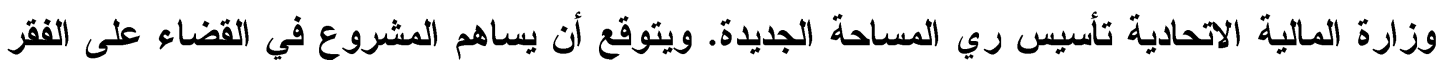

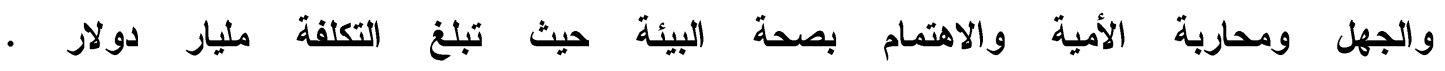
http://www.sudacon.net/2012/07/blog-post_5473.html

إنتاج السكر بمنطقة الارسة

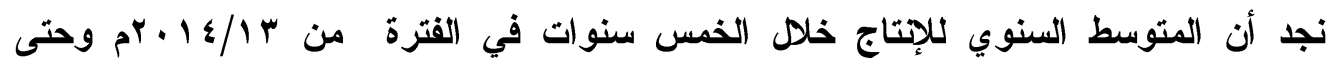

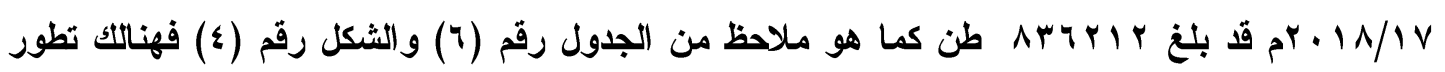

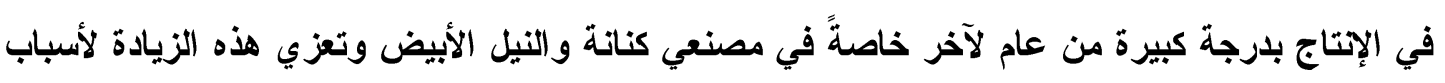

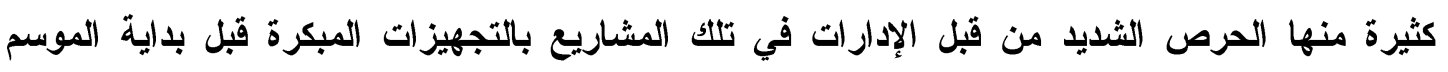

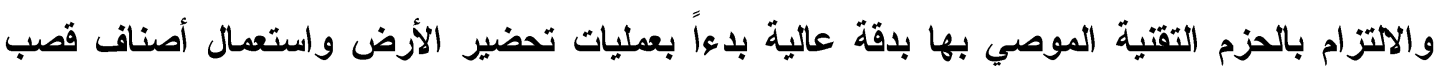

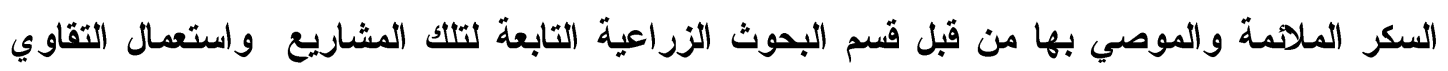

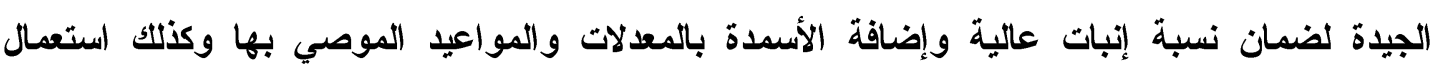

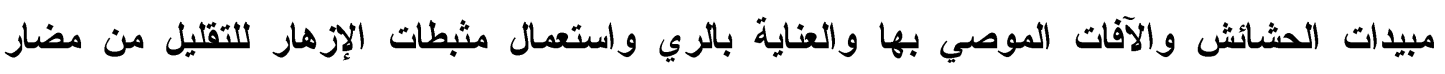

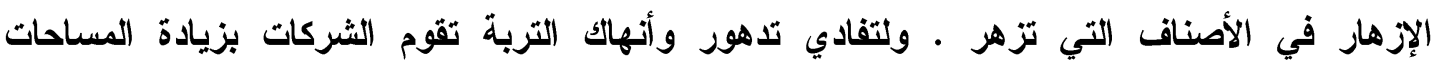

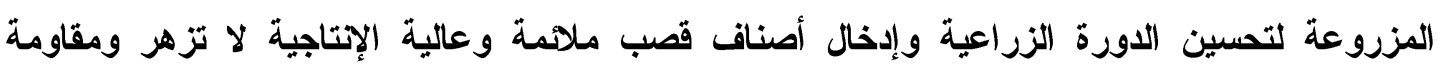

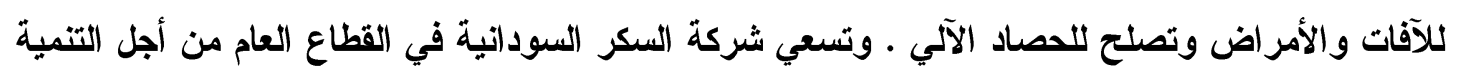

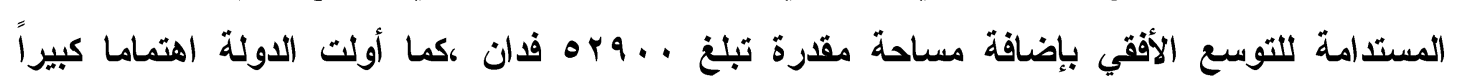

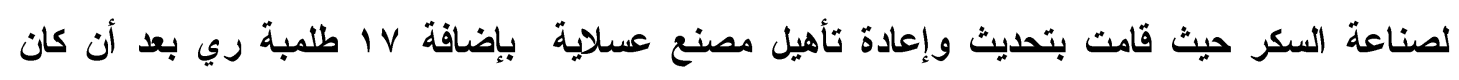

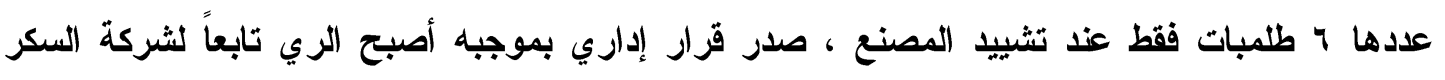

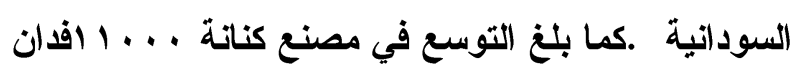

وفي نافلة القول نلاحظ أن للتخطيط الإستراتيجي للاولة منذ أن نالت إستقلاها القدح المعلي في تنمية

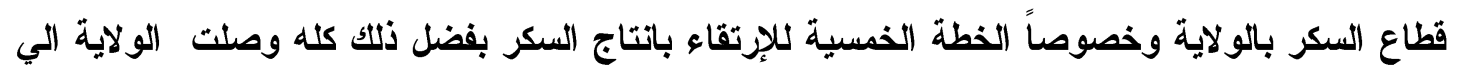

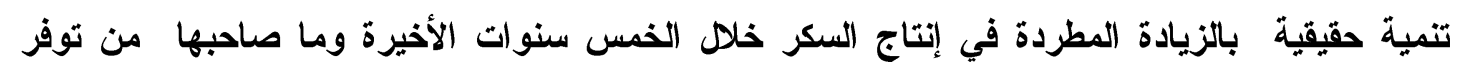
للذذمات واستقرار للسكان . لئل 


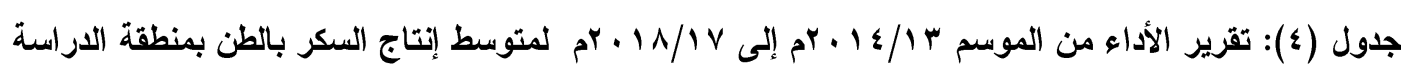

\begin{tabular}{|c|c|c|c|c|c|}
\hline$r+11 / 1 V$ & $r+1 v / 14$ & $r .17 / 10$ & $r .10 / 1 \varepsilon$ & $r+1 \varepsilon / 1 r$ & المصنع \\
\hline $1 \times 10 \ldots$ & $1119 \ldots$ & $1.7 \leqslant V$. & $1.1 \leqslant v 0$ & ヘTVIV & عسلاية \\
\hline$\{\leqslant \ldots$ & $\varepsilon r v \ldots$ & $\varepsilon 1 \leqslant \ldots$ & $\varepsilon \ldots$. & ros... & كناتة \\
\hline$\varepsilon r+\ldots$ & \&rrr.. & $\varepsilon \mid r \ldots$ & rr.... & $1+1 \ldots$ & النيل الأبيض \\
\hline 993500 & 960900 & 932470 & 721475 & 572717 & الجملة \\
\hline
\end{tabular}

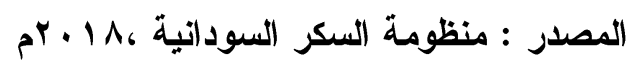

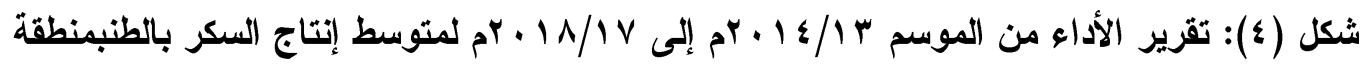
الار اسة

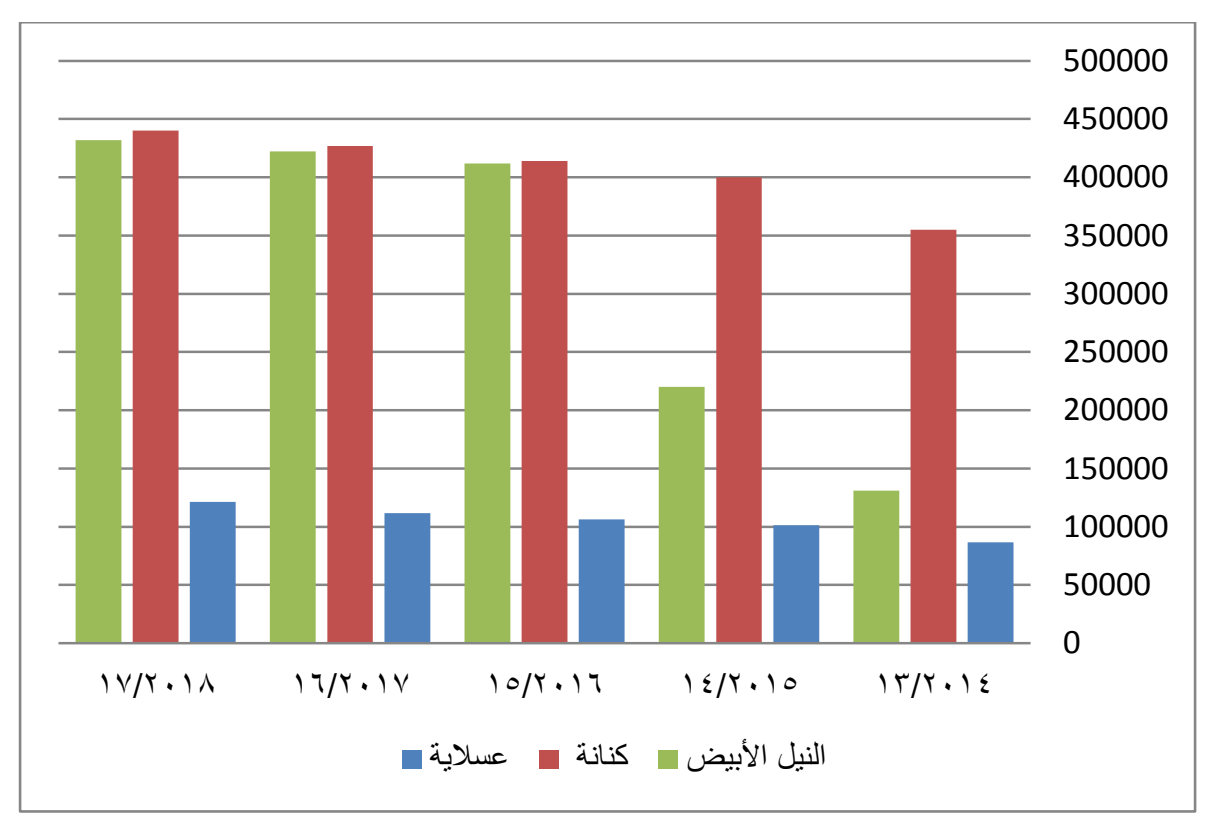


/ / ارتفاع تكلفة احتياجات المصانع من آليات وقطع غيار وغيره . / / عدم توفر عملات اجنبية لاعم قطاع السكر بالمنطقة .

r/ ملوحة التربة نسبة لاتحاد بعض الاملاح مع السكروز مما يؤثر في عملية التبلور عند التصنيع.( سكر (النيل الأبيض ملوجه

\&/ عدم التمكن من الاستمرار في زيادة التوسع الافقي بسبب إعتراض بعض الأهالي خصوصا الأراضي

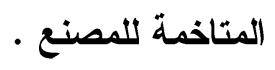

ه/ ظهور بعض الآفات والأمراض التي تصيب (أحيانا) قصب السكر مثل مرض التفحم الاسود ومرض . الاض

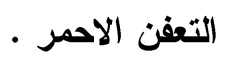

/ / الحصار الإقتصادي المفروض علي السودان أثر بلرجة كبيرة في توفير مدخلات الإتتاج لقطاع صناعة

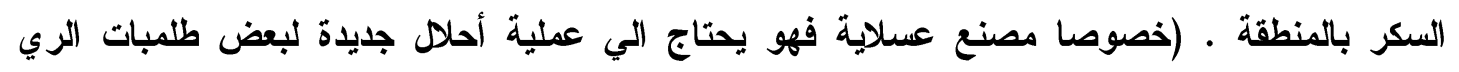

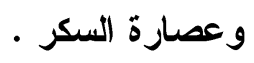

$$
\text { النتائج }
$$

$$
\text { توصلت الاراسة الي النتائج التالية : }
$$

/ / إن العوامل الطبيعية الجيدة هي العامل الأساسي لإنجاح زراعة قصب السكر وبالتالي ساهمت في

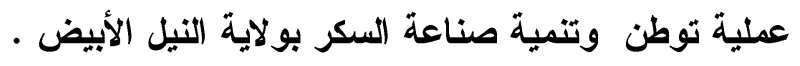

/ / أن الخطط الإستراتيجية للتمية في الاولة منذ استقلال البلاد وحتي الآن تسعي الي تنمية القطاع

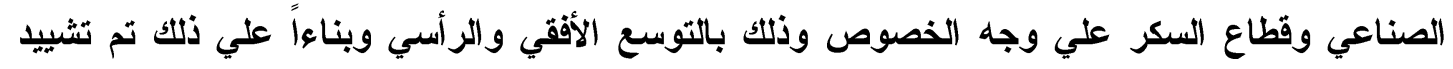

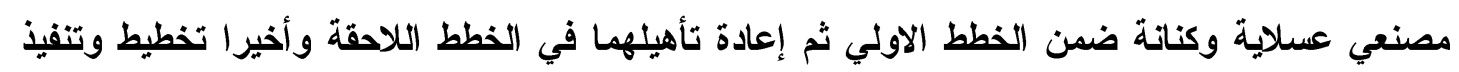
مشروع سكر النيل الأبيض.وبذلك نستطيع قول أن هنالكك تنمية حقيقية في صناعة السكر بالتولاية . r/ / هنالك زيادة مطردة في انتاج السكر بالولاية بضل الجهود المبزولة من قبل الجهات المسؤلة

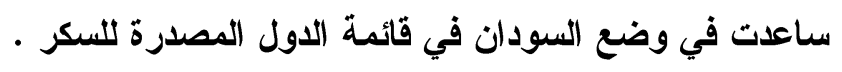

عاتمثل صناعة السكر المحرك الرئيس للأقتصاد في البلاد بتأثيرها في القطاع الزراعي وحركة النقل وفي

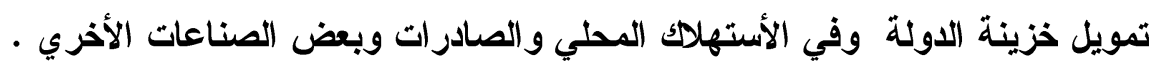


/ هنالك بعض المعوقات النسبية التي تحد من استمرار وتيرة التنمية في صناعة السكر بالولاية

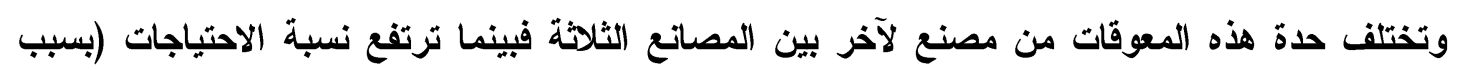

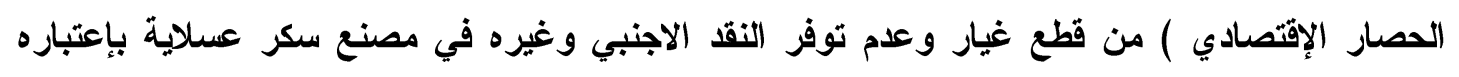

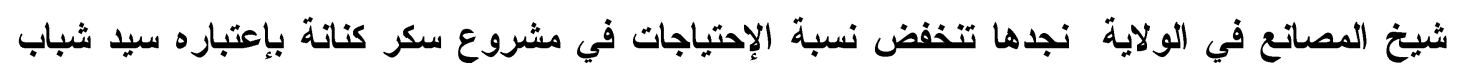

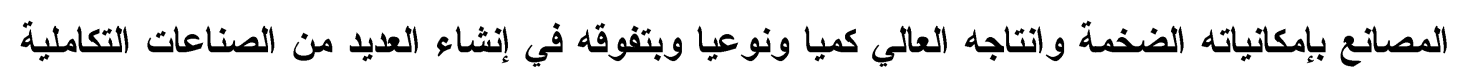

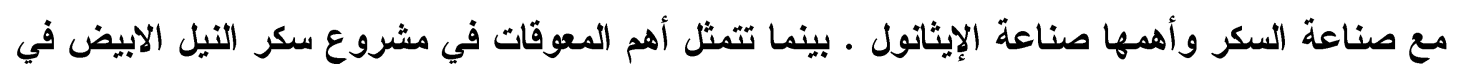

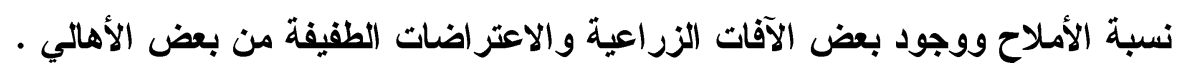

/ / استطاعت مشاريع صناعة السكر بالولاية دفع عجلة التنمية الإجتماعية والإقتصادية من خلال توفير

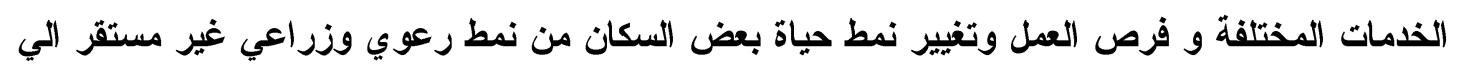
مجتمع أكثر إستقراراً. التوصيات أوصت الار اسة بالآتي: / ضرورة تشجيع الاستثمار الخارجي العربي والأجنبي للاخول في مجال الصناعات في السودان وصناعة

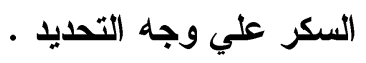
/ / تشجيع القطاع الخاص للاستثمار في مجال قطاع السكر • r/ ضرورة توفير العملات الأجنبية لقطاع السكر بالولاية لمواجهة كافة المشاكل والتحديات . ء/تطوير البنية التحتية للمصانع ( خصوصاً مصنع عسلاية ) مثل طلمبات الري وطرق ووسائل النقل و المخازن .

/ ضرورة مراجعة وتحديث التشريعات التي لها صلة بالقطاع الصناعي كافة (وصناعة السكر خاصة ) ،

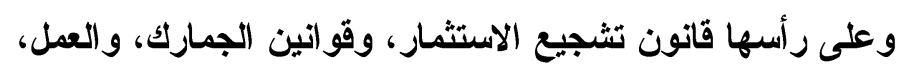
4/ وضع قو انين مرنة تسهم في النهوض بالقطاع الصناعي و التنمية الصناعية. / إعطاء القطاع الصناعي أولوية قصوى في إطار البرنامج الاقتصادي الوطني، بجاتب التخفيض ما

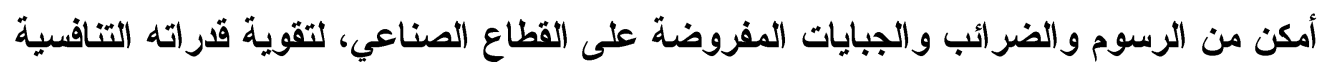




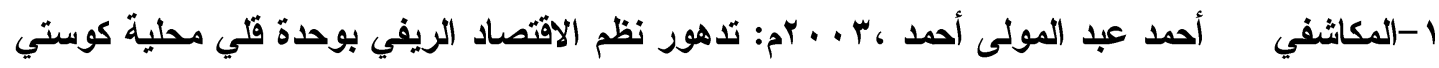

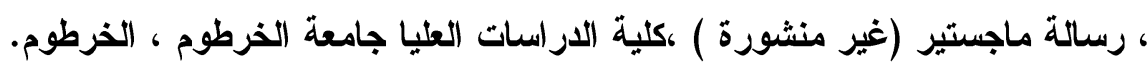

r-أبكر ،علي صديق، ؟ . . بم : مظاهر وأبعاد التدهور الحضري في ولاية النيل الأبيض ،دراسة حالة

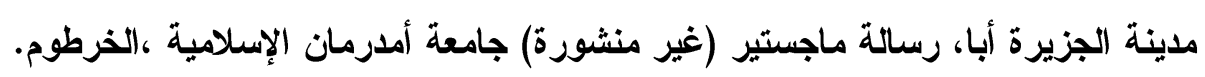

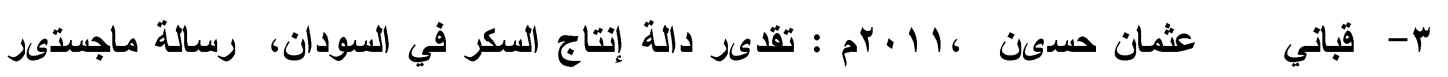

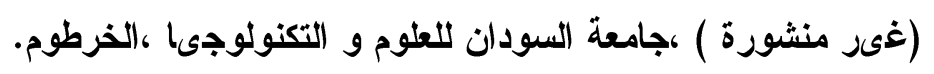

ع -المنظمة العربية للتنمية الزراعية 99 و ام : دراسة تنمية قطاع إنتاج المحاصيل السكرية وتصنيعها في الوطن العربي ، الخرطوم. ه-شركة السكر السودانية ،11 ـ بم : التقرير الإحصائي السنوي لصناعة السكر ،الخرطوم.

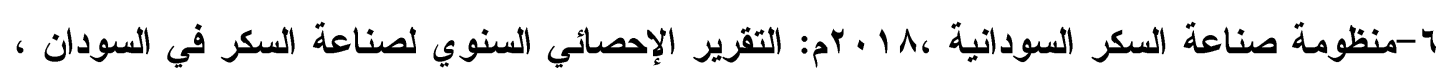
وزرارة الصناعة الإتحادية ، الخرطوم.

V- مهذي زهير عبد الحسين ، ـ191ام : نشأة وتطور صناعة السكر في السودان ، رسالة ماجستير

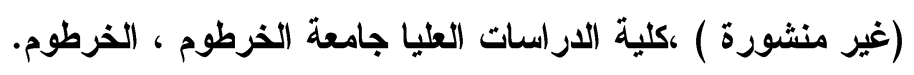

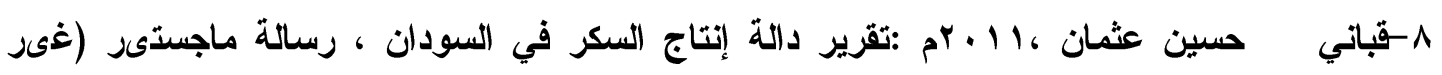

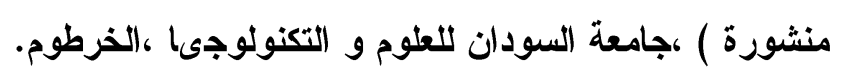

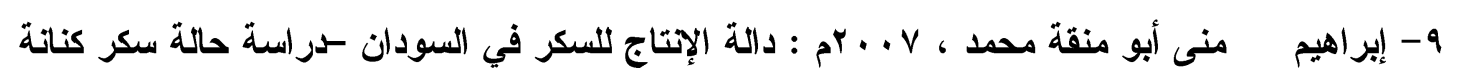

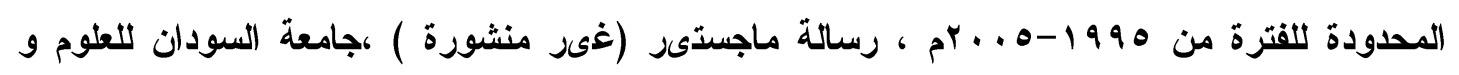
التكنولوجىا ،الخرطوم.

• 1 - الزوكة محمد خميس ، ... . بم، جغر افيا الزراعة ،منشاة دار المعارف ، الإسكندرية.

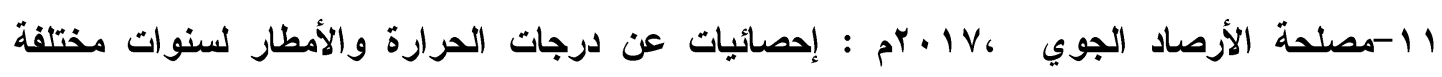
كوستي ،السودان ، الخرطوم.

r ا-مصلحة المساحة ولاية النيل الأبيض ،1 . . rم : أطلس ولاية النيل الأبيض ، السودان ،الخرطوم. 


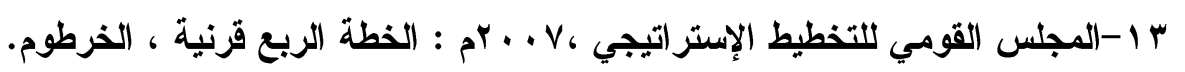

ع ا- منصور، محمد أحمد علي (9VYY) " التطور الصناعي في السودان بالأرقام"، الصناعة و التنمية، مركز البحوث والاستشار ات الصناعية . مندي

1. Ministry of Finance and National Economy. (2006). The performance of Sudan economy2000-2005 Sudan Ministry of Finance and National Economy, Khartoum, Sudan, 2006 (pp. 16-18).

2. Sudan Ministry of Finance and National Economy.(2008). Unpublished report. Sudan Ministry of Foreign Trade and Central Bank of Sudan Annual Foreign Trade Statistical Digest various issues.

https://www.aaaid.org/ar/white-nile-sugar-company-wnsc

)kenanaonline.com https:- 4

http://www.tpsudan.gov.sd/index.php/ar/home/show_export/80 $-5$

https://alsudanalyoum.com/reports-and-investigations

$-6$ 
المنظور الجغرافي لتوزيع الأربطة الخيرية ودور الرعاية الاجتماعية بمدينة الطائف

$$
\begin{aligned}
& \text { أ. سلوى بنت حسن بن محمد قحل ليلى بثت صالح بن محمد زعزوع } \\
& \text { كلية الآداب والعلوم الإنساتية - جامعة الملك عبد العزيز } \\
& \text { المستخلص }
\end{aligned}
$$

تهاف الاراسة إلى إبراز دور الجغرافيا في التعرف على الخصائص المكانية وخمات أماكن الإيواء الخاصة للمسنين بمدينة الطائف ، وقد تم تصنيف أماكن الإيواء الخاصة للمسنين إلى نوعين هي: أماكن الإيواء للمسنين بدار الرعاية الاجتماعية ، أماكن إيواء للمسنين بالأربطة الخيرية المنقسمة إلى قسمين : الأربطة الخيرية الحكومية القائمة تحت إثراف الاولة ، الأربطة الأهلية القائمة تحت إثراف ملاكها و القائمة بأسمائهر · وأجريت هذه الاراسة على جميع نزلاء الأربطة الخيرية والمسنين بدار الرعاية الاجتماعية في مدينة الطائف خلا شهر ربيع الأول من عام بr أهـ. واعتمدت الاراسة على الاستبيان كأداة لتجميع البياتات. وناقشت الاراسة الخصائص الايموغرافية والتعليمية والاجتماعية و الاقتصادية للمسنين المقيمين بدار الرعاية الاجتماعية ونزلاء الأربطة الخيرية بمدينة الطائف ـ وأظهرت أهم نتائج الاراسة أن الغالبية العظى من نزلاء الأربطة الخيرية بمدينة الطائف تتمثل أعمارهم فوق اله\%\% بنسبة r\%\% في حين أن معظم المسنين المقيمين بدور الرعاية الاجتماعية أعمارهم دون الثماتين إذ يوجد هr\% أعمارهم اقل من ه \%\% والغالبية العظى من نزلاء الأربطة الخيرية بمدينة الطائف هم من الإناث بنسبة ^.1 ؟\%. كما أظهرت نتائج الاراسة من صعوبة الوصول إلى مواقع الأربطة الخيرية والتعرف إلى نزلاتها بسهولة بسبب وقوعها ضمن المناطق العشوائية في المدينة، أو لأنها تنسب لملاكها. وأفاد معظم المسنين بار الرعاية الاجتماعية بعدم وجود أنثطة يتم مزاولتها داخل الدار حيث تمنع أنظمة الدار خروج المسنين للخارج خوفا عليهم من الضياع لإصابة البعض منهم بأمراض تفقدهم الثعور بأماكن تو اجدهم. 
Abstract:

The current study aims at revealing the role of geography in recognizing the spatial characteristics and the services presented in the places provided to lodge the aged in Taif. The aged lodging places are classified into two types: lodging places at the social welfare, lodging places at the charitable houses that are divided into two parts: the governmental charitable houses operating under the state supervisory, and the national houses operating under supervisory of their owners in their own names. This study involves all the lodgers in the charitable houses and the aged in the social welfare houses in Taif during Rabie 1 1433H. The study depends on the questionnaire to collect the data. The study discusses the demographic, educational, social and economic characteristics of the aged residing in the social welfare house and the lodgers' charitable houses in Taif. The most important results of the study reveal that the ages of majority of the charitable houses lodgers in Taif are over $65 \%$ with ratio reaching $23 \%$, whereas most of the aged residing in the social welfare houses are of ages under 80 , and $35 \%$ are of ages under $65 \%$ and the majority of the loders of the charitable houses in Taif are females with a ratio reaching $68.8 \%$. Also the study results revealed the difficulty to access the charitable lodging places in Taif ,to identify their guests easily due to locating at rural areas or it is belonged for its proprietors.

Most of the aged in the social welfare house informed that there are no activities, where the management prevent the aged to get out, because they may lose their way depending on the diseases they suffer 


\section{المقدمة}

يعتبر موضوع إيواء المسنين والاهتمام بهم من أهم المواضيع التي يتتاولها المختصون والمهتمون في مختلف المجالات ولا شك بأن توفير السكن المناسب لهم يستند إلى عدد من العوامل الرئيسة التي تعمل بشكل متكامل لتحقيق أهداف مشتركة تخدم المسنين ونظراً لتغير ظروف الحياة المختلفة في عالمنا العربي فقد نشأت الحاجة لإقامة مساكن مخصصة لخدمة كبار السن من العجزة و الأرامل الأين لا عائل لهم. ومن ابرز ذلك المساكن "الأربطة الخيرية" ، و كذلك دور الرعاية الاجتماعية التي تقدم خدماتها لكبار السن

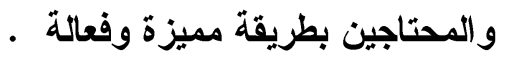

وتعتبر المملكة العربية السعودية من الدول التي تهتم برعاية المسنين فيها وتقديم الخدمات لهم على مدار العام. وتثير الإحصائيات إلى أنه في العام ^ץ؛ اهـ بلغ عدد المسنين - . . عاما فأكثر - في

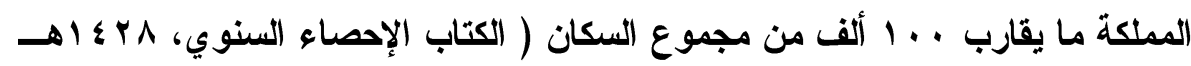

وتركز هذه الاراسة على توزيع مواقع الأربطة الخيرية، بمدينة الطائف ودور الرعاية الاجتماعية بمدينة

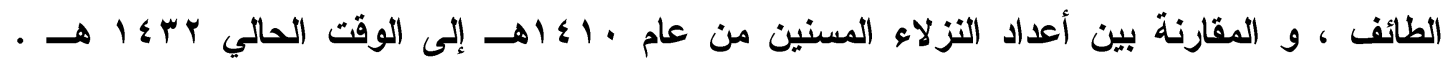
وأسباب التفاوت بين أعداد المسنين في دور الرعاية من عام لآخر ، وأسباب لجوء البعض منهم إلى إلى الأربطة ومدى استجابة الاور والأربطة للزيادة السكانية من هذه الفئة (ه آوأكثر ) ودورها في المجتمع، و التعرف على خصائص المسنين الاجتماعية والاقتصادية ثم تقديم التوصيات لتطوير أو للزيادة في أعداد الأربطة ودور الرعاية .

\section{مشكلة البحث وتساؤلات الاراسة :}

أصبحت رعاية المسنين من المهام الرئيسة في المجتمعات ، حيث يظهر الاهتمام برعايتهم من خلال النظم و اللوائح التي تنظم أوجه الرعاية ، وتثثير الدراسات المتنوعة إلى ازدياد عدد المسنين في دول العالم ، حيث أثشارت دراسة بعنوان "ثيخوخة السكان في العالم لعام 9 ...ץ" الأي نشر في إدارة الثؤون الاقتصادية والاجتماعية في منظمة الأمم المتحدة ، ( السدحان، 9 ب ع 1، 9 9).

وتعتبر مشكلات إيواء المسنين من القضايا الهامة على صعيد المجتمعات الصناعية والمجتمعات النامية. ومن هذا المنطلق فان هذه الاراسة تسعى للتعرف على خصائص المسنين الاجتماعية والاقتصادية و دور الإيواء الخاصة بالمسنين بمدينة الطائف ، ومعرفة الأسباب التي دعت المسنين للإقامة بهذه الأماكن، و الوقوف على الخدمات المقدمة لهم. ومن ثم إلقاء الضوء على مدى كفاية الدور للمسنين مستقبليا 
ومدى استجابة الدور للزيادة المستمرة في أعداد السكان وهل يحتاج الأمر إلى زيادة في بناء أعداد من دور الرعاية أو الأربطة بمدينة الطائف. تساؤلات الار اسة : • التعرف على خصائص دور الرعاية الاجتماعية للمسنين ، وخدماتها المقدمة . • التعرف على التوزيع الجغرافي للمسنين في الأربطة ودور الرعاية الاجتماعية في مدينة الطائف. • التعرف على الموقع الأمثل لار الرعاية الاجتماعية بدينة الطائف. • التعرف على الخصائص الايموغرافية ، والاجتماعية، والاقتصادية، للمسنين المقيمين بالأربطة. • التعرف على أسباب إقامة المسن بدينة الطائف.

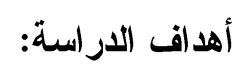
تسعى هذه الاراسة لتحقيق عدد من الأهداف التي يمكن تلخيصها في النقاط التالية: • التعرف على خصائص وخدمات أماكن الإيواء الخاصة للمسنين بمدينة الطائف . • التعرف على نمط التوزيع الجغرافي للمنين في الأربطة ودور الرعاية الاجتماعية في مدينة الطائف. • التعرف على الموقع الأمثل لإششاء دار الرعاية الاجتماعية بدينة الطائف. • التعرف على الخصائص الديموغرافية، والاجتماعية، والاقتصادية، للمسنين في مدينة الطائف. • التعرف على أسباب إقامة المسن بالأربطة و دور الرعاية الاجتماعية للمسنين.

$$
\text { أهمية الار اسةة: - n }
$$

• تكمن أهمية هذه الاراسة في كونها من الاراسات التي تتاول إيواء المسنين من منظور جغرافي يركز على الجوانب المكاتية التي تتمثل في معرفة خصائص خدمات الإيواء وتوزيعها بمدينة الطائف وخصائص المسنين الاجتماعية والاقتصادية . • تعتبر من الاراسات الجغرافية التي تتناول الموضوع من منظور الجغرافيا الاجتماعية التي تعالج مشكلة مهمة من مشكلات المسنين. 
فيما يلي توضيح لأهم المصطلحات المستخدمة في الاراسة وأهم المعاتي التي تلال عليها وهي كالتالي:

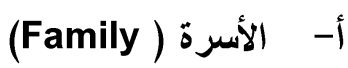

وهي مجموعة من الأفراد الذين ينتمون إلى جماعة مستقلة داخل المجتمع ويرتبطون الواحل بالآخرين عن طريق روابط الام أو الزواج أو غيرها من الروابط المشتركة وغيرها من العلاقات الخاصة التي تجمعهم.)

(1V:1990، (حمد

ب- مؤسسات الرعاية الاجتماعية(Social welfare institutions)

• مجموعة التظيمات الرسمية وشبة الرسمية وغير الرسمية (غير الحكومية ) التي تمارس نشاطا أو

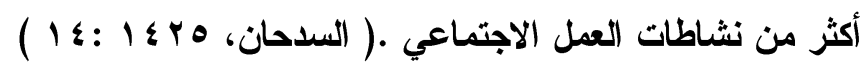

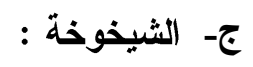

التغيرات الفسيولوجية غير قابلة للرجوع والتي تحدث في الجسم نتيجة لتقدم العمر وتستمر بصفة

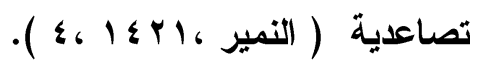

د- الأربطة (Charity housing):هي عبارة عن بيوت وقف لله تعالى يتم من خلالها إسكان الأثخاص المعرين ماديا وعدم قرتهم على اتخاذ مسكن لهم والإنفاق عليهم من خلال تقديم

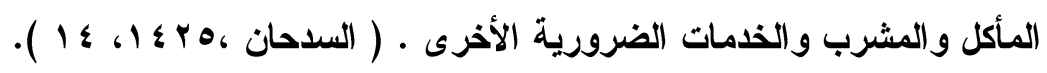

$$
\text { الار اسات السابقة: - ت إبة }
$$

هناك العديد من الدراسات التي تناولت موضوع رعاية المسنين وإيوائهم داخل دور الرعاية الاجتماعية، و البعض الآخر تمَّ على المتقاعدين والملاجئ. وتتنوع هذه الاراسات بين كونها دراسات محلية عن مختلف مناطق المملكة العربية السعودية أو دراسات أجنية في مناطق عالمية تتناول نفس أفكار الموضوع العامة

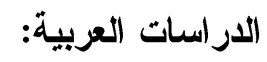

ا- دراسة (أسماء خميس - 7 • ـ اهـ) حول رعاية المسنين ودور الخدمة الاجتماعية فيها وهي

$$
\text { در اسة وصفية }
$$


r- دراسة (راثد أبا خليل -V • ع اهـ) عن الثيخوخة ومراكز العناية بالمسنين في العالم وتهدف الار اسةةإلى تحايل ملى الحاجة إلى منشآت اجتماعية صحية للمسنين في المملكة r- دراسة (ثريا جبريل -1 • ؛ اهـ) حول المشاكل التي يعاتي منها المسنون في المملكة العربية السعودية ودور الخدمة الاجتماعية في مواجهتها وتهدف إلى التعرف على أنواع المشكلات التي يعاني منها المسنون في المملكة العربية السعودية

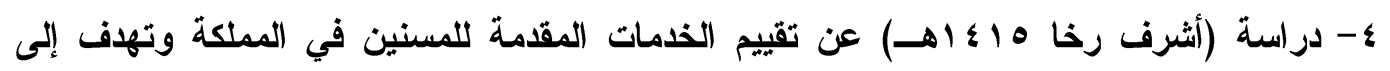
تقييم الخدمات المقدمة للمسنين ه- دراسة (محمد المرعود 991 1) تكامل الأسرة و المؤسسات الاجتماعية في رعاية المسنين والتي تهدف هدفت إلى توضيح طبيعة التكامل في دور الأسرة والمؤسسة الاجتماعية في رعاية المسنين والإحاطة بأبعاده لتطويره

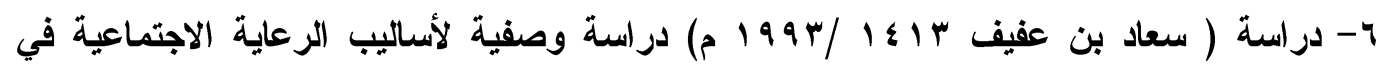
بيوت الفقراء بمدينة جدة حيث ركزت في هذه الار اسة على بداية نثأة الربط في المجتمع المسلم وتوضيح ومقارنة أنو اعها ومن أهم التوصيات التي أوصى بها الباحث: 1 - توعية المجتمع بضرورة احترام الكبير، وفهم ما جاء في ذلك من النصوص القرآنية الكريمة و السنة النبوية الثريفة، خصوصا ما يأمر منها ببر الو الدين واحتر امهم وعدم إهاتتهم. r - أن يعمل المجتمع جاهدا على الحد من إرسال المسنين إلى دور المسنين، لأنه ورغم ما يقدم لهم من رعاية إلا أن العديد منهم يعاني من عدم الراحة النفسية.

r - أن يقوم المسلمون بإتشاء دور للمسنين خاصة بهم تعمل على الفصل بين الرجال والنساء، وتعمل على الالتز ام بتعاليم الإسلام. الاراسات غير العربية: - n هنالك مجموعة من الاراسات غير عربية التي تناولت طرح موضوع الرعاية الاجتماعية للمسنين. وفيما يلي عرض لأهم هذه الدراسات وهي كالتالي: ا. تناولت دراسة مارغريت بو تشل ع 919 ام (Margaret bochel) السياسة العامة لتوفير المناطق السكنية للمسنين ، بريطاتيا ومدى استجابة القطاع العام والقطاع الخاص و القطاع التطوعي ، في 
توفير الرعاية السكنية للمسنين وتدقق هذه الدراسة في المستويات النسبية والاختلافات المكاتية في

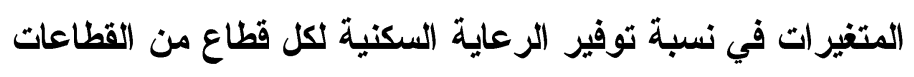

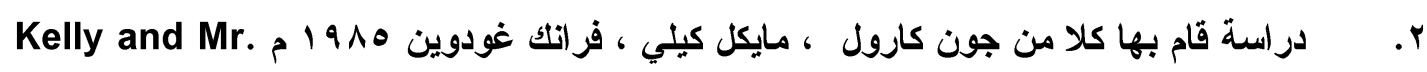
الرعاية المؤسسية لإسكان المسنين، ايرلندا،

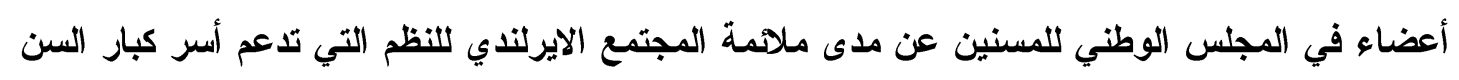

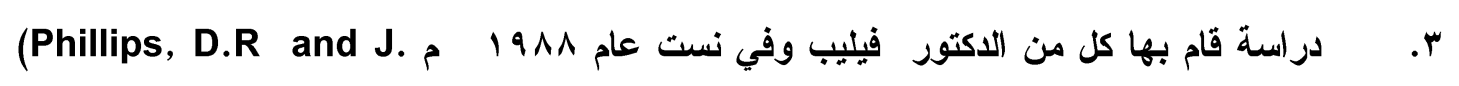
Vincent)

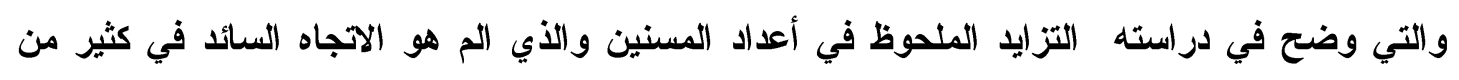

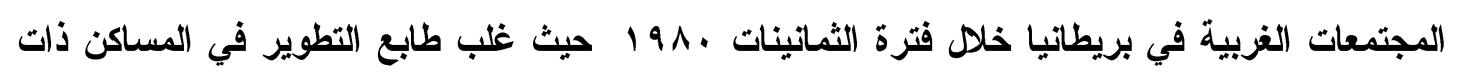

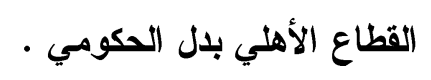
الإطار النظري

- - المغنى الاصطلاحي للمسن ( الثيخوخة ) :

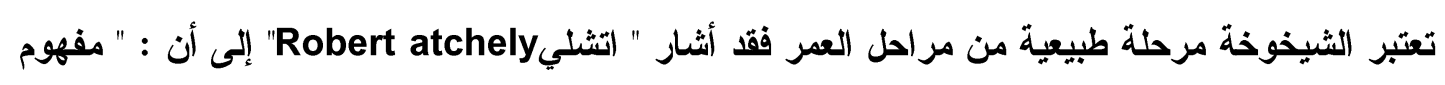

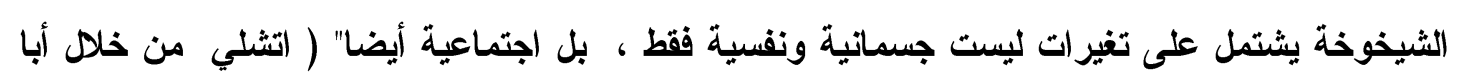

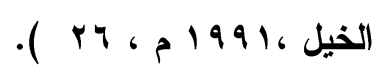

واختلف الباحثون والدارسون حول تحديد مفهوم التقام في العمر والأي يؤدي إلى مرحلة الثيخوخة ،

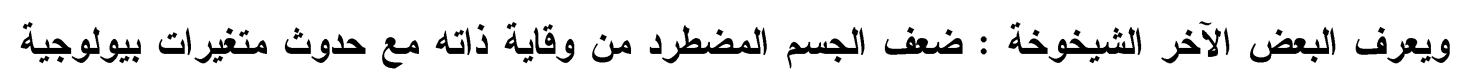

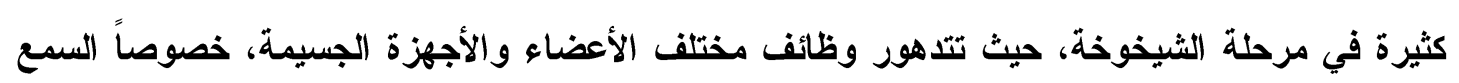

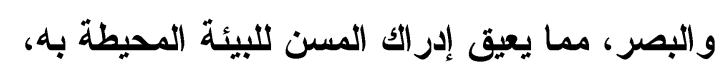
وتقل مقاومته للأمراض والتقلبات الجوية وآثارها كنزلات البرد ودرجات الحرارة العالية، ويكون معرضاً

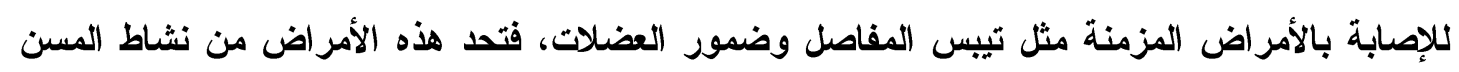

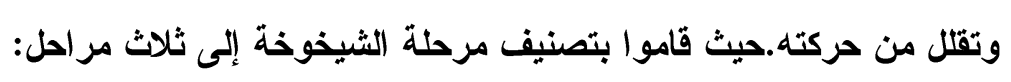

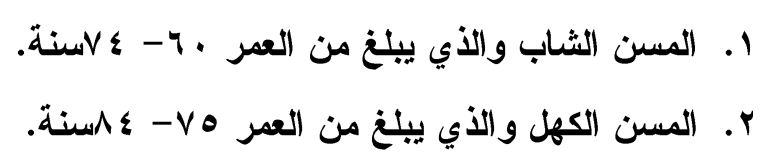


r. المسن الهرم والذي يبلغ ع دمنالعمر فأكثر.

وبين ليفنسـون ودارو وكلاين وكيكي (Levinson; Darrow;Klien; Ckee) من خلال تقسيمهز لاورة الحياة إلى مراحل متتــالية، أن المرحلة الأخيرة هي مرحلة الثيخوخة (Late Adulthood)، وتبدأ حسب رأيهم في سـن · ج وما فـوق (Darrow; lien; Ckee Levinson; $19 \vee \wedge)$.

$$
\text { المفهوم الإجرائي للمسن: }
$$

هو ذللك الفرد من الأكور الأي بلغ سن ، ج سنة فأعلى سعودي الجنسية يعيش في مدينة الرياض خاليا من الأمر اض والعاهات التي تعوق من أدائه لنشاطاته بحيث يكون قادرا على العمل والنشاط مع مراعاة الاختلافات و الفروق في تلك القدرة والدوافع والظروف الأسرية والمادية سواء كاتت تلكك النشاطات تطوعية أم ذات عائد مادي أو اجتماعي. مع الأخذ في الاعتبار تلك الاختلافات والفروق الفردية ، والعمرية ، والاجتماعية ، و الاقتصادية ـ (مرجع سابق، 9 (1).

وعرفت الأمم المتحدة وجامعة الدول العربية المسن تعريفًا إجرائيًا للتعامل مع هذا المصطلح، وذلك بأن حدَّتتاه بمن تجاوز عمره الستين سنة. ( الطيطي و جبر).

$$
\text { 1- 1. مفهوم المسن عند الفقهاء ( الثيخوخة ): }
$$

لم يفرد الفقهاء أبوابا خاصة في حليثهم عن المسنين في كتبهم الفقهية، ولعل معظم الفقهاء الذين تحدثوا عن الأحكام الفقهية المتعلقة بمرحلة الشيخوخة في شتى الأبواب الفقهية، من صلاة وصيام وحج وجهاد وغير ذلك، لم يتطرقوا إلى تعريف خاص بهذه المرحلة، باعتبار أن هذه المرحلة من الأثياء المطلومة التي لا تحتاج إلى بيان وتعريف. ومن تعريفات المعاصرين للمنين التعريفات الآتية: 1- المرحلة التي تقل فيها مقدة الفرد على تجديد خلاياه r- تطور طبيعي في حياة الإنسان كمرحلة الرضاعة و الطفولة r- تراكم ظواهر خارجية وداخلية وتقلبات نفسية وعصبية تؤدي إلى الاضمحلا r- إضع المسنين عالمبا : أصيبت المجتمعات المعاصرة بمرض اجتماعي ترك أثره على المسنين، وهذا المرض يكمن في تفكك الروابط العائلية وتفرق أفراد الأسرة لأسباب متعددة كظروف العمل أو وهن الوازع الايني والخلقي وضعفه، وهذا التغير كان له أكبر الأثر السلبي على حياة المسنين الأين يعانون الوحدة والفراغ، أو يعانون في بيوت العجزة ودور المسنين، وهي جريمة في حق المجتمع وفي حق بعض الأفراد الأين قدموا جهوداً 
وأعمالاً كثيرة.وتظهر مؤشرات الإحصاءات السكاتية اختلال شكل الهرم السكاتي في بعض الدول، وذللك بضخم قمة الهرم السكاني ويعود ذلك بعد قدير الله عز وجل إلى:

$$
\text { r. ا. بزايد عدد كبار السن وقل في المواليد. }
$$

r. تطور الخدمات الصحية المقدمة إلى كبار السن. ونتيجة لطبيعة هذه الأمور الثلاثة تزايد الاهتمام بفئة المسنين، وهذا الاهتمام يكثر في الاول الغربية أكثر منة في دول العالم الثالث، ويعود هذا إلى تزايد أعداد

$$
\text { المسنين في المجتمعات الغربية، أكثر منها من دول العالم. }
$$

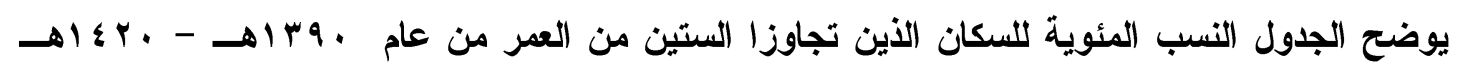

\begin{tabular}{|c|c|c|c|c|}
\hline \multicolumn{5}{|c|}{ نسبة المسنين إلى مجموع السكان } \\
\hline$\rightarrow$ ا & ه & 更 & (1) أهـ. & \\
\hline مr... & $p^{199 .}$ & pl9^. & plqv. & المنطقة \\
\hline $9, r$ & $\wedge, q$ & $\wedge, 9$ & $\Lambda, \varepsilon$ & 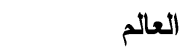 \\
\hline 11,0 & $i \vee, \wedge$ & $17, v$ & $17, V$ & 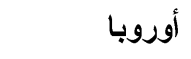 \\
\hline $10, \varepsilon$ & $10, r$ & $1 \leqslant, 9$ & $1 r, \Lambda$ & أمريكا الثمالية \\
\hline $11, r$ & $1 \cdot, r$ & 9,1 & $\wedge, 0$ & شرق آسيا \\
\hline
\end{tabular}

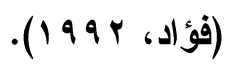

جدول رقم( - 1) نسبة المسنين إلى مجموع سكان العالم 


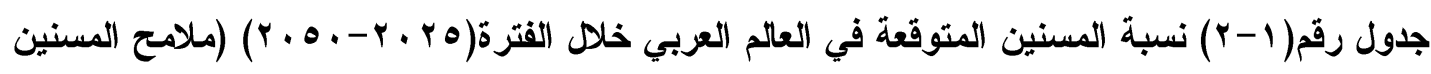

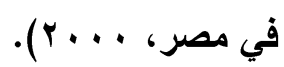

\begin{tabular}{|c|c|c|c|c|c|}
\hline r.o. & $r \cdot r_{0}$ & الدولة & r.o. & r.ro & \\
\hline$r \leqslant, q$ & $1 ., 0$ & الكويت & $19, r$ & $11, r$ & مصر \\
\hline$r \varepsilon, r$ & 11,1 & الجزائر & $I r, \Lambda$ & Y, & العراق \\
\hline $1 r, 0$ & $V, \varepsilon$ & موريتانيا & 19,1 & $v, q$ & سوريا \\
\hline$r \varepsilon, r$ & $1 \leqslant, r$ & البحرين & $r r, V$ & $1 \leqslant, \varepsilon$ & لبنان \\
\hline$r \varepsilon$ & $0, \varepsilon$ & الإمارات & 19 & $\wedge, \cdot$ & الأردن \\
\hline$r_{\cdot,, \varepsilon}$ & $9, r$ & عمان & 11 & $\wedge, \diamond$ & السعودية \\
\hline 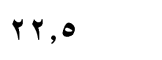 & $\Lambda, 0$ & قطر & $9, \xi$ & $\varepsilon, \wedge$ & اليمن \\
\hline$\Lambda, r$ & $0, r$ & الصومال & r & $1,, \varepsilon$ & ليبيا \\
\hline $1 \cdot, \wedge$ & 0,9 & فلسطين & $1 \%, 4$ & $v, r$ & السودان \\
\hline Ir,r & v, & جيبوتي & rr,q & $1 Y, 4$ & المغرب \\
\hline $1 Y, \varepsilon$ & ४, & جزر القمر & $r \Lambda, l$ & $1 \leqslant, \varepsilon$ & س س \\
\hline
\end{tabular}

ومن الواضح تزايد نسبة المسنين إلى المجموع العام للسكان، وهذا بقدرة الله بسبب ارتفاع معدل الحياة للجنسين في العالم الغربي مقارنة بالعالم الثالث فمن خلال الجدول الآتي يتضح لنا التزايد في العالم الغزبي نظرا لارتفاع نسبة الثباب فية مقارنة بالعالم الثالث (السدحان، اب ع اهـ، ب ـ 1). r-r r r المسنبن في بعض قار ات العلام :

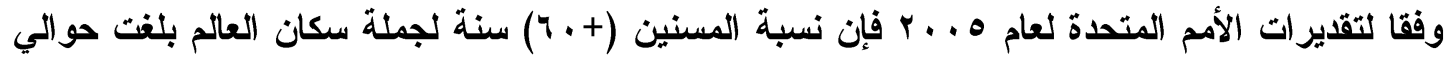
• 1\% وتأتي قارة أوروبا بالمرتبة الأولى حيث تصل نسبة المسنين بها إلى اب٪ من جملة السكان 
مقارنة بمثيلتها في قارة أفريقيا والتي تبلغ حوالي ه\% من جملة السكان ـ ومن المتوقع أن تصل نسبة

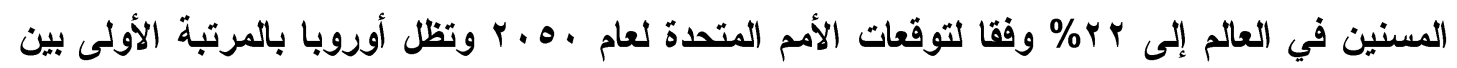
قارات العالم حيث بلغت نسبة المسنين بها إلى هץ\% من جملة السكان وترتفع النسبة في أفريقيا لتصل

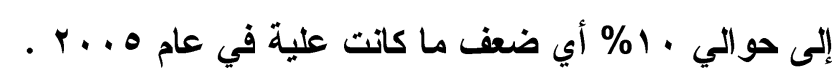

r-r دور الأمم المتحدة في توفير الخدمات الصحية و الرفاهة في سن الثيخوخة: (قسم خدمات الشبكة

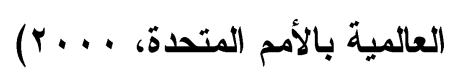

ساهم برامج تعزيز الصحة في تثجيع الناس على مراقبة صحتهم والعمل من أجل تحسينها. وترد الاستراتيجيات الأساسية لتعزيز الصحة في ميثاق أوتاوا لتعزيز الصحة (؟19 1 ). وقد وضع المؤتمر الاولي للسكان والتنمية ( 99 ( ) أهدافا تتمثل في زيادة سنوات الحياة المليئة بالصحة ، وتحسين نوعية الحياة للجميع، وخفض معدلات الوفيات، والأمراض، وزيادة العمر المتوقع عند الميلاد. ويمكن تحقيق هذه الأهداف بطريقة أكثر فعالية بتنفيذ الإجراءات التي أوصت بها منظمة الصحة العالمية من أجل تحسين الصحة العامة وسبل الحصول على الرعايا الصحية الملانمة. الأطفال والمسنون أثثد تأثرا بمختلف ضروب التلوث البيئي من متوسطي العمر، و أكثر عرضة لخطر التضرر حتى من أدنى مستويات التلوث. وتؤدي الحالات الطبية الناجمة عن التلوث البيئي إلى انخفاض الإنتاجية وتؤثر على نوعية حياة الأثخاص مع تقدمهم في السن. الم-r رعاية المسنين في المملكة اهتم التشريع الإسلامي بأمر كبار السن وجعل لهم مكانة مرموقة في المجتمع وضمن لهم من خلا

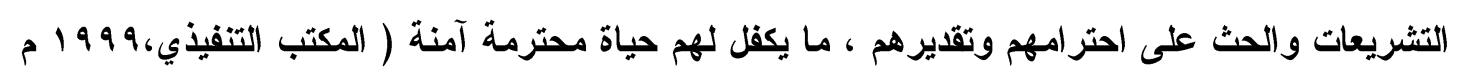

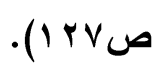
فللمسن مكانة متميزة في المجتمع المسلم ، فهو يتعامل معه بكل توقير واحترام يحدوه في ذلك قول الرسول صلى الله علية وسلم " ليس منا من لم يرحم صغيرنا ويوقر كبيرنا") عبدالله

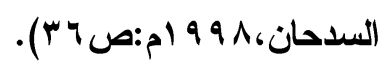
وأولت الملكة العربية السعودية برامج رعاية خاصة للمسنين ، فبدأت خدماتها في عه الملك عبد العزيز آل سعود ـ طيب الله ثراه _ فأولى العجزة و المسنين عناية خاصة ، فأمر بصرف مخصصات لهم و إنثاء

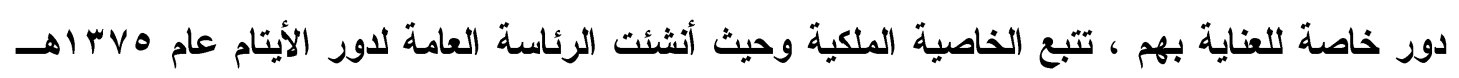
تولت الإثراف على خدمات رعاية المسنين ، ثم ضمت الرئاسة العامة لدور الأيتام إلى وزارة العمل

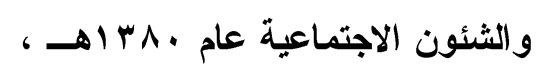


حيث تولت الوزارة مسؤولية خدمات رعاية المسنين وتطويرها ، وأصدرت اللوائح الخاصة بدور الرعاية

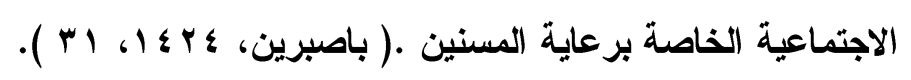
حيث يمكن توضيح ما سبق من خلال المحاور التالية : r- الرئية الاقتصادبة للمسنين في المملكة

حيث يقوم هذا النوع من الرعاية للمسنين في المملكة العربية السعودية عبر أنظمة ثلاثة ظهرت في المملكة منذ سنوات طويلة وهي: r-1- 1- 1- نظام التقاعد:

وهو نظام يخلم فئة المدنيين والعسكريين في الاولة ،بعد بلوغهم مرحلة متقدمة من العمر أو العجز عن العمل، بحيث يتم حسم نسبة من الراتب الموظف الثهري تعادل(9\%) من الراتب الأساسي ، ويلاحظ أن الراتب التقاعدي يتأثر بعدد سنوات الخدمة ( عبد الله السدحان، . . . rم:ص^مه).

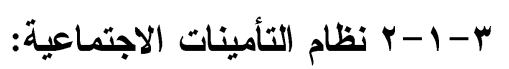

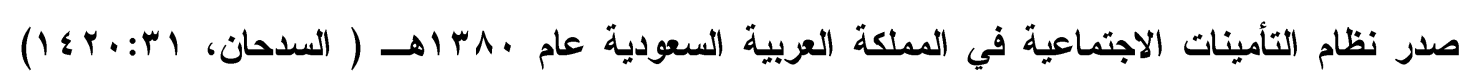
وهو نظاما اجتماعيا تكافليا ، تتجسد فيه رعاية الدولة لفئة العاملين في قطاعاتها المختلفة لتوفير حياة كريمة مستقرة لهم وأسرهم بعد بلوغهم سنا يعجزون فيه العمل ويتم ذلكك باستقطاع

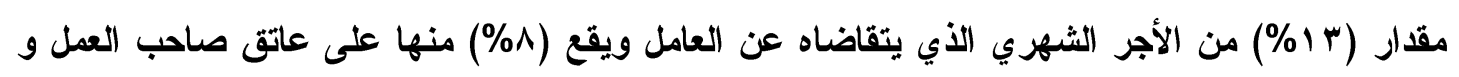

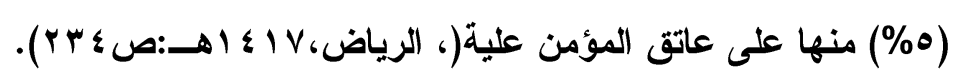

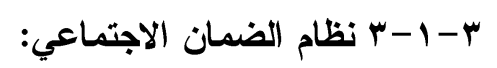
أسست وزارة العمل و الثئون الاجتماعية في عام (، r أهـ) وبدأت ترعى الجمعيات الخيرية و التعاونية ، وتثرف على دور الأيام والعجزة. وفي عام( r r I r اهـ) أحثث مصلحة للضمان الاجتماعي ترتبط بوزارة الثئون الاجتماعية وقد كان من طبيعة عملها أن تساعد الأسر وترفع عنة ذل المسالة وحفظ كرامته ، وقد صنف الضمان خدماته إلى نوعين من الإعانات.( معاثنات ، مساعدات ) وتم صرف هذه المساعدات

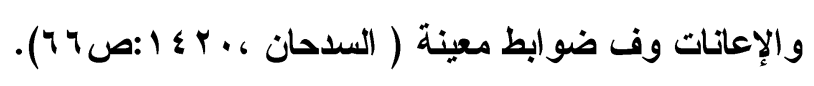
r-r الرعاية الاجتماعية المفتوحة: وتتمثل ذلك في ممارسة بعض العمليات الاجتماعية ، لامجج المسن في المجتمع الخارجي وعدم تركة للعزلة التي قد يمارسها المسن بغير اختيار منة. ويمثل هذا النوع " مركز الأمير سلمان الاجتماعي بمدينة الرياض".وتعود فكرة هذا المركز إلى ما دلت علية بعض الاراسات التي أجريت في المجتمع السعودي وأظهرت 
رغبة كبار السن في وجود مؤسسة تتناسب مع سنهم وتلبي احتياجاهم ( الثيخوخة ومراكز الغناية بالمسنين

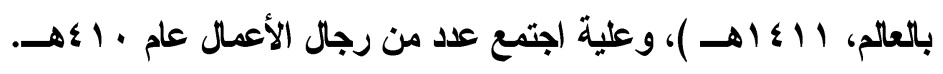
r-r الرعاية الإيوائية الثاملة للمسنين بالمملكة العربية السعودية:

$$
\text { وتنقسم إلى قسمين : }
$$

r-1 - الرعاية الإيوائية الحكومية :وتهذف دور الرعاية الاجتماعية إلى تقديم أوجه الرعاية لكل مواطن ذكر أو أنثى بلغ الستين سنة أو أكثر، و أعجزته الثيخوخة عن إمكانية العمل والقيام بشئون حياته الخاصة . لرك

شروط الالتحاق بدور الرعاية الاجتماعية: أن يكون المتقدم سعودي الجنسية وتنطبق علية الثروط السابقةو أن يثبت كل من البحث الاجتماعي و الفحص الطبي أن ظروف المتقدم تستلزم البقاء في الادار.و أن يثبت الفصص الطبي خلوة من الأمراض المعدية.

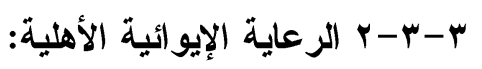
حيث تقوم الدولة على دعم الجمعية لتحقيق الإعانات التالية: إعانة نقدية (إعانة عند التأسيس، إعانة سنوية ، إعانة إسهاميه للإنشاء و البناء) إعانة فنية (خاصة بتعيين الموظفين ذوو خبرة بالجمعيات ) إعانة عينية (تدعم الخدمات ) إعانة طارئة( في حالة الصعوبات والأزمات) •اعانات متنوعه (اقامة دورات - شر اء أراضي - الكهرباء ). 1- أهمية رعاية المملكة العربية السعودية لمسنين : الافء العائلي والروحي والإحساس بالأمن.و فرص التفاعل الطبيعي مع الأبناء، والأزواج، والأقارب، والمعارف والأصدقاء.و تحقيق الاطلاق والتعبير الحر عن الأت لاى المسنين.و تكوين علاقات متعددة وقوية داخل الأسرة وخارجها.و تحقيق المكانة الاجتماعية واحترام الأات.و الارتباط بالمجتمع والأسر الأخرى من خلال الزيارات، واستقبال الضيوف. (عبد اللطيف، 999 (1)). 
مظاهر رعابة المسنين

يوجد العديد من الممارسات العملية لرعاية كبار السن في المجتمع المسلم وأبرزها باعتبارها احد مظاهر رعاية المسنين فلقد أوصى الله بالو الاين خيرا ، وأمر ببرهما وجعل الإحسان إليهما قرين عبادته ،قال

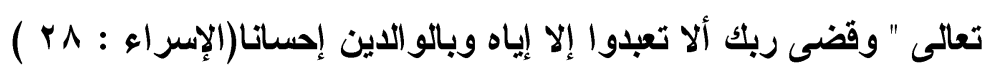

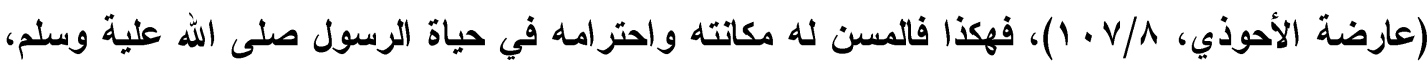
ولقد اتبع ذلك أصحابه - رضي الله عنه - ولقد تطبع أفراد المجتمع المسلم بذلك الخلق وتوارثوا توقير الكبير واحترامه وتقديره انقيادا لتعاليم دينهم ، وإتباعا لسنة النبي صلى الله علية وسلم ، كما تثرب المجتمع المسلم ذلك الانطباع وهذا الاحترام لكبار السن ، وأصبح سمة من سماته ، فلا تكاد تجد كتاب ، حديث ،أو زهد أو توجيهات ، أو نصح إلاويعقد فيه باب أو أكثر عن توقير الكبير، ،و احترامه، و إكرامه

\section{r- الوقف الخيري}

يعتبر نظام الوقف قاعا خيريا ومصدرا مهما لحيوية المجمع وفاعليته وتجسيد حي للتكافل الاجتماعي وترسيخ لمفهوم الصدقة الجارية برفدها الحياة الاجتماعية بمنافع مستمرة..."(السدحان، ، ب ؛ اهـ). أهداف الوقف وحكمة مشروعيته :أن الهـف العام للوقف في الإسلام هو إيجاد مورد دائم ومستمر لتحقيق غرض مباح من اجل مصلحة معينة. • - نبذة عن مدينة الطائف النمو السكاني : (1)

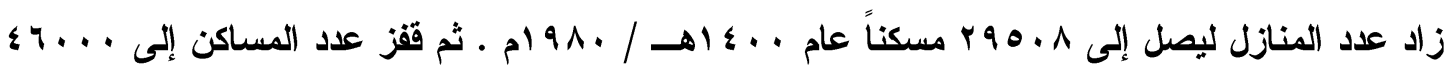

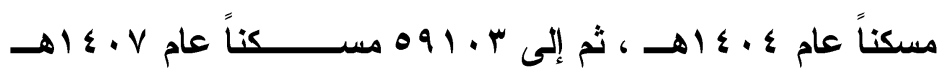

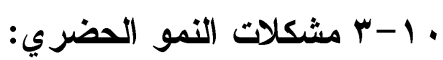
ترتب على النمو السكاني في مدينة الطائف بعض المشكلات الحضرية التي تعاني منها مدن دول العالم الثالث أيضا كأزمة السكن ،الضغط على المرافق والخدمات المتمثلة بمياه الثرب، استهلاك الكهرباء ، تصريف المجاري وتلوث البيئة ـ كما ترتب على زيادة السكان ظهور الأحياء العثوائية غير المخططة، • 1- ـ توزيع الأربطة ودار الرعاية الاجتماعية في أحياء مدينة الطائف: 
لجأت الطالبة إلى جمع العديد من البيانات المختلفة عن الأربطة (الخيرية - الأهلية ) ودور الرعاية الاجتماعية بمدينة الطائف من وزارة الأوقاف والحج والأمانة بمدينة الطائف عن طريق تحليل مضمون لاراسة حالة النزلاء في الأربطة ( الخيرية - الأهلية ) من خلا الاراسة الاستطلاعية التي أجرتها الطالبة عن الربط. علما بان هذه البيانات لا تعتبر مسحا شاملا للربط (لعدم وجود بيانات وافية عنها خاصة بالأربطة الأهلية التي تتسب لملاكها) حيث يبلغ عدد الربط حسب علم الطالبة وبناء على معلومات تم

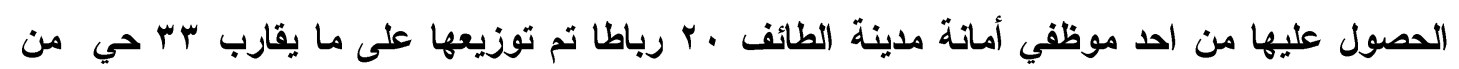
أحياء مدينة الطائف كما يظهر في خريطة (1-r) أدناه حيث تقسم إلى ؛ 1 رباطا حكوميا و ؟ أربطة أهلية • وكما يلاحظ في الخريطة إن معظم الأربطة تتركز بمكان واحد وبالقرب من بعضها البعض بالأات الأربطة

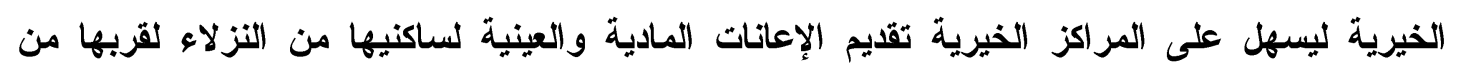
بعضها البعض في حين أن بعض الأحياء الشمالية مثل( حي الثهداء) يصعب وصول الصدقات إلية وان وصلت تكون متأخرة عن بقية الأربطة الخيرية ـ لبعدها وعدم توفر الخدات فيها ،

وينصح بضرورة إنشاء دار خاصة للمسنين في المستقبل القريب تكون مؤهلة بالاحتياجات الخاصة لهم من ترفية والقرب من الخدمات حتى يسهل التنقل من مكان لآخر و(حي شهار) بمدينة الطائف هو الحي الأسب حسب معلومات الموظف (أ ، م ) لإنشاء دار الرعاية الاجتماعية حيث يعتبر حي شهار من الأحياء التي تتميز بكثرة الخدمات المتنوعة وقربها من بعضها البعض لوقوعها بوسط المدينة الجهات المسئولة عن رعاية الربط: يثارك في مسؤولية إنثاء وصياتة مباني الربط ورعاية النزلاء اجتماعيا الأفراد والجهات الحكومية و الأهلية ـ تمثل هذه المشاركة جاتبا من جواتب التكافل الاجتماعي تجاه الفئة الفقيرة في المجتمع ، وفيما يلي تعريف لهذه الجهات المسئولة عن الربط. 1- المشرفون على الربط:

تتنوع طريقة الإشراف على الربط إذ يوجد الإثراف الخارجي من قبل صاحب الرباط الناظر، مندوب وزارة الحج والأوقاف، الأخصائية الاجتماعية. وإثراف داخلي من قبل ألثيخه المدير/المديرة. كما يكف الحارس في بعض الربط ببعض مهام المشرف على الرباط. r - الاحتباجات الاجتماعبة والنفسبة للمسنبن

توصلت الاراسات في مجال الاهتمام بمعرفة الاحتياجات النفسية والاجتماعية للمسنين إلى تحديد احتياجات المسنين والتي تم تلخيصها في الحاجة إلى الأمن ، والاحترام ، والتقدير ، والحاجة إلى مساعدة الأبناء ، 
وتجنب الاعتماد على الآخرين ، والحاجة إلى ضبط الانفعالات والثعور بالانجازات، والحاجة إلى معرفة الإمكانات والموارد و الخدمات و البر امج المتاحة. كما وصلت جماعة من الباحثين إلى أن المسن يواجه عددا من المشكلات تقف بينة وبين التواقق النفسي والاجتماعي منها العزلة، وطول وقت الفراغ، وانخفاض الاخل الثهري، والتعرض للمشكلات الجسمية، و النفسية، وظهور الخلافات الأسرية، ومشكلة تعرضه السخرية والاستهز اء من الآخرين. r- مشكلات المسنين:تعاني شرائح عديدة من كبار السن لعدة مشكلات من أهمها: (المشكلات الصحية:المشكلات النفسية :المشكلات الاقتصادية: المشكلات الاجتماعية:

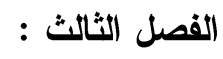

- منهج الاراسة :استخدمت الطالبة المنهج الإحصائي الاستدلالي - - أسلوب جمع البيانات:اعتمدت الباحثة الاستبانة كوسيلة لجمع البيانات من المسنينوقد راعت الطالبة - عند تصميم الاستبانة- الثروط و المواصفات العلمية الاقيقة التي حددتها كتب المنهج العلمي عند إعداد الاستبانة - مجتمع الاراسة:هم المسنون المقيمون باور الرعاية الاجتماعية والأربطة الخيرية بمدينة الطائف، ويبلغ دور الرعاية الاجتماعية الرسمية بمدينة الطائف دور واحد ، في حين بلغ عدد الأربطة الأهلية (؟) ستة أربطة تابعه لملاكها وأربعه عشر رباطا حكوميا لتصبح عشرون رباطا بمدينة الطائف.

- - صدق الاستباتة:اعتمدت الطالبة للتحقق من صدق الأداة على طريقة الصدق الظاهري - بات الاستباتة:وللتأكد من ثبات الاستبانة تم حساب معامل الثبات باستخدام معادلة الفاكرونباخ، وبلغت قيمة المعامل ( VVY. . . وهو معامل ثبات يمكن الاطمئنان له في تطبيق الأداء - مصادر جمع البيانات :المصادر الوثائقية. - الخرائط: عد الخرائط والصور الجوية على اختلاف أنو اعها. - - الار اسة الميدانية

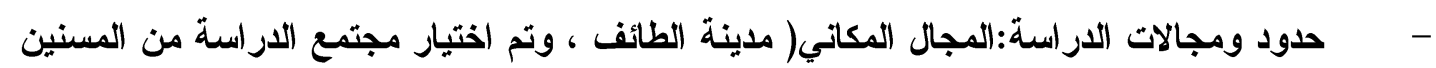
في دور الرعاية الاجتماعية والأربطة الخيرية) المجال الزماني: (استغرق جمع بيانات الاراسة مدة

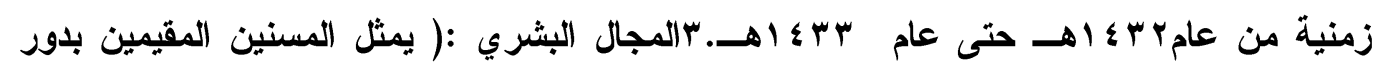
الرعاية الاجتماعية والبالغ عددهم r م مسن والمقيمين في الأربطة الخيرية والأهلية البالغ عددهم 
1- قامت الطالبة باستخدام برنامج الجداول الاكترونية (Excel) لتفريغ البيانات من الاستبيانات، وإعداد ملف البيانات، ثم مراجعتها والتحقق من صحة التفريغ، وبعد ذللك إدخال البيانات

وتحليلها على برنامج (SPSS) ، ومن ثم قامت الطالبة باستخدام الأساليب الإحصائية التالية :

$$
\text { r- r- التكرارات، والنسب المئوية . }
$$

ك- مربع كاي Chi-Square.

النتائج

نتائج الأربطة الخيرية بمدينة الطائف:

•أن الغالبية العظىى من نزلاء الأربطة الخيرية بمدينة الطائف تتمثل أعمارهم فوق اله †\% بنسبة هץ.\%

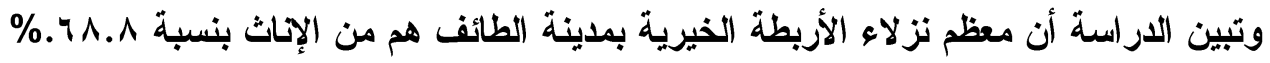

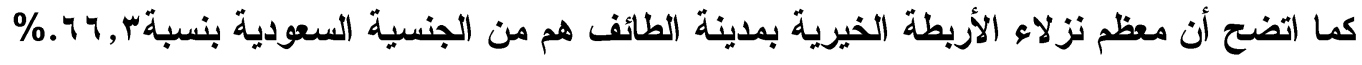

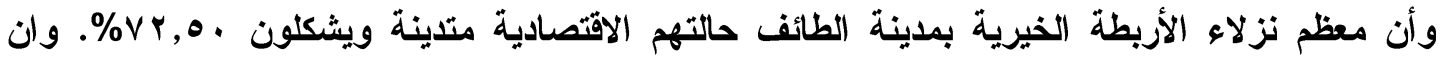
الصدقات من التجار والجمعيات الحكومية تمثل المصدر الرئيسي لهموتثير الاراسة أن نزلاء الأربطة الخيرية بمدينة الطائف يحصلون على الصدقات من المحسنين من خارج الرباط بنسبة ^,بـ.و\%ويتضح من خلال الاراسة أن الغالبية العظى من نزلاء الأربطة الخيرية أفادوا بوجود مصدر آخر للاخل غير الصدقات ينحصر في أعمال حرفية بنسبة ه,r r ـ\% كما أن الغالبية العظى من نزلاء الأربطة الخيرية بمدينة الطائف يعتبر العمل لايهم المصدر الثاني لهم بعد الصدقات.وتثير الاراسة أن \%०V من نزلاء الأربطة بمدينة الطائف من موظفي القطاع الخاص وتبين الاراسة أن أVه\% من نزيلات الربط ممن هم

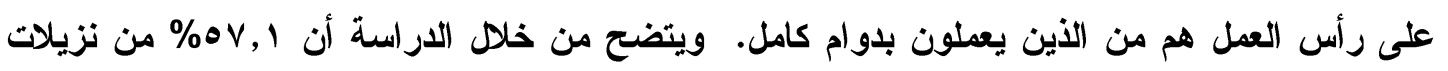
الربط ممن هم على رأس العمل تتطلب أعمالهم جها نفسيا وجسمانيا. كما تثير الاراسة أن الغالبية العظى من نزلاء الأربطة منقطعين عن العمل بسبب المرض بنسبة 9, 11. نزلاء الأربطة الخيرية المنقعين عن العمل مصدر دخلهم الحالي ينحصر في المعونات الخيرية بنسبة

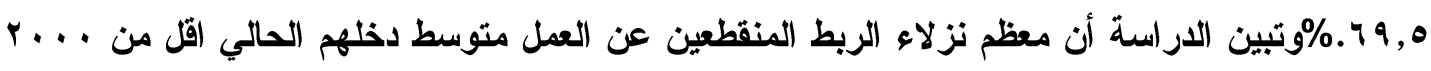

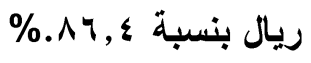

متبين من خلا الاراسة أن معظم نزلاء الأربطة الخيرية حالتهم الصحية دون المتوسطة بنسبة \%. $\uparrow \wedge, \wedge$ 
كما يتضح من خلا الاراسة أن الغالبية العظمى من نزلاء الأربطة الخيرية بمدينة الطائف بعانون من أمراض عضوية مثل الربو، السكر، القلب، الكلى.وتثير الاراسة أن معظم نزلاء الأربطة الخيرية بمدينة الطائف يرون أن صحتهم اقل من صحة من هم في مثل سنهم من أقاربهم بنسبة ه, V؛.\%وأن الغالبية العظى من نزلاء الأربطة الخيرية بمدينة الطائف لا يتبعون نظاما غذائيا معينا بنسبة r, I. 1.

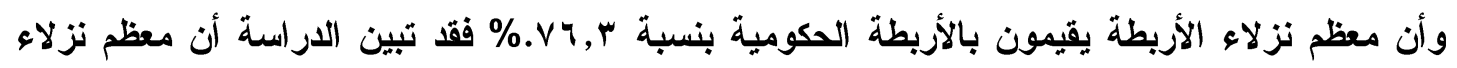
الأربطة بمدينة الطائف يقيمون في أربطة بعيدة عن وسائل النقل والمواصلات بنسبة س, ؟ ـ.\%وتثبير الاراسة أن معظم نزلاء الأربطة بمدينة الطائف يستخدمون سيارات خاصة بأصدقائهم للتنقل من مكان

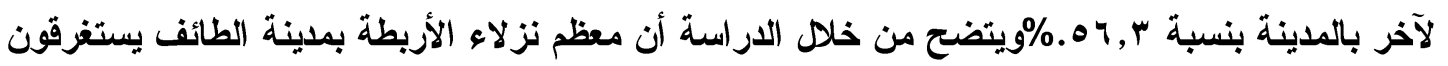

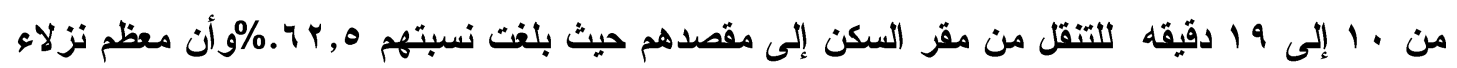
الأربطة الخيرية يخرجون من الرباط مرة أسبوعيا حيث بلغت نسبتهم . r.\%ويلاحظ من خلا الاراسة

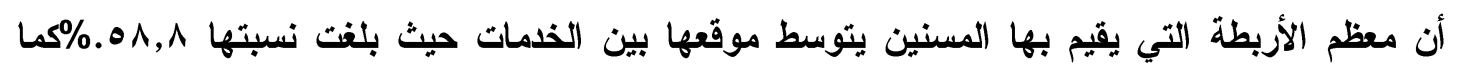
يتضح من خلال الاراسة أن معظم نزلاء الأربطة يقيمون في وحدات سكنية تحتوي على غرفتين يقيم بها

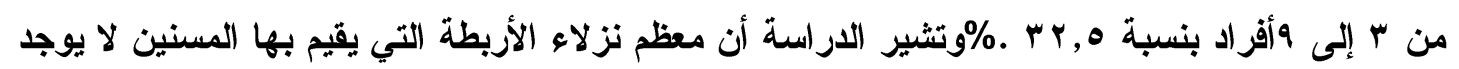
بها شخص يقوم بنظافة المرافق بنسبة .^.٪\%ويتضح من خلا الدراسة أن معظم نزلاء الأربطة التي يقييم فيها المسنون لا يوجد بها شخص يقوم بنظافة الملابس بنسبة ه9.و\%وأن الوحدات السكنية التي

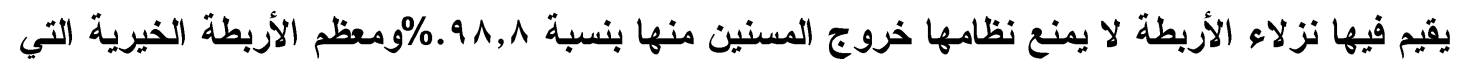

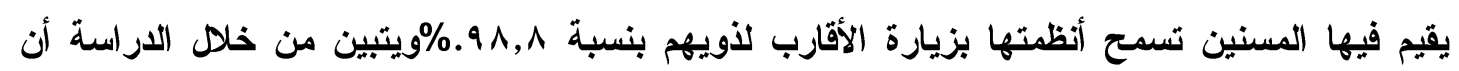
معظم نزلاء الأربطة بمدينة الطائف يتبادلون الزيارات فيما بينهم داخل الرباط بنسبة هو.\%كما تثبر الاراسة أن معظم نزلاء الأربطة بمدينة الطائف يخرجون مع نزلاء آخرون إلى السوق أو المستثفى لرع \%.VV,० بنسبة

• أن الغالبية العظمى من نزلاء الأربطة يقضون وقت فراغهم داخل الرباط بحكم كبر عمرهم وصعوبة تنقله من مكان لآخر بنسبة هو.\%وأن الغالبية العظى من نزلاء الأربطة كان السبب الرئيسي

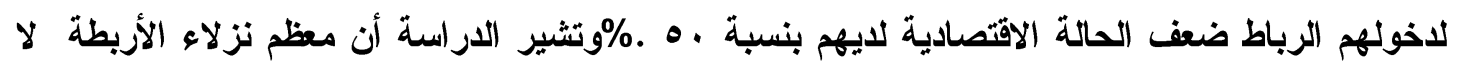
يوجد لايهم احد الأقارب يسكن بالقرب من الرباط لوقوع بعض الأربطة بأحياء عثوائية بنسبة

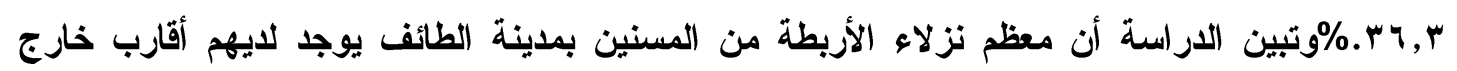
الرباط بنسبة ^,^هـ\%وأن الغالبية العظمى من نزلاء الأربطة هم من السعوديين المقيمين بالمملكة لأقل

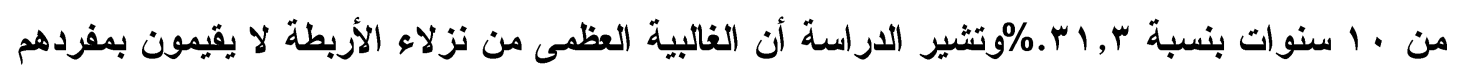




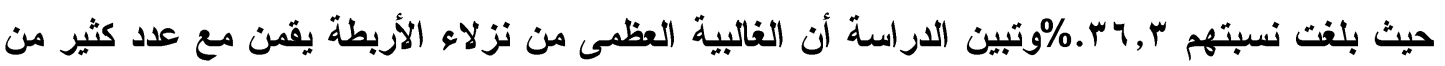

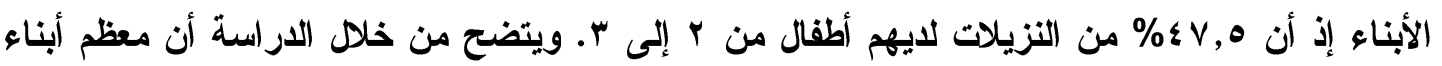

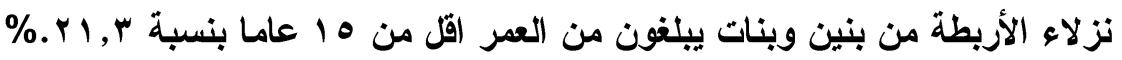
نتائج دار الرعاية الاجتماعية بمدينة الطائف:

• أن معظم المسنين المقيمين باور الرعاية الاجتماعية أعمارهم دون الثماتين إذ يوجد هب\% أعمارهم اقل من ه †.\%ويتضح من خلال الدراسة أن معظم المسنين المقيمين بدور الرعاية الاجتماعية

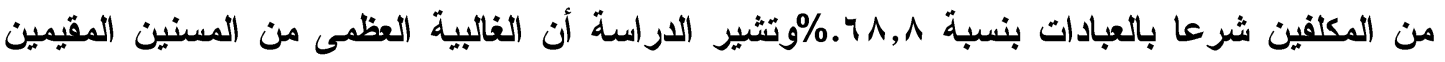

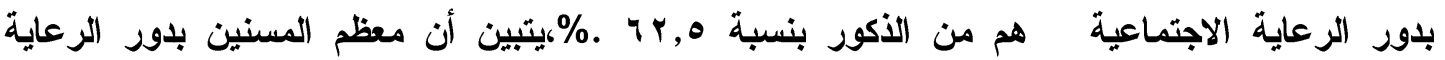
الاجتماعية هم من السعوديين حيث يشكلون نسبة ه.9 .9\%، .أن معظم المسنين المقيمين بدور الرعاية الاجتماعية من المطلقين بنسبة ه,r.r.\%وأن الغالبية العظمى من المسنين المقيمين باور الرعاية الاجتماعية يتصفون بضعف الحالة الاقتصادية.وتثير الاراسة أن معظم المسنين المقيمين بدور الرعاية الاجتماعية لم يسبق لهم العمل قبل دخولهم لار الرعاية بنسبة ، ـ. ـويتضح من خلا الاراسة انتثار الأمية بين معظم المسنين المقيمين بدور الرعاية الاجتماعية بنسبة ه. ب ؛ ـ\%ويتبين من خلا الاراسة أن

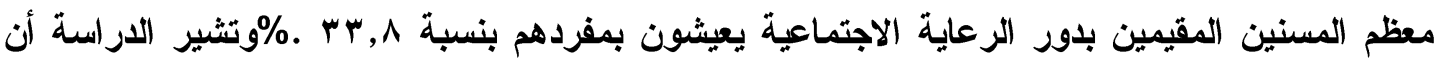
معظم المسنين المقيمين بلور الرعاية الاجتماعية قام أسر هم بضمهم إلى الادار بنسبة س, ؟ ؛ ـ\%ويتضح من خلا الاراسة أن من أسباب دخول معظم المسنين بدار الرعاية الاجتماعية علم وجود من يرعاهم

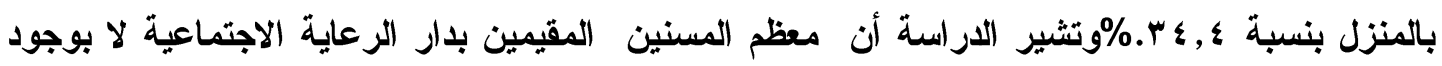

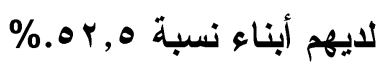

وأن معظم المسنين بدار الرعاية الاجتماعية مضى على بقائهم بدار الرعاية الاجتماعية خمس سنوات بنسبة r,ף ז.\%وتثير الاراسة أن أكثر من نصف المسنين المقيمين بدار الرعاية الاجتماعية كانوا

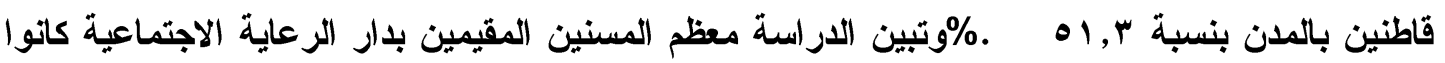

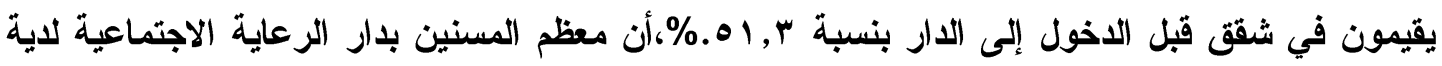

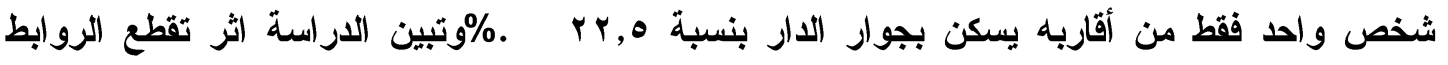
الأسرية من حيث وجود أقارب ، أبناء ، أزواج في حياة المسن خلال إقامتهم بدار الرعاية الاجتماعية

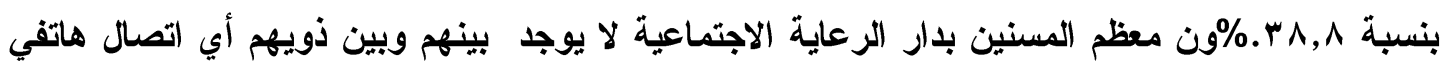
إلا في المناسبات والأعياد بنسبة ه؛.\% وأن الغالبية العظى من المسنين المقيمين بدار الرعاية الاجتماعية بطئنون على أسرهم خارج دار الرعاية بنسبة r, ؟ ـ.\%وتثير الاراسة أن معظم المسنين 


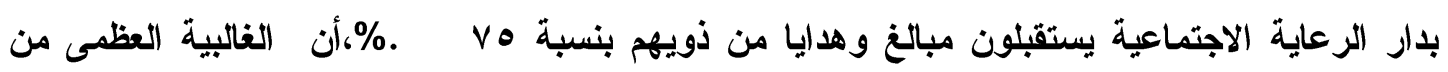
المسنين بدار الرعاية الاجتماعية أفادوا بعدم حصولهم على صدقات من خارج الدار بنسبة

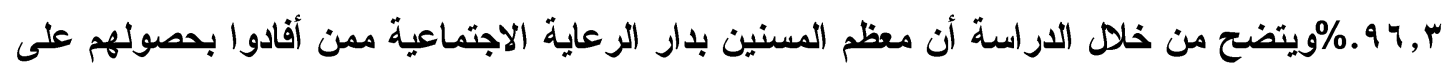

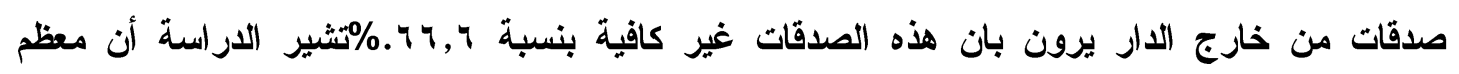
المسنين بدار الرعاية الاجتماعية أفادوا بوجود من يساعدهم على قضاء حاجاتهم الخاصة بنسبة \% \& . Av,0

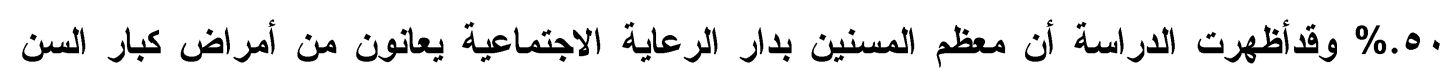

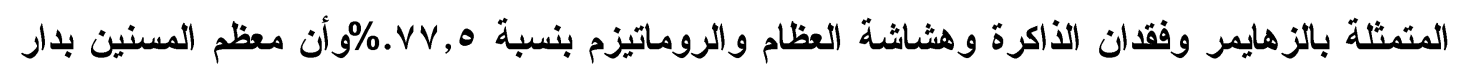

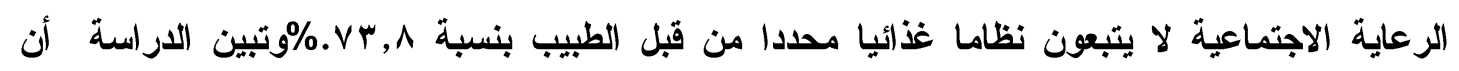
الغالبية العظى من المسنين المقيمين بدار الرعاية الاجتماعية أفادوا بأتهم لا يستطيعون أداء أي عمل

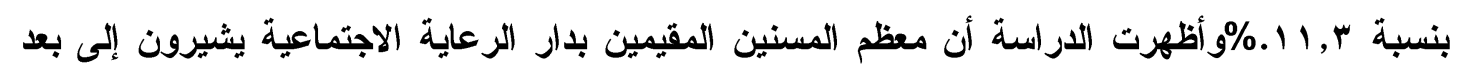

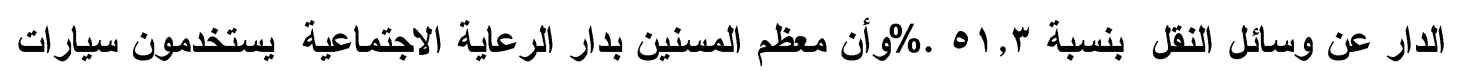
خاصة بهم للتنقل من مكان لآخر بنسبة ه, ب 7.\%وتبين الاراسة أن الغالبية العظمى من المسنين المقيمين بار الرعاية الاجتماعية يستغرقون من · 1 إلى 19 دقيقه للتنقل من مقر السكن إلى مقصدهم بنسبة

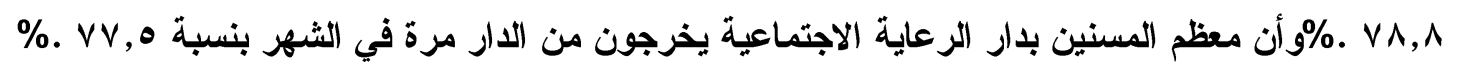
وأن معظم المسنين بدار الرعاية الاجتماعية بشيرون إلى بعد الخدمات عن دار الرعاية بنسبة هـ.و أظهرت الاراسة أن الغالبية العظى من المسنين بدار الرعاية الاجتماعية يقيمون في وحدات

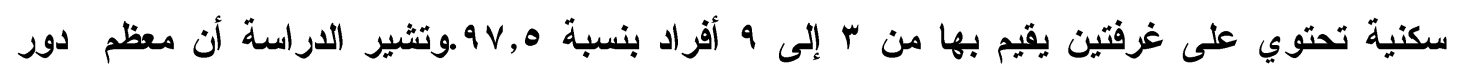
الرعاية الاجتماعية التي يقيم بها المسنين يوجد بها شخص مسئول عن الخدات بنسبة ه9.\%ويتبين من خلال الاراسة أن معظم دور الرعاية الاجتماعية التي يقيم بها المسنين يوجد بها شخص يقوم

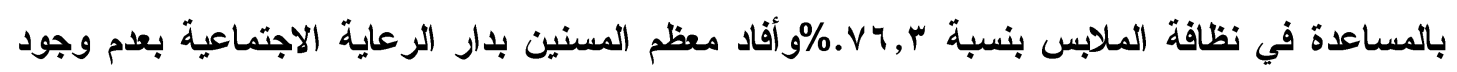

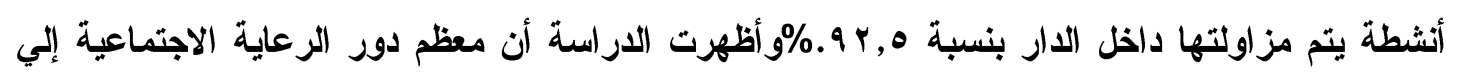
يقيم فيها المسنين لا يمنع نظامها من زيارة الأقارب بنسبة ه, ب.9\%وأن معظم المسنين بدار الرعاية

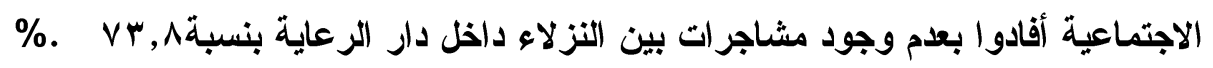
التوصيات العامة الأربطة الخيرية ودور الرعاية الاجتماعية بمدينة الطائف: ا. .إعداد برامج توعية وتثقيفية خاصة برعاية المسنين في جميع الجوانب الطبية والاجتماعية 
r. التوسع في إنثاء أندية وأماكن ترفيهية للمسنين وكنلك دور للرعاية الاجتماعية طبقاً للمو اصفات و الثروط التي تقرها الوزارة المعنية.

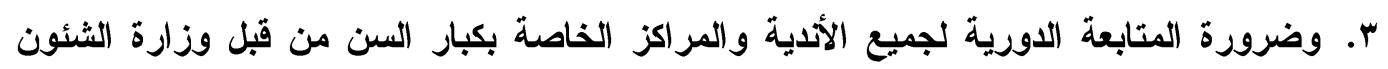

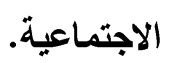
ع. ضرورة إذخال العلاقات الأسرية وحقوق المسنين داخل الأسرة ضمن برامج تدرس في مختلف

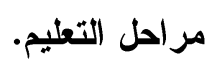
ه. تخصيص مادة علمية تربوية عن كبار السن وتدرس في كليات التربية والخدمة الاجتماعية و وأقسام علم النفس. 1. التخطيط المسبق لبناء الربط الجديدة بناء على احتياجات النزلاء الاجتماعية والاقتصادية

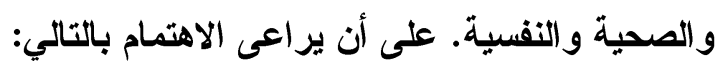

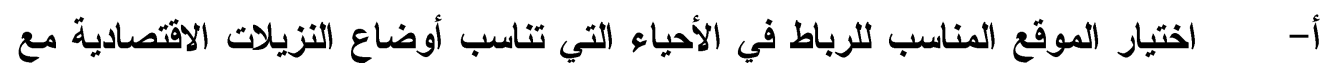
توفير المو اصلات ب- بناء الوحدات السكنية سواء من غرف أو شقق بمساحه تتناسب مع عدد الأثخاص الذين سيقيمون بها.

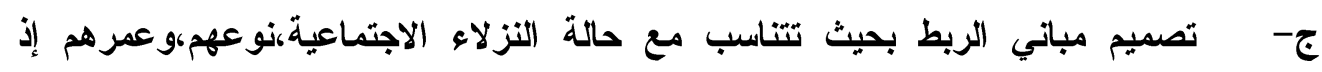
توضح بيانات الارلسة أن الأربطة الخيرية ذات تصميم تقليدي التي تتكون من غرفة أو الو غرفتين لا تناسب حجم الأسرة التي تسكن فيها.

أن يعدا صحاب الربط على معايير موضوعية في اختيار موظفين ذوي كفاءة إدارية، لان ألثيخه في

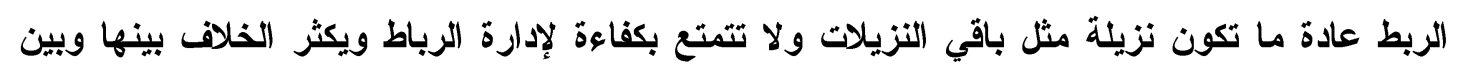
باقي النزيلات

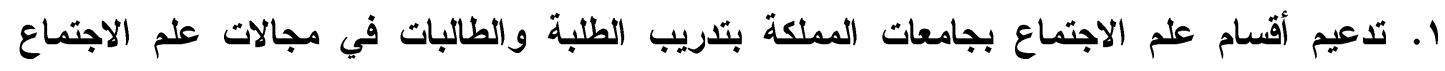

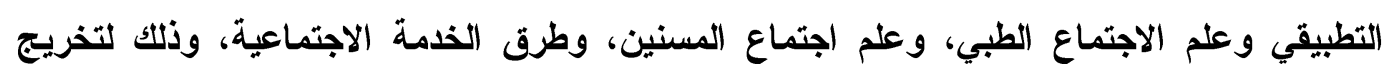

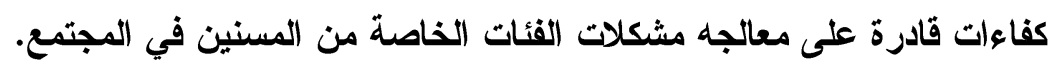
r. إنثاء مشاغل تلحق بالأربطة الخيرية من قبل الدولة أو فاعلي الخير ليتم تثغنيل النزيلات. r. حل مشكلة المواصلات التي تعتبر عائق لعمل معظم نزلاء الربط.

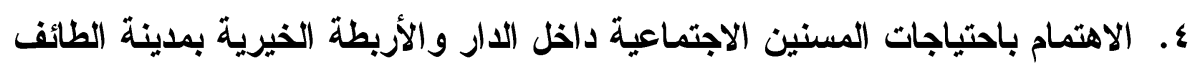

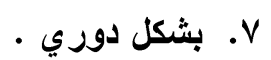


^. الاهتمام بنظافة المر افق الخاصة بالمسنين بكلأ من دور الرعاية الاجتماعية والأربطة الخيرية. 9. ضرورة التعاون بين كل من مدرية الثئون الاجتماعية ومكتب رعاية الثباب والرياضة لتوفير الأخصائيين الرياضيين والاجتماعين والإمكانيات لسد الفجوة بين النشاط الاجتماعي السائد في الأندية والنشاط الرياضي السائد. في المراكز وتحقيق التكامل والترابط في جميع الأشطة وتنفيذها في كل من المراكز والأندية الخاصة بكبار السن . • ا.ضرورة توفير سيارات خاصة لتنقل المسنين من مكان لآخر في كلا من دور الرعاية الاجتماعية والأربطة الخيرية مما يسهم في راحة المسنين وعدم شعورهم بأنهم مصدر ثقيل على غيرهم.

$$
\text { المصادر والمر اجع }
$$

$$
\text { المر اجع العربية }
$$

أبا الخيل، راثد محمد، (11 1 1 هـ)، مراكز العناية بالمسنين بالعالم نموذج مركز اجتماعي صحي للمسنين في المملكة العربية السعودية بحث مقدم لنيل درجة الاكتوراه، جامعة بوسطن، 911 ا. البريكان، لولوه بريكان ،(· ؟ ؟ هـ)، تغير دور المسن في الأسر السعودية نموذج للحصول على درجة

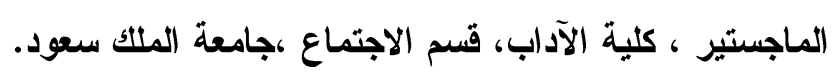
البخاري ، محمد اسماعيل ،صحيح بخاري، ،تحقيق مصطفى البغا،دار القلم، 1 ــ اهـ الحجاج ، مسلم، صحيح مسلم'،دار الباز ،مكة المكرمة، بدون تاريخ. الحميدان، عادل عبد الوهاب ، (11 ب r م ) كرسي أبحاث تطوير الرعاية الصحية للمسنين http://www.qmksu.com/newsletter/?p=1387

الحصين ، محمد عبد الرحمن، ( V V VV/ V ام.) دور الوقف في تأسيس المدارس والأربطة و المحافظة عليها في المدينة المنورة، مجلة جامعة الملك سعود ( العمارة و التخطيط )، جامعة الملك سعود • السلاحان، عبد الله ناصر ، (1) (1) رعاية المسنين في الإسلام ، الطبعة الأولى ـ المملكة العربية السعودية، الرياض.

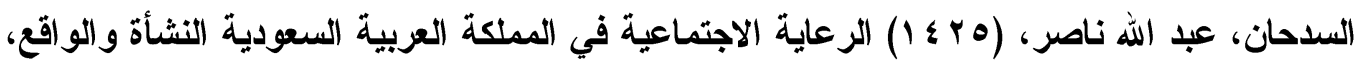

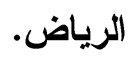




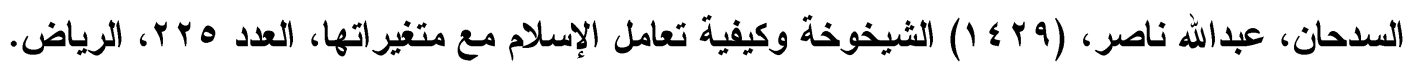

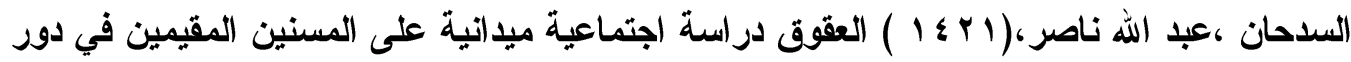
الرعاية، مكتبة الملك فها، الرياض.

السدحان، عبد الله ناصر، (1 ا I I ) الأوقاف والمجتمع مجموعة بحوث عن العلاقة التبادلية بين الأوقاف

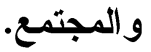

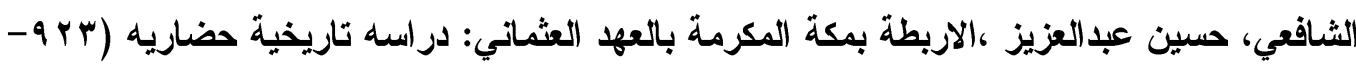

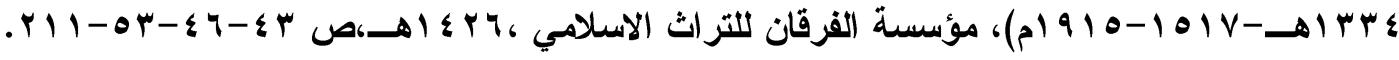
الثافعي، حسين عبدالعزيز، الاربطة في مكة المكرمة منذ البدايات حتى نهاية العصر المملوكي: دراسه تاريخيه حضاريه ،مؤسسة القرقان للتراث الاسلامي، ب ؟ ع اهـــ

الثمري، موضي مطني، (1) I I ) أثر العو امل الاجتماعية والاقتصادية والصحية في بعض النشاطات المختلفة لكبار العن، نموذج للحصول على متطلبات درجة الماجستيركلية الآداب .قسم الاراسات الاجتماعية ، جامعة الملتك سعود. الصقور، صالح، (r . . r) الهجرة الاخلية و التضخم الحضري،المملكة الأردنية ، عمان. عفيف ، سعاد عبود ، ( إ؛ اهـ ). مجتمع الربط ، دراسة وصفية لأساليب الرعاية الاجتماعية في بيوت الفقراء بمدينة جدة. جامعة الملك عبد العزيز ، بجدة. فهمي محمد ، رعاية المسنين اجتماعيا، ، المكتب الجامعي الحديث، الاسكندريه، \&19 ام محمود حسن. الخدمات الاجتماعية المقارنة ـ الطبعة الثانية ـ دار النهضة العربية بيروت، ب 91 اصص .$r r_{-} r$

المشهراوي ، سميرة جمال (1 أع ا ) الروابط الأسرية وصلتها بمشكلات كبار السن ، دراسة للحصول على درجة الماجستير ، قسم الاراسات الاجتماعية ، علم اجتماع. مرسي ، إبراهيم ، (YV \& ) كبار السن ورعايتهم في الإسلام وعلم النفس ، دار النشر للجامعات، مصر. موقع الأمم المتحدة، • 1 ـ مقال بعنوان: ارتفاع “رئيسي” في عدد المسنين في العالم: استناداً إلى تقرير

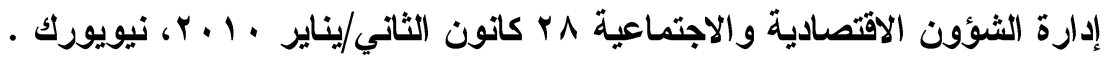


محمود حسن، عنوان الخدمات الاجتماعية المقارنة. الطبعة الثانية. دار النهضة العربية بيروت، به 19 ـ مصطفى، إبر اهيم وآخرون(9 9 9 1)."المعجم الوسيط"، دار الاعوة، تركيا. المر اجع الأجنبية

Allen, I. (1994): Elderly People, Choice, Participation and Satisfaction, 100Park Village East: London

Australian Housing and Urban Research Institute http://www.ahuri.edu.au

Ayoub, A (2002) Elderly care in Alexandria, paper introduced in the 3rd National Congress for Care for the Elderly

Phillips, D.R and J. Vincent (1988) Privatising residential care for elderly people: The geography of developments in Devon, England. Social Science \& Medicine, Volume 26, Issue 1, Pages 37-47

Examples and their Implication to Korean Counterparts

Victor, C (1987) Old age in modern society, New York, Croom Helm LTD,.

Gross, T.(1990): General Test and State Anxiety in Real Examinations, Educational Research Quarterly. (U.S.A).

Hong,E. (1999): Effects of Gender, Math Ability, Trait Test Anxiety, StatisticsCourse Anxiety, Statistics Achievement, and Perceived Test Difficulty on StatTest Anxiety. (U.S.A).

Health Supportive Design in Elderly Care Homes/ Swedish .

Iskandar, M: Care with love training programme for home health care providers, Al-Raida, 16, Pp57-58, 1999 
Okasha, A: Focus on psychiatry in Egypt, the British Journal of Psychiatry, 185, pp185-266, 2004.

Ogg, J. (2005): Social Exclusion and Insecurity Among Older Europears: The Infiuence of Welfare Regimes. Ageing Society, 1. 69- 90.

Rowan, D \& Ears, C. (1987): Fears and Anxiety. Longman, New York

Sadek, Amal, and Abou-Hatab, K: The community care for elderly people in Egypt: the current 
اتجاهات المعلمات نحو استخدام الوسائط الكارتوجر افية لرياض الأطفال في مدينة جدة

$$
\text { أ. سهام بنت سعدي بن سعيد السلكي }
$$

ماجستير الجغرافيا والخرائط، جامعة الملك عبدالعزيز، ومحاضرة "متعاونة " بجامعة جذة

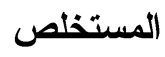

استعرضت الاراسة وجهات نظر معلمات الأطفال و المتخصصين في أهية استخلام الوسائط الكارتوجرافية في تلقي الطقل ، وذلك في ضوء اختلاف المؤهل الدراسي ومدة خبرة المعلمة في التريس ونوع المدرسة

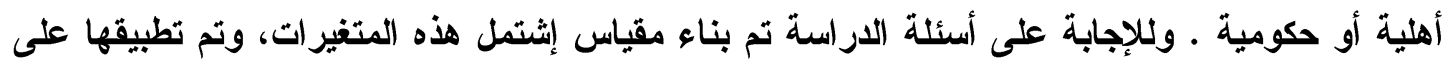

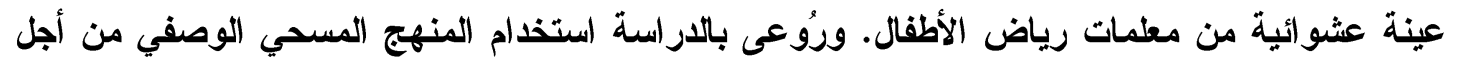
الوصول إلى تحقيق الأهداف الموضوعة للاراسة ، ولتقييم الدراسة تم إعداد استبانة تكونت من سابل عبارة تتطلق باتجاهات معلمات رياض الاطفال والمتخصصين لأهمية استخذام الوسائط الكارتوجرافية. وتوصلت الدراسة إلى تبين توافق معظم المعلمات المبحوثات على أهية استخام الوسائط الكارتوجرافية في مرحلة رياض الاطفال في تنمية المفاهيم المكاتية والإدراك المكاني واكتساب المطومات عن البيئة المحيطة ومعرفة الطفل للأماكن من حوله ، كنلك تو افق معظم المبحوثات (المعلمات) على أن الوسائط الكارتوجرافية في مرحلة رياض الأطفال تجذب انتباه الأطفال بأثكالها المختلفة ، وبما تحتويه من رسوم كارتونية وألوان متتوعة ، توصي الدراسة بضرورة تصميم وتنفيذ برامج إثرائية لتنمية وتدريب الأطفال

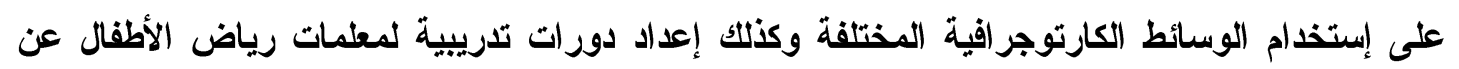
إستخدام الوسائط الكارتوجرافية وتوضيح أثارها الإيجابية ، وكنلك تفعيل المسابقات لإخراج وسائط كارتوجر افية من إعداد الأطفال والمعلمات تناسب بيئة الملكة العربية السعودية وتبني أفكار هم . 


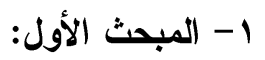

إجراعات الار اسة

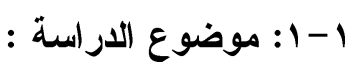

استعرضت الاراسة وجهات نظر معلمات الأطفال والمتخصصين في أهمية استخدام الوسائط الكارتوجر افية في تلقي الطقل ، وذلك في ضوء اختلاف المؤهل الدراسي ومدة خبرة المعلمة في التدريس ونوع المدرسة أهلية أو حكومية .

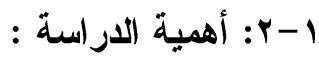

تعود أهمية هذه الاراسة إلى قلة الدراسات العربية المتعلقة بالنواحي الكارتوجر افية للطقل، فضــلاً عـن إمكاتية أن تسهم هذه الارسة في إعطاء صورة علمية واضحة عـن وجهــات نظــر معلمــات الأطفــال و المتخصصين في أهمية استخدام الوسائط الكارتوجر افية في تلقي الطفل.

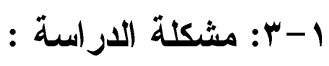

نظراً لأهمية مرحلة رياض الأطفال في نمو إدراك وفهم الطقل للمكان المحيط به ، تتأكد ضــرورة تنميـة المهارات اللازمة للطقل لتحسين وعيه المكاني ـ وتؤكد الدارسات على أن تعليم الطقل وتنميــة مداركــهـ ومعارفه في سن مبكرة، يعتبر من أهم العوامل المؤثرة إيجابياً في مستويات الأكاء والـــاكرة، والنثــاط العقلي في مراحل حياته المختلفة (2 ، Cohen ، 1994). وللوسائط الكارتوجرافية دور إيجابي في تنمية الإدراك المكاني لاى الطقل، ومع ذلك فهناكك قصور في المكتبة العربية على وجه الخصوص في الاراسات التي تناولت هذا الجانب من حيث وجهات نظر معلمات الأطفال والمتخصصين في أهمية استخدام الوسائط الكارتوجر افية في تلقي الطقل .

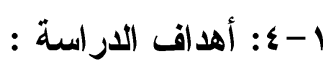

تسعى الاراسة لتحقيق عدد من الأهداف يمكن تلخيصها في النقاط التالية: أ- التعرف على وجهات نظر معلمات رياض الأطفال والمتخصصين التربويين لأهمية استخدام الوسائط

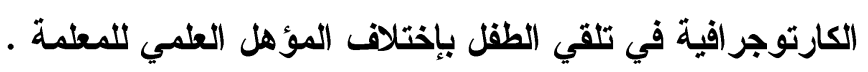
ب- التعرف على وجهات نظر معلمات رياض الأطفال والمتخصصين التربويين لأهمية استخدام الوسائط الكارتوجر افية في تلقي الطقل بإختلاف الخبرة العملية في التدريس للمعلمة 
ت- التعرف على وجهات نظر معلمات رياض الأطفال والمتخصصين التربويين لأهمية استخدام الوسائط

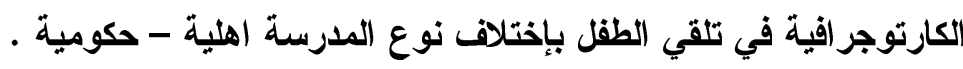

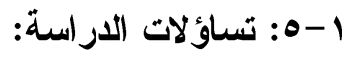

أ- ما هي وجهات نظر معطمات رياض الأطفال لأهمية إستخدام الوسائط الكارتوجرافية ، وهل تختلف هات

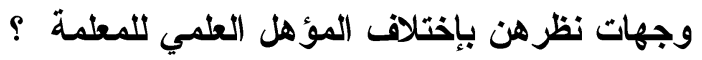

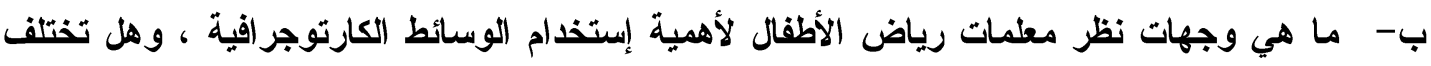

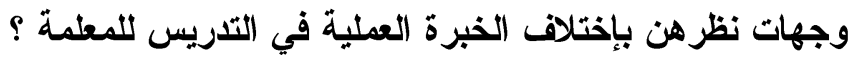

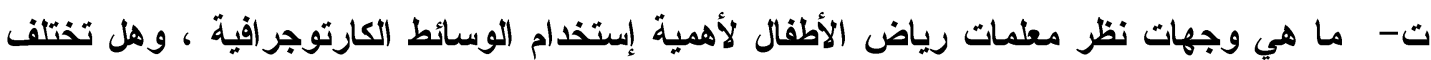

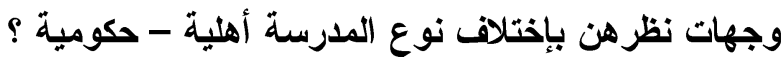

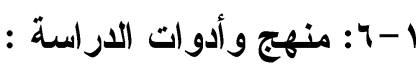

اتبعت الاراسة المنهج الوصفي التحليلي في وصف وتحليل رأي المتخصصات التربويــات فــي اســتخلم الوسائط الكارتوجرافية في مرحلة رياض الأطفال .واستعاتت الباحثة بالكتب والبحوث و الرسائل العلميــة، و المقالات الجغرافية العربية والأجنبية، والتي ترتبط بموضوع الاراسة للإحاطة بأبعاد الموضوع ـ كما تم بناء إستبانة إستطلاع رأي المعلمات. وتم استخدام الأساليب الإحصائية ببرنامج تحليـل بياتــات الحــزم الاحصائية (SPSS) لتحليل الاستبانة ، وعمل الرسوم البيانية .

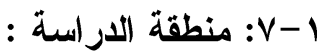
أجريت الاراسة في مدينة جدة في المناطق التعليمية (شمال جدة - جنوب غرب جدة - جنوب شرق جدة - وسط جدة) التي يوضحها شكل (1- (1) .

وقل بلغ عدد مدارس رياض الأطفال الأهلية بمدينة جدة . أ مدرسة ، OV مدرسة تابعة للمنطقة التعليمية بشمال جدة ، و هو مدرسة تابعة للمنطقة التعليمية بوسط جدة ، و أ مدرسة تابعة للمنطقة التعليمية بجنوب غرب جدة ، و 1 امدرسة تابعة للمنطقة التعليمية بجنوب شرق جدة . كما بلغ عدد مدارس رياض الأطفال الحكومية ع ع مدرسة ، فيها ب ا مدرسة تابعة للمنطقة التعليمية بشمال جدة ، وی مدارس تابعة للمنطقة التعليمية بوسط جدة ، و9 مدارس تابعة للمنطقة التعليمية بجنوب غرب جدة ، و ع مدارس تابعة للمنطقة التعليمية بجنوب شرق جدة ـ وقا تم أختيار المدارس التالية كعينة عشوائية تمثل بنسبة على مستوى المنطقة وهي (ملرسة القراعات النموذجية الأهلية - الروضة السابعة عشر) بمنطقة جنوب شرق جدة ، و(مدرسة الأمجاد الأهلية - الروضة العشرون) بمنطقة جنوب غرب جدة ، ومدرسة (أمال السعودية الأهلية - روضة الحسون الأهلية - روضة المميزون الأهلية - الروضة العاشرة) بمنطقة 
وسط جدة، و(مدرسة الالال الأهلية - مدرسة الثعلة الأهلية - مدرسة الأمم الأهلية - مدرسة أم القرى الأهلية - الروضة السادسة) بمنطقة شمال جدة ، والتي يوضحها شكل( (1-r). 1-1 : مجتمع الاراسة والحدود الزمنية : استخدمت الاراسة عينة من المعلمات في بعض مدارس رياض الأطفال الأهلية والحكومية بمدينة

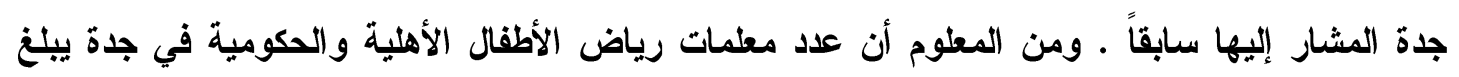

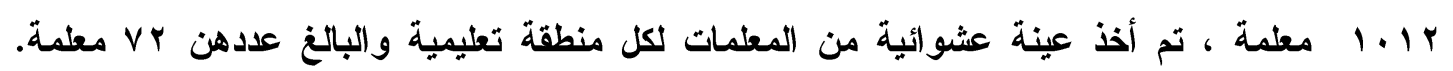

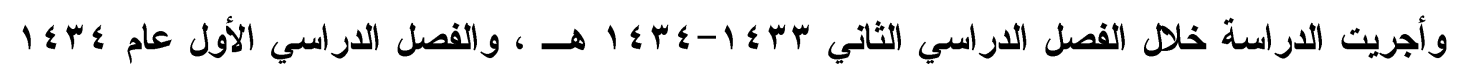

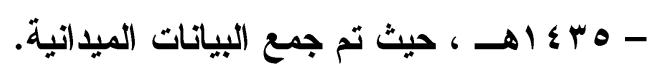
(الدات

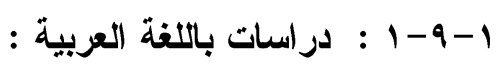

• دراسة شكر الله حاجي (، 9 ام) ذكر الباحث المهارات الأساسية في تعلم الجغر افيا، وتم الاقتصار في

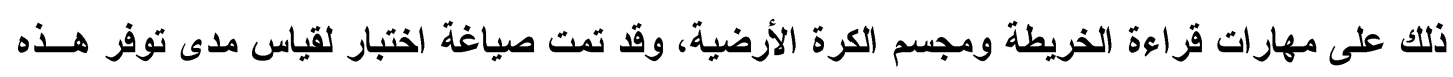
المهارات لاى طلاب المرحلة الثانوية، وقد تبين من الاختبار تدني مستوى الطلبة في هذه وأه المهارات.

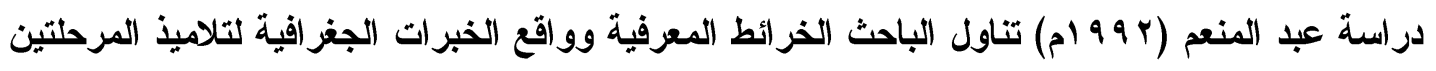
الابتدائية والمتوسطة بالمملكة العربية السعودية ، وتكونت عينة البحث من إيأ التميذًا من بعض المدارس الابتا ائية والمتوسطة بمدينة أبها ، وقد استخدمت الاراسة الأسلوب الكيفي النوعي الإحصائي. 


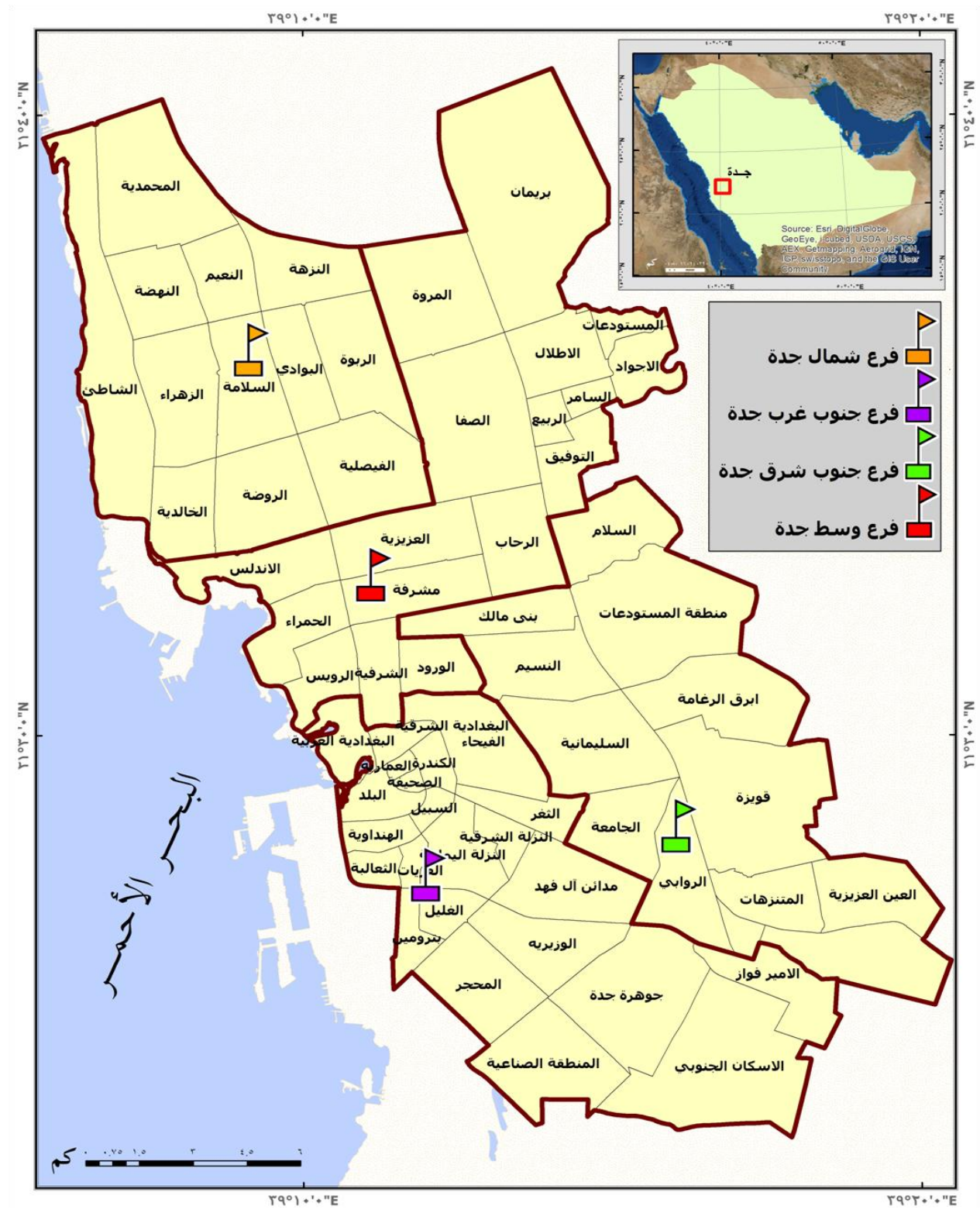

شكل (1- 1) فروع المناطق التعليمية بمدينة جدة ونطاقاتها

المصدر : من إعداد الباحثة

لذا تحددت أداة البحث في توجيه سؤال مفتوح إلى التلاميذ عينة البحث ،وهو تصور أنه طلب منك رسم خريطة تخطيطة للطريق الذي تسلكه من المنزل إلى المدرسة يوميًا، سواء بالسيارة أو سيراً على الأقدام توضح عليها الأماكن والأشخاص والظواهر البيئية المختلفة التي يأتي منها في ذاكرتك تصويريًا ولفظيًا ، مستخدمًا الرسم التخطيطي والرموز والألفاظ ـ وقد أثثارت الاراسة إلى افتقاد معظم الرسوم للخرائط التخطيطية الإثارة إلى الأماكن البعيدة ، كما خلصت الاراسة إلى أن سلوك التلاميذ البيئي يعتبر وظيفة 
مباشرة لمدى التعلم الأي يحصل عليه هؤلاء التلاميذ، وأتهم بحاجة إلى المعرفة البيئية ، وضرورة الربط بين ما يتعلمون في الجغرافية وبين خبراتهم المكانية و البيئية.

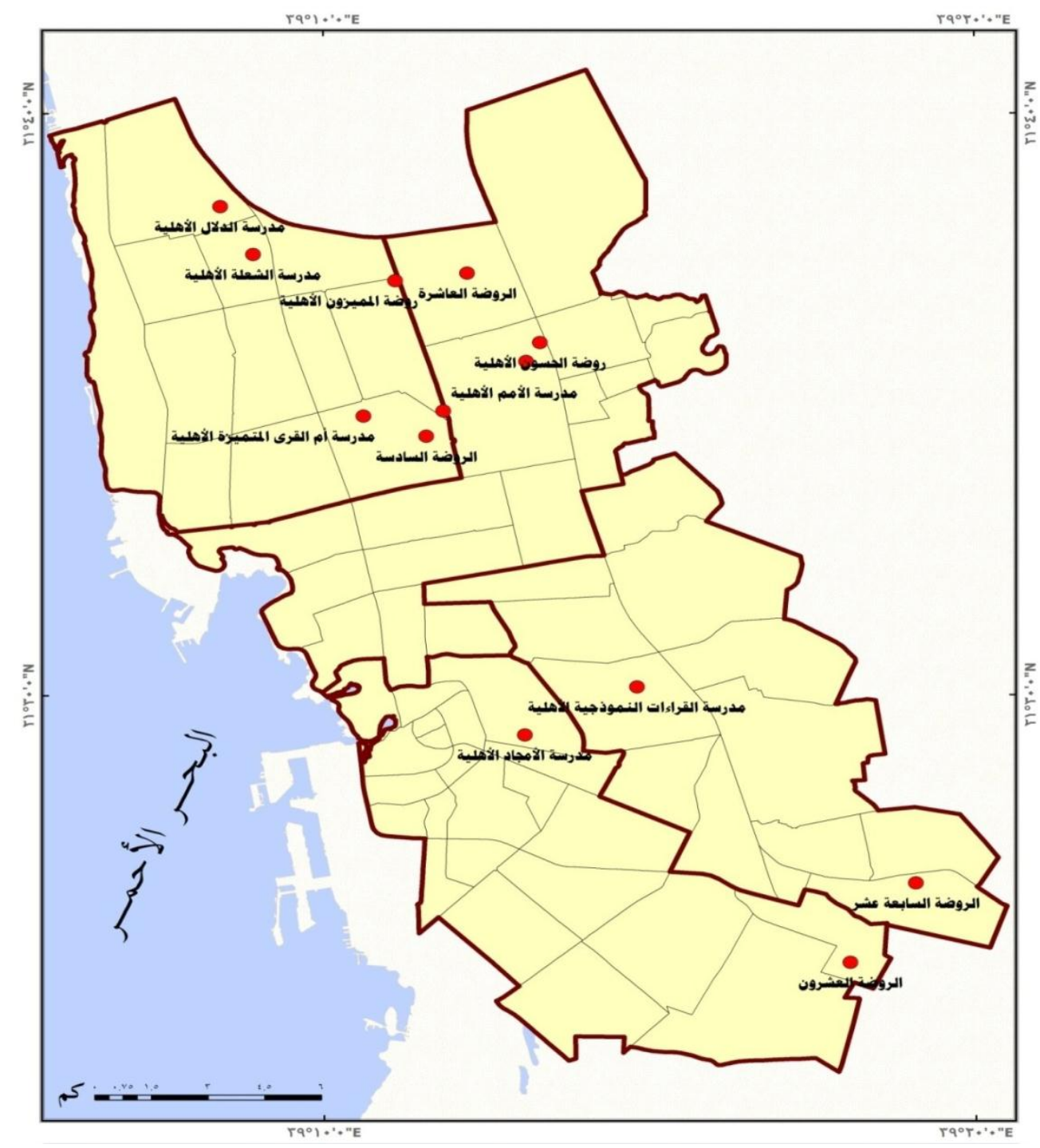

شكل (1- ب) توزيع مدارس العينة بمدينة جدة

المصدر: من إعداد الباحثة

دراسة حسن عايل (1 إكاهـ) ذكر الباحث أنه من خلا الخرائط الجغرافية يكتسب الطلاب خبرات تعليمية متعددة مثل مواقع الظواهر الجغرافية الطبيعية والبشرية. ويتم تمثيل تلك المعلومات والبيانات و المفاهيم الجغرافية بالرموز النوعية والكمية والألوان المختلفة وغيرها من وسائل التمثيل الكارتوجر افي. 
وتعتبر قراعة الخرائط وتفسيرها وسيلة اتصال هامة بين القارئ والمجردات التي تمثل الأرض أو جزاً منها، بواسطة الرموز كالخطوط و النقط والألوان وغيرها .

• دراسة سامع عبدالوهاب (19 (9 ام) قام الباحث بتقييم مستويات التلقي لأنماط مختلفة من التمثيل البياني للكثافة السكانية التي قام بتصميمها على خرائط الكوروبلث عن سكان مدينة القاهرة. • دراسة إسماعيل يوسف (991 ام) كثفت الاراسة عن بعض الجوانب السلبية الهامة في ملامح الثقافة المكانية القومية للشباب، وأسباب ضعف هذه الثقافة وعواقبها على المجتمع المصري ،وكيفية

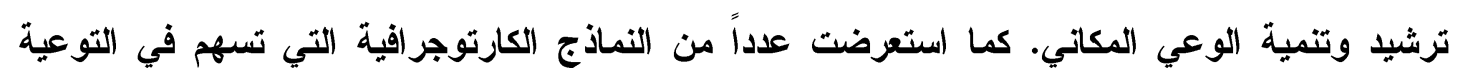

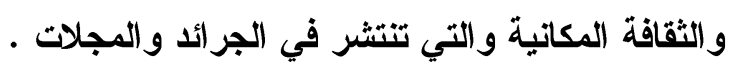

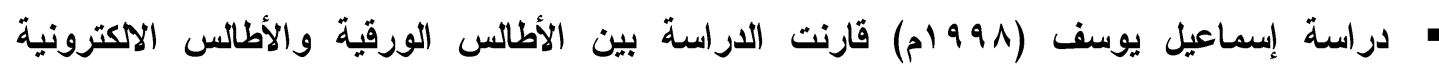

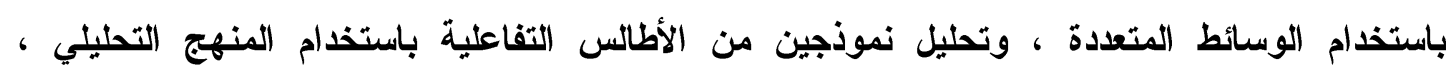

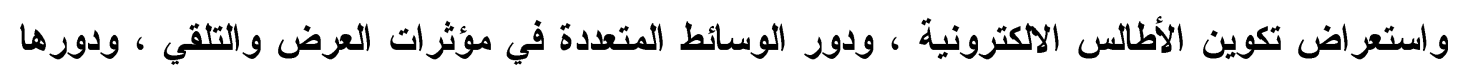
في المعرفة الجغزافية .

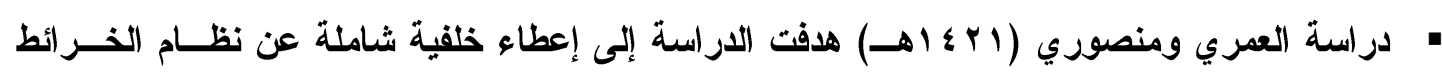

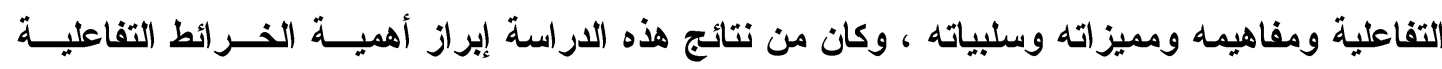

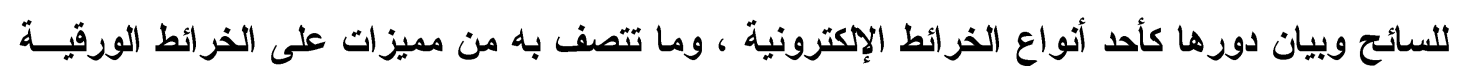
التقليدية . • دراسة زهير مكي وآخرون (1 . . آم) هدفت الدراسة إلى تثخيص الإدراك الذهني لخارطة الوطن

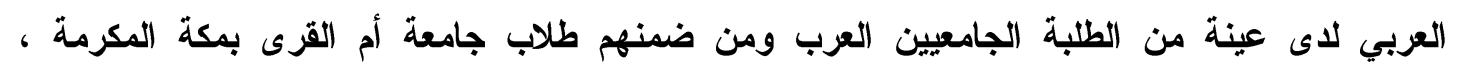
وهدفها كثف مواطن القوة والضعف في إدرالك تلك الخارطة.

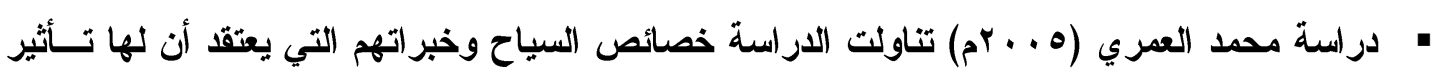

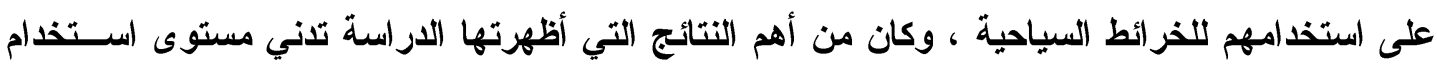

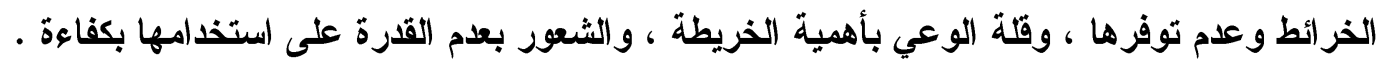

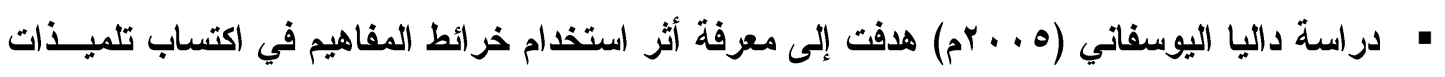

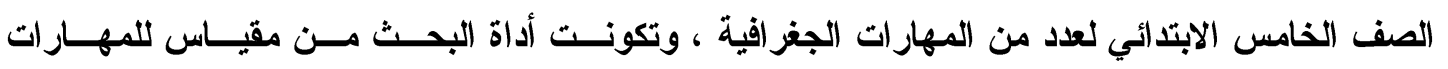
الجغر افية . الصفية

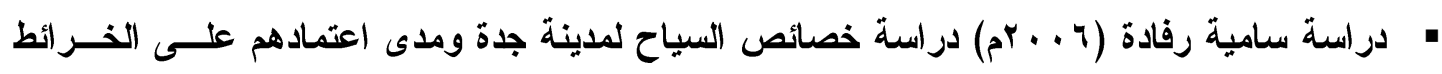

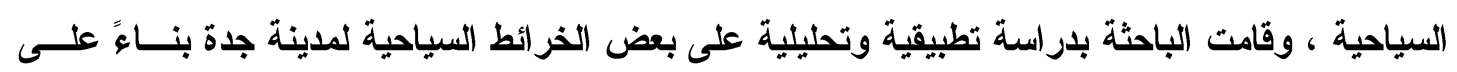
عدد من المعايير الخرائطية .

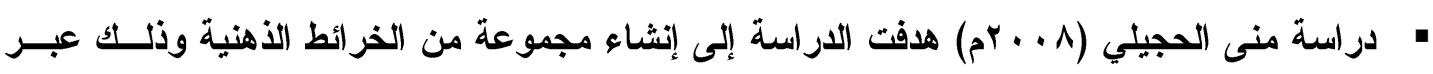

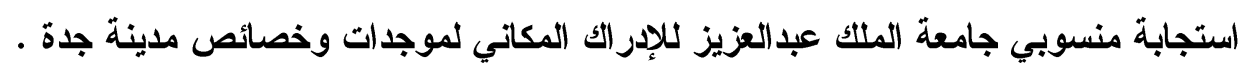




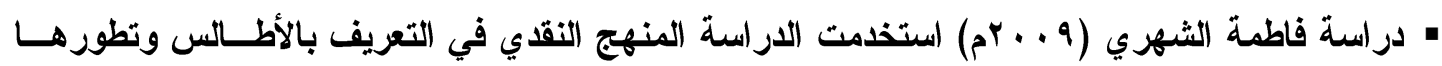
وتصنيفها، وأسس تصميمها وعو امل إنتاجها. واستخدمت المنهج التحليلي في تحليل التركيب الفني لعينة

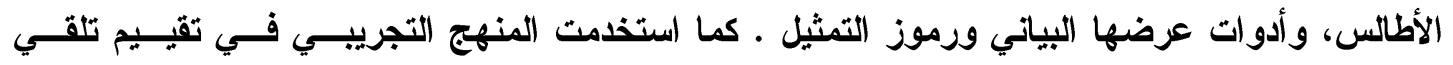
مستخدمي الأطالس التعليمية في العينة بناء على عدد من المعايير ، والكشف عن إتجاهــات مســتخدمي

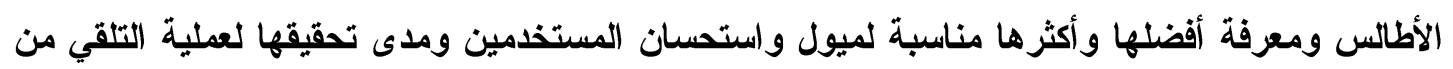
وجهه نظرهم. • دراسة جواهر القحطاتي (9 . . rم) هدفت الدراسة إلى وضع أطلس شارح يضم خرائط تفصيلية لتوزيع الأمر اض المتوطنة وكذلك هدفت إلى التعريف بماهية الأطالس والخرائط الطبية وتطورها التارئ التاريخي و استخدامها في الاراسة كأداة اتصال تمكن من نقل قرك كبير من البيانات والمعلومات في وقت قصير ومساحة صغيرة من خلال نظرية الاتصال الكارتوجر افي.

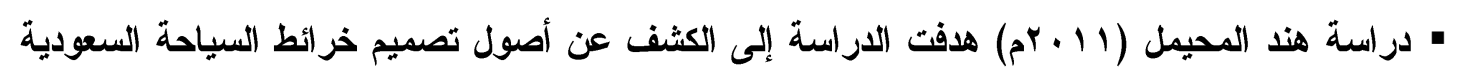

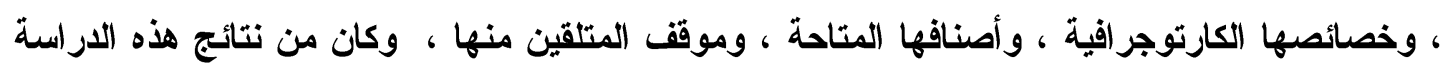

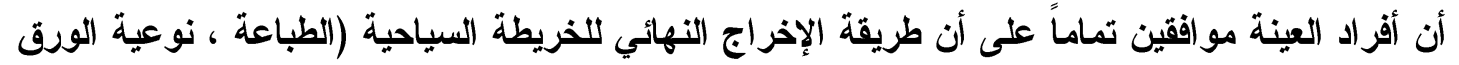

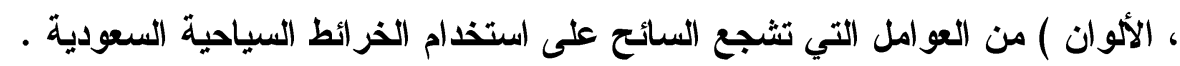

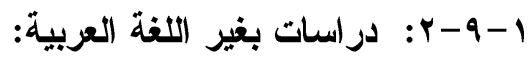

• دراسة Catling C (9v9 ام) هدفت إلى التعرف على قرات الأطفال الصغار في رسم الخرائط المعرفية ، وتوصلت الاراسة إلى أن الأطفال الصغار يبدعون حقا في رسم الخرائط المعرفية ويستخدمون المعلومات لحل المواقف الراهنة ، وأن قرات الأطفال على رسم الخرائط المعرفية وكفاء|تهم في تمثيلها تنظور وتظهر كلما نضج الطقل . • دراسة Hewes (ץ 9 (ام) هدفت إلى وضع تصور لتنمية حاسة الأطفال في سن ما قبل المدرسة

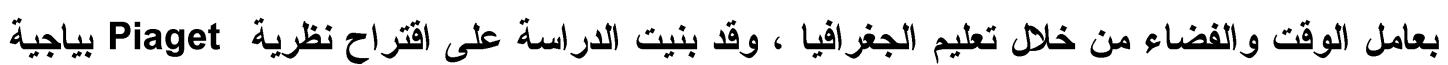

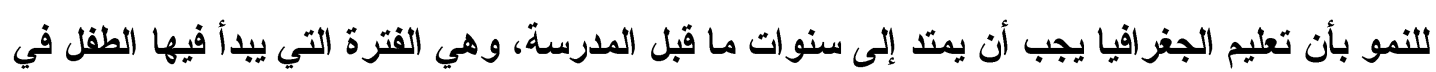
ترميز وتصنيف العالم الخاص به ـ وتوصلت الاراسة إلى أن اكتساب الأطفال الصغار للمعلومات الجغر افية الجية

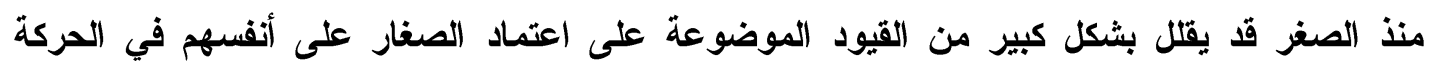
والاتتقال من مكان إلى آخر ، كما أوصت بضرورة حصول معلمي ما قبل المدرسة على تدريب كاف في تعليم الجغر افيا لاى الأطفال الصغار.

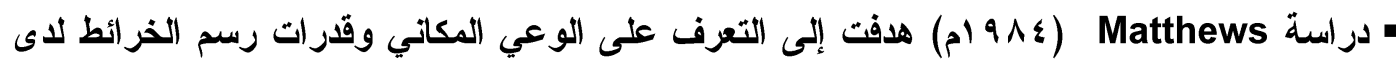

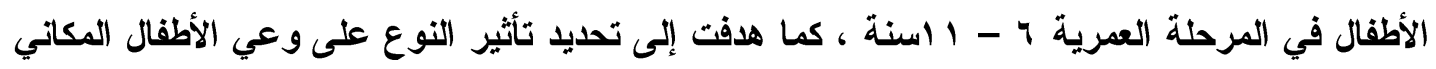

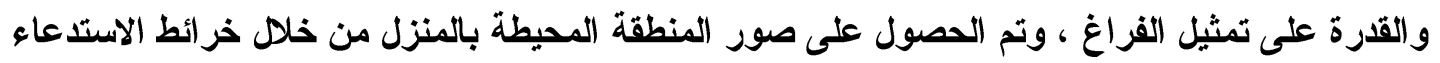

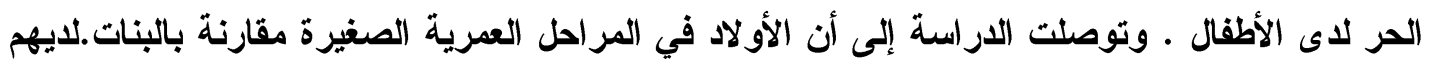

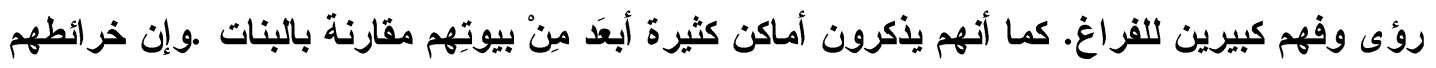


أكثر تعقيدا في عرض العلاقات المكانية .كما توصلت الاراسة إلى أن للنوع دورًا قويًا في الرسم الكارتوجر افي ودقة الخريطة .

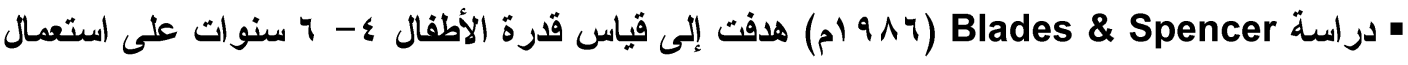

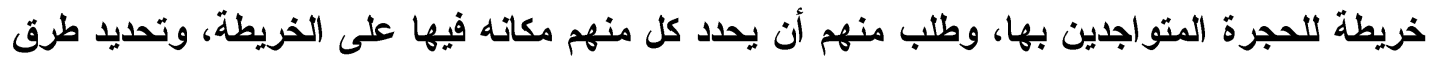

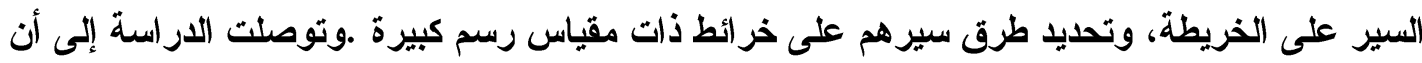

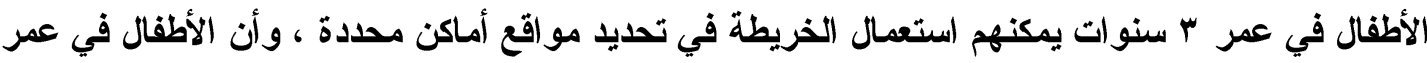

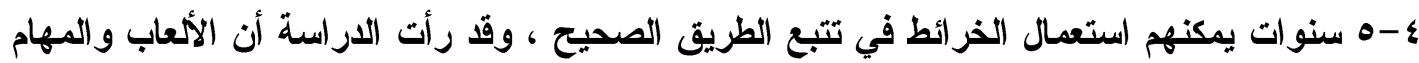
المتضمنة لاستعمال الخريطة قـ تكون طريق فعال لتعريف الأطفال الصغار بمفهوم الخريطة . • دراسة Gauvain \& Rogoff (9/9 ام) هافت إلى التعرف على أثر العمر في تطوير مهارات

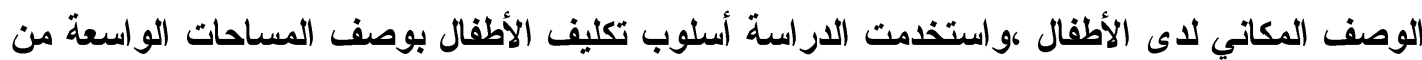

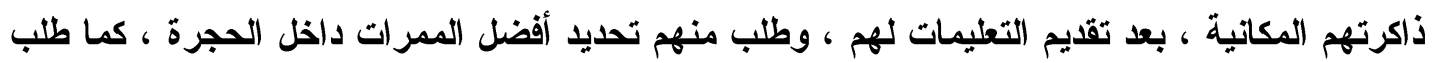

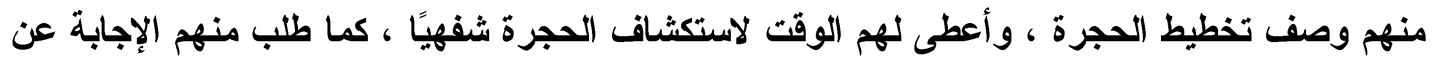

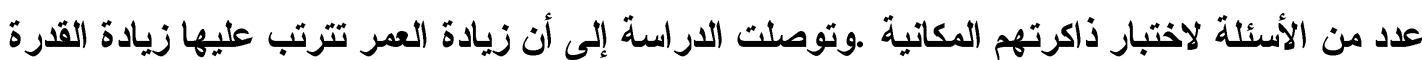
على الوصف بدقة. • دراسة Rosângela Doin de Almeida (9qv) ام) تهاف الدراسة إلى إعداد أطالس مدرسية

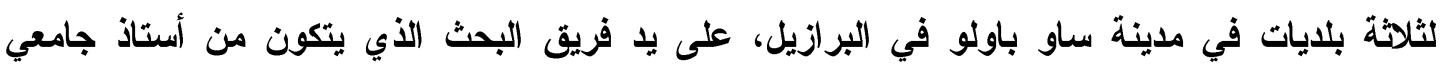
ومعلمين مدارس ابتائية وعينة من الطلاب، وتم إجراء اختبارات التلقي على الطلاب للتحقق من فاعليتّا

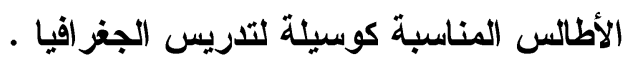
• دراسة Regina Araujo de Almeida (99 ا ام) هذفت الدراسة إلى تعريف الأطفال بالمفاهيم

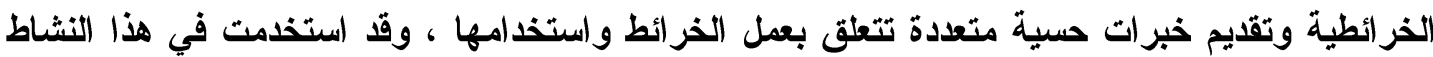

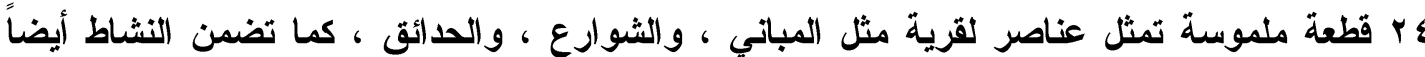

$$
\text { استخام البوصلة ، ومفتاح رموز الخريطة. }
$$

• دراسة Jacqueline Anderson (19 (9 ام) هدفت الاراسة إلى تقايم مفهوم مفتاح رموز الخريطة

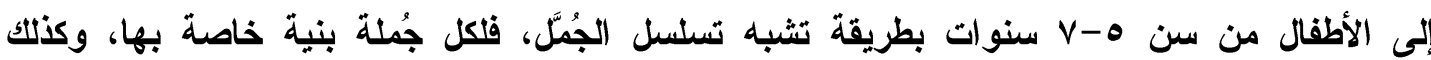
الخريطة بها صور وعلامات وما تمثله هذه العلامات (تقدم في شكل صور الأثياء أو المعالم والكلمات).

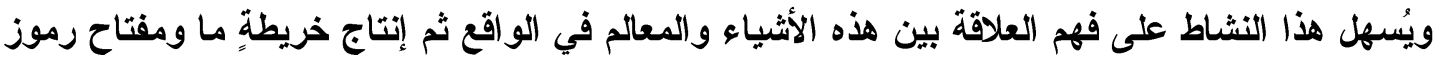

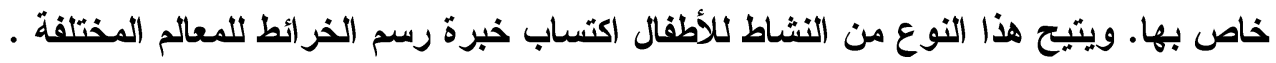

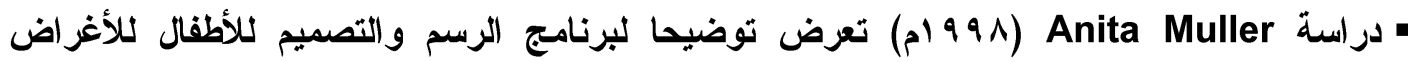
الخرائطية وهو برنامج يقوم بتديم وتثجيع الأطفال على الإبداع ويسمح لهم باستخدام الكمبيوتر بطريقة

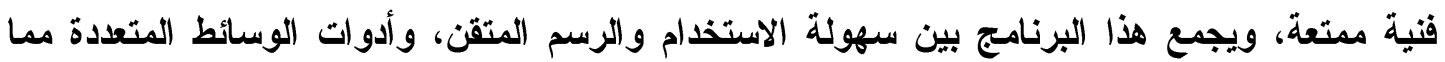

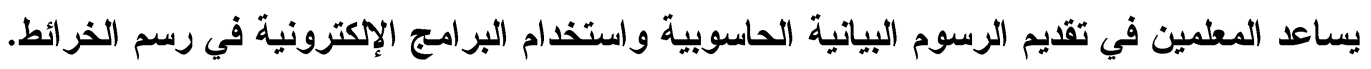




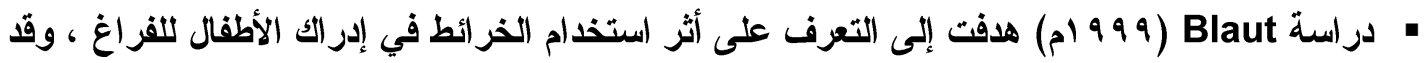
توصلت الاراسة إلى أن الأطفال يتطلمون ويطورون من قدراتهم في الخرائط المعرفية من خلال استكثافهر للطرق التي بسيرون بها ، وأن الأطفال في هذا مثلهم مثل الكبار يستخدمون خبراتهم البيئية في تمثيل الأماكن المحيطة بهر.

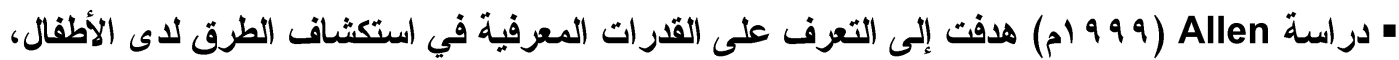
وتوصلت الاراسة إلى أن الملاحظة تمكن الأطفال من خلال حركة تنقلاتهم اليومية من أن يتذكروا الطرق

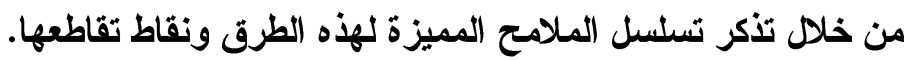
• دراسة Peter Pulsifer (999 (99) هدفت إلى إستخدم الخرائط وصور القمر الصناعي والفيديو و النصوص لنقل صورة المناطق والبيئات والثقافات المختلفة للتلاهيذ في كندا، كما تم ابتكار النسخة التعليمية التي تناسب الأطفال في سن المدرسة.

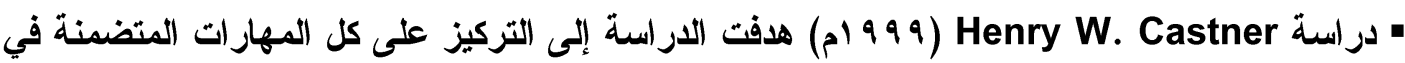

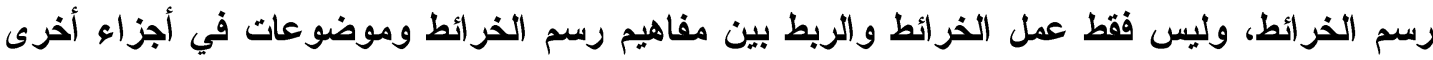
من المنهج وضبط مشكلات التصميم الخاصة بالأطفال، والتي يقومون فيها بعمل استعار التهات بيانية، وكذلكت تقايم العديد من التقنيات لرسم الخرائط للأطفال، وليس فقط التقنيات الإكترونية.

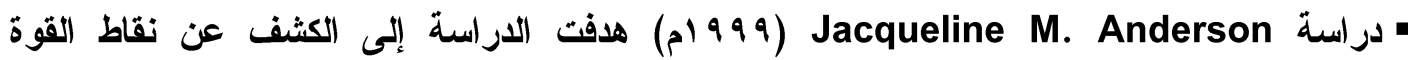

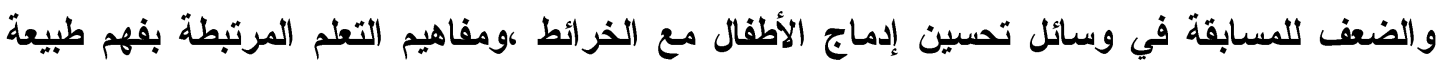
ودور الخرائط. • دراسة Joséphine Barry Davis (999 ام) هلفت اللدراسة إلى إلقاء نظرة على البيئة والمنهج الأي يمكن أن يقود الأطفال البالغين من العمر ؛ أعوام إلى التحول من الإحساس البايهي بالوقت (الماضي،

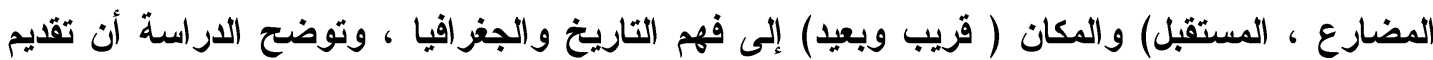

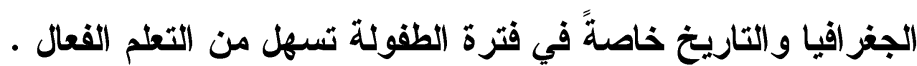

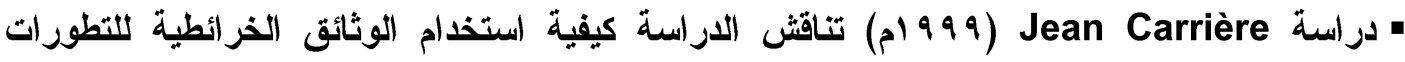
التكنولوجية في الاستذام التربوي ، حيث تؤثر التكنولوجيا على الطريقة التي يطور بها الأطفال معرفتهم الخرائية، سواء كاتت رسم أو قراعة خرائط. • مقالة Janine Gisèle Le Sann (99 ا99) تتحدث هذه المقالة عن إنتاج الأطالس المدرسية، وتهذف هذه الأطالس إلى تحسين قدرات وإمكاتيات الأطفال في تعلهه طوال حياتهم ومدى اكتسابهم لمعرفة. - لمقالة Vasiliki Filippakopoulou Nakos et.al. دراسة تقام الغناصر البيانية الأساسية التي يقوم عليها تصميم الرموز الخرائية لطلاب الفصل الأول

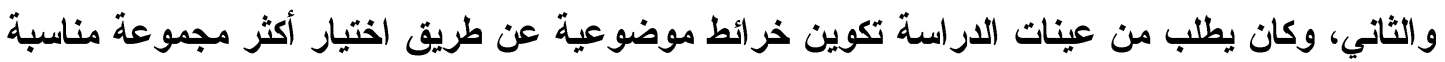

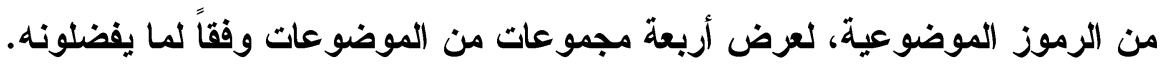


• دراسة Tania Targino (... Trم) تناولت الاراسة مدى فاعلية مناهج التعليم المتعدد في عدة

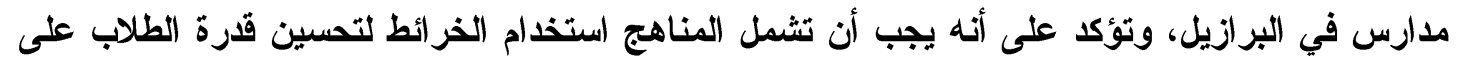
بناء المعرفة، كما أن استخدام الأسلوب الخرائطي يطور من القدرة على الفهم الأكثر شمولاً، ويجب تقديمه في سن مبكرة لتعزيز عملية التعلم الفعال. • دراسة Tammy Kwan (. . . rم) هدفت الاراسة إلى تمكين الأطفال من استخدام الخرائط لتسهيل عملية إيجاد الطريق way tinding ، وتطوير إدرالك أهمية معرفة مفاهيم الخرائط وممارسة مهاراتها. وقد أثتبت نتائج الاراسة أن المعلمين يمكنه الاستفادة من المعلومات الناتجة فيما يتعلق بقدرة الأطفال

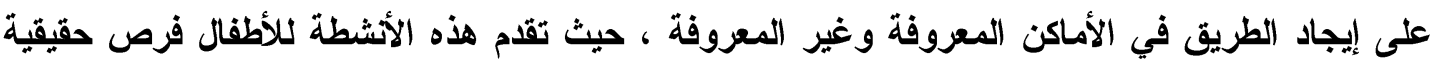
لاستخدام الخرائط في البيئة الفعلية، وبالتالي تعمل على تطوير مهار اتهم في حل فل المشكلات.

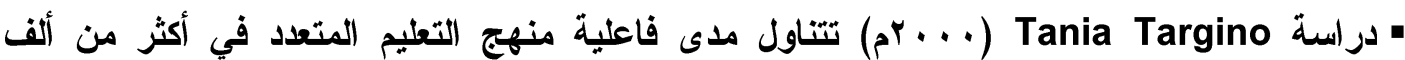
مدرسة في البرازيل، وتؤكد على أنه يجب أن يشمل هذا المنهج نمط خرائطي في الممارسة التربوية، وقدا فأه أثشارت الار اسة إلى أن هذا يعمل على ظهور ممارسات جليدة في التدريس لتحسين قارة الطلاب على بناء

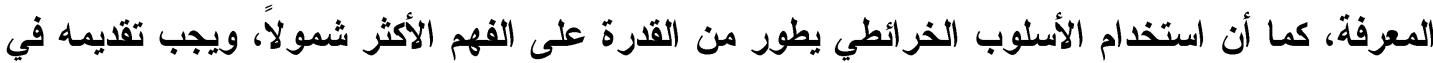
سن مبكرة لتعزيز عملية التعلم الفعال.

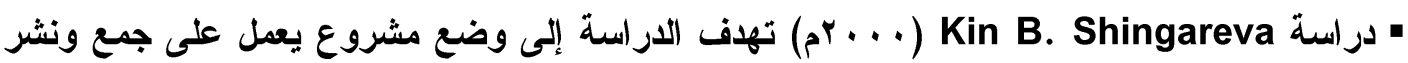
سلسلة من الخرائط الكنتورية ومخططات لكل من عطارد والزهرة والمريخ والأرض والقمر وأقمار الكواكب العملاقة ، وتم وضع بعض المعلومات عن خرائط الكواكب للأطفال ووصف الجغرافيا خارج

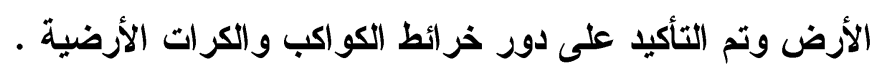

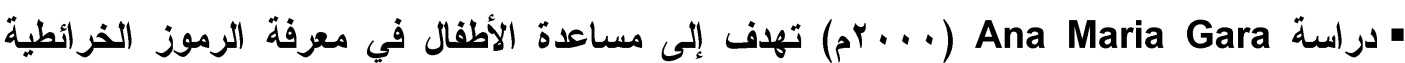
واكتساب المعرفة الخرائطية وتسهيل عملية استبعاب المفاهيم.

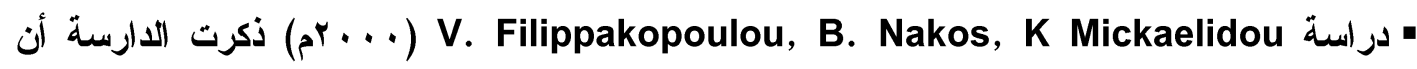
الأطفال الذين يستخدمون الخرائط يستطيعون أن يقدموا بيئته المحية وبلدهم أو قريتهم أو الدول

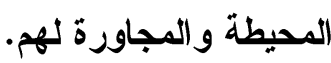

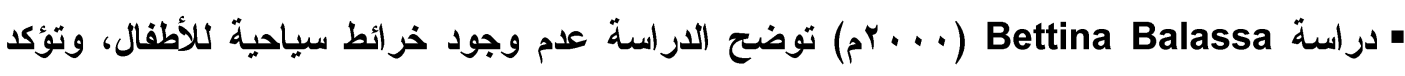
الار اسة على ضرورة وضع خرائط سياحية وتدريسها للأطفال .

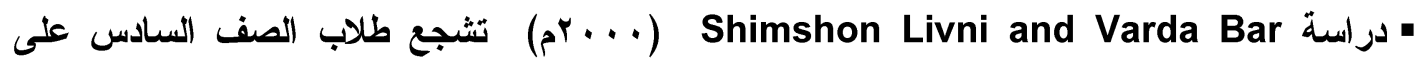
استخدام الخرائط لاكتساب خبرة تعلميه عن بعض المواقع في المدينة المركزية المجاورة ، ويشرح هذا

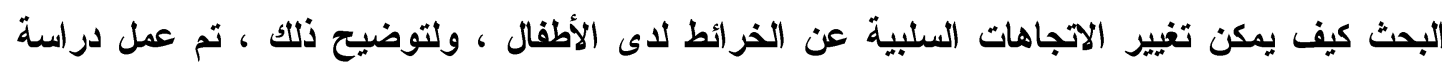
تجريبية تضمنت رحلة تجول لتقييم استخلام الخرائط ، وقامت بتقييم وفحص اتجاهات الطلاب نحو الخرائط

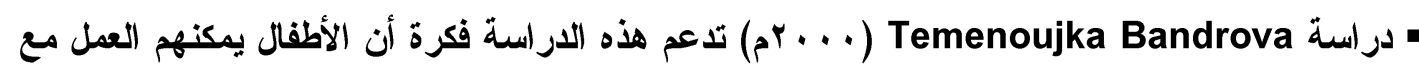
رسامي الخرائط والمعلمين لتكوين وتصميم خرائط وأطالس. وقا أجريت دراسة تجريبية ضمت أطفال 
تتراوح أعمارهم من ^-1. سنوات وكانت تهدف لفحص الطرق المقترحة وذلك عن طريق السماح للأطفال بالعمل مع رسامي الخرائط لتطوير خريطةٍ ما وأثبتت النتائج الأثر الإيجابي للممارسة في فئ تعزيز فهم الأطفال لكلا من المعرفة المرئية والخر ائطية.

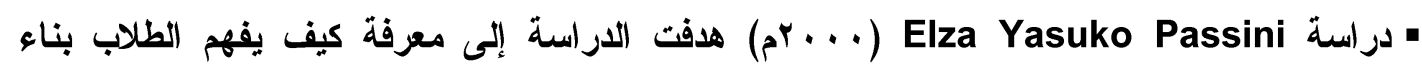
وقر اعة الرسوم الجغر افية مع المعنى الحقيقي لها، وملاحظة أثنكال التنسيق بين (الموضوع) والهدف، وقد اقتر اح منهجية لتحسين مهارات الطلاب وفهم الرسوم الجغر افية.

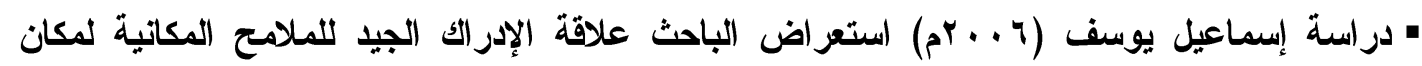
معين بمدى تآلف الفرد مع بيئته، وذلك من خلا تقييم بعض المدركات المكاتية، والتي تعبر عن تكيف السكان في بيئته الحضرية. وبعد استعراض الدراسات السابقة العربية والأجنبية نلاحظ أن الدراسة الحالية تثابهت مع دراسة

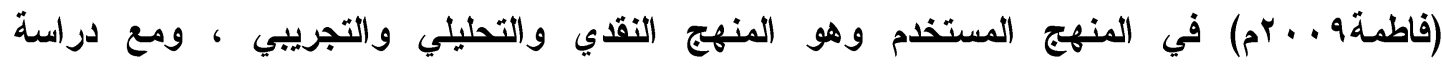

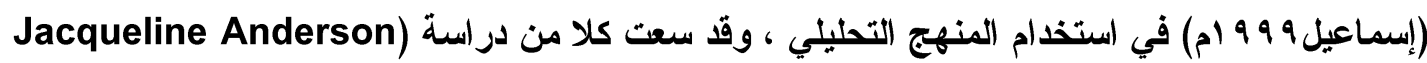

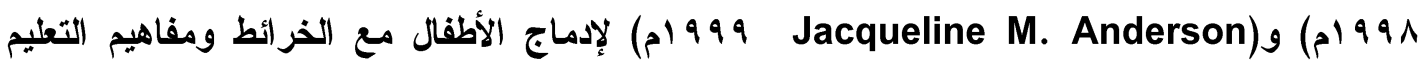
Anita (المرتبطة بفهم طبيعة ودور الخرائط ، وتثابهت دراسة (99 Jacqueline Anderson)

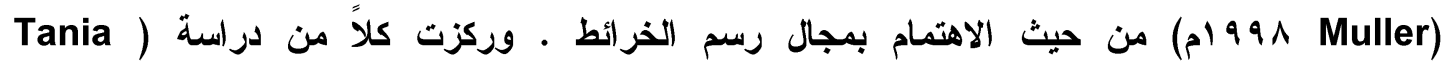

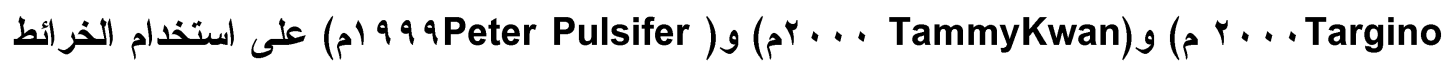
كأسلوب للتدريس في سن مبكرة لتعزيز تعلم الطقل الفعال وتنمية مهاراته في حل المشكلات. وبذلك

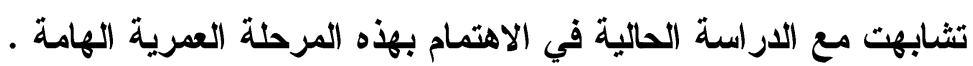

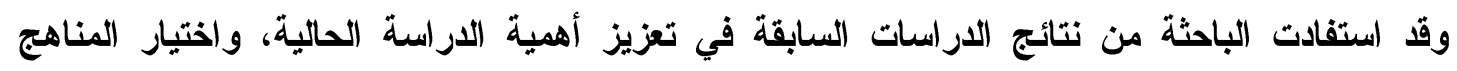

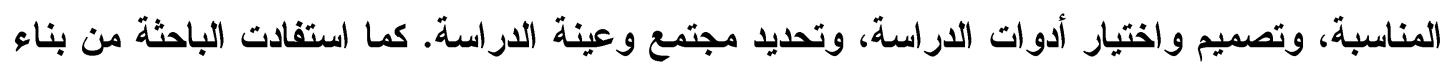

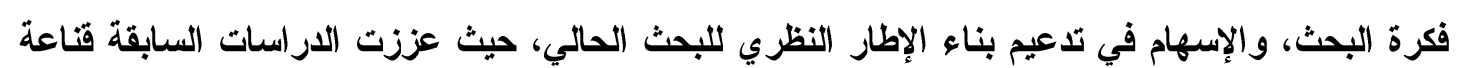
الباحثة بأهية الموضوع ، واستفادت الباحثة أيضاً من الاراسات الأجنبية التي تناولت المراحل لإلت العمرية

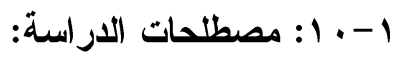

: Cartography الكارتوجر افيا

يهتم علم الكارتوجرافيا ( علم الخرائط ) بالخريطة من حيث المادة التي تحتويها ، وطريقة تمثيلها ، ومراحل إنتاجها ، وكيفية الاستفادة منها ـ (عبدالباسط، ؛ . . rم، ؟) ، الكارتوجر افيا هو التخصص الأي ينشئ الخريطة ويدرسها من مختلف جوانبها العلمية . ( إسماعيل ويكير ، 999 ام ، V ) . وتهتم Map Legend الكارتوجر افيا بقواعد الإخراج القني للخرائط ، وتعديد الثكل الأسب لمفتاح الخريطة ومكاته الصحيح ، وأيضاً شكل ومكان مقياس الرسم ، وقواعد توجيه الخريطة نحو الشمال الجغرافي 
الحقيقي ، وشكل الإطار الخارجي والداخلي للخريطة ، والموقع الأفضل لعنوان الخريطة ، وهذه القواعد الفتية تعتبر من أهم متطلبات عرض المعلومات الخرائطية .( عزيز ، 1991 م ، بـ ) . وتهتم الكارتوجرافيا بوضع الخرائط بلاءا بتصويرها وبدراسة أصنافها وأسس صياغتها ومعالجتها و إنجازها .

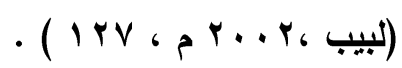

الروية الاتصالية للخريطة Communication focus :

هي توصيل المعلومة الجغرافية الممثلة على الخريطة إلى مستخلم الخريطة بطريقة يفهما المستخدم. هذه الطريقة تبنى على أسس محددة لطريقة التمثيل والترميز على سطح الكرة الأرضية من مطلومات على

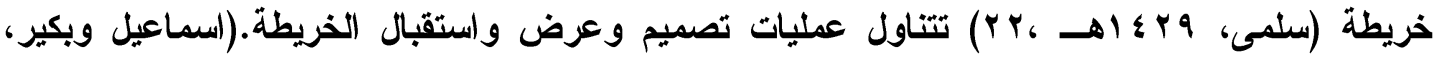
$\cdot(r \leq 6) 999$

\section{خرائط الأطلس Atlas maps :}

هي عبارة عن مجموعة من الخرائط المتنوعة والرسوم البياتية ،والأثنكال التوضيحية والصور الجوية والصور الفوتوغرافية بالإضافة إلى الفهرس والكشاف والمعجم والملاحق والإحصاءات والثروحات ،و المصادر والمراجع التي ترتبط جميعها بالموضوعات الجغرافية وتكون في مجلا واحد . ( يحيى،

$$
.(\leqslant 9-\leqslant \Lambda \text {. }) 99 \Lambda
$$

\section{خرائط الحائط Wall maps}

تم تصميمها لتهيئة الفرصة أمام التلاميذ لار اسة البيانات و المعلومات الجغر افية وهي كخر ائط الأطلس من حيث المحتوى وقد تكون طبيعية أو سياسية أو اقتصادية أو اجتماعية وحجمها أكبر من خرائط الأطلس .

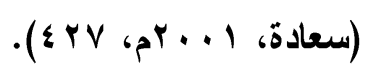

رياض الأطفال Kindergarten

هي مؤسسات تربوية تعليمية ترعى الأطفال في المرحلة السنية من ثلاث حتى سن السادسة، وتسبق

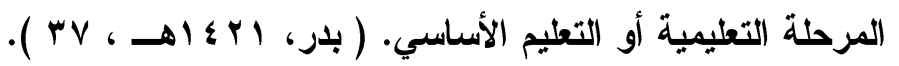




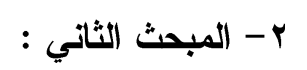

\section{اتجاهات المعلمات نحو استخدام الوسائط الكارتوجر افية}

r- 1 : اتجاهات المعلمات نحو استخدام الوسائط الكارتوجر افية في مرحلــة ريــاض الروضــة : تــــ تخصيص (r 1) فقرة لقياس آراء المعلمات نحو استخدام الوسائط الكارتوجرافية في مرحلة رياض الأطفال ، وتم حساب التكرارات والنسب المئوية والمتوسطات الحسابية والاتحر افات المعيارية ،و الرتب لاستجابات أفراد عينة الاراسة على عبارات محور اتجاهات المعلمات لأهمية استخدام الوسائط الكارتوجر افبــة فــي

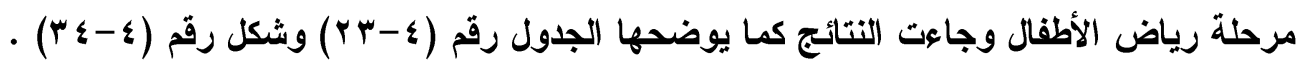

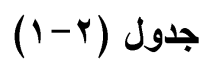

المتوسطات الحسابية والاححر افات المعيارية و الترتيب لفقرات اتجاهات المعلمات نحو استخدام الوسائط

\begin{tabular}{|c|c|c|c|c|c|}
\hline الموجة & الترتيب & المعياري & المسابي & الفقرات & b \\
\hline عالية جدا & 1 & .,OH & $\varepsilon, V \varepsilon$ & يصف الطفل شكل الكرة الأرضية. & $v$ \\
\hline عالية جدا & $r$ &., $07 r$ & $\varepsilon, V r$ & الكرة الأرضية. الطفل اليابس والماء على نموذج & $\wedge$ \\
\hline عالية جدا & r & .,orv & $\varepsilon, V r$ & 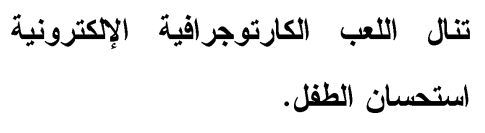 & ir \\
\hline عالية جدا & $\varepsilon$ & $\cdot, \varepsilon \wedge \wedge$ & $\varepsilon, \vee$ & مع المرحلة العمرية لرياض الأطفال. & 1 \\
\hline عالية جدا & 0 & 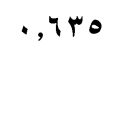 & $\varepsilon, \uparrow \varepsilon$ & بتفاعل الطقل مع الوسائط الكارتوجر افية & 11 \\
\hline عالية جدا & 4 &.,$O \vee V$ & $\varepsilon, \diamond \mathrm{V}$ & 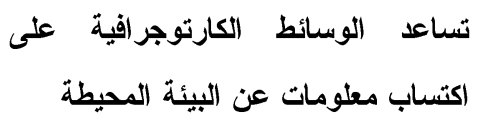 & 0 \\
\hline عالية جدا & $v$ &.,$O \vee V$ & $\varepsilon, \diamond \mathrm{V}$ & تجذب الوسائطالكارتوجرافية الطقل & 9 \\
\hline
\end{tabular}
الكارتوجر افية في مرحلة رياض الأطفال مرتبة تنازليا حسب المتوسطات الحسابية 


\begin{tabular}{|c|c|c|c|c|c|}
\hline لاجة المو افقة & الترتيب & الالتحر اف المعياري & المتوسط & الفقر ات & b \\
\hline & & & & بأثنكالها المختلفة. & \\
\hline عالية جدا & $\wedge$ & גדז, • & $\varepsilon, O V$ & تجذب الرسوم الكارتونية في الوسائط & Ir \\
\hline عالية جدا & 9 & $\cdot, 7 \cdot r$ & 0,07 & تساعد الوسائط الكارتوجر افية في معرفة & $\varepsilon$ \\
\hline عالية جدا & 1. &., $0 \wedge$. & $\varepsilon, 0 \leqslant$ & 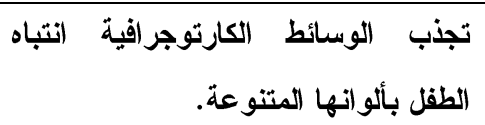 & 1. \\
\hline عالية جدا & 11 &., $7 r V$ & \&,OT & 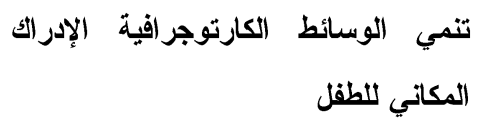 & r \\
\hline عالية جدا & ir & מצו, & $\varepsilon, 01$ & المكي الوسائط الكارتوجر افية المفاهيم & $r$ \\
\hline عالية جدا & ir & $\cdot, \wedge 17$ & $\varepsilon, \varepsilon$. & 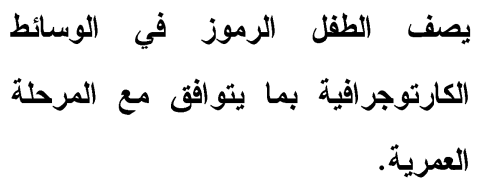 & 7 \\
\hline \multicolumn{2}{|c|}{ عالية جدا } & $\cdot, \varepsilon r V$ & $\varepsilon, 7$. & 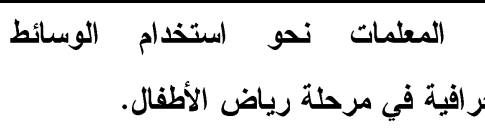 & الكاهات \\
\hline
\end{tabular}




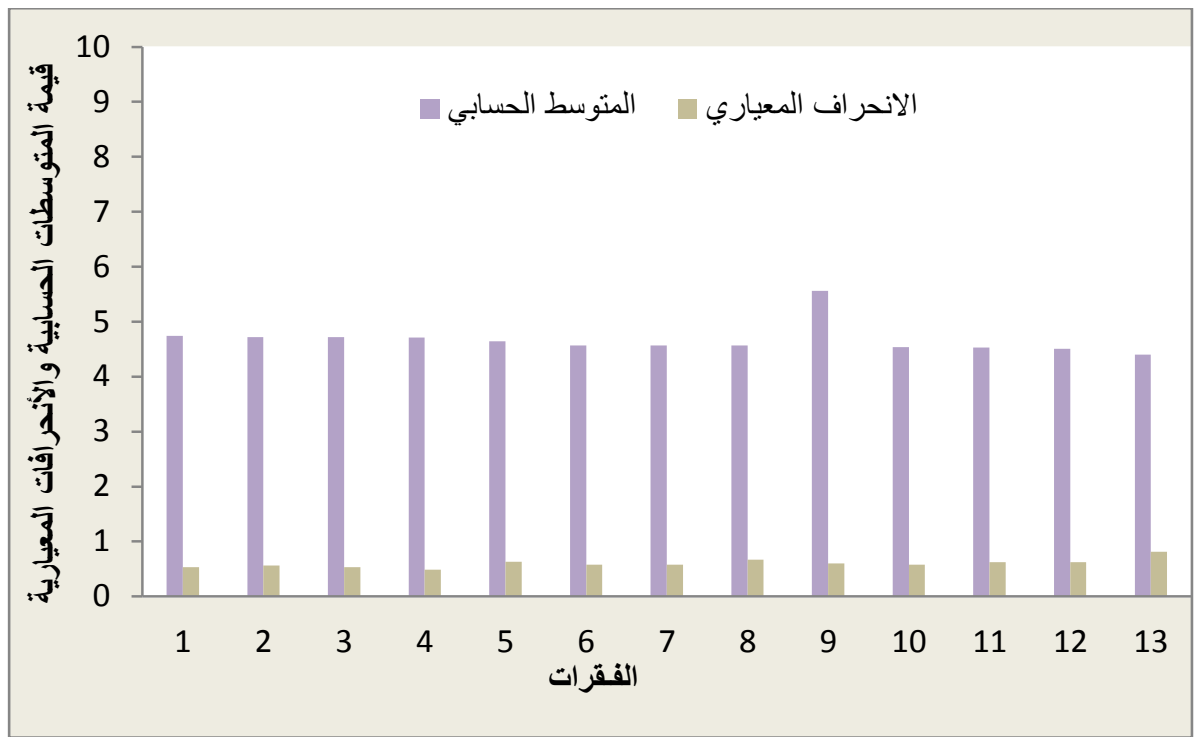

شكل رقم (r - 1) المتوسطات الحسابية والانحر افات المعيارية والترتيب لفقرات اتجاهات المعلمات نحو استخدام الوسائط الكارتوجرافية في مرحلة رياض الأطفال.

ومن خلال النتائج الموضحة أعلاه يتضح أن أفراد عينة الدراسة من المعلمات يتفقن على أهية استخدام الوسائط الكارتوجر افية في مرحلة رياض الأطفال بمتوسط ( • ؟, ؛ من •) وبلرجة موافقة عالية جداً، مما يدل على أن المعلمات لايهن إدراكاً عالياً جلاً لأهمية استخدام الوسائط الكارتوجرافية وذلك نتيجة التغيرات التي يعيثها المجتمع وعمق النظرة لهذه المرحلة الهامة من عمر الطقل، كما إن احتياجات المناهج الحالية تتطلب توفير هذه الوسائط الكارتوجر افية لتعيق مفاهيم الوحدات المختلفة للمنهج.

جاعت الفقرة رقم (V) وهي "يصف الطفل شكل الكرة الأرضية" في الرتبة الأولى بمتوسط حسابي (ع V, ؛)

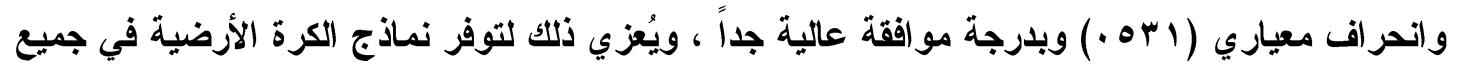
المدارس وحرص المعلمات على استخدامها في غرفة الصف ، كما جاعت الفقرة رقم (^) والتي تتحدث عن " يحدد الطقل اليابس والماء على نموذج الكرة الأرضية" في الرتبة الثانية بمتوسط حسابي (Y.V.؛)

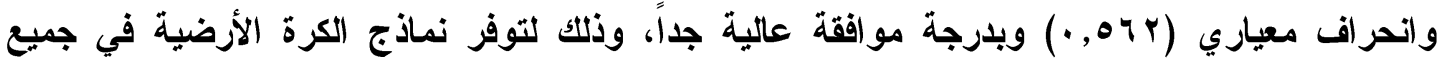
المدارس سواءً كاتت حكومية أوأهلية ، مما يحقق هدف هام للطقل وهو تحديد مكان اليابس والماء على هل نموذج الكرة الأرضية، وجاعت الفقرة رقم (r I) وهي " تنال اللعب الكارتوجر افية الاكترونية استحسان

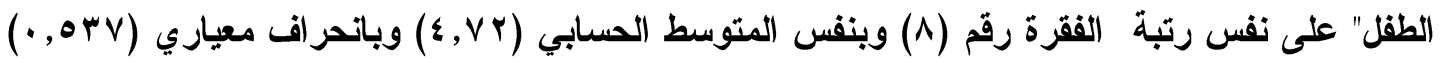
وبدرجة مواققة عالية جداً وذلك لميل الأطفال إلى اللعب الاكترونية مما يعزز استخدامها كوسيلة هامة لتحقيق أهداف العملية التعليمية في هذه المرحلة الهامة من حياة الطقل. 
وجاهت الفقرة رقم (1) وهي " يتناسب استخلام الوسائط الكارتوجرافية مع المرحلة العمرية لرياض

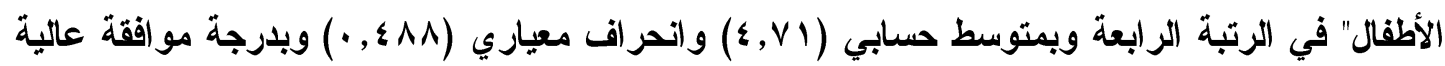
جاً، مما يشير إلى أن هناك حرص واهتمام من المعلمات لاختيار الوسائط الكارتوجر افية الملاممة مع عمر الطقل وهو ما يشير كذلك إلى وعي المعلمات لأهمية هذه المرحلة العمرية واحتياجاتها الخاصة.

وجاعت الفقرة رقم (11) وهي "يتفاعل الطفل مع الوسائط الكارتوجر افية الاكترونية في الرتبة الخامسة

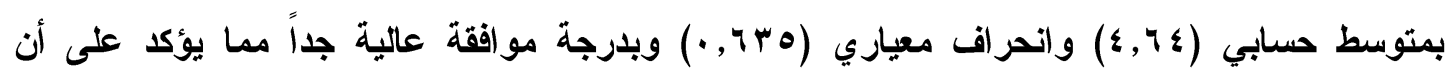
الألعاب الاكترونية من الوسائط الكارتوجر افية الهامة التي تؤثر في الطقل في هذه المرحلة العمرية.

وجاعت الفقرة رقم (•) وهي " تساعد الوسائط الكارتوجرافية على اكتساب معلومات عن البيئة المحيطة"

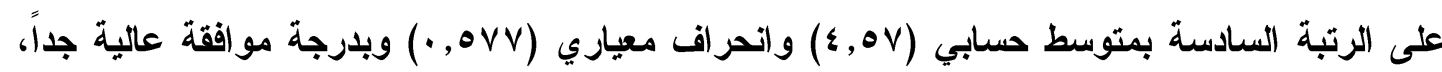
مما يؤكد على أهية استخدام الوسائط الكارتوجرافية بما تمنحه من معلومات هامة عن البيئة التي يعيش التهابه فيها (الطقل.

وجاءت الفقرات(9، r 1، 1 ) في الرتبة السابعة والثامنة و العاثشرة على التوالي بمتوسطات حسابية على

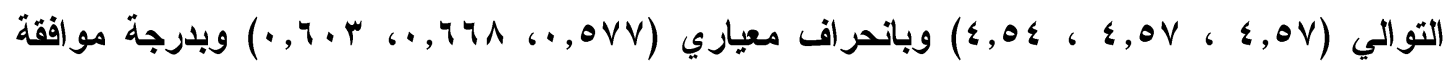
عالية جداً، ويعزي ذلك للتأثير الأي تلعبه الأثكال المختلفة والرسوم الكارتونية والألوان المتنوعة في إدراك الطقل وملاعمته لعمر الطقل الأي ينجذب لاختلاف الأثكال والألوان وتواجد الرسوم الكارتونية. وجاعت الفقرة رقم (ع) وهي " تساعد الوسائط الكارتوجر افية في معرفة الطفل بالأماكن من حوله" في

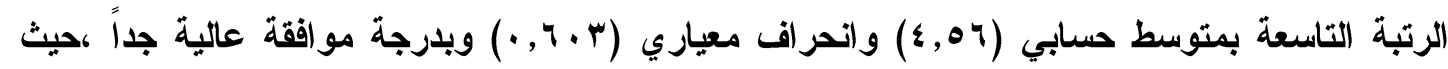
تتفق عينة الاراسة من المعلمات على أن الوسائط الكارتوجرافية معززة لنمو الطقل المعرفي ومعرفته بالأماكن من حوله كمعرفته للاتجاهات ودلالاتها، وموقفه من البيئة التي يعيش فيها.

وجاءت الفقرتان رقم (r، r) وهي " تنمي الوسائط الكارتوجرافية الإدرالك المكاني للطفل" و" تنمي الوسائط الكارتوجر افية المفاهيم المكانية للطفل " في الرتبة الحادية عشر والثانبة عشرة بمتوسط حسابي الثيائ

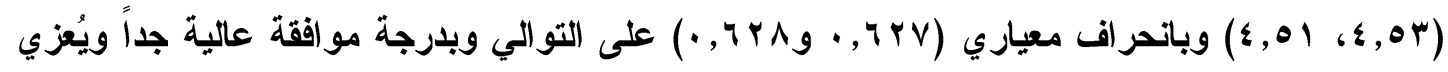
ذلك إلى المهارات التي يمكن أن يكتبها الطقل والتي تزيد من إدراكه للمفاهيم المكانية من خلا الوسائط الكارتوجر افية. 
وجاءت الفقرة رقم (†) وهي " يصف الطقل الرموز في الوسائط الكارتوجر افية بما يتو افق مع المرحلة

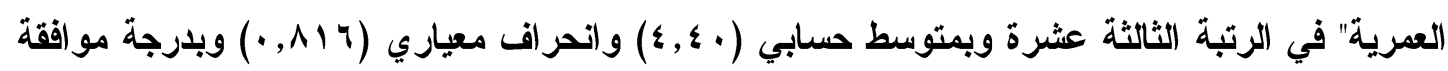
عالية جداً، ويعزي ذلك لتأثير الوسائط الكارتوجرافية في إدرالك الطقل لبعض الرموز والتي تتفق مع مرحتله النمائية.

يوضح جلول رقم (ع - §؟) اتجاهات المعلمات نحو استخدام الوسائط الكارتوجر افية ، ويوضح شكل رقم (ع -ه r) المكون النسبي لاتجاهات المعلمات نحو استخدام الوسائط الكارتوجرافية ، ويوضح شكل رقم

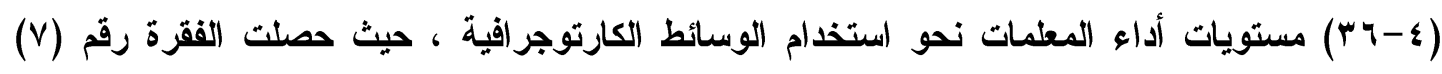
ونصها "يصف الطفل شكل الكرة الأرضية "على اعلي نسبة في مستوى الأداء بمعدل . . . ٪ بينما حصلت الفقرة رقم (؟) ونصها "يصف الطقل الرموز في الوسائط الكارتوجرافية بما يتوافق مع المرحلة

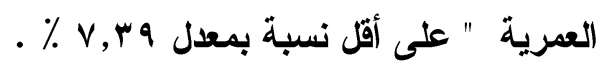




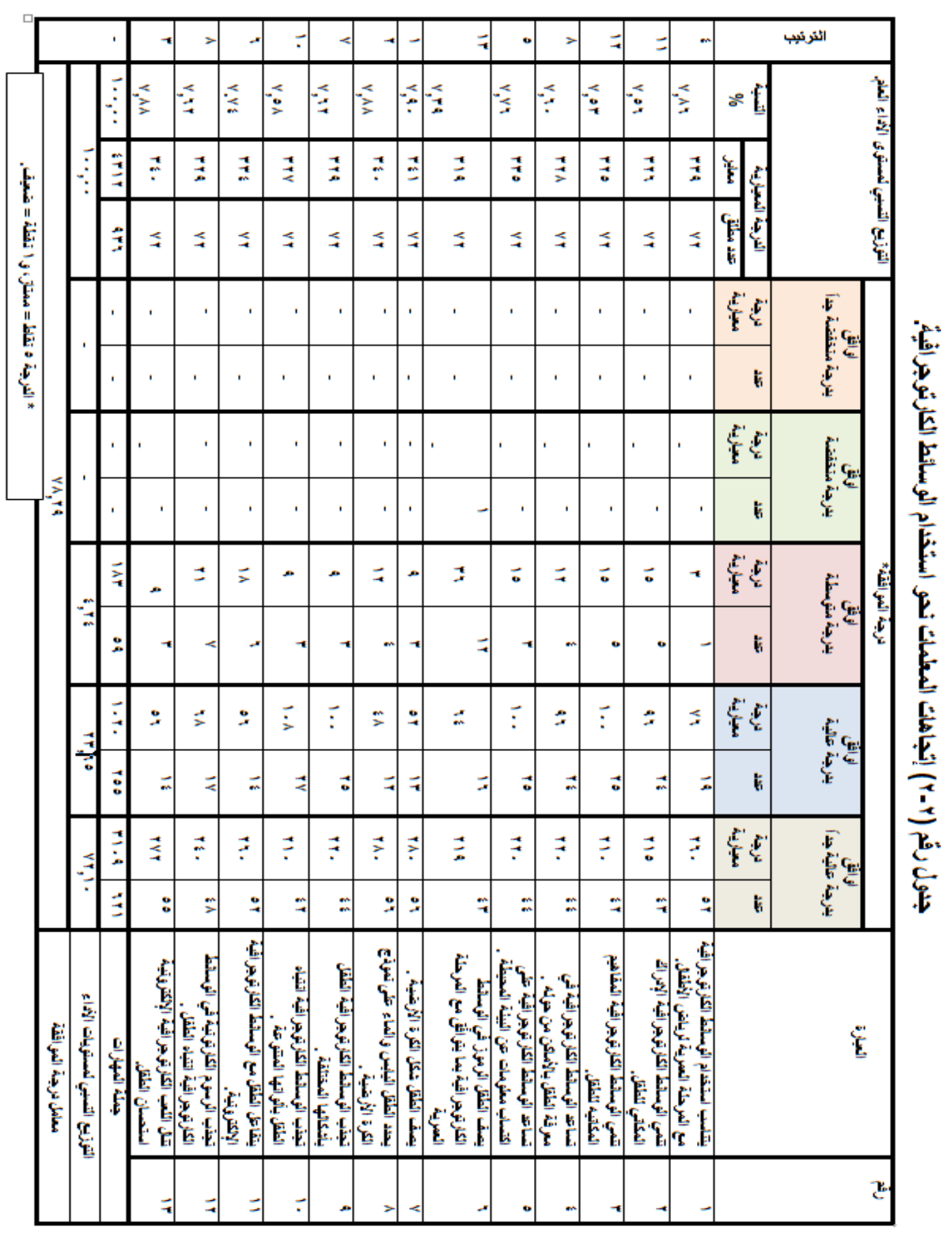




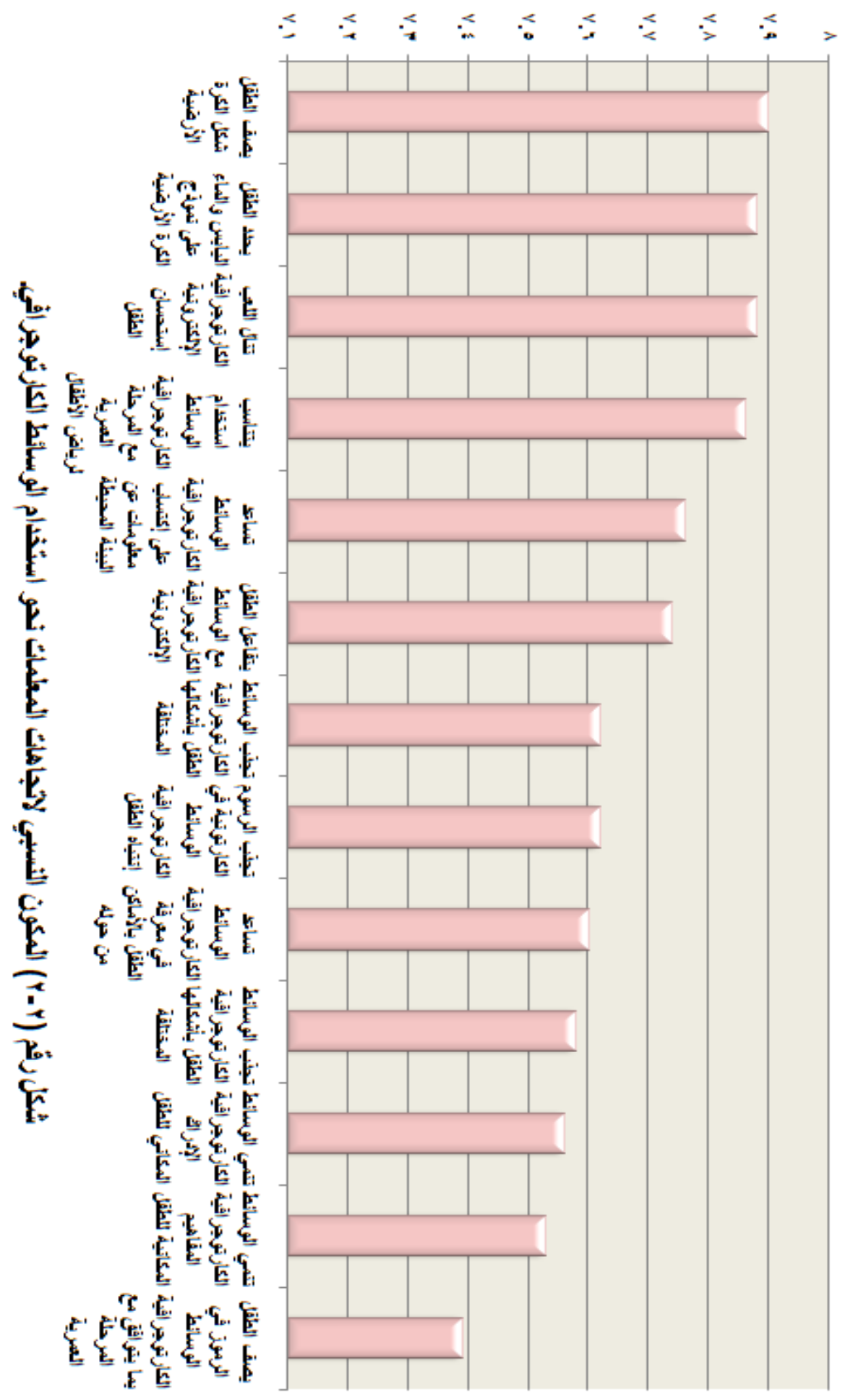




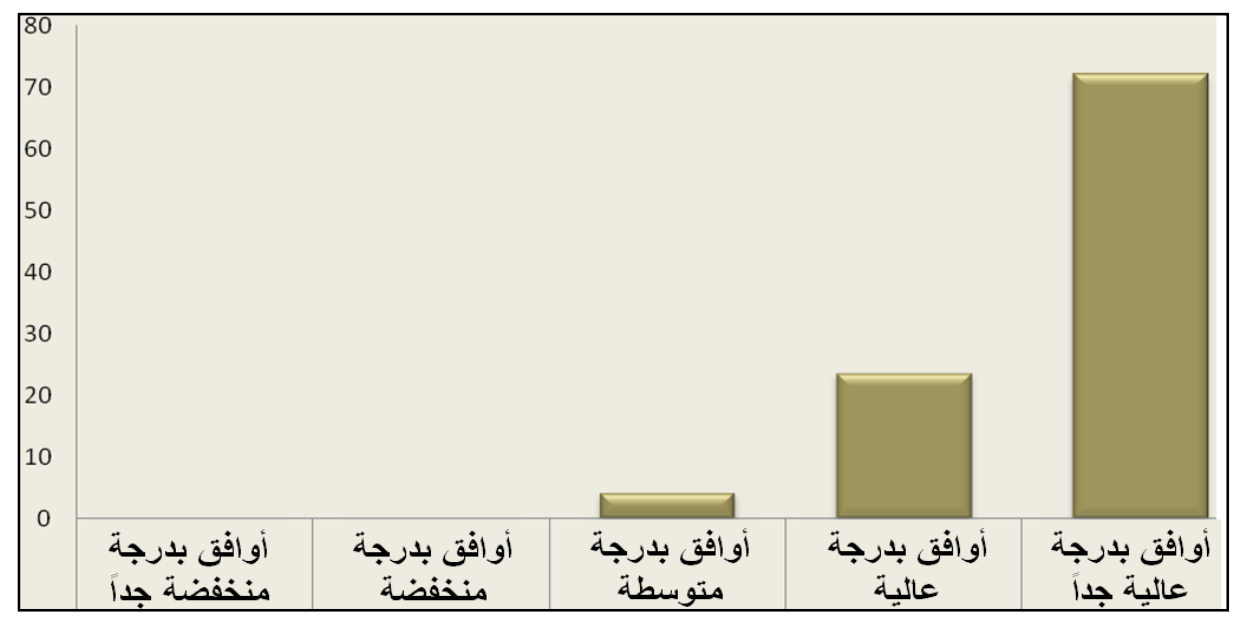

شكل رقم (r-r) مستويات أداء المعلمات نحو استخدام الوسائط الكارتوجر افية.

r r r r : أهمية إستخدام الوسائط الكارتوجر افية لطقل الروضة :

r- r- 1 - : أهمية إستخدام الوسائط الكارتوجر افية لطفل الروضة تبعاً للمستوى التعليمي للمعلمة:

لمعرفة درجة اختلاف وجهات نظر المعلمات لأهمية استخدام الوسائط الكارتوجرافية في تلقي الطقل باختلاف (المؤهل العلمي - الخبرة العملية في التدريس - نوع العدرسة) ، قامت الباحثة بإجراء اختبار "ت" للمجموعات المستقلة (Independent Samples T-Test) واختبار تحليل التباين الأحادي (انوفا) لتحديد دلالة الفروق بين وجهات نظر المعلمات لأهمية استخدام الوسائط الكارتوجرافية في تلقي الطفل

$$
\text { باختلاف (المؤهل العلمي - الخبرة العملية في التدريس - نوع المدرسة). }
$$

تم تقسيم متغير المؤهل الارسي في هذه الدراسة إلى خمس فئات هي: ماجستير وبكالوريوس تربوي وبكالوريوس غير تربوي ودبلوم وثانوي، ولذلك تم استخدام اختبار تحليل التباين للمقارنة بين متوسطات

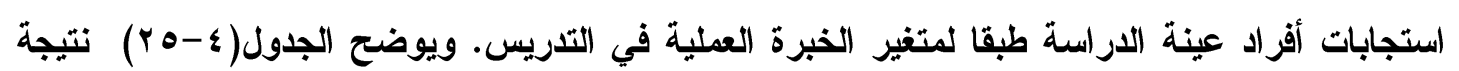
اختبار التباين لالالة الفروق بين المتوسطات. 
جدول (r-r) نتائج تحليل التباين الأحادي لالالة الفروق في وجهة نظر المعلمات لأهمية استخدام الوسائط الكارتوجر اقية في تلقي الطفل باختلاف المؤهل الاراسي.

\begin{tabular}{|c|c|c|c|c|c|c|}
\hline مستوى الدلالة & قيمة F & المربعات & درجات & المربعات & مصدر التباين & المحور \\
\hline \multirow[t]{3}{*}{., 009} & $\cdot, v \circ \diamond$ &., $1 \leq 7$ & $\varepsilon$ & $\cdot, 0 \wedge \varepsilon$ & بين المجموعات & \multirow{3}{*}{ ألثية استخدام } \\
\hline & &., $19 \varepsilon$ & TV & 17,979 & داخل المجموعات & \\
\hline & & & vi & Ir,oor & الكلي & \\
\hline
\end{tabular}

يتضح من الجدول عدم وجود فروق ذات دلالة إحصائية في وجهة نظر المعلمات لأهمية استخدام الوسائط الكارتوجرافية في تلقي الطفل باختلاف المؤهل الارسي حيث كاتت قيمة (ف) (0ه . •) وكان مستوى الالالة (009. • ) وهو مستوى غير دال.

r- r-r - أهمية إستخدام الوسائط الكارتوجر افية لطفل الروضة تبعاً لمدة خبرة المعلمة :

تم تقسيم متغير الخبرة العملية في التذريس في هذه الاراسة إلى أربعة فئات هي : أقل من ه سنوات ومن ه إلى · 1 سنوات ومن 11 إلى 10 سنة وأكثر من 10 سنة ولذلك تم استخدام اختبار تحليل التباين للمقارنة بين متوسطات استجابات أفراد عينة الدراسة طبقا لمتغير الخبرة العملية في التدريس. ويوضح الجدول (ع- r ץ) نتيجة اختبار التباين لالاهة الفروق بين المتوسطات.

جدول (r - §) نتائج تحليل التباين الأحادي لالالة الفروق في وجهة نظر المعلمات لأهمية استخدام الوسائط الكارتوجر افية في تلقي الطقل باختلاف الخبرة العملية في التدريس.

\begin{tabular}{|c|c|c|c|c|c|c|}
\hline مستوى & قيمة F & متوسط & درجات & المربعوع & مصدر التباين & المحور \\
\hline \multirow[t]{3}{*}{$\cdot, r \cdot 1$} & $1,7 \leq 1$ & $\cdot, r \cdot \Lambda$ & $r$ &., 717 & بين المجموعات & \multirow{3}{*}{ أهمية استخدام } \\
\hline & & $\cdot, \wedge \vee$ & 79 & Ir,quV & داخل المجموعات & \\
\hline & & & vi & Ir,oor & الكلي & \\
\hline
\end{tabular}

"وجود دلالة عند مستوى ه... 
يتضح من الجدول عدم وجود فروق ذات دلالة إحصائية في وجهة نظر المعلمات لأهمية استخدام الوسائط الكارتوجر افية في تلقي الطفل باختلاف الخبرة العملية في التدريس حيث كانت قيمة (ف) (اء 7. 1) وكان مستوى الدلالة (1 •r.. . ) وهو مستوى غير دال.

ونظراً لعدم وجود فروق ذات دلالة إحصائية في اتجاهات المعلمات باختلاف المؤهل العلمي أو الخبرة في التدريس تعزو الباحثة ذلك لتكثيف الاورات التدريبية لمعلمات رياض الأطفال مما يزيل من قرة المعلمات على تفهم طبيعة هذه المرحلة واحتياجاتها من وسائل تعليمية مختلفة ،بالإضافة إلى وجود تحفيز لمعلمات رياض الأطفال باختلاف مؤهلاتهن العلمية وخبراتهن في التدريس نحو أهية استخدام الوسائط الكارتوجر افية و إدراكهن لمتطلبات الطفل وما يحتاجه لإثارة جميع حواسه لتقبل المعلومات ونجاح العملية التعليمية إضافة إلى أن المجتمع السعودي أصبح يعي أهمية هذه المرحلة بشكل كبير مقارنة عما كان عليه في السابق من حيث نظرة المجتمع لهذه المرحلة.

r - r - r - أهية إستخدام الوسائط الكارتوجر افية لطقل الروضة تبعاً لتبعية المدرسة حكومية - أهلية : تم تقسيم متغير نوع المدرسة في هذه الاراسة إلى قسمين هما: حكومي وأهلي ولألك تم استخدام "ت" للمجموعات المستقلة (Independent Samples T-Test) للمقارنة بين متوسطات استجابات أفر اد عينة الاراسة طبقا لمتغير نوع المدرسة. ويوضح الجدول (ع rV) نتيجة اختبار التباين لدلالة الفروق بين المتوسطات.

جدول (r-0) نتائج تحليل ت لالامة الفروق في وجهة نظر المعلمات لأهمية استخدام الوسائط الكارتوجر افية في تلقي الطقل باختلاف نوع المدرسة.

\begin{tabular}{|c|c|c|c|c|c|c|}
\hline الإحصائية & قيمة (ت) & الالمعراف & الحسابي & العدد & نوع المدرسة & الدحور \\
\hline \multirow[t]{2}{*}{$\cdot, v \cdot 4$} & $-\cdot, r \vee \wedge$ & $\cdot, \infty$ & $\varepsilon, O V$ & $r$ & حكومية & أهمية استخدام \\
\hline & & $\cdot, r \wedge \vee$ & $\{, 7$ & 01 & أهلية & الكلارتوجر افية في \\
\hline
\end{tabular}


يتضح من الجدول عدم وجود فروق ذات دلالة إحصائية في وجهة نظر المعلمات لأهمية استخدام الوسائط الكارتوجر افية في تلقي الطفل باختلاف نوع المدرسة للمعلمة عند مستوى دلالة (ه . . ) ، حيث

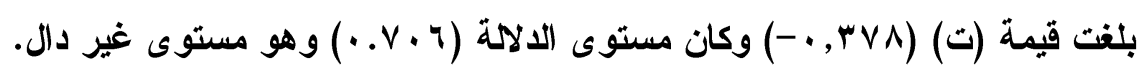

وتعزو الباحثة ذللك للاهتمام المُلاحظ بمرحلة رياض الأطفال في المدارس الحكومية مع توفير كامل ما يلزم من الوسائل التعليمية المناسبة للطقل في هذه المرحلة العمرية الهامة ومقارنة ذك بما تبذله المدارس الأهلية من جها في توفير ما يلزم إضافة إلى وعي المعلمات ومحاولتهن توفير العديد من الوسائط الكارتوجر اقية عن طريق الخامات البسيطة.

تناول هذا الفصل تقييم إستخدام الوسائط الكارتوجرافية من خلال تقييم تلقي وتفاعل الأطفال مع الوسائط الكارتوجرافية ، وتقييم مهارات وقدرات إستخدام الأطفال للوسائط الكارتوجرافية مع معرفة إتجاهات المعلمات نحو إستخدام هذه الوسائط تبعاً للمستوى التعليمي ، ومدة الخبرة ، وتصنيف المدرسة

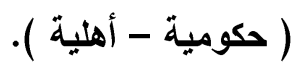

$$
\text { (النتائج: }
$$

توصلت الاراسة إلى النتائج التالية :

ا. تعتبر الوسائط الكارتوجرافية من مصادر العصول على المعرفة المكانية اللازمة لتنمية مهارة

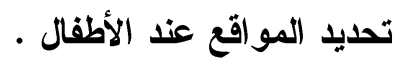

r. اتجاهات المعلمات نحو استخدام الوسائط الكارتوجرافية في مرحلة رياض الأطفال حازت على العثل

متوسطات حسابية تقع في درجة "عالية جدا" من الموافقة، وتراوحت المتوسطات الحسابية

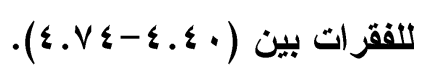

r. توافق معظم المبحوثات (المعلمات) على أهمية إستخدام الوسائط الكارتوجر اقية في مرحلة رياض الأطفال في تنمية المفاهيم المكانية، والإدرالك المكاني واكتساب المعلومات عن البيئة المحيطة

ومعرفة الطقل للأماكن من حوله.

ع. توافق معظم المبحوثات (المعلمات) على أن الوسائط الكارتوجرافية في مرحلة رياض الأطفال

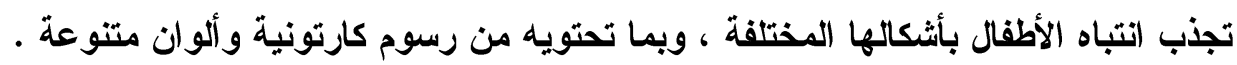

ه. توافق معظم المبحوثات (المعلمات) على أن اللعب الكارتوجرافية الإكترونية تجذب الأطفال وتنال

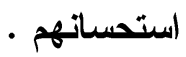


في ضوء النتائج التي توصلت إليها الارسة ، توصى الباحثة بما يلي :

1. إستخدام الوسائط الكارتوجرافية في جميع وحدات المنهج الاراسي والاستمرارية في إستخدام

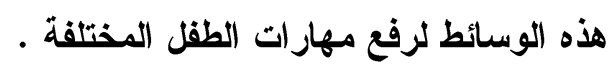

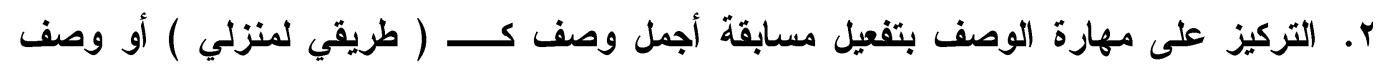

مكان محبب لاى الطقل، وبذلك يكتسب الطقل المفاهيم المتعلقة بالمكان والجهات.

r. تفعيل المسابقات لإخر اج وسائط كارتوجر افية من إعداد الأطفال وتبني أفكار هم البسيطة.

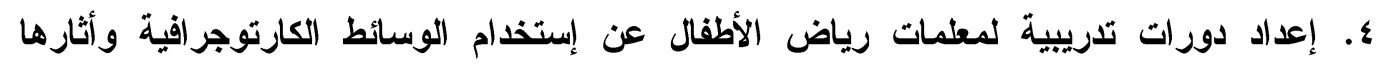

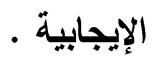

\section{قائمة المر اجع}

إبر اهيم، مجدي (ع . . rم) موسيوعة التتربس، الجزء الأول، عمان: دار المسيرة. أبو حطب، فؤاد (79 (9 ام) القدرات العقلية، طه، القاهرة: مكتبة الأبلو المصرية.

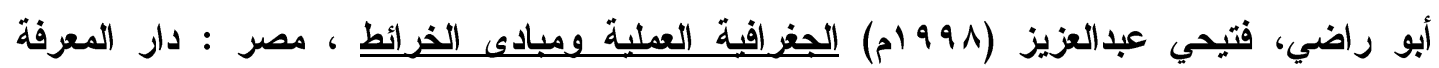
الجامعية .

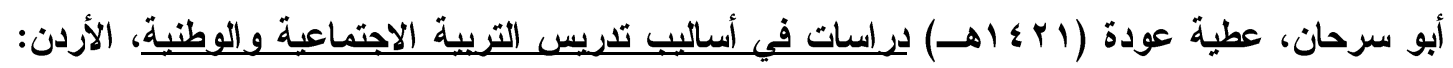
دار الخليج.

أبو علام، رجاء محمود (11 ـ بم) مناهج البحث في العلوم النفسبة والتريوية ، طج ، القاهرة : دار النشر

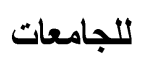

الأحمد، نضال شعبان (991 ام) العلاقة بين قرة التصور البصري المكاني والنمو المعرفي والتحصيل الادر اسي في مادة العلوم بمدارس مدبنة الامام، دراسات تربوية واجتماعية، المجلد (ع) ، العدد

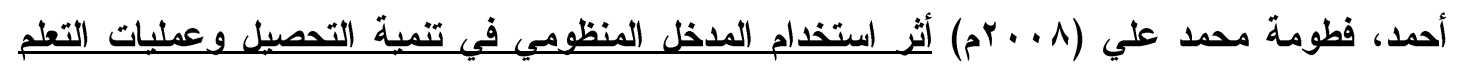

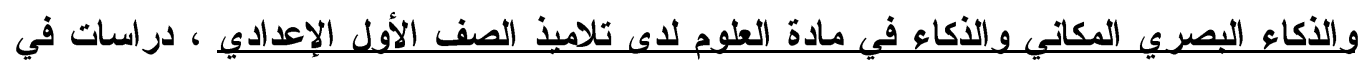

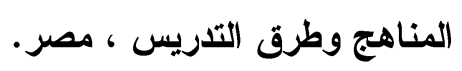

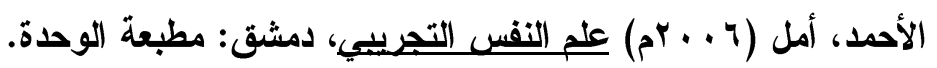

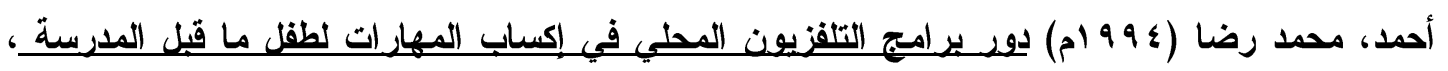

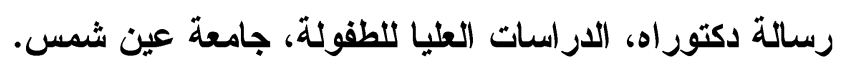
إسماعيل، إسماعيل يوسف وبكير ، سلوى محمد (999 ام) الملحق في تصميج وإنتاج الخرائط، كلية

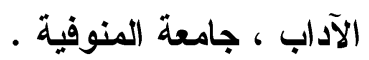


إسماعيل، إسماعيل يوسف (49 99 ام) تصمبيم وتنفبذ رموز التمثلي البياني للخريطة بالحاسب الثخصيك. القاهرة: دار الفكر.

إسماعيل، إسماعيل يوسف (19 ا9 ام) الأطالس الإكترونبة بالوسائط المتعددة والأطلالس المطبوعة ودورها

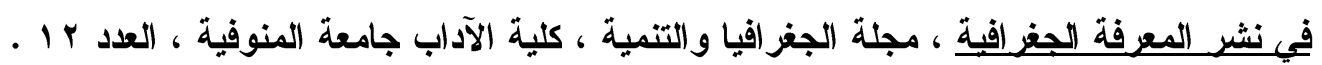

إسماعيل، إسماعيل يوسف (9 99 ام) تنمبة الثقافة المكاتبة لتحقيق الأمن المعرفي بالوسيائل الكارتوحر افبية في مصر، المؤتمر البيئي الثامن لجامعة المنوفية ، القاهرة.

إسماعيل، إسماعيل يوسف (9 9 ام) قر اعات في البحث والتحليل الكارتوجرافي، شبين الكوم، المنوفية:

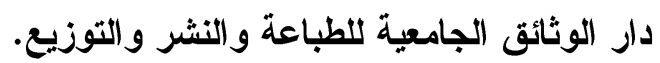

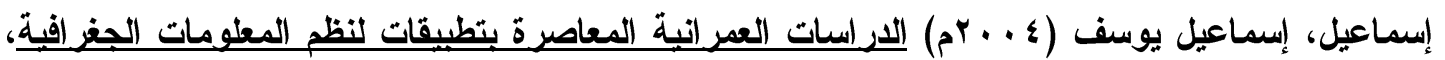
الإسكندرية: منشئة المعارف.

إسماعيل، إسماعيل يوسف (991 ام) تصميب وقر اعة وتحليل الخرائط ، مركز معالجة الوثائق، المنوفية: شبين الكوم.

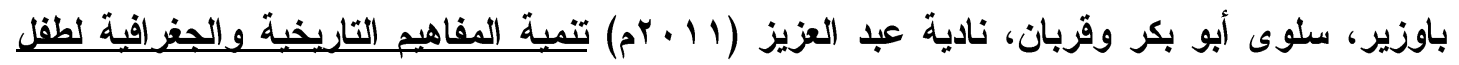

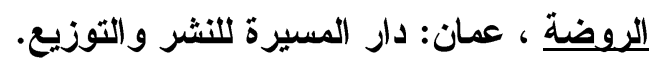

بلدر، سهام محمد (1 أ أهـ) اتجاهات الفكر التريوي في مجال الطقولة، الكويت:مكتبة الفلاح للنشر و التوزيع.

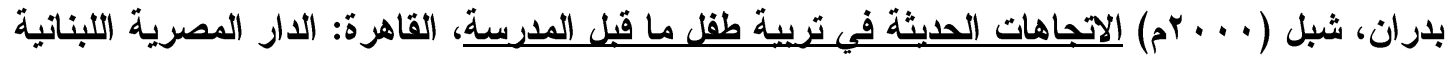

بدير ، كريمان (ع · بم) الرعابية المتكاملة للأطفال، القاهرة: عالم الكتب.

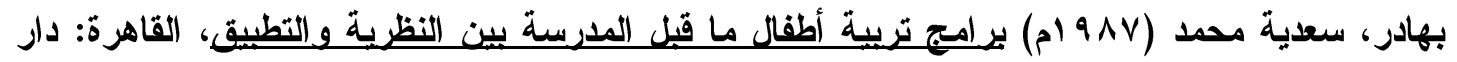
الصدر للخدمات و الطباعة.

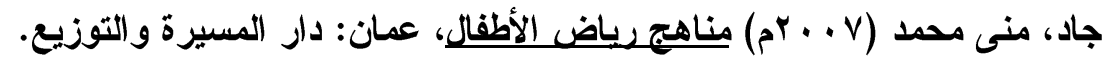

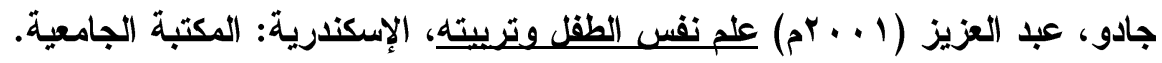

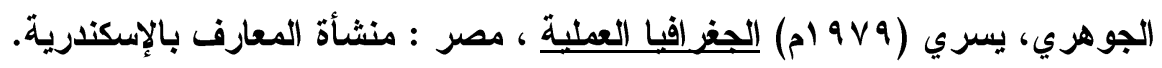

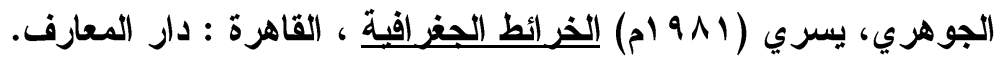

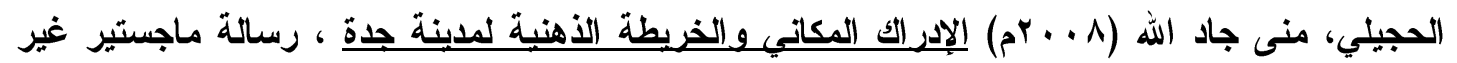
منشورة ، جدة ، جامعة الملك عبد (لعزيز.

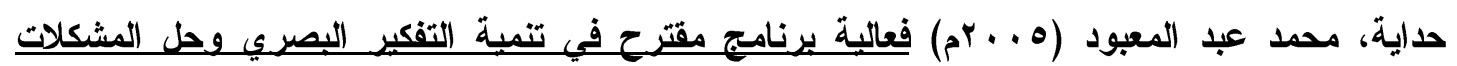

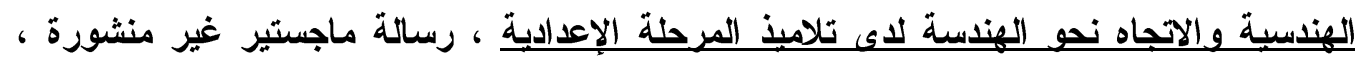
كلية التربية ، جامعة طنطا. حسن، مصطقى محمد (9 . . rم) سيكولويبة التعبير الفني عند الأطفل ، القاهرة : مكتبة الأنجلو المصرية 
حطيبة، ناهد فهمي (q . . rم) منهج الأشطة في رياض الأطفال ، عمان : دار المسيرة للنشر والتوزيع و الطباعة . لمانهان.

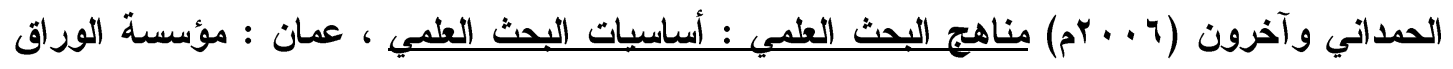

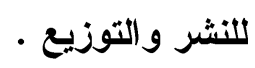

الخولي، أمين أنور وآخرون (ع 99 ام) التربية الرياضبة المدرسبة - دلبل والمراهت وطالب التربية العملية، القاهرة: دار الفكر العربي.

خير الله، سيد (1911م) علم النفس التريوي أسسه النظرية والتجريبية ، بيروت: دار النهضة العربية.

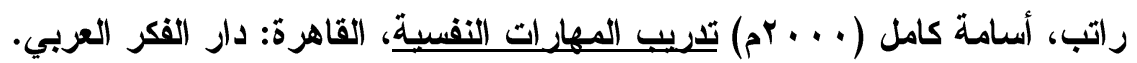

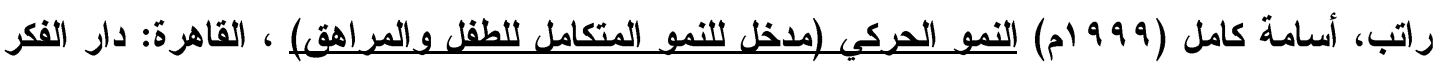
العربي. رسول، فوزي أحمد (9^^ ام) التعبير البيئي في الرسب العراقي المعاصر، رسالة ماجستير، كلية الفنون الجميلة، جامعة بغداد الد.

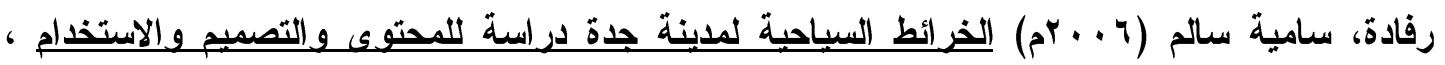
رسالة ماجستير غير منشورة ، جلة ، جامعة المثلك عبدالعزيز.

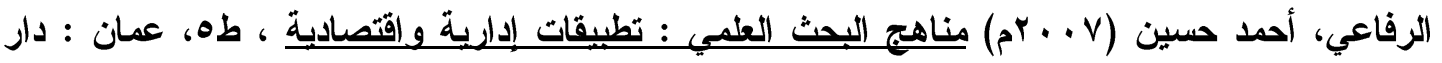

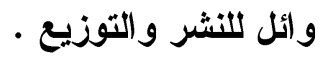

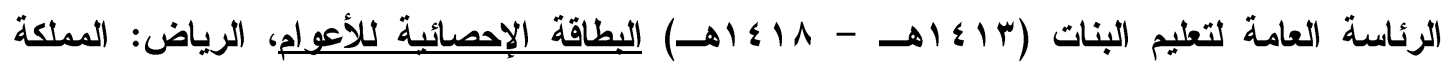
العربية السعودية.

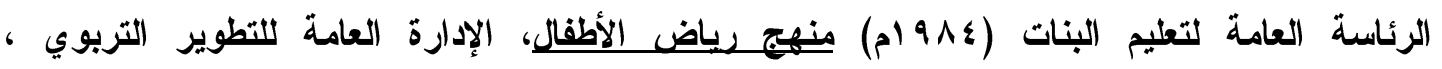

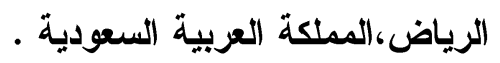
الهيئة العامة للسياحة والآثار (ه . . rم) خريطة رموز تصويرية للمملكة العربية السعودبية ، الملكة العربية السعودية . زهران، حامد (، 99 ام) علم نفس الطقولة و المراهقة ، طه ، القاهرة : دار العالم لنشر الكتب .

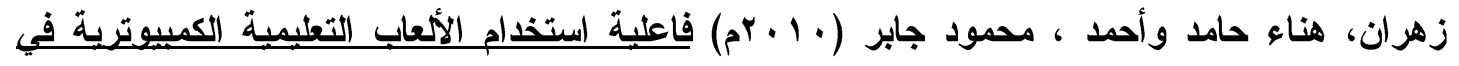

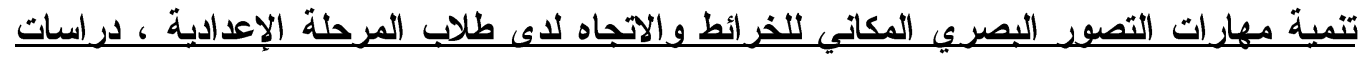
في المناهج وطرق التّريس، الجمعية المصرية للمناهج وطرق التدريس ، العدد 101 ، الجزء الأول . الزهراني، سعود حسين (10 الهـ) الحقائب التعلبيبة، رسالة ماجستير منشورة، قسم مناهج طرق

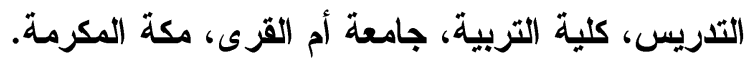
الزيدي، نجيب عبدالرحمن ومسعود ، حسين مجاهد (ه . . rم) علي الذرائط، الأردن : دار اليازوري للنشر

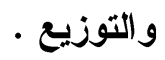
سطحية، محمد (ع و ام) الجغر افبا العملبة وقر اعة الخربطة، طب، بيروت: دار النهضة العربية. 
سعادة، جودت أحمد (1 . . rم) تدريس مهارات الخرائط ونماذج الكرة الأرضبة، الأردن: دار الثروق للنشر و التوزيع

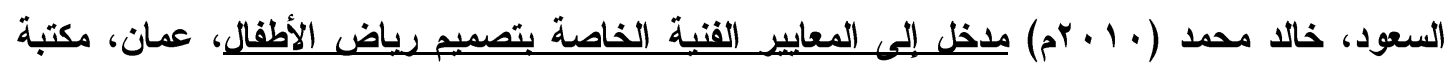
المجتمع العربي للنشر والتوزيع.

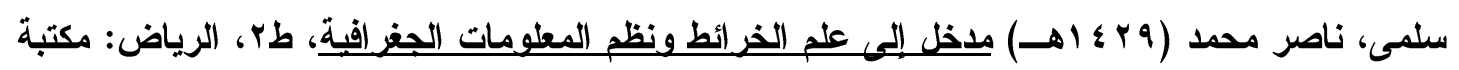
كنوز المعرفة. سليمان، شحاته سليمان محد (9 . . rم) برامـج الأطفال روئية نظرية وأمثلة تطيقية ، الرياض : دار

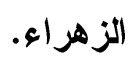
شحاته، حسن (99v ام) اساسبات التدريس الفعال في العالم العريي ، طب، القاهرة : الارار المصرية

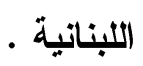

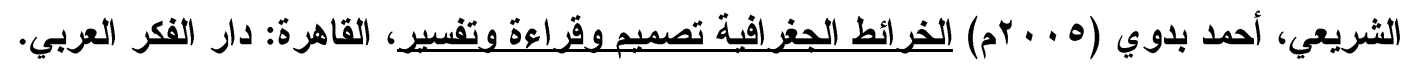

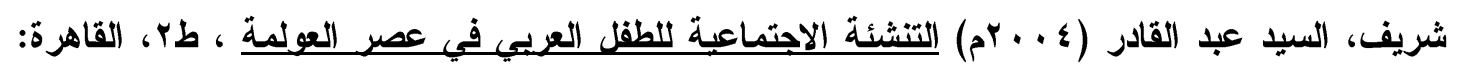
دار الفكر العربي.

شكر الله، عهر الله حاجي (، (91 ام) المهيرات في تعليم الجغرافيا ، الكويت : وكالة المطبوعات.

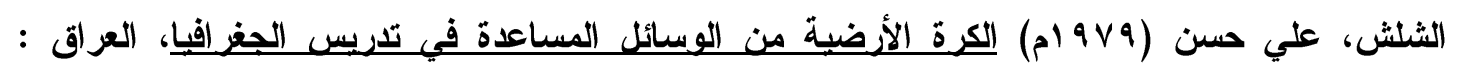
مطابع جامعة البصرة. الشهري، فاطمة محمد (9 ( . Yم) الأطلس التعليمي بالمملكة العريبة السعودية، رسالة ماجستير غير منشورة، أبها، جامعة الملك خالا. صو الحة، محمد أحمد (ع . . rم) علم نفس اللعب، عمان: دار المسيرة للنشر والتوزيع.

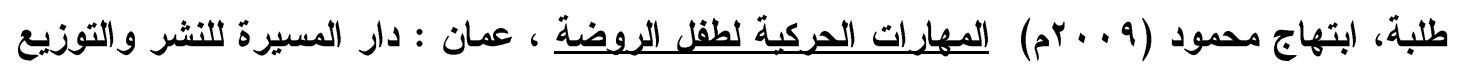

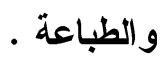
الطوبجي، حسين حمدي (9 ا9 ام) وسائل الاتصال والتكنولوجيبا في التعلبِ ، طه ، الكويت : دار القلم

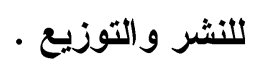
عايدة، عدنان سليم (99 99 ام) القدرة المكانبة لدى تلامبذ المرحلة الابتائبة ومتغيرات مرتبطة بها في

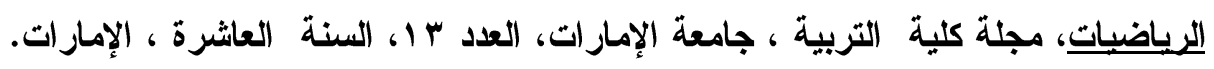

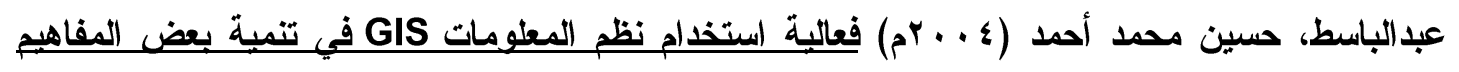

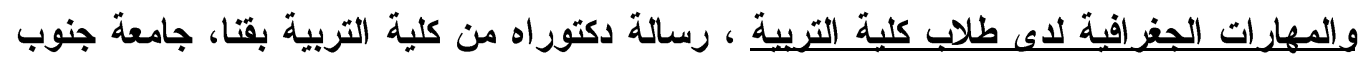
اللو ادي. عبدالباسط، حسن محمد أحمد (1 . . rم) تأثير الخيرات البيئة في تنمبة الإدر الك المكاتي للمعالم الجغر افبة

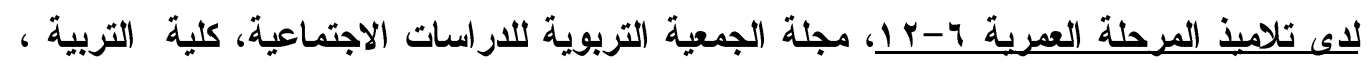

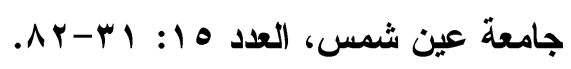


عبدالحى، رمزى أحمد (q . . rم) الوسائل التعلبيبة والتقتبات التريوية (تكنولوجبيا التعلبم) ، القاهرة :

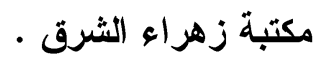

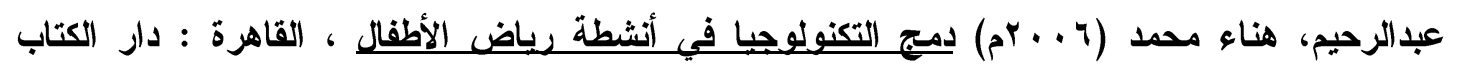
الحديث.

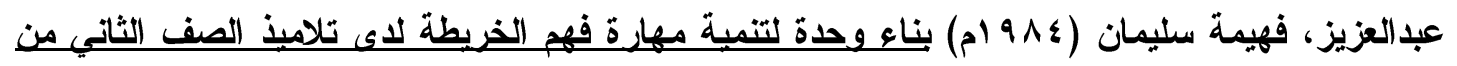

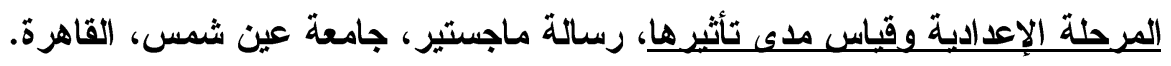

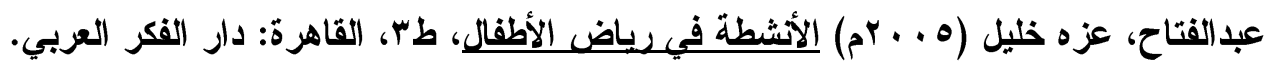

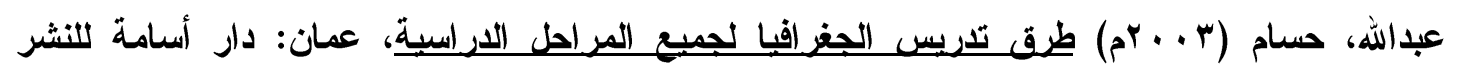
و التوزيع.

عبدالمنعم، منصور أحمد (ب9 ام) الخرائط المعرفية وواقع الخبرات الجغرافية لاى تلامبذ المرحتبن الابتدائبة والمتوسطة ، دراسة ميدانية بالمملكة العربية السعودية : مجلة دراسات في المناهج

$$
\text { وطرق التدريس . }
$$

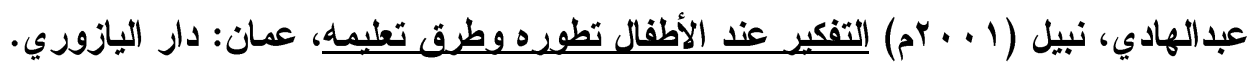

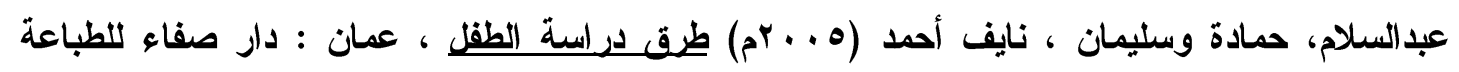

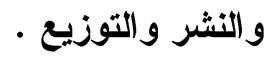

عبدالوهاب، سامح إبر اهيم (799 أم) التغبر ات السكانبة في القاهرة : دراسة في الكارتوجر افبا والتحليل الجغرافي ، رسالة ماجستير غير منثورة ، كلية الآداب جامعة القاهرة.

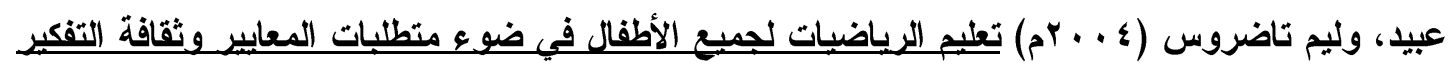

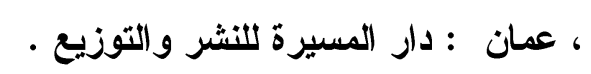

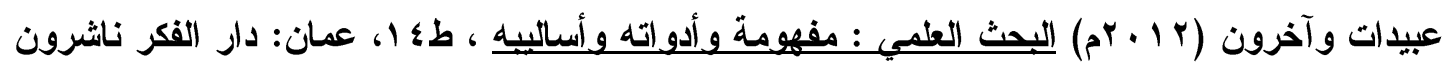
وموزعون

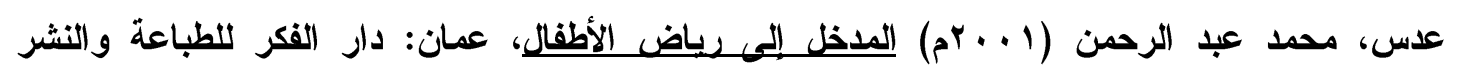
والتوزيع.

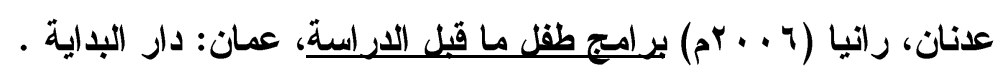

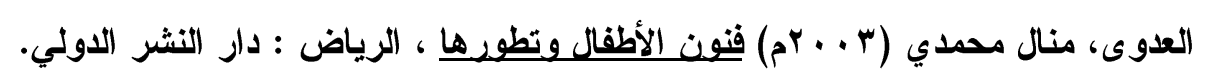

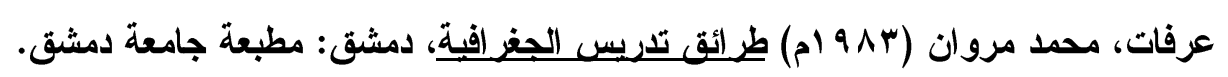

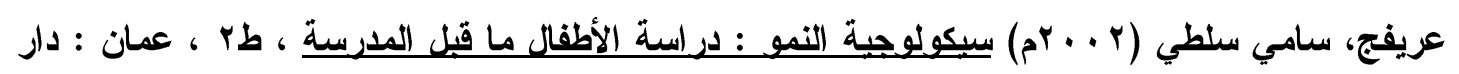

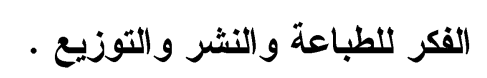

عزيز، محمد الخز (مي (9191 ام) نظم المعلومات الجغر افبة أساسبات وتطبيقات للجغفر افيبين، مصر : منشأة

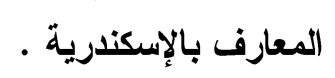

العساف، جمال عبد الفتاح وأبو لطيفة ، رائد فخري (9 . . بم) مناهج رياض الأطفال (روئية معاصرة) ، عمان : مكتبة المجتمع العربي للنشر والتوزيع. 
عطار، عبدالله إسحاق وكنسارة، إحسان محمد (ه . . rم) وسائل الاتصال التعلبية ، طr، مكة المكرمة: فهرسة مكتبة الملك فهذ الوطنية أثناء النشر.

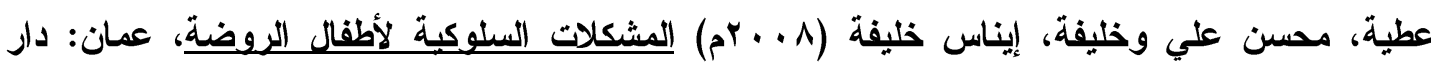
المناهج للنشر و التوزيع.

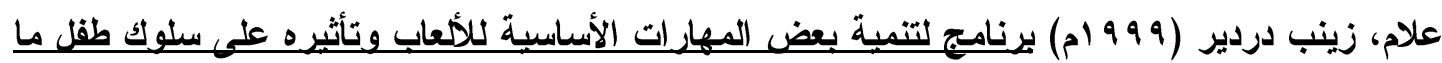
قبل المدرسة ، رسالة دكتور اه، كلية التربية، جامعة الزقازيق.

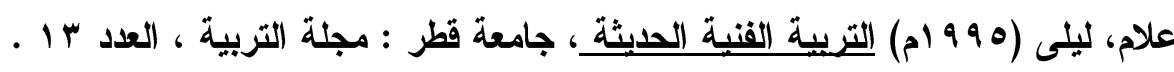

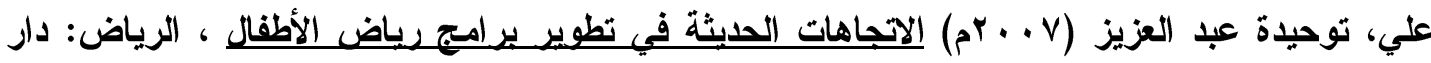

$$
\text { الخريجي للنشر و التوزيع. }
$$

علي، صبري إبر اهيم (ع 99 ام) تطوير تريبة طقل ما قبل المدرسة في مصر في ضوء الاتجاهات التريوية

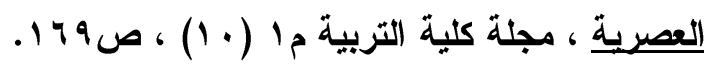

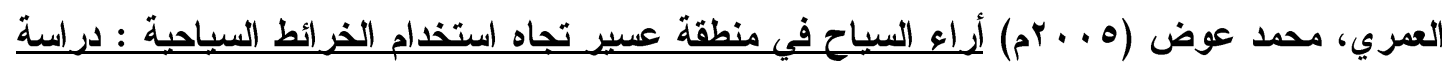

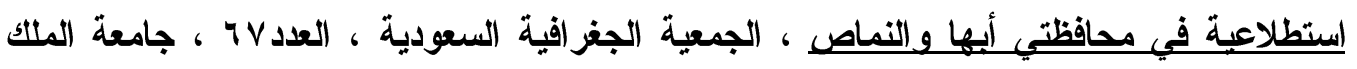

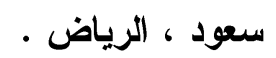

العمري، محمد عوض ، ومنصوري، محسن أحمد (1 ك أهـ) الخر ائط التفاعلبة وإمكانبة توظيفها لخدمة السباحة في المملكة العريية السعودبية ، ندوة الإعلام والسياحة الداخلية الواقع والآفاق المستقبلية ،

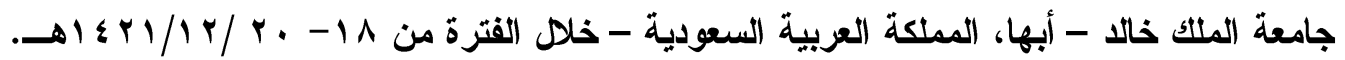

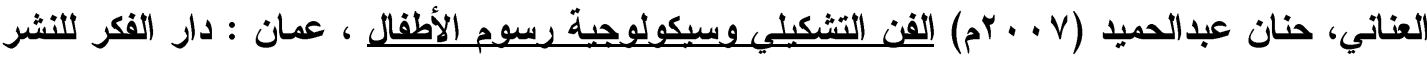
و التوزيع -

الفايز، حصن سليمان (1 إ؛ اهــ) دمج الأطفال ذوي الحاجات الخاصة مي العادبين في مؤسسات رياض الأطفال، الرياض: مطابع الفرزدق التجارية.

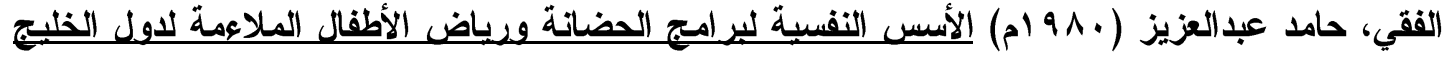

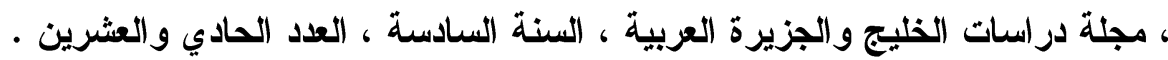

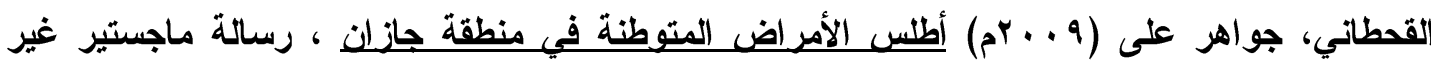
منشورة ، أبها ، جامعة الملك خالد. القصاص، محمد عبدالقتاح (r99 ا9 م) ندوة الإعلام العربي وقضابيا البيئة في مصر والعالم العربي - دور

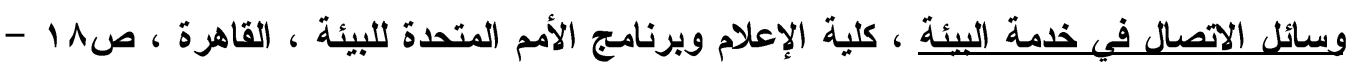
. rr قطامي، يوسف ( . . . rم) نمو الطفل المعرفي و اللفوي ، عمان : الأهلية للنشر والتوزيع.

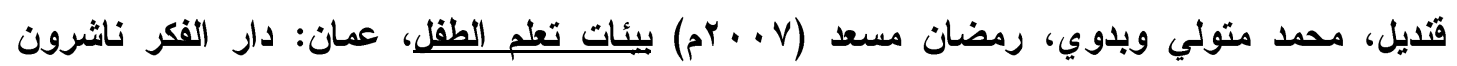
وموزعون. 
قنديل، محمد متولي ومحمد ، داليا عبدالواحد (• ( •rم) الحس المعماري عند الأطفال ، القاهرة: دار

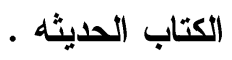

كلوب، بشير (91^ام) التكنولوجيا في عملية التعلم والتعليم، عمان: دار الثروق.

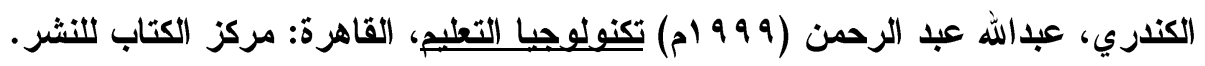
لبيب، على والمثلوثي ، الهادي و الحجري ، جميل والنويصر ، خالد وذياب ، محسن و الثعباني، عبدالحمبل

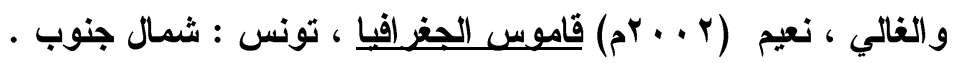

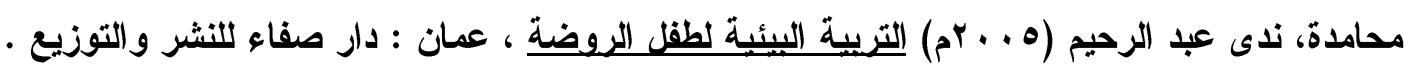

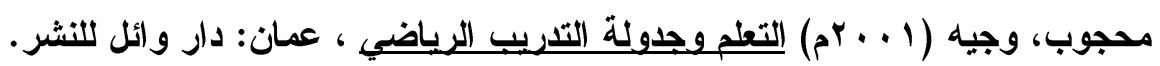

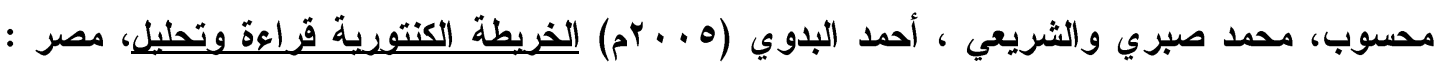

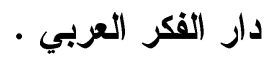

محمد، جاسم محمد (ع . . rم) النمو والطقولة في رياض الأطفال ، عمان : مكتبة دار الثقافة للنشر و التوزيع •

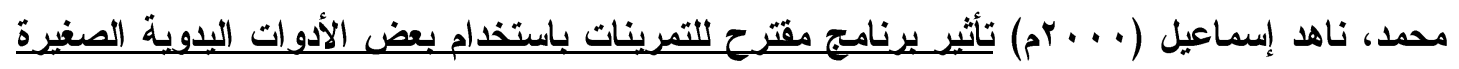

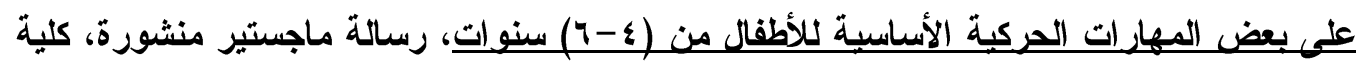
التربية، جامعة حلوان. محمود، صباح والقاعود، إيراهيم والمومني، محمد (؟9 99 ام)، طرائق تلريس الجغرافيا ، عمان : دار

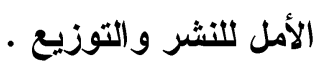

المحيمل، هند عبدالله (11 • rم) خرائط وأدلة السباحة السعودية ، رسالة ماجستير غير منشورة ، أبها ، جامعة الملك خالا. معوض، خليل ميخائيل (ع 99 ام) القدرات العقلية ، طب، الإسكندرية : دار الفكر الجامعي.

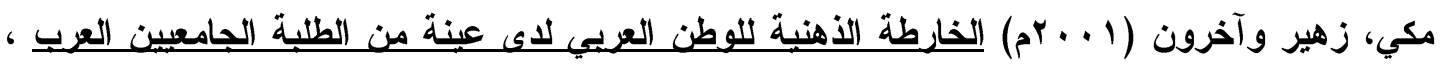
مجلة دراسات العلوم الإنسانية والاجتماعية ، المجلا ^^r ، عمادة البحث العلمي ، الجامعة الأردنية

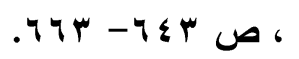

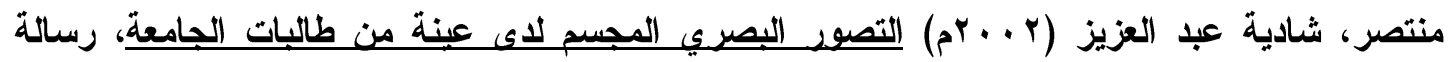
دكتور اه غير منشورة، كلية البنات للآداب والعلوم والتربية، جامعة عين شمس، القاهرة.

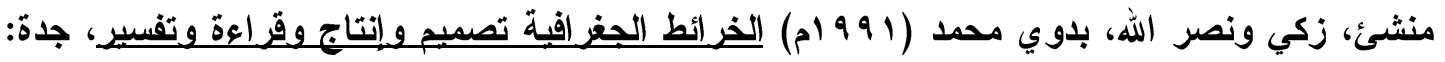
مكتبة الصباح. الناشف، هدى محمود (1 . . rم) استراتبيجيات التعلبم والتعلم في الطقولة المبكرة، القاهرة: دار الفكر - العربي

نصار، عزو إسماعيل (9 . . rم) أثثر استخدام الألغاز في تنمبة التفكير الناقد في الرياضبيات و المبل نحوها

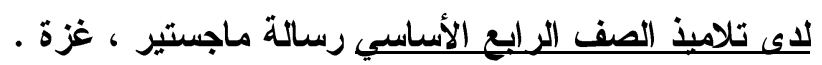
نصر، ياسر (11 (1 بم) موسوعة طقلي مبدع، مصر : مؤسسة اقر أ للنشر و التوزيع و الترجمة. 
الهنيدي، منال عبدالفتاح (9 . . r م) سبكولوحية رسوم الأطفال ، عمان : دار المسيرة والتوزيع والطباعة

الهيثي، هادي نعمان (911 ام) ثقافة الأطفال ، الكويت: عالم المعرفة.

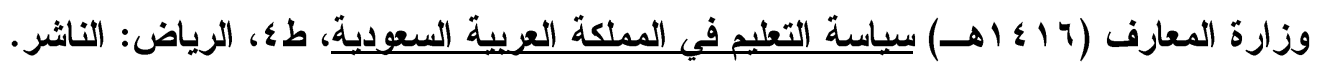

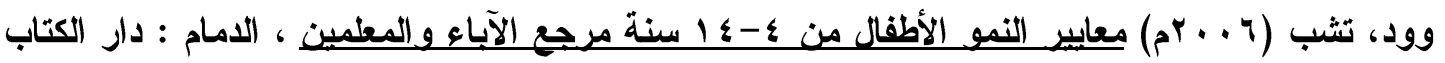

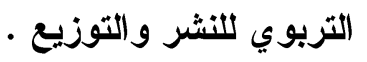

يحيى، حسن عايل أحمد (14 أهـ) صعويات تعلم مهارات الخرائط في المرحلة الثانوية، دراسة مبدانبة

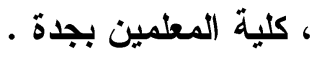

Anita Ganeri (2012) pop -up my world atlas, Templar, 1st edition.

Anita Muller (1998) Kidpix studio deluxe - soft ware overview, Argentina.

Bettina Balassa (2000) A Tourist Map for Children , E[tv[s Lor]nd University , Hungary .

Blades, M. \& Spencer, C.(1986) Map use by young children Geography , Vol.(71), pp.47-52.

Blaut, J. M. (1999) Maps and spaces The Professional Geographer, Vol.(51), pp.510-515.

Briony Penn (2008) The Kids Book of Canadian Geography, Kids Can Press, Ltd, 1st edition.

Byron Nakos, Evanthia Michaelidou , and Vasiliki Filippakopoulou (1999) The use of primary graphic elements in map design by first and second grade students, Greece.

Berry Farm Knott's ,From: https://www.knotts.com/plan-a-visit/park-map,

Retrieved, November, 26, 2014.

Catling, S J.(1979) Maps and cognitive maps The Young Child's Perception Geography, Vol.(64),pp.288-295.

Cohen, S. (1994) Children's environmental knowledge, In R. Wilson (Ed). Environmental education at the early childhood level, North American Association for Environmental Education, Vol.(4),pp.19-22. 
Costa. A\& Kallick, B(2000) Habits of Mind Activating and Engaging Habits of Mind, U.S.A, Association for Supervision and Curriculum Development, Virginia.

Castle Howard map , From:http://www.emillustration.co.uk/blog/index.php? $\underline{m}=05 \& y=10 \&$ entry =entry100506-144052, Retrieved, December, 19, 2014.

Crumpled City Junior map , From: http://www.littlestarblog.com/thecrumpled-city-map, Retrieved, January 1, 2015.

Corcoran For Design, From: http://www.wallstickeroutlet.com/wall-decordetail.php?recordid=108318, Retrieved, November, 23, 2014.

David Dean (2011) world atlas, Barefoot Atlas, 1st edition.

David J Smith (2009) If America Were a Village, Kids Can Press, Ltd, 1st edition.

David Mumford (2010) Collins Maps, 1st edition.

Deborah Chancellor (2007) Maps and Mapping, Kingfisher, 1st edition.

Deborah Chancellor (2010) Sticker Atlas, Kingfisher, 1st edition.

Deborah Saathoff Broadman \& Holman Pub (1999) Address Planet Earth ،1st Edition.

Deno,J.A.(1995) The relationship of previous experiences to spatial visualization ability , Engineering Design Graphics Journal, Vol.(59),pp.5-17.

Dora saves map, From:http://www.nickjr.com/games/dora-saves-map.jhtml, Retrieved, December, 10, 2014.

Ink Scape From: http://inkscape.org/showcase/gallery/inkscape_rpg_map.png, Retrieved, December, 15, 2014.

Elza Yasuko Passini (2000) Graphs Make and Understand, Brazil. 
Esmael Yossef (2006) Geographic analysis of Sadat town cognitive map ,egypt.

First picture Atlas (2006) Science Arabian home for publish, 1st edition.

Gauvain, M. , \& Rogoff, B. (1989) Ways of speaking about space the development of children's skills in communicating spatial knowledge, Cognitive Development, Vol. (4) ,pp. 295-307.

Guy Fox (2007) London Children's Map, 1st edition.

Haugland (2000) a computers and young children R.A.G arider, Cartography and mind of man cartographic jourenal, Vol. (18), pp.111-112.

Henry W. Castner (1999) Setting the scene - Discovering concepts basic to mapping, USA.

Healthy Interactions map, From: Healthy Interactions.com, Retrieved, November, 28, 2014. 


\title{
استخدام نظم المعلومات الجغرافية في إدارة النفايات الصلبة
}

\author{
بمدينة الخرطوم \\ الدكتور /أمل الماحي الخليفة محمد \\ أستاذ الجغرافيا المساعد - كلية العلوم الانسانية- جامعة الملك خالد- أبها
}

الملخص

تعل مشكلة التخلص من النفايات الصلبة من المشكلات التي واجهت الإنسان قديما وحيثا. وقث

تزايدت حدة هذه المثكلة في الوقت الحاضر كنتيجة لزيادة معدلات التحضر بزيادة عدد السكان، التقلم الحضاري،

الاقتصادي. وتزداد بوضوح في المدن ذات الكثافات السكانية العالية خاصة.

الخرطوم عاصمة السودان السياسية والتي مرت بحقب تاريخية مختلفة بمثلها الامتداد السكاني

و العمراني والصناعي لتلك الحقب حتى وصلت إلى ما هي عليه في يومنا هذا، مما كان له الأثر الأكبر في ظهور كثير من المشكلات الحضرية خاصة التلوث بالنفايات الحضرية الصلبة التي صارت لفترة غير بعيدة محل اهتمام و معالجة منهجية صارمة من قبل السلطات المعنية.

تهذف هذه الورقة الى إبراز أهمية استخدام نظم المعلومات الجفرفية (G/S). لتحليد مواقع الطمر الصحي، ادارة وجمع ونقل النفايات الصلبة وايضا مراقبة مطامر النفايات المغلقة ثم كتابة التقارير الدورية وعرض المعلومات على شبكة الانترنت

أظهرت النتائج الأولية أنه لا توجد إستراتيجية واضحة تدمج الأبعاد البيئية و التشريعية و المالية في آن واحد أمام توسع المدينة و تطور الصناعة و تغير أنماط الحياة فيها، فالملاحظ أن أدى ذلك إلى تزايد كمية النفايات

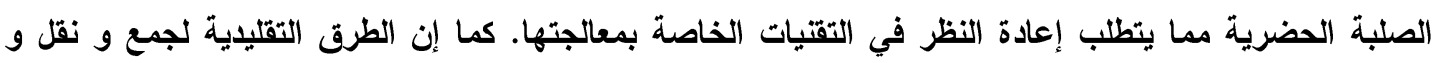
معالجة النفايات الصلبة تتبعها مشاكل تهدد الصحة العامة.

لذلكك أوصت الورقة: انه لابد من توجيه اهتمام خاص نحو جمع النفايات الصلبة والتخلص منها وابتكار أساليب إدارية وفنية وتقنية تضمن القيام بمختلف عمليات الجمع والتخلص والمعالجة واستخدام الأساليب والتقتيات الحديثة والاتجاهات الحديثة في هذه المجالات وذلك في إطار إستراتيجية الإدارة المتكاملة للنفايات. ومن ثم عرض خطة عمل لإذخال تقنية نظم المعلومات الجفرافية (GIS).في إدارة النفايات الصلبة في مدينة الخرطوم. 


\section{Abstract}

The problem of solid waste disposal is one of the problems faced by humans in ancient times. This problem has been exacerbated at the present time as a result of the increasing rates of urbanization by population growth, cultural progress, and economic growth. And are clearly increasing in cities with high population densities

Khartoum, the political capital of Sudan, which has passed through different historical periods represented by the demographic, urban and industrial extension of those periods until it reached the present day, which has had a major impact on the emergence of many urban problems, especially pollution of urban solid waste, which has become a matter of interest and Strictly addressed by the authorities concerned

The aim of this paper is to praise high the role of GIS as tool to administer, and to determine dumping sites for Khartoum garbage. Also, such a method highly effectual in monitoring such dumping sites and inscribing reports on them. This plus displaying these reports on the Worldwide Web (WWW)

The research initial results indicate the absence of a clear strategy to merge all the environmental, legal and financial dimensions of the garbage disposal issue. The rapid expansion of Khartoum city, plus the speedy expansion of the city, rapid boosting of the industry and variation of life style have work to boost up both the amount of garbage and its assortment. This nictitates reviewing the current policy of garbage disposal. This is due to that current traditional methods are out-dated. Due to that, various environmental and ecological problems are escalating to cause multiple human hygiene problems that defy public health.

For all that the paper recommends the authorities should pay attention, especially for garbage collection, disposal and dumping. All these procedure should be completed via applying the most up-to-date methods, in order to 
guarantee the ultimate accuracy and keen work. One effective means of these methods is GIS, which pledge a highly effective outcome regarding garbage collection, disposal and dumping.

المقدمة:

تعد النفايات من المشاكل البيئية المعاصرة التي تواجه معضم دول العالم وخصوصا الدول العربية وذلك لكونها أحد أهم مصادر التلوث في هذه الدول. فتزايد انتثار النفايات الصلبة بانواعها بصفة عامة يسهم بثكل

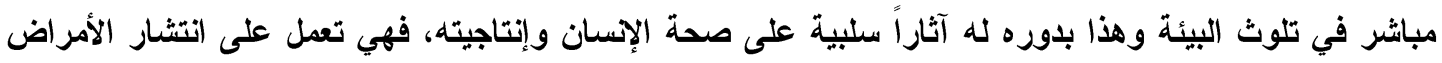
المعدية وزيادة نسبة الوفيات وانخفاض مستويات الرفاهية.

فالإنسان القديم لم يكن يهتم كثيراً بالتخلص من النفايات وذللك لأنه كان دائم التنقل والترحال، ولهذا كان يلقي بمخلفاته في كل مكان ولا تخطر مثكلة التلوث على باله حيث كان يقوم بمبارحة المكان والاتتقال إلى مكان آخر تاركاً وراءه هذه المخلفات، وبعد أن استقر الإنسان وسكن في هذه التجمعات الكبيرة أصبح لزاماً عليه أن يبتكر بهر طر ائق فعالة لجمع هذه المخلفات و التخلص منها.

ظهرت الحاجة الاستخدام أساليب علمية في التحليل و التخطيط لإدارة المشاكل البيئية باتخاذ القرارات المناسبة بسبب ضخامة حجم المشاكل البيئية و التي غدت تداخلاتها على درجة عالية من التعقيد أن صارت الأساليب التقليدية التي تعتمد الخبرة الذاتية و التجربة لمتخذ القرار غير فعالة. من ناحية أخرى فنتائج القرارات إن لم تكن محسوبة و مقدرة تقديرًا صحيحًا، فقد تترتب عليها أضراراً جسيمة وخسائر لا يمكن تعويضها. ومن هنا تأتي أهمية استخدام أهمية نظام المعلومات الجغرافية كأحد أهم الأدوات المستخدة في حل المشاكل الكبيرة و المعقدة، ولما لها من دورٍ مهمٍ في إدارة النفايات الصلبة ذلتك لان جوانب عديدة من عمليات التخطيط والإدارة للنفايات تعتمد على المعطيات و المعلومات المكانية، وبذللك فان هذا النظام يقوم على تخزين البياتات ومعالجتها بدقة لتسهيل عمليات جمع و إزالة النفايات، تحديد أفضل المواقع كحطات للترحيل، تخطيط الطرق التي ستسلكها الثاحنات التي تقوم بنقل النفايات إلى محطات الترحيل؛ ثم إلى المطامر، و من ثم تحديد مواقع طمر جديدة ومناسبة بحيث تسهل مر اقبة هذه المطامر.

تعرف نظم المعلومات الجغرافية (Geographical Information System: GIS) بأنها نظم حاسوبية لجمع،إدخال، معالجة، تحليل،عرض و إخراج المعلومات الجغرافية والوصفية لأهداف محددة. وهذا التعريف يتضمن مقدرة النظام على إذخال المعلومات الجغرافية (خرائ،، صور جوية، صور فضائية)، والوصفية و المعلومات الجدولية، من حيث معالجتها، تخزينها، استرجاعها، تحليلها تليلا مكانيا و إحصائيا، ومن ثم عرضها

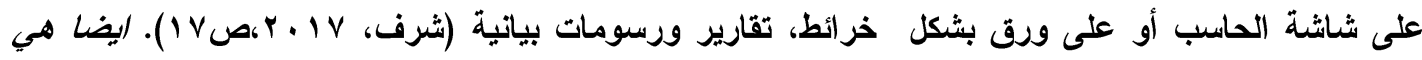


برنامج حاسويي بريط البيانات الجنرافية المكانية (Spatial Data)، كأماكن ومواقع الظواهر على الطبيعة مع البيانات الوصفية لهذه الظواهر Attribute Data) اي ما هي هذه الظواهر. وبخلاف الخريطة الورقية

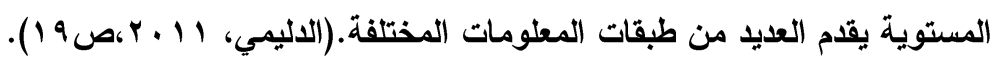

إن استخدام الخريطة من أجل الاراسات المختلفة في المجالات البيئية، المعمارية، الجيولوجية، إدارة الموارد البيئية...الخ وعمليات التحليل الجغرافية ليست جديدة، لكن الجديد هو ان نظم المعلومات الجغرافية تقوم بإجر اء هذه العمليات بشكل أفضل وأسرع من الطرق الكارتوجر افية القديمة.(رحمة :بدون تاريخ .ص YV) تم إنثاء أول نظام معلومات جغرافي في كندا عام ع 197 لمعرفة صلاحية الأراضي الزراعية و التأثير المتبادل بين الإنسان و البيئة، لذلكك يمكن القول بأن أولى تطبيقات نظم المعلومات الجغرافية هي تطبيقات بيئية. حيث تتطلب الاراسات البيئية استخدام كم هائل من البيانات المعقدة و الكثيرة، و في غالب الأحيان لا يمكن تقييم هذه البيانات وربطها بصورة صحيحة بسبب ضيق الوقت والموارد، وإن التحدي الكبير في الربط بين هذه البيانات و تحليلها بطرق سريعة ودقيقة للوصول إلى الحلول المثلى. وتأتي نظم المعلومات الجغرافية كتقنية حاسوبية تقوم بأداء المهمة على أكمل وجه، وهي تساعد في دمج المعلومات الجغرافية المكانية مع المعلومات الوصفية في نظام تحليلي متكامل يمكن الخبراء البيئيين من تصور و نمذجة العالم الحقيقي رقميا وتنظيم المطلومات.(سامح،

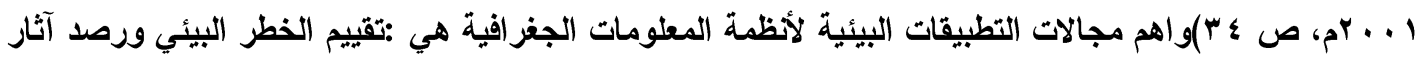
التلوث، التخطيط و الإدارة البيئية، إدارة المصادر المائية، إدارة مرافق المياه العامة، إدارة النفايات الصلبة، و إدارة الكوارث البيئية كالزلازل والأعاصير،..الخ. كما يمكن أيضًا إستخدام الGIS لايجاد العلاقة بين القرب من مصادر التلوث المختلفة وانتثار بعض الأمراض، وذلك بإسقاط الإحصائيات المختلفة لانتثار المرض على الخرائط و مقارنتها مع توزع مؤشرات التلوث و قرب مناطق الكثافة السكانية من مصادر التلوث(عبده، . . . Y، r r). تطبيقات نظم المعلومات الجغر افية (G/S) في إدارة المدن

يتطلب التخطيط في المدن عموما، معرفة شاملة بالمعلومات الكثيرة جدًا في حيزها المكاني والزماني لأن البيانات في معظم المشاريع الحضرية تمتلك مكونات ذات صلة بالمواقع الجغرافية، وهي مهمة صعبة عند استخدام الطرق التقليدية، لكن بوجود نظام معلومات يربط المواقع الجغرافية والمكاتية بقواعد البياتا،وبالتالي يمكن ضمان عملية التخطيط السليم و والذي يساهم GIS كثيرا في الاستفلال الأمثل للموارد والتي يجب على الإدارات في المناطق الحضرية، تطبيق نظام المعلومات الجغرافية في تحقيق مستوى أفضل من تخطيط الخدمات وتوفيرها للمواطن حيث يعمل هذا النظام على ربط البيانات المدخلة عن طريق مختلف الإدارات بالخرائط الجغرافية لتحديد أماكنها مما يسهل على المستخدم أخذ صورة وافية عن موضوع ما والاستفادة منه لاتخاذ قرارات صحيحة، ويقوم النظام بتحليل ودر اسة البيانات وعرضها بطرق جديدة تفيد الإدارة والمواطن. 
استخدمت تقنية نظم المعلومات الجغرافية في المناطق الحضرية خلا العقود الثلاثة الماضية لإجاز المهام الموكلة اليها. كما اتضح بصورة واضحة استخدام نظم المطومات الجغرافية (GIS)(المكانية في إنجاز هذه المهام لأن معالجة العوامل المختلفة المؤثرة على الصحة ونوعية حياة و أمن سكان المدينة، يعتمد بثكل أساسي على معرفة جغرافية وفهم خصائص المواقع والتشريعات والموارد الطبيعية والثقافية والنقل والمرافق والبنية التحتية، و إن العوامل التي تؤثر على كل من هذه الخصائص مهمة جدًامن أجل إدارة بيئة المدينة وتأمين الخدمات بثكل

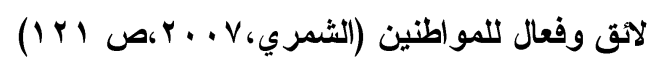

تم تطبيق نظم المطلومات الجغرافية في مؤسسات العديد من المدن العربية ، وتعد تجربة بلدية دبي من

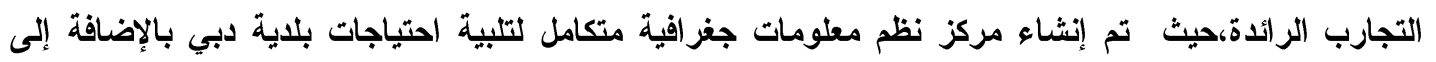

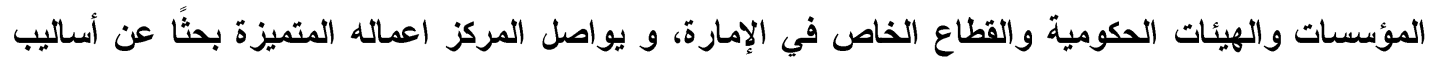
مبتكرة وفعالة لتوفير أحدث التقتيات بما يرفع من القدرات التشغيلية والتخطيطية لبلدية دبي ، وبالتالبي يساهم في تحسين نوعية الحياة لكافة المواطنين. ويساعد المركز على توفير بيانات ومعلومات (مكانية) جغرافية دوقيقة وحديثة إلى مختلف الدوائر المحلية والهيئات والمؤسسات العامة والخاصة والأفراد في الموقع المعين، وذلك لإعداد الخرائط ودعم اتخاذ القرار الصحيح. ويتم دمج المعلومات الجغرافية من مختلف الدوائر الحكومية في المناطق الحضرية، وتحديد الأماكن المهمة،لايجاد الخرائط وفقا للفرض المطلوب. مما بسهل عملية البحث عن الطرق والعناوين، لتحديد مواقع المدارس والمستثفيات والفنادق وأماكن الخدمات الأخرى المهمة. ويمكن للمستخدمين النفاذ إلى صور جوية ذات دقة عالية لقياس المناطق والمسافات .وبواسطة النظام الجديد سيتمكن المستخدمن من طباعة أو إرسال الخرائط عبر البريد الإكتروني في غضون ثوان: كما يتم توفير الكثير من التكاليف والوقت .وفي الحقيقة فإن استخدام نظم المعلومات الجغرافية الجديد، يمكن من استرجاع البيانات من

$$
\text { مختلف المؤسسات والوكالات ويمكن النفاذ إلى معلومات الموقع الجغر افي بسهولة. }
$$

وفي مدينة القاهرة تم بناء العديد من نظم المعلومات الجغرافية واستخدام تقتيات الاستثعار من بعد لإدارة التنمية العمرانية بإقليم القاهرة الكبرى وتسهيل عرض وتحليل وتحديث البيانات العمرانية الخاصة بثبكات الثوارع و المر افقى و المنثات و الخدمات (عبده، A . . . r ، ع ع ه). كما استخدمت بلاية جونية في لبنان نظم المعلومات الجغرافية في مركز البلاية، حيث تم ربط قواعد البياتاتS/S الإدارية والمالية بالمعلومات الجغرافية مما وضر للبلاية الكثير من المعلومات الجديدة التي تساعد في عمليات التدقيق والتحقى و التكليف وإنجاز المعاملات والبحث عن معلومات جغر افية في مجالات متعددة من العمل البلاي. ويثمل هذا النظام أكثر من سبعين طبقة مختلفة من المعلومات الإدارية والمالية والهندية المرتبطة بالمعلومات الجغرافية والتي تساعد المراكز البلاية في اتخاذ القرارات فيما يتعلق بتقييم حاجات البلاية لمشاريع مستقبلية إنمائية وسياحية وصناعية والتخطيط لها، كما تساهم في تعزيز الثفافية والمساعلة في عمليتي التحقى و التحصيل وفي التأكد من صحة، رخص البناء والإعلانات وغيرها التي تمنحها البلاية للشركات والمواطنين. 
ويساعد تطبيق ال GIS في المدن على المشاركة في المعلومات بين الإدارات المختلفة، تقليل المصاريف، التسهيل الوصول إلى المعلومات لجميع المستخدمين و المساعدة في اتخاذ القرار .( شايش، و حمودي. • 1. ؟.ص

\section{تطبيقات نظم المطلومات الجغرافية G/S في إدارة النفايات الصلبة:}

ساهت التظورات الاقتصادية والاجتماعية خلال العقدين التاسع عشر والعشرين في ظهور انماط معيثية جليدة ادت الى زيادة متطلبات الاسان واحتياجاته، ومن بين ابرز واهم هذه المشاكل و اكثرها خطورة ، أدارة النفايات الصلبة حيث رافق هذا التطور تزايد كميات النفايات الصلبة.

تعدّ مشكلة النفايات الصلبة في مقدمة المشاكل البيئية في المناطق الحضرية، وذلك بسبب تأثيرها المباثر على نوعية حياة الإسان والمظهر الحضاري، وما يترتب على ذلك من انعكاسات خطيرة على التنمية الثاملة .حيث أصبحت كميات النفايات الصلبة هائلة و تتزايد كمياتها طرديًا مع زيادة عدد السكان فيما يرتفع محتواها من المواد الضارة التي يصعب التعرف إليها أو الحد من تراكمها، و تعتبر النفايات الصلبة ثروة وطنية،

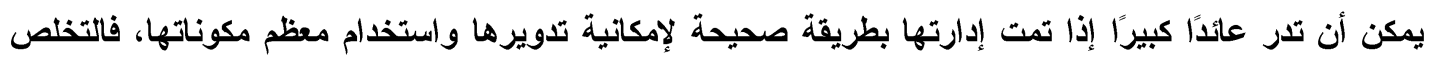
العثوائي يهدر مواد قد تكون ذات قيمة اقتصادية إضافة إلى ما يرافقها من آثار سلبية على البيئة والصحة. تمثل عملية تجميع المخلفات الصلبة والمعالجة السليمة لها و التخلص من الكميات المتزايدة منها تحديًا يوميًاللمدن و البلايات، حيث أن التخلص غير المدروس وحرق المخلفات الصلبة يمثل مثكلة بيئية رئيسة، وتعثبر إدارة المخلفات الصلبة بطرق سليمة في الخرطوم أولوية كبرى لوزارة البيئة والتنمية العمرانية، كما إن عملية النظافة العامة والتخلص من النفايات في المدن و البلدان أصبحت عملية متخصصة بالغة التعقيد لا تعتمد فقط على المعرفة العلمية والتقنية والحصول على الوسائل التكنولوجية المناسبة، و لكنها تعتمد في المقام الأول على حسن الإدارة. تحتاج المؤسسات للتخطيط لاحتواء مخاطر النفايات الصلبة على البيئة والمجتمع، و إيجاد طريقة متكاملة لإدارة النفايات الصلبة تضمن حماية البيئة حاضرا ومستقبلا للتعامل مع كميات النفايات المتوقع توليدها لفترة طويلة. ولنظام المعلومات الجغرافية (GIS)، قدرات كبيرة يمكن أن بساهم بها كثيرا في تخطيط الخدمات ورفع مستوى توفرها للمواطن، حيث يعمل هذا النظام على ربط البياتات المختلفة بالخرائط الجغرافية مما يسهل على المستخلم أخذ صورة كاملة عن موضوع ما لاتخاذ قرارات صحيحة، ويقوم النظام بتحليل ودراسة البيانات وعرضها بطرق جديدة تفيد الإدارة وأقسامها المختلفة والمواطن. يساعد GIS الباحثين وأصحاب القرار في كل مراحل التخطيط لإدارة النفايات الصلبة بما في ذلت التنبؤ بكميات النفايات المتولدة ومعالجتها وتحديد مواقع التخلص منها وتحديد مسارات نقل النفايات 
وفي كثير من البلاد العربية تم بناء العليد من التطبيقات البيئية باستخدام تكنولوجيا نظم المعلومات الجغرافية والاستثعار عن بعد لخدمة متذذي القرار في مجالات البيئية المختلفة، و يتم إعداد نظام معلومات جغر افي لإدارة المخلفات الصلبة، زراعية، صناعية او حضرية. وعند الانتهاء من هذا النظام سيكون له دورًا هامًا وحيويًا للمساهمة في رسم السياسات الخاصة والآفاق المستقبلية في إدارة ومعرفة حجم ونوعية المخلفات الصلبة على كافة المستويات ونزولا إلى مستوى المراكز المختلفة، كما يقوم النظام بتوفير الخرائط الجغرافية لأماكن هذه المخلفات مما بساهم في وضع الإطار العام للضوابط الفنية والآمنة في المعالجة والتخلص منها .بالإضافة إلى تعظيم دور التعاون والتكامل بين الجهات والوزارات المختلفة لحل معظم المشاكل المترتبة عن تلك هذه المخلفات(المعهو العربي لإنماء المدن، الإدارة البيئية للنفايات في المدن العربية)،لب، الجمهورية العربية

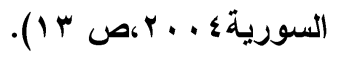

استخدام نظام المعلومات الجغرافي في إدارة، جمع و نقل النفايات:

تعدّ عملية جمع النفايات الصلبة من أهم وظائف إدارة النفايات وتدبيرها وهي الأكثر كلفة من ناحية اقتصادية حيث تصل نفقاتها إلى نحو •v\% من نفقات أنظمة إدارة ومعالجة المخلفات الصلبة(مصدر سابق، ص ه 1). إن عملية جمع ونقل المخلفات الصلبة تعتبر المسألة الأولى و الأساسية في إدارة النفايات الصلبة ،حيث تبدأ هذه العملية من وضع المخلفات في الحاويات إلى تفريغ هذه الحاويات في سيارات النقل ومن ثم نقلها إلى محطات التجميع و الطمر ـ ولذلك فضبط هذه العملية لمدينة أو ولاية بالطرق المتبعة يعتبر عملا صعبا إلى حد ما، وفي كثير من الأحيان يكون عملا غير منظم. إلا أنه باستخدام نظام المعلومات الجغرافي يستطيع متخذ القرار تخطيط و تنظيم عملية جمع و نقل المخلفات بأفضل الطرق و أدقها و بأقل كلفة اقتصادية ممكنة .حيث نقوم في البداية بإخخال المعطيات و البيانات كطبقات مثل، طبقة شبكة الثوارع و المسارات، طبقة توزع الاحياء السكنية ومعلومات عن تولد النفايات الناتجة عنها، طبقة حركة السيارات العادية في المدينة و أوقات الازدحام، طبقة مواقع الحاويات، طبقة مناطق....الخ) إضافة إلى مطلومات أخرى عن أوقات الجمع،عدد الثاحنات وأنواعها، عدد العمال و نوع وحجم حاويات جمع النفايات، يستطيع متذذ القرار باستخدام G/S تحليل هذه البيانات للحصول على مسارات الجمع المثالية، زمن الجمع المثالي، فضمن بيئة ال GIS يتم وضع برنامج تسيير عربات جمع النفايات والجدولة الزمنية لعملها في نظام إدارة النفايات الصلبة وقد تم تطبيق هذا البرنامج في منطقة محددة في تايوان، لهان يسمح هذا للبرنامج لأصحاب القرار باختيار عدة بائل لجمع النفايات قبل اختيار سيناريو التثغيل النهائي

(Wilson, 1999, Austin, p. 65)

تحديد مواقع الطمر الصحي للنفايات الصلبة باستخدام نظم المعلومات الجغرافية:

تعدّ عملية اختيار موقع الطمر الصحي من الأمور الصعبة، نظرًا لأهمية أخذ العديد من العوامل بعين الاعتبار، فمن أهم العوامل لتحديد ملايمة موقع للطر الصحي في المرحلة الأولى، البعد عن المصادر المائية 
السطحيةوالجوفية، البعد عن مناطق الجريان السطي والسهول الفيضية، كمية التساقط المطري، اتجاه الريح السائدة في المنطقة، نوع التربة، التركيب الجيولوجي ووجود الفوالقى والثقوق، الكلفة المادية، البعد عن المناطق السكنية، التأثير الخطير على أنواع نباتية أو حيوانية، بعد المرحلة الأولى يتم اختيار عدة مواقع محتملة تتم دراستها بدقة.

اما في المرحلة الثانية فتتم المفاضلة بين تلك المواقع لاختيار الأفضل حيث تؤخذ بعين الاعتبار معايير خاصة مثل: حجم الموقع، فعالية التربة من أجل التظطية، استخدامات الأرض والكلفة، مسافة وزمن النقل، الاتحدار، الارتفاع، إضافة إلى ذلك يساعد ال GIS على إعلام السكان التأثيرات البيئية الثانوية ومدى تقبل السكان المحليين لموقع الطمر ومعرفة ردة فعلهم ومحاورتهم من اجل الوصول الى إنتاج الخرائط الأساسية للمواقع المقترحة أو نشرها على شبكة الاتترنت.

وهنا تلعب تقنية الGIS دوراً كبيراً في تحديد المواقع المثلى لمطامر النفايات الصلبة، من خلا النظرة الثمولية الواسعة لهذه التقنية وربط جميع العوامل التي تدخل في تحديد هذه المواقع وتستخدم أدوات التطابق من أجل اختيار البدائل المقترحة في المرحلة الأولى، وفي المرحلة الثانية تستخدم (Buffer, Overlay)

مزيج من أدوت وزن الأفضليات في عمل التحليل المكاني وأدوات اتخاذ القرار مثل ال (Weighting) Preferences).من أجل تحديد الحل المثالي، بالإضافة إلى أن الوصول إلى القرار السليم بالطرق المتبعة التقليدية يحتاج إلى وقت طويل جدًا، لكن يمكن باستخدام نظام المعلومات الجغر افي تحديد موقع مناسب للطمر بدقة كبيرة و بسرعة فائقة .فعملية اختيار أنسب المواقع لمكبات النفايات تعتبر عملية صعبة ومعقدة، وتمر بمراحل متعددة، فهي تحتاج إلى وساىل ومكانيات متعددة للقيام بها ، وسيتــم في الاختيار أخذ مجموعة من المعايير بعين الاعتبار والتي منها نوع التربة، والماء الجوفي، والبعد عن الطرق، وكذلكك استخدامات الارض المختلفة، و التجمعات السكنية، وغيرها من المعايير للوصول في النهاية إلى خيارات لاتلحق الاذى أو تقلل من الضرر الناتج عن مكبات النفايات إلى أدنى مستوياتها. وسيتــم اختيار الاماكن والمواقع التي تحصل على أكثر الايجابيات وأقل السلبيات والتي سيقع عليها الاختيار لتكون مكبات نفايات صحية. فبعد أن يتم جمع المعلومات المطلوبة سيقوم النظام بتنفيذ عمليات مخفية عن المستخدم وبالنهاية يقوم بعرض المناطق المحتملة واختيار افضل موقع للطمر للوصول إلى القزار السليم. للبحث عن موقع ملام لحقل طمر صحي باستخدام نظم المعلومات الجغرافية، يمكن استخدام المعلومات المكانية لإظهار الطبقات مع بعضها البعض باستخدام عملية تسمى التفطية المكانية(Spatial Overlay) ، وعند اختيار حقل الطمر الصحي يجب أن يوضع في الاعتبار التالي. ا.نوع التربة من اجل منع وصول الملوثات إلى الماء الجوفي.تستخدم طبقة نوع التربة. 
r.في منطقة لا يوجد فيها تصدعات جيولوجية اوفوالق (تضاف طبقة الفو الثق). r.ب.منطقة لا يمكن أن يحدث فيها فيضان، تضاف طبقة مناطق الفيضان والسيول. ؛ كما أنه يجب أن يكون بعيداً عن المناطق السكنية، تضاف طبقة المناطق السكنية (استخدامات الارض). يقوم ال GIS بإيجاد المواقع الملانمة التي تحقق كل المعايير المطلوبة حيث التربة الملانمة، بعيدة مناطق الفو الثق والفيضاتات و التجمعات السكانية والخدمات عموما. وقديما كان من الصعب اختيار موقع طمر صحي بواسطة مجموعة كبيرة من الخرائط والمراجع لان هذه الخرائط تكون مرسومة بمقاييس مختلفة، ولكن باستخام الG/S اصبح من السهل ان يتم اختيار موقع الطمر من

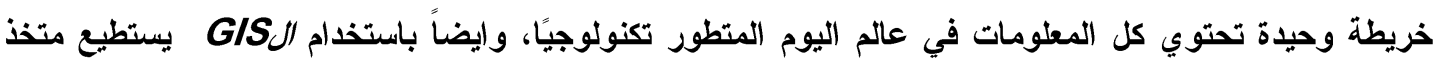
القرار أن يريط الخرائط الرقمية مع كميات هائلة من البيانات من أجل إنتاج الخرائط وتحليلها.

وقد تم تصميم نظام المعلومات الجغرافي بحيث يأخذ في الاعتبار المعايير والاشتراطات البيئية المطلوب

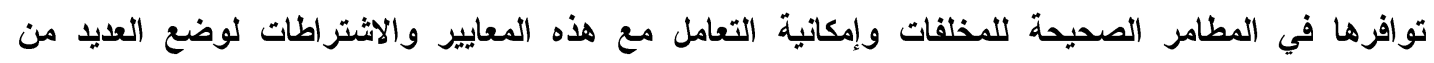

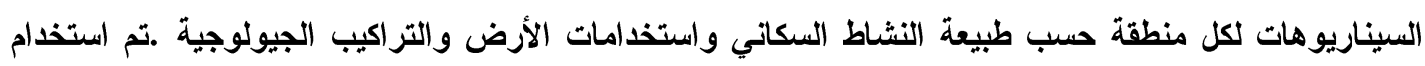

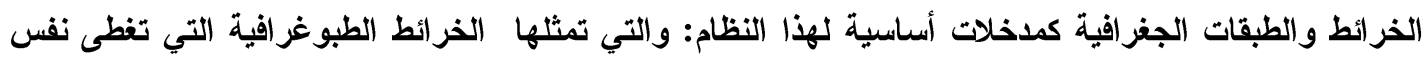

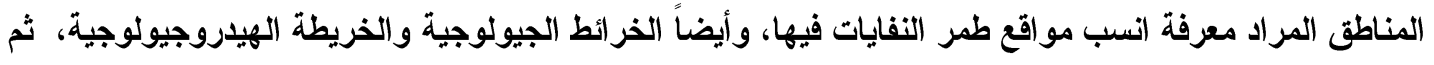
خريطة الحدود الإدارية للمنطقة.كما تم ربط الخرائط والطبقات الجغرافية بالبيانات الخاصة بتعداد السكان ومعدلات التيات

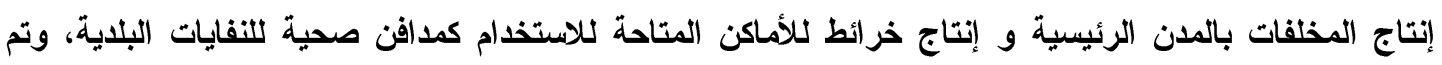
التحقق على الطبيعة من صلاحية هذه الأماكن وتحديد الاختيارات النهائية لاماكن الافن الصحي للمخلفات بكل منطقة ومن ثم تقييم الأثر البيئي لهذه المواقع قبل استخدامها. استخام نظام المعلومات الجغرافي GIS :في كتابة التقارير الدورية:

إن السؤال عن المعلومات من قبل أي جهة مسؤولة حول موضوع النفايات الصلبة و ما يتطلق بها يحتاج من

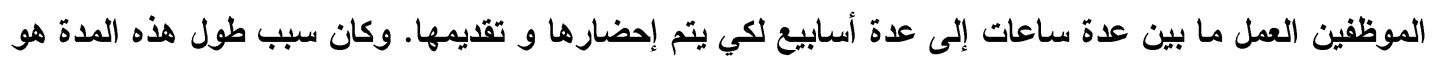

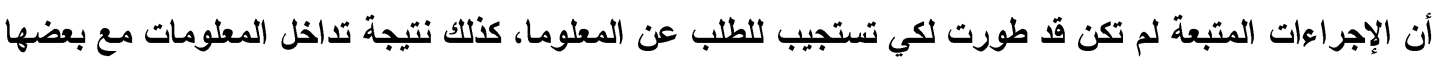

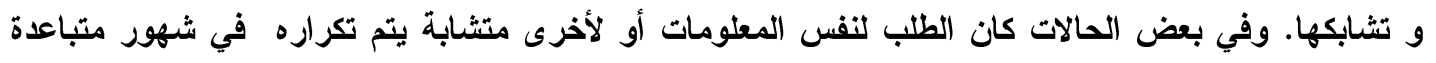

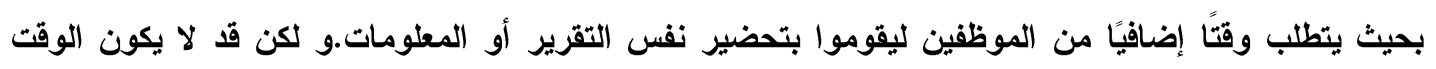

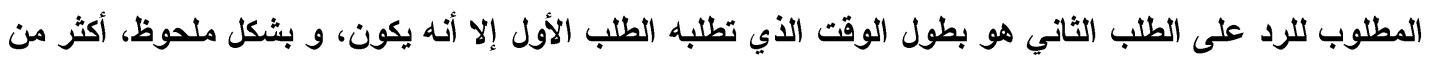

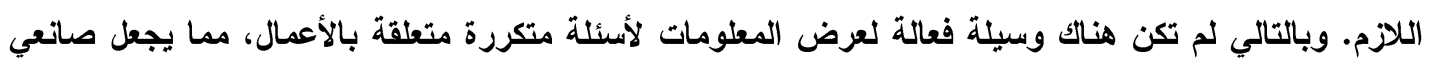


القرار والموظفين محبطين من الوقت المطلوب للرد على متطلبات ما. لذلك فان نظام المعلومات الجغرافي هو الوسيلة القادرة على تقليم المعلومات الحديثة الملخصة و السهلة الاستخدام بالإضافة إلى الوسيلة البصرية: فاستخدام نظام المعلومات الجغرافي في إعداد التقارير يتطلب عدة أمور أساسية: متحديد نوعية المستخدمين وكذلتك تحديد احتياجاتم من المعلومات.(رحمة بدون تاريخ ص 9 م) •التأكيد على ضرورة توفر المعلومات اللازمة أو وضع خطة أو طريقة لجمع المعلومات التي لم تكن متوفرة و الضرورية والتي تلبي حاجات المستخمين.

•التحكم في نوعية المطومات الموجودة أو الجديدة التي هي عنصر رئيسي في نظام التقارير، حيث أن الدقة في المعلومات المعروضة و الجداول البيانية و الرسوم البيانية وكذلك النصوص يجب تفقدها بثكل دائم. مباء و تعديل البنية التكنولوجية للمطومات وذلك للسماح بعلية الجمع والعرض للمعلومات المطلوبة للإجابة على الأسئلة المطروحة. ويمكن كنلك استخذام نظام المعلومات الجغر افي لعرض المعلومات على شبكة الإترنت في صورة تقارير بثكل يتميز بدقة المعلومات ونوعيتها وبشكلها السهل و المفهوم؛ و كذلك قدرته على تقريب و تبعيد منطقة ما و إلقاء الضوء عليها بثكل مفصل، مما جعل إمكانية عرض التقارير على شبكة الاتترنت ممكنًا بحيث يسمح للجهات المسؤولة وكذلك الباحثين في مجال البيئة مراقبة هذا الموضوع عن كثب ودراسة المثكلات وحلها. استخدام نظام المعلومات الجغرافي في مراقبة مطامر النفايات المغلقة: من الممكن استخدام نظام المعلومات الجغرافي بعد إغلاق موقع الطمر ليرصد الاستقرار لأراضي الموقع، وهذا

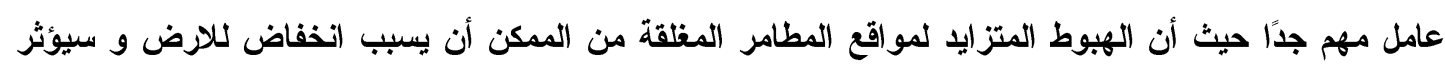
هذا على السطح بطريقتين: -الطريقة الأولى: بتثكيل جسم مائي على السطح وبالتالي زيادة الحمولة. -الطريقة الثانية: هي أن محتوى الرطوية الأعلى سيسمح للماء بالتسرب إلى جسم موقع الطمر في الأرض مثكلا مواقع جديدة للتسربات المائية. إن أنواع الهبوط المتفاوتة فوق مناطق ذات كثافة منخفضة وأخرى مرتفعة تسبب ضفطاً في طبقة

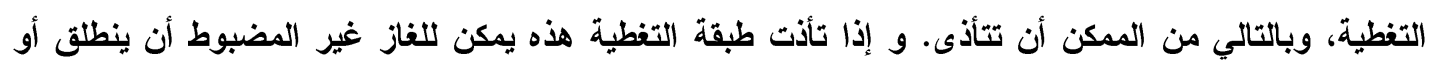

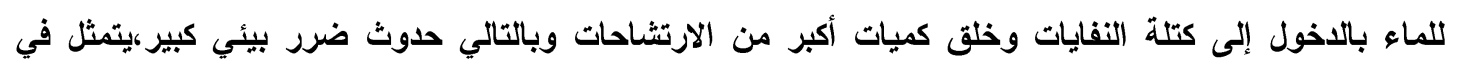
التلوث البيئي.كنلك يمكن أن ينجم عن تفاوت الضغط ضرر بأنابيب الترشيح أو بفتحات استخراج الفاز فيسبب ذلك 
تركيب غازات قابلة للاحتراق أو ملوثات وهذا ضرر بيئي آخر.ذلتك يمكن باستخدام نظام المعلومات الجغرافي، دراسة و مراقبة موقع الطمر بجمع المعلومات التالية:

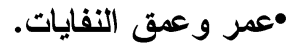
متركيب النفايات. محتوى الرطوبة للنفايات. • مستوى الترشيح في النفايات. موجود الغاز و درجة الحرارة لموقع الطمر. ويتم الحصول على بعض من المعلومات السابقة كالتالي:

عندما تأتي النفايات إلى الموقع فانه يتم وزنها عند البوابة و تسجيل الوزن مع وصف لنوع النفايات وبعد أن يتم ملع الخلية في الموقع يتم حساب معدل التركيب للنفايات وكنلك من تجارب حقلية معتمدة على المخبر يتم اختيار الكثافة الأفضل لتركيب النفايات. يمكن بعد ذلك أن تُحسب كثافة كل خلية من أجل تحديد محتواها ويقوم نظام

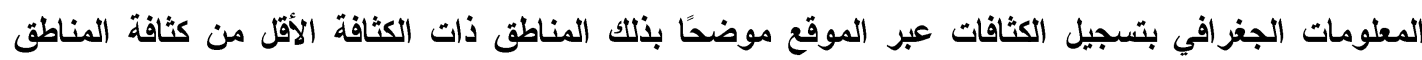
المحيطةبهاوهنا تأتي أهمية النظام بعد أن يتم إغلاق المطمر و يصبح جاهزًا لإعادة استثماره و تطويره كما يحدث أحيانًا كبناء ملاعب ومناطق للزراعة من أجل تجنب الأماكن غير المستقرة ومعالجتها إضافة إلى منع حدوث الأضرار البيئية السابقة

إدارة النفايات الخطرة باستخدام نظم المعلومات الجغرافية GIS. للنفايات الخطرة عدة صفات تميزها عن النفايات الصلبة الاخرى وهي (Reactivity) بالإضافة الى عدد من الصفات الأخرى ويعتبر القطاع الصناعي أكبر مصدر المخلفات الخطرة الصلبة، يليه القطاع الصحي الذي بثمل المستثفيات والعيادات والمختبرات الطبية. ولا بـ من الإثارة إلى أن مؤسسات التعليم العالي ومراكز البحث العلمي يُسهم كل منها كمصدر من مصادر المخلفات الخطرة الصلبة.ولا توجد في السودان دراسات توضح كميات النفايات الخطرة الصلبة وأنواعها. يمكن التخلص من المخلفات الخطرة بدفنها تحت سطح الأرض أو بحقتها في آبار عميقة. أما النفايات النووية ضعيفة أو متوسطة الإثعاع فتدفن بعد تبريدها في أماكن خاصة محاطة بالإسمنت في باطن الارض. في حين أن 
النفايات ذات النثاط الإثعاعي التي تدفن في باطن الأرض على عمق كبير في مناطق بعيدة عن العمران تبقى مصدراً للاهر اض وخاصة السرطانات.

موقع مدينة الخرطوم:

تقع الخرطوم في وسط السودان، يحدها من الجهة الثمالية الثرقية ولاية نهر النيل ومن الجهة

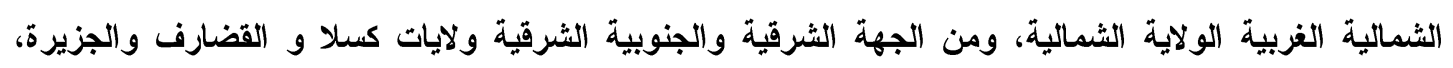

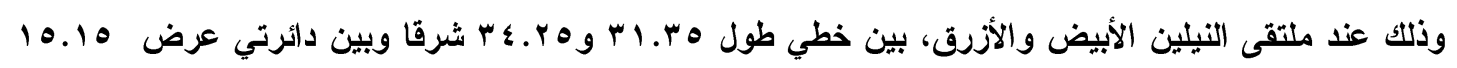

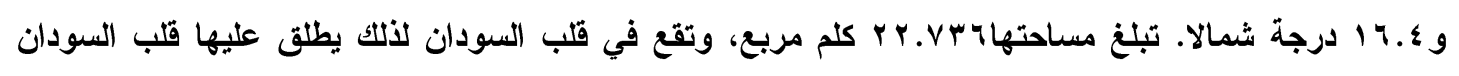
النابض، جعلها موقعها ملتقى طرق برية وبحرية وخطوط سكك حديدية تربطها بكل أجزاء السودان، وهي عاصمة

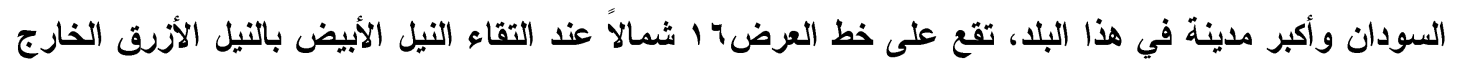
من بحيرة تانا الحبثية حيث يثكلان معاً جزيرة توتي التي تقع في المقرن. وعليها تثرف مدئ مدينة الخرطوم بأجزائها

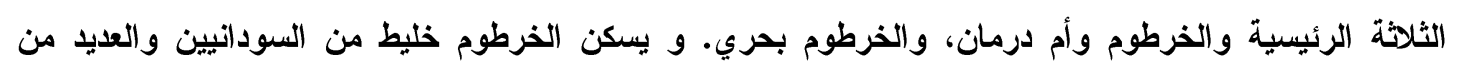

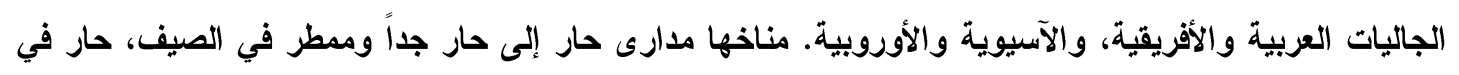
الصيف، حار إلى دافئ في الثتاء. يبلغ عدد سكان ولاية الخرطوم 5,274,321 نسمة، ومدينة الخرطوم وحدها

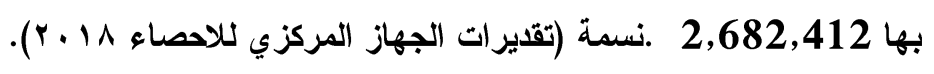

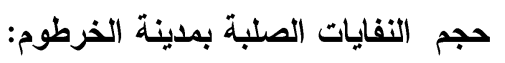

أقر المجلس الأعلى للبيئة والترقية الحضرية والريفية بولاية الخرطوم بوجود نقاط ضعف تواجه

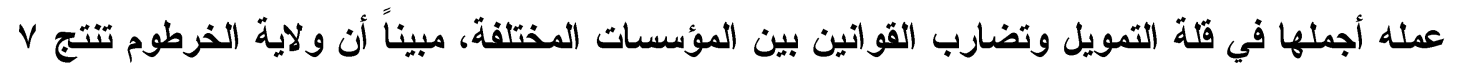

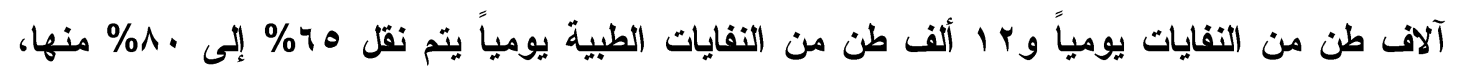

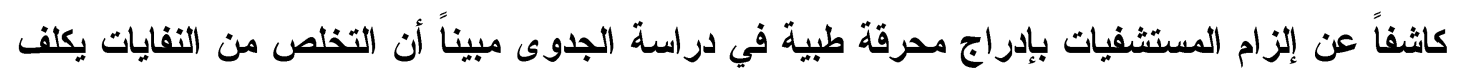
الولاية V مليون جنيه شهرياً.

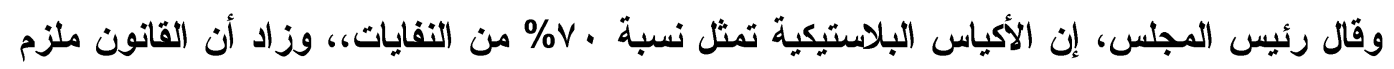

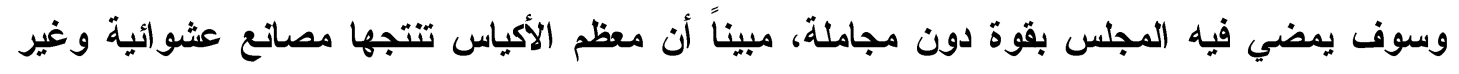

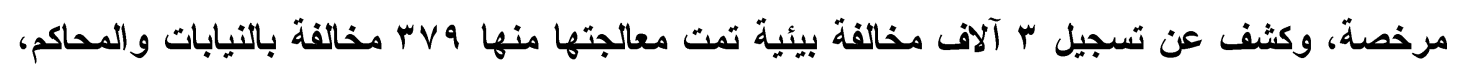
لافتاً إلى وجود ضعف في مواد التشريع، ويجب تقوية قانون العقوبات البيئية. وأقر بوجود خلل كبير في الهيكل الإداري وعدم كفاءة أداء طريقة النظافة بجانب وجود قصور في ولئي

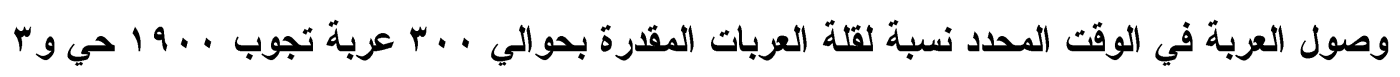

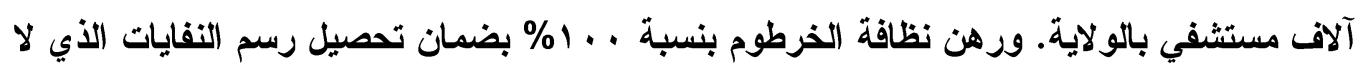

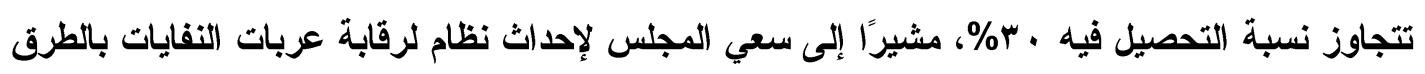




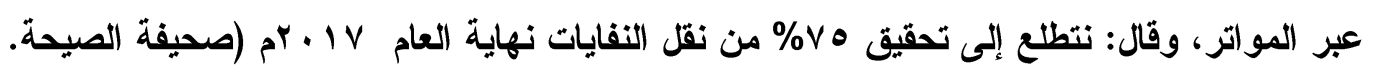

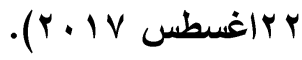
شكل يوضح انواع النفايات الصلبة

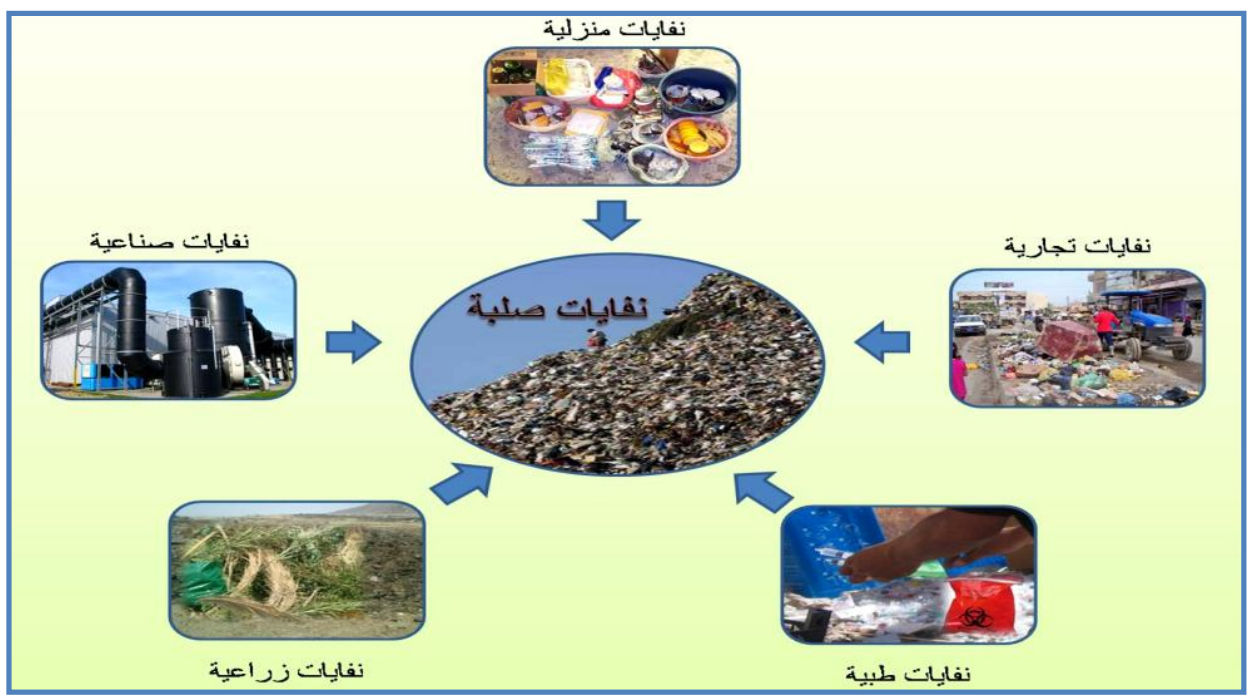

من اعداد الباحثة بالاعتماد على مجموعة بيانات من ناحية عالمية فإن إنتاج الفرد من المخلفات والنفايات يبلغ تقريباً طن في العام إذا أحسن تجميعها، ولذلك فإن ولاية الخرطوم يمكن أن يبلغ ناتج مخلفاتها حوالى . . . . . . . لطن في في السنة.

\begin{tabular}{|c|c|c|}
\hline \multicolumn{3}{|c|}{ جدول رقم( 1 ) حجم النفايات في مدنة الخرطوم } \\
\hline 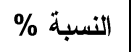 & الفضلات بالطن & متوسط النفايات الصلبة بالخرطوم: \\
\hline & 300 & متوسط فضلات الإسان في اليوم \\
\hline & 300 & متوسط فضلات الإسسان في السنة \\
\hline & 109.5 & متوسط فضلات الإسلان بالكليوجر ام \\
\hline & 0.1095 & متوسط فضلات الإسسان بالطن \\
\hline & 39.9675 & متوسط فضلات الإسسان في السنة بالطن \\
\hline & 7900000 & عدد سكان الخرطوم \\
\hline & 865050 & كمية الفضلات في السنة بدينة الخرطوم \\
\hline & 3507 & متوسطة الفضلات الصلبة بالخرطوم في اليوم \\
\hline & 1280055 & متوسطة الفضلات الصلبة بالخرطوم في السنة \\
\hline & 21.45105 & 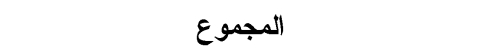 \\
\hline
\end{tabular}

المصدر:ولاية الخرطوم،المجلس الاعلى للتخطيط.الاماتة العامة. V . . . . 
طرق التخلص من النفايات الصلبة بالخرطوم:

يوجد نظام متبع لجمع النفايات الصلبة ويتم ذلك أسبوعياً من أمام المنازل وتثرف عليه اللجان الثبعية

والوحدة الإدارية ونسبة من أقروا بذلك 9.r\%٪ من السكان. يتم التخلص من النفايات الصلبة حرقاً بنسبة

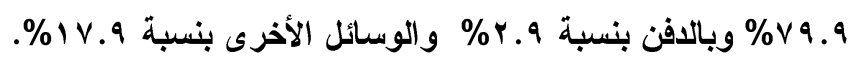

جدول ( ) يوضح كميات النفايات بمدينة الخرطوم حسب تصنيفها لثهر مارس V V. r.

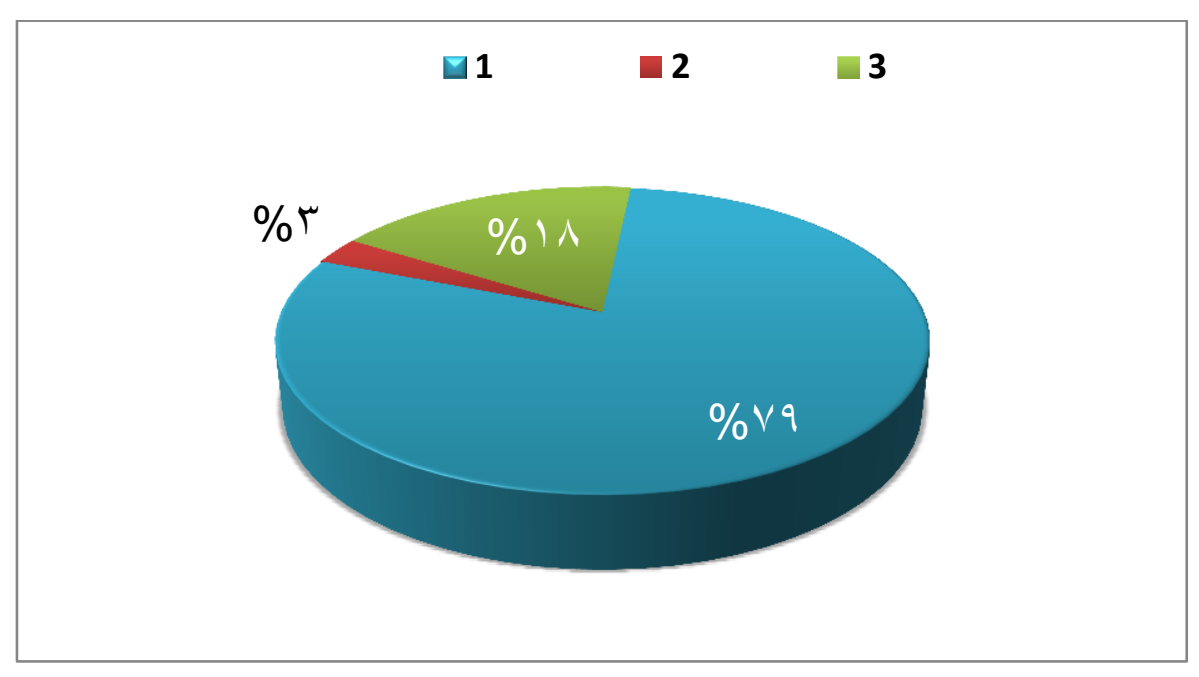

المصدر : مختصر المخطط الإستراتيجي للولاية الخرطوم يناير IV. r.

تجربة مدينة الخرطوم في ادارة النفايات الصلبة:

كانت أولى خطوات العمل على ادارة النفايات الصلبة بمدينة الخرطوم عندما صدر قرار بانثاء

برنامج اسعافي من والي ولاية الخرطوم بمعالجة النفايات بمنطقة الخرطوم الكبرى بموجب (القرار رقم بـ (1)،

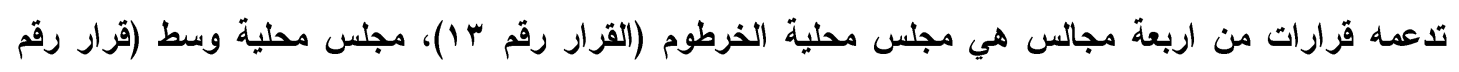
؛ 1)، ومجلس محلية غرب (قرار رقم \&) ومجلس محلية الثجرة (قرار رقم ، 1).تلتها قرارات مجالس المحليات

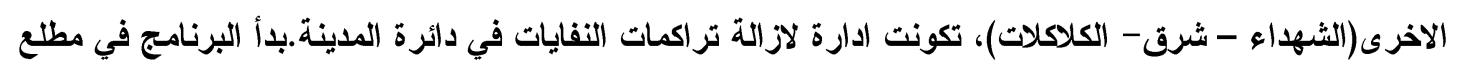

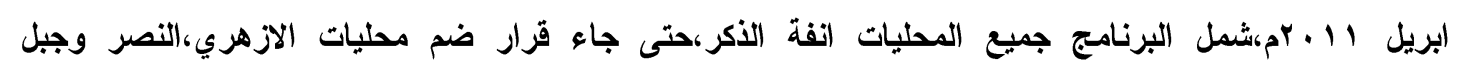

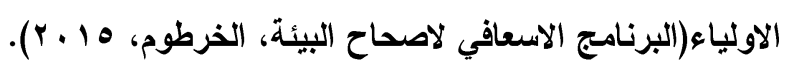
تتكون النفايات الصلبة بمنطقة الخرطوم من نفايات المنازل والنفايات التجارية والصناعية(قطاعي الثجرة وغرب) و النفايات الطبية الاكثر خطورة،حيث لا توجد طرق معالجة صحيحة لها ممايجطلها اكثر المخاطر التي تواجه المدينة. نجح البرنامج في توفير الاليات والعمالة ومعينات العمل المطلوبة وقسمت المنطقة الى عشرة قطاعات يتم التنسيق 
فيما بينها، مما مكنها من ازالة تراكم النفايات الصلبة بنجاح غير مسبوق، وتوسعت الخدمة لكل القطاعات حتى الفي

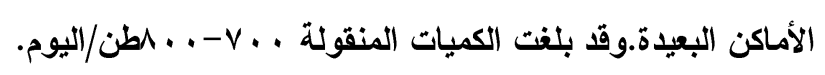

تم جمع وترحيل النفايات المنزلية وفق برنامج يومي حسب المناطق بمعدل مرتين للمنزل في الاسبوع بالجمع

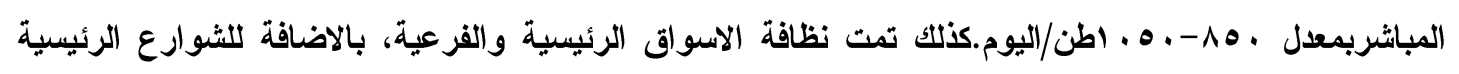

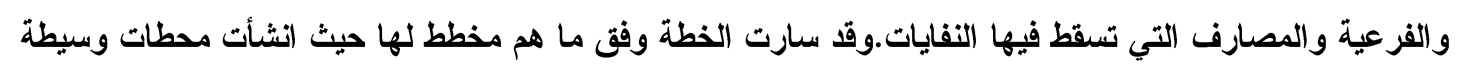

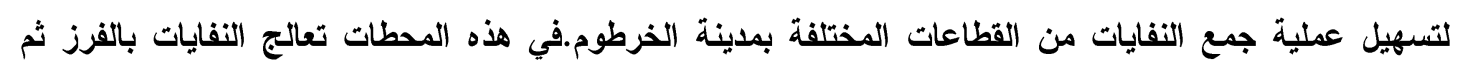

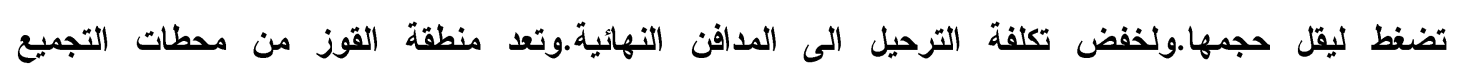
الوسيطة.بعدها تنقل إلى مناطق التخلص النهائي عن طريق شاحنات سعة ه لوتر مكب.

يتم نقل النفايات الى مناطق الطمر الصحي النهائية بواسطة العربات الضاغطة.حيث تم تأهيل المكبات العشوائية

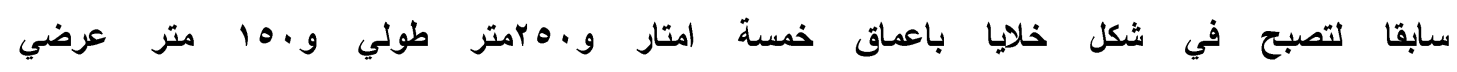
(رسم توضيحي).توضع النفايات في شكل طبقات تصل الى ع طبقات.نسبة لكثرة شكاوي الاهالي تم اغلاقها جميعا

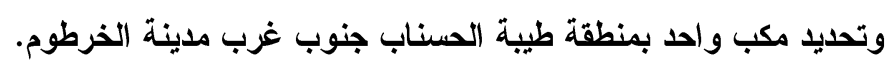

رسم توضيحي لمكب نفايات تم تاهيله بمدينة الخرطوم

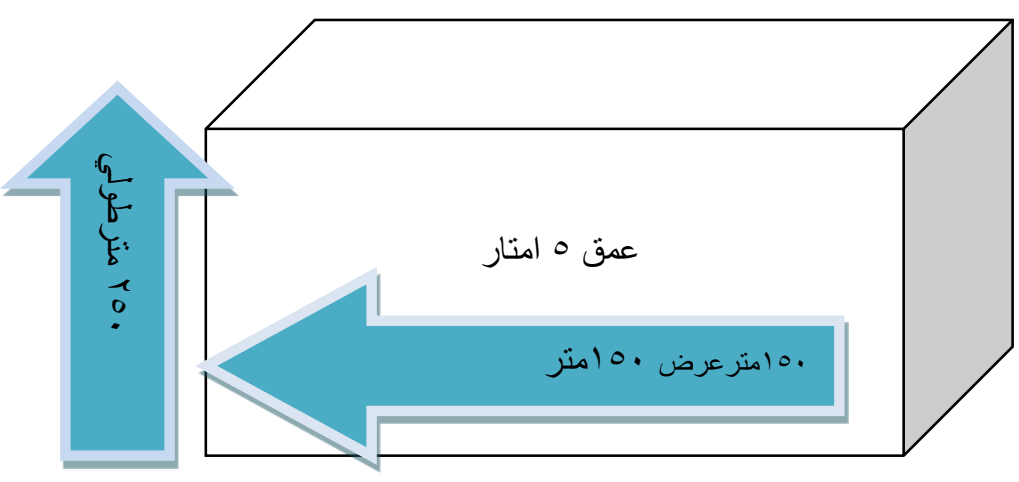




\section{خريطة رقم (1) منطقة الدراسة}

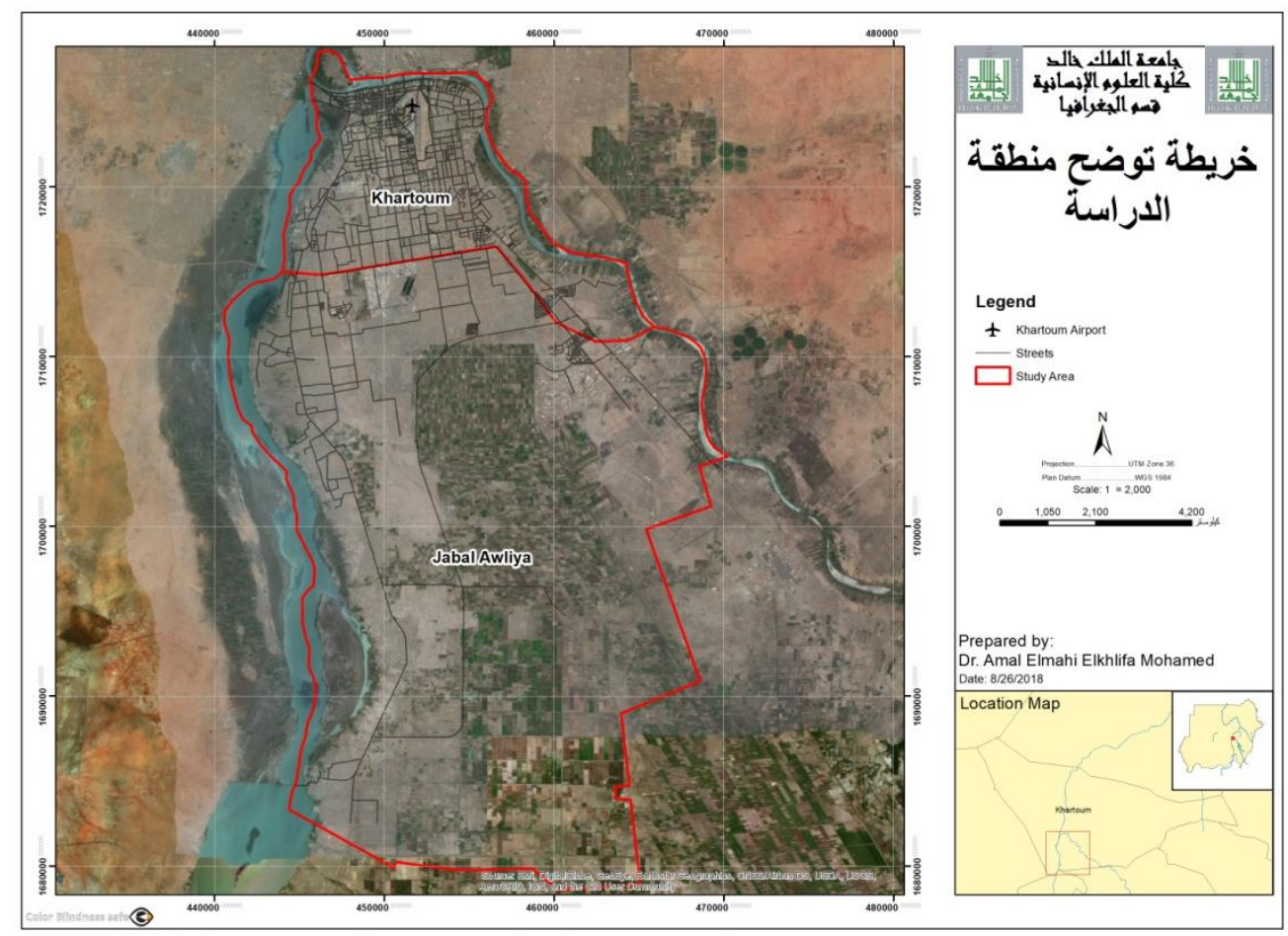

Arc gis المصدر :من اعداد الباحثة بالاعتماد على برنامج 5-10

تأرجحت مسئولية جمع ونقل النفايات الصلبة بولاية الخرطوم بين المحليات ووزارة الصحة الولايةية لوقت طويل مما أدى الى تدني واضح في صحة البيئة، حيث تحولت العاصمة الى مكب كبير للنفايات الصلبة وتراكم الأوساخ في الثوارع الرئيسية والأحياء وأطراف المدينة، ساعد على ذلك نقص الاليات والعجز عن توفر العمالة الكافية،النقص الحاد في المقدرة المادية لتسييير عمليات ادارة النفايات.لكل هذه الأسباب وصل الوضع الصحي

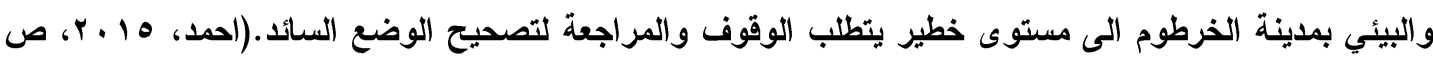

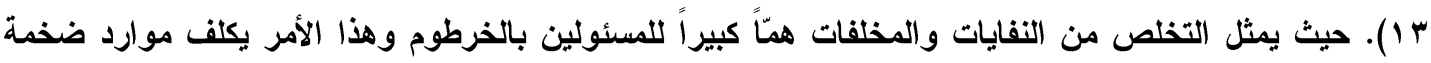
من حيث الجمع والنقل والتخلص النهائي. وعليه لابد من قيام مشروع متكامل لاستيعاب هذه المخلفات بحيث يتم استغلاهها لإنتاج الطاقة والمنتجات الفرعية الأخرى كما في أنحاء عديدة من العالم.

وبناءُ على ذلك تتقلم الدراسة بذا المشروع و هو عبارة عن تصورا مبلئي حتى تتم المو افقة عليه من قبل أجهزة الولاية العليا ثم للاتصال بالثركة لتقوم بدراسة الجدوى الاقتصادية والفنية، ثم تقديم عرضه المتكامل حتى يتم التفاوض عليه بولاية الخرطوم. 
خطة عمل لاستخدام نظم المعلومات الجغرافية في إدارة المخلفات الصلبة في مدينة الخرطوم:

هناك مشاكل عديدة تعاني منها المدن السودانية فيما يتعلق في مجال إدارة النفايات الصلبة خاصة مدينة الخرطوم عاصمة السودان.

تفتقز الطرق المتبعة للتخلص من النفايات الصلبه في المدن السودانية إلى الثروط والمعايير البيئية الصحيحة فجميعها تعاني من حالات تقصير واضح في جمع ونقل النفايات، ويتم التخلص من القسم الأعظم من النفايات التي يتم جمعها في مكبات مفتوحة موجودة في اواسط المدن، وقد أدت قلة الموارد المالية وطبيعة البنية التحتية غير من في الملاثمة وعدم وجود الكفاءات المدربة إلى ضعف في إدارة ومعالجة النفايات الصلبة في المدن السودانية

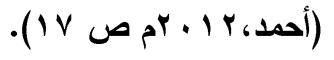

ويمكن تلخيص المشاكل العديدة التي تعاني منها هذه الددن فيما يتعلق في مجال إدارة النفايات الصلبة فيما يلي: 1 - 1 يشتكي المواطنون غالبًا من عدم تفريغ حاويات النفايات و يلاحظ بأن الحاويات ممتلئة و تنتشر النفايات حولها وتبقى لأيام حتى يتم نقلها إلى المكب.(مقابلة شخصية) 2-تعاني أكثر المدن السودانية وخاصة الخرطوم من نقص في القوة العاملة و التجهيزات و السبارات اللازمة ووجود الآليات القديمة. 3-قدرة نقل النفايات، أقل من كميات تراكم النفايات اليومي. 4-كيس هناك معلومات كافية عن عدد عمال النظافة و المراقبين. 5-عدم وجود دراسات لتقييم الأثر البيئي لمرافق إدارة المخلفات الصلبة. 6-عدم وجود مسح كامل للحاويات (مكبات النفايات) و مواقعها في المدينة. 7- البياتات غير متوفرة حول معدل تراكم النفايات في المناطق المختلفة من المدينة.(مقابلة شخصية) 8-تخطيط مسارات نقل النفايات غير معدة بثكل مدروس و إنما بثكل عثوائي و آني.. q - يتم التخلص من القسم الأكبر من النفايات في أماكن مكثوفة على أطراف المدن، حيث يتم رمي النفايات في العراء مما يجطلها عرضة للاحتراق وتطايرها في الهواء وغالبا ما تكون منطقة رمي النفايات غير محددة بسور ولا تتوفر الآليات اللازمة لتجميعها وتكديسها. 
10-تتم تغطية النفايات بالتزراب منعا من احتراقها وتطايرها في الهواء في كثير من المدن السودانية، كما ان هناك بعض الآليات المخصصة للطمر ولكن في جميع الأحوال فان عملية الطمر هذه لا تأخذ بعين الاعتبار تسرب بعض النفابات المتحللة إلى ماء الحوض الجوفي.

11 - في معظم الأحيان تمزج النفايات الطبية و الصناعية الخطرة مع النفايات المترلية في المكبات النهائية. r ا - عدد الحاويات المتوفرة أقل بكثير من الحاويات المطلوبة. r ا - حملات التوعية لا تزال قاصرة عن تفعيل دور المواطن في النظافة العامة. ع ا -عدم وجود خطة شاملة لإدارة النفايات الصلبة. ه 1 - عدم وجود فوارق تخطيطية بين المناطق المنظمة ومناطق السكن العشوائي بسبب صعوبة عمليات جمع النفايات فيها. 17 - عدم الاستفادة من المواد القابلة للتدوير. IV - عدم إعطاء موضوع إدارة النفايات الصلبة الاهتمام المطلوب إعلاميًا. 11 - نقص وجود في الكفاءات المدربة و المتخصصة في إدارة النفايات. 9 1 - نقص الوعي البيئي والتعاون لاى المواطنين. يمكن اعتبار إدارة النفايات الصلبة في العديد من الدول العربية مشابة للحالة السودانية. استخدام نظم المعلومات الجغرافية :

إن أهم الأثباء المفتقدة في نظام إدارة النفايات الصلبة الحالي هو عدم استخدام البيانات بثكل صحيح بسبب الإدارة غير الصحيحة للبيانات والسجلات وهذا يجعل من الصعب في أغلب الأحيان العمل بكفاعة. لذلك فإن الإدارة المتكاملة لنظام بياتات المؤسس، هي الطريق الوحيد لتحسين الخدمات وتخفيض المصاريف. تكون البيانات غالبًا في أكثر المحليات منفصلة، أي أن البيانات الخاصة بإدارة النفايات الصلبة غير متوفرة في مكان واحد بحيث يمكن الوصول إلى القرارات الصحيحة بخصوص الترتيبات الإدارية والتخطيط وفي النظام الحالي ليس هناك مراقبة كافية للعمال، إدارة النقل ناقصة والتخطيط المكاني ضعيف، كما إن تحديد مواقع حقول الطمر الصحي يتم بالاعتماد على معلومات غير كاملة إما لعدم توفر هذه المعلومات أو لصعوبة ربط هذه المطوما مع بعضها البعض. 
يمكن البدء بإدارة سليمة وتصحيح الإدارة السيئة للنفايات الصلبة من خلا ربط قواعد البيانات من أجل تظوير نظم دعم القرار الذي يساعد على إدارة البياتات المتنوعة المأخوذة من مصادر مختلفة، فا GIS يسمح بالعمل على مجموعة ضخمة من البيانات، مكونة من عدة خرائط، كما يسمح بدمج شريحة واسعة من الرسوم والصور النقطية والصور الجوية وصور الأقمار الصناعية .ويدعم أيضًا عددًا كبير من أنواع الصور ذات المرجعية

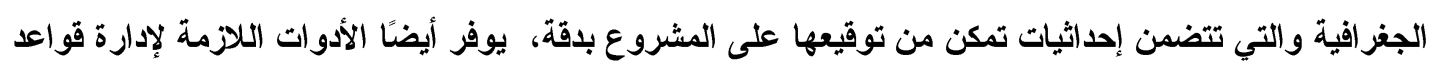

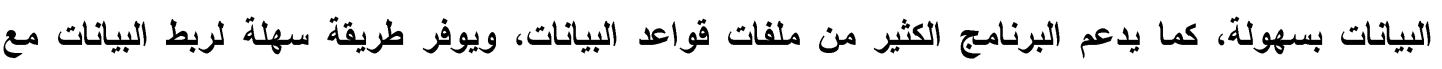
الكائنات الرسومية، والتي تمثل هنا المعالم الجغرافية (Features).كنلك يوفر أدوات خاصة للتحليل المكاني، ويتيح إنثاء الخرائط الموضوعية، ويمكن عبر واجهة Arc map|السهلة الاستخدام، ثم عرض و إدارة كل موارد المشروع، كالرسوم والاستعلام والطبولوجيا، وقواعد البيانات، وباستخدام ال GIS تصبح العلاقة المكانبة بين

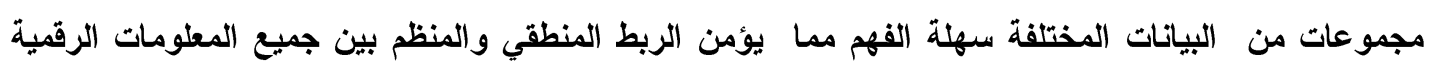
و والوصفية المتوفرة.

الههف من وضع خطة العمل باستخدام نظم المعلومات الجغرافية:-

يساعد وضع خطة العمل هذه على إعادة هيكلة نظام إدارة النفايات الصلبة (جمع، نقل، معالجة، مراقبة). كما يُبنى باستخدام نظام الGIS أساس للاستثمارات في البنية التحتية وآلية التخلص بكفاءة من النفايات الصلبة، و هو يهدف إلى:

•جعل ال GIS أداة من أجل اتخاذ القرار في الاستثمار في مرافق البنية التحتية • استخدام ال. G/S كأداة فعالة وذات كفاءة عالية في إدارة النفايات. • تحديد المسارات المثالية لنقل النفايات من نقاط الجمع إلى المكبات. •المساعدة في اتخاذ القرار حول اختيار أماكن التخلص من النفايات، تصنيف المناطق، تحديد أماكن محطات النقل ومسارات الثشاحنات مع زيادة حجم المناطق التي تصلها الخدمة. متحسين الإمكانيات الإدارية من اجل إدارة المخلفات الصلبة متطوير وتحسين الأداء ومستوى الخدات و توفير خدمات أفضل للمواطنين. •تخفيض التكاليف في تقديم الخدمة وزيادة الإيرادات. متأمين معلومات دقيقة وحديثة عن الخدمات. 


$$
\text { •الرد على الثكاوي بسرعة. }
$$

من اهم أسباب الحاجة إلى الG/S ، ان ه^ \% من المعلومات المستخدمة من مسؤولي إدارة النفايات الصلبة ذات ارتباط مكاني. كما ان الحاجة إلى تكامل البيانات على المستويات المختلفة: الولايات، المحليات، الوحدات الادارية. كذلك الحاجة إلى استيعاب المعلومات الكثيرة للتمكن من تحليلها. كما يمكن أن تستخدم إدارات النفايات الصلبة الخرائط والبيانات المكانية بثكل يومي حيث تحتاج الى.تحديث البيانات بثكل منتظم و صحيح، لذا يجب وضع خطة عمل من أجل تامين إدارة مقبولة للمخلفات الصلبة و مع محدودية الموارد المالية المتوفرة تعتمد على عنصرين أسنسين:

•إنخال نظام المعلومات الجغرافي في إدارة المخلفات الصلبة.

متطوير الهيكلية الإدارية في مجال إدارة المخلفات الصلبة. G/S أولا :"إذخال نظام المعلومات الجغرافي ولوضع نظام معلومات جغرافي في المدن السودانية وخاصة مدينة الخرطوم يجب اتباع الخطوات التالية: •جمع و ترقيم الخرائطو تحويل الخرائط الورقية إلى الصيغة الثعاعية وتخزينها ضمن الG/S). •صياغة متطلبات البيانات و تصميم قاعد البيانات. Attribute Data (الجدولية) (البيانات الوصفية) •إذخال ودمج البيانات الوصفية مع الخرائط الرقمية. متدريب الإداريين على استخدام نظام المعلومات الجغرافي في إدارة النفايات و على تحديث هذه البيانات. كلما كاتت هناك طبقات أكثر كلما كاتت عمليات اتخاذ القرار أفضل، لذلك يُقترح بثكل أولي وضع الطبقات التالية من اجل إدارة نقل وجمع النفايات الصلبة في المدن: | - إبقة الثوارع في مدينة الخرطوم. r - بطقة الأحياء و توزيع السكان فيها. r -طبقة المسارات الحالية لجمع النفايات الصلبة من داخل الاحياء (ان وجدت) ع -طبقة تثكل توزيع النفايات الصلبة ومناطق إنتاجها. 
ه - طبقة خطوط النقل المقترحة و الخطط المكانية المثتقة من الطبقات السابقة

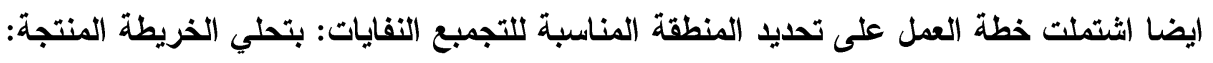

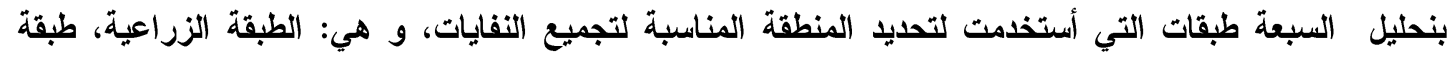

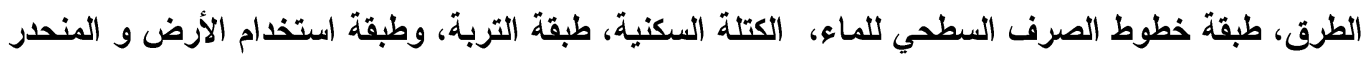

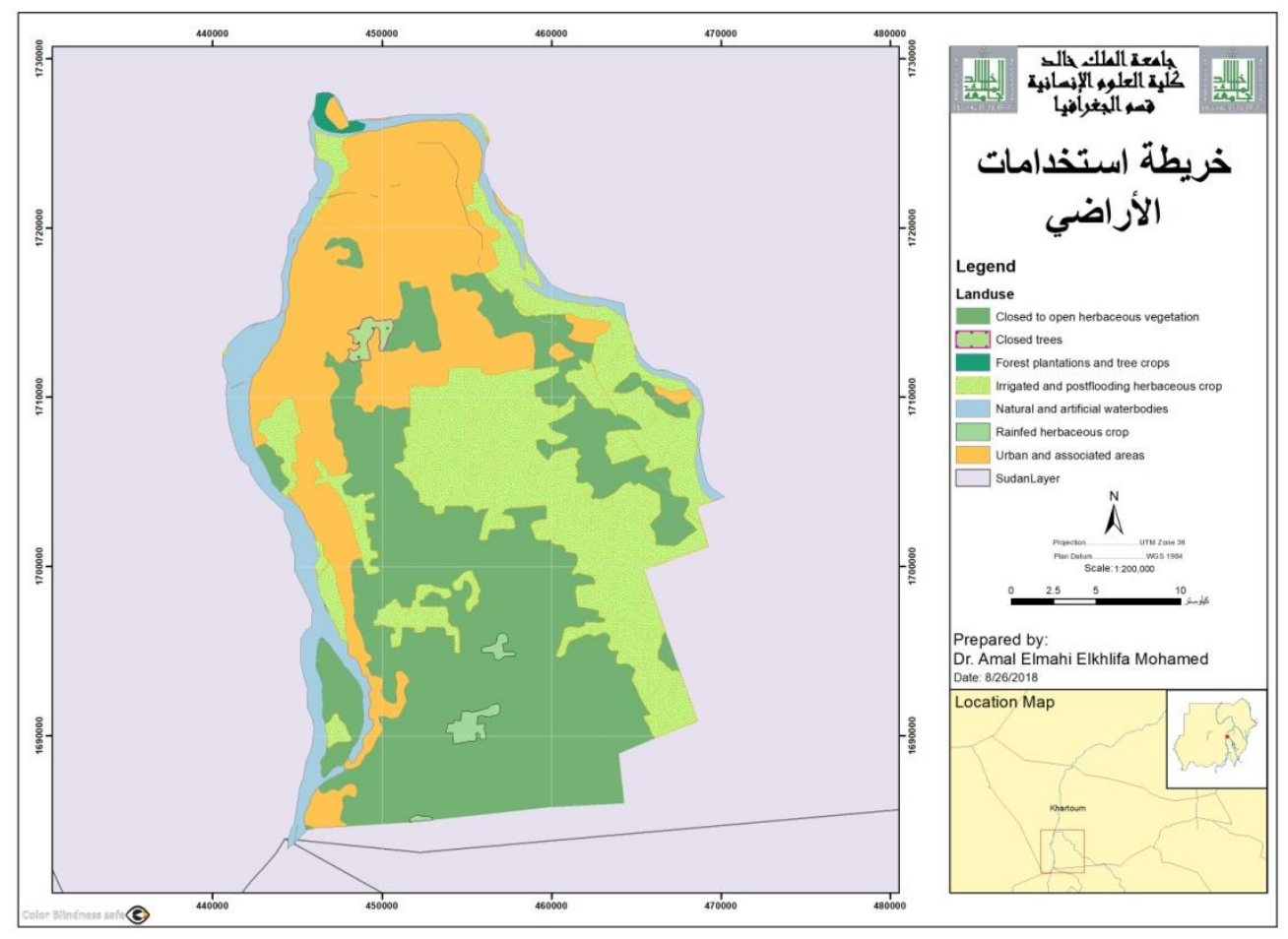

تثتتمل طبقة استخدام الأرض بنطقة الاراسة على سبعة أنواع من نظم استخدام الأرض، كما في

\begin{tabular}{|c|c|c|}
\hline الامكاتية & 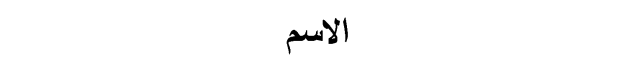 & 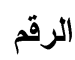 \\
\hline سيء & غابات و محاصيل شجرية & 1 \\
\hline سيء & جمعات مائية طبيعية وبشرية & $r$ \\
\hline 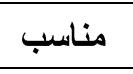 & أثنجار مفلقة & $r$ \\
\hline سيء & مناطق حضرية وامتداداتها & $\varepsilon$ \\
\hline جيد & نباتات حثائش بين مغلقة (كثيف) وغير كثيفة & 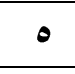 \\
\hline 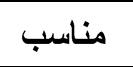 & محاصيل حشائشية مطرية & 8 \\
\hline سيء & محاصل حشائشية مروية ومسقي ببرطوبة التربة & $\mathrm{V}$ \\
\hline
\end{tabular}


ا - الطبقة الزراعية: تمثل هذه الطبقة المنطقة المستخدمة لزراعة المحاصيل، وهي غير مناسبة لتجميع القمامة r - ب بقة الطرق: تثمل كل الطرق في منطقة الاراسة، ويفضل اختيار نقاط تجمع القمامة ليس بعيدا عن الطرق.

r- طبقة الصرف المائي السطحي: وهي ممرات لتصريف ماء المطر الموسمي، و هي خطرة إذا استخدمت كنقاط لتجميع القمامة. ع - طبقة التربة: هناك نوعان من التربة في منطقة الاراسة: الأول له امكانية تسريب مائي عالية، بما يعني أن كل أن كل المواد السامة يمكن أن تتسرب عبرها نحو أحواض الماء الجوفي وتلوثه. وعليه استبعادها كنقاط لتجميع القمامة. والنوع الآخر الأي هو غير مسرب للماء بلرجة عالية، و يمن استخدامه كنقاط لتجميع القامة.

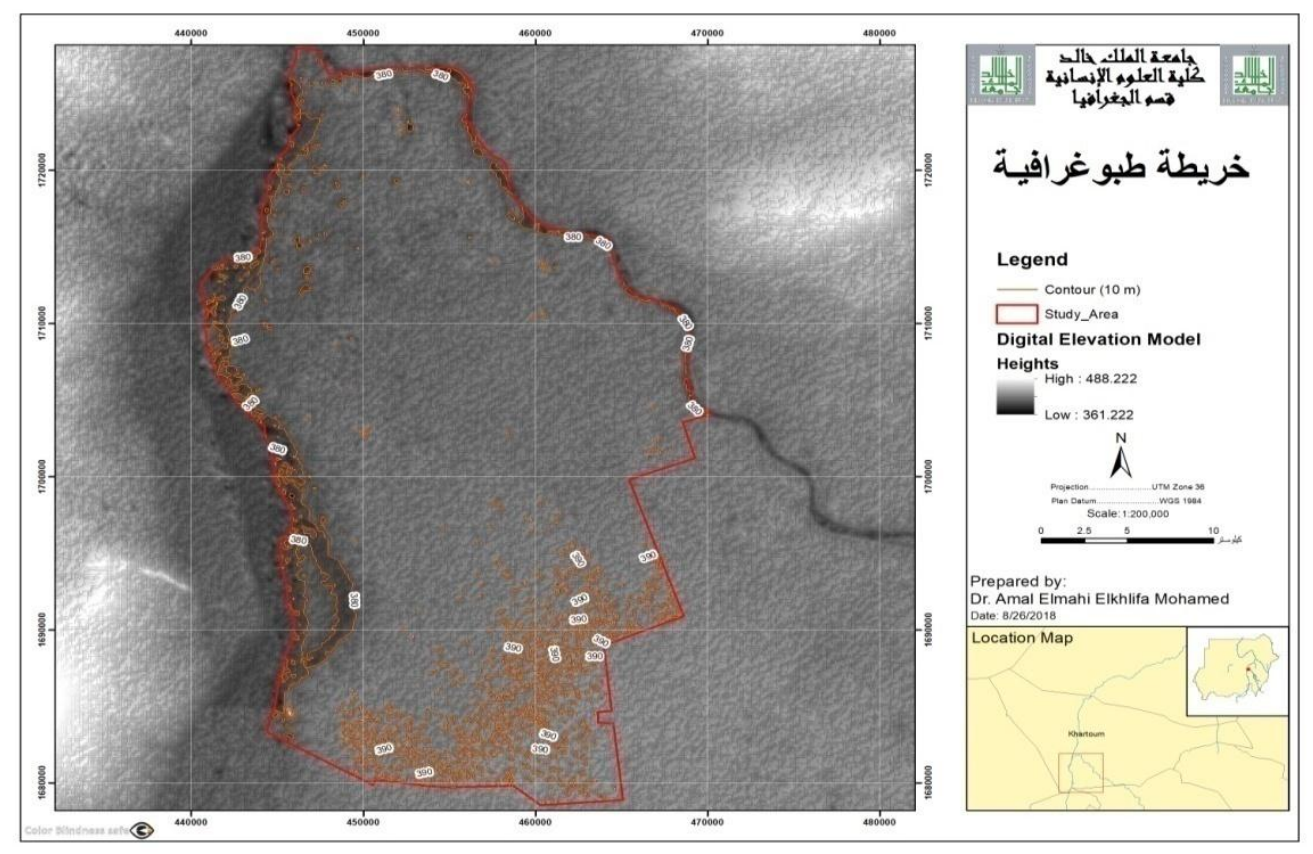

ه- طبقة الكتل السكنية: تمثل هذه الطبقة كل لمنطقة المستغلة للسكن، و عليه يجب أن تكون نقاط تجميع القمامة بأبعد ما يمكن من مسافة

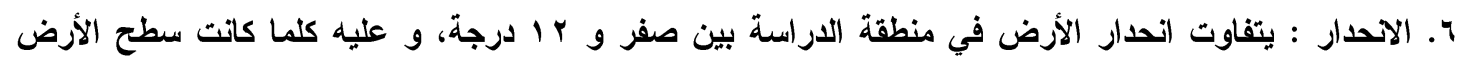
مستوي كلما كان مناسبا كنقاط لتجميع القمامة. 
V. طبقة استخدام الأرض: تثمل منطق الاراسة V أنواع من نظم استخدام الأرض، كما في الجدول: يعد اختيار موقع الطمر الصحي خطوة مهمة في انجاز برنامج إدارة النفايات الصلبة، وحيث انه من الصعب العثور على موقع مثالي لعملية طمر النفايات الصلبة من حيث الخصائص الجيولوجية والمائية، إلا أن تحديد الموقع كأفضل ما يمكن الوصول إليه يمكن أن يخفض التكاليف المصاحبة لاستخدام طبقات التبطين والتصميم و المر اقبة، ولهذا الغرض أعدت مجموعة من الخرائط الرقمية لمدينة الخرطوم باستخدام تطبيقات نظم المعلومات الجغر افية شملت كل من: المناطق السكنية والطرق الرئيسية والثانوية والمطارات وشبكة الوديان والسبخات،
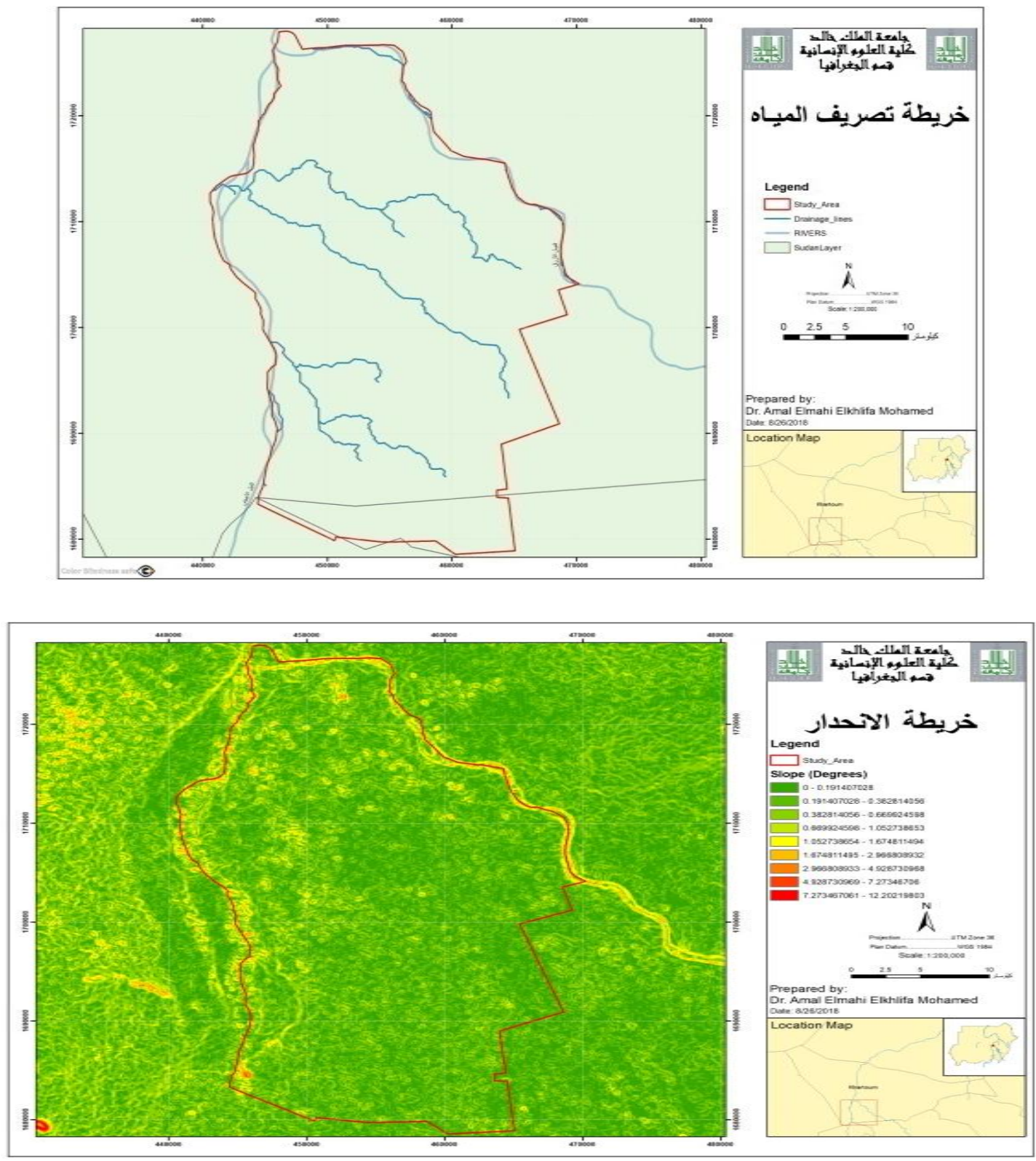
وتحديد مسافة الحرم لكل منها، إضافة إلى الأخذ بنظر الاعتبار عامل اتجاه الرياح العائدة في المدينة. وبعد

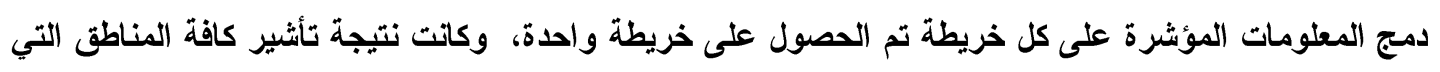
يمنع الطمر فيها هي الحصول على ما تبقى من المناطق على الخريطة المركبة والتي تمثل المناطق المسموح الطمر فيها.

التحديد:أسس تم تحديد المناطق المناسبة لتحليد مواقع نقاط تجميع النفايات، بناء على المعايير التالية: الوزن النسبي لتاثير كل عامل في اختيار الموقع المناسب لمكب النفايات في منطقة الدراسة

\begin{tabular}{|c|c|c|c|}
\hline نوع البياتات & المعيار او الاساس & المزن النسبي \% & 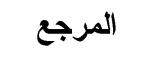 \\
\hline استخدام الارض & لابد ان تكون المطقة خالية من استخدامات الارض & 10 & المسح العام \\
\hline المناطق السكنية & لابد ان تكون بعيدة & 35 & المسح العام \\
\hline المناطق الزراعية & لايتم اختيار المناطق الزراعية & 10 & المسح العام \\
\hline خطوط تصريف المياه & لابد ان تكون بعيدة جدا عن المكب & 10 & المسح العام \\
\hline الاتحدار & يفضل الارض المستوية & 20 & المسح العام \\
\hline نوع التربة & يجب ان لا تكون التربة الثي سهلة التشرب & 5 & المسح العام \\
\hline 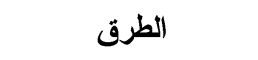 & تكون قريبة من المكب & 10 & المسح العام \\
\hline المجموع الم الم & & 100 & \\
\hline
\end{tabular}

وبوضع كل هذه المعايير في الحسبان، تبين انها تنطبق على مساحة صغيرة بنمطة الاراسة (يمثلها اللون الاخضر الغامض) وقد تم ترشيح هذه المنطقة لتكون مكب للنفايات بناءا على النتائج من الخرائط. 


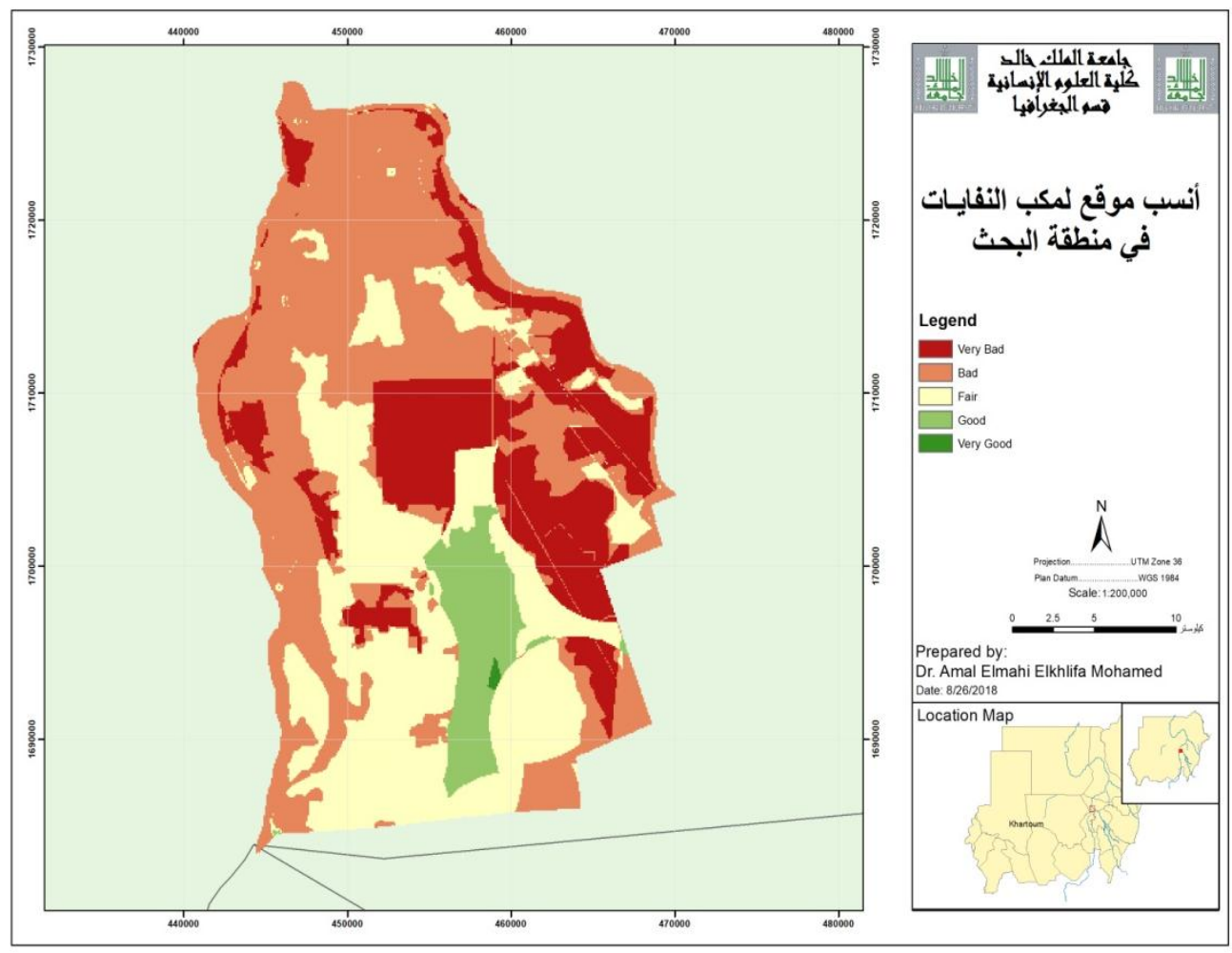

تمثل الخريطة السابفة إمكانية أي نقطة في منطقة الاراسة لتكون مكانا لتجميع النفايات. ويتضح أن هنالك نقطة واحدة تنطبق عليها جميع الثروط السابقة.

ثانيا :تظوير الهيكلية الإدارية في إدارة المخلفات الصلبة يجب التأكيد على ضرورة إقامة ورشات عمل تدريبية للإدارات و الكوادر المسؤولة عن عملية إدارة النفايات و التدريب أيضا "على مفهوم إدارة قواعد البيانات وكل ما هو جديد ومتطور في هذا المجال لمواكبة الأظمة الحديثة في مفهوم الإدارة و تأهيل الكادر العلمي التخصصي سواء كان من واضعي البرمجيات و النظم أو من المسؤولين عن إعادة و تخطيط النظام و مدخلي المعلومات و حتى المستخدمين العاديين. قـ يلاقي المشروع بعض الرافضين لأسلوب الإدارة الجديد لذلك لابد من : •إثرأك كبار الموظفين في وضع خطة العمل لإجاز المشروع. متوضيح مر احل سير العمل بثكل مفصل للمسؤولين. 
• تثجيع الموظفين الذين يعلون بالنظام الجديد

$$
\begin{aligned}
& \text { التدريب المستمر على جميع المستويات. } \\
& \text { مثر الوعي و التدريب. }
\end{aligned}
$$

أخيرًا: إن تقنية هذا النظام لا بد أن تفرض ذاتها كباقي تقنيات هذا العصر. ولذا من المفيد استباق الأحداث و التحضير لتطبيق و استثمار أفضل لهذا النظام و توحيد الجهود برعاية الدولة و كلنا أمل في تحقيق ما هو خير لهذ الوطن.

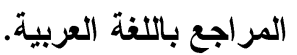
1- أحمد، سيد حاج النور، ادارة المخلفات المنزلية بمنطقة الخرطوم الكبرى، وزارة البيئة والتنمية العرانية، ادارة

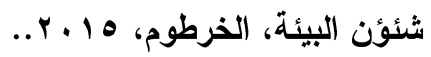

ا- الثمري، احمد صالح، المعلومات الجغرافية من البداية Geographical Information Systems From start GIS r- جزماتي سامح، مقدسي سامي، أنظمة المعلومات الجغرافية (GIS) - منشورات دار الثرق، العربي، 2001 r- استخدامات بيئية في العالم العرب، [4IS)

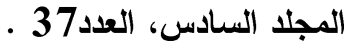

ع - محد مصطفى، I. Y - تطبيقات نظم المطلومات الجغرافية وتقتيات الاستثعار من بعد في التنمية المتواصلة إدارة المدن والتحكم في العمران .دراسة حالة :إقليم القاهرة الكبرى، الحلقة الدراسية السابعة لمنظمة العواصم والمدن العربية، تطبيقات نظم المعلومات الجغرافية في التخطيط والتنمية المتواصل، القاهرة،مصر .شباط $r \ldots 1$ هـ أ.د عادل رفقي عوض، د. محمد توفيق أبو العلا ـ هندسة المدن وعلوم البيئة، المنظمة العربية للتربية و الثقافة والعلوم - تونس r . . ب (مجلدين). צ- النظافة العامة والتخلص من النفايات في الددن العربية ـ دراسة استطلاعية، المعهد العربي لإنماء المدن

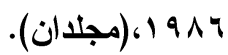


V- النعيم، عبد الله العلي، تقنية التخلص من النفايات وتجربة مدينة الرياض - بحث قدم في مؤتمر مسقط بسلطنة

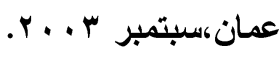

^- المعهة العربي لإنماء المدن، أبحاث وأوراق عمل ندوة (الإدارة المتكاملة للنفايات)، جدة، المملكة العربية 1999. السعودية

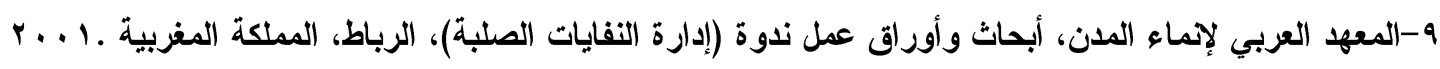
• 1 - المعهد العربي لإنماء المدن، أبحاث وأوراق عل ندوة (إدارة النفايات الصلبة القابلة للتدوير وإعادة الاستخذام)

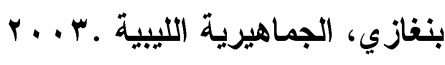
1 1- المعهة العربي لإمماء المدن، أبحاث وأوراق عمل ندوة (الإدارة البيئية للنفايات في المدن العربية)،حلب،

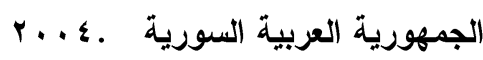

rا - شرف، محمد ابراهيم محمد،نظم المعلومات الجفرافية،أسس وتدريبات، دار المعرفة الجامعية،

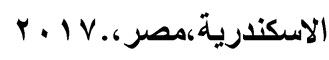

r ا - الاليمي، خلف حسن، نظم المعلومات الجغرافيةGIS. اسس وتطبيقات، دار صفاء للطباع والنشر

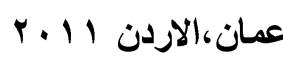

با اموقع معهد أبحاث النظم البيئية، (Environmental Systems Research Institute) URL :http: //www.esri.com

$$
\begin{aligned}
& \text { ع ا- موسى، موسى إبراهيم، -نظم المطلومات البيئية في جمهورية مصر العربية ورقة عمل،مؤتمر نظم }
\end{aligned}
$$

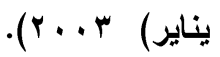

19

V V - عبده،وسام الدين محمد، مقدمة إلى نظم المعلومات الجغر افية،منشأة المعارف، الاسكندرية، مصر- II بـ. 


$$
\text { المراجع بالانجليزية. }
$$

[1] Andrew Paul Romanek et al.1999- Bulding the foundation of Environmental Risk Assessment at the Marcus Hook refinary using geographic information systems, The University of Texas at Austin. URL: http://www.crwr.utexas.edu/0nline.html

[2] Antonio Caputo, Pacifico Marcello Pelagagge, Federica Scacchia, 2002GIS Assisted waste management in a protected area.Environmeental Management and Health. Bradford:2002.Vol.13,Iss.1;pp.71-9.

[ץ] C.O. Uy and T.D. O'Rourke, 2000-Advanced GIS Applications for Civil Infrastructure Systems, Draft Version: 8 September, W.

[๕] Damian C. Green, 1996- GIS and its Use in Waste Management, 1996 ESRI European User Conference, London, 2nd - 4th October.

[॰] Darryl L. Petker P.E., Doug Ralston and Steve Barnett ,200 - California Integrated Waste Stream Profiles: GIS Application, 2000 ESRI International User Conference - June 26-30.

[^] Enterprise GIS for Municipal Government- 2013, An ESRI White Paper • July.

[v] Introducing Arcview GIS Version 10-1-2,2013-ESRI. 2003.

[^] Lesley Hay wilson, Andrew P. Romanek, et al, 1999- using a geographic information systems to implent Risk Based Decisions in Corrective Action. The University of Texas at Austin.

[9] L. R. Levick, M. R. Kidwell, and H. D. Fox, 201. - Integration of Watershed and Ecological Site Land Classification Scales Using GIS Technology, (ASCE). 
[1.] Milan Pctkovic, Andrcja Milcnkovic, Dcjan Mitrovic and other. Several Examples of GIS Applications in urban and environmental planning.

[1 1] Ni-Bin Chang, 1997, GIS Technology for Vehicle Routing and Scheduling in Solid Waste Collection Systems, Journal of Environmental Engineering , Vol. 123, No. 9, September 1997, pp. 901-10.

[1r] Pual Schiffer,1997- The ABCs of GIS,World Wastes;Jun 1997,40,6; ABI/INFORM Global. 
التنمية المتوازنة بين مدن منطقة عسير ومؤشرات المرصد الحضري

\author{
الاكتورة / سلمى بنت عبدالله حسن الغرابي \\ جامعة الملك خالد
}

مقدمة :

تعد الدراسات التنموية من أكثر الدراسات التي تجمع بين الرؤي النظرية والجواتب التطبيقية والتخطيطية

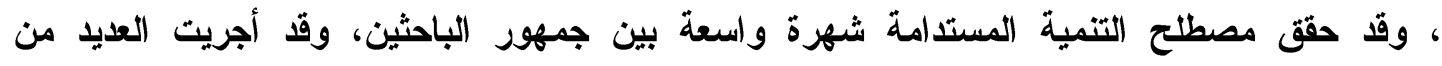

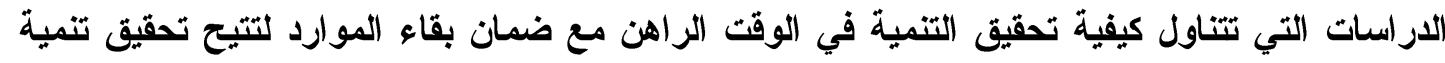

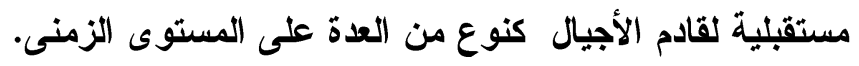

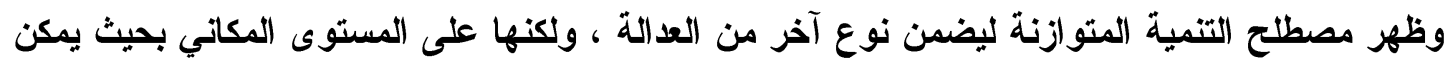

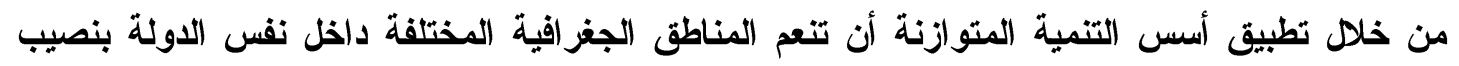
متقارب من التنمية وعو ائدها.

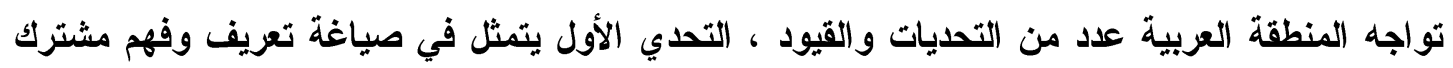

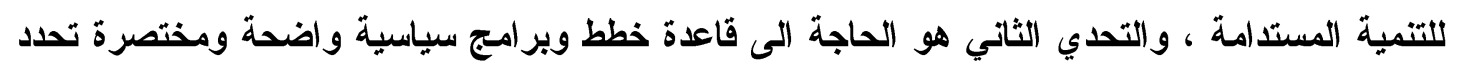

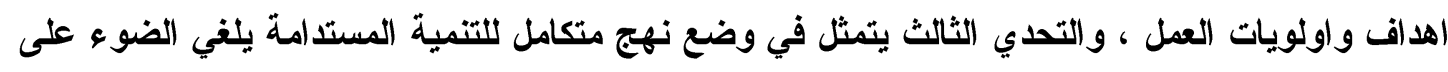

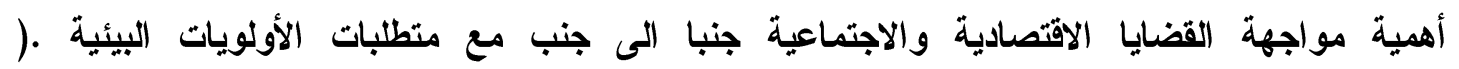

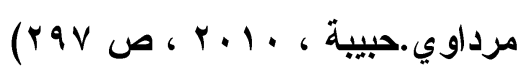

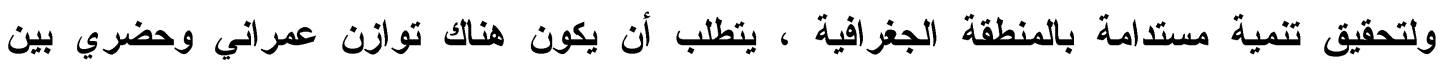

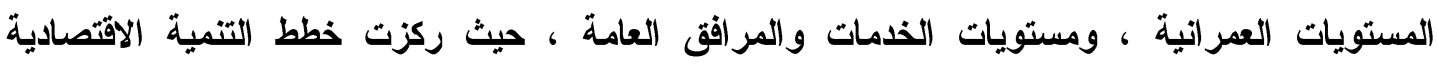

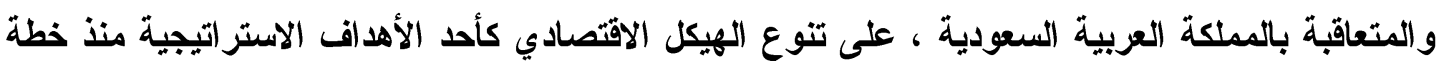

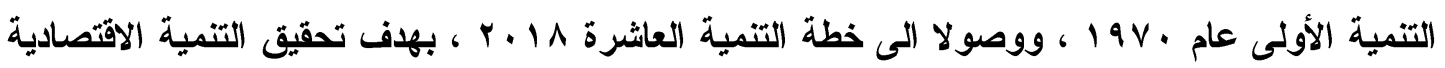

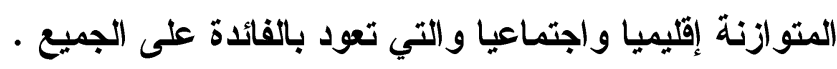

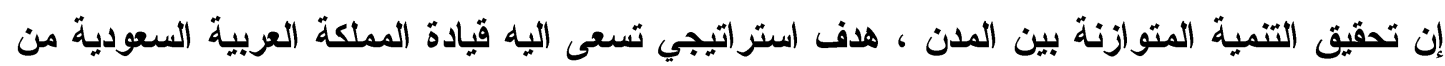

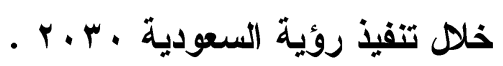

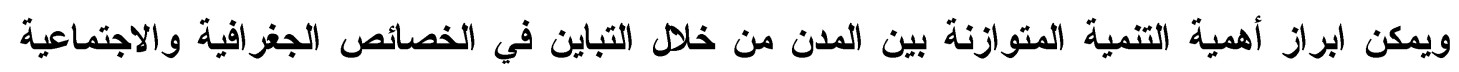

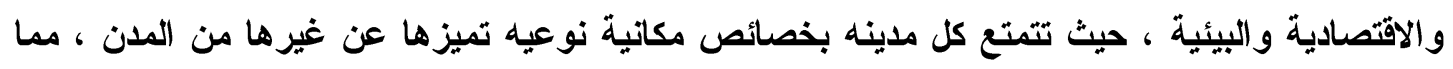

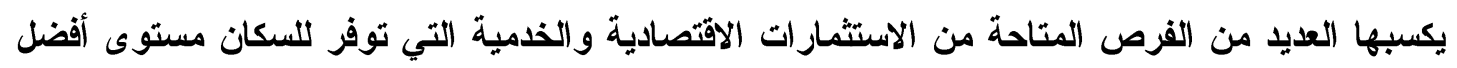
من الاستمتاع بالحياة . 
وتعل منطقة عسبر واحدة من المناطق الإدارية الواعدة على المستوى التنموي بالمملكة العربية السعودية

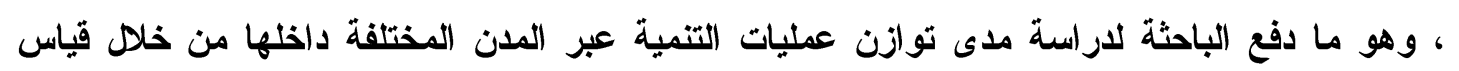

$$
\text { حزمة من المؤشرات الاقتصادية والاجتماعية و البيئية. }
$$

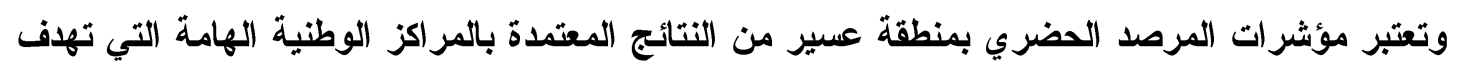

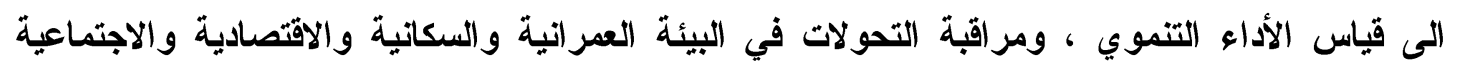
للمدن تساؤلات الاراسة :

يمكن صياغه مشكلة الار اسة في الإجابة على الأسئلة التالية :

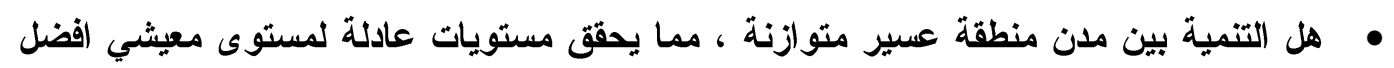

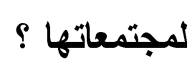

• ما هو مستوى المقارنة بين المؤشرات الحضرية بمدن منطقة عسير مع مثيلتها من مدن المملكة

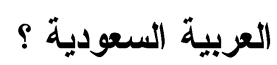

• هل تسهم المؤشرات الحضرية بمدن منطقة عسير الى تحقيق الهداف التنمية المستدامة العالمية ؟ مناهج وأساليب الار اسةة : تستخدم الاراسة المنهج الوصفي التحليلي ، واستخدام أدوات التحليل المكاتي ، وتمثيل البيانات

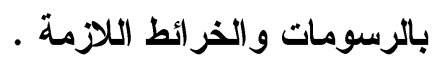

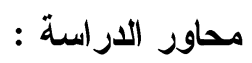

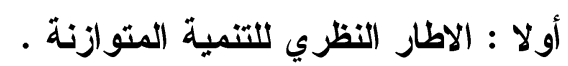

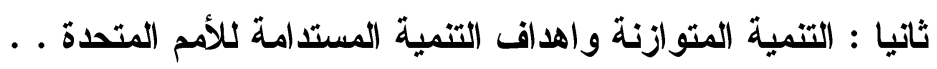

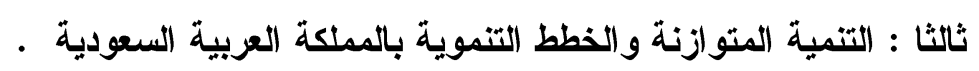

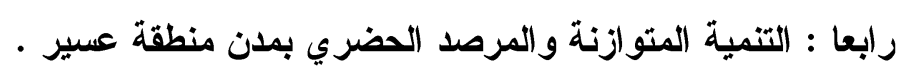

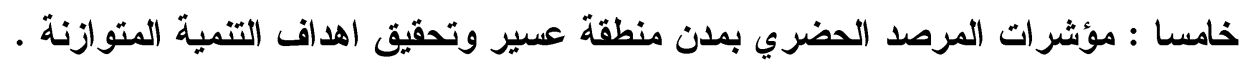

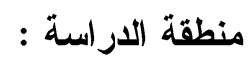
تركز منطقة الاراسة على النطاقات المعتمدة لاى مصلحة الإحصاءات العامة ، و النطاقات العمرانية لعام

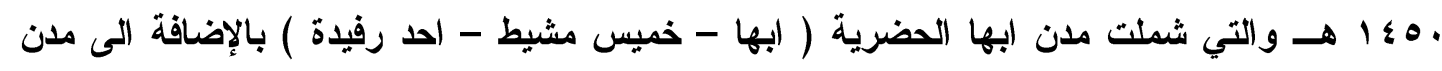

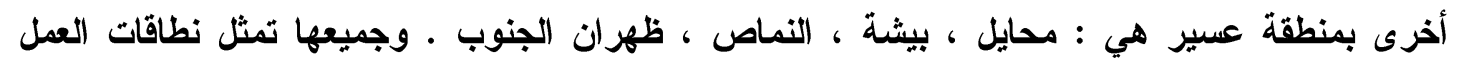

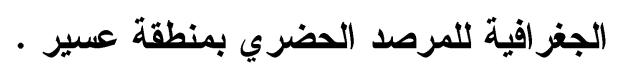
وقد شملت مدن الدراسة مواقع هامة بمنطقة عسير شمالا وجنوبا ، وشرقا وغربا ، وبذلكك تمثل مواقع

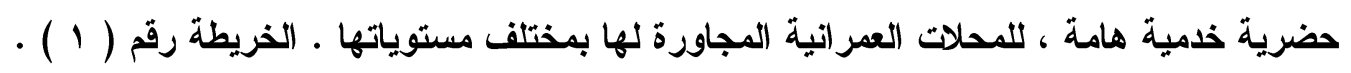

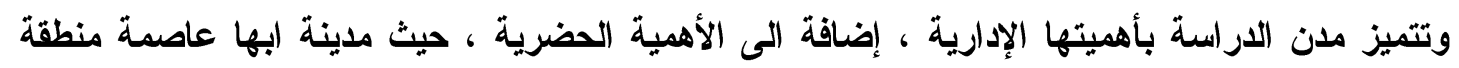

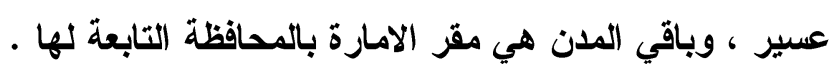




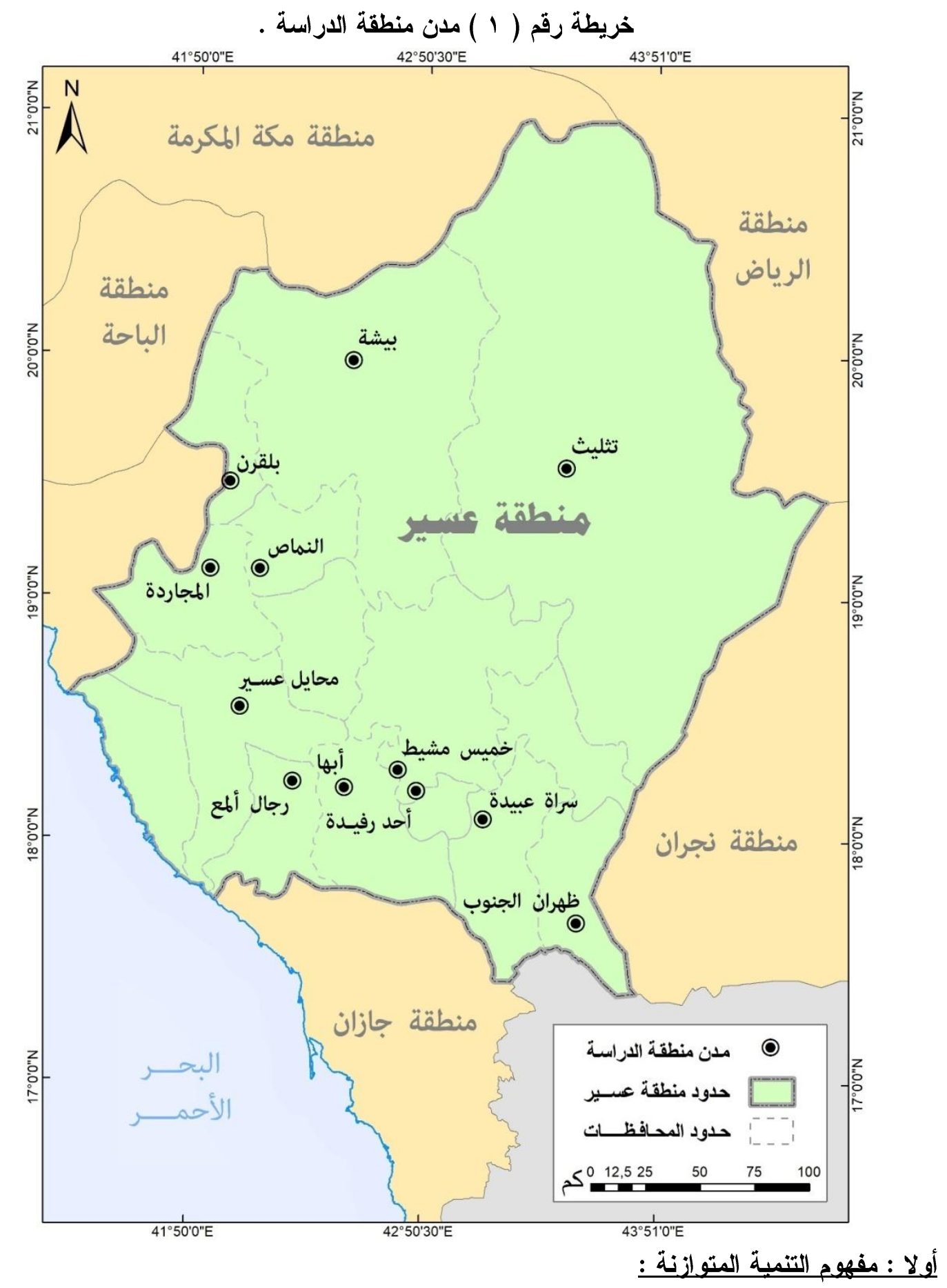

صيغت العديد من التعريفات لثرح مفهوم التنمية المتوازنة ومن تلك التعريفات المهمة ما قدمه

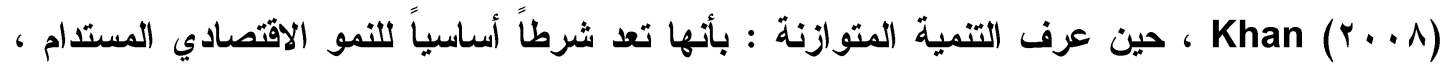

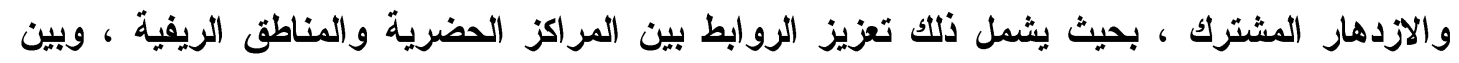
المناطق الأكثر نموا والاقل نموا ، والتوزيع العادل لضرورات العياه ، وخلق فرص عمل بردية مجزية منتجه ، 
ويمكن للبنية التحتية والخدمات الفعالة ،ان تسهل التنمية الريفية والحضرية التكميلية مع تنويع الاقتصاديات الريفية وتسويقها ( Faheem Jehangir Khan,2008,p1 ) . ومعا صعتبراً أن التنمية الإقليمية المتوازنة

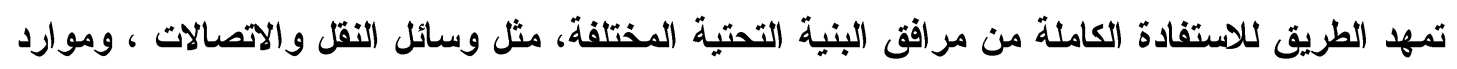

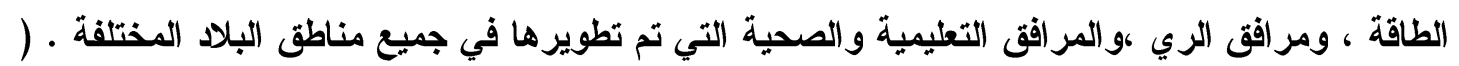
. (Matasha,kwat,2010,p2 أهداف عملية التنمية المتوازنة : يمكن صياغة العديد من أهداف عملية التتمية المتوازنة، ومن أهم تلكك الأهداف ما يلي:

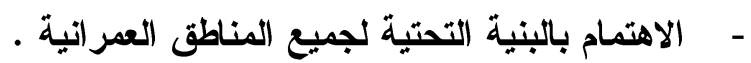

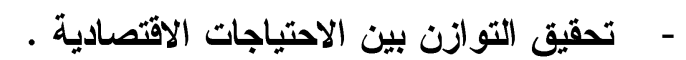
- تقليص الفجوة التنموية بين المناطق العمرانية ـ ل

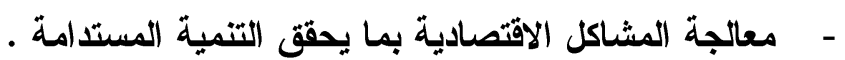
- توافق اهداف التنمية الا|خلية بين المناطق ، مع الأهداف العامة للاولة .

$$
\begin{aligned}
& \text { محددات التنمية المتوازنة : } \\
& \text { تخضع التنمية المتوازنة لعدد من المحددات أهمها: }
\end{aligned}
$$

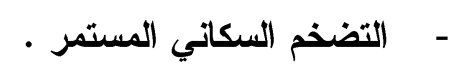

- - الحكم الرشيد لإدارة التنمية بالمناطق التنموية .

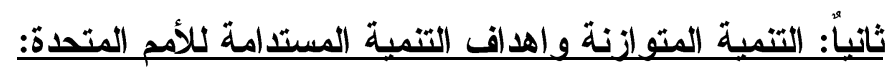

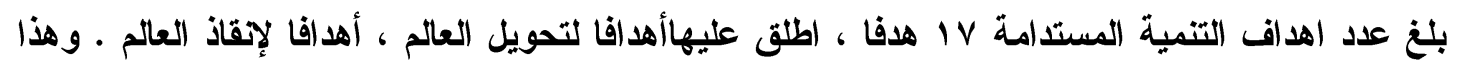
يدل على أهمية الأهداف للعمل بها ، وتطبيق مقاصدها على الصعيد المحلي لجميع الدول من اجل تنمية

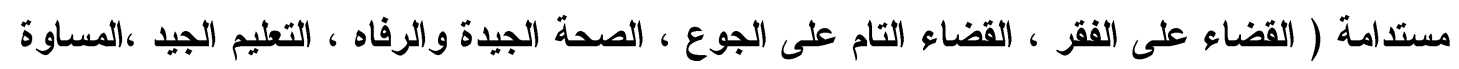

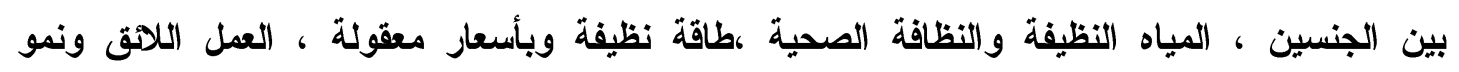
الاقتصاد ، الصناعة والابتكار والهياكل الأساسية ،الحد من علم المساواة ، مدن ومجتمعات محلية 
مستدامة ، الاستهلاك والإتتاج المسؤولان ،العمل المناخي ، الحياه تحت الماء، الحياة في البر ،السلام و العدل ، عقد الشركات لتحقيق الأهداف ).

و أكلات الأمم المتحدة بأن المدينة هي مركز الأفكار والتجارة والثقافة والعلم والإتتاجية والتنمية الاجتماعية الإنة

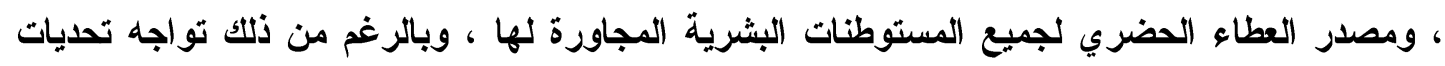
تعيث استمرار العطاء الحضري مثل زياد عدد السكان ، نقص الإسكان اللاثق ، تدهور البنية التحتية ،

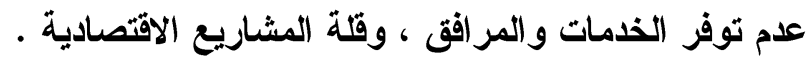

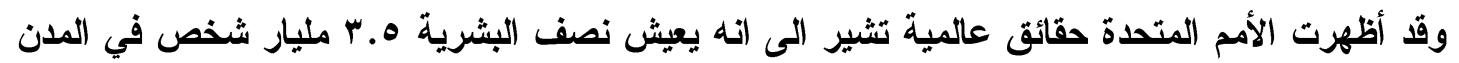

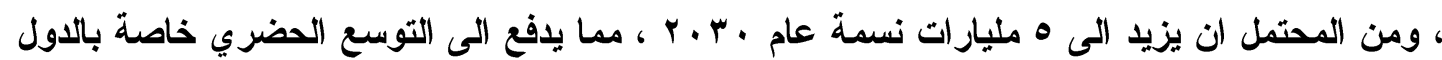

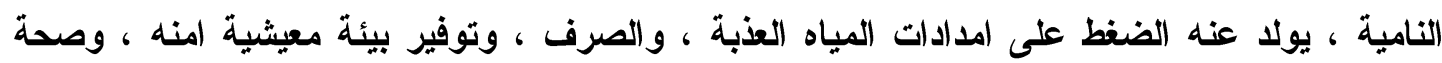
عامة .

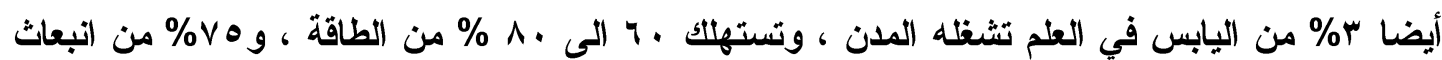
الكريون • في حين حددت الأمم المتحدة عدد من المقاصد الهامة والتي تساعد على جعل المدن والمستوطنات

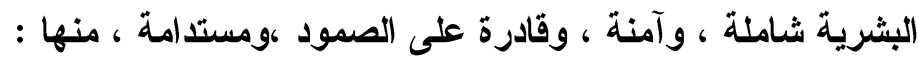

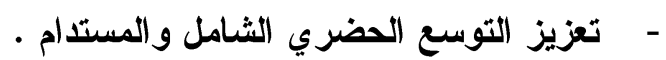

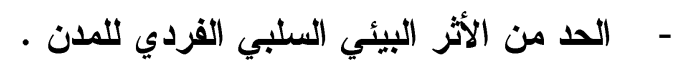

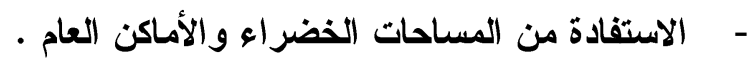

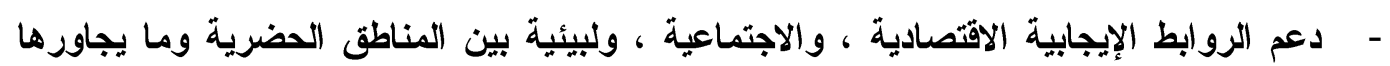

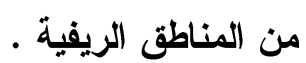

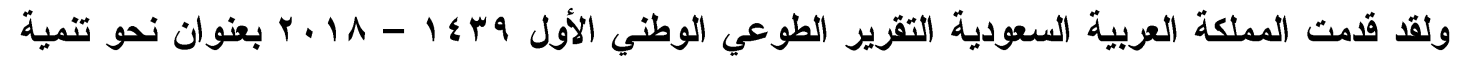

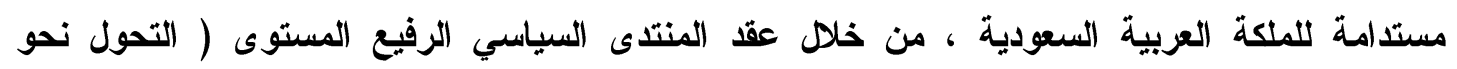

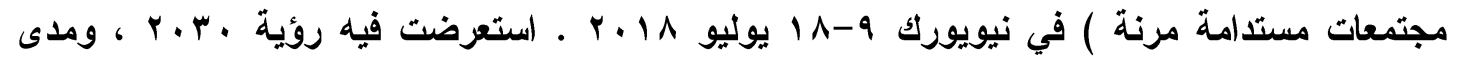
ترابطها مع اهداف التنمية المستدامة في الأطر الوطنية ، وابرز التحديات ، والتقام المحرز في تحقيق

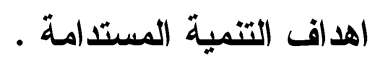

وكان من اهم التحديات التي تواجه المملكة|العربية السعودية في تحقيق الأهداف التنموية الاتي : مؤامة اهداف التنمية المستدامة ومقاصدها ومؤشر اتها ، مع الأوضاع و الظروف المحلية .

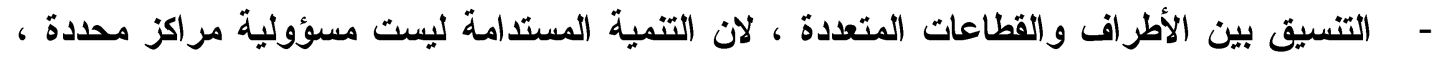

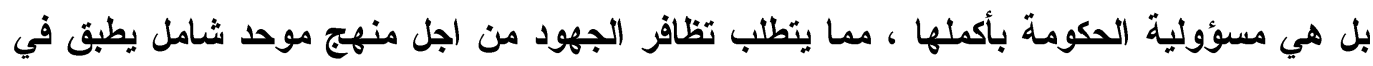

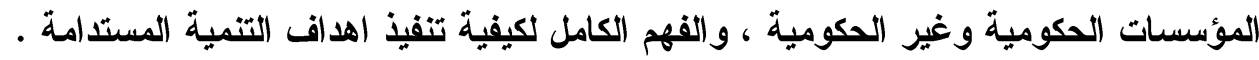
توفر البيانات والقدرات الإحصائية ،لمتابعة تقدم تحقيق اهداف التمية المستدامة ، وسهولة ولثئة الحصول

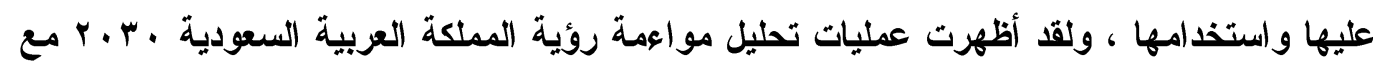

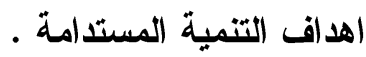


البناء على الأطر المؤسسية القائمة ، ولأهمية تنفيذ أجندة التنمية المستدامة ، في المؤسسات القائمة تظهر تحديات التنفيذ ، في الفهم الأفضل لأهداف التنمية المستدامة من جاتب المئه المسؤولين الحكوميين

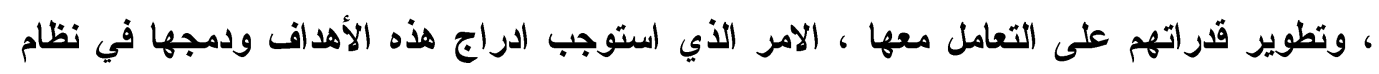

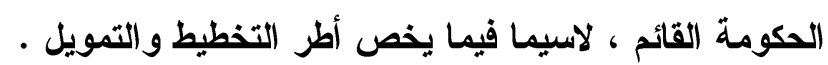

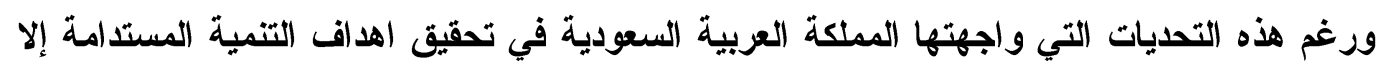

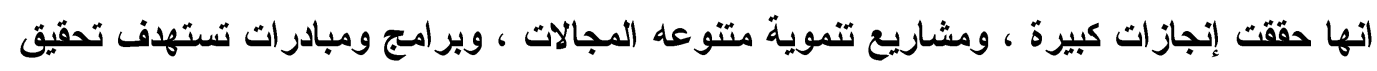

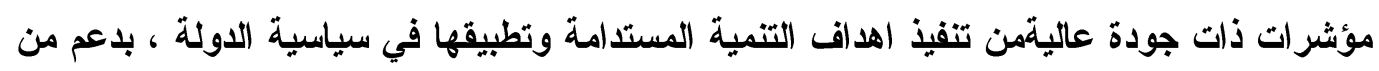

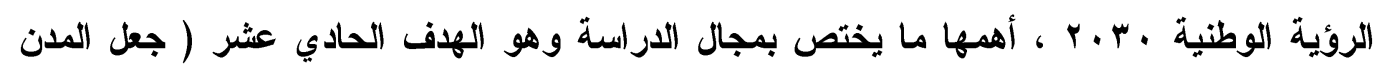

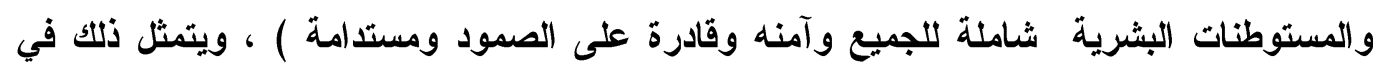

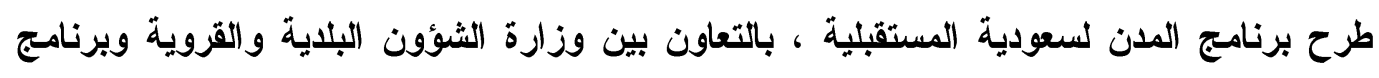

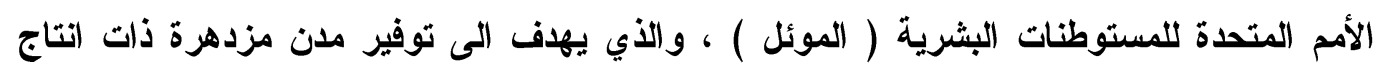

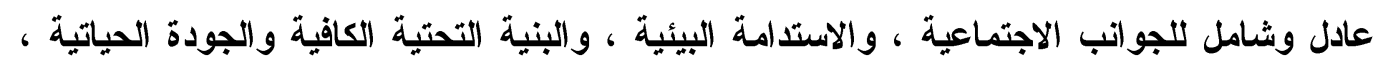

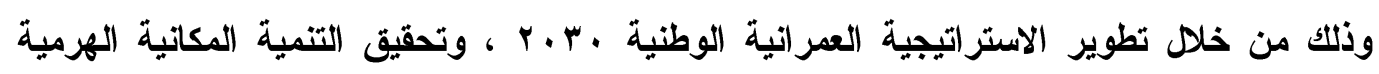

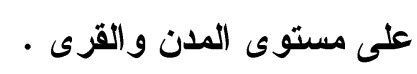

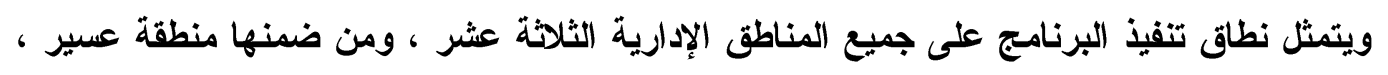

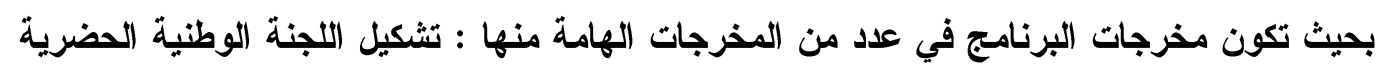

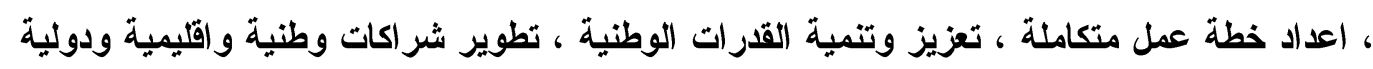

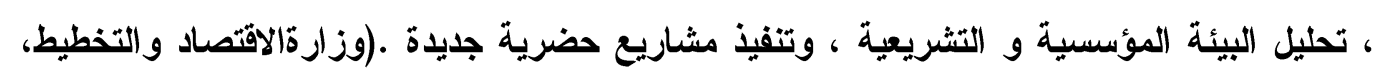

$$
\text { (1) }
$$

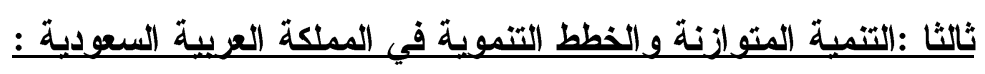
- 1 / تم تصنيف المدن والقرى بالمملكة العربية السعودية وفقا لتصنيف الاستراتيجية العمرانية

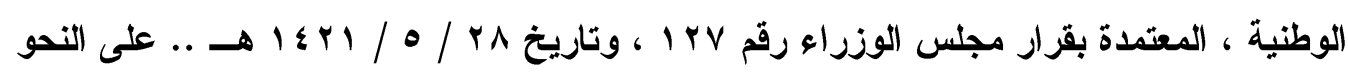
التالمي :

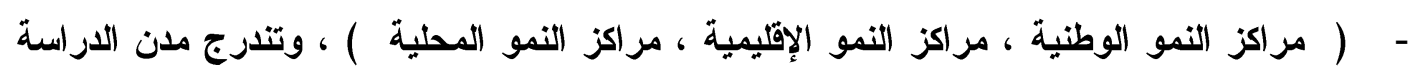

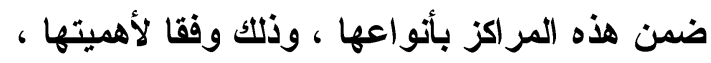

$$
\begin{aligned}
& \text { - مراكز النمو الوطنية : مدينتي أبها - خميس مشيط . }
\end{aligned}
$$

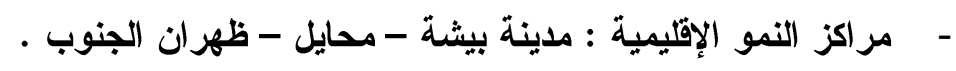

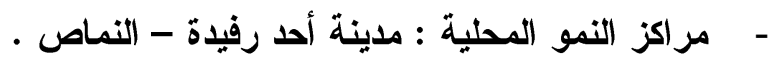

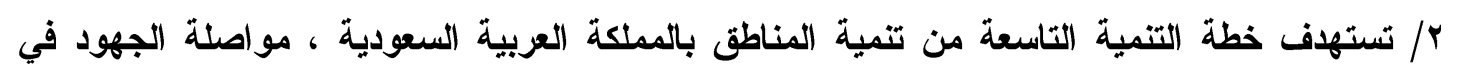

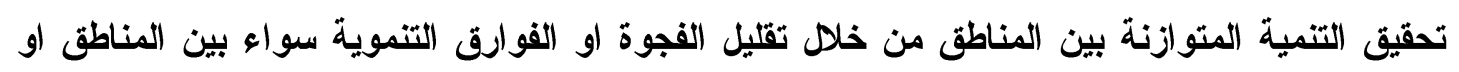

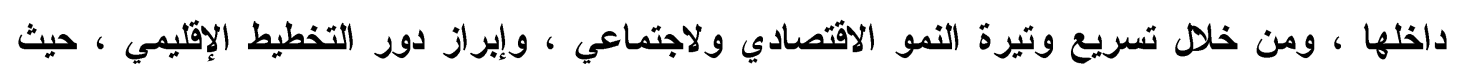

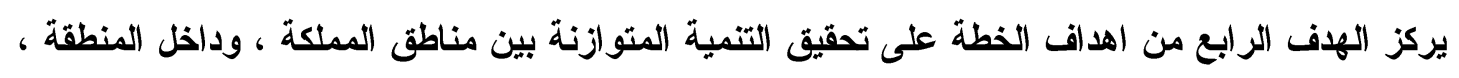


بتوفير الذمات الهامه ، والمرافق العامة ، وبناء قاعدة انتاجيه وتعزيز دورها في التتمية الاقتصادية

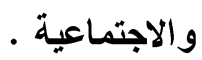

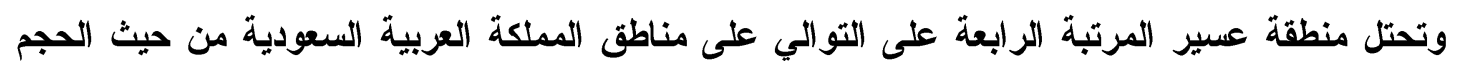

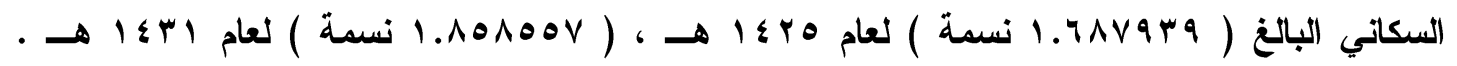

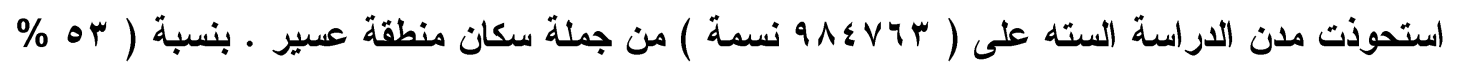

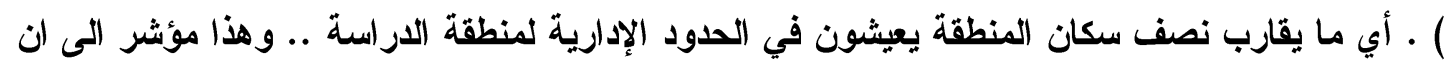

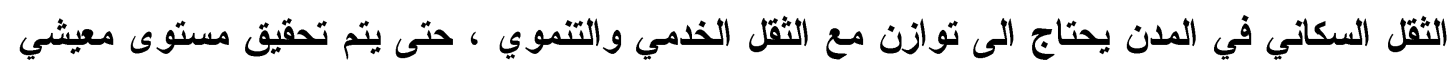

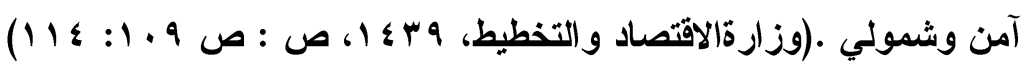

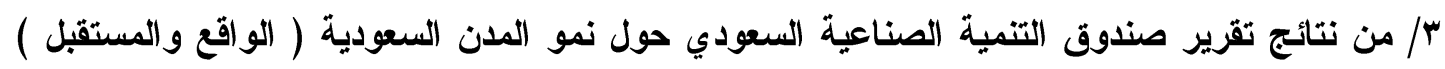

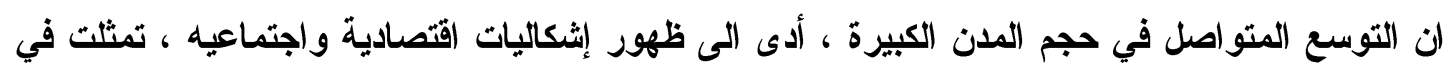

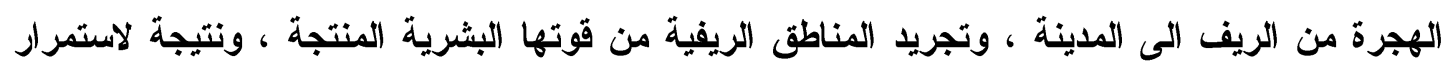

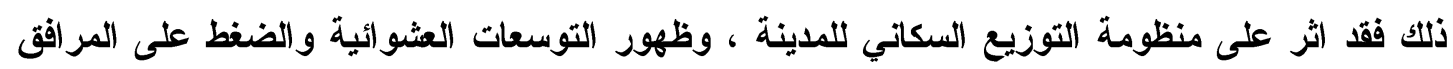

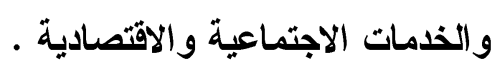
وقد بدأت الجهات ذات العلاقة في المملكة العربية السعودية الى معالجة هذه الإنكالية العاتيات ،وتحقيق تنمية

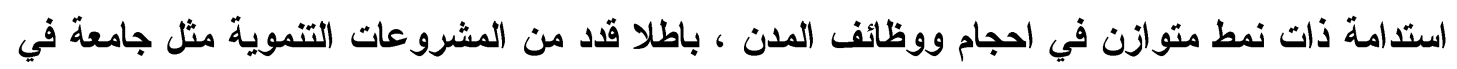

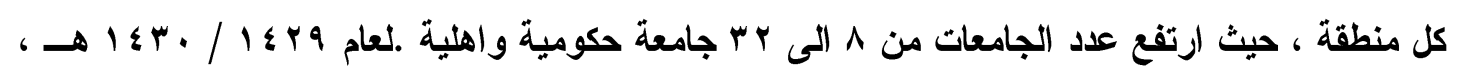

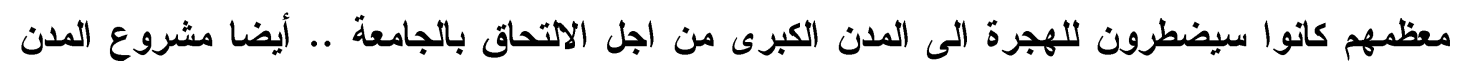

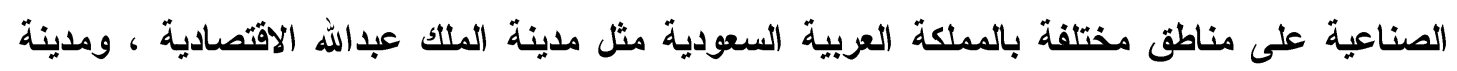

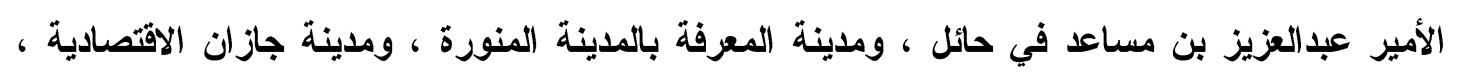

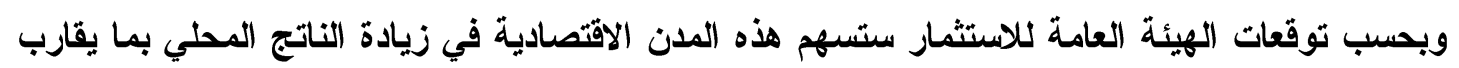

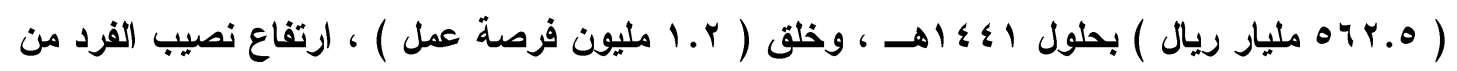

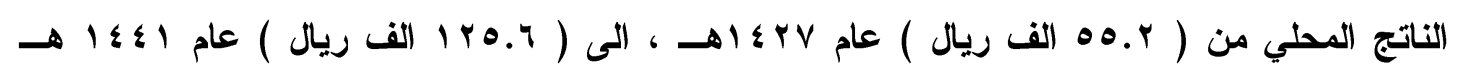
.

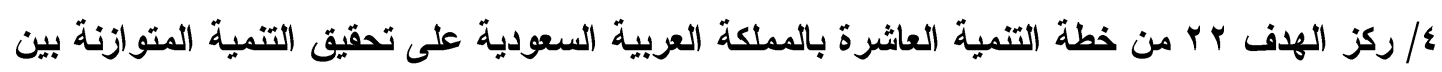

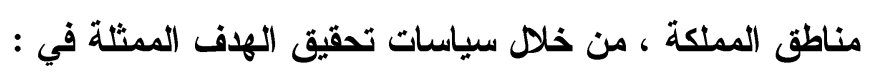
-

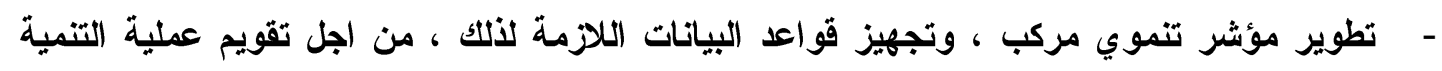

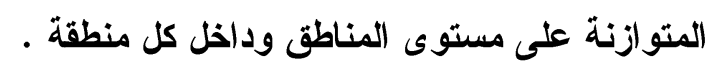

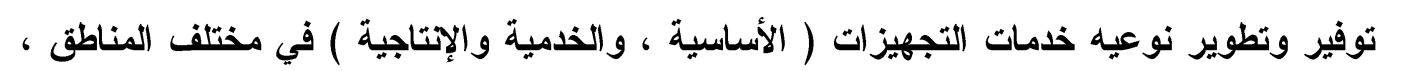
وخاصة في المدن الصغيرة و والمتوسطة .

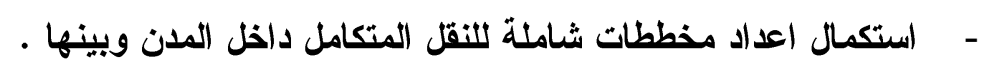
- - مث مؤسسات المجتمع المدني لتوجيه أنثطتها نحو المناطق الأقل نمواً . 
ومن اهم الأهداف المستهلف تحقيقها من الخطة خلال فترة التنفيذ حتى عام اء؛ اهـ ، قياس دور

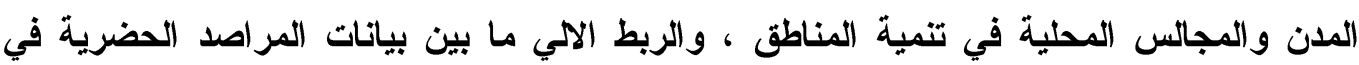

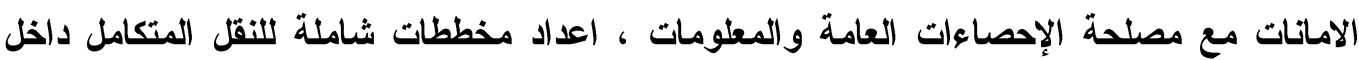

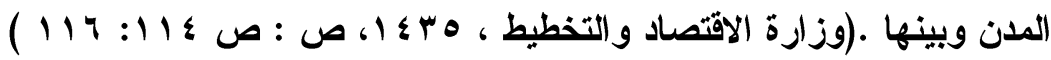

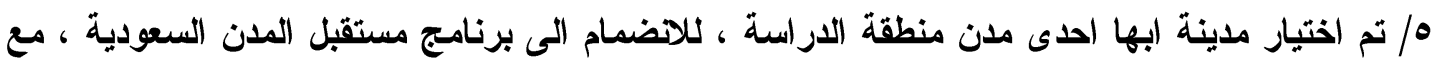

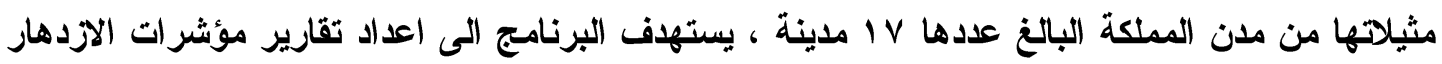

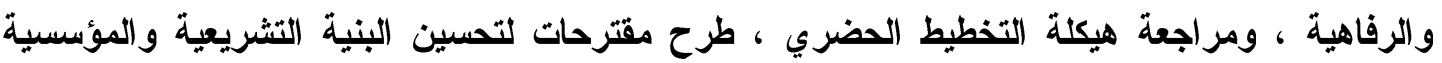

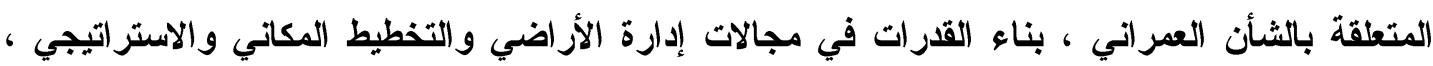

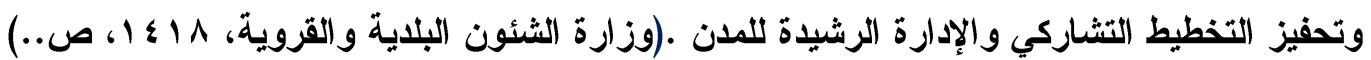
4/ تمكن البعد الاستراتيجي تحسين مستويات المعيشة والسلامة ، احد الابعاد الثمانية لبرنامج التحول الوطني بالمملكة العربية السعودية ، من العصول على خمسة اهداف استراتيجية ، و با 1 مؤشر رئيسي ، و اء مؤشر فرعي ، لعدد VY مبادرة لتحقيقه ، من خلال استراتيجيات تحقيق الهاف روئية المملكة

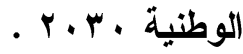
ويهوف البعد الثاني لبرنامج التحول الوطني ، تحسين مستويات المعيثة الى الارتقاء بالمدن ، ذات جودة

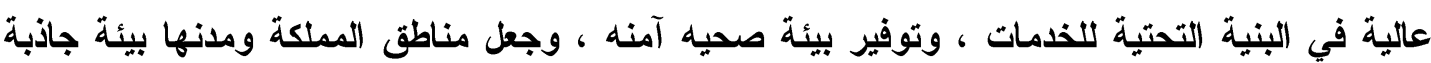
للكفاءات العالمية . ومن استراتيجيات تحقيق المستهدفات للبعد الثاني الارتقاء بجودة الخدمات المقدمة في المدن السعودية ، وتحسين المشهر الحضري في المدن السعودية ،والحد من التلوث بأنواعه ، يتم تحقيقها عن طريق تنفيذ الجيذ عدد من المبادرات الهامة للتنمية والتطوير ، ومعالجة المشكلات ، منها : تطبيق مفهوم الإدارة الحضرية

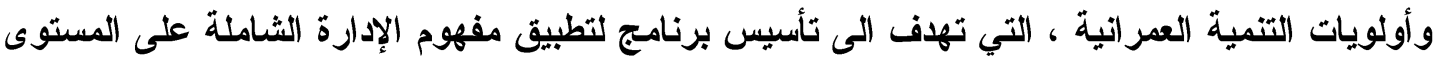

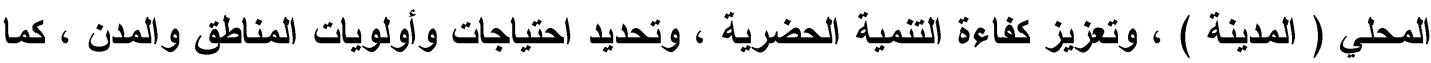

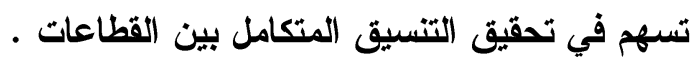
أيضا من المبادرات الهامة : تطوير المراصد الحضرية كأحد آليات متابعة تحسين المشهر الحضري ، التي تهذف الى بناء القاعدة اللازمة لتوفير البيانات والمعلومات ، وتحليلها لاستخلاص المؤشرات المتعلقة

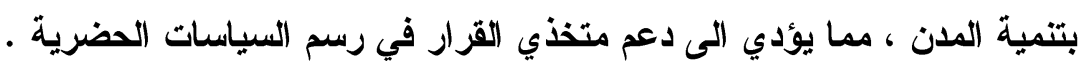

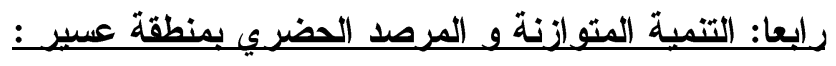

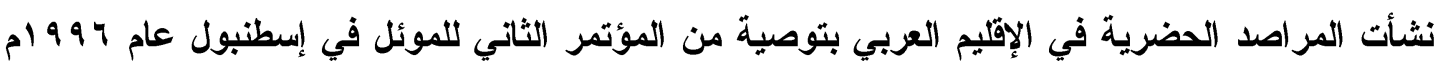

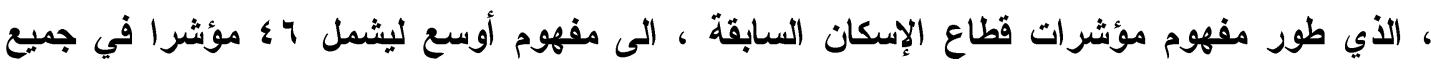
القطاعات الهامه ( الإسكان - النقل - البنية التحتية - التنمية الاقتصادية والاجتماعية ) أعدتها دول

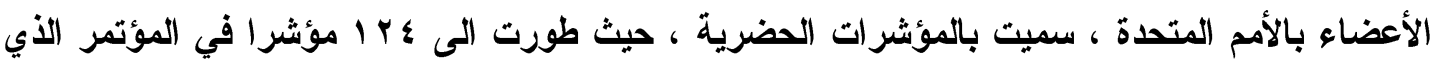

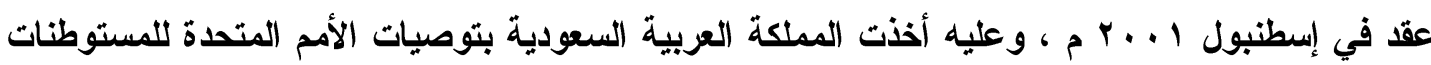
البثرية بأنشاء المر اصد الحضرية لمئول 
المرصد الحضري هو مركز متخصص يعمل على جمع وتحليل واستخدام المؤشرات الحضرية في اعداد

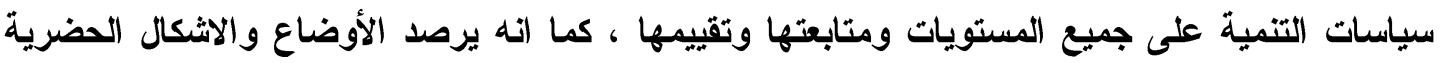
وتغذية صناعة القرار في شئون التنمية العضرية بالمعلومات على المستوى الوطني .( التقرير الثامل

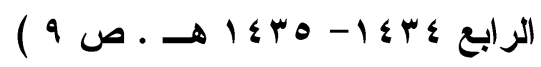

ويحتل المرصد العضري لابها الحضرية المركز الثالث للمراصد الحضرية على مستوى المملكة العربية

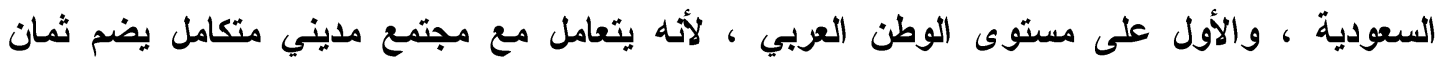

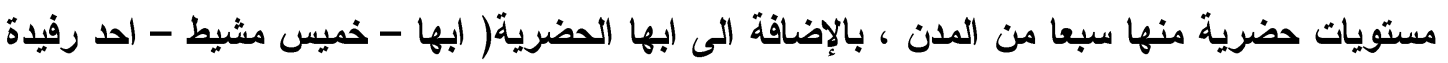

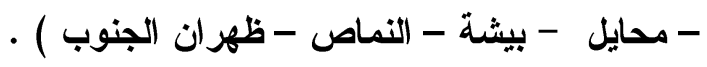

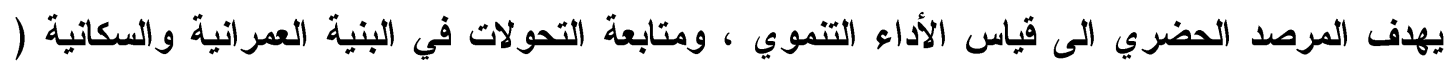

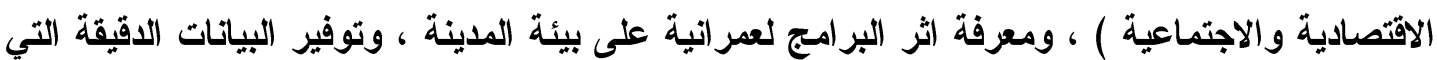

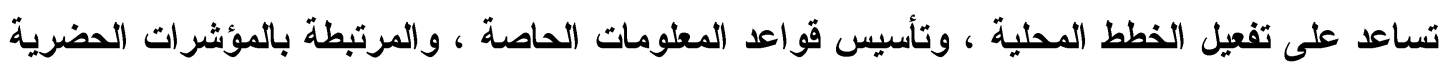
وتفعيلها في عمليات اتخاذ القرار ضمن اطار عملية التنمية العمرانية المستدامة.( التقرير الثامل الرابع

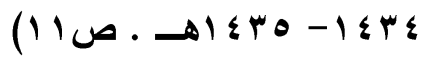
ولقد ركز مجال العمل للمرصد الحضري لابها الحضرية ومدن منطقة عسير على النطاقات العمرانية لعام • 1 ؛ هـ ، المعتمدة لاى مصلحة الإحصاءات العامة و المعلومات بالمملكة العربية السعودية ـ هي ( ابها الحضرية - ابها - خميس مشيط - احد رفيدة - محايل - بيشة - النماص - ظهران الجنوب ) ، تتم فيها دراسة وقياس ه9 مؤشر ، مقسمة بناء على ^ حزم رئيسية تم استخر اجها واعتمادها وفقا للبرامج

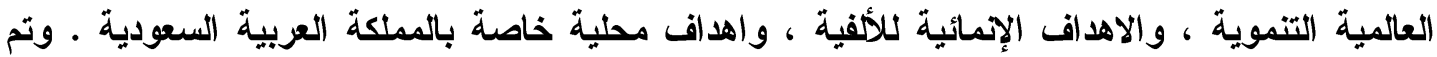

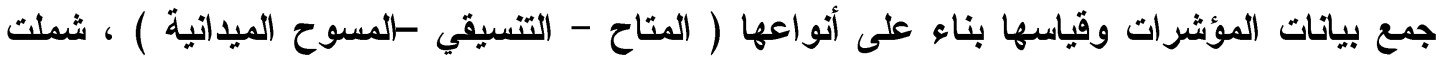

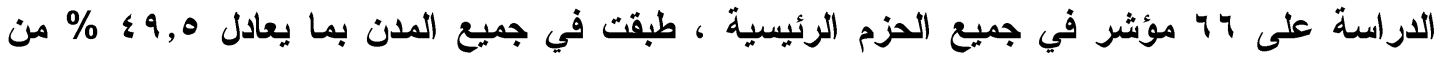
اجمالي مؤثرات المرصد الحضري ، كما هو موضح بالجدول .

\begin{tabular}{|c|c|c|c|c|}
\hline ملدن تطبيق & مؤشرات الدراسة & مؤشرات المرصد & مصادر جمع & الحزم \\
\hline \multirow{3}{*}{ خميس مشيط } & 9 & 12 & \multirow{8}{*}{ مسوح ميدانية - متسية - متساح } & البيانات الاساسية \\
\hline & 21 & 33 & & التنمية الاجتماعية والاقتصادية \\
\hline & 6 & 6 & & البنية التحتية \\
\hline \multirow{4}{*}{ أحد رفيدة } & 4 & 9 & & النقل و المو اصلات \\
\hline & 4 & 7 & & إدارة البيئة \\
\hline & 5 & 7 & & الحكم المحلي \\
\hline & 11 & 11 & & الإسكان \\
\hline \multirow[t]{2}{*}{ ظهران الجنوب } & 6 & 10 & & التنمية السياحية \\
\hline & 66 & 95 & \multicolumn{2}{|c|}{ 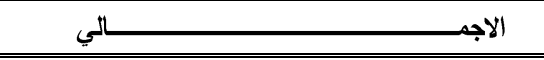 } \\
\hline
\end{tabular}

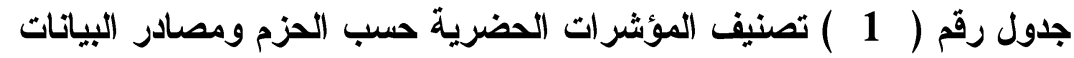

الجدول : من اعداد الباحثة . الجي 


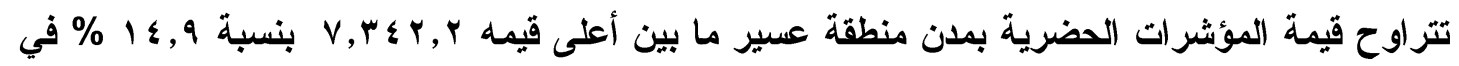

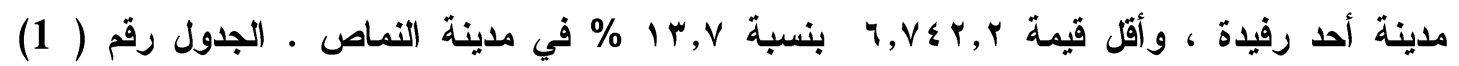
بالمـلاحق.

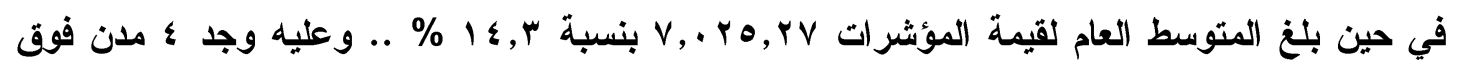

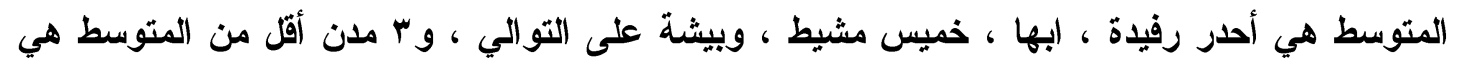

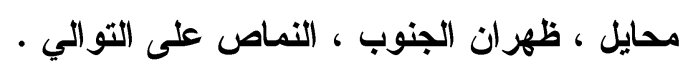

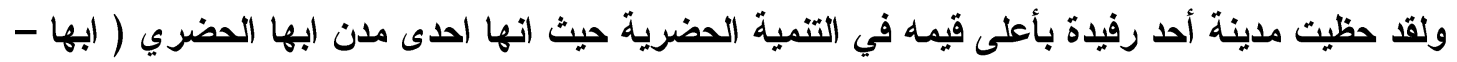
خميس مشيط · (حد رفيدة ) الامر الذي اكسبها جزء من أهية المنطقة ، وبتنفيذ عدد من المشاريع الحضرية التنموية . أثثار تفاوت القيم لمؤشرات التنمية بين مدن منطقة عسير ، بأنها متقاربة بفارق . . 1 درجة فقط ، وهذا

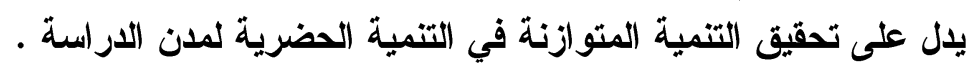

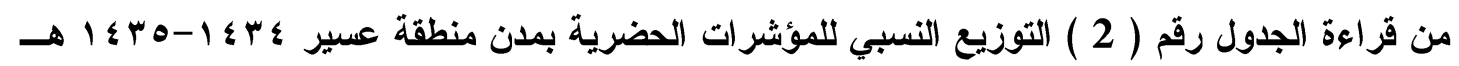

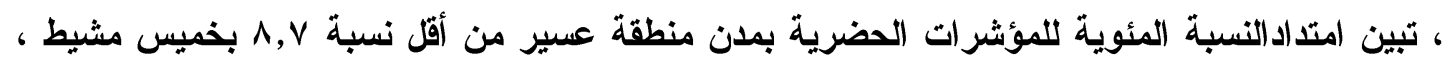

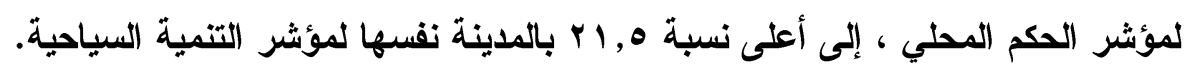

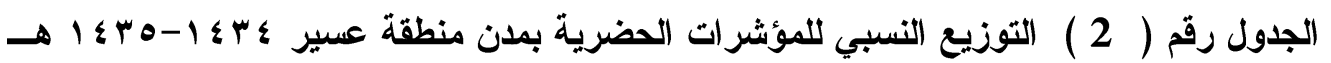

\begin{tabular}{|c|c|c|c|c|c|c|c|c|}
\hline الإجمالي & الجنوب & النماص & بيشة & 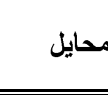 & أحدرفيدة & خميس مشيط & ابها & المؤشر ات \\
\hline 1541.2 & 193.1 & 207.4 & 235 & 200.8 & 201.7 & 270.5 & 232.7 & البيانات الأساسية \\
\hline 100 & 12.5 & 13.5 & 15.2 & 13 & 13.1 & 17.6 & 15.1 & النسبة المئوية \\
\hline 12307.8 & 1838.4 & 1651.1 & 1722.8 & 1755.3 & 1903.8 & 1665.6 & 1770.8 & والاجتماعية الاقتصادية \\
\hline 100 & 14.9 & 13.4 & 14 & 14.3 & 15.5 & 13.5 & 14.4 & النسبة المئوية \\
\hline 2563.4 & 284.8 & 285.7 & 328.5 & 336.1 & 437.6 & 407.6 & 483.1 & البنية التحتية \\
\hline 100 & 11.1 & 11.2 & 12.8 & 13.1 & 17.1 & 15.9 & 18.8 & النسبة المئوية \\
\hline 794.2 & 104.7 & 105.8 & 103.6 & 99.6 & 104.1 & 139.9 & 136.5 & النقل و المو اصلات \\
\hline 100 & 13.2 & 13.3 & 13.1 & 12.5 & 13.1 & 17.6 & 17.2 & النسبة المئوية \\
\hline 1785.21 & 193 & 250.2 & 289.5 & 288.1 & 301.7 & 188.51 & 274.2 & إدارة البيئة \\
\hline 100 & 10.8 & 14 & 16.2 & 16.1 & 16.9 & 10.6 & 15.4 & النسبة المئوية \\
\hline 1568.1 & 196.7 & 244 & 311.5 & 248.5 & 199.7 & 136.6 & 231.1 & الحكم المحلي \\
\hline 100 & 12.5 & 15.6 & 19.9 & 15.9 & 12.7 & 8.7 & 14.7 & النسبة المئوية \\
\hline 2900.4 & 391.7 & 394 & 411 & 392.8 & 422.5 & 488.7 & 399.7 & الاسكان و المأوى \\
\hline 100 & 13.5 & 13.6 & 14.2 & 13.5 & 14.6 & 16.8 & 13.8 & النسبة المئوية \\
\hline 2254.3 & 368 & 465.8 & 283.1 & 199.1 & 200 & 484.4 & 253.9 & التنمية السياحية \\
\hline 100 & 16.3 & 20.7 & 12.5 & 8.8 & 8.9 & 21.5 & 11.3 & النسبة المئوية \\
\hline
\end{tabular}


المصدر من اعداد الباحثة : استتادا الى مؤشرات المرصد الحضري لأبها الحضرية ومدن منطقة عسير.

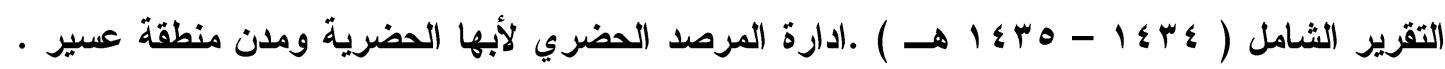
اماتة منطقة عسير ويمكن من قراءة وتحليل الجدول استنتاج الدلائل التالية :

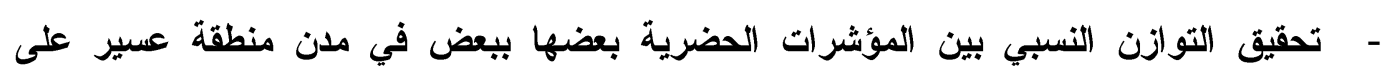

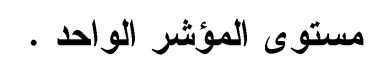
تحقيق التوازن النسبي بين المؤشرات الحضرية بعضها ببعض على على مستوى المدينة الواحدة ، كإحدى مدن منطقة الدراسة .

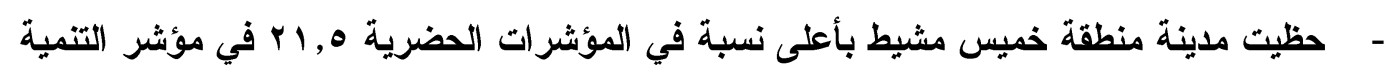

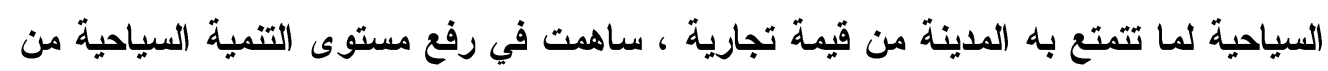

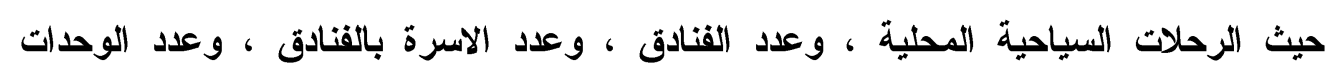

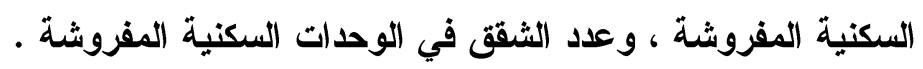

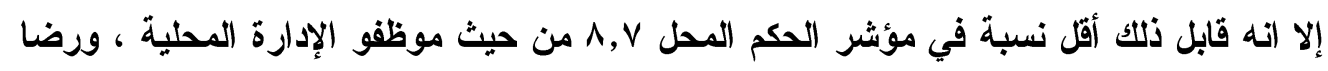

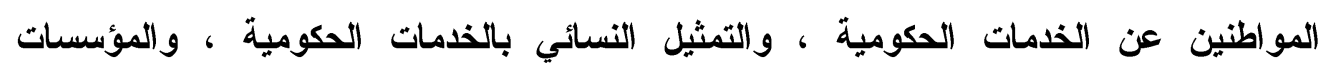

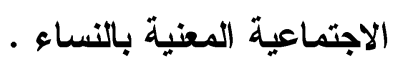

خامسا : مؤشر ات المرصد الحضري بمدن منطقة عسبر وتحقيق اهداف التنمبة المتوازنة. بالاعتماد على بيانات الجدول رقم ( 1 ) بالملاحق ، واستخدام منهج التحليل المكاني الهريمي •

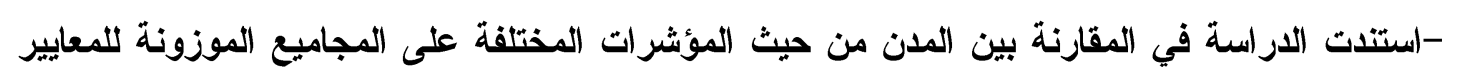
والمؤشرات التفصيلية، حسب منهجية التحليل الهرمي The analytic hierarchy process (AHP) لتحديد الأوزان لكل معيار من تلك المعايير، ومن ثم حاسب المؤشرات الرئيسية للمدن والمقارنة بينها بشكل صحيح. - وينتمي اسلوب التحليل الهرمي AHP إلىمجموعة الأساليب الكمية (بحوث العمليات) حيثي تميز

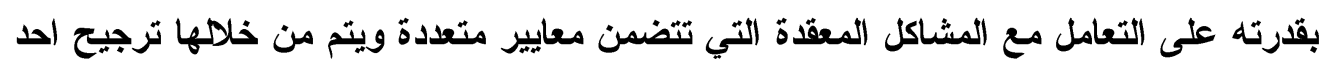

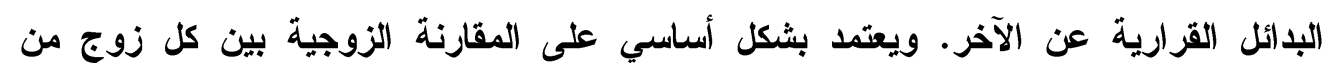
المعايير Pair-wise Comparison وإعطاء نتيجة المقارنة قيمة تلد على مدى أفضلية معيار عن الأخر بكل زوج من المعايير، ومن ثم التحليل الاحصائي لتلتك المقارنات والخروج بالوزن النهائي لكل معيار يقوماتحليلAHPعلى منهج تحليل التفضيلات على مجموعة من الأسس يمكن تحديدها على النحو التالمي:

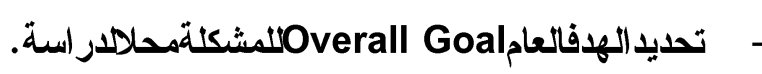
- - تحديدمجوعة(المعاييرمأو الأهداف الفرعية التي تساهم في اختيار الهدف العام. 
حصر البائلAlternatives|لمتاحة التي يتم تقييمها و المفاضلة بينها وفقا للمعايير • ويعبر عن

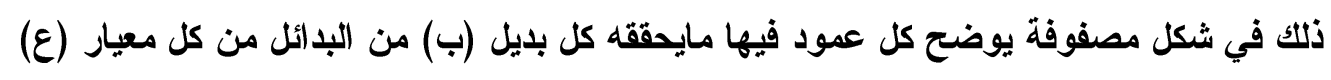

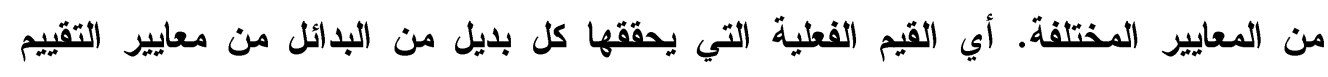

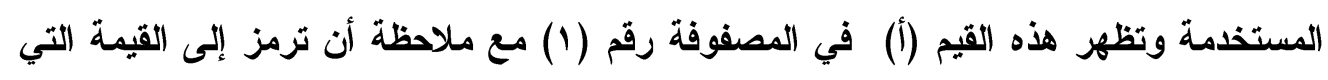

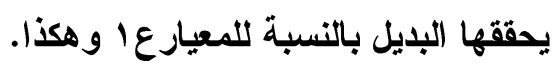
ثم بعد ذلك تأتي مرحلة تحديد الأفضلية الكلية للمعايير، توضيحهاعلى ولئل النحو التالي: إيجاد مجموع كل عمود من الاعمدة في مصفوفة المقارنة المزدوجة للبدائل مع كل معيار .

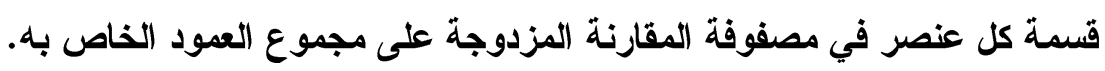
حساب متوسط مجموع نسب العناصر في كل صف في المصفوفة السابقة للوصول إلى الأفضلية النسبية للبدائل مع كل معيار من المعايير، ويطلق على متوسط مجموع نسب العناصر الجذور

المميزة Eigen values. بعد ذلك تأتي مرحلة تحديد نسبة الاتساق consistency ratio، وهو مقياس لحساب مدى

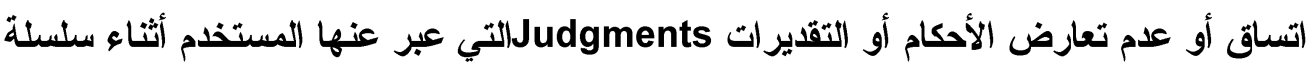

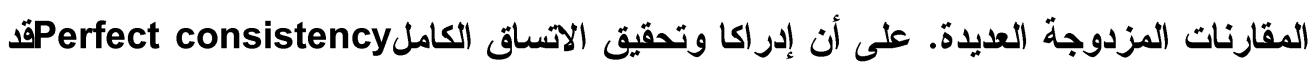

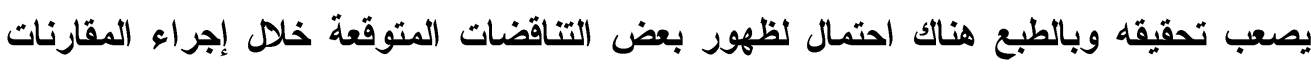
- وإذا كاتت نسبة الاتساق أكثر من . 1\% فان ذللك بدل على أنا لتقديرات كاتت غير متسقةinconsistent judgments المستخدم تعديلا لقيمالأساسية في مصفوفة المقارنة المزدوجة.

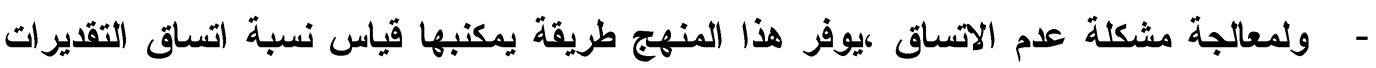

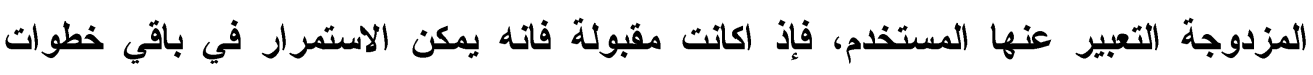

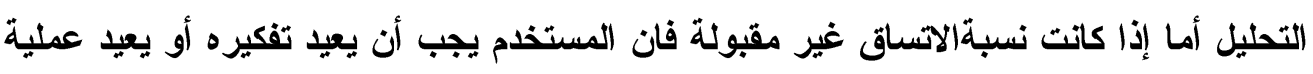
الاراسة، ومن الممكن تعديل تقديرات المقارنة الثنائية قبل الاستمرار في عمليات التحليل التالية. ويتم حساب نسبة الاتساق طبقا للخطوات التالية:

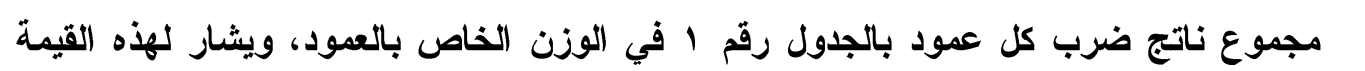
max $\lambda$. الحصول على مؤشر الاتساق(Cl)consistency Index (CI خل خل المعادلة التالية:

$$
\begin{aligned}
& \frac{\lambda \max -n}{n-1}=c i \\
& \text { - ميث n تمثل عدد المعايير. }
\end{aligned}
$$

- ويتم العصول على نسبة الاتساق CR من خلا عل المعادلة التالية:

$$
\frac{\bar{C} I}{R I}=(C R)
$$


- حيثأنRوأشر عشوائيمتيمد على عدد العناصر الاخلة في عملية المقارنة ويستخرج من جداول خاصة أعدت لهذا الغرض كما يتضح من الجدول التالي:

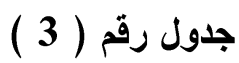

\begin{tabular}{|c|c|c|c|}
\hline المؤشر العشوائي & عدد المعايير & المؤشر العشوائي & عدد المعايير \\
\hline 1.5365 & 12 & $\mathbf{0}$ & 2 \\
\hline 1.5551 & 13 & 0.58 & 3 \\
\hline 1.5713 & 14 & 0.9 & 4 \\
\hline 1.5838 & 15 & 1.12 & 5 \\
\hline 1.5978 & 16 & 1.24 & 6 \\
\hline 1.6086 & 17 & 1.32 & 7 \\
\hline 1.6181 & 18 & 1.41 & 8 \\
\hline 1.6265 & 19 & 1.45 & 9 \\
\hline 1.6341 & 20 & 1.48 & 10 \\
\hline 1.6409 & 21 & 1.48 & 11 \\
\hline
\end{tabular}

ويوضح الجدول التالي ناتج حساب نسبة الاتساق لأوزان المعايير المحسوبة، والتي يتضح منها أن قيمة

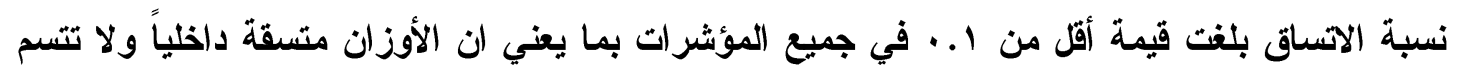
جدول رقم ( ع ) نسبة الاتساق لأوزان المعايير المحسوبة

\begin{tabular}{|c|c|c|c|c|c|c|c|c|c|}
\hline 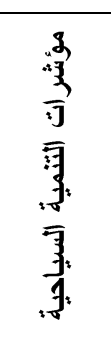 & 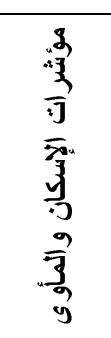 & $\begin{array}{l}\frac{8}{3} \\
\frac{3}{3} \\
\overline{3} \\
\overline{3} \\
\overline{3}\end{array}$ & 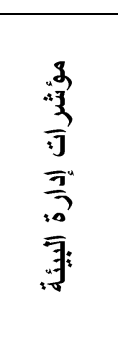 & 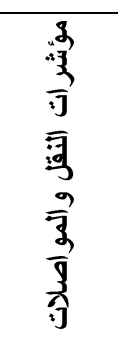 & 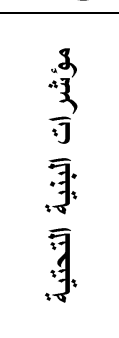 & 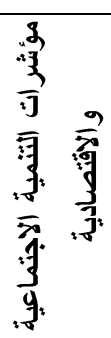 & 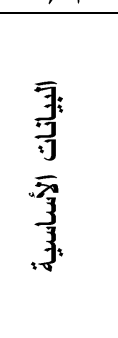 & الرمز & المتغير \\
\hline 6.10 & 11.02 & 5.46 & 4.11 & 4.16 & 6.10 & 21.62 & 9.09 & $\max \lambda$ & الإجمالي الميتون \\
\hline 0.020 & 0.002 & 0.116 & 0.038 & 0.053 & 0.020 & 0.031 & 0.011 & $\begin{array}{r}\text { Consistency } \\
\text { Index (Cl) }\end{array}$ & مؤشر الاتساق \\
\hline 1.24 & 1.48 & 1.12 & 0.90 & 0.90 & 1.24 & 1.64 & 1.45 & $\begin{array}{l}\text { Random } \\
\text { Index (RI) }\end{array}$ & موائشر \\
\hline 0.016 & 0.001 & 0.103 & 0.043 & 0.059 & 0.016 & 0.019 & 0.007 & $\begin{array}{r}\text { Consistency } \\
\text { Ratio }\end{array}$ & نسبة الاتساق \\
\hline
\end{tabular}




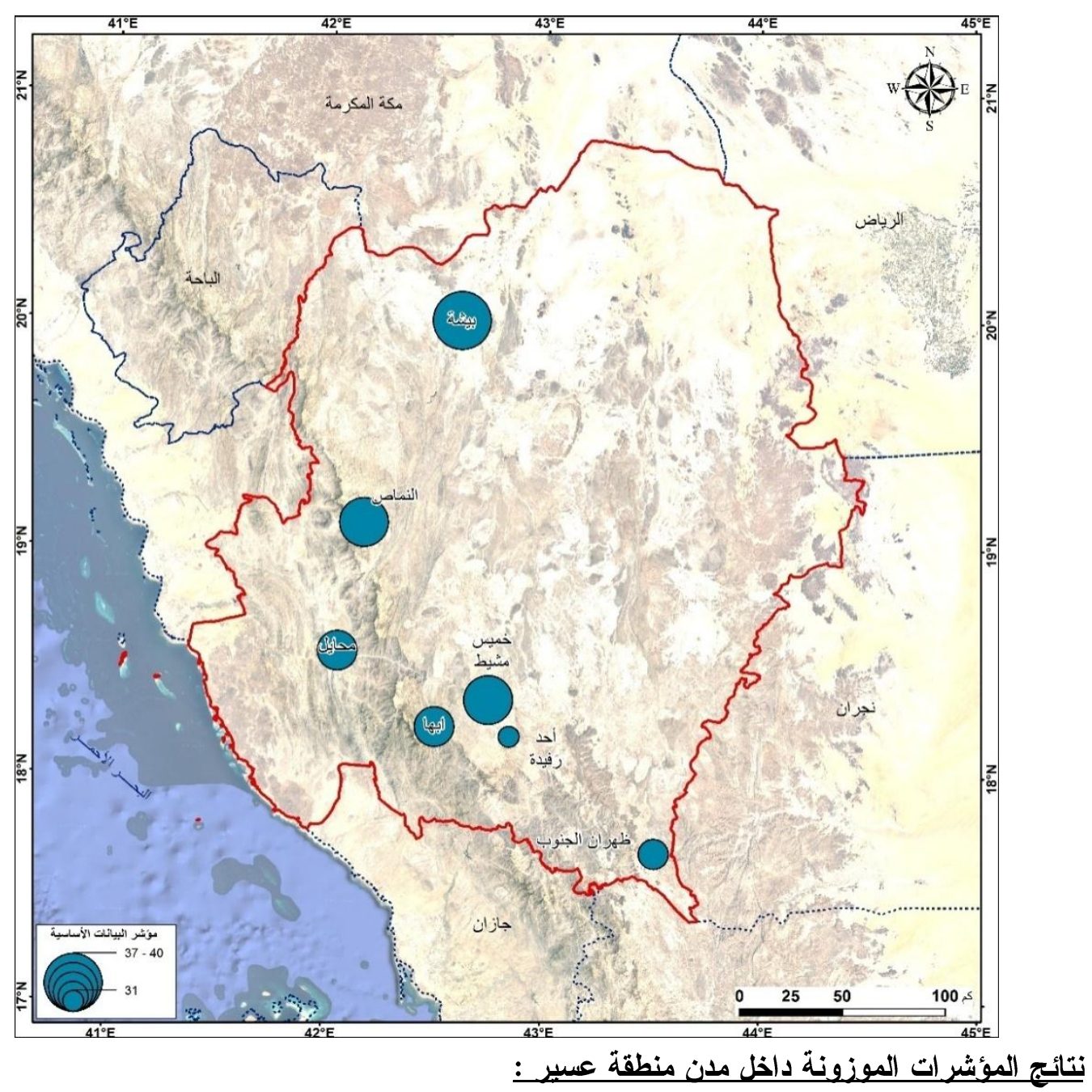

أولاً: البيانات الأساسية:

\begin{tabular}{|c|c|c|c|c|c|c|c|c|c|c|}
\hline | ظهران الجنوب| & 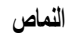 & 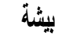 & 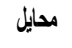 & أحلرفيدة & خيس مشبط & ابها & 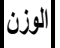 & 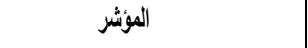 & \multicolumn{2}{|c|}{ 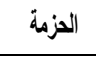 } \\
\hline 0.19 & 0.41 & 0.67 & 0.23 & 0.33 & 1.77 & 0.97 & 0.05 & نسبة استعالات الأراضي من الاجمالي \% & B1 & \\
\hline 0.25 & 0.29 & 0.89 & 0.60 & 0.60 & 4.54 & 2.49 & 0.10 & نسبة حجم السكان \% & $\mathrm{B} 2$ & \\
\hline 4.98 & 5.28 & 5.16 & 5.56 & 5.32 & 5.51 & 5.56 & 0.10 & توزيع السكان حسب النوع نكور \% & B3 & $\tilde{\omega}$ \\
\hline 3.79 & 3.54 & 3.65 & 3.32 & 3.51 & 3.36 & 3.32 & 0.08 & توزيع السكان حسب النوع إناث \% & B4 & 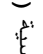 \\
\hline 0.19 & 0.19 & 0.14 & 0.23 & 0.19 & 0.21 & 0.22 & 0.09 & معدل النوو السكاني (\%) & $\mathrm{B} 5$ & - \\
\hline 0.21 & 1.10 & 0.80 & 2.49 & 5.83 & 5.42 & 4.19 & 0.18 & نسبة المهاجرين السعودين الى جملة السكان \% & B6 & 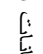 \\
\hline 0.32 & 0.22 & 0.32 & 0.09 & 0.17 & 0.12 & 0.21 & 0.05 & معدل التكوين الاسري (\%) & B7 & $\underline{\underline{t}}$ \\
\hline 0.40 & 0.42 & 0.51 & 0.33 & 0.18 & 0.20 & 0.23 & 0.04 & الاستر التي تبليها امراة \% & B8 & \\
\hline 21.92 & 23.82 & 28.37 & 20.81 & 14.79 & 14.56 & 16.26 & 0.33 & نوع حيازة المسكن / ملك (\%) & B9 & \\
\hline 32.26 & 35.28 & 40.50 & 33.66 & 30.94 & 35.70 & 33.46 & & العجموع & & \\
\hline
\end{tabular}

الخريطة رقم ( 2 ) والجدول رقم ( 5 ) مؤشرات البيانات الأساسية الموزونة لمدن منطقة عسير 
ومن الشكل السابق رقم (5/2) يمكن الخروج بعدة نتائج أهمها:

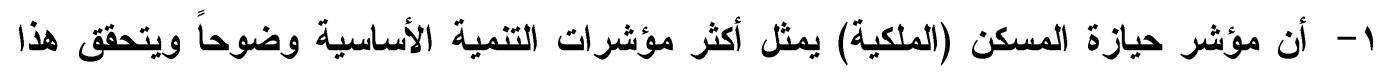

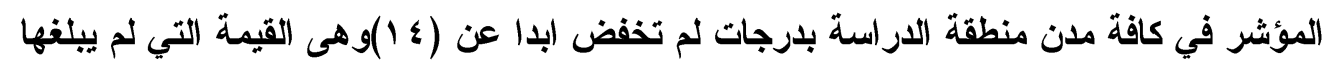
أي مؤشر آخر ضمن مجموعة مؤشرات التنمية الأساسية.

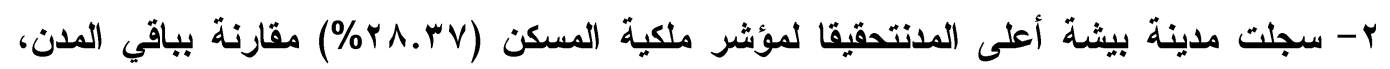
ويليها في ذلك مدينتي النماص وظهران الجنوب، والملقت للنظر في هذا المؤشر أن المدن الثلاث

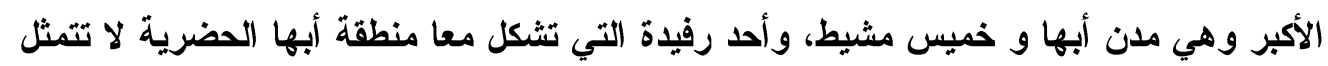

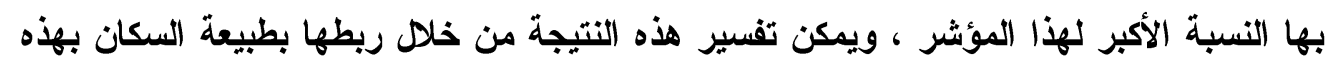

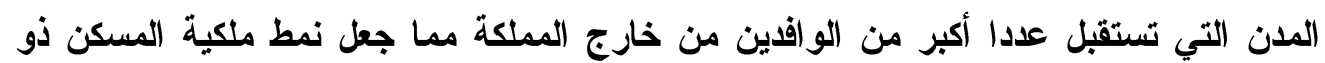
دلالة واضحة . ب- يمثل مؤشر معدل التكوين الأسرى أدنى مؤشرات البنية الأساسية تسجيلا بالمنطقة،وهو الأمر

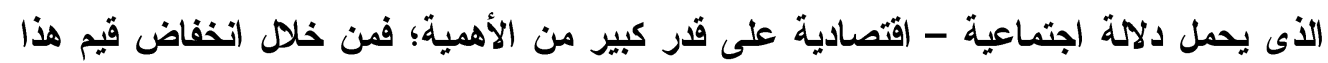

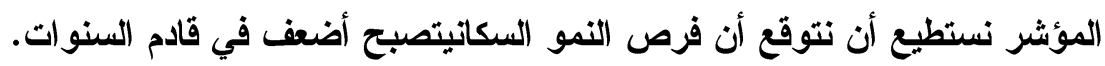
ثاتيا : مؤشر ات التمية الاجتماعية والاقتصادية :

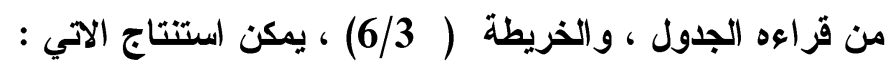

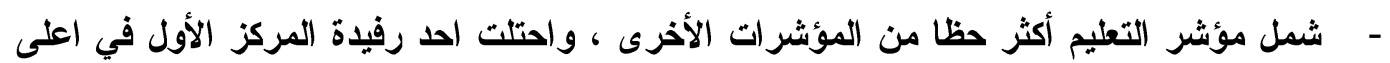

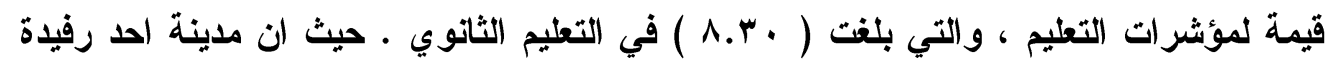
مقر عمل لعدد من افراد المجتمع الساكنين من خارجها ، الامر الذي ساهم في ربط مؤشر التعليم

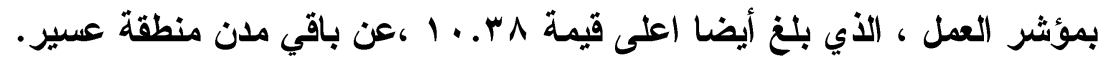

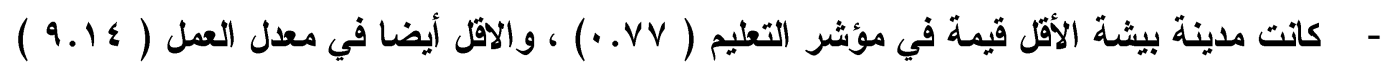

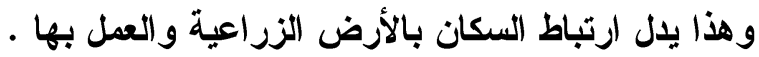

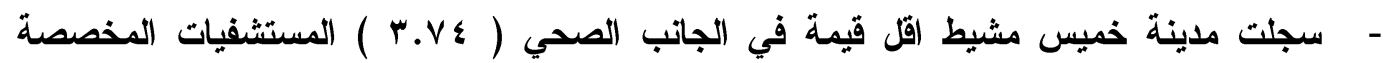
للأطفال ، لأنها مدينة تجارية ركزت على الثمولية في التخصصات الصحية للمستشفيات لخدمة

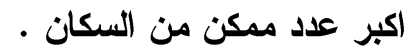




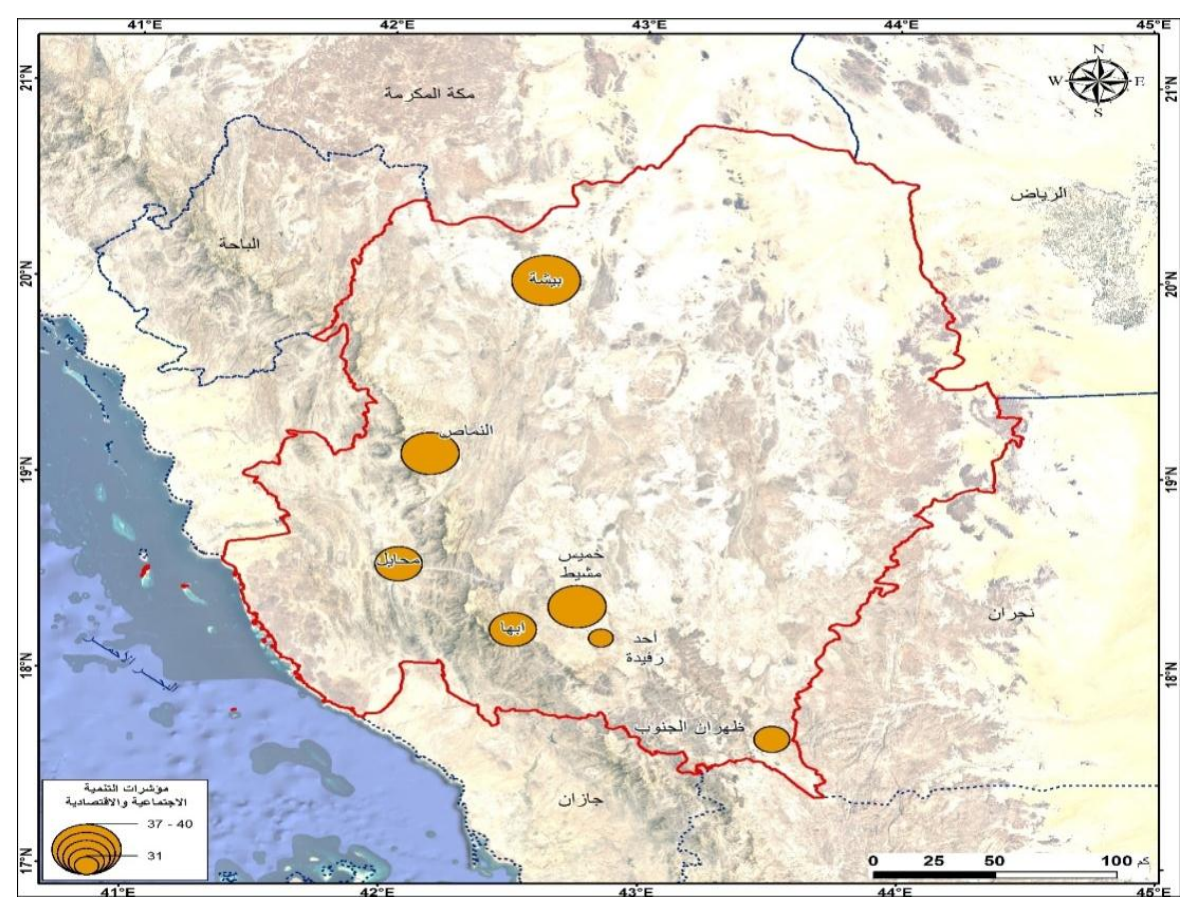

الخريطة رقم ( 3 ) مؤشرات التتمية الاجتماعية والاقتصادية الموزونة لمدن منطقة عسير

\begin{tabular}{|c|c|c|c|c|c|c|c|c|c|c|}
\hline 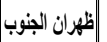 & التماص & بيثة & مدايل & أدرفيدة & خيس مشيط & ابها & 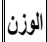 & 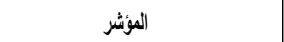 & \multicolumn{2}{|c|}{ الحزهة } \\
\hline 6.52 & 6.64 & 6.59 & 6.63 & 6.70 & 6.56 & 6.02 & 0.07 & نسب الآسر العتَرة فرق من 2000ريال (\%) & SE1 & \\
\hline 5.23 & 5.23 & 5.23 & 5.23 & 5.23 & 3.74 & 4.48 & 0.05 & المستُفيفات المخصصه للأطفال \% & SE2 & \\
\hline 5.23 & 5.23 & 5.83 & 5.23 & 5.19 & 5.17 & 4.97 & 0.05 & الأطفال المدصنين ضد الأوبنة \% & SE3 & \\
\hline 1.05 & 0.78 & 0.77 & 0.81 & 1.20 & 0.83 & 0.98 & 0.01 & 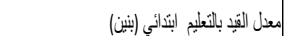 & SE4 & \\
\hline 1.97 & 1.48 & 1.35 & 1.79 & 2.17 & 1.37 & 2.09 & 0.02 & 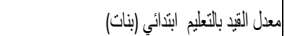 & SE5 & \\
\hline 2.87 & 2.07 & 1.76 & 2.21 & 3.10 & 2.41 & 2.42 & 0.03 & 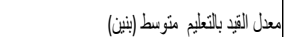 & SEG & \\
\hline 3.88 & 2.90 & 2.24 & 3.59 & 5.00 & 2.93 & 3.83 & 0.04 & معدل القئ بالتُعلي متر سط (بنات) & SE7 & 笭 \\
\hline 5.16 & 4.42 & 3.64 & 3.89 & 6.27 & 4.73 & 4.95 & 0.05 & معل القبّ بالتُعليم ثالوي (بنين) & SE8 & t' \\
\hline 6.63 & 5.65 & 4.11 & 6.14 & 8.30 & 5.60 & 6.05 & 0.07 & معدل القنب بالتعليم ثألوي (بنات) & SE9 & 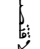 \\
\hline 1.06 & 0.96 & 1.30 & 1.06 & 0.93 & 1.05 & 1.04 & 0.01 & 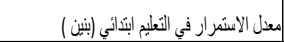 & SE10 & \\
\hline 1.98 & 1.95 & 2.87 & 1.91 & 1.72 & 1.73 & 1.84 & 0.02 & 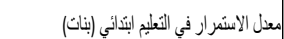 & SE11 & \\
\hline 2.86 & 2.48 & 3.06 & 2.87 & 2.57 & 3.00 & 2.63 & 0.03 & 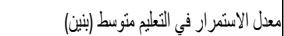 & SE12 & $\underline{\underline{v}}$ \\
\hline 3.99 & 3.71 & 4.10 & 4.15 & 4.07 & 3.74 & 3.56 & 0.04 & 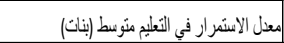 & SE13 & 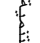 \\
\hline 5.23 & 4.25 & 5.33 & 6.71 & 4.59 & 5.01 & 6.04 & 0.05 & 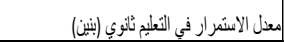 & SE14 & E \\
\hline 6.66 & 6.40 & 6.90 & 6.82 & 6.06 & 4.97 & 5.04 & 0.07 & معثل الاستُر ار في التعليم ثلازي (بنات) & SE15 & 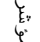 \\
\hline 4.77 & 3.83 & 3.75 & 2.43 & 3.66 & 4.37 & 4.60 & 0.10 & 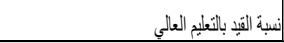 & SE16 & \\
\hline 3.98 & 3.99 & 3.93 & 3.95 & 3.99 & 3.95 & 3.97 & 0.04 & معدل الالمام بالقر اءة والكتلبة (15-24 سنة) & SE17 & \\
\hline 9.31 & 9.26 & 9.14 & 8.92 & 10.38 & 9.65 & 9.92 & 0.13 & معلى العطل & SE18 & \\
\hline 1.84 & 1.92 & 1.84 & 1.88 & 1.92 & 1.88 & 1.91 & 0.02 & معدل الزواج للإنان 30 سنة فاكر & SE19 & \\
\hline 1.62 & 1.65 & 1.97 & 1.72 & 2.09 & 2.15 & 2.17 & 0.05 & مستخفمي شُبكة المعلومات الولولةً (الآترنت ) \% & SE20 & \\
\hline 0.43 & 0.40 & 0.36 & 0.48 & 0.51 & 0.67 & 0.88 & 0.05 & نبلة السعودة في القطاع الخاص & SE21 & \\
\hline 82.26 & 75.23 & 76.07 & 78.44 & 85.66 & 75.50 & 79.40 & & 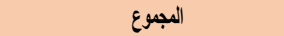 & & \\
\hline
\end{tabular}

الجدول رقم (6 ) مؤشرات التنمية الاجتماعية والاقتصادية الموزونة لمدن منطقة عسير

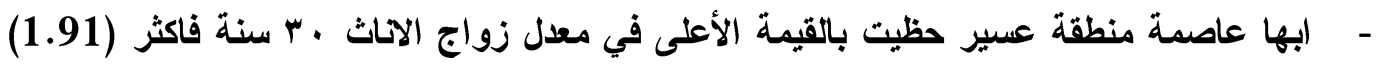
ومستخدمي شبكة الآترنت ( 2.17 ) ونسبة السعودة في القطاع الخاص ( $(0.88)$ وهي من الهم 
العدن التي تتركز بها الخدمات وتحمل طابع العمومية ، نتيجة طبيعة الافتتاح في البيئة الاجتماعية والاقتصادية .

إلا انها بالمقابل حصلت على اقل قيمة بمستوى بسيط في معدل الأطفال المحصنين ضد الأوبئة (4.97) ، في حين انه حقق ارتفاعا في باقي الدلن اعلى من ( 5 ) الامر الأي يتطلب التركيز

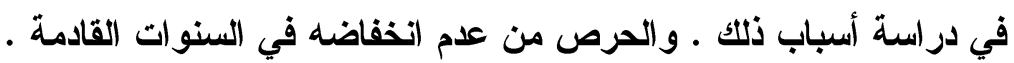

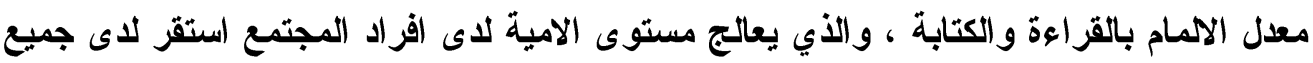

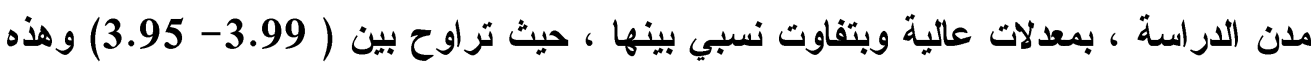

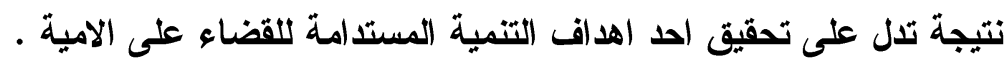

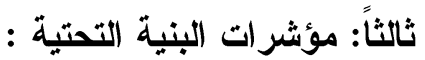

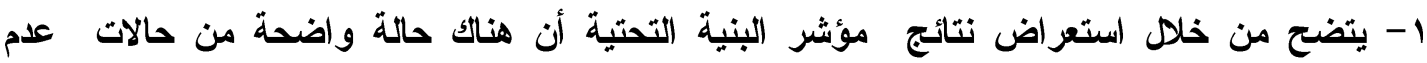
التوازن في توزيع خدمات ومرافق عناصر البنية التحتية على مستوى مدن منطقة الدراسة حيث ترنية ترنكز

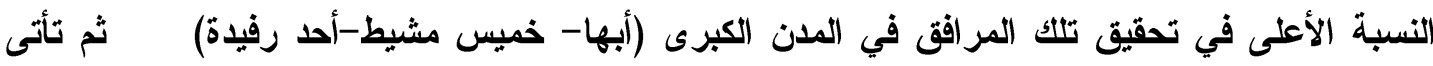

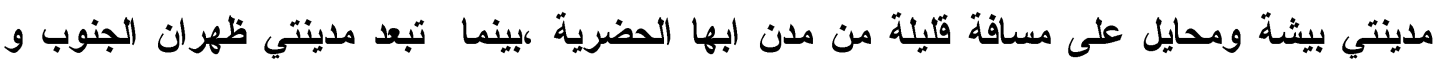

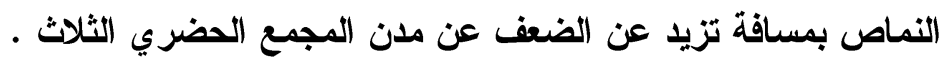
r - يع توفر المياه بمثابة العامل المشترك على مستوى خذمات البنية التحتية على مستوى جميع المدان

داخل نطاق منطقة الدراسة r- تكاد تتساوى فرص اتاحة مياه نقية على مستوى كافة المدن ، وان كانت الفرصة الأقلفى مدينة

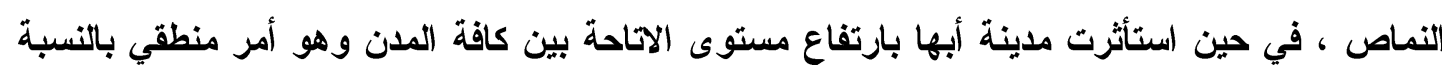

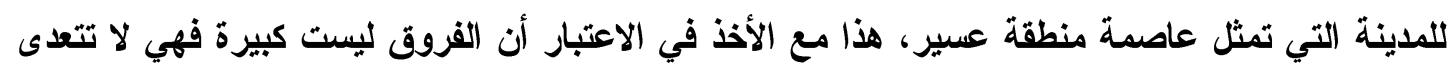

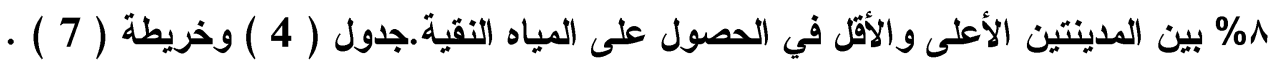

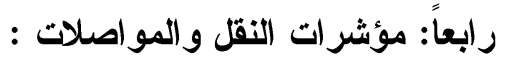

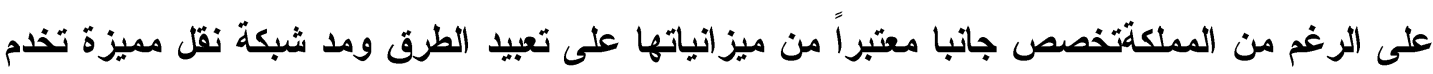

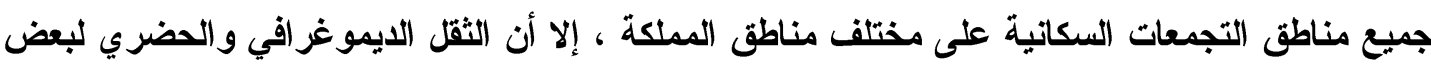

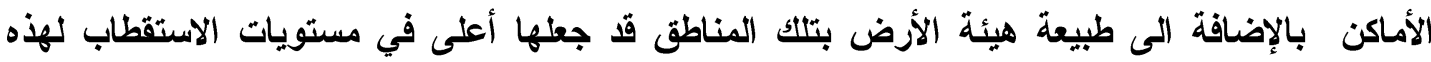

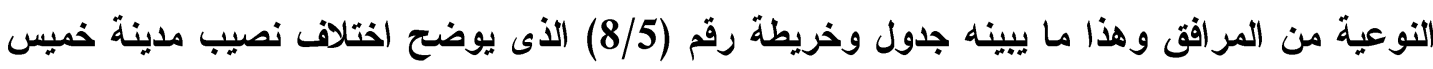

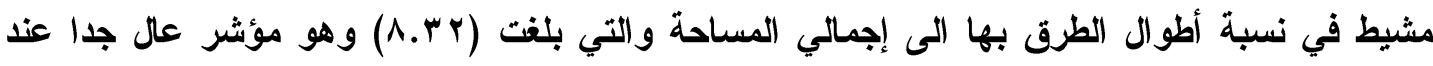

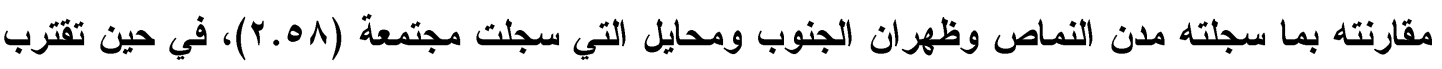

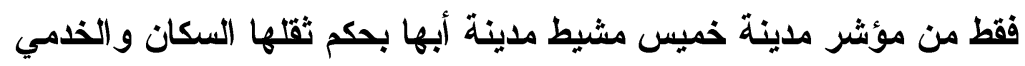

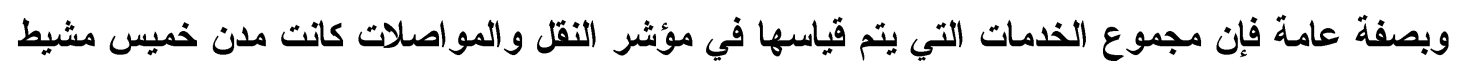
وأبها في الترتيب الأول بينما تفوقت مدينة ظهران الجنوب على المدن الأربع المتبقية. 


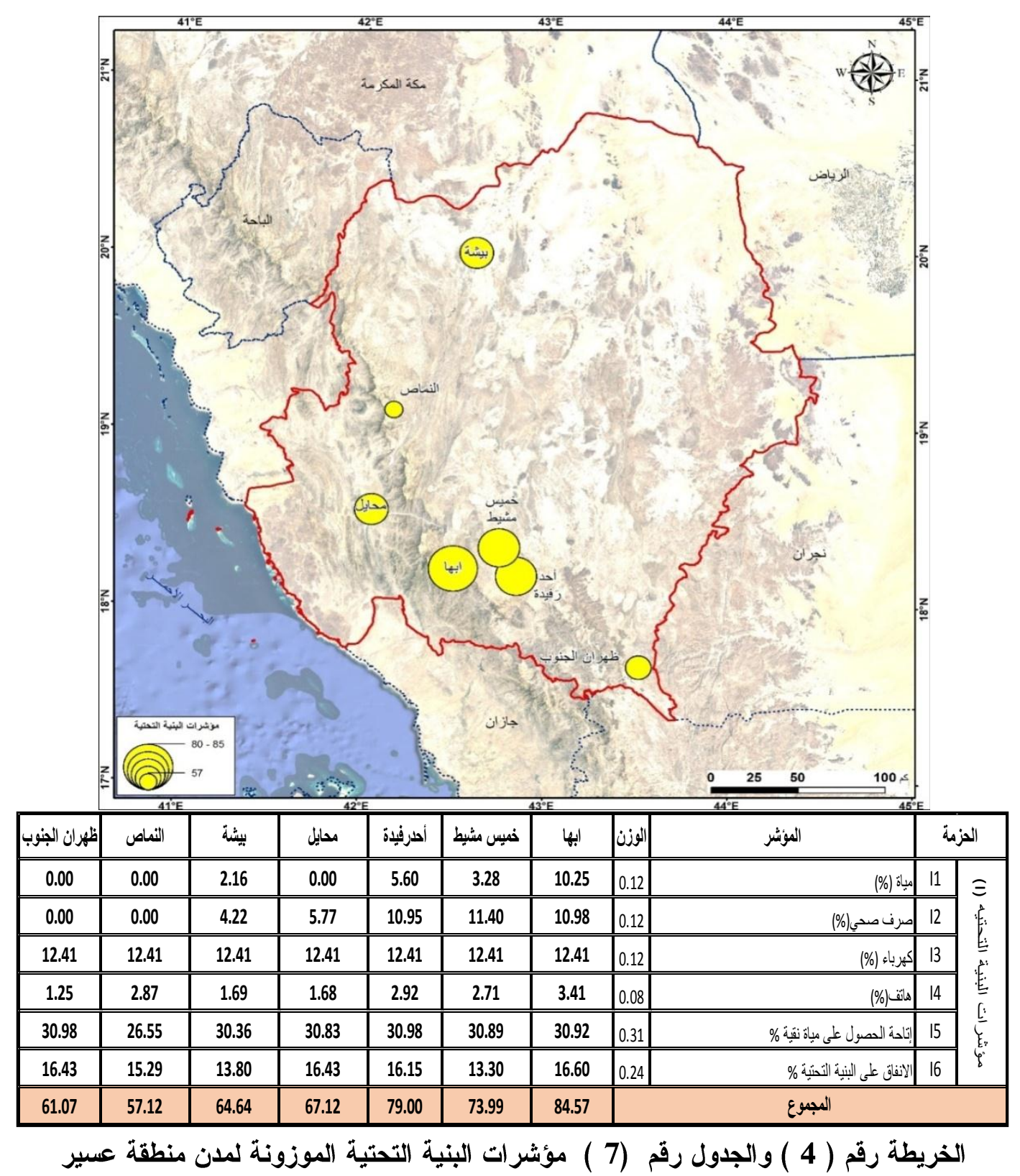




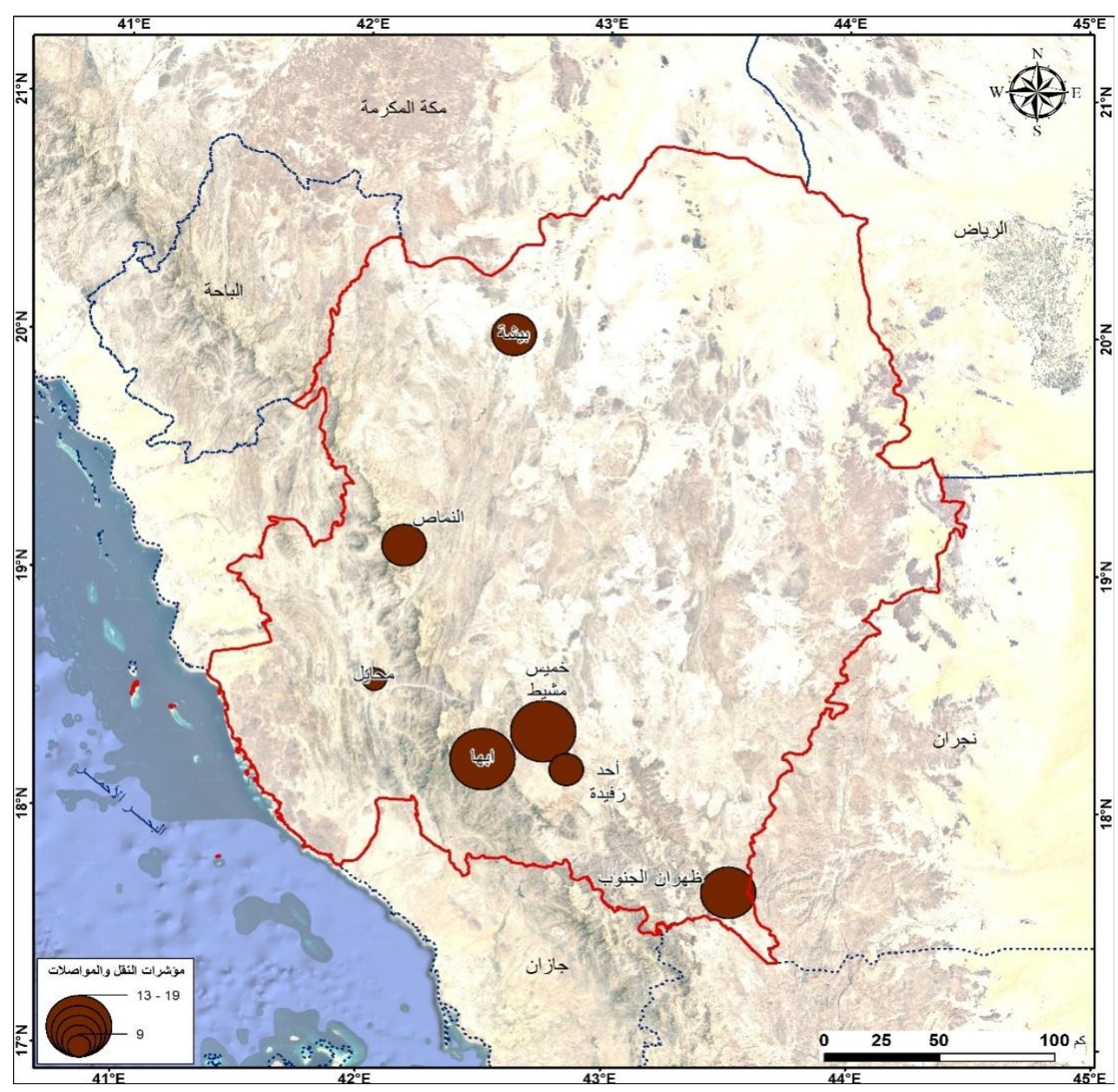

\begin{tabular}{|c|c|c|c|c|c|c|c|c|c|c|}
\hline |ظهران الجنوب & النعاص & بيثة & مدايل & أدرفيدة & خبيس مشيط & ابها & |لهزن |لهز & المؤشُ & \multicolumn{2}{|c|}{ الحزهة } \\
\hline 8.10 & 8.31 & 8.11 & 8.20 & 8.44 & 7.84 & 8.26 & 0.09 & وسبلة الانتقال للعمل سبارة خاصة \% & TR1 & כ) \\
\hline 2.39 & 0.74 & 0.60 & 0.28 & 0.28 & 2.48 & 1.06 & 0.46 & وسلة الانتقال للعمل حافلات وباصات \% & TR2 & E; \\
\hline 0.20 & 0.76 & 0.28 & 0.08 & 0.00 & 0.53 & 0.25 & 0.25 & وسلة الانتقال للعمل سبرا على الأقام \% & TR3 & 6 \\
\hline 0.82 & 0.82 & 1.31 & 0.58 & 0.98 & 8.20 & 7.37 & 0.20 & نسبة طو ال الطرق من الإجمالي & TR4 & 6 \\
\hline 11.51 & 10.63 & 10.29 & 9.13 & 9.70 & 19.05 & 16.94 & & 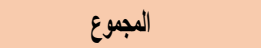 & & \\
\hline
\end{tabular}

الخريطة رقم ( 5 ) والجدول رقم (8 ) مؤشرات النقل والمواصلات الموزونة لمدن منطقة عسير

خامساً: مؤشر ات إدارة البيئة : يعد هذا المؤشر من أهم المؤشرات ذات الالالة التنموية التي يتم من خلالها الربط بين التنمية البيئة

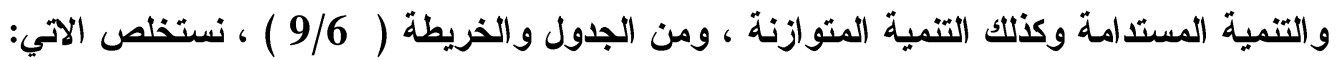
1- يعتبر مؤشر نسبة المسطحات الخضر اء بالنسبة لأجمالي مساحة المدينة، من أهم تلك المؤشرات

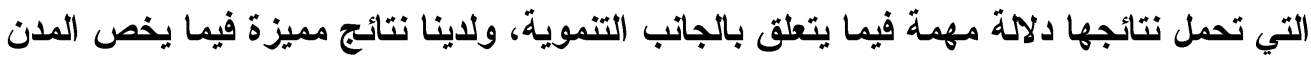
التي لم تحقق القيم الأعلى في المؤشرات السابق ذكرها، حيث تمثل مدينة النماص صاحبة بانة 
النصيب الأعلى في هذا العنصر بين كل مدن منطقة الدراسة مسجلا (هr ـ ع) بينما لا تبلغ قيمة

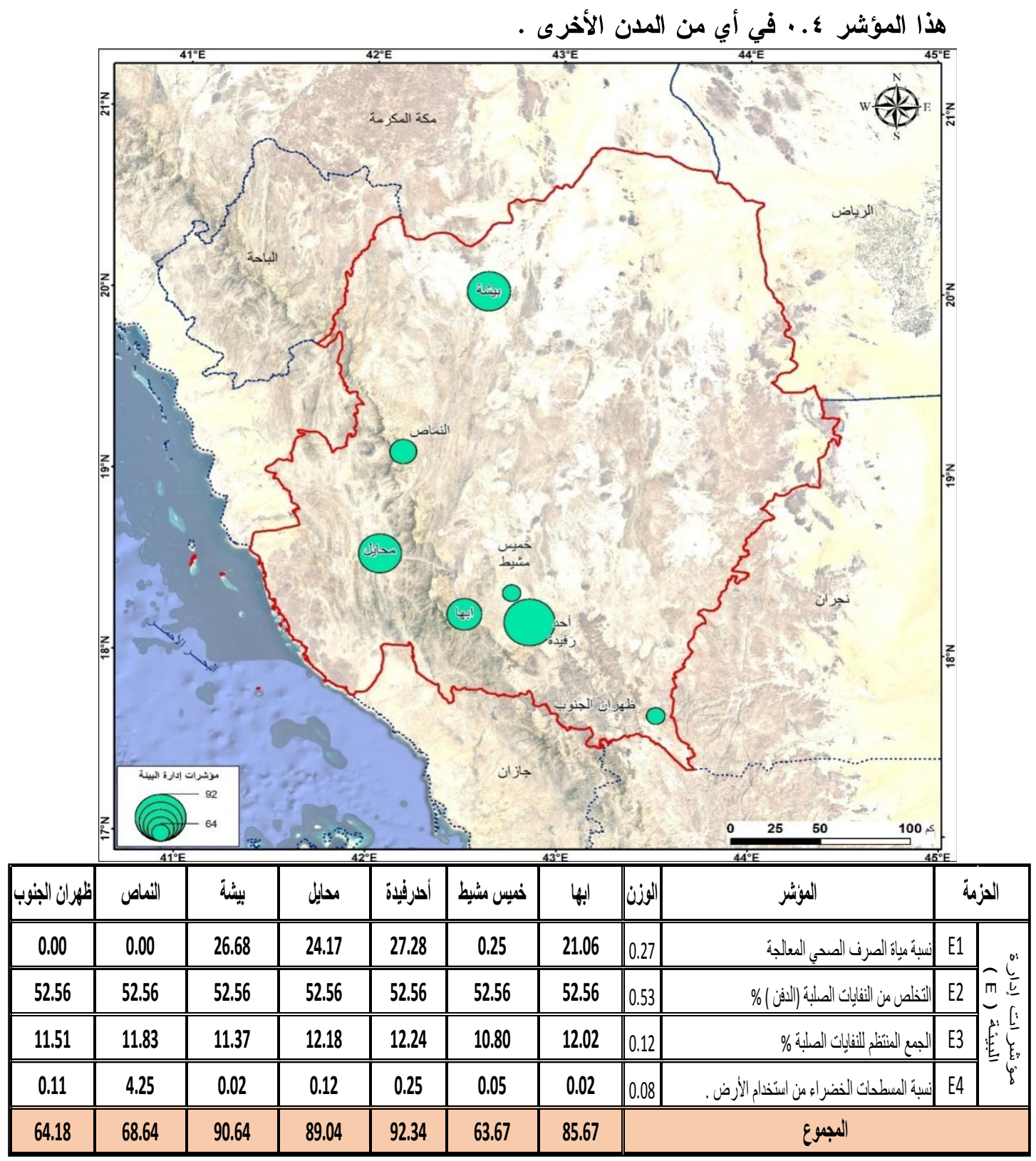

الخريطة رقم ( 6 ) والجدول رقم (9 (9 ) مؤشر اتإدارة البيئة الموزونة لمدن منطقة عسير

r- يمكن القول أن قيم مؤشرات (التخلص من النفايات الصلبة بالدفن، نسبة الجمع المنتظم للنفايات

الصلبة) تكاد تتساوى بين مختلف منطقة الاراسة نظر اللطبيعة الحكومية والخدمية التخطيطية

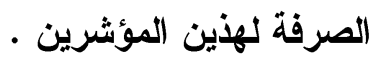

r- سجلت مدينة أحد رفيدة المدينة الأولى بين من منطقة الدراسة فيما يتعلق بمؤشر مياه الصرف

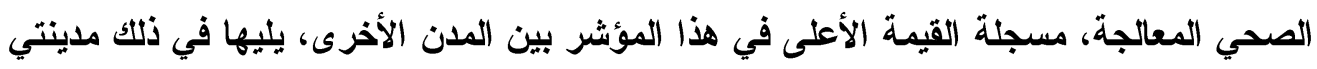

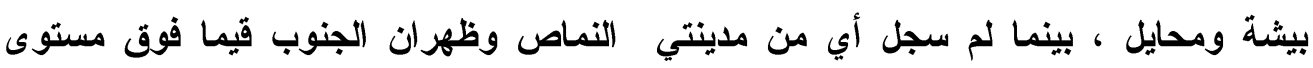
الصفر بالنسبة لهذا لمؤشر . 
من خلا مراجعة عناصر مؤشر الحكم المحلى لمختلف مدن المنطقة بالجدول والخريطة رقم

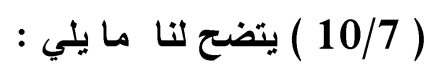
1 - تكاد تتساوى قيم هذا المؤشر يشكل عام على مستوى مدن منطقة الاراسة .

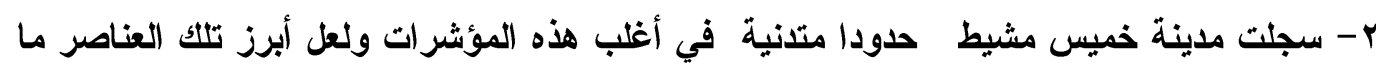

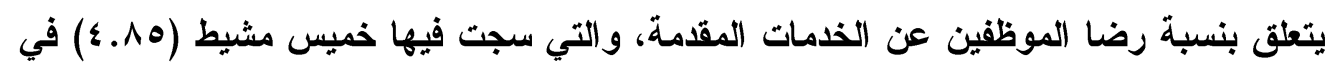
حين لم تقل أي من المدن الأخرى عن (ع r) وهو الأمر الأى انعكس على القيمة النهائية لهئا

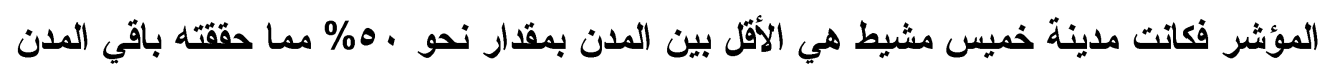
بثكل عام.

$$
\text { سابعاً: مؤشر ات الإسكان و المأوى: }
$$

يتكون هذا العنصر من أحد عشر مؤشراً تتناول موضوع الإسكان والمأوى حيث اشدارت النتائج بالجدول

$$
\text { و الخريطة رقم (11/8 ) إلى: }
$$

1- يظلب على نوع المساكن كل من (المسكن التقليدي الحديث ، والعمارات السكنية ) بينما تتضاعل نسبة الفيلات والمساكن القديمة التي لم تبلغ اعن أوع في كل المدن باستثناء مدينة بيشة التي وصلت

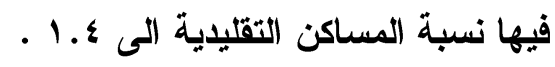

ץ- يمكن اعتبار مدينة أبها هي الأعلى في قيم إيجارات المساكن ، بمقارنة مي باقي المدن كما

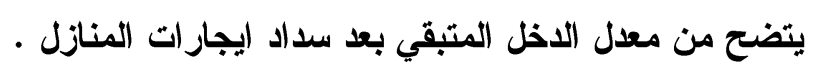

r- يعد الحصول على قروض لتمويل المساكن سلوكا واضحا في مدن أبها وخميس مشيط وأحد

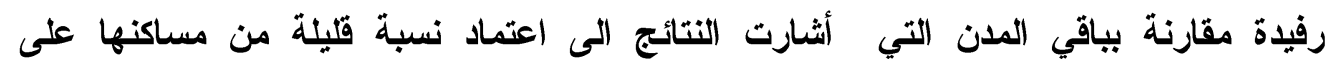
القزوض.

ثامناً: مؤشرات التنمية السياحية :

من خلال دراسة الجدول والخريطة رقم (12/9) ومر اجعة نتائج هذا المؤشر نخرج بالنتائج التالية:

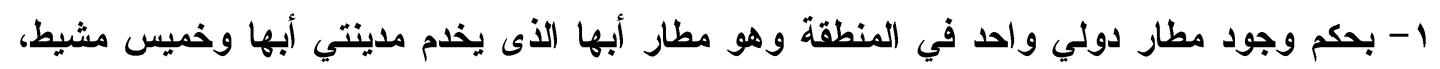
فإن نتيجة نسبة القادمين للمنطقة جواً تقتصر فقط على هاتين المدينتين، وهو نتيجة ونطة منطقية.

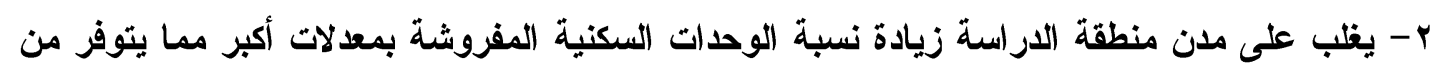
فنادق بمختلف الفئات وهو مؤشر يستحق الاراسة ان كاتت هنالك رغبة في تحقيق تنمية سياحية فعلية وخاصة في مجال السياحة الاولية. 
ץ- يمكن القول أن الزيادة التي تسجل في مدينتي خميس مشيط وأبها من رحلات السياحة الدولية،

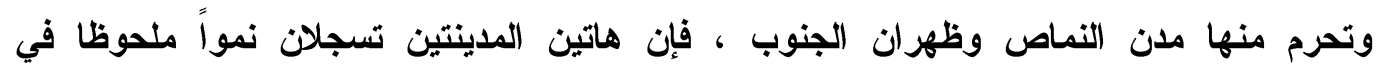
استقطاب رحلات السياحة الداخلية ، وهى نتيجة مهمة عند الحديث عن الأنماط التنموية بالمنطقة.

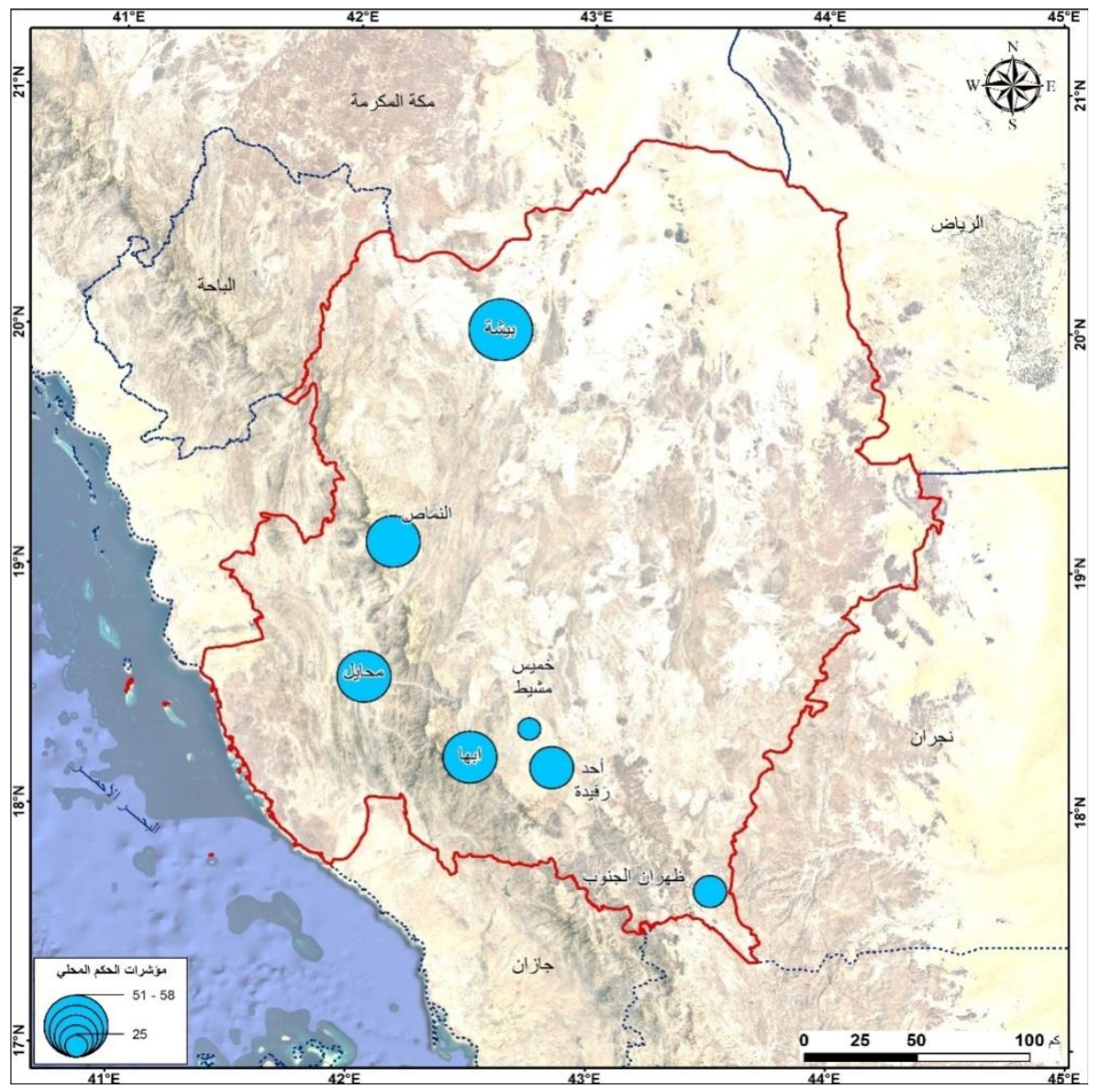

\begin{tabular}{|c|c|c|c|c|c|c|c|c|c|c|}
\hline |نيران الجنوب| & النعاص & 望 & مدليل & أدرفيدة & فيسن مُنبط & ابها & 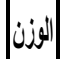 & 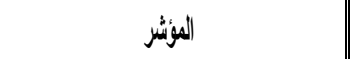 & \multicolumn{2}{|c|}{ الحزهة } \\
\hline 6.13 & 5.63 & 7.41 & 4.26 & 5.57 & 4.32 & 3.75 & 0.30 & إنببة الأجور والرواتب بن إبلالي البزلنية & G1 & i \\
\hline 11.61 & 11.98 & 11.21 & 12.92 & 12.27 & 13.11 & 13.45 & 0.16 & 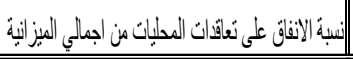 & G2 & $\underline{E}$ \\
\hline 24.46 & 25.39 & 25.98 & 25.80 & 26.91 & 4.58 & 26.82 & 0.30 & النبةز رضا العو الطين عن الخمات الحكمبة \% & G3 & E \\
\hline 3.22 & 2.19 & 4.47 & 2.48 & 2.04 & 2.43 & 2.87 & 0.16 & 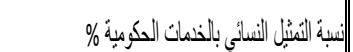 & G4 & $\underline{E}$ \\
\hline 0.00 & 4.45 & 8.90 & 4.45 & 0.00 & 0.74 & 2.22 & 0.09 & 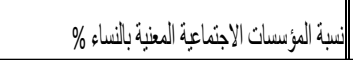 & G5 & $\xi$ \\
\hline 45.42 & 49.64 & 57.97 & 49.90 & 46.78 & 25.17 & 49.12 & & المجوبع & & \\
\hline
\end{tabular}

الخريطة رقم ( 7 ) و الجدول رقم (10 ) مؤشرات الحكم المحلي لمدن منطقة عسير 


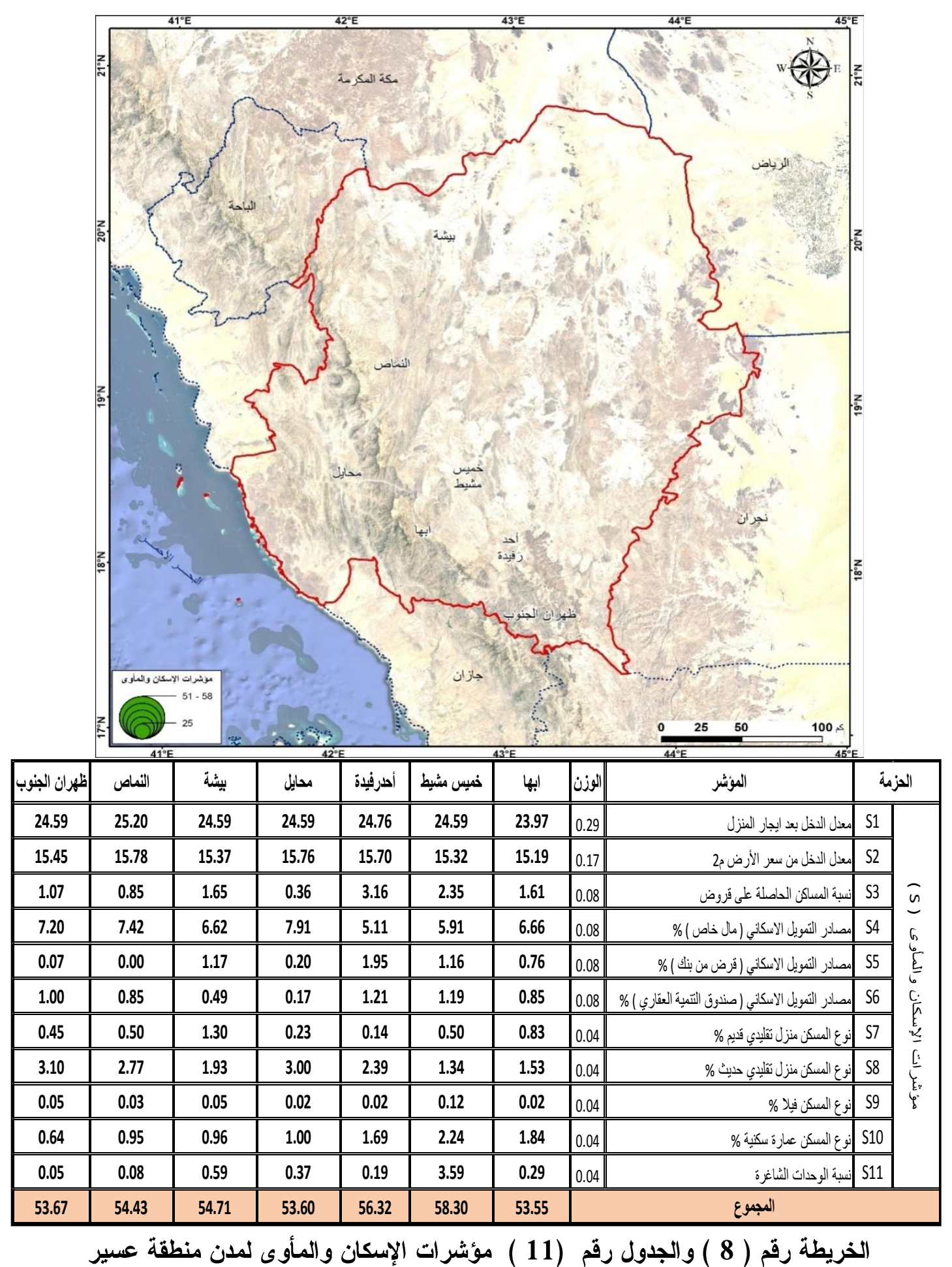




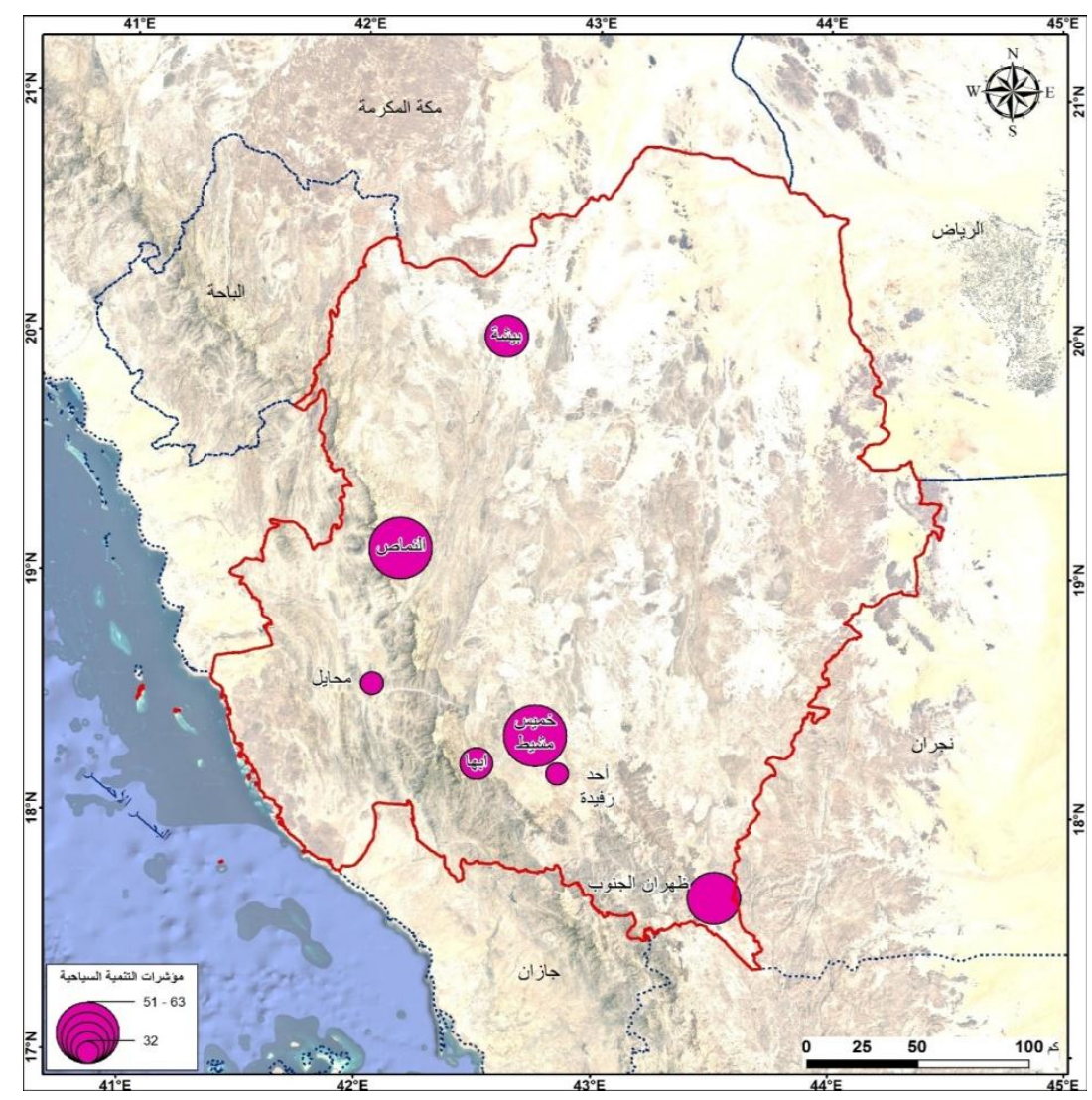

\begin{tabular}{|c|c|c|c|c|c|c|c|c|c|c|}
\hline | تيهران الجنوب & النماصن & بيُة & مدايل & أحلرفّبة: & فيبس مُشبط & إيا & 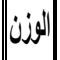 & المؤتُش & \multicolumn{2}{|c|}{ الحزهة } \\
\hline 23.71 & 23.71 & 23.71 & 22.52 & 23.71 & 3.67 & 20.79 & 0.24 & 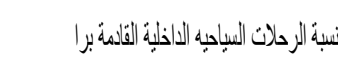 & $\mathrm{T} 1$ & $\exists$ \\
\hline 0.00 & 0.00 & 0.00 & 1.27 & 0.00 & 4.03 & 3.81 & 0.31 & 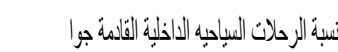 & T2 & 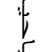 \\
\hline-3.40 & -1.60 & -2.21 & 0.00 & 0.00 & 1.63 & 6.69 & 0.12 & لزيلادة السنوية في الردلان البياديه الو الفة \% & $\mathrm{T} 3$ & \\
\hline 20.85 & 32.99 & 10.31 & 0.00 & 0.00 & 42.54 & -4.00 & 0.12 & 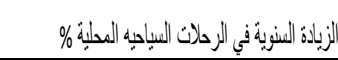 & T4 & $\underline{E}$ \\
\hline 0.96 & 0.00 & 0.34 & 0.50 & 0.00 & 0.52 & 0.50 & 0.12 & سبةً الفلاق من الودات السباديه. . & T5 & $\underline{E}$ \\
\hline 7.46 & 8.08 & 7.86 & 7.76 & 8.08 & 7.74 & 7.76 & 0.08 & 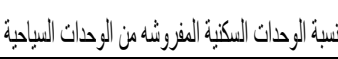 & T6 & $\xi$ \\
\hline 49.57 & 63.17 & 40.01 & 32.05 & 31.79 & 60.13 & 35.55 & & الججموع & & \\
\hline
\end{tabular}

الخريطة رقم ( 9 ) والجدول رقم (12 ) مؤشرات التنمية السياحية لمدن منطقة عسير 


\begin{tabular}{|c|c|c|c|c|c|c|c|}
\hline ظلجنوب & النماص & بيثة & محايل & رفيدة & خشيط & ابها & المدينة \\
\hline 399.95 & 414.15 & 434.82 & 412.94 & 432.53 & 411.52 & 438.26 & المؤشير \\
\hline
\end{tabular}

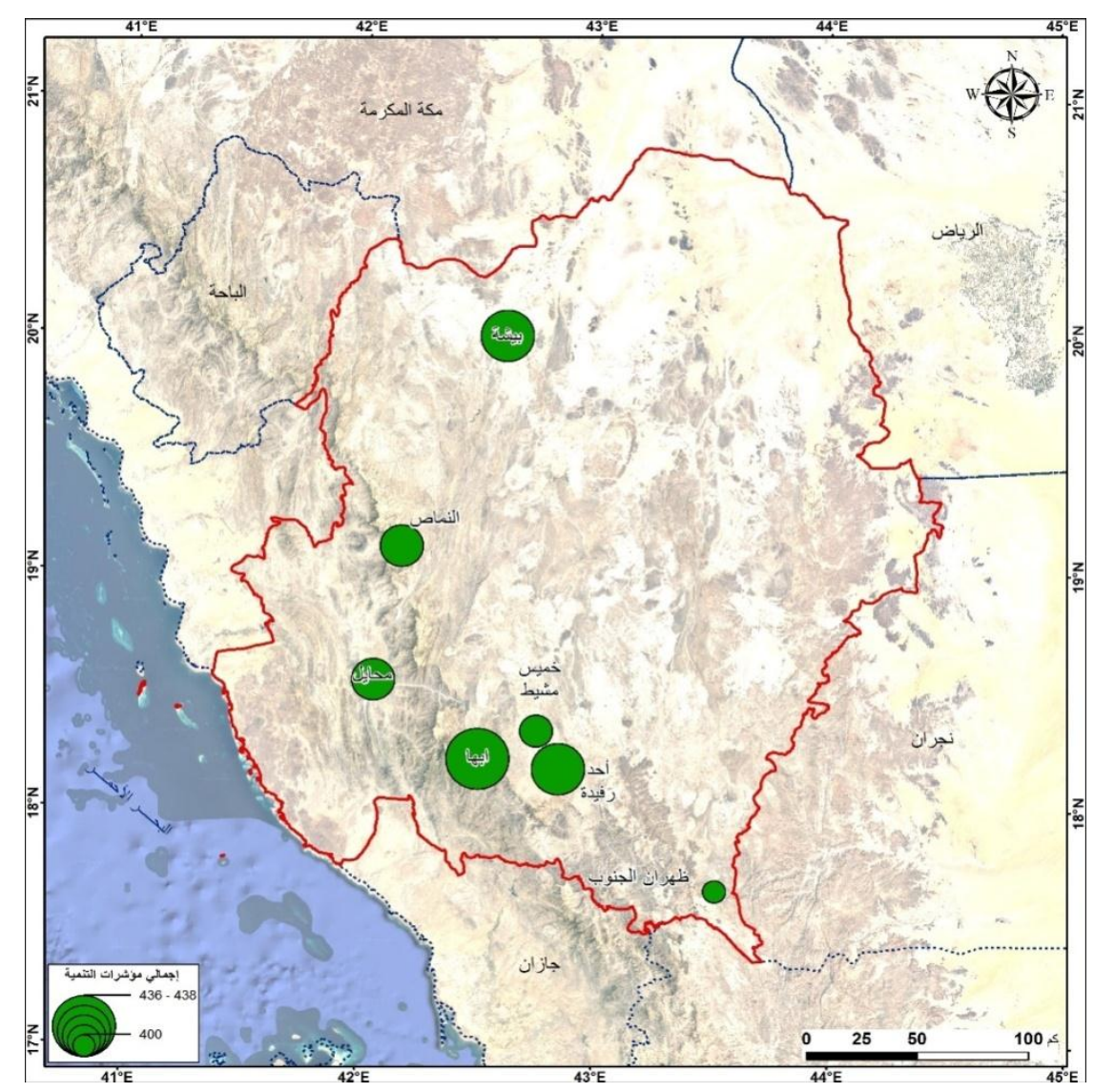

الخريطة رقم ( 10 ) والجدول رقم (13 ) اجمالي مؤشرات التنمية لمدن منطقة عسير

$$
\text { إجمالي التنمية في المدينة (إجمالي المؤشرات الموزونة) }
$$

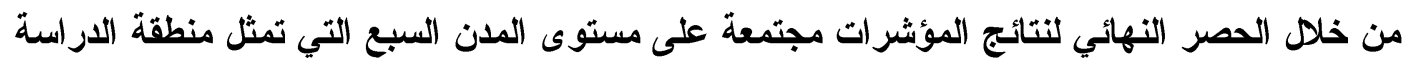
كما في الجدول والخريطة رقم (13/10) يصبح بمقدورنا الخروج بالملاحظات التالية:

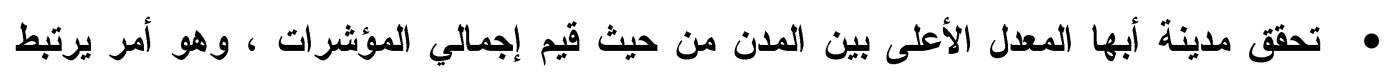

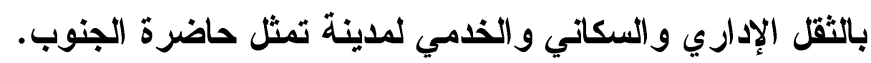

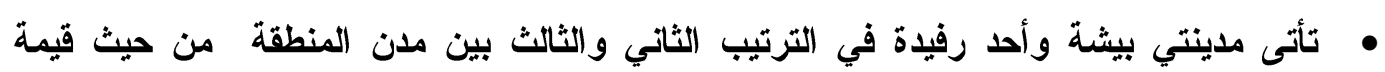
إجمالي المؤشرات متفوقتان على مدن مهمة مثل حميس مشيط ومحايل هما ثقلهما في نطاقهما

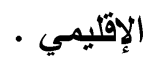


• تعتبر ظهران الجنوب هي المدينة الأقل حظاً في اجمالي مؤشرات التنمية بين مدن منطقة

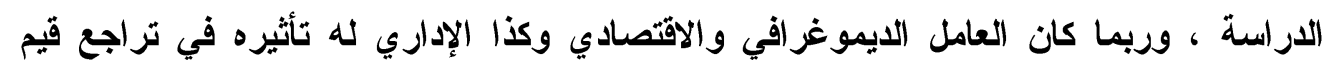

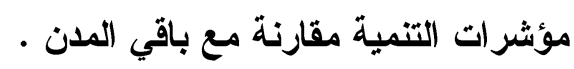

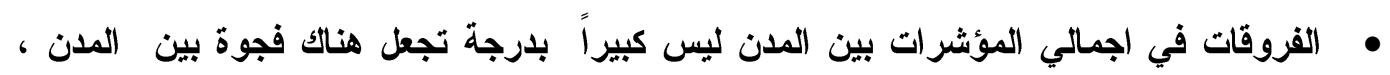

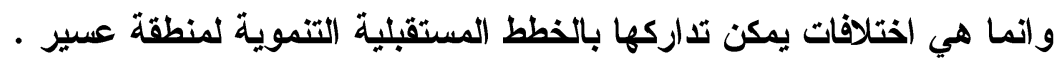

\section{نتائج الار اسةة:}

- كان النصيب الأكبر في معدل التعليم في مدينة احد رفيدة ، بينما الأقل في مدينة بيشة ، وقد اثر

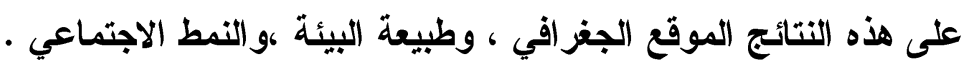

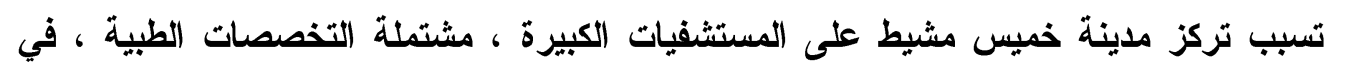
ضعف نصيبها من المستثفيات المخصصة للأطفال .

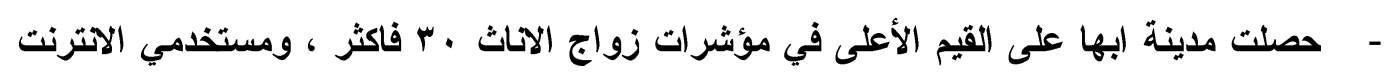

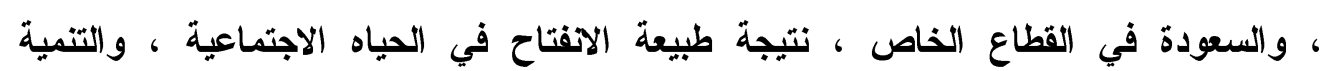

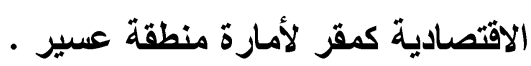

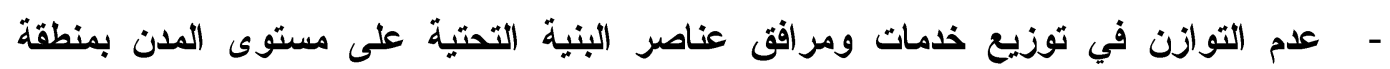

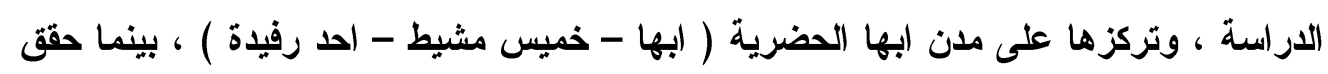

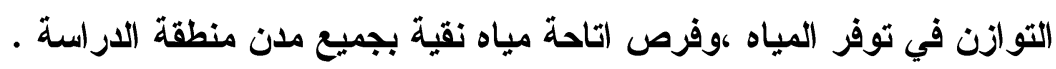

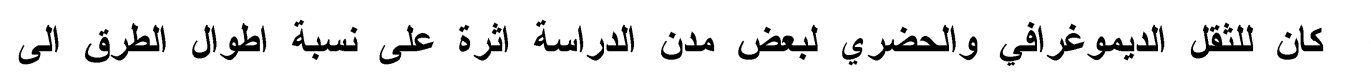
الإجمالي في كل من خميس مشيط وابها . كاتت مدينة النماص الأكثر حظا في مؤشر المسطحات الخضر فيط واء ، نسبة لإجمالي مساحة المدينة

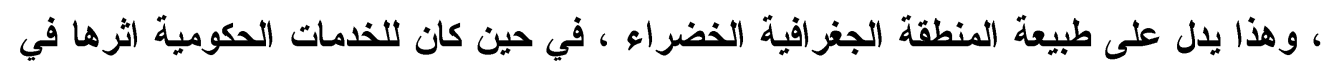
تحقيق العدالة بين مدن منطقة الاراسة في التخلص من النفايات الصلبة بالدفن والجمع المنتظم

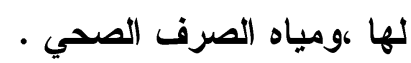

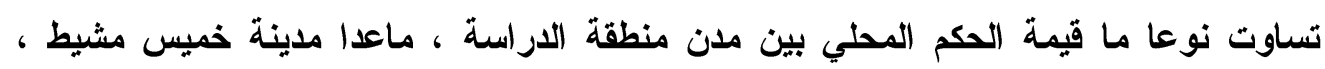

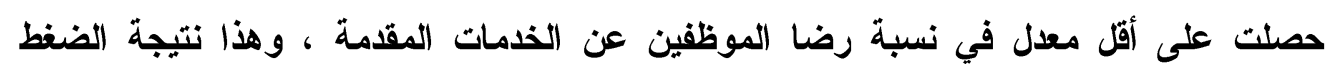

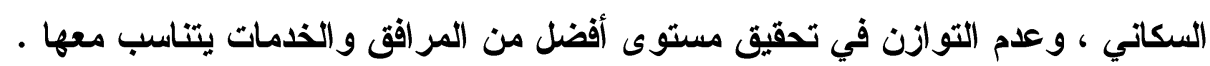

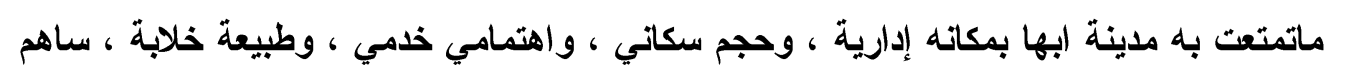

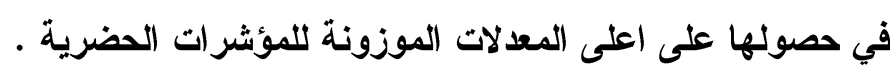

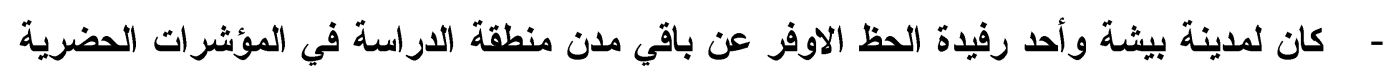

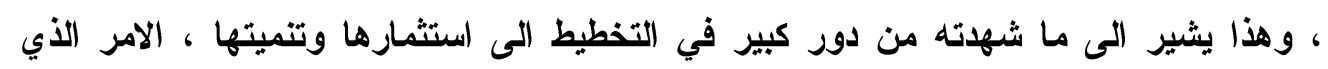

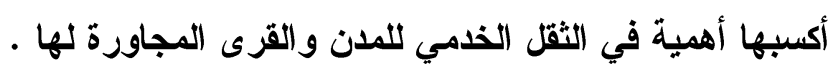


- موقع مدينة ظهران الجنوب في اقصى الثرق من منطقة عسير ، وطبيعتها الجغرافية، جعلها

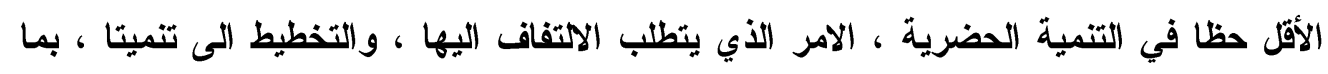
يحقى توزنها النسبي مع باقي مدن الاراسة .

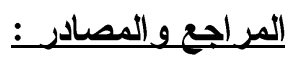

- امانة منطقة عسير ، مؤشرات المرصد الحضري لأبها الحضرية ومدن منطقة عسير ، التقرير

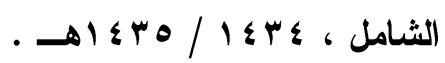

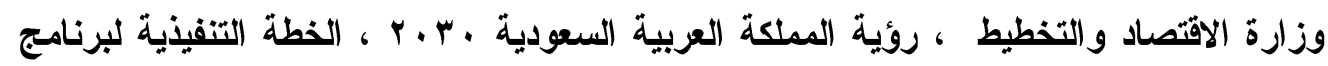

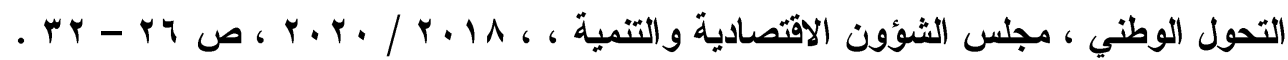

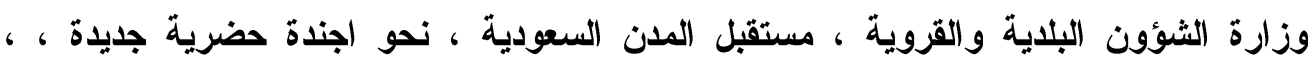
1

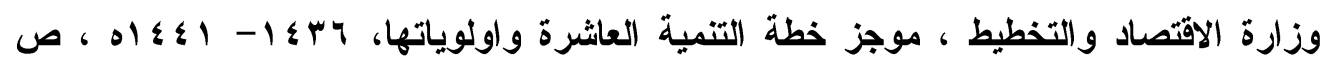
. $\mid 17-11 \varepsilon$ - صندوق التنمية الصناعية السعودية ، نمو المدن السعودية : الواقع والمستقبل ، تقرير احصائي

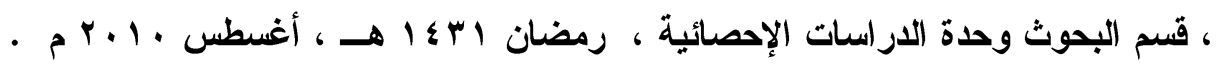

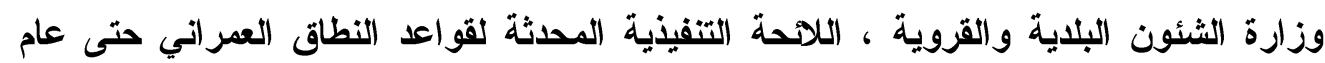

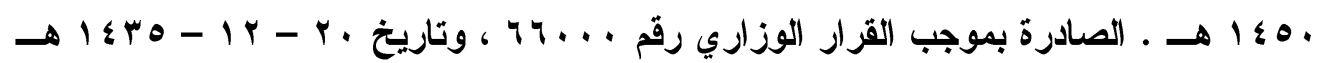

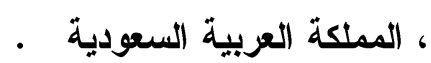
- ( وزارة الاقتصاد والتخطيط ، خطة التنمية التاسعة ،الفصل الثاني ، والثاني عشر ، تنمية

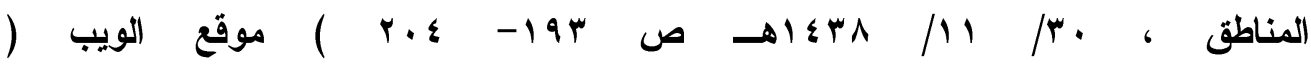
( https://www.mep.gov.sa وزارة الاقتصاد والتخطيط ، نحو تنمية مستدامة للمملكة العربية السعودية ، الاستعراض

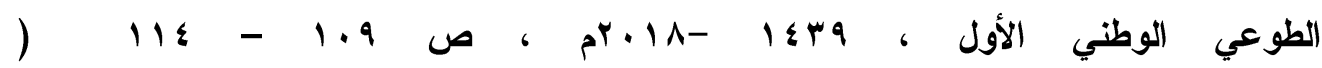
- ( https://www.mep.gov.sa مرداوي كمال،حيبة شعور، الإطار التحليلي للتنمية المستدامة وتطيقاتها على الدول العربية ،

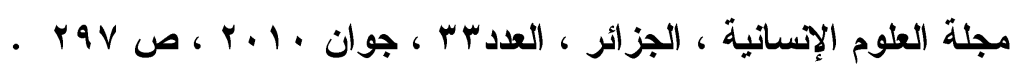
Natasha Kwat,(2010)Balanced Regional Development: Meaning and Considerations. Development and Journal. Faheem Jehangir Khan.( 2008) MEDIUM TERM DEVELOPMENT FRAMEWORK (2005-2010) (MID-TERM REVIEW) PARTIII-BALANCED DEVELOPMENT, https://www.researchgate.net/publication/315791425. 
المبلاحق

الجداول رقم ( 2) الأوزان لكل معيار داخل المؤشرات المختلفة حسب عملية التحليل الهرمي للأوزان:

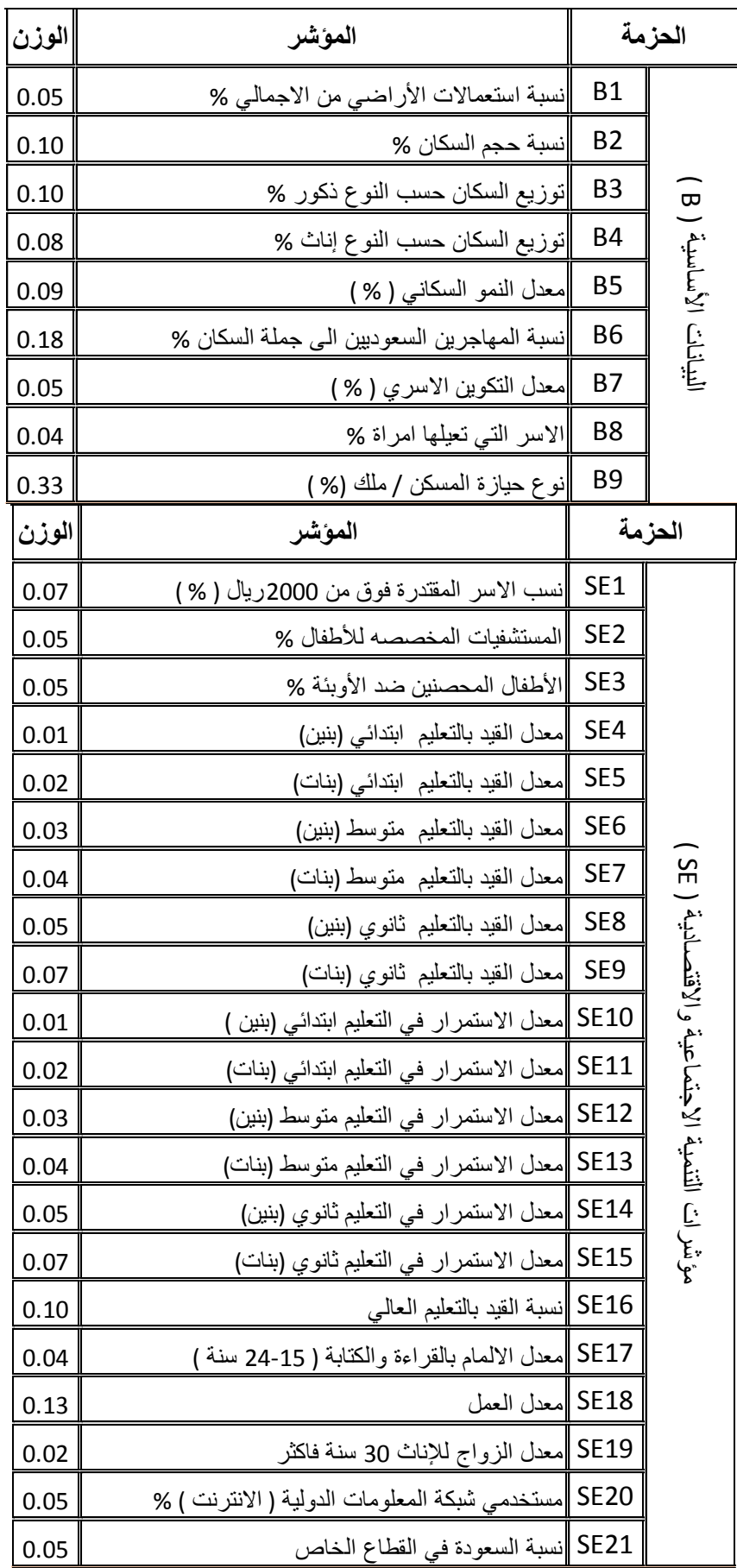




\begin{tabular}{|c|c|c|c|}
\hline 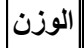 & المؤشر & \multicolumn{2}{|c|}{ 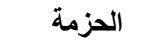 } \\
\hline 0.12 & (\%) مياة (\%) & $\mathrm{I1}$ & \multirow{6}{*}{ 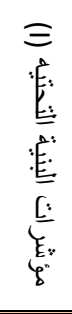 } \\
\hline 0.12 & |صرف صحي(\%) & 12 & \\
\hline 0.12 & (كهرباء (\%) & 13 & \\
\hline 0.08 & هاتف(\%) & 14 & \\
\hline 0.31 & |إناحة الحصول على مياة نقية \% & 15 & \\
\hline 0.24 & |الانفاق على البنية التحتية \% & 16 & \\
\hline 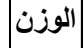 & المؤشر & \multicolumn{2}{|c|}{ الحزمة } \\
\hline 0.09 & || سوسلة الانتقال للعمل سيارة خاصة \% & TR1 & \multirow{4}{*}{ 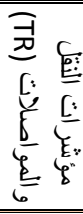 } \\
\hline 0.46 & ||رسيلة الانتقال للعمل حافلات وباصات \% & TR2 & \\
\hline 0.25 & 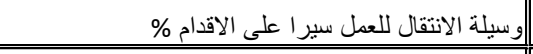 & TR3 & \\
\hline 0.20 & ||نسبة اطو ال الطرق من الإجمالي & TR4 & \\
\hline 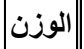 & المؤشر & \multicolumn{2}{|c|}{ 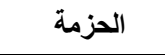 } \\
\hline 0.30 & |نسبة الأجور والرواتب من اجمالي الميزانية & G1 & \multirow{5}{*}{ 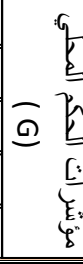 } \\
\hline 0.16 & لنسبة الانفاق على تعاقدات المحليات من اجمالي الميز انية & G2 & \\
\hline 0.30 & |نسبة رضا المو اطنين عن الخدمات الحكومية \% & G3 & \\
\hline 0.16 & |نسبة التمثيل النسائي بالخدمات الحكومية \% & G4 & \\
\hline 0.09 & |نسبة المؤسسات الاجتماعية المعنية بالنساء \% & G5 & \\
\hline 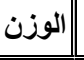 & المؤشر & \multicolumn{2}{|c|}{ 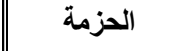 } \\
\hline 0.29 & |معدل الدخل بعد ايجار المنزل & S1 & \multirow{11}{*}{ 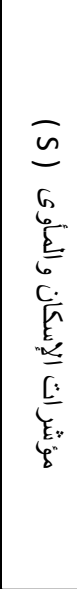 } \\
\hline 0.17 & معدل الدخل من سعر الأرض م2 & $\mathrm{S} 2$ & \\
\hline 0.08 & نسبة المساكن الحاصلة على قروض & S3 & \\
\hline 0.08 & مصادر التمويل الاسكاني ( مال خاص ) \% & S4 & \\
\hline 0.08 & مصادر التمويل الاسكاني ( قرض من بنك ) \% & S5 & \\
\hline 0.08 & مصادر التمويل الاسكاني ( صندوق التتمية العقاري ) \% & S6 & \\
\hline 0.04 & انوع المسكن منزل تقليدي قديم \% & S7 & \\
\hline 0.04 & |نوع المسكن منزل تقليدي حديث \% & S8 & \\
\hline 0.04 & نوع المسكن فيلا \% & S9 & \\
\hline 0.04 & |نوع المسكن عمارة سكنية \% & S10 & \\
\hline 0.04 & نسبة الوحدات الثناغرة & S11 & \\
\hline 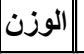 & المؤشر & \multicolumn{2}{|c|}{ 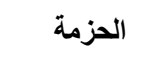 } \\
\hline 0.24 & |نسبة الرحلات السياحيه الداخلية القادمة برا & $\mathrm{T} 1$ & $\exists$ \\
\hline 0.31 & لنبة الرحلات السياحيه الداخلية القادمة جوا & $\mathrm{T} 2$ & t \\
\hline 0.12 & الزيادة السنوية في الرحلات السباحبه الوافدة \% & $\mathrm{T3}$ & \\
\hline 0.12 & |الزيادة السنوية في الرحلات السياحيه المحلية \% & T4 & $\underline{\underline{E}}$ \\
\hline 0.12 & نسبة الفنادق من الوحدات السياحيه . & T5 & $\underline{E}$ \\
\hline 0.08 & نسبة الوحدات السكنية الدفروشه من الوحدات السباحية ـ & T6 & $\xi^{\prime \prime}$ \\
\hline
\end{tabular}




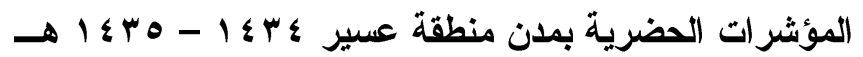

\begin{tabular}{|c|c|c|c|c|c|c|c|c|c|}
\hline الجنوب & النماص & بيشة & 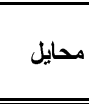 & رفيدة & خشيط & | ابها & المؤشر & & الحزمة \\
\hline 4.2 & 9 & 14.7 & 5 & 7.2 & 38.7 & 21.2 & 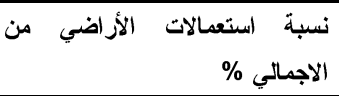 & B1 & \multirow{9}{*}{ 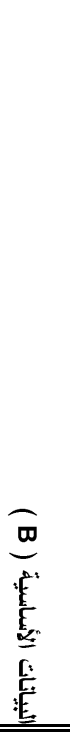 } \\
\hline 2.6 & 3 & 9.2 & 6.2 & 6.2 & 47 & 25.8 & 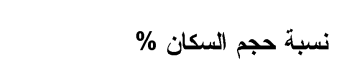 & B2 & \\
\hline 51.6 & 54.7 & 53.4 & 57.6 & 55.1 & 57 & 57.6 & توزيع السكان حسب النوع ذكور \% & B3 & \\
\hline 48.4 & 45.3 & 46.6 & 42.4 & 44.9 & 43 & 42.4 & توزيع السكان حسب النوع إناث \% & B4 & \\
\hline 2.2 & 2.1 & 1.6 & 2.6 & 2.2 & 2.4 & 2.5 & معدل النمو السكاني ( \% ) & B5 & \\
\hline 1.2 & 6.2 & 4.5 & 14.1 & 33 & 30.7 & 23.7 & نسلة السكان \% م المهاجين السعوديين الى & B6 & \\
\hline 6.9 & 4.9 & 6.9 & 2 & 3.8 & 2.7 & 4.7 & معدل التكوين الاسري ( \% ) & B7 & \\
\hline 9 & 9.4 & 11.4 & 7.3 & 4.1 & 4.5 & 5.1 & الاسر التي تعيلها امراة \% & B8 & \\
\hline 67 & 72.8 & 86.7 & 63.6 & 45.2 & 44.5 & 49.7 & نوع حيازة المسكن / ملك (\% ) & B9 & \\
\hline 97 & 98.9 & 98.1 & 98.7 & 99.7 & 97.6 & 89.6 & 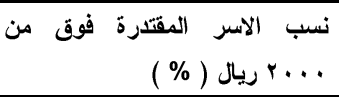 & SE1 & \multirow{10}{*}{ 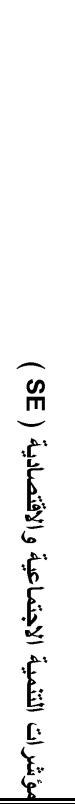 } \\
\hline 100 & 100 & 100 & 100 & 100 & 71.4 & 85.7 & المستثفيات المخصصه للأطفال \% & SE2 & \\
\hline 100 & 100 & 111.5 & 100 & 99.2 & 98.7 & 95 & الأطفال الحصنين ضد الأوبئة \% & SE3 & \\
\hline 99.7 & 73.9 & 72.4 & 76.6 & 113.6 & 78.3 & 92.4 & معدل القيد بالتعليم ابتائي (بنين) & SE4 & \\
\hline 99.5 & 74.8 & 68.2 & 90.3 & 109.7 & 69.2 & 105.5 & معدل القيد بالتعليم ابتائي (بنات) & SE5 & \\
\hline 98.9 & 71.2 & 60.6 & 76.1 & 106.8 & 83 & 83.4 & معلل القيد بالتعليم متوسط (بنين) & SE6 & \\
\hline 96.7 & 72.4 & 55.9 & 89.6 & 124.6 & 73.1 & 95.5 & معلد القيد بالتعليم متوسط (بنات) & SE7 & \\
\hline 98.6 & 84.5 & 69.5 & 74.4 & 119.9 & 90.3 & 94.6 & معدل القيد بالتعليم ثانوي (بنين) & SE8 & \\
\hline 98.7 & 84.1 & 61.2 & 91.4 & 123.5 & 83.4 & 90.1 & معدل القيد بالتعليم ثانوي (بنات) & SE9 & \\
\hline 99.9 & 91.1 & 123.1 & 100.2 & 87.7 & 99.3 & 98.1 & معنين الاسترار في التطيم ابتائي & SE10 & \\
\hline 99.8 & 98.5 & 145.2 & 96.3 & 86.8 & 87.6 & 92.8 & مبنات الاستمرار في التعليم ابتائي & SE11 & \\
\hline 98.5 & 85.5 & 105.4 & 98.9 & 88.6 & 103.4 & 90.7 & معلين الاستمرار في التُعليم متوسط & SE12 & \\
\hline 99.4 & 92.6 & 102.1 & 103.5 & 101.5 & 93.3 & 88.7 & معلاتل الاستمرار في التعليم متوسط & SE13 & \\
\hline 100 & 81.3 & 101.8 & 128.3 & 87.8 & 95.7 & 115.4 & معلدل الاستمرار في التعليم ثانوي & SE14 & \\
\hline 99.1 & 95.3 & 102.7 & 101.6 & 90.2 & 74 & 75 & مبنات) الاستمرار في التعليم ثانوي & SE15 & \\
\hline
\end{tabular}




\begin{tabular}{|c|c|c|c|c|c|c|c|c|c|}
\hline 50 & 40.2 & 39.3 & 25.5 & 38.4 & 45.8 & 48.3 & نسبة القيد بالتعليم العالي & SE16 & \\
\hline 99.1 & 99.5 & 98 & 98.5 & 99.4 & 98.5 & 99 & 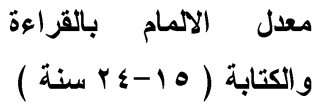 & SE17 & \\
\hline 71.5 & 71.1 & 70.2 & 68.5 & 79.7 & 74.1 & 76.2 & معدل العمل & SE18 & \\
\hline 92.7 & 97.1 & 93.1 & 94.8 & 96.9 & 95.1 & 96.5 & معلة فاكثر الزواج للإناث . معل & SE19 & \\
\hline 31 & 31.5 & $\mathbf{3 7 . 7}$ & 32.9 & 40 & 41 & 41.5 & 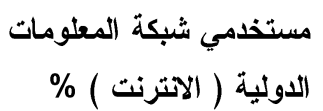 & SE20 & \\
\hline 8.3 & 7.6 & 6.8 & 9.2 & 9.8 & 12.8 & 16.8 & نسبة السعودة في الفطاع & SE21 & \\
\hline $\mathbf{0}$ & $\mathbf{0}$ & 17.4 & 0 & 45.1 & 26.4 & 82.6 & مياة (\%) & 11 & \multirow{6}{*}{ 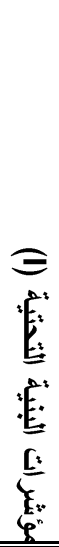 } \\
\hline $\mathbf{0}$ & $\mathbf{0}$ & 34 & 46.5 & 88.2 & 91.9 & 88.5 & صرف صدي(\%) & 12 & \\
\hline 100 & 100 & 100 & 100 & 100 & 100 & 100 & كهرباء (\%) & 13 & \\
\hline 15.5 & 35.5 & 20.9 & 20.8 & 36.2 & 33.5 & 42.2 & هاتف(\%) & 14 & \\
\hline 100 & 85.7 & 98 & 99.5 & 100 & 99.7 & 99.8 & 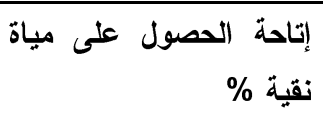 & 15 & \\
\hline 69.3 & 64.5 & 58.2 & 69.3 & 68.1 & 56.1 & 70 & \% الانفاق على البنية التحتية & 16 & \\
\hline 94.6 & 97.1 & 94.7 & 95.8 & 98.6 & 91.6 & 96.5 & وسيارة خاصة الاتثقال للعمل & TR1 & \multirow{4}{*}{ 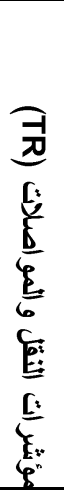 } \\
\hline 5.2 & 1.6 & 1.3 & 0.6 & 0.6 & 5.4 & 2.3 & حافيلةت وباصات \% الاتقال للعمل & TR2 & \\
\hline 0.8 & 3 & 1.1 & 0.3 & 0 & 2.1 & 1 & على الاقدام \% الاتقال للعمل سبرا & TR3 & \\
\hline 4.1 & 4.1 & 6.5 & 2.9 & 4.9 & 40.8 & 36.7 & نسبة الإجمالي ال الطرق من & TR4 & \\
\hline 0 & 0 & 97.8 & 88.6 & 100 & 0.91 & 77.2 & نسبة مياة الصرف الصحي & E1 & $\bar{\pi}$ \\
\hline 100 & 100 & 100 & 100 & 100 & 100 & 100 & 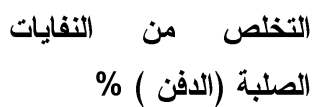 & E2 & 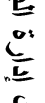 \\
\hline 92.6 & 95.2 & 91.5 & 98 & 98.5 & 86.9 & 96.7 & الجمع المنتظم للنفايات & E3 & $\xi$ \\
\hline
\end{tabular}




\begin{tabular}{|c|c|c|c|c|c|c|c|c|c|}
\hline & & & & & & & | الصلبة \% & & \\
\hline 1.4 & 55 & 0.2 & 1.5 & 3.2 & 0.7 & 0.3 & من استخدة المسطحات الخضر اء أرض . & E4 & \\
\hline 20.6 & 18.9 & 24.9 & 14.3 & 18.7 & 14.5 & 12.6 & اجمالي الميزانية والجور والرواتب من & G1 & \\
\hline 73.5 & 75.9 & 71 & 81.8 & 77.7 & 83 & 85.2 & المبلة الاتفات على تعاقدات & $\mathbf{G} 2$ & \\
\hline 82.2 & 85.3 & 87.3 & 86.7 & 90.4 & 15.4 & 90.1 & الخدمات رضا المكومية \% اطنين عن & G3 & \\
\hline 20.4 & 13.9 & 28.3 & 15.7 & 12.9 & 15.4 & 18.2 & بالخدمات الحكومية \% التمثيل النسائي & G4 & \\
\hline 0 & 50 & 100 & 50 & 0 & 8.3 & 25 & ن الاجنماعية المعنية بالنساء & G5 & 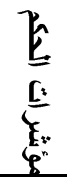 \\
\hline
\end{tabular}


تقييم تلقي أطفال الروضة للخرائط والألعاب الرقمية ذات الصبغة المكانية في مدينة جدة

أ/ سهام بنت سعدي سعيد السلمي

محاضرة " متعاونة" جامعة الملك عبد العزيز - جدة لدئ

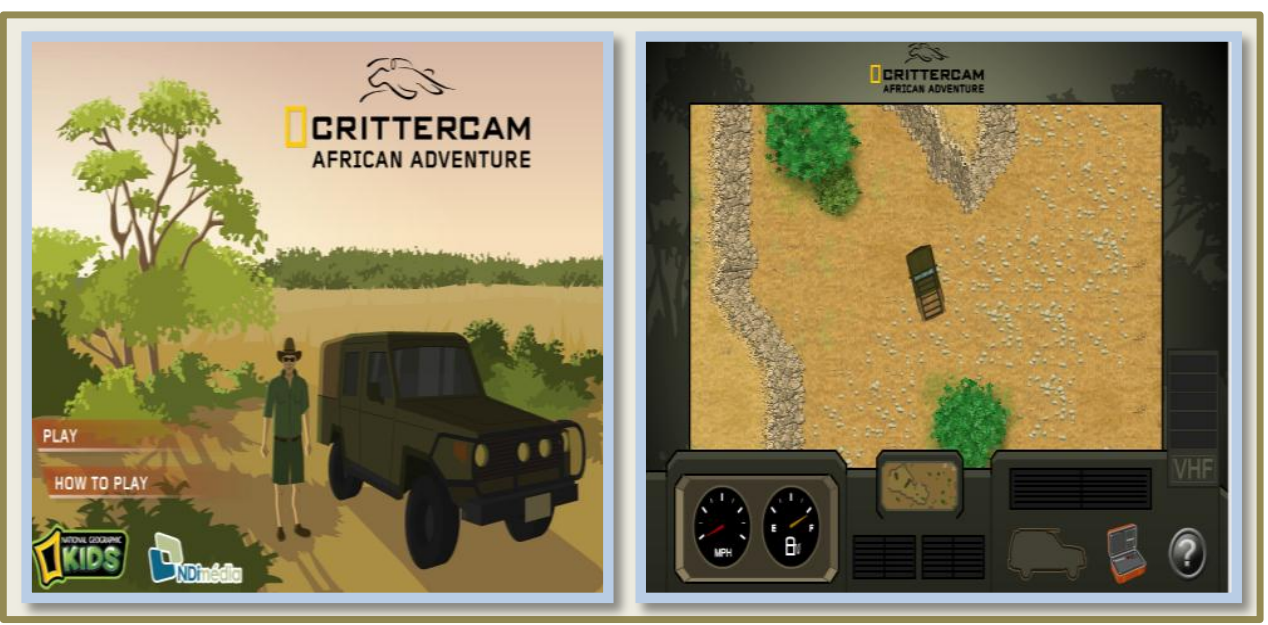

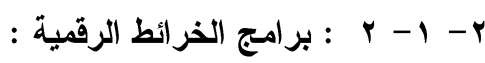

شهر العالم خلال العقدين الماضيين ثورة علمية ، تمثلت في اتجاهين أساسيين أولهما الكم الهائل من البيانات والمعلومات وخاصة الجغرافية منها، التي توافرت من المصادر المتنوعة، مثل بيانات الإحصاعات والتعدادات، والقياسات البيئية، والخرائط المتتوعة وأجهزة الاستشعار عن بُعد، والصور الجوية ، فضلاً عن القياس المياني وتعدد أساليبه وتوافر إمكانياته ـ والاتجاه الثاني تمثل في الثورة التكنولوجية وتطور أجهزة الحاسب الآلي، وتثعب استخداماتها والعمل عليها. وقث توافرت أجيال وأنواع مختلفة منها باءعاً من الأجهزة الخادمة العملاقة وحتى الوحدات الشخصية الصغيرة .

وتساعد الخرائط الرقمية الطفل على التعرف على المعلومات المتصلة بالأماكن والنباتات والحيوانات واللغات والثقاقات السائدة فيها ، يوضح شكل رقم (r-1 ( ) خريطة رقمية تفاعلية للطفل ، حيث يسمح هذا الموقع لأطفال المدارس في مدينة " Hastings " في الولايات المتحدة الأمريكية تحميل فيديو لقصصهم عن محيطهم على شبكة الإنترنت، ومن ثم تحديد موقع هذه القصص من قبل خطوط الطول والعرض على خريطة جوجل وبعد هذا يمكن نشر القصة، ومشاهدته مع أقر انهم. 


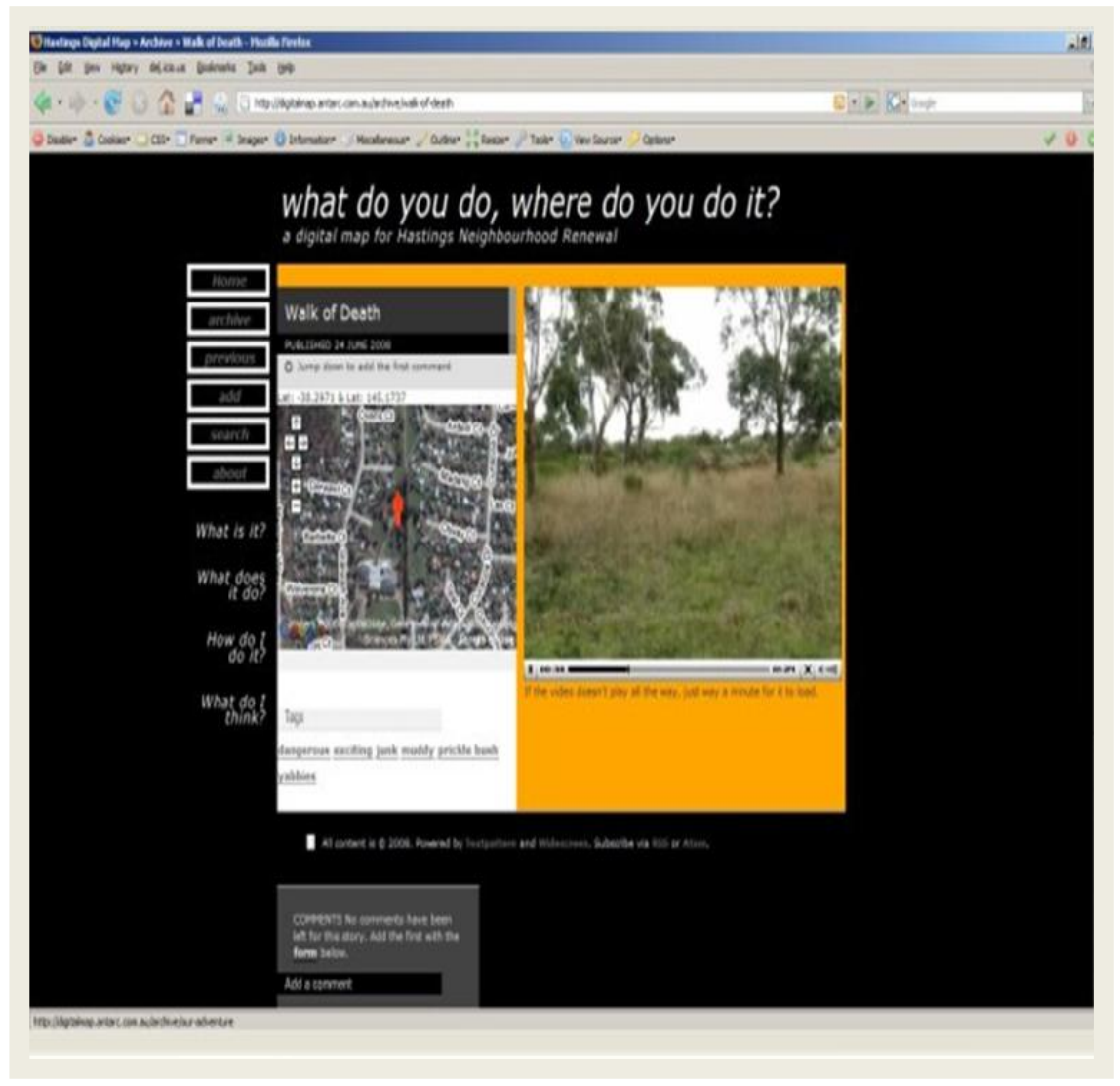

شكل رقم (r-11) خريطة رقمية تفاعلية للطفل

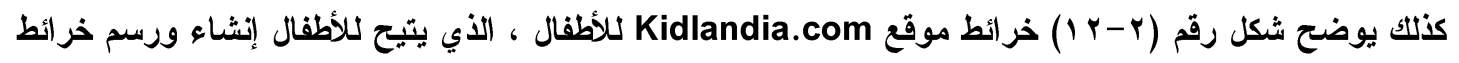
خيالية شخصية، تظهر حسب الطلب خرائط وبها الأسماء والأماكن التي كاتت جزءا من حياة الطفل، وهي تخلق بـاء متعة لا نهاية لها من المرح والخيال. حيث يستطيع

الطفل ببساطة اختيار واحدة من عناصر الخريطة ويطلب التطبيق إدخال اسم الطقل أو أي شخص آخر يرغب به، مثل الأسرة والأصدقاء، والحيوانات الأليفة، وما إلى ذلك،، ويعرض الموقع تلقائيا خريطة عامة للمدن وأسماء الأماكن، كما يمكن للطفل حفظ وتبادل الخرائط الرقمية مجانا، أو الحصول على نسخ مطبوعة ، من السئل السهل للأطفال استخدامها وطباعتها بثكل جيد. 


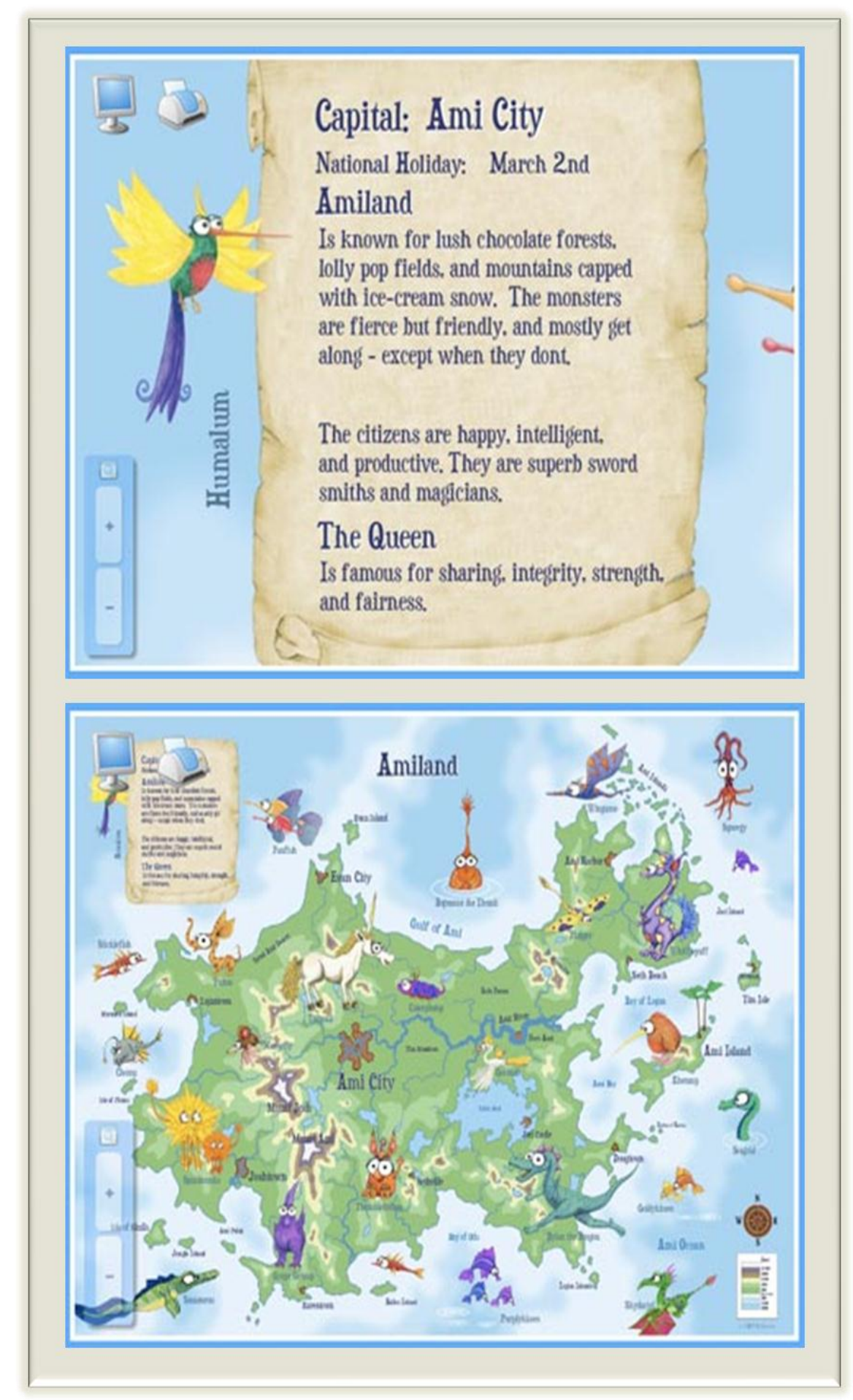

شكل رقم (r-r I I ) برنامج إنثاء ورسم خر ائط للطفل 
أما شكل رقم (r-r ا I) فيوضح لعبة "صانع الخريطة"، حيث يستطيع الطقل إنشاء وتجهيز الأرضية الخاصة به مع

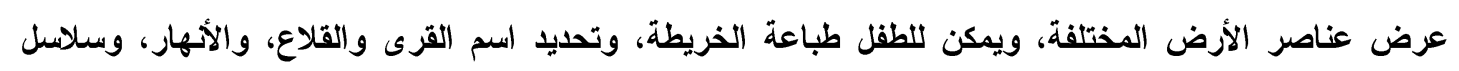
الجبال والصحارى، والغابات والبحيرات والمحيطات. ويتيح التطبيق للطفل تدوين بعض الملاحظات حول هذه

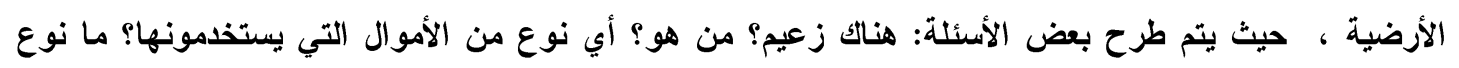

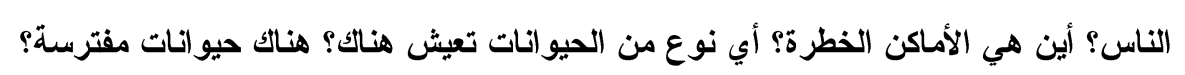

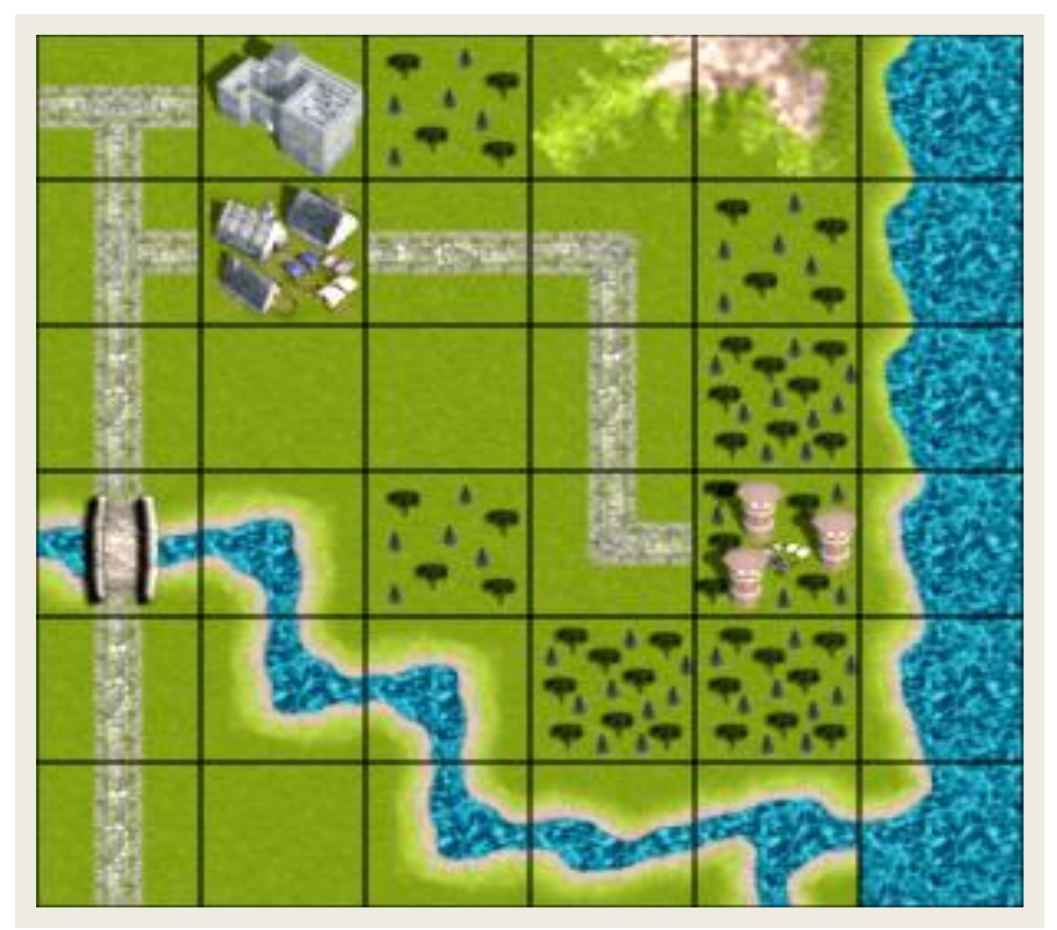

شكل رقم (r-r ا ) لعبة صاتع الخريطة

كما يوضح شكل رقم (Y- - ( ) برنامج " Ink Scape " وهو تطبيق وضع لتعليم رسم الخرائ للأطفال حيث نجد مقياس الرسم في يسار الخريطة وكنلك يوجد مجموعة من الرموز للأثجار والجبال والحشائش وغيرها، ويوجد بالبرنامج مجموعة من الأدوات يستطيع الطقل من خلاها رسم وتحرير العناصر الرسومية كالأثجار والجبال و الحشائش والأههار والثواطئ وغيرها، بما في ذلك علامات، التدرجات، الأثكال، ومسارات ، لكنه أيضا يسمح

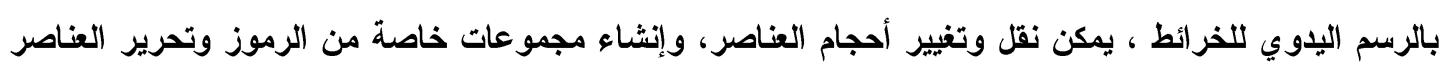
المتعددة. 


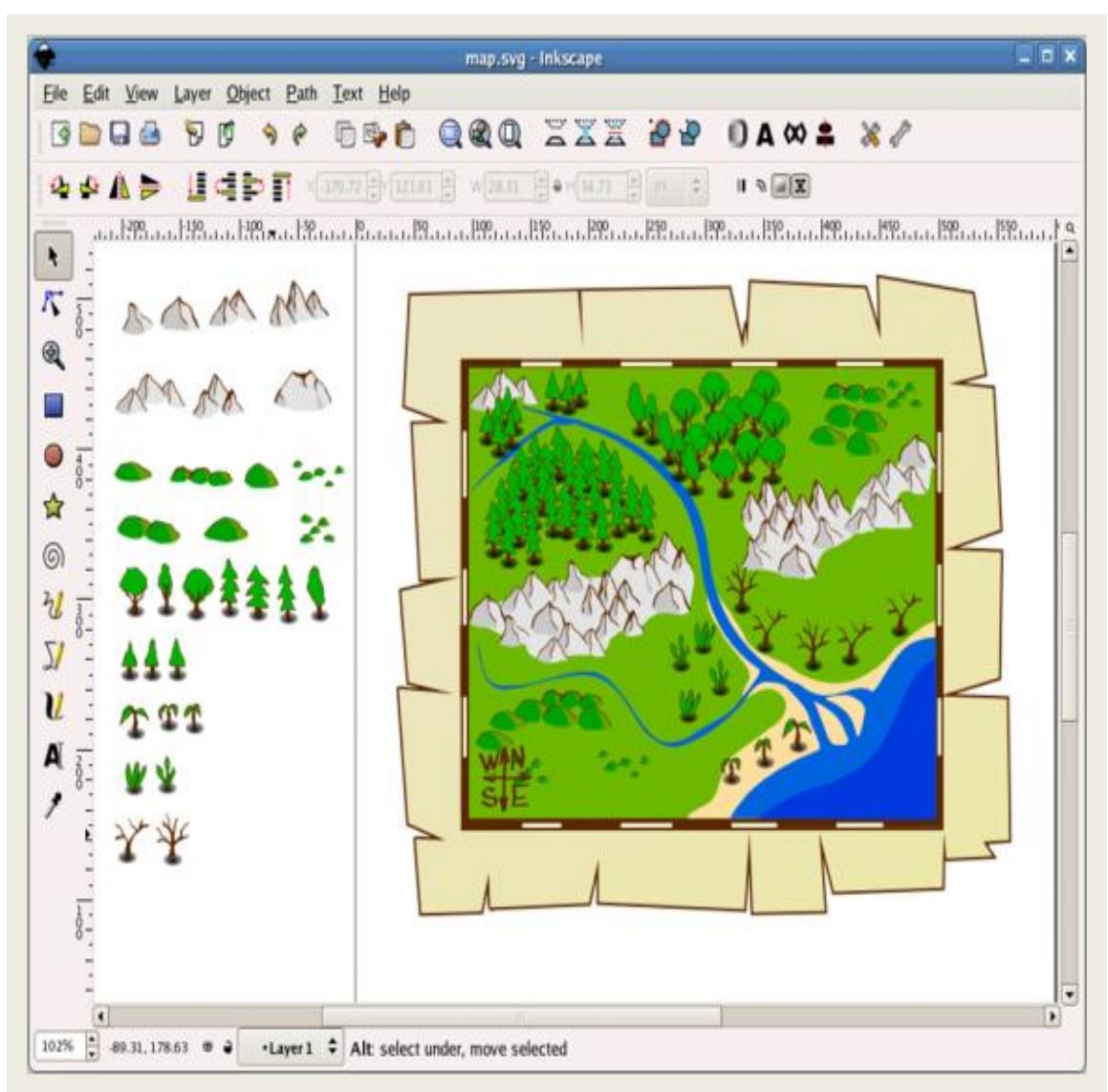

\section{شكل رقم (r- أ ا) برنامج "Ink Scape " لرسم الخرايط}

ويوضح شكل رقم (ץ-0 (1) برنامج رسم خرائط رقمية تفاعلية " Map Maker Interactive Beta "، يسمح للطفل في استكثاف الجوانب البيئية والثقافية الحيوية من العالم ، مما يساعد على بناء مهاراتهم في التفكير النقدي، وتمثيل البيانات، ورسم الخرائط وكنلك يمكن لطفل من تحميل وطباعة ، وتجميع خرائط للعالم أو القارات الفردية في مجموعة متنوعة من الأحجام ، يحاول الطفل الرسم عبر الخرائ التفاعلية من خلا طبقات من من فئل

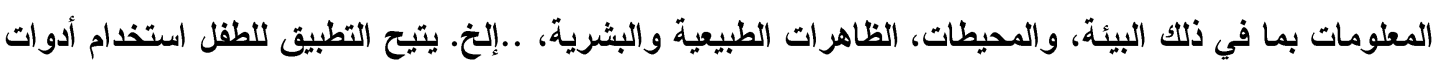
الرسم بكل سهولة والتي تحتوي على أدوات: (الخطوط المتكسرة، الخطوط الحرة، المضلعات، والعناوين النصية) كما يمكن تحريك هذه العناصر بالإضافة إلى إمكانية حذفها وإضافة رابط تثعبي لها، ويتيح البرنامج أيضاً لطفل وضع الرموز على الخريطة، حيث يحتوي التطبيق على مكتبة رموز لتمثيل الظاهرات الطبيعية والبثرية مثل أماكن: (الأثجار ، والمطارات والبواخر وتربية الأبقار وتساقط الثلوج وتو اجد الأسماك والأمواج و المصانع... الخخ). 


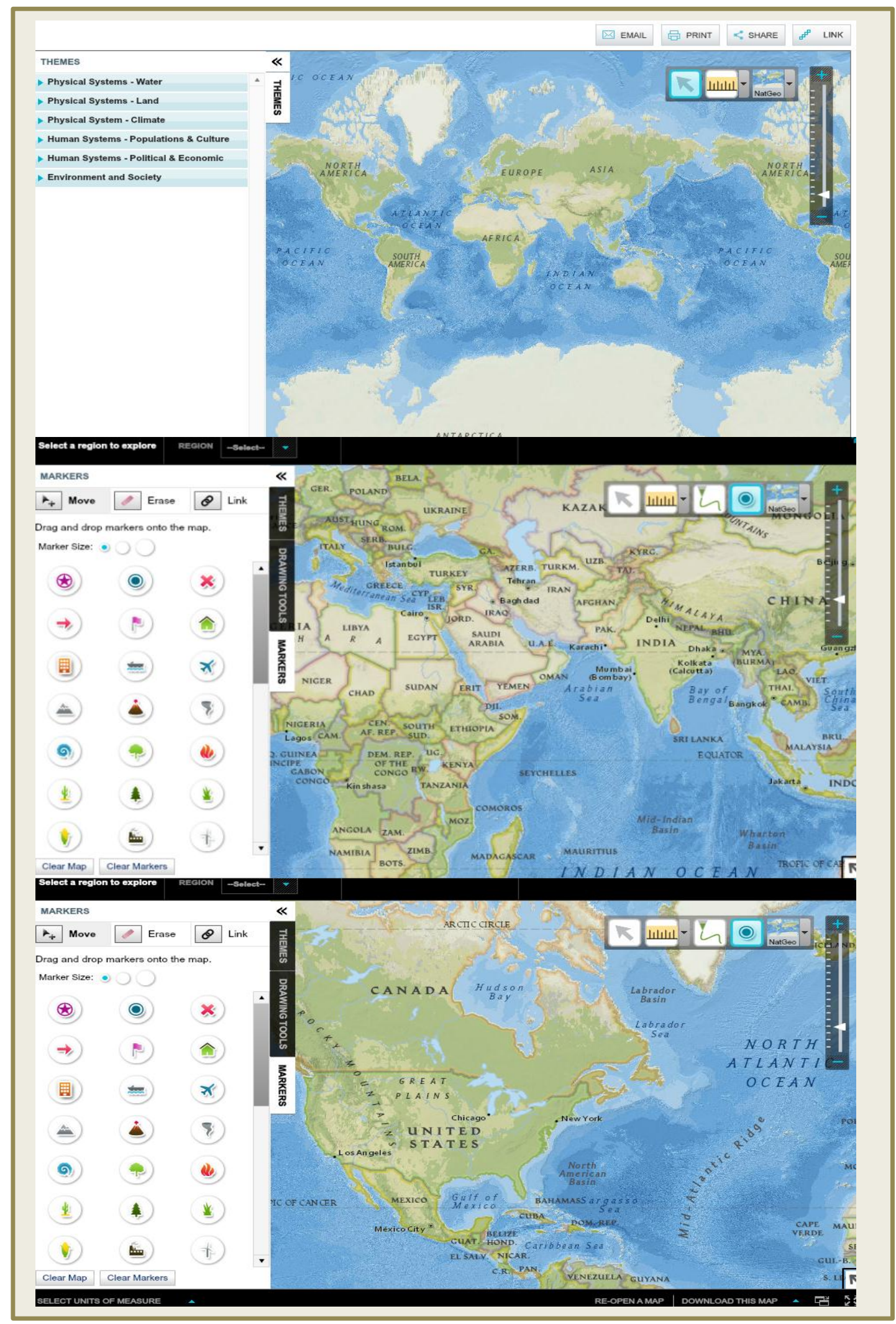

شكل رقم (ץ-0 1) برنامج رسم خرائط رقمية تفاعلية للطقل 


\section{" Map Maker Interactive Beta "}

يوضح شكل رقم (ץ-r 1) خرائط للأطفال مصمة من قبل "ميريت" ويبدو أن هذه الخرائط تتعدى مرحلة رياض الأطفال ، هذه الخرائط تفطي مواضيع مختلفة ـ وغالباً ما يتم إنتاج خرائط تصويرية للأطفال، تبين مناطق مختلفة نئة وتسلط الضوء على الحياة والصناعات في الأجزاء التي تغطيها من العالم، وتحتوي على عشرة تطبيقات هي:

الإمبر اطورية الرومانية: حيث تسح للأطفال للتعرف على حجم وامتداد الإمبراطورية الرومانية في أقصى اتساع لها. شبه الجزيرة الأيبيرية: تمثل الخريطة المرجعية للأطفال عن شبه الجزيرة الأيبيرية. • الصفائح التكتونية: خريطة موضوعية لصفائح العالم و العناصر التكتونية بها.

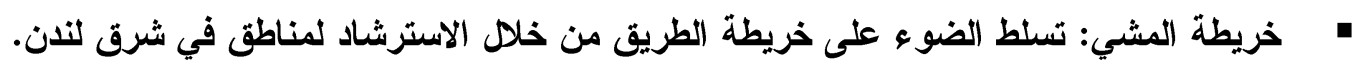

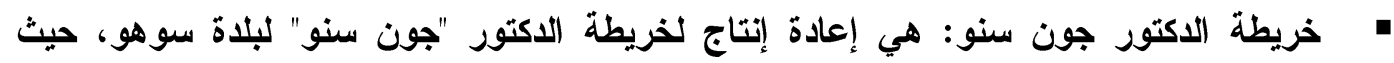

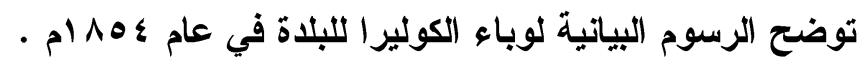
• المناطق القطبية: تبين المناطق القطبية وتسلط الضوء على الحياة البرية والصناعات التي تحدث في هذه الأجزاء من العالم.

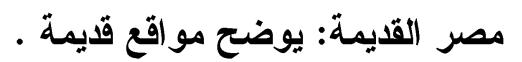

ولاية أوريغون تريل: خريطة مبسطة توضح طريق الهجرة في أمريكا الثمالية.

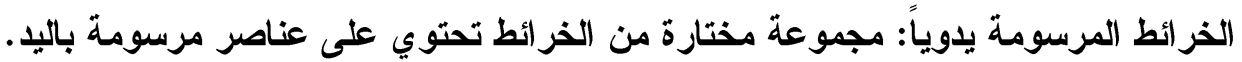
المحيط الأطنطي: يوضح التيارات البحرية السطحية للمحيط الأطلسي. 


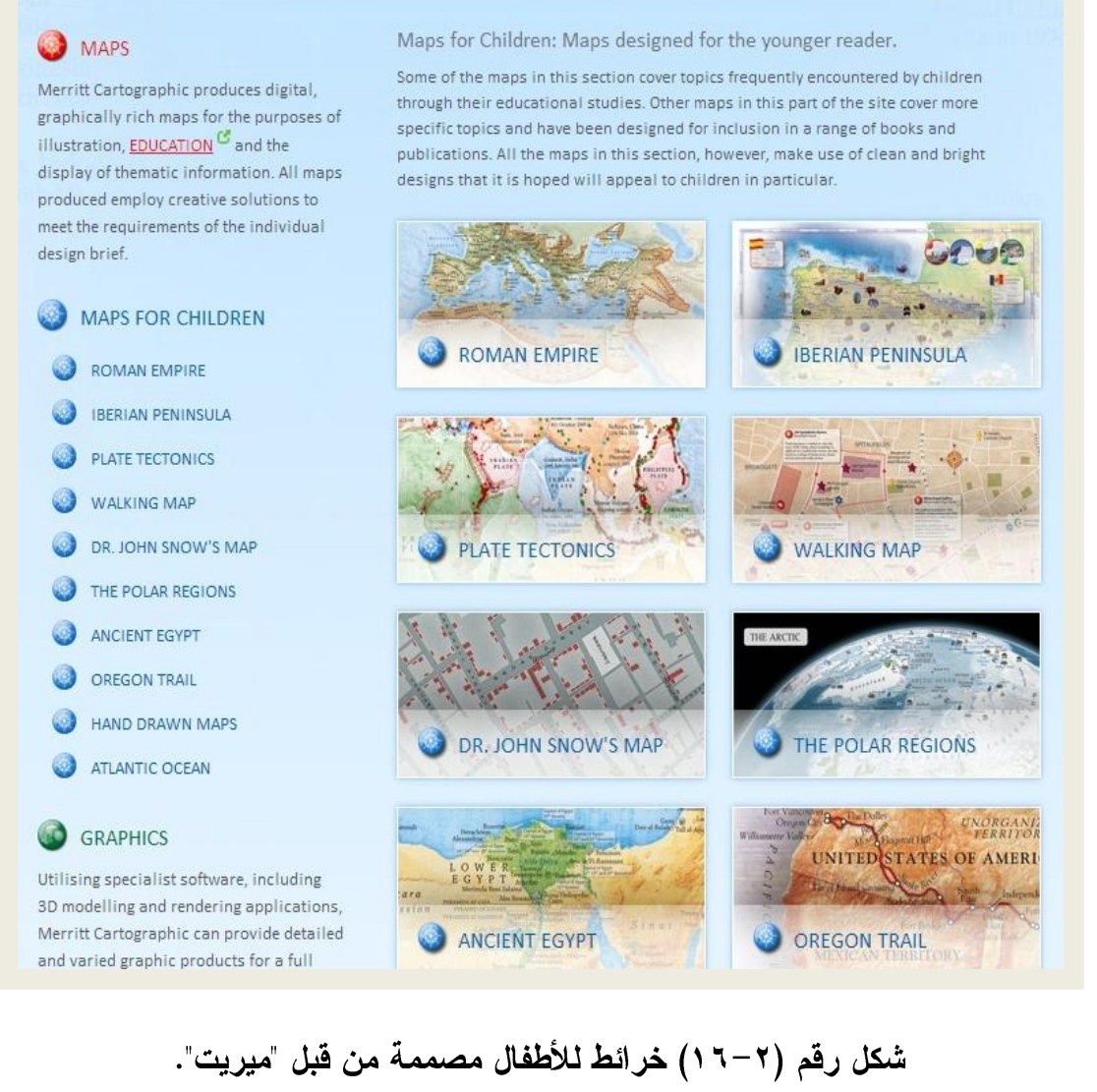

يوضح شكل رقم (Y- IV) برنامج خرائط رقمية من ESRI ، وهي خرائط قصصية تجمع بين خرائط

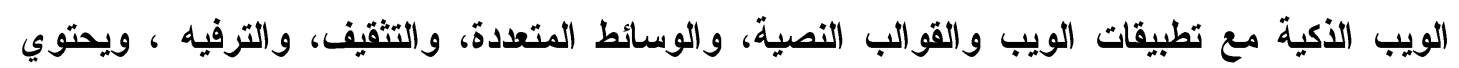

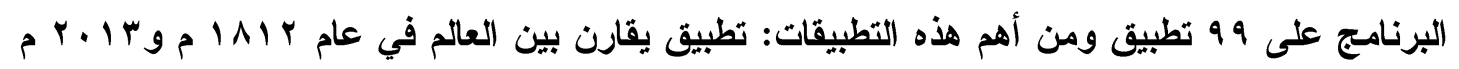

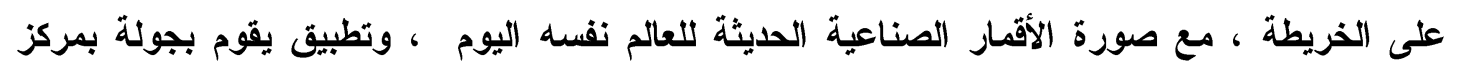

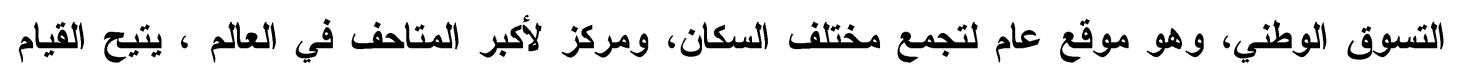

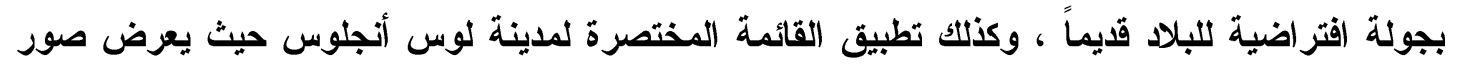

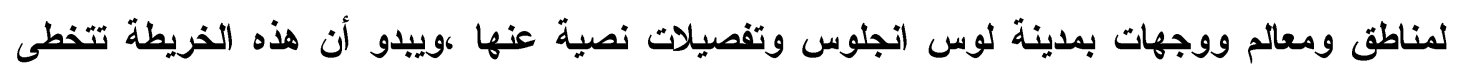
مرحلة رياض الأطفال . 


\section{Storytelling with Maps}

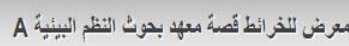

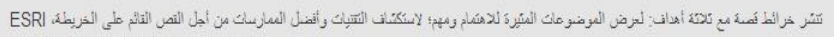

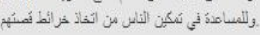

Search maps $\quad$ Q

H:
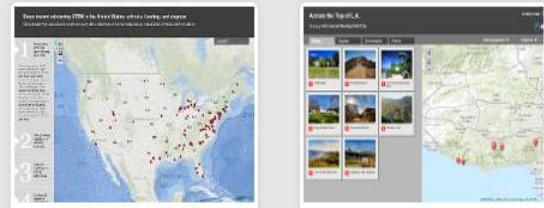

Sirsis

저물

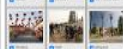

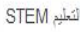

LA

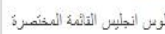

حول خرانط نُصنة

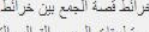

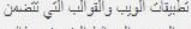

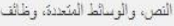

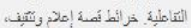

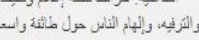

الموارد والوصلات

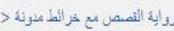

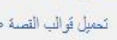

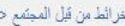
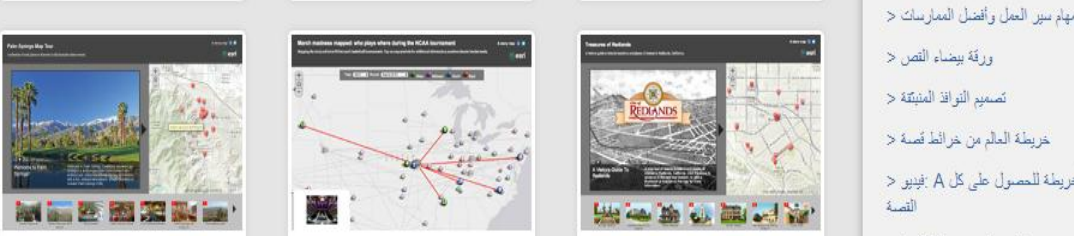

> رئة بيضاء التصن

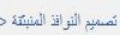

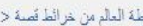

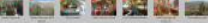

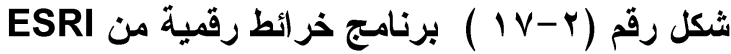

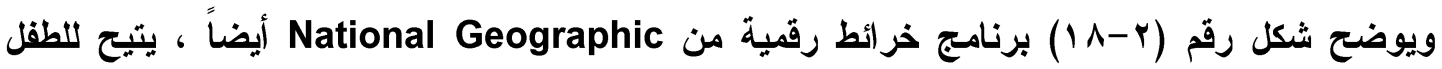

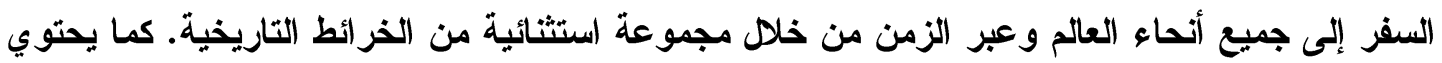

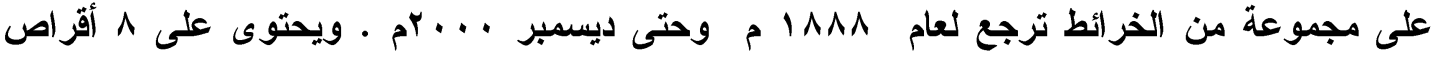

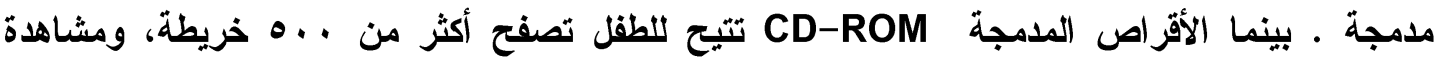
الجولات المصحوبة بمرشدين، ويمكن الطباعة أيضا. وتتميز أيضا بوجود ملفات الصوت وكنلك خيارات البحث المتقدمة, ويبدو أنها تتخطى مرحلة رياض الأطفال. 


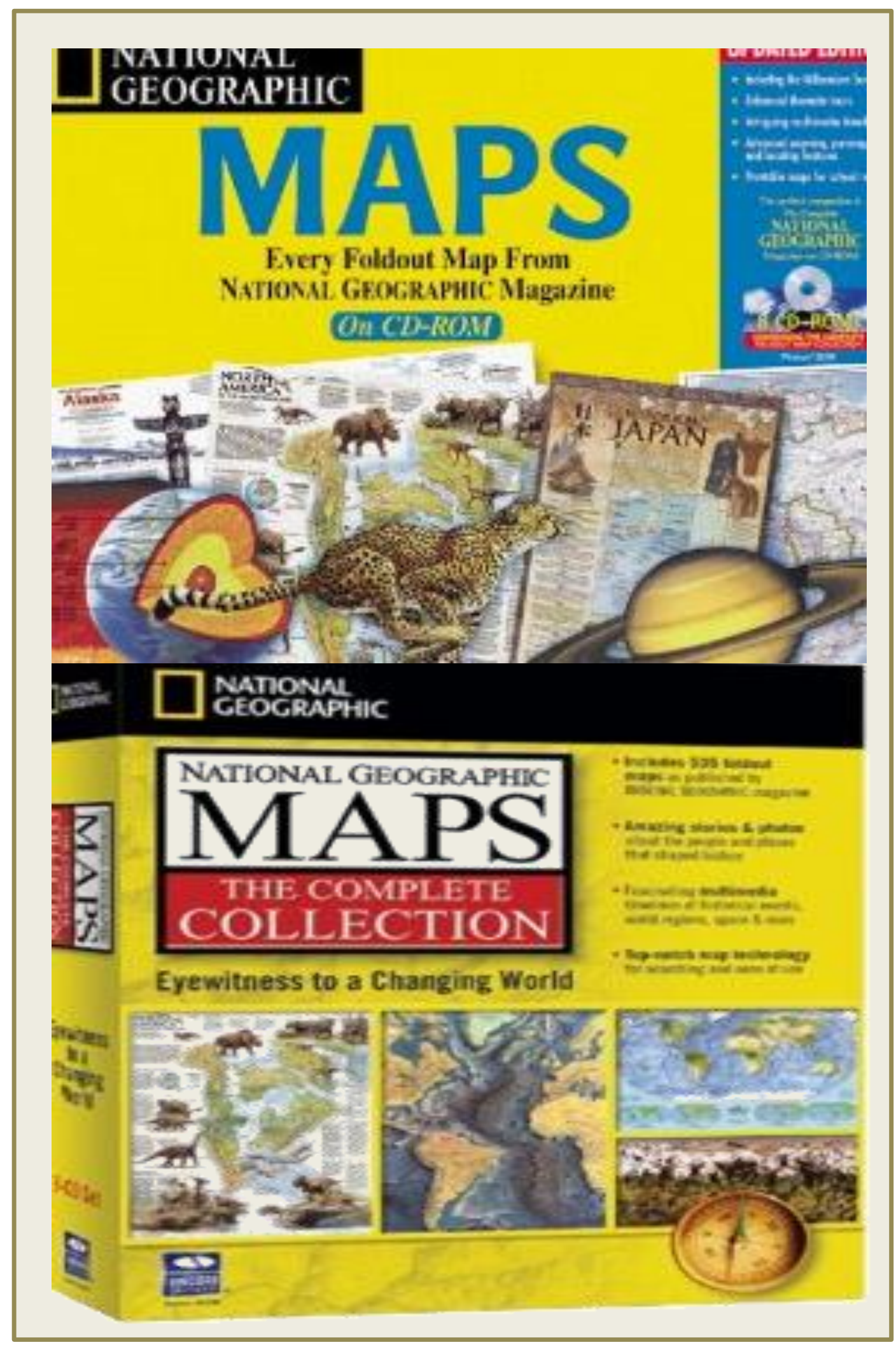

National Geographic شكل رقم (r-1 ) برنامج خر ائط رقية نموذج 
يوضح شكل رقم (r-9 (1) خريطة العالم التفاعلية من موقع MrNussbaum.com ، حيث يعرض

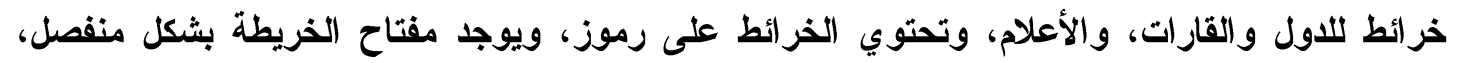
ويمكن حفظ الخرائط وطباعتها بالألوان وهي تستخدم للتعرف على حقائق جغرافية عن الدول .

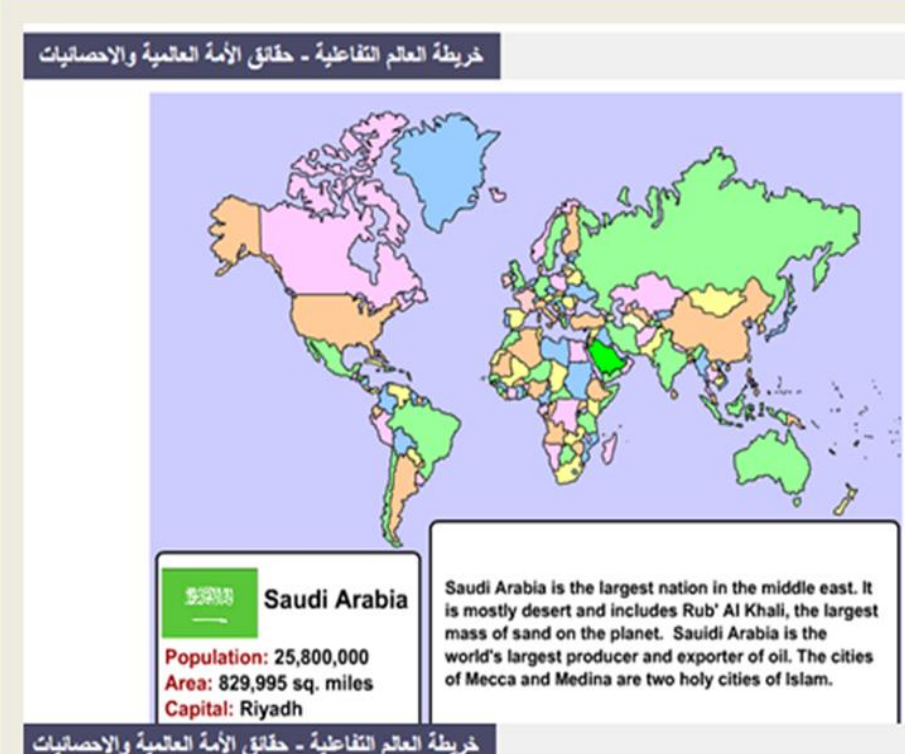

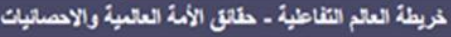

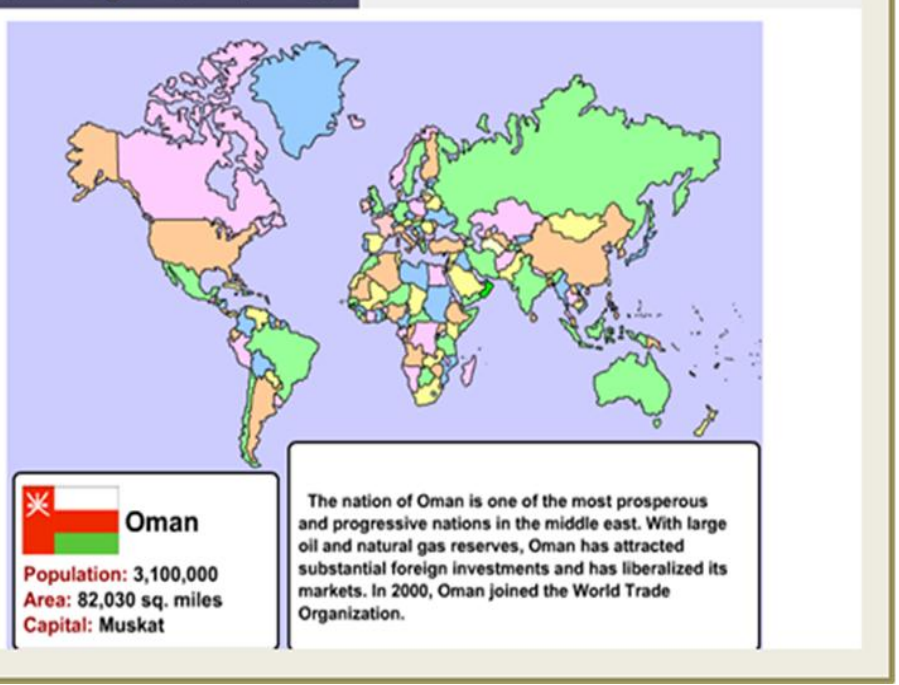

شكل رقم (ץ-9 1 ) خريطة العالم التفاعلية.

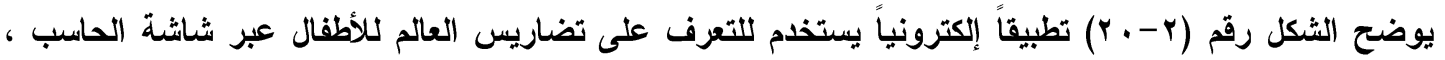
حيث يوجد بالتطبيق تعريف محدد مع إدراج صورة للظاهرة على سبيل المثال: نهر: عبارة عن تيار كبير من المياه الطبيعية ، دلتا: عبارة عن مروحة تحتوى على طين عند مصب النهر. 


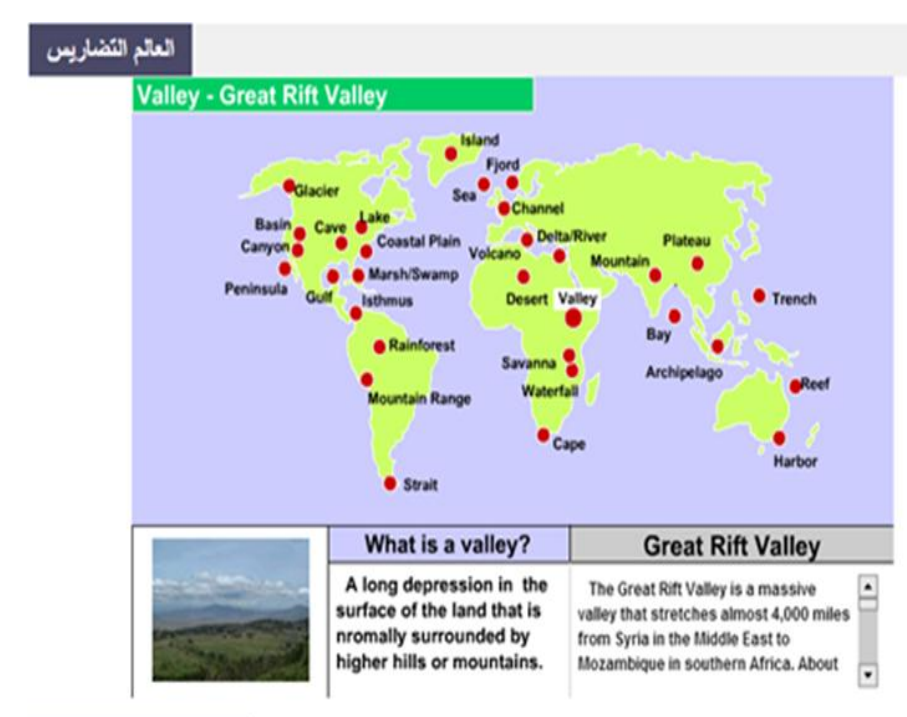

World Landforms

\section{World Landforms!}

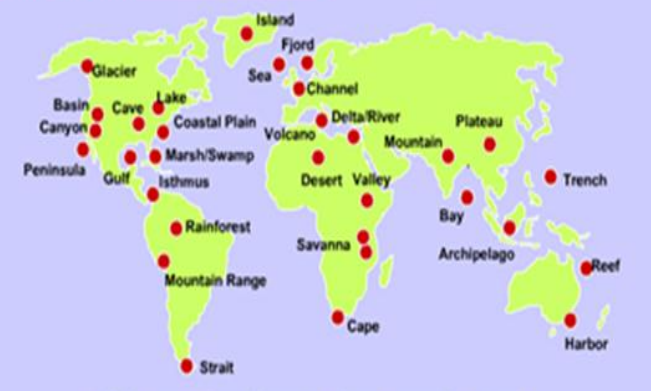

Click on a landform to learn much more!

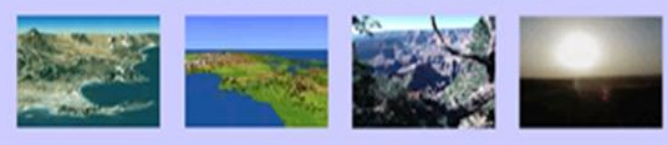

شكل رقم (r - r r) تطبيقاً إلكترونياً للتعرف على تضاريس العالم للأطفال.

أما شكل رقم (Y-Y (Y) فهو تطبيق لإمداد الطفل بمعلومات عن قارات العالم السبعة ومحيطات العالم الستة ومثال

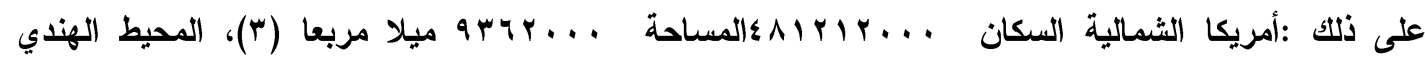

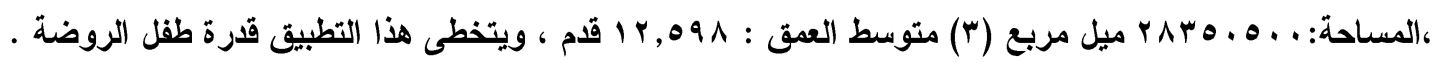




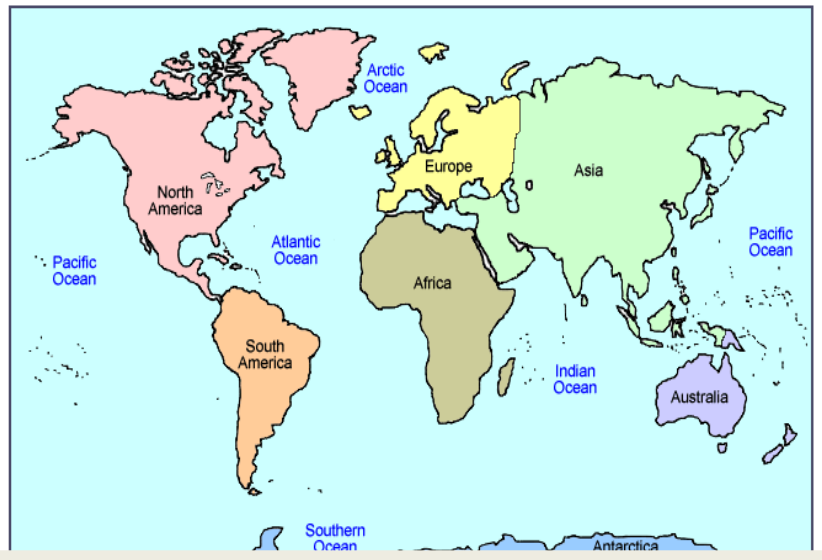

شكل رقم (Y - 1 1) تطبيقاً إمداد الطقل بمعلومات عن قار ات العالم السبعة ومحيطات العالم

يوضح شكل رقم (Y-Y r r تطبيقاً يتيح للطقل التعرف على المناطق الحيوية بالعالم بتمثيلها على خرائط موضوعية من خلال العديد من العناصر مثل: (الغابات المطيرة، أرضي عشبية، أماكن صحر اوية، الغابات

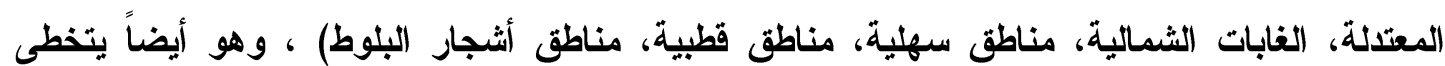

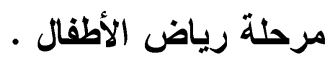




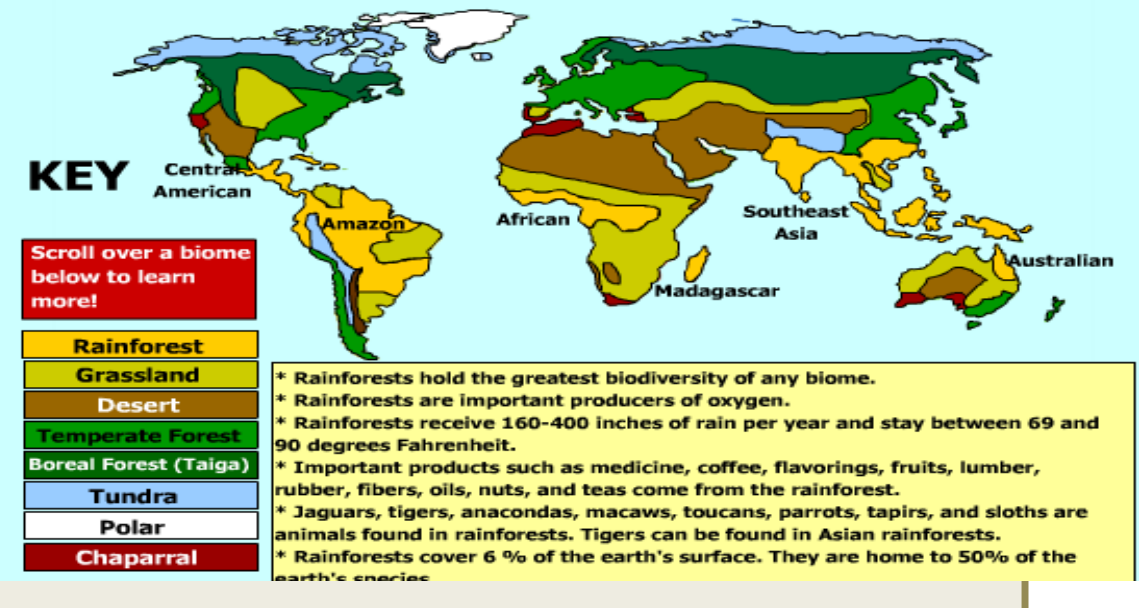

\section{المناطق الحيوية العاتم}

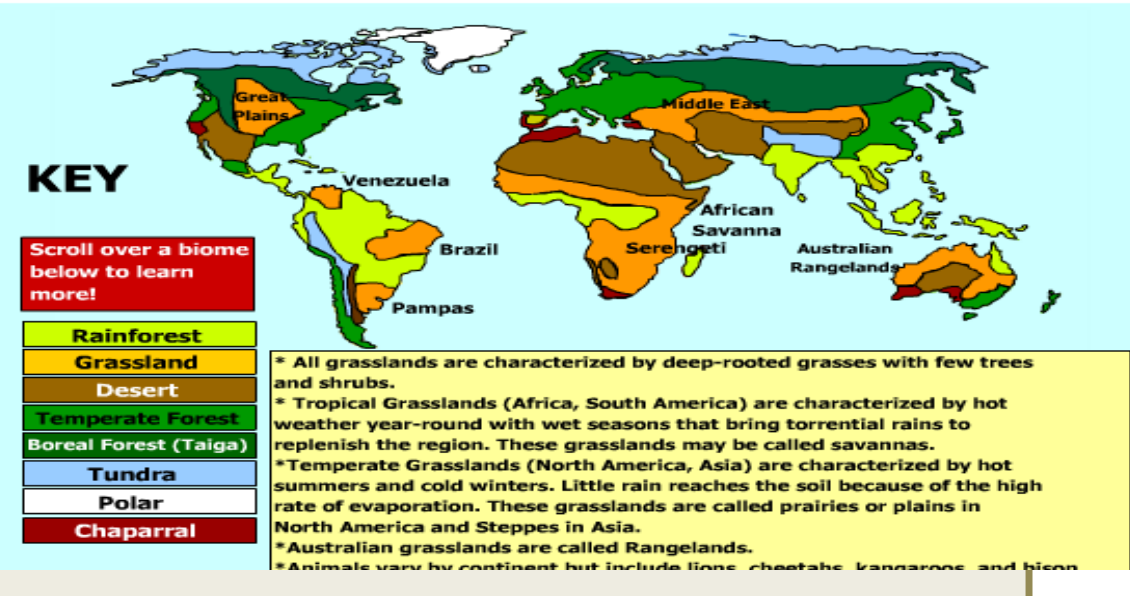

شكل رقم (r r r r تطبيقاً يتيح للطقل التعرف على المناطق الحيوية بالعالم.

يوضح شكل رقم (r-rr) تطبيقاً يتيح للطفل بيانات عن فرنسا وأنهارها مثل (نهر السين ونهر لوير

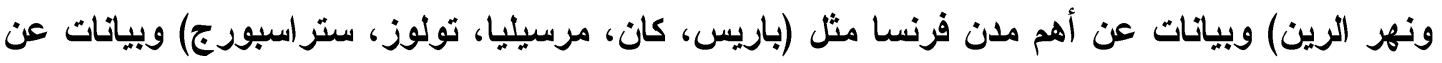

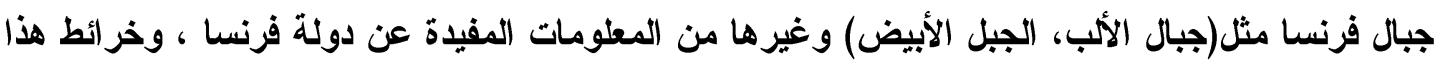

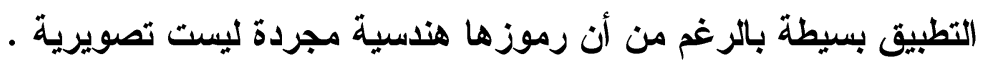




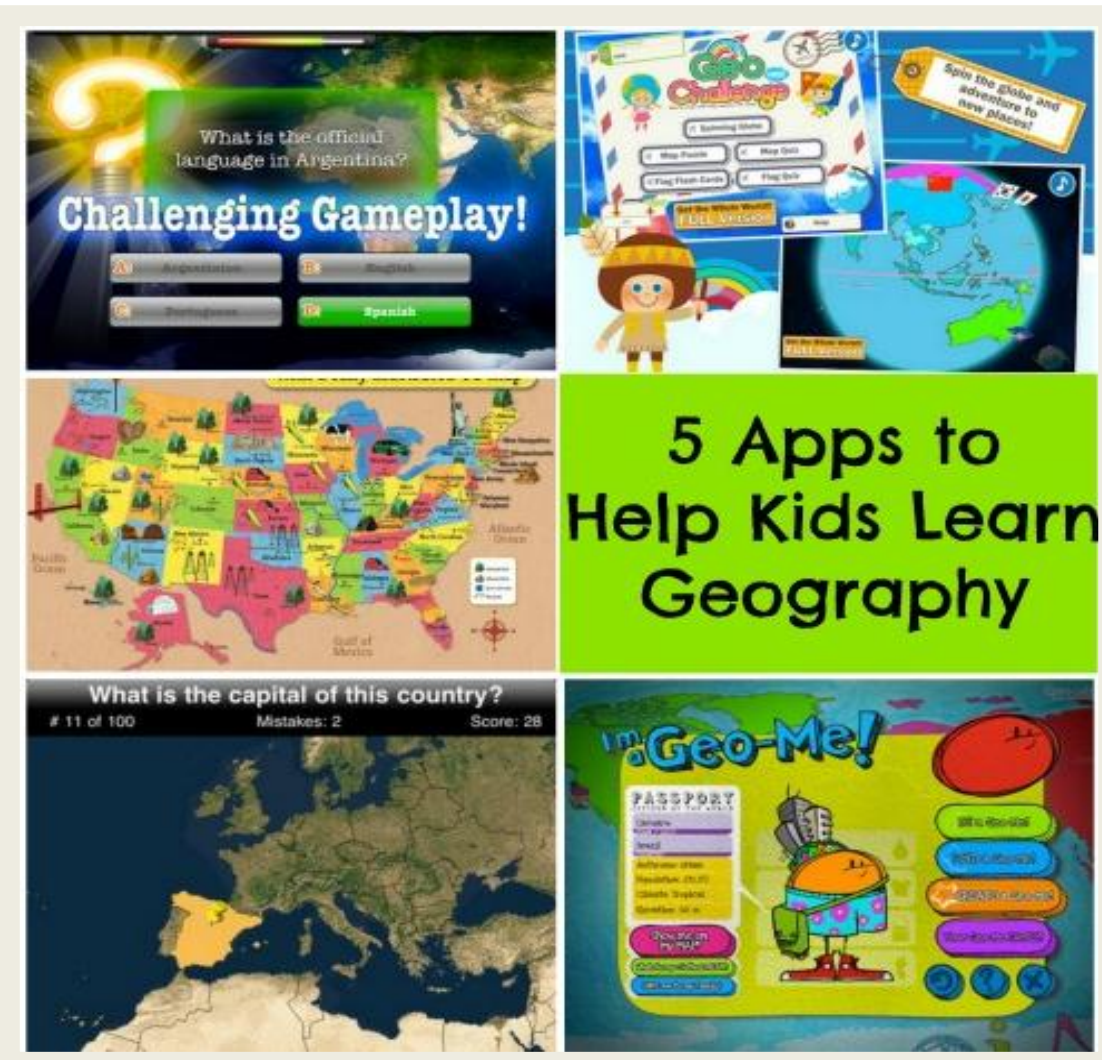

شكل رقم (ro-r r ) خمسة تطبيقات خر ائطية محمولة

r-r : نماذج الوسائط الكارتوجرافية التي استخدمت في تقييم التلقي في البحث :

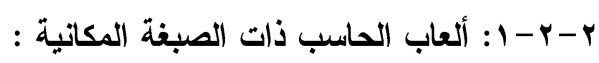

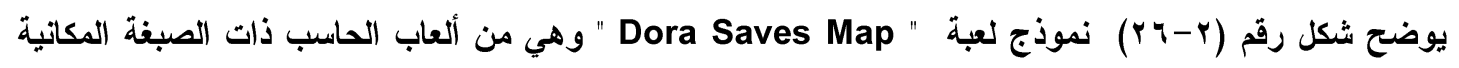
وتساعد الطفل على تعليم الحركة في المكان ، حيث تتنقل Dora داخل الغابة وتتبع مفاتيح الأسهم للتحرك في الاتجاهات وتجمع النجوم الذهبية ، واللعبة عبارة عن مغامرة على ب مستويات ، على الطفل المحافظة على النجوم

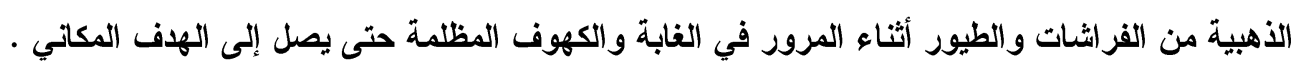




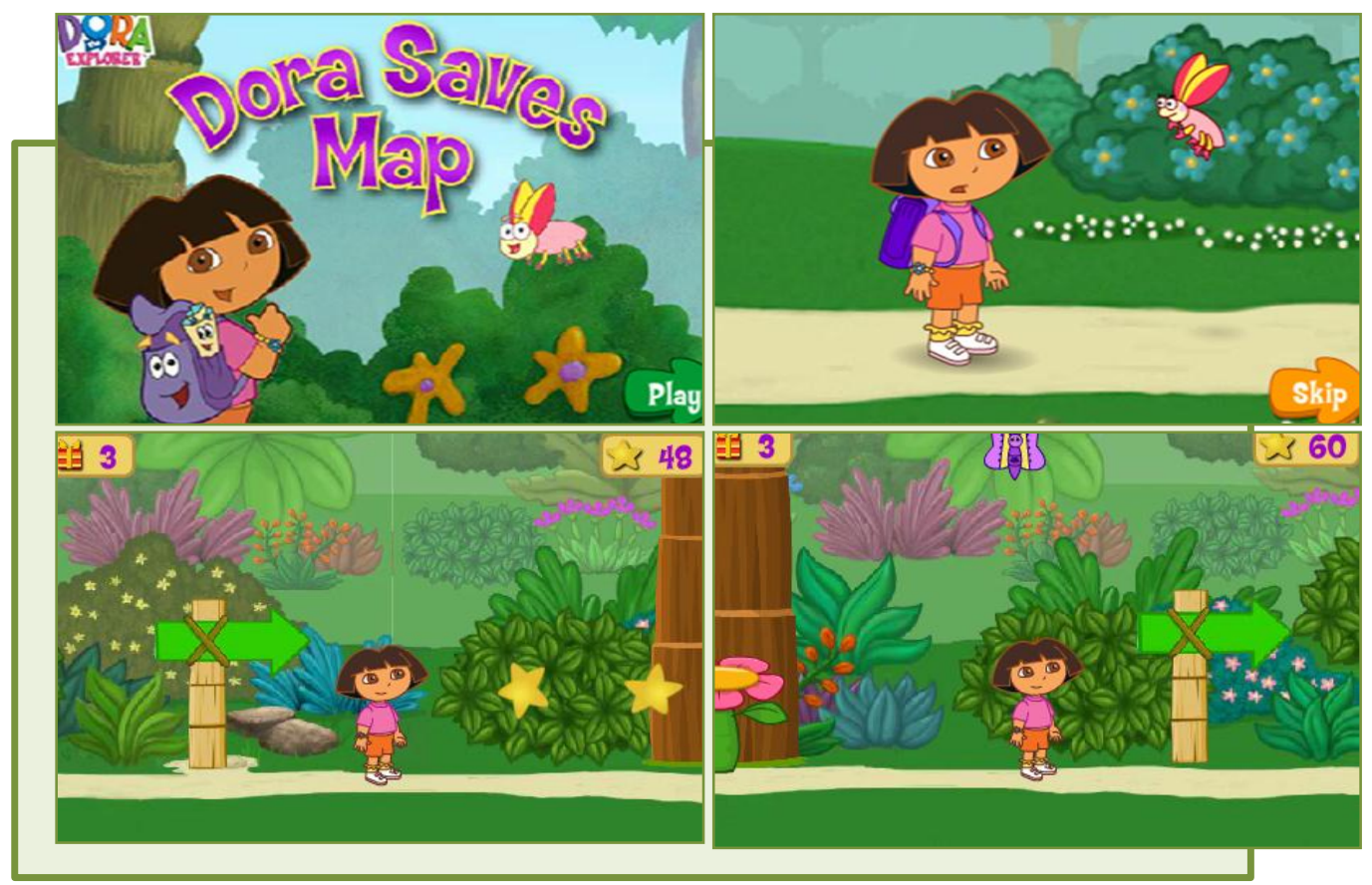

Dora Saves Map شكل رقم (r-r r (r) نموذج لعبة

يوضح شكل رقم (rV-r) نموذج لعبة "Map GIS Zone" وهي عبارة عن خريطة تحتوي على مواقع ومباني وملعب ومدينة ترفيهية وطرق وميناء ووسائل مواصلات ، لابد أن يتبع الطفل اتجاه العهم والتعليمات للتنقل بين المو اقع والمنازل وأماكن الترفيه ، ولكل موقع رحلة ومجموعة من الخرائط التفاعلية، من خلاها يستكثف الطفل المواقع ، وتخلق نوعاً من التحدي للوصول للهذف المكاني . 


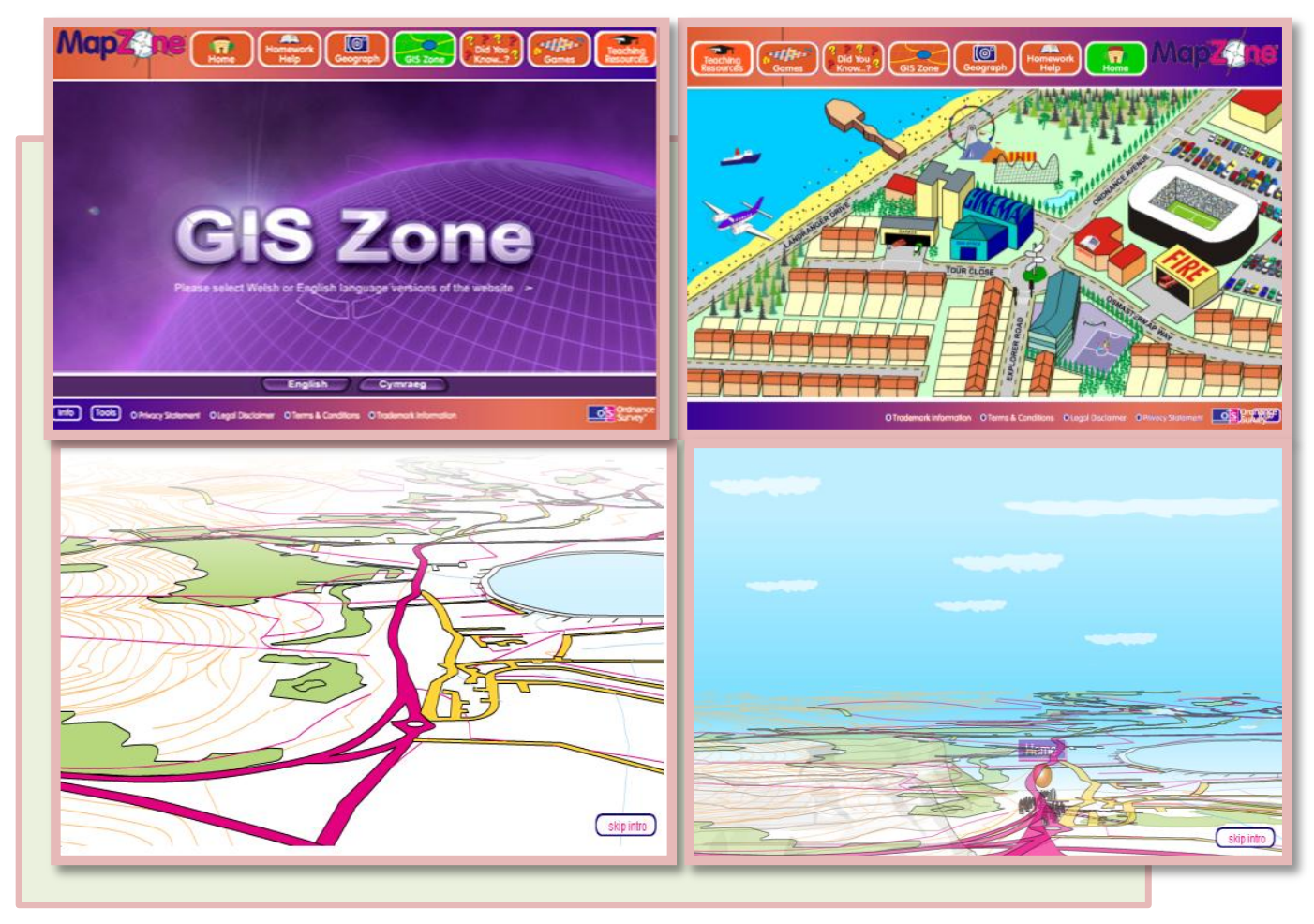

Map GIS Zone شكل رقم (rV-r) نموذج لعبة

من خلا حصر الوسائط الكارتوجر افية المتاحة للطقل والمستخدمة في منطقة الدارسة ، ومقارنتها بما هو

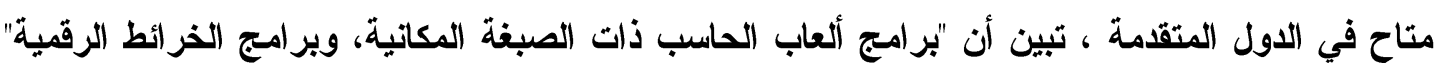

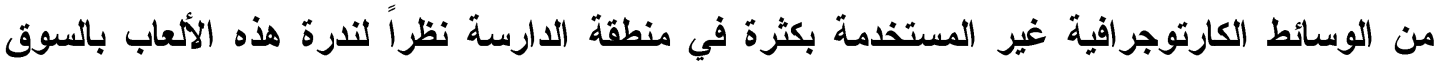

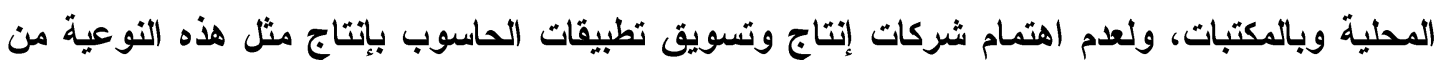

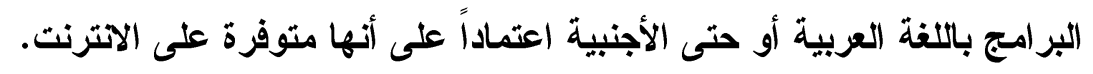
ب- المبحث الثالث :

تقييم استخدام برامج الخرائط الرقمية ذات الصبفة المكانية

r- 1: تقييم تلقي وتفاعل الأطفال مع برامج الخرائط الرقمية ذات الصبغة المكانية: هدفت الدراسة إلى قياس مستويات تلقي الطفل وتفاعله مع برامج الخرائط الرقمية ذات الصبفة المكانية ، وتوضيح اختلاف مستويات تلقي الطفل وتفاعله باختلاف نوع الطفل (ذكر - أنثى). وقد تم استخدام المنهج التجريبي ، ويعرف بأنه المنهج الذي يعتمد على التطبيق الميداني للتجربة ويستخدم للمفاضلة بين طريقتين أو أسلوبين لاختيار أحدها للتطبيق مباشرة أو التطبيق بعد التعديل حسبما تدعو إليه النتائج 
أو الحاجة (أبو علام ، V. . . Yم ، 9 1) ، كما يعتمد المنهج التجريبي على استخدام التجربة في الإجابة على أسئلة

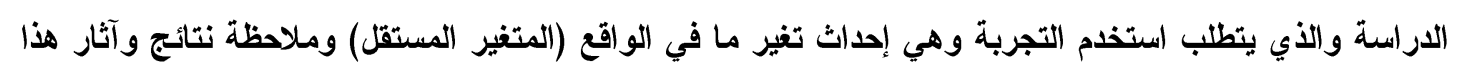

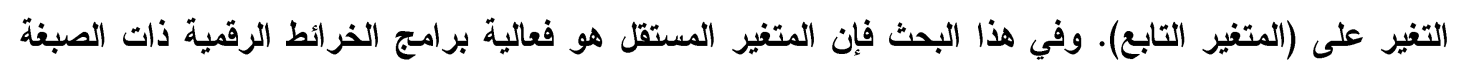

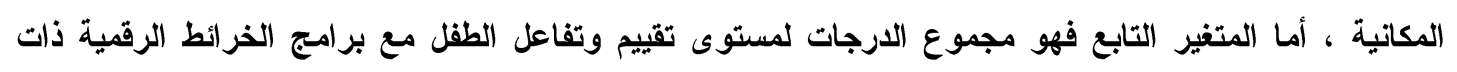
الصبغة المكانية.

وتم إجراء البحث على مجموعتين الأولى وهي المجموعة التجريبية وهي التي تم عرض البرامج عليها مع شرح

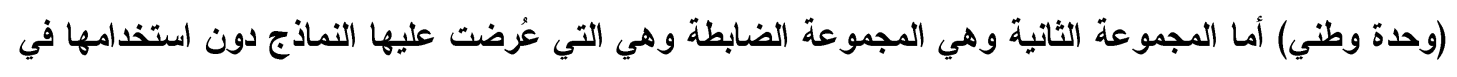
(وحدة وطني) ( )

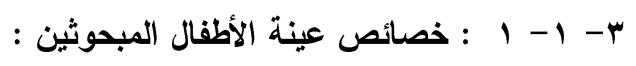
تكون مجتمع الاراسة من أطفال مرحلة رياض الأطفال في المدارس الحكومية والأهلية في مدينة جدة، وقد تم أخذ

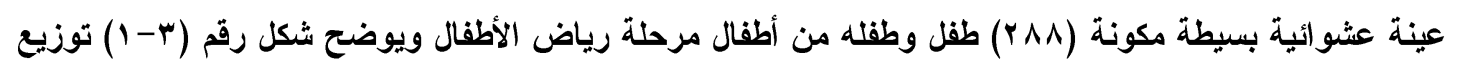
الأطفال تبعاً للنوع. 


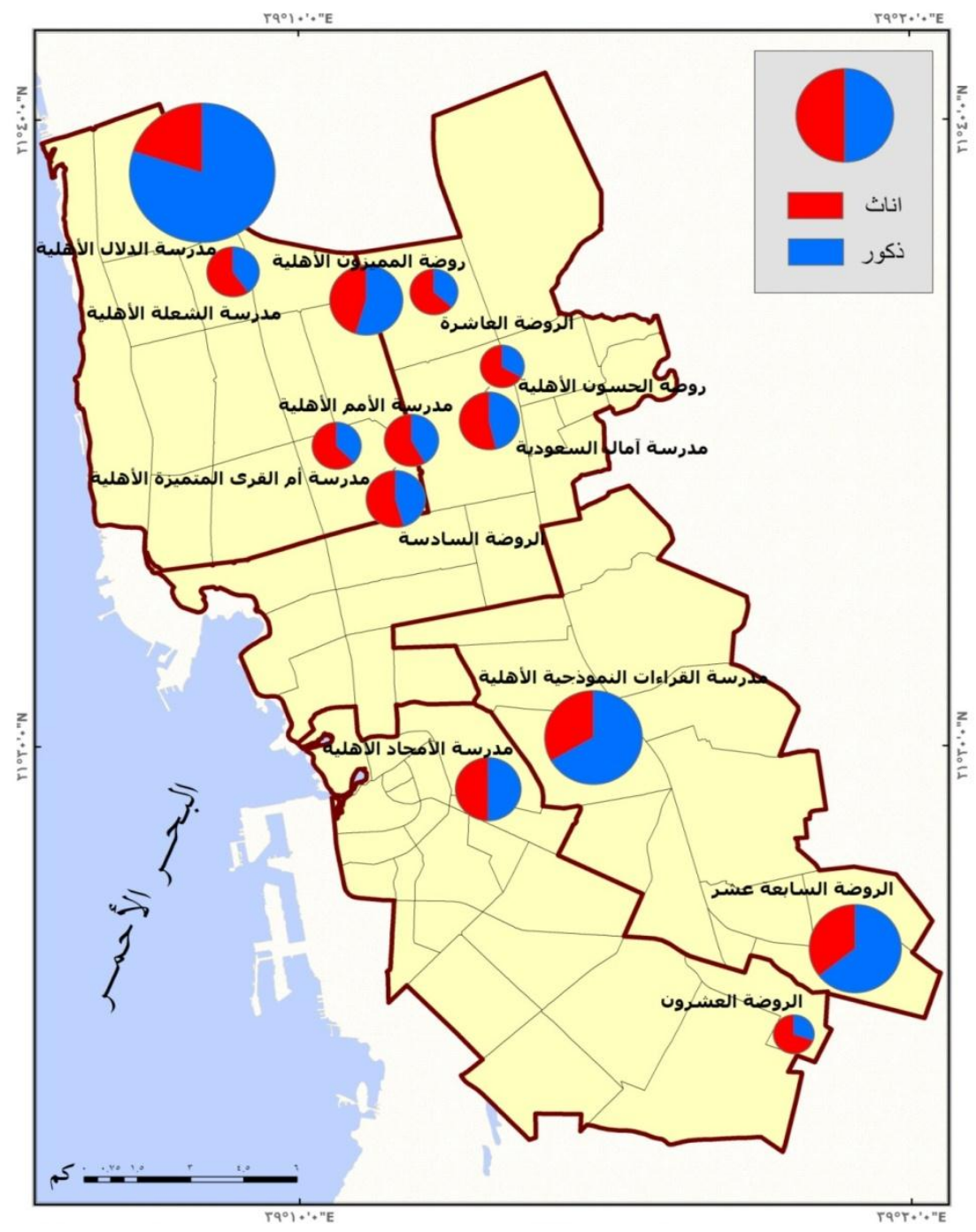

شكل رقم (r-1) توزيع الأطفال تبعاً للنوع

تتساوي أفراد عينة البحث من المجموعة التجريبية مع أفراد عينة البحث من المجموعة الضابطة بنسبة ... ــ لكل منهما، ومعظم أفراد عينة البحث من أطفال المجموعة التجريبية ينتمون إلى مدارس أهلية حيث بلغت نسبتهم

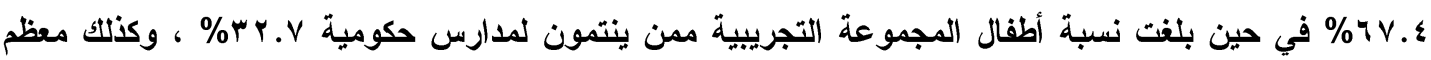

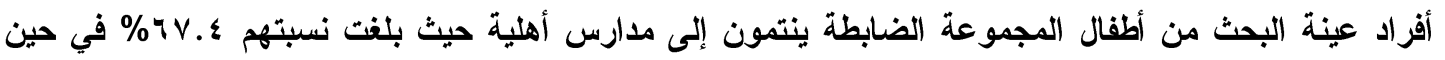
بلغت نسبة أطفال المجموعة التجريبية ممن ينتمون لمدارس حكومية vr.v\%\%. تتكون عينة الأطفال في المجموعة التجريبية من v. . ه\% ذكور في حين بلغت نسبة الإناث ץ.9 ٪\%. وتتكون عينة الأطفال في المجموعة الضابطة

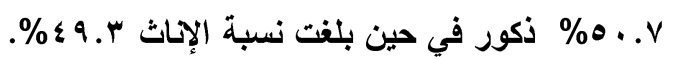




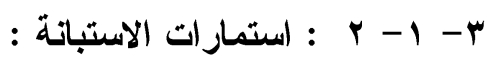

تم تصميم استمارات الاستباتة للأطفال وللتأكد من صدقها الظاهري تم عرضها على على عدد سبعة من المحكمين اثنان من أعضاء هيئة التّريس بالجامعات وخبيز ومستثار تربوي في وزارة التربية والتعليم، وأربعة مشرفين تربويين في إدارة التربية والتعليم. وفي ضوء آرائهم قامت الباحثة باعتماد الاستمارة بصورتها النهائية . ويوضح الجدول التالي أن قيم معاملات الارتباط للمحور بالدرجة الكلية للمقياس تراوحت (بء^. •) مما يعني

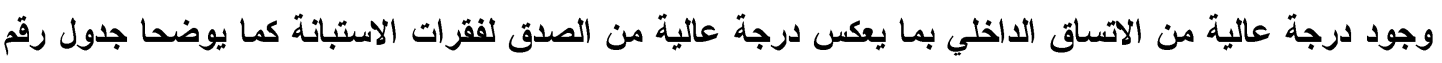

جدول (r- 1) معامل الارتباط بين درجة كل محور والدرجة الكلية لمقياس تقييم تلقي وتفاعل الطفل

\begin{tabular}{|c|c|}
\hline تقييم تلقي وتفاعل الطفل مع اللعب الكارتوجر افية الحاسبية \\
\hline
\end{tabular}

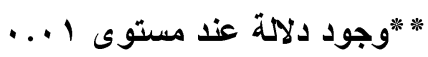

r- r- r r م : وصف البيانات و المعالجة والأساليب الإحصائية المستخدمة :

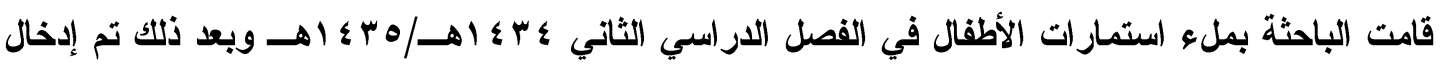

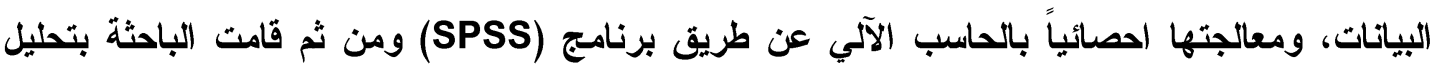
البيانات واستخر اج النتائج. ولتحقيق أهداف الدراسة وتحليل البيانات التي تم تجميعها تم استخدام العديد من الأساليب الإحصائية المناسبة باستخدام الحزم الإحصائية للعوم الاجتماعية Statistical Package For Social -SPSS Sciences وذلك الفك بعد أن تم ترميز و إدخال البيانات إلى الحاسب الآلي. وقد أثتمل مقياس تقييم تلقي وتفاعل الطفل مع اللعب الكارتوجرافية الحاسبية على 1 أهداف. وقد استخدمت الباحثة أسلوب ليكرت (Likert) خماسي التدرج (ممتاز - جيد جدا - جيد - مقبول- ضعيف) وذلك لقياس مستوى تلقي وتفاعل الطفل مع برامج الخرائط الرقمية ذات الصبغة المكانية . وبعد ذلك تم حساب المقاييس الإحصائية التالية: • المتوسط الحسابي الموزون (المرجح) وذللك لمعرفة مدى ارتفاع أو انخفاض استجابات أفراد الاراسة

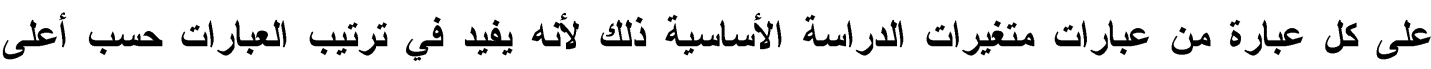
متوسط حسابي موزون. 
• المتوسط الحسابي (Mean) وذلك لمعرفة مدى ارتفاع أو انخفاض استجابات أفراد الاراسة عن المحاور الرئيسية(متوسط العبار ات)، حيث يفيد في ترتيب المحاور حسب أعلى متوسط.

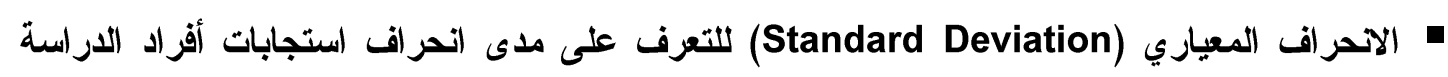

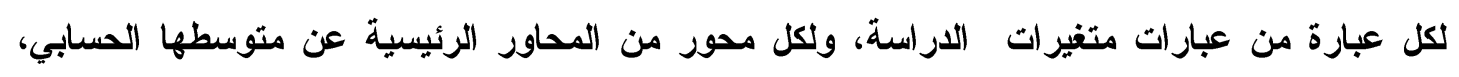

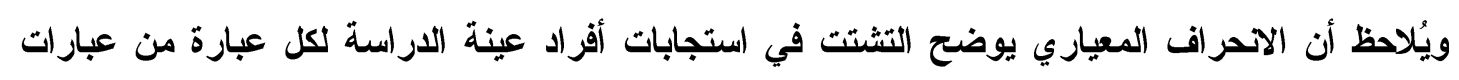

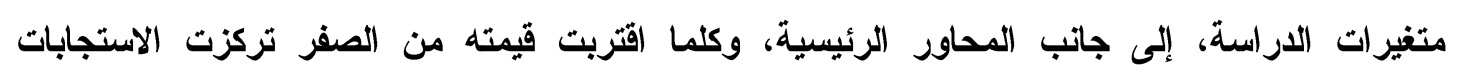

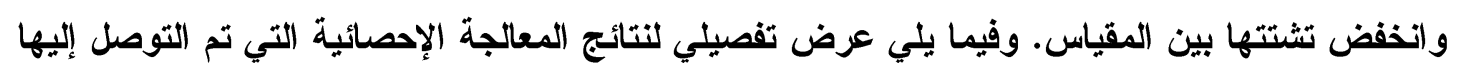
في ضوء أسئلة الاراسة وأها(فها مع تفسير النتائج. تم استخدام الأساليب الإحصائية التالية لتحليل البيانات التي تم جمعها من واقع تطبيق الاستبانة على أفر اد عينة الار اسلة: الإحصاء الوصفي: وذلك من خلال الأساليب التالية:

• التكرارات والنسب المئوية لوصف مجتمع الدراسة بالنسبة للمعلومات الأولية.

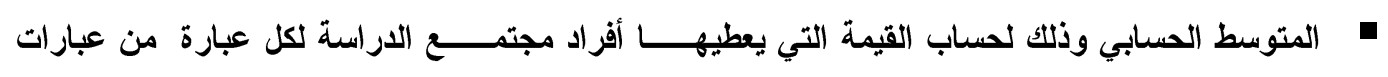
المقياس. الاحمرافات المعيارية للتعرف على التباين في استجابات أفراد العينة على كل عبارة من عبارات المقياس.

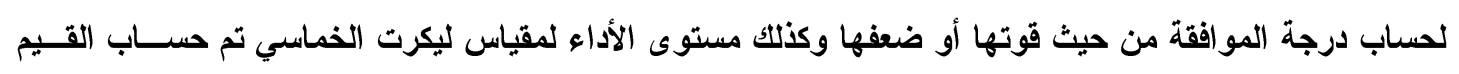

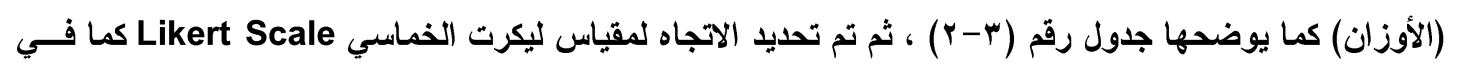

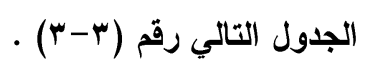

جدول رقم (r-r (r) حساب مقياس ليكرت الخماسي

\begin{tabular}{|c|c|}
\hline الوزن & مستوى الأداء \\
\hline 1 & ضعيف \\
\hline$r$ & مقبول \\
\hline$r$ & جيد \\
\hline$\varepsilon$ & جيد جـاً \\
\hline 0 & ممتاز \\
\hline
\end{tabular}




\begin{tabular}{|c|c|}
\hline مستوى الأداء & المتوسط المرجح \\
\hline ضعيف & من 1 إلى 9 1.v9 \\
\hline مقبول & من ·. 1.1 إلى 9ه.r \\
\hline جيد & 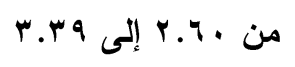 \\
\hline جيد جداً & من · ـ ــ إلى 9 1. ـ \\
\hline 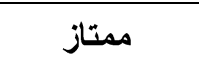 & 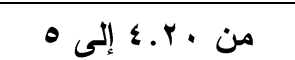 \\
\hline
\end{tabular}

الإحصاء الاستدلالي : وذلك من خلال :

اختبار ( ت ) لعينتين مستقلتين (Independent Samples T-Test) للتعرف على ما إذا كاتت هنالك فروق ذات دلالة إحصائية بين اتجاهات مفردات عينة الاراسة نحو محاور الاراسة باختلاف متغيــراتهر

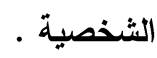
اختبار ( ف ) تحليل التباين الأحادي ( One way anova ) للتعرف على ما إذا كاتت هنالك فروق ذات

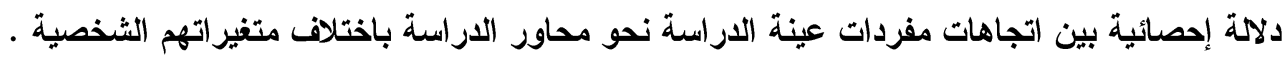

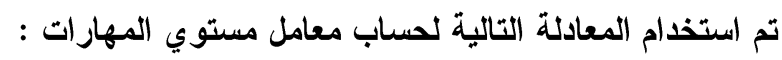

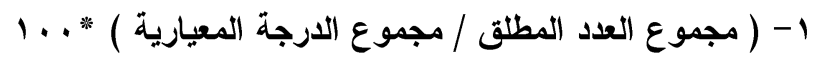
r- 1- r ب : تقييم تلقي وتفاعل أطفال العينة تبعاً للمجموعة : ولقد تم تحليل نتائج الدراسة وفقا لأسئلتها وذلك بعرض كل سؤال ثم الإجابة عليه على النحو التالي: للإجابة على السؤال اختلاف مستويات تلقي الطفل وتفاعله ، قامت الباحثة باستخدام اختبار "ت" للمجموعات المستقلة (Independent Samples T-Test) لتحديد وجود فروق ذات دلالة إحصائية بين متوسطي درجات

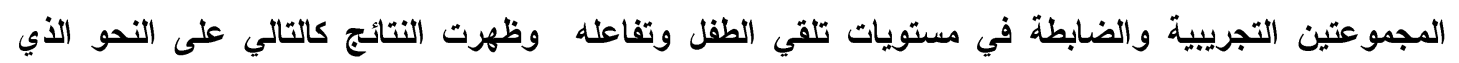
يوضحه جدول رقم (r- ع) ). 
جدول (ץ-\&) نتائج تحليل أختبار "ت" للمجموعات المستقلة لدلالة الفروق بين متوسطي درجات المجموعتين التجريبية والضابطة في مستويات تلقي الطفل وتفاعله

\begin{tabular}{|c|c|c|c|c|c|}
\hline الإحصائية & قيمة (ت) & الاحمراف المعياري & الحستوسي & المجموعة & المحور \\
\hline \multirow[t]{2}{*}{$*, \ldots$} & \multirow[t]{2}{*}{ סז , , } & $\cdot, r \vee q$ & $\varepsilon, \leqslant 7$ & التجريبية & \multirow{2}{*}{ تلقيبم تلقي وتفاعل الطقل مع } \\
\hline & & $\cdot, r \leqslant V$ & r,rA & الضابطة & \\
\hline
\end{tabular}

"وجود دلالة عند مستوى ا...

ويتضح من الجدول (r- §) التالي:

- وجود فروق ذات دلالة إحصائية بين متوسطي درجات المجموعة التجريبية والضابطة في مستوى تقييم

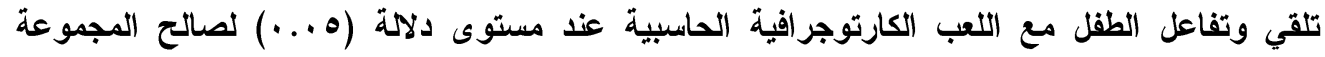

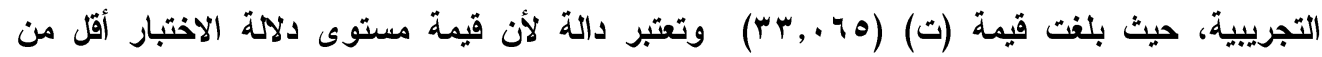

ويؤكد ما سبق إستجابة أطفال المجموعة التجريبية للتفاعل مع برامج الخرائط الرقمية ذات الصبغة المكانيـة عـن

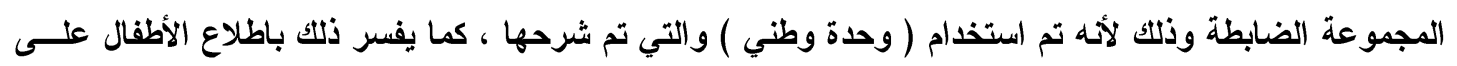
نماذج متعددة من البرامج وتراكم الخبرات وانتقال الخبرات بالاحتكالك بين الأطفال في المجموعة التجريبية . ץ- 1- ـ : تقييم تلقي وتفاعل أطفال العينة تبعاً للنوع :

وللإجابة على سؤال اختلاف مستويات تلقي الطفل وتفاعله مع الوسائط باختلاف نوع الطفل ، قامت الباحثة باستخدام اختبار "ت" للمجموعات المستقلة (Independent Samples T-Test) لتحديد وجود فروق ذات دلالة إحصائية بين متوسطي درجات الأطفال الذكور والإحاث في مستويات تلقي الطفل وتفاعله مع برامج الخرائط الرقمية ذات الصبغة المكانبة وظهرت النتائج كما يوضحها جدول رقم (ب-ه) : 
جدول (r-ه) نتائج تحليل ت لدالة الفروق بين متوسطي درجات الأطفال الأكور والإحاث في مستويات تلقي الطفل وتفاعله

\begin{tabular}{|c|c|c|c|c|c|}
\hline الإحصائية & قيمة (ت) & الانحراف & المتوسط & جنس & المحور \\
\hline \multirow[t]{2}{*}{$\cdot, r \leq \varepsilon$} & \multirow[t]{2}{*}{$1,1 \vee 0$} & $\cdot, \varepsilon$ & $\{, \varepsilon$. & ذكر & \multirow{2}{*}{ الكارتوجرافية الحاسبية وتفاعل الطفل مع اللعب } \\
\hline & & , ror & $\{, 01$ & أنثى & \\
\hline
\end{tabular}

يتضح من الجدول (r-ه) التالي:

- مجود فروق ذات دلالة إحصائية بين متوسطي درجات الأطفال الذكور والإناث في مستوى تقييم تلقي

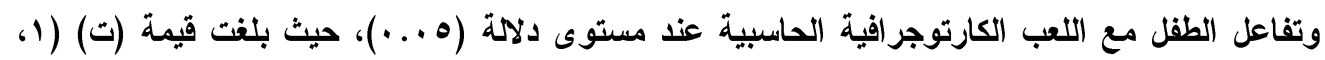

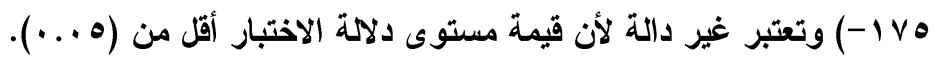

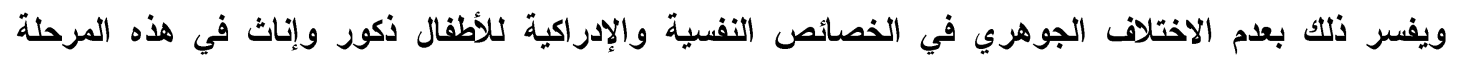
العمرية، ولكن هذا الفرق يبدأ في الظهور في بداية مرحلة المراهقة ـ لذلك جاءت النتائج متقاربة بين الذكور والإناث .

r- r ب تقييم مهارات وقدرات إستخذام الأطفال للبرامج الخرائط الرقمية ذات الصبغة المكانية: يتناول هذا العنوان تقييم مستوى المهارات والقدرات الكارتوجر افيه المختلفة للطفل أثناء تعامله مع برامج الخرايط

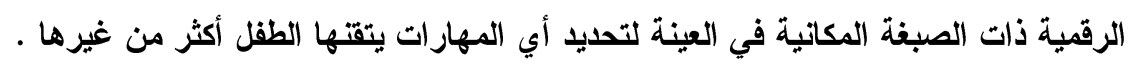

وحدة وطني هي أحدى وحدات المنهج التعليمي لطفل الروضة وضعتها إدارة التربية والتعليم بالمملكة ، قامت الباحثة بتصميم درس من وحدة وطني عن "موقع المملكة وأهم المدن للمجموعة التجريبية".

أ- الأدوات المستخدمة في الارس : خرائط ، ألعاب كارتوجر افية حاسبية .

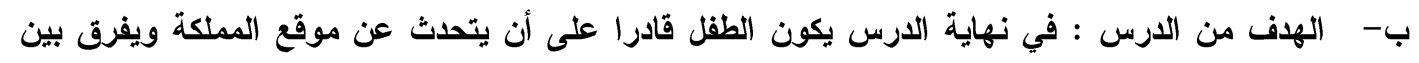

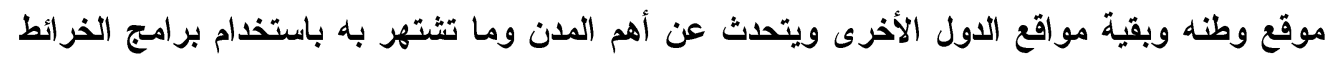
الرقمية ذات الصبغة المكانية. ركن الحاسب الآلي : إضافة العاب الحاسب الكارتوجرافية كما يوضحها شكل رقم (ب-r) ، نماذج الأسئلة : (ماذا تثاهد أمامك - حدد موقع السهم - ما فائدة السهم في اللعبة - إلى أين يتجه السهم - هل يوجد غابات في المملكة كما في لعبة Dora - كيف تتنقل من مكان لآخر - لماذا تبتسم Dora - حدد موقع مدينة الملاهي - حدد موقع 
Dora Saves Map الميناء - حدد موقع الملعب - هل أعجبتك اللعبة - ما رأيك في اللعبة - ما الفرق بين لعبة ولعبة Map GIS Zone).

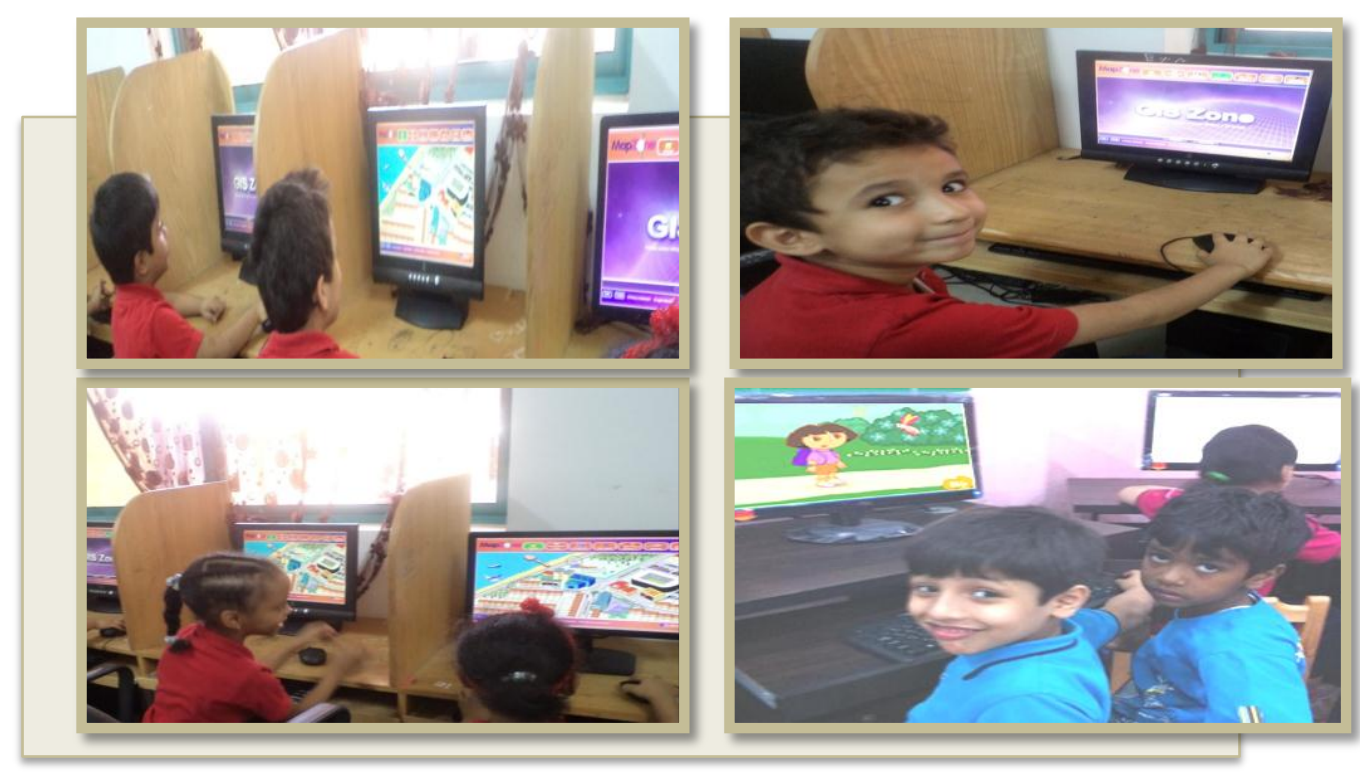

شكل رقم (r-r) الأطفال في ركن الحاسب

• تقييم تلقي وتفاعل الأطفال مع برامج الخرائط الرقية ذات الصبغة المكانية: قياس مدى وصول

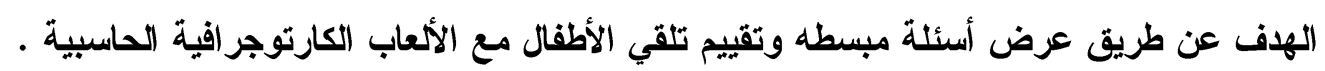
r-r r-r - 1 - 1 : مهارات وقدرات إستخدام اللعب الكارتوجر افية الحاسبية : يوضح جدول رقم (ץ-7) مهارات وقدرات إستخدام اللعب الكارتوجرافية الحاسبية ، ويوضح شكل رقم (ץ-r)

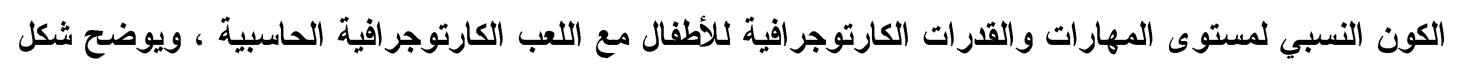

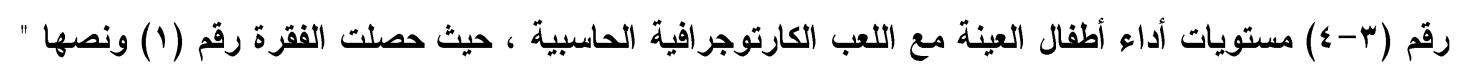

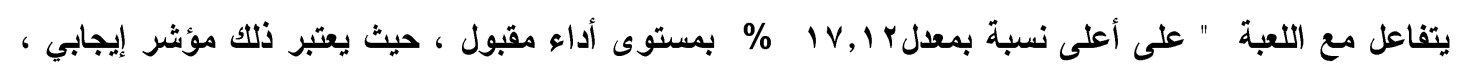

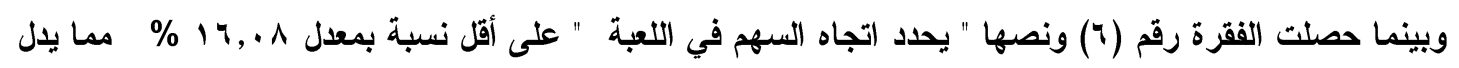
على ضرورة الإستمرار في تفعيل اللعب الكارتوجرافية الحاسبية حتى يصل الطفل إلى المرحلة المتقدمة في تحديد الإتجاهات والإستفادة القصوى من اللعب الكارتوجر افية . 


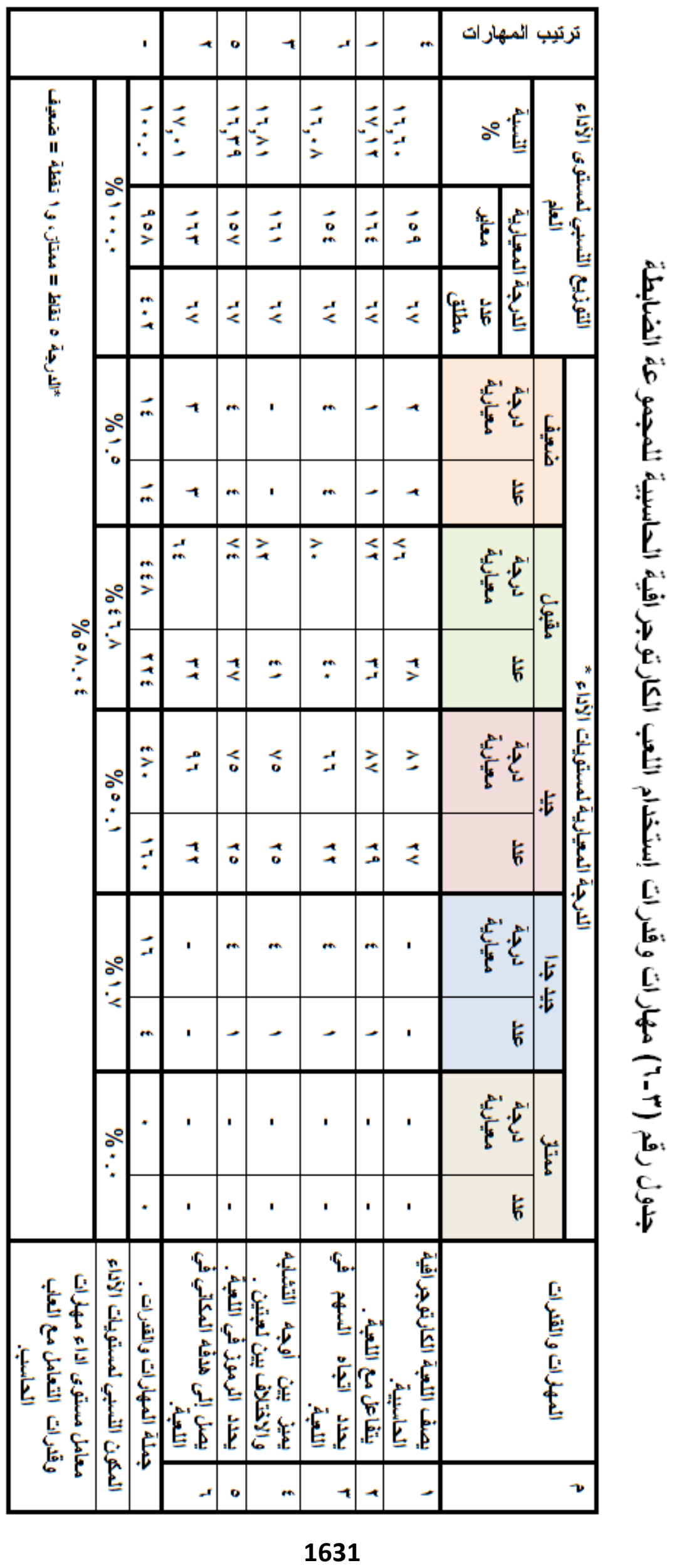




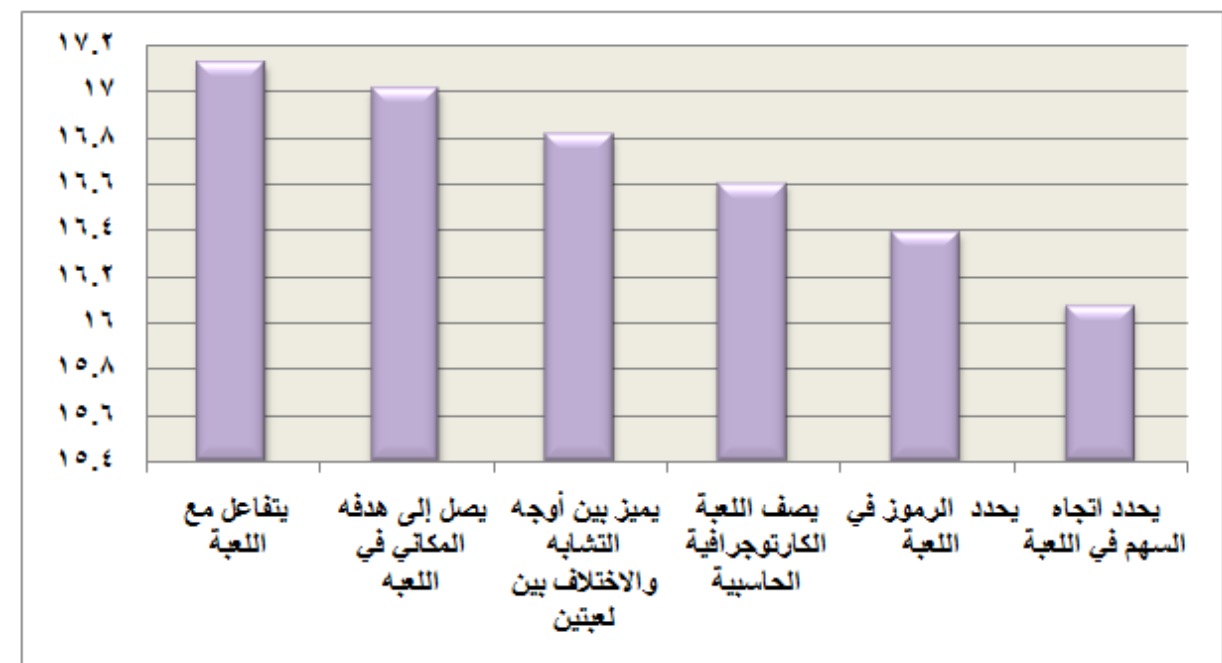

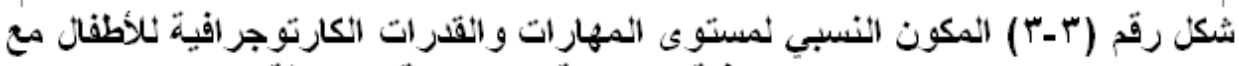

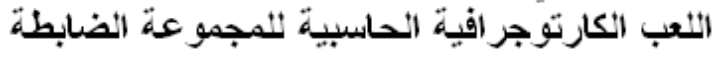

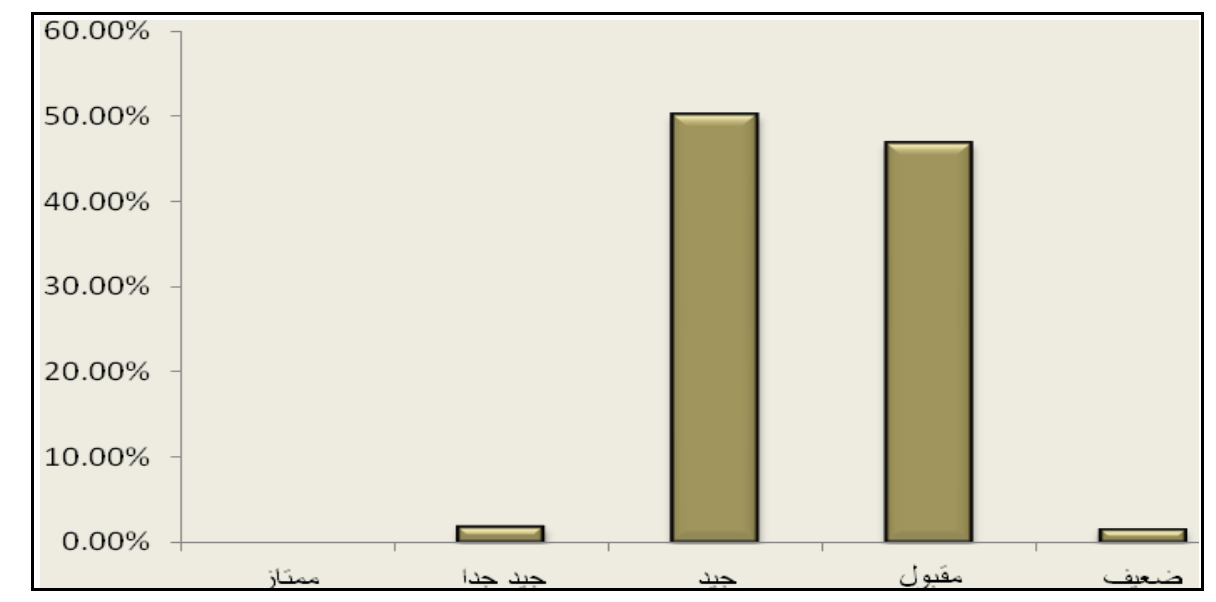

شكل رقم (r- ؛) مستويات أداء أطفال العينة مع اللعب الكارتوجرافية الحاسبية للمجموعة الضابطة

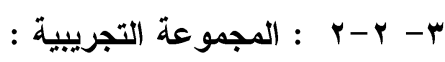

\section{r-r-r-r}

يوضح جدول رقم (r-Y) مهارات وقدرات إستخدام اللعب الكارتوجرافية الحاسبية ، ويوضح شكل رقم

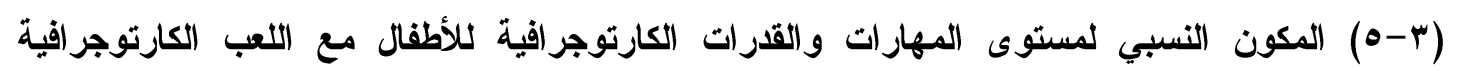

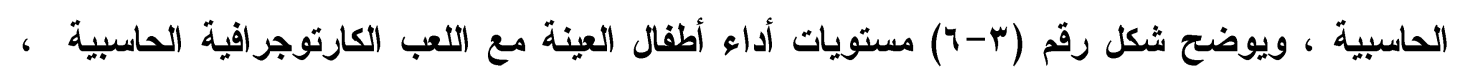
حيث حصلت الفقرة رقم (1) ونصها " يصل إلى هدفه المكاني في اللعبة " على أعلى نسبة بمعدل

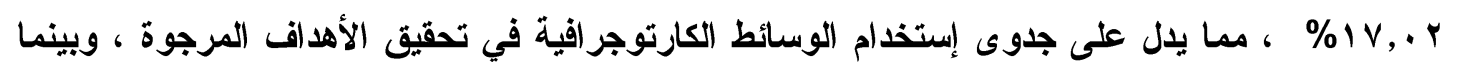

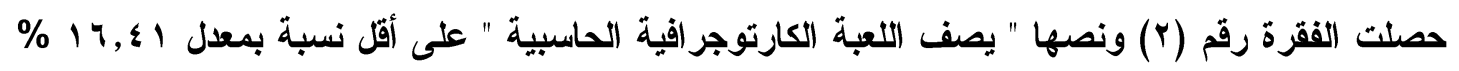


، وذلك لان الطقل في هذه المرحلة العمرية يميل إلى التفاعل والوصول إلى آخر اللعبة دون الإهتمام بوصف اللعبة التي أمامه . ومن خلا العرض السابق لمستويات تلقي وتفاعل الأطفال مع برامج الخرائط الرقمية ذات الصبغة

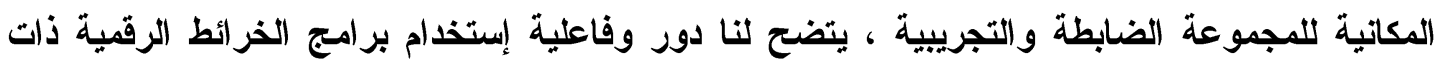
الصبغة المكاتية في رفع مستوى التلقي والتقاعل عند الأطفال بسبب تر اكم الخبرة وانتقال الخبرة بالاحتكالك

(النتائج::

$$
\text { توصلت الار اسة إلى النتائج التالية : }
$$

7 . 1 تؤكد الاراسات الأجنبية على أهمية إستخدام الوسائط الكارتوجرافية في تنمية قرات الطفل

المكانية وتثكيل البناء المعرفي، وفهم العلاقات المكاتية لاى الطفل في البيئة التي يعيش فيها. V. تعتبر الوسائط الكارتوجرافية من مصادر الحصول على المعرفة المكاتية اللازمة لتنمية مهارة وفئه

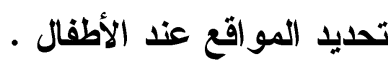
^. إن أفراد الار اسة كاتت لهم استجابات إيجابية كبيرة في مهارة وصول الطقل لهدفه المكاني في

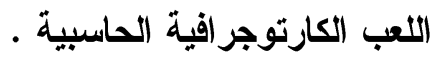
9 ـ . تثير الوسائط الكارتوجر افية تساؤلات عند الطفل .

$$
\text { في ضوء النتائج التي توصلت إليها الاراسة ، توصى الباحثة بما يلي : }
$$

هـ دمج تعزيزات صوتية ومرئية ولفظية في الألعاب الكارتوجرافية الحاسبية لتشجيع الطفل واستمراريته مما

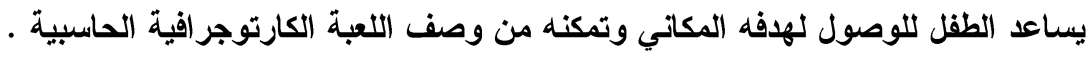

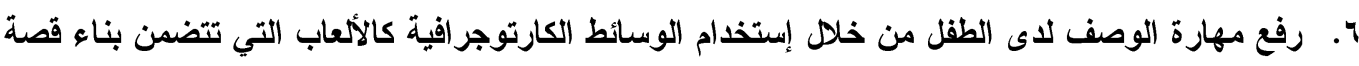

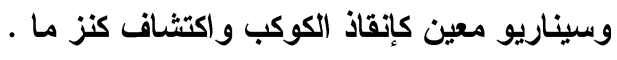

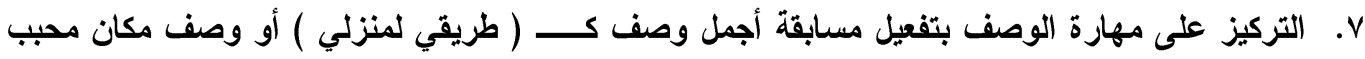
لاى الطفل، ويذلك يكتب الطفل المفاهيم المتعلقة بالمكان و الجهات.

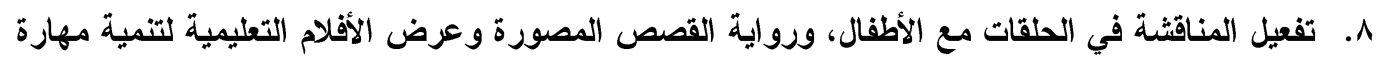
الوصف لاى الطفل . 9. دراسة فاعلية الوسائط الكارتوجر افية في تنمية الإدراك المكاني للطفل . 


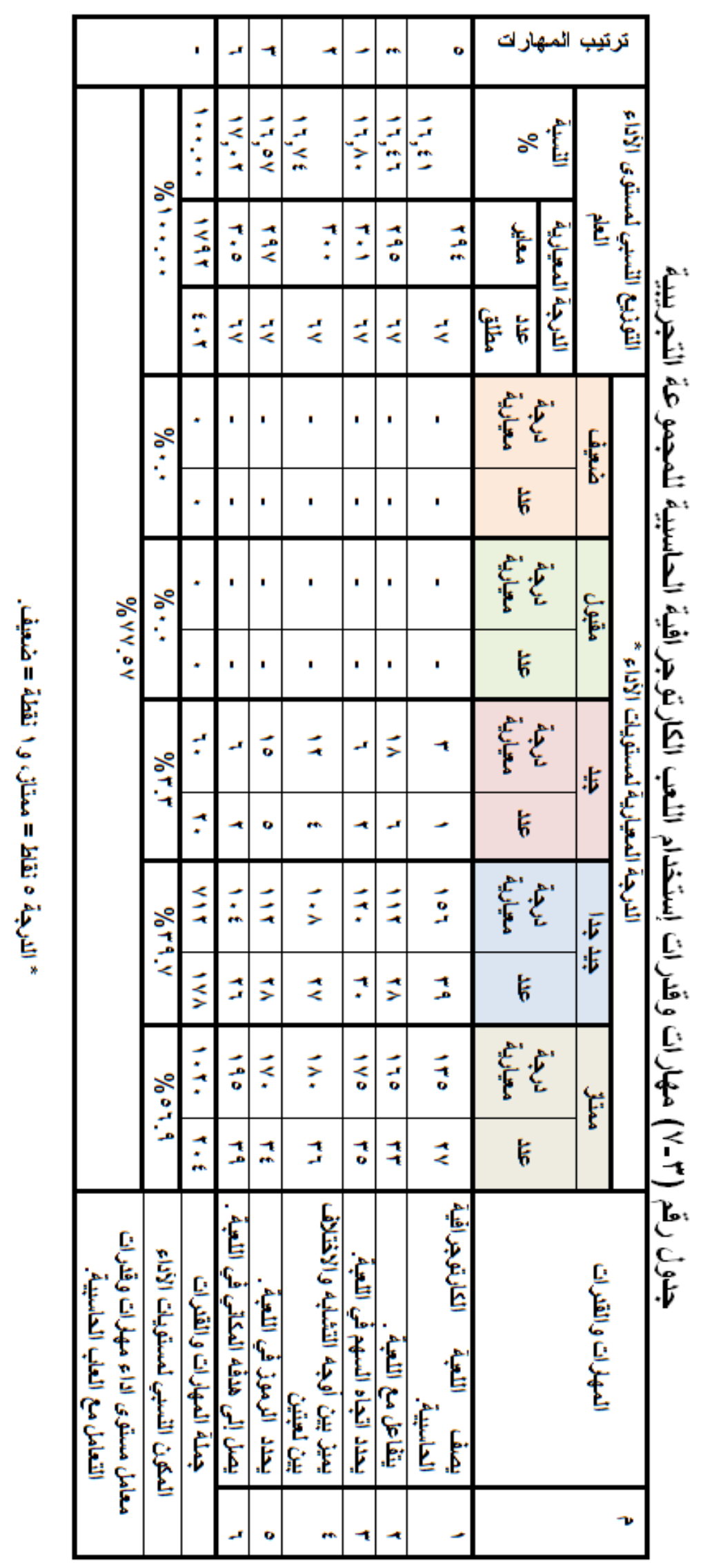



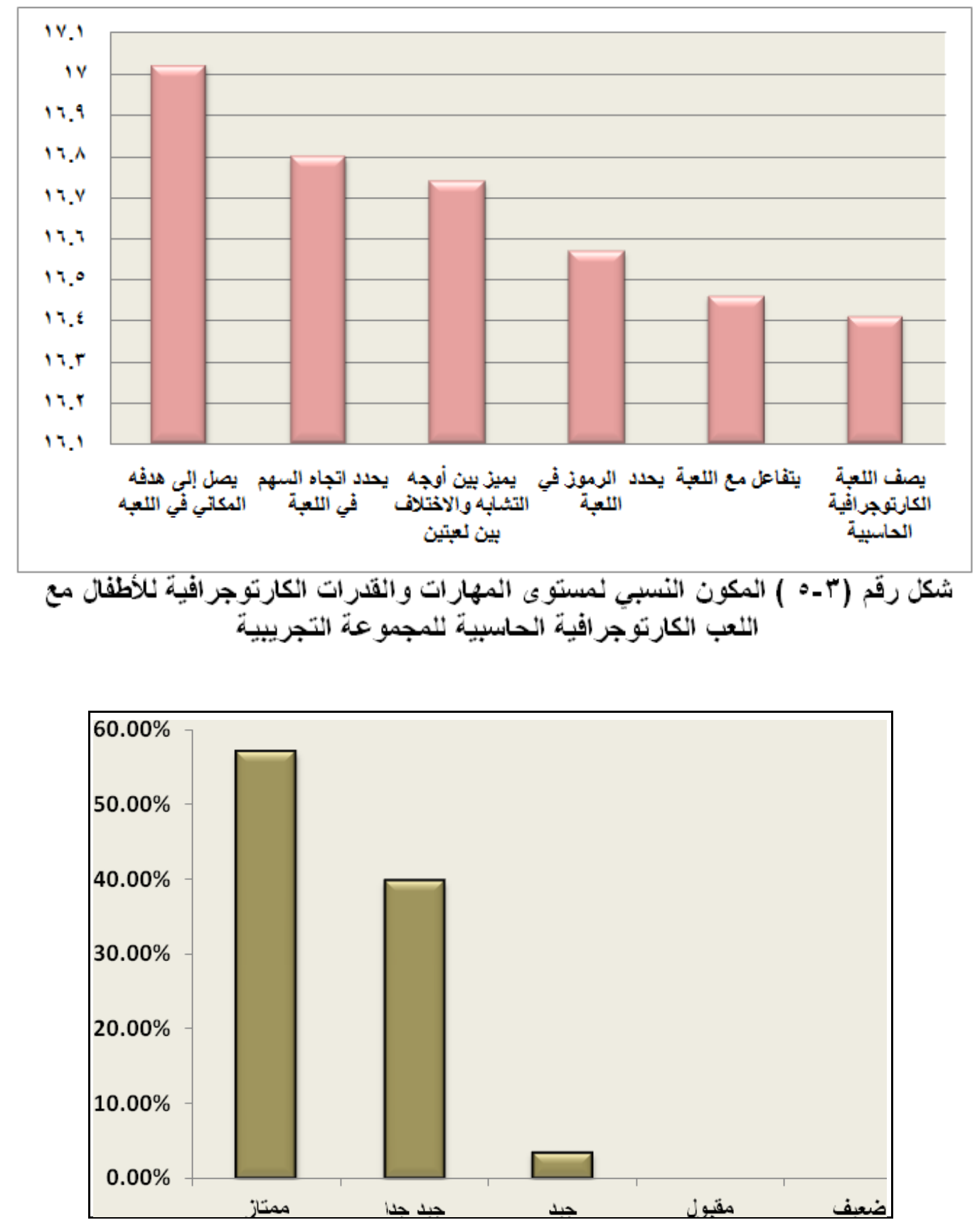

شكل رقم (r-7 ) مستويات أداء أطفال العينة مع اللعب الكارتوجرافية الحاسبية للمجموعة التجريبية 


\section{قائمة المراجع}

إبر اهيم، مجدي (ع + . rم) موسوعة التدريس، الجزء الأول، عمان: دار المسيرة.

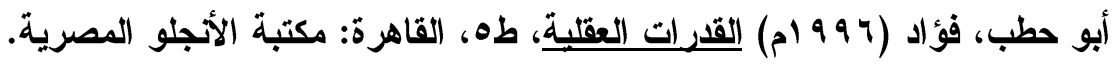

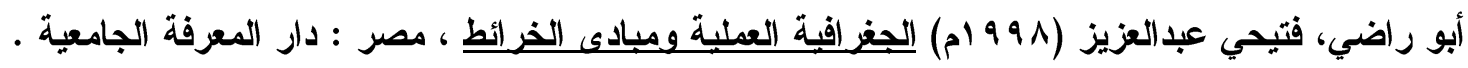

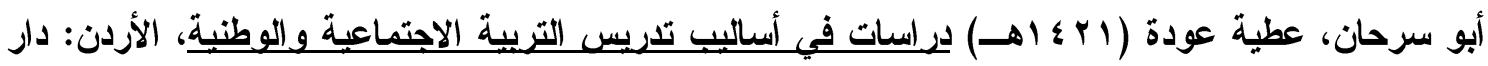

$$
\text { الخليج. }
$$

أبو علام، رجاء محمود (11 +rم) مناهج البحث في العلوم النفسية والتريوية ، طج ، القاهرة : دار النشر

$$
\text { لامبعات }
$$

الأحمد، نضال شعبان (919 ام) العلاقة بين قرة التصور البصري المكاني والنمو المعرفي والتحصبل

الار اسي في مادة العلوم بمدارس مدينة الامام، دراسات تربوية واجتماعية، المجلا (ع) ، العدد (Y) .

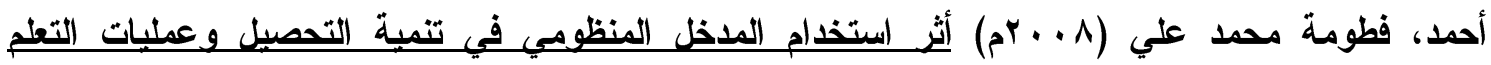

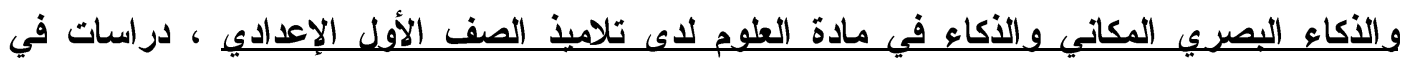

$$
\text { المناهج وطرق التدريس ، مصر . }
$$

الأحمد، أمل († + . rم) علم النفس التجريبي، دمثق: مطبعة الوحدة.

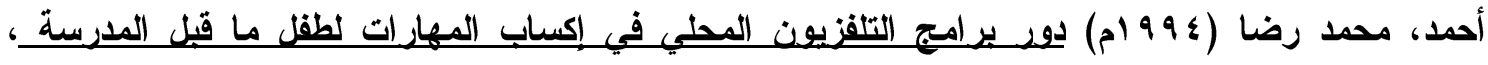
رسالة دكتور اه، الار اسات العليا للطفولة، جامعة رئة عين شمس. إسماعيل، إسماعيل يوسف وبكير ، سلوى محمد (999 ام) الملحق في تصمبير وإنتاج الخرائط، كلية الآداب ، جامعة المنوفية . إسماعيل، إسماعيل يوسف (99 99 ام) تصمبيم وتنقبذ رموز التمثلي البياني للخريطة بالحاسب الشخصية

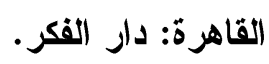
إسماعيل، إسماعيل يوسف (9 9 ام) الأطالس الإكترونبة بالوسيائط المتعددة والأطالس المطبوعة ودور ها في ،

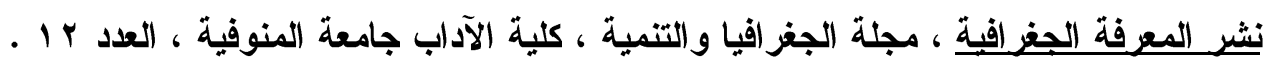

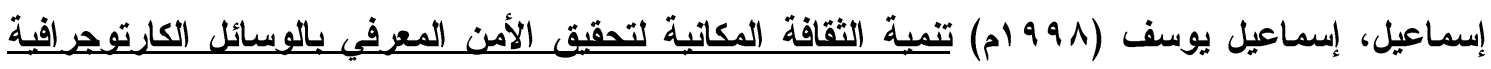
في مصر، المؤتمر البيئي الثامن لجامعة المنوفية ، القاهرة. إسماعيل، إسماعيل يوسف (9191 ام) قر اعات في البحث والتحليل الكارتوجرافي، شبين الكوم، المنوفية: دار الوثائق الجامعية للطباعة والنشر و التوزيع.

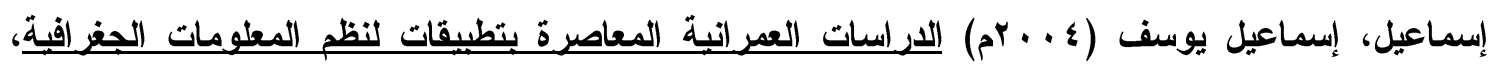
الإسكندرية: منثئة المعارف. إسماعيل، إسماعيل يوسف (991 ام) تصميِ وقراعة وتحليل الخرائط ، مركز معالجة الوثائق، المنوفية: شبين الكوم.

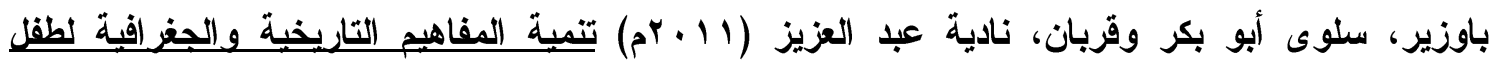

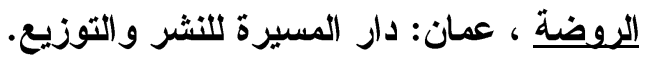


بلر، سهام محمد (1) إهـ) اتجاهات الفكر التريوي في مجال الطقولة، الكويت:مكتبة الفلاح للنشر و والتوزيع.

بدران، شبل ( . . rم) الاتجاهات الحبثية في تريية طقل ما قبل المدرسة، القاهرة: الدار المصرية اللبناتية .

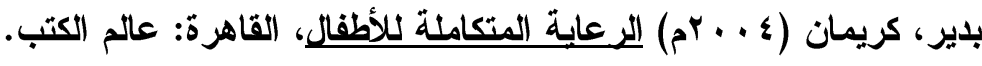

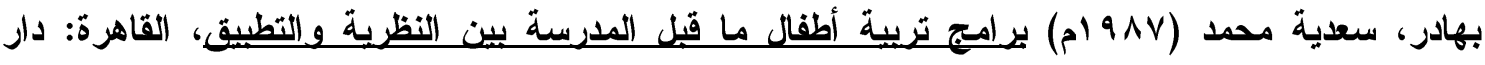
الصدر للخدمات و الطباعة.

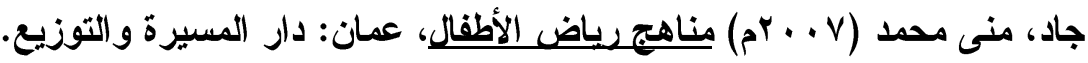

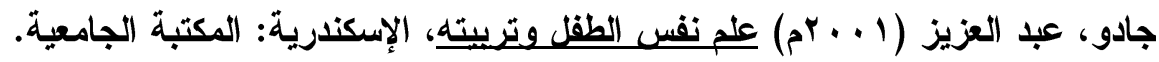

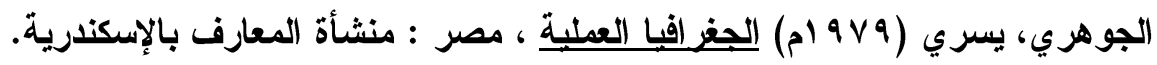

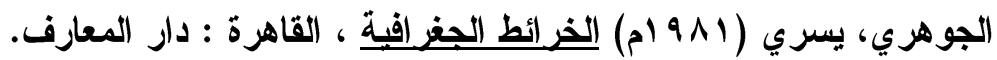

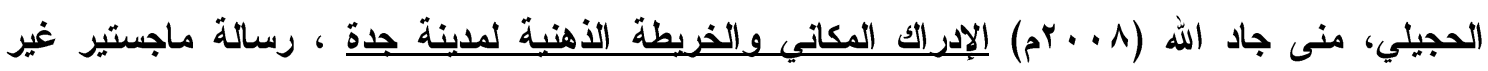
منشورة ، جدة ، جامعة الملك عبدالعزيز.

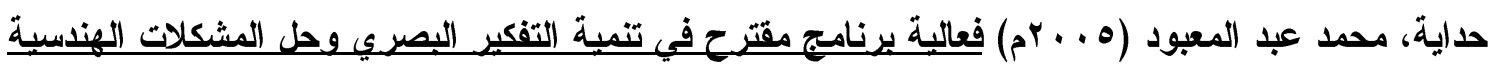

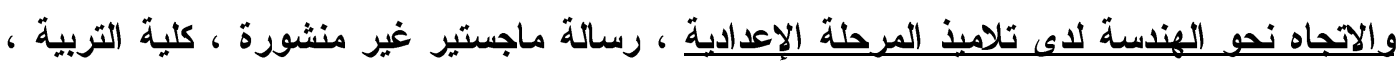
جامعة طنطا.

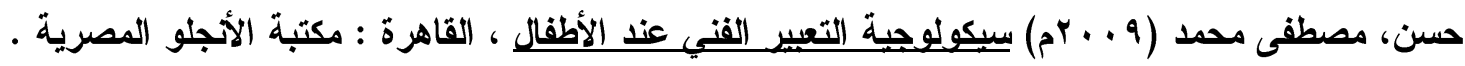

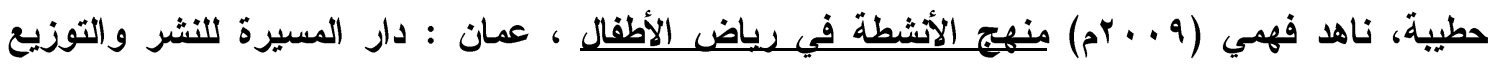
والطباعة . مانه

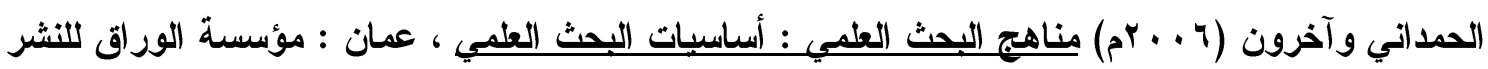

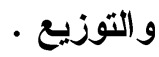

الخولي، أمين أنور وآخرون (ع 9 ام) التربية الرياضبية المدرسبة - دلبل والمراهق وطلب التربية العملية، القاهرة: دار الفكر العربي.

خير الله، سيد (1919 ام) علم النفس التريوي أسسه النظربة والتجريبية ، بيروت: دار النهضة العربية.

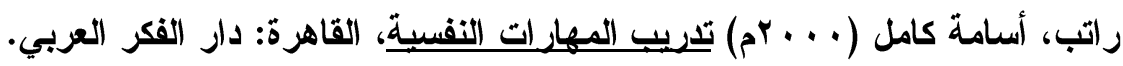
راتب، أسامة كامل (999 ام) النمو الحركي (مدخل للنمو المتكامل للطقل والمر اهق) ، القاهرة: دار الفكر العربي. رسول، فوزي أحمد (1 91 ام) التعبير البيئي في الرسم العراقي المعاصر، رسالة ماجستير، كلية (الفنون

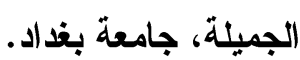

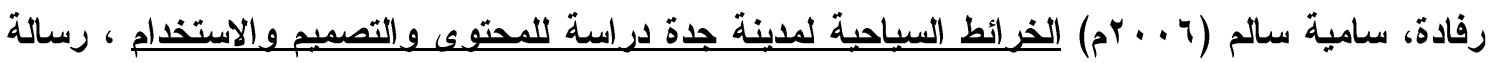
ماجستير غير منشورة ، جدة ، جامعة الملك عبدالعزيز. الرفاعي، أحمد حسين (V . . r. مناهج البحث العلمي : تطبيقات إدارية واقتصادبة ، طه، عمان : دار وائل للنشر والتوزيع · 
مركز البحوث الجغرافية و الكارتوجر افية - قنم الجغرافيا - كلية الآداب - جامعة المنوفية المؤتمر الجغرافي الدولي الثاني

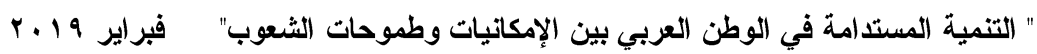

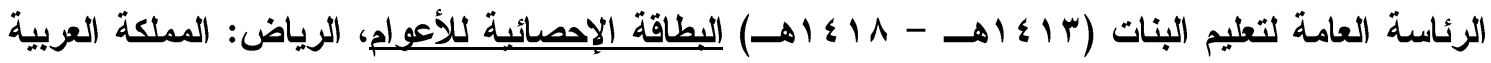

$$
\text { السعودية. }
$$

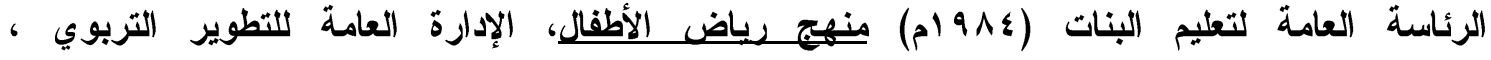

$$
\text { الرياض،المملكة العربية السعودية . }
$$

الهيئة العامة للسياحة والآثار (ه . . rم) خربطة رموز تصويربة للمملكة العريبة السعودبة ، المملكة العربية

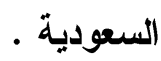

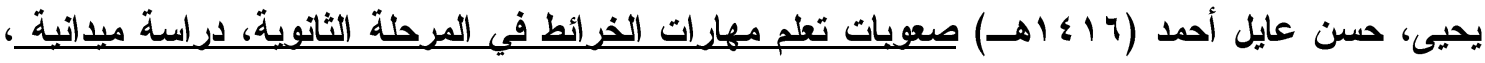

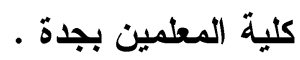

يحيى، حسن عايل أحمد (9191م) المعايير الواجب توافرها في الأطلس المستخدم في العملية التعليمبة في

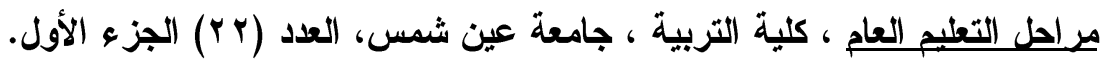

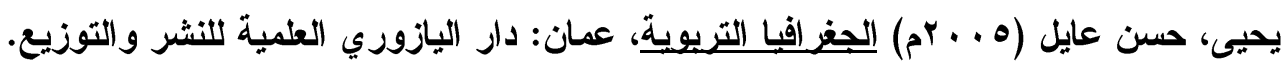

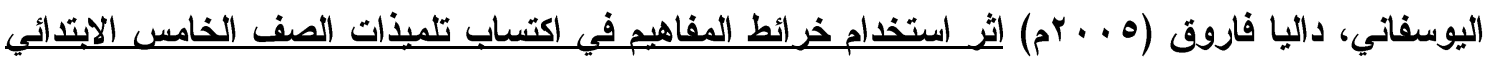
لبعض المهارات الجغرافية ، رسالة ماجستير غير منشورة ، كلية التربية الأساسية ، جامعة الموصل.

Anita Ganeri (2012) pop -up my world atlas, Templar, 1st edition.

Anita Muller (1998) Kidpix studio deluxe - soft ware overview, Argentina.

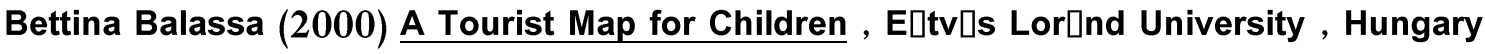

Blades, M. \& Spencer, C.(1986) Map use by young children Geography, Vol.(71), pp.47-52.

Blaut, J. M. (1999) Maps and spaces The Professional Geographer, Vol.(51), pp.510515.

Briony Penn (2008) The Kids Book of Canadian Geography, Kids Can Press, Ltd, 1st edition.

Byron Nakos, Evanthia Michaelidou, and Vasiliki Filippakopoulou (1999) The use of primary graphic elements in map design by first and second grade students, Greece .

Berry Farm Knott's ,From: https://www.knotts.com/plan-a-visit/park-map, Retrieved, November, 26, 2014.

Catling, S J.(1979) Maps and cognitive maps The Young Child's Perception Geography, Vol.(64),pp.288-295. 
مركز البحوث الجغرافية والكارتوجر افية - قسم الجغرافيا - كلية الآداب - جامعة المنوفية المؤتمر الجغر افي الدولي الثاني

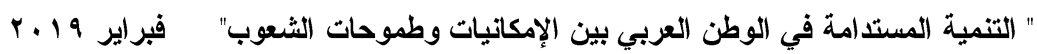

Cohen, S. (1994) Children's environmental knowledge, In R. Wilson (Ed). Environmental education at the early childhood level, North American Association for Environmental Education, Vol.(4),pp.19-22.

Costa. A\& Kallick, B(2000) Habits of Mind Activating and Engaging Habits of Mind,

U.S.A, Association for Supervision and Curriculum Development, Virginia.

Castle Howard map , From:http://www.emillustration.co.uk/blog/index.php? m=05\&y=

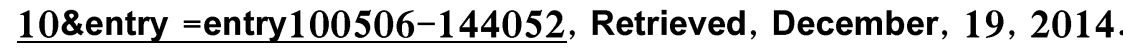

Crumpled City Junior map , From: http://www.littlestarblog.com/the-crumpled-citymap, Retrieved, January 1, 2015.

Corcoran For Design, From: http://www.wallstickeroutlet.com /wall-decordetail.php?recordid=108318, Retrieved, November, 23, 2014.

David Dean (2011) world atlas, Barefoot Atlas, 1st edition.

David J Smith (2009) If America Were a Village, Kids Can Press, Ltd, 1st edition.

David Mumford (2010) Collins Maps, 1st edition.

Deborah Chancellor (2007) Maps and Mapping, Kingfisher, 1st edition.

Deborah Chancellor (2010) Sticker Atlas, Kingfisher, 1st edition.

Deborah Saathoff Broadman \& Holman Pub (1999) Address Planet Earth ،1st Edition.

Deno,J.A.(1995) The relationship of previous experiences to spatial visualization ability , Engineering Design Graphics Journal, Vol.(59),pp.5-17.

Dora saves map, From:http://www.nickjr.com/games/dora-saves-map.jhtml, Retrieved, December, 10, 2014.

Ink Scape , From: http://inkscape.org/showcase/gallery/inkscape_rpg_map.png, Retrieved, December, 15, 2014.

Hiroshi Ota (1999) Children s skills and performance and the new cartographic education environment in Japan, Japan.

Holland, C.T.(1996) The Effects of Formal Reasoning Ability, Spatial Ability , and Type of Instruction on Chemistry Achievement ,Dissertation Abstracts International ,Vol.(57),pp. $628-629$.

HarperCollins Publishers (2012) World Atlas, 1st edition.

J Arthur Davis (2010) Panoramic Maps, from: www.panoramic-maps.com.

, Retrieved, November, 15, 2010. 


$$
\begin{aligned}
& \text { مركز البحوث الجغر افية والكارتوجرافية - قسم الجغرافيا - كلية الآداب - جامعة المنوفية المؤتمر الجغرافي الدولي الثاني }
\end{aligned}
$$

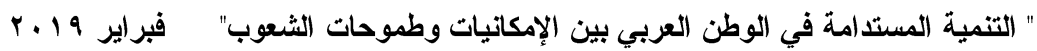

Jackie Anderson (2005) children map the world, Esri press, 1st edition. Jacqueline Anderson (1998) Introducing the map legend concept, Canada.

Jacqueline M. Anderson (2000) An Atlas Designed for children - the Electronic Approach and Reality, Canada.

Jacqueline M. Anderson(1999) Prompting children s: Cartographic concepts through an international map, Canada.

Janine Gisèle Le Sann (1999) An Atlas: The perfect tool to learn geography, Brazil.

Jean Carrière (1999) Spatial cartographic literacy and the atlas of Quebec project, Canada.

Jinny Johnson (2007) Maps and Mapping, Kingfisher, 1st edition.

Johanson (2001) Using Solid Modeling Tutorials to Enhance Visualization skills, London, Brown Communication.

José Jesús Reyes Nuñez (2000) Hungarian Homepage about Maps for Children, Hungary.

Joséphine Barry Davis (1999) Environment and curriculum designed to enhance the concept of time and space at the age of four, USA.

Kin B. Shingareva, Bianna V. Krasnopevtseva (2000) Our Experience in Extraterrestrial Mapping for Children, Moscow State University for Geodesy and Cartography , Russia.

Kentucky,From: $\quad$ http://www2.ca.uky.edu/arboretum/photos/Childrens_Garden_ map_large jpg, Retrieved, December, 16, 2014.

Mathewson ,j.h(1999) visual Spatial Thinking an Aspect of Science over looked be Educators, Science Education Journal, Vol.( 83), pp. 33-41.

Matthews, M. H. (1984) Environmental cognition of young children: images of journey to school and home area, transactions of the institute of British geographers, New Series, Vol.(9), pp. 89-105 .

Matthews, M. H.(1984) Cognitive mapping abilities of young boys and girls Geography, Vol.(69), pp.327-335.

Necla Uluğtekin and Oztug Bildirici (1999) Electronic atlases in the national education system in Turkey, Turkey . 
مركز البحوث الجغرافية والكارتوجر افية - قسم الجغرافيا - كلية الآداب - جامعة المنوفية المؤتمر الجغر افي الدولي الثاني

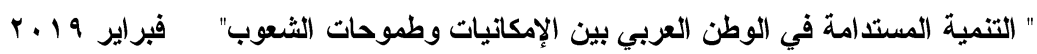

National Geographic ,From: http://kids.nationalgeographic.com, Retrieved, October ,18, 2014.

Navitz ,From: http://www.cminteriors.com/city-map-children-area-rug-39x58,

Retrieved, December, 1, 2014.

Pasty L.pierce (1994) Technology Integration into Early Childhood Curricula, where wave Been, Where we Are, where we shoulelgo.

Push pin x kokka, From: http://www.modes4u.com/en/kawaii/p4361_cute-childrenmap-Kokka-fabric-from-Japan-green.html,Retrieved, October, 26, 2014.

Patrice Pitre and Sylvie Vachon (2000) Atlas of Quebec project, 1st edition. .

Ramsey, J. \& Volk,T. (1992) Environmental education in K-12 curriculum finding a Niche, Journal of Environmental Education, Vol.(33),pp. 3545.

Rand Mcnally (1995) Beginner's classroom Atlas, 1st edition.

Robinson, A., Morrison , J., Sole, R., and Muehrcke, P. (1984) Element of Cartography, Fifth Edition, John Wiley and Son, Inc. Network.

Robinson, A.Sale, R, Morrison ,and Muehrcke (1984) Elements Cartography. 5th Ed ,John Wiley and Sons, New york.

Robinson, A.sale, R. Morrison, J.and Muehrcke (1985) Elements of cartography Fifth Edition, new York.

Rochelle Strauss (2007) The Story of Water on Earth, Kids Can Press, 1st edition.

Rosângela Doin de Almeida (1997) development of school atlases for local studies , Brazil.

Rorck publishment (2009) Keys and Symbols on Maps, 1st edition.

simon and schoster (2008) Atlas of the Universe, 1st edition.

Sam Brian (1999) Teaching Geography and mapping from terrain models ,USA.

Sara Fanelli (2001) My Map Book, Harper Festival, 1st edition.

Scot Ritchie (2009) Follow The Map, Kids Can Press, 1st edition.

Tammy Kwan (1999) The cartographical significance of a proposed map unit in the new Hong kong junior geography syllabus and teacher response, china.

Tania Targino (2000) A Rio de Janeiro School Atlas: a proposal for a local study, Rio de Janeiro, Brazil. 
مركز البحوث الجغر افية والكارتوجر افية - قسم الجغر افيا - كلية الآداب - جامعة المنوفية المؤتمر الجغر افي الدولي الثاني

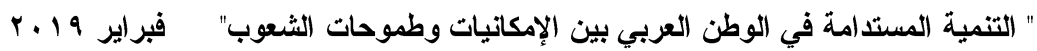

Tania Targino (2000) Cartographic language and the multi-education curriculum , Brazil.

Temenoujka Bandrova (1999) The Bulgarian national competition "A WORLD MAP" and the Barbara peacenik children s map award report, Bulgaria.

Temenoujka Bandrova, Valentina Nikolova (2000) Knowledge of Maps and Information Extraction from Them in the Bulgarian Schools, Bulgaria.

V. Filippakopoulou, B. Nakos, K Mickaelidou (2000) Children's Understanding of Generalization Transformations, National Technical University, Athens.

World Classroom Furnishing, From: http://www.classroom-furnishing.com/schoolcarpets/j-1499-wild-america-classroom-rug.htm, Retrieved, November ,12, 2014.

World Globes, From: http://www.1worldglobes.com/GeoSafari/geosafari-wonderworld-usa.htm, Retrieved, October, 11, 2014.

zone map gis ,From: http://mapzone.ordnancesurvey.co.uk/mapzone, Retrieved, December, 8, 2014.

الترقيم الدولي ” ISSN 2357-0091 


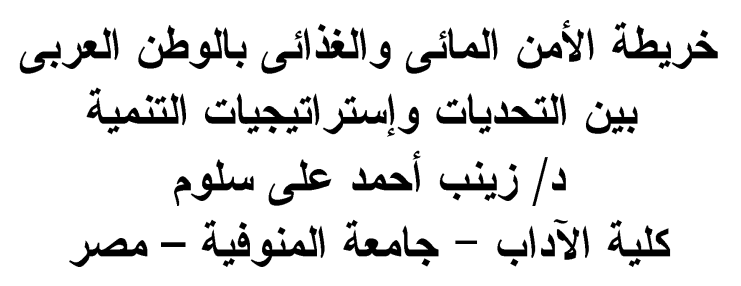

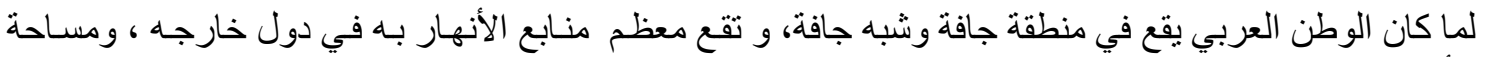

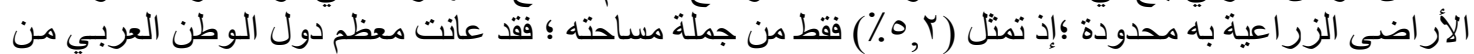

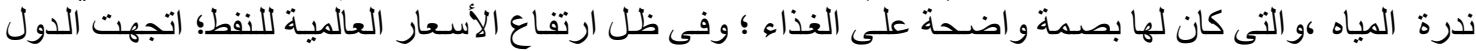

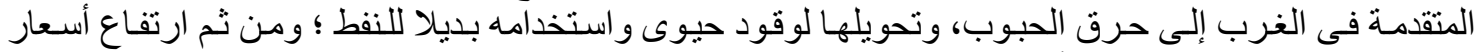

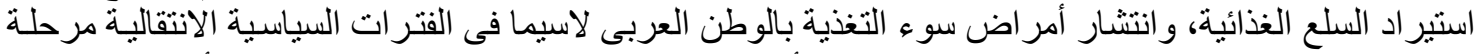

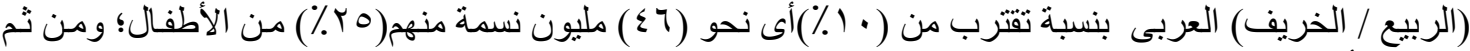

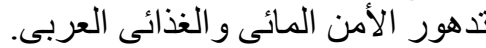

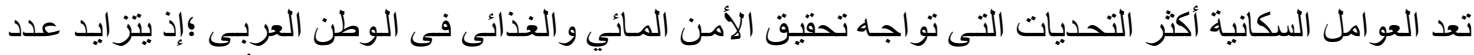

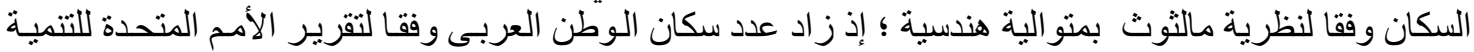

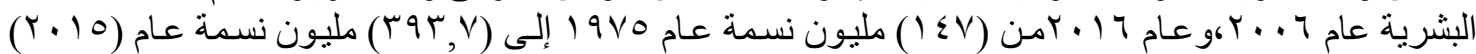

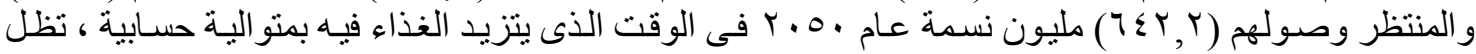

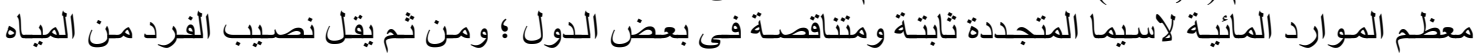

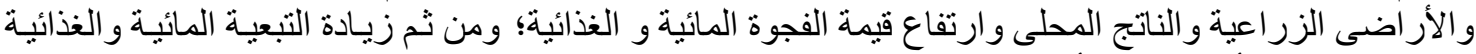

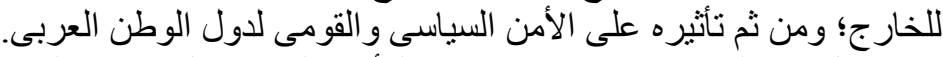

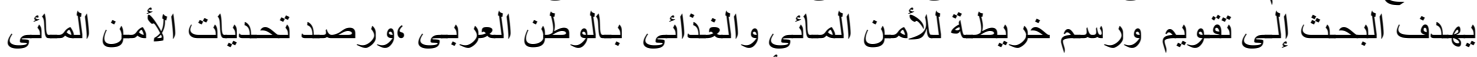
و الغذائى ، وصو لا لوضع إستر اتيجية متكاملة لتنمية الأمن المائى و الغذائى بالوطن الئن العنى العربى.

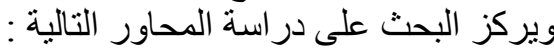

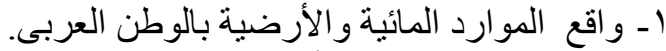

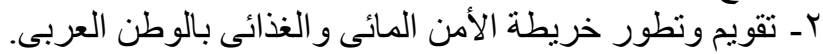

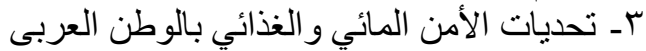
ـ - إستر اتيجية تنمية الأمن المائى و الغذائى بالوطن العربى العربى . مقدمة

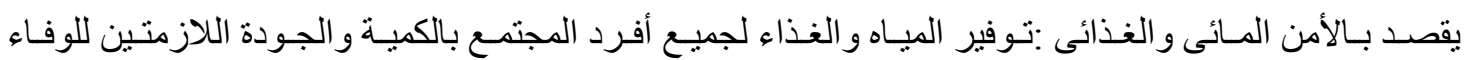

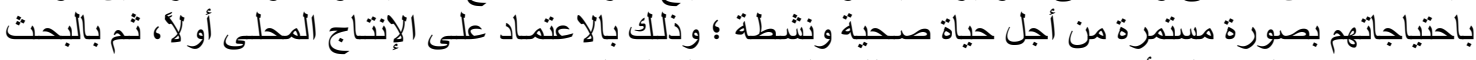

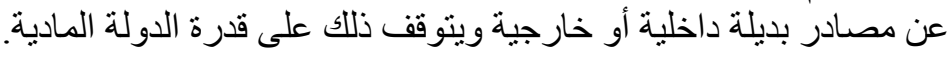

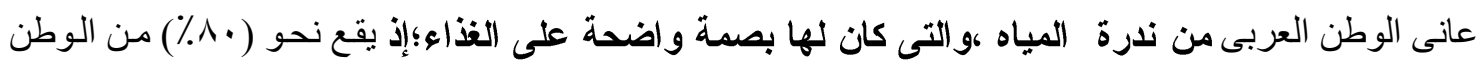

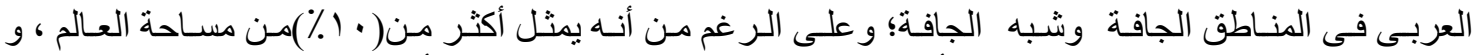

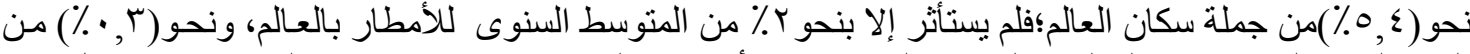

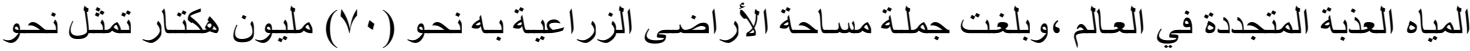

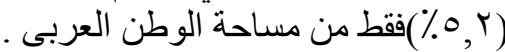

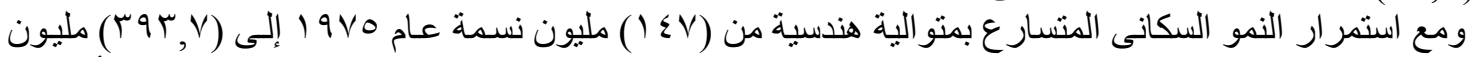

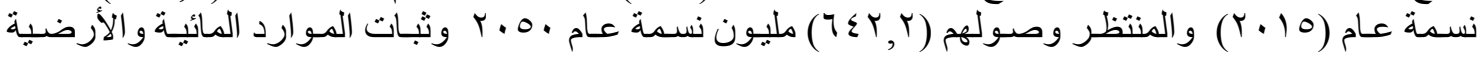




\section{مركز البحوث الجغرافية والكارتوجراقية - المؤتمر الجغرافى الدولى الثانى(r - ؛) فبراير 9 ـ بrم د/ زينب أحمد على سلوم - خريطة الأمن المائى والغذائى بالوطن العربى}

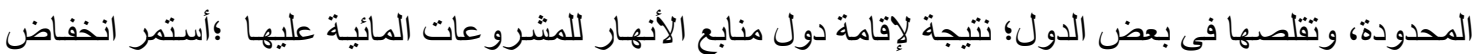

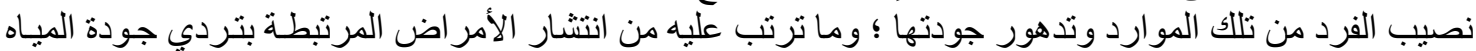

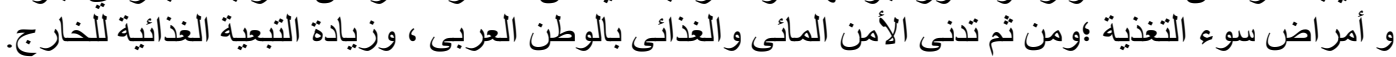

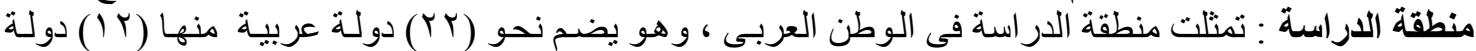

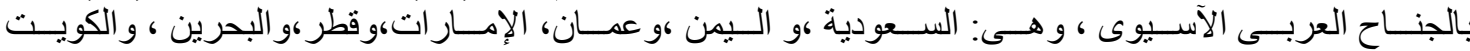

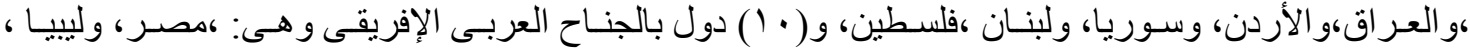

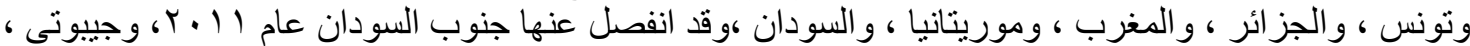

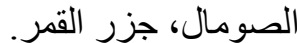

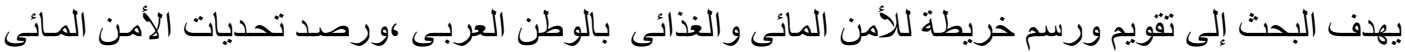

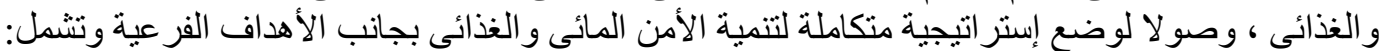

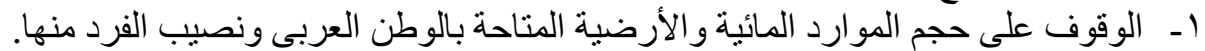

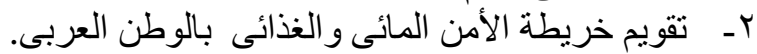

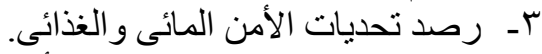
ع - و وضع إستر اتجية متكاملة لتنمية الأمن المائى و الغذائى.

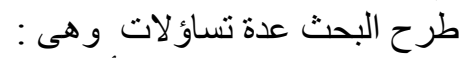

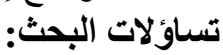

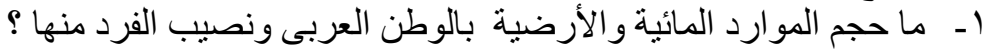

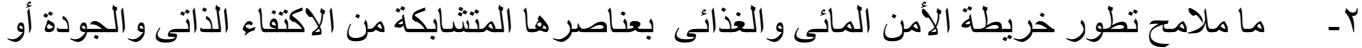

الفجوة و التبعية الغذائية ؟ مانط

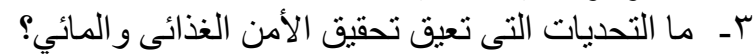

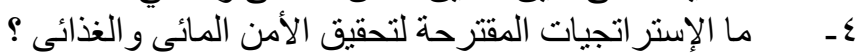

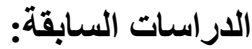

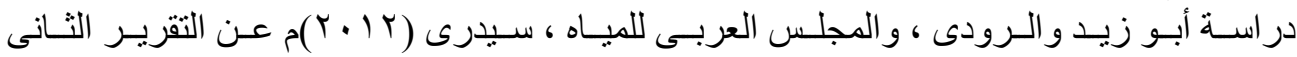

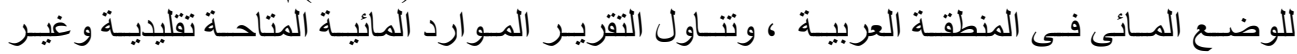

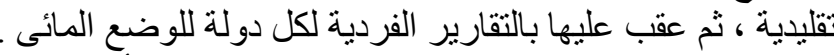

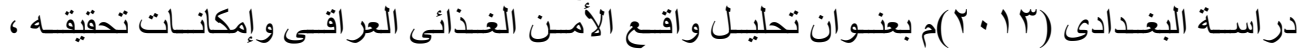

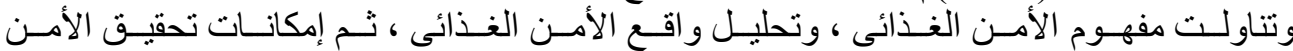

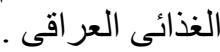

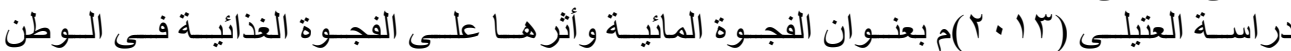

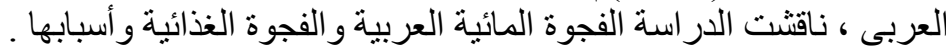

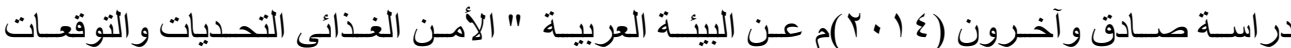

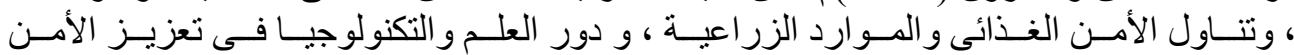

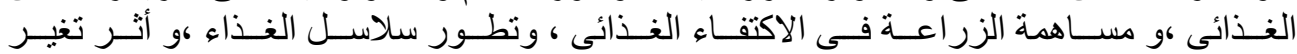

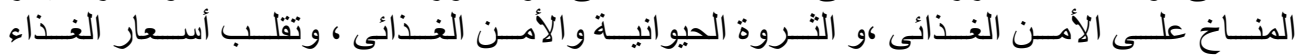

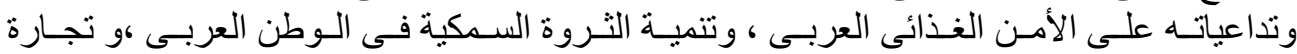

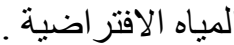

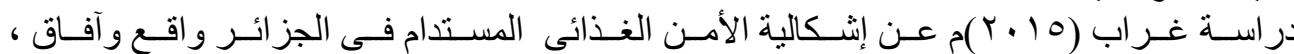

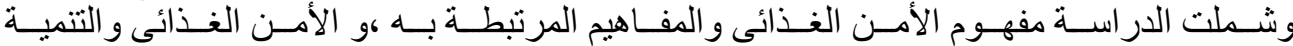
الزر اعية المستدامة ،و الإستر اتيجيات اللازمة لتحقيق الأمن الغذائى المستدام فى الجزائر . لألئ 
مركز البحوث الجغر افية والكارتوجرافية - المؤتمر الجغرافى الاولى الثانى(r - ع) فبراير 9 أمبام

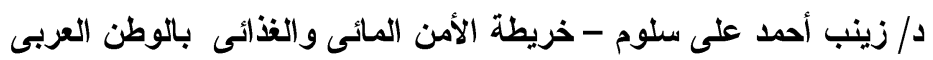

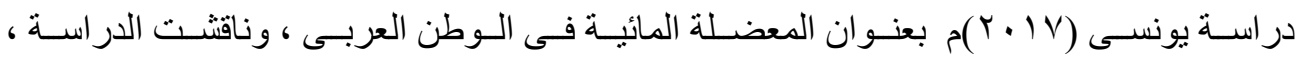

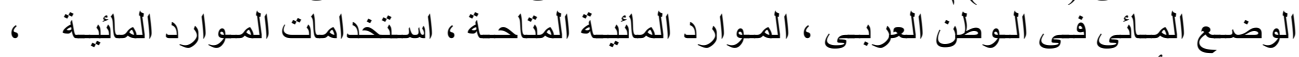

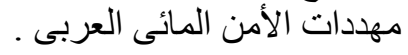

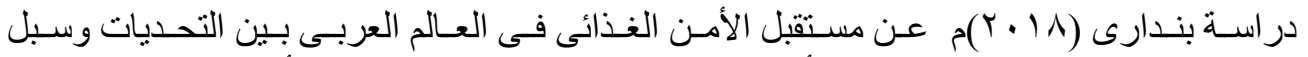

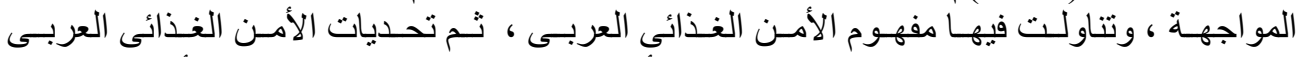

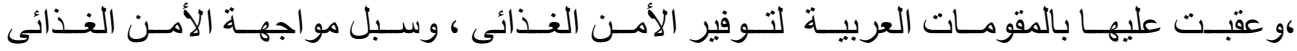

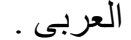

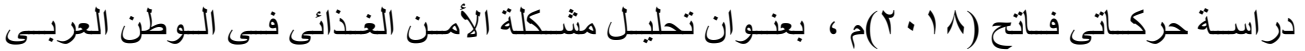

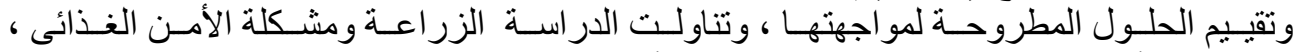

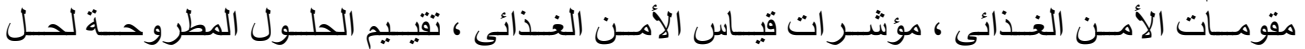

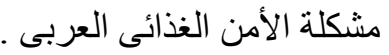

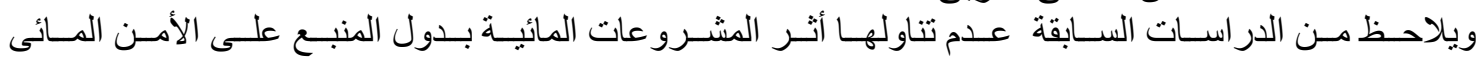

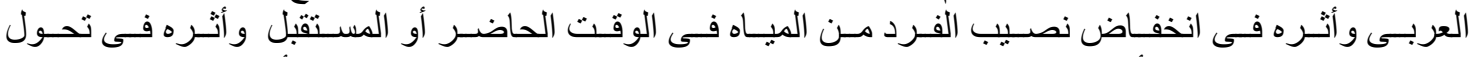

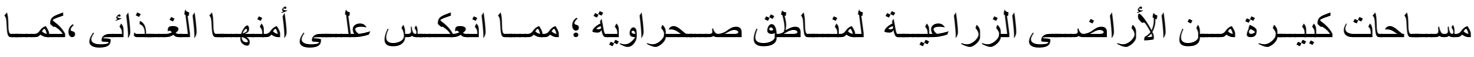

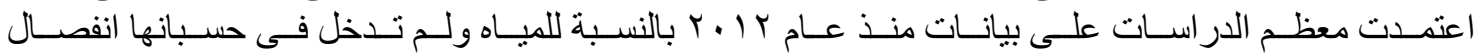

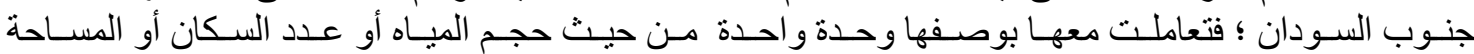

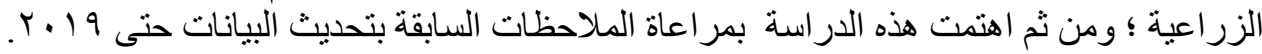
منهجية البحث:

استخدم البحث المنهج التحليلى، وقد اهتم باستخراج التثابهات والتباينات المكاتية لتوزيـــع المــوارد المائيــة

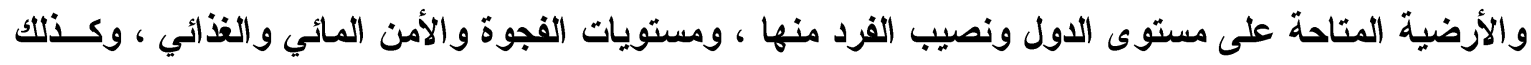

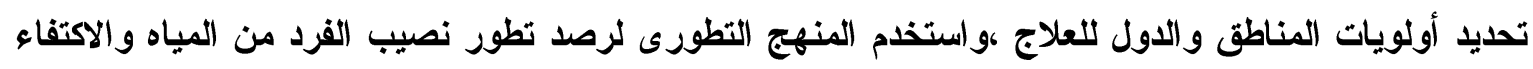

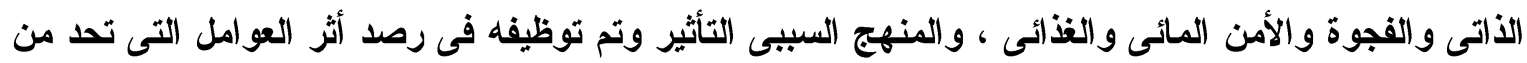

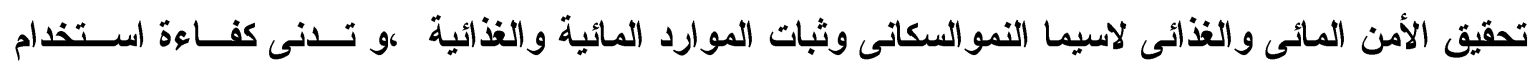

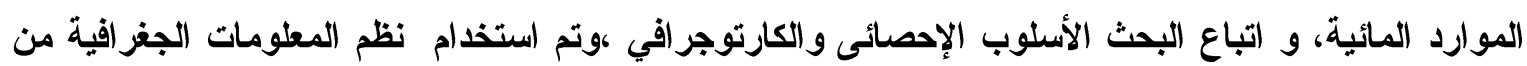

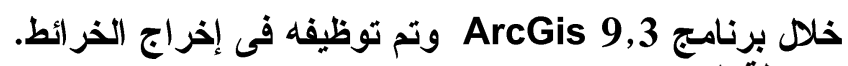

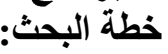

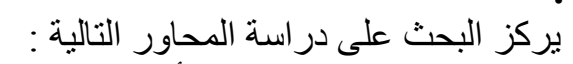

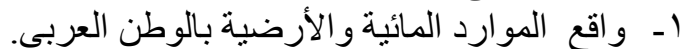

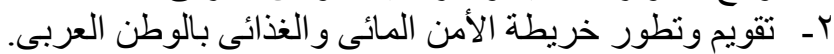

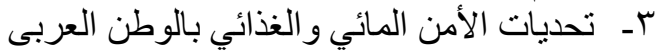

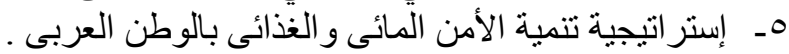

\section{(1) واقع الموارد المائية والأرضية.}

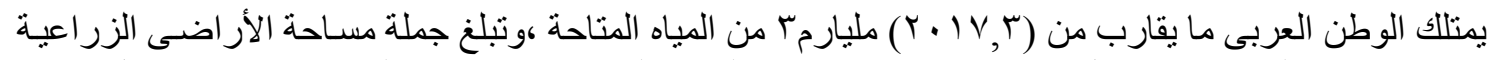

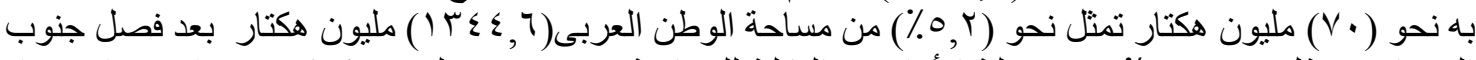

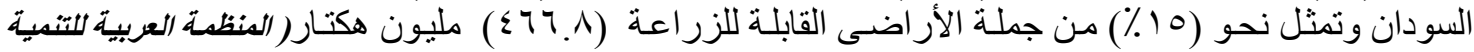

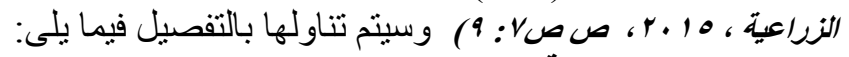
( ) الموارد المائية: 


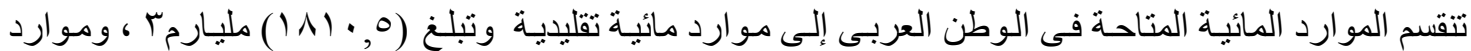

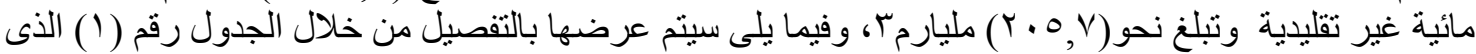

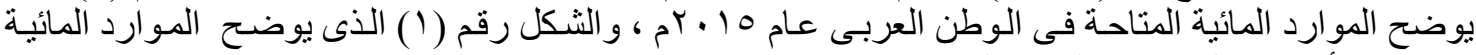

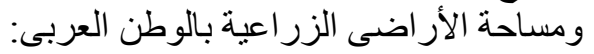

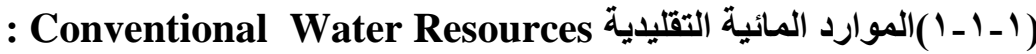

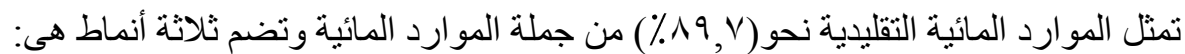

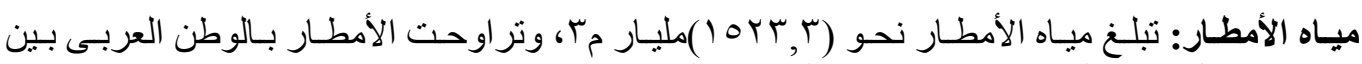

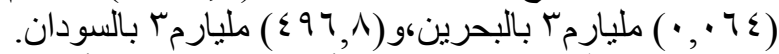

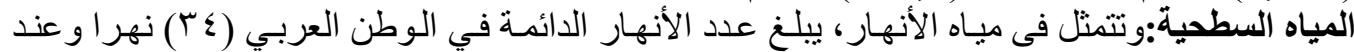

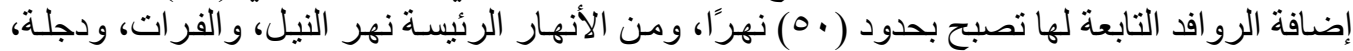

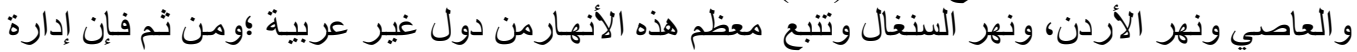

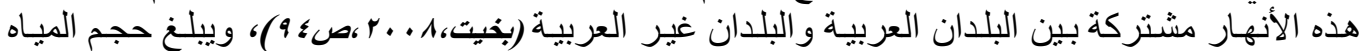

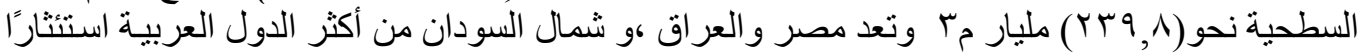

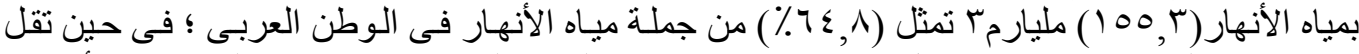

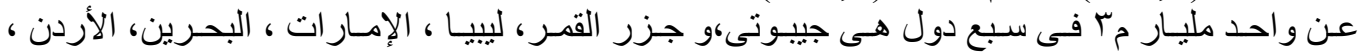

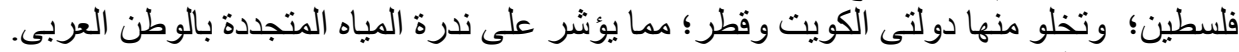

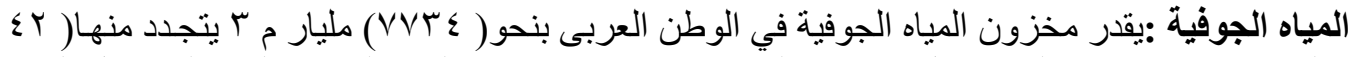

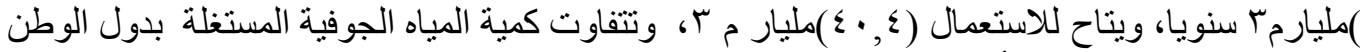

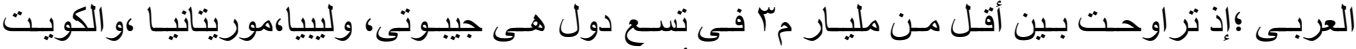

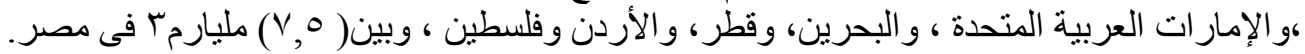

\begin{tabular}{|c|c|c|c|c|c|c|c|c|c|c|c|c|c|c|c|c|c|}
\hline 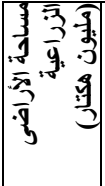 & $\bar{\jmath}$ & 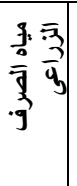 & $\begin{array}{l}\frac{g}{9} \bar{y} \\
\bar{y} \\
\cdot \mathfrak{g}\end{array}$ & $\begin{array}{l}\overline{3} \\
\overline{3} \\
\overline{3} \\
\overline{2}\end{array}$ & 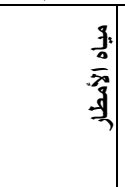 & 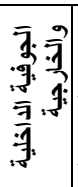 & 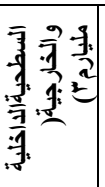 & |لبيان & 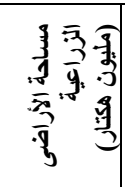 & $\overline{7}$ & 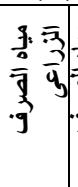 & 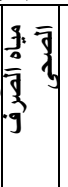 & 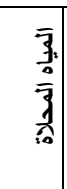 & 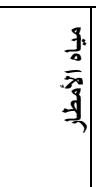 & 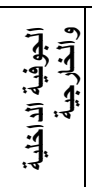 & 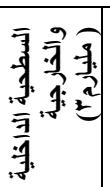 & /البيان \\
\hline$\because \cdot r$ & $r$ & $\cdot, \cdot$ & $\cdot, 1$ & $\cdot,\{$ & $r, r$ & $\cdot, \cdot$ & $\cdot$, & |الكويت & $r, v \leq$ & $7 V$ & $\cdot, 9$ & 1,1 & $1, \cdot$ & $1, r$ & $v, 0$ & 00,0 & مصر \\
\hline 1.71 & 94 & $1, \cdot$ & $\cdot, \cdot$ & $\cdot, \cdot$ & $\wedge \wedge, r$ & 1,0 & $r$, & |اليمن & YI,VT & Ory & $\cdot, \cdot$ & $\cdot, \cdot$ & $\cdot, \cdot$ & $\leq 97, \wedge$ & $r$, & $r 0, \wedge$ & السودان \\
\hline$\cdot .1 \leq$ & $\leqslant 1$ & $\cdot, \cdot$ & $\cdot, \cdot$ & $\cdot, r$ & $r \wedge, \nu$ & $1, r$ & 1,1 & عمان & $\cdot, \cdots \leq 1$ & 0 & $\cdot, \cdot$ & $\cdot, \cdot$ & $\cdot, \cdot$ & 0,1 & $\cdot, \cdot$ & $\cdot, r$ & جيبوتى \\
\hline$\because \wedge$ & 1. & $1, \mathrm{v}$ & $\cdot, r$ & $1, \cdot$ & 7,0 & $\cdot, 1$ & $\cdot, r$ & الإمارات & $1,0$. & 199 & 1, & $\cdot, \cdot$ & $\cdot, \cdot$ & $1 \vee 9,1$ & $r, r$ & $1 \leqslant, \leqslant$ & الصومال \\
\hline$\because \cdots$ & 1 & $\cdot, r$ & $\cdot, \cdot$ & $\cdot, 1$ & $\cdot, 1$ & $\cdot, 1$ & $\cdot, \cdot$ & البحرين & $\cdot, 1 Y$ & $r$ & $\cdot, \cdot$ & $\cdot, \cdot$ & $\cdot, \cdot$ & $1, \mathrm{v}$ & $1, \cdot$ & $\cdot, r$ & جزر القمر \\
\hline$\because \cdot 1$ & 190 & $\cdot, \cdot$ & $\cdot, \cdot$ & $19 \leq, r$ & $\cdot, 9$ & $\cdot, 1$ & $\cdot, \cdot$ & قطر & Y,T $1 \leq$ & 99 & $\cdot, \cdot$ & $\cdot, \cdot$ & $\cdot, \cdot$ & 91,0 & $\cdot, 7$ & $\cdot, r$ & ليبيا \\
\hline $0 . Y V$ & $171, r$ & $\cdot, \cdot$ & $\cdot, \cdot$ & $\cdot, \cdot$ & $9 \leq$, & $r, r$ & $7 \leq$ & العراق & $\{, 07$ & rq & $\cdot, 1$ & $\cdot, \cdot$ & $\cdot, \cdot$ & $r r, q$ & 1,7 & $r, \varepsilon$ & تونس \\
\hline$\cdot r \cdot$ & 11 & $\cdot, \cdot$ & $\cdot, 1$ & $\cdot, \cdot$ & 9,9 & $\cdot,^{\circ}$ & $\cdot, \mathrm{V}$ & الأردن & $\Lambda, \leqslant \vee$ & $\leqslant 7$ & $\cdot, 1$ & $\cdot, \cdot$ & $\cdot, \cdot$ & $r r, q$ & 1,0 & $1 \cdot, r$ & الجزائر \\
\hline .90 & $1 \leqslant$ & $\cdot, \cdot$ & $\cdot, \cdot$ & $\cdot, 1$ & 7,9 & $r, r$ & $r, \wedge$ & لبنان & 9,19 & $1 \wedge V$ & $\cdot, \cdot$ & $\cdot, \cdot$ & $\cdot, \cdot$ & $10 \leqslant, 0$ & $1 \cdot, \cdot$ & $r r, \cdot$ & المغرب \\
\hline $0 . V Y$ & 74 & $\cdot$ & . & $\cdot$ & $\leq 7, V$ & $7, r$ & $1 \%, 7$ & ستوريا & $\cdot, r Y$ & 1.7 & $\cdot, \cdot$ & $\cdot, \cdot$ & $\cdot, \cdot$ & $9 \leq, 1$ & $\cdot, r$ & 11,1 & موريتانيا \\
\hline .10 & $r$ & $\cdot$, & $\cdot$, & ${ }^{\circ}$, & $r$, & $\cdot, 1$ & $\cdot 1$ & فلسطين & $\varepsilon, 19$ & Irr & $\cdot 0$ & $\cdot, r$ & 1, & $1 \times 7,1$ & r, & $r, Y$ & السعودية \\
\hline$v \cdot, \cdot \leq$ & $r+I V, r$ & 0,7 & 1,1 & $19 \wedge, r$ & lorr,r & $\leqslant V, \varepsilon$ & $r r q, \wedge$ & \multicolumn{10}{|c|}{ المجموع } \\
\hline$(\wedge \wedge$, & a & & & & & & $\dot{a}^{\prime}$ & & & & & & & & 11 & 4 & 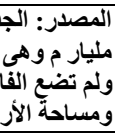 \\
\hline
\end{tabular}

شكل رقم (1) الموارد المائية ومساحة الأراضى الزراعية بالوطن العربى عام 1 ـ ب م 
مركز البحوث الجغرافية والكارتوجرافية - المؤتمر الجغرافى الدولى الثانى(r - ؛) فبراير 9 ـ ب م

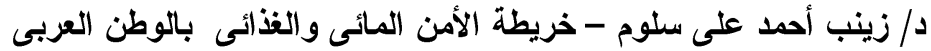

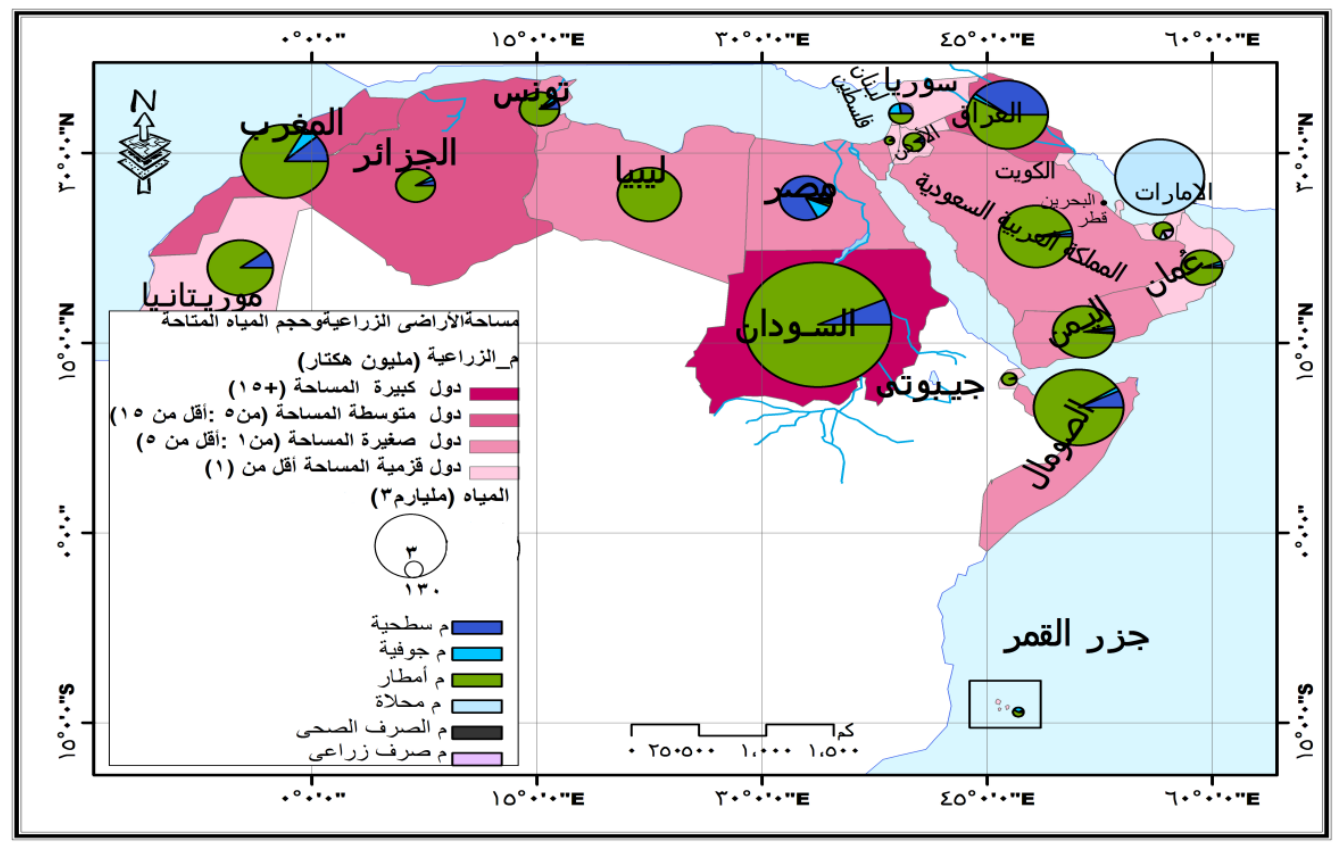

المصدر: الثكل من إعداد الباحثة اعتمادا على بيانات الجدول رقم (1)

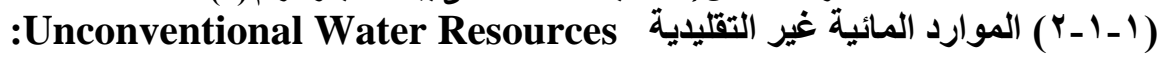

وتمثل الموارد المائية غير التقليدية نحو (r, • (\%) من جملة الموارد المائية وتشمل :

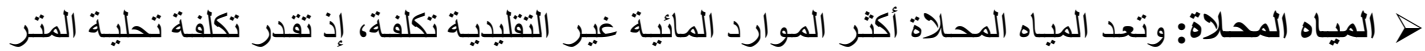

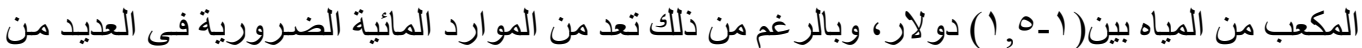

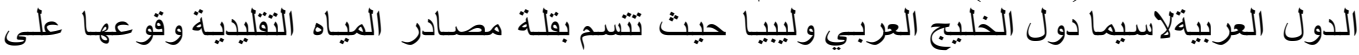

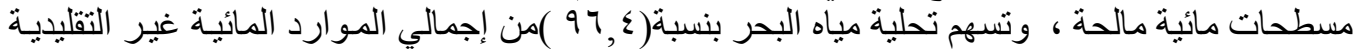

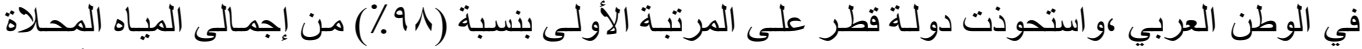

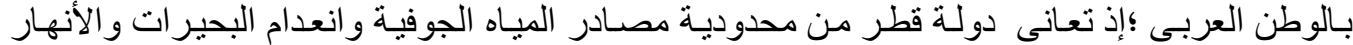

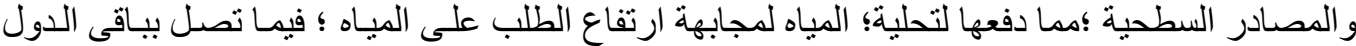

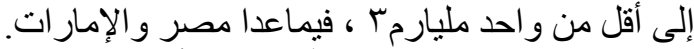

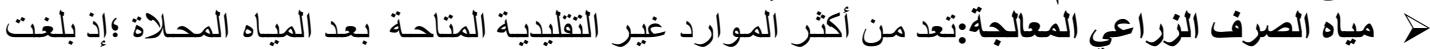

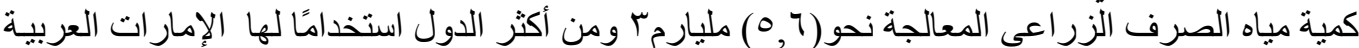

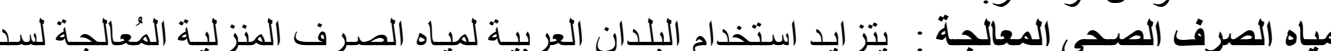

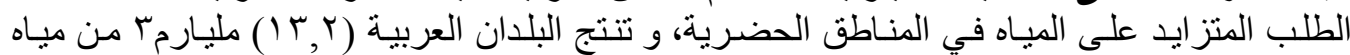

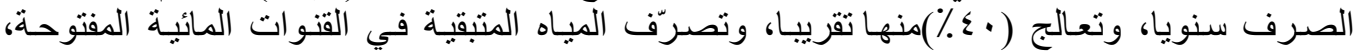

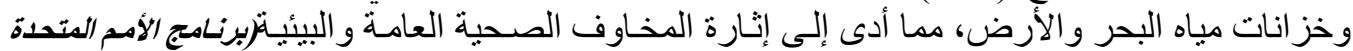

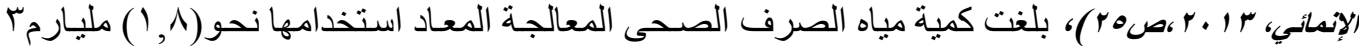

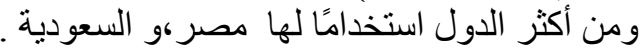

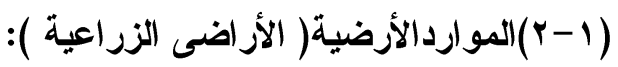

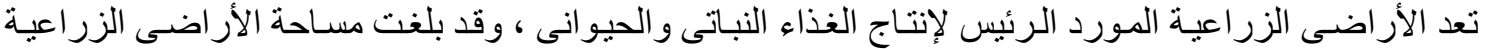

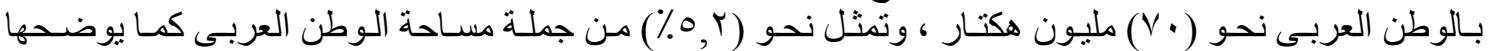


الجدول رقم (1) و الثكل رقم (1) السـابق الإشـارة إليهمـا ، وقد تباينت المسـاحة المزروعـة من دولـة إلى أخرى

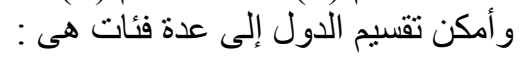

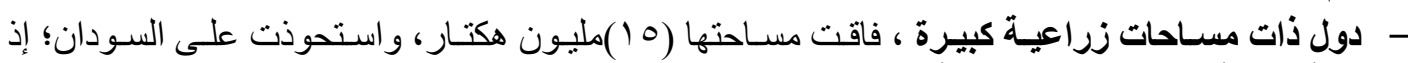

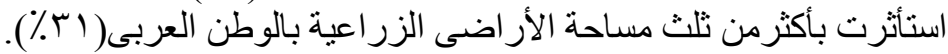

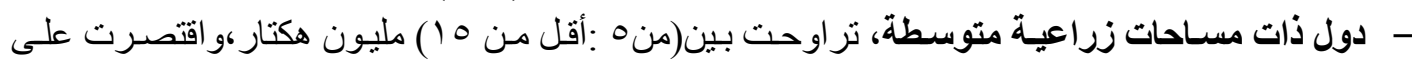

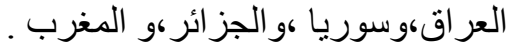

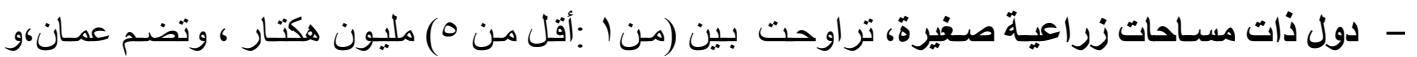

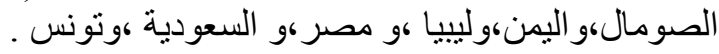

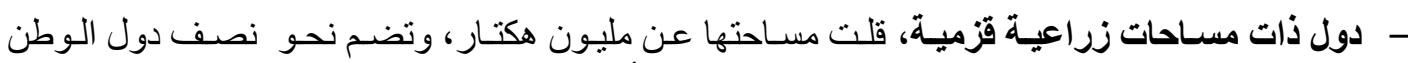

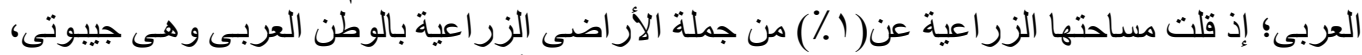

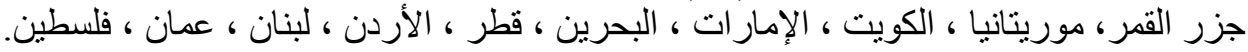

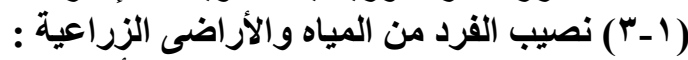

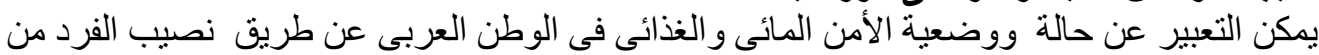

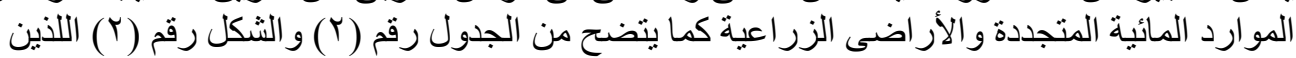

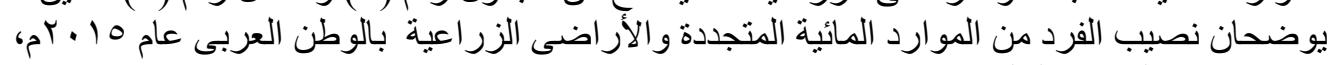
منهما تتضح الحقائق التالية:

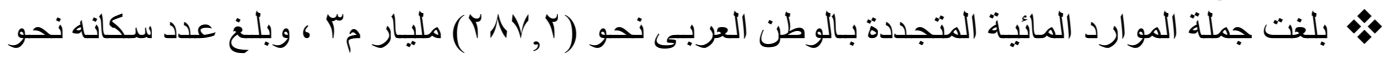

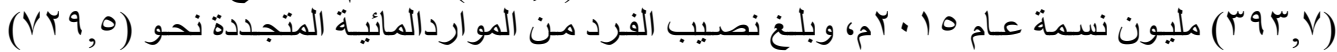

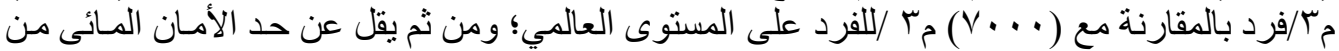

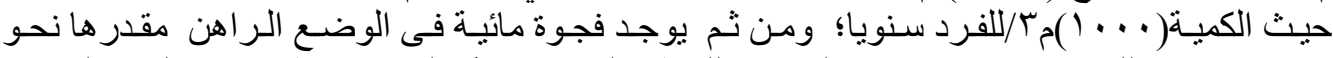
(YV.,0)

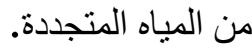

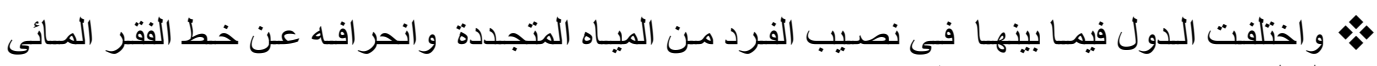

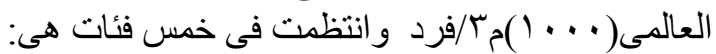

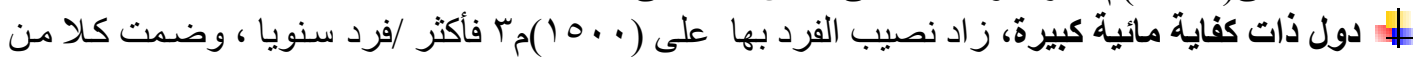

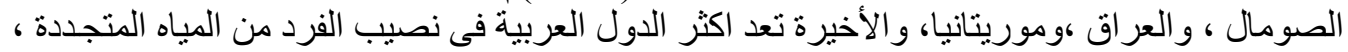

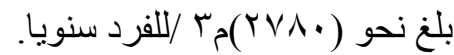

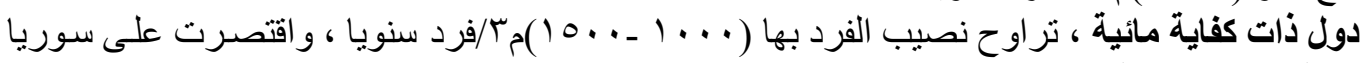

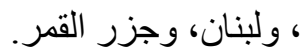

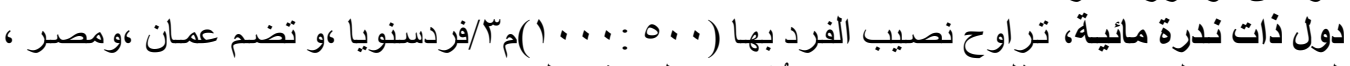

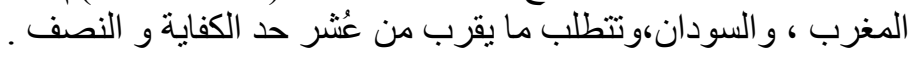

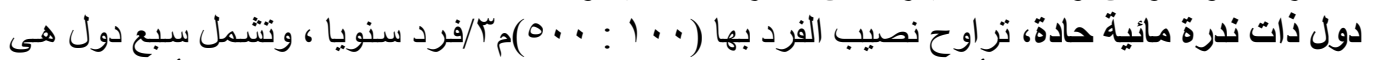

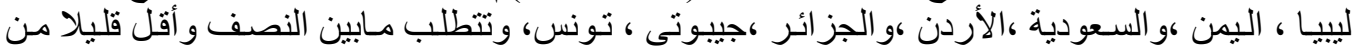

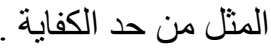




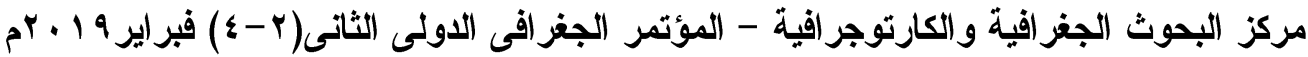

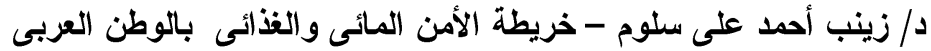

\begin{tabular}{|c|c|c|c|c|c|c|c|c|c|c|c|}
\hline \multicolumn{12}{|c|}{ 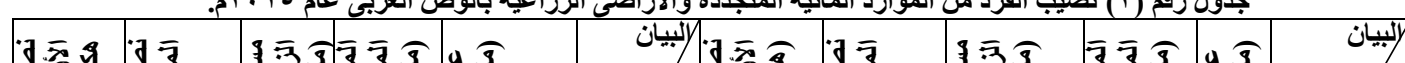 } \\
\hline 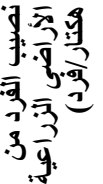 & 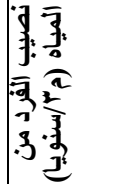 & 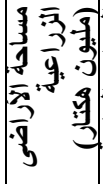 & 言示 & 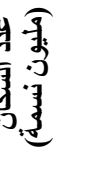 & & 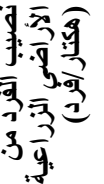 & 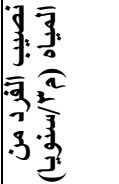 & 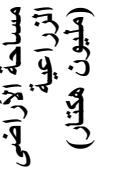 & 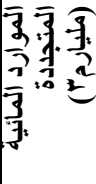 & 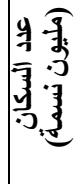 & \\
\hline$\ldots . . r$ & $\varepsilon . \Gamma$ & $\ldots r$ & $\ldots r$ & $\varepsilon . V$ & الكويت &.,.,$\varepsilon$ & $\Upsilon \wedge \Lambda, 0$ & $r, V \varepsilon$ & $i r,$. & 91,0 & مصر \\
\hline$\ldots 4$ & $14 . .4$ & 1.71 & r.० & Y4.A & اليهن & $., 0\}$ & $970, r$ & $r 1, v 4$ & $r \wedge, \Lambda$ & $\varepsilon \cdot, r$ & السودان \\
\hline$\ldots r$ & 009.0 &. $.1 \varepsilon$ & Y. & $\varepsilon . Y$ & عمان &,$\ldots \ldots$ & roo, & $\cdot, \ldots \leqslant 1$ & $\cdot, r$ & $\cdot, 9$ & جييوتى \\
\hline$\ldots 1$ & rq.r & $\ldots 1$ &.$r$ & Q.Y & الإمارآت &., $1 \varepsilon$ & $17 r \lambda, 9$ & $1,0$. & $\mathrm{IV}, \mathrm{V}$ & $1 \cdot, \Lambda$ & الصوممآ \\
\hline (...rI & AY.q & $\ldots$ &. .1 & $1 . \varepsilon$ & البحرين &., 10 & $10 \ldots$, & $\cdot, I Y$ & $1, Y$ & $\cdot, \wedge$ & جزر القمر \\
\hline$\ldots 1$ & Yo.. & $\ldots .1$ &. .1 & Y.\& & قط &.,$\leqslant Y$ & IYV, & $Y, Y \leqslant$ & $\cdot, \wedge$ & $4, r$ & ليبيا \\
\hline. $.1 \varepsilon$ & IAYT.A & $0 . \mathrm{TV}$ & TV.T & 47.9 & البعراق & .,ई। & $\varepsilon\{\xi, \xi$ & $\varepsilon, 04$ & $\theta,$. & $11, r$ & تونس \\
\hline$\ldots \varepsilon$ & 174.4 & . .r. & $1 . Y$ & V.Y & الأردن &.,$Y I$ & Yqr, & $\Lambda, \xi V$ & $11, v$ & r9,9 & الجزائر \\
\hline$\ldots \varepsilon$ & $1114 . \varepsilon$ & $\therefore r_{0}$ & V. & 0.9 & لبنان &.,$Y V$ & qYV, & 9,19 & $r r,$. & $r \leqslant, 0$ & المغرب \\
\hline . .r1 & $1.1 \varepsilon .7$ & $0 . V^{\mu}$ & $1 \wedge . \wedge$ & $1 \lambda .0$ & سوريا & $\cdot,, \wedge$ & YVA.,Q & $\cdot, r Y$ & $11, \varepsilon$ & $\varepsilon, 1$ & موريتانيا \\
\hline$\ldots r$ & Y0.1 & $\therefore 10$ &. .1 & $\varepsilon . V$ & فلسيطين &., $1 \mu$ & $1 \xi 1$, & $\varepsilon, 19$ & $\varepsilon, \xi$ & $r 1, r$ & السعودية \\
\hline., $1 \wedge$ & $V Y 9,0$ & $\mid v,, . \varepsilon$ & $Y \wedge V, Y$ & rar,v & & & & & & & \\
\hline
\end{tabular}

شكل رقم (ץ) نصيب الفرد من الموارد المائية المتجدة والأراضى الزراعية بالوطن العربى عام 10 ــrم.

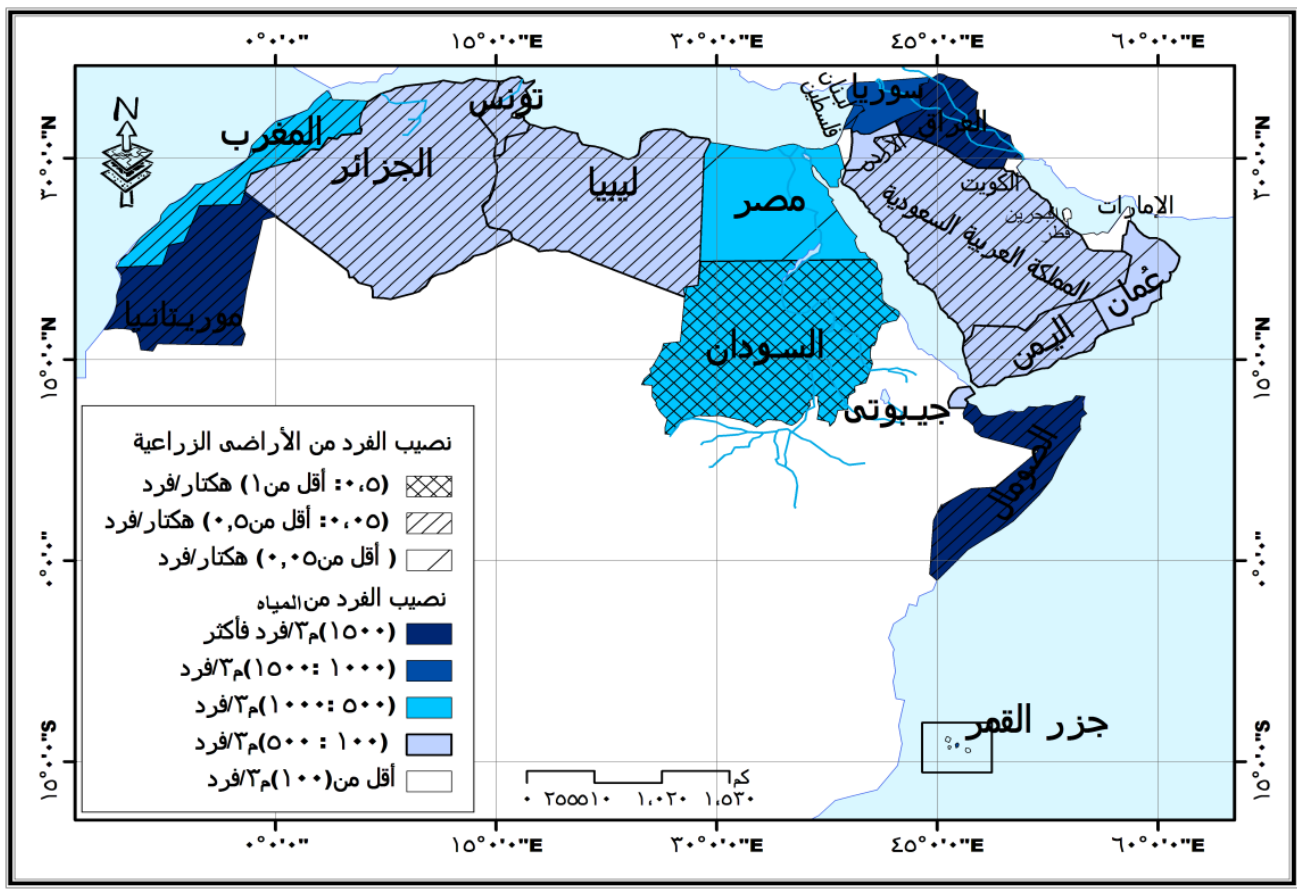

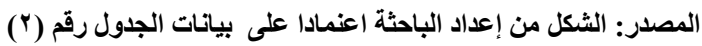

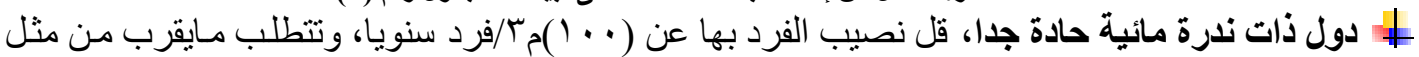

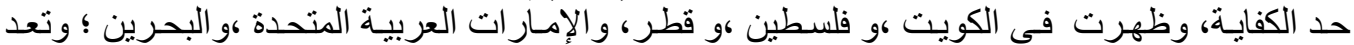

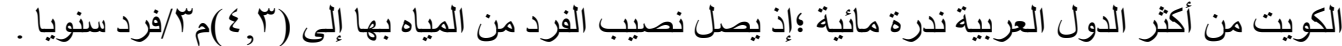

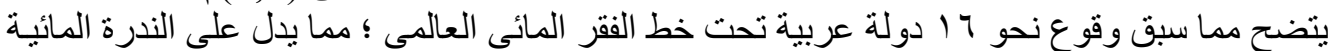

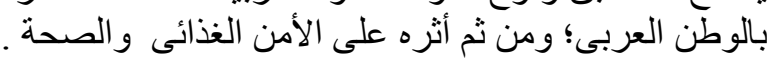




\section{مركز البحوث الجغرافية والكارتوجراقية - المؤتمر الجغرافى الدولى الثانى(r-؛) فبراير 9 ــrم د/ زينب أحمد على سلوم - خريطة الأمن المائى والغذائى بالوطن العربى}

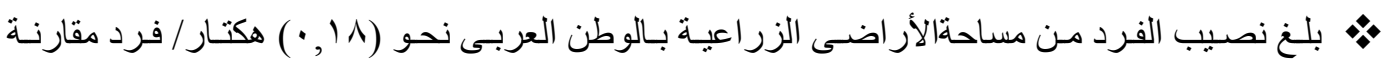

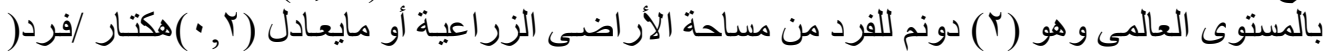

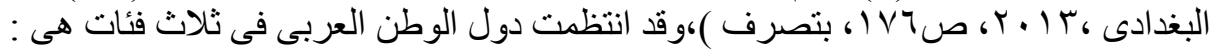

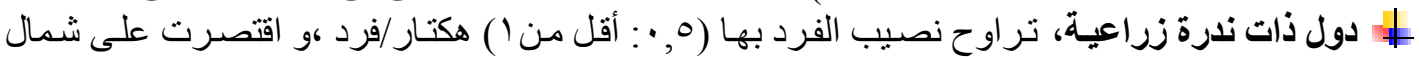

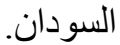

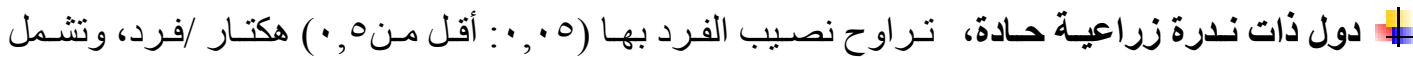

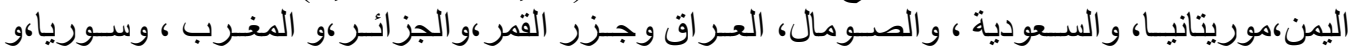
تونس،و ليبيا.

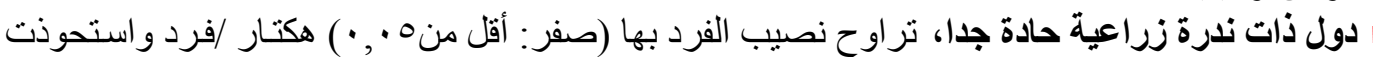

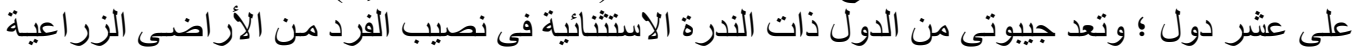

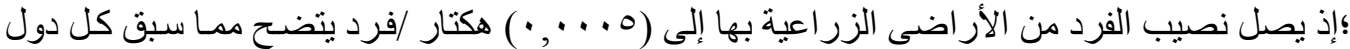

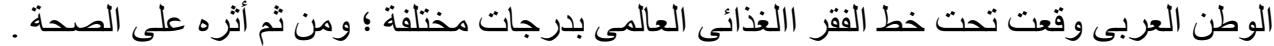

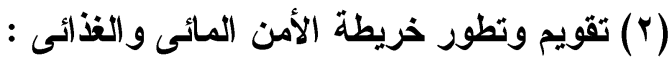

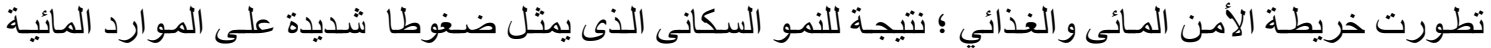

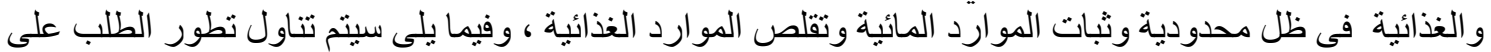

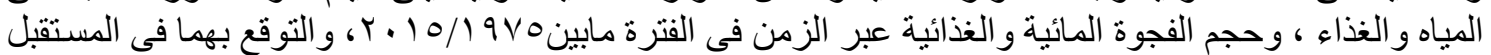

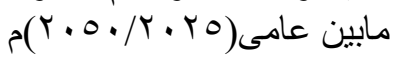

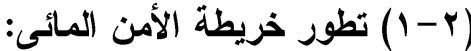

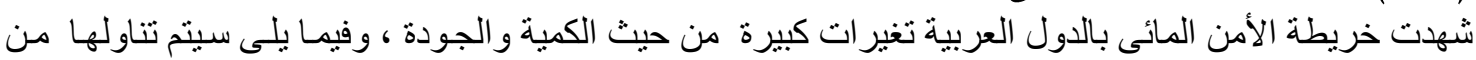

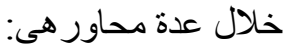

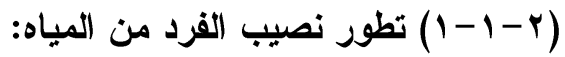

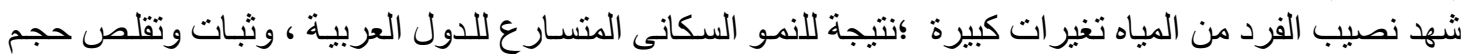

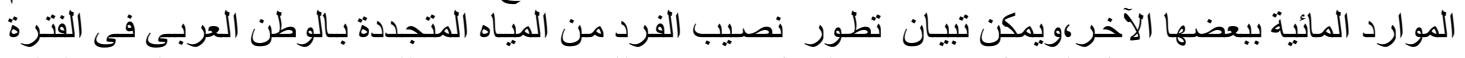

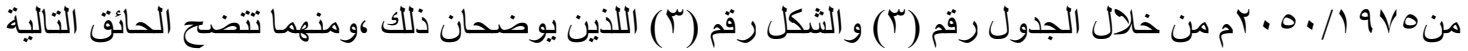

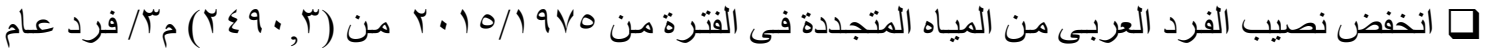

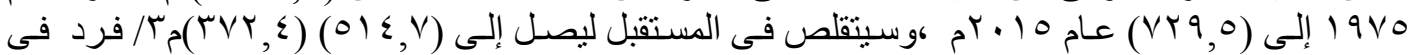

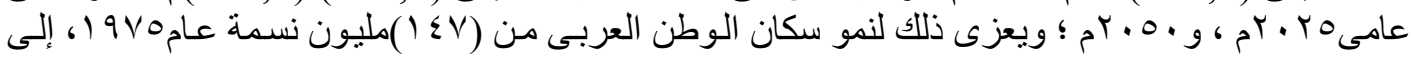

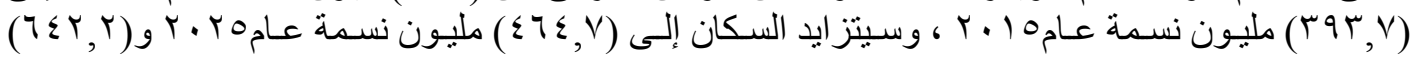

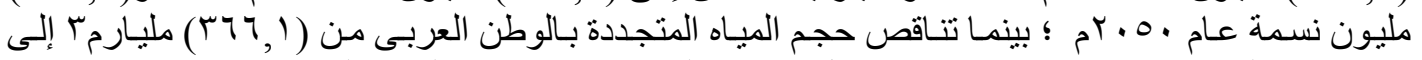

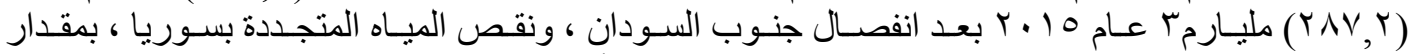

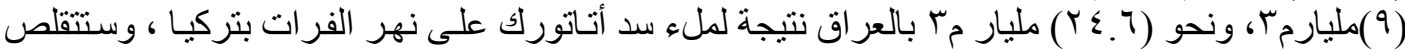

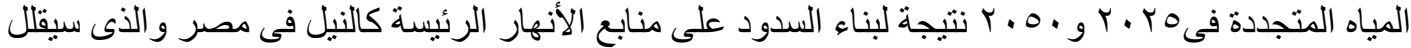

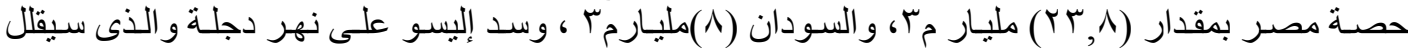

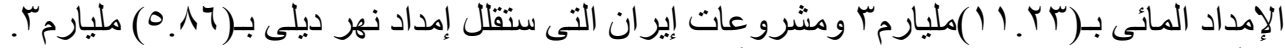

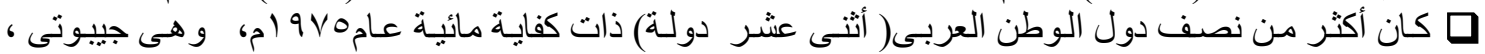

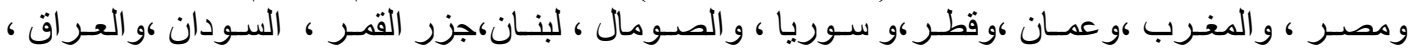

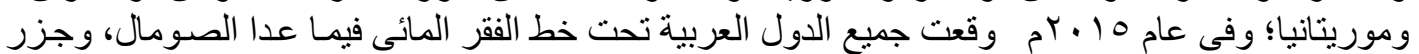

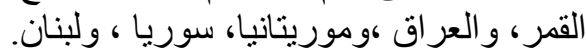




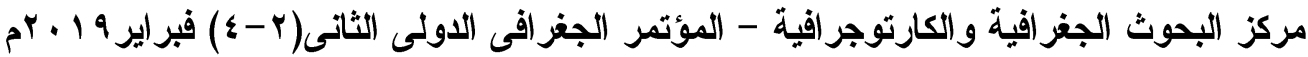

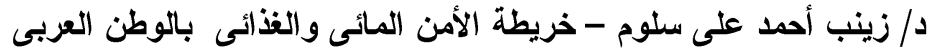

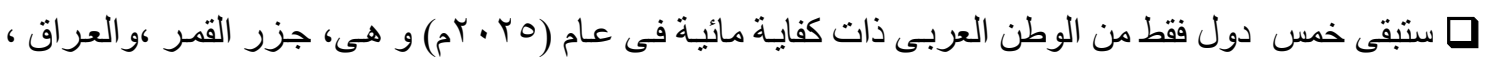

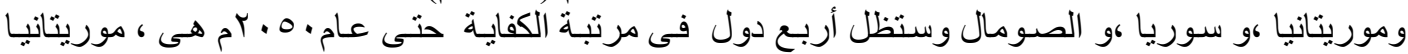

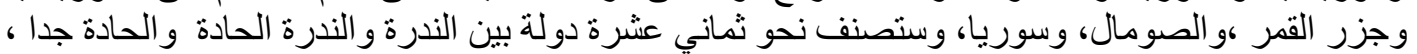

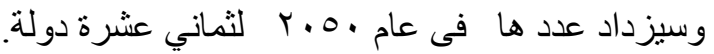

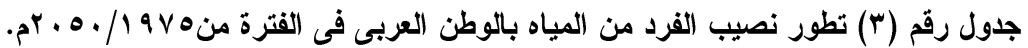

\begin{tabular}{|c|c|c|c|c|c|c|c|c|c|c|c|}
\hline فى & /فرد/ سنوي & لمتجددة & من الميا & نصيب الفرّة & \multirow[t]{2}{*}{ الأبيانة } & \multicolumn{5}{|c|}{ 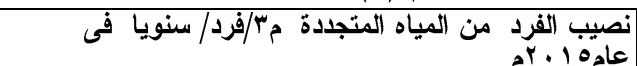 } & \\
\hline Y.O. & Y.YO & $Y .10$ & $\gamma_{\ldots} . . \varepsilon$ & $19 \sqrt{2}$ & & Y.O. & Y.YO & $r .10$ & $r \ldots \leqslant$ & 1980 & \\
\hline 1.1 & r. & $\varepsilon . \Gamma$ & $V . V$ & $r \cdot{ }^{\prime}$ & الكويت & $Y \otimes \wedge, T$ & $7 \%, 7$ & $7 \Lambda \Lambda, 0$ & 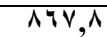 & $17.4,1$ & \\
\hline VY.V & $1 . V_{.} \cdot$ & $14 \cdot .7$ & IVT.E & $0 \ldots$ & اليمن & 001 & 994 & $970, r$ & rq.., & orqv, & \\
\hline$r \leqslant \leqslant . \wedge$ & $\varepsilon 1 Y . \Gamma$ & 009.0 & $9 \leqslant .$. & Y 711.1 & عمان & Y $47, V$ & TrY, & $r 00,7$ & $\varepsilon \cdots$, & $17 \cdots$, & \\
\hline $1 \cdot .9$ & $19 . v$ & Y9.r & $r \leqslant .9$ & $r \leqslant .9$ & الإمارات & $1.04,7$ & $1 \leqslant 17$, & $17 r \wedge, 9$ & $19 \Lambda \Lambda, \Lambda$ & rV7 , & \\
\hline TY. & $00 . Y$ & Ar.q & $170 . \mathrm{V}$ & rर४.V & البّحرين & $10 \ldots, 9$ & $10 \cdots$, & $10 \cdots$, & $10 \cdots$, & $\xi \ldots, \cdot$ & القة \\
\hline$\Lambda_{.} \cdot$ & 10.5 & ro. & VYO. & rq... & قطز & $9 V, 7$ & 118,9 & TrV, & $1 \leqslant ., \varepsilon$ & Trr, & \\
\hline$\vee \wedge \bullet . \wedge$ & $11 Y 0.1$ & IAYY.A & Yrq9.V & VTO..s & العراق & $r r r, r$ & $\varepsilon .7,0$ & $\leqslant \leqslant 7, \leqslant$ & $0 \cdots, \cdot$ & $\Lambda \vee V, r$ & \\
\hline$\Lambda \wedge .7$ & 1151.9 & Tr. & YYI.\& & 704.7 & الاردن & TNT, $\varepsilon$ & Yo.,o & Yqr, r & זั1, & $V \Gamma 1, r$ & \\
\hline 011.0 & 人ัฐ. & $11 \times 4 . \varepsilon$ & r....* & $\Gamma \wedge \Lambda . \wedge$ & لبنان & $v \cdot 1, \Lambda$ & $\Lambda \leqslant \Lambda, \wedge$ & $q r V, 0$ & $1 . r Y, r$ & $1 \wedge \leqslant q, V$ & ز \\
\hline $1 . \mu 1 . r$ & $1 \cdot r \cdot .1$ & $1.1 \leqslant .7$ & $1 . r V .7$ & rOVY.r & سوريا & $10 \cdots$, & TrTO, r & $r V A \cdot, 0$ & rs.., & $\Lambda 1 \leqslant r, q$ & \\
\hline $1 \varepsilon . \varepsilon$ & $Y \cdot . V$ & YO. & TY.N & $9 \cdot .1$ & فلسطين & $\Lambda, r$ & $117, \mathrm{~V}$ & $1 \leqslant 1,0$ & $T \wedge \Gamma, r$ & $7 . r, V$ & \\
\hline$r v \cdot, q$ & $01 Y, 7$ & VYq,o & $1 \cdot \Lambda Y, \cdot$ & $r \leqslant q \cdot, r$ & & & & & & & \\
\hline
\end{tabular}

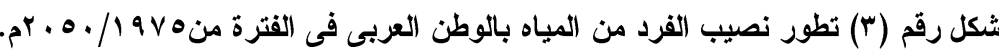

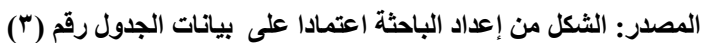

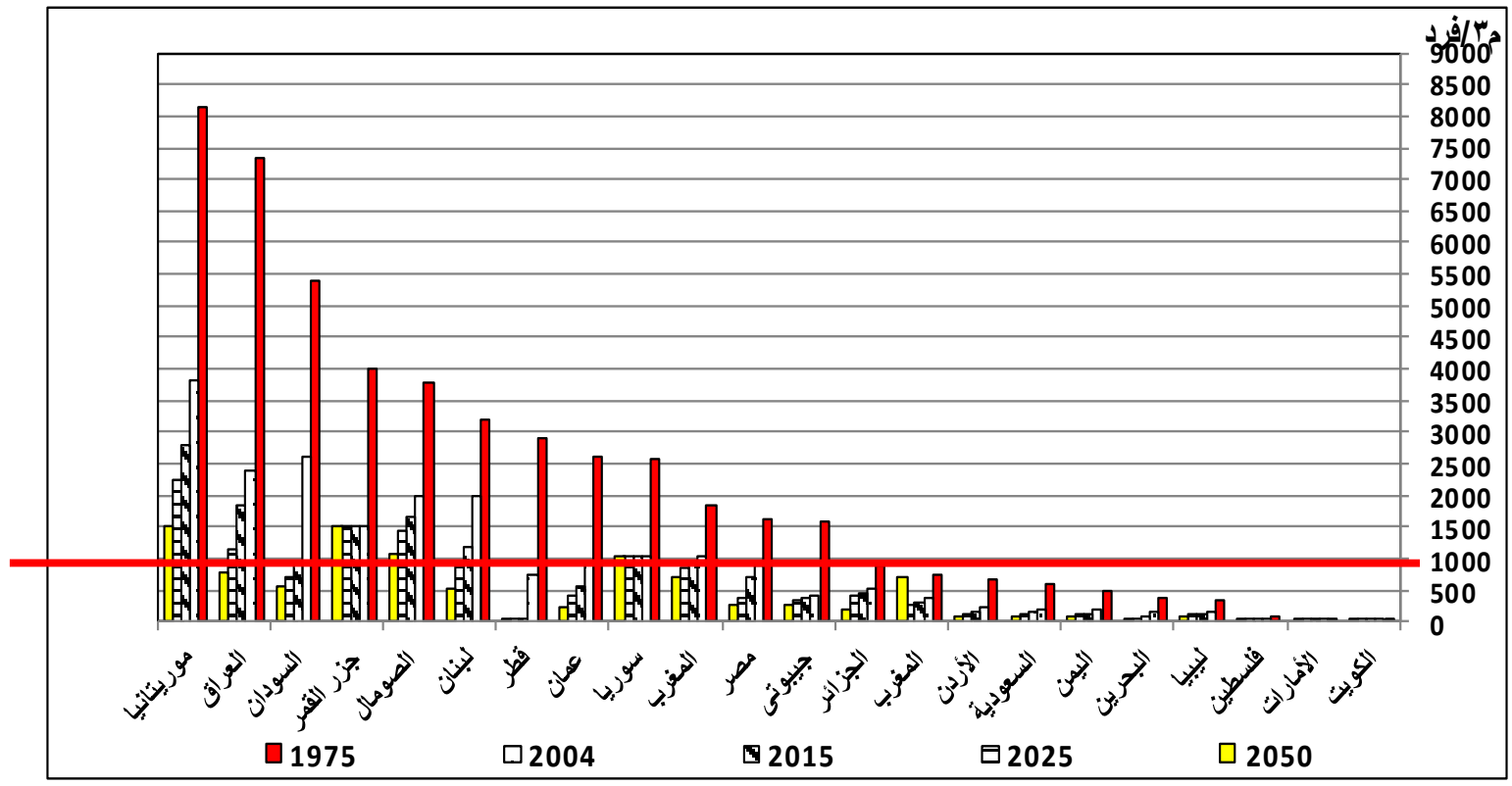




\section{مركز البحوث الجغرافية والكارتوجراقية - المؤتمر الجغرافى الدولى الثانى(r-؛) فبراير 9 ــrم

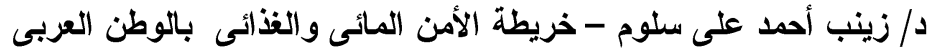

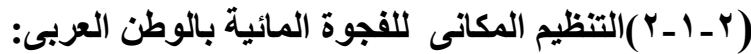

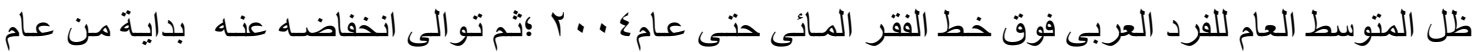

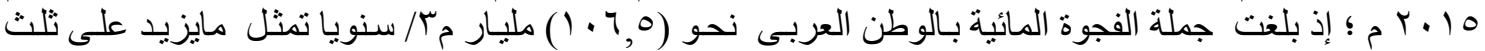

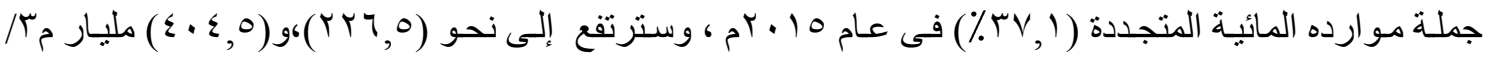

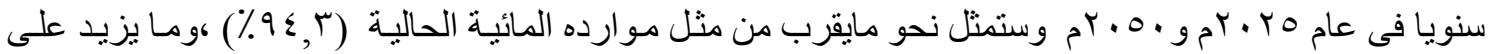

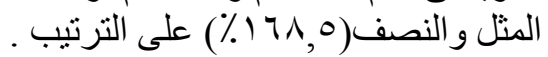

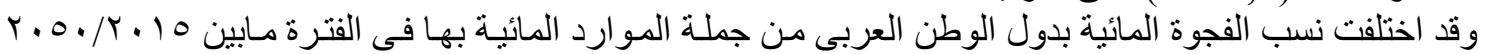

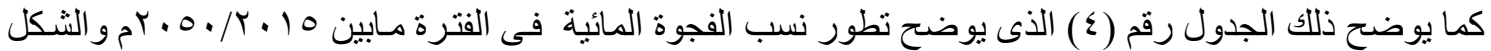

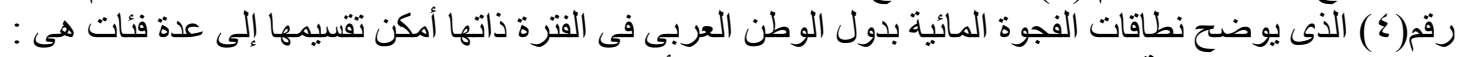

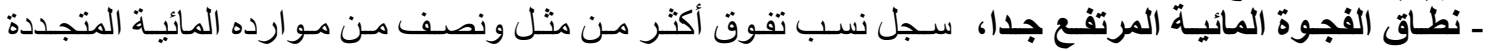

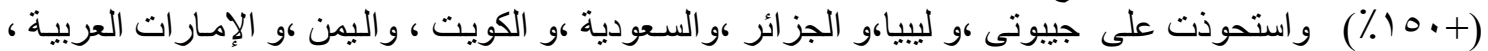

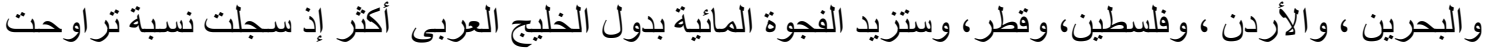

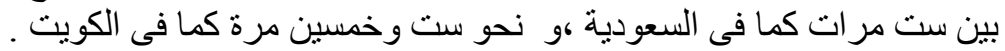

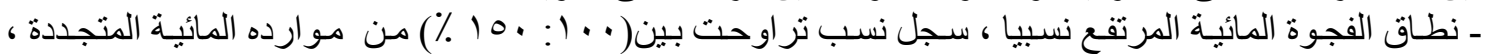

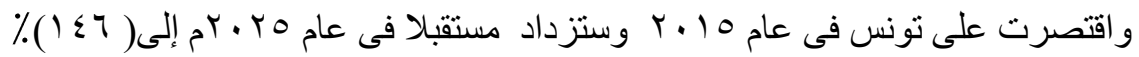

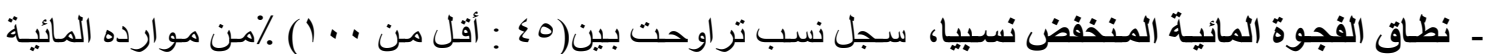

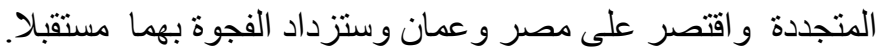

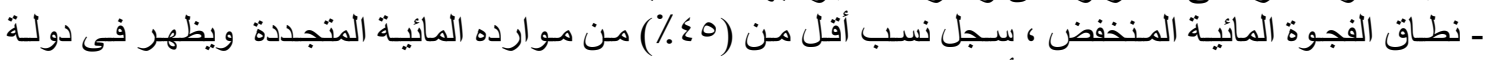

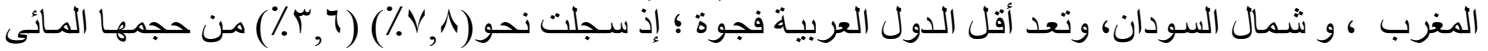
r. 10

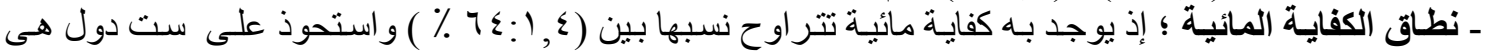

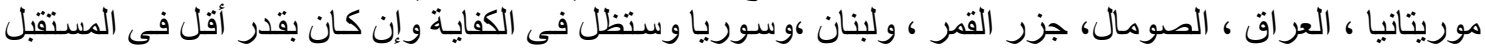

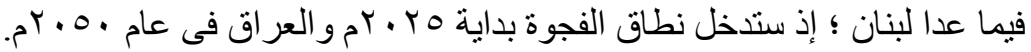

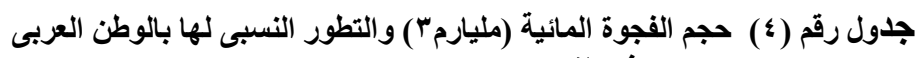

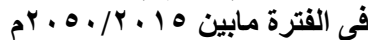

\begin{tabular}{|c|c|c|c|c|c|c|c|c|c|c|c|c|c|}
\hline \%.r. o. & r. ro\% & $\% r+10$ & 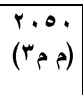 & 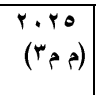 & 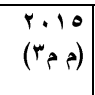 & |لبيان & \%r.o. & \%r.ro & $\%$ r. 10 & 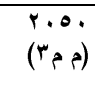 & 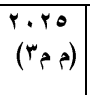 & 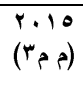 & \\
\hline $099 \ldots . \cdot-$ & rrq..." & Yrs..." & $11.2-$ & $7.7-$ & $\varepsilon . v-$ & الكويت & 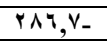 & $I V V^{\prime}, r_{-}$ & $\left\lfloor 0, Y_{-}\right.$ & $11 Y, \varepsilon-$ & $79,0-$ & Y $\wedge, 0-$ & مصر | (مصر \\
\hline 1rov.1- & $\Lambda T \leqslant . r-$ & $790 . \mathrm{V}-$ & $\varepsilon \varepsilon \ldots-$ & ५৭.५- & rr.r- & | اليمن & $T, V_{-}$ & ro,7- & $r, 7-$ & $r \varepsilon, \varepsilon-$ & $1 \Psi, \lambda-$ & $1, \varepsilon-$ & السودان \\
\hline$r \cdot \Lambda_{.} 0_{-}$ & $1 \leq 4.7-$ & $\vee \wedge . v_{-}$ & V.r- & r.\&- & $1.9-$ & | عمان & rVo,- - & $r \cdot 9,4-$ & $111, r-$ & $\cdot, 9-$ & $\cdot, \mathrm{v}-$ & $\cdot, 7-$ & جيبوتى \\
\hline$q . \wedge 0 . Y-$ & ะ9Vะ. 1- & $r T \cdot V . \leq-$ & $r \varepsilon .0-$ & $1 T . \varepsilon-$ & $\Lambda .9-$ & |الإمارات & 0,1 & Yq, & $r q, \cdot$ & $\cdot, 9$ & $0, r$ & 8,9 & الصومال \\
\hline$r \ldots r .{ }^{\prime}$ & $\mid V I \cdot . r-$ & $11.7 .9-$ & $r .0-$ & r...- & $1 . r-$ & |البحرين & $r r, r$ & $r r, r$ & $r r, r$ & $\cdot, \varepsilon$ & $\cdot, \varepsilon$ & $\cdot, \varepsilon$ & جزر القمر \\
\hline $\mid r \leqslant \ldots . \cdot-$ & $7 \leqslant \ldots$. & rq.... & $v . \varepsilon-$ & r.A- & T.r- & |قطر | قطر & $9 Y 0, \cdot-$ & $v 0 \cdot, \cdot-$ & $\checkmark \wedge \vee, \triangle_{-}$ & $V, \varepsilon-$ & $\checkmark, \cdot-$ & $0,0-$ & ليبيا \\
\hline rV.r- & 11.4 & $\leqslant 0 . Y$ & $14 . v-$ & 0.7 & $r \cdot . \varepsilon$ & | العراق & $r \cdots, \cdot-$ & $1 \leqslant 7, \cdot-$ & $1 r \leqslant, \cdot-$ & $1 \cdot, \cdot-$ & $\mathrm{v,r-}$ & $Y, Y-$ & تونس \\
\hline $1 . \times 9 .$. & $901.1-$ & 01 r.9- & IY.A- & A.Y- & ז. $4-$ & | الأردن & $\leqslant \leqslant 0, \Gamma-$ & rq৭,1- & $r \leqslant 1,--$ & or, 1- & ro,.- & $r \Lambda, r-$ & الجزائر \\
\hline 9..9- & $10.5-$ & $10 . \mathrm{V}$ & 1.0- & $1.1-$ & 1.1 & | كبنان & $\leqslant r, O_{-}$ & $I V, \Lambda_{-}$ & $\vee, \wedge_{-}$ & $1 \%, 7-$ & $0, \mathrm{~V}-$ & $r, 0-$ & المغرب \\
\hline r.. & Ү.. & $1 . \varepsilon$ &. .7 &. .4 &.$\mu$ & |سوريا & $r r, r$ & $00, r$ & $T \leqslant, \cdot$ & $r, \Lambda$ & $\square, r$ & $v, r$ & موريتانيا \\
\hline $7 \wedge \leqslant 9 . Y-$ & $\leqslant V r \cdot . O_{-}$ & rA^r.I- & A.1- & $0.7-$ & \&.7- & فلسطين & $11 \times 9,0-$ & $\vee \bullet ४, \wedge-$ & $7.9,1-$ & $\varepsilon 9, v-$ & $r r, r-$ & $r \square, \wedge-$ & السعودية \\
\hline $1 \leqslant$ & $9-$ & - & $\varepsilon \cdot \varepsilon-$ & $\begin{array}{r}-\bar{v} \\
Y q, V\end{array}$ & $1,7,0$ & & & & & & & \multicolumn{2}{|c|}{ بملة الوطن العربى } \\
\hline
\end{tabular}




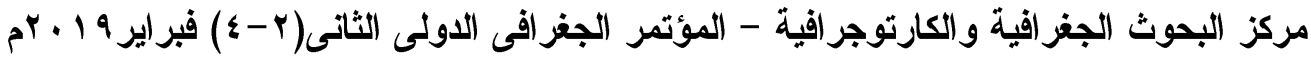

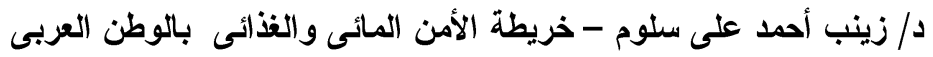

الثكل رقم (؛ ) نطاقات الفجوة المائية بدول الوطن العربى فى الفترة مابين ه 1 ـ r/ • ه ب م

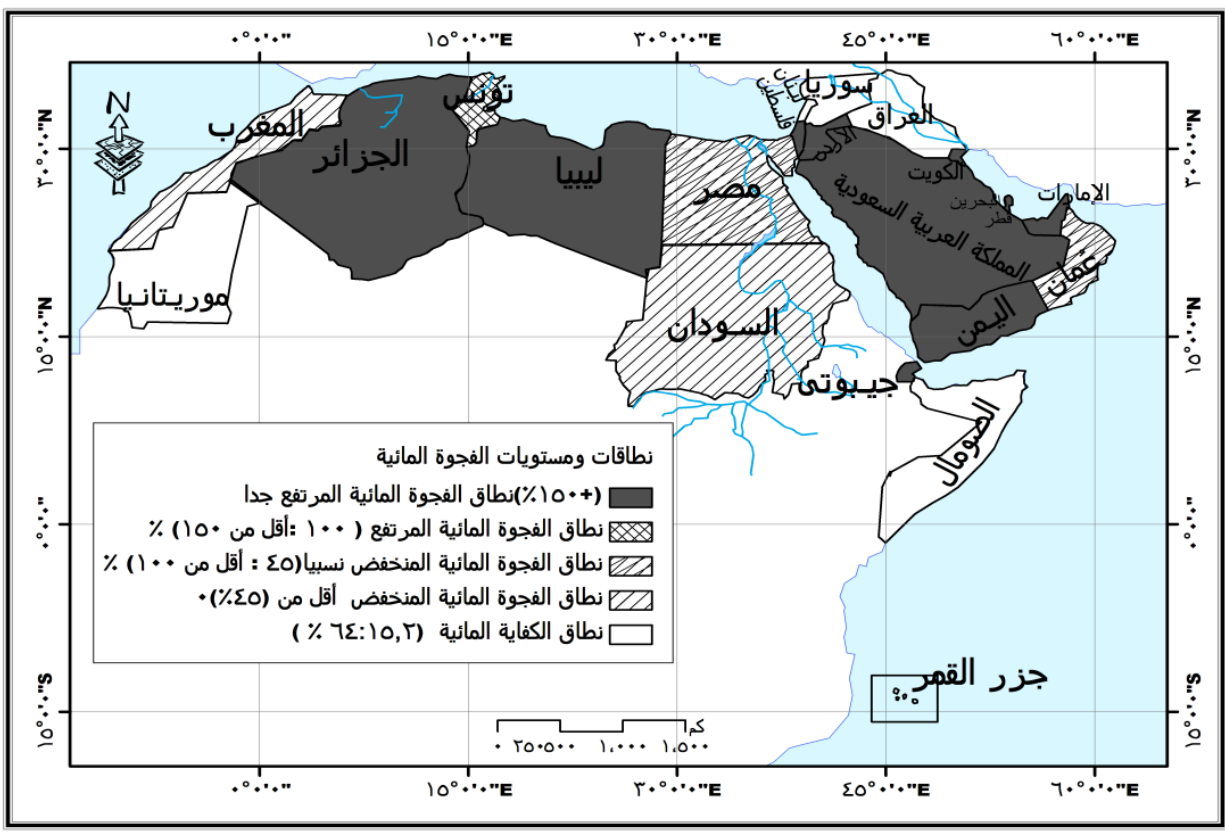

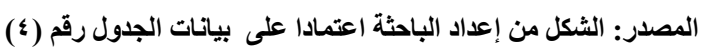

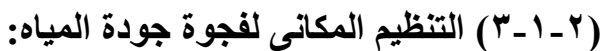

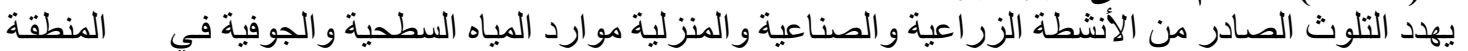

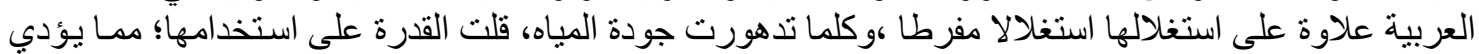

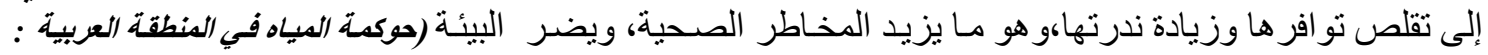

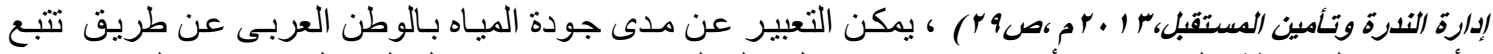

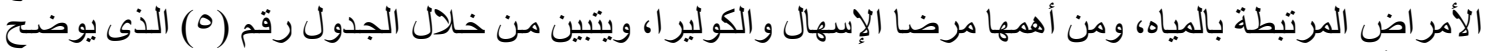

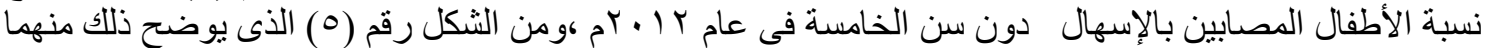

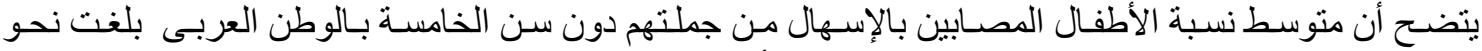

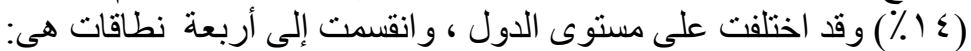

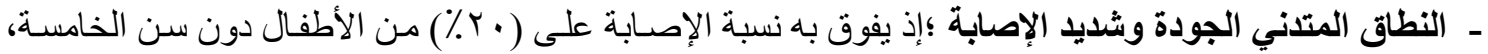

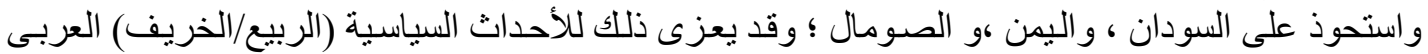

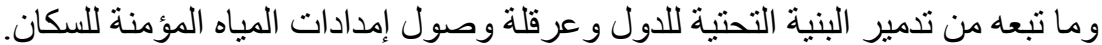

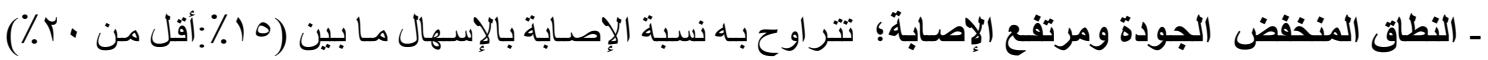

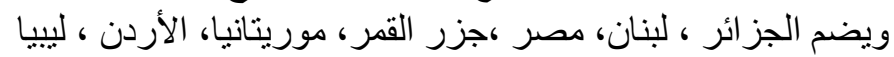

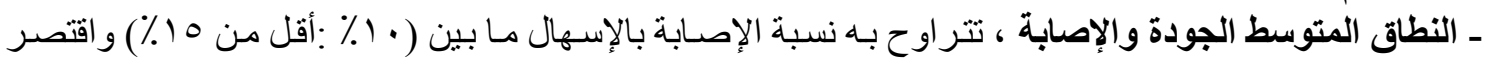

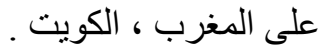
ـ النطاق المرتفع الجودة نسبيا، وتقل به نسبة الإصابة بالإسهال عن ( • (\%)،ويشمل تونس، السعودية

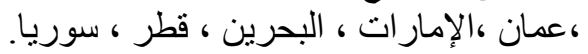




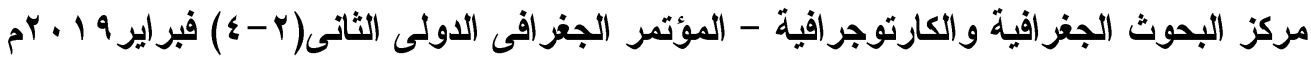

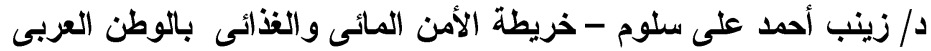

جدول رقم (0) الذى يوضح نسبة الأطفال المصابين بالإسهال شكل رقم (0) الذى يوضح نسبة الأطفال المصابين بالإسهال

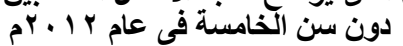

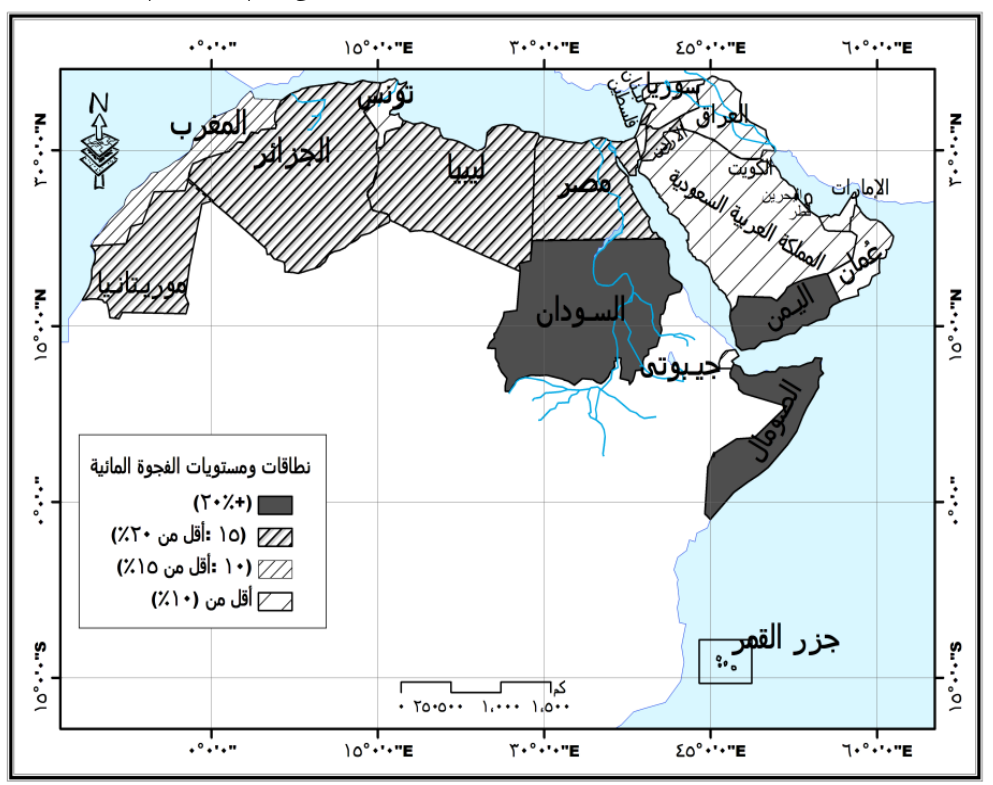

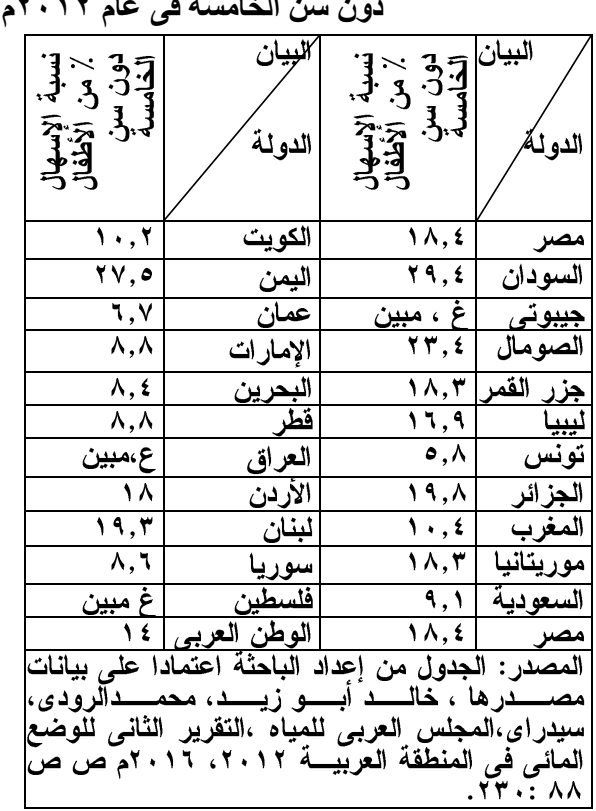

المصدر: الشكل من إعداد الباحثة اعتمادا على بيانات الجدول رقم (•).

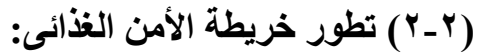

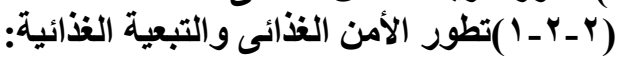

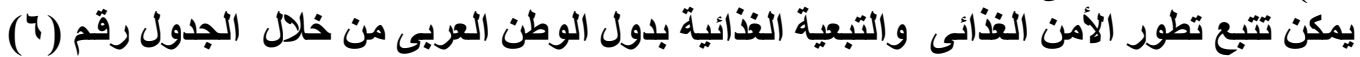

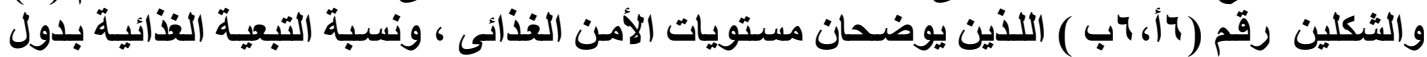

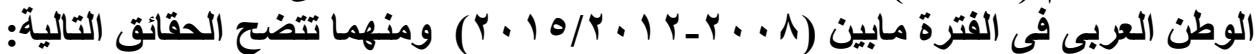

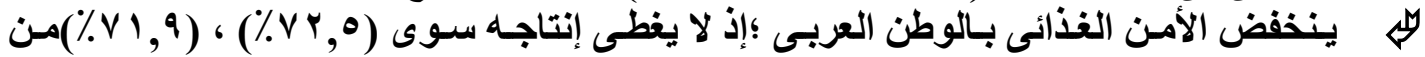

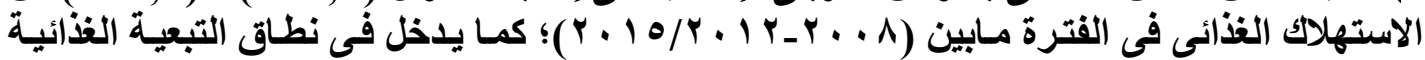

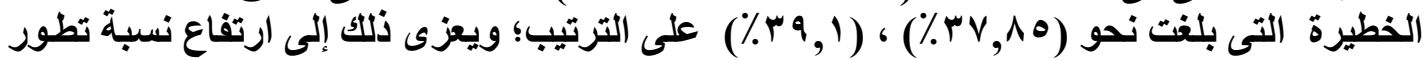

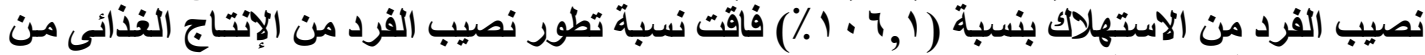

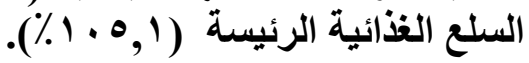




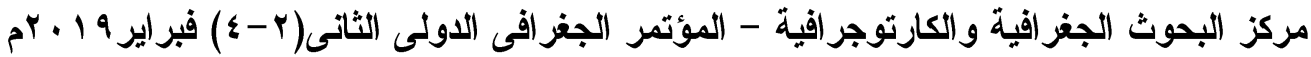

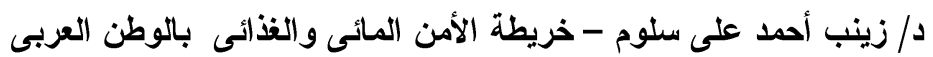

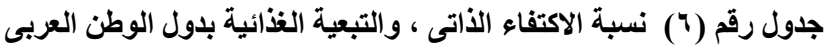

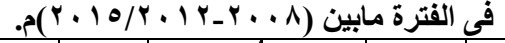

\begin{tabular}{|c|c|c|c|c|c|c|c|c|c|}
\hline 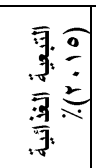 & 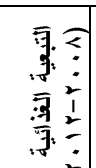 & $\begin{array}{l}\overline{7} \div \\
\frac{9}{4} \div \\
\frac{7}{3}\end{array}$ & 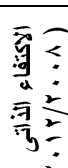 & لالبيان & 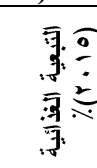 & 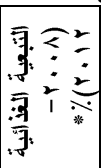 & 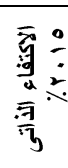 & $\begin{array}{l}y^{2}< \\
a^{2} \\
\overline{7}^{2}\end{array}$ & لالبيان \\
\hline orl,o & $01 Y, V$ & 17,1 & $18 . r$ & الكويت & $1 \wedge, \wedge$ & Ir,. & $\Lambda \varepsilon, r$ & $\wedge q, r$ & مصر \\
\hline $11 \%, \cdot$ & $11 \%, \varepsilon$ & $\varepsilon \checkmark, r$ & $\varepsilon \%, 9$ & اليمن & $18, r$ & $1 r, \Lambda$ & A & $\wedge \wedge, \uparrow$ & السودان \\
\hline 100,7 & $1 \leq \varepsilon, 1$ & $r q, 1$ & $\leqslant 1,0$ & عمان & YVY.,0 & $\varepsilon r \mid \cdot, r$ & $r, 0$ & $r, r$ & جييوتى \\
\hline Irr,o & $\varepsilon, 0, \varepsilon$ & $\varepsilon 0, \cdot$ & 19,1 & الإمار ات & $r r, 0$ & $\mathrm{rq}, \cdot$ & $V \varepsilon, q$ & $\times 1,9$ & الصومـال \\
\hline 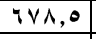 & $i v \cdot, v$ & $1 Y, \Lambda$ & $1+,$. & البحرين & Pغ & غ.غ & غُوم & غُغ & جزر القمر \\
\hline $9 r 9,1$ & 101,0 & $1 \mathrm{H}, \mathrm{V}$ & 1,0 & قطر & $11 \cdot, r$ & $1 Y \wedge, 9$ & $\varepsilon v, 7$ & $\varepsilon r, v$ & ليبيا \\
\hline $9, \cdot$ & $r V, \varepsilon$ & 91,1 & $\vee \wedge, 0$ & العراق & $r \checkmark, \wedge$ & $r \varepsilon, 7$ & $v r, 1$ & $v \varepsilon, r$ & تونس \\
\hline$\varepsilon \wedge, 9$ & $\wedge \varepsilon, V$ & $i v, r$ & $0 \leqslant, 1$ & الأردن & IY, & $09, \cdot$ & $\because, v$ & $9 r, 9$ & الجزائر \\
\hline ir, & $\bullet \cdot, \cdot$ & $71, \varepsilon$ & $78, v$ & لبنان & $10, r$ & 11,7 & $\wedge ५, \vee$ & $\wedge 9,7$ & المغرب \\
\hline $9, v$ & $1 \wedge, v$ & $91, r$ & $\Lambda \varepsilon, Y$ & سوريا & $r q, 0$ & $\varepsilon \varepsilon, 9$ & $V Y, r$ & 79,0 & موريتانيا \\
\hline$r \wedge, r$ & or, \& & $V r, r$ & $70, Y$ & فلسطين & roq, \& & $1 \vee 9, v$ & $r \wedge, 1$ & $r \bullet, \Lambda$ & السعودية \\
\hline$r q, 1$ & $r v, \wedge$ & $v 1,9$ & $V Y, 0$ & & & & & العربح & جملة الو \\
\hline
\end{tabular}

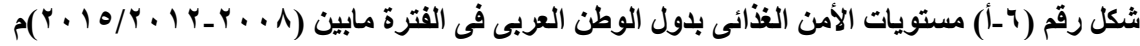

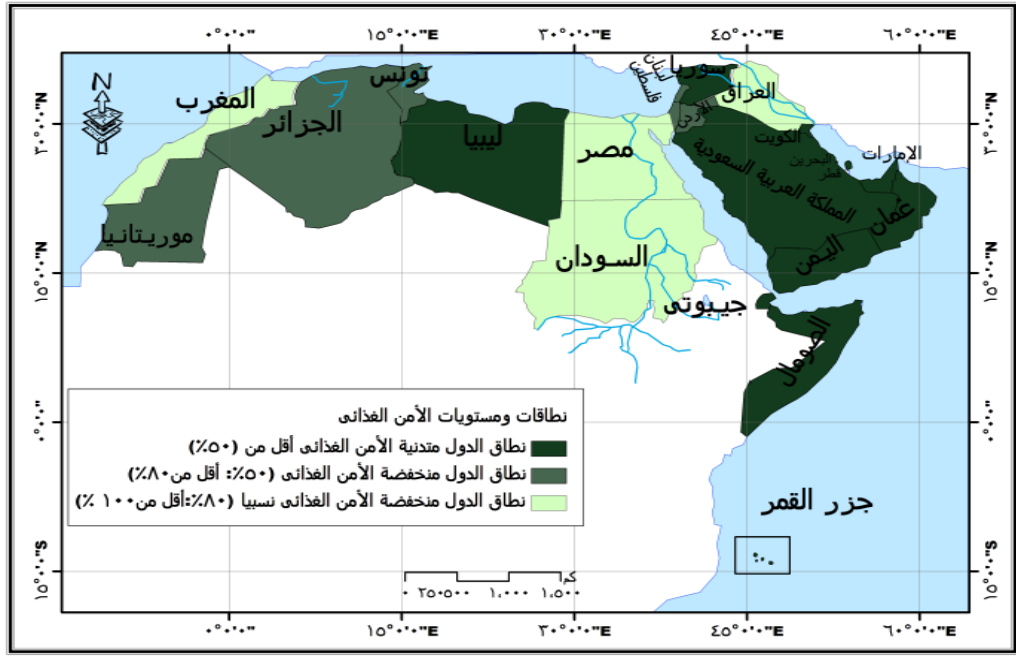




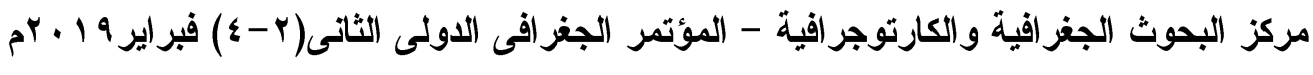

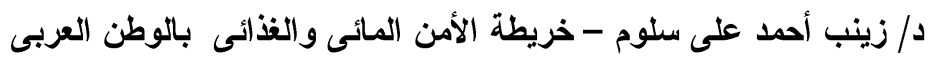

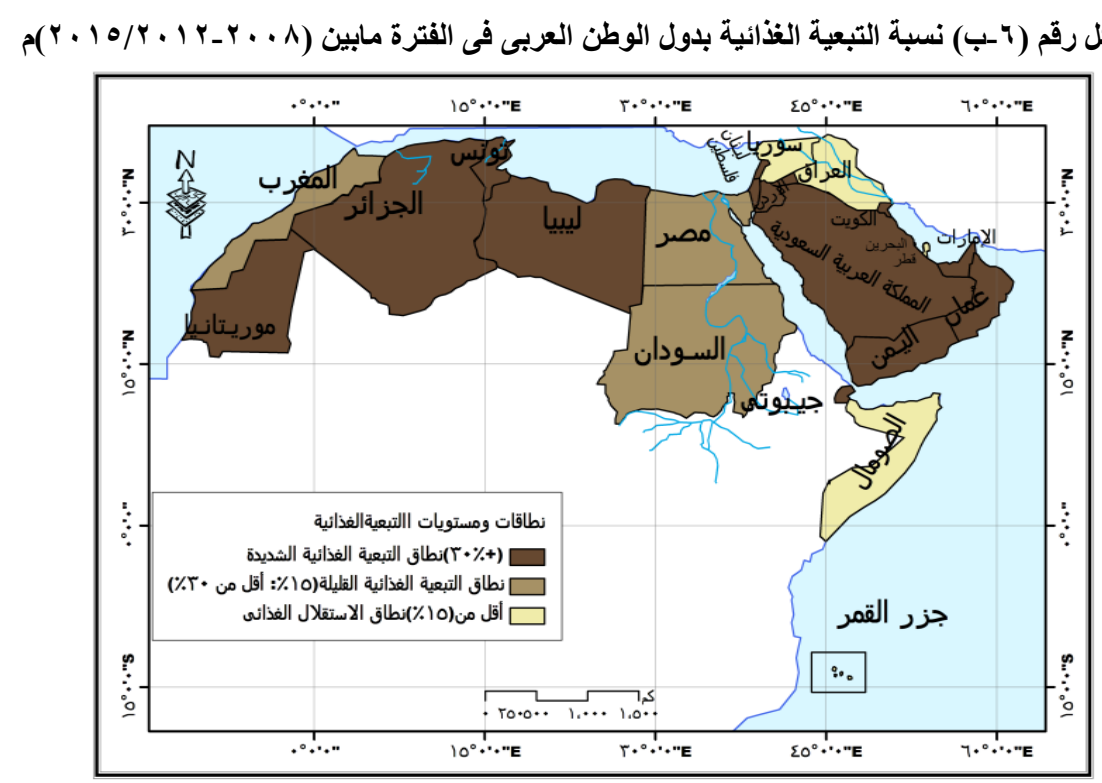

المصدر: الثكل من إعداد الباحثة اعتمادا على بيانات الجدول رقم (†).

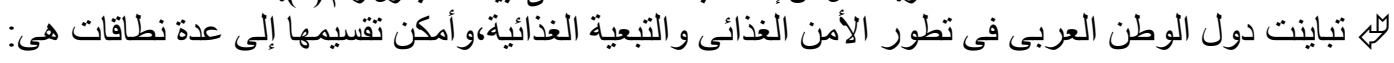

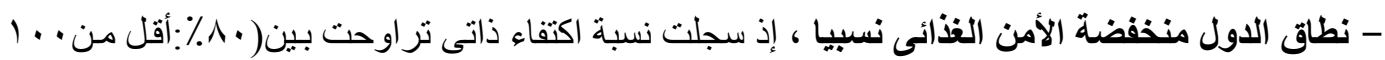

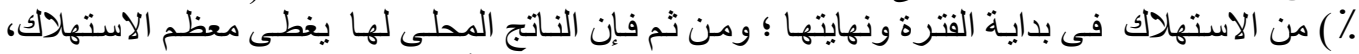

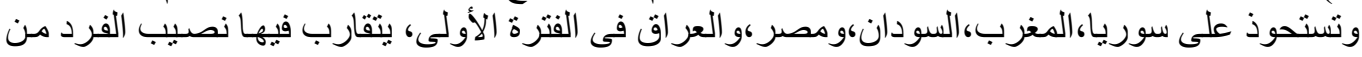

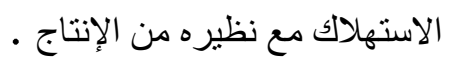

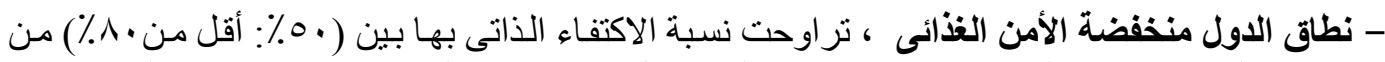

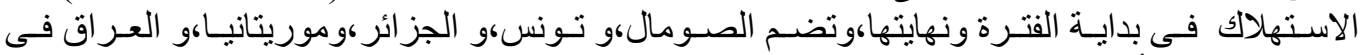

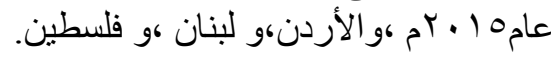

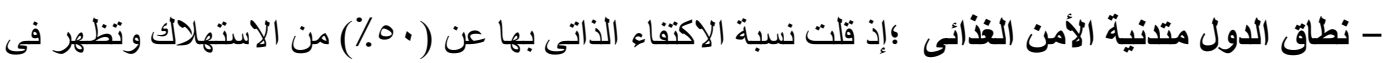

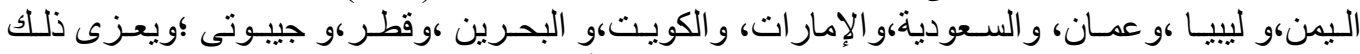

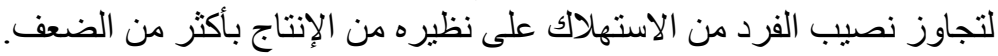

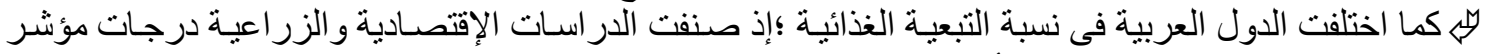

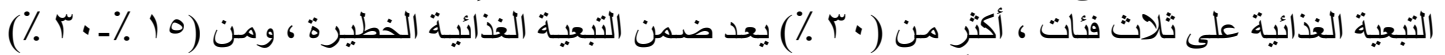

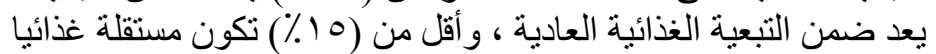

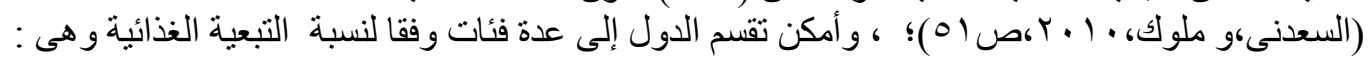

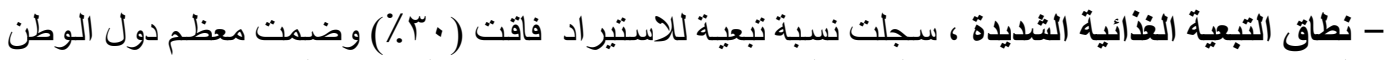

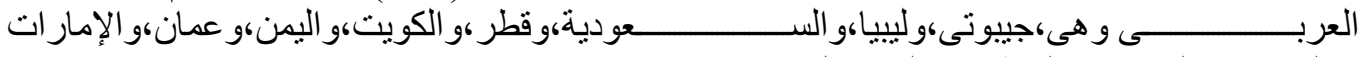

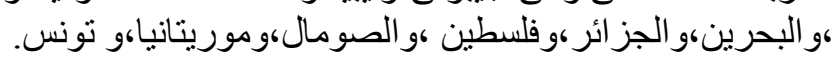

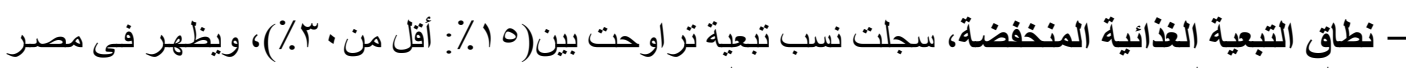

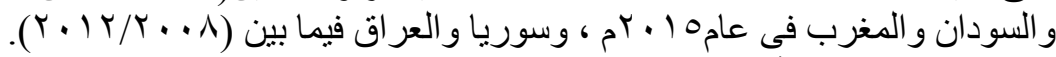

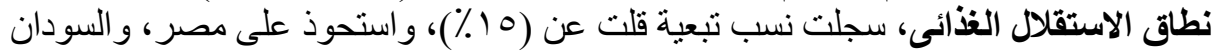

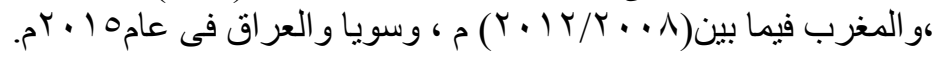




\section{مركز البحوث الجغرافية والكارتوجراقية - المؤتمر الجغرافى الدولى الثانى(r-؛) فبراير 9 ــrم

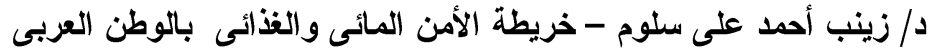

( ب-r-r)

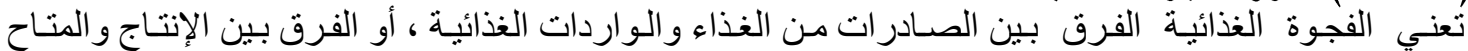

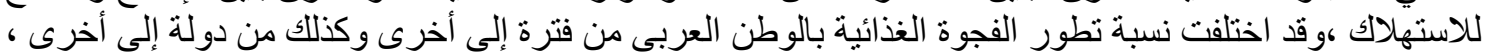

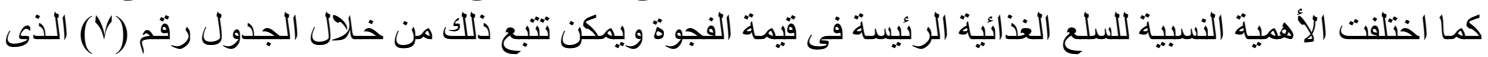

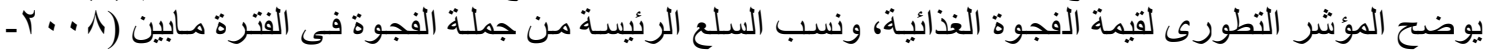

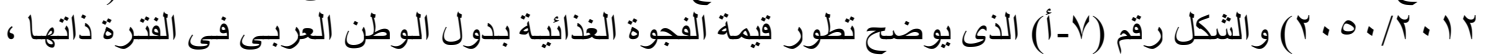

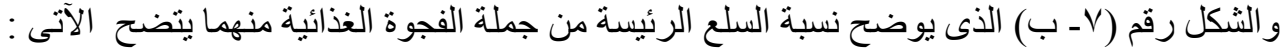

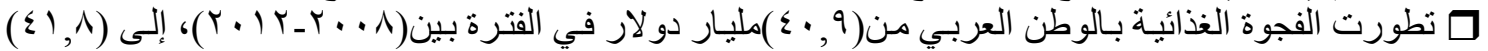

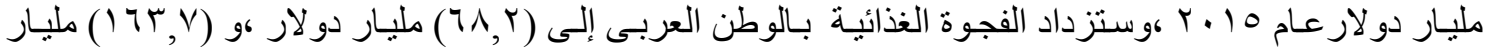

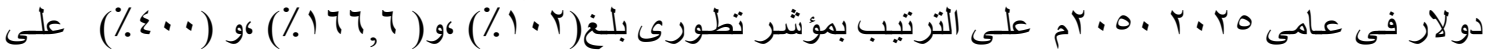

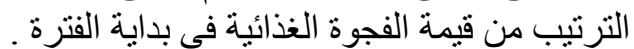
ص تفاوتت دول الوطن العربى فى تطور قيمة الفجوة الغذائية بها فى الفترة المذكورة

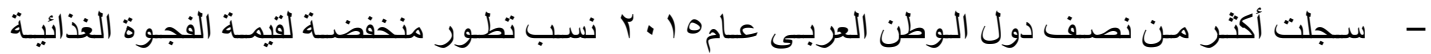

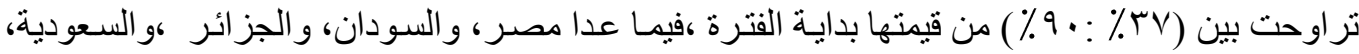

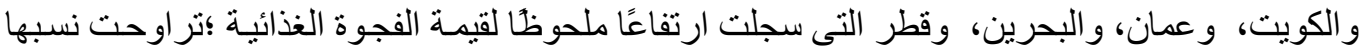

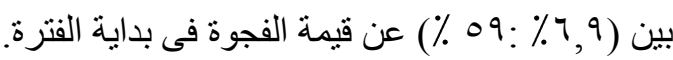

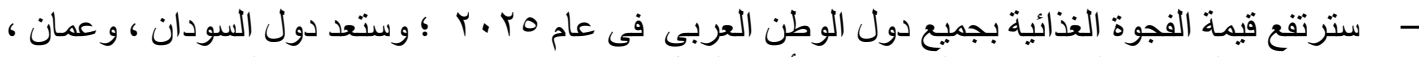

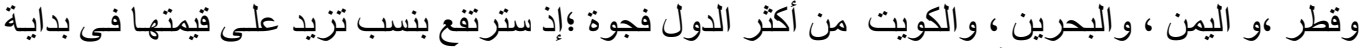

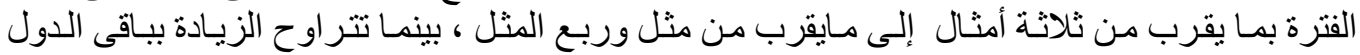

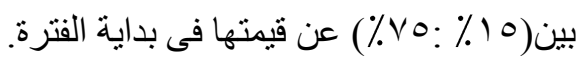

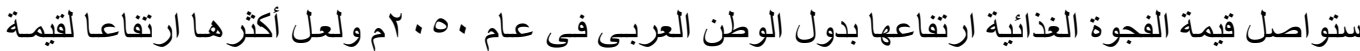

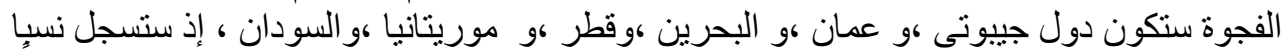

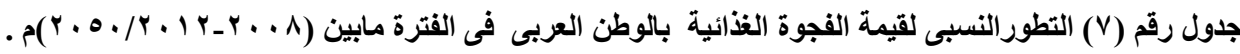

\begin{tabular}{|c|c|c|c|c|c|c|c|c|c|}
\hline 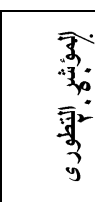 & त्र & 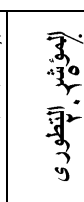 & 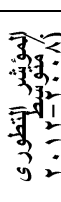 & الدولة & 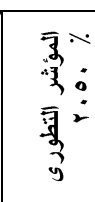 & 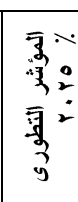 & 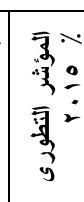 & 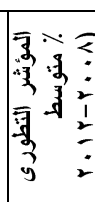 & \\
\hline ror, \& & $1 v, 1$ & $\mid \leqslant \square, r$ & $1 \ldots$ & الكويت & IVq,Y & 19,0 & Or,A & $1 \ldots$ & \\
\hline$r Y \xi, A$ & $\Lambda, \cdot$ & $94, \Lambda$ & $1 \ldots$ & اليمن & $9 \wedge 0,0$ & $r v r, 1$ & 1०4,. & $1 \ldots$ & يودان \\
\hline$i v v, r$ & $v$ & $\varepsilon, V$ & *. & عمان & I $\vee \vee ৭, \varepsilon$ & ir 1,0 & $V \varepsilon, Y$ & $1 \ldots$ & \\
\hline$i r v, r$ & $\mathrm{~V}, \varepsilon$ & $\varepsilon \vee, \varepsilon$ & $\cdots$ & الإمارات & $r \wedge \bullet, r$ & $1+9,9$ & 99,7 & $1 \ldots$ & بومال \\
\hline , &, 1 & $v, q$ & $1 \ldots$ & البحرين & م. & م.غे & م.غे & |غ & القمر \\
\hline $1 \wedge 9,0$ & $r \leqslant V, 1$ & 109,1 & $1 \ldots$ & قطر & $r+1, \varepsilon$ & 110,9 & 79,7 & $1 \ldots$ & ي \\
\hline YAY,O & $v, 0$ & $0 \wedge, 7$ & $1 \ldots$ & العراق & $0,9,9-$ & Irr, & $1 ., 1$ & $1 \ldots$ & نس \\
\hline $0.0,0$ & $0, \cdot$ & $\Lambda \varepsilon, 1$ & $1 \ldots$ & الأردن & $174, \varepsilon$ & $1 \times q, r$ & $1.9,1$ & $1 \ldots$ & الجزائر \\
\hline DIr,r & $v 1,0$ & $9 \%, \cdot$ & $1 \ldots$ & لبنان & $\varepsilon \curlyvee \wedge, \cdot$ & 119,0 & $\cdot, 1$ & $1 \ldots$ & المغرب \\
\hline$\varepsilon \cdot \wedge, q$ & 101,4 & 00,0 & $1 \ldots$ & سوريا & $\Lambda V_{r}, r$ & $\mid \vee \varepsilon, \wedge$ & qז, & $1 \ldots$ & ريتانيا \\
\hline rrr, & 10,9 & $1,1, r$ & $1 \ldots$ & فللسطين & $Y \backslash A, Y$ & $1 \%, \lambda$ & $119, r$ & $1 \ldots$ & السعودية \\
\hline$\varepsilon, \ldots$, & 191,7 & $\bar{r}$ & 1. & & & & & 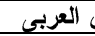 & \\
\hline
\end{tabular}

المصدر : الجدول من إعداد الباحثة اعتمادا على بيانات الملحق رقم (؟) 


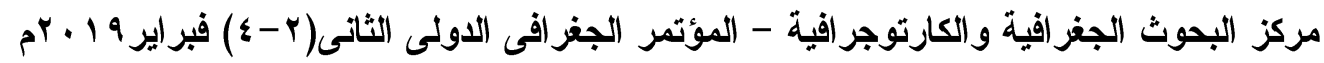

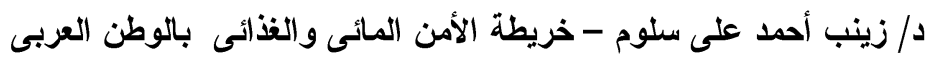

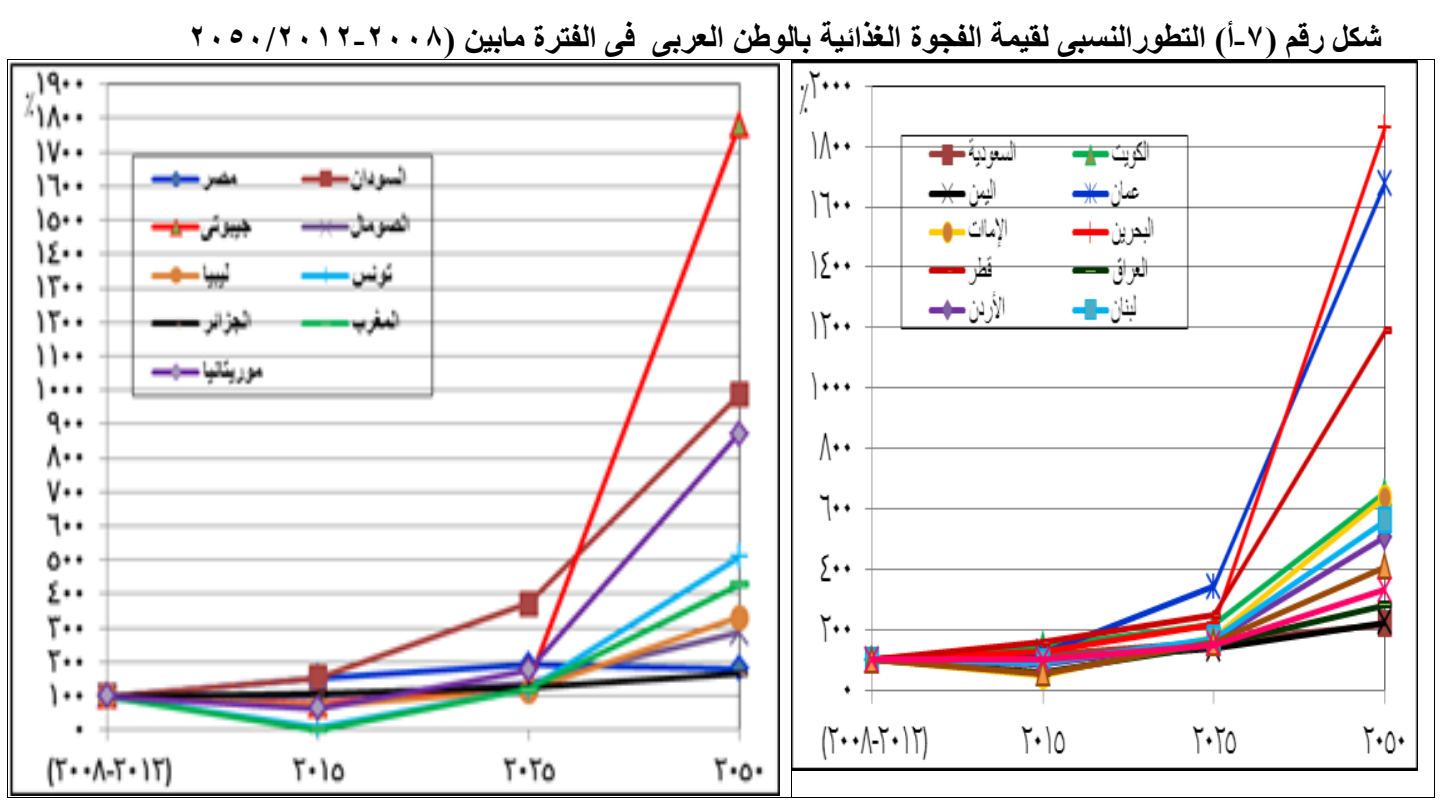

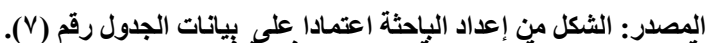

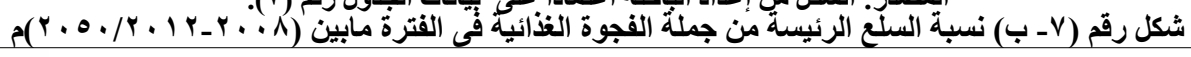

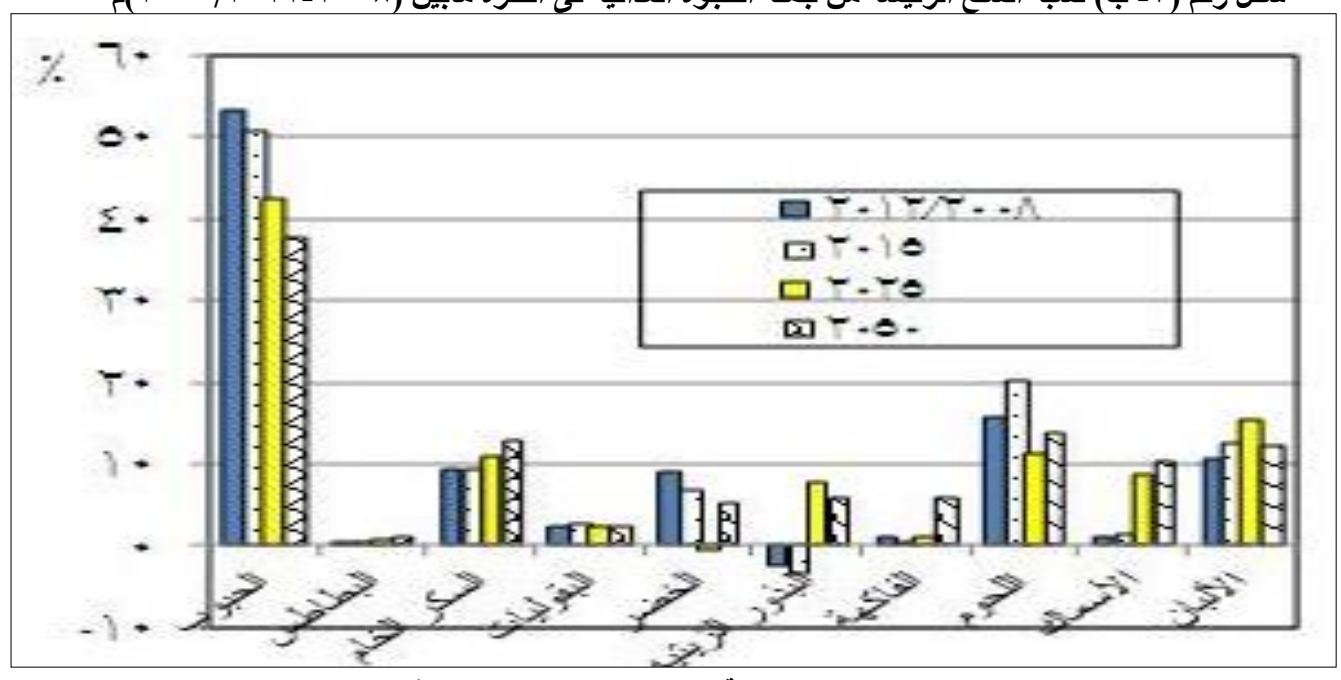

المصدر: الثكل من إعداد الباحثة اعتمادا على بيانات الجدول رقم (V).

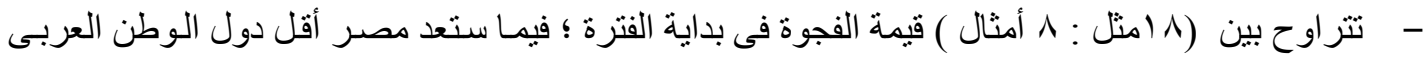

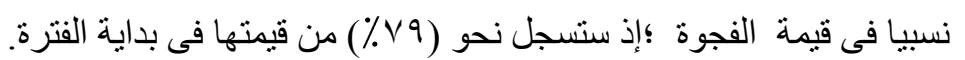

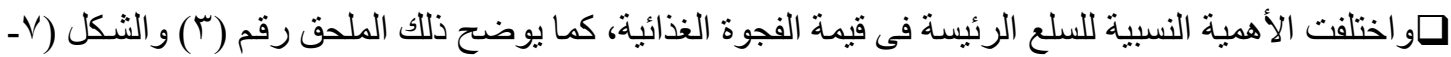

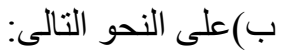

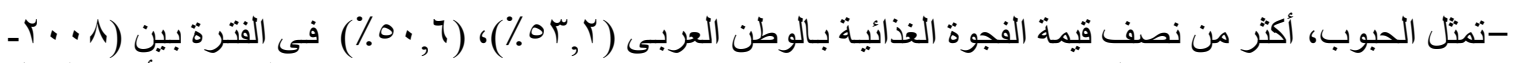

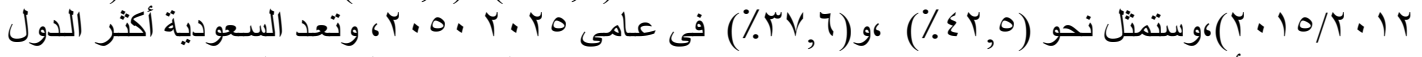

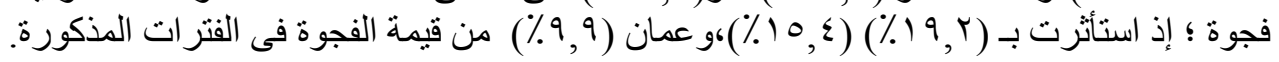




\section{مركز البحوث الجغرافية والكارتوجراقية - المؤتمر الجغرافى الدولى الثانى(r - ؛) فبراير 9 ـ بrم \\ د/ زينب أحمد على سلوم - خريطة الأمن المائى والغذائى بالوطن العربى}

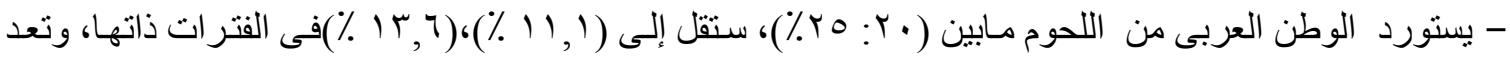

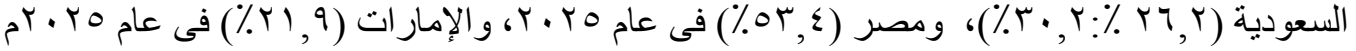

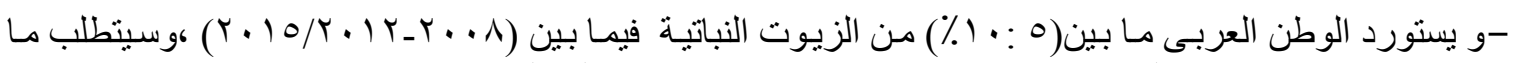

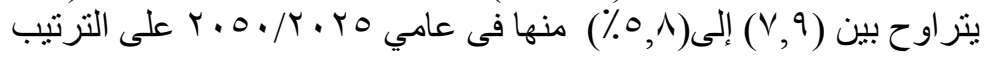

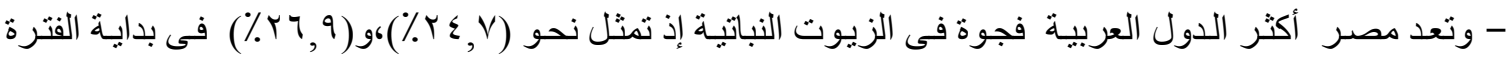
ونهايتها .

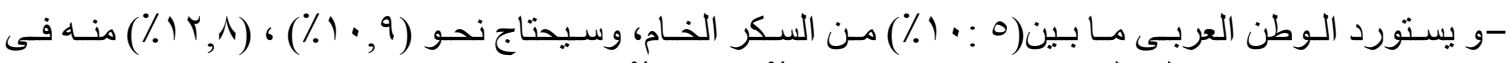

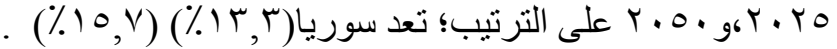

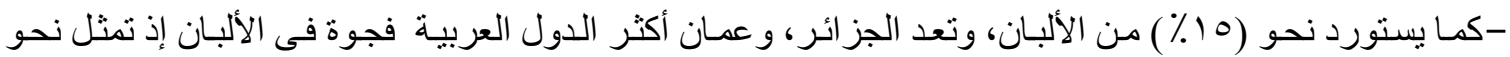

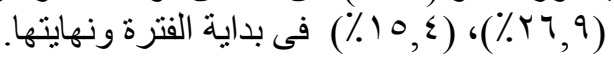

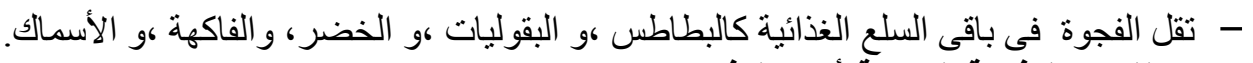

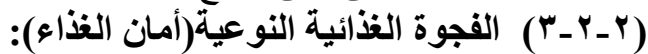

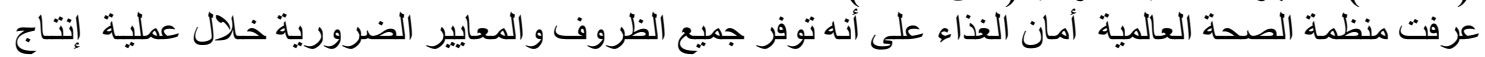

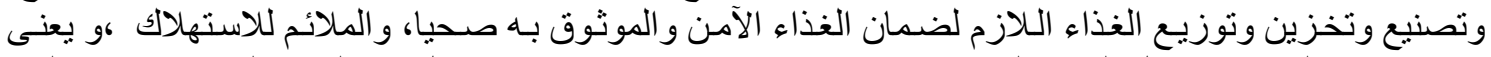

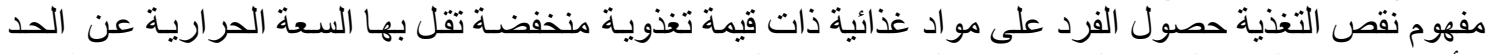

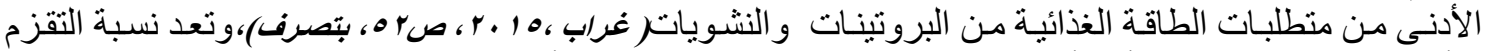

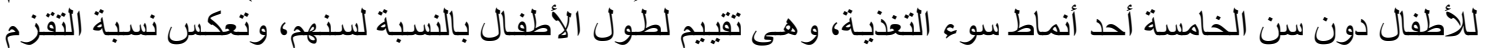

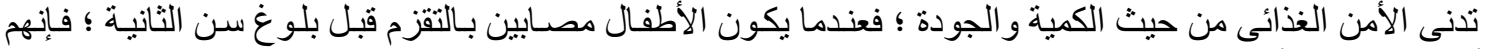

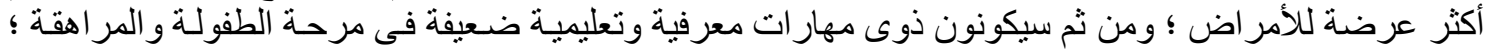

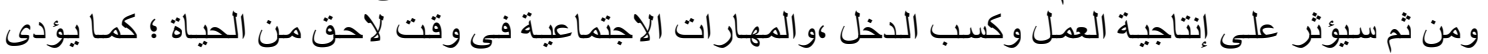

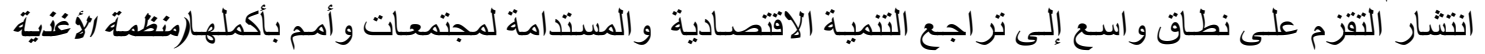

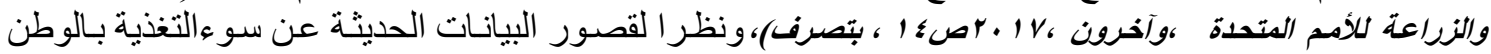

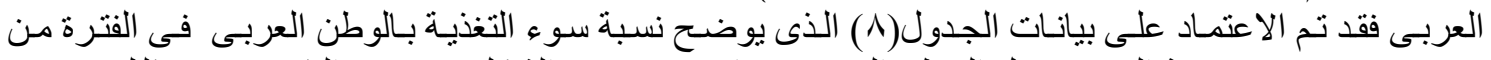

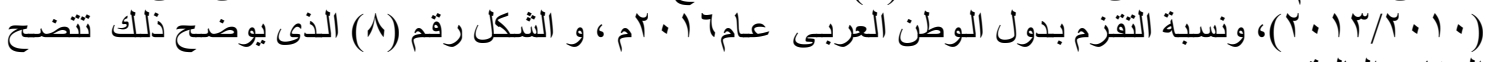

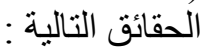

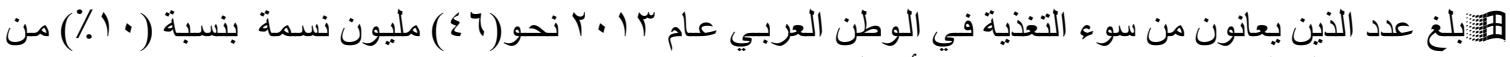

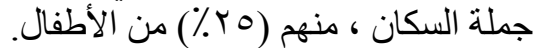

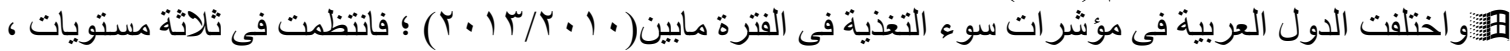

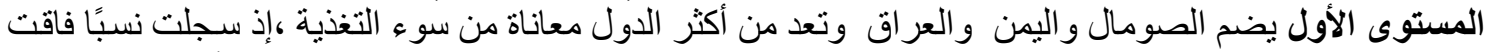

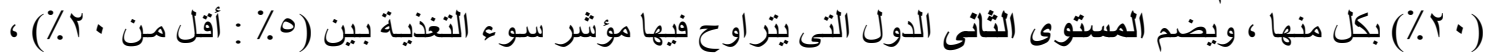

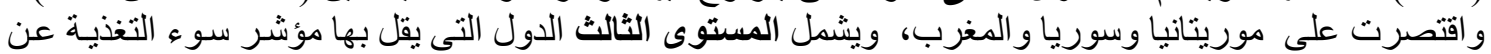

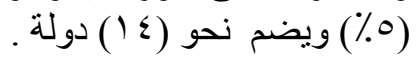


مركز البحوث الجغر افية والكارتوجرافية - المؤتمر الجغرافى الاولى الثانى(r - ع) فبراير 9 أمبام

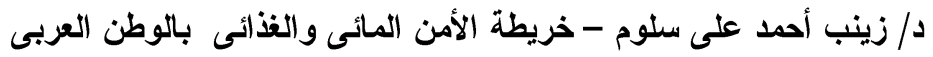

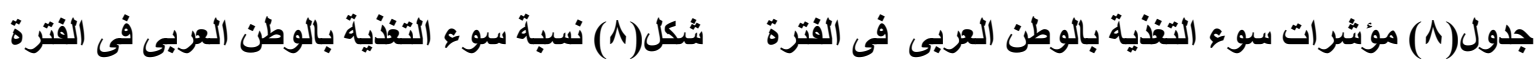

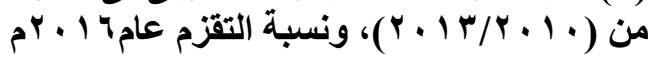

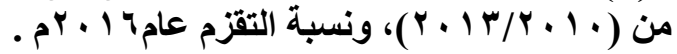

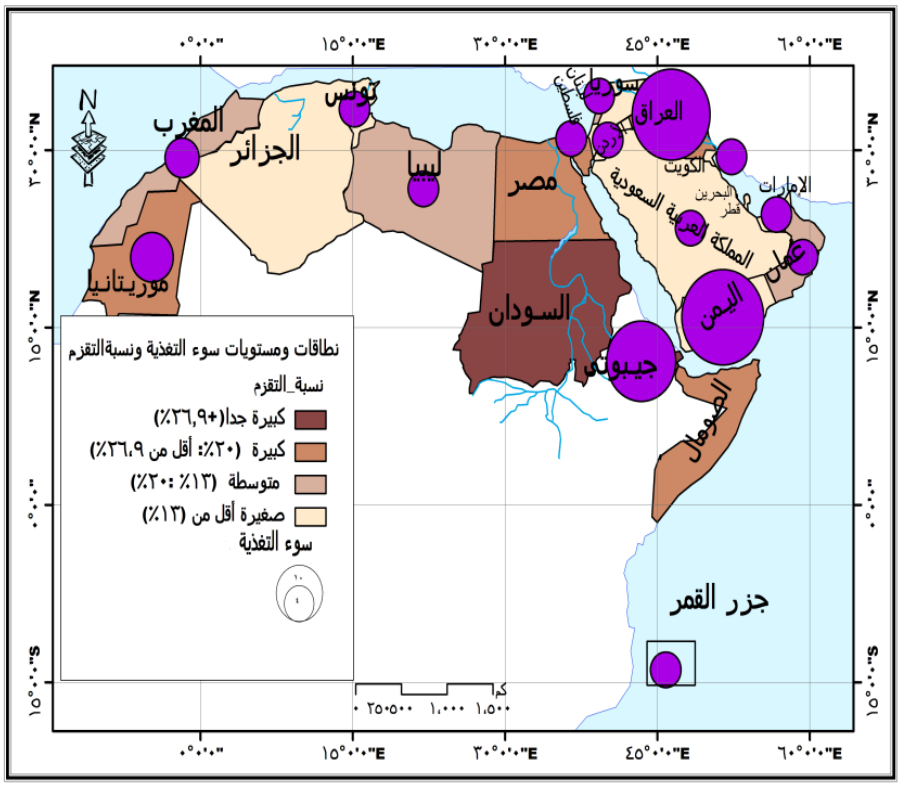

\begin{tabular}{|c|c|c|c|c|c|c|c|}
\hline 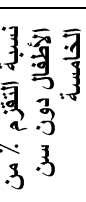 & $\stackrel{-}{*}$ & 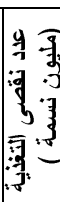 & | الدودير & 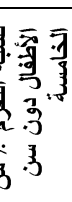 & $\therefore$ & 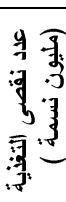 & الدووكة \\
\hline $0, \wedge$ & $0<$ & $\cdots$ & |الكويت & $r Y, r$ & $0<$ & $\ldots$ & مصر | (2 | مصر \\
\hline- & $r \wedge, \wedge$ & $v, \varepsilon$ & |اليمن & $\mathrm{rA}$ & $\ldots$ & $\cdots$ & السودان \\
\hline $1 \varepsilon, 1$ & $\ldots$ & $\ldots$ & | عمان & $r \mu, 0$ & $r \cdot, 0$ & $\cdot, \mathrm{Y}$ & جييوتى \\
\hline ... & $0<$ & & | الإمارات & $r 0, q$ & $\cdots$ & ... & الصومال \\
\hline$\cdots$ & $\cdots$ & $\cdots$ & |البحرين & $r r, 1$ & $\cdots$ & $\cdots$ & القزمر \\
\hline$\cdots$ & $\ldots$ & $\ldots$ & قطظر & ri & $0<$ & $\ldots$ & ليييا \\
\hline$r, Y$ & $r ४, r$ & $\Lambda, \wedge$ & | العرق |ق & $1 \cdot, 1$ & $0<$ & ... & تونس ت تونس \\
\hline $\mathrm{v}, \wedge$ & $0<$ & $\cdots$ & | الأردن & $11, v$ & $0<$ & $\cdots$ & الجز ائر \\
\hline 18,0 & $0<$ & $\cdots$ & | لبنان & $1 \leqslant, 9$ & 0 & 1,7 & المغرب \\
\hline$r v, 0$ & 7 & $1, r$ & سوريا & rr & $v, \wedge$ & $\cdot, r$ & موريتانيا \\
\hline$\vee, \varepsilon$ & $\cdots$ & $\cdots$ & |فلسطين & $9, r$ & $0<$ & $\cdots$ & السعودية \\
\hline & 1. & $\leqslant 4$ & & \multicolumn{4}{|c|}{ جملة الوطن العربي } \\
\hline
\end{tabular}

المصدر: الثكل من إعداد الباحثة اعتمادا على بيانات الجدول رقم (^).

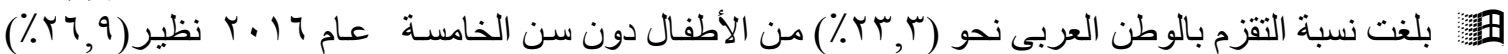

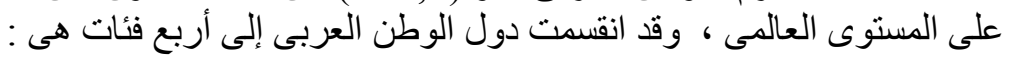

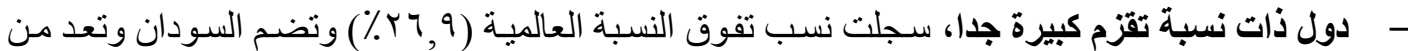

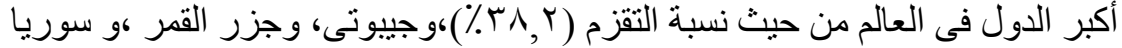

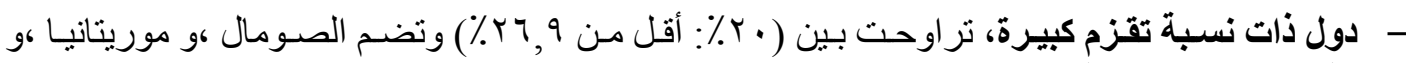
العر اق ،ومصر كول فو ليبيا.

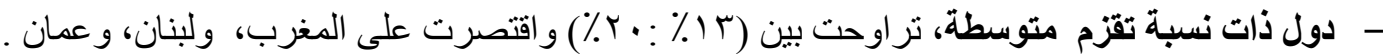

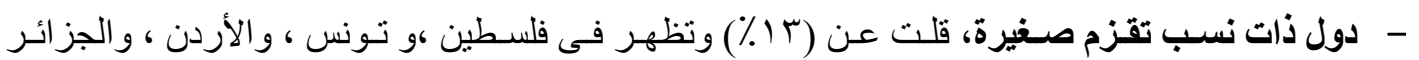

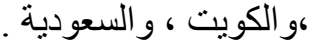

$$
\begin{aligned}
& \text { (r) آحديات الأمن المائى و الغذائى. }
\end{aligned}
$$

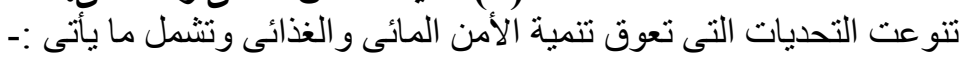

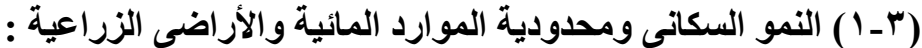

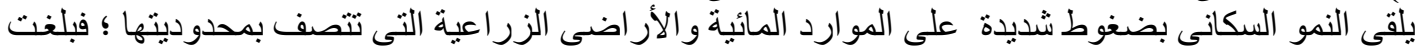

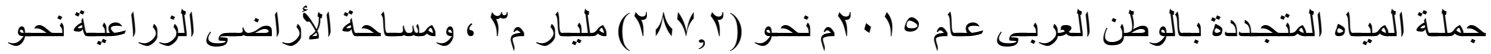

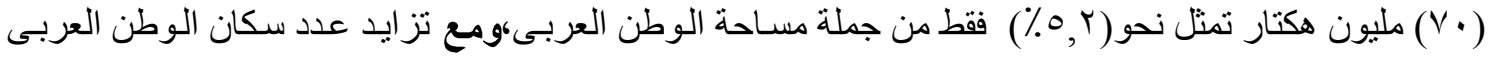

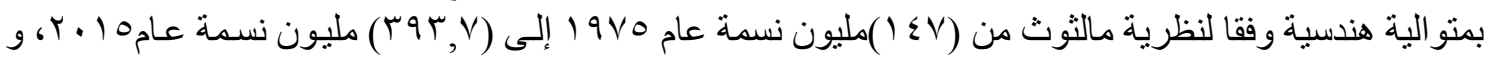

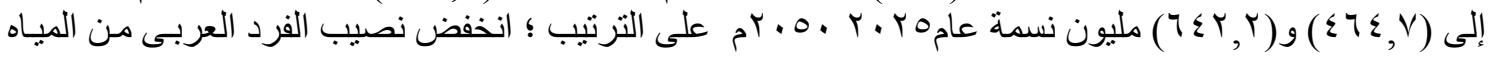

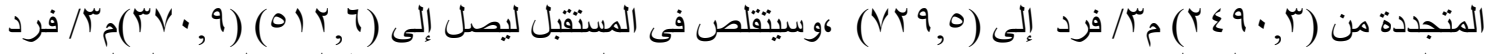

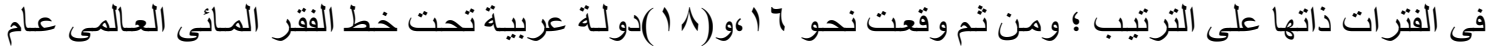




\section{مركز البحوث الجغرافية والكارتوجراقية - المؤتمر الجغرافى الدولى الثانى(r-؛) فبراير 9 ــrم \\ د/ زينب أحمد على سلوم - خريطة الأمن المائى والغذائى بالوطن العربى}

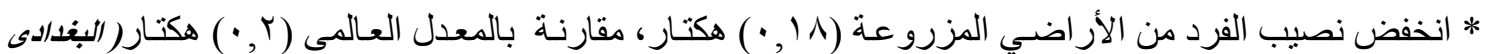

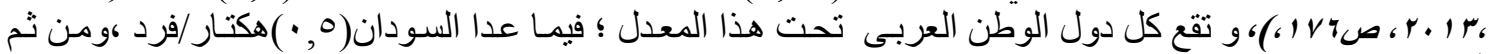

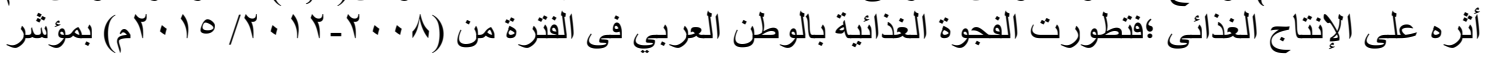

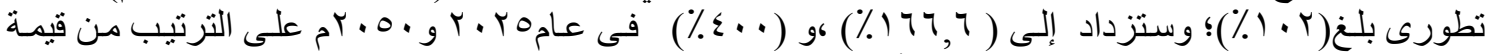

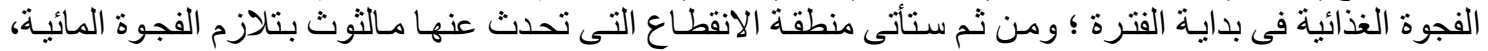

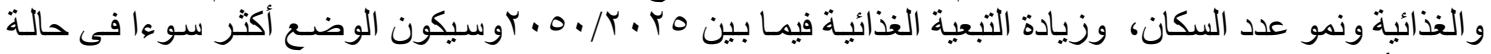

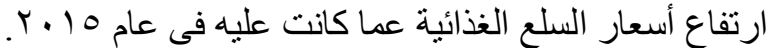
: وقاع (r-r)

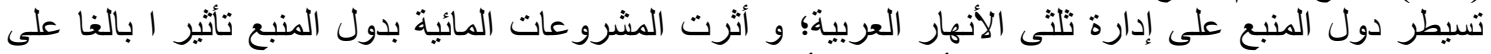

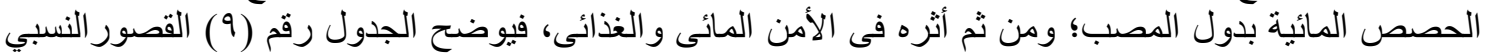

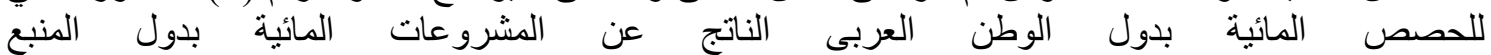

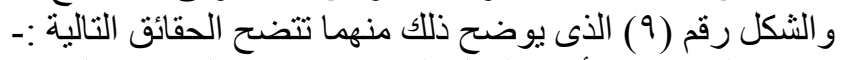

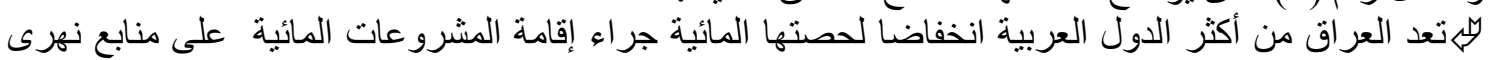

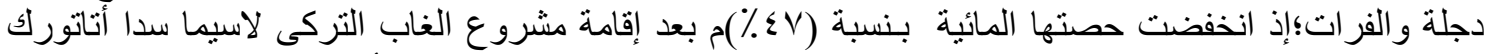

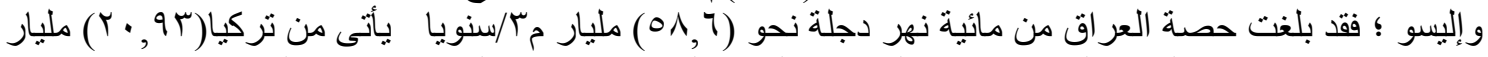

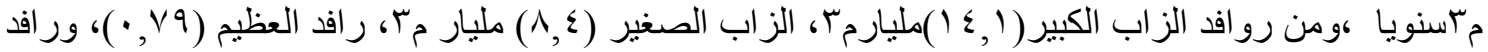

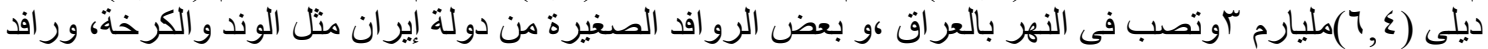

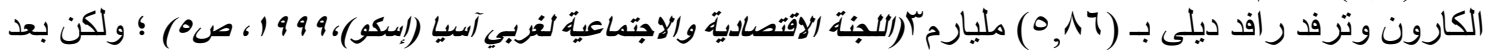

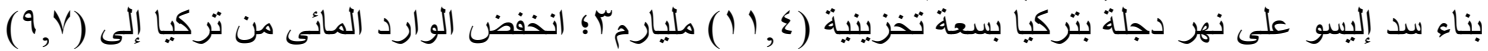

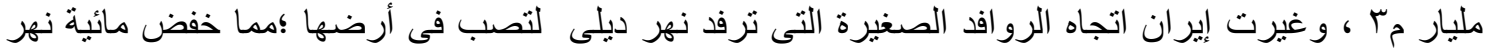

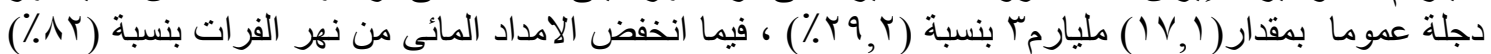

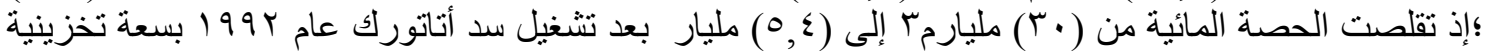

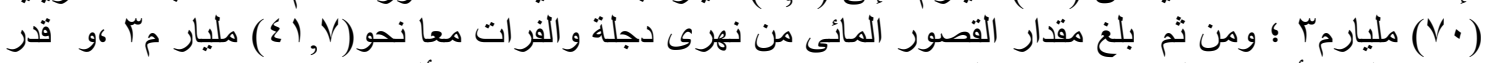

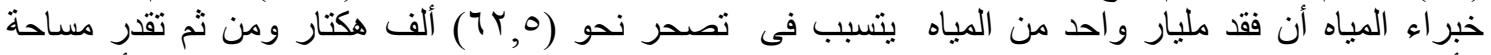

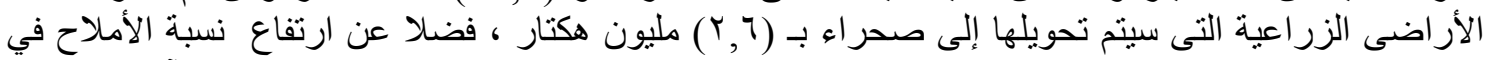

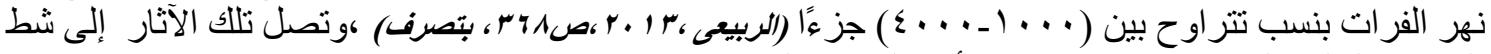
العرب و الخليج العربي ؛ ومن ثم تدنى الأمن المائى و الغذائى.

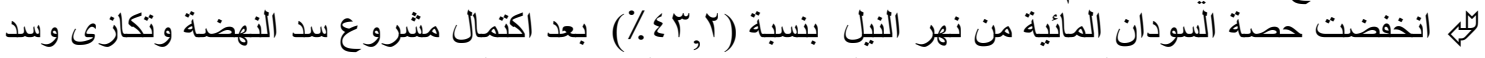

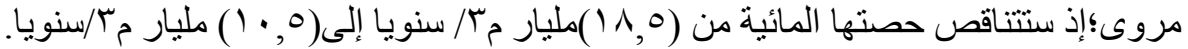

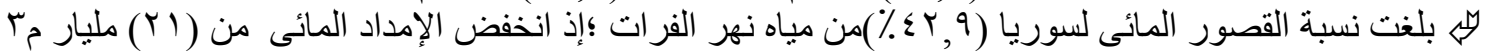

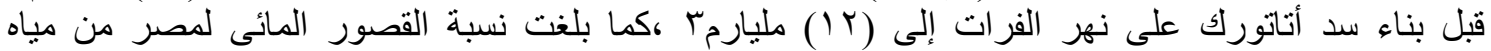

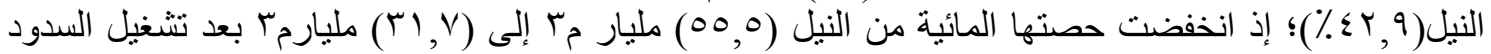

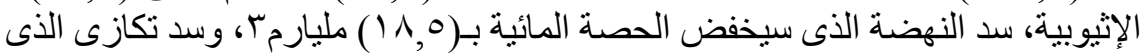

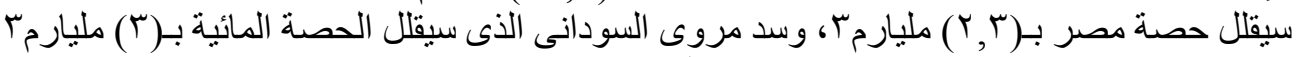

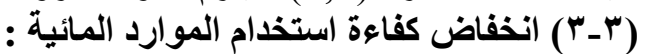

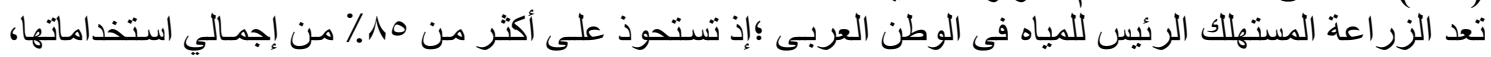

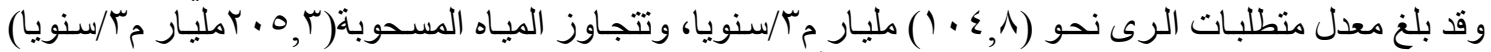

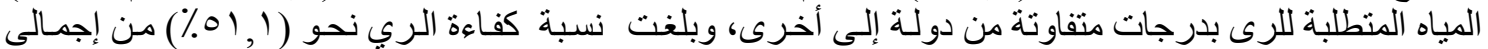

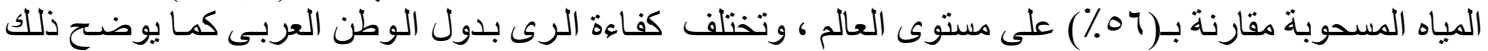

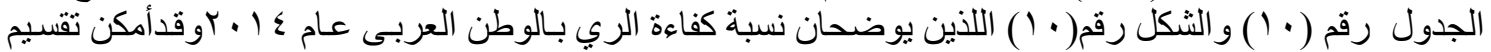

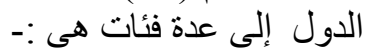




\section{مركز البحوث الجغرافية والكارتوجراقية - المؤتمر الجغرافى الدولى الثانى(r-؛) فبراير 9 ــrم د/ زينب أحمد على سلوم - خريطة الأمن المائى والغذائى بالوطن العربى}

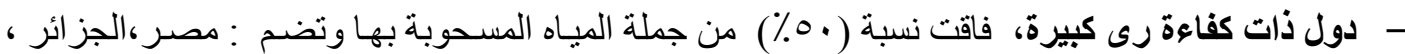

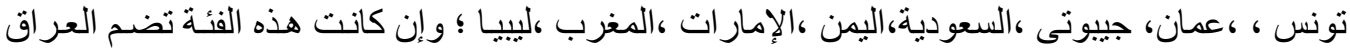

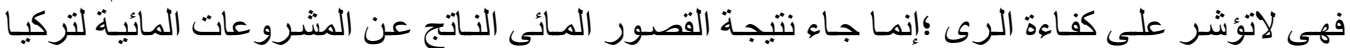

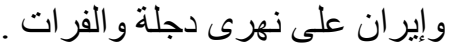

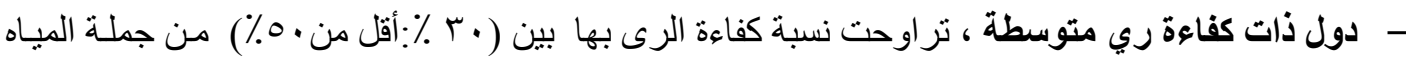

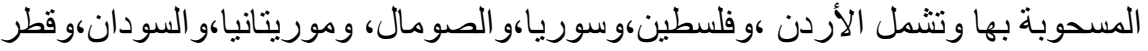

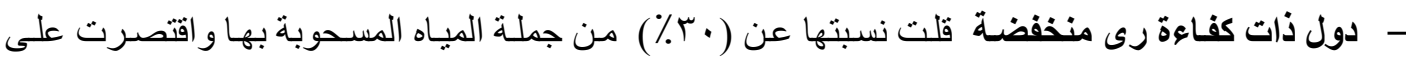

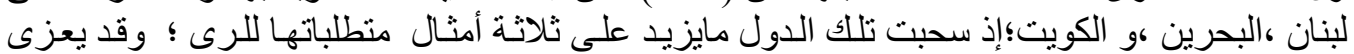

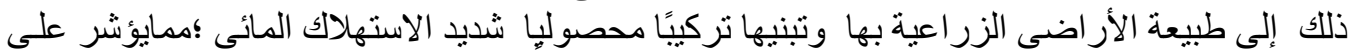

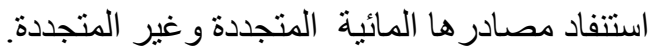

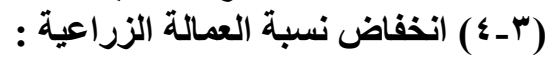

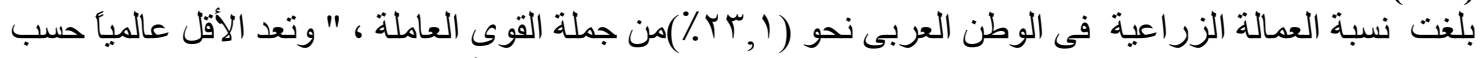

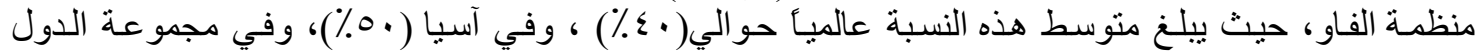

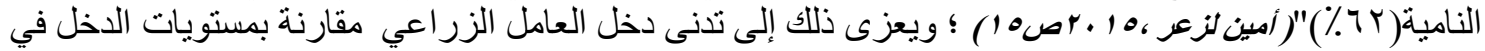

شكل رقم (9) القصور النسبي للحصص المائية بدول

الناتج عن المشروعات المائية بدول المنبع
جدول رقم (9) القصور النسبي للحصص المائية بدول الوطن العربى الوطن العربى الناتج عن المشروعات المائية بدول المنبع

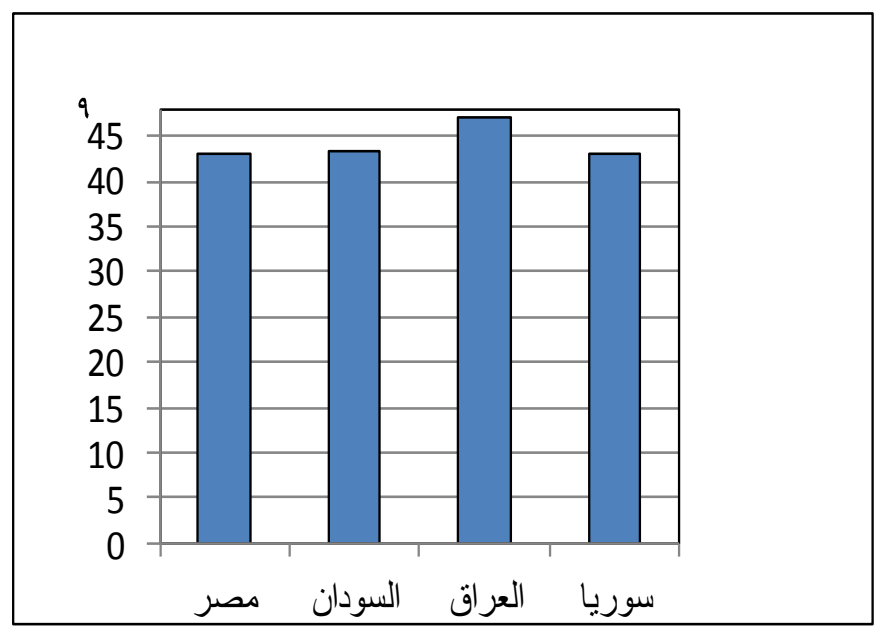

المصدر: الثكل من إعداد الباحثة اعتمادا على بيانات الجدول رقم (9).

شكل رقم ( • (1كفاءة الرى بدول الوطن العربى عام ـ ا ـ بم.

\begin{tabular}{|c|c|c|c|c|c|}
\hline 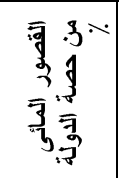 & 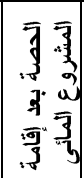 & 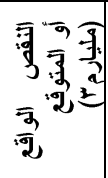 & 高 & |سم المشروع & الدولة \\
\hline$r \mu, r$ & \multirow[t]{4}{*}{$r 1, v$} & 11,0 & \multirow[t]{3}{*}{$0,0,0$} & م إثيوييا(سد النهضة) & \multirow[t]{3}{*}{ 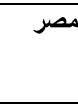 } \\
\hline$\varepsilon, 1$ & & $r, r$ & & م إثيوبيا( (سد تكازى) & \\
\hline $0, \varepsilon$ & & $r$ & & م السودان (سد مروى) & \\
\hline$\varepsilon r, q$ & & $r \mu, \Lambda$ & 00,0 & & الجملة \\
\hline$\overline{Y Y, Y}$ & \multirow[t]{4}{*}{$1 \cdot, 0$} & $7, Y$ & 11,0 & |م إثيوبيا( (سد النهضة) & \multirow[t]{3}{*}{ السودان } \\
\hline$\varepsilon, r$ & & $\bullet, \wedge$ & & | مـ إثيوبيا( (سد تكازى) & \\
\hline $0 . \varepsilon$ & & 1 & & |م السودان (سد مروى) & \\
\hline$\varepsilon r, r$ & & $\wedge$ & 11,0 & & الجملة \\
\hline $19, Y$ & \multirow[t]{2}{*}{$\leqslant 1,0$} & $11, r r$ & \multirow[t]{2}{*}{$\Delta \wedge, \uparrow$} & نهر دجلة (سد أليسو) & \multirow[t]{3}{*}{ العراق } \\
\hline 1. & & $0, \wedge 4$ & & مـ إيران على دجلة & \\
\hline Ar & $0, \varepsilon$ & $r \varepsilon, \uparrow$ & $r$. & نهز الفرات( سد أتاتورك) & \\
\hline$\varepsilon v$ & $\leq 4,9$ & $\approx 1, v$ & $\wedge,, v$ & & الجملة \\
\hline$\varepsilon r, q$ & Ir & 9 & $r_{1}$ & نهر القرات( سد أتاتورك) & سوريا \\
\hline وارد المائية & 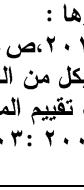 & 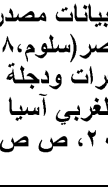 & 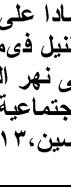 & 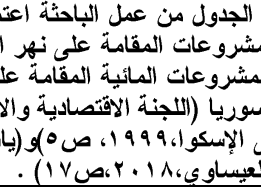 & الب-1 \\
\hline
\end{tabular}

جدول رقم ( • 1)كفاءة الرى بدول الوطن العربى عام \& ا ـ بم. 


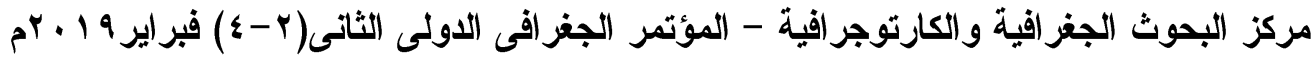

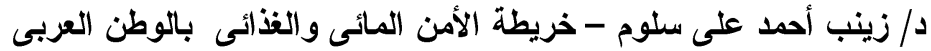

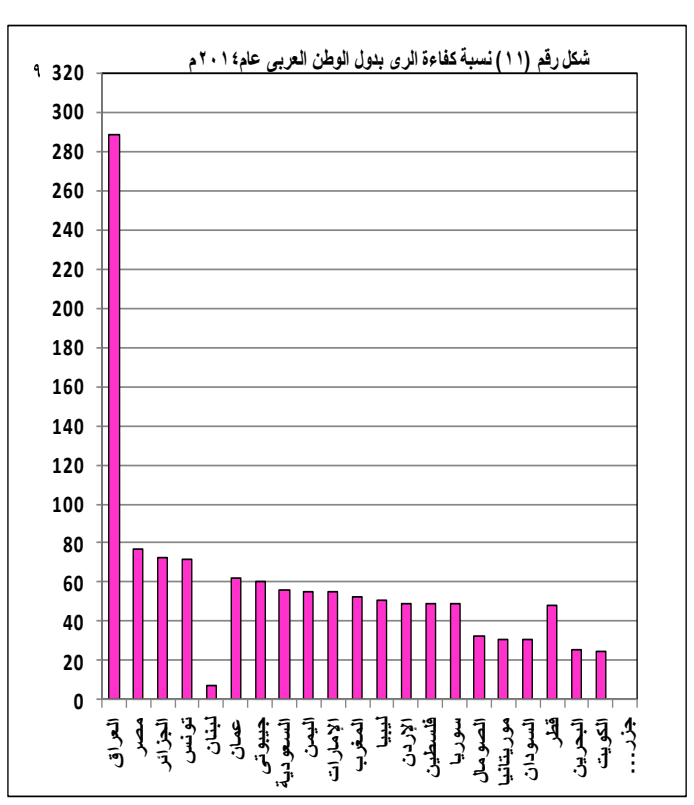

\begin{tabular}{|c|c|c|c|c|c|c|c|}
\hline 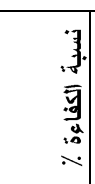 & 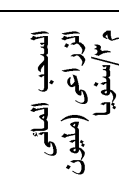 & 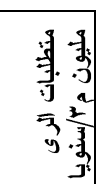 & 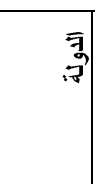 & | & 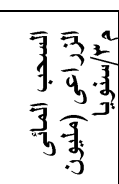 & 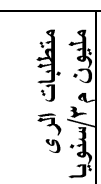 & الدولة \\
\hline$\varepsilon q, r$ & $\$ 11,$. & $r+1$ & |الإردن & $r \wedge \wedge, q$ & or..,. & $10 . \mathrm{YT}$ & العراق \\
\hline$\varepsilon q, Y$ & I৯9,. & 94 & |فلسطين & 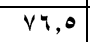 & $\Delta q \ldots, \cdot$ & $\{0111$ & مصر \\
\hline$\varepsilon \wedge, 4$ & $1 \leq 7 V \cdot, \cdot$ & VITY & سوريا & $V Y, \Lambda$ & $r 0 . r, \cdot$ & rool & الجزائر \\
\hline$r r, 1$ & $\Lambda r \cdot, \cdot$ & ry & الصومال & $v 1, v$ & r190, & $100 Y$ & تونس \\
\hline$r \cdot, v$ & IRYT, & rvo & موريتانبا & $\square, \Lambda$ & $v \wedge,, \cdot$ & $\Delta r, q$ & كلبنان \\
\hline$r \cdot, \tau$ & rாוOr,. & 1.10 & |السودان & $\because, v$ & $117 \wedge, \cdot$ & VYI & عمان \\
\hline$\varepsilon v, \Lambda$ & 109,0 & 87 & ق قطر & 7. & $\Lambda \bullet, \cdot$ & 01 & جييوتى \\
\hline$r 0, r$ & 109,0 & $\varepsilon$ & |البحرين & $\Delta, v$ & $r \cdot \wedge r \cdot, \cdot$ & 11099 & |السعودية | \\
\hline$r \varepsilon, r$ & $\varepsilon 94,$. & 119 & |الكويت & $0 \varepsilon, \wedge$ & rYMo,. & IVVr & اليمن \\
\hline- & $\cdot, \cdot$ & & النقمر & $0 \varepsilon, \wedge$ & rTIY, & 1110 & الإمارات \\
\hline \multirow[t]{2}{*}{01,1} & \multirow[t]{2}{*}{ roroe, } & \multirow[t]{2}{*}{$1 . \leqslant \vee \wedge 4$} & \multirow{2}{*}{ 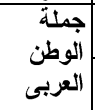 } & Or,q & $11 \cdot 1 \cdot, \cdot$ & OAYr & المغرب \\
\hline & & & & 01,1 & rOA\&,. & IATH & ليبيا \\
\hline \multicolumn{8}{|c|}{ 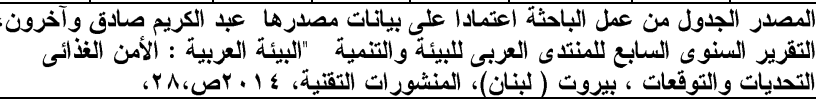 } \\
\hline
\end{tabular}

المصدر: الثكل من إعداد الباحثة اعتمادا على بيانات الجدول رقم (• (1).

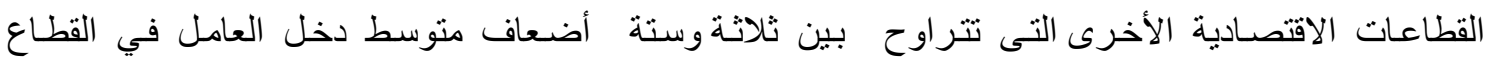

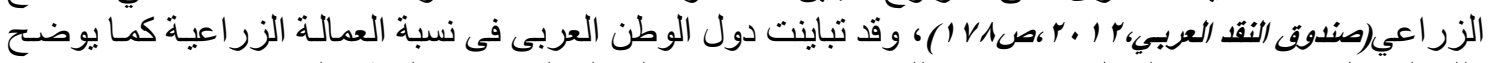

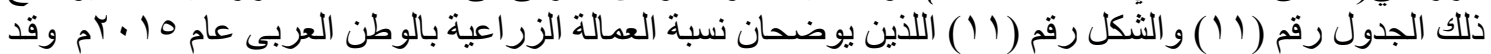

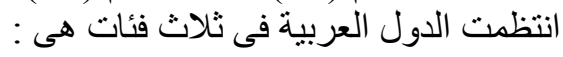

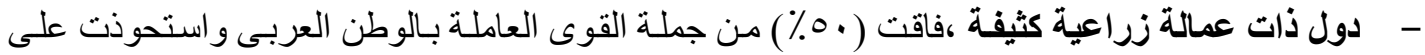

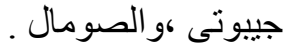

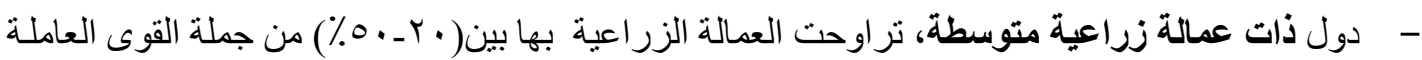

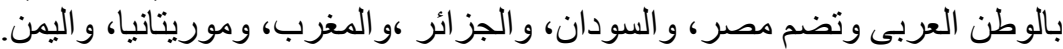

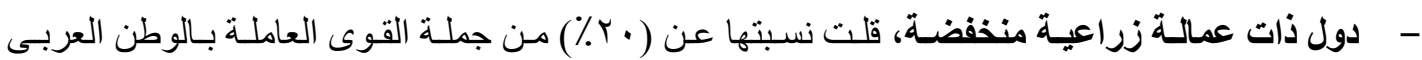

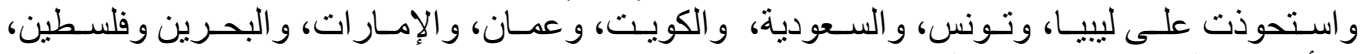

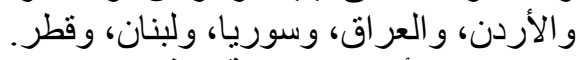

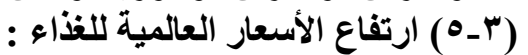

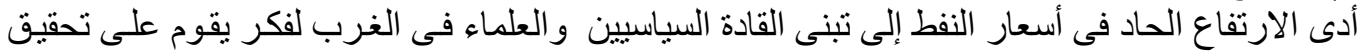

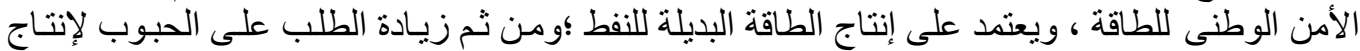

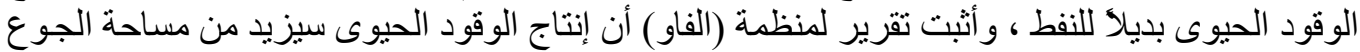

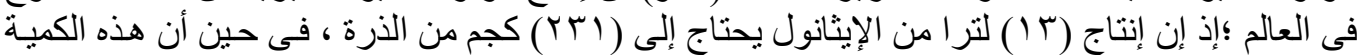

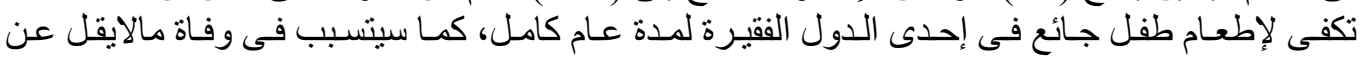

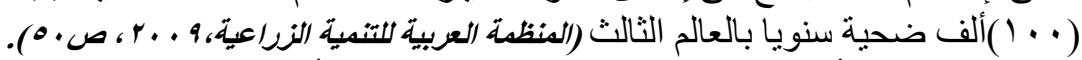

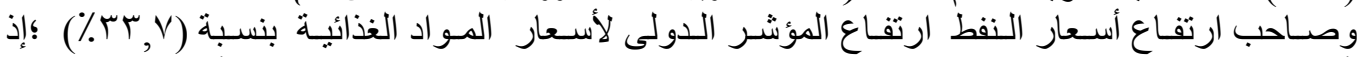

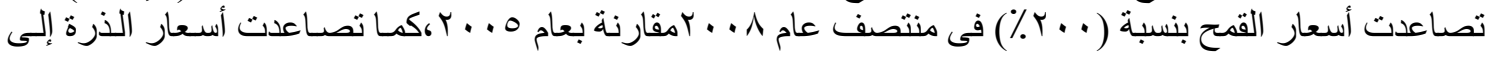




\section{مركز البحوث الجغر افية والكارتوجرافية - المؤتمر الجغرافى الدولى الثانى(r - ع) فبراير 9 ـ ـم د/ زينب أحمد على سلوم - خريطة الأمن المائى والغذائى بالوطن العربى}

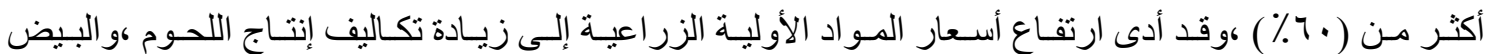

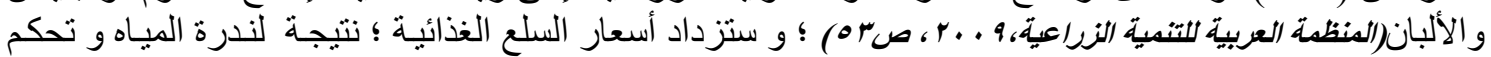

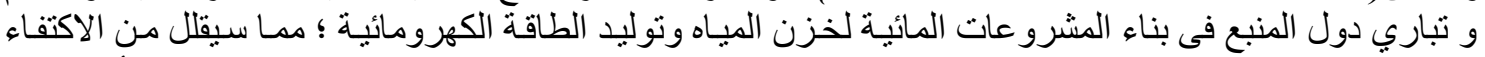

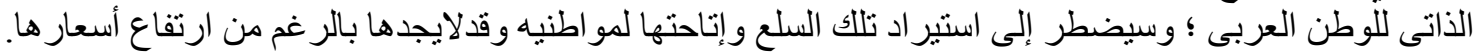

شكل رقم (1') - العمالة الزراعية بالوطن العربى

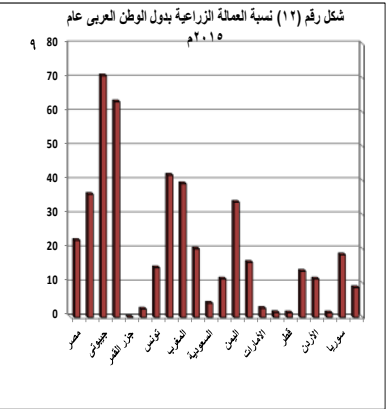

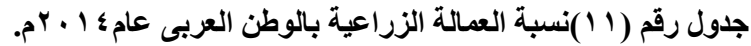

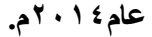

\begin{tabular}{|c|c|c|c|c|c|c|c|}
\hline 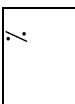 & 高哥产裹 & 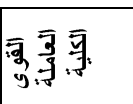 & الكيبان & & 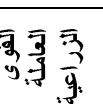 & 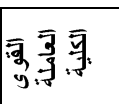 & "التيان \\
\hline$\mu \mu, v$ & YYIY, & rov1,r & اليمن & YY,O & 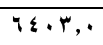 & $r \wedge\{\Psi, \cdot$, & هصر \\
\hline 14,1 & $r \leqslant \xi, V$ & $r \mid \varepsilon, r$ & عمان & r४, & $r \leqslant q \theta, \xi$ & $9 V \cdot \Lambda, r$ & الشودان \\
\hline$Y, Y$ & $10 \leqslant, 0$ & $0991, r$ & الإمارات & $v \cdot, v$ & $r \wedge V, \cdot$ & $\xi .4, r$ & \\
\hline $1, \varepsilon$ & 9,0 & $14 \mathrm{~V}, 0$ & البحرين & $8 \pi, 1$ & $r A V_{.,}$ & $\varepsilon 001, \varepsilon$ & الصومال \\
\hline $1, r$ & $r \varepsilon, \cdot$ & $|A| \varepsilon, V$ & قطر & Pن & م. & 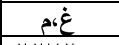 & جزر القر \\
\hline $1 \%, 0$ & ITr,Y & 11911,0 & العراق & $r, \xi$ & $0 \leqslant$, & YYVY, & ليييا \\
\hline $11, r$ & $Y \xi Y, Y$ & Y114, & الأردن & $1 \xi, 0$ & $0, \varepsilon, V$ & $r \leqslant \vee \wedge, V$ & تونس \\
\hline $1, r$ & $\overline{r y, \cdot}$ & $190 \wedge, 1$ & لبنان & $\$ 1,4$ & $\$ 909, \wedge$ & $11941, \cdot$ & الجزائر \\
\hline$\overline{l \Lambda, r}$ & Iror, & $\frac{V Y Y V, .}{V T}$ & سوريا & $r 9,1$ & $\xi 119,0$ & 1.0YY, & المغرب \\
\hline$\Lambda, v$ & $\Delta \uparrow, v$ & 94 & فلسطين & $r \cdot, \cdot$ & $1 v \cdot, 4$ & A०Y,q & موريتانيّا \\
\hline$r+1$ & rqvoo,v & IYAVAY,० & جملة الوطن & $\varepsilon, 1$ & $\varepsilon 90, \xi$ & $|r| r q, \varepsilon$ & السعودية \\
\hline$r \mu, v$ & YYIY, & $10 \times 1,1$ & اليمن & $11, r$ & $r r 1, \cdot$ & YAV•,, & الكويت \\
\hline
\end{tabular}

المصدر: الثكل من إعداد الباحثة اعتمادا على بيانات الجدول رقم (1').

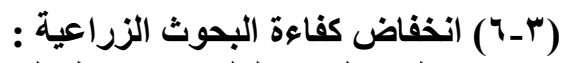

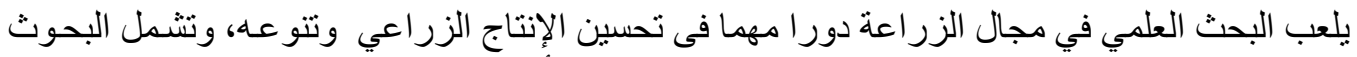

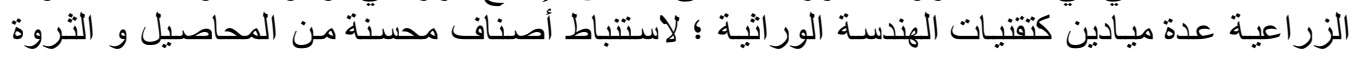

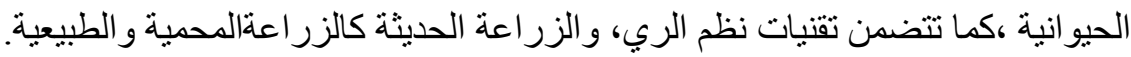

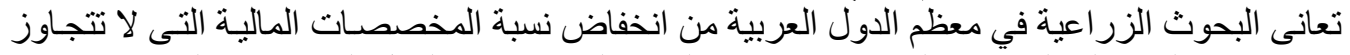

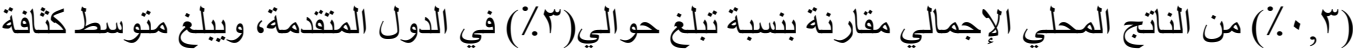

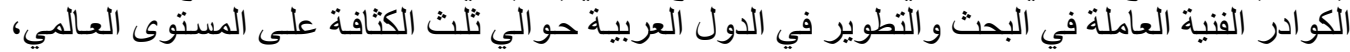

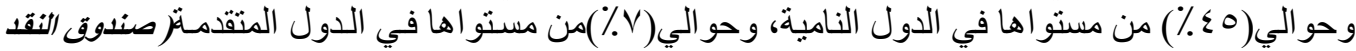

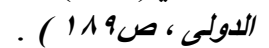

(V-r)

تو اضعت الاستثمار ات المبمارت الموجة للزر اعة مقارنة بالقطاعات الأخرى في معظم الدول العربية؛؛ إذ قدرت

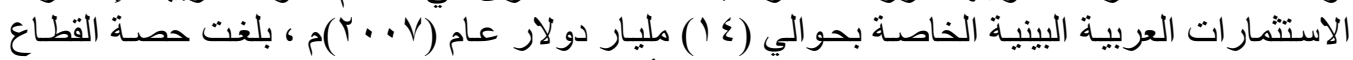

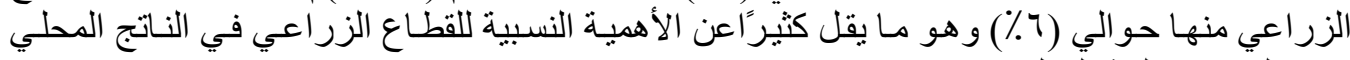

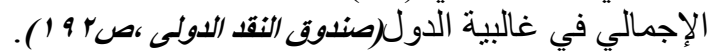

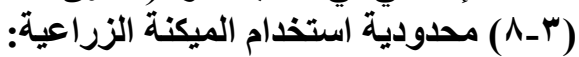

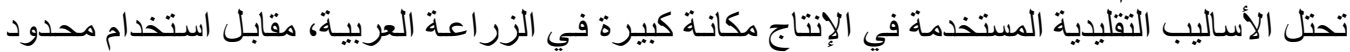

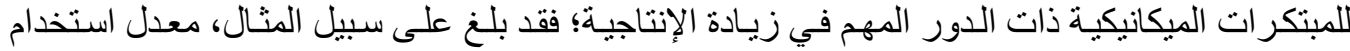




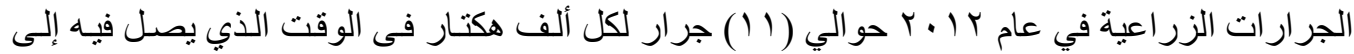

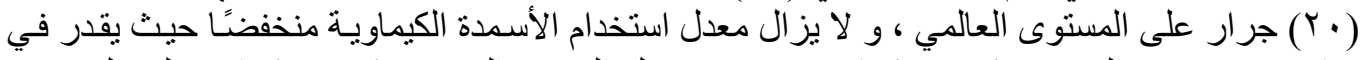

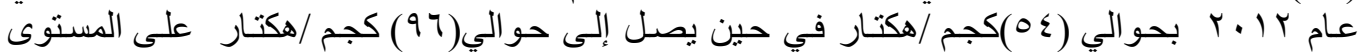
(؛) ) إستر اتيجيات تنمية الأمن المائى والغذائى.

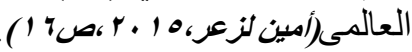

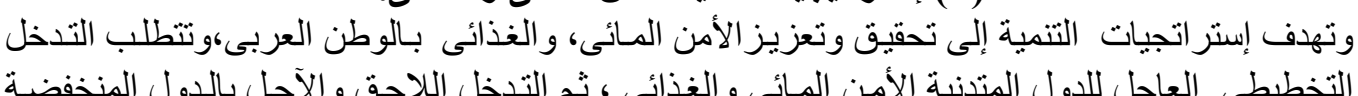

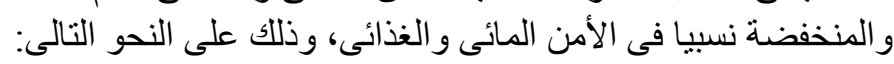

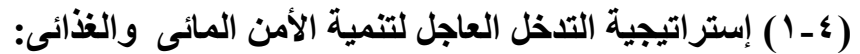

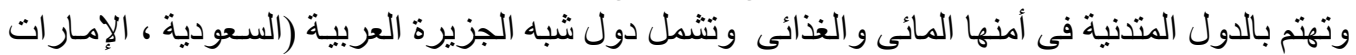

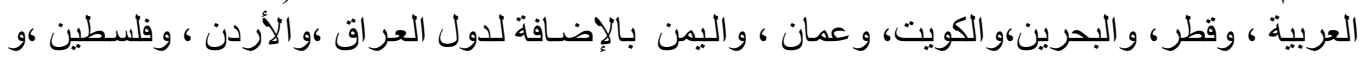

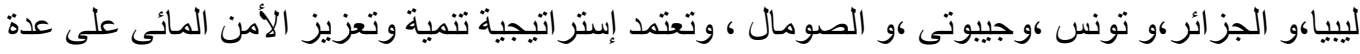

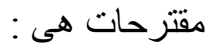
• ضبط النمو السكانى و السيطرة على مكوناته ؛إذ يعد المحرك الرئيس فى الفجوات الفئ المائية و الغذائية عندما

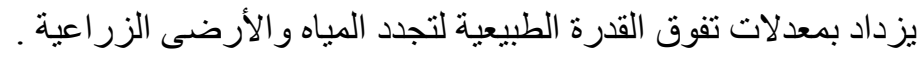

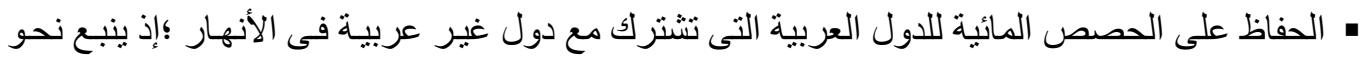

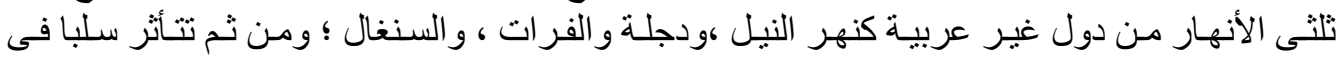

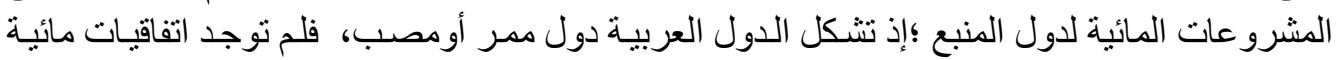

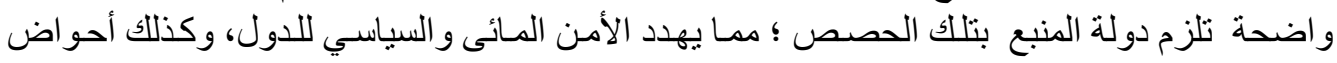

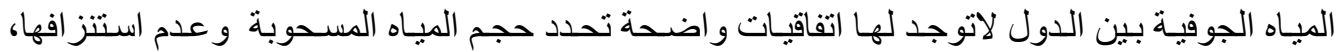

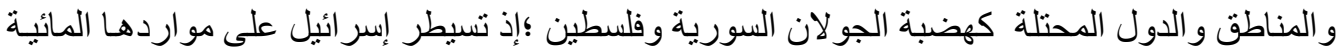

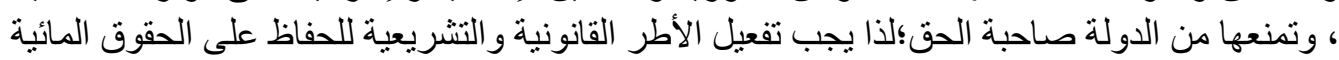

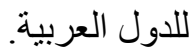

• رفع كفاءة استخدام الموارد المائية لاسيما فى الزر اعة ؛ إذ تعد الزر اعة الاستخدام الرئيس فى استهلاك

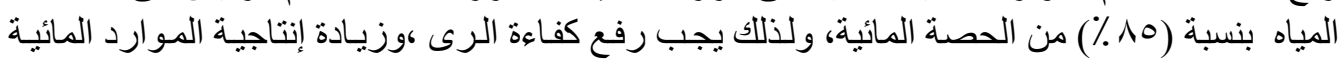

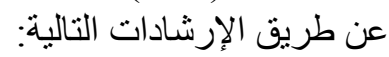

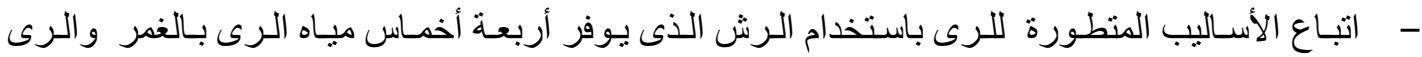

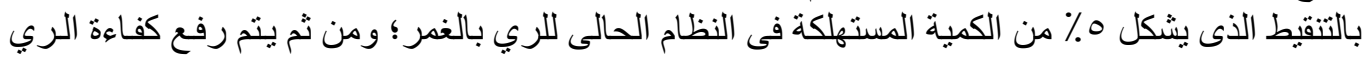

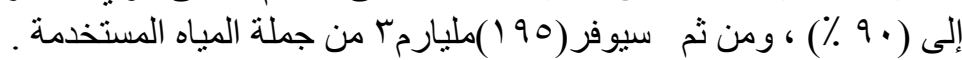

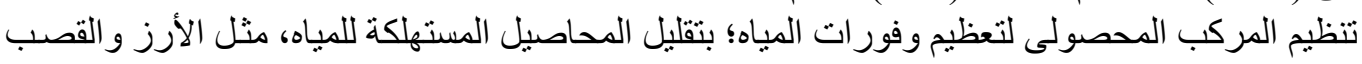

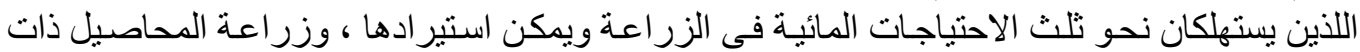

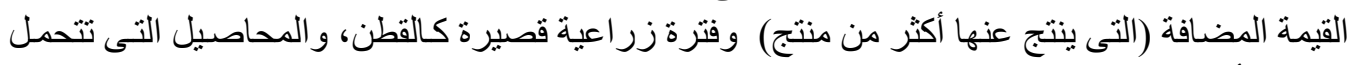
درجات أعلى من الملوحة.

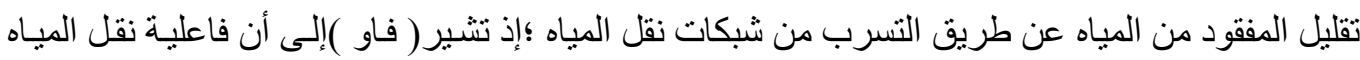

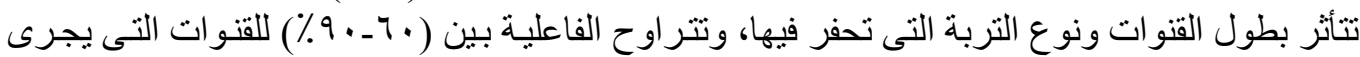

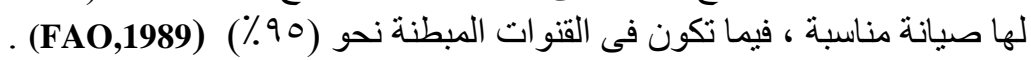

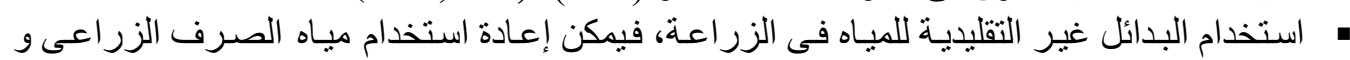

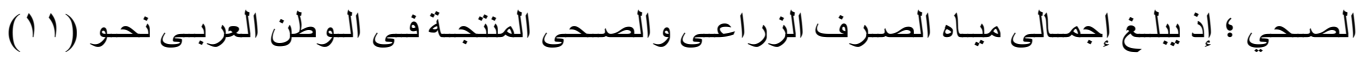




\section{مركز البحوث الجغر افية والكارتوجرافية - المؤتمر الجغرافى الدولى الثانى(r - ع) فبراير 9 ـ ـم د/ زينب أحمد على سلوم - خريطة الأمن المائى والغذائى بالوطن العربى}

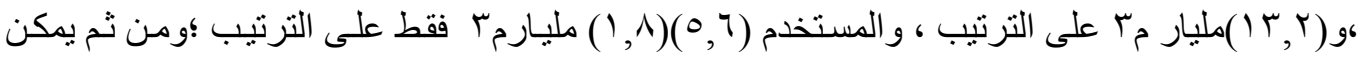

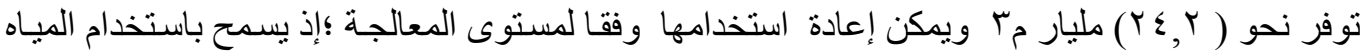

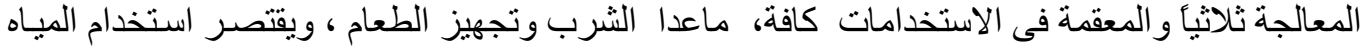

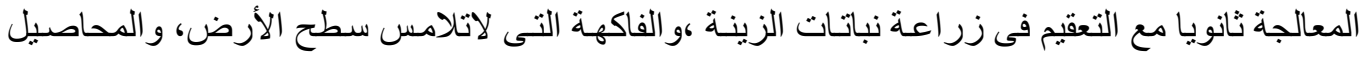

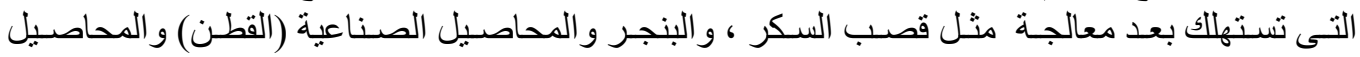

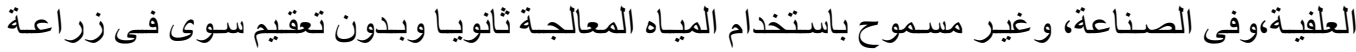

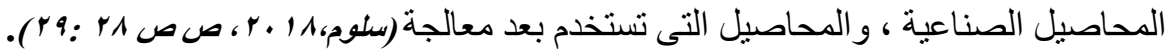

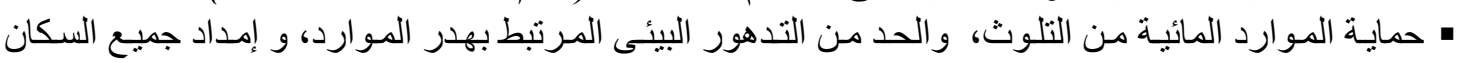

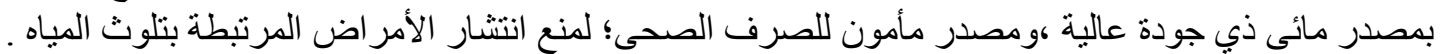

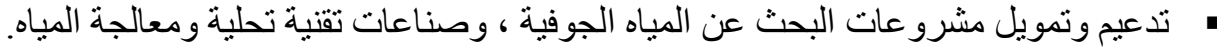

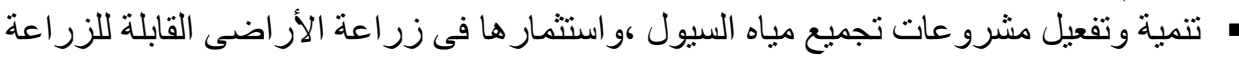

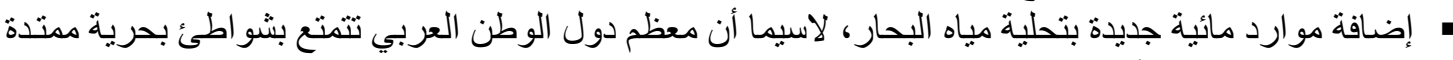

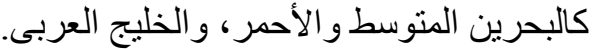

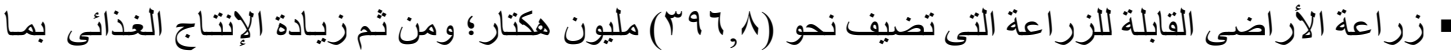

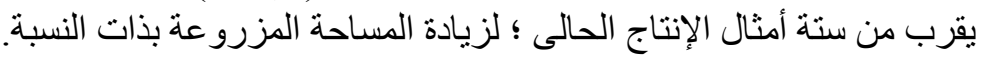

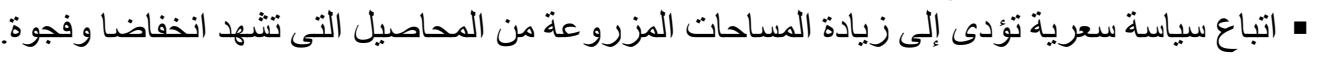

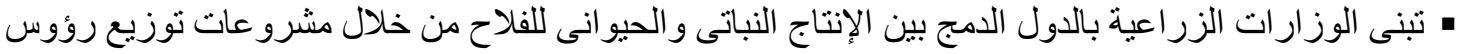

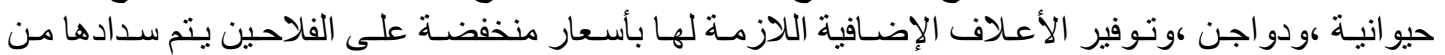

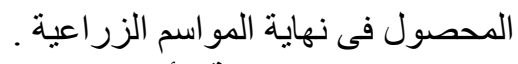

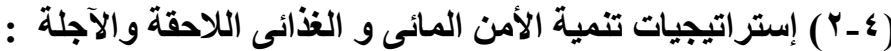

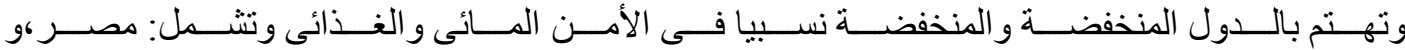

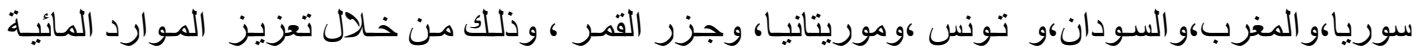

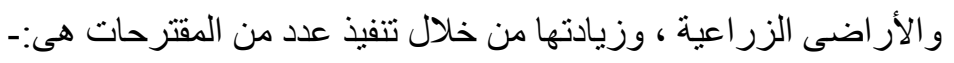

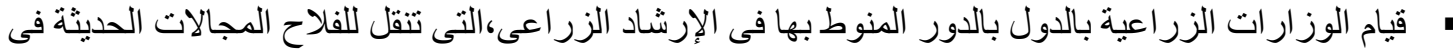
اختيار أكثر أنواع المحاصيل و السلالات الزات الحيو النية و الداجنة إنتاجا.

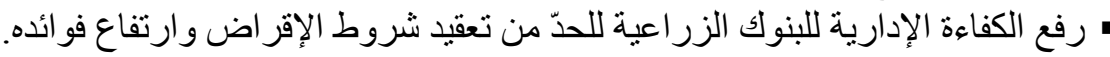

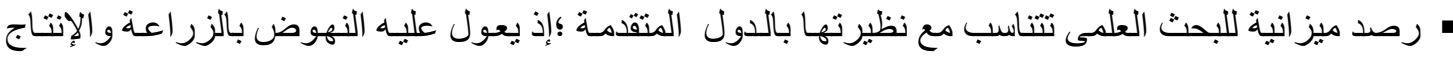

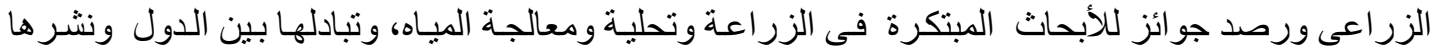
على شبكة المعلومات الدولية • ينبغى على الدول ملاحقة التقدم التكنولوجي للآلات الزر اعية ،وتيسير ها للفلاح بأسعار منخفضـة لاسيما فى لئى

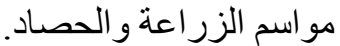
ـ التنسيق بين الخطط و السياسات التنموية الزراعية بالدول العربية، ودعم التخصص الإنتاجي بين هذه الدول ؛ وتبادله من خلال التجارة العربية البينية.

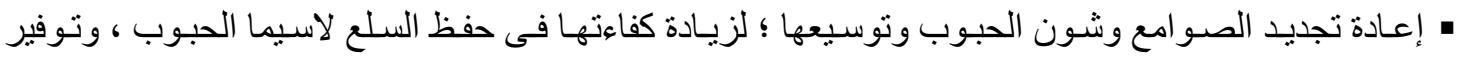

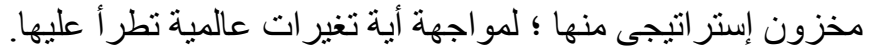

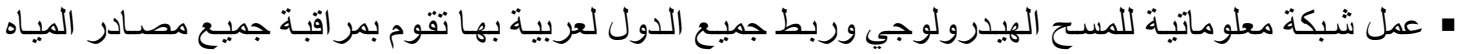

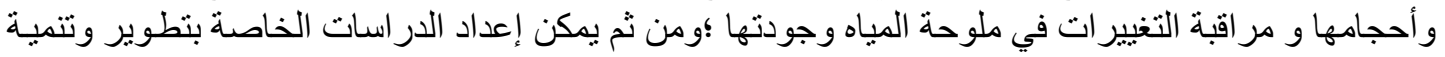

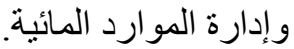




\section{مركز البحوث الجغر افية والكارتوجرافية - المؤتمر الجغرافى الدولى الثانى(r - ع) فبراير 9 ـ ـم \\ د/ زينب أحمد على سلوم - خريطة الأمن المائى والغذائى بالوطن العربى}

\section{نتائج وتوصيات البحث}

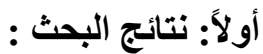

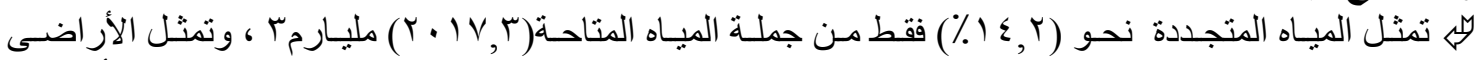

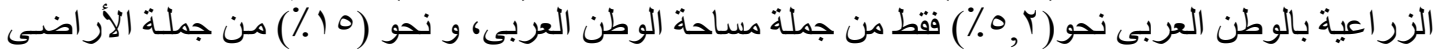
القابلة للزر اعة بالوطن

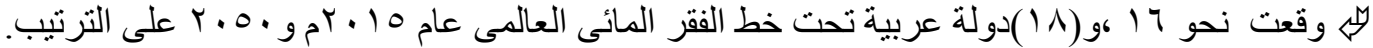

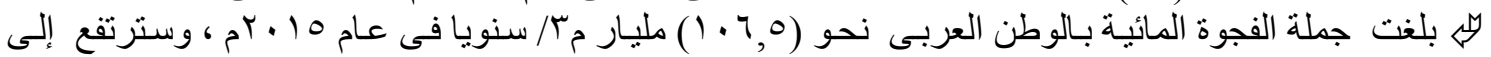

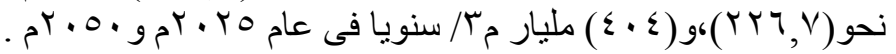

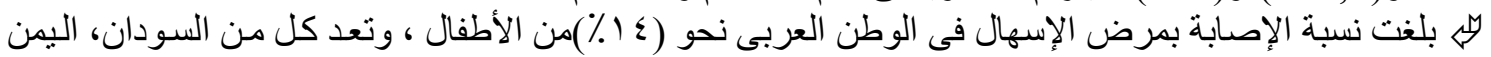

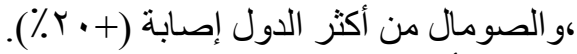

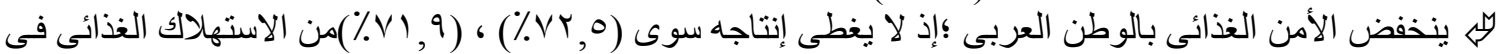

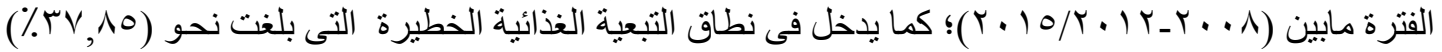

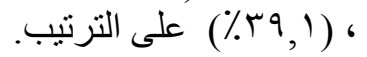

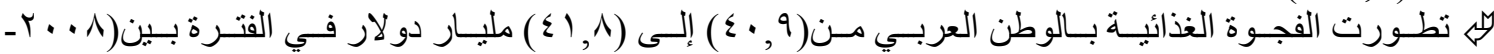

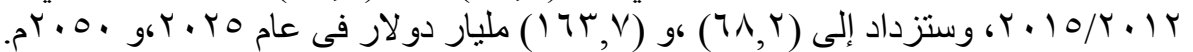

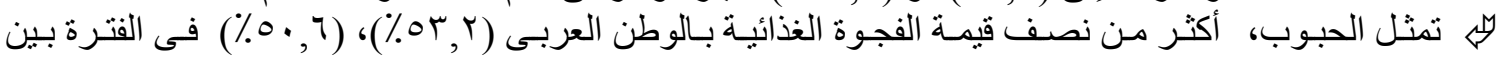

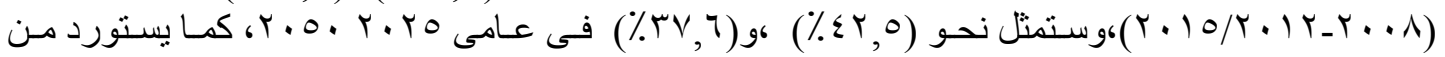

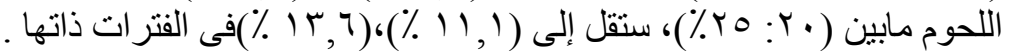

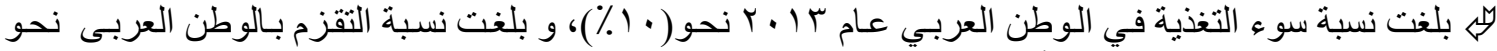

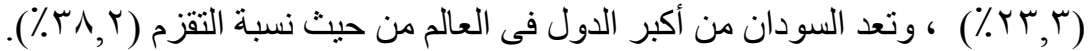

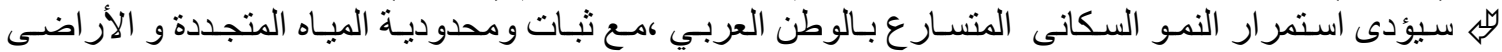

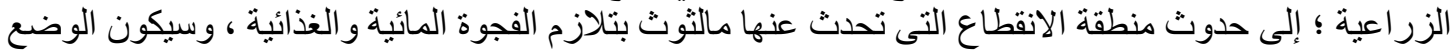

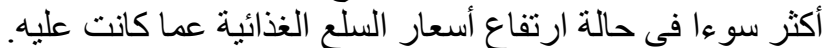

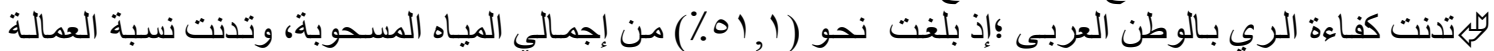

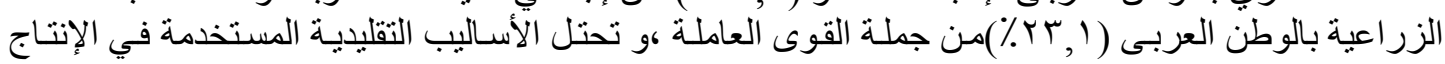

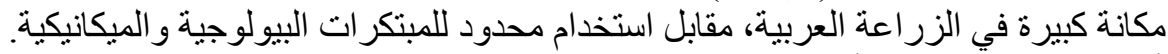

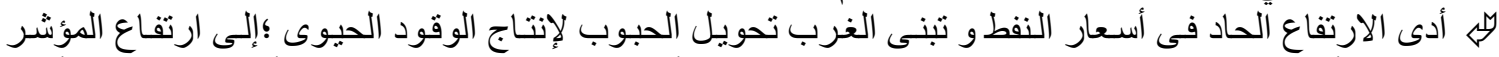

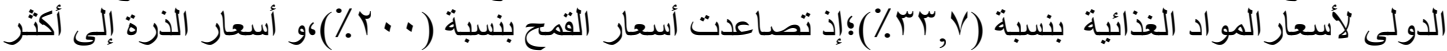

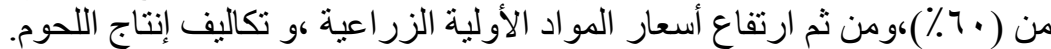

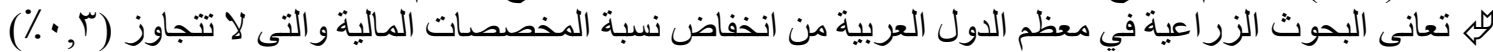

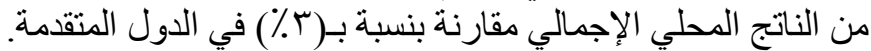

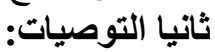

" يجب على الدول العربية ضبط النمو السكانى و السيطرة على مكوناته ؛إذ يعد المحرك الرئيس للفجوات .

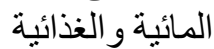

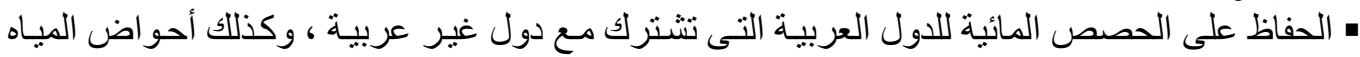

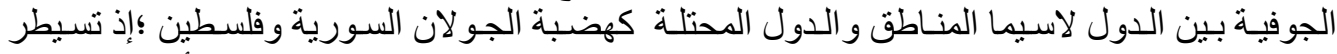

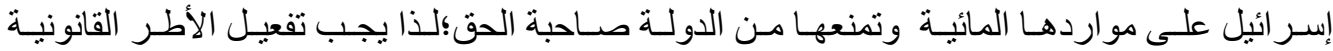
و التشريعية للحفاظ على الحقوق المائية للدول العربية. 


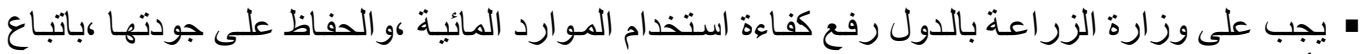

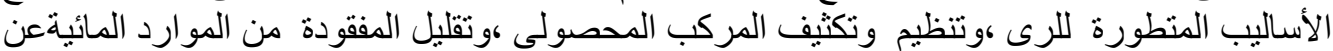

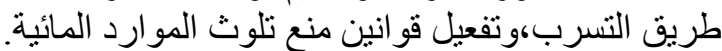

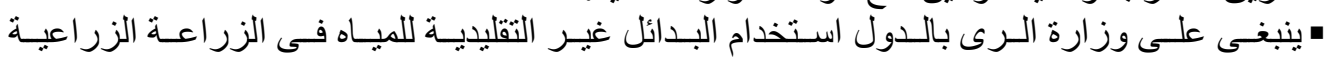

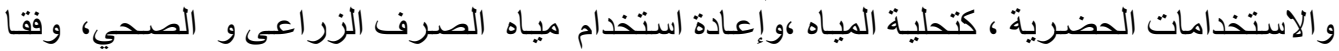

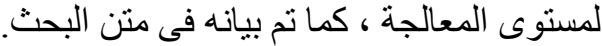

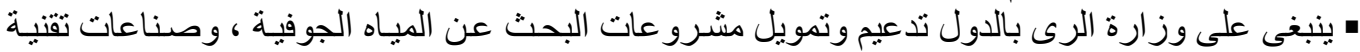
تحلية ومعالجة المباه. • ينبغى على وز ارة الرى بالدول تتميـة وتفعيل مشرو عات تجميع مياه السيول ،و استثمار ها فى زر اعـة

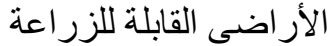

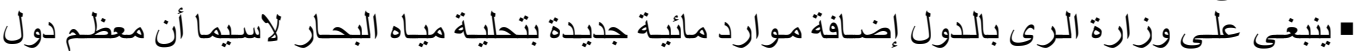

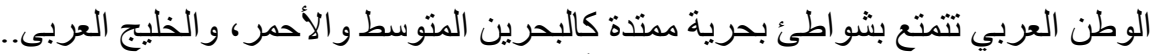

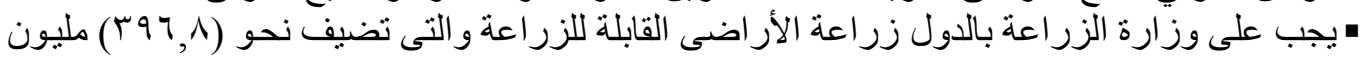

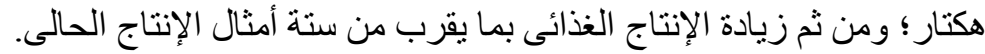

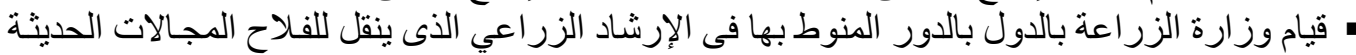

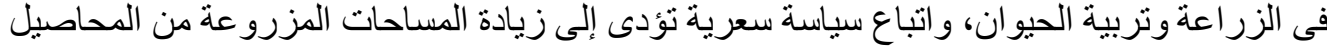

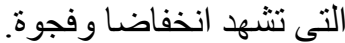
• تبنى وز ارة الزر اعة بالدول رفع الكفاءة الإداريـة للبنوك الزر اعية للحدّ من تعقيد شروط الإقر اض،

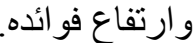

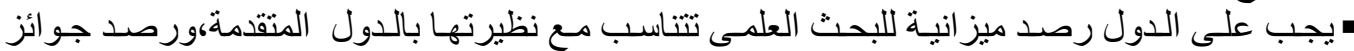

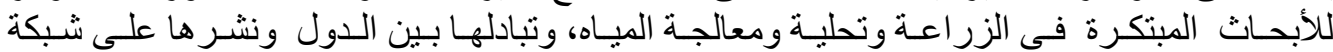

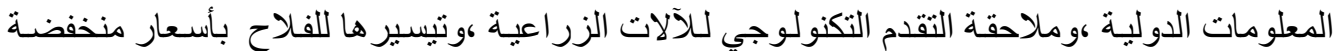

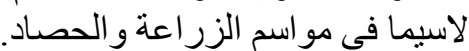

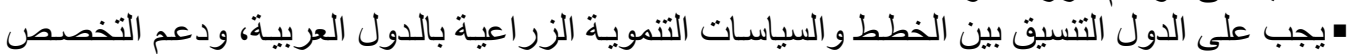

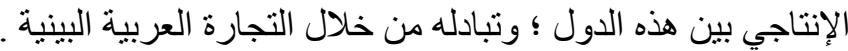

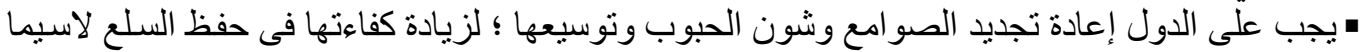

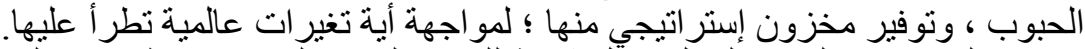

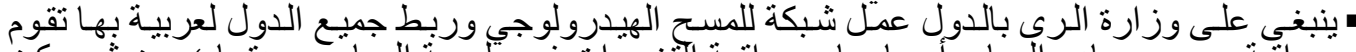

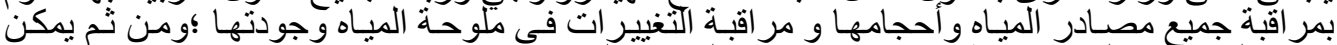

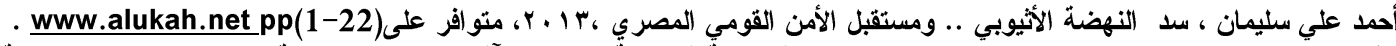

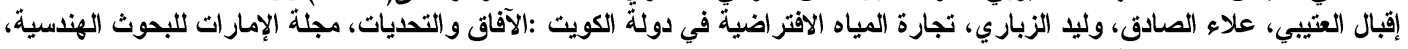

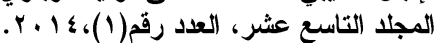

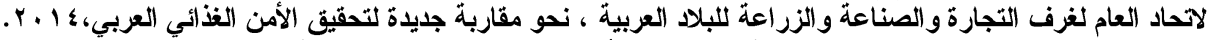

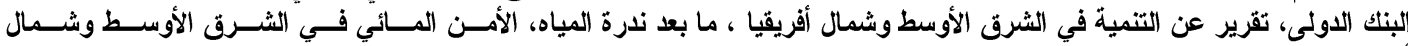

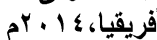

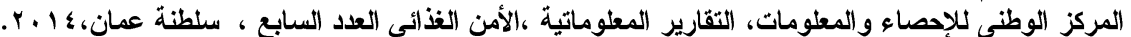

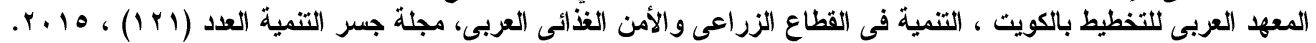

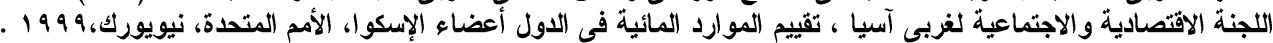

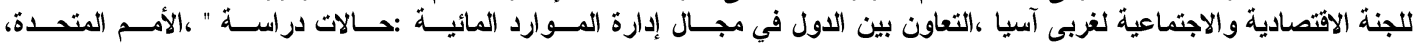
لمنظمة العربية للتنمية الزراعية، دراسة تحليلية تقيمية لآثار استخدام المحاصيل الزراعية فى إنتاج الوقود الحيوى،9 . . r. 


$$
\begin{aligned}
& \text { مركز البحوث الجغرافية والكارتوجر افية - المؤتمر الجغرافى الدولى الثانى(r- ـ) فبر اير } 9 \text { ــrم }
\end{aligned}
$$

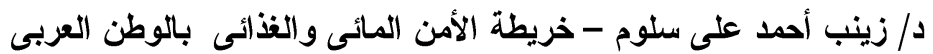

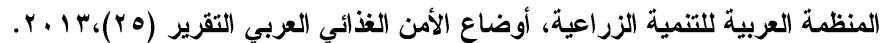

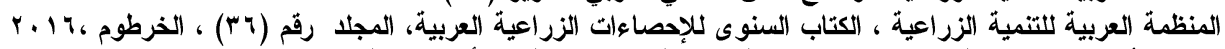

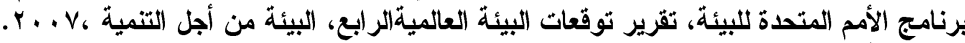

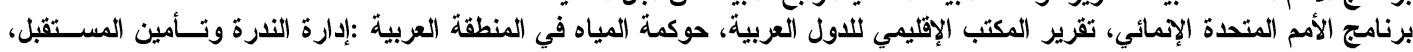
2013.

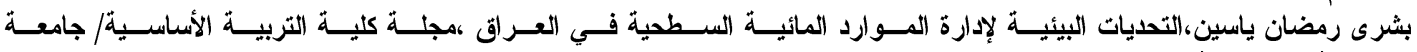

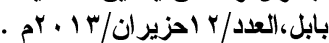

جمهورية العراق ،الرقابة المالية،تقرير عن تانئى كميات تدفق المياه فى نهرى دجلة والفرات،وانتشار الجزارات الوسيطة ،وأثرها على

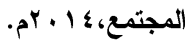

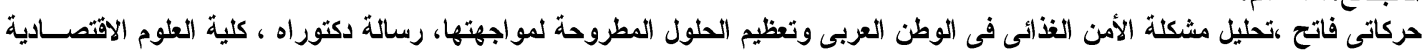

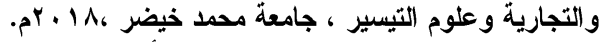

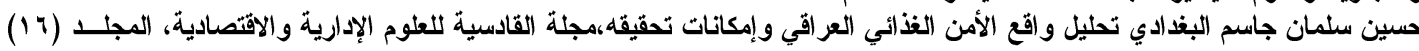

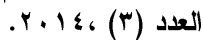

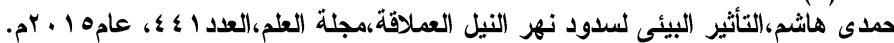

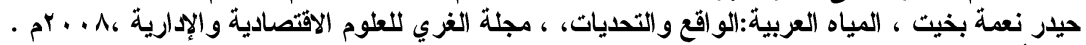

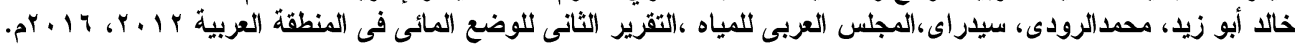

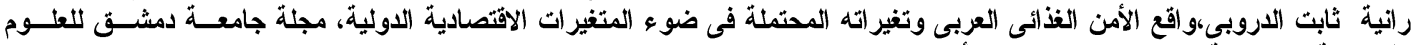

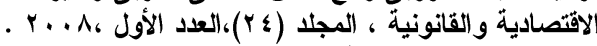

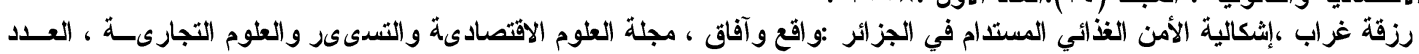

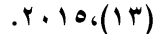

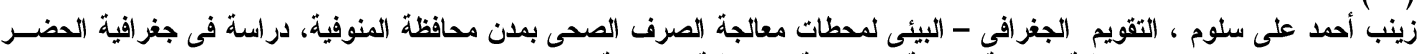

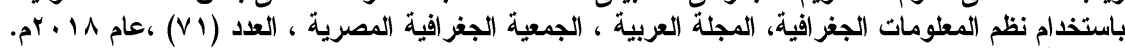

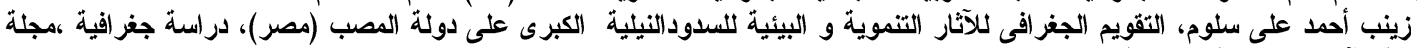

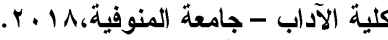

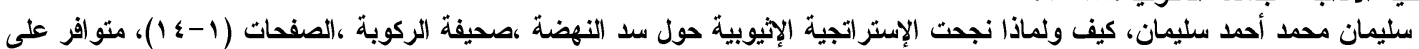

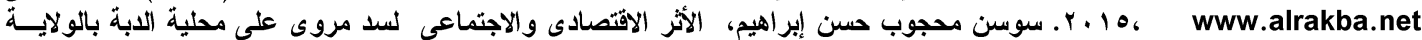

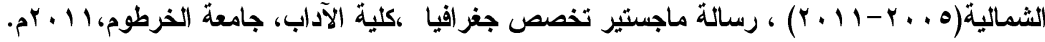

-1 .

$-11$

$-1\}$

$-14$

$-1 \varepsilon$

$-10$

$-17$

$-18$

$-11$

$-19$

$-r$.

- Y

$-Y Y$

$-r r$

$-r \varepsilon$

$-r o$

$-r y$

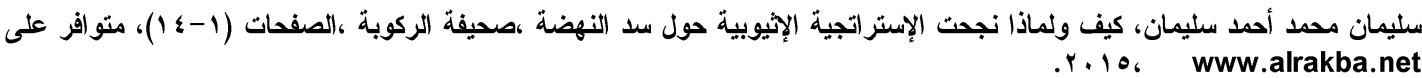

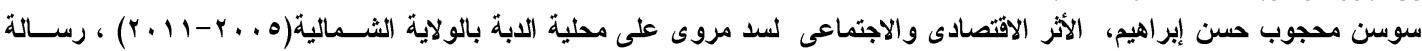

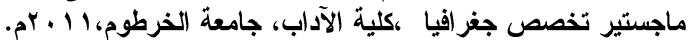

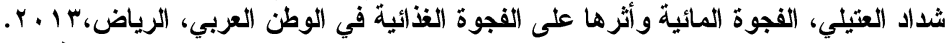

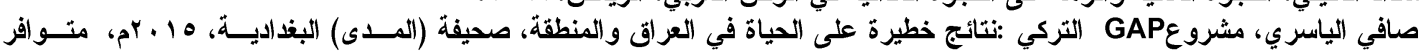

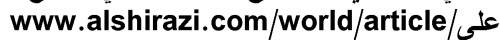

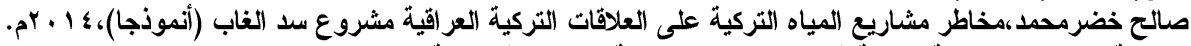

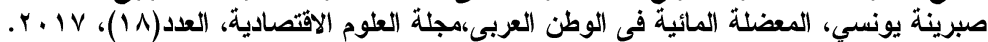

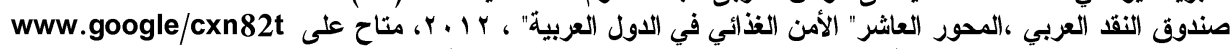

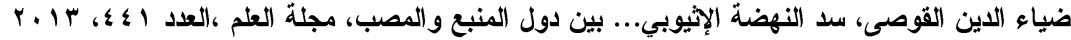

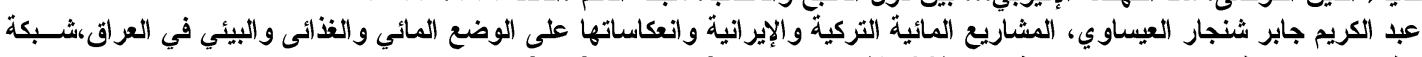

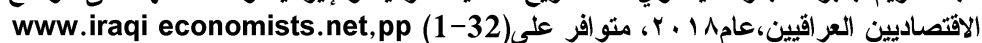

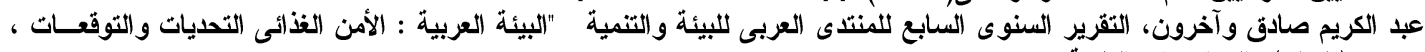

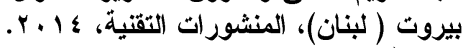

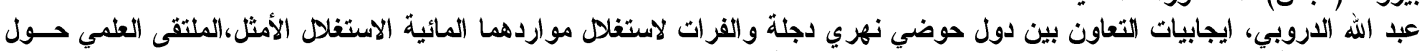

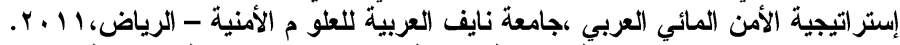

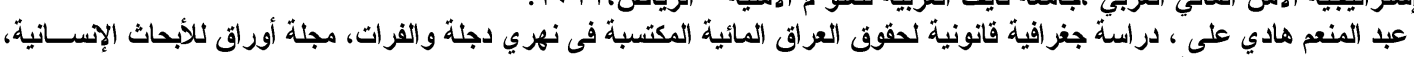

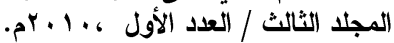

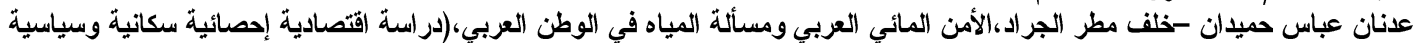

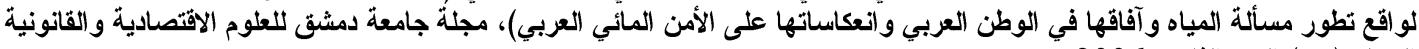

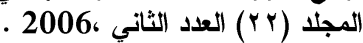
عليان محمود عليان ، المياه العربية من النيل للفرات، مجلة المستقبل ، مركز دراسات الوحدة العربية، بدون تاريخ.

-

r

Is

$\bullet$

7

v

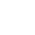




$$
\begin{aligned}
& \text { مركز البحوث الجغز افية والكارتوجرافية - المؤتمر الجغرافى الاولى الثانى(r - ع) فبر اير } 9 \text { أمبم } \\
& \text { د/ زينب أحمد على سلوم - خريطة الأمن المائى والغذائى بالوطن العربى } \\
& \text { فراس عبد الجبار الربيعي، أثر المشاريع الخزنية والاروائية في سوريا على الأمن المائي العراقي ،مجلة كلية التربية الأساسـية/ جامعـة }
\end{aligned}
$$

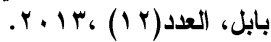

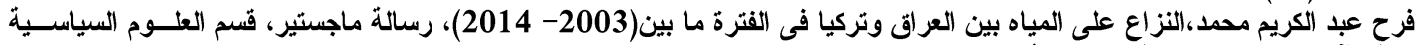

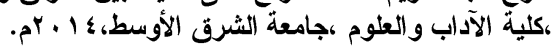

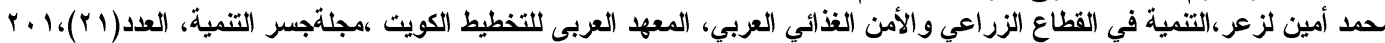

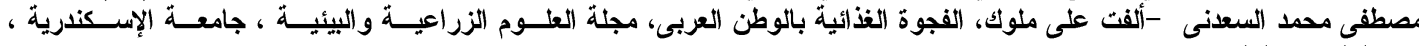

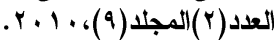

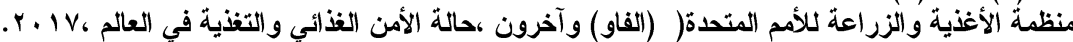

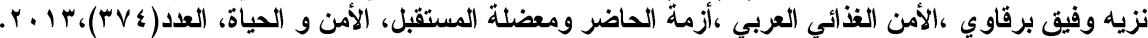

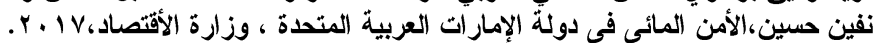

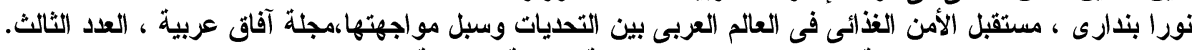

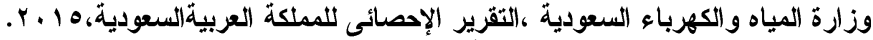

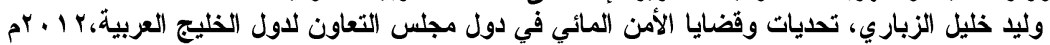

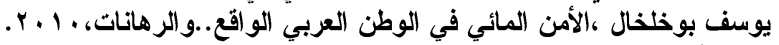

$$
\begin{aligned}
& \text { ثانياً :المراجع غير العربية: }
\end{aligned}
$$

1- Arab Water Counicil and CEDARE "State Of The Water First Report In The Arab Region,2004

2- Arab Water Counicil ,Perspectives on water and climate change adaptation," Vulnerability of arid and semi-arid regionsto climate change Impacts and adaptive strategies, 2008

3- Food and Agriculture Organization," Understanding Aquastat FAO'S Global Water Information System",2014 Available at :WWW,Fao.org/nr/water/aquastat/main/index.stm

4- Food and Agriculture Organization, "Water for food security and nutrition report no 9 ",2015, Available at :www.fao.org/fileadmin/user upload/hlpe/hlpe documents/HLPE Reports/HLPE5

5- FAO., " AQUASTAT Main Database WATER AND population In The Arab World, 2016 Available at : WWW,Fao.org/nr/water/aquastat/main/index.stm

6- Food and Agriculture Organization, AQUASTAT data, World Development Indicators, Freshwater2017pp1-6, Available at :WWW,Fao.org/nr/water/aquastat/main/index.stm

7- Gunn.E\& And Others," The concept of water and foodsecurity in Spain, DESTEFANO_Book.indb,2012

8- United Nations," Water and climate change impacts and adaptation strategies", 2011

9- U.S. Government" Global Food Security Strategy Fy 2017-2012",2016

10- W H O " Health Guidelines For The Use Of Wastewater In Agriculture And Aquaculture Genev,1989.

11- World Bank And Others," Water Reuse In The Arab World, From Principle To Practice" DubaiUAE,2011. 


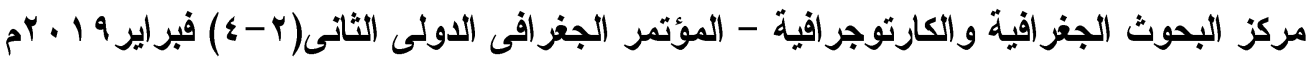

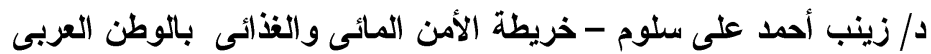

ملحق رقم (1) عدد السكان (مليون نسمة) وحجم المياه المتجدةة( مليار مج )

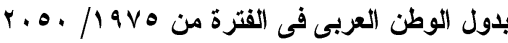

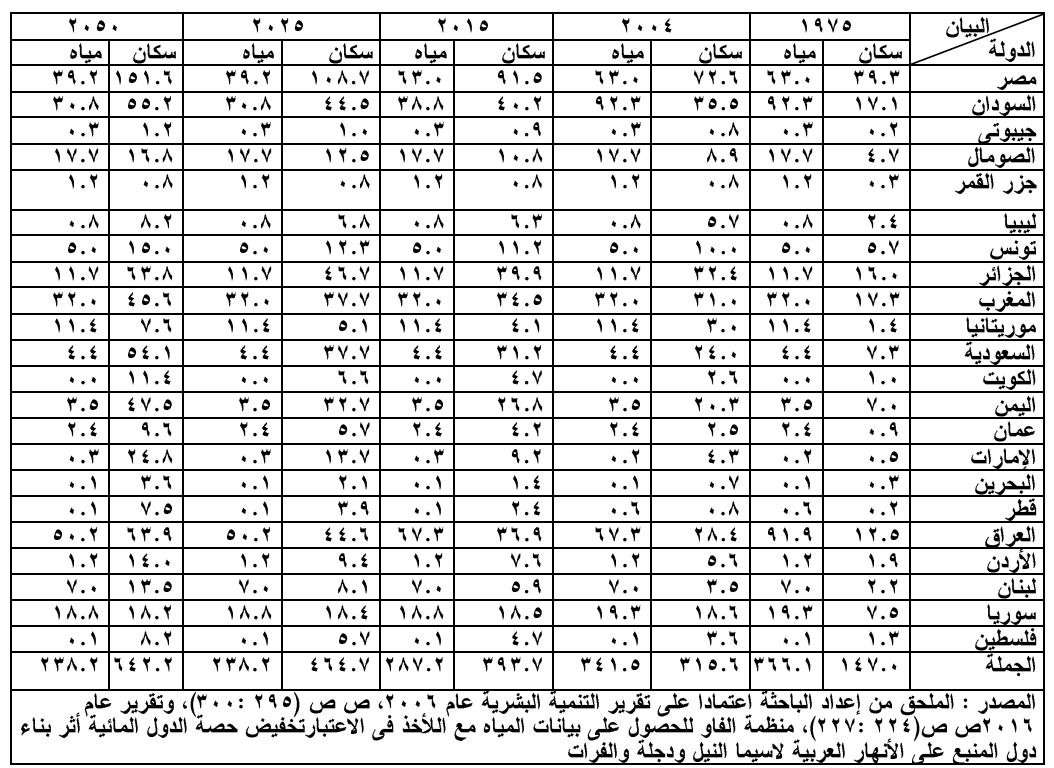

ملحق رقم (Y) نصيب الفرد من الإنتاج و الاستهلاك فى الفترة

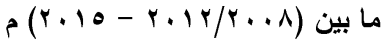

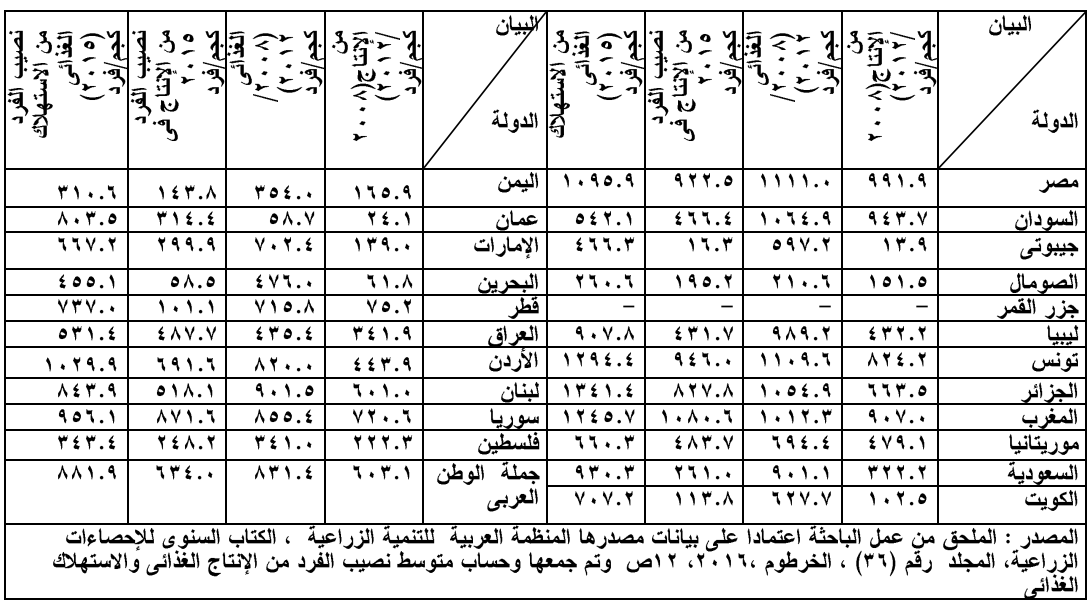




\section{مركز البحوث الجغرافية والكارتوجراقية - المؤتمر الجغرافى الدولى الثانى(r-؛) فبراير 9 ــrم

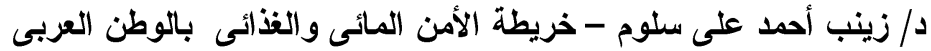

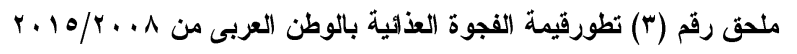

\begin{tabular}{|c|c|c|c|c|c|c|c|c|c|c|c|c|c|}
\hline عمان & العراق & |الصومال & سوريا & |السودان & السعوديةً & جيبوتى & الجزائر & تونس & البحرين & الإمارات & |الأردن & |الفترة & السلّع الغذائية \\
\hline OYY.\&Y- & $r \leqslant \Lambda . r V-$ & IVV.7- & r. T. $\{-$ & $\vee \backslash \wedge . \wedge-$ & $\leqslant \leqslant \varphi . .9-$ & or.r- & $\begin{array}{r}- \\
\text { rorr.a }\end{array}$ & $904 . \Lambda-$ & $1 \ldots \overline{9}$ & $9 \ldots .1-$ & OY\&.O- & $r+10$ & الحبوب \\
\hline$r \leqslant \Lambda . V \vee-$ & TH.\&V- & $101 . \varepsilon-$ & $9 \leqslant 9.1-$ & $\% \wedge 9 . \%-$ & $\{1 \% \Lambda . \%-$ & iv.V- & $\begin{array}{r}- \\
.79 . r \\
\end{array}$ & $\wedge \leqslant \psi .0-$ & QY.V- & $|r| . \bar{r}$ & v....9- & $\begin{array}{r}r .1 T \\
r+.1 \\
\end{array}$ & \\
\hline YE.TE- & $17.49-$ & $r . v-$ & 14.4 & $. .0-$ & rA.V- & r.I- & $94 . \leqslant-$ & IV.0- & $1 . r+$ & $17.0-$ & 1 Ir..- & $r+10$ & البطاطس \\
\hline$r r . r-$ & $7.79-$ & r.1- & 7.9 & $. . r-$ & Y0.Y & Y.A- & Ar.I- & $1 \wedge .1-$ & $r . r-$ & $r V . r-$ & $1 \% . \leqslant-$ & $\begin{array}{r}r+1 r \\
r \ldots i \\
\end{array}$ & \\
\hline $00.7 \varepsilon-$ & $r .1 .01-$ & $07.7-$ & iqY.V- & $\leqslant 01.1-$ & $101.7-$ & $V \leqslant .9-$ & 0 0IV..- & $1 \vee \wedge .9-$ & $9 . .-$ & $197 . \%$ & $1 \leqslant Y . Y-$ & $r+10$ & الكسكر الخام \\
\hline Tr.00- & rAl.VV- & iv.o- & $0 . \leqslant . \leqslant-$ & v.1- & 099..- & 7r.7- & $10 . . r-$ & $190.1-$ & rv.r- & MIV.r & 1V५.V- & $\begin{array}{r}r .1 T \\
r+.1 \\
\end{array}$ & \\
\hline $1 V .0 Y-$ & $2.10-$ & r.०- & $1 . .1$ & iv.v- & $10 . .7-$ & $. .7-$ & rrq.0- & $0.1-$ & $1.9-$ & $101.7-$ & $\leq V .9-$ & $Y+10$ & البقوليات \\
\hline 1..ri- & $9.1-$ & V.\&- & rr.. & $\ldots 1$ & A५.. - & $11 . v-$ & Y. 9. $\{-$ & V. $\{-$ & $0 . \Lambda-$ & IV^.\&- & $\leqslant \leqslant . \wedge-$ & $\begin{array}{r}r .1 \\
r \ldots \lambda \\
\end{array}$ & \\
\hline $11.1 \leqslant-$ & IY..Y- & $11.1-$ & $1 \leqslant V . r-$ & $1 \varepsilon .1-$ & $0 \leqslant V .1-$ & $0 . \Lambda-$ & $111.0-$ & $\wedge \wedge \vee . Y$ & rV.A- & $1 \ldots .9-$ & $17 \mathrm{~V} . \mathrm{A}-$ & $r+10$ & الخضر \\
\hline Y.YY- & $1 \leqslant 1.99-$ & $1 . . r-$ & $91.1-$ & $99 . .-$ & $19 \% . Y-$ & $11.1-$ & V99.1- & 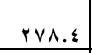 & $r \leq . r-$ & $+.1 .9-$ & IA५.V- & $\begin{array}{r}r .1 T \\
r \ldots \lambda \\
\end{array}$ & \\
\hline$r V . \leqslant 0-$ & $7 V .7 \varepsilon-$ & $0 . .-$ & $1 \wedge 9.8$ & r.q- & rYA.1- & $1.1-$ & $r \leqslant \ldots-$ & r..1 & $7+.9-$ & $1 \varepsilon . T$ & $01 \Lambda . v$ & $r+10$ & البذور الزيتيه \\
\hline$\{0.1 \%-$ & Ar.T9- & Ir..- & Y... & $\therefore v-$ & $1 \ldots r-$ & $10 . v-$ & I.V- & VY.O & r1..- & $\{v 1.0-$ & rvo.r & $\begin{array}{r}r \\
r \\
r \\
\ldots\end{array}$ & \\
\hline Irr.tr- & AY.\&)- & r.r & $r+1.1$ & r..\&- & V.r.q- & r.1- & rq1.v- & $r \leqslant \leqslant .9$ & $\Lambda \leq . \wedge-$ & $r+\Lambda .1$ & 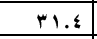 & $r+10$ & الفاك \\
\hline $101.99-$ & A9.r.- & r.V & $1 \times 9.9$ & $1+.1-$ & ror.s- & $\varepsilon . \varepsilon-$ & ra.q- & r.१.. & r9.9- & ort.\&- & $7 r .1-$ & $\begin{array}{r}r+1 Y \\
r+.1 \\
\end{array}$ & \\
\hline$r \leqslant 1.1-$ & Wr.\&Y- & $\therefore v-$ & iv.V- & $1 \% .$. & YOQY.Y- & v.०- & YY..Y- & $10.7-$ & $\begin{array}{r}- \\
r 90.9 \\
\end{array}$ & $\wedge \wedge \leqslant . \leqslant-$ & $\leqslant 1 \leqslant \ldots-$ & $r+10$ & اللحو \\
\hline r.r.rY- & $0 \leqslant \ldots \wedge 9-$ &. .1 & rr.V- & r.v & IV.T.Y- & $r \leqslant . r-$ & IAv.r- & ra.A- & $1 \leqslant \Lambda . \overline{9}$ & $\begin{array}{r} \\
\wedge \wedge 0 . \wedge \\
\end{array}$ & rYo.1- & $\begin{array}{r}r+1 \\
r \ldots i \\
\end{array}$ & \\
\hline$v \vee . .1$ & $7 \leqslant-$ & $r . r$ & $0 . r-$ & ...- & rYT.V- & ...- & $11 \mathrm{r.r}-$ & $0 V .7-$ & $1 \ldots-$ & IVT.r- & $11 \ldots \varepsilon-$ & $r+10$ & الأسماك \\
\hline 71.71 & Or.\&Y- & $r . r$ & $00 . V-$ & r.9- & $Y \Psi \leq . Y-$ & ...- & $\leqslant V . Y-$ & $r v . r-$ & $\{. .-$ & r.r.o- & V५..- & $\begin{array}{l}r .1 r \\
r \ldots \lambda\end{array}$ & \\
\hline$|\wedge 0 . r|-$ & $\leq 0 . .0-$ & $9.1-$ & $r r . r$ & r...- & $910.9-$ & $10 . \%-$ & $11 \% \bar{r}$ & T.\& & $\leqslant 0 .$. & $\{\wedge \vee . r-$ & $r . r . .-$ & $r+10$ & الألبان \\
\hline$|r \ldots v|-$ & $\{0 . . \leqslant-$ & $9.1-$ & 10.4 & rv.1- & Vro.v- & $1 \leq .9-$ & $117 . \bar{r}$ & $1 . . v-$ & VY...- & ०qV.Y- & $109.7-$ & $\begin{array}{r}r \ldots 1 \\
r \ldots i \\
\end{array}$ & \\
\hline IIOr.OV- & $11.9 . .4-$ & roq.V- & irk.1- & Irao.r & $1 \ldots V_{1.4-}$ & $170 .+$ & หง91. & $0 \wedge .0-$ & $\begin{array}{r}- \\
\text { ovo.r }\end{array}$ & riva.r & $1 . \times 1 . \overline{-}$ & $r+10$ & الجملة \\
\hline$q Y \leq . r-$ & $1191 . .0-$ & หч... & $11 \leqslant 9 . \varepsilon$ & $\Lambda \leq \Upsilon . V-$ & $\Lambda \leqslant \leqslant v .1-$ & YYY.S- & $\begin{array}{r}- \\
\text { I }\end{array}$ & OV५.द- & $\leq \leqslant 9 . \overline{9}$ & $\begin{array}{r}- \\
\leq 09 \leqslant .9 \\
\end{array}$ & $\begin{array}{r}- \\
r v \leq . . \\
\end{array}$ & $\begin{array}{r}r .1 Y \\
r \ldots 1 \\
\end{array}$ & \\
\hline
\end{tabular}

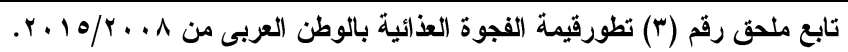

\begin{tabular}{|c|c|c|c|c|c|c|c|c|c|c|c|}
\hline الجملة & اليمن & موريتانيا & المغرب & مصر & ليبيا & لبنان & الكويت & قطر & فلسطين & |الفترة & السلع الغذائية \\
\hline r11r1.1- & $1 Y \wedge \leqslant .9-$ & 1०.०- & $1+1 \leq .7-$ & $\leq Y \leq \leqslant .0-$ & \&V9.1- & TrT.A- & $0 . r .1-$ & $r \cdot V . r-$ & $\Lambda 0 . \wedge-$ & $r .10$ & \multirow[t]{2}{*}{ الحبوب } \\
\hline rivio- & IT.T. $\leq \leq-$ & $1+\ldots 1-$ & IVAY.०Y- & rvor..o- & $v \cdot \eta . . v-$ & rหA.T- & 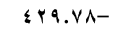 & ro1.9 $9-$ & 1rv.9v- & $|r+\Lambda / r+1 r|$ & \\
\hline lor.Ao- & r.19- & $r .9-$ &. $.1 \mathrm{~V}$ & 74.7 & $\leqslant . \leqslant \mu-$ & r..tr- & 1 r.^9- & $1 \mathrm{H.TY-}$ & ..rA- & $r \cdots 1$ & \\
\hline r^ar.r- & $\varepsilon .9 .1-$ & $\leq 4.1-$ & $\{.7 .7-$ & M11.9- & I.Y.r- & พร.V- & $\leq \varepsilon . Y-$ & $r \varepsilon . V-$ & r.. & $r .10$ & \multirow[t]{2}{*}{ السكر الخام } \\
\hline พV97.17- & $5.9 .99-$ & $0.911-$ & $\leqslant 00 . \leqslant \wedge-$ & rr^.9V- & $90.0 \mathrm{~V}-$ & $11 . \wedge \wedge-$ & Tr.YO- & $r \leq .11-$ & T.Y $\leqslant-$ & $r \ldots \lambda / r+1 r$ & \\
\hline $1 . \vee Y .9-$ & $19.5-$ & $. .1-$ & $0 . \varepsilon-$ & rVV.O- & $1.1-$ & rV.O- & ห५..- & YV.s- & r...- & $r .10$ & \multirow[t]{2}{*}{ البقوليات } \\
\hline 199.7ะ- & $r \varepsilon . r V-$ & $.00 \leqslant-$ & $r . . r V-$ & Pr..99- & $4.91-$ & Tr.\&Y- & $11 . Y Y_{-}$ & $1 \mathrm{V.01-}$ & $1.0 \mathrm{~V}-$ & $\cdots N / r+1 r$ & \\
\hline rVVa.A- & r..r- & .7 & 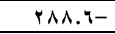 & $11 \mathrm{Vr} . \mathrm{r}-$ & $79.1-$ & rY\&.9- & 1.V. $\{-$ & 19.2 - & ro.0 & $r .10$ & \multirow[t]{2}{*}{ الخضر } \\
\hline$r v . \varepsilon . r q-$ & $179.11-$ & ००.V०- & 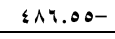 & $914 . \vee \wedge-$ & $19 . \$ 1-$ & $11 \Lambda . Y 1-$ & $\Lambda \Lambda . \% \mathrm{H}$ & $71.9 \mathrm{~V}-$ & $0.1 \mathrm{~V}$ & $\Lambda / r+1 r$ & \\
\hline $1 \leqslant V \leqslant . \leqslant$ & $10 . \mathrm{ri}_{-}$ & $11 . .9-$ & (TI.VI & $\wedge \wedge 0.0 Y$ & $1.0 Y-$ & Tr.ri- & IVv.vo- & IV..rY- & ro..v & $r .10$ & \multirow[t]{2}{*}{ البذور الزيتيه } \\
\hline $909 . .9$ & IV.or- & $11 . r Y-$ & $1 \leqslant 0.7 \mathrm{~V}$ & $0 \wedge \vee . \leqslant 9$ & rr.vi- & $r . .1 \leq-$ & ᄉq.v9- & VV.A- & 11.71 & $r \ldots \mu / r \cdot 1 r$ & \\
\hline $10 \mathrm{~V} .4-$ & YY.VT & $1.9 \leq-$ & $\leq$ Yr.O & rv^. $\leq 1$ & OV.rA- & rY. $\varepsilon \leq$ & FIA.V7- & $1 \mathrm{HO} . \wedge \mathrm{r}-$ & $0.11-$ & $r .10$ & \multirow[t]{2}{*}{ الفاكهة } \\
\hline$\leqslant 09.01-$ & IV.ro & $2.10-$ & $\{17.04$ & $\vee \wedge 1 . \leqslant \wedge$ & O..ro- & $10.19-$ & $99.97-$ & AN.97- & $7.7 \%-$ & $\cdots N / r+1 r$ & \\
\hline$\wedge r .1 . V \wedge-$ & Irq.rV- & $11.90-$ & $0 \leq .7 \leqslant-$ & Y.qV.T $1-$ & $\leqslant V . \wedge r-$ & $\leq Y . \leqslant Y-$ & $\leqslant 9 \wedge . \wedge \leqslant-$ & $\leqslant \wedge r . v o-$ & $\leqslant 0 . \wedge-$ & $r .10$ & \multirow[t]{2}{*}{ اللحوم } \\
\hline TE.T.ON- & $111.10-$ & V. $\leqslant 0-$ & $r \wedge . \leqslant \leq-$ & ATV.VY- & Tr.rV- & 17V.V9- & rap.०१- & YYo.rs - & rA.. V- & $r \ldots N / r, 1 r \mid$ & \\
\hline $0 \leqslant \Psi . \leqslant A-$ & $1 \leqslant V . V Y$ & 9A.Y & VVq.ri & orr.Av- & rq.४А- & Ar.qH- & V1.9V- & IY.Or- & Ir.ro- & $r .10$ & \multirow[t]{2}{*}{ الأسماك } \\
\hline rAV.AA- & $1 . Y . \leqslant \Lambda$ & $11 \% .9$ & VTV.Aq & $\{11 . \leqslant Y-$ & ra.५A- & $\wedge \Lambda . \diamond \Lambda-$ & $r 0 . r \leqslant-$ & $11.10-$ & Q.. Y- & $r \ldots \Lambda / r+1 r \mid$ & \\
\hline $0191 . .1-$ & एчч.1- & $\varepsilon \wedge . r-$ & $114 . .1-$ & $\varepsilon r \ldots v r-$ & $194.11-$ & r9.. $\leqslant \mathrm{V}-$ & 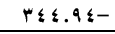 & ron.Tr- & rA... - & $r .10$ & \multirow[t]{2}{*}{ الألبان } \\
\hline $2417 . \% 9-$ & rY..Vq- & EV.rV- & $1 \leqslant V . r-$ & $r \wedge .94$ & PYY.ST- & YqL.rq- & $r \leq 9.91-$ & $190.41-$ & $19.7 \%-$ & $r \ldots \Lambda / r \cdot 1 r$ & \\
\hline$\{1 \vee 0\}-$ & $r . \leqslant 1 . . v-$ & $1 \times \leq .9 \leqslant-$ & $1 . r 9-$ & $\vee \curlyvee \wedge \bullet . \diamond V-$ & $994 . \leqslant \leqslant-$ & $11 r \ldots 0-$ & Y1Y $\{\leqslant V-$ & $17 Y 0 . v 1-$ & TY⿱.T⿰- & $r .10$ & \multirow[t]{2}{*}{ الجملة } \\
\hline$\{.9$ ४.. & $\$ 1.9 .1 \leq-$ & $191.44-$ & $11 r \leqslant \ldots \Lambda-$ & $0 . r . . \leqslant \mu-$ & $1 \leqslant$ Y O.AT- & $1 \times 1 \wedge . \leqslant \varepsilon-$ & $1 \leqslant V 9 . \leqslant V-$ & $1 . Y 1 . \Upsilon 1-$ & rRT.YI- & $r \ldots N / r \ldots|r|$ & \\
\hline
\end{tabular}




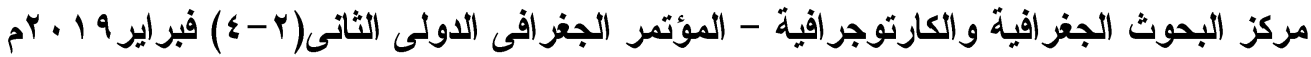

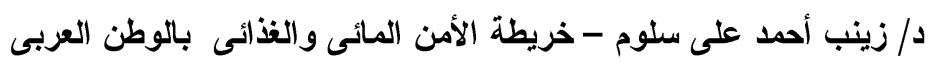

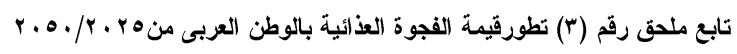

\begin{tabular}{|c|c|c|c|c|c|c|c|c|c|c|c|c|}
\hline العراق & الصومال & سوريا & السودان & |السعودية & جييوتى & الجزائر & تونس & |البحرين & الإمارات & الأردن & |الفترة & الغذائية \\
\hline- & & & & $\leqslant \leqslant v \leqslant, V$ & & r9०५,0Y- & $1 \cdot 10,7-$ & & roqv, \& $\varepsilon-$ & - & 0 & \multirow[t]{2}{*}{ الحبوب } \\
\hline rYOO.VY- & $\{-$ & $\leqslant-$ & $90-$ & & $v-$ & $0094, \% \wedge-$ & $0 .-$ & $\varepsilon-$ & - & A1- & .0. & \\
\hline rq.rr- & $\leqslant 0-$ &, 90 & ra- & $1,19-$ & $V \varepsilon-$ & $\cdot 1,71-$ & $0,7,-$ & $r \leqslant, 09-$ & $1, v$. & $0, \leqslant \leqslant-$ & r.ro & \multirow[t]{2}{*}{ البطاط. } \\
\hline A..rq- & $\mathrm{AV}-$ & $\leq ৭, \wedge \leq$ & $.7-$ & $V r, I V-$ & $r-$ & $r$ r,vq- & $1+v, \leqslant 9-$ & $r-$ & 179,19 & $r, .1-$ & r.o. & \\
\hline $11 . .1-$ & ra- & $11, \ldots-$ & $\leq \leqslant, 0 \leq-$ & $\Lambda \uparrow, ० Q-$ & ri- & VVY,VV- & r $10, \vee \wedge-$ & $94-$ & $1 \times 7, \vee \wedge-$ &,$V r-$ & r. ro & \multirow[t]{2}{*}{ السكر } \\
\hline rYA.V9- &,$\ldots-$ & $11,9 \vee-$ & $r \leqslant 4$ & $r r-$ & $.1-$ & $000, \wedge i-$ & rr४,rs- & $\leqslant \uparrow, \leqslant \uparrow-$ & $1 \wedge \leqslant 9, \wedge 0-$ & $10, Y 1-$ & r.o. & \\
\hline $17.19-$ & $\varepsilon-$ & ,Vr & va- & ᄉ :- & $\{1-$ &,$r \leq-$ & $.0 \mathrm{~V}-$ & 9.- & $.0 \%-$ &, $.0 \mathrm{~V}-$ & r. ro & \multirow[t]{2}{*}{ البقوليا } \\
\hline $1 \wedge . .0-$ & $r q, 1,-$ & $0,1 \%$ & $Y, A Y-$ & $09, \Gamma 1-$ & $\{.-$ & rVY,AI- & $1 \wedge, 1 \leqslant-$ & $9 .-$ & $V H \varepsilon, r V-$ &., 79 & r.o. & \\
\hline $1 \cdot 0 . \wedge \mathrm{V}-$ & & ro & & $19-$ & & Y,YA- & $7, .7$ & rq- & $1-$ & $V, i$. & r.ro & \multirow[t]{2}{*}{ الخض } \\
\hline $1.9 .7 \leq-$ & $r r, \ldots-$ & $7,9 \mathrm{~V}$ & $\leqslant 1-$ & $\leqslant 99, \leqslant V-$ & $1 \ldots, \diamond \vee-$ & Or,TV- & riq,.V & . $\vee \wedge, \vee \vee-$ & $r \Lambda \cdot v, \Lambda 1-$ & $19 ., 10$ & r.o. & \\
\hline rrE...O- & IV,Or- & $\{r, 01-$ & $1,9 \Lambda-$ & $14 \leqslant, 1 \wedge-$ & $18-$ & $11, \wedge r-$ & $1 \wedge \times 4,19$ & $i r, V 1-$ & $\Lambda \wedge, r^{\prime}{ }_{-}$ & $0,19-$ & r. ro & \multirow{2}{*}{ الزيتية } \\
\hline$r 01 . . r-$ & $\{, 19-$ & , rr- & $\Lambda \vee, . \Delta-$ & $1 \% 1,1 \leq-$ & $94 \leqslant, V 9-$ & $1, \mu 1,0 \%-$ & $\leq \because+V, 9 \%$ & $119,99-$ & $1 \wedge \leqslant \mu, 9,-$ & $\uparrow \leqslant, \wedge \uparrow-$ & r.o. & \\
\hline $1 . v .9 .-$ & $n$ & $0, \leqslant \psi$ & $\leqslant 1-$ & $91-$ & $. r-$ & $04,09-$ & $9 \leqslant,+r$ & $01-$ & Yr,Vq- & $1,0,-$ & r. ro & \multirow[t]{2}{*}{ الفاكهة } \\
\hline $11 . . \leqslant 1-$ & 10 & $0, \leqslant \wedge$ & $r \mu, \cdot 1-$ & VIr,lo- & $1,1,00-$ & ए01,7 $1 \leq-$ & $\{\varepsilon \cdot, \pi$ & 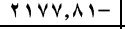 & $17 \leqslant 0, \wedge \wedge-$ & $V \leq, \pi 1-$ & r.o. & \\
\hline 9 9V.97- & $99-$ & $r v-$ & , Ir & $119, \wedge r-$ & $4 \wedge-$ & $i r, 10-$ &., $11-$ & va- & $999,9 \wedge-$ & $.19-$ & r. ro & \multirow[t]{2}{*}{ اللحو. } \\
\hline $1, \ldots \wedge . \leqslant Y-$ & Vo- & rะ, $10-$ & $1, \leqslant 0$ & $\{r \mid \vee, v ч-$ & $r \cdot r, \Delta r-$ & พ & $11 \%, 0 \wedge-$ & $\wedge \vee \neg, \wedge q-$ & $\Lambda \vee \leqslant, \leqslant 1-$ & IV70,1r- & r.o. & \\
\hline V५.Ar- & & $10-$ & $9 .-$ & $\Lambda, \wedge 1-$ & $1, r \wedge-$ & $1 \%, \varepsilon,-$ & I.Y,Or- & $r, r Y-$ & $\{\wedge \vee, \leqslant \wedge-$ & $0, r \varepsilon-$ & r. ro & \multirow[t]{2}{*}{ الأسماك } \\
\hline VA.1.- & 8,99 & $r \wedge, r 1-$ & $0 \leq-$ & $91, \leqslant,-$ & $\varepsilon r, O H-$ & $r \mid \Lambda, r r-$ & $r \leq \cdot, 0 \wedge-$ & $\mathrm{r} 0_{0, \mathrm{~V}} \mathrm{A-}$ & 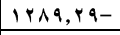 & $9 r, \leqslant Y-$ & r.o. & \\
\hline $01 . \varepsilon Y-$ & $\cdot, \wedge \wedge-$ & , YT & r,9А- & $1 \mathrm{rq, \wedge v-}$ &,$\wedge \bullet-$ & $. \Delta V, \cdot A-$ & $\Lambda, 90-$ & หั, ห & $\Lambda \leqslant 1,0 \mathrm{r}-$ & $\mid Y \div, \vee 1-$ & r. ro & \multirow[t]{2}{*}{ الألبان } \\
\hline or..o- & $17, .9-$ & $.9, r r$ & $\wedge ৭, \vee \vee-$ & $1 T, V, \ldots-$ & $\{\leqslant, \wedge 1-$ & $1.01,71-$ & $\leqslant 0,10-$ & $17 r V, 91-$ & vos, rq- & $r r \checkmark, \wedge r-$ & r.o. & \\
\hline rVAG.rY- & $1 \leqslant, \wedge-$ & $r Y, r,-$ & $0 ., 7 \mathrm{~V}-$ & $1 \% 0 \wedge \bullet, 9-$ & $99,10-$ & $11 \leqslant 9,07-$ & $.1, .9$ & A.,91- & $101,1,-$ & $11,1, \leq 4-$ & r. ro & \multirow[t]{2}{*}{ الجملة } \\
\hline$r \leqslant \varphi .09-$ & $\{\varphi, \tau-$ & $\leqslant 799, \vee \leqslant-$ & $A \Psi \leqslant \leqslant, A-$ & $11 \leqslant 70,1-$ & $q \Delta V, r^{\prime}-$ & $1 . V \times 4, \Lambda-$ & 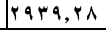 & $A r \Lambda,, 0,-$ & 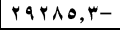 & $T \leqslant r q, r 1-$ & r.o. & \\
\hline
\end{tabular}

\begin{tabular}{|c|c|c|c|c|c|c|c|c|c|c|c|c|}
\hline الجملة & اليمن & موريتانيا & المغرب & مصر & ليبيا & |لبنان & |الكويت & قطر & فلسطين & عمان & |الفترة & الفذائية \\
\hline rq.rA.Y०- & IOYY.\&Y- & IAY.\&Y- & rYIS...r- & \& MAT.Vฯ- & Vq०.Vq- & $\leq \leqslant \wedge . \leqslant \leq-$ & OrY.A9- & rq0.rq- & $r \leqslant T . r Y-$ & $1 \leq 4 \wedge . \Delta \wedge-$ & r. ro & \multirow[t]{2}{*}{ الحبوب } \\
\hline$\| \leqslant 9$...V- & TOST.TY- & $09 . .94-$ & OITY.YY- & \&qr\&.r.- & IN10.v.- & 1.or.VA- & irq..1- & $\wedge ৭ ৭ . \wedge \mathrm{r}$ & $\leq 9 . .79-$ & $7.1 .19-$ & r.o. & \\
\hline 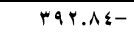 & $0 . r 0-$ & $17.99-$ & $\leqslant 1.9 .-$ & rqv.90 & 1.0r- & $71.99-$ & $1 \wedge 0.0 .-$ & $r \varepsilon . \leqslant Y-$ & 1.20 & $00 . \Lambda_{-}$ & r. ro & \multirow[t]{2}{*}{ البطاطس } \\
\hline $10 \leqslant$ Y.0Y- & $r \leqslant . \leqslant r-$ & $01.4 T_{-}$ & IrE.AT- & $A \leqslant 0 . r \leqslant$ & ro.r.- & rar.os- & V५..r $\leqslant-$ & $19 \mathrm{~V} . \mathrm{YV}-$ & $0 . . \leqslant$ & ห. ..V $\leqslant-$ & r.o. & \\
\hline$V \leqslant 1 . .9 Y-$ & OrT.IT- & $\Pi . \varepsilon r-$ & oro.11- & พ9१.ะ१- & $11 V_{. .} \mathrm{r}_{-}$ & rrT.V.- & $9 \wedge . \wedge \bullet-$ & $\varepsilon \ldots \times \leqslant-$ & or.rr- & $1 \leq 9 . \leqslant \leq-$ & $r \cdot r_{0}$ & \multirow[t]{2}{*}{ السكر الخام } \\
\hline 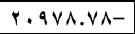 & $1.47 .81-$ & 1 1 $0.94-$ & Q.A.YY- & $99 \vee . \wedge 0-$ & $17 \leq . V 1-$ & $|1 r \ldots r|-$ & YV\&.VY- & VY.IV- & PV৭.9ะ- & $7 . \wedge .09-$ & r.o. & \\
\hline $10 \mathrm{~V} . .10-$ & rr.rq- & $. . \wedge \cdot-$ & $19.11-$ & r.A.०१- & $\varepsilon .99-$ & $\leq \wedge . \Upsilon \leq-$ & ro. $\leqslant V-$ & 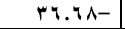 & $1 . . r r-$ & $\leq q . r v-$ & r. ro & \multirow[t]{2}{*}{ البقوليات } \\
\hline Кчหร.4.- & $9 . .04-$ & $r . \wedge v-$ & $01.11-$ & $\{r q .1 \%-$ & $1 \times .0 .-$ & $1 \leqslant \wedge .99-$ & Ar... & $q \ldots v-$ & r9.9.- & $r .\{.01-$ & r.o. & \\
\hline ra५.rq & 19.94 & $1 \% . r \wedge-$ & VIT.O. & IYAY.0E & $r \leqslant .00-$ & Y A.V०- & rYV.A $\leq-$ & rY\&.०Y- & rV.OA & $79.89-$ & r. ro & \multirow[t]{2}{*}{ الخضر } \\
\hline$\Lambda \curlyvee \wedge . . r \leq-$ & RY.YY- & r...q- & VYq.VI & $1.7 \leq \leqslant 9$ & rrq.0r- & $0.91-$ & Irqr..9- & $r_{1} \cdot 9.41-$ & $\leq 7.74$ & rq1. $\leqslant 0-$ & r.o. & \\
\hline OYOS.AN- & $\mu .1 . \Lambda \leq-$ & 1.0.vi- & צ. צ.\% & $1 \leqslant \% \wedge .9 \leqslant-$ & r^০.Vr- & 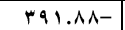 & $11 \wedge .9 \mathrm{~V}-$ & $1.0 . .9-$ & AV.17 & OY.r\&- & r. ro & \multirow{2}{*}{ الزيتية } \\
\hline$q \leq 7 q . r Y-$ & \& Yq.Yr- & I.Y I.rq- & $v .1 .0 v-$ & 1 rqr...0- & $184 \ldots 9-$ & Irrv.vo- & $194 . \leqslant 7-$ & หरร.т०- & $\leqslant \vee q . \vee \leqslant$ & rIY.I $\leqslant-$ & r.o. & \\
\hline$\Pi \leq . \wedge 1-$ & ra.rv & I.r. & $\leqslant 0 . . \leqslant V$ & 1717.90 & V...II- & $|\varepsilon . r|$ & VYA.Y $\varepsilon_{-}$ & IV०.A.- & A.Y०- & P0५.94- & r. ro & \multirow[t]{2}{*}{ الفاكهة } \\
\hline $90.0 .7 \mathrm{r}$ & rY.OT & $\{4.9 \leqslant-$ & $\{0 \wedge .0 \leqslant$ & V०५.\&1 & 10Y.V.- & YY.OY- & rro9.7Y- & $9 \mathrm{rv.9 \Lambda -}$ & หั.А1- & r.Or.1A- & r.o. & \\
\hline vorv....- & ro..vr- & \&4.7V- & V५. $\{r-$ & $\leq \cdot r \leqslant . r .-$ & in.rY- & $r \leqslant v .17-$ & $090.90-$ & V^०.Vฯ- & Or.ri- & тr.Ar- & r.ro & \multirow[t]{2}{*}{ اللحوم } \\
\hline rrror.q1- & Mll.rv- & roq. \& V- & Ar.97- & ห9тร.1 $\leqslant-$ & $19 \leq . \wedge \mathrm{H}-$ & $1 \wedge 9 . . \leqslant r-$ & $1 \times 19.1 \leq-$ & 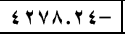 & $1.1 .1 .-$ & 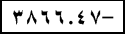 & r.o. & \\
\hline ०9^५.0Y- & r.9.11 & $149 . v 9$ & VVY.Ar & $V \leqslant Y . \leqslant Y-$ & $\$ 1.01-$ & IrE.rT- & $1 \times 0 . . \wedge-$ & rq.人ץ- & $17.78-$ & rIT. $\leq \leqslant$ & r. ro & \multirow[t]{2}{*}{ الأسماك } \\
\hline 797V.YY- & $r \leqslant \ldots V \tau$ & \&9V.Y૫ & 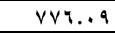 & $7 \leqslant 7.17-$ & Or.ro- & 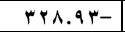 & $0 \leqslant \ldots . .0,-$ & ro0.0Y- & $\leqslant 9 . \leqslant 0-$ & $1 r \leq 1 . r \leq$ & r.o. & \\
\hline 1.01r.rv- & \&VY.Or- & Or.s.- & IVV.T $\varepsilon-$ & 1.Ar.qr- & PYY.Aะ- & $\$ 1 Y . \mid A-$ & \&Tr..०- & 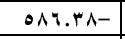 & Y.Ar- & $010.11-$ & r. ro & \multirow[t]{2}{*}{ الألبان } \\
\hline $190 \vee v .10-$ & $0 \leq V . . r-$ & $9 \vee . r .-$ & $198 . .1-$ & $V Y \leqslant . V Y-$ & \& $1 . \wedge 1-$ & IYA.\&V- & $|r| \leqslant . r q-$ & rrr..rY- & rᄉo.r. & $r \cdot r 1 . .+1-$ & r.o. & \\
\hline INIVI.AN- & rq11.r.- & $r \leqslant V . Y O-$ & 1 1 $0 \leq .10-$ & $90 \wedge r .99-$ & $1701.1 \leq-$ & $r .9 . .1 .-$ & rr11.97- & rors.Ir- & rrv.\&T- & TITV.r.- & r. ro & \multirow[t]{2}{*}{ الجملة } \\
\hline IrVYr.rq- & $\leqslant v \leqslant 1 . \wedge,-$ & IVYq..Y- & \&A०Y.r - & $9.10 .1 \leqslant-$ & $\leqslant \vee \gamma_{0} \leqslant \leqslant 1-$ & $\because \wedge \leqslant 9.0 \leqslant-$ & ดหษข..०- & $|r| \leqslant V . \leqslant$. & $v \leqslant r .0 .-$ & $100.4 . .1-$ & r.o. & \\
\hline
\end{tabular}




\title{
التحضر في مدينة ههيا وآثاره الجغرافية
}

\author{
د. إبراهيم السيد إبراهيم عسكورة \\ أستاذ مساعد ـ قسم الجغرافيا - جامعة أم القرى \\ قسم الجغرافيا - جامعة حلوان
}




\section{ملخص}

مدينـة ههيا تقع في المركز الهندسي لمحافظة الثرقية، وهي من المدن القديمة ذات الأصول الفرعونية، كما تم ذكرها في موسوعة وصف مصر تحت أسم (مدينة)، وهذه

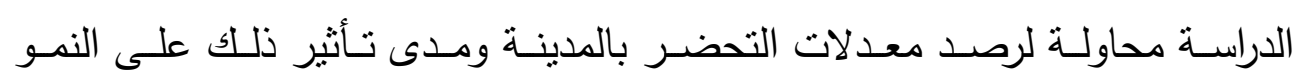

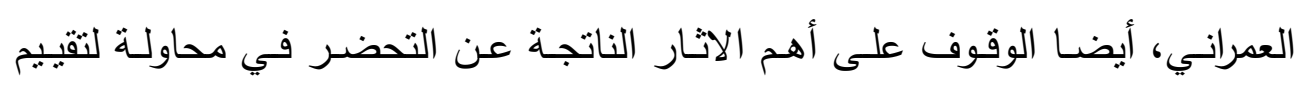
مشـاكل التحضـر ووضـح حلـول لهـا، وذلك مـن خـلال عـدة منــاهج أهمها المـهـج التاريخي والمنهج الإقليمي. الأصول التاريخية للمدينة ووقوعها وسط شبكة حضرية قديمـة امتدت عبر آلاف السنين، ووجود شبكة قويـة للنقل الحديدي والمـائي والبري سـاهم أيضـا في زيـادة معدلات التحضـر بالمدينـة وتأهلهـا لتصـبح حاضـرة مركزهـا الإداري منذ نحو هبا عام بدون انقطاع. وقد بلغ عدد السكان بمدينة هيا في التعداد

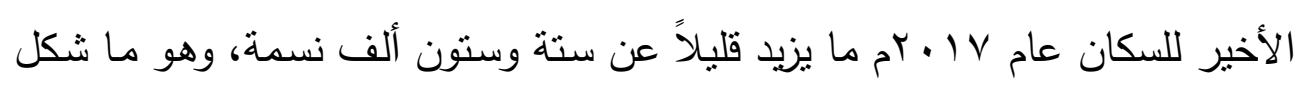

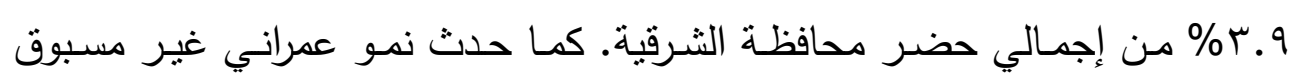
بالمدينة، فبلغت مساحتها ستة أضعاف ما كانت علية في منتصف القرن العشرون. وبالتأكيد أثر النمو العمراني السريع على فقدان مئات الأفدنة التي تعد من أخصب

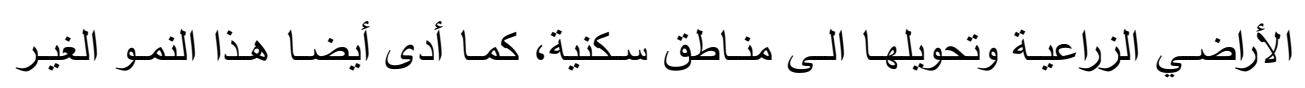
مخطط الى دخول عدة نويات ريفية والتحامها بالمدينة، من جهة أخرى خلفت تلك المرحلة العديد من الاثار والتي ظهر في تبعية المدينة للمدن المجاورة وظهور أثكال من العشوائيات داخل الكتلة العمرانية. 


\section{Résumé}

\section{L'urbanisation de la ville d'Hehia et ses effets géographiques}

Hehia est une des villes du centre de la province de Sharkia. Elle est une ancienne ville aux origines pharaoniques. L'encyclopédie de la description de l'Égypte l'a mentionnée sous le terme (ville). Cette étude se fixe comme objectif le suivi du taux de croissance démographique de la ville et son impact sur l'extension urbaine, ainsi que les effets les plus importants de l'urbanisation; en essayant de proposer des solutions aux problèmes liés à l'expansion urbaine. Cette étude a utilisé plusieurs approches, dont les plus importantes étant l'approche historique et l'approche régionale. Outre les atouts historiques de la ville et sa situation au cœur d'un ancien réseau, l'existence d'un réseau voie ferrée, fluviale et terrestre a également contribué à l'augmentation du taux d'urbanisation de la ville. Tout cela a permis à Hehia de devenir le chef-lieu du district administratif pendant 1 To ans sans interruption.

En $Y . \mid \mathrm{V}$, la population de la ville était plus de $7 \% \ldots$ habitants, soit $r, 9 \%$ de la population urbaine de la province de Sharkia. La ville a également connu une croissance démographique sans précédent, six fois plus grande que sa taille du milieu du XXe siècle. La croissance urbaine rapide s'est traduite par la conversion des centaines feddans de terres agricoles les plus fertiles en zones résidentielles. Elle a également conduit à intégrer plusieurs noyaux ruraux dans ville. D'autres nombreux effets sont apparus dans la dépendance de la ville aux villes voisines. Ainsi de nouvelles formes spontanées sont apparues dans la masse urbaine. 


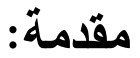

تعثبر المدن في مصر أهم الظاهرات البشرية الجديرة بالدراسة والاهتمام من

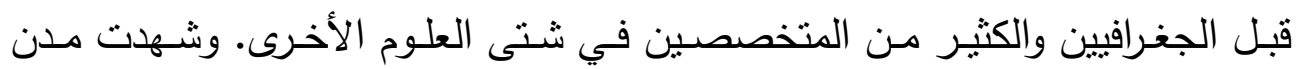

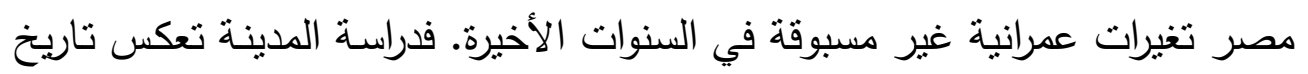
وثقافة سكانها وإذا أضفنا لها دراسات المدن المجاورة تتضـح معالم الإقليم وتطوره.

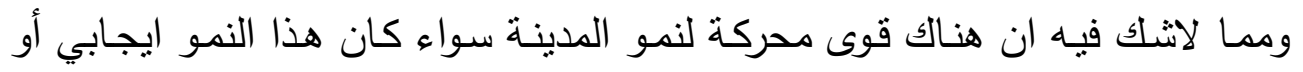

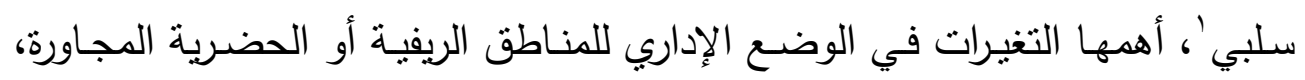

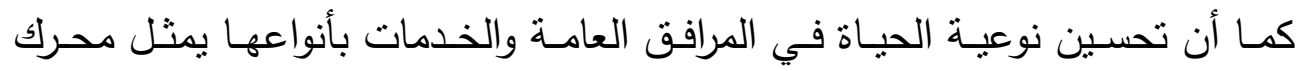
أساسي للنمو والتطور ، ولا يمكن تجاهل السياسات الاقتصادية والاستثمارية ودورهما

على الثخصية الحضرية للمدينة.

وبالرغم من تأثثر هذه القوى على النمو الإيجابي أو السلبي للمدينة، إلا أن

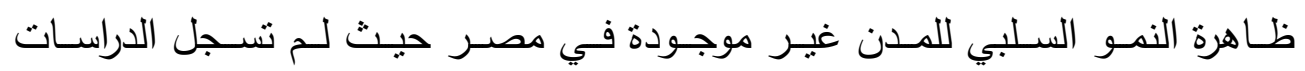

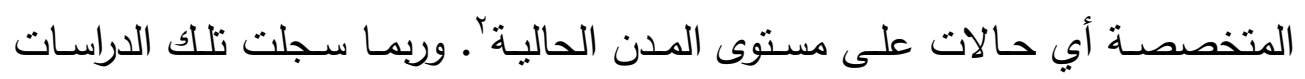

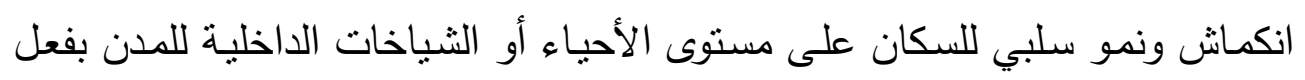

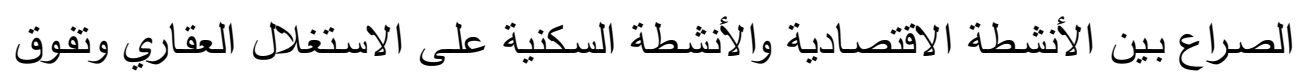

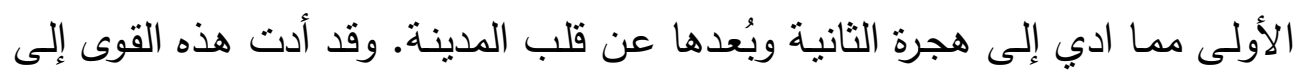

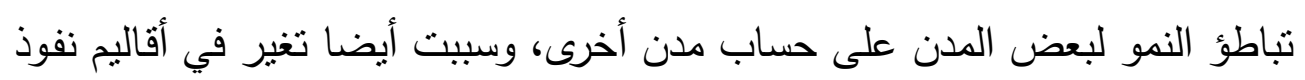
كثير من المدن وبالتالي تغير في الخريطة الحضرية للإقليم.

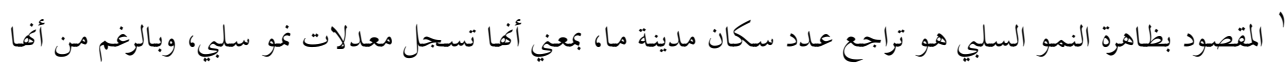

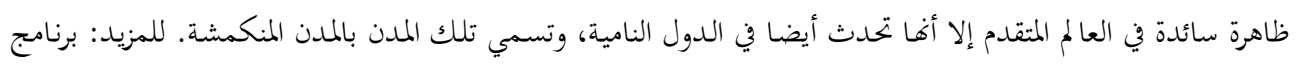

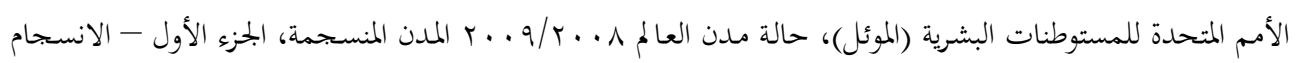

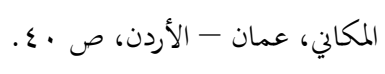

' الكلام هنا يستثى مدن قناة السويس وسيناء أثناء فترات العدوان الإسرائيلي الغاشم. 
وتعتبر مدينة ههيا محل الدراسة من المدن التي واجهت تباطؤ ملحوظ في نموها السكاني وأدى هذا بالتبعية إلى تباطؤ في النمو العمراني. ومدينة ههيا من أقدام القدان

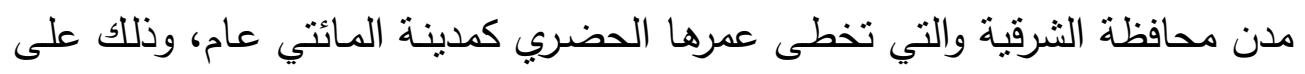

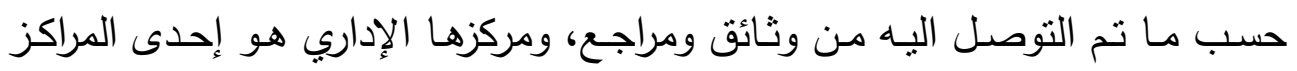

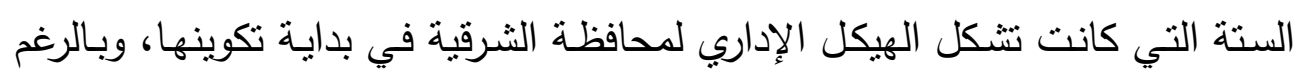

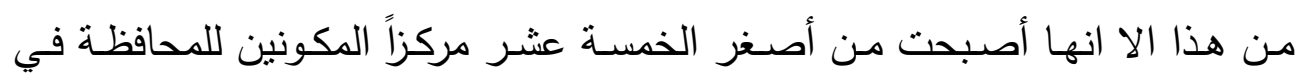

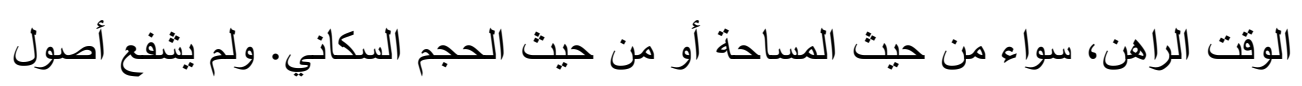

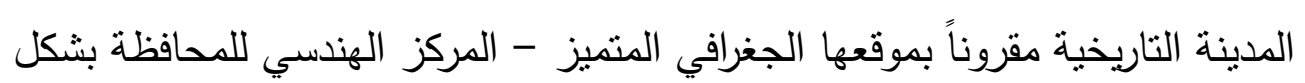

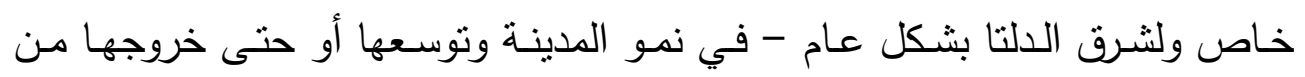

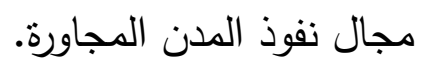

\section{أسباب اختيار الموضوع ومنطقة الدراسة:}

في الواقع يعتبر ارتفاع معدلات التحضر ظاهرة عالمية، وتظهر لـه آثاراً سلبية

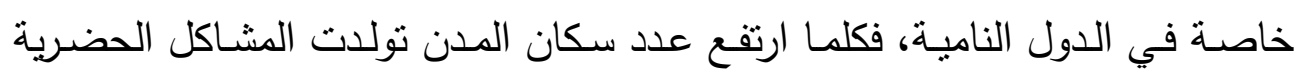

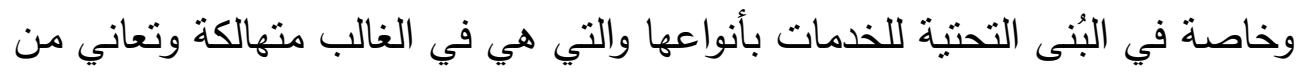

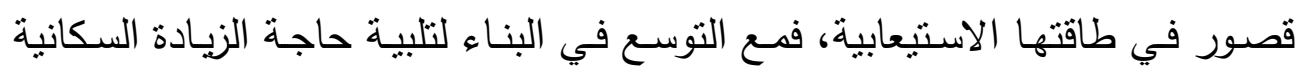

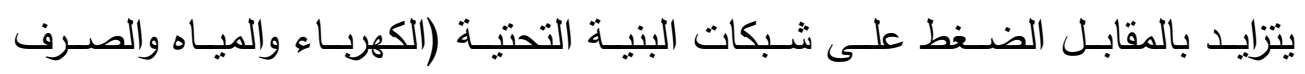
الصحي). بالإضـافة إلى مشاكل الازدحام والتلوث ونقص في الاحتياجات الغذائية

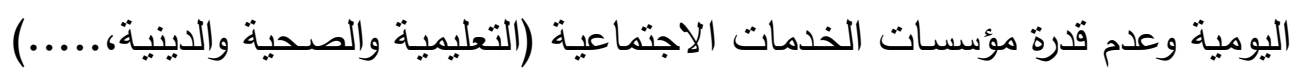
على استيعاب الزيادة في أعداد السكان.

وبالرغم من كون مدينة ههيا من أقدم المدن بمحافظة الثرقية وذكرت أيضا

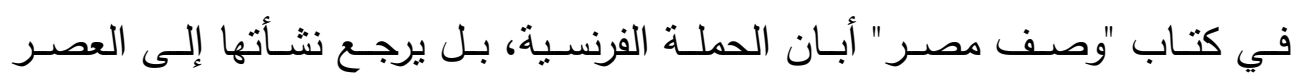
الفرعوني، إلا أن تلك المدينة لم تتل حقها من الدراسة الجغرافية. كما يمكن اعتبار

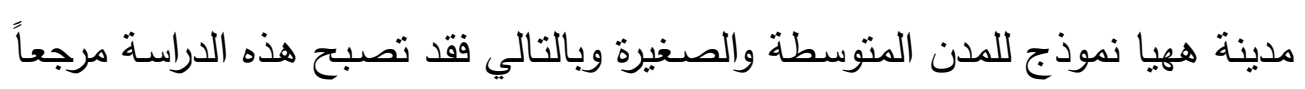


هاماً لمن يدرس تلك النوعية من الددن، فمن الأكيد وجود اختلافات جوهرية بين آلية النمو لهذه المدن الصغيرة وبين الددن الكبيرة؛ عواصم المحافظات.

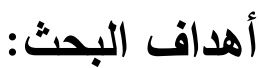

الهدف الرئيسي للبحث هو رصد معدلات التحضر في مدينة ههيا ومدى

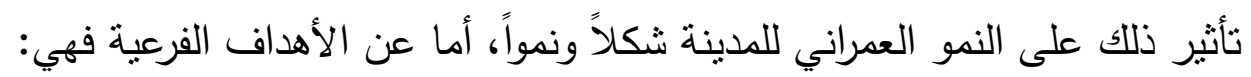
- دراسة محددات التحضر الايجابية والسلبية وتأثيرها على النمو السكاني للمدينة - رصد مدى تأثنير التحضر على الحيز العمراني والريفي المحيط بمدينة ههيا

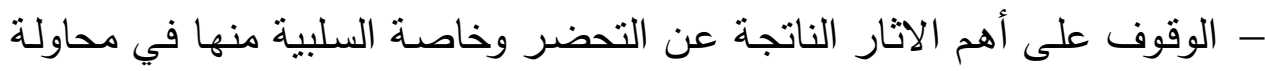
لوضع تخطبط لعلاج أكثر مشاكل التحضر شيوعاً بالمدينة.

\section{مناهج وأساليب الاراسة:}

استخدم المنهج التاريخي لدراسـة نشأة المدينة وتطورها والتعرف على الزيادة

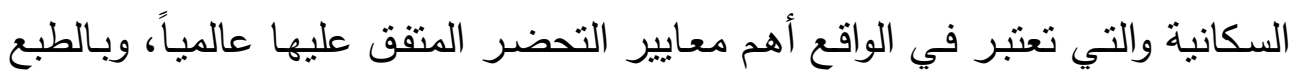

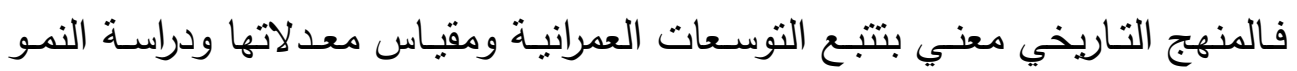

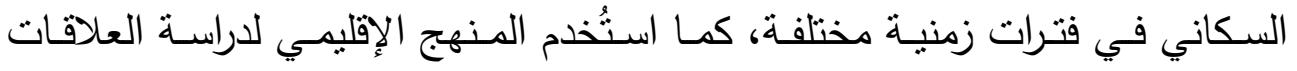

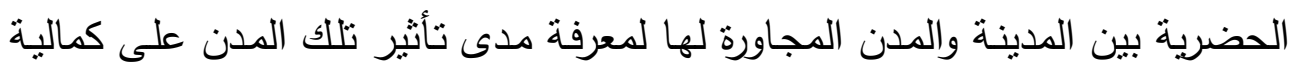

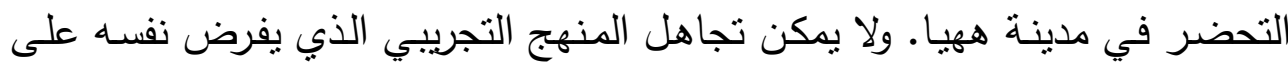

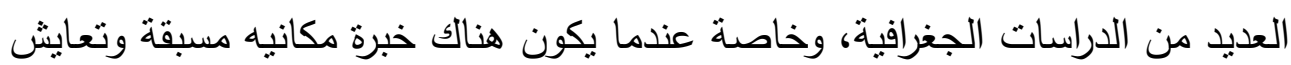

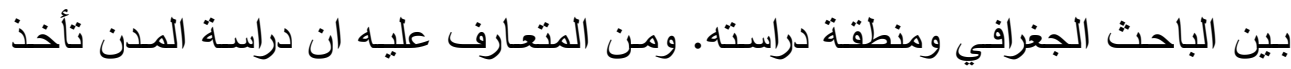

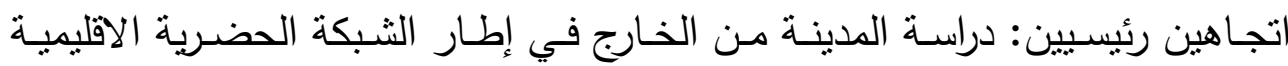

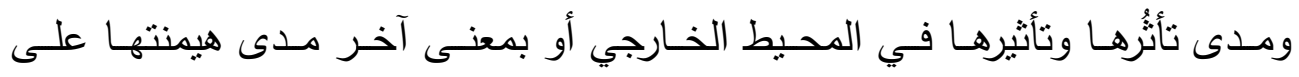

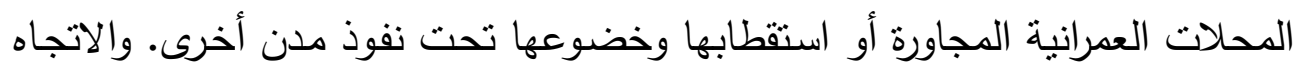

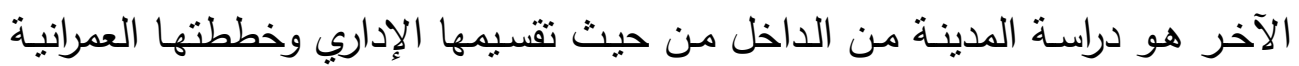

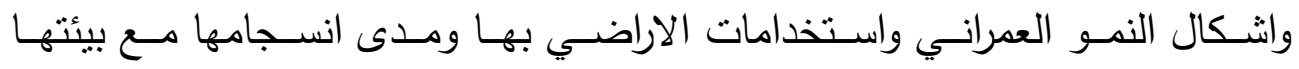
الاجتماعية والطبيعية، ودراسة خصائص سكانها وتوزيعهم وتأثيرهم في هوية المدينة 
الاقتصــادية ووظيفتهـا، بالإضـافة الـى دراســة خـدمات البنـــة التحتبـة والخـدمات الاجتماعية من حيث الكفاءة والكفاية.

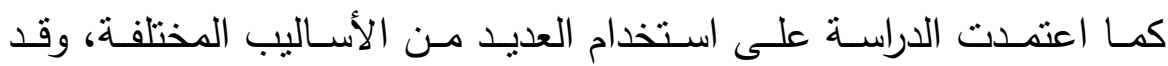
ساعدت التطورات التي طرأت على تقنيات البحث العلمي في مجال التعرف على التركيـب الــداخلي للمـدن وإجـراء قياسـات سـريعة ودقيقـة للمسـافات والاتجاهـات والمساحات والارتفاعات وإنتاج خرائط المدن والمناطق الحضرية وتحديثها في وقت سـريع بدقـة لم تتوفر في الطـرق التقليديـة' . كمـا تم الاستعانة بالعديد مـن الاسـاليب التقنية سواء نظم المعلومات الجغرافيـة والاستشعار عن بعد او الكمبـة والكارتوجرافية لإدخـال البيانـات ومعالجتهــا وتحليلهـا وتفسـير واسـتخلاص النتـائج مـن الخـرائط الطبوغرافية والصور الفضائية في تواريخ متعددة ومعالجة الجداول الاحصائية بهدف تتبع مراحل النمو العمراني وتحديد اتجاهاته والنمو السكاني وتطوره.

\section{أولاً: محدداث التحضر}

العديــ مـن المحددات أثنرت على عمليـة التحضـر بمنطقة الدراسـة، سـواء

التحضـر بـالمفهوم السكاني ومـا يشـمله من حجم السكان وخصائصـهم المختلفة، أو التحضـر بـالمفهوم العمراني ومـا يحتويـه من مورفولوجيـة المدينـة العمرانيـة بدايـة مـن خطتها واشكال النمو العمراني بها واستخدام الارض وحالات المباني والخدمات سواء البنى التحتية أو الخدمات الاجتماعية مروراً بالسياسـات التشريعية والسياسية المنظمة لعلاقة الانسان باستغلال المكان. ويمكن حصر أهم تلاك المحددات فيما يلي: - 


$$
\text { 1 - الموقع والموضع الجغرافي }
$$

تقع مدينة هيا تقريباً في المركز الهندسي لمحافظة الثرقية عند تقاطع خط

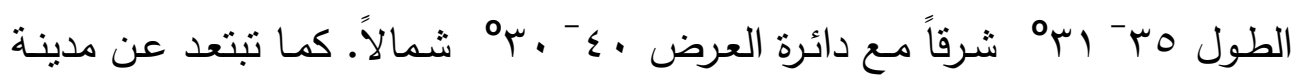

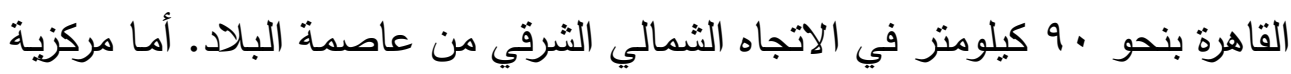
المدينة بالنسبة إلى إقليمها فمن بين الخمسة عشر مركز المكونين لمحافظة الثرقية

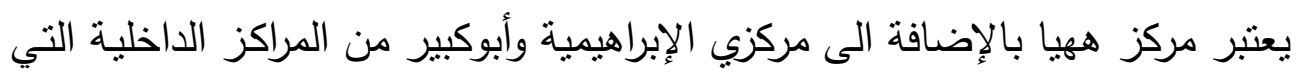

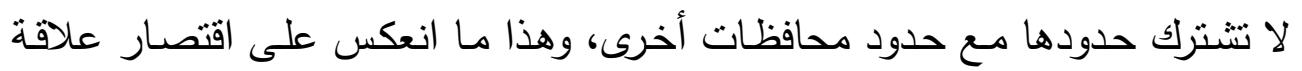

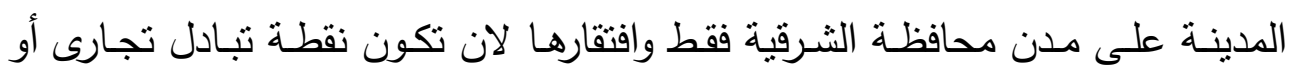
خدمي مع الستة محافظات المجاورة لمحافظة الثرقية، (شكل ( ). 
شكل ( ا ) الموقع الجغرافي لمدينة ههيا بالنسبة لمحافظة الثرقية وشرق الدلتا

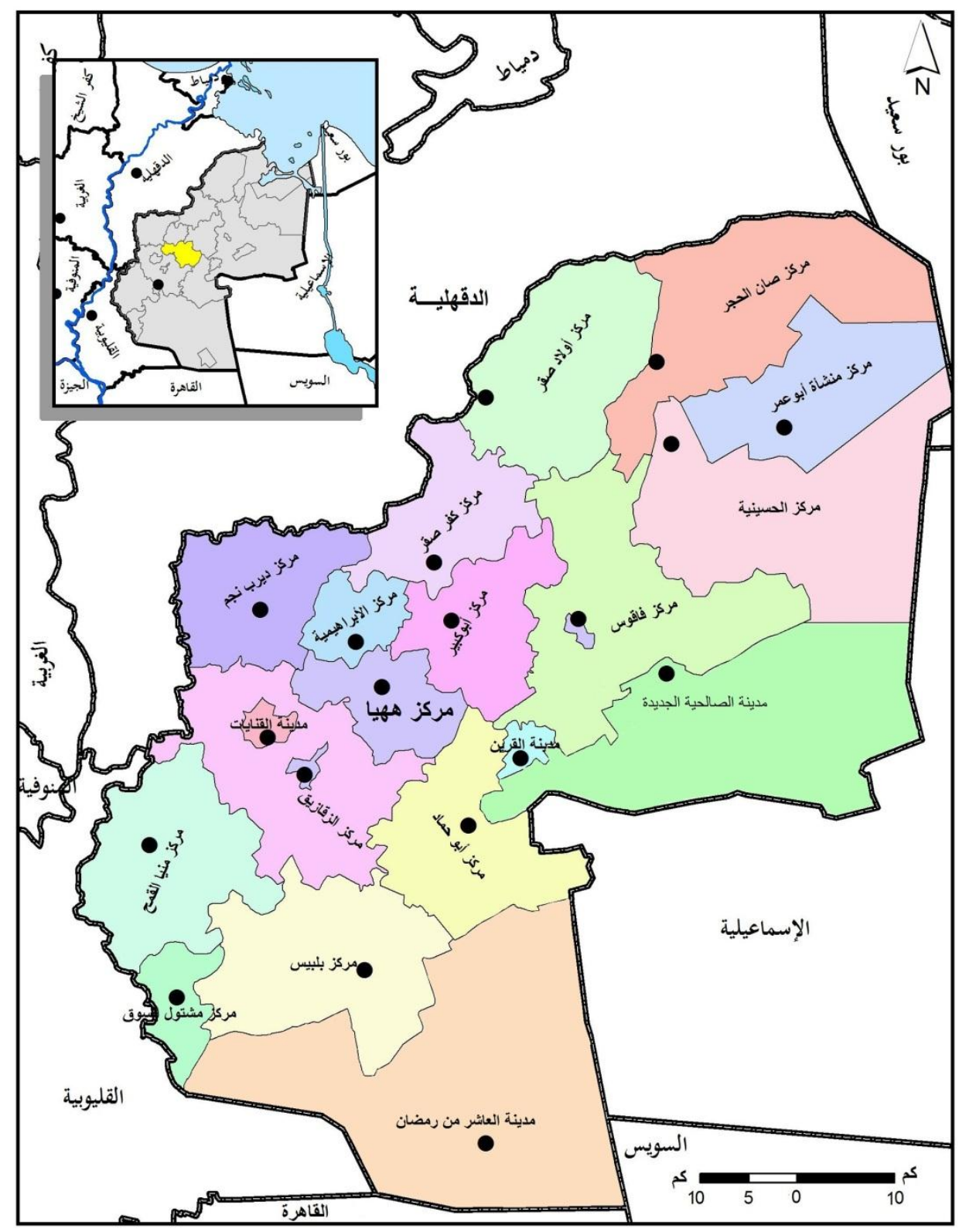

المصدر:من إعداد الباحث اعتمادا على بيانات الجهاز المركزي للتعبئة العامة والأحصاء، التعداد السكاني لمحافظة الشرقية، V ا ـrم 
أما موقع المدينة بالنسبة إلى إقليمها الريفي وهو قرى مركز هيا، فتقع المدينة في

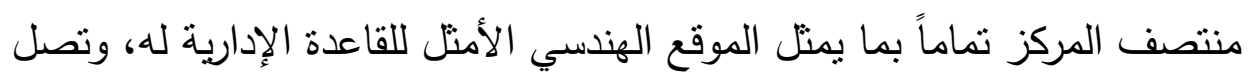
الخدمات إلى جميع القرى من الددينة بشكل عادل، ويمكن لسكان الريف من الوصول

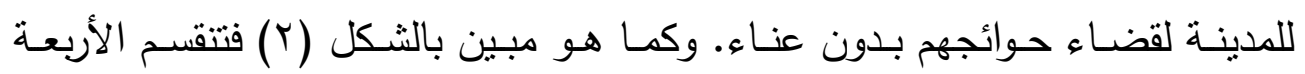

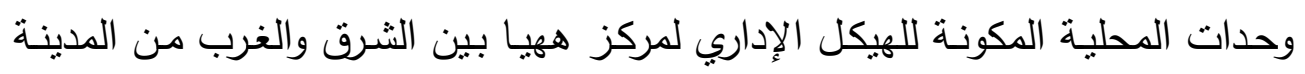

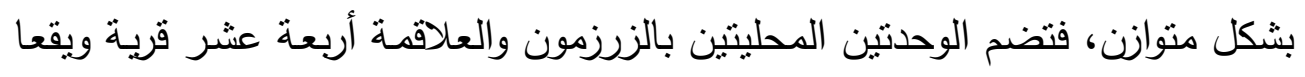

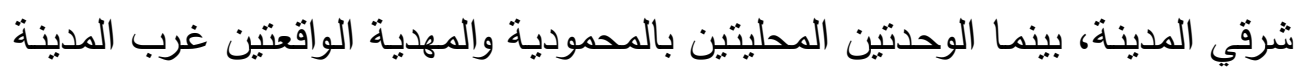

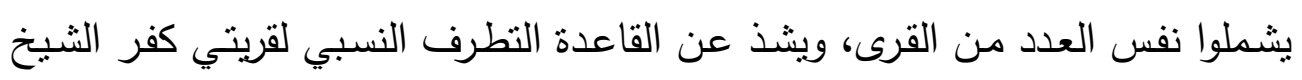
الظواهري ومنشأة غالى منصور ، حيث تقع كلتا القريتين في أقصى الغرب.

شكل ( r ) الموقع الجغرافي لمدينة ههيا بالنسبة إلى مركزها الاداري و القرى التابعة

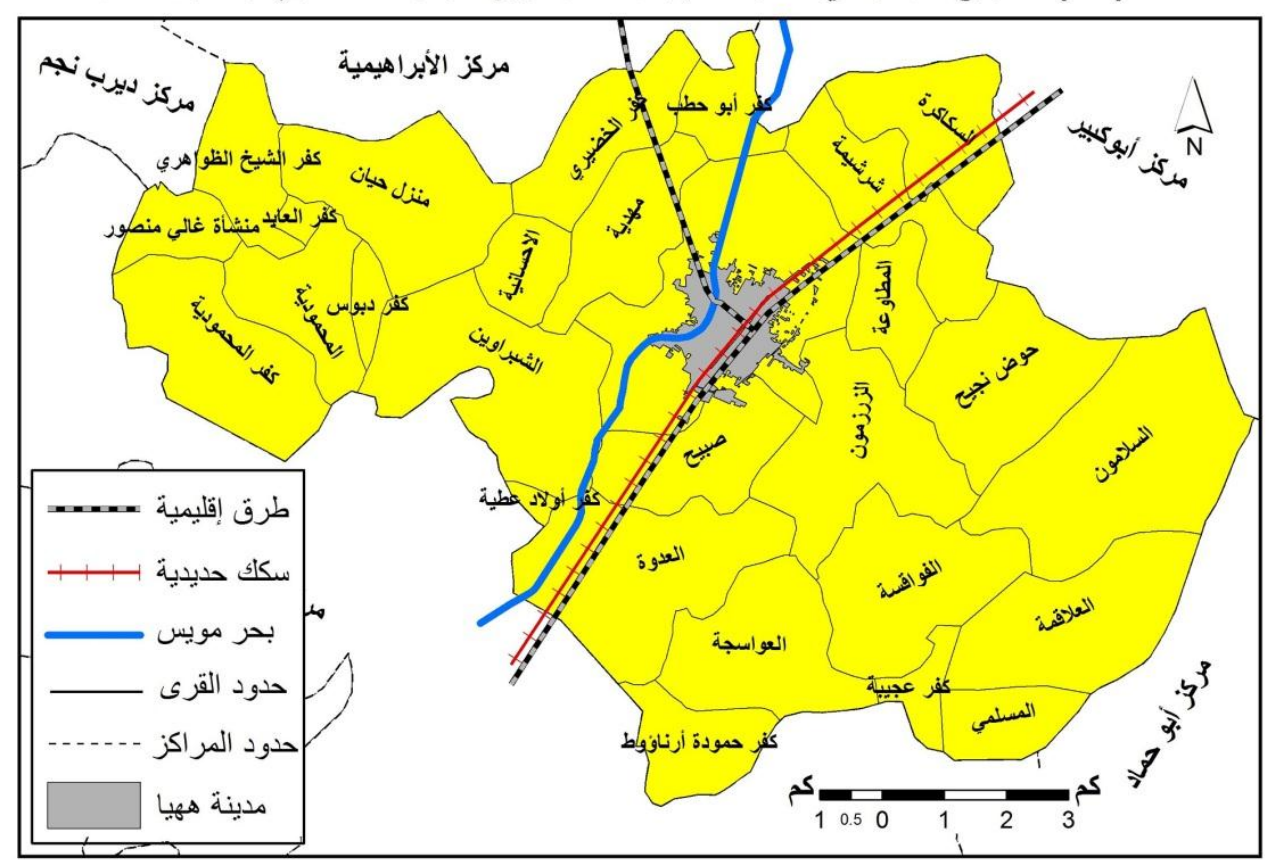

المصدر: من إعداد الباحث اعتمادا على الخر ائط الطبو غرافية .... 0: المحافظة الثرقية 
ويتضـح ان موضـع مدينـة ههيـا بجوار مدينـة الزقازيق - العاصمة الإداريـة

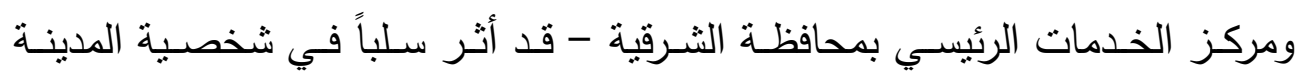

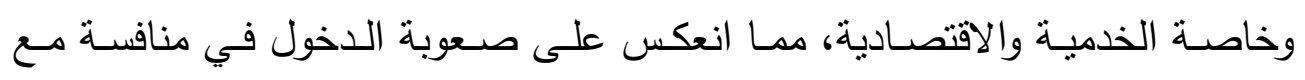
المدينة الأكبر في المحافظة، وجعلها تدخل في نطاق الأسر والنفوذ الحضري لمدينة

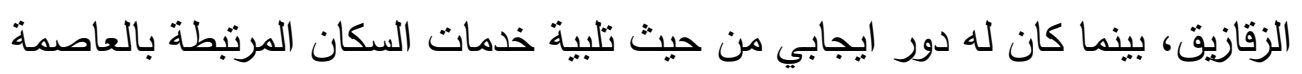

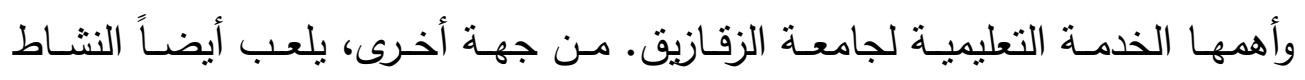
الاقتصادي في مدينة أبوكبير دور في جعل تلك المدينة ذات شخصية جغرافية فريدة عن بقية مدن المحافظة، فان كانت مدينة هيا تقع تحت نفوذ الأنثطة الثناثية لمدينة

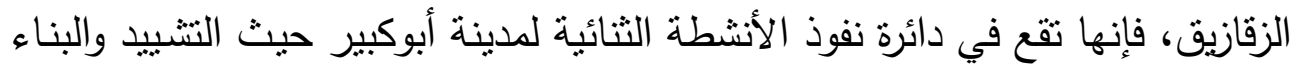
والصناعات التحويلية والورش المنزلية. ولذا فالموضع الجغرافي لهدينة هيرة نهيا أثر سلباً على تحضرها منذ بداية تحول الزقازيق كحاضرة لدحافظة الثرقية. r - التاريخ الحضري للمدينة رجح "رمزي" في قاموسه الجغرافي للبلاد المصرية ان مدينة هريا بلدة فرعونية

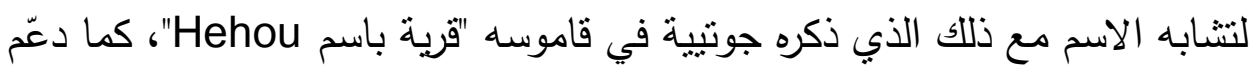


شكل ( r ) الموقع الجغرافي لمدينة ههيا بالنسبة لبعض عواصم مصر القديمة

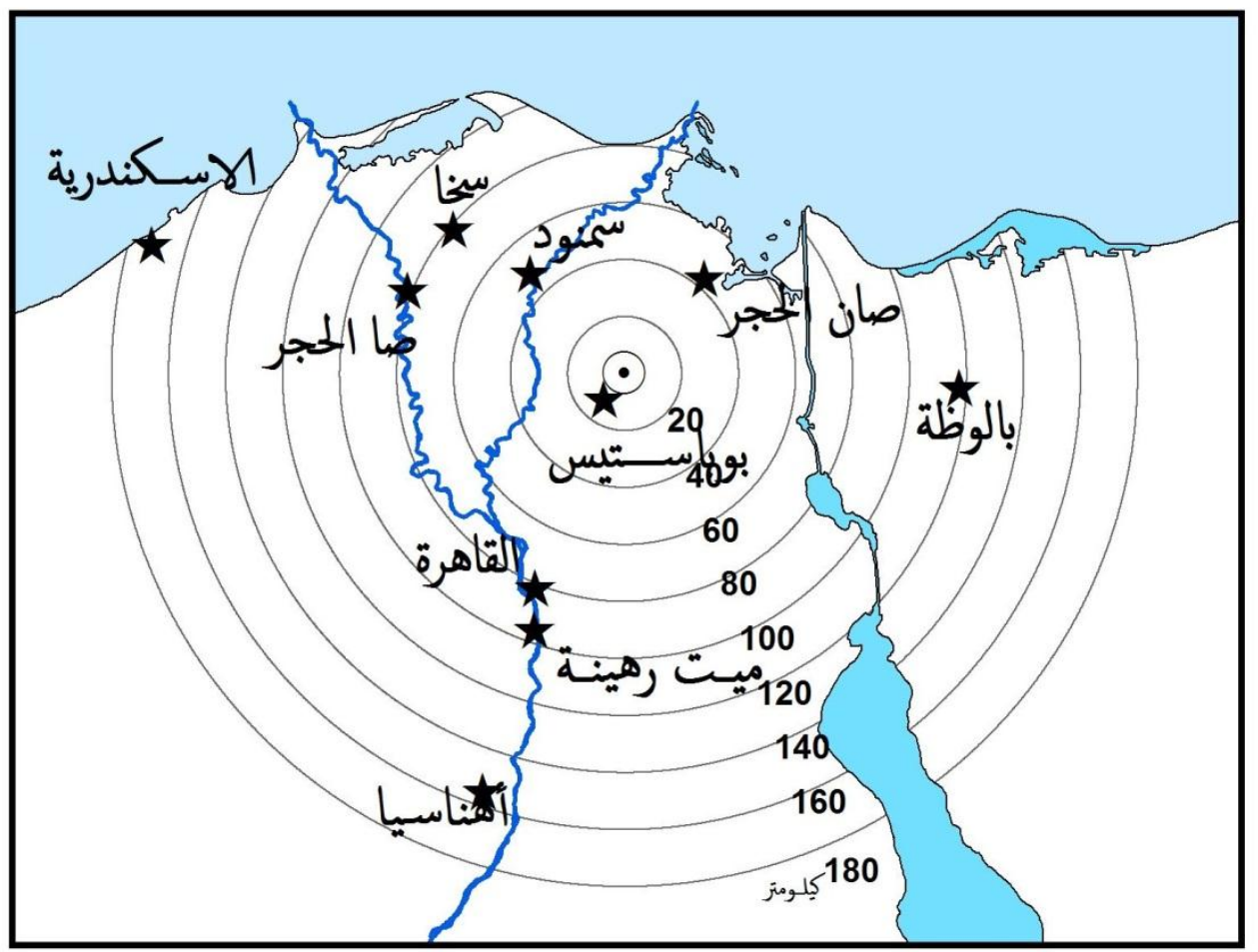

المصدر:من إعداد الباحث

هذا الرأي بورودهـا في قوانين ابن مداتي وفى تحفة الإرشـاد "هيهيـه" مـن

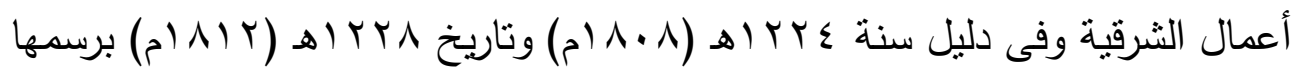

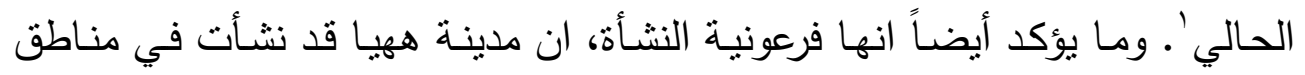
تمركز سكاني وفى وسط شبكة حضرية قديمة موروثة من بقايا العديد من عواصم

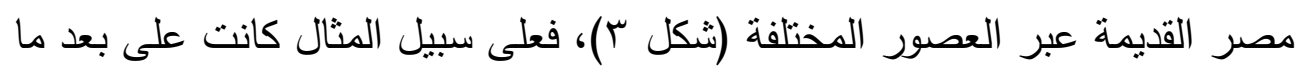

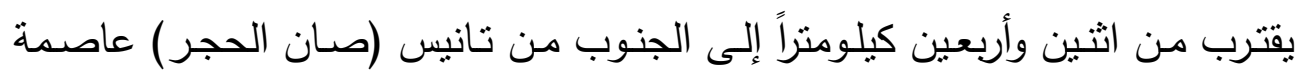

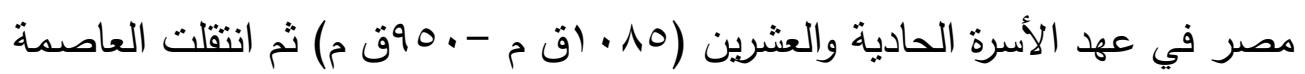

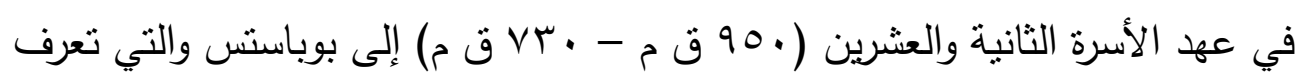

ا محمد رمزي، القاموس الجغرافي للبلاد المصرية من عهد قدماء المصريين إلى سنة هـو ام، القسم الثاني، البلاد الحالية،

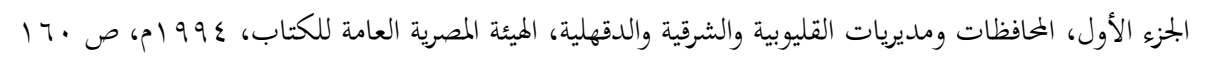


اليوم باسم تل بسطة الواقعة جنوب ههيا بحوالي ثنلاث عشر كيلومتر فقط' . وهنالك

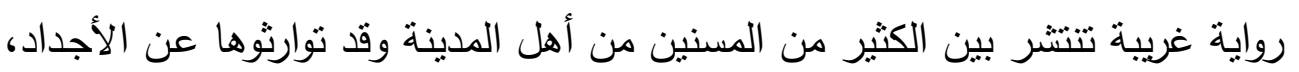
أن أصل التسـية يرجـع الى الفتح الإسـلاهي حيث نـادى أحد الجنود مخاطبـاً قائده (هاهي المدينة)، قاصداً بذلك البلدة التي كانوا سيقيمون فيها معسكرهم. وقــ ذكرهـا باسـمها الحـالي علمـاء الحملـة الفرنسـية في موسـوعة "وصـف مصـر" '، حيـث أثــاروا أنهـا مدينـة واقعـة على ترعـة بحـر مـويس. ومـن الجدير بالملاحظـة انهم ذكروهـا باسـم (مدينـة) ووصـفوا سـكانها بـأنهم أكثر (تحضـراً) مـن مرك شكل ( ؛ ) مدينة هويا كما ظهرت على خرائط موسوعة وصف مصر عام 11 ام

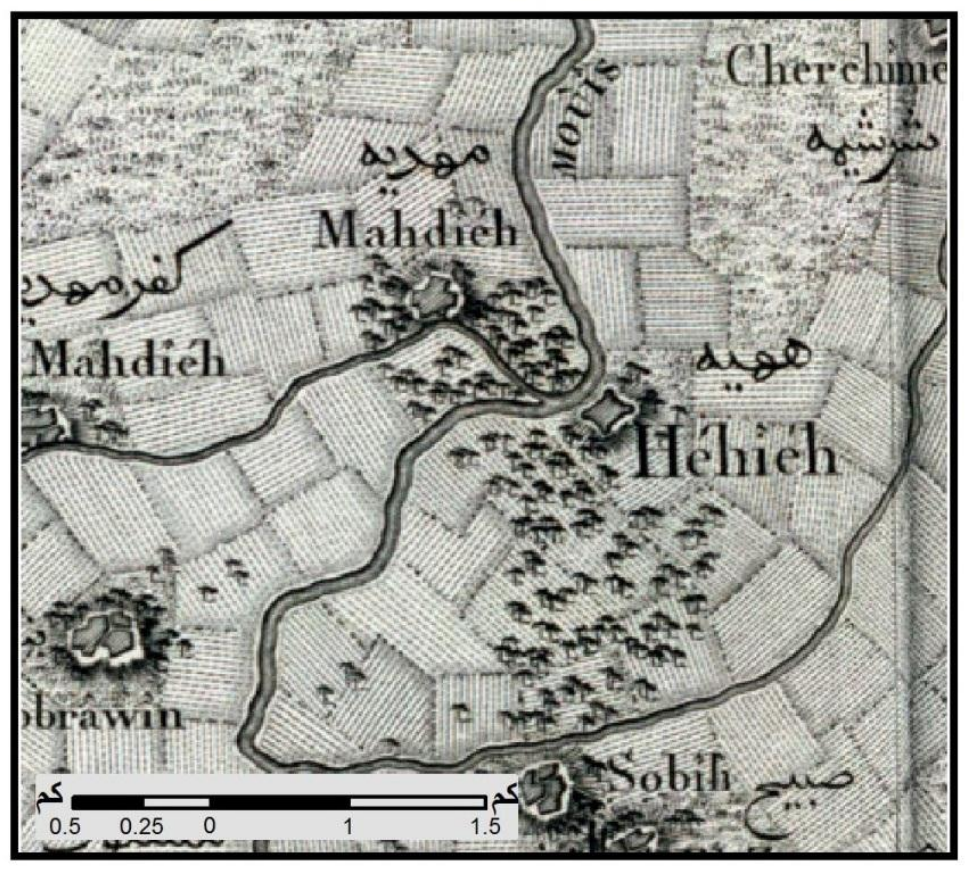

المصدر: , Description de de l'Egypte, Vol 6, Atlas Géographique, p.76 planche 30, CARTE TOPOGRAPHIQUE, Bubaste, Salhieh,

Bibliotheca Alexandrina, Alexandrie

جان فير كوتير، مصر القديمة، ترجمة ماهر جويجاتي، دار الفكر للدراسات والنشر والتوزيع، القاهرة، ب99 ام، ص ص

r موسوعة وصف مصر، دراسات عن المدن والأقاليم المصرية، ترجمة زهير الشايب، الجزء الثالث، الهيئة المصرية العامة

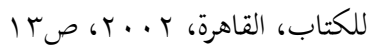


جيرانهم. وهذا يعكس تصور معني المدنية والتحضر لدي الفرنسيين في ذللك الوقت في أربعة مؤشرات، أولها في السلوك الاجتماعي لسكان المدينة، حيث قدموا للفرنسيين

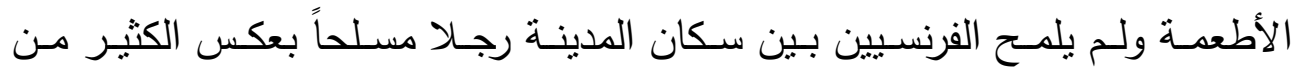

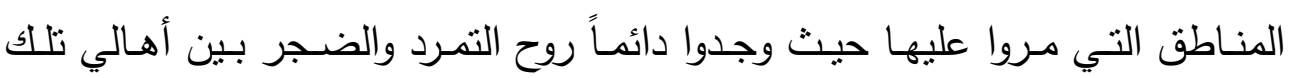

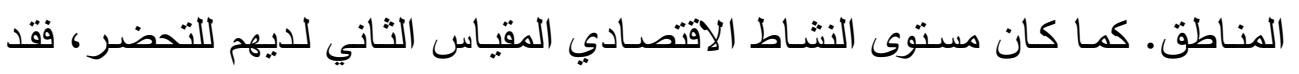

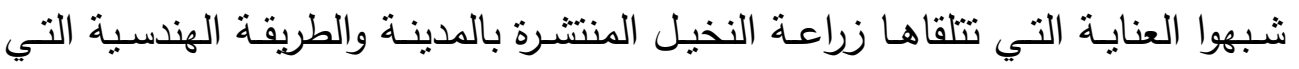

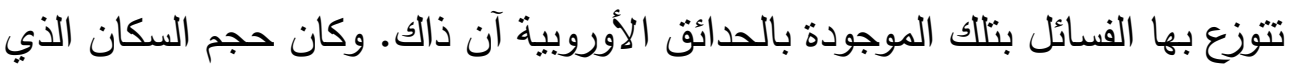

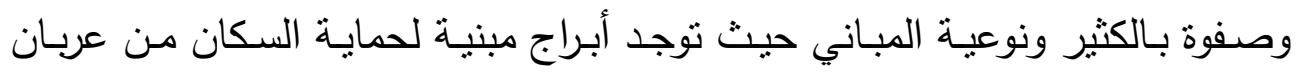

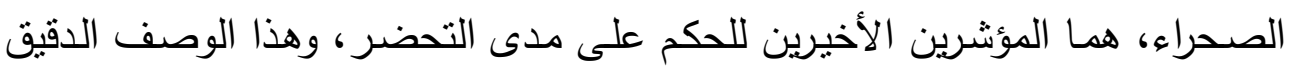
تم تمثيله على خرائط موسوعة وصف مصر (تشكل \&).

وفى العصر الحديث أنثـئ قسم باسم الصوالح سنة بـ1 ام وجُعلت هريا

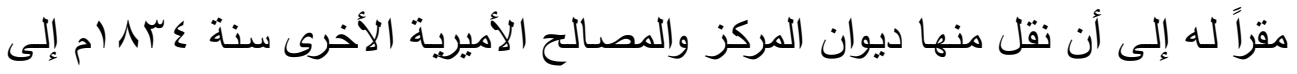

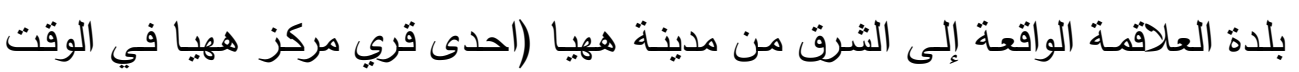

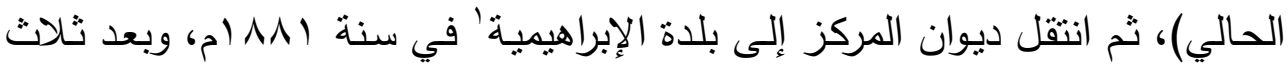

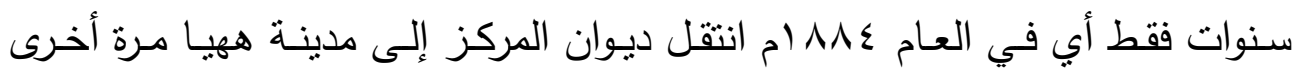
واستقر الى يومنا هذا، وقد كان السبب الرئيس في عودة ديوان المركز الى مدينة هييا

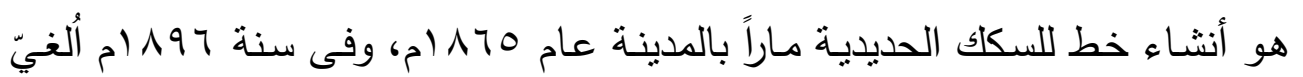

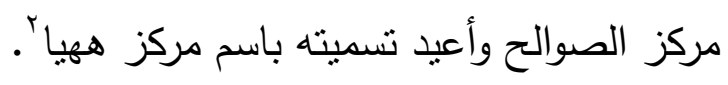
r - الطرق والقتوات المائية

تتحدد أهميـة المدينة من وقوعها على تقاطعات أو تلاقي الدحاور المرورية

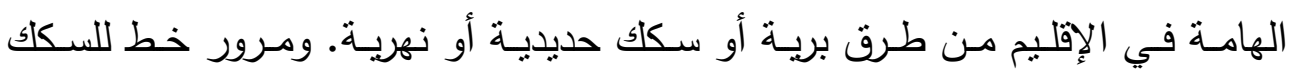
الحديدية الإقليمية بالمدينة كان في الواقع عنصر مؤثر وفعال من عناصر التحضر 
الذي أدى إلى بقاء مدينة ههيا كقاعدة المركز الحضرية منذ عام ع 1 ام وحتى يومنا

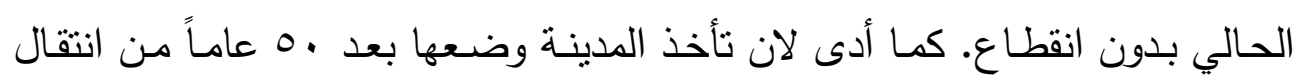

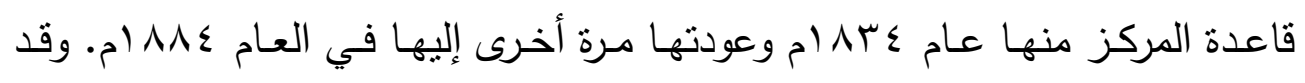

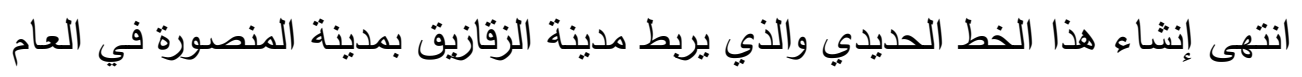

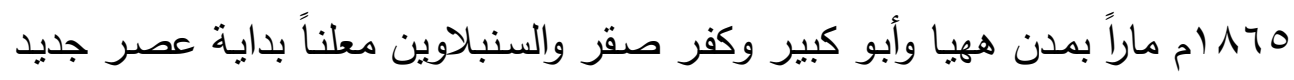

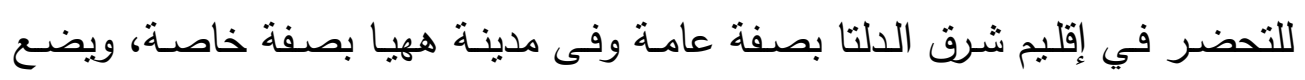
الخطوط العريضة لأقدم شبكة مدن حديثة في هذا الإقليم'. وبالرغم من دور هذا الخط الحديدي (والمسمي في الوقت الحالي بخط الثرق)

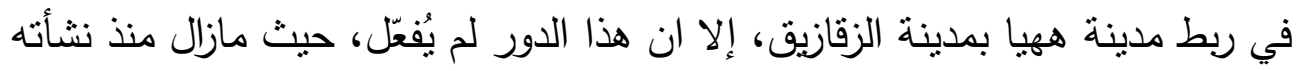

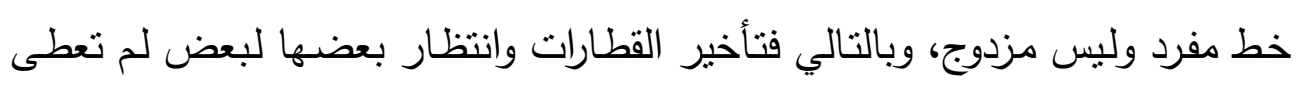

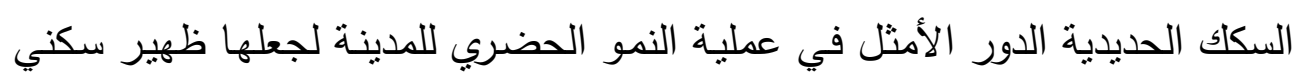
مباشر لمدينة الزقازيق عاصمة محافظة الثرقية. 
شكل ( • ) شبكة الطرق والسكك الحديدية والقتوات المائية بمدينة ههيا

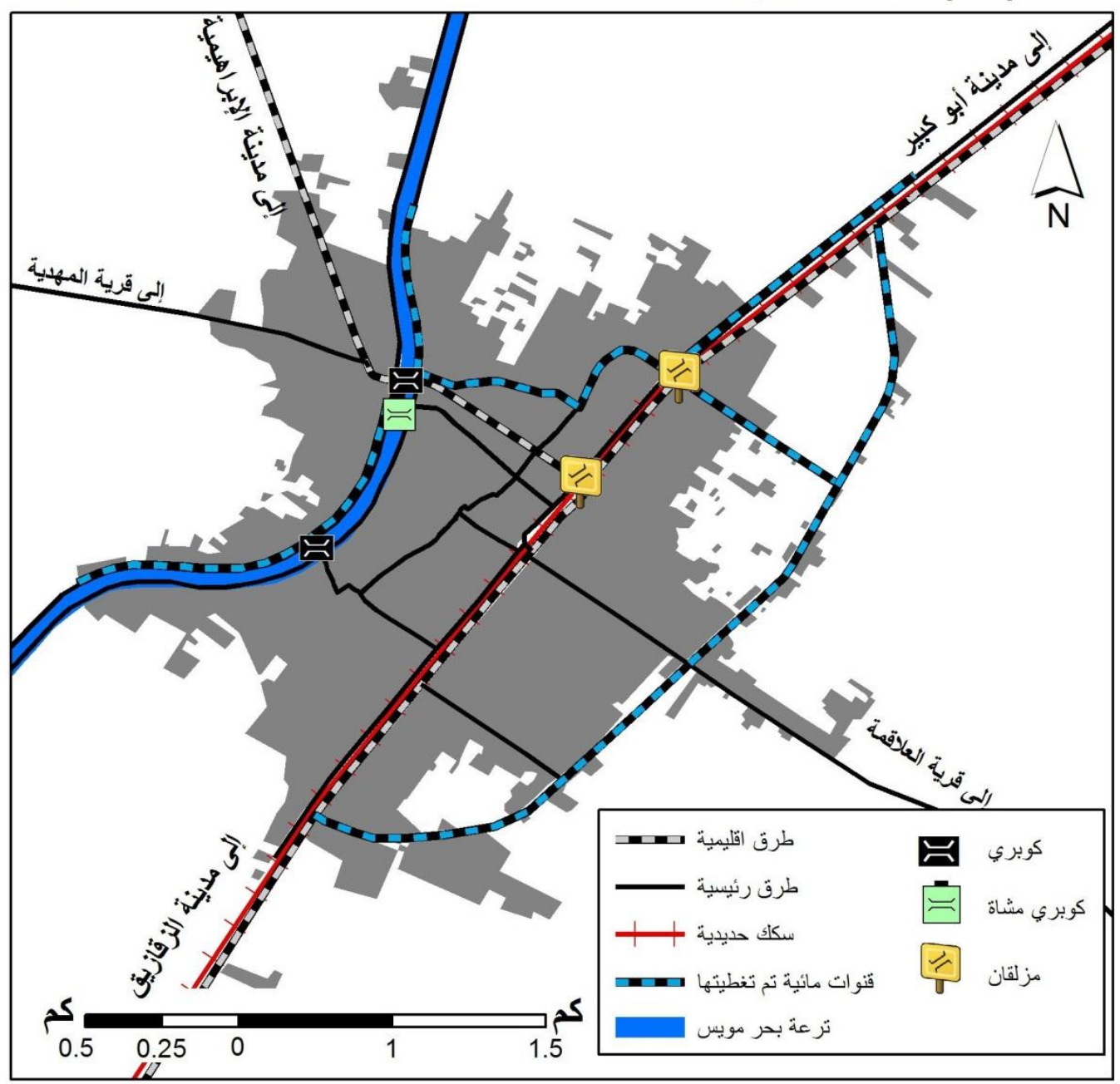

المصدر:من إعداد الباحث

كما تقع مدينة هيا على ترعة بحر مويس' التي يبلغن متوسط عرضـها . ؟ متراً، وتعتبر هذه الترعة في الوقت الراهن هي المصدر الوحيد لتغذية المدينة بمياه

ترعة بحر مويس والمتفرعة من الرياح التوفيقي هي إحدى فروع الدلتا القديمة وكانت تسمي الفرع التانيسي. وقد كتب عنها

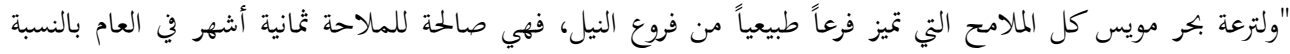

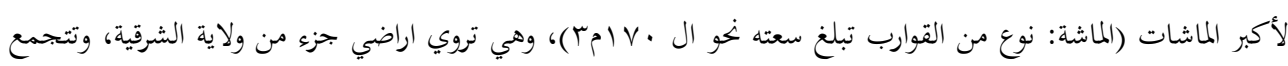

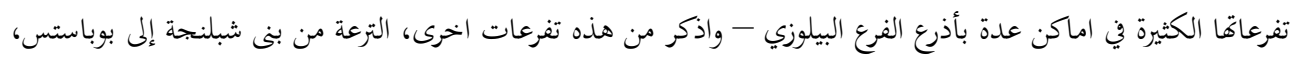


الثـرب النقيـة بعد افتتـاح المرحلـة الأولى لمحطـة معالجـة الميـاه اليابانيـة في مـايو

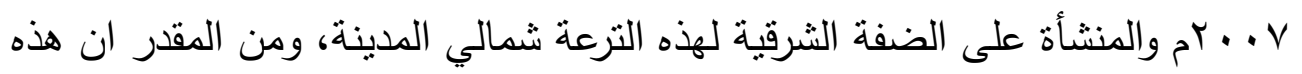

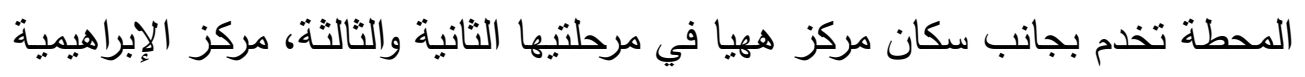

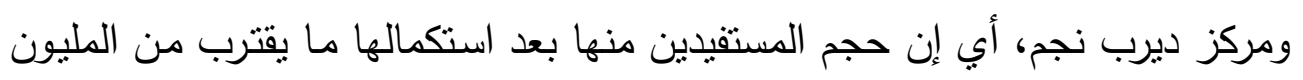

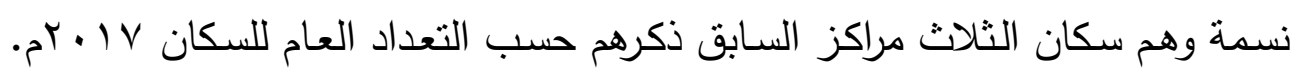

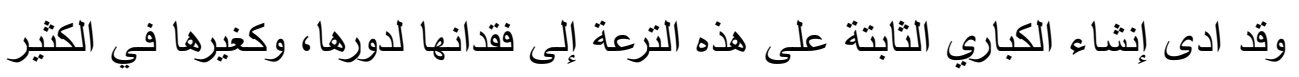

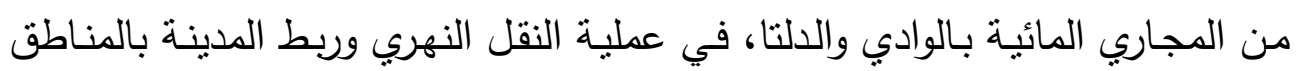
الأخرى والتي استمرت حتى بداية السبعينات.

وبمقدار أهميـة الطرق الحديديـة والمائية، فـان الطرق البريـة تنتشر في كل

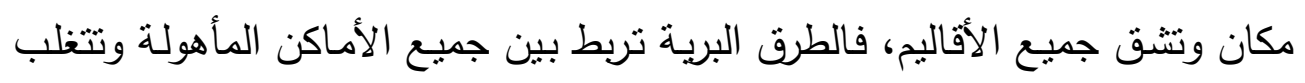

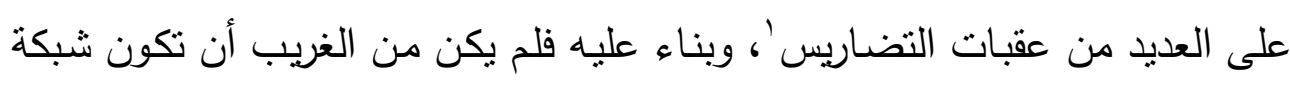

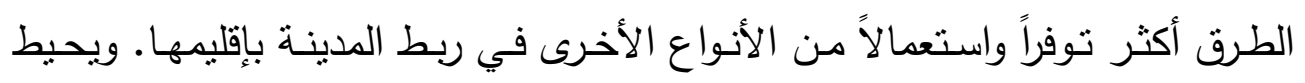

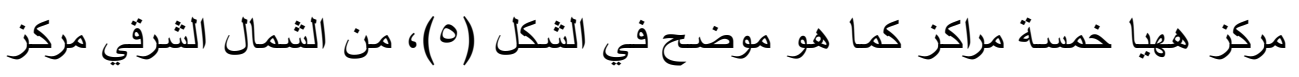

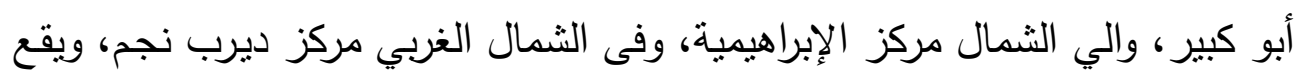

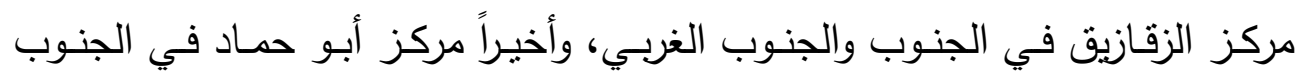
الثرقي. وترتبط مدينة ههيا بمدن تلاك المراكز عن طريق شبكة من الطرق البرية. ويعتبر الطريق البري الذي يربط مدينة ههيا بمدينتي الزقازيق جنوباً وأبوكبير شمالاً، أحد الطرق الإقليمية والثريان الرئيسي لعملية النقل البري بمحافظة الثرقية.

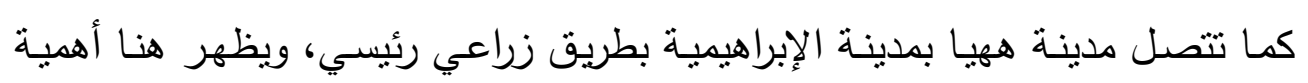

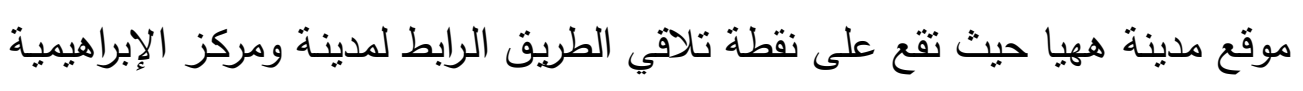

وتلك التي تبدأ من شبراويين إلى هربيط"، وللمزيد موسوعة وصف مصر، دراسات عن المدن والأقاليم المصرية، ترجمة زهير

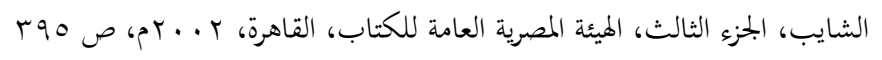
MERENNE Émile, Géographie des transports, Nathan, Paris, 1990, p 10.' 
بالطريق الإقليمي الرئيسي بوسط الثرقية، وبالتالي فمدينة ههيا هي المعبر الوحيد الرابط مدينة الإبراهيمية بالزقازيق ومدن محافظة الثرقية الأخرى، ويستنثى من ذلك التك مدينة ديرب نجم التي ترتبط مباشرة بمدينة الإبراهيمية. وبالرغم من ان مركز ديرب الإبيا

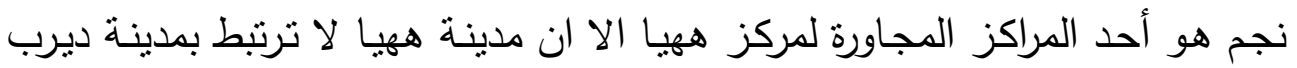

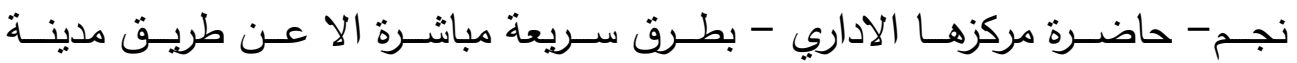

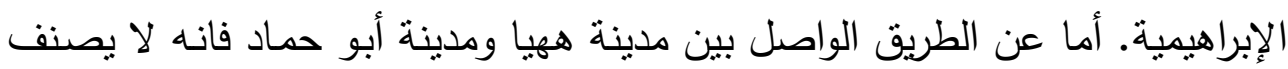
من الطرق الإقليمية الرئيسية، حيث يصنف على انه من طرق الدرجة الثانية. وفى مركز ومدينـة هيها لا تتتـابه كل الطرق ولا تستعمل لنفس الوظائف.

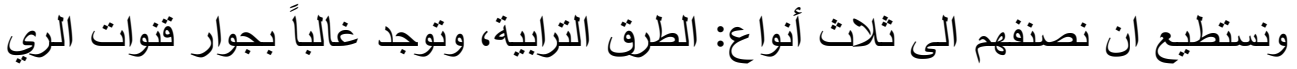
وتربط المدينة بالحقول الزراعية المجاورة، ثم الطرق المسفلتة الضيقة، وتربط الددينة

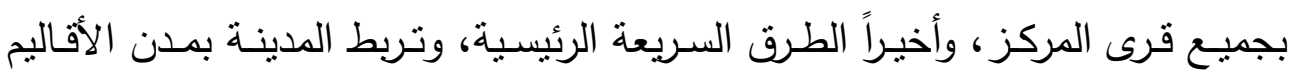
الأخرى منل طريق هيا - الزقازيق، الإبراهيمية، أبو كبير.

\section{ع - و - وظيفة المدينة}

في المجتمع الدصري يصعب إيجاد مدينة ذات وظيفة واحدة، بل إن السمة الرئيسية أن المدن المصرية متعددة الوظائف. إن التصنيفات الخاصة بوظائف المدن التهان

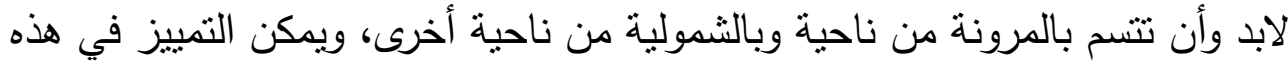

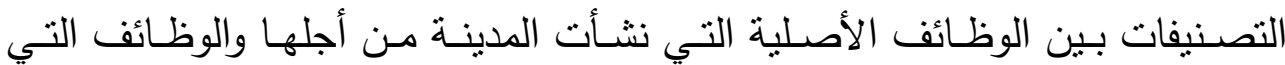

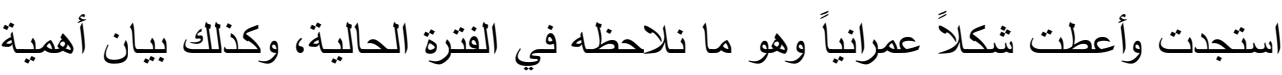

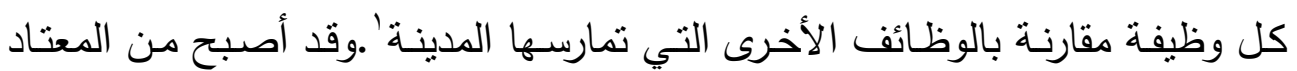

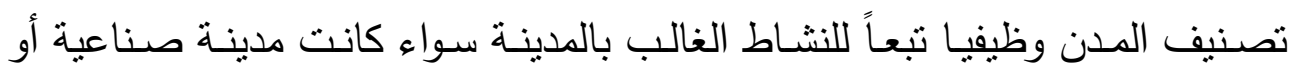
تجارية أو ترفيهية...، ويستبعد العديد من الجغرافيين الزراعة عند التحدث عن وظائف

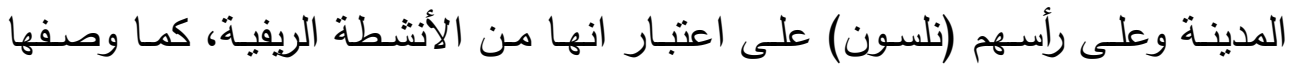

' جاكلين بوجو جارنييه، دراسات في جغرافية العمران الحضري، تعريب، كممد على بكجت الفاضلي، مطابع القدس،

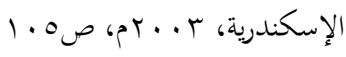


حمدان بأنها من الأنشطة الأولية غير المدنية، بل ان الدينة في وصفة هي الحلة اللازراعية'.

اذاً فالمدن تتخصص بالحرف ذات النشاط الثنائي والثناثي، وبشكل عام بلغت

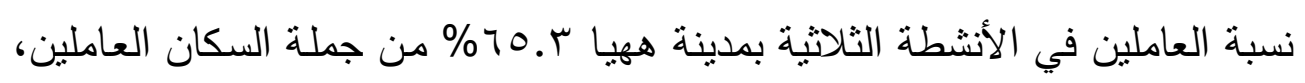

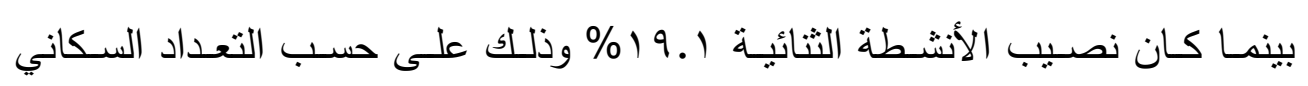

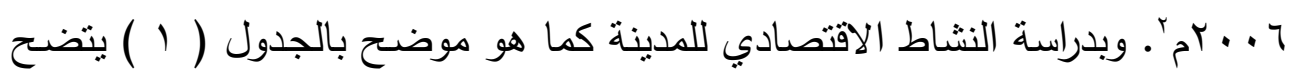

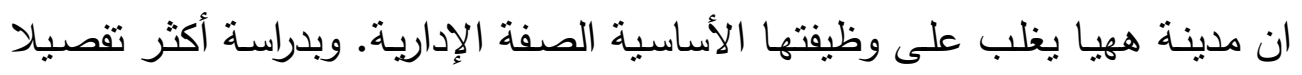

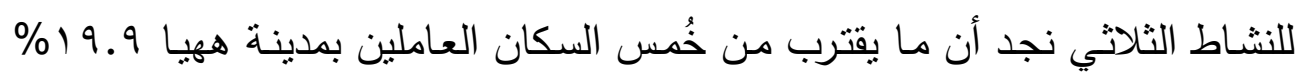
يعملون في قطاع التعليم بمراحله، أي أن وظيفة المدينة إدارية ذات طابع تعليمي.

\begin{tabular}{|c|c|c|c|}
\hline \multicolumn{4}{|c|}{ دول ( 1) توزيع سكان مدينة ههيا حسب الأنشطة الاقتصادية عام ؟ + . Yم } \\
\hline 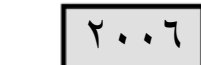 & $\%$ & المهنة & النشاط \\
\hline 10.7 & 10.9 & 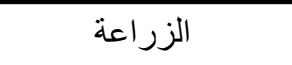 & أولى \\
\hline \multirow{2}{*}{19.1} & $\overline{1 \cdot . \wedge}$ & التثييد والبناء & \multirow{2}{*}{ ثنائي } \\
\hline & $\Lambda_{.}{ }^{\top}$ & الصناعات التحويلية & \\
\hline \multirow{4}{*}{ ro.r } & 19.9 & التعليم & \multirow{4}{*}{ ثلاثي } \\
\hline & $1 \leqslant . V$ & الإدارة العامة و الدفاع & \\
\hline & $9 . \wedge$ & تجاره الجملة و التجزئة & \\
\hline & 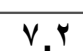 & النقل و التخزين & \\
\hline
\end{tabular}

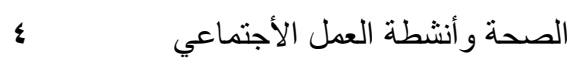

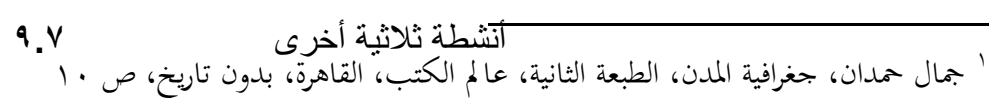

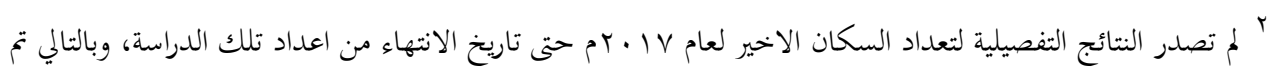

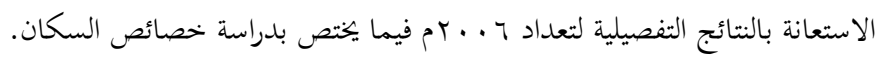


وفي الواقع تصبح الزراعـة ذات أهميـة في المدن الصغرى بـالوادي والدلتا،

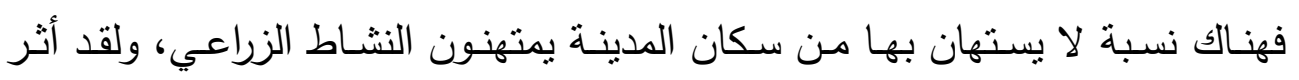

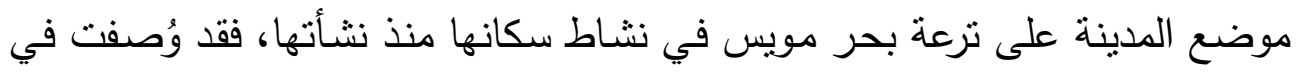
موسوعة وصف مصر والمراجع التاريخية الأخرى مثل الخطط التوفيقية بأنها مدينة

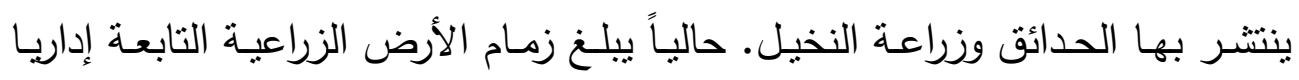

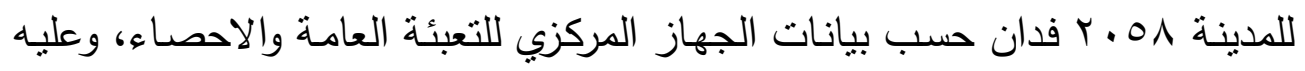

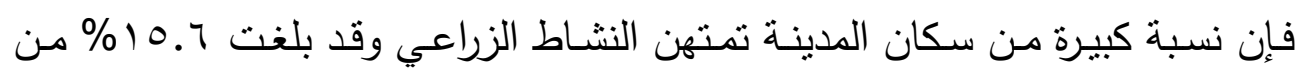

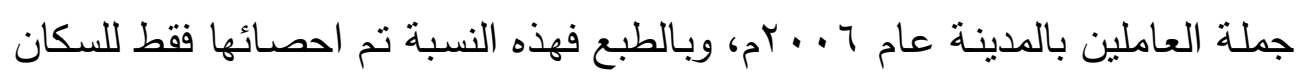

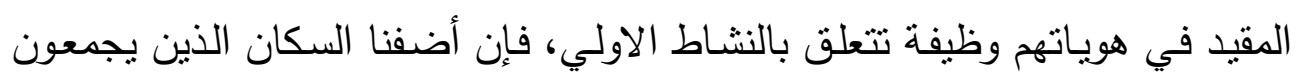

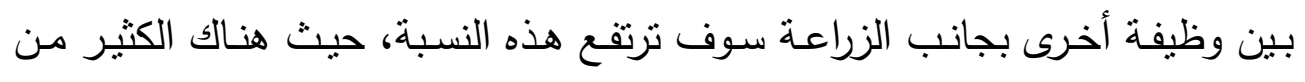

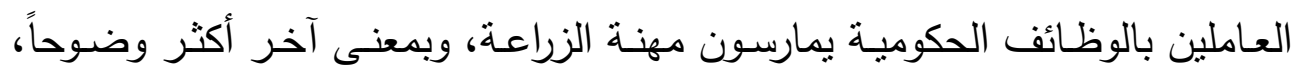

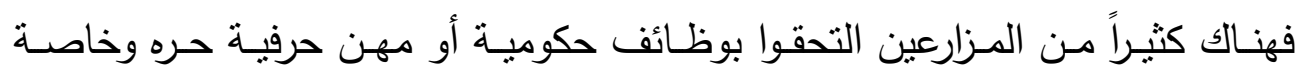
المتعلقة بالتشييد والبناء.

وتكمن أهية دراسة الزراعة كنشاط لسكان المدينة لما في تأثيرها على حياة

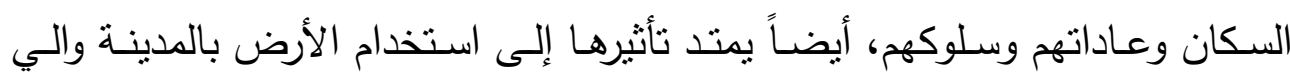
التركيب الداخلي للمنازل حيث بحتوي بيت المزارع غالباً على حظيرة أو فناء لنتربية

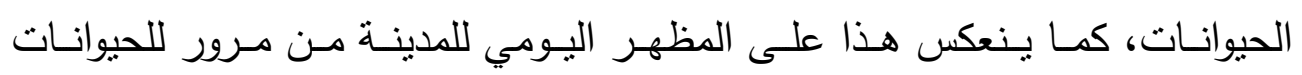

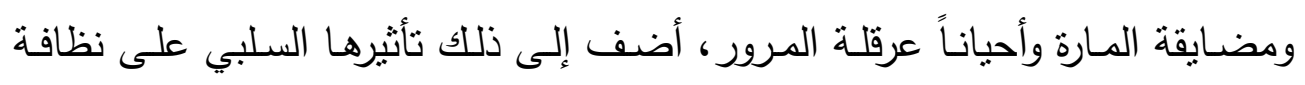

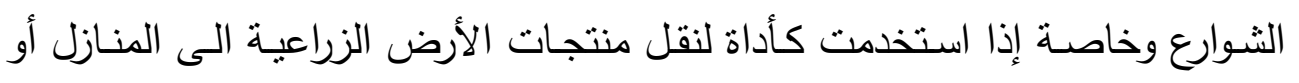

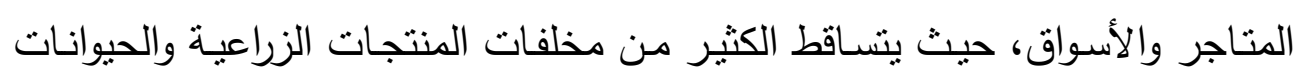

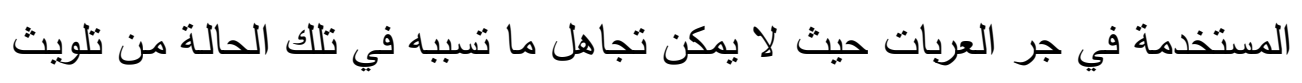
لشوارع المدينة بمخلفاتها العضوية. 


\section{ثانياً: النمو السكاني وأثره على معدلات التحضر بمدينة ههيا

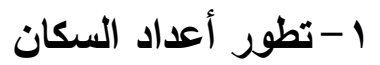

السكان هم المؤشر الأكثر سهولة للالالة على أهمية ونمو المدن، كما بمكن

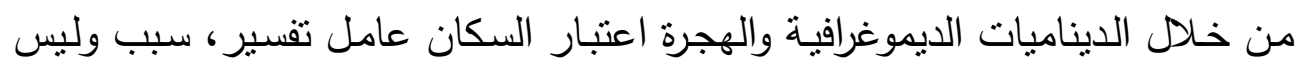
نتيجة'، ولذلاك تتأثر معدلات التحضر بشكل كبير بأعداد السكان ونموها وتطورها وخصائصها، فجوهر عملية التحضر يقاس بنسبة ساكني المدن إلى إجمالي سكان لئل

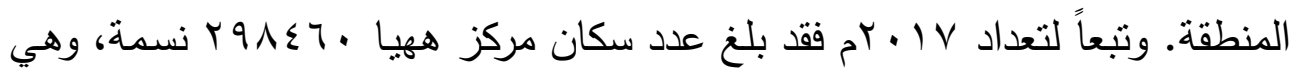

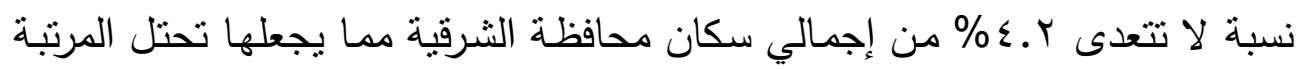

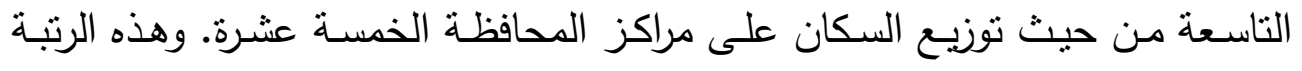

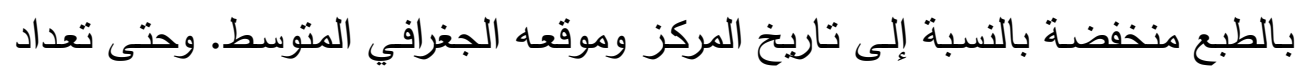

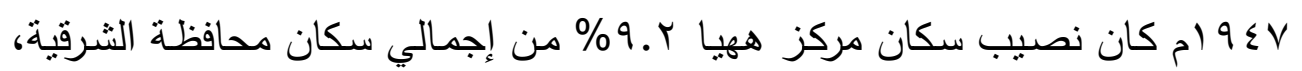

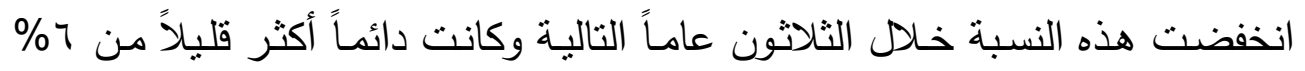

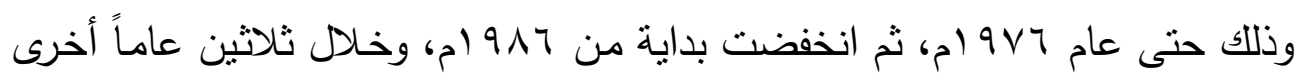

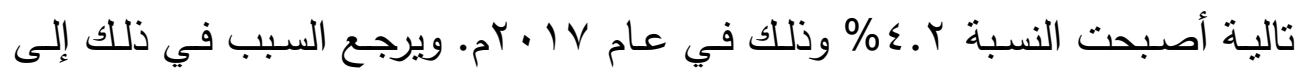
التغيرات الني طرأت في الخريطة الإدارية لهحافظة الثرقية واستحداث مراكز إدارية

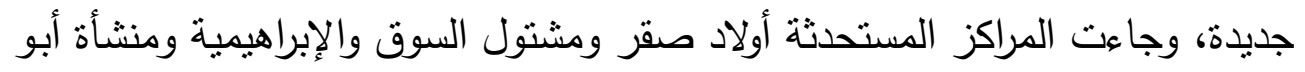

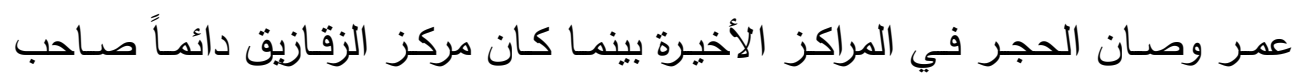
النصيب الأكبر من سكان المحافظة لكونه يضم العاصمة الإدارية لها.

وعند دراسة نصيب مدينة هريا من إجمالي سكان الحضر بمحافظة الثرقية،

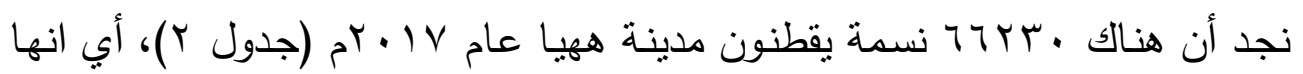
تستحوذ على 9.\%\% من إجمالي سكان الحضر بالمحافظة، وهي بذللك تحتل المرتبة

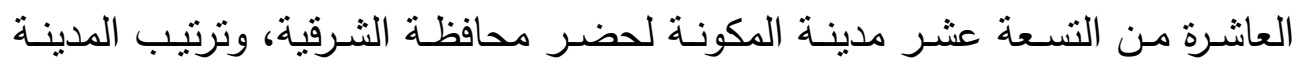


بالنسبة لمدن المحافظة يكاد يتوافق مع نفس ترتيب المركز بالنسبة لمراكز المحافظة. أما السبب في خلل التوزيع الحضري للسكان بين مدن الحافظة هو استقطاب أربعة

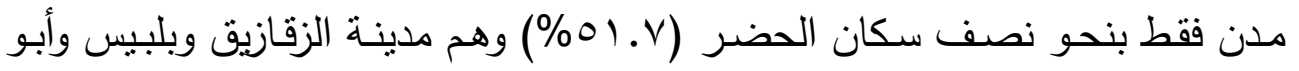

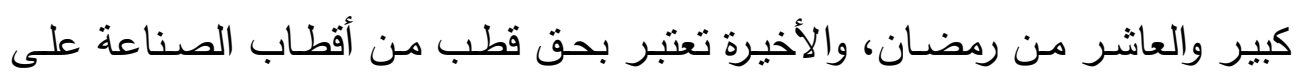

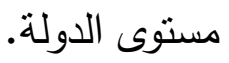

\begin{tabular}{|c|c|c|c|c|c|c|c|c|c|}
\hline \multicolumn{3}{|c|}{ معدلات التحضر \% } & \multicolumn{3}{|c|}{ متوسط معدلات النمو السنوي } & \multicolumn{3}{|c|}{ أعداد السكان بمدينة ههيا } & \multirow{2}{*}{ التعداد } \\
\hline | الجمهورية | & المحافظة & المدينة & الجمهورية حضر & المحافظة & المدينة & $\%$ & الزيادة & المدينة & \\
\hline rr.o & 14 & 9.9 & - & - & $1 . \varepsilon$ & - & - & 11094 & $19 \leqslant V$ \\
\hline rA.Y & 17.1 & 14.1 & T.0 & r.9 & Y.r & rr.q & एवYq & 10019 & 197. \\
\hline$\varepsilon r . \wedge$ & $r \cdot . r$ & $1 \varepsilon . r$ & r.. & r.V & Y. & $\varepsilon ५ . V$ & VYOD & YYVVE & 1987 \\
\hline «.. & Y.. & $r \cdot . q$ & Y. 9 & r. 1 & Y.O & $Y \wedge . \xi$ & $7 \leqslant 7$. & YqYTE & 1919 \\
\hline \&Y. & YY.T & YI.r & 1.1 & $r .{ }^{\prime}$ & Y.Y & $Y \xi . \cdot$ & $V \cdot Y T$ & mirov & 1999 \\
\hline$\varepsilon r .1$ & YT. & YI.V & Y.Y & r.० & Y. & YY.T & $\Lambda Y \cdot \Lambda$ & $\leqslant \leqslant \leqslant 70$ & $r \ldots T$ \\
\hline & & & $r$ & & $r v$ & 19 & PIVTe & $7 \pi T$ & r.tv \\
\hline
\end{tabular}

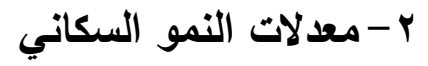

العديد من الششاكل المرتبطة بالغذاء والصحة والسكان في مجتمعاتتا يكون مصدرها الأساسي عدم التوازن بين النمو السكاني وبين خطط التتمية الاقتصادية

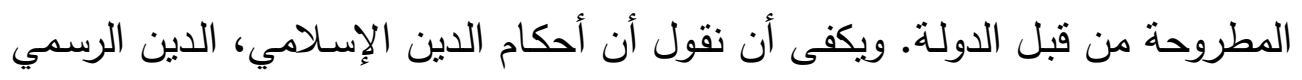

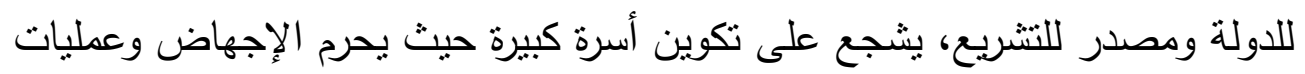


منع الحمل في ظل معدلات خصوبة مرتفعة' . وخـلال دراسـة النمو السكاني لمدينة هعيا داخل الإطار الإقليمي لمحافظة الثرقية والإطار القومي لمصر تم تقسيم مراحل النمو السكاني الى الفترات التالية:

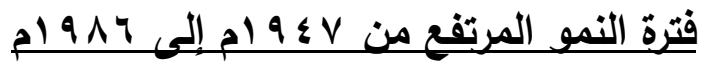

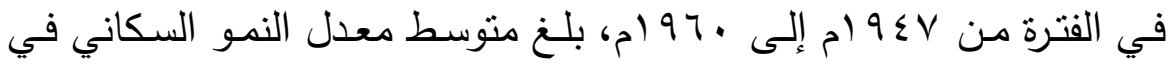

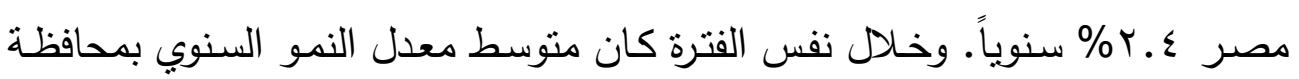

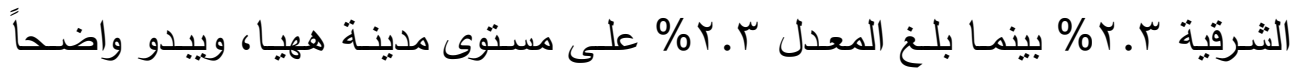

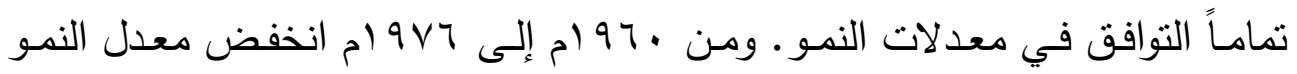

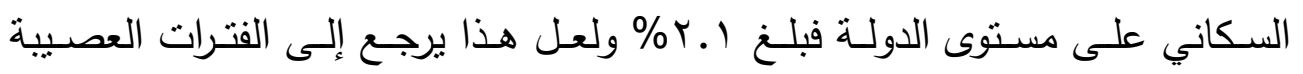

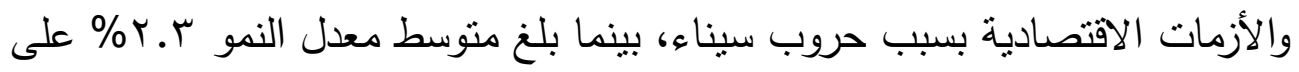

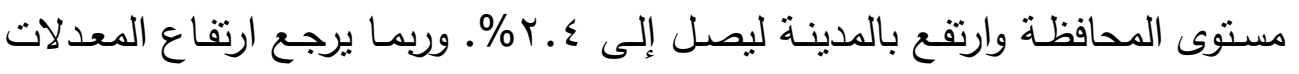

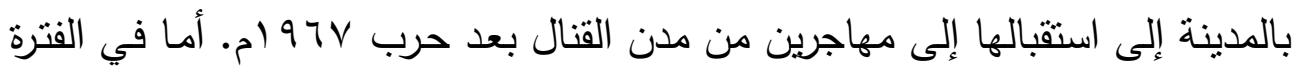

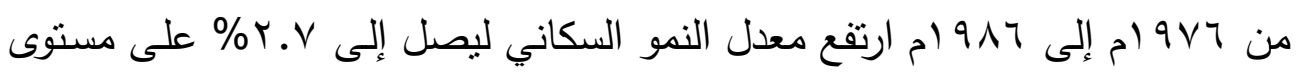

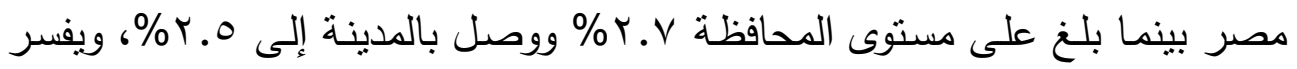

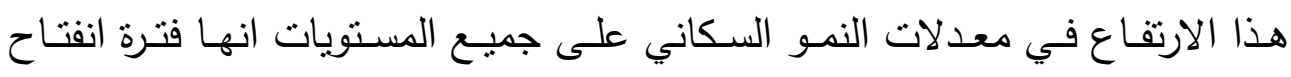
اقتصادي وبداية ظاهرة الهجرة المؤقتة إلى الدول البترولية للعمل ولجلب رؤوس التوس أموال ساعدت بالتأكيد على التوسع العمراني وتتشيط معدلات الزواج وبالتالي الإنجاب.

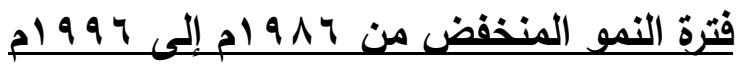

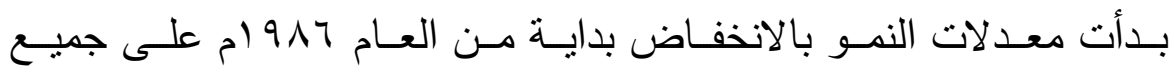

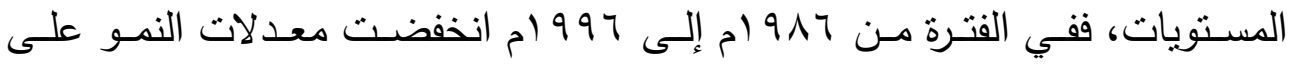


المستوى القومي والإقليمي والمحلي، حيث وصل معدل النمو للجمهورية ا.ب٪\% وعاد نظيرة علي مستوى الدحافظة للاستقرار ليصل إلى ب.r\% بينما سجل معدل الددينة

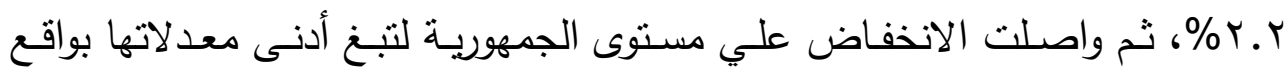

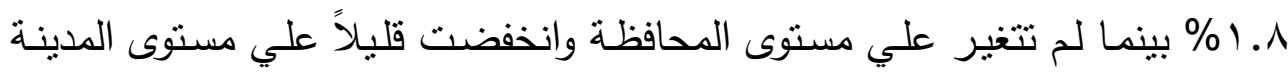

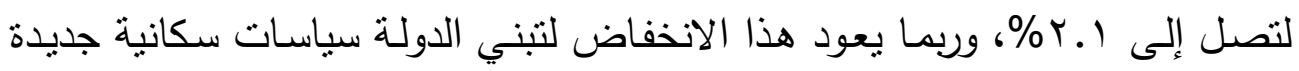
من شأنها تتظيم الأسرة لمواجهة الانفجار السكاني.

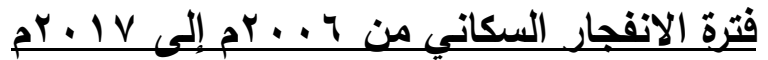

شهـدت تلك الفترة حالـة فريدة مـن الزيادة السكانية، فقد بلـغ معدل النمو

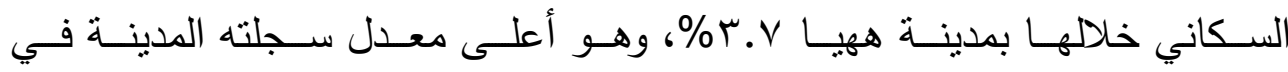

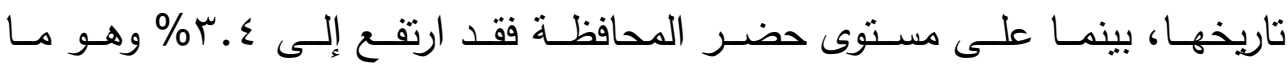

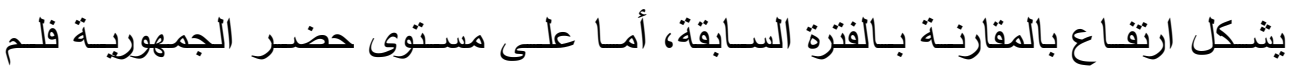

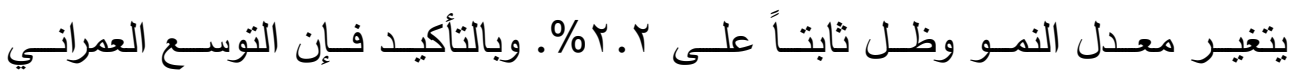

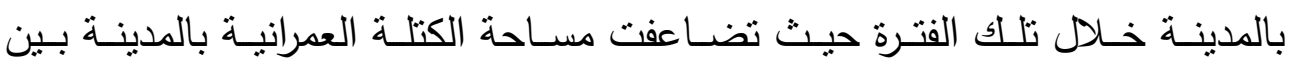

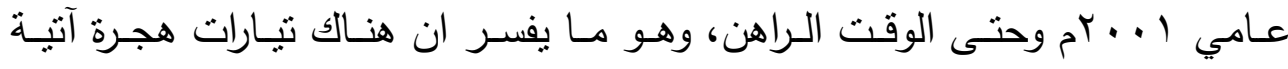

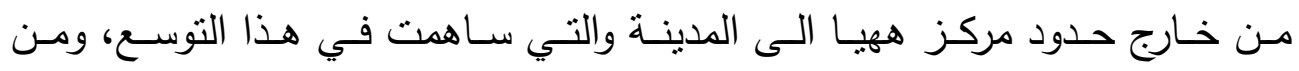

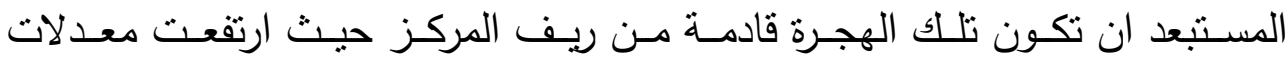

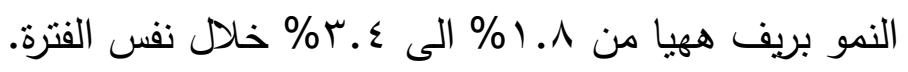

\section{ب- معدلات التحضر بمركز ههيا}

وعمليـة التحضـر هي التي تعنى الاتجـاه نحو سُكنى المدن، وهى عمليـة مستمرة، وتمثل اتجاهاً دولياً عاماً عن طريق الهجرة المستمرة الى المدن، بالإضافة الهاهي

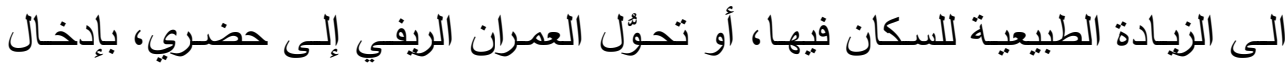

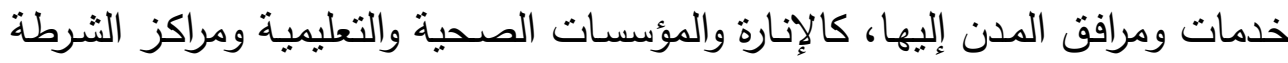




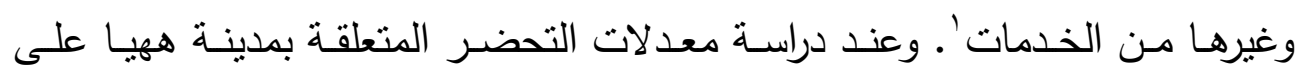

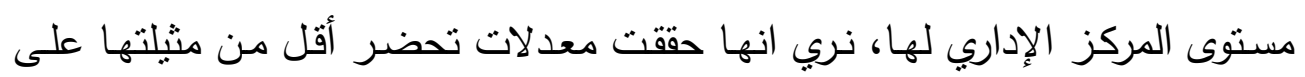

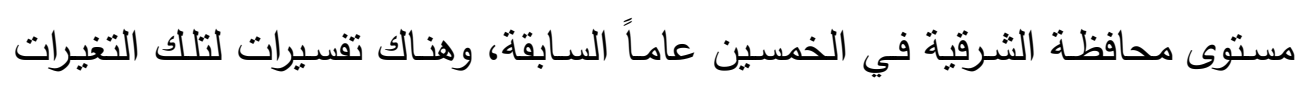
بين معدلات التحضر بمركز هـيا ونظيرتها على مسنوى المحافظة:

لم يكن سكان مدينة هيا يشكلون سوى Y.Y\% من إجمالي سكان مركزها

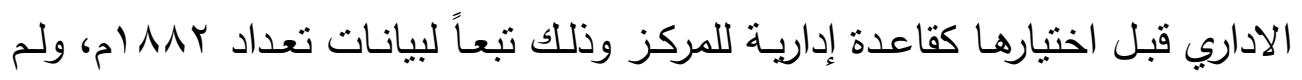

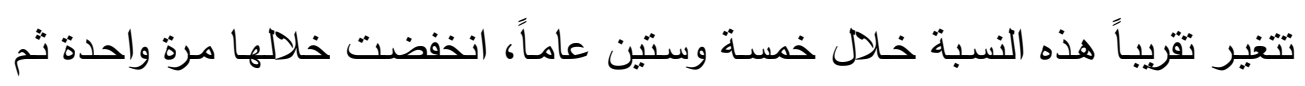

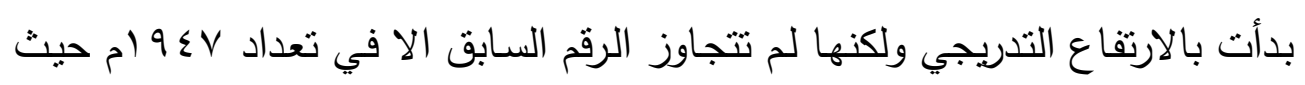

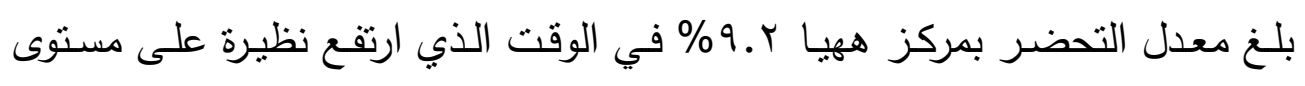

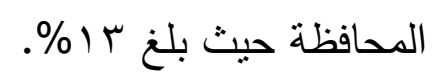

وربما برجع ارتفاع معدلات التحضر للمدينة بتلك الفترة إلى بداية الهجرة من

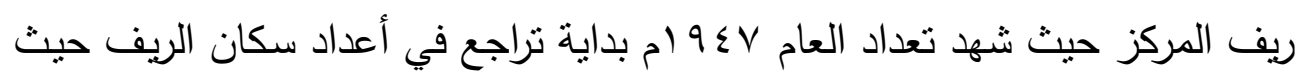

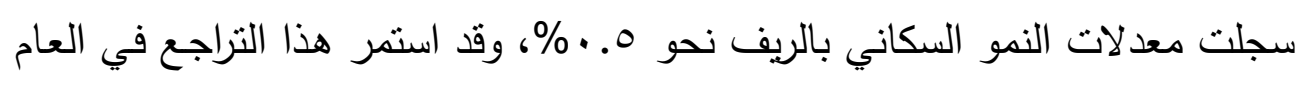

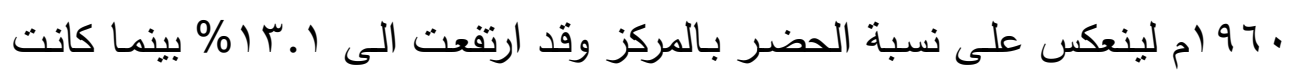

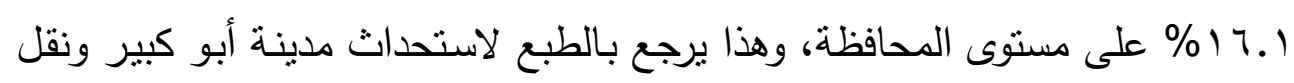
تبعية مدينة ومركز ديرب نجم من محافظة الدقهلية الى محافظة الثرقية (جدول بالم). 


\begin{tabular}{|c|c|c|}
\hline \multicolumn{3}{|c|}{ جدول (r) المدن المستحدثة بمحافظة الشرقية حتى تعداد V V ا م } \\
\hline المدن المستحدثة & بالمحافظة & 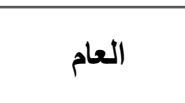 \\
\hline الزقازيق - ههيا - بلبيس - فاقوس - كفر صقر - منية القمح & 7 & حتى Vr \\
\hline ابو حماد - الحسينية & $\wedge$ & p) $9 \leq V$ \\
\hline ابو كبير - ديرب نجم & 1. & م). \\
\hline مشتول السوق - الابراهيمية & ir & م)9V7 \\
\hline أولاد صقر - القنايات ـ القرين - الصالحية ـ العاشر من رمضان & IV & م)914 \\
\hline صان الحجر - منشأة ابو عمر & 19 & $b_{r+1 R}$ \\
\hline \multicolumn{3}{|c|}{ المصدر: من حساب الباحث اعتمادا على بيانظة الجرقاز المركزي للتنبئة العامة والإحصاء، تعداد السكان } \\
\hline
\end{tabular}

ولنفس السبب ازدادت الهوة في العام 9 ام حيث استحدثت مدن مشتول السوق والابراهيمية من جهة لتزبد رصيد المحافظة إلى r . . r\% بينما أدى انفصال مدينة الإبراهيمية عن مركز ههيا واستحداث مركز اداري جديد باسمها إلى عدم تقدم المعدل بمركز ههيا سوى r.؛ (\%). في العام 9191 ام كادت النسبة تتساوي في ههيا

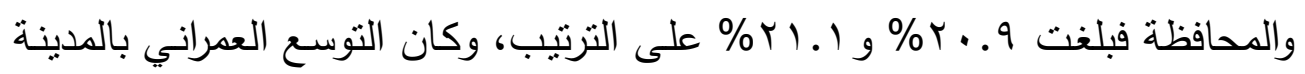
على حسـاب الأرض الزراعيـة هـي الظـاهرة الرئيسـية التـي اسـتوعبت كثيـر مـن المهاجرين من ريف المركز ، بينما سبب الزيادة على مستوى المحافظة هو استحداث

$$
\text { اربعة مدن جديدة (جدول r). }
$$

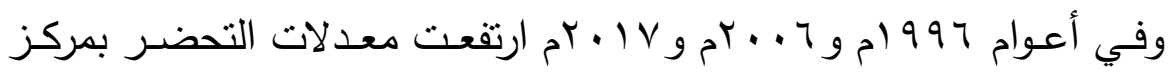

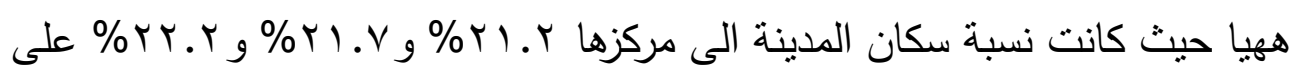
التوالي، بينما أدى النمو السكاني الكبير لمدينة العاشر من رمضان إلى زيادة معدلات

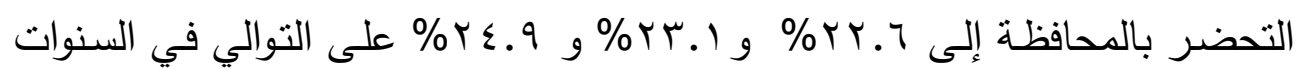
السابق ذكرها، فقد اعتمد النمو السكاني لمدينة العاثر من ردضان في بداية تكوينها 
على الهجرة الوافدة من مختلف مدن وقرى محافظة الشرقية، الأمر الذي كان له ظله على جميع معدلات النمو بالمحلات العمرانية بالمحافظة، والآن بدأت تساهم الزيادة الطبيعيـة بمدينـة العاشـر مـن رمضـان في ارتفـاع تلك النسبة السكانية بعد اسـتقرار المهاجرين بالمدينة.

ثالثاً: تأثير التحضر على النمو العمراني ان العلاقة بين النمو العمراني والنمو السكاني علاقة تبادلية، فقد أثر النمو

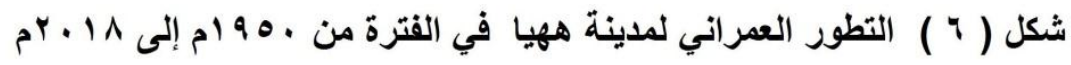

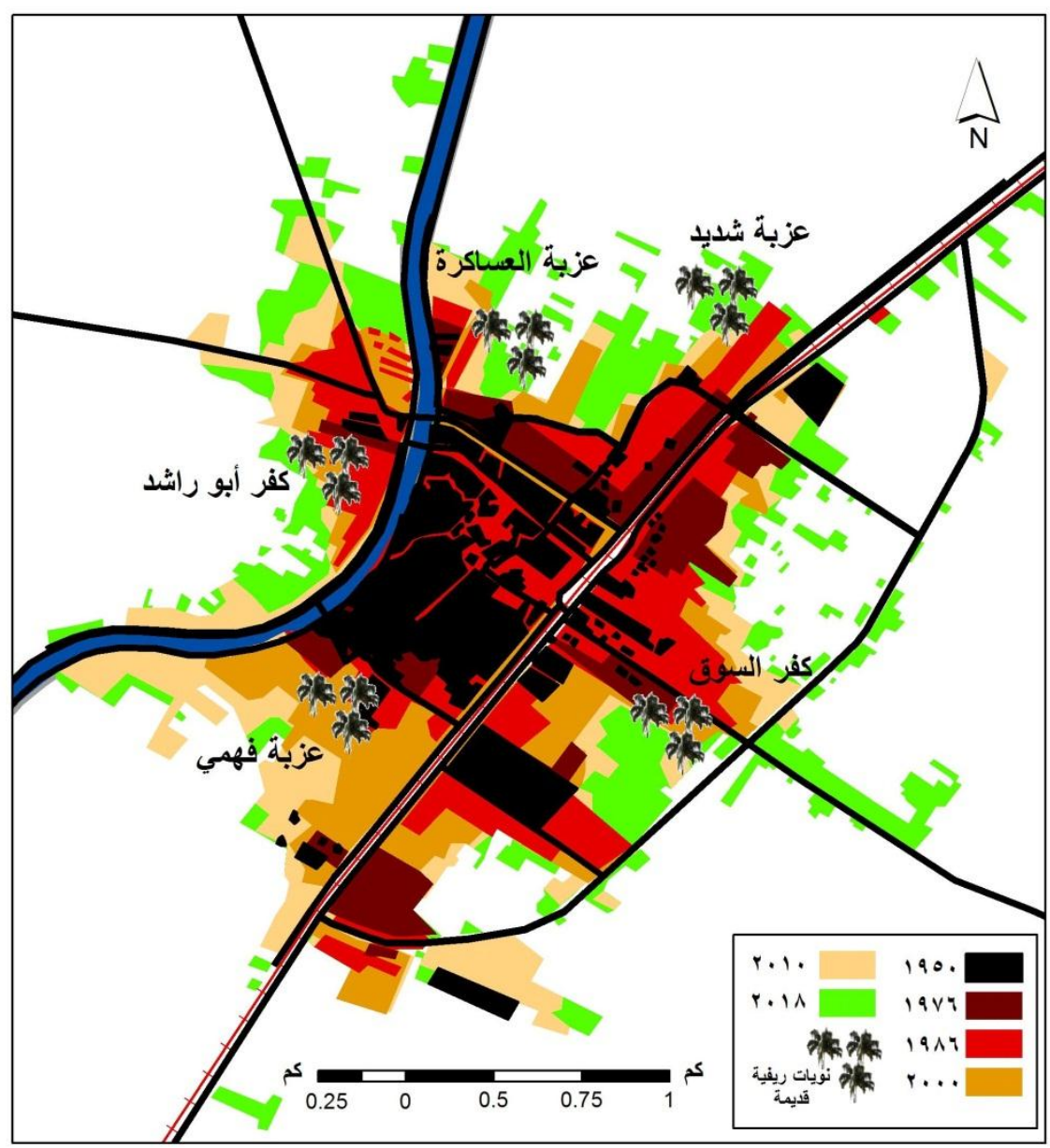

المصدر:من إعداد الباحث اعتمادا على الخر ائط الطبو غر افية ومرئيات الاقمار الصناعية لاعوام مختلفة 
السكاني الى توسع في الكتلة البنائية وفي الوقت نفسه أدى الاستثمار العقاري والتوسع

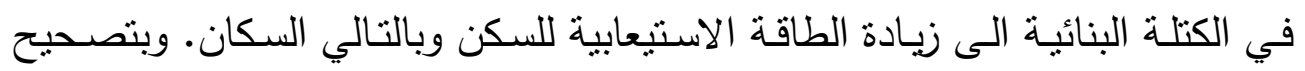

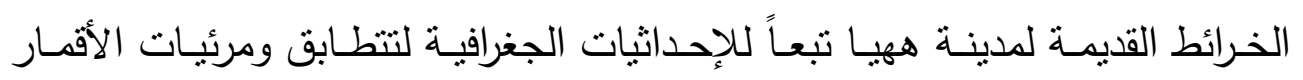

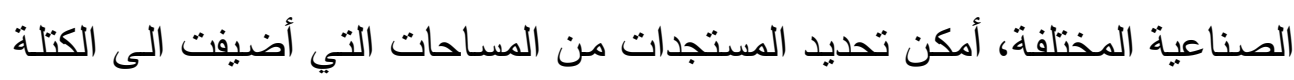

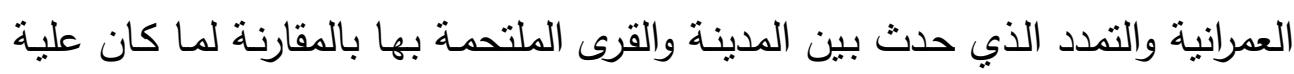

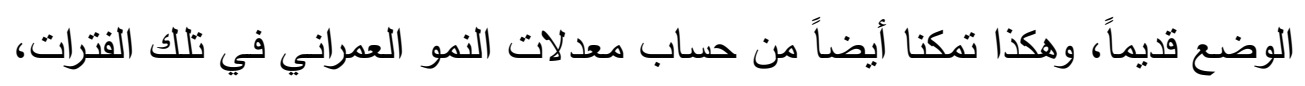
وكانت النتيجة كما هو واضح وهك بالثكل (†).

\begin{tabular}{|c|c|c|c|c|c|}
\hline \multicolumn{6}{|c|}{ 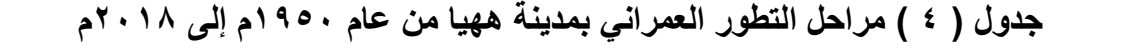 } \\
\hline 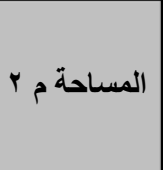 & المعدل السنوي & المضاف \% المساحة & بالفان & فالمساحة الكلية & 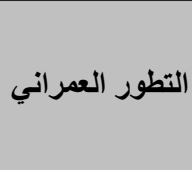 \\
\hline rAvarr & & & & qr & p 90. \\
\hline$\varepsilon r 7001$ & $\cdot . \varepsilon$ & $1 Y .0$ & ir & $1 \cdot \varepsilon$ & pl9v \\
\hline$V r \leqslant r \cdot T$ & 1.9 & $71 . Y$ & VI & IVo & م) $9 \wedge \varepsilon$ \\
\hline 977194 & 9.7 & 4.7 & 00 & rr. & p)99. \\
\hline 1т0Y74 & $\Lambda . \varepsilon$ & $\varepsilon \cdot . \cdot$ & 94 & TYY & مr... \\
\hline$r \cdot 1 \wedge .14$ & $1 V .7$ & $\leqslant \wedge . \wedge$ & 101 & $\varepsilon \wedge$. & مr. \\
\hline Y074Y.0 & $Y \cdot . T$ & YV.O & 170 & $7 \leqslant 4$ & $\frac{\rho^{r} \cdot 11}{11}$ \\
\hline
\end{tabular}

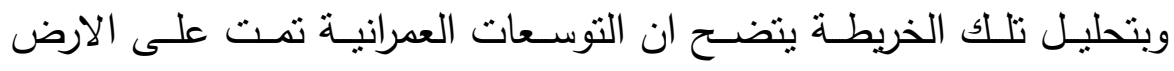

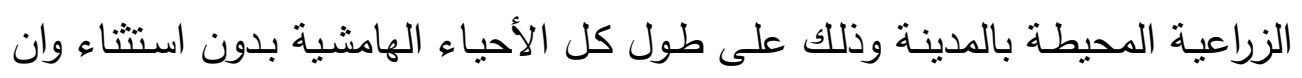

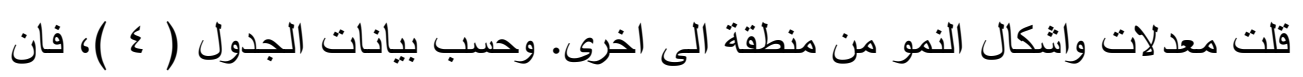

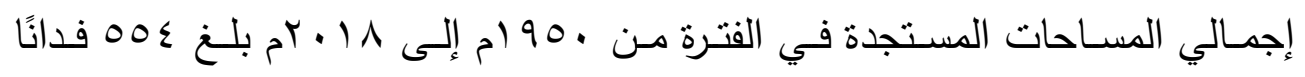


تحولت بالفعل إلى مساحات عمرانية أي ما يزيد عن ؟.r كيلومتز مربع، وهذا يعني

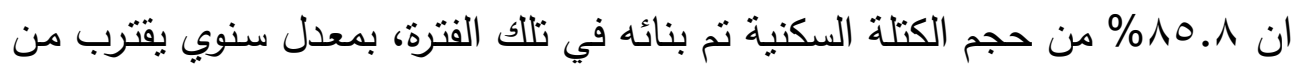

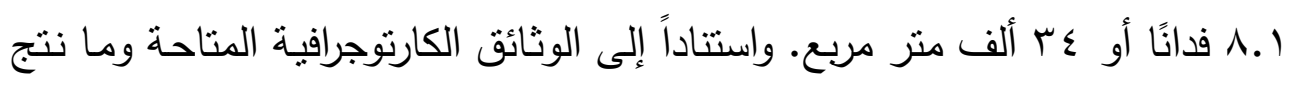

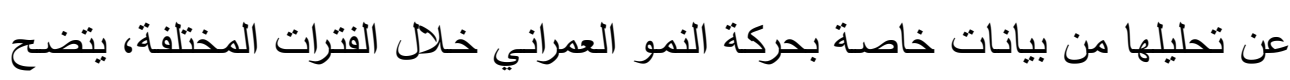

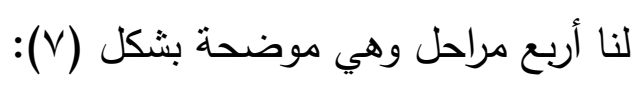

\section{المرحلة الأولى (العمران القديم)}

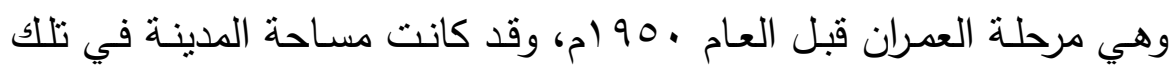

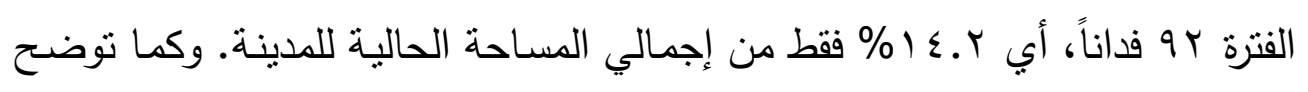

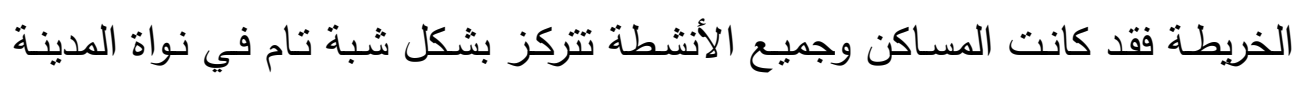
الواقعـة بين خط السكة الحديد وترعـة بحر مويس، وبالتحديد بحي الجامع الكبير

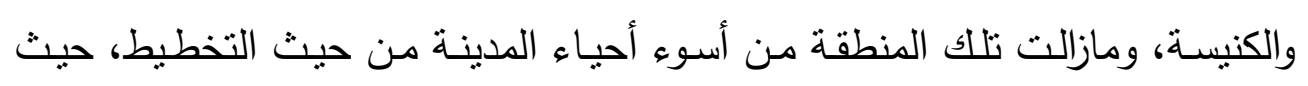

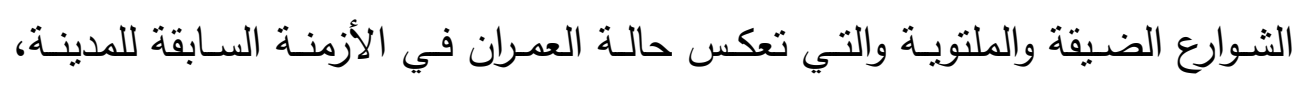

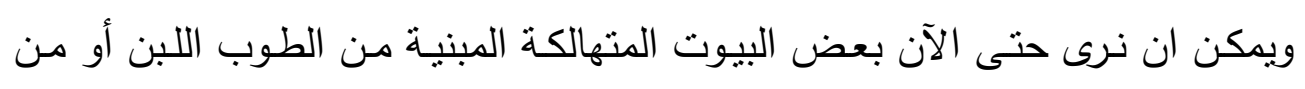

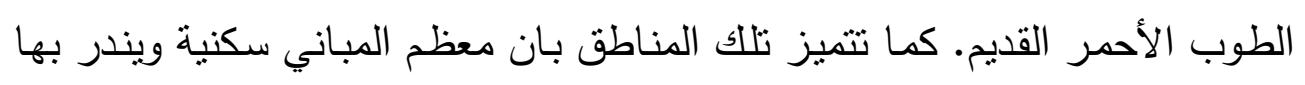

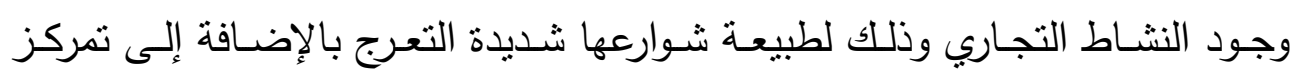
الأنشطة التجارية في الثشارع الرئيسي وهو شارع سعد زغلول.

ويحدد الخط الحديدي الضيق (سوارس)، والتي تمت إزالته، الكتلة العمرانية

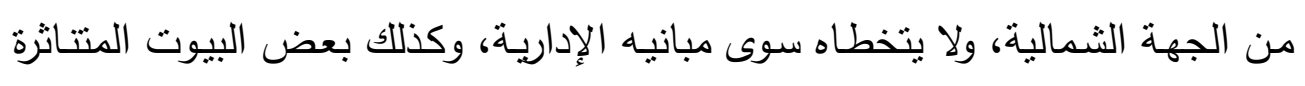

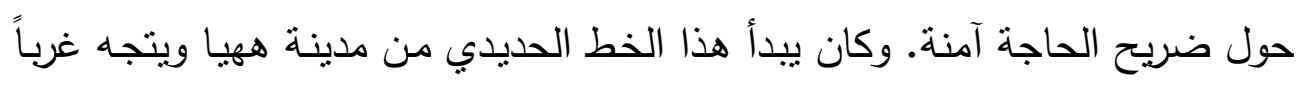

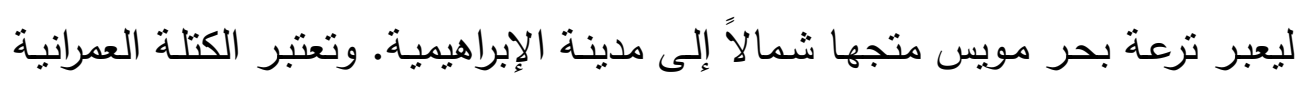

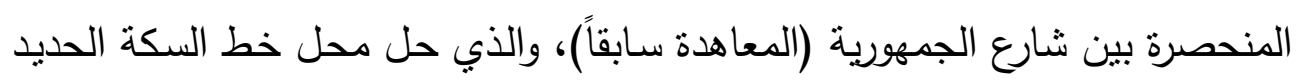

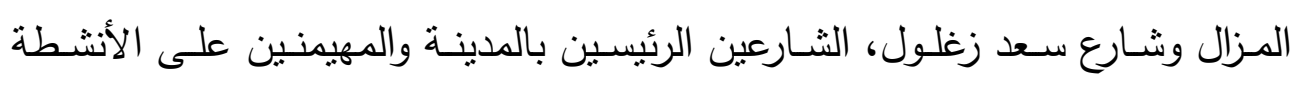

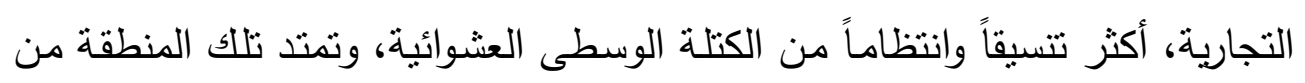


محطة السكة الحديد شرقاً وترعة بحر مويس غرباً تحديداً حتى مبنى مركز شرطة ههيا وحي الدبايشه الواقع خلف مركز الثرطة.

ويفصل الثطر الثرقي للمدينة عن كتلتها العمرانية ثناث حواجز (حديدية،

مائيـة، بريـة) تمنع الامتداد العمراني آن ذالك، وهم خط السكة الحديد والذي مـازال

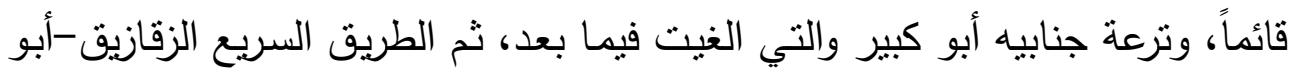
كبير • ولذلك فلم يتواجد سوى تجمع سكني صغير في شرق محطة السكة الحديد وبالتحديد بين تلك الحواجز السابق ذكرها وبين الأرض المخصصـة لإقامـة السوق الأسبوعي للمدينة في تلك الفترة. وغير ذلك من العمران في الثطر الثرقي عبارة عن الثن مؤسسات خدمية فقط، ففي أقصى الثمال، يعتبر مستشفى هيا ذو المبنى التاريخي،

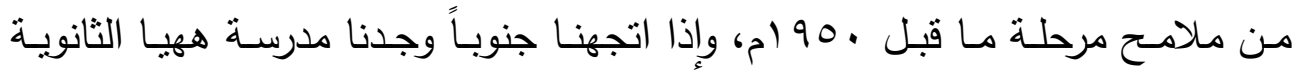

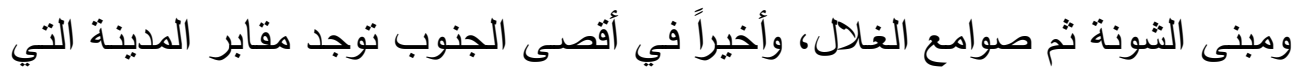

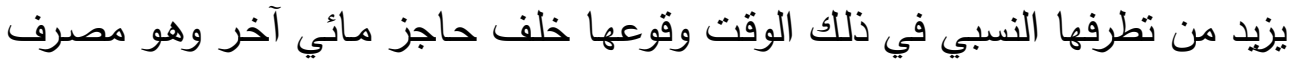

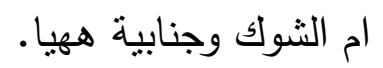

كما يتضح من الخريطة النويات القديمة لعزبـة شديد الواقعة شمال المدينة،

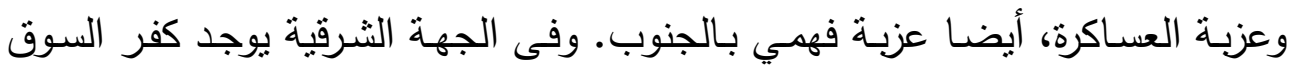
القديم، وفى الثطر الغربي كتلة عمرانبة صغيرة وتسمى حتى الآن كفر ابو راثد. كما

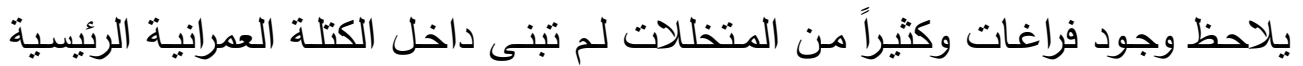

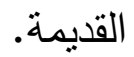

\section{المرحلة الثانية (مرحلة النمو البطىء)}

وهي مرحلة النمو العمراني من •90 ام إلى 974 ام، حيث توسعت المدينة

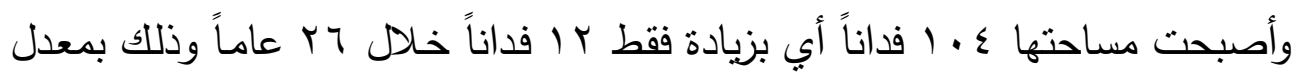

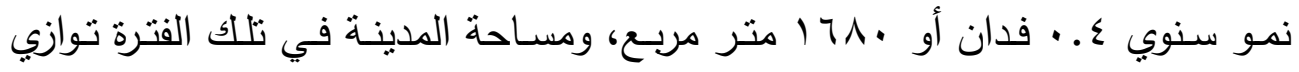

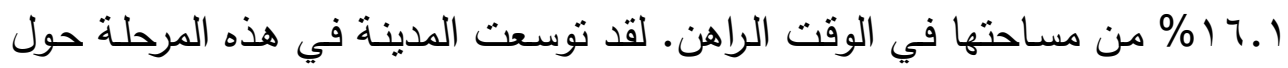
الكتلة القديمة وملئت الفراغات بين شارع سعد زغلول وحي الجامع الكبير ، كما امتـ 
العمران بين محطة السكة الحديد وشارع على بن ابي طالب (ميدان السكة الحديد)

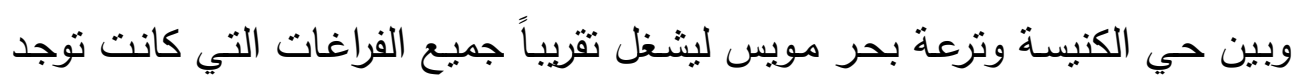

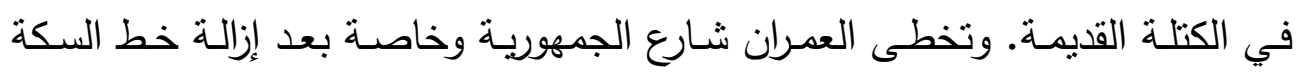
الحديد الضيق (سوارس) والذي كان يشغل هذا الثارع ليصبح من أهم شوارع المدينة

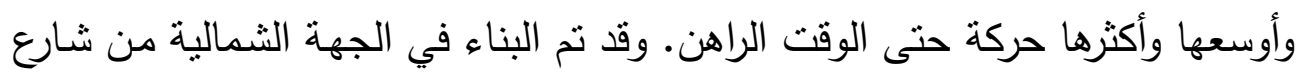
الجمهورية منوجهاً شمالاً إلى عزبة شديد الرهات وغرباً حتى حي الحاجة آمنة. 


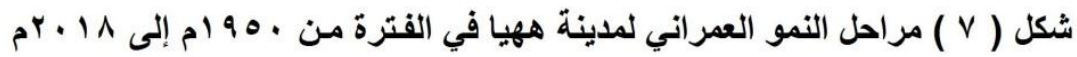
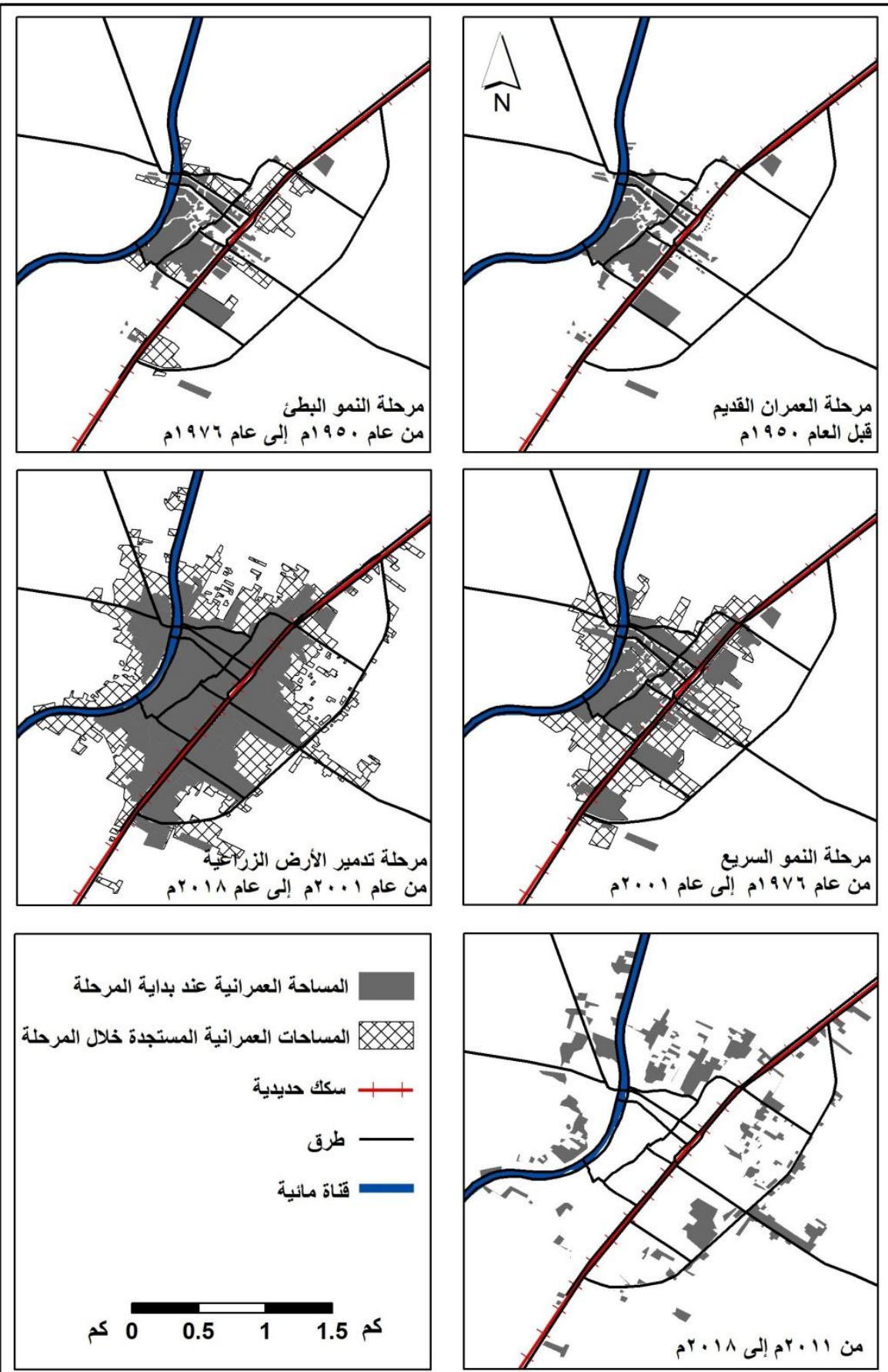

المصدر:من إعداد الباحث اعتمادا على الخر ائط الطبو غرافية ومرئيات الاقمار الصناعية لاعوام مختلفة 
اما المناطق الغير ملتحمة فظهرت في حي عزبة العساكرة الواقع شمالي المدينة على ترعة بحر مويس، أيضاً امتد العمران شرق طريق عمر بن الخطاب وبالتحديد

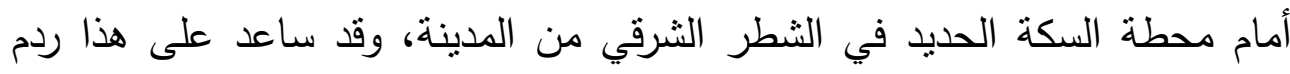

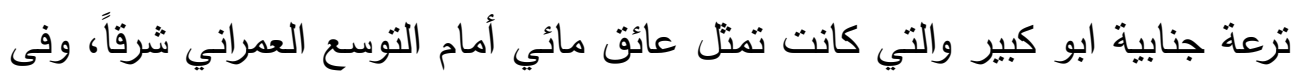

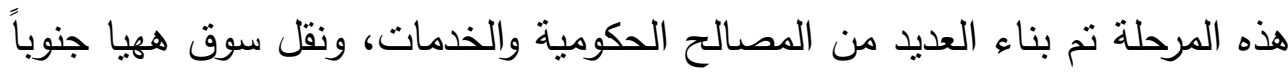

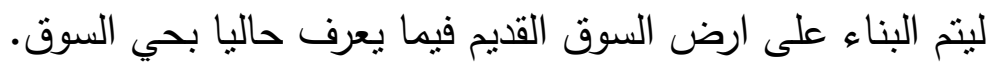

ومن العوامل التي ساعدت على النمو العمراني تيارات الهجرة المتتالية من

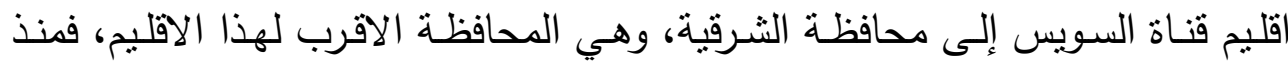
حرب 907 ام و 97 ام استقبلت المدينة العديد من الاسر والتي على أثرها تم بناء

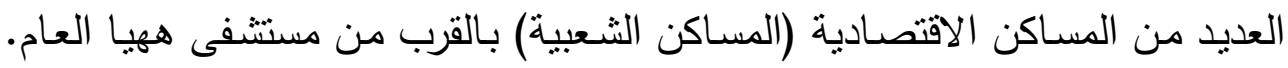

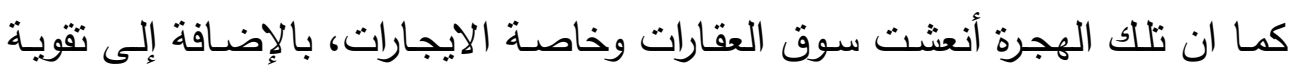

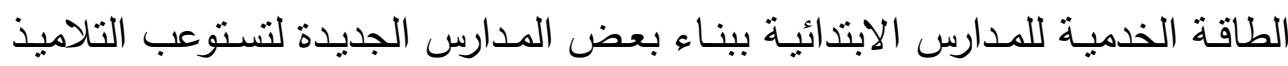

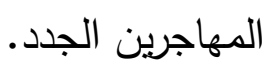

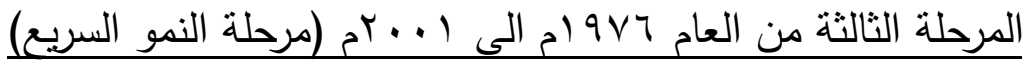

منذ نهاية فترة السبعينيات وحتى مطلع القرن الواحد والعشرون شهدت المدينة

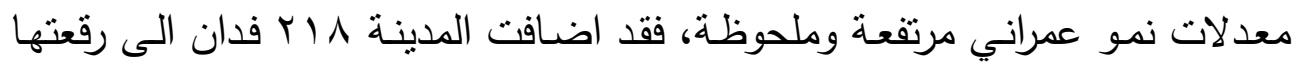

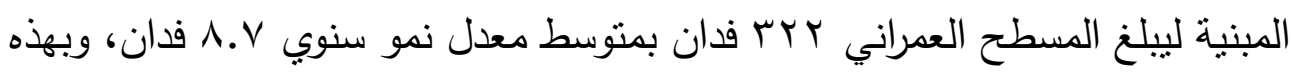
الزيادة العمرانية اقتربت مساحة المدينة من نصف المساحة في الوقت الراهن. وبعد

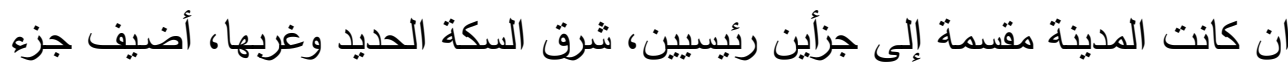

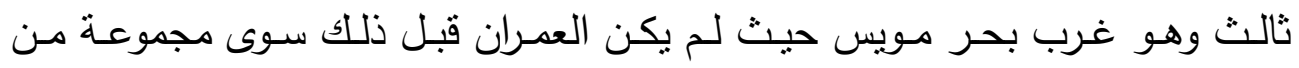

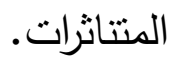

وامتدت الكتلة العمرانية على عثرات الافنية، فتم استكمال بناء ساحة ههيا الثعبية شرقي المدينة على أكثر من خمسة افدنة، كما ظهرت المباني السكنية حولها،

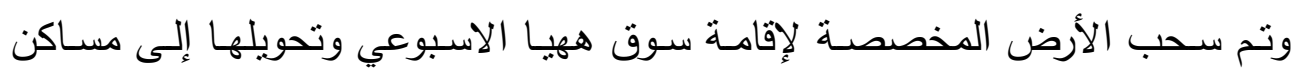


اقتصادية تحت الضغط الديموغرافي، حيث تم بناء (9 ؛ وحدة سكنية ومدرسة ابتدائي ويطلق عليها مساكن ومدرسة السلام مضيفةً للمدينة حي جديد ييتعد عن قلب المدينة بمسافة تقترب من .. منز ، وهذا ما ادى إلى انتشار البناء حول تللك المساكن والتي التحمت بالكامل في المرحلة التالية، والمثال السـابق يعتبر من آليات النمو العمراني التي الحقت الضـرر بالعديد مـن مدن الدلتا، حيث التوسـع يتتم بألقاء نقطـة خدميـة بالقرب من الكتلـة العمراني، ثم يتم التمدد من جانبي المدينـة وهذا النقطة حتي يتم التهام جميع الأراضي الزراعية البينية ويحدث الالتحام التام، وهذا ما حدث بالفعل عند بناء معظم مقرات الجامعات الإقليمية بعواصم المحافظات.

وفي هذه المرحلة تم بناء العديد من المصالح الحكومية وأهمها مجلس المدينة والمباني التابعة، والتي أدت أيضاً إلى التوسع العمراني حيث تم البناء بجوار وخلف مجلس المدينة لتلتحم المباني على طول شارع عمر بن الخطاب (الطريق الإقليمي الزقازيق -أبو كبير). وفى الثطر المحصور بين السكة الحديد وترعة بحر موبس امتد العمران بحي السراحنة جنوبي المدينة ليلتحم مع النسيج العمراني القديم بعزبة فهمي.

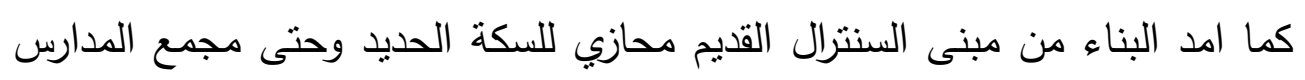
المقابل لمستشفى ههيا المركزي لتتصل عزبة شديد بالكتلة العمرانية الرئيسية وبالتالي بدأت المدينة في مرحلة النمو متعدد النوى. وفى الشطر الغربي للمدينة (غرب ترعة بحر مويس) امدت العمران بشكل بسيط خلف النادي الرياضي وأول الطريق الإقليمي لمدينة الإبراهيمية ليدخل أيضا كفر ابو راثد ضمن الخربطة العمرانية الحضرية لمدينة ههيا. 
ومما يجدر الإشارة اليه انه بين عامي ع 9 ام و •99 ام شهدت المدينة نسارعاً

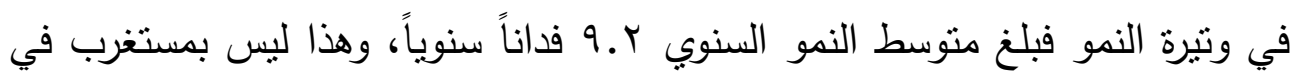

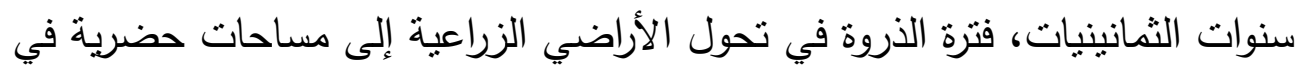

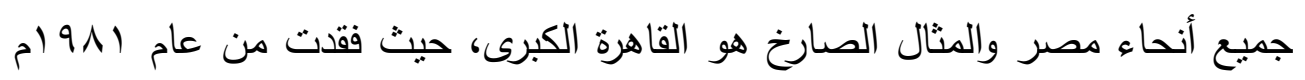

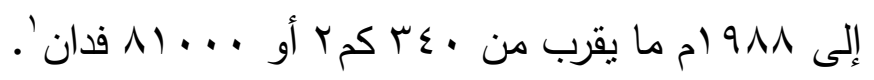

وفي هذه المرحلة توسعت المدينة بجميع الاتجاهات وتم ملئ جميع المساحات البينية التي كانت تفصل بين المتناثرات العمرانية في السنوات المتتالية لتصبح الكتلة

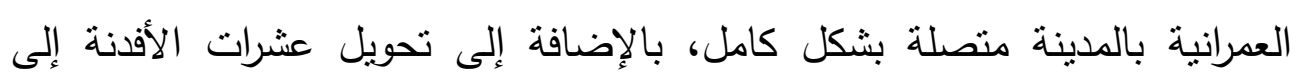

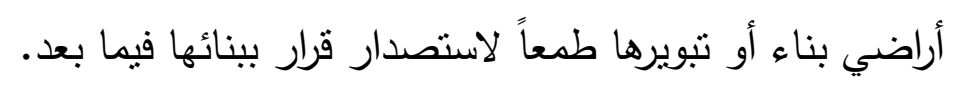

وهناك أسباب تثرر هذه النسب العالية في فترة الثمانينيات وبداية التسعينات،

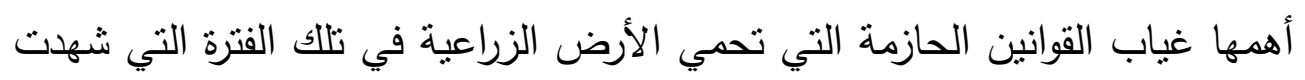

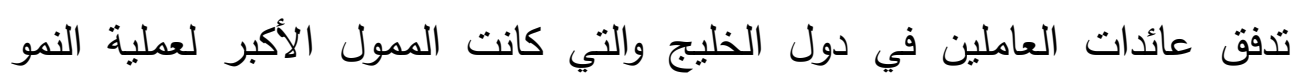

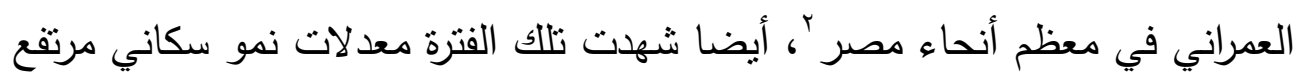

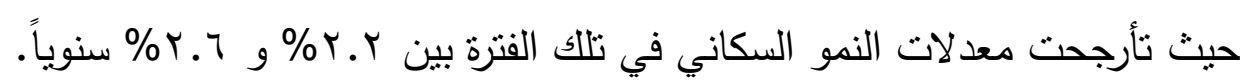

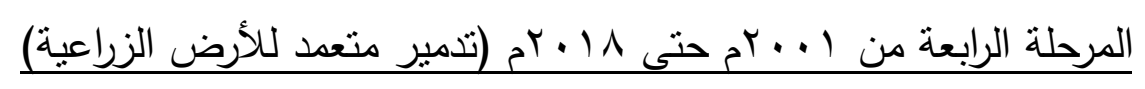

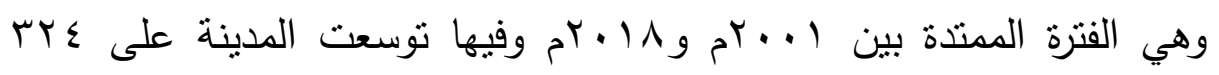

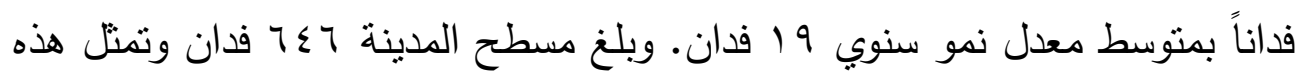
المرحلة r..0\% من الخريطة العمرانية للمدينة في الوقت الحالي، أب ان المدينة

' Urban growth and environmental degradation: The case of Cairo (Egypt, Cities, Volume 19, Issue ؟, December), r.. r, P. rqr

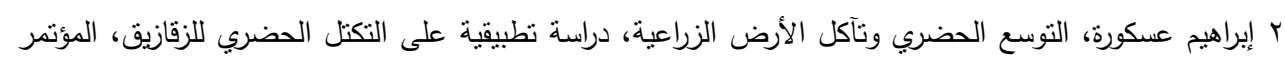

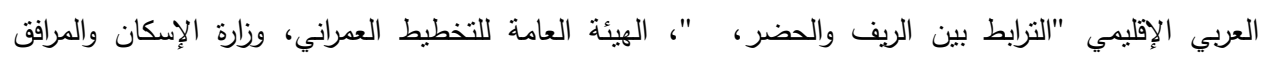

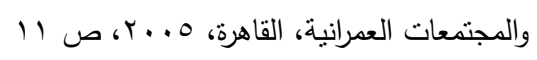


خلا السبعة عشرة عاماً الأخيرة ضمت لرقعتها البنائية مساحات أكثر من تلك المكنسبة منذ نشأتها من مئات السنين.

ولا يمكن انكار مرحلة ما بعد ثورة هب يناير 11 إبم وحاله الانفلات واستغلال

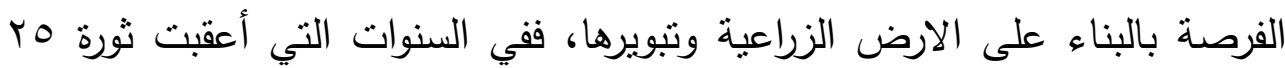

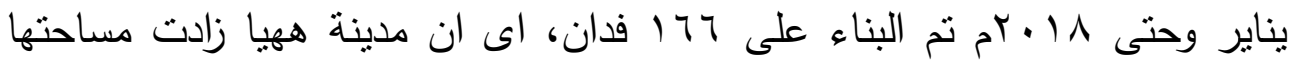

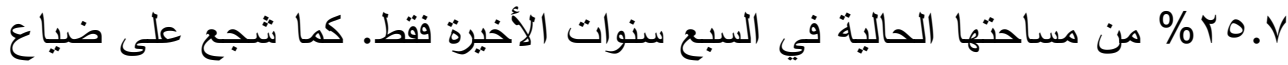
الارض الزراعية وتحويلها إلى ارض بناء الوضع الاقتصادي وعدم استقرار اسعار

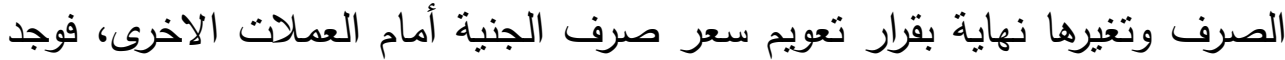
الكثير ان الامان هو الاستثمار في شراء الاراضي والادخار بها بدلا من استثمارها في مشاريع اخرى يمكن انهيارها امام النقلبات الاقتصادية.

\section{رابعاً: بعض آثار التحضر لمدينة هريا}

خلال رحلة التحضر بالددينة والممتدة عبر مئات السنين، تغيرت اثكال العمران بمدينة ههيا عدة مرات، كما تغير نمط استخدام الأرض ووظيفة المدينة. كما ان التغير في التركيب الاداري والتغير في استخدام الارض وحركة السكان والمشاريع القومية وشبكة الطرق قد نأثروا وأثروا بشكل جوهري على عملية التحضر بمركز هريا وشخصية مدينتها، كما أثروا على مكانة المدينة الحضرية وأهميتها بالنسبة إلى إقليم

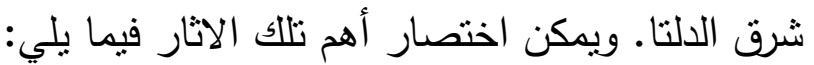
1- - 1 - إستقطاب المدن المجاورة

إن المدينة ليست مجرد وحدة جغرافية وأيكولوجية فقط، بل هي في الوقت ذاته

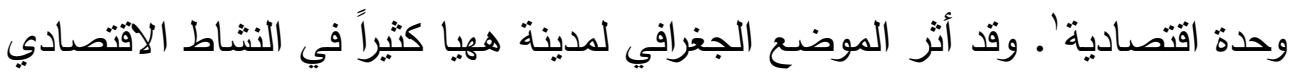
للسكان وبالتالي في نموها الحضري ومستقبله، فنجدها تقع بين ثلاث مدن تؤثثر بشكل مباشر على الحياة الاقتصادية للسكان، بالإضافة إلى مدينة العاثر من رمضان التي 
غيرت المنظومة الحضرية بشكل كامل لمحافظة الشرقية في الفترة الأخيرة فيما يخص الأنشطة الاقتصادية للسكان، وامتذ نفوذها وتأثنرها إلى جميع مدن وقرى محافظة الثرقية. ومن الجدير بالذكر ان مدينة ههيا هي أقدم دن جميع المدن المجاورة لها بشكل مباشر بالرغم من وقوعها تحت نفوذهم الاقتصادي والخدمي. فمدينة الزقازيق القاعدة الحضرية لمحافظة الثرقية وعاصمتها الإدارية قد استحدثت عام ظهرت مدينة أبو كبير بداية من تعداد.97 ام، وفي تعداد 9V7 ام تحولت الإبراهيمية إلى مدينة منفصلة بعدد من القرى عن مركز ههيا ومكونة مركز مستقل

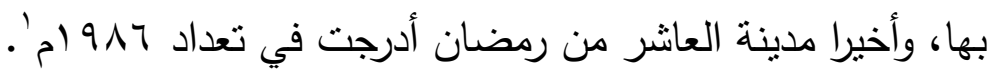
وإن كانت الأنشطة الثنائية والثلاثية هي المحدد الرئيسي للتحضر أو لإسباغ صفة المدنية على المحلة العمرانية، فيلاحظ مدى التأثير الكبير لمدينة العاثنر من ردضان على مستوى الأنشطة الثنائية واجتذابها لليد العاملة، وهذا يتضح عند دراسة مفردات النشاط الثنائي وخاصة الصناعة التحويلة والتي احتلت مدينة ههيا بها المرتبة الأخيرة بالمقارنة مع المدن المحيطة فيما يخص التصنيع (جدول 0). وقد أوضحت هل تحليلات الأرقام المتعلقة بأن ع. . ج\% من سكان مدينة العاشر من رمضان يمتهنون النشاط الثنائي من بينهم 07\% في الصناعات التحويلية وحدها، كما أن المدينتين الأقرب إلى ههيا، (أبو كبير والإبراهيمية)، قد فاقت نسبة الأنشطة الثنائية لسكانهم

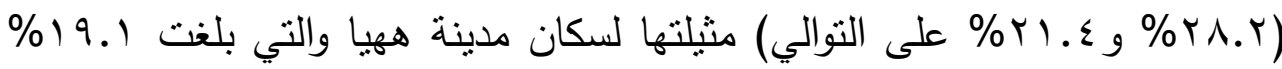
فقط، وبالتالي يلجأ سكان مدينة ههيا إلى الأسواق الرئيسية بتلك المدن لقضاء احتياجاتهم من البضائع المختلفة والمتعلقة بنلك الأنشطة.

محمد رمزي، مرجع سابق، مصلحة الاحصاء والتعداد، التعداد العام للسكان، محافظة الشرقية، الجزء الاول، . 79 ام، الجهاز المركزي للتعبئة العامـة والاحصـاء، التعـداد العـام للسـكان والاسـكان، تعـداد السكان، النتـائج التفصيلية، محافظة الشرقية، 7 9V (م، الجهاز المركزي للتعبئة العامة والاحصاء، التعداد العام، النتائج النهائية، الحصر الشامل، خصائص السكان، محافظة الشرقية،

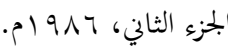




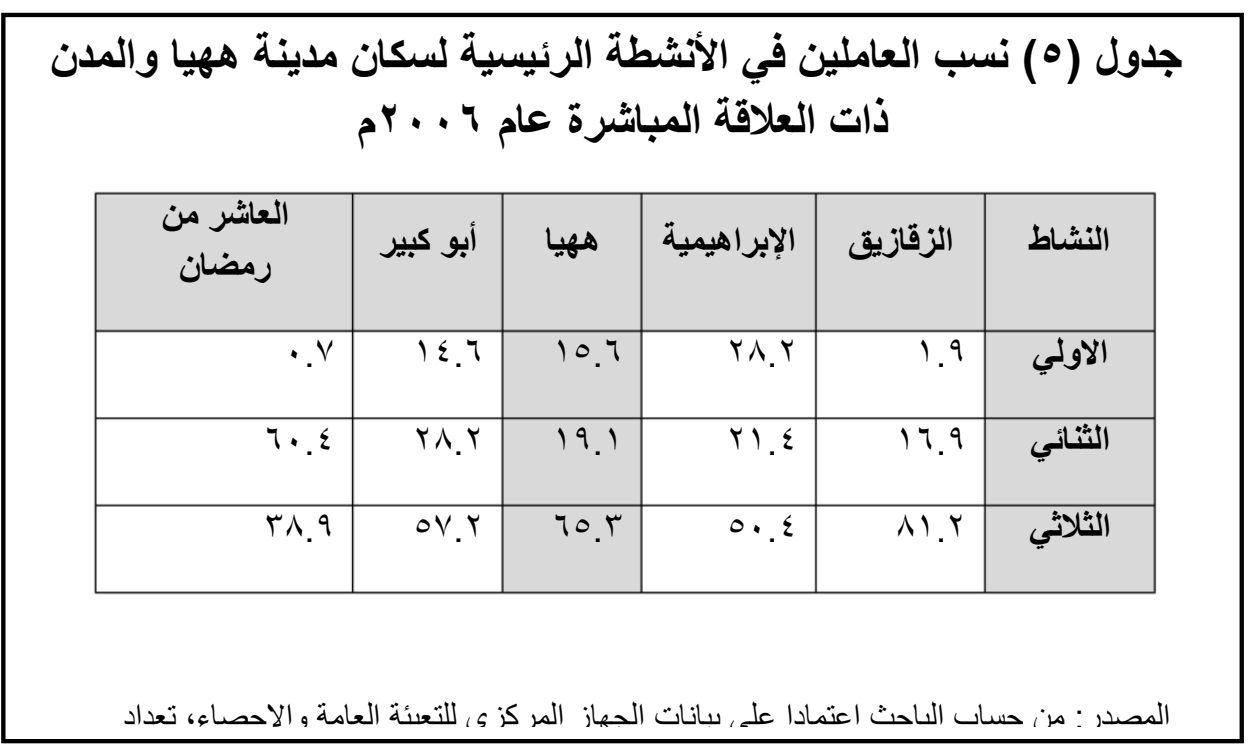

وإن كانت نسبة السكان الذين يمتهنون الأنشطة الثالاثية مرتفعة بمدينة هريا

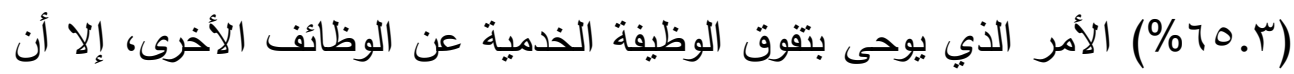
السكان يلجئون إلى مدينة الزقازيق فيما يخص الخدمات الرئيسية (فروع الوزارات

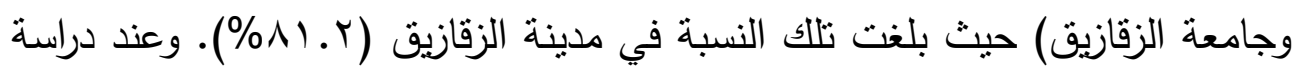
مفردات النشاط الثناثي للسكان نلاحظ اعتماد سكان المدينة على المدن المجاورة فيما يخص التجارة حيث ثبوأت مدينة ههيا المرتبة الأخيرة فلم يكن لهذه الفئة سوى ^.9\% من بين إجمالي الأنشطة الاقتصادية بالمدينة.

\section{r - الاندماج الحضري الريفي وتحضر الارض الزراعية}

تساهم هجرة الأفراد من الريف إلى الحضر في زيادة معدلات التحضر الزائف للمدن وخاصة المدن الكبرى والتي تتوافر بها فرص العمل بما يتتاسب مع المستوى العلمي أو المستوى الفني للمهاجر • وفي المدن الكبرى يتوجب على المهاجر الاستقرار بجوار عمله لعدة أسباب أهمها بُعد المسافة عن قريته وتوفيراً لنفقات النقل، أما في 
المدن الصغرى فتكون الهجرة من أبناء الريف إلى تلك المدن هجرة ترددية، أب العمل

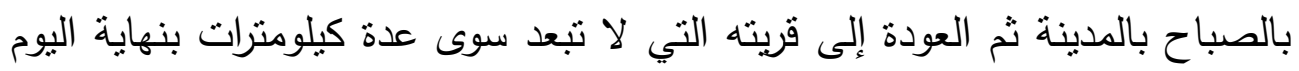

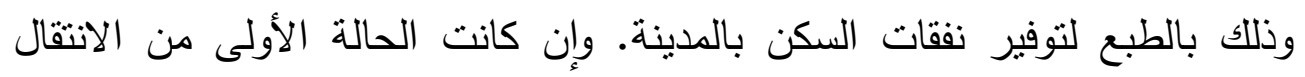

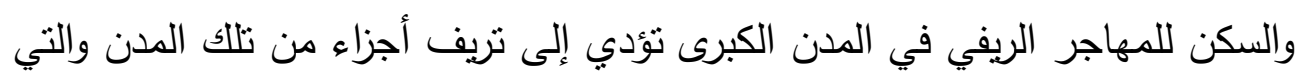

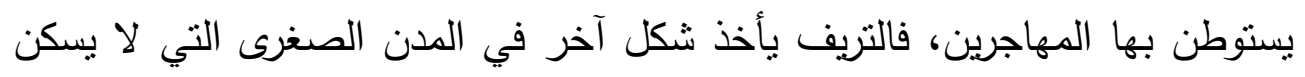
بها المهاجر في الغالب لقرب قريته، بل يحدث التريف عن طريق الاندماج العمراني الحضري-الريفي بين الددينة وبعض العزب والقرى المجاورة لها. ولذا فالاندماج الحضري الريفي أصبح ظاهرة تصاحب التوسع العمراني في مدن الوادي والدلتا المحاطة بالأرض الزراعية. فاندماج الوحدات الريفية الدجاورة للحيز

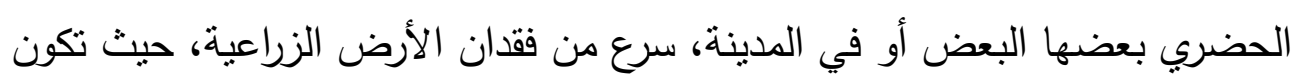

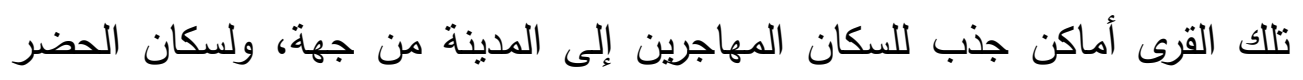

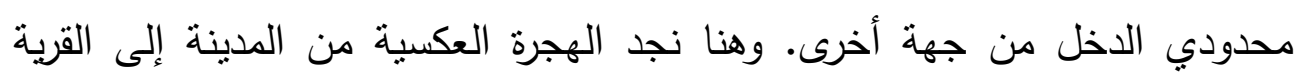

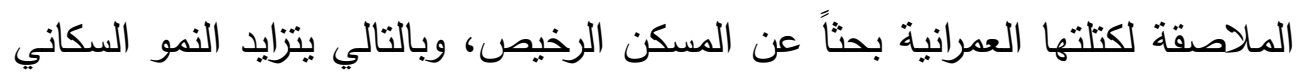

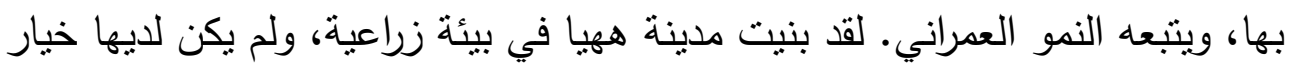
للنمو والتنوسع إلا على الأرض الزراعية وعلى حساب المحلات العمرانية الريفية

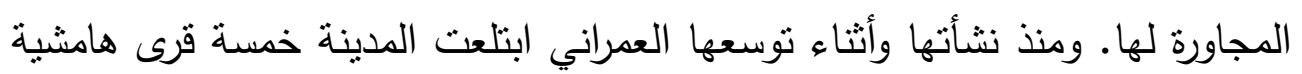

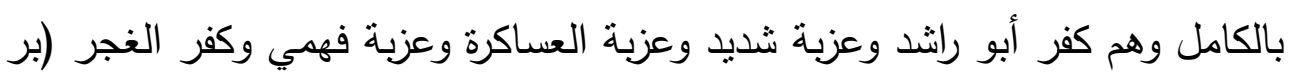
السوق)، وهم حالياً من المناطق المصنفة على انها عشوائيات بالمدينة. كما يمكن اختصار هذا النوع من الاندماج في ثلاث مراحل: نمو الحيز المبني

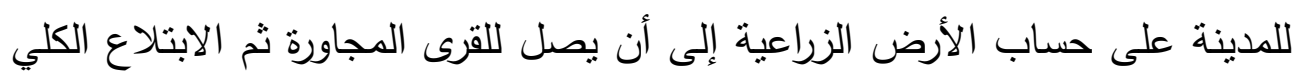

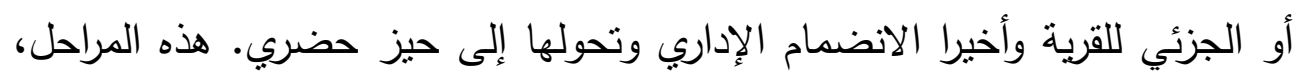

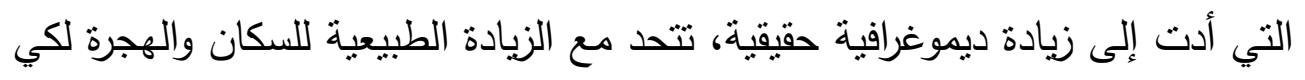

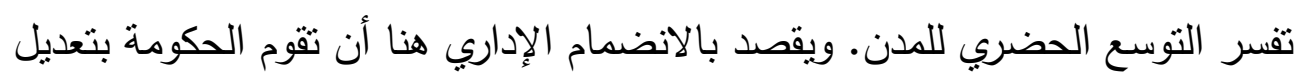

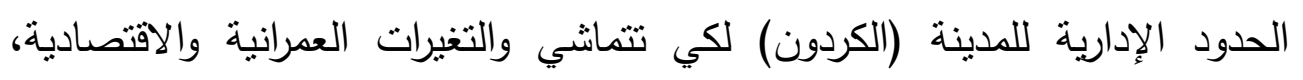


والاهم من ذللك التغيرات الإدارية التي تراها الحكومة ضرورية، وبالتالي نجد أن

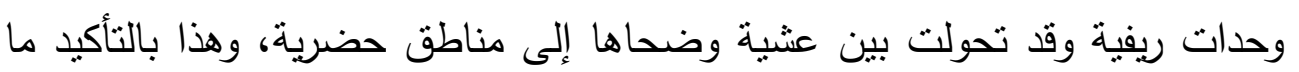
يسمي بالتحضر الزائف. وكل المدن بشكل عام قد مرت بهذه بهذه المرحلة. قرار الانضمام

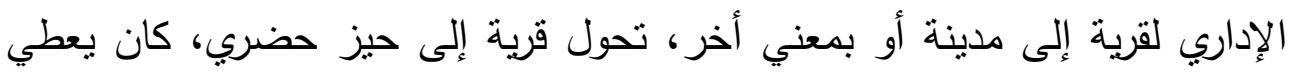

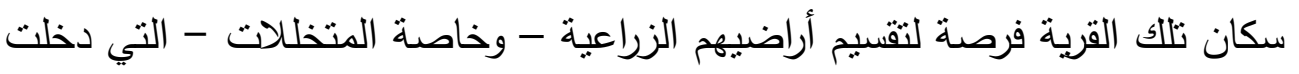

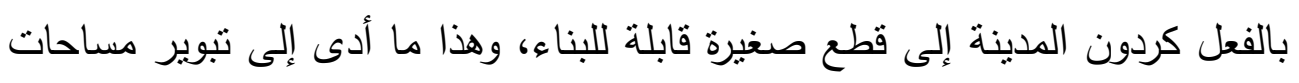

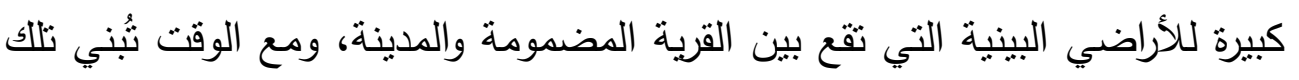

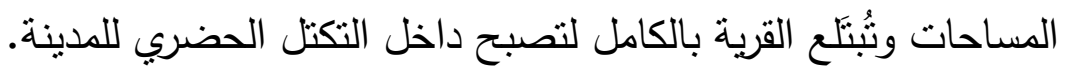
في مدينة ههيا ومع نهاية القرن العشرين، خمسة عزب قد تم اندماجها بالكامل داخل حيز المدينة. وهنا يمكن تمييز مجموعتين من الوحدات الريفية الملتحمة: المجموعة الأولي: هي قرى وعزب التحمت بالكامل في الكتلة الحضرية،

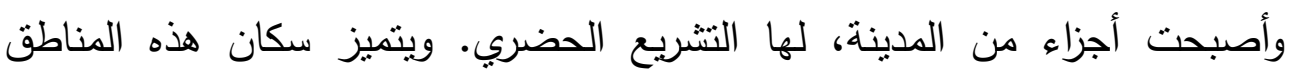

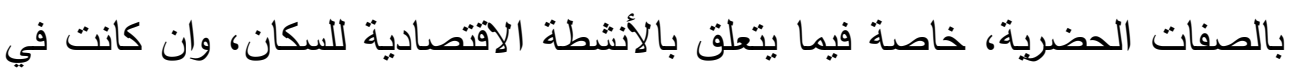

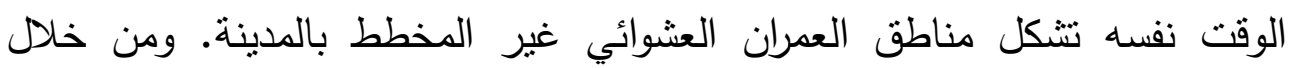

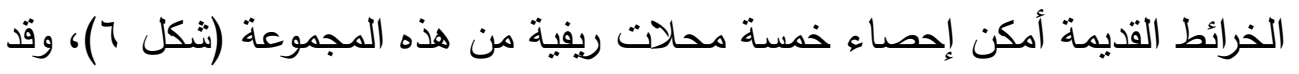
تحولوا إلى احياء سكنية قبل سنوات الخمسينيات، وهم: كفر أبو راثند وعزبة شديد إنداء

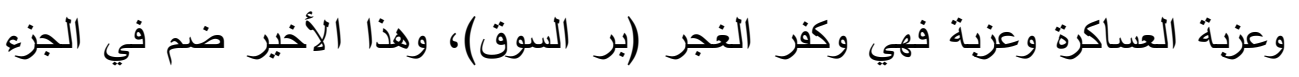

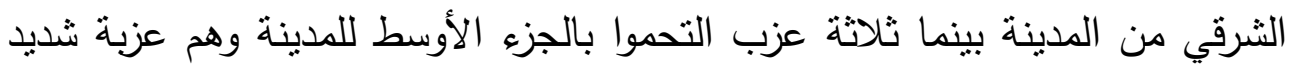

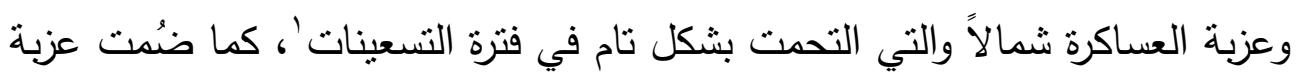
فهي جنوباً، بينما التحم كفر أبو راثند بالجزء الغربي.

' كانت هناك أرض زراعية تفصل عزبة العساكرة عن المدينة تسمى (ارض المولد) حيث يقام سنويا مولد الحاجة آمنة،

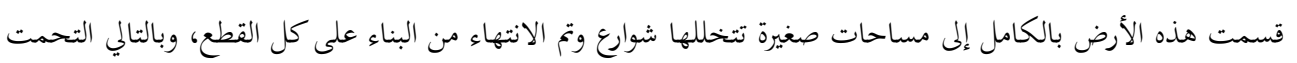
عزبة العساكرة بالنسيج العمراين للمدينة. 
وهذه المجموعة تعتبر البيئة المناسبة لاستقبال الهجرات الواردة إلى المدينة. فالمهاجر إلى الددينة يجد السكن الرخيص، وان كان قادمًا من قرية، فيجد بها

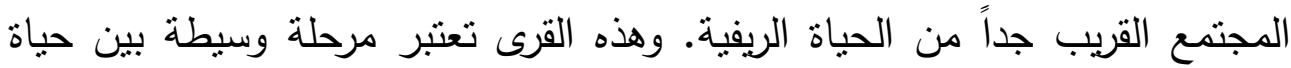
الحضر وحياة الريف، فهي تقع في النسيج الحضري، ولكن تحتفظ بكثير من الخصائص الريفية. جزء من سكان تلك المناطق يمارس الأنشطة الأولية، بعد تحويل

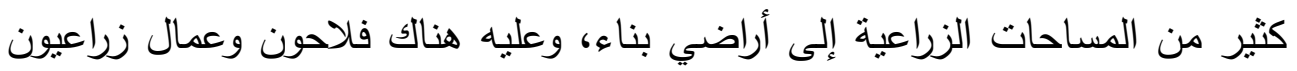

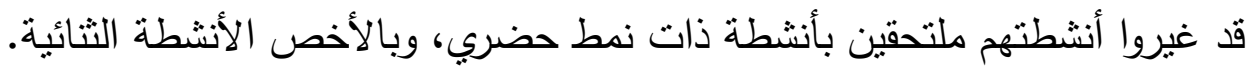
المجموعة الثانية: هي نسبياً بعيدة عن المدينة حيث التزابط العمراني شريط من الأراضي المبنية أو المستغلة في أنشطة غير زراعية على الطرق الونية الواصلة بين القرية والمدينة. وهذه القرى تعتبر مكان نزوح سكان المدينة إليها بغرض السكن، فبها نجد الديد

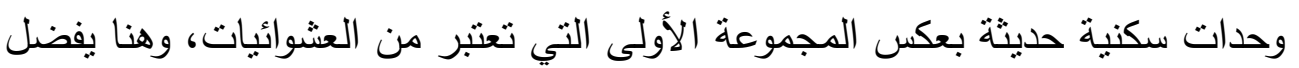
السكان الإقامة في البنايات القريبة من الطرق الرئيسية.

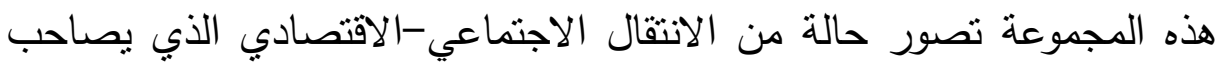
آلية التوسع العمراني للمدينة بشكل عام. وهذه القرى تعاني بشكل خطير من البناء

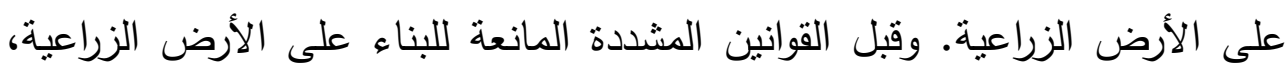

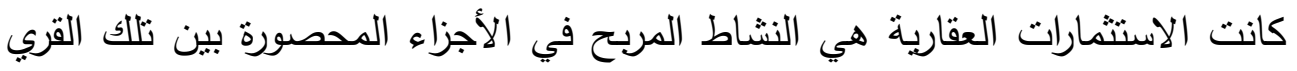

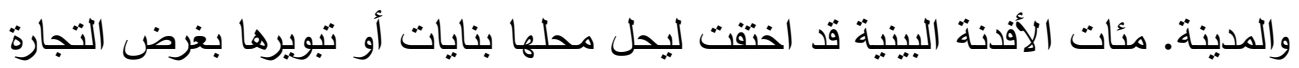
العقارية بها، وحتى وقت قريب (العقد الأول من القرن الواحد والعشرين) كانت هذه لهنه

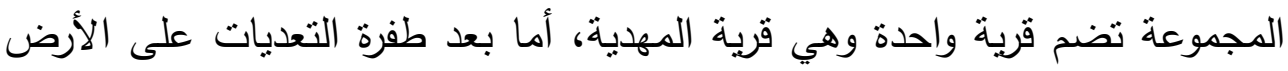
الزراعية التي صاحبت ثورة الخامس والعشرين من يناير ، اتصلت قرية الثيخ سعيد

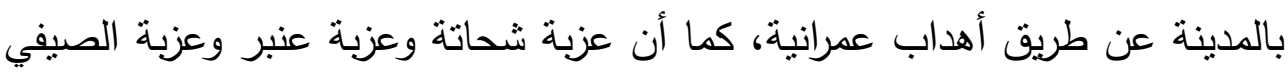
الواقعتين شرقي المدينة مرشحين لللخول في هذه المجموعة.

هذا الاندماج والتوسع العمراني على حساب الارض الزراعية ترك بعض التر

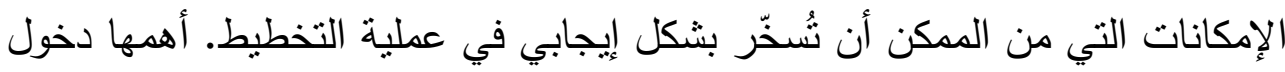


أجزاء من التزع وقنوات الري داخل الكتلة العمرانية، وقد غُطيت أو ردمت 'تلك الترع

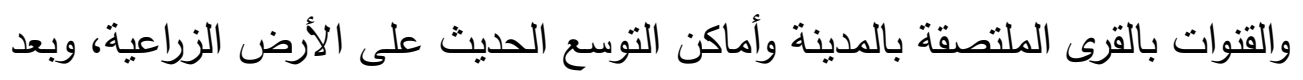

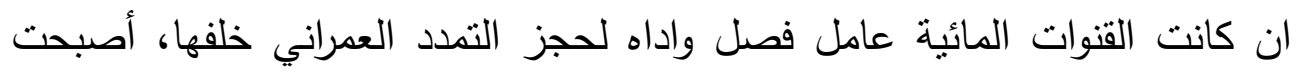

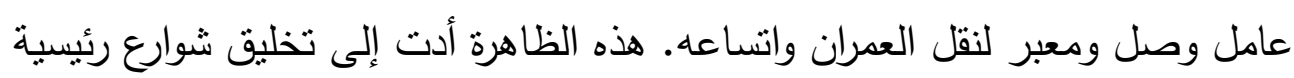
جديدة لها أثر في إحداث تغييرات تخطيطية (تنبكة الطرق، البنية التحتية...)

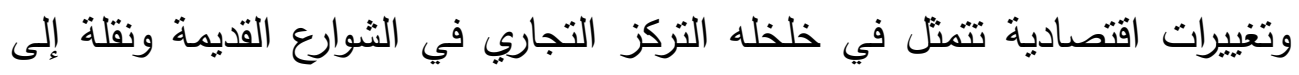

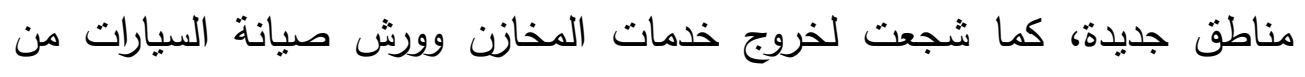

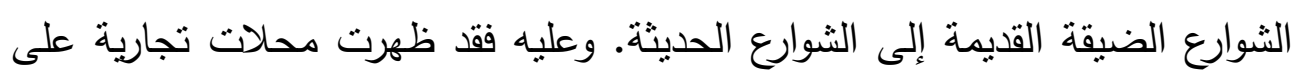
طول الثوارع الرئيسية المستحدثة، بسبب النخفاض القيمة الإيجارية للمحلات والعقارات بالمقارنة بوسط المدينة.

وكما يتضح من الثكل (ج) يعتبر الطريق الدائري شرق الددينة نموذج ايجابي

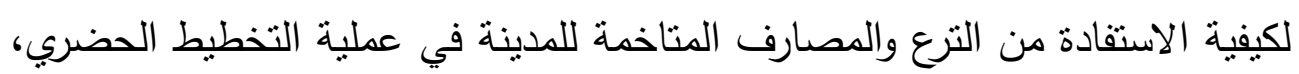

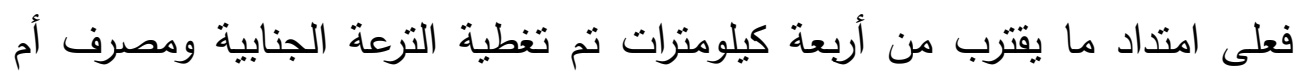

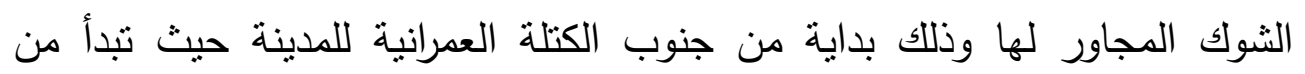
الطريق الرئيسي السريع (الزقازيق-ههيا-أبو كبير)، ثم ينحرف الطريق شرق الهئ المدينة

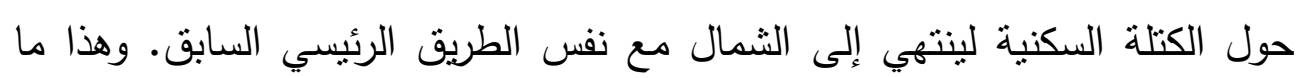

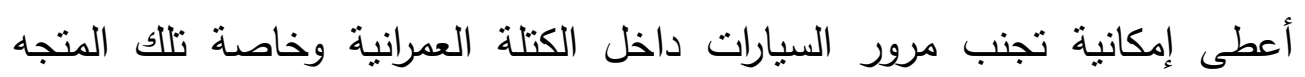

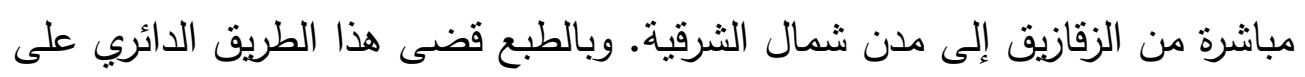

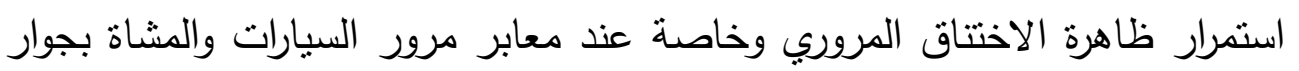
محطة السكة الحديد.

' المقصود بالتغطية هو تمديد مواسير ذات أقطار كبيرة بالجمرى المائي للقناه المائية (الترعة) لمرور المياه بما، ثم يتم تدعيمها

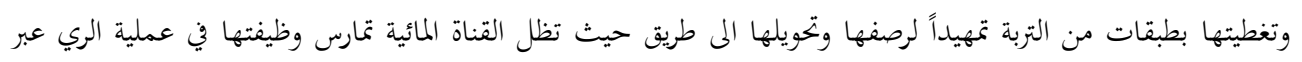

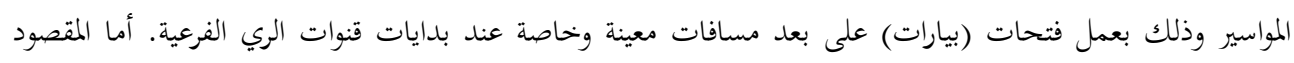

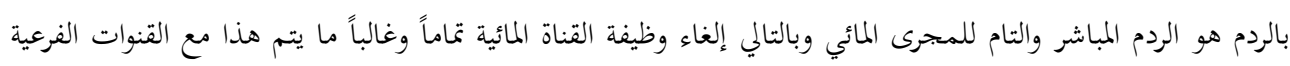
المتواجدة في المتخللات العمرانية الحديثة على الأرض الزراعية. 
كما تم تغطية ترعة الحاجة آمنة (يبلغ طولها نحو 1.7 كيلومتز) واصبحت طريق يخفق الضغط عن الجزء الممتد داخل الددينة من الطريق الإليمي (هريا-

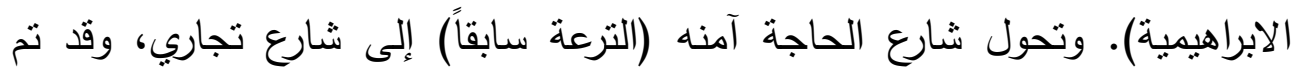

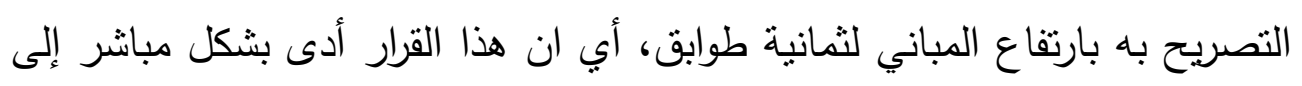

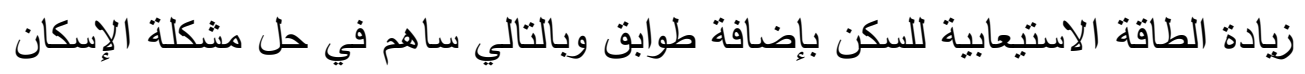

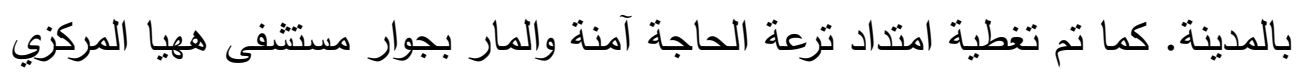

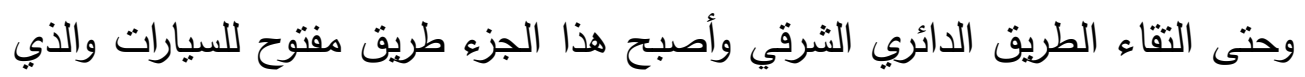
ساعد بربط شرق الددينة بغربها تجنبا للمرور داخل شارع السوق القديم بوسط الددينة. تم تغطية جزء من ترعة العساكرة نحو .0؛ مثر والاستفادة من المساحات

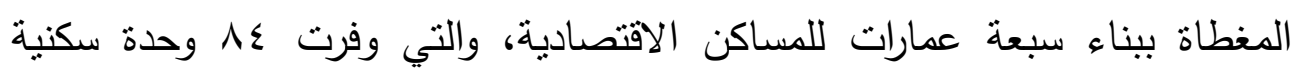
منخفضة التكاليف. كما تم نقل إدارة كهرباء المدينة بها وإدارة الثؤون الاجتماعية.

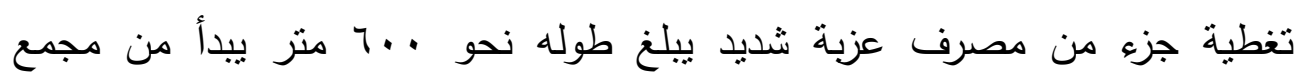

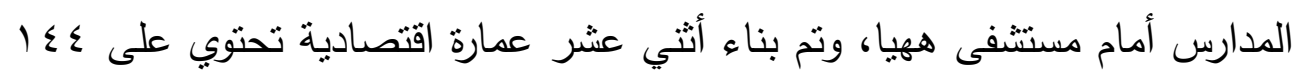
وحدة سكنية اقتصادية لمحدودي الدخل.

\section{ب-التمزق العمراني والسكن العشوائي} أ- انمزق الكتلة العمرانية

من أهم عواقب التحضر في المدينة هو تمزق الكتلة العمرانية للمدينة وما نرتب

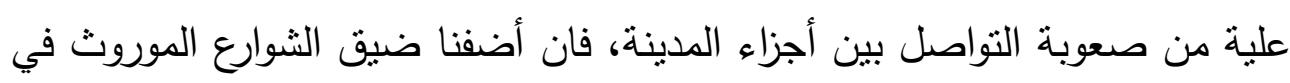

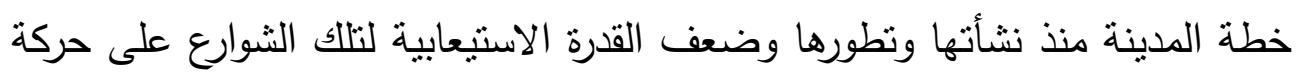
المرور المتزايدة سواء من السيارات وتطور أنواعها وأحجامها أو الدراجات البخارية

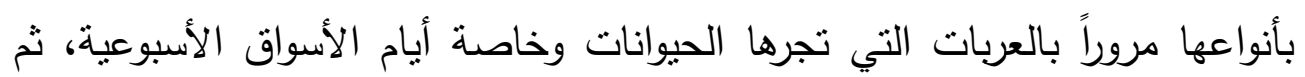
يضاف إلى كل ما سبق حركة المشاة ليصبح الوضع معقداً. وفي الواقع فمشكلة التمزق العمراني يرجع جزورها لنشأة المدينة نفسها، فقد أنثأت بجوار ترعة بحر مويس والتي حجزت العمران على الضفة الثرقية فقط (صورة 
1)، ولم يكن هناك الا معبراً واحداً ولم يتم إنثاء المعبر الثاني إلا مع إنشاء خط السكة الحديد الضيق والذي تم إزالته مع بداية سنوات السبعينات من القرن العشرين.

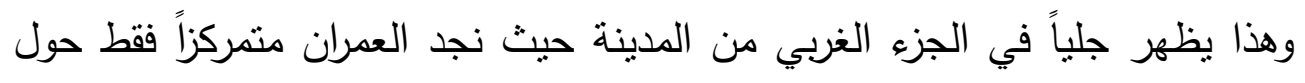

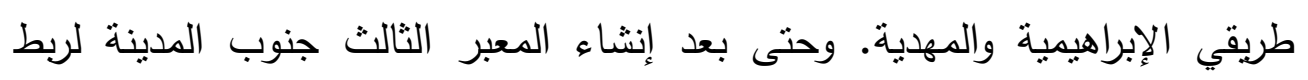

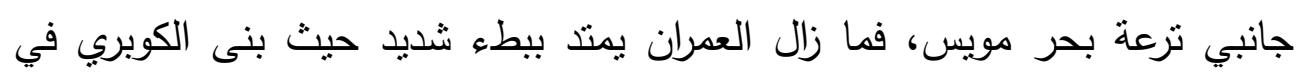

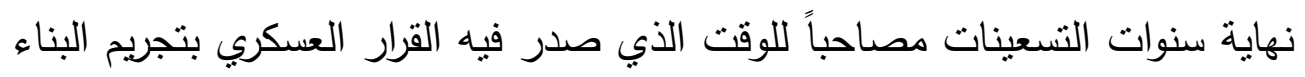

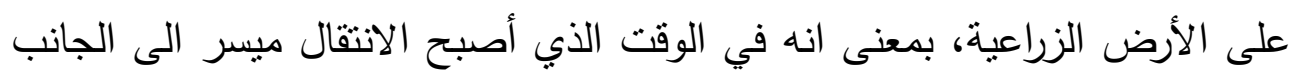

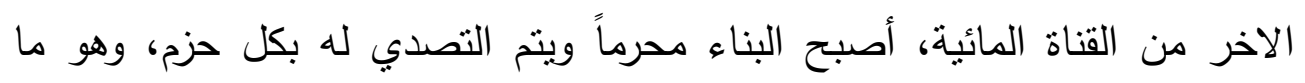
يوضحه الثكل (0) حيث نجد ان الكتلة العمرانية تتغل فقط نصف مساحة القسم الغربي من المدينة. وبعد انتصاف القرن التاسع عشر نم إنثاء خط السكة الحديد الزقازيق-المنصورة

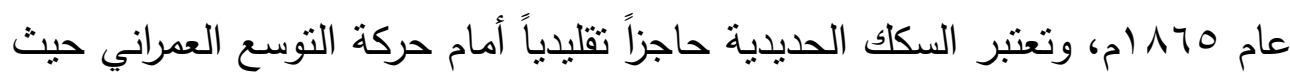
لم يكن يتخطاها ولكن يمشى بموازاتها. ومنذ انثاء السكة الحديد بالمدينة تم بناء

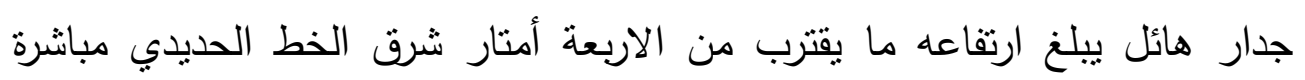

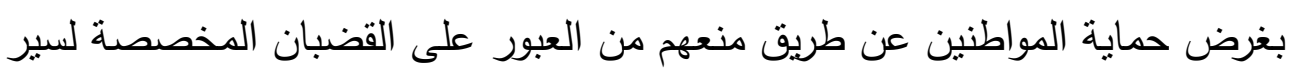

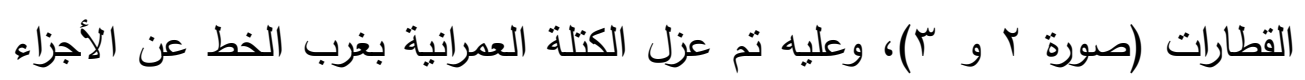
الواقعة شرقه، والمنفذ الوحيد للمشاة والسيارات هو مزلقان لا يتعدى اتساعه العشرة

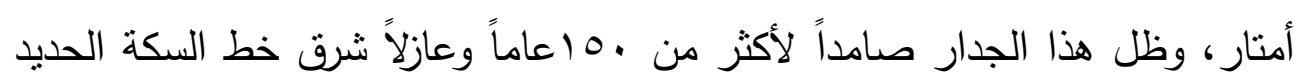

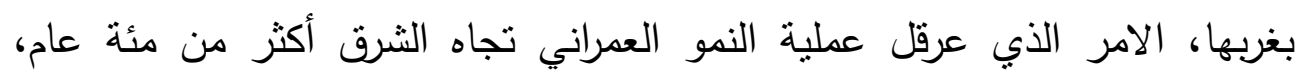

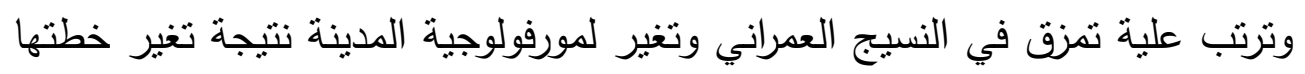

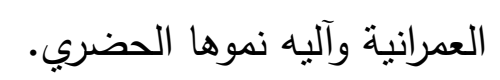

وقد امتدت التوسع العمراني من اقصى الثمال الى اقصى جنوب المدينة ليتجاوز

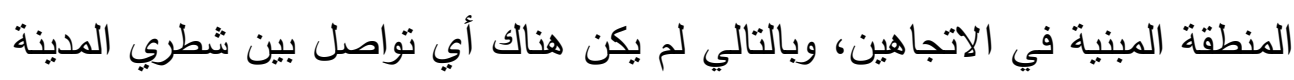

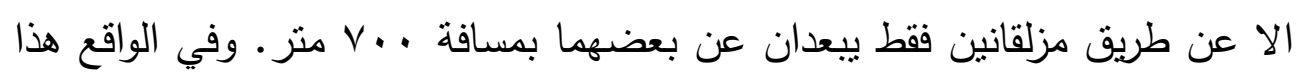


الجدار المتكرر في معظم المدن المصرية بجوار خطوط السكك الحديدية والمنشئة من فبل الخبرات البريطانية، كان لها واقع معنوي بمرور الوقت على السكان وانحصارهم في المنطقة الوسطى من المدينة' . كما مثلت هذه الجدران مشاكل في خطة الئل المدينة

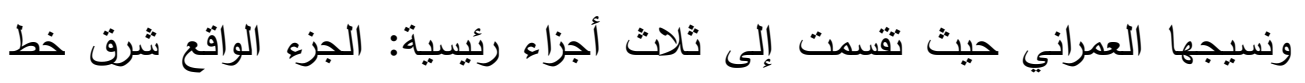

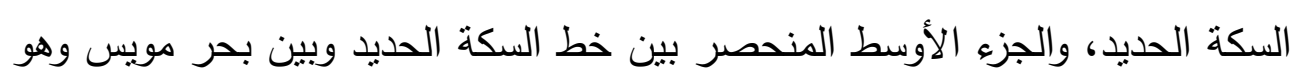
الجزء الرئيس للمدينة، وأخيرا الجزء الواقع غرب بحر مويس. لالجئ ومع بداية القرن الواحد

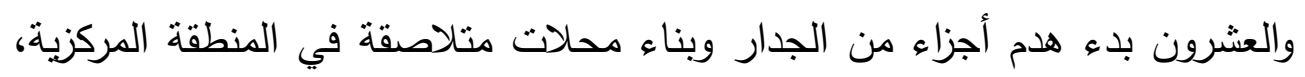

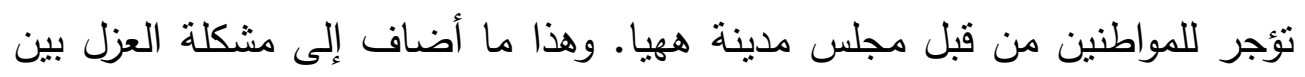

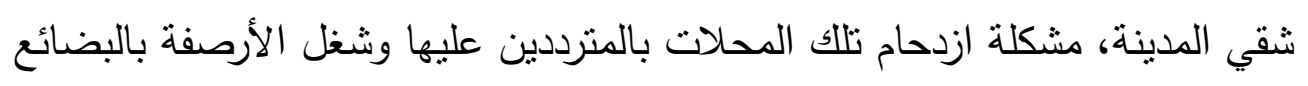

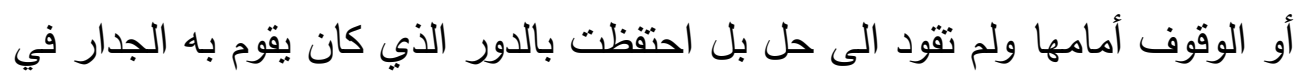

$$
\text { عزل أجزاء المدينة (صورة ع). }
$$

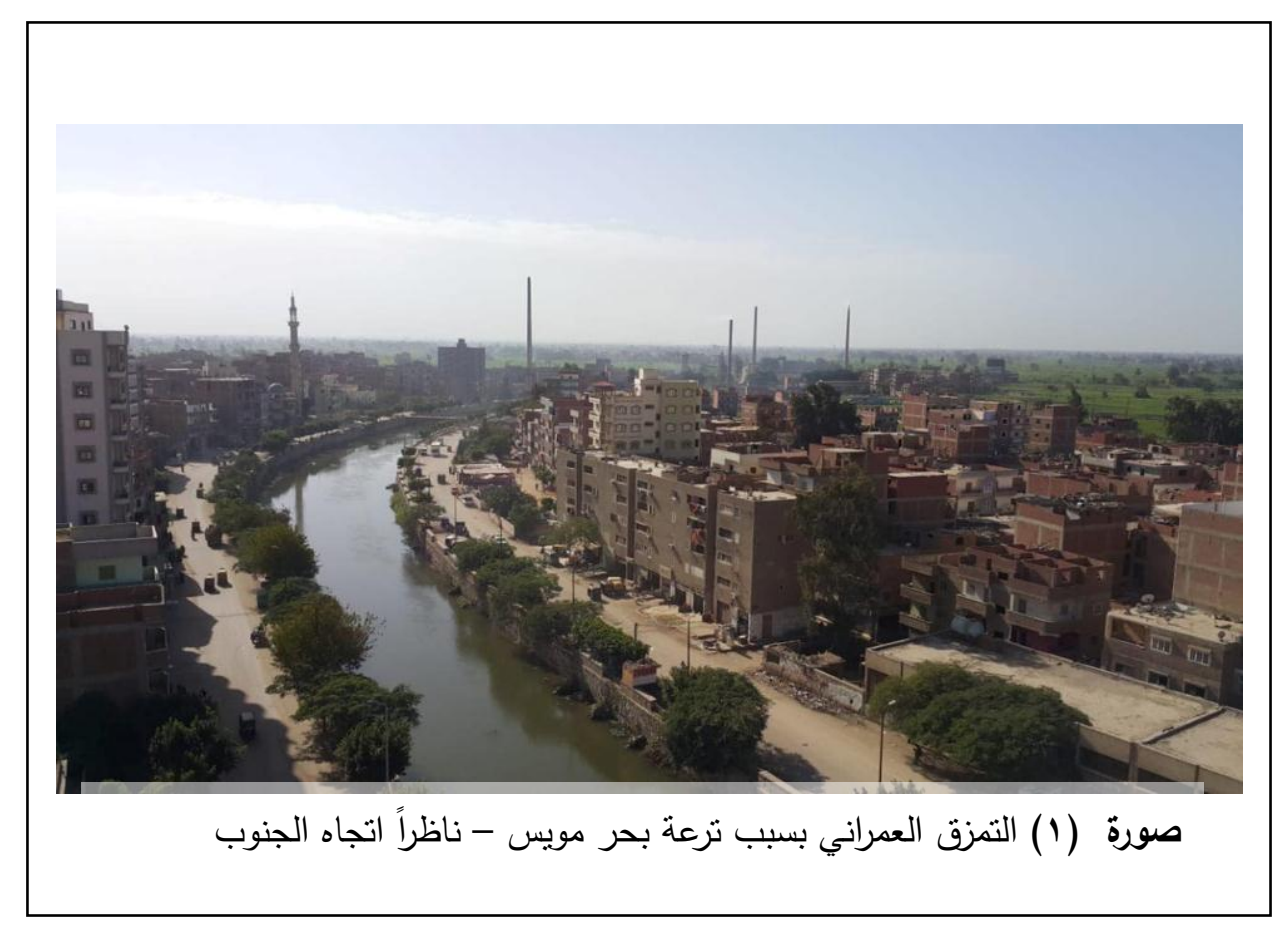

' يظهر هذا في مفردات المصطلحات الخلية، فقد أطلق على العمران الواقع شرق الجدار مصطلح (البر الثاني أو البر. الشرقي) 


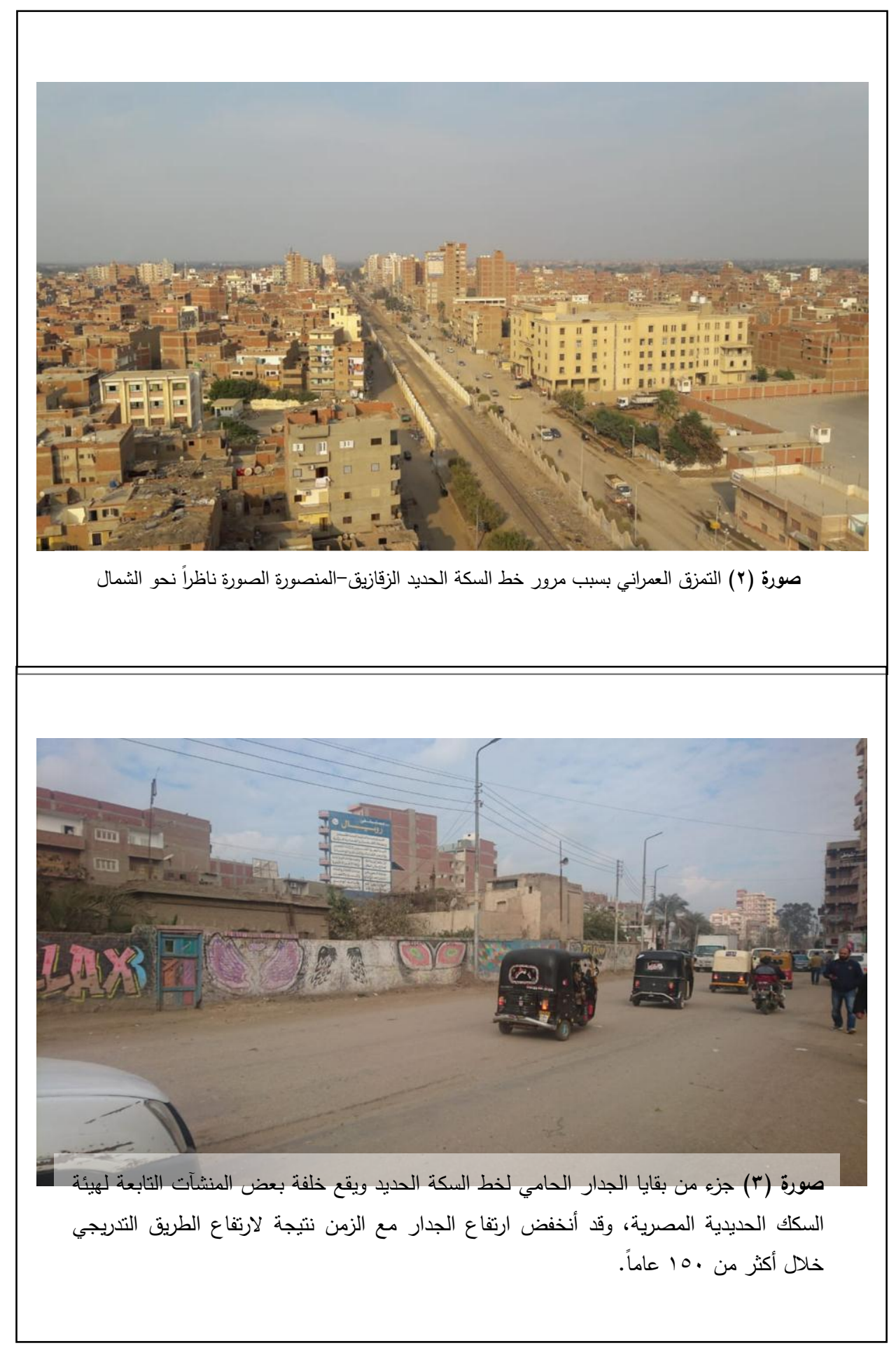




\section{ب - أنماط العشوائيات بالمدينة}

بالرغم من تعدد أنماط النمو العشوائي، الا انها لا توجد جميعها في مدينة ههيا، ويمكن ملاحظة أربعة فقط من عشرة أنماط لأشكال النمو العشوائي داخل المدن' والتي خلفها النمو الحضري للمدينة وهم:

\section{التقاسيم الأهلية في الأحياء الهامشية:}

وهذا النوع يعتبر هو المسبب الرئيس للنمو العمراني للمدينة، يحث يقوم أحد الأشخاص المالكين للأرض الزراعية بتقسيم ملكيته الزراعية الملاصقة للكتلة المبنية وتحويل قنواتها إلى طرق وبيعها قطع سكنية. ثم أصبحت ظاهرة اشتراك مجموعة من الأشخاص بتحديد قطعة أرض كبيرة نبلغ أحياناً عدة أفدنه ومساومة أصحابها لشرائها أو الورثة المالكين لها بأسعار كبيرة ثم تقسيمها وبيعها. ولا يمكن تجاهل شكل خريطة التوسع العمراني للمدينة والتي يظهر بها إضافة أجزاء تأخذ الثكل الهندسي (المستطيلات) من عام إلى آخر وذللك نتيجة تحويل قطع من الأراضي الزراعية إلى مناطق سكنية في نواريخ منقاربة. القرى المتلاحمة بالمدينة أو الغارقة داخل النسيج الحضري:

في غالب الأحيان يتم ابتلاع القرى أمام التوسع الحضري للمدن مما يخلف بؤر عشوائية داخل النسيج العمراني العام، ولكن هذه الظاهرة لم تأخذ هذا الثكل بمدينة ههيا، حيث أن القرى التي تم التحامها والتصاقها بالمدينة كانت مجرد عزب صغيرة مكونه من عدد قليل من المنازل المبنية بالطين، والتي تم إحلالها بمنازل حديثة. ولكن ظهرت العشوائية في ضيق عرض الشوارع وهذا يتضح في كفر أبو راشد خلف النادي الرياضي، وبالرغم من إحلال معظم المباني بالحي بالمباني الحديثة الخرسانية، الا ان ضيق الشوارع بسبب اختتاق لحركة سير السيارات وخاصة الكبيرة منها، كما يؤدي إلى مخاطر بسبب اقتراب كابلات الكهرباء الهوائية الواصلة بين أعمدة الانارة من

' فتحى محمد مصيلحي، العمران العشوائي: تنظير علمي، العمران العشوائي في مصر، الجزء الاول، البحلس الاعلى للثقافة، 
شرفات المنازل، يضاف إلى ذلك خطورة الوضع عن حدوث كوارث منل الحرائق وصعوبة دخول سيارات الإطفاء أو الإسعاف (صورةه).

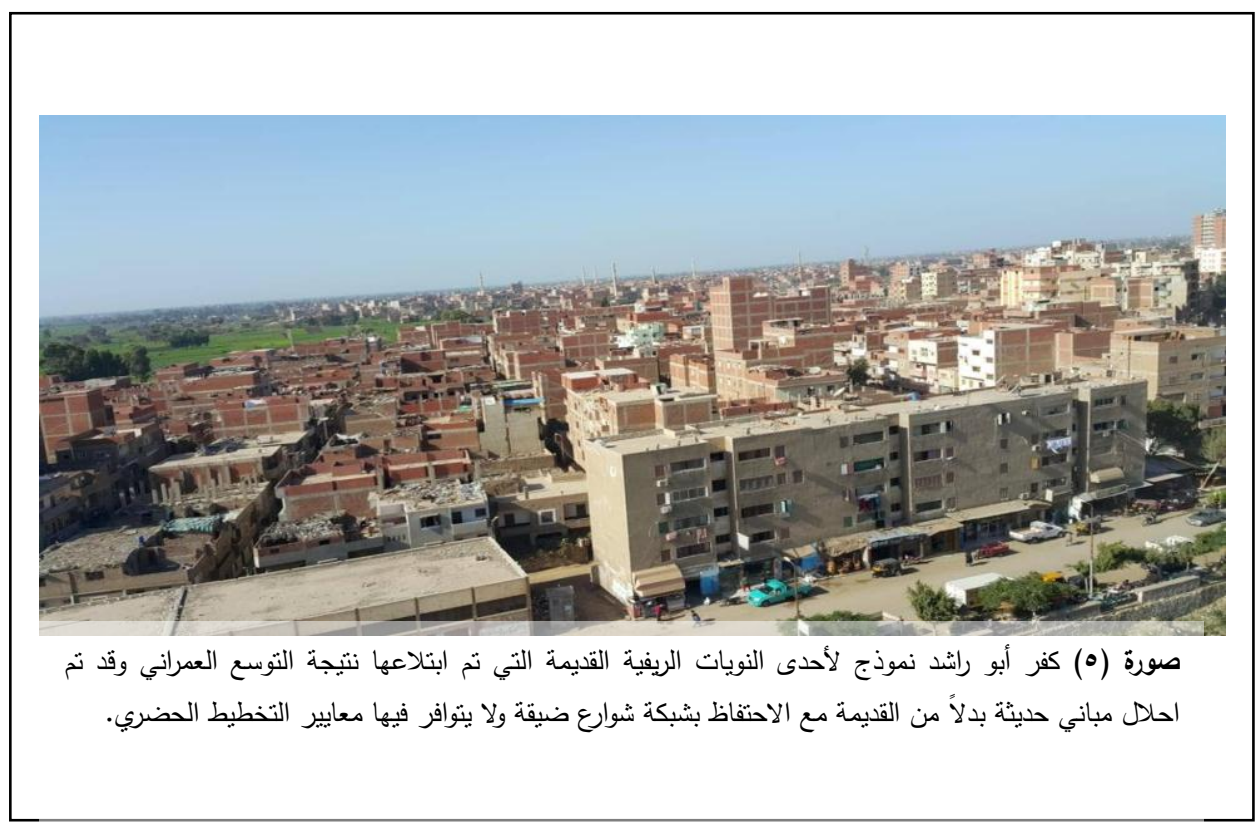

الإسكان المتاهور في الاحياء القليمة:

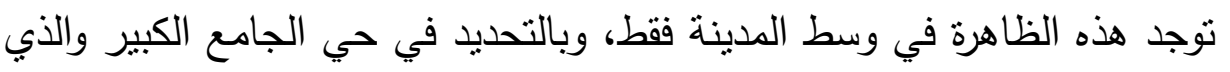

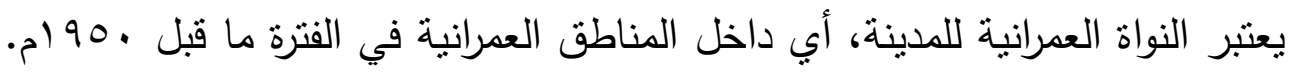

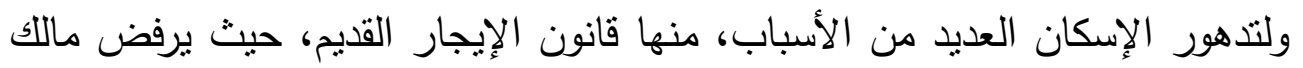

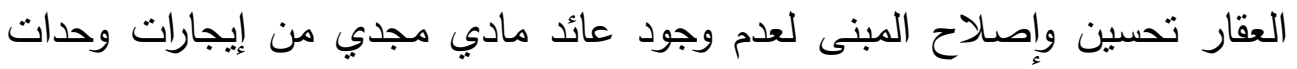

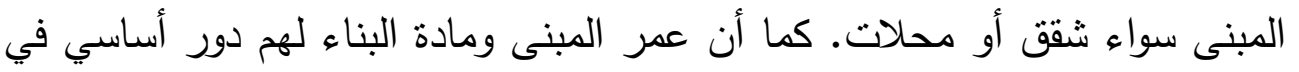
تدهور حالة البناء وخاصة في ظل غياب شبكة تصريف مياه الامطار وتسرب المياه

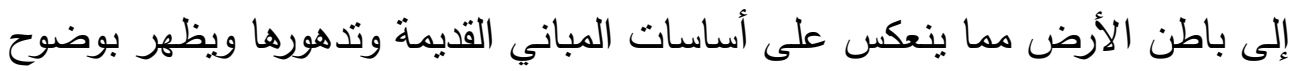

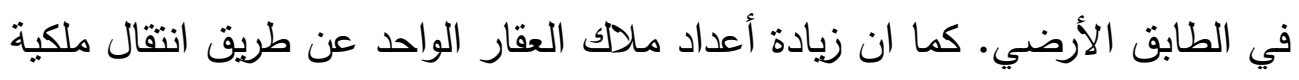

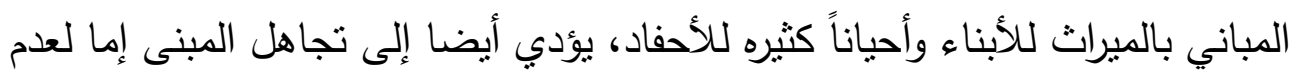

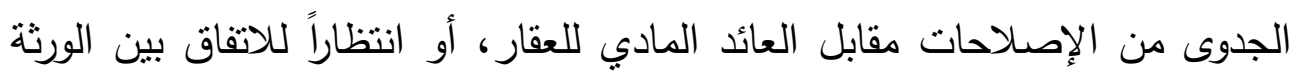
بغرض بيعة لمالك جديد يقوم بهامة وإحلاله ببناية جديده. 
الإسكان في تجاوزات النمو الرأسي: التراء

ينتشر هذا النوع في معظم أحياء المدينة وليس بمنطقة أو حي معين، ويقوم به الهيه

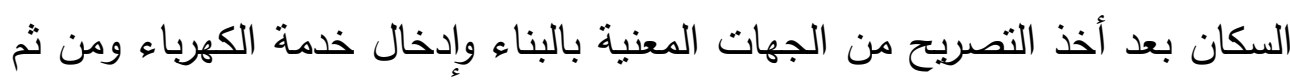
يقوم المالك بإضافة طابق أو أكثر للمنزل. وبالتأكيد يرجع هذا إلى التى ارتفاع أسعار

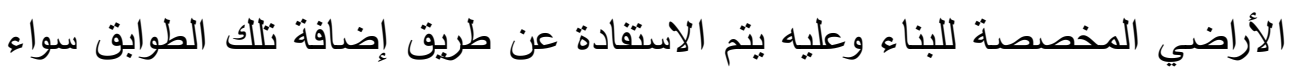

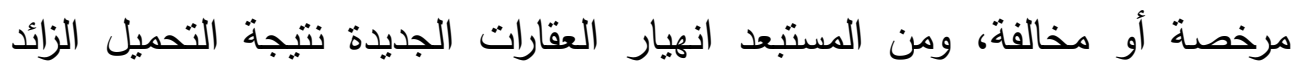

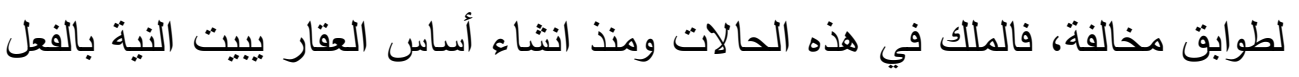

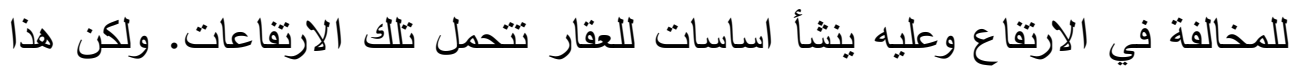
النوع من العشوائية تظهر خطورته في التحميل الزائد على شبكة البنية التحتية (الكهرباء والمياه والصرف الصحي)، فالثبكات الحالية قد صممت للطاقة الاستيعابية للوحدات السكنية المرخصة بالفعل أو من خلال عمل تخطيط استراتيجي للمدينة

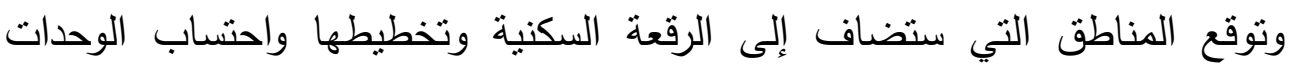

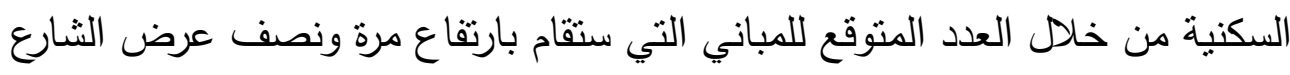
الجديد. وهذا بالتأكيد ما يسبب في الكثير من انقطاع التيار الكهربائي نتيجة انهيار

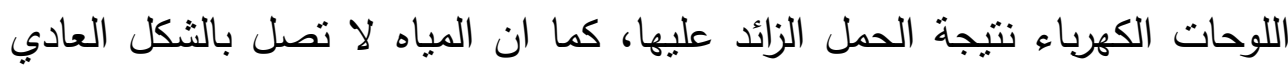

للطوابق العليا الا عن طريق مواتير رفع المياه (صورة)).

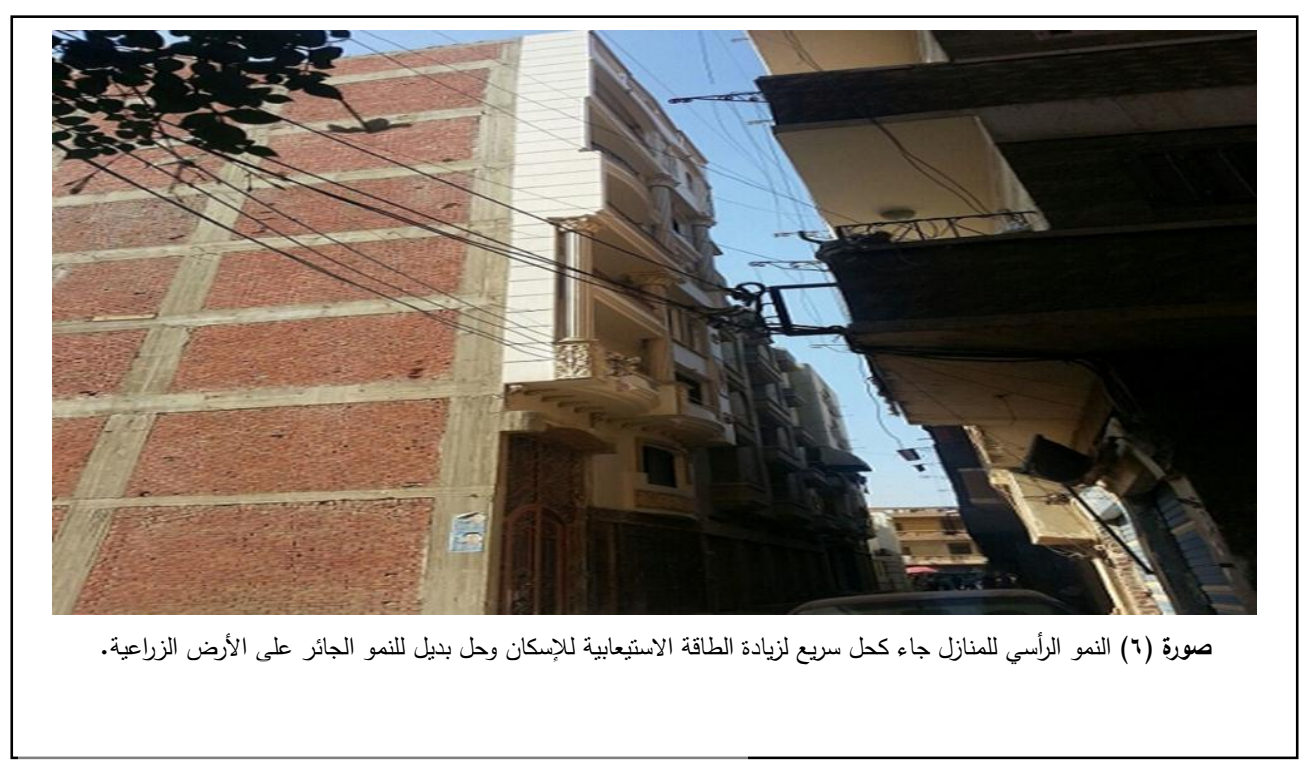


التتائج والتوصيات

أثز الموقع الجغرافي في تحديد مصير النمو الحضري للمدن البعيدة عن محاور النقل الرئيسية في دلتا النيل (الطرق الإقليمية، السكك الحديدية ذات الخطوط المزدوجة، القنوات المائية، السواحل البحرية)، وتلك الواقعة داخليا بعيداً عن نقاط التبادل التجاري وغير متصلة بحدود المحافظات المجاورة. وبالرغم من نواجد مدن الدلتا وسط شبكة حضرية وبين أكثر من عشرة عواصم تاريخية تمتد بجذورها لآلاف هرئ السنين، الا ان الأصول التاريخية لكثير من المدن المتوسطة والصغرى لم تؤُثر بشكل كبير لتغيير الواقع العمراني بتلك المدن، فقط ساعدت على الاستمرارية لتلك المواضع العمرانية بالمكوث وعدم الزوال من الخربطة الحضرية. وبيدوا أيضا ان التغير في الأنشطة الاقتصادية لسكان المدن قد شكل خرائط نفوزهم عبر التاريخ.

تأثز النمو السكاني للمدينة بشكل كبير بالتطور في شبكة الخدمات في المائة عام الأخير، وهو ما أدى الى وجود هجرات من الريف الى الحضر وان كانت بشكل بسيط، كما ان التغير في الخريطة الإدارية لمراكز محافظة الثرقية والقرارات الادارية التي خصت الكثير من القرى وتحولها الى مدن، ساهم كل هذا في معدلات التحضر سواء بمركز ههيا او المراكز المجاورة. ويتضح من دراسة التغير في الكتلة العمرانية خلال فترة الدراسة ان النمو العمراني أخذ الاتجاه الإشعاعي، حيث بدأ من محاور الطرق المتشعبة من المدينة وتركز بشكل أساسي بجوار تلك الطرق، أما بعيدا عن الطرق فقد أتخذ النمو العمراني الثكل الاقرب الى الزوايا القائمة (الثطرنجي) حيث تشكلت الاحياء الحديثة المبنية على الارض الزراعية بنفس الثكل التي كانت علية شبكة الري وتقسيمات الحقول الزراعية.

ويعتبر ضياع الأرض الزراعية من أكثر الآثار الجغرافية التي سبيتها عمليات

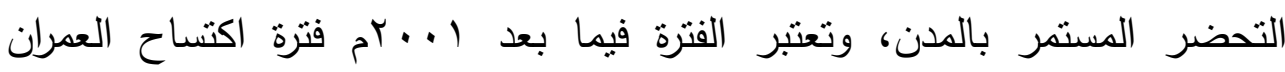
للأرض الزراعية، حيث تخطت الزيادة العدرانية في هذه الفترة مساحة المدينة القديمة منذ نشأتها، وكان من أهم الآليات التي اتبعتها المدينة في النمو العمراني هو جاهزية 
الأرض الزراعية للبناء والتوسع عليها، فالمساحات المحيطة بالمدينة مستوية تماماً ولا

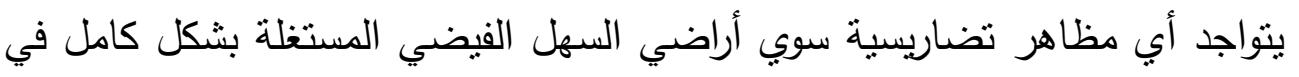

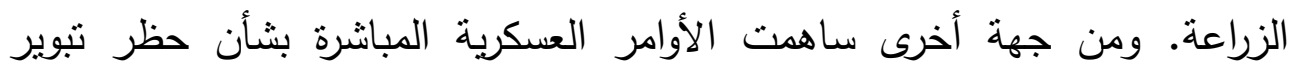
وتجريف الأراضي الزراعية وإقامة مباني أو منشآت عليها بحامية الأرض الزبن الزراعية

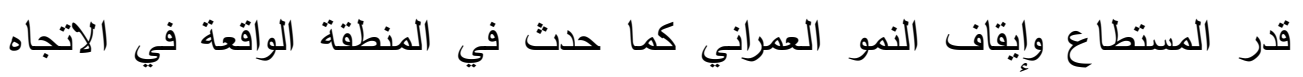

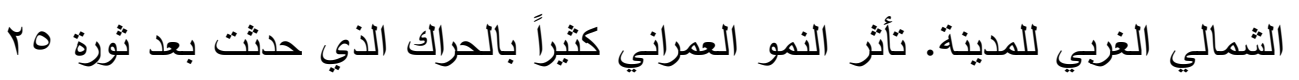

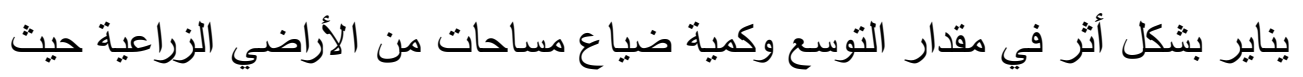

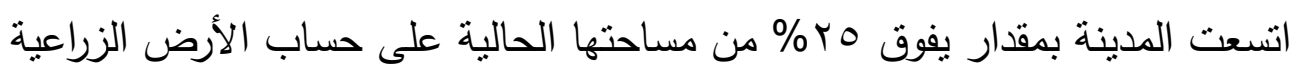
وهذا ما يمكن ان نعمده على المدن الواقعة بجوار الأراضي الزراعية في دلتا النيل. ساهمت قرارات تغطية القنوات المائية الواقعة داخل الكتلة العمرانية (ترع

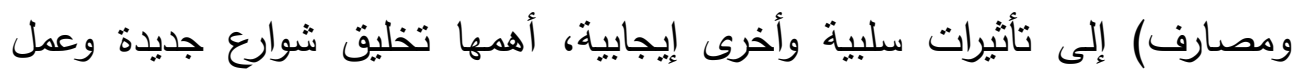

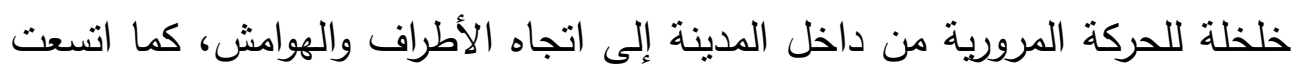

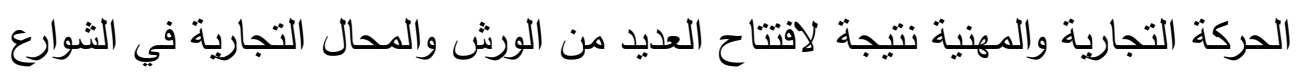

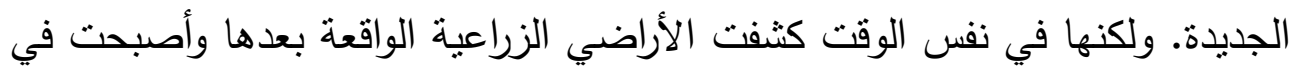

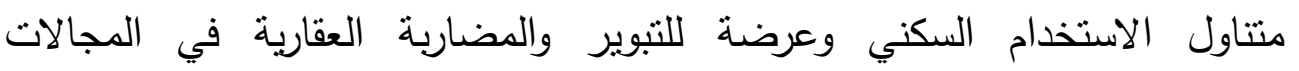
الحضرية.

تمثلت العشوائيات في المدينة في أربع صور فقط وهو التقاسيم الأهلية في الأحياء الهامشية بدون رقابة تخطيطية وبعيدا عن اعين متخذي القرار ، ثم في القرى

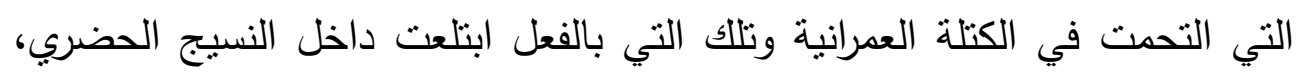
أيضا شكل الإسكان المتدهور في الاحياء القديمة بالمدينة شكلاً آخر من أشنكال

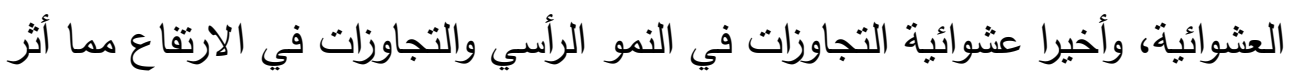
سلباً على الطاقة الفعلية لنشبكة البنى التحتية. ويقترح ان من عليه بناء ارض في نطاق المتخلات نقل التربة الطيية المزالة

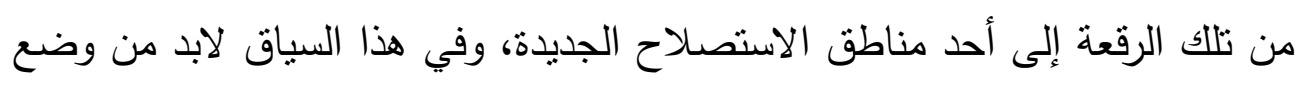


تيسيرات لتملك الاراضي في النطاق الصحراوي لمحافظة الثرقية وايجاد توسع بديل

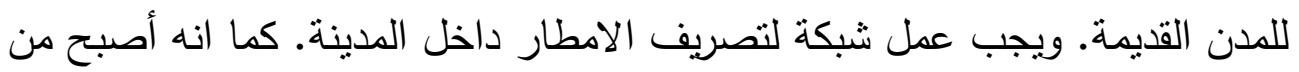
الضروري تخصيص أرض لعمل السوق الأسبوعي واليومي لتفريغ وسط المدينة

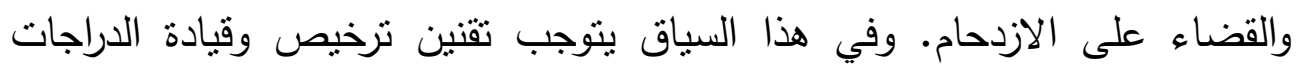
البخارية سعة الثلاث افراد (التوكتلك) وتحديد أعداد معينه تبعا للكتافة السكانية. ويوصي برصف الطريق الجنوبي الواقع غرب خط السكة الحديد والواصل بين المدينة وقرية صبيح لتخفيف الضغط على المزلقانات. 


\section{المراجع}

إبراهيم عسكورة، التوسع الحضري وتآكل الأرض الزراعية، دراسة تطبيقية على التكنل الحضري

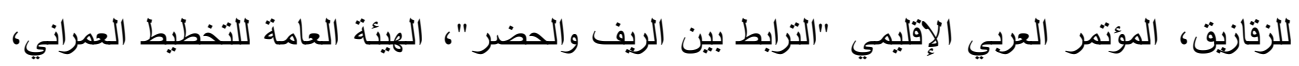

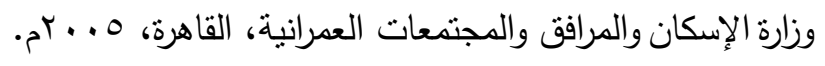

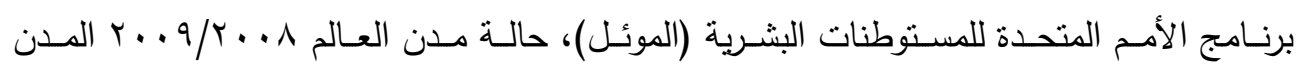
المنسجمة، الجزء الأول - الانسجام المكاني، عمان - الأردن. جاكلين بوجو جارنييه، دراسات في جغرافية العمران الحضري، تعريب، محمد على بهجت الفاضلي،

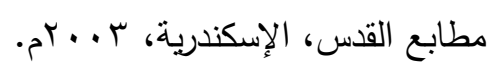

جـان فير كوتير، مصـر القديمـة، ترجمـة مـاهر جويجاتي، دار الفكر للاراسـات والنشـر والتوزيـع،

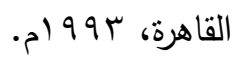
جمال حمدان، جغرافية المدن، الطبعة الثانية، عالم الكتب، القاهرة، بدون تاريخ. الجهاز المركزي للتعبئة العامة والاحصاء، التعداد العام للسكان والاسكان، تعداد السكان، النتائج

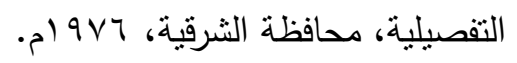
الجهاز المركزي للنعبئة العامة والاحصاء، التعداد العام، النتائج النهائية، الحصر الثامل، خصائص

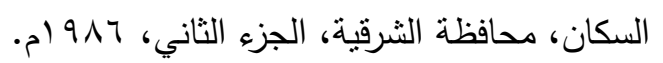
خريطة الحدود الإداريـة لنواحي ومدن محافظة الثرقية (محفوظة بشكل رقمي على CD بواسطة

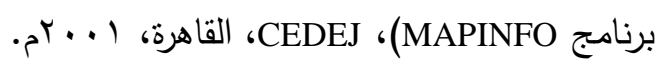
خريطة الزقازيق الطبوغرافية (1/..... )، الهيئة المصرية العامة للمساحة، القاهرة، س99 ام.

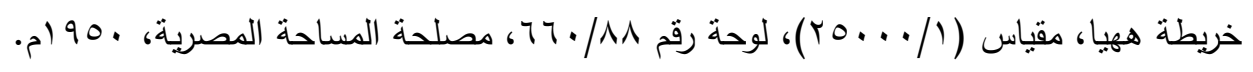
عبد الحكيم ناصر العشاوى، جغرافية المدن، المكتب الجامعي الحديث، الإسكندرية، V +. ז م. فتحى محمد مصيلحي، العمران العشوائي: تتظير علمي، العمران العشوائي في مصر، الجزء الاول،

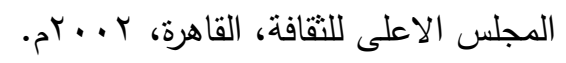

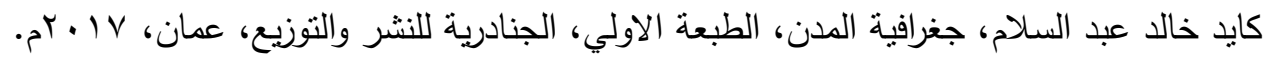




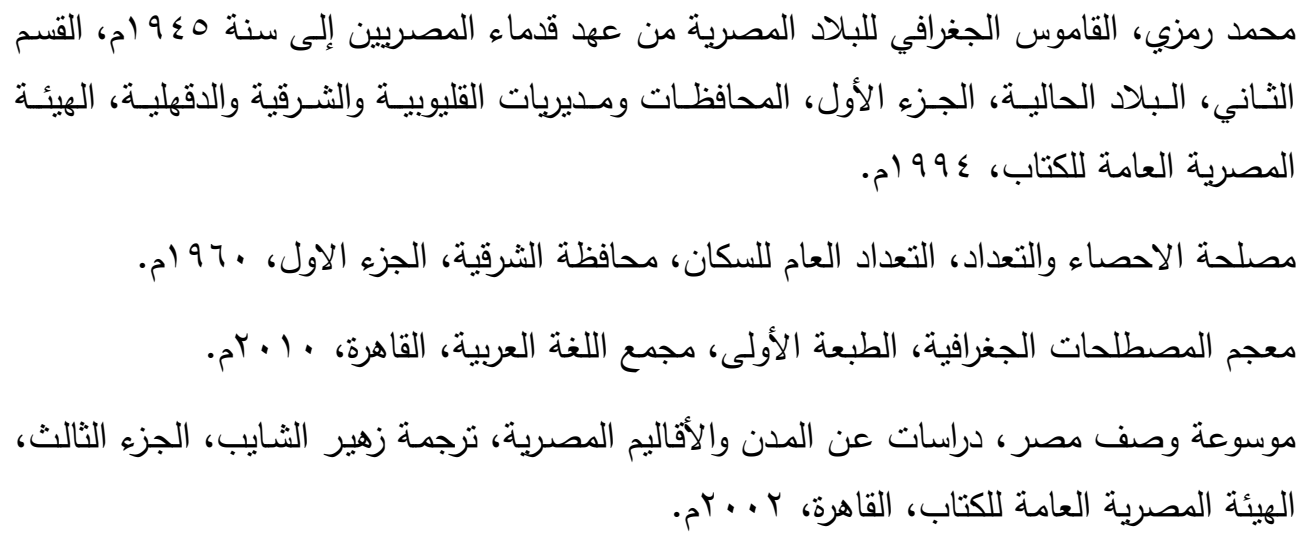

Description de de l'Egypte, Vol $\$, Atlas Géographique, p. $\vee\urcorner$, planche $r \cdot$, CARTE TOPOGRAPHIQUE, Bubaste, Salhieh, Bibliotheca Alexandrina, Alexandrie.

Image Landsat (TM), mode multispectral, $19 \vee 7$.

Image Landsat (TM), mode multispectral, $19 \wedge \varepsilon$.

MERENNE Émile, Géographie des transports, Nathan, Paris, 1990.

RONCAYOLO Marcel, La ville et ses territoires, Gallimard, Paris, 199.

SABATELLO Eitan, "Croissance démographique et urbanisation au Maghreb et dans la péninsule Arabique", dans Croissance démographique et urbanisation; politiques de peuplement et aménagement du territoire, Séminaire international de Rabat $\left(10_{-}\right.$IV mai 199•), AIDELF, Paris, $199 \%$.

Urban growth and environmental degradation: The case of Cairo (Egypt), Cities, Volume 19, Issue 7 , December, $\uparrow \ldots r$.

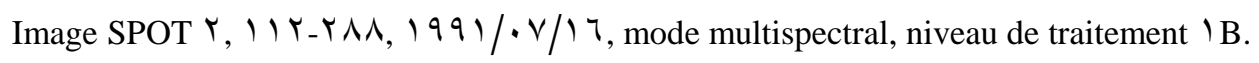
Image SPOT $, \mathcal{1} \mid \mathrm{r}-\mathrm{\wedge} \wedge, 199 \mathrm{~V} / \cdot \wedge / 10$, mode multispectral, niveau de traitement $/ \mathrm{B}$.

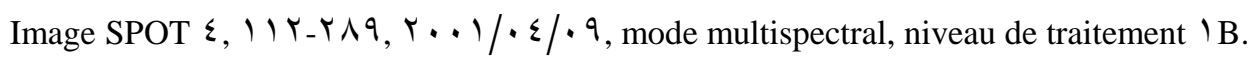

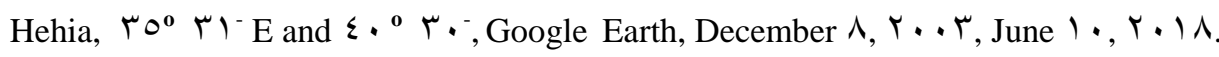




\section{اهكانات تطوير النشاط السياحي في اهوار جنوب العراق وافاقها المستقبلية}

م. هيلين محمد عبدالحسين البديري

مدرس بقـسم الجغرافيا

كلية التربية للبنات

جامعة الكوفة/ العراق
I. م . نهاد خضير كاظم الكناني

أستاذ مساعد بقسم الجغرافيا

كلية التربية للبنات

جامعة الكوفة/ العراق 


\section{الـمـستخلص :}

تعاني صناعة السياحة في العراق من تدهور واضح أهمال متزايد ، رغم الاهمية

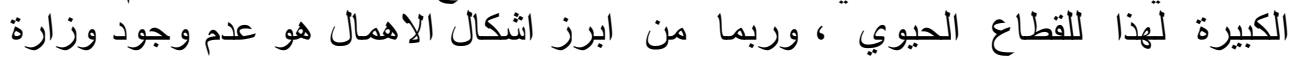

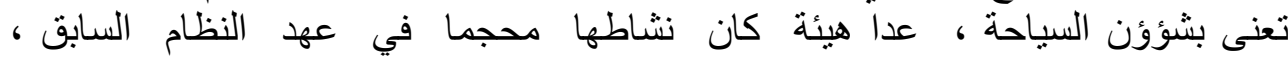

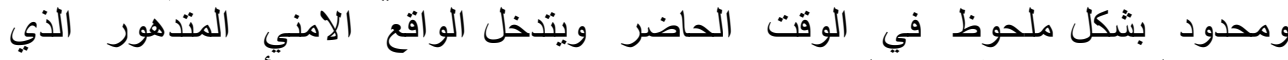

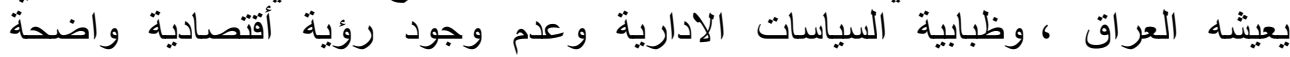

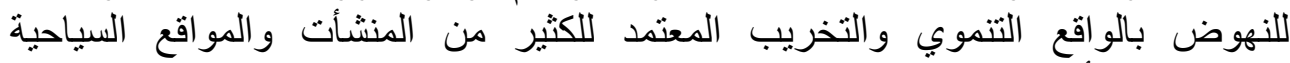

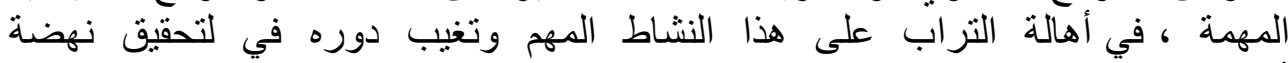

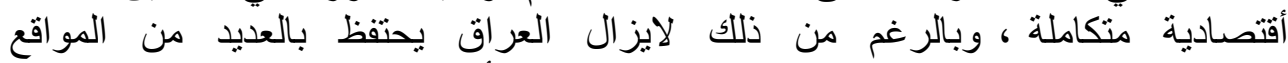

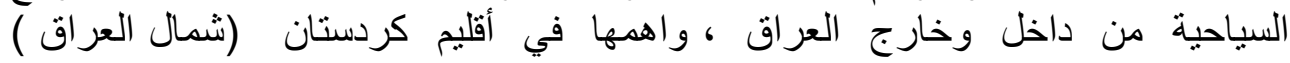

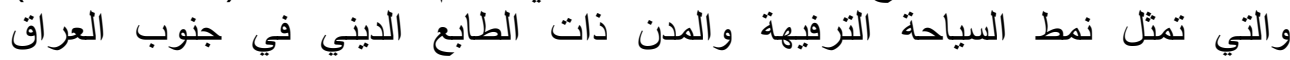

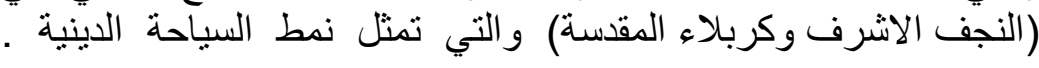

وتعد الاهوار واحدة من المواقع العراقية التي تمتلك مقومات النشاط السياحي

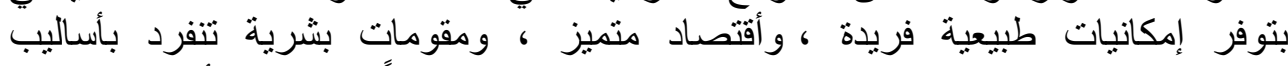

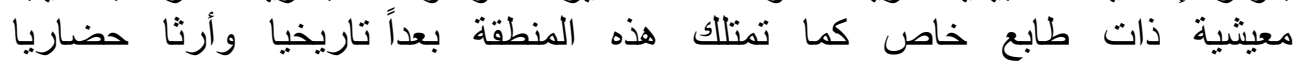

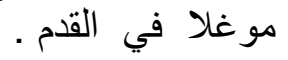

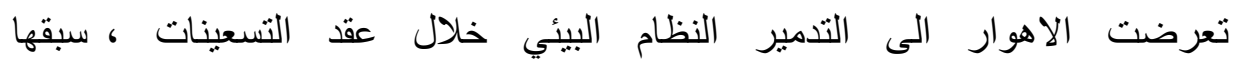

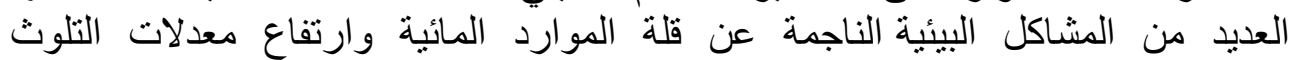

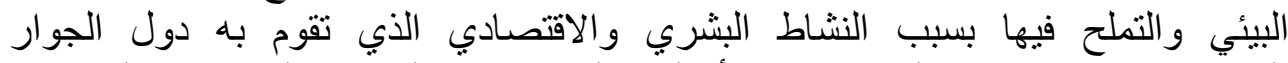

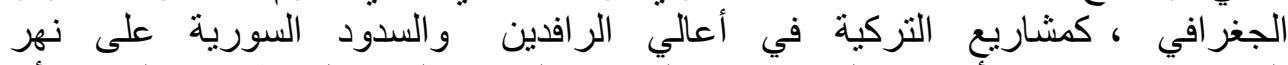

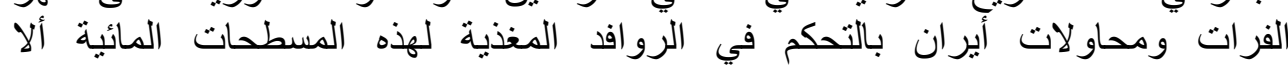

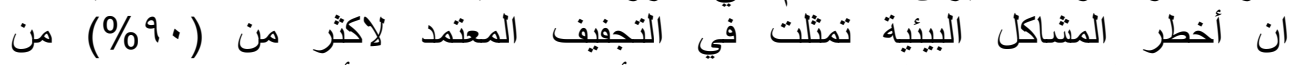

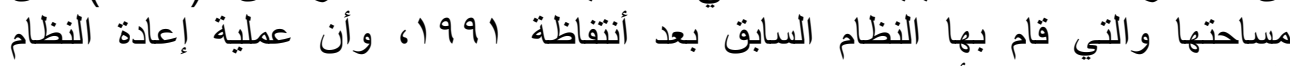

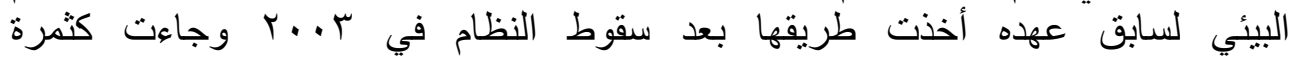

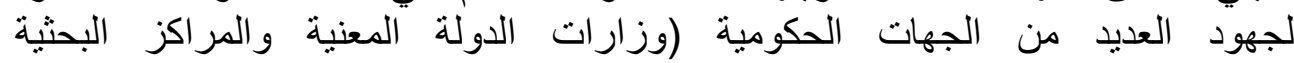

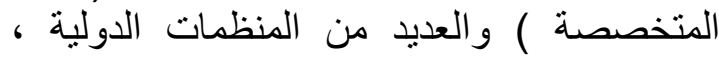

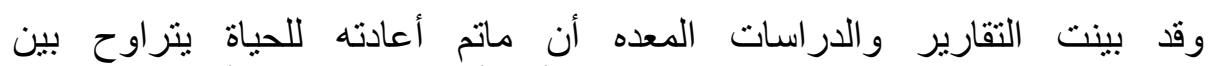

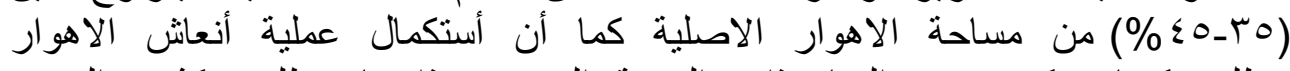

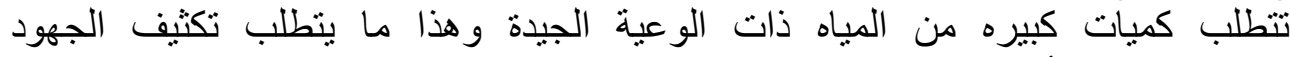

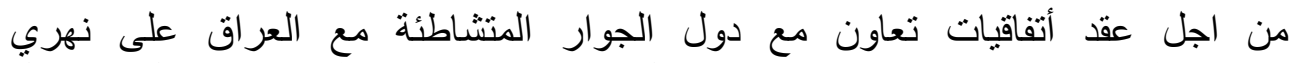

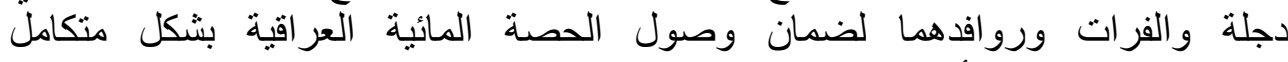

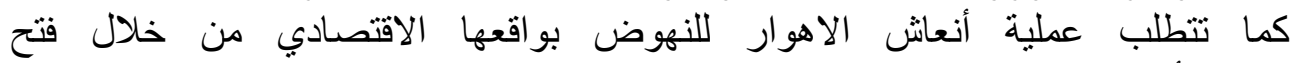

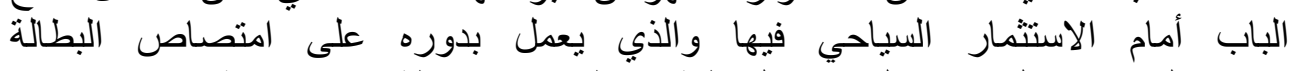

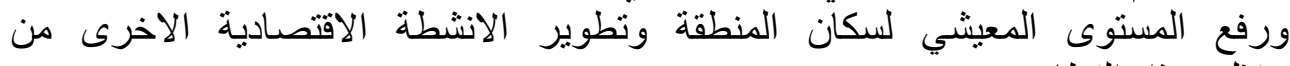
خلال هذا القطاع . 
Theoretical : الـمــحث الاول : الاطـار الـنظرى لـلـدر اسة

\section{framework}

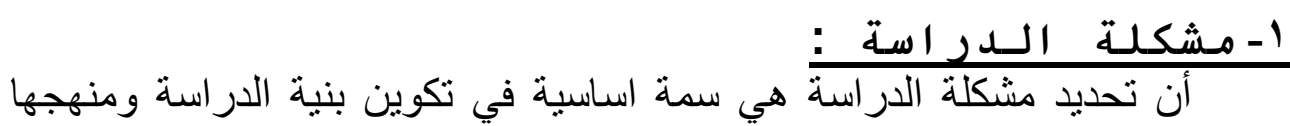

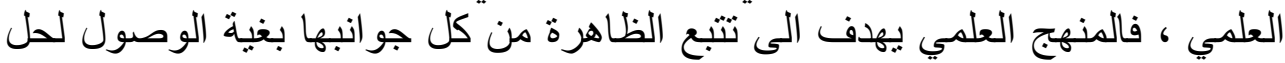

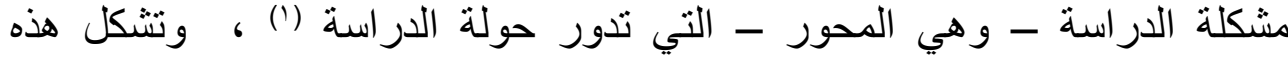

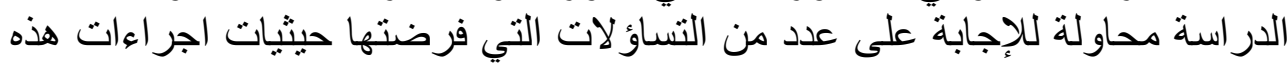

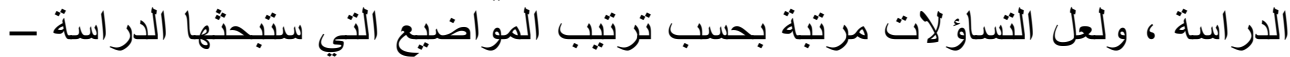

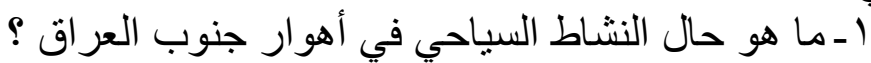

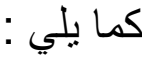

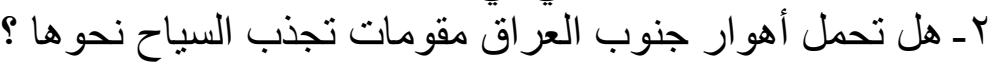

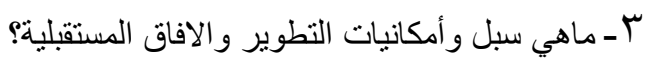

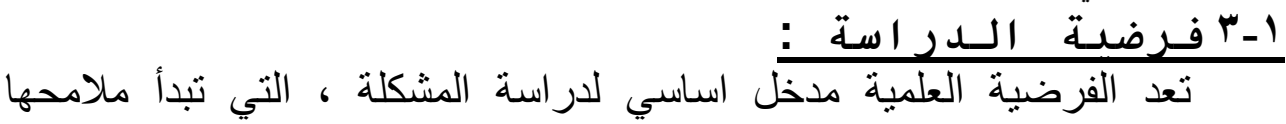

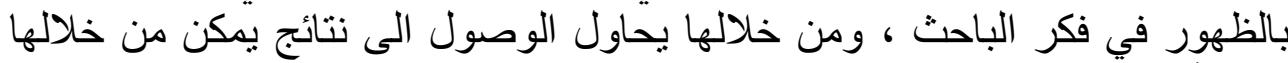

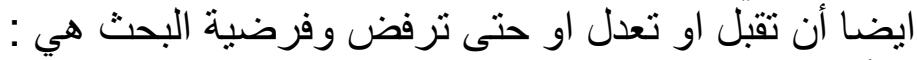

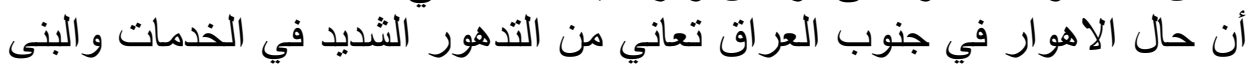

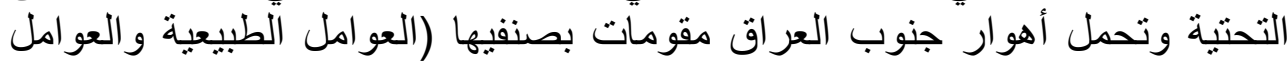

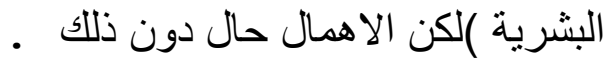

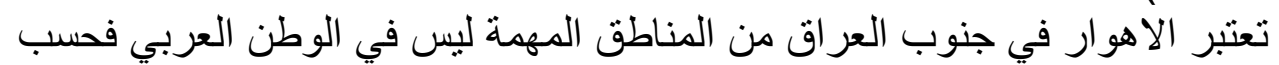

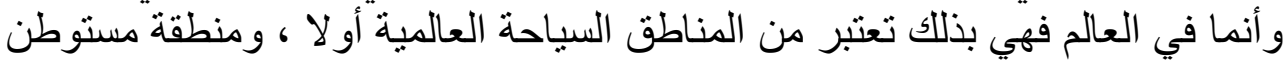
لكثير من الاسماك و الحيو انات وتعتبر ثروة اقتصادية ثنانيا .

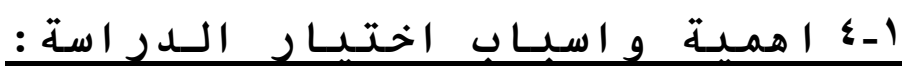

يهدف البحث من وراء السعي للحصول على منطقة ذات خصائص إيجابية

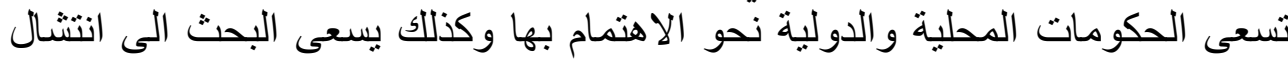

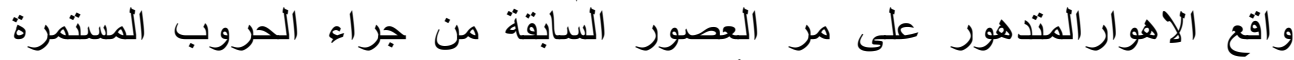

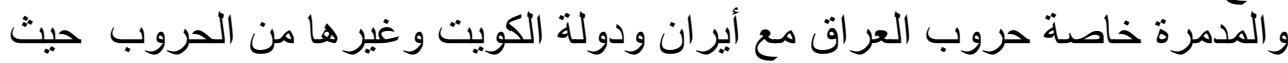

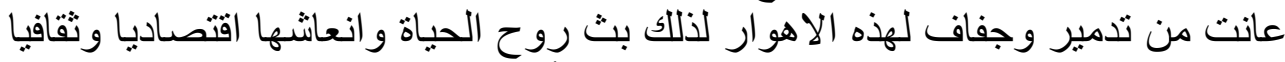

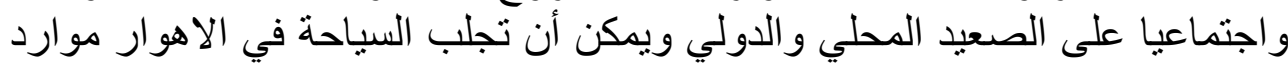

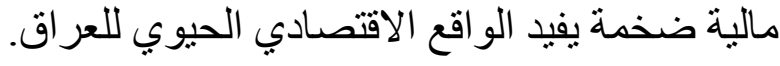

، (') عبد الرزاق محمد البطيحي ، طرائق البحث الجغرافي ، دار الكتب للطباعة والنشر ، الموصل 


\section{:}

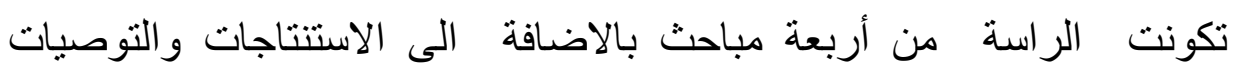

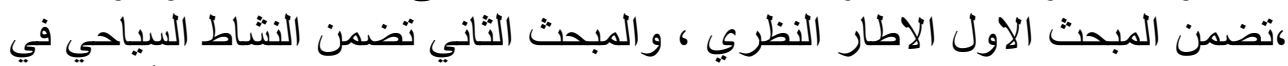

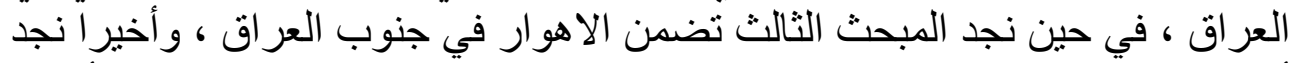

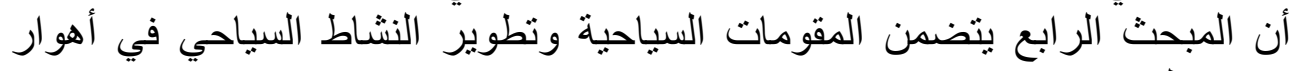

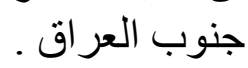

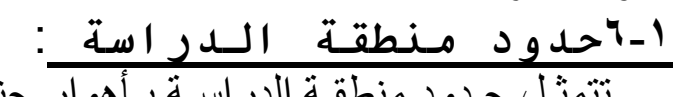

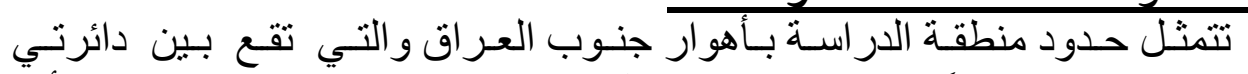

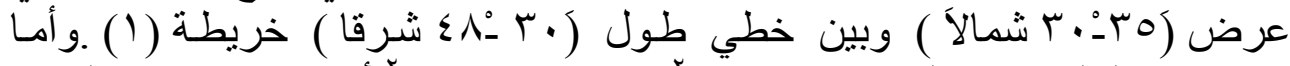

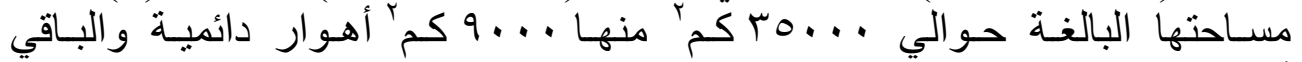

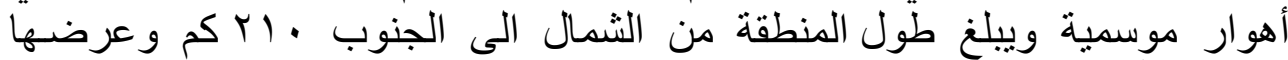

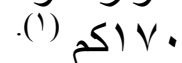

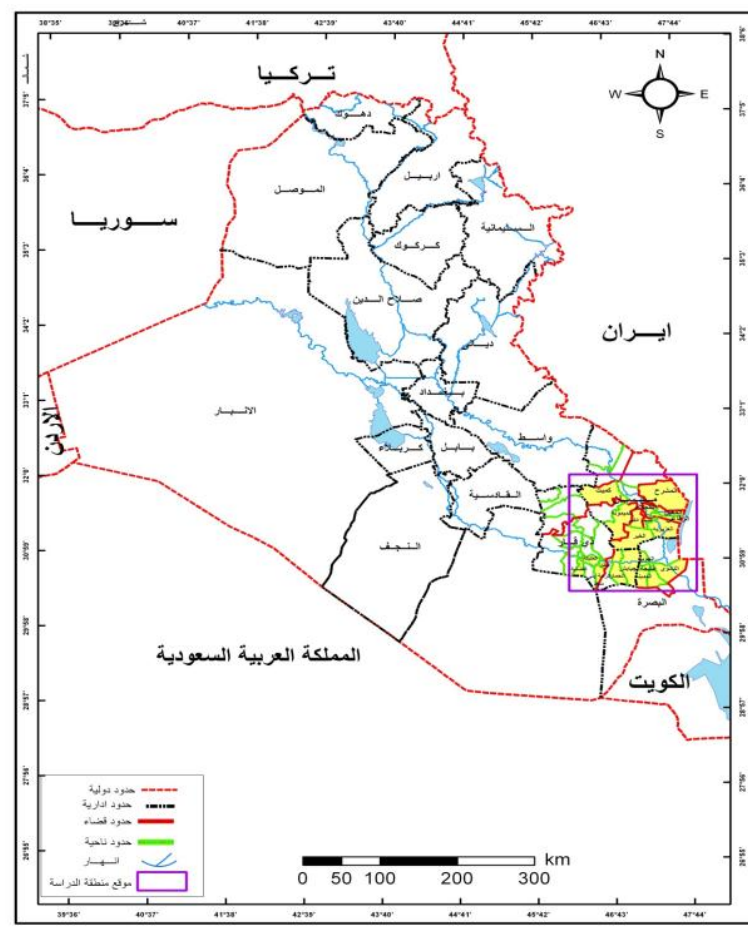

الخريطة (1) مناطق الاهوار في جنوبي العراق

المصدر : عمل الباحثين بالاعتماد على : المناطي

- مزارة الموارد المائية ، مديرية العامة للمساحة قسم انتاج الخرائط ، خريطة العراق

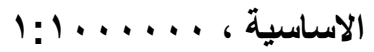

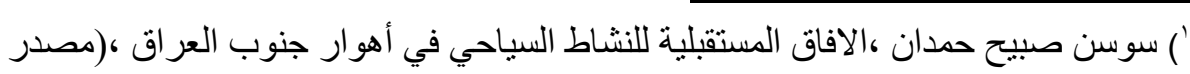
سابق)، صع صع 19. 


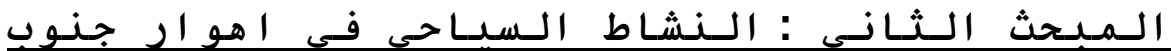

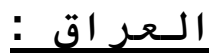

\section{: 1-r}

دأب الانسان منذ القدم على الحركة والانتقال من مكان الى أخر لتحقيق اهدافه ، وقد مارس التنقل والترحال بحثا عن الراحه والاقامه ليجد لله المأكل

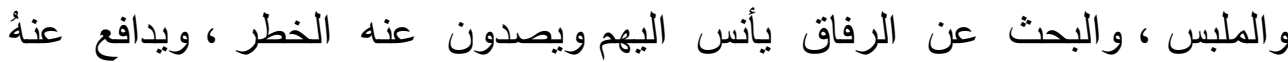

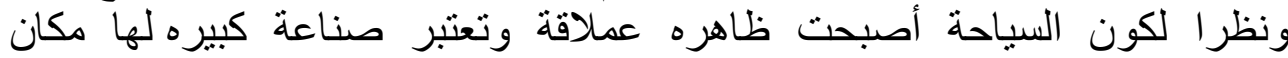

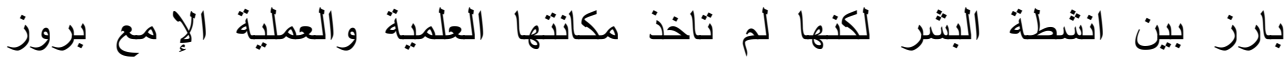

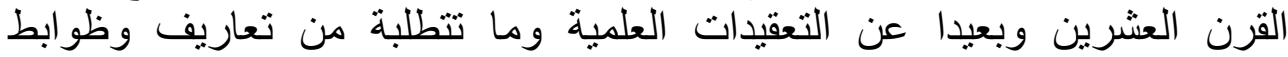
ومواصفات سنرى أن السياحة نشاط انساني يتمثل ويتجسد في أنتقال الانسان وتحركةُ من مكان الى اخر لتحقيق هدف معين (1) (1).

وللسياحة مفاهيم متعددة ومختلفة تختلف باختلاف الاختصاصات العلمية

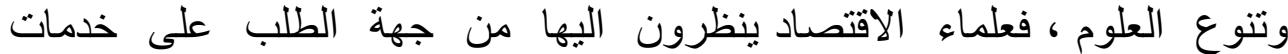

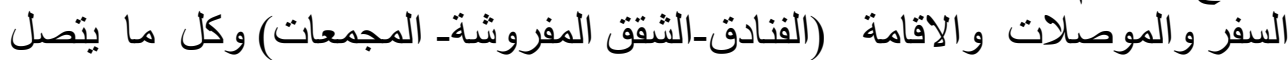

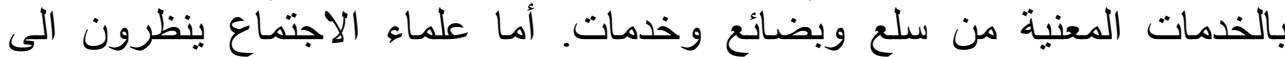

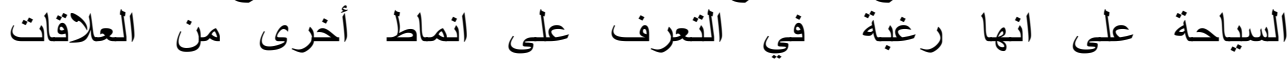

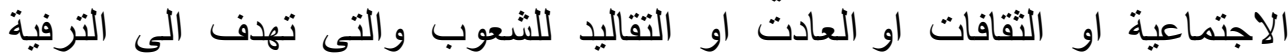

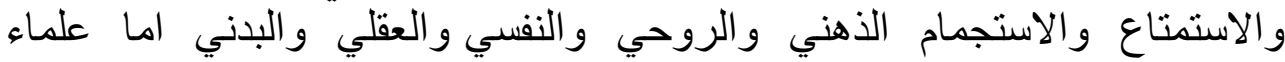

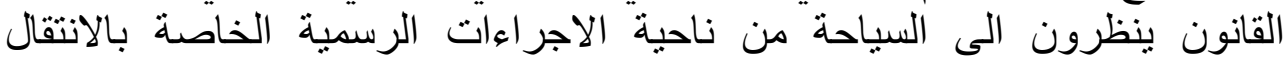

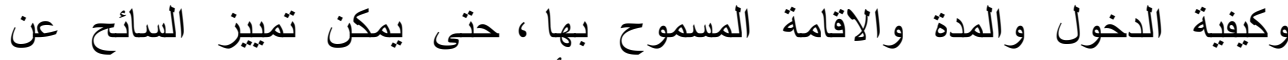

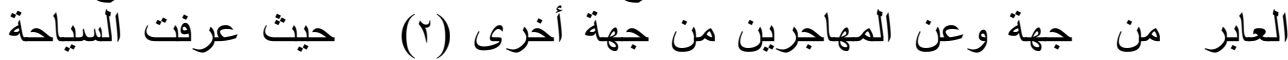
بمفهومها البسيط هو الانتقال الذي يتم فردي أو جماعي و الذي يني ينتهي بالعودة الى الى نقطة

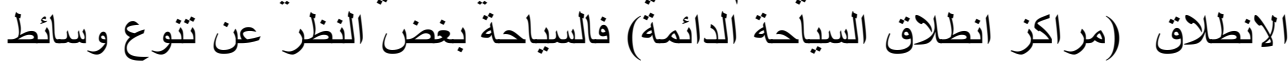

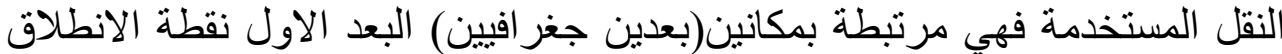

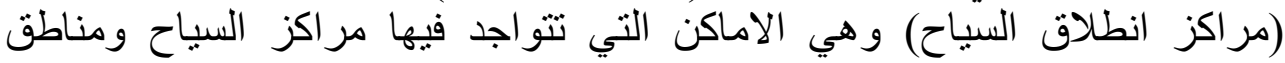

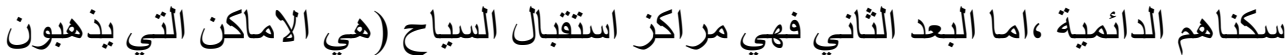
اليها) وييقون فيها بشكل مؤقت وهذا يوجد بين هرئ اماكن انطلاق السياح ومراكز

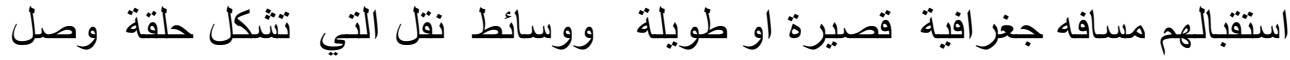


في السياحة بين هذين البعدين (1)،اما مفهوم السياحة قد ذاه ذكر في اللغة العربية

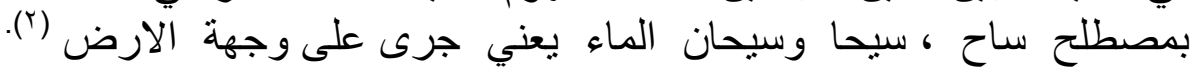
(tornos)

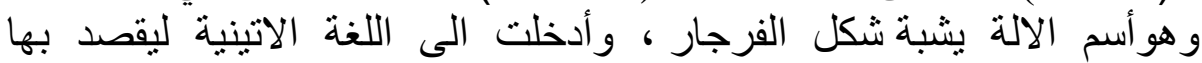

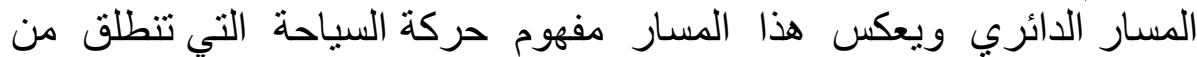

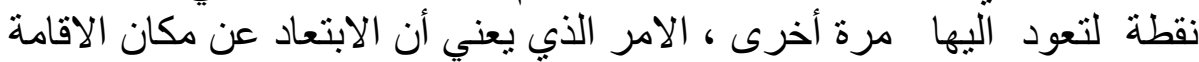

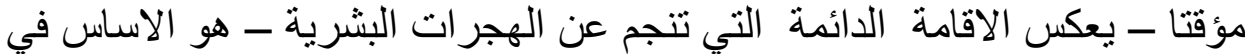

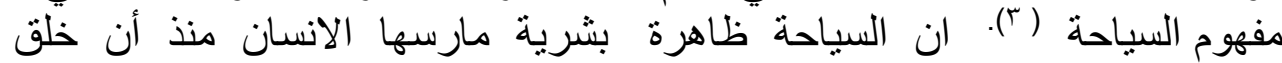

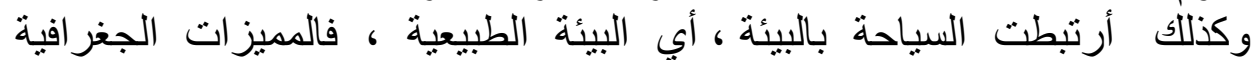

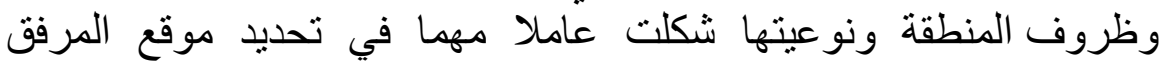

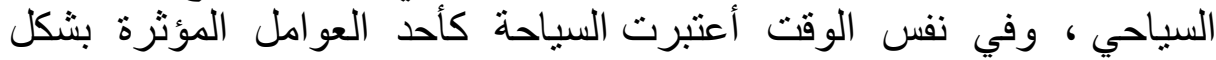

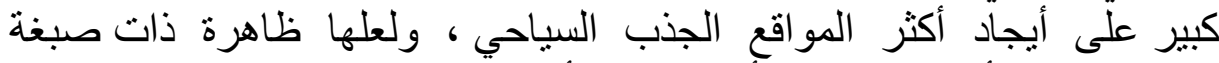

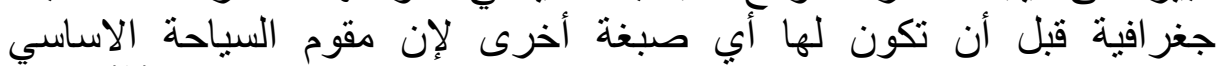

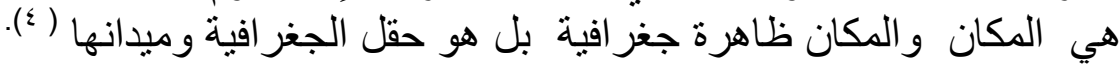

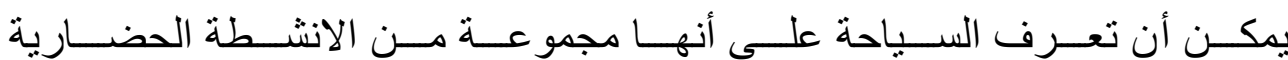

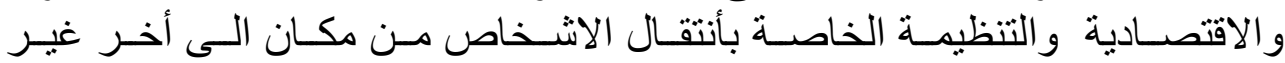

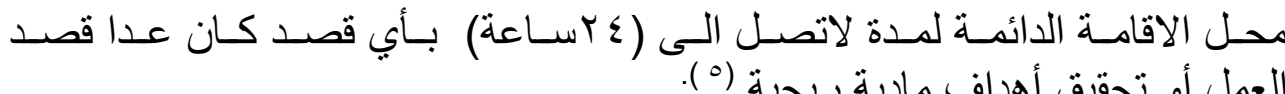

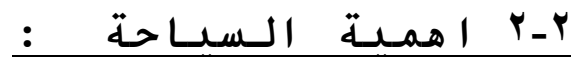

تعد موارد السياحة من الصادرات الغير منظورة التي تساهم مساهمة فاعلة في العادي

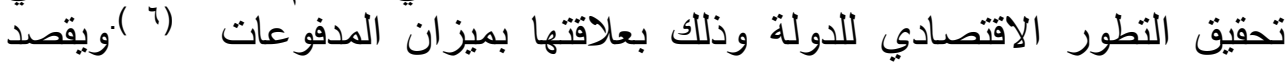

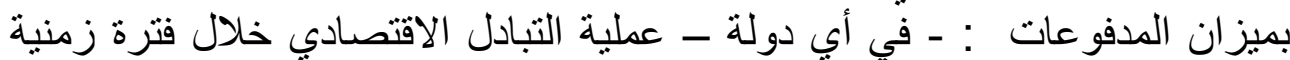

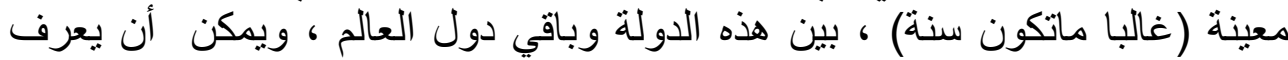

') الصباح محمود محمد وأخرون، الجغر افية السياحية مع الدراسة التطبيقية عن القطر العر اقي ،مطبعة بغداد،

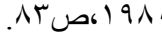

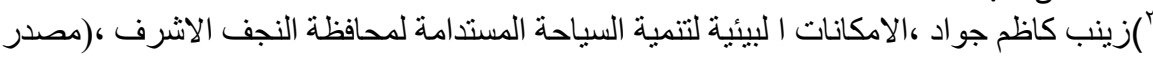

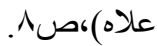
) أبر اهيم بظاظو ، السياحة البيئية واسس أستدامتها ،طا ، مؤسسة الوراق للنشر و التوزيع ، عمان ،الاردن ،

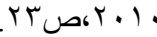

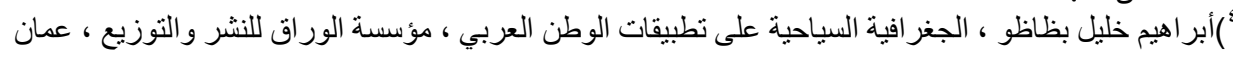

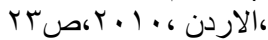
“ونور صبحي عبد الدليمي ،أمكانات مركز قضاء المدائن بأستخدام الصور الجوية ونظم المعلومات الجغر افية (gis)

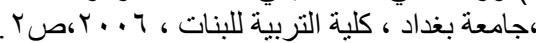
")(صباح محمود محمد و أخرون ، الجغر افية السياحية مع دراسة تطبيقية عن القطر العر اقي (مصدر سابق )، صبr. 
على أنة بيان للاخل و المنصرف على مستوى الدولة (1 ). وتأثير ها على الدخل

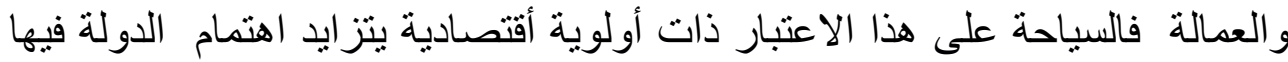

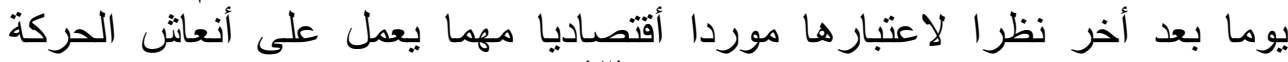

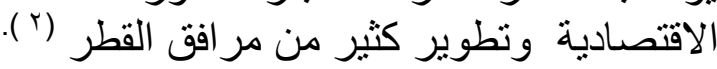

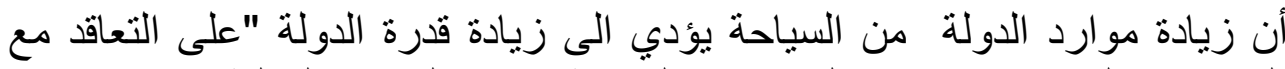

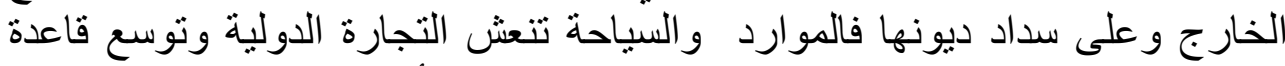

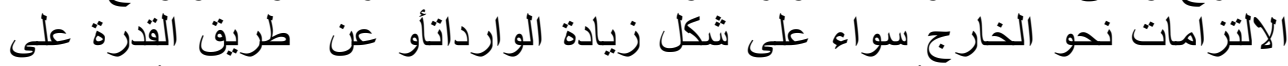

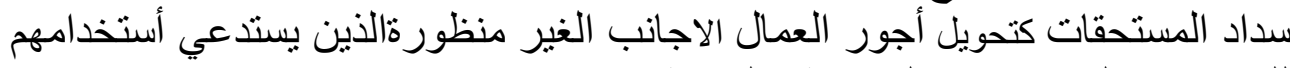
للتوسع في المشرو عات السياحية و الفندقية".

ولهذا فأن النشاط السياحي يؤدي الى نشاط متز ايد في كل القطاعات الاقتصادية

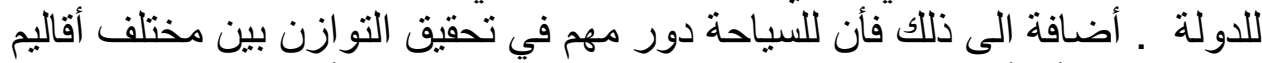

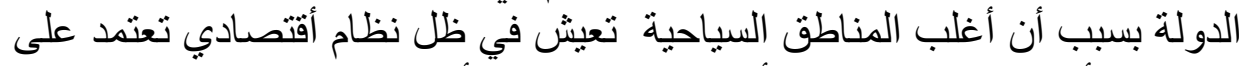

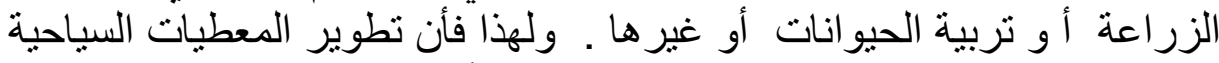

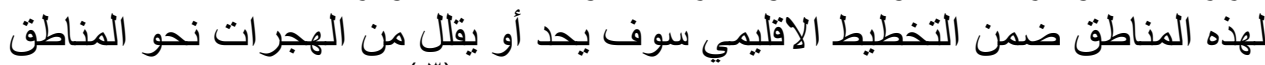

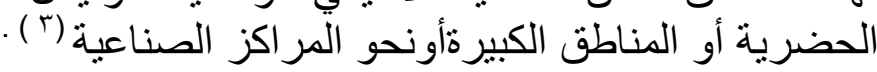

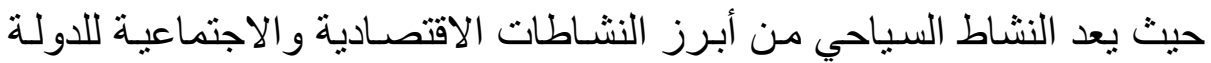

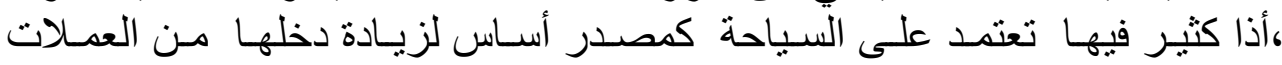

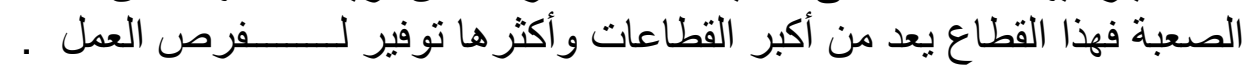

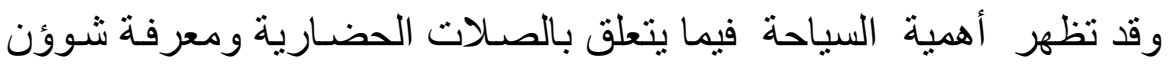

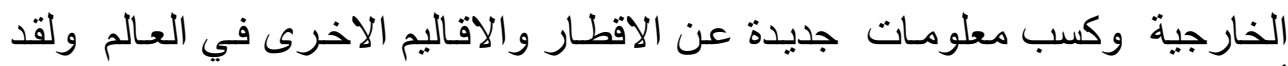

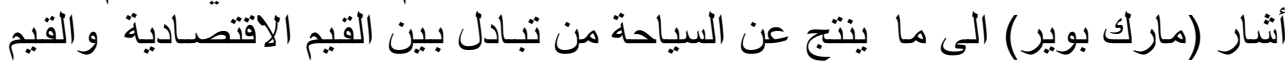

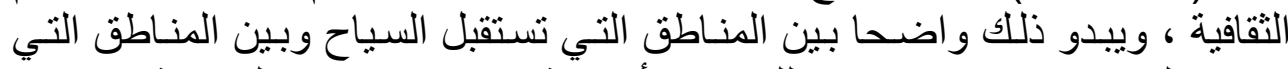

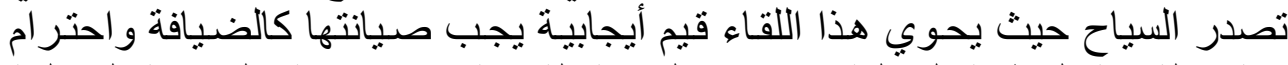

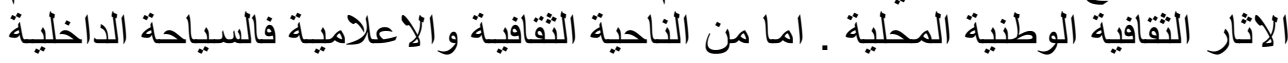

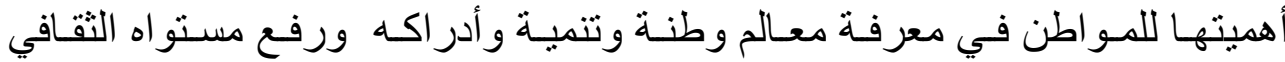

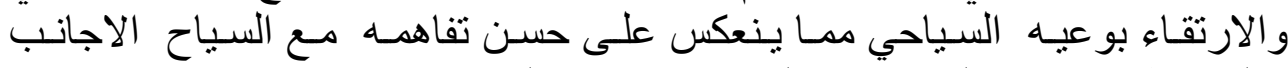

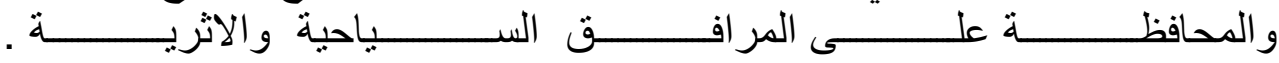

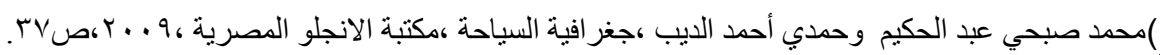

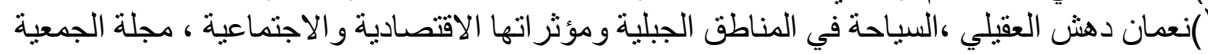

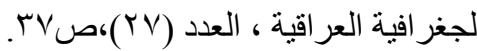

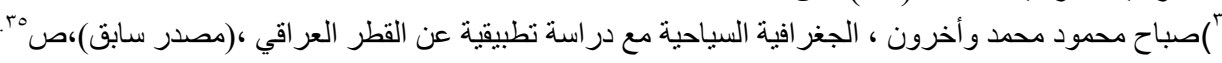




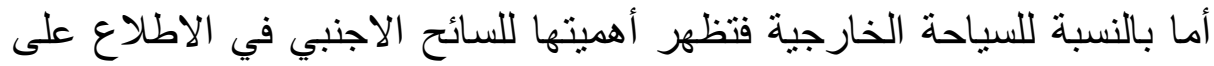

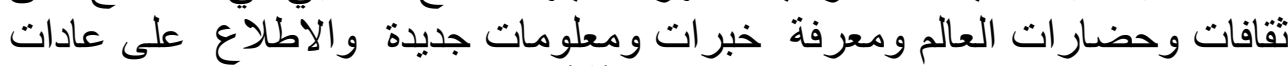

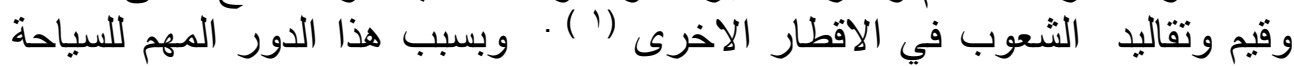

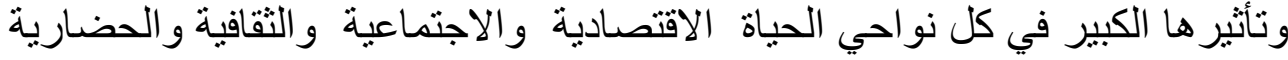

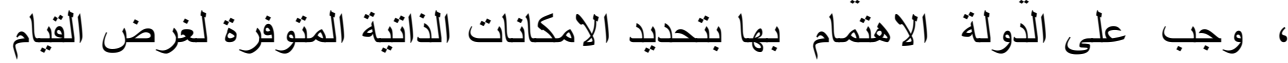

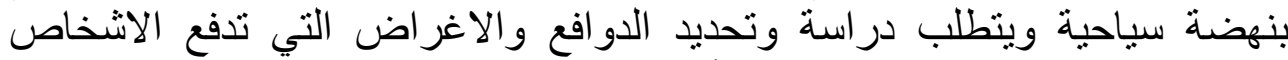

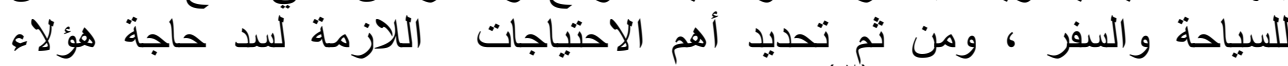

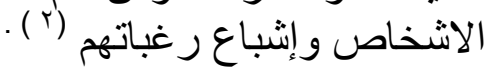

:

كان العراق يتمتع بعلاقات سياحية مع العديد من المنظمات والمؤسسات

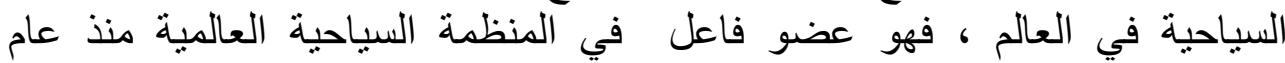

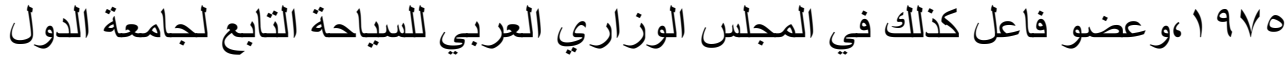

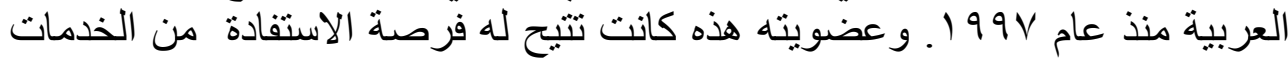

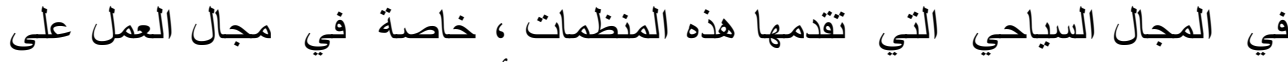

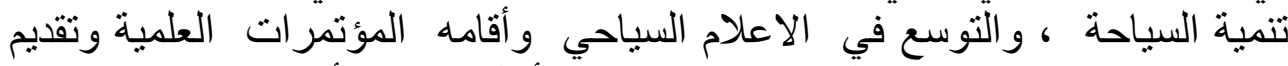

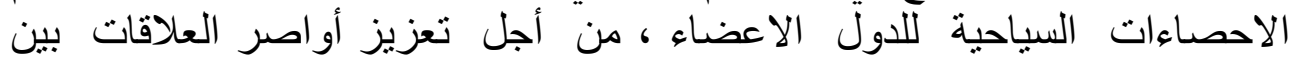

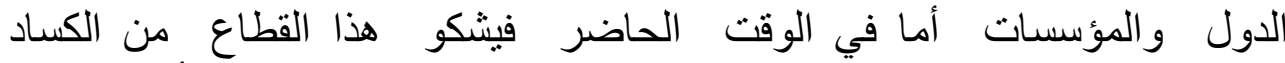

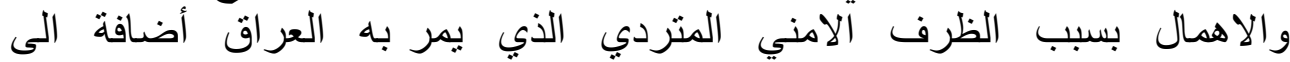

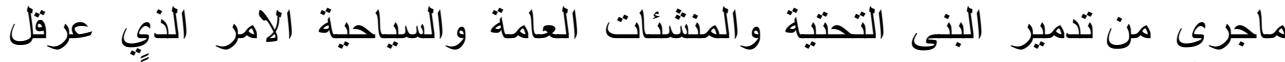
ويعرقل نمو وتطوير النشاط السياحي ، حتى في المناطق الهادئة نسبياً. ويقتصر النشاط السياحي حاليا على منطقتين رئيسيتين في العراق :

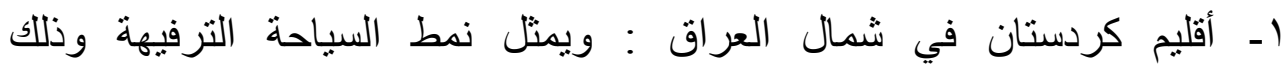

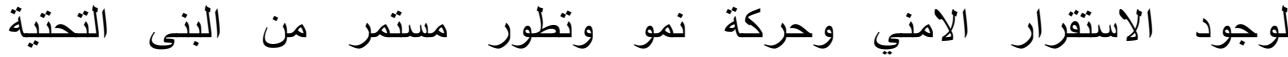

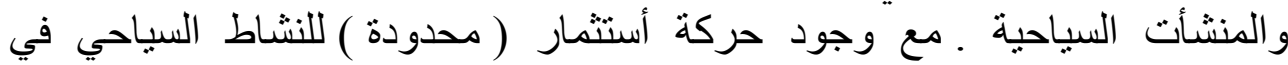

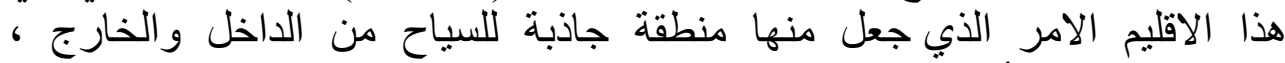

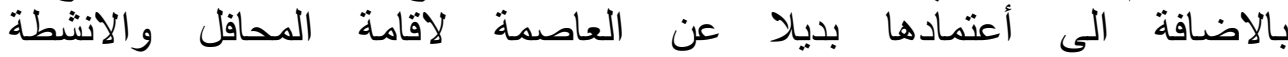

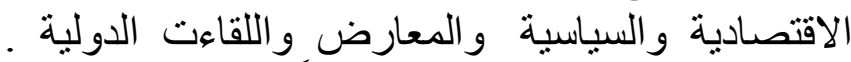

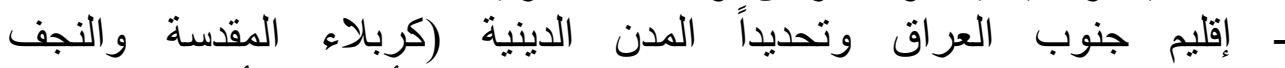

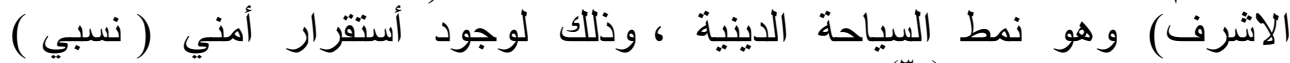

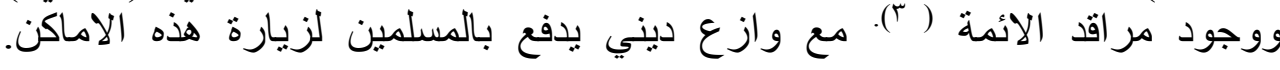

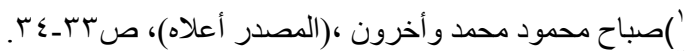

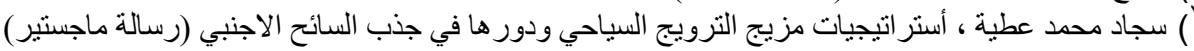

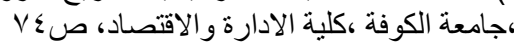

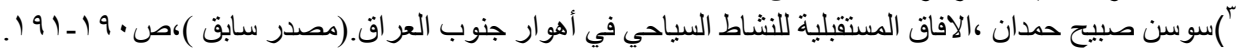




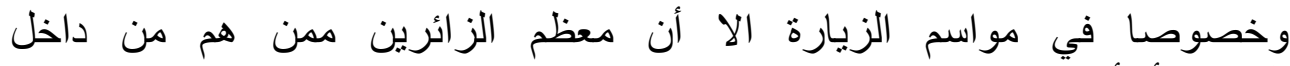
العراق أذ أن تردي الاوضاع الامنية في عموم العراق يحجم حركة المسلمين

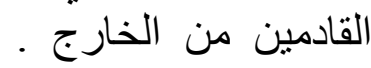

:

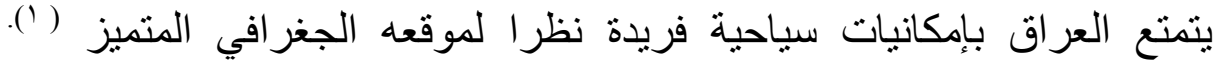

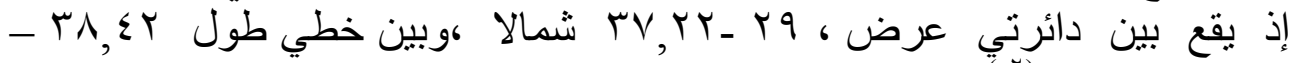

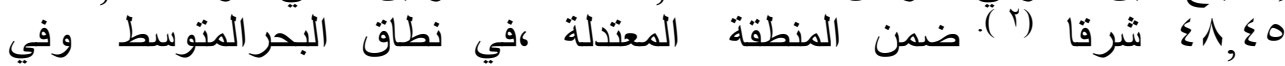

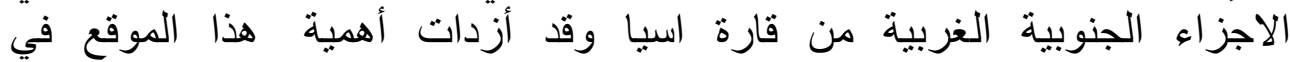

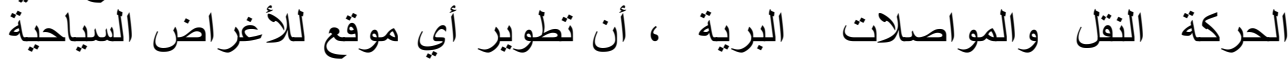

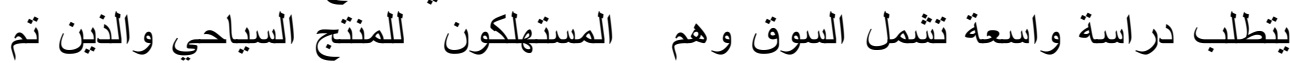
التعبير عنهم بالسياح كما يشمل الجدوى من هذا التطوير الذي عبر عنه البحث.

مفهوم المردود الاقتصادي والاجتماعي و البيئي للسياح ويشمل أيضا عنصر ا هاما

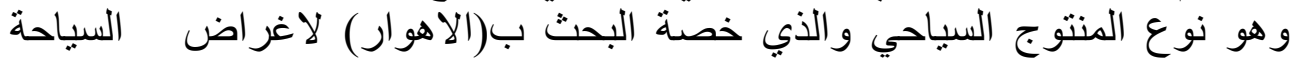

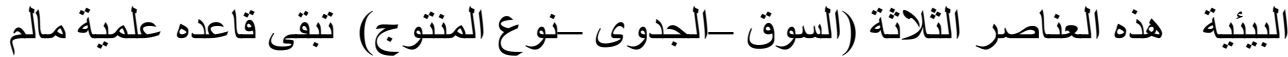

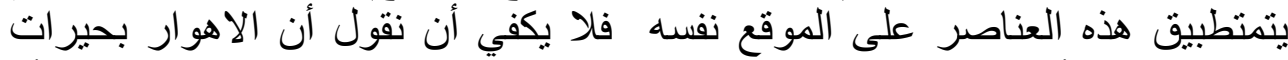

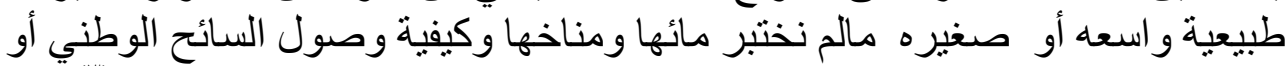

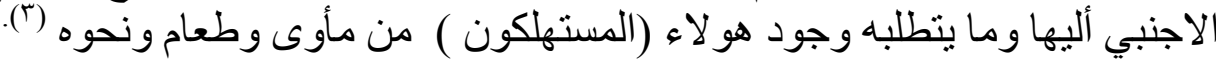

يعود المردود المادي على العراق من السياحة بأنواعها المختلفة كبير

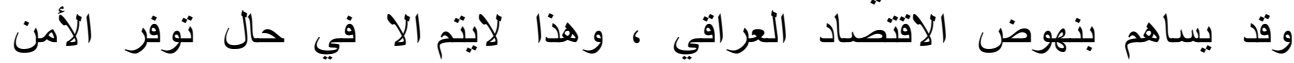

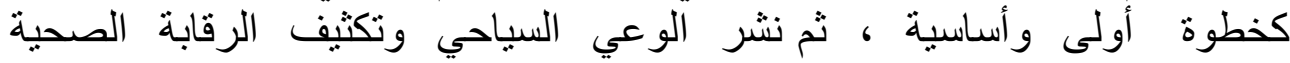

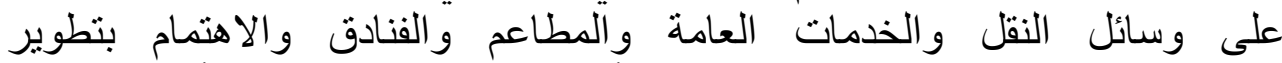

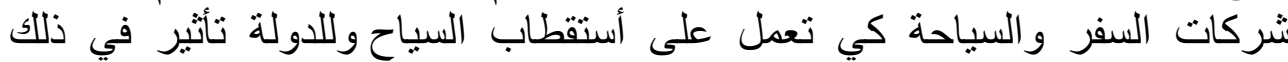

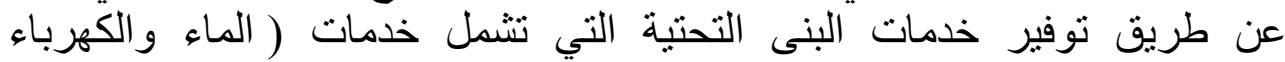

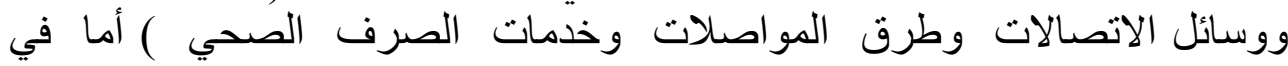

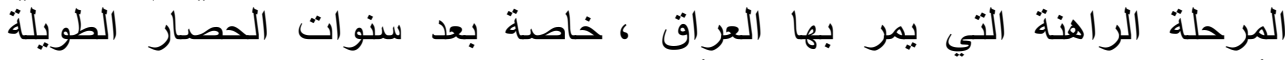

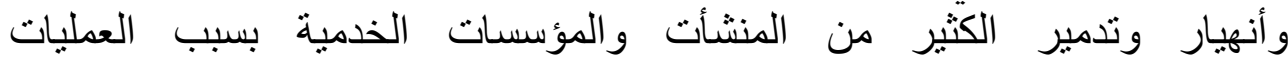

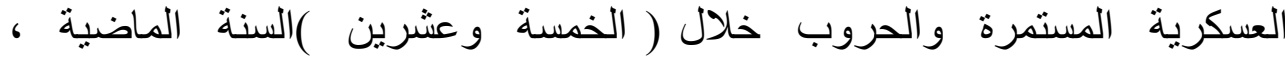

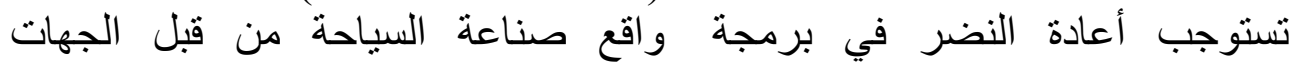

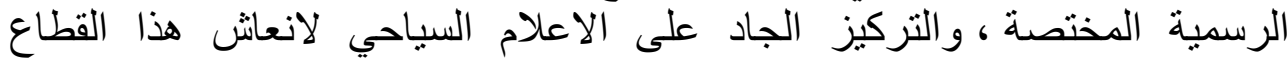

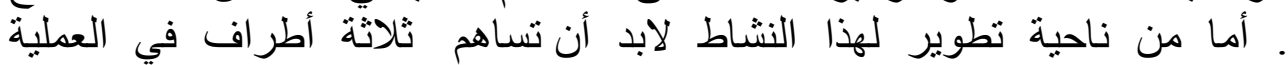

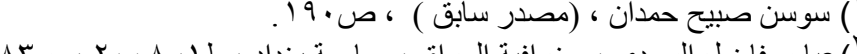

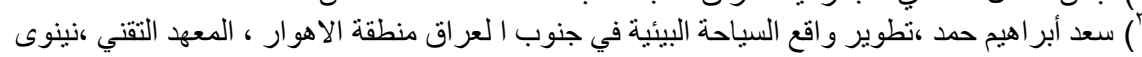


السياحية وهي ( الدولة ، القطاع الخاص السياحية ، ، الاستثمار الاجنبي ) ويتطلب

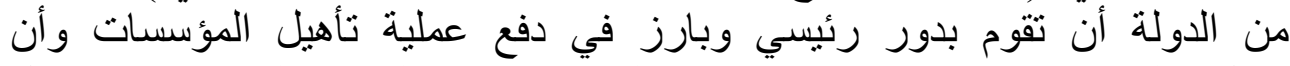
تعمل على تشجيع القطاعين الاخرين بالنهوض بهذي فئا النشاط الههم ، لانه يعطل على : على

1ـ توفير فرص للعمل وحل مشكلة البطالة المتزايدة في الاجنبية للاستثمار

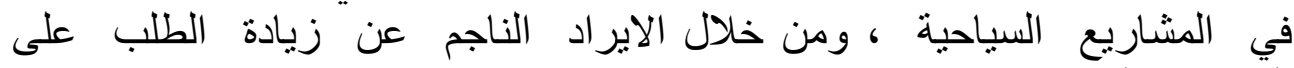

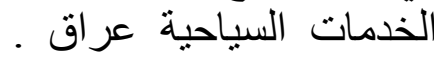

r- تحسين ميزان الددفوعات من خلال تدفق روؤس الاموال المتنوعة. r- تحقيق تنمية منوازنة بين الاقاليم والدحافظات وذلك يعود إلى إمكانية إنشاء

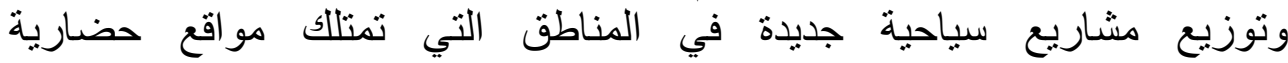

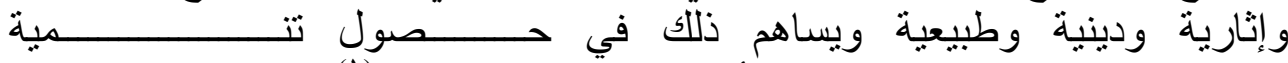

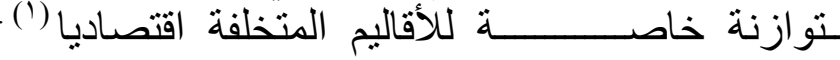

ويمكن أن نشير الى أن السياحة منطورة من خلال تحسن وسائل النقل

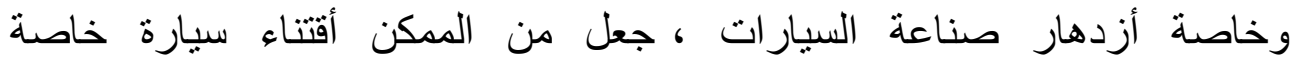

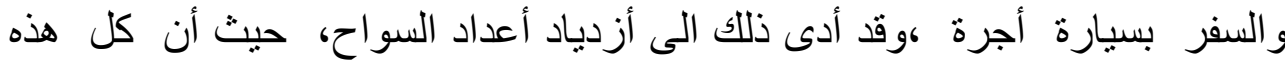

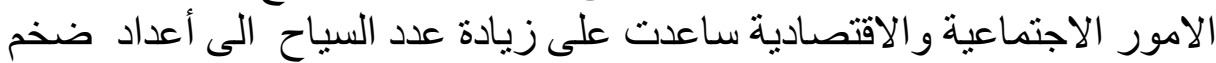

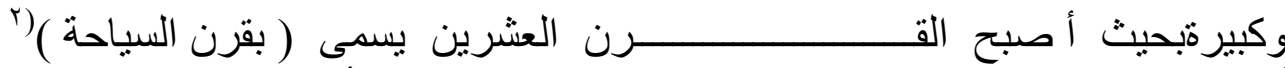

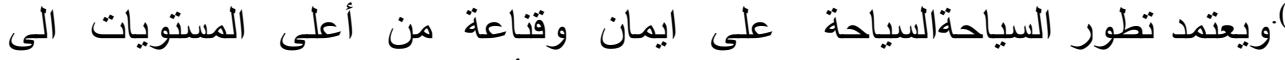

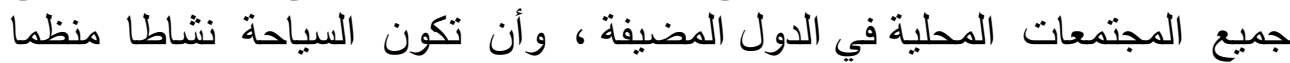

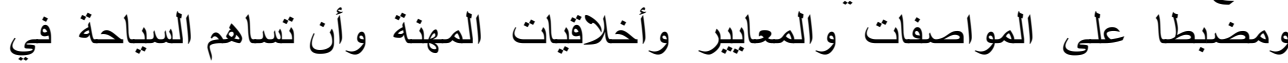

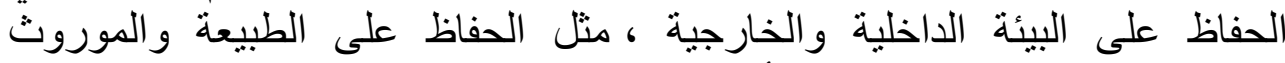

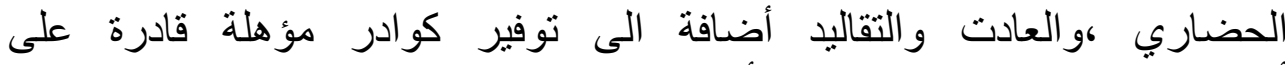

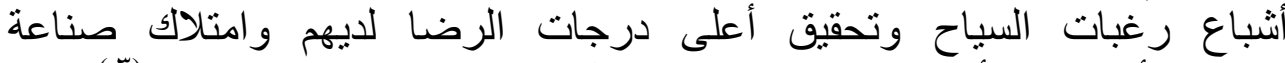

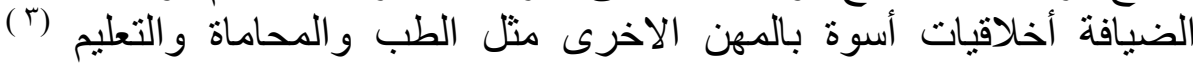




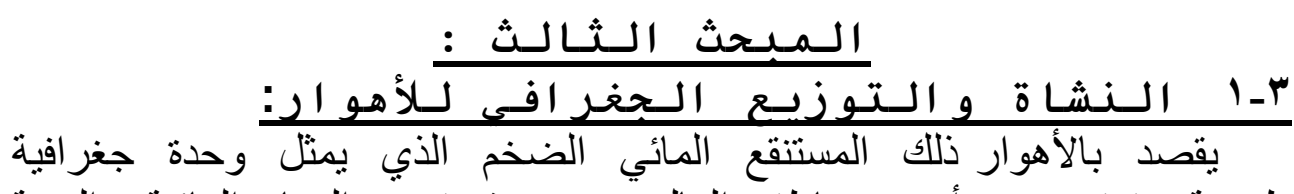
طبيعية وتعتبر من أغنى مناطق العالم ، من حيث تنوع العنى الحياة المائية والبرية

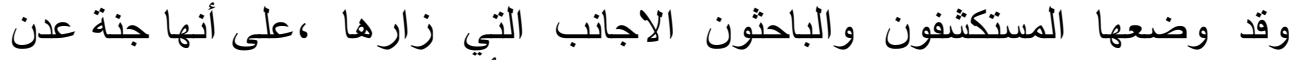

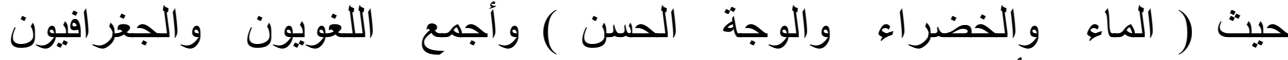

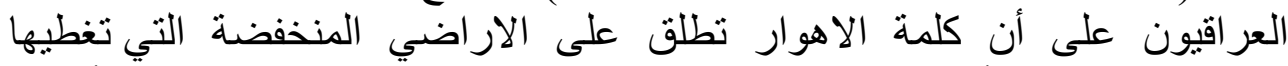

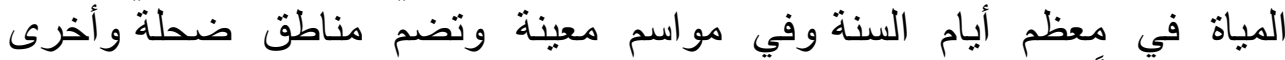

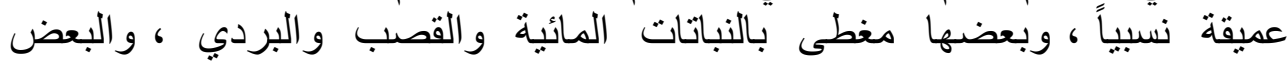
الاخر مفتوح بطلق علية أسم (بركة) فهي تللك الاجسام المائية الموجودة في فئن مناطق

جنوب العراق والتي تتميز بموصفات خاصة تختلف عن مواصفات البحيرات

والانهار و المستنقعات ومسطحات الميز المد والجزر (1).

أما من حيث (نشأة الاهوار ) فقد قام فريق من الجيولوجيين على رأسهم "

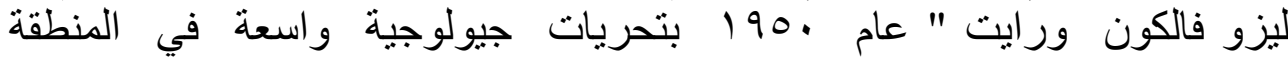

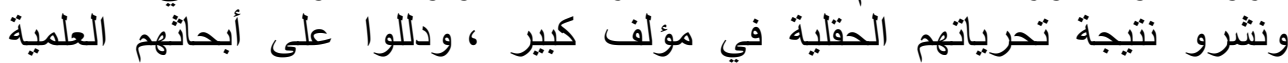

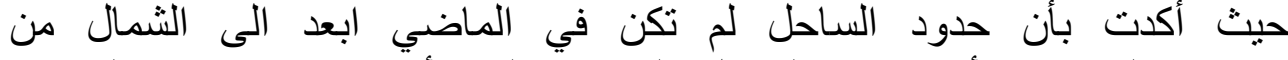

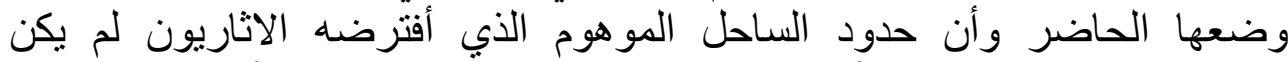
له وجود على الاطلاق وأضهرت نتائج تحريات ذلك الفريق أن هذه المنطقة

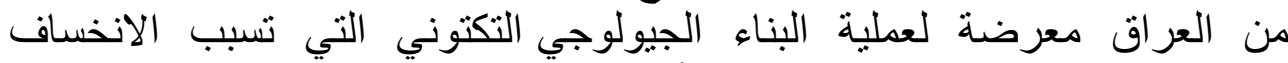

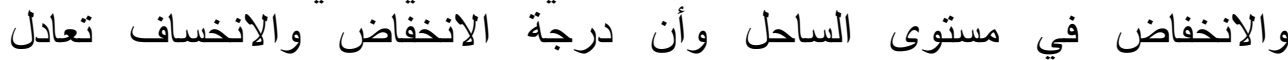

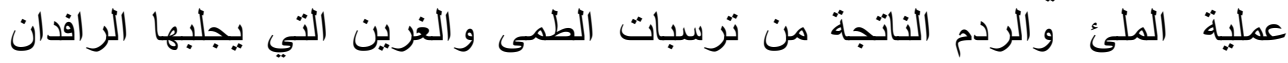

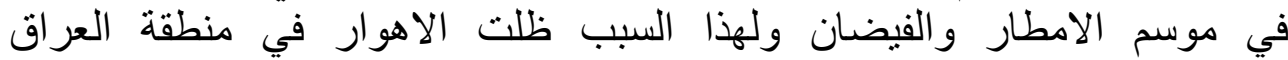

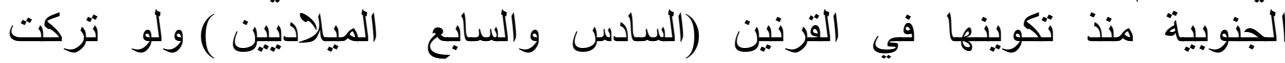

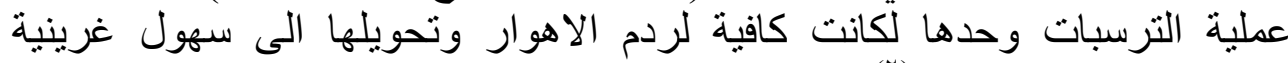
في هذا الزمن الطويل (r).

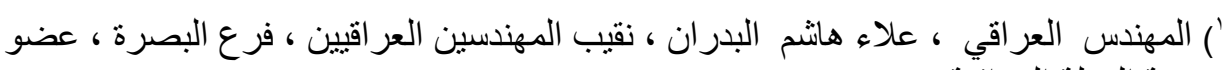

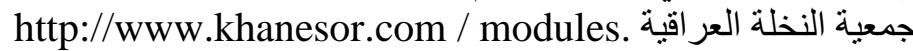
http://www.khanesor.com/modules بر هان شاكر ، شبكة الانترنت 


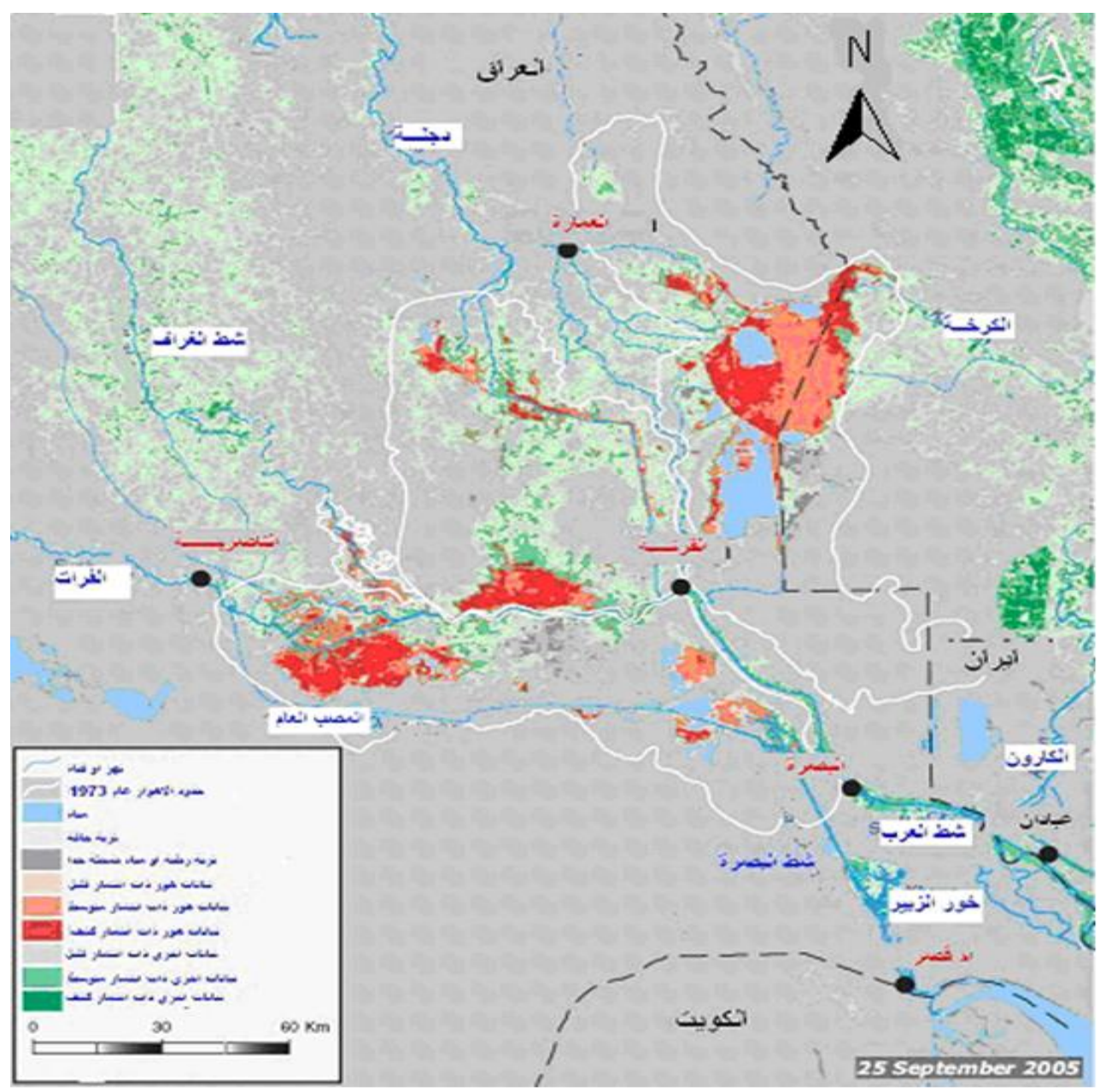

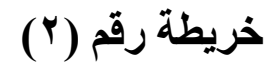

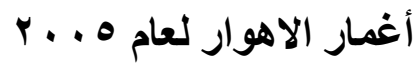

المصدر: أقبال عبد الحسين أبو جري ، الاثار البيئية لتجفيف الاهوار في جنوب العراق، أطروحة

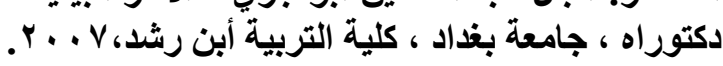

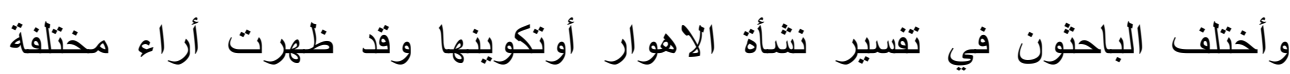
لتفسير نشؤئها :

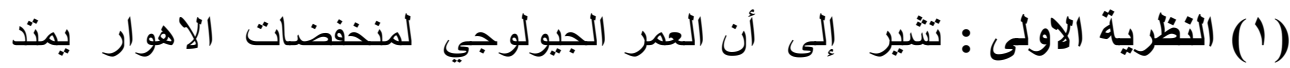

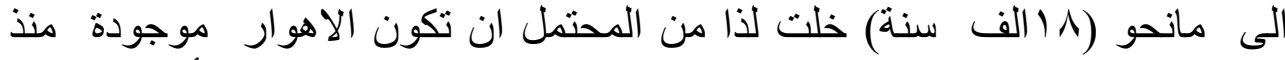

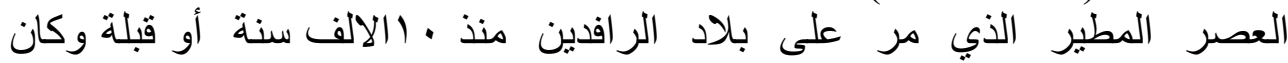

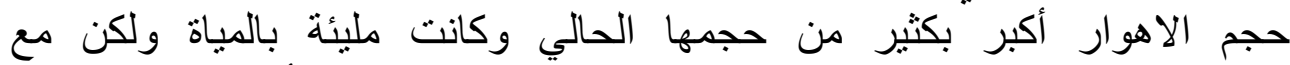
تراجع العصر المطير عن المنطقة وتزايد دئرة الجفاف أدى الى الى الجفاف 


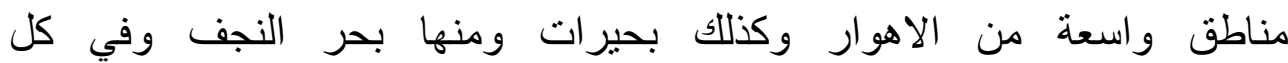

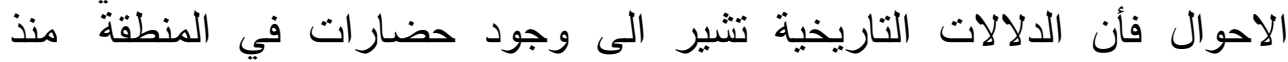

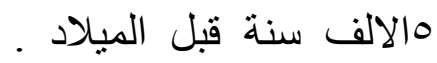

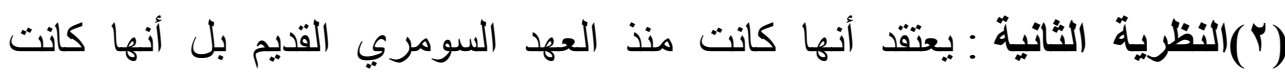

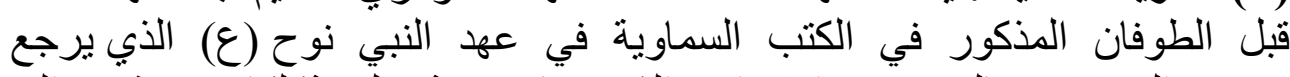

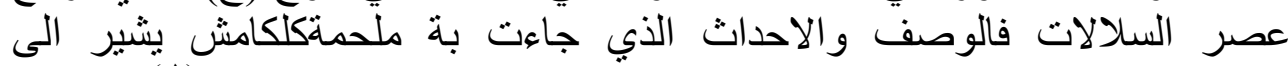

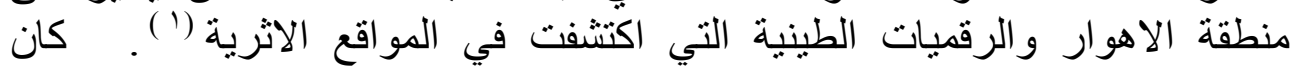

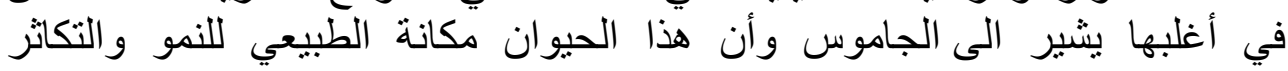
هو مناطق الاهوار ومازال لوقتئا الحاضر.

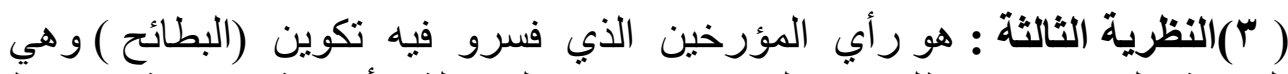

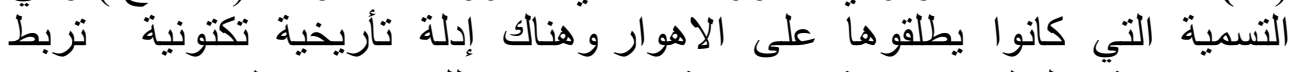

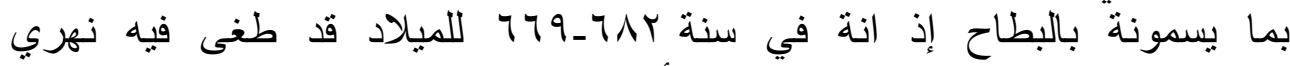

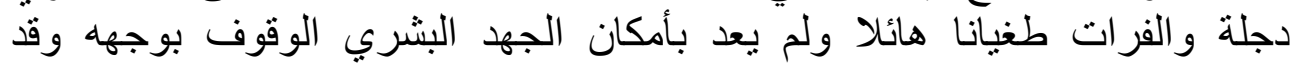

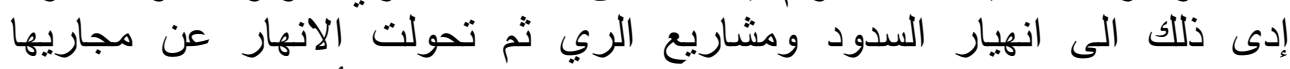

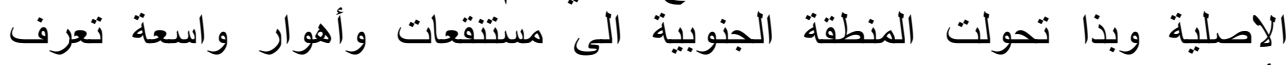

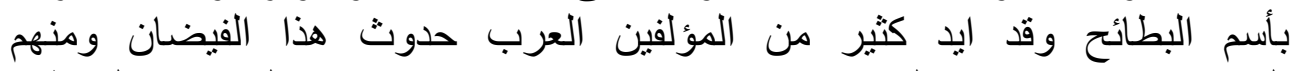

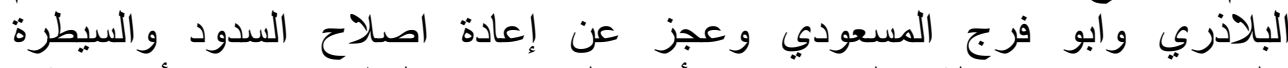

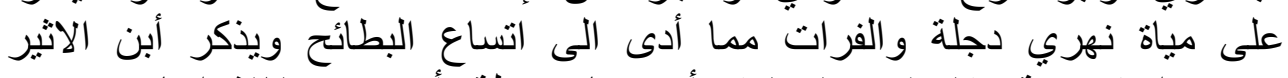

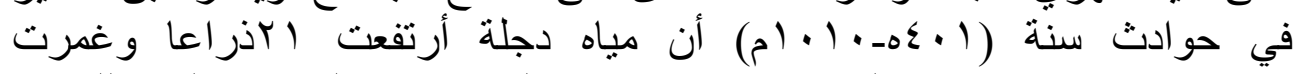

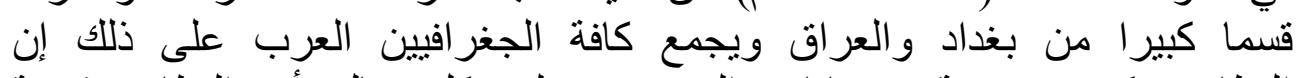

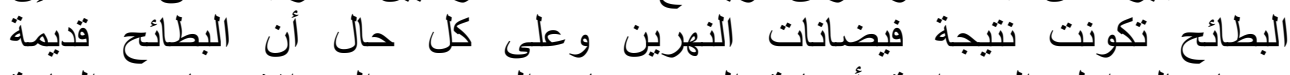

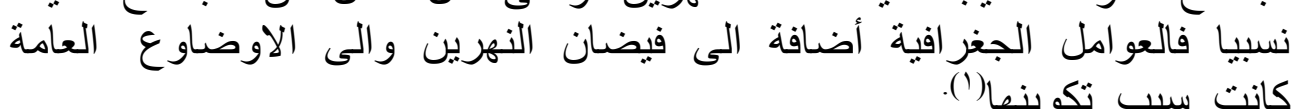

(؛)- النظرية الرابعة : وهو الاعتقاد السائد الى أو ائل الخمسينيات تبناها" سيتون

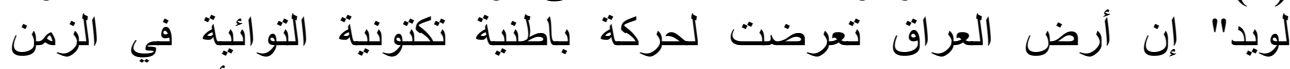

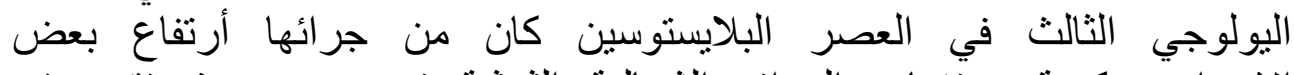

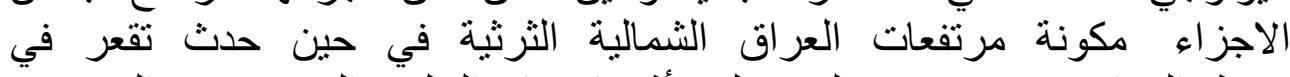

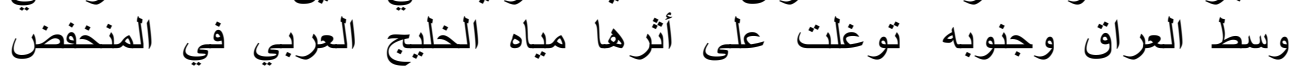

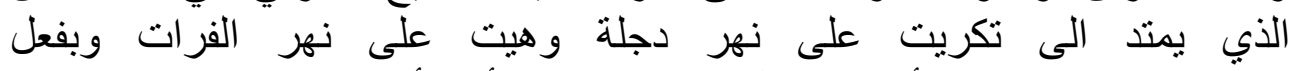

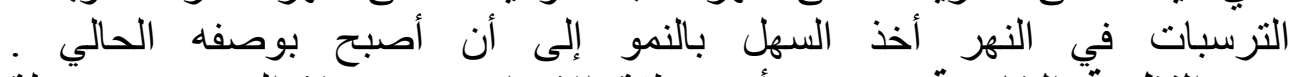

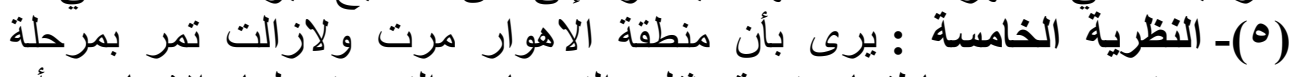

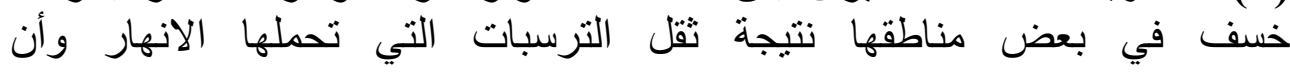

$$
\begin{aligned}
& \text { ( ) أقبال عبد الحسين أبو جري،الاثار البيئية لتجفيف الاهوار في جنوب العراق، أطروحة }
\end{aligned}
$$

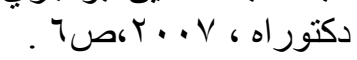




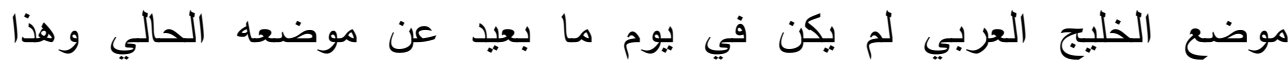

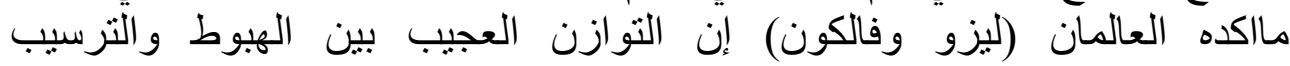

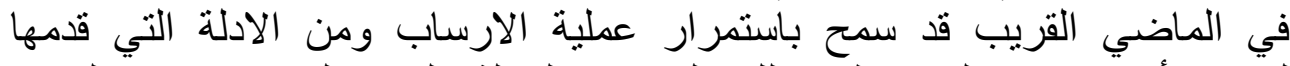

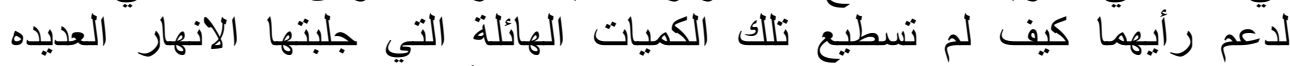

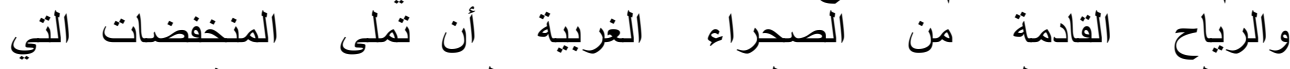

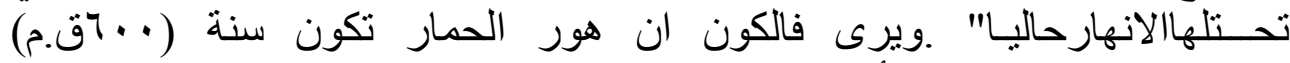

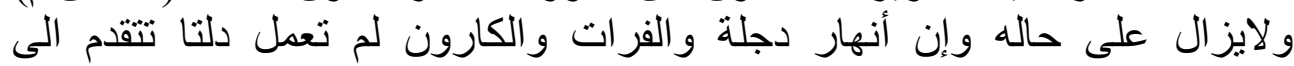

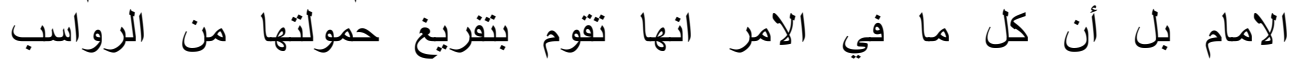

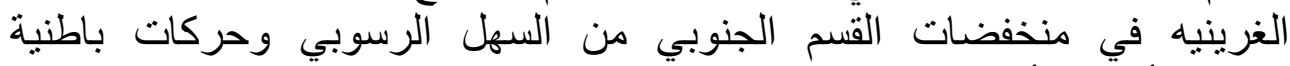
تكتونية أعقبها أنحناء محدب تراك اكت فئ في في الماضي الالف الامتار المكعبه

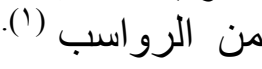

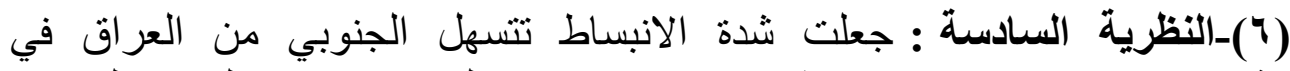

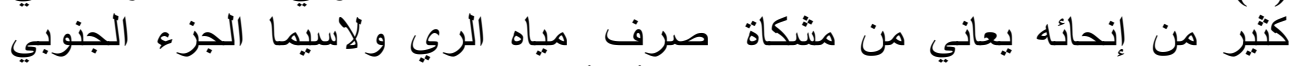

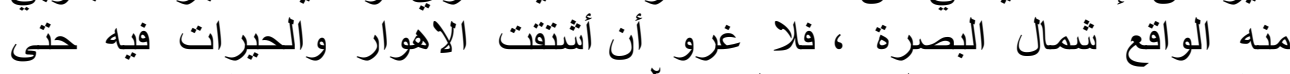

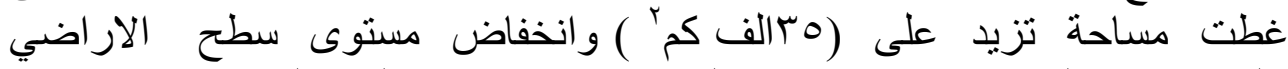

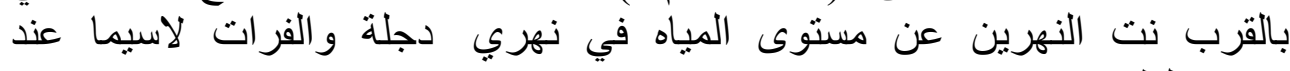

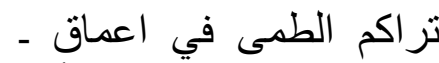

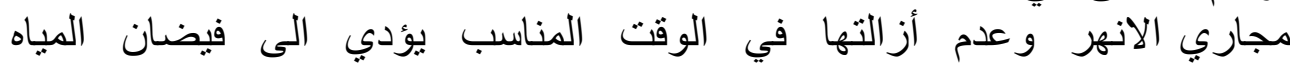

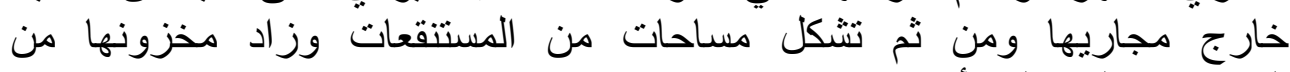

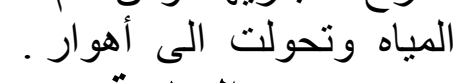

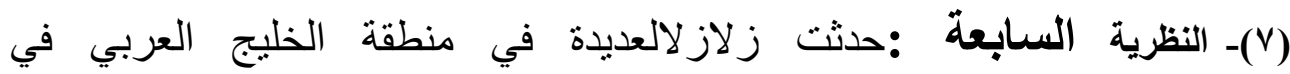

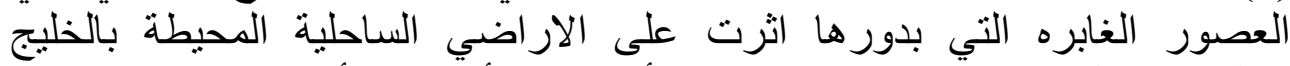

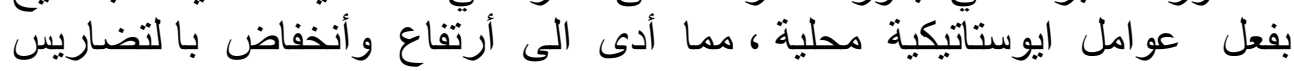

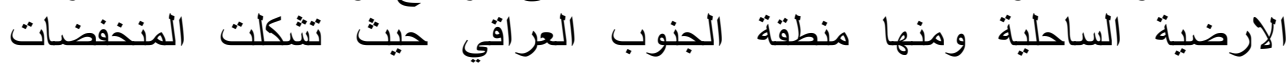

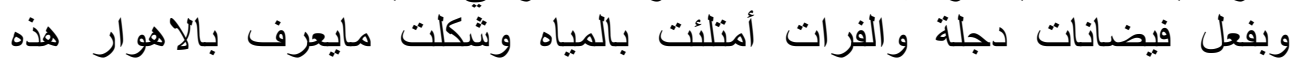

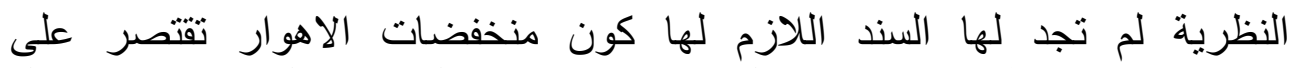

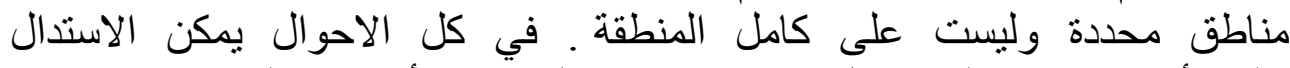

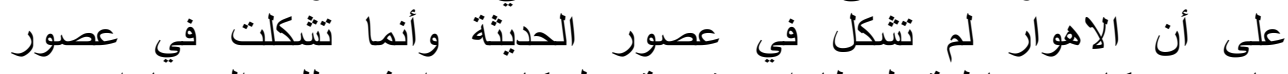

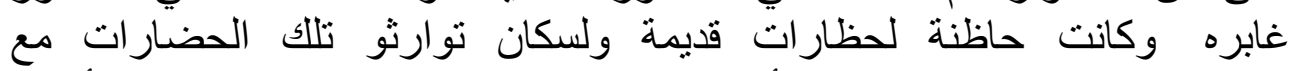

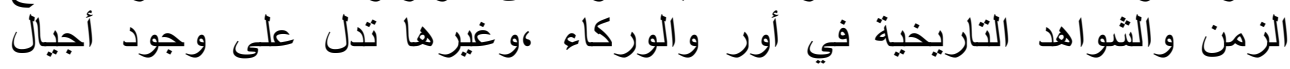

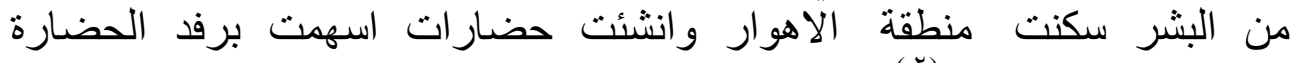

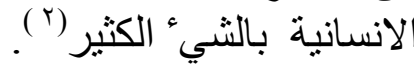

') أقبال عبد الحسين ابو جري ،الاثار البيئة لتجفيف الاهوار جنوب العراق ،(أطروحة دكتوراه)

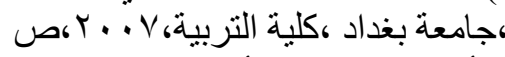

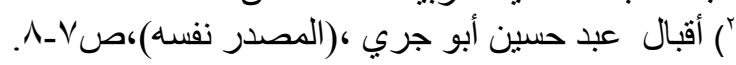




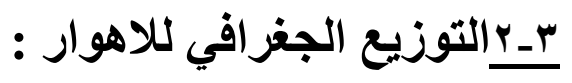

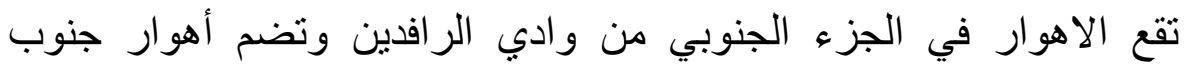

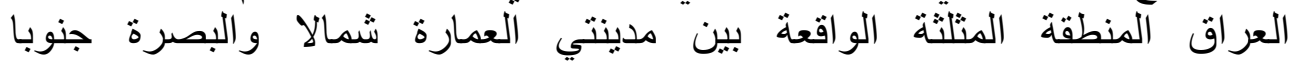

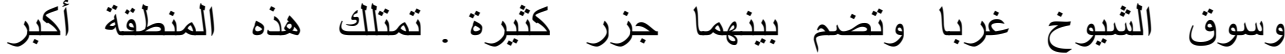

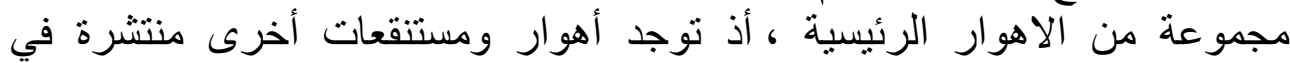

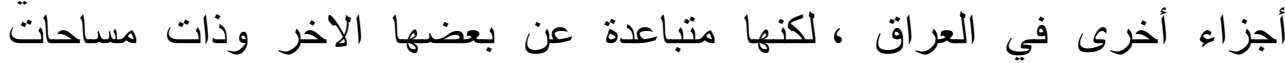

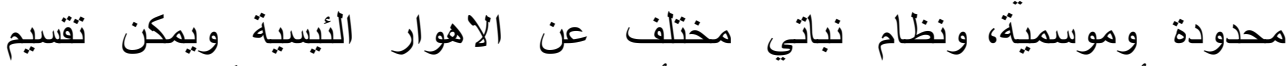
الاهوار أو (توزيعها الجغرافي ) الى أربعة مجموعات وني وهي كالآتي : اـ اهوار شرق نهر دجلة وتمتد بين محافظة واسط شمالا الى الاهوار جنوبا

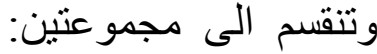

الاولى / الاهوار بين واسط وميسان

الثانية / أهوار ممتدة بين نهر دجلة والحدود الثرقية العراقية الايرانية وأهم

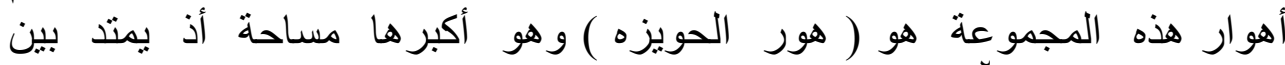

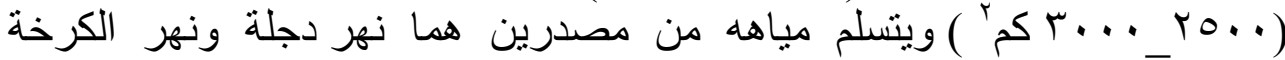

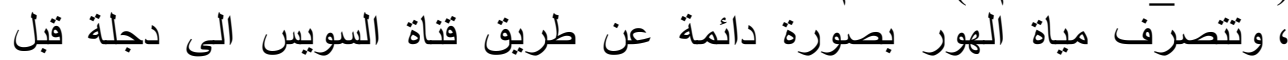

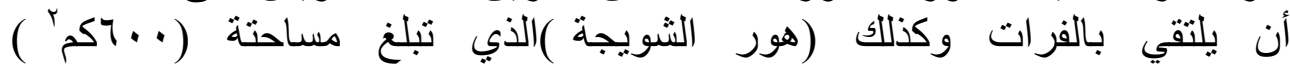
وتنصرف الية المياة من الاودية المنحدرة من المرتفية الأفيات عند الحدود الثرقية

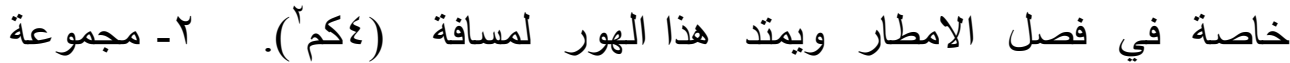

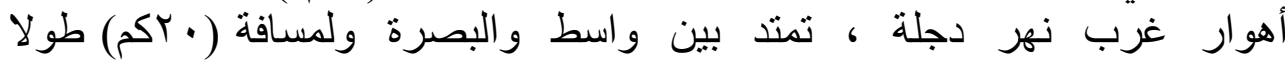

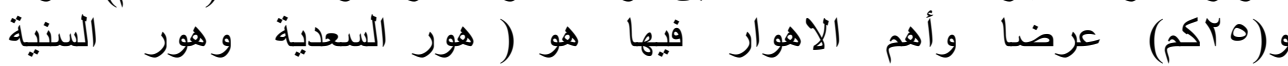

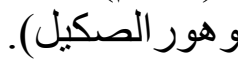

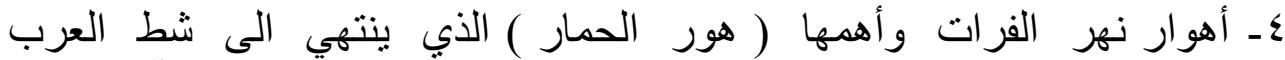

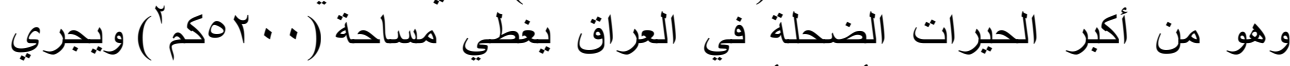

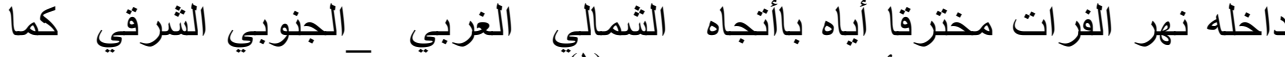
تصب داخله العديد من أفرع نهر الفرات بات (').

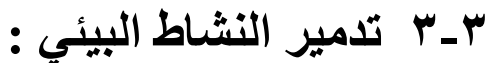

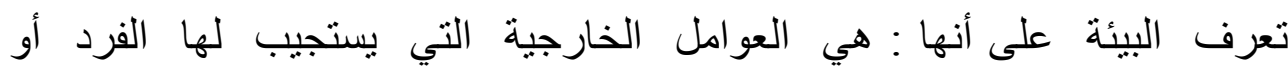

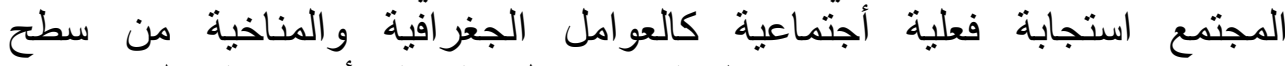
ونبات وموجودات وحرارة ورطوبة وعوامل ثقافية وأجتماعية التي تسود

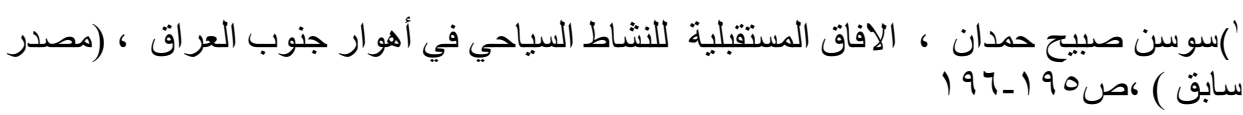


وتؤثر في حياة الفرد والمجتمع ، وتتشير لفظة البيئة أيضا الى الوسط الذي لهي

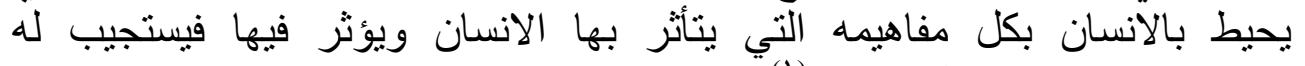

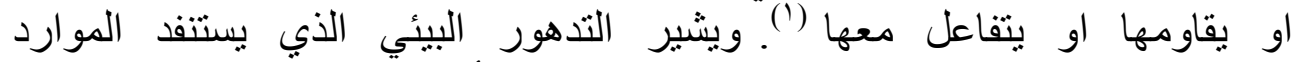

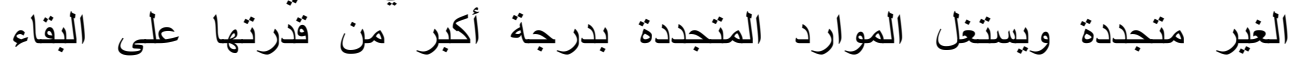

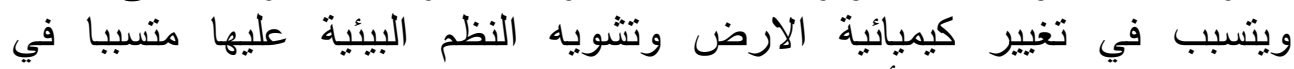
حدوث اضرار لايمكن أصلاحها من الارض وضائل والماء والهواء في بيئة المواقع فئ

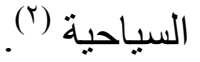

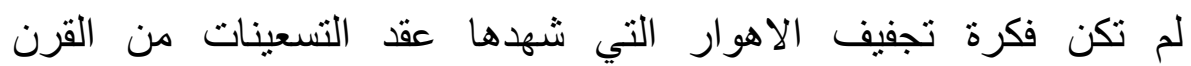

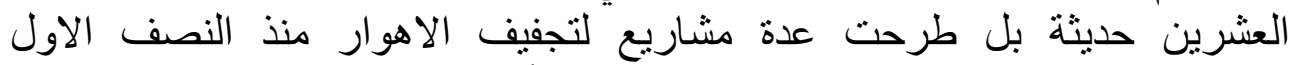

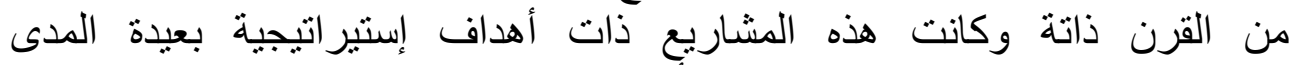

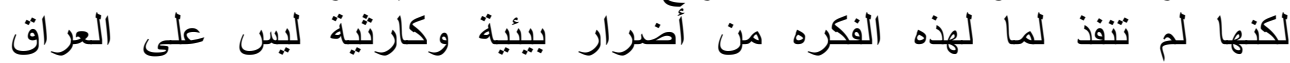

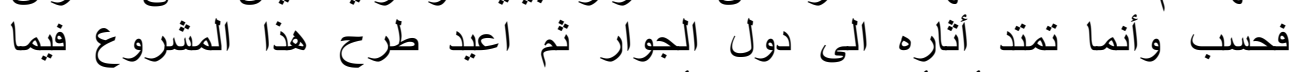

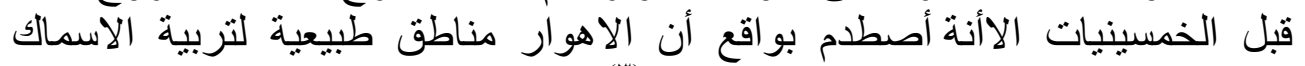

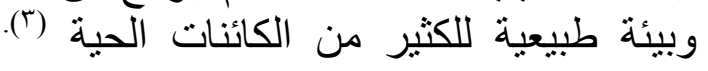

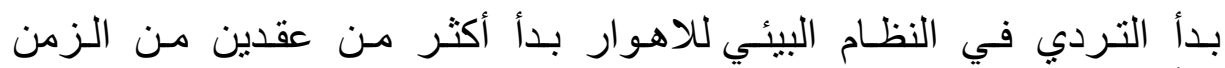

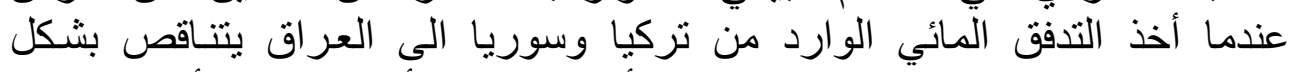

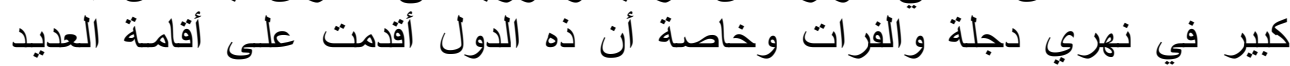

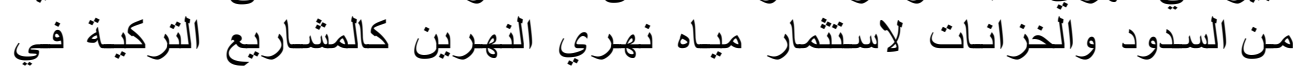

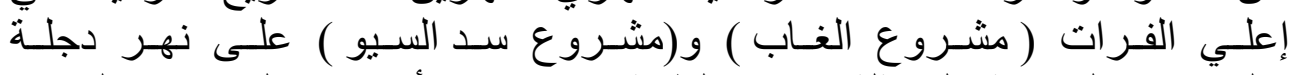

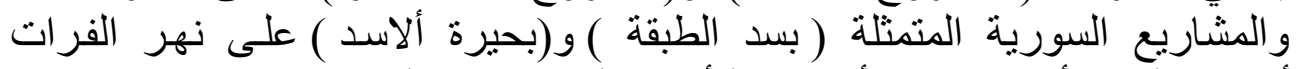

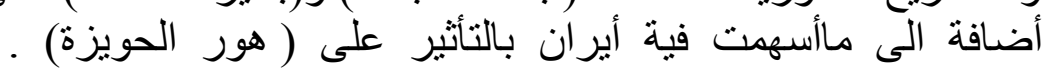

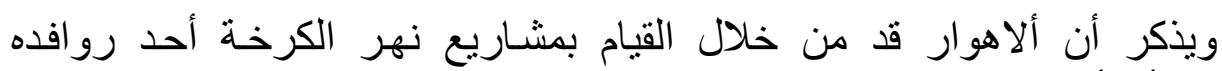

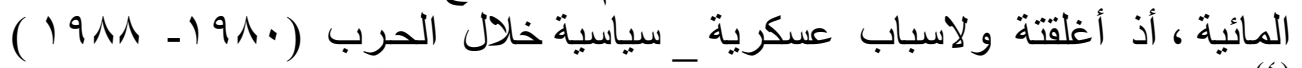

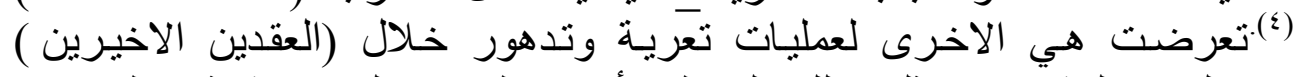

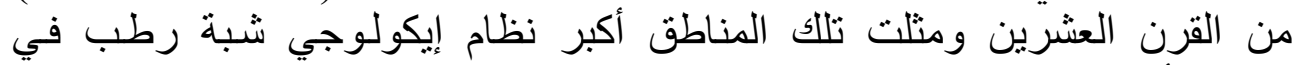

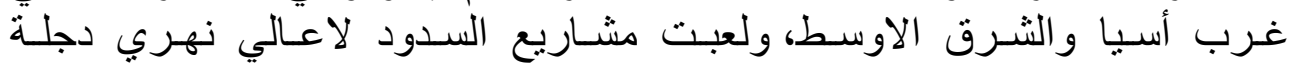

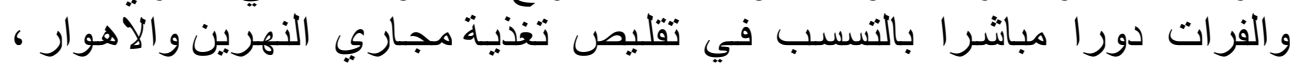

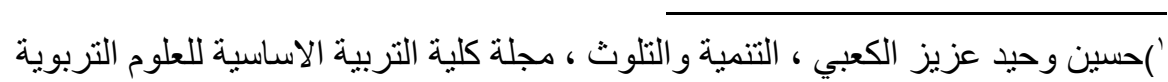

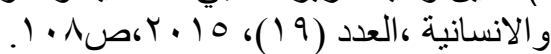

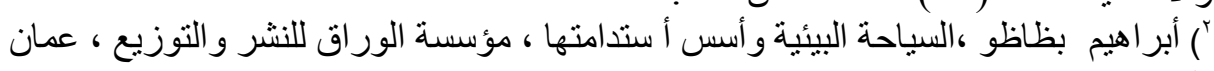

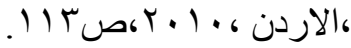

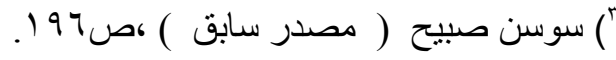

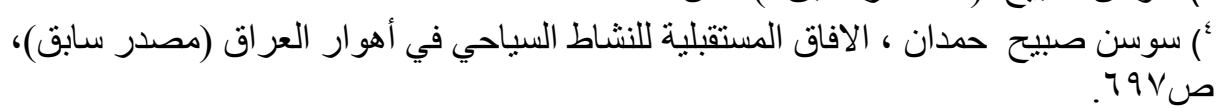


حيث أدى ذلك الى الجفاف وتقلص فترات هطول الامطار الى تظاؤل كمية

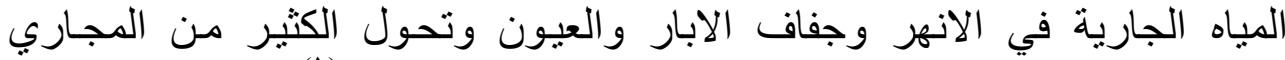

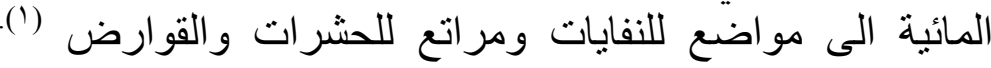

ولم تقتصر عواقب بناء السدود على حجز المياة وتدفقها عن منطقة

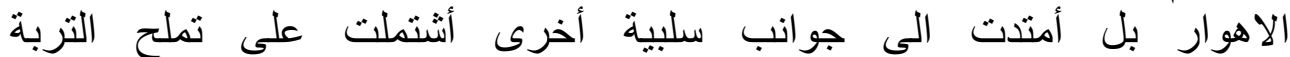

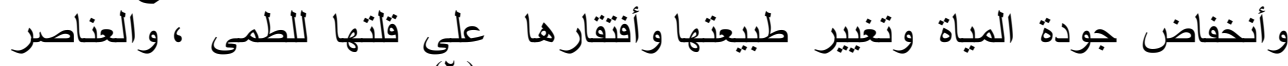
الغذائية الني كانت تعطي نربة الاهوار خلغير خصوبنها (r).

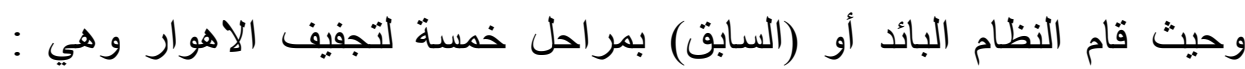

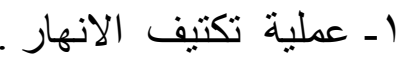

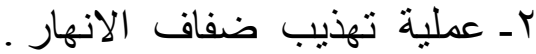

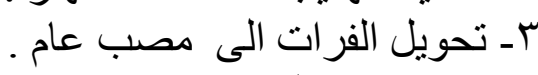

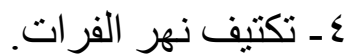
هـ تقسيم الاهو ار (r).

نتج عن عمليات التجفيف مجموعة من الاثار هذه الاثار هي (بيئية

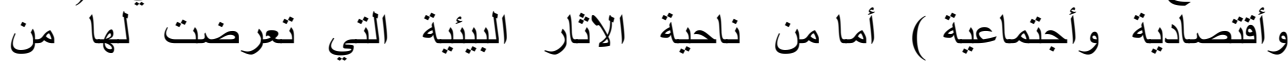

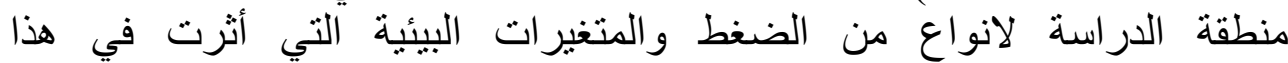

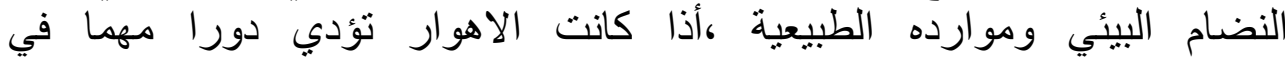

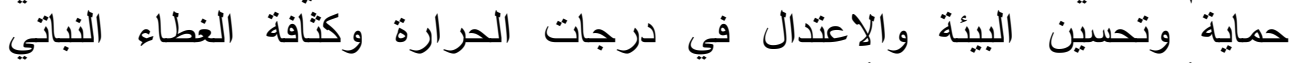

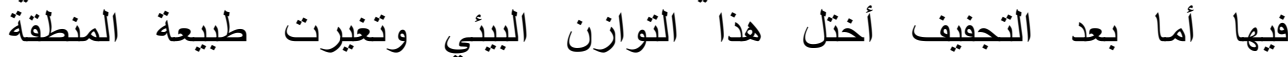

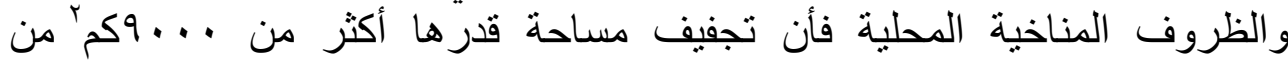

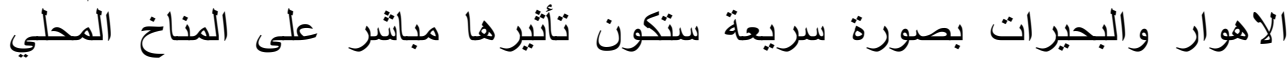

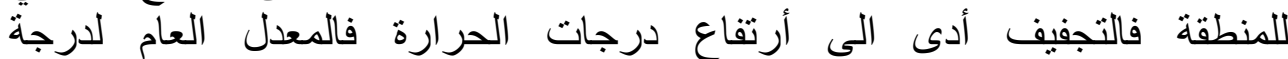

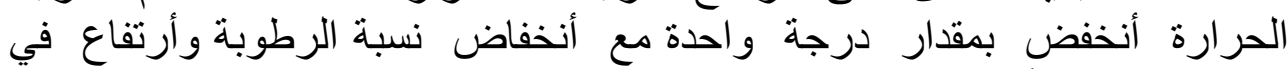

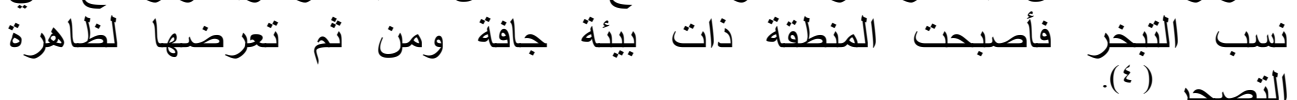

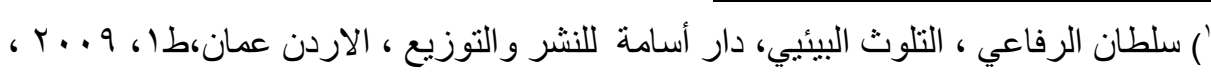

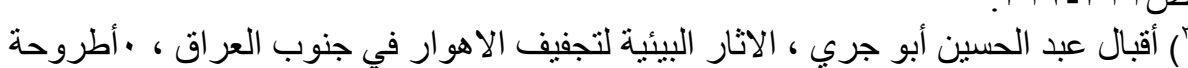

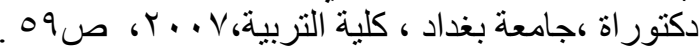

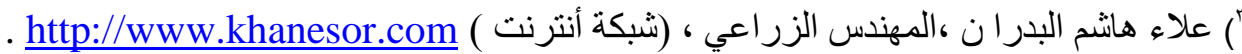

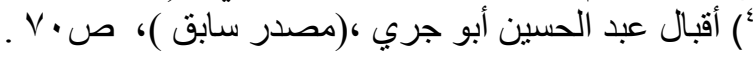




\section{بــ أعادة تأهيل منطقة الاهوار :}

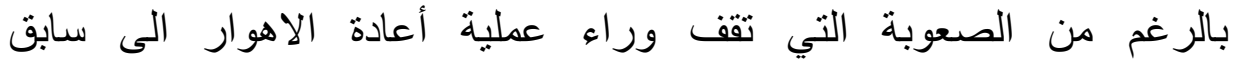

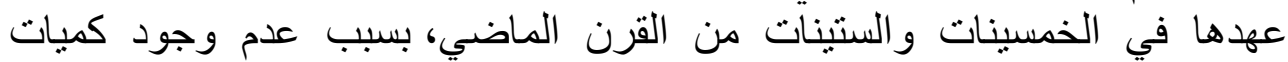

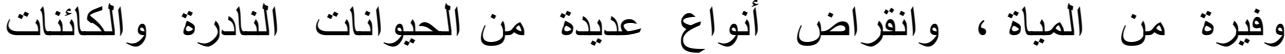

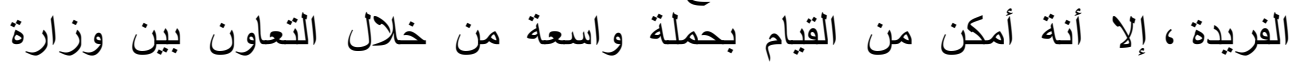

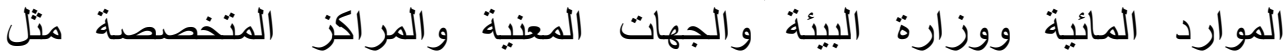

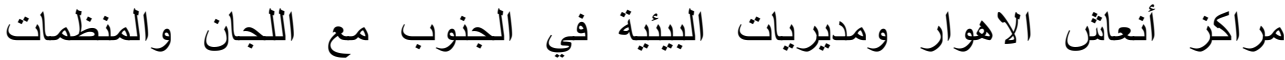

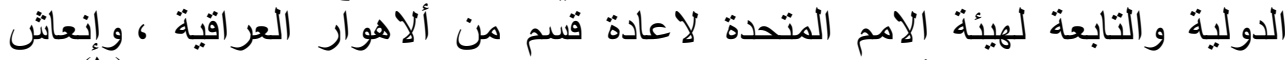

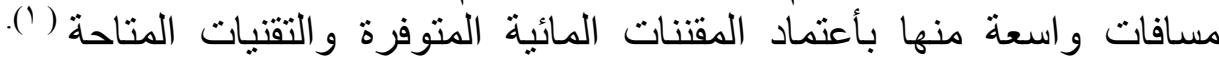

ويجب توفير عدد من الامور حتى يمكن إنعاش الاهوار في الوقت الحاضر

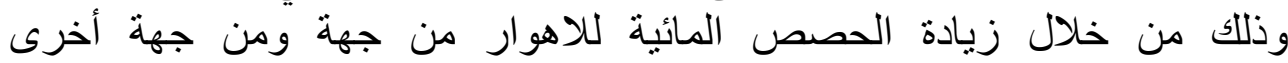

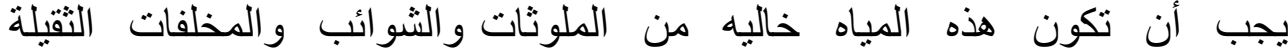

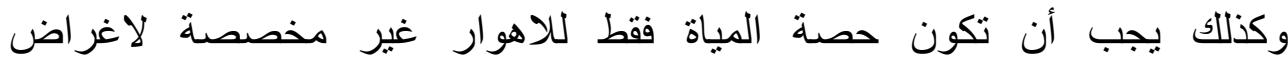
الزراعة والاغراض الصناعية وغيرها.

أما هناك عدد من الدصاعب التي تقف حائلا امام أستكمال النظام البيئي للاهوار الى سابق عهده ناتج عن : رلئ

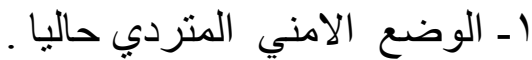
r آـ نقص في الكو ادر البشرية المتخصصة لتنفيذ الخطط والبرامج المتعلقة بانعاش

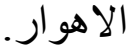

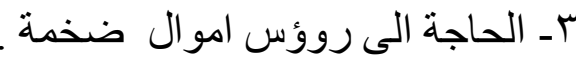
عـ الحاجة الى قو انين لتنظيم الصيد في المسطحات المائية والبحير ات وكو ادر لتنفيذ

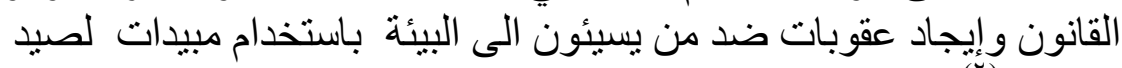

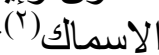

تتم عملية أنعاش الاهوار عن طريق توفير الخدمات الانسانية والجهود الحكومية للاعادة تأهيل و وأنعاش (الاهو اري) من خلال عدة مشاريع منها :

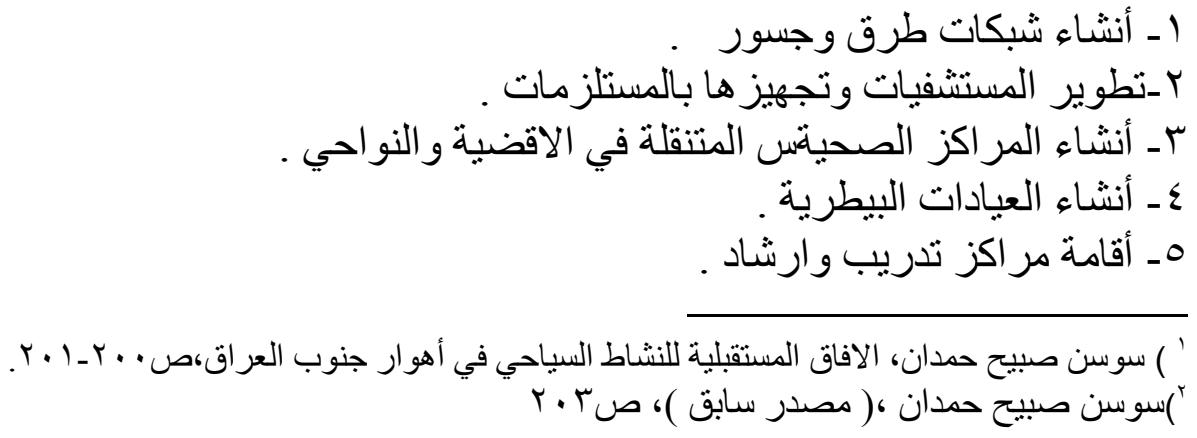


7ـ _انشاء معامل تعليب أسماك.

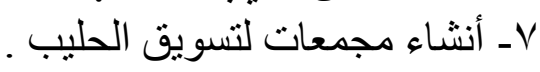

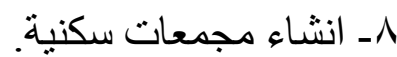

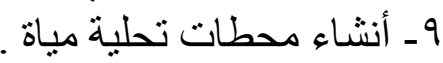

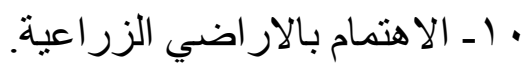

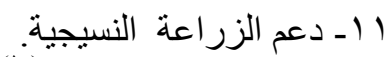

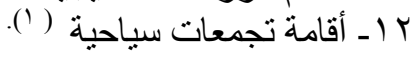

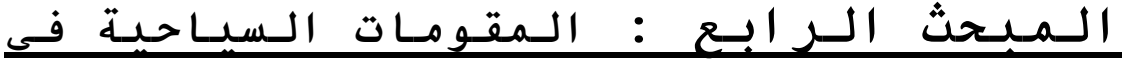

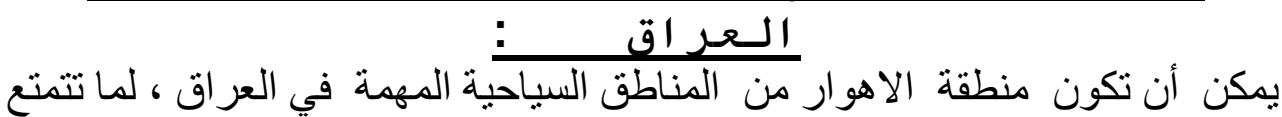

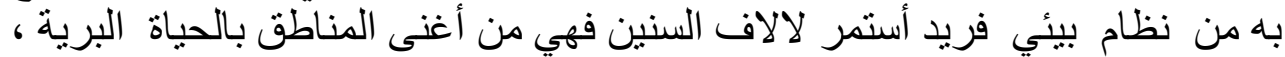

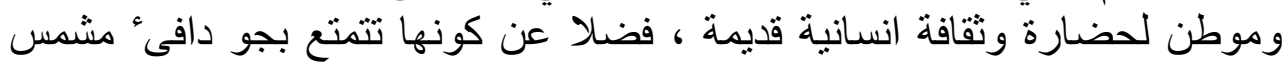

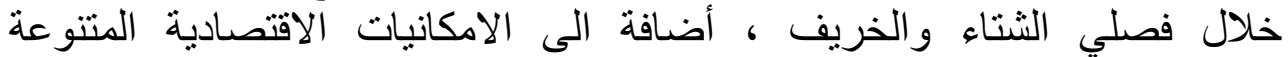

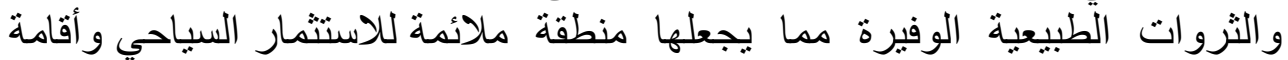
المنتجعات السياحية الجاذبة للكثير من السياح للتعرف على والئه واحدة من المناطق

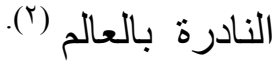

حيث أن هناك وسائل وطرق و أقتراحات عديدة لتطوير النشاط السياحي في أي

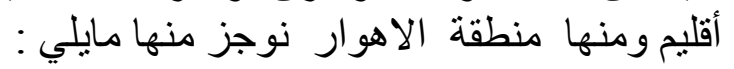

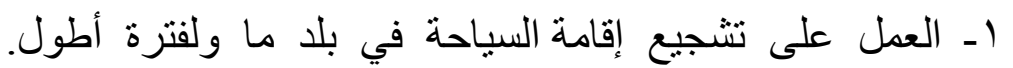

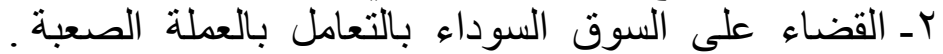

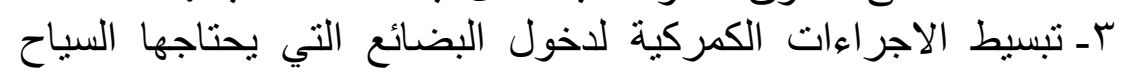

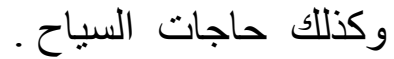
ع ـ تشجيع الاستثمار في صناح صناعة السياحة و الفندقة هـ تطوير المصادر البشرية العاملة في صناعية العاعة السياحة و الفندقة.

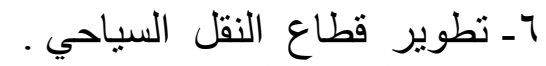

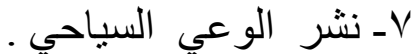

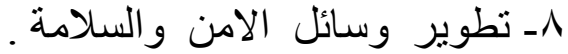
9- إنشاء مر اكز سياحة وطنية .

') شبكة الانترنت ، علاء هاشم البدران http://www.khanesor.com

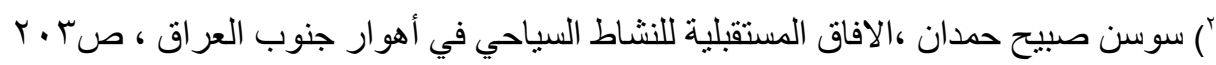


• ـ ـ تخصيص جزء من إيرادات السياح لتتمية الموارد السياحية (1).

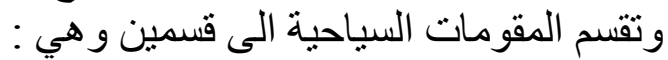

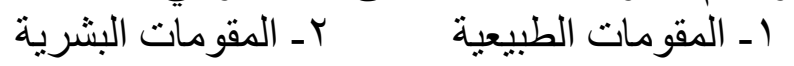

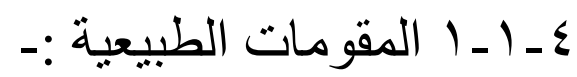

أن المميزات الطبيعية الخاصة بهذه المنطقة تتمثل بالمسطحات المائية الواسعة

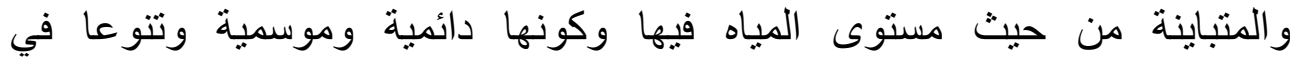

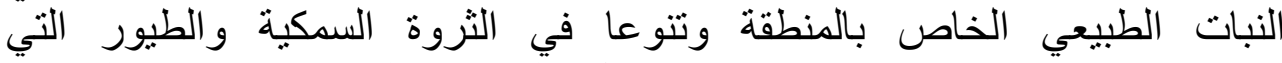

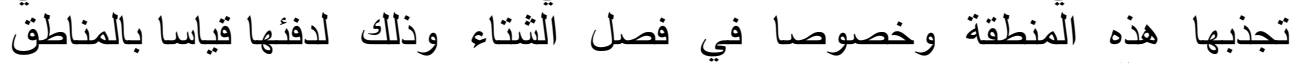

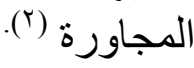

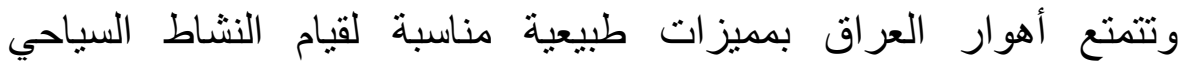
فهي تجمع بين جمال الاهوار الطبيعي كونها مسطحات ماتئية واتئية واسعة الانتشار

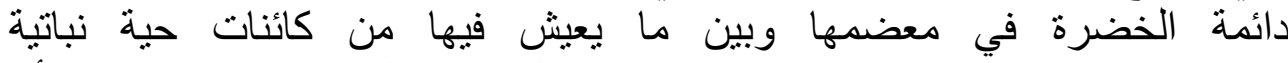

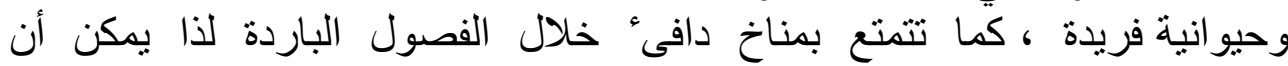

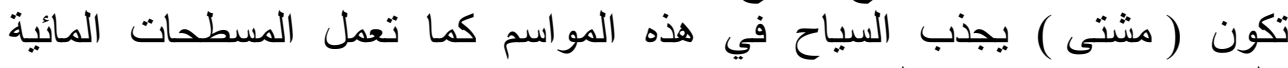
على تخفيف من حده الحراره صيفاح فيا

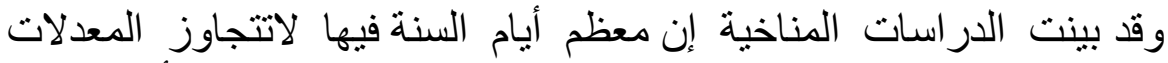

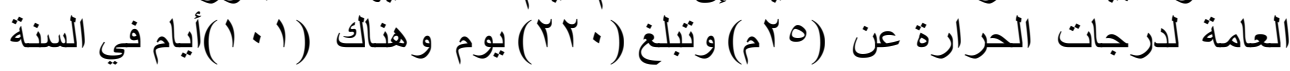

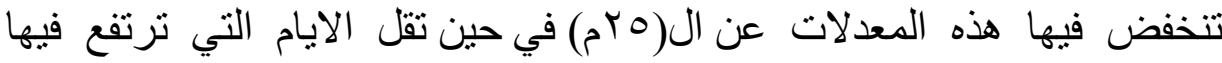

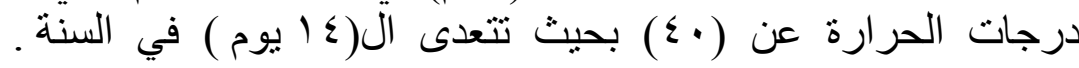

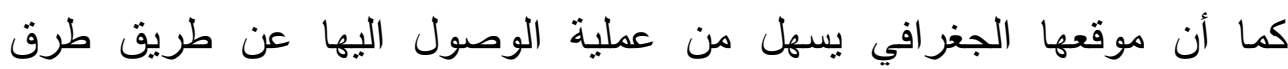
النقل المتنوعة فهنالك طرق برية التي تربط الاهوار بمحافظات العراق اق وهي:-

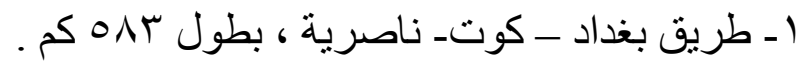

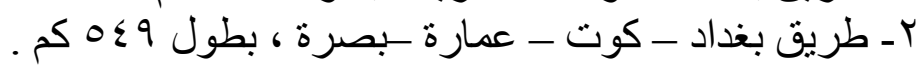

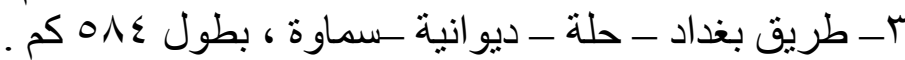

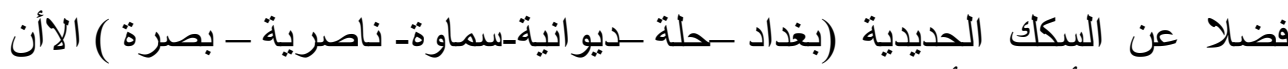

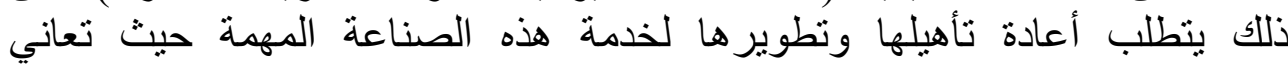

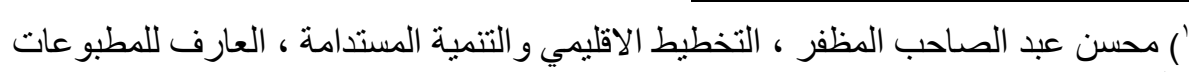

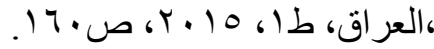

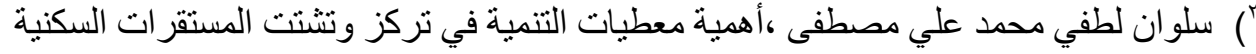

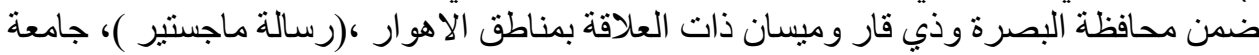

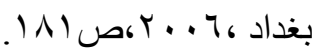




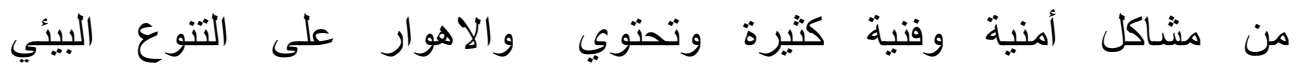

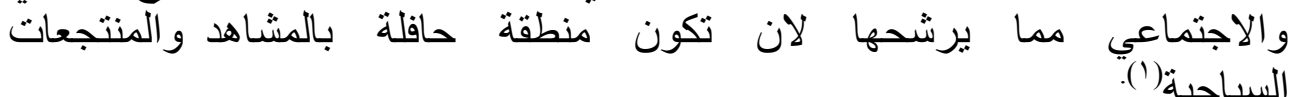

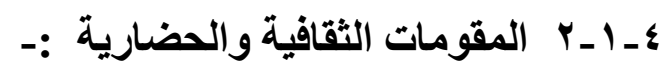

الهمت هذه الطبيعة الرائعة سكان الاهوار الاوائل (السومريون) على بناء

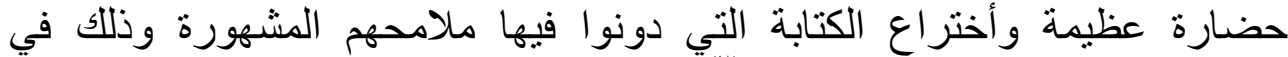

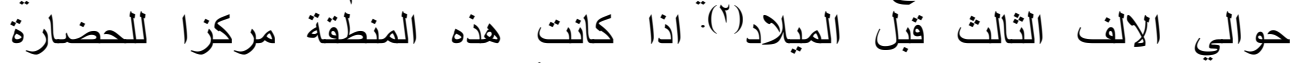

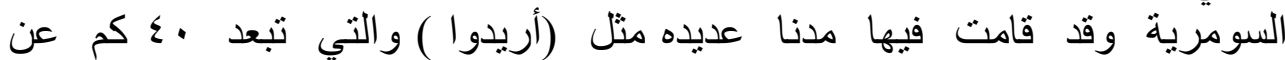

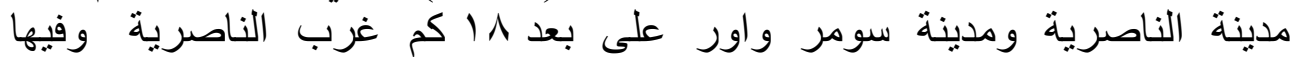

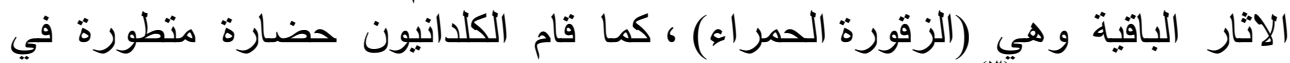

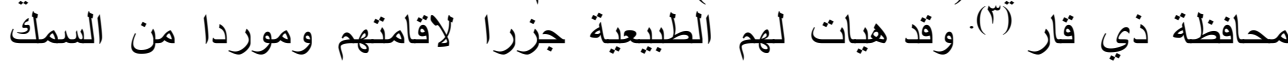

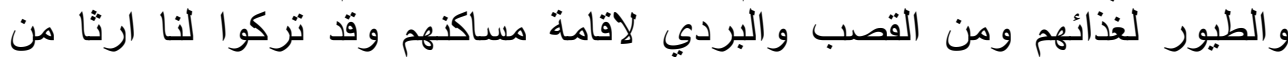

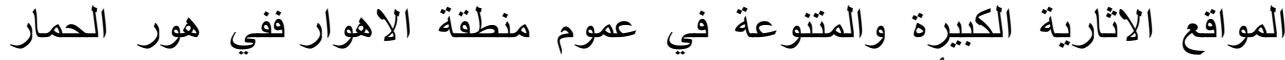

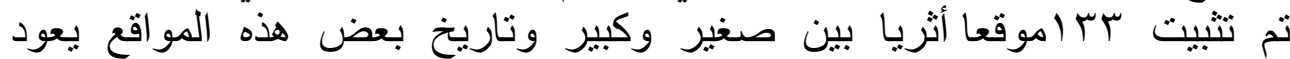

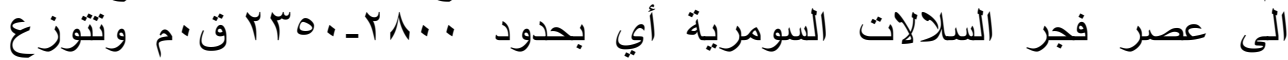

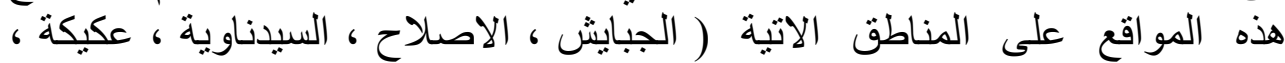

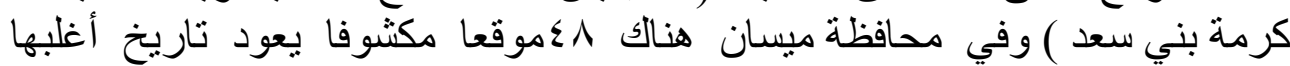

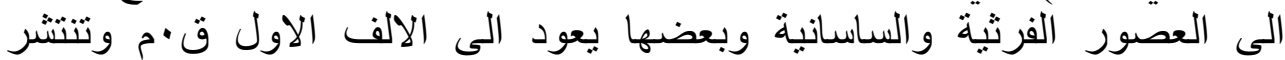

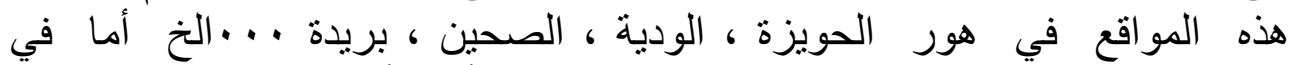

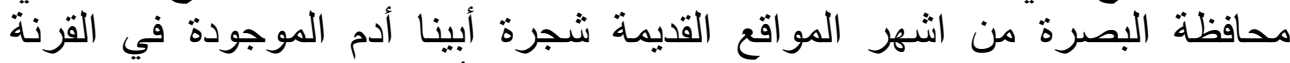

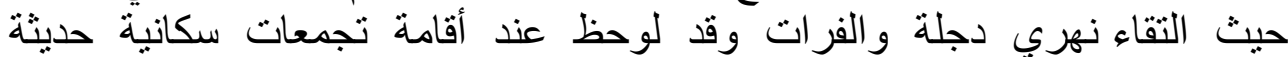

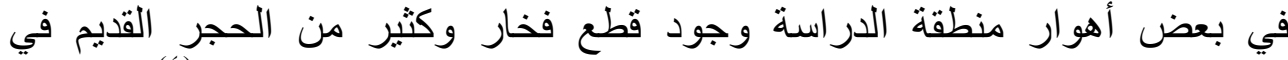

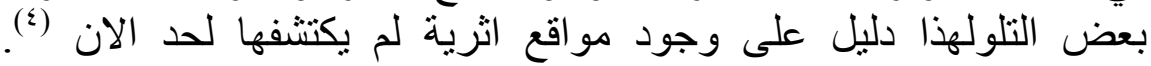

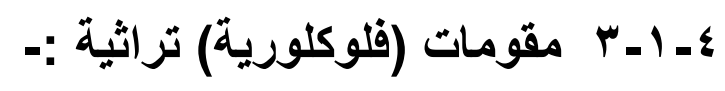

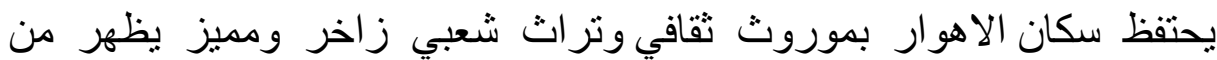

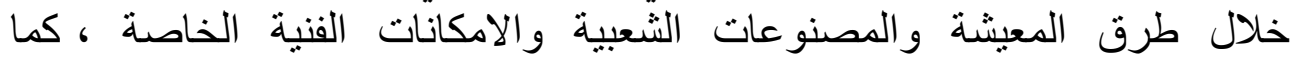

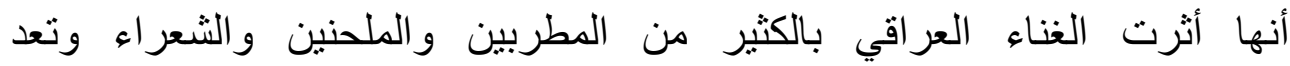

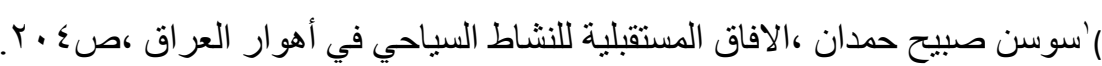

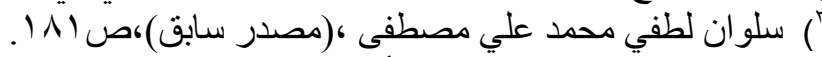

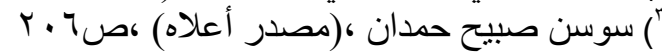

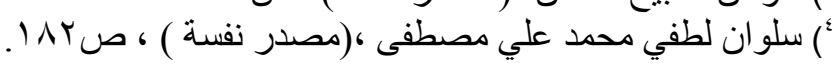


المنازل المنتشرة و العائمة في المسطحات المائية والمضايف جزء المئه من هذا

الفلكلور خاصة انها تعتمد على البيئة الطبيعية في بنائها (1).

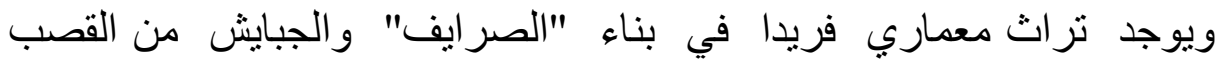

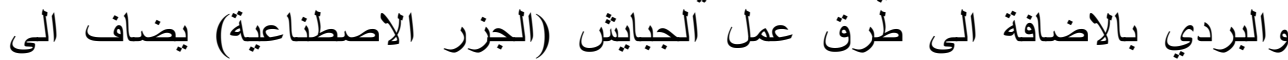

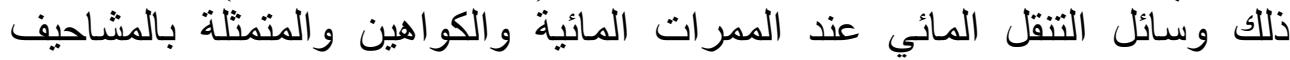

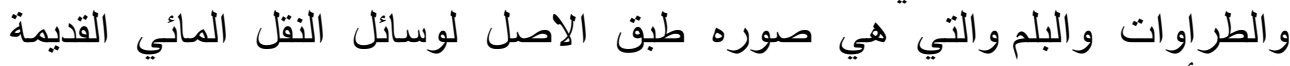

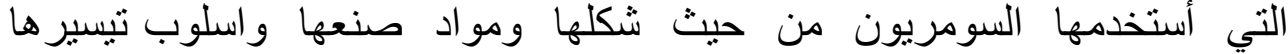

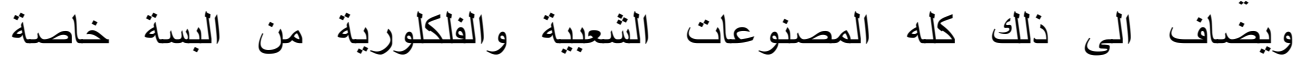

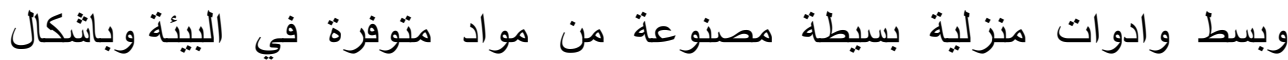

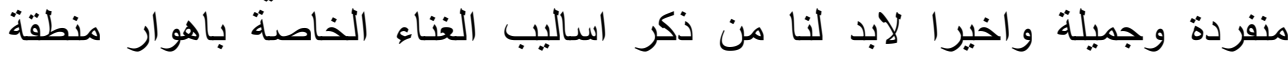

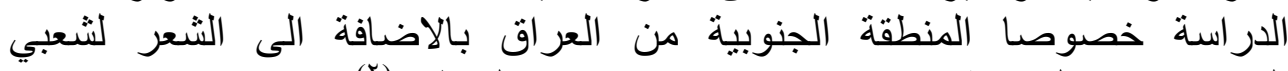
الخاص وهذا كله ارثا فنيا جميلا يعتز به ابناء المنطقه (Y).

عـ 1-ـ المقومات الاقتصادية :-

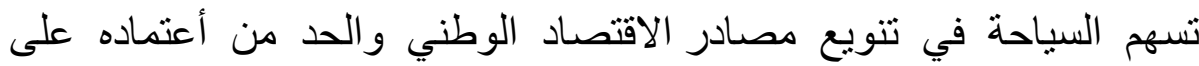

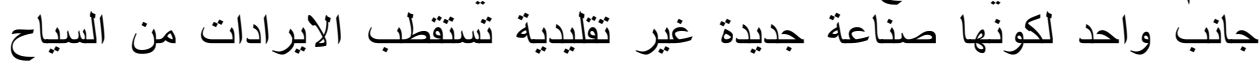

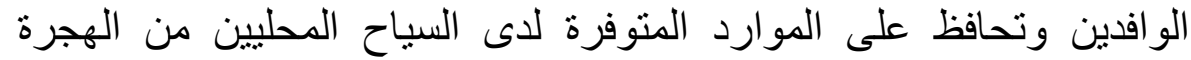

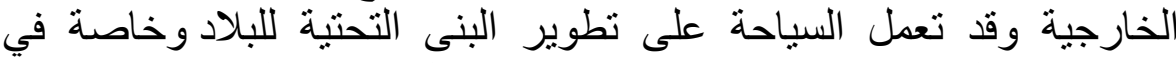

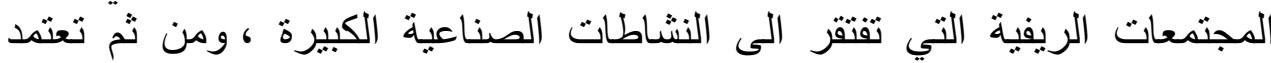

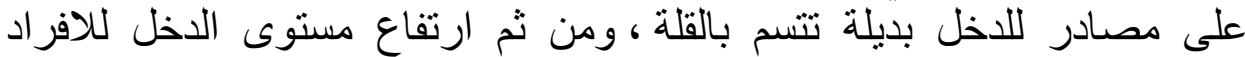

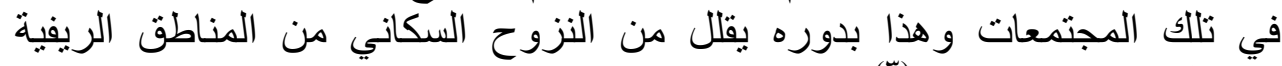
إلى المناطق الحضرية (َ).

$$
\begin{aligned}
& \text { ومن أهم هذه المقومات هي :- } \\
& \text { 1ـ الثروة النباتية :- }
\end{aligned}
$$

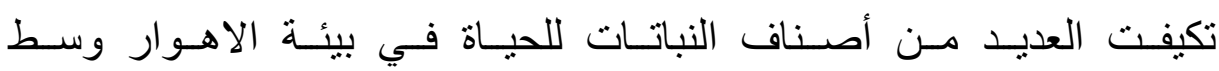

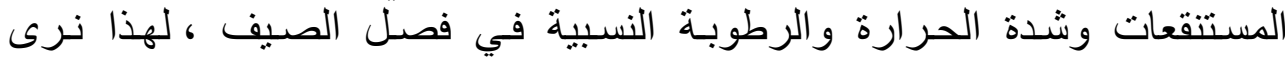

') سوسن صبيح حمدان،الافاق المستقلية للنشاط السياحي في أهوار جنوب العراق ، (مدر

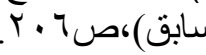

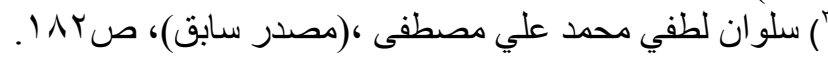

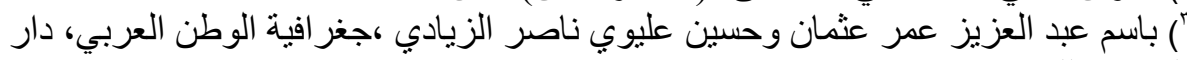

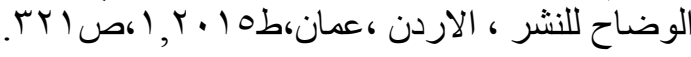




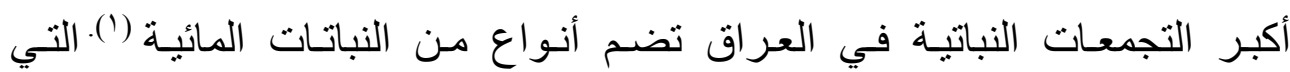

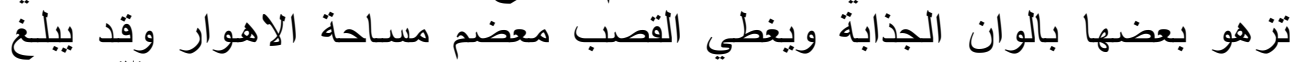

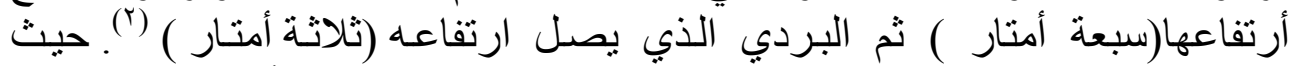

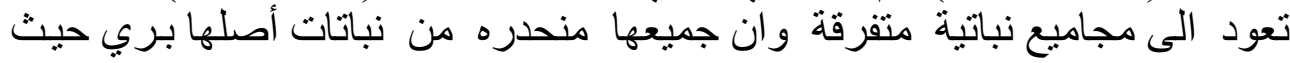

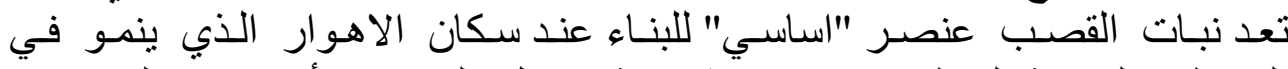

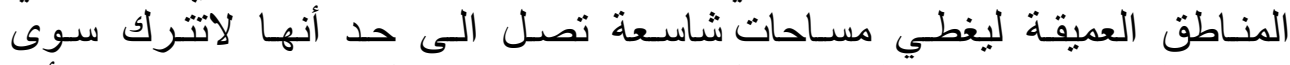

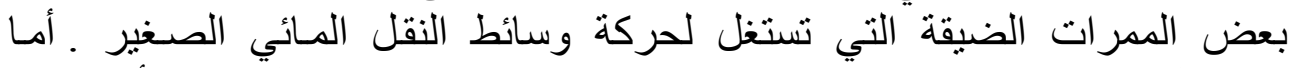

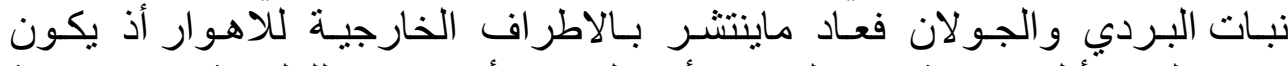

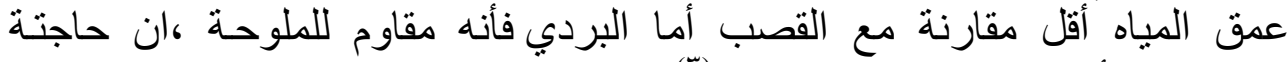

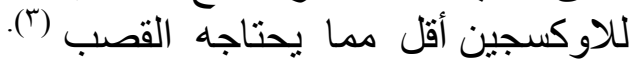

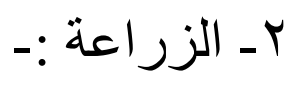

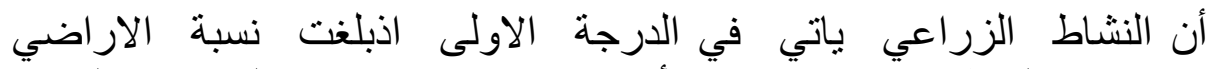

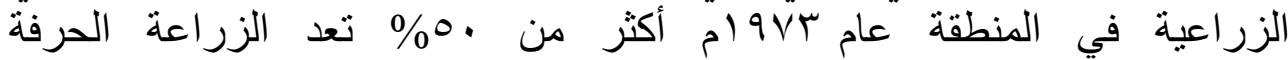

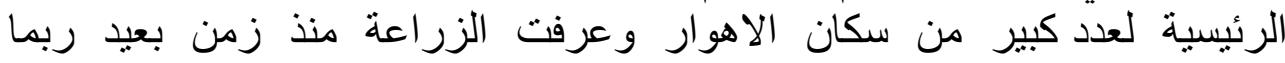

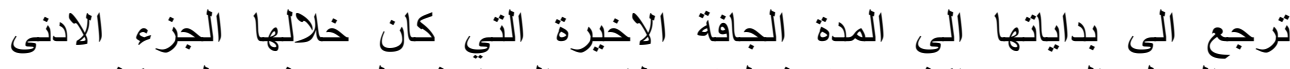

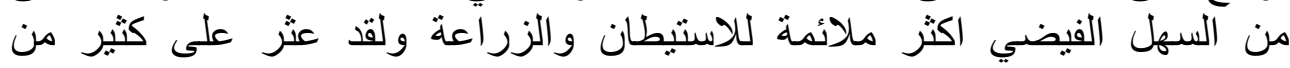

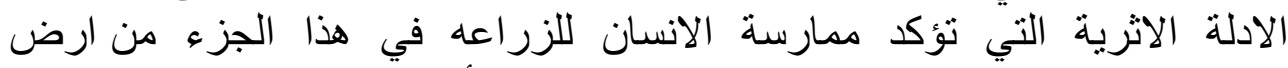

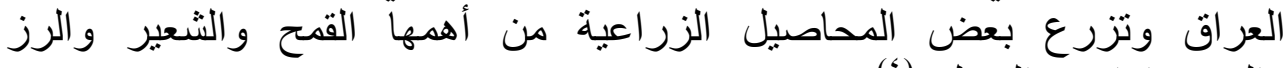

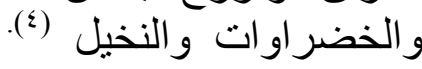
بـ الثروة الحيو انية :-

تتميز الاهوار بييئة طبيعية كان لها الاثر في تحديد الثروة الحيوانية التي

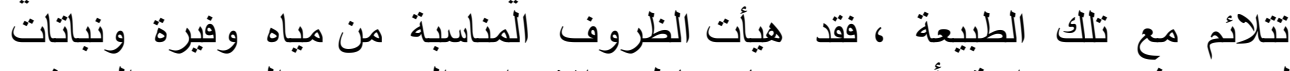

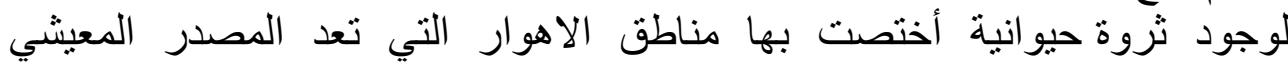

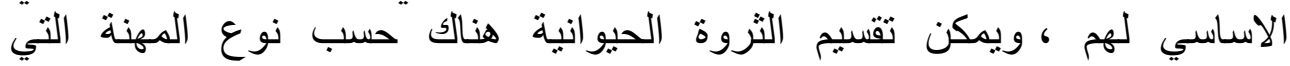

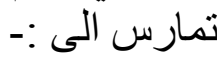

') أقبال عبد الحسين أبو جري،الاثار البيئية لتجفيف الاهوار في جنوب العراق ،كلية تربية، جامعة

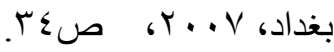
") سعد ابر اهيم حمد، تطوير واقع السياحة البيئية في جنوب العر اق فيمنطقة الاهو ار، ،المعهد التقني

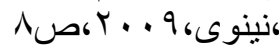
") سعدد ابر اهيم حمد، تطوير واقع السياحة البيئية في جنوب العر اق فيمنطقة الاهو ار، ،لمعهد التنتي

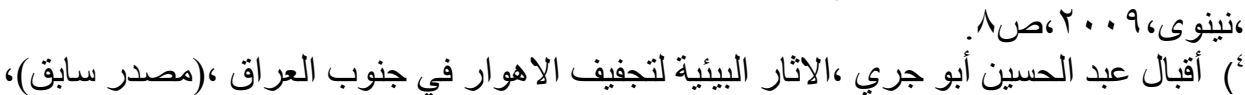


اـ تربية الحيوان :- يعد الجاموس الحيوان البارز في المنطقة لملائمتها بيئة

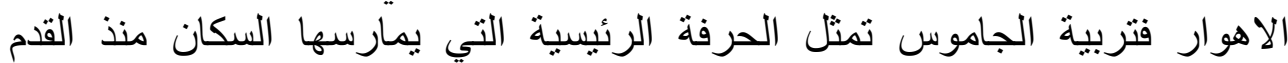

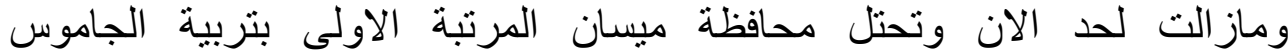

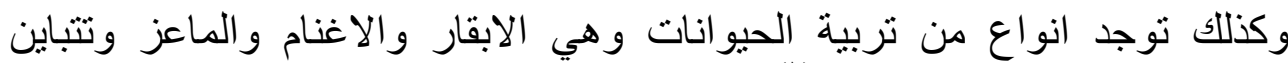
أعداده من منطقة الى اخرى (1) ترنية

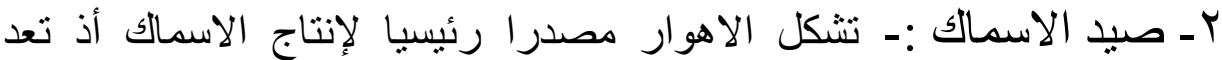

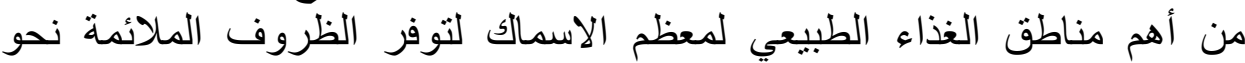
الاحياء النباتية بالإضافة الى هذاء فأن منطقة الأنياك

منطقة الاهوار تعد من المسطحات المائية الدافئة والخالية من التبارات التي في لاتئي

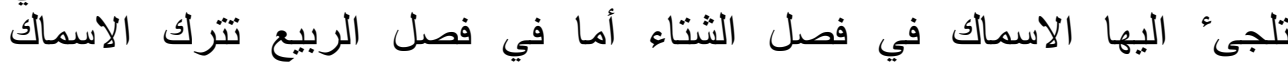

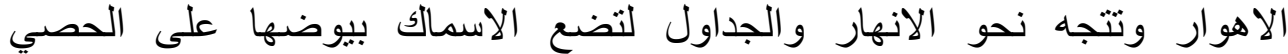

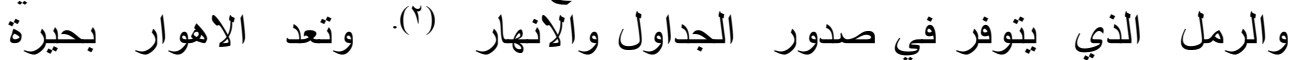

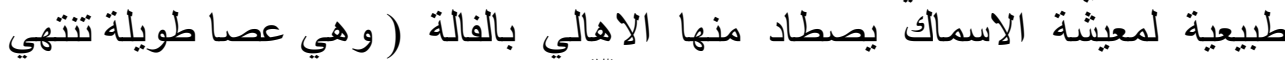
بكف حديدية ذات خمس أصابع او بشبكة )(").

r- صيد الطيور :- تشكل الاهوار في العراق على المستوى البيئي مجموعة

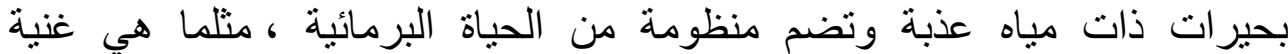

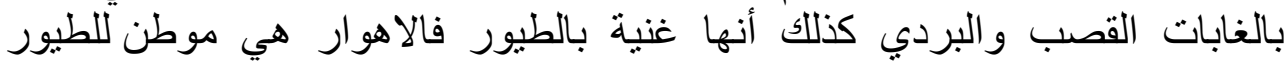

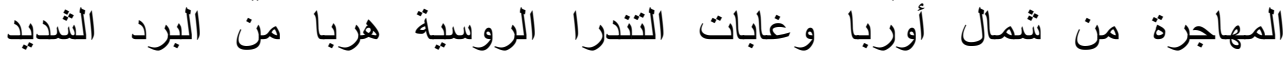

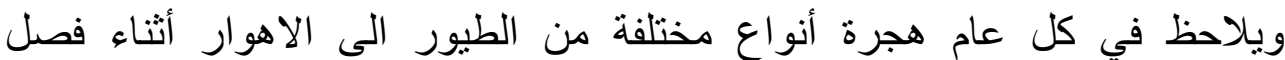

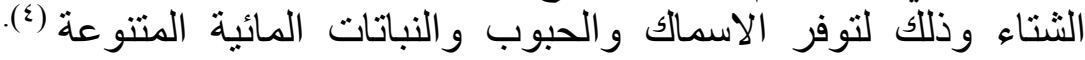
الثزوة النفطية :-

قد نم الكثف عن حقول نفطية في المنطقة من قبل شركة فرنسية ( إيراب )

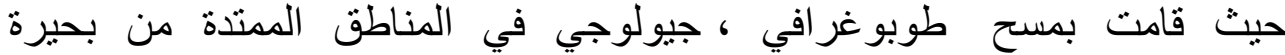

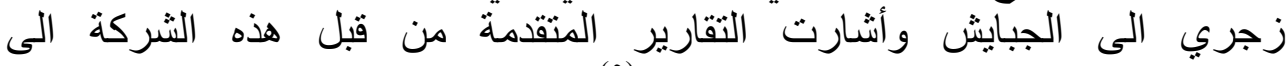
وجود كميات تجارية ضخمة من النفط (o).

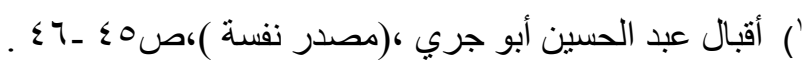

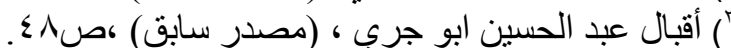

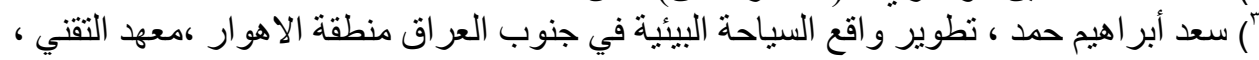

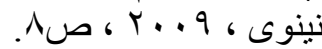

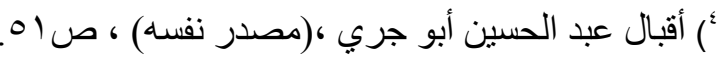

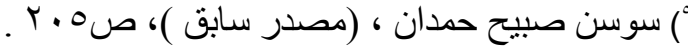




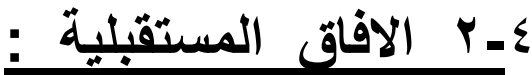

من المعلوم كانت الاهوار في السنوات السابقة في وضع منردي ومتدهور

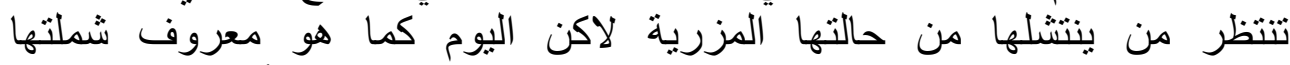

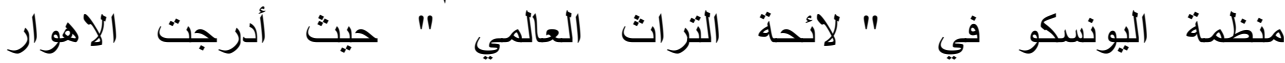

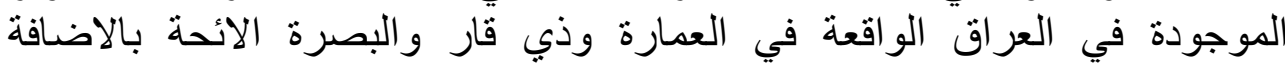

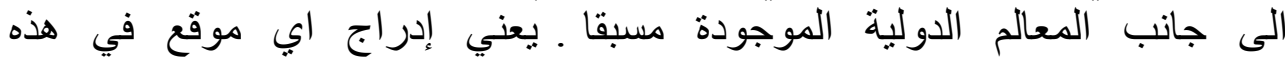

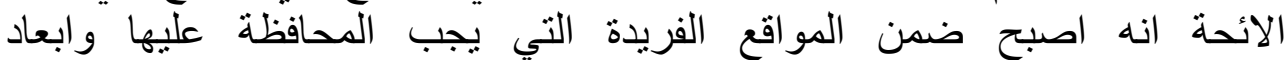

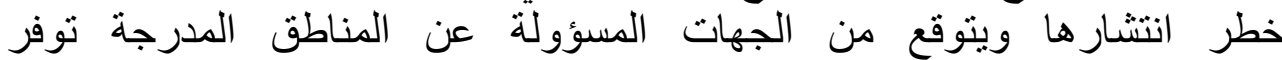

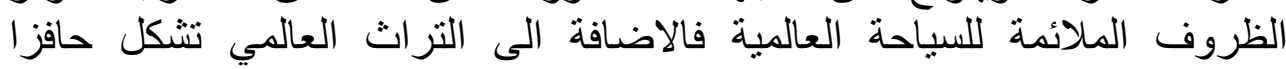

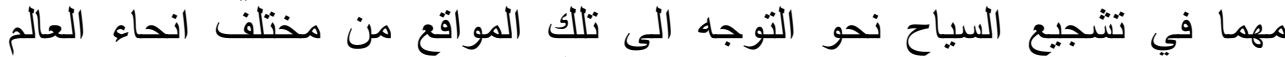

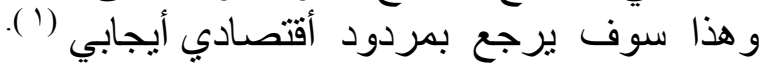

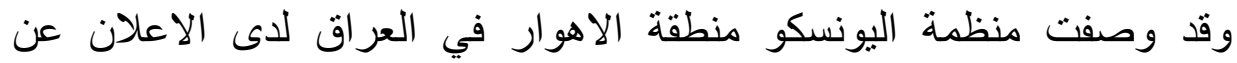

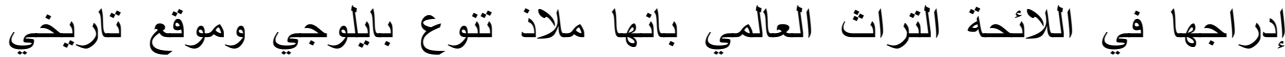

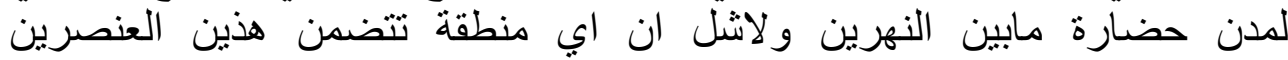

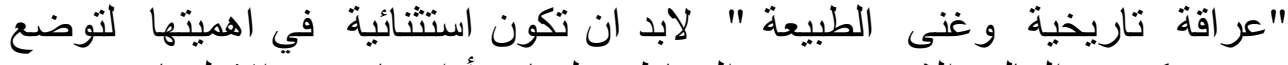

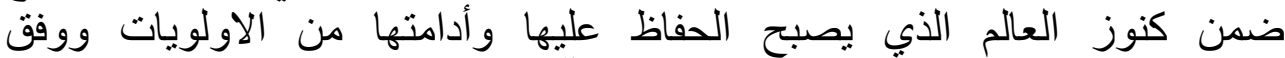

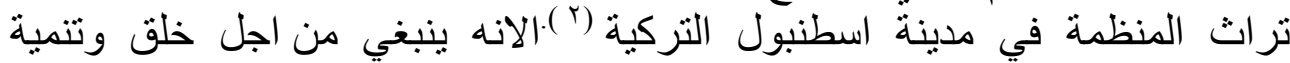

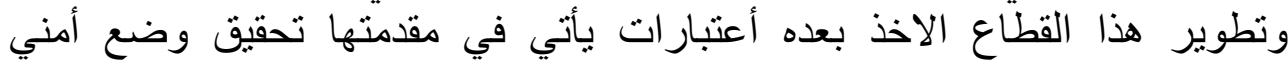

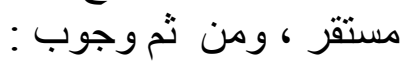

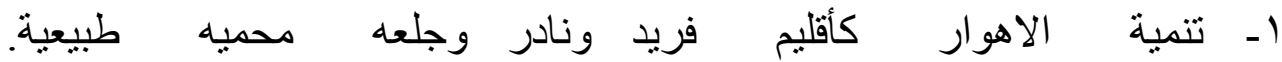

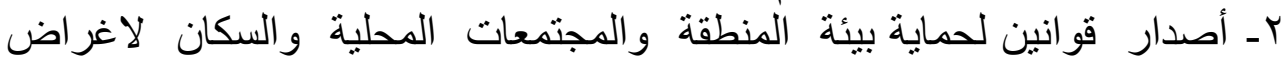
حماية

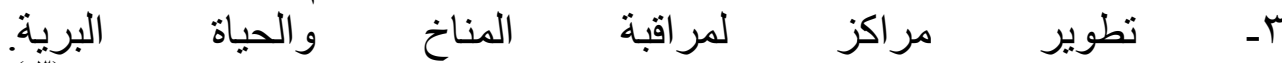

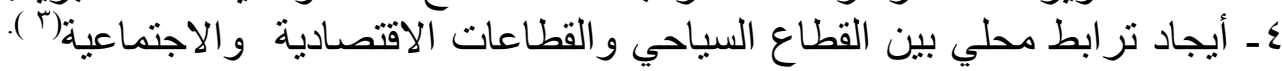

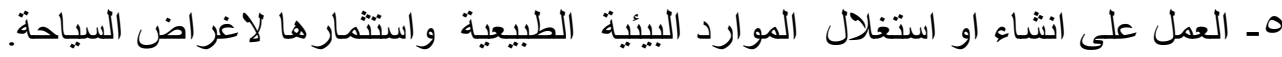

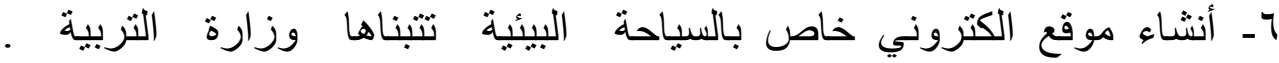

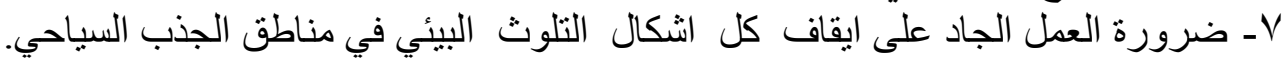

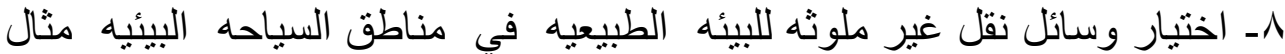

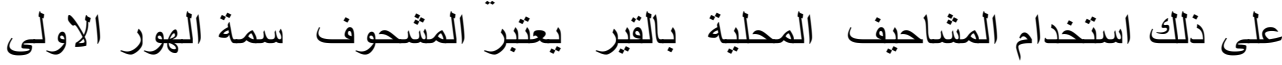

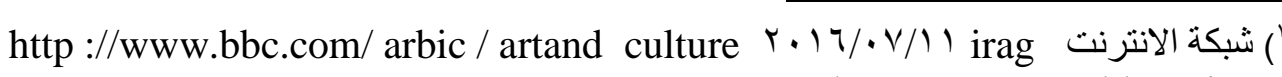
marshes unesco world neritage (') شبكة الانترنت (مصدر سابق).

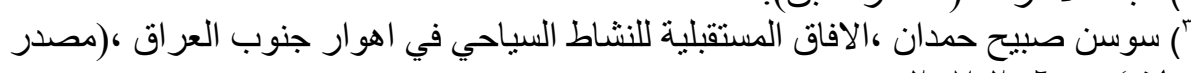


فهو يستخدم في صيد الطيور والاسماك والتنقل و هذه المشاحيف التي تسيرها ايادي الانسان دون محركات في الطيور

9 وـ دمج سكان المجتمع المحلي من خلال التوعيه و والتثقيف البيئي و والسياحي

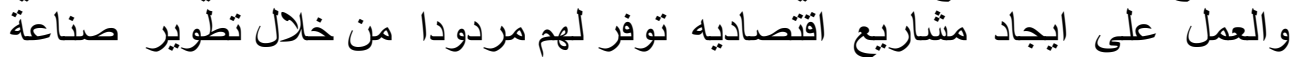
السياحة لتحسين ظروفهم المعانثيه (1).

ولكي تصبح منطقة الاهوار من الاماكن المهمه لممارسة النشاط السياحي خلال فصلي الخريف والشتاء بعد توفير المنطلبات السياحيه التالية :

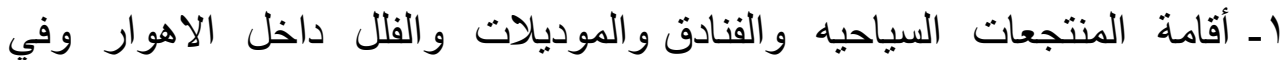

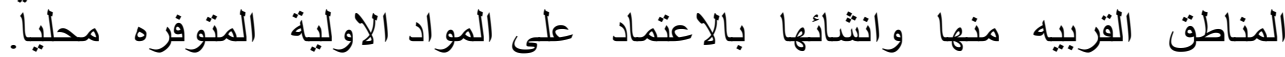

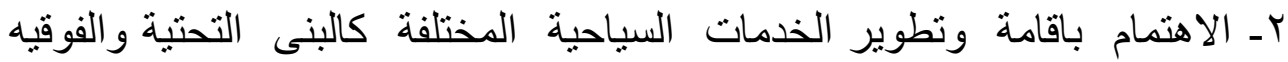

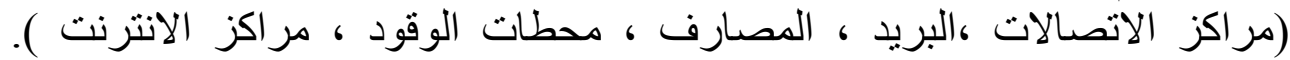

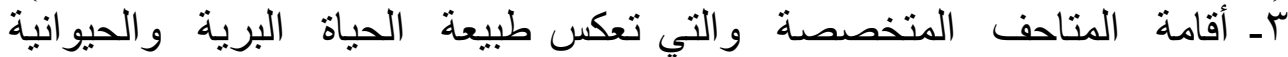

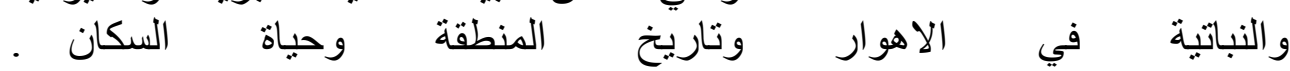

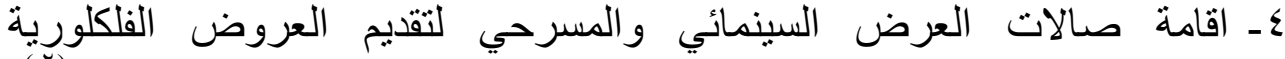
والمهرجانات والاحتفالات التي لها علاقه بطبيعة السكان المحليين وتقاليدهم (r).

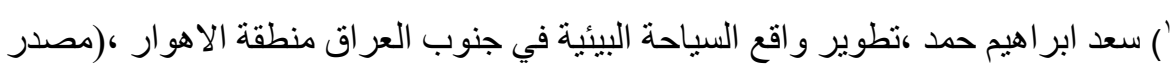

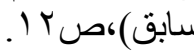

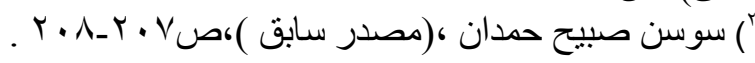




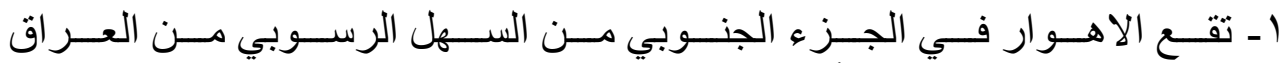
حيث تكون على شكل مثلث رأسه في الاسفل وقاعدته في الاعلى.

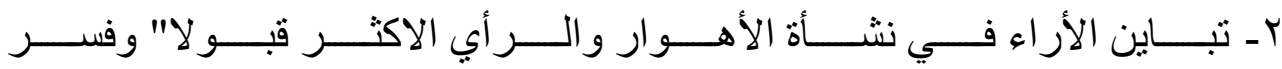

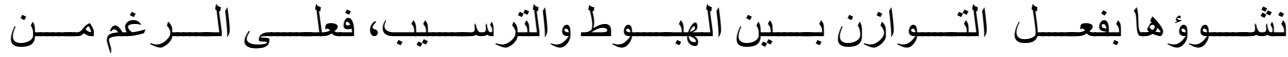

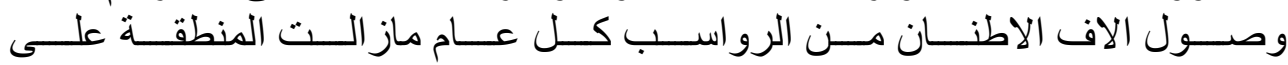

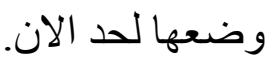

rـ أن الاهو ار بيئة طبيعية لتربية الاسماك و الكائنات الحية.

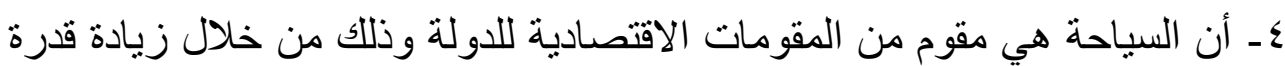

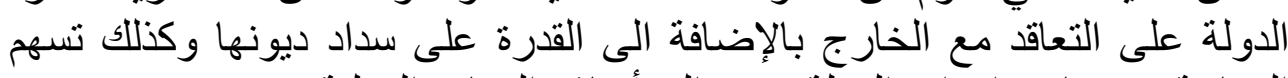

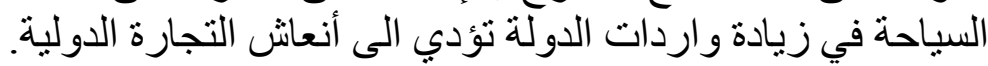
๑ـ أن النشاط السياحي يدعم كافة القطاعات الموجودة في العراق هي الزراعة و الحيو انبة و القطاعات الاخرى.

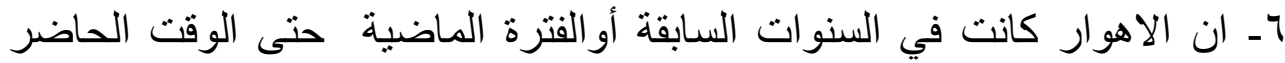

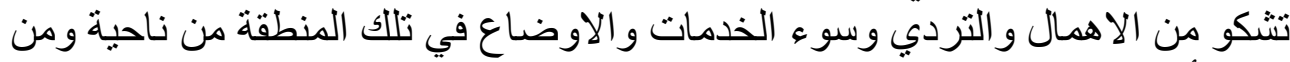

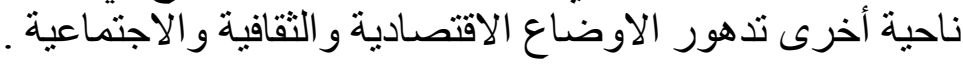

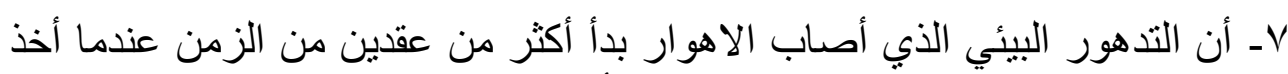

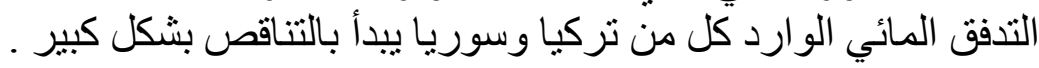

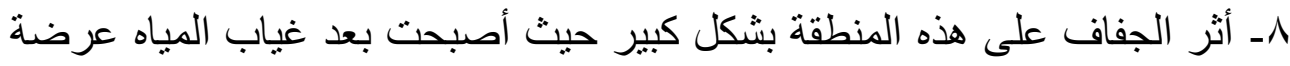

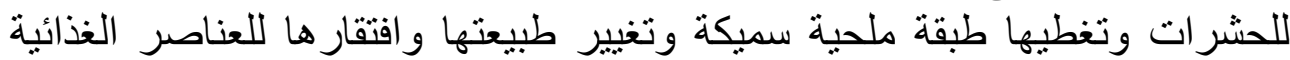

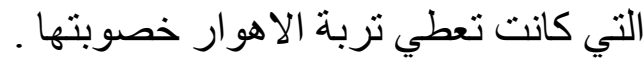

9ـ نتج من عمليات التجفيف العديد من الاثار منها البيئية والاقتصادية والاجتماعية منها تثنق التربة نتيجة وجود النفط والغاز الطبيعي.

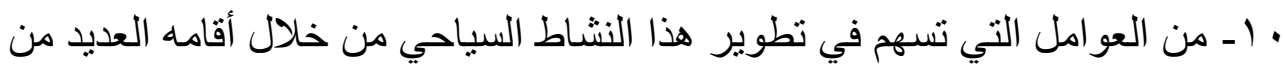

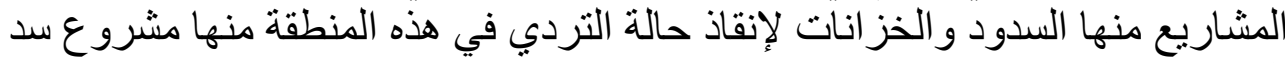

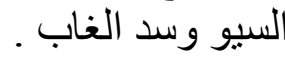

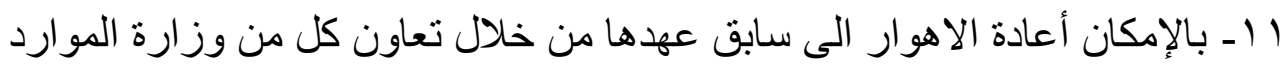

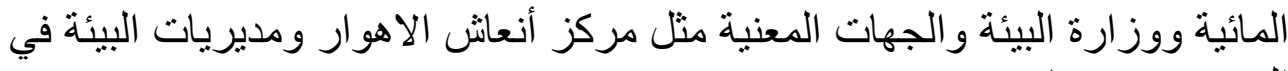

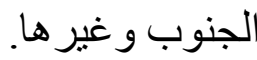


r ا ـ نستطيع تطوير نشاط هذه المنطقة من خلال تطوير المقومات الطبيعية والبشرية. rا ـالإمكان تطوير النشاط السياحي في الوقت الحاضر وذللك من خلال إعادة

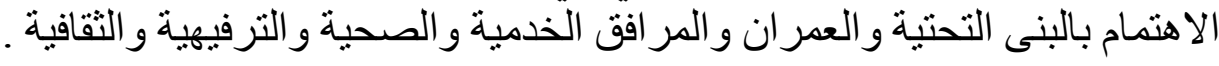
ـ ا ـ أن تطوير وسائل الاعلام تسهم في تطوير وزيادة الوعي و الاهتمام بالأهو ار.

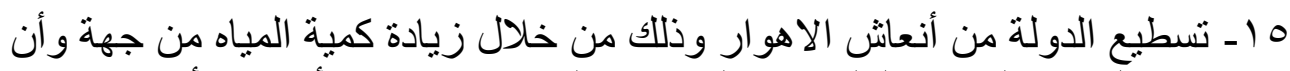

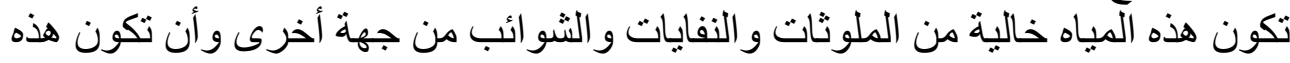

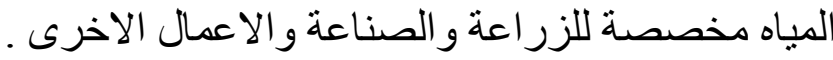

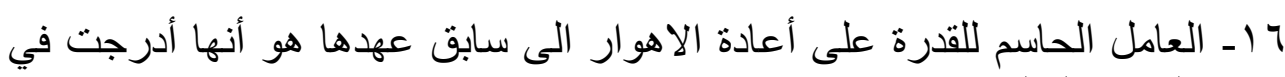

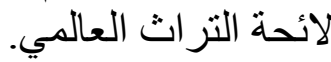

الـ العتبر منطقة الاهو ار من المناطق النادرة بالعالم حيث تعد منطقة غنية بالموارد

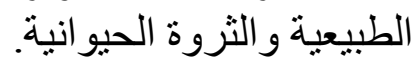

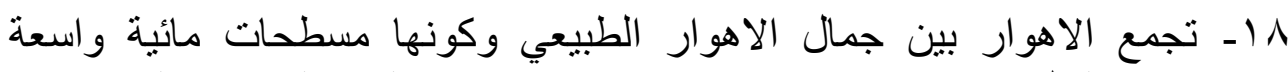
الانتشار دائمة الخضرة في معضمها ويعيش فيها كائنات حية نباتية وحيو انية فريدة .

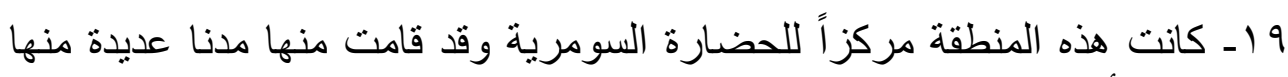

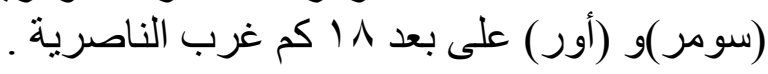

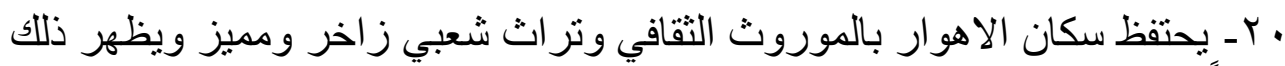

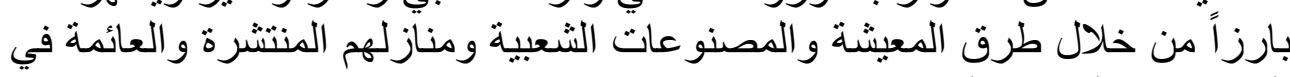
المسطحات المائية و المضايف و الاكو الخئة والئ.

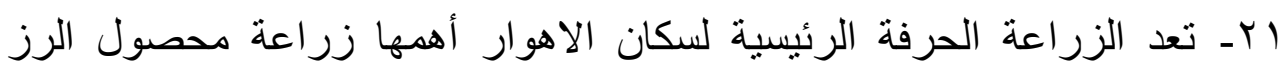

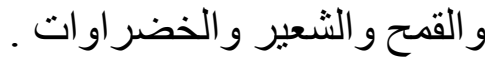
r r الثروة الحيوانية التي تلائم تلك المنطقة وهي تربية الحيوان الجاموس هو

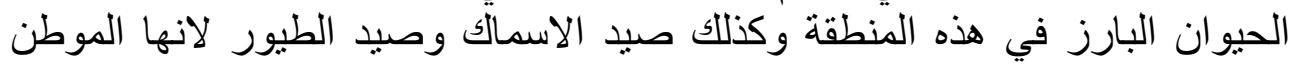
الذي لهجرة أنواع مختلفة من الطيور الطنة 


\section{المهاكر:}

\section{اولا: الحتميث}

ا ـ أبو حجر ، أمنة ، الجغرافيا السياحية ،دار أسامة للنشر والتوزيع، عمان الاردن r.11،

r ب- بظاظو، أبراهيم خليل، السياحة البيئية واسس أستدامتها ،طا، مؤسسة العراق

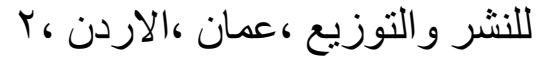

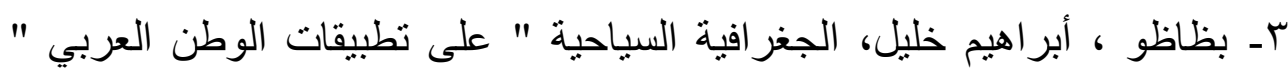

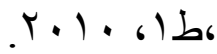

ع ـ الحكيم ، محمد صبحي عبد، وحمدي أحمد الديب،جغر افية السياحة ،مكتبة الانجلو

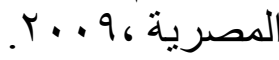

هـ الرفاعي ، سلطان ،التلوث البيئي ،ط ،دار أسامة للنشر و التوزيع ،الاردن ،عمان r...9،

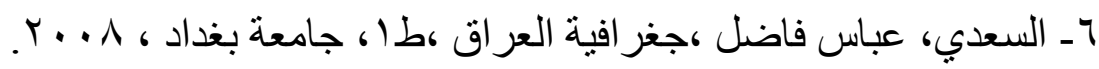
V- عثمان ، باسم عبد العزيز وحسين عليوي ناصر الزيادي، جغر افية الوطن العربي

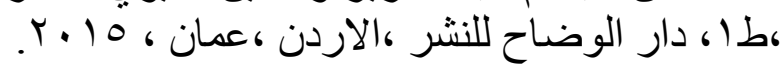

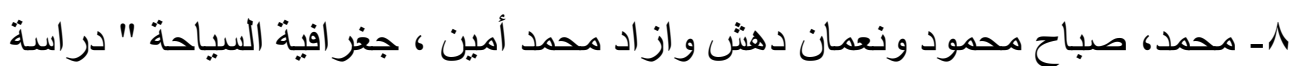

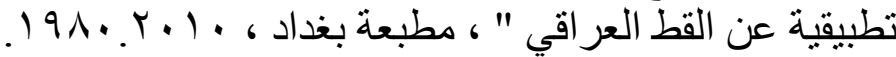

9ـ المظفر، محسن عبد الصاحب ، التخطيط الاقليمي والتنمية المستدامة ، طا،

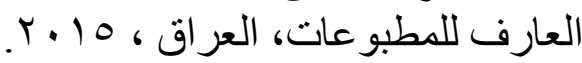

\section{ثانياً: الاوريات والبحوث}

ا - حمد ، سعد أبراهيم ، نطوير واقع السياحة البيئية في جنوب العراق منطقة

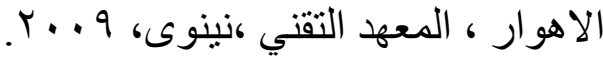

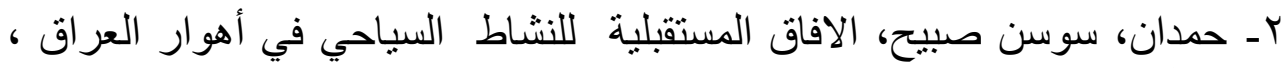

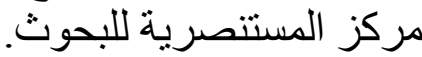

r- العقيلي ،نعمان دهش ،السياحة في المنطقة الجبلية ومؤثراتها الاقتصادية

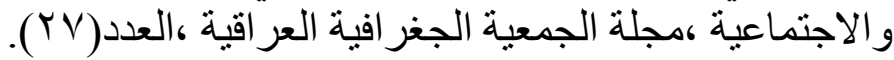




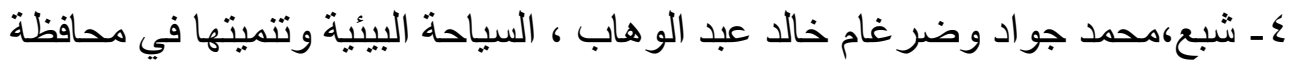
النجف الاشرف،مجلة الدولية للبيئة والتغيرات المناخية العالمية ، العدد( (1)، مجلة النية

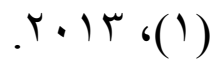

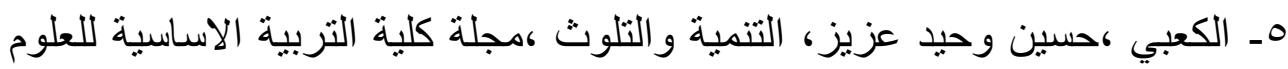

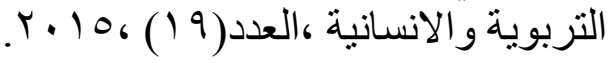

ثالثًاً: الرسائل والاطاريح

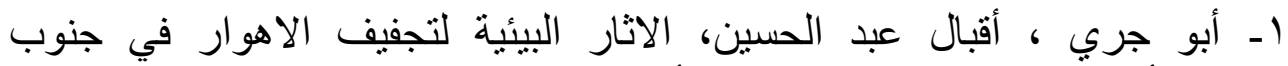

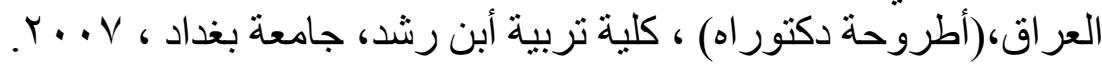

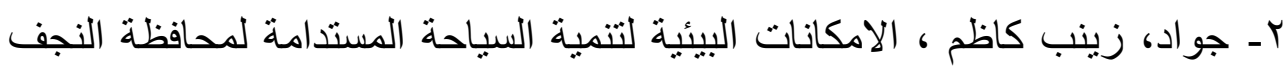

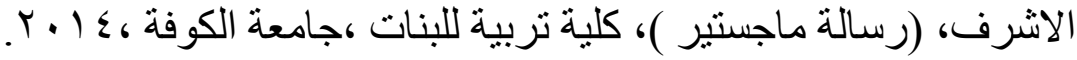

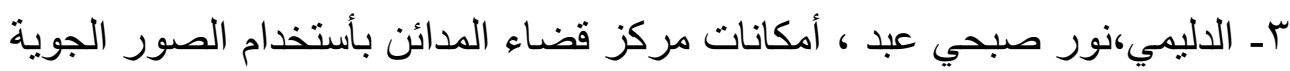

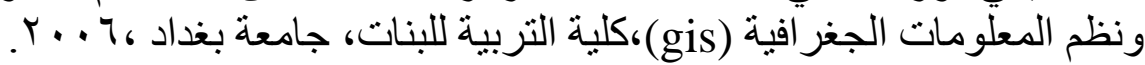

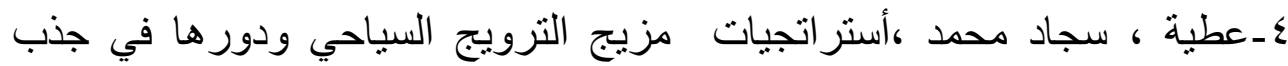

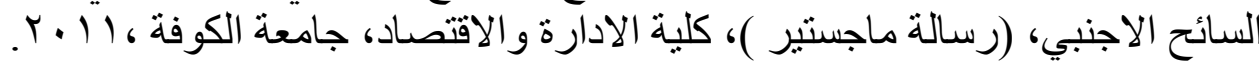

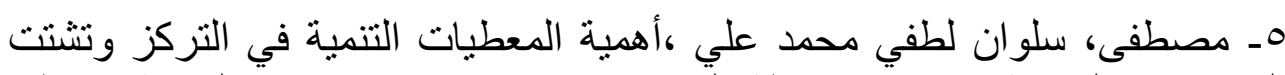

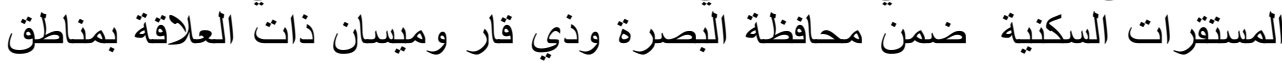

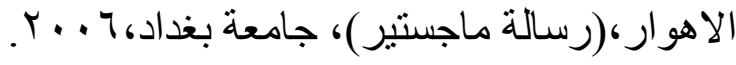
رابعأ: الانترنت الانت

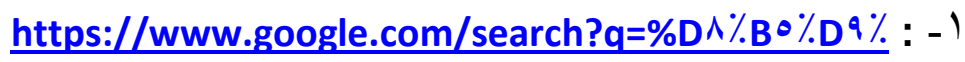
r- شبكة الانترنت ، علاء هانشم البدران http://www.khanesor.com 


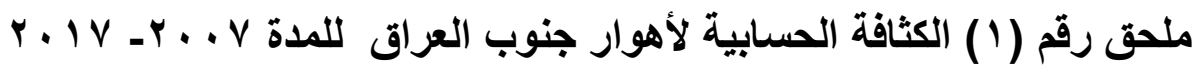

\begin{tabular}{|c|c|c|c|c|c|}
\hline \multicolumn{2}{|c|}{ الكثافة عام V V V } & \multicolumn{2}{|c|}{ الكثافة عام V . . . P } & \multirow{2}{*}{ المساحة } & \multirow{2}{*}{ المنطقة } \\
\hline الكثافة كم r & نسمة & الكثافة كم r r & نسمة & & \\
\hline 17.1 & Mrrvr & 1r.0 & Y०^q & 1918 & 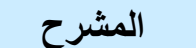 \\
\hline Or. E & $9 \cdot \leq 09$ & rq. & ه & 1790 & كميت \\
\hline rYO.E & $\neg$ ษคᄉ & $\neg \mu \wedge \odot \Lambda$ & $\varepsilon \diamond \vee q Y \backslash \wedge r$ & ro. & قلعة صالح \\
\hline YYV.O & 110150 & 187.7 & $\Lambda q \Psi \varepsilon V$ & 0.7 & المجر الكبيز \\
\hline$\varepsilon 1.1$ & YrlOE & rq. & $Y \backslash \leqslant \Lambda \wedge$ & orq & العدل \\
\hline$\varepsilon 1.1$ & $\varepsilon \wedge \bullet \leq q$ & A. & $\varepsilon \cdot \varepsilon q Y$ & 1171 & العزيز \\
\hline $0 . \varepsilon$ & . & Ir. & $0.0 \leqslant \mu$ & $\Lambda \ldots$ & الكحلاء \\
\hline 99.7 & $0 \leq \wedge \mid \leq$ & $1 \ldots 0$ & OOYAE & 00. & الميمونة \\
\hline ry. & rq & Y^.q & PVY P & Ir.r & السلام \\
\hline$\varepsilon 0.0$ & $\circ 9+\Delta V$ & ro. & Y TV. T & $1.7 r$ & الجبايش \\
\hline $11 . V$ & I rVOr & 7.1 & 2177 & $7 \wedge 1$ & الحمار \\
\hline VV. 9 & $\& \diamond q 9 Y$ & 07.7 & 0. & 09 . & الفهود \\
\hline q. & IVTIY & $19 V . r$ & $1 \leq 7 \ldots$ & $V \varepsilon$ & الطار \\
\hline r. & I HYEVY & I Y.V & $\varepsilon 9 \leq 99$ & $\varepsilon \ldots$ & كرمة بني سعيا \\
\hline 10.7 & IoryV & 70.1 & $07 \wedge 9$. & $\Lambda \neg \varepsilon$ & العكيكة \\
\hline $1 \cdot \varepsilon .1$ & $7 \leq \varepsilon \wedge 9$ & $7 . .7$ & MVYVI & 910 & الفضلية \\
\hline$\mu \cdot V . \Lambda$ & $\wedge Y \wedge \mid q$ & 190.1 & OYษ \& & rqq & المدينة \\
\hline 1 1 & I I rqr & 91.1 & VOVAT & NYo & الدير \\
\hline $77 . r$ & M०५AV & $\varepsilon \varepsilon . \varepsilon$ & rrqqV & orq & النشوة \\
\hline $1 \leqslant \mu$ & 81979 & 90.2 & $\varepsilon \vee q 7 V$ & $0 . \mu$ & الكهوير \\
\hline$\varepsilon r \mu . r$ & $q \backslash \wedge \nvdash \wedge$ & YVO. $\varepsilon$ & $09 \vee 79$ & YIV & طلحة \\
\hline$\wedge \varepsilon .7$ & I. & OY.Y & $\Lambda q \mu \varepsilon \wedge V$ & 10roq & المجموع \\
\hline
\end{tabular}




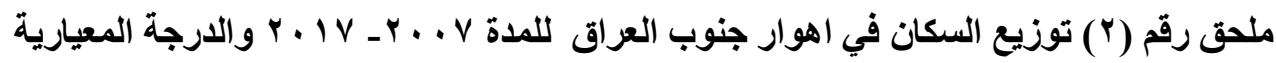

\begin{tabular}{|c|c|c|c|c|}
\hline الدرجة المعيارية & $r . i v$ & الدرجة المعيارية & $r \ldots v$ & الوحدات الادارية \\
\hline ros. & TYYVT & rqY..r. & Y०^q & المشرح \\
\hline $11 V_{+}$ & $9 . \leqslant 09$ & $q r \leqslant q . r=$ & $\varepsilon \varepsilon r r_{0}$ & كميت \\
\hline$v .99+$ & $7 r \wedge \bullet \wedge$ & $v \cdot 0.2+$ & $\varepsilon \Delta V q r$ & قلعة صالح \\
\hline Y19+ & 110110 & $1.11 \vee \varepsilon+$ & $\wedge q \Psi \leq V$ & المجر الكبير \\
\hline $17 \varepsilon$ & PYlOE & $\varepsilon \Delta \vee \Lambda_{-}$ & $r \mid \leq \Lambda \Lambda$ & العدل \\
\hline $00 . \cdot$ & $\leq \wedge 0 \leqslant 9$ & sOr.Y. & $\varepsilon . \leq 7 Y$ & العزيز \\
\hline$\wedge \wedge_{.} \wedge_{-}$ & פ.r.r. & IVRA.r & $0.0 \leq r$ & الكحلاء \\
\hline rq.r. & $0 \leqslant \wedge 1 \leqslant$ & rVTq+ & OOYA & الميمونة \\
\hline $94 . \varepsilon$ & एqया। & 1.71. & TVIro & السلام \\
\hline $94 . \varepsilon-$ & OqTOV & $r \leqslant \leq \leqslant-$ & YqV. & الجبايش \\
\hline$r \cdot r_{.} r_{-}$ & IrVOr & 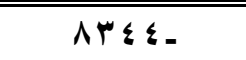 & \$197 & الحمار \\
\hline rI0.0. & $\{099 r$ & 19^V.r. & ס. & الفهود \\
\hline 1Ar.O. & IVTIY & $7.20 .-$ & $1 \leq 7 \ldots$ & الطار \\
\hline $\bar{r} \cdot r_{-}$ & IrY & $1011.4+$ & ะ9 999 & كرمة بني سعيد \\
\hline$\{1 . Y+$ & T0YTV & $M \| \Lambda_{+}$ & $0 \curlyvee \wedge 9$. & العكيكة \\
\hline r.0.r & $7 \leqslant \leqslant \wedge 9$ & $11 \leq V_{-}$ & FVYVI & الفضلية \\
\hline$\Lambda ฯ \cdot .+$ & AYAIq & YY.SE+ & OYYA & المدينة \\
\hline r. & lirqr & VYYO+ & VovAr & الاير \\
\hline $1 \cdot \Lambda_{-}$ & r०५AV & $\varepsilon \cdot r q$ & rrqqV & النشوة \\
\hline$\varepsilon 1 . r+$ & 81979 & $11 V \Lambda_{+}$ & EVq VV & الهوير \\
\hline Irrt & qIArA & $r v \leq \varepsilon+$ & $09 \vee 79$ & طلحة \\
\hline . & $|r \ldots r| \mid$ & . & 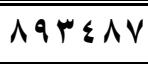 & المجموع \\
\hline & & 91910 & $\leq Y 0 \leq V$ & الوسط الحسابي \\
\hline & & $r \leqslant 7$ & 8.7 & الانحراف المعياري \\
\hline
\end{tabular}




\section{ملاحق الصور :}

صورة ( ) تربية الجاموس في مناطق جنوب العراق (الاهوار )

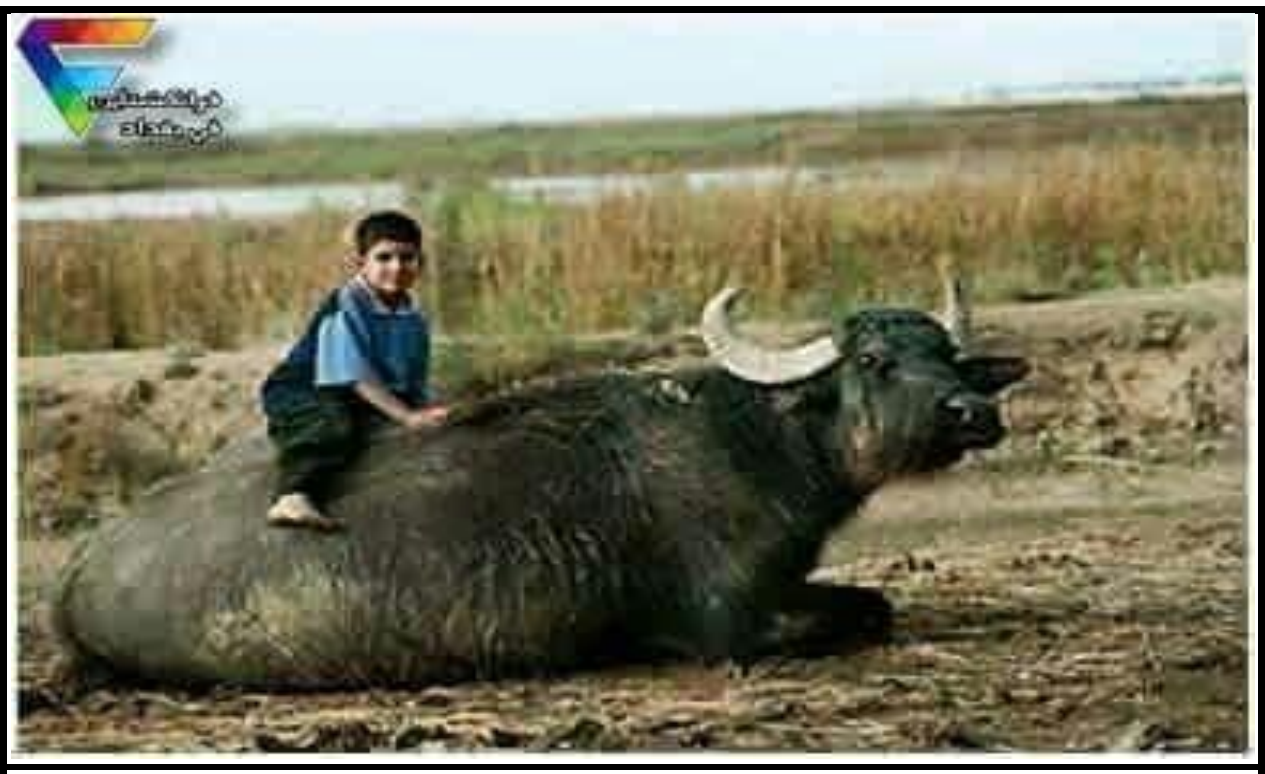

https://www.google.com/search?q=\%D^\%B०\%.Dq\% : المصدر

صورة (r) صناعة البواري في مناطق الاهوار

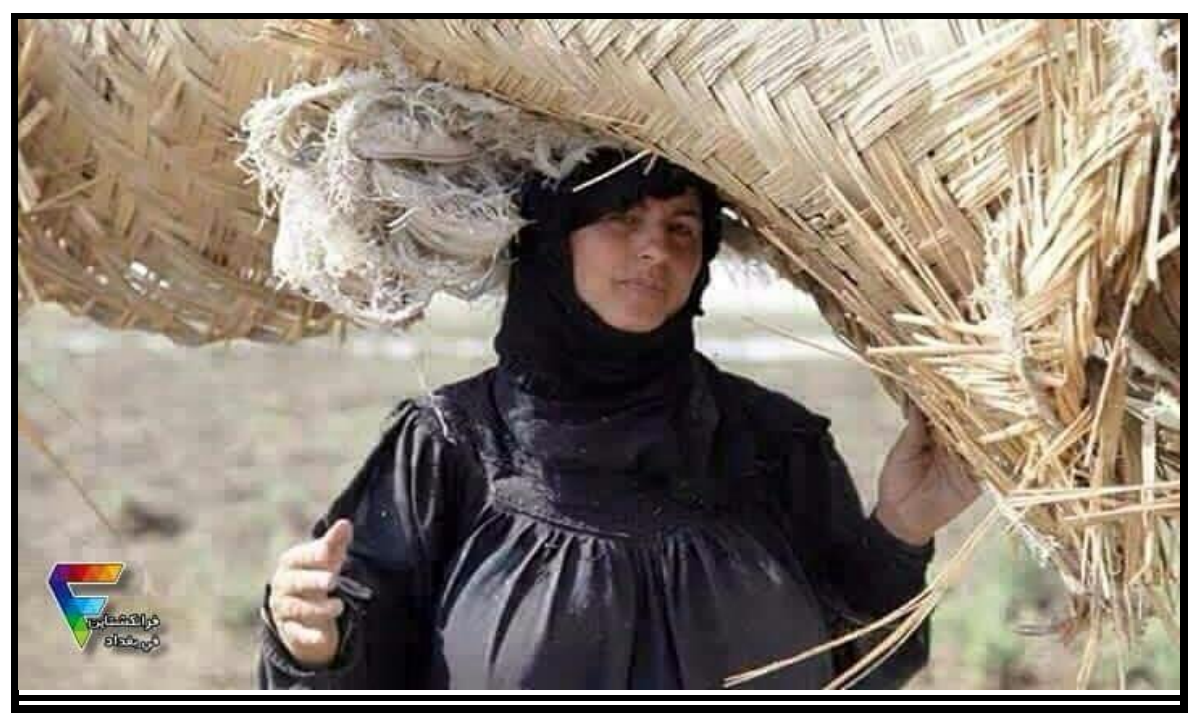

https://www.google.com/search?q=\%DA\%BO\%Dq\% : المصدر 
صورة (ץ) غنى مناطق الاهوار بالثروة الحيوانية

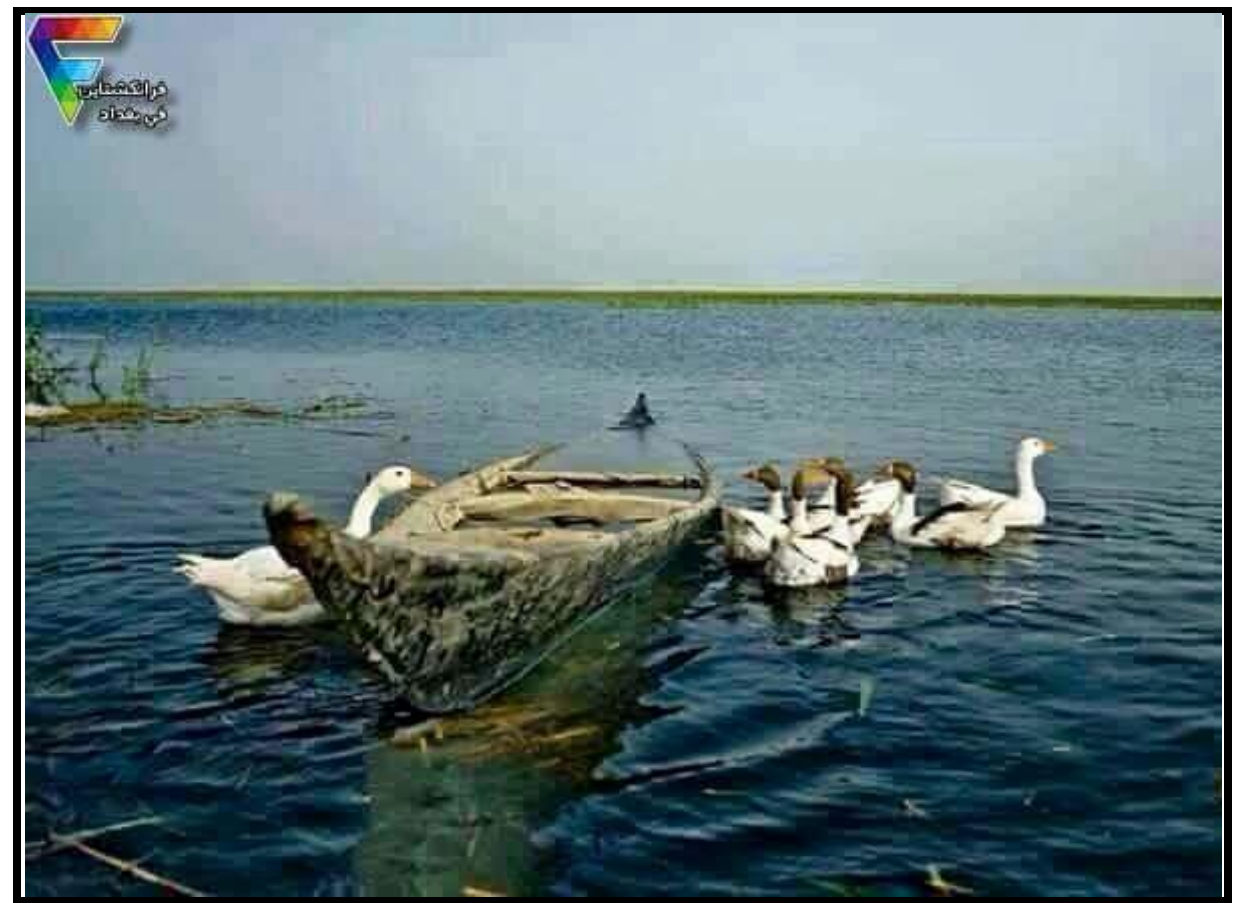

https://www.google.com/search?q=\%D^\%B0\%.Dq\% : المصدر

صورة (ع ) صناعة الزوارق وبناء المضايف في مناطق الاهوار

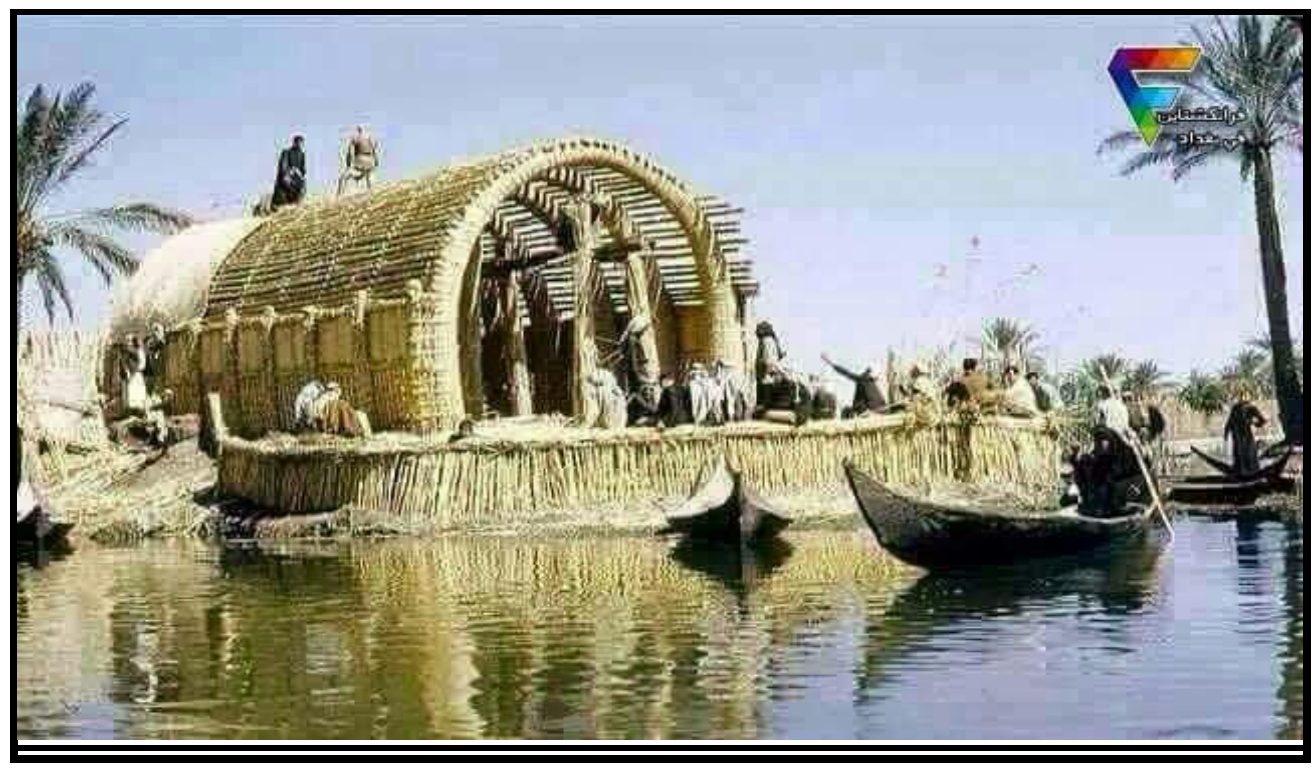

https://www.google.com/search?q=\%D^\%B0\%Dq\% : المصدر 
صورة (0) تربية الحيوانات في مناطق جنوب العراق

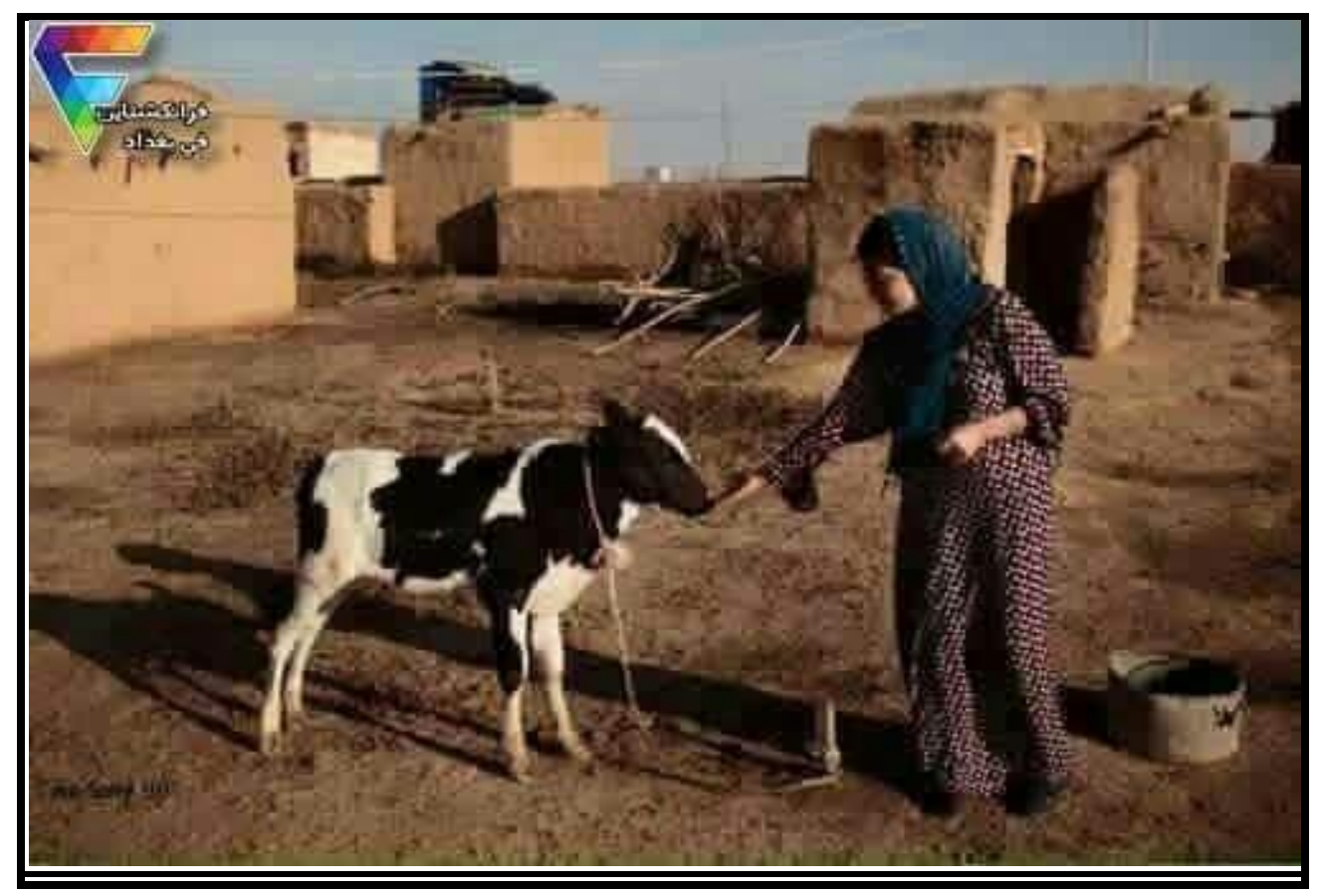

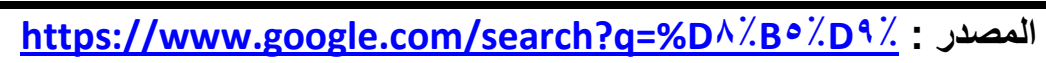
صورة (7) بناء المضايف من مادة القصب في مناطق الاهوار

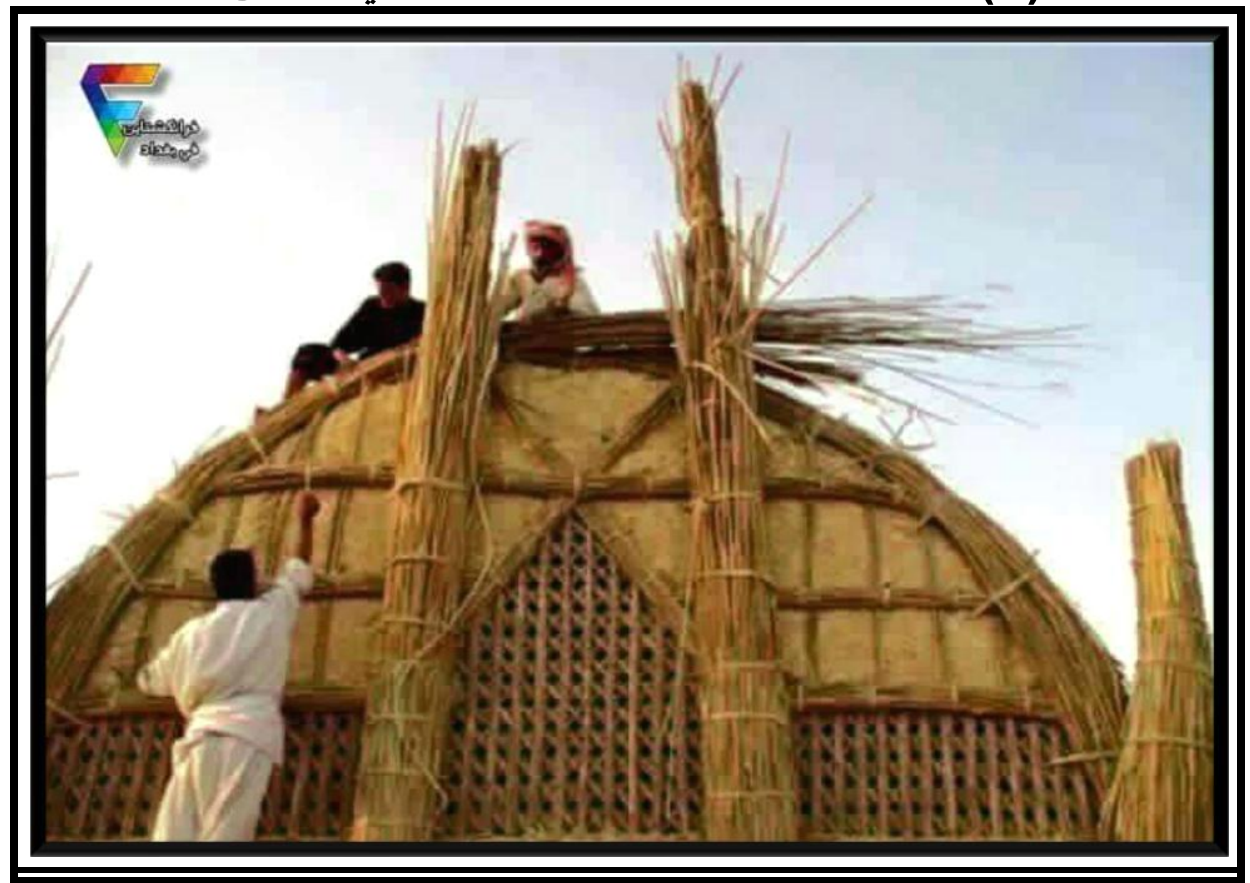

https://www.google.com/search?q=\%DA\%B0\%Dq\% : المصدر 
صورة (V) تهيئة مادة القصب والبردي لأستعمالها كمادة بناء

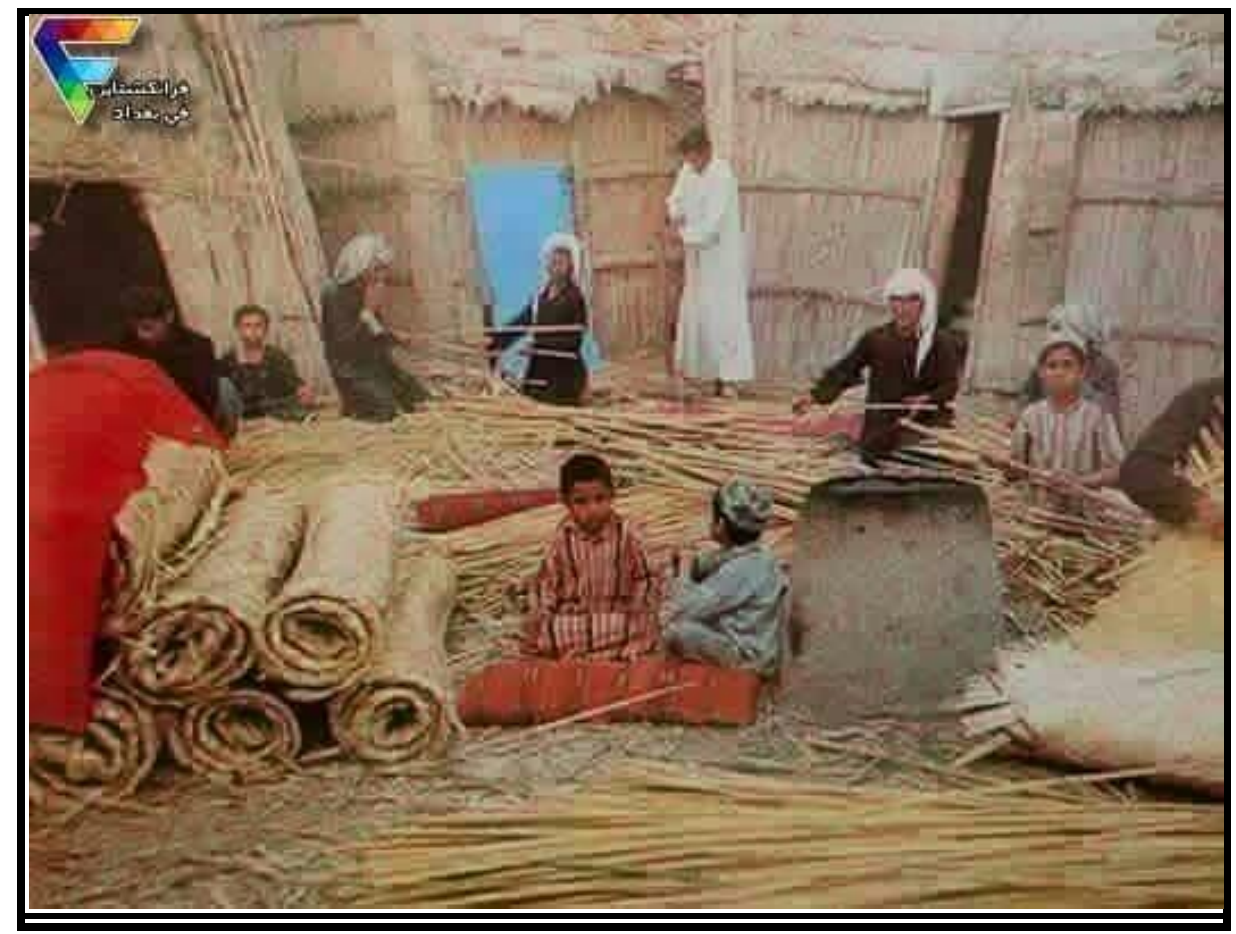

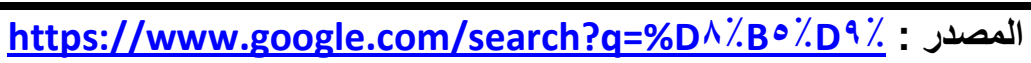

صورة (^) مشاركة المراءة الرجل في اعمال البناء ونقل مواد البناء

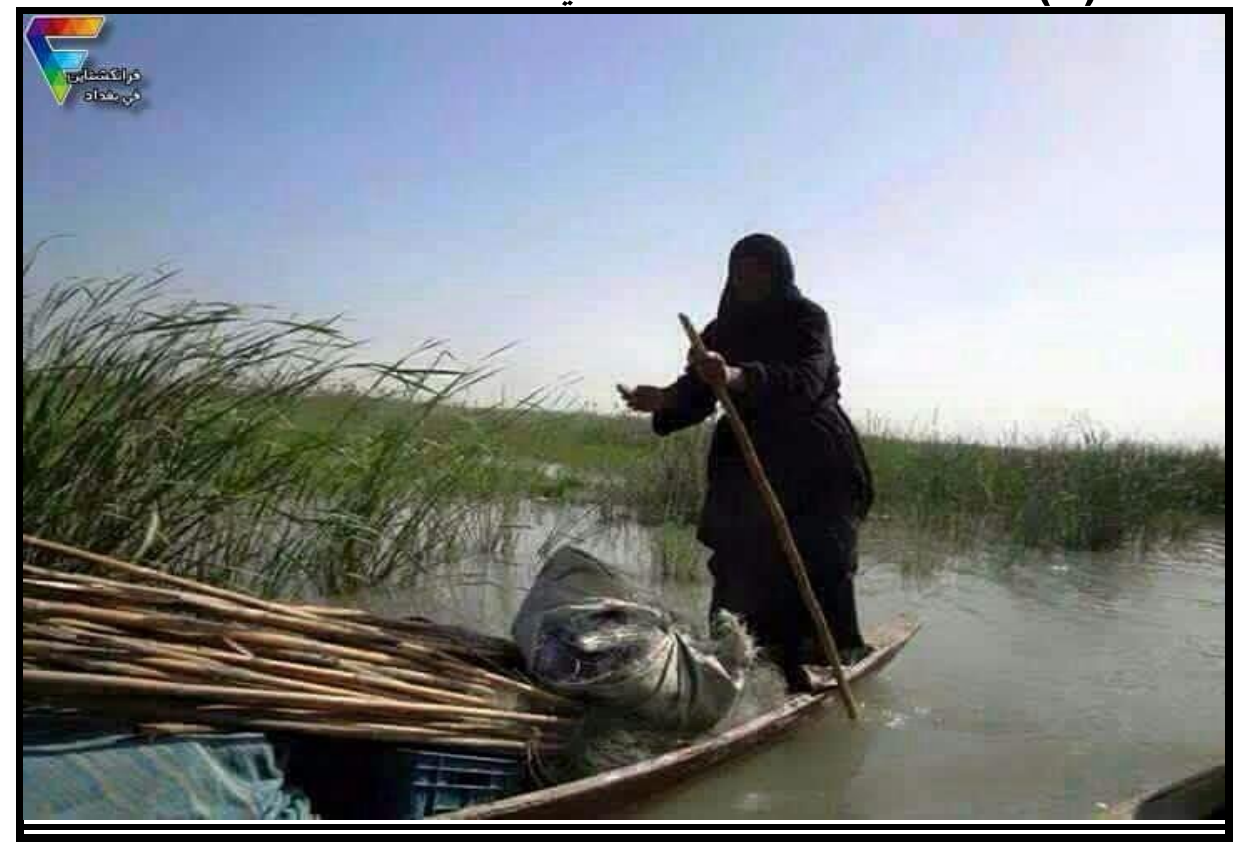

https://www.google.com/search?q=\%DA\%BO\%Dq\% : المصدر 


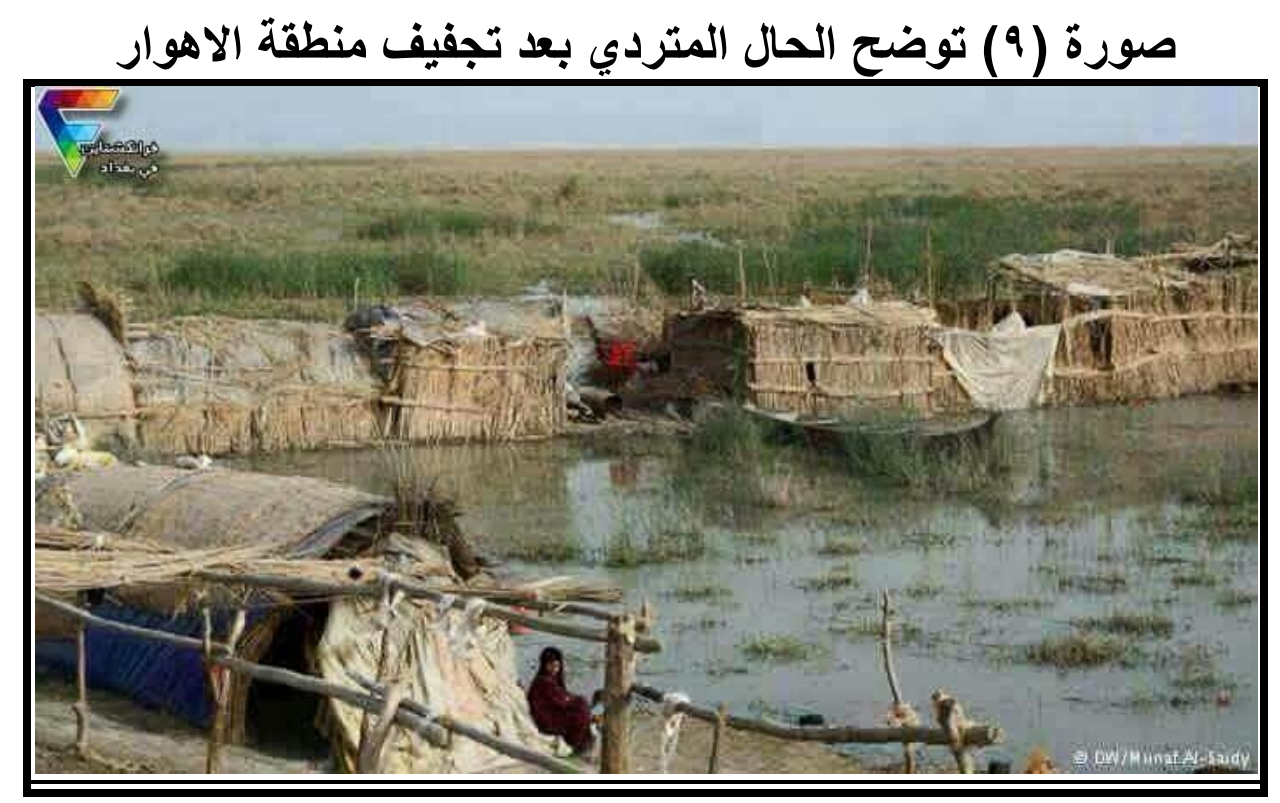

https://www.google.com/search?q=\%D^\%B०\%.Dq\% : المصدر صورة ( · 1) بعد تجفيف الاهوار اصبحث الحياه فيها اكثر صعوبة

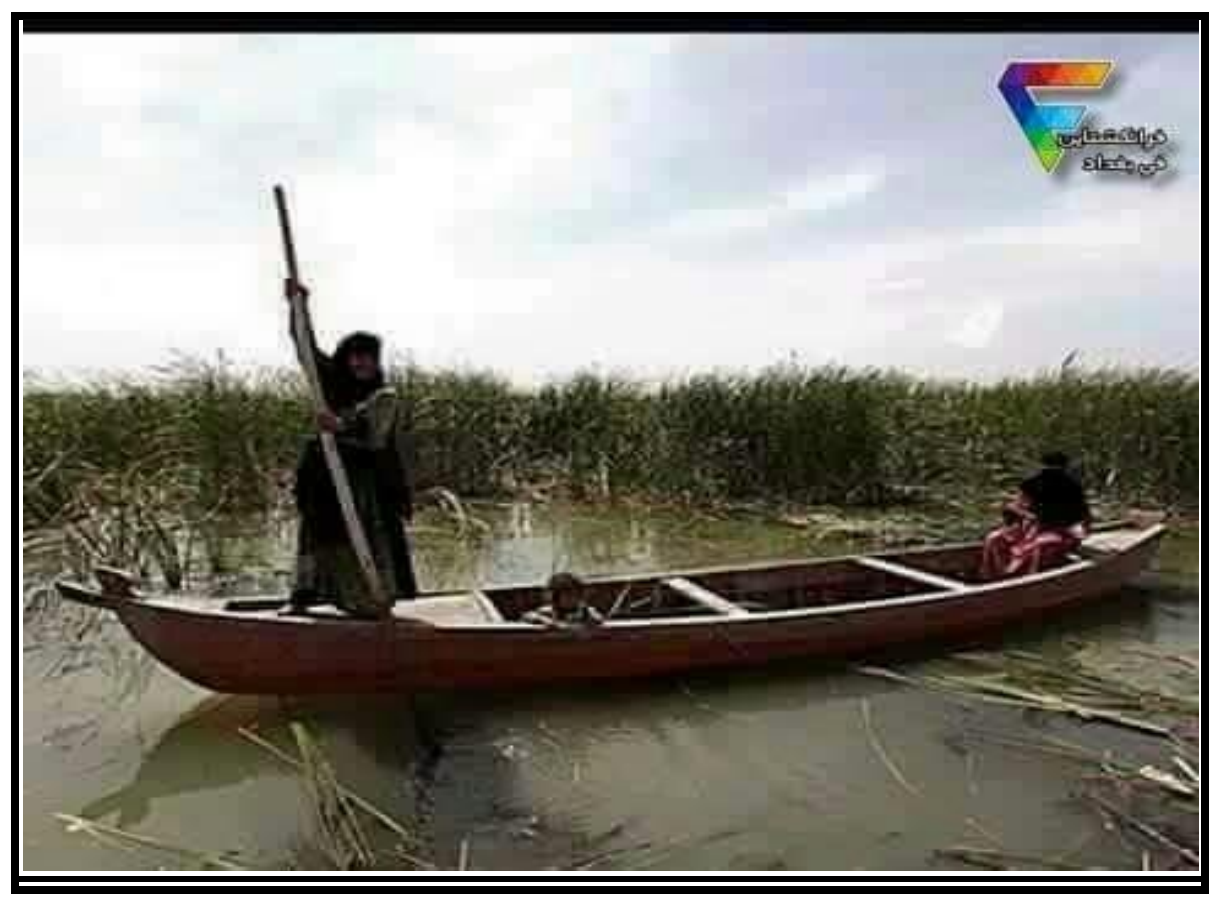

https://www.google.com/search?q=\%D^\%B०\%Dq\% : المصدر 


\section{قياس مستوى الوعي بمفهوم التنمية المستدامة لاى طلبة كلية التربية للعلوم الإنسانية-جامعة كريلاء "دراسة تطبيقية"}

$$
\text { تقدمَّ به الباحثين: }
$$

الباحث. مؤيد فضل حسين المسعودي

جامعة الكوفة - كلية الإدارة والإقتصاد
أ.د. رياض محمد علي المسعودي

عضو مجلس النواب العراقي 


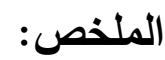

يرهذ البحث إلى التعرف على مستوى درجة الوعي لمجتمع طلبة الجامعات

بمفهوم ومتغيرات التتمية المستدامة في العراق. عينة البحث كانت ( • ب) إستمارة إستبانة موزعة على طلبة خمسة أقسام هي (اللغة العربية، اللغة الإنجليزية، التاربخ، الجغرافيا التطبيقية والعلوم النفسية والتربوبة) في كلية التربية للعلوم

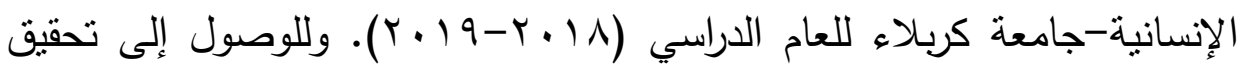
الهدف من الدراسة جرى إعداد استمارةالاستبانة، وتكونت من (·r) سؤال، وادخلت البيانات الناتجة من توزيع الاستبانة في البرنامج الاحصائي وخضت للعديد من الاختبارات الإحصائية وأظهرت مجموعه من النتائج منها وجود تباين كبير بين قسم علمي وآخر بمدى وضوح مفهوم التتمية المستدامة لدى الطلبة وبالتالي ضعف التعامل والتفاعل الإيجابي مع المشاريع التنموية. الكلمات المفتاحية: درجة الوعي، التنمية المستدامة، القسم العلمي. 


\title{
Measuring the level of awareness of the concept of sustainable development
}

Students of the Faculty of Education for Human Sciences -

\author{
Karbala University \\ "An Empirical Study"
}

\section{Abstract:}

The aim of the research is to identify the level of awareness of the university students community with the concept and variables of sustainable development in Iraq. The study sample was (250) questionnaires distributed among students in five sections (Arabic language, English language, history, applied geography and psychological and educational sciences) in the Faculty of Education for Human Sciences - Karbala University for the academic year (2018-2019). In order to reach the objective of the study, the questionnaire was prepared and consisted of (30) questions, and the data obtained from the distribution of the questionnaire was included in the statistical program (spss). It was subjected to many statistical tests and showed a large number of results. Sustainable development of students and thus poor interaction and positive interaction with development projects..

.Keywords: degree of awareness, sustainable development, scientific section. 


\section{المُقََِّمَة:}

مما لاشثك فيه ذلك الحيز الكبير من الإهتمام الذي حظت به موضوعة التتمية المستدامة:Sustainable Development، وعلى الأصعدة كافة لما لها من أهمية بالغة الأثز على المستويات السياسية والإقتصادية والإجتماعية والبيئة وأثزها المباشر وغير المباشر في حياة السكان. ومما مهذ الطريق لهذا الإهتمام هو النمو السكاني السريع وتغير سلوك متطلبات الحياة في ظل النمو الحضري المضطرد والاتصالات ومنها وسائل النواصل وتغير نمط مستلزمات الحياة والإختلالات الطبقية كلها عوامل ساعد على التتافس الحاد وغير المشروع في بعض الحالات على الموارد، مما أستلزم المزبد من الجهود للسعي لتطوير وتحسين مستوى وعي السكان بالتتمية المستدامة وضرورتها لهم، فضلًا عن أهمية التعامل وفق أطرها العامة والتقصيلية لغاية الحصول على منافع

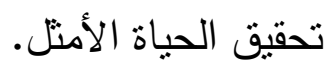
مشكلة الدراسة: يُعد موضوع التتمية المستدامة احد أبرز القضايا التي اصبحت تتتاولها الادبيات والاعلام بشكل متزايد ، ونظراً لأهميتها في تحسين الاوضاع الاقتصادية والاجتماعية والبيئية للطلبة. كما ان خطاب التتمية المستدامة أصبح متداولاً كثيراً وما نتج عنها من برامج وخطط. واعتبرت الجغرافيا مسألة شديدة العلاقة مع موضوع التتمية المستدامة في ابعادها الاقتصادية والاجتماعية والبيئة اضافة إلى المقاربات المنهجية التي ترتكز عليها ، كما ان موضوع التتمية المستدامة دخل مجال اهنمام المناهج التربوية والمصادر الجامعية.

ومما يدعم الاحساس بالمشكلة ، فان طلبة كليات التربية للعلوم الإنسانية لهم تأثيرات على قدراتهم حال تمكنهم من التدريس، وفي ضوء ما تشير اليه الدراسات 
السابقة والابحاث ، واهتمام الباحثنان بمحور الدراسات الاجتماعية ومن خلال خبرتهم في التعليم لاحظا ان هناك حاجة ماسة إلى معرفة مدى وعي طلبة كليات التربية للعلوم الإنسانية لمعايير التتمية المستدامة في العراق.

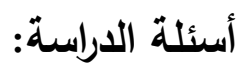

\section{تتحدد اسئلة الدراسة فيما يأتي:}

1. إ ما هي التنمية المستدامة؟

r. ما درجة وعي طلبة كلية التربية للعلوم الإنسانية بمعايير التنمية المستخامة

$$
\text { في العراق؟ }
$$

r. هل نوجد فروق ذات دلالة احصائية في درجة وعي الطلبة لمعايير التتمية

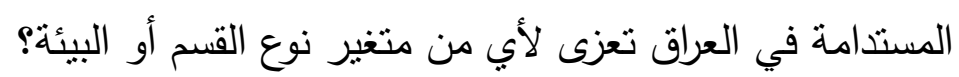

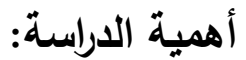

نتبثق أهمية الدراسة مما بأتي:

1. استجابة لمتطلبات الحياة المعاصرة توجهات التطوير التربوي ، والاتجاهات

الحديثة في مجال تعلم وتعليم المواد العلمية وفق التتمية المستدامة.

r. تشجع الباحثن والمدرسينبالاهتمام بالتتمية المستدامة.

r. تزويد الباحثين بالخلفية النظرية نحو التنمية المستدامة.

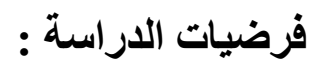

ا ـ هنالك فروق ذات دلالة احصائية في مستوى الوعي بمفهوم التنمية المستدامة

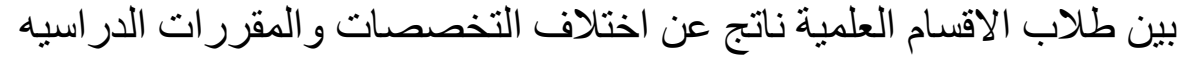

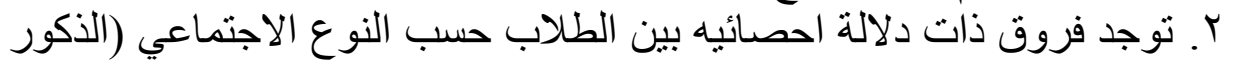

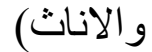
"ا. هنالك فروق ذات دلالة احصائيه بين الطلبه حسب بيئة السكن (الحضر و 


\section{حدود الدراسة ومحدداتها:}

اقتصرت هذه الدراسة على طلبة كلية التربية للعلوم الإنسانية / جامعة

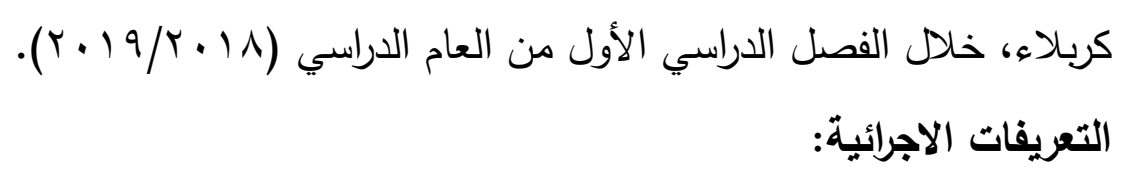

ورد في هذه الدراسة عدد من المصطلحات الاساسية ، ومنها:

ا ـ درجة الوعي: مدى الادرالك القائم والمعرفة الككتسبة إتجاه قضية محددة.

r. التنمية المستدامة:هي التتمية التي تحقق رغبات وحاجات الأجيال الحالية

دون التأثثر على قدرة الأجيال القادمة على تحقيق رغباتها وحاجاتها وتحقق تهن

التوازن بين الجوانب البيئية والاقتصادية والاجتماعية.والتتمية المستدامة هي

نشاط بشري ناجم من تحقيق نمو وتتمية اقتصادية تتلاءم مع قدرات وإمكانات البيئة ضمن الحيز المكاني الحالي.

\section{منهجية الدراسة}

إعتمدت الدراسة المنهج الوصفي التحليلي وذللك لمناسبته في الوصول إلى ملى

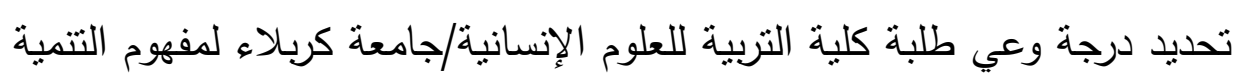

$$
\text { مجتمع الدراسة وعينتها: }
$$

عينة البحث كانت (ب0. إستمارة إستبانة موزعة على طلبة خمسة أقسام هي (اللغة العربية، اللغة الإنجليزية، التاريخ، الجغرافيا التطبيقية والعلوم النفسية

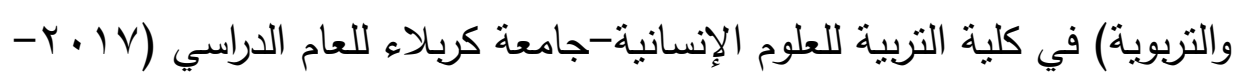


المبحث الأول: الإطار المفاهيمي (مفهوم التنمية المستدامة النشأة والتطور):

ظهر مصطلح التتمية المستذامة الذي يعده بعض الاقتصاديين من

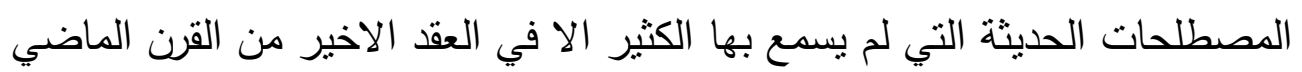

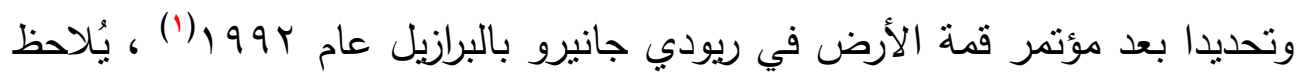

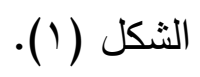

الثكل (1) التطور المفاهيمي لمفهوم التنمية المستدامة.

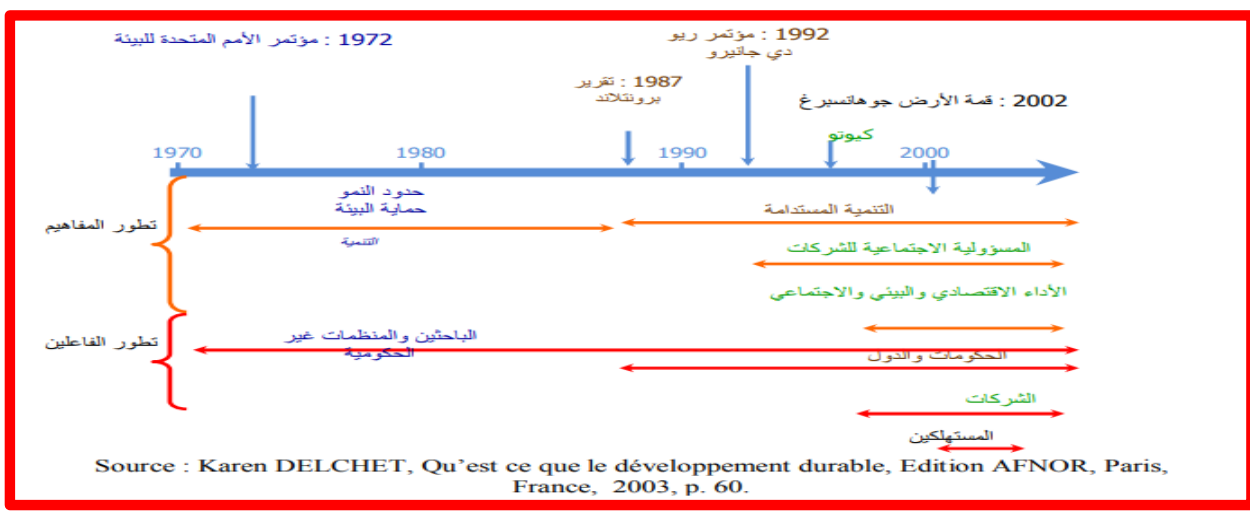

إلاًّ ان العودة إلى جذور هذا المفهوم توضح انه كان موجودا منذ الاف

السنين في الحضارات القديمة وان اختلفت التسمية ، وبالذات في حضارة شمال افريقيا بالقرب من قرطاج القديمة (تونس حاليا) والحضارة الفرعونية في مصر اذ كان عدد سكان قرطاج في عصرها الذهبي اكثر من مليون نسمة ، وكانت تتمتع بوفرة من موارد الغذاء نتيجة ازدهار الزراعة والرعي ، وعندما قامت روما بغزو قرطاج قررت ان تجعل منها مستعمرة لتوريد الطعام للإمبراطورية الرومانية ، وبدأت دورة من دورات تدهور الأرض لا يمكن تغييرها مما قاد إلى تدمير كبير لخصوبة الأرض وافقار الناس على مر التاريخ حتى وقتتا الحالي ، وكان ذللك نتيجة قيام الامبراطورية الرومانية باستخدام الزراعة الكثيفة لإنتاج اكبر قدر ممكن من المحاصيل الزراعية 
دون الالتفات إلى تدني خصوبة الأرض وانخفاض انتاجيتها مما ادى إلى في النهاية إلى تدمير الأرض للابد ، وعلى العكس من حضارة قرطاج فان الحضارة الفرعونية ترتكز على اساس مستدام منذ اكتر ايام كليوباترا حتى القرن العشرين اذ كان الفيضان السنوي لنهر النيل في فصل الصيف يوفر المياه ويزود التربة من جديد بالمواد

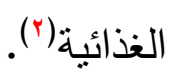
وفي العصر الحديث ولد مفهوم التتمية المستدامة للمرة الاولى عام rVI عندما قام كارلوتز بتأليفاول كتاب بعلم الغابات وذكر فيه بان الخشب وبالتحديد (خشب البناء) سيكون مهما جدا وبأهمية الخبز اليومي ولهذا يجب ان يكون هناك توازن بين معدل نمو هذا الخشب ومعدل استخدامه وهذا فقط ما سيسمح باستدامة استخدام وتوافر هذا الخشب ، وهذا يعني اثشارة مبئية إلى مبدا الاستدامة والحفاظ على المورد الاقتصادي لأطول فنرة ممكنة. أصبح مفهوم التتمية المستدامة من المفاهيم العامة والثائعة في العالم والتي لها دور لهرد لهرد كبير في صياغة جزء كبير من السياسة البيئية المعاصرة ، ولكون هذا المفهوم يتصف بشكل كبير بالعمومية فان ذلك كان له دور في جعله شعارا شائعا وبراقا مما جعل معظم الحكومات تتبنى التتمية المستدامة كأجندة سياسية حتى لو عكست تلاك الاجندات التزامات سياسية مختلفة جدا تجاه الاستدامة ، حيث تم استخدام المبدأ لاعم وجهات نظر متتاقضة كليا حيال قضايا بيئية منل التغير المناخي والتتهور البيئي اعتمادا على زاوية التفسير ، فالاستدامة يمكن ان تعني اثياء مختلفة ، بل متتاقضة احيانا ، للاقتصاديين ، وانصار البيئة ، والدحامين ، والفلاسفة. ولذا يبدو ان التوافق بين وجهات النظر تللك بعيدة المنال. عرف الاقتصادي روبرت سولو التتمية المستدامة على انها (عدم الاضرار بالطاقة الاتتاجية للأجيال المقبلة وايصالها اليهم بنفس الوضع الذي ورثه الجيل الحالي) ، 
وبين سولو ان الحديث عن الاستدامة يعني الاخذ في الحسبان ليس الموارد التي نستهلكها اليوم وتلكك التي نورثها للأجيال القادمة فحسب ، بل ينبغي ايضا توجيه الاهتمام الكافي لنوعية البيئة التي نخلفها للمستقبل ، وهذه البيئة تشمل اجمالي الطاقة الانتاجية للاقتصاد ، بما في ذلك المصانع والمعدات والثقنية السائدة وهيكل

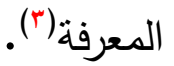

اما البرنامج الانمائي للأمم المتحدة (UNDP) فقد بين ان التتمية المستدامة هي تتمية موالية للناس وموالية لفرص العمل وموالية للطبيعة وهي تعطي اولوية للحد من الفقر والعمالة المنتجة والتكامل الاجتماعي واعادة نوليد البيئة وهي نوازن بين الاعداد البشرية وبين ما لدى المجتمعات من قدرات متتوعة وما لدى الطبيعة من قدرات هائلة(أ). فضلاً عن ذلك فأن بعض الباحثين برى ان التنمية المستدامة قد استحوذت على اهتمام الاقتصاديين اكثر من غيرهم ذلك لارتباطها بشكل مباشر بواقع المستوى الاقتصادي للسكان والناجم من متغيرات التتمية المستدامة المتمثلة بالموارد الطبيعية والبشرية المتاحة واستثمارها وتوجيهها بشكل امتل لتحقيق غايات واهداف نبيلة (०). فالإنسان في جميع مراحل حياته بحاجة إلى التربية البيئية ، أي ينبغي عليه ان يتعلم كيف بسلك سلوكا حاسما نحو البيئة التي يعيش فيها ، وان يتعامل مع مواردها بحب وتقدير من اجل المحافظة على حقوقه وحقوق الاخرين سواء اكانوا من الجيل المعاصر او القادم • وبذلك فان التربية البيئية عملية من شانها ان تشاعد على تكوين القيم والاتجاهات والمهارات والمعارف ، وفهم العلاقات المعقدة التي تربط الانسان بالييئة التي يعيش فيها ، وتوضح حتمية المحافظة على مواردها ، واستغلالها 
لصالح الانسان ، وحفاظا على حياته الكريمة من أجل تحسين مستوى معيشته ، وعليه فالبيئة تعني (التعلم من اجل البيئة)(").

ومما لا شك فيه ان عدم الوعي والمعرفة بما يضر البيئة او ينفعها يعتبر

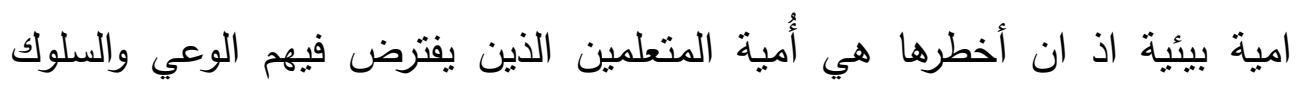
الايجابي نحو البيئة الذي يسهم في حل مشكلاتها ، اذ يعد نشر الوعي البيئي ضرورة وطنية وقومية يجب مراعاتها في التخطيط التربوي نظرا لانعكاساتها الايجابية والسلبية على البيئة . ومن هنا فان تتمية الوعي البيئي لدى طلبة الجامعات يعد على غاية الاهمية ، وهذا ما تسعى الدراسة الحالية إلى الكثف عنه خلال تحديد مستوى البيئي بدى عينة من طلبة جامعة مؤته.

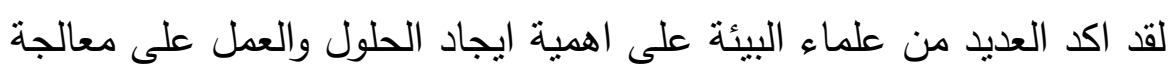
المشكلات البيئية في الوقت الراهن ، لان المشكلات البيئية اليوم تشكل التهديد

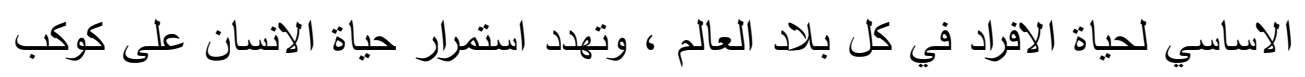

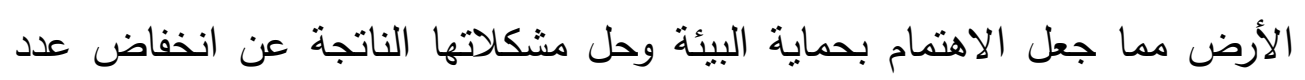
الأثجار وازدياد استهلال الدياه العذبة وبناء الددن وانتشار الدصانع والسيارات وسمومها مطلبا اساسيا للحفاظ على بقاء الانسان وسعادته ـ وتتشا المشكلات البيئية عادة نتيجة لأسباب بشرية او طبيعية ، فقد ينشا الاختلال بالتوازن البيئي بسبب

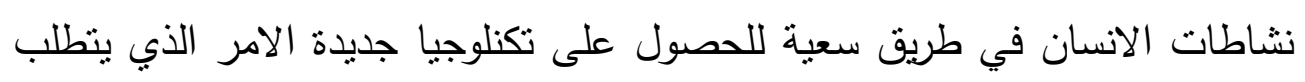

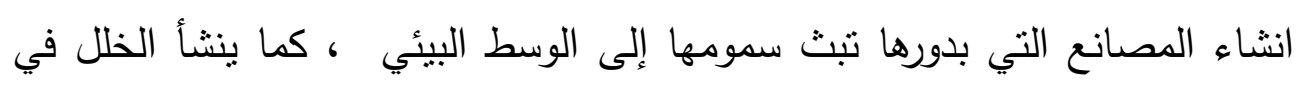

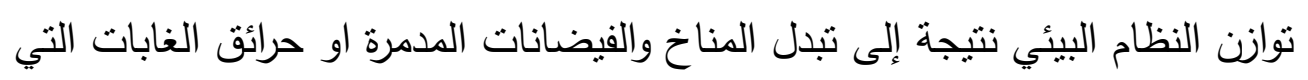

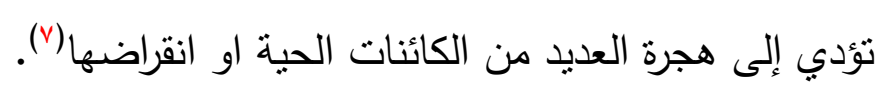
وعليه ، فان مفهوم الوعي البيئي لابد من ان يكون شموليا بدءا من المعرفة

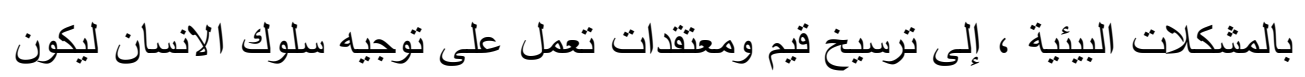


اكثر حماية للبيئة ، واكثر ترشيدا في استهلاك مواردها ـ لذلك لابد للإنسان ان يمنلك وعيا للمشكلات البيئية المحلية والعالمية ، والمشكلات البيئية التي اتفق على انها اهم التحديات في الالفية الحالية(^). لذلك لابد من مشاركة الانسان في عملية التخطبط لحماية البيئة ، وفي المراقبة البيئية ، واتخاذ القرار البيئي السليم من خلال ما يلي: ا.الوعي بالمشكلات البيئية العالمية: هناك العديد من المشكلات البيئية العالمية ، من مثل : الزيادة السكانية وانعكاساتها على البيئة سواء من ناحية زيادة استتزاف الموارد الطبيعية او التلوث ، اضافة إلى محدودية الموارد الطبيعية غير المتجددة (كالبترول والخامات المعدنية) ، واثر الاستهلاك بما يفوق سرعة التجديد للموارد المتجددة (كالثروة السمكية ، والموارد المائية السطحية) ، ومشكلات تغير المناخ وانحباس الامطار ، وفقدان التتوع لهرتئ البيولوجي ، والتصحر وغيرها ، يعد من أهم المشكلات البيئية العالمية.

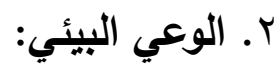

وعي الانسان بأهم تحديات هذه الالفية ، وتدخله ومشاركته في صون بيئته عملا وقولا ـ واهم هذه التحديات ما اتفق عليه في مؤتمر جوهانسبرج عام (r . . ب) ، وتتثمل المياه والصحة والطاقة والزراعة والتتوع الحيوي ، وقد اضيف اليها الموارد الساحلية والبحرية نظرا لأهميتها الكبيرة. r. الوعي بأهمية المشاركة في المراقبة واتخاذ القرار: إنَّ مشاركة الانسان في الرقابة البيئية واتخاذ القرار والاسهام في تتفيذه ، يعتبر من العوامل التي تتمي ارتباط المواطن بييئته ، اذ ان ذللك يعزز شعورة بإمكانية المشاركة في ادارتها والمحافظة عليها ، غير ان تحقيق هذا الهدف يتطلب تتجيع التعليم والتنقيف البيئي الوطني ، ورفع مستوى معرفته بمكونات البيئة ، كذلك تتمية 
اتجاهات حماية البيئة المتوقعة مستقبلا ، بغية التدخل السليم لحماية البيئة ومواردها وتسهيل المشاركة الفاعلة في حلقات النقاش المتصلة بالبيئة المحلية والمتوقعة مستقبلا ، آثارها الاجتماعية والاقتصادية اضافة إلى اثارها البيئية ، والتخطيط وسن القوانين والقرارات التشريعية البيئية لحل تلك المشكلات ، والسعي إلى تتفيذها(9).

\section{المبحث الثاني: الجانب التطبيقي (نتائج الاراسة ومناقشتها).}

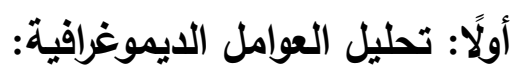

يُلاحظ من نتائج الجدول أدناه إنَّ القسم العلمي الذي شغل المرتبة الاولى

تمنل في قسم العلوم النفسية، وقسم اللغة الانكليزية بتكرار بلغ (9 ) أب بنسبة مئوية قدرها (؟r\%) للقسمين موزعة على اساس النوع الاجتماعي ومناطق السكن، اذ كان النوع الاجتماعي الاعلى تكرار لقسم العلوم النفسية ضمن فئة الذكور بتكرار بلغ (YV)

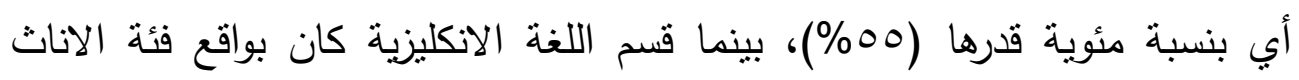
بتكرار قدره (1§) أي بنسبة مئوية بلغت (ع^\%)، في حين مناطق السكن لقسم العلوم النفسية، وقسم اللغة الانكليزية تمحورت في مناطق الحضر كونها حصلت على

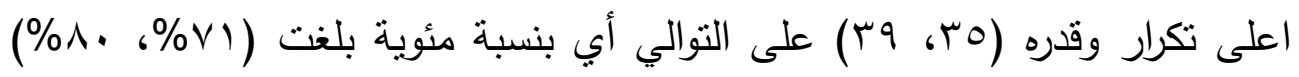
على التوالي. في حين جاء قسم الجغرافية بالمرتبة الثانية بتكرار قدره ( (ع) أي بنسبة مئوية بلغت (·r\%) موزعة على اساس النوع الاجتماعي ومناطق السكن، فعلى اساس النوع الاجتماعي ومناطق السكن كانت الفئة السائدة ضمن الذكور، ومناطق الحضر بتكرار منساوي نوعا ما وقدره (Y) أبي بنسبة مئوية قدرها (10\%). وجاء قسم التأريخ في المرنبة الثالثة بتكرار بلغ (ب0) أي بنسبة مئوية قدرها (VI\%)، موزعة على اساس النوع الاجتماعي ومناطق السكن، اذ ان الفئة السائدة كانت ضمن فئة الاناث بالنسبة الى النوع الاجتماعي بتكرار قدره (9 1) أي بنسبة مئوية بلغت 


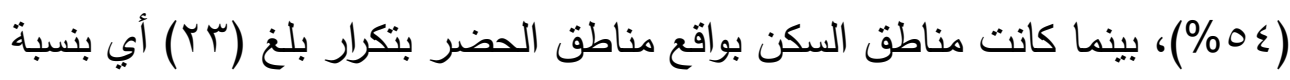
مئوية قدرها (T7\%).وجاء بالمرتبة الاخيرة قسم اللغة العربية بتكرار قدره (YV) أي بنسبة مئوية بلغت (T (\%))، موزعة على اساس النوع الاجتماعي ومناطق السكن، اذ كان النوع الاجتماعي ضمن فئة الاناث بتكرار بلغ (0) أي بنسبة مئوية قدرها (70\%)، بينما مناطق السكن كانت ضمن فئة مناطق الحضر بتكرار قدره (9 () أي بنسبة مئوية بلغت ( · ) (\%).

الجدول (1) خصائص عينة البحث

\begin{tabular}{|c|c|c|c|c|c|c|c|c|}
\hline \multirow{4}{*}{ الالمرتبة } & \multicolumn{2}{|c|}{ السكن } & \multicolumn{2}{|c|}{ النوع الاجتماعي } & \multirow{2}{*}{\multicolumn{3}{|c|}{ القسم العلمي }} & \multirow{2}{*}{ ت } \\
\hline & \multirow{2}{*}{ ريف } & \multirow{2}{*}{ هضر } & \multirow{2}{*}{ أنثى } & \multirow{2}{*}{ ذكر } & & & & \\
\hline & & & & & 49 & ث' & \multirow{2}{*}{ العلوم النفسية } & \multirow{2}{*}{1} \\
\hline & $29 \%$ & $71 \%$ & $45 \%$ & $55 \%$ & $24 \%$ & ${ }^{r} \%$ & & \\
\hline \multirow{2}{*}{ الاولّى } & 11 & $r q$ & $\leqslant 1$ & $\wedge$ & 49 & $ت$ & \multirow{2}{*}{ اللغة الإنكليزية } & \multirow{2}{*}{$r$} \\
\hline & $22 \%$ & $80 \%$ & $84 \%$ & $16 \%$ & $24 \%$ & $\%$ & & \\
\hline \multirow{2}{*}{ الثالثة } & ir & 23 & 19 & 17 & 35 & $ت$ & \multirow{2}{*}{ التاريخ } & \multirow{2}{*}{$\mu$} \\
\hline & $34 \%$ & $66 \%$ & $54 \%$ & $46 \%$ & $17 \%$ & $\%$ & & \\
\hline \multirow{2}{*}{ الثانية } & $r$. & 21 & $r \cdot$ & rl & 41 & $ت$ & \multirow{2}{*}{ الجغرافية } & \multirow{2}{*}{$\varepsilon$} \\
\hline & $49 \%$ & $51 \%$ & $49 \%$ & $51 \%$ & $20 \%$ & $\%$ & & \\
\hline \multirow{2}{*}{ الرابعة } & $\wedge$ & 19 & 10 & ir & 27 & $ت$ & \multirow{2}{*}{ اللغة العربية } & \multirow{2}{*}{0} \\
\hline & $30 \%$ & $70 \%$ & $56 \%$ & $44 \%$ & $13 \%$ & $\%$ & & \\
\hline & \multicolumn{2}{|c|}{201} & \multicolumn{2}{|c|}{201} & & & \multirow{2}{*}{ المجموع } & \\
\hline & \multicolumn{2}{|c|}{$\% 1 \ldots$} & \multicolumn{2}{|c|}{$\% 1 \ldots$} & & & & \\
\hline
\end{tabular}

المصدر: الباحثان.

'(ت) = التكرارات.

(\%) = النسبة المئوية. 
ثانيا: - قياس ثبات اداة البحث.

ومن اجل قياس ثبات اداة البحث بتعين اخضاع البيانات المسحوبة عن طريق اداة الاستبانة الى اختبار كرونباخ الفا الذي يعمل على قياس ثبات الاداة المستعملة، والجدول ادنى يوضح اختبار كرونباخ الفا. الجدول (Y) اختبار معامل كرونباخ الفا

\begin{tabular}{|c|c|}
\hline \multicolumn{2}{|c|}{ Reliability Statistics } \\
\hline Cronbach's Alpha & N of Items \\
\hline 0.812 & 30 \\
\hline
\end{tabular}

نلاحظ من النتائج الواردة في الجدول اعلاه ان اختبار كرونباخ الفا قد بلغ (Y (A.. ) الامر الذي يعني ان الاستبانة اداة القياس تتسم بالثبات والمصداقية العالية وهذا يعني قبول فقرات الاستبانة على طبيعتها الحالية. ثالثاً:- الاحصاء الوصفي لبيانات البحث. تتطرق هذه الفقرة الى قياس الاوساط الحسابية والانحرافات المعيارية ومعاملات الاختلاف ومعاملات التباين بين الاقسام العلمية والاهمية النسبية لكل قسم على حدة. الجدول (r) الاحصاء الوصفي على اساس الاقسام العلمية

\begin{tabular}{|c|c|c|c|c|c|c|c|}
\hline ترتيب & الاهمية & الاختلاف معامل & معامل & الانحراف & الوسط & القسم العلمي & ت \\
\hline$\varepsilon$ & $50 \%$ & $9 \%$ & 0.054 & 0.233 & 2.51 & العلوم النفسية & 1 \\
\hline$r$ & $53 \%$ & $8 \%$ & 0.043 & 0.208 & 2.66 & اللغة الإنكليزية & $r$ \\
\hline 0 & $48 \%$ & $11 \%$ & 0.071 & 0.266 & 2.41 & التاريخ & $r$ \\
\hline 1 & $54 \%$ & $7 \%$ & 0.036 & 0.189 & 2.68 & التطبيقية & $\varepsilon$ \\
\hline$r$ & $53 \%$ & $10 \%$ & 0.069 & 0.263 & 2.63 & اللغة العربية & 0 \\
\hline$* * * *$ & $52 \%$ & $4 \%$ & 0.013 & 0.115 & 2.58 & لمعدل العام & \\
\hline
\end{tabular}

المصدر : الباحثان. 
نلاحظ من النتائج الواردة في الجدول اعلاه ان قسم الجغرافية اتى بالمرنبة الاولى بوسط حسابي عالي نوعا ما وقدره (Y.7^) وبانحراف معياري منخفض وقد

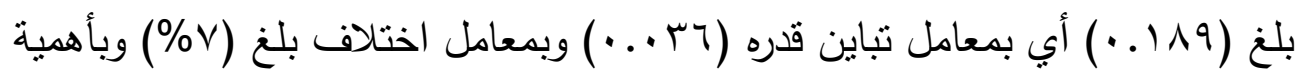
نسبية قدرها (§ه\%)، الامر الأي يعني ان طلاب قسم الجغرافية يمتلكون مستوى عالي من الوعي بمفهوم التنمية المستدامة. وجاء قسم اللغة الانكليزية، واللغة العربية بالمرتبة الثانية بوسط حسابي بلغ (T.T.T، r.T.Y) على التوالي وبانحراف

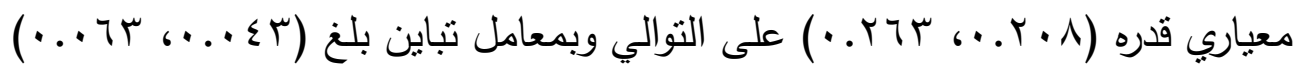
على التوالي و بمعامل اختلاف قدره (^^\%، • (\%) على التوالي وبأهمية نسبة منساوية بلغت (rه\%). بينما جاء قسم العلوم النفسية في المرتبة الثالثة بوسط

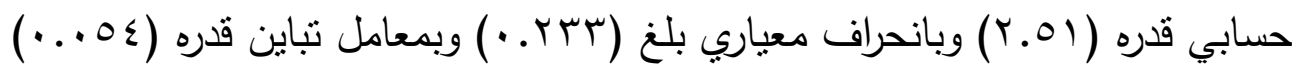
أي بمعامل اختلاف بلغ (9\%) وبأهمية نسبة قدرها (.0\%). وكانت المرتبة الاخيرة

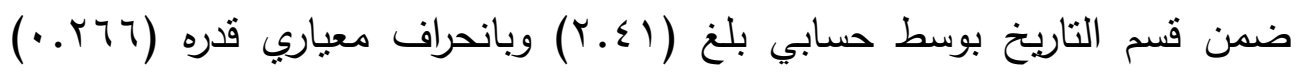

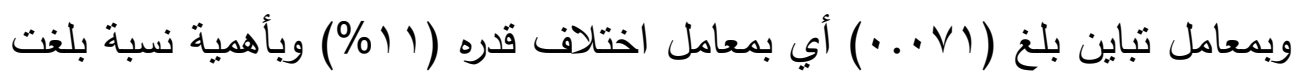

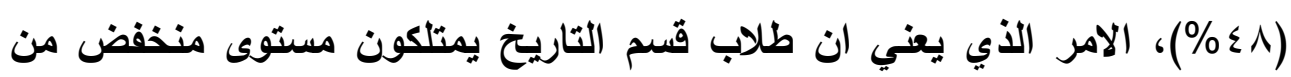
الوعي بمفهوم التنمية المستدامة ، الامر الذي يتيعن زيادة وعي طلاب بمفهوم التنمية المستدامة من خلال اضافة مقررات دراسية تختص بموضوع التنمية

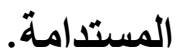


والثكل (Y) يوضح ترتيب الاهمية النسبية للأقسام العلمية.

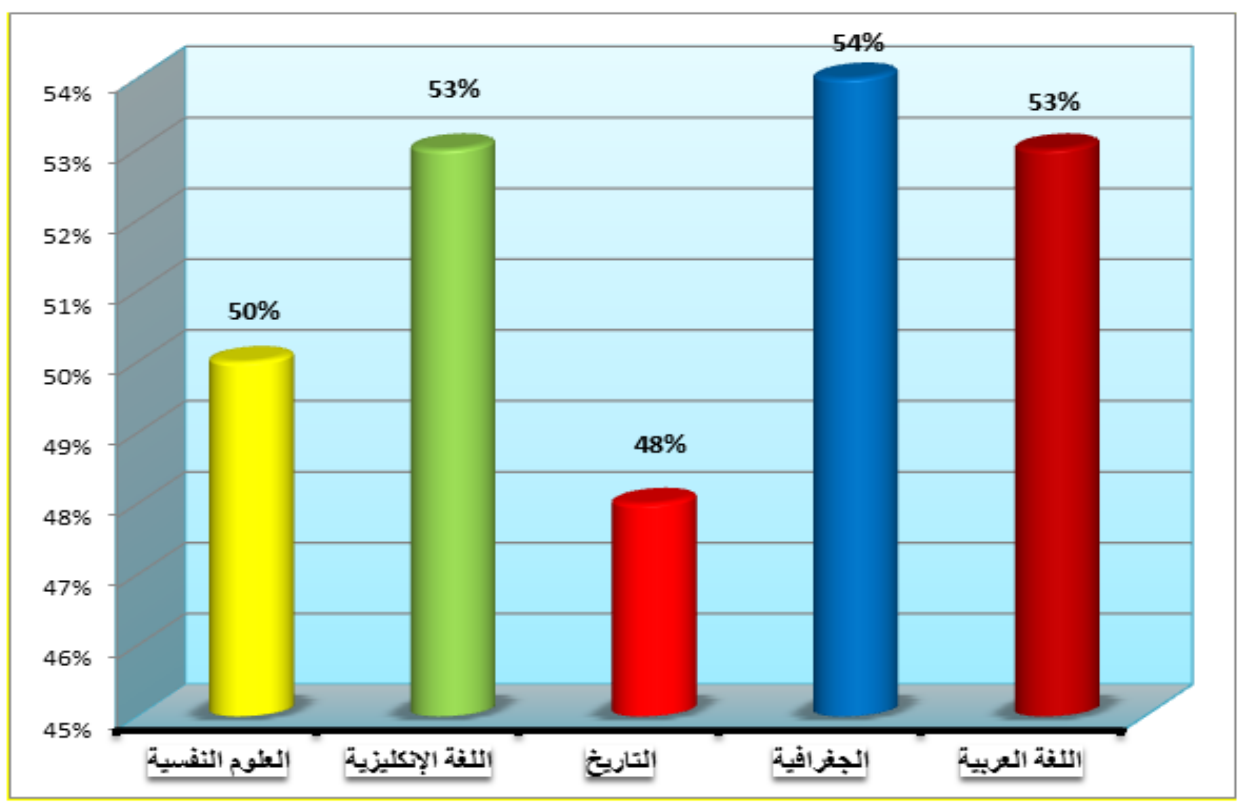

المصدر : الباحثَان.

رابعاً:- قياس مستوى التباين ا.قسم العلوم النفسية والتريوية.

تثشير النتائج الواردة في الجدول ادنى الى عدم وجود فروقات فردية ذات دلالة احصائية لتأثنر قسم العلوم النفسية على النوع الاجتماعي (الجنس)، و مناطق السكن، اذ ان القيمة المعنوية لقيمة (F) هي اعلى من (0...)، الامر الذي يعني عدم وجود تباين او اختلاف في الوعي بمفهوم التتمية المستدامة بل ان كلا الجنسين سواء الذكور او الاناث يمتلكون نفس مستوى الوعي بمفهوم التتمية المستدامة،

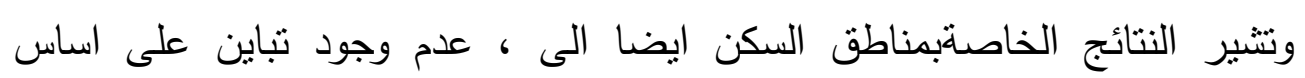
المنطقة السكنية اذ ان كلا المنطقتين تثتلك نفس الوعي بمفهوم التتمية المستدامة سوى على مستوى الحضر او الريف. 
الجدول ( ) نتائج تحليل التباين الاحادي لتأثير متغير الوعي البيئي لاى طلاب العلوم النفسية في النوع الاجتماعي (الجنس)، ومناطق السكن

\begin{tabular}{|c|c|c|c|c|c|}
\hline مستوى & ق قيمة F & متوسط المربعات & الحرجة & المربعات & \\
\hline \multicolumn{6}{|c|}{ النوع الاجتماعي (الجنس) } \\
\hline \multirow[t]{3}{*}{. vor } & $. .1+1$ & $\cdots$ & 1 & $\ldots .4$ & بين المجموعات \\
\hline & & $\ldots .00$ & $\leqslant v$ & Y.१. T & المجموعات \\
\hline & & & $\varepsilon \wedge$ & r.TIY & المجموع \\
\hline \multicolumn{6}{|c|}{ منطقة السكن } \\
\hline \multirow[t]{3}{*}{. .01} &. .411 & $\ldots$ IV & 1 & $\ldots+v$ & بين المجموعات \\
\hline & & $\ldots .00$ & $\leqslant V$ & r.090 & المجموعات \\
\hline & & & $\varepsilon \wedge$ & r.TIY & المجموع \\
\hline
\end{tabular}

المصدر:الباحثان.

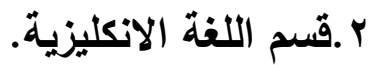

نلاحظ من النتائج الواردة في الجدول ادنى ان معنوية قيمة (F) لقسم اللغة

الانكليزية هي اعلى من (0...) سوى على اساس النوع الاجتماعي (الجنس) او المنطقة السكنية، الامر الذي يعني عدم وجود فروق فردية ذات دلالة احصائية لدى طلاب قسم اللغة الانكليزية سواء على اساس النوع الاجتماعي او المنطقة السكنية، أي ان طلاب قسم اللغة الانكليزية الذكور، والاناث، سواء في المناطق السكنية الحضر او الريف، فانهم يمتلكون نفس المستوى من الوعي بمفهوم التتمية المستدامة. 
الجدول (0) نتائج تحليل التباين الاحادي لتأثير متغير الوعي البيئي لاى طلاب اللغة الانكليزية في النوع الاجتماعي (الجنس)، ومناطق السكن

\begin{tabular}{|c|c|c|c|c|c|}
\hline مستوى الالالة & قيمة F F & المربعات & الحرجة & المريعات & \\
\hline \multicolumn{6}{|c|}{ النوع الاجتماعي (الجنس) } \\
\hline \multirow[t]{3}{*}{ •.AYT } & $\ldots \leqslant q$ & $\cdots r$ & 1 & $\cdots r$ & بين المجموعات \\
\hline & & $\cdots \leq \varepsilon$ & $\leqslant V$ & r...VT & المجموعات \\
\hline & & & $\varepsilon \wedge$ & r..Vq & المجموع \\
\hline \multicolumn{6}{|c|}{ منطقة السكن } \\
\hline \multirow[t]{3}{*}{$\cdot r \leqslant 0$} & .91. & $\ldots r q$ & 1 & $\ldots+q$ & بين المجموعات \\
\hline & & $\cdots \leqslant r$ & $\leqslant V$ & r...rq & المجموعات \\
\hline & & & $\varepsilon \wedge$ & r...vq & المجموع \\
\hline
\end{tabular}

المصدر : الباحثان.

r.قسم التاريخ.

أسفرت النتائج الواردة في الجدول ادناه الى عدم وجود فروقات فردية على اساس الوعي بمفهوم التتمية المستدامة بين طلاب قسم التاريخ سواء على اساس النوع الاجتماعي او المنطقة السكنية، فكلاهما يمنلك قيمة معنوية اعلى من (0 ...). 


\begin{tabular}{|c|c|c|c|c|c|}
\hline مستوى الدلالة & قيمة F & متوسط المربعات & درجة الحرية & مجموع المربعات & \\
\hline \multicolumn{6}{|c|}{ النوع الاجتماعي (الجنس) } \\
\hline \multirow[t]{3}{*}{$\cdot . \leqslant 7 V$} & $.0 \leqslant$. & $\cdots r q$ & 1 & $\ldots+r q$ & بين المجموعات \\
\hline & & $\cdots V Y$ & 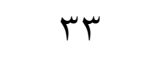 & r.MTo & داخل المجموعات \\
\hline & & & $r \varepsilon$ & T.乏. & المجموع \\
\hline \multicolumn{6}{|c|}{ منطقة السكن } \\
\hline \multirow[t]{3}{*}{.$V T \varepsilon$} & $.11 \mathrm{~V}$ & $\cdots 9$ & 1 & $\cdots 9$ & بين المجموعات \\
\hline & & ...vr & 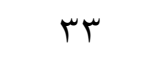 & r.r90 & داخل المجموعات \\
\hline & & & r & Y. $\varepsilon \cdot \varepsilon$ & المجموع \\
\hline
\end{tabular}

ع .قسم الجغرافية التطبيقية.

نلاحظ من النتائج الظاهرة في الجدول ادناه الى عدم وجود فروق فردية ذات دلالة احصائية للوعي البيئي على النوع الاجتماعي (الجنس) اذ ان مستوى معنوية التباين لقيمة (F) هي اعلى من (0 . . •) الامر الذي يعني عدم وجود اختلافات بين مستويات الطلاب بالنسبة للوعي بمفهوم التتمية المستدامة سواء من حيث الذكور او الاناث.بينما يلاحظ المتبع لنتائج الجدول ادنى الى وجود فروق فردية ذات دلالة احصائية للوعي البيئي في مناطق السكن على اساس الحضر او الريف، الامر الذي يعني وجود ثأثير معنوي للوعي البيئي في مناطق السكن وبقيمة معنوية مقدراها (Tr • . •)، أي ان الفرق بينهما (بين المجموعات) وبقيمة ثابته بلغ (VY I . • ) عندما يكون الفرق داخل المجموعات هو (9 ( ب. ())، وعليه فان قيمة الوعي بمفهوم التتمية المستذامة بالنسبة للحضر هي اعلى من الريف. 
الجدول (V) نتائج تحليل التباين الاحادي لتأثثر متغير الوعي البيئي لدى طلاب الجغرافية في النوع الاجتماعي (الجنس)، ومناطق السكن

\begin{tabular}{|c|c|c|c|c|c|}
\hline الدلالة & ق قيمة F & متوسط المريعات & لدرجة & مجموع المربعات & \\
\hline \multicolumn{6}{|c|}{ النوع الاجتماعي (الجنس) } \\
\hline \multirow[t]{3}{*}{$\cdot . r \wedge 9$} &.$\vee \vee 4$. & $\ldots r v$ & 1 & $\ldots r V$ & بين المجموعات \\
\hline & & ...rq & rq & $1 . \Gamma 95$ & داخل المجموعات \\
\hline & & & $\varepsilon$. & $1 . \leqslant r$ & المجموع \\
\hline \multicolumn{6}{|c|}{ منطقة السكن } \\
\hline \multirow[t]{3}{*}{...r4 } & $0 . T V Y$ &..$I V r$ & 1 & $\because \mathrm{VYr}$ & بين المجموعات \\
\hline & & $\ldots r r$ & rq & $1 . r \leqslant 9$ & داخل المجموعات \\
\hline & & & $\varepsilon$. & $1.2 r_{1}$ & المجموع \\
\hline
\end{tabular}
المصدر : الباحثان.

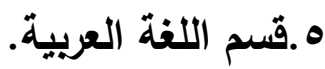
تبين النتائج الواردة في الجدول ادنى عدم وجود فروق فردية ذات دلالة احصائية بين الوعي بمفهوم التتمية المستدامة والنوع الاجتماعي (الجنس)، ومناطق السكن، أي ان النوع الاجتماعي ومناطق السكن لا يؤثر على مستوى الوعي بمفهوم

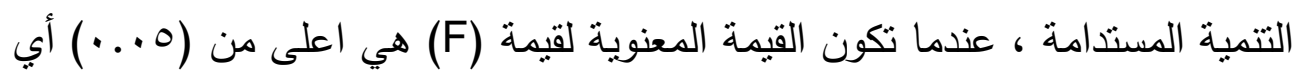
ان الامر يثير الى قبول فرضية العدم التي تفرض عدم وجود تباين أي عدم وجود

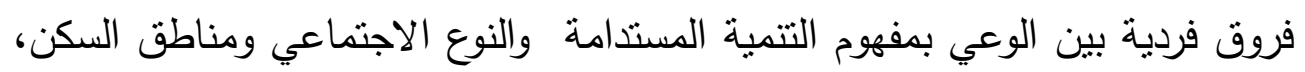
ورفض الفرضية البديلة التي تفرض وجود تباين بينها. 
الجدول (^) نتائج تحليل التباين الاحادي لتأثير متغير الوعي بمفهوم التنمية المستدامة للى طلاب اللغة العربية في النوع الاجتماعي (الجنس)، ومناطق السكن

\begin{tabular}{|c|c|c|c|c|c|}
\hline مستوى الدلالة & Fيمة F & متوسط المربعات & | درجة الحرية & مجموع المربعات & \\
\hline \multicolumn{6}{|c|}{ النوع الاجتماعي (الجنس) } \\
\hline \multirow[t]{3}{*}{$. .11 \leqslant$} & r.TAV &. $.1 V \varepsilon$ & 1 &. $.1 \vee \varepsilon$ & بين المجموعات \\
\hline & & $\ldots 70$ & ro & 1.711 & داخل المجموعات \\
\hline & & & TY & l.var & المجموع \\
\hline \multicolumn{6}{|c|}{ منظقة السكن } \\
\hline \multirow[t]{3}{*}{$\therefore \leqslant 00$} &. .084 & $\ldots \varepsilon$ & 1 & $\ldots \leqslant$ & بين المجموعات \\
\hline & & $\ldots v$. & ro & l.vor & داخل المجموعات \\
\hline & & & Y & I.Var & المجموع \\
\hline
\end{tabular}

خلاصة تحليل التباين الاحادي بين الاقسام:

يُلاحظ من النتائج الواردة في الجدول ادناه الى ان الفرضيات البديلة لجميع الاقسام ضمن النوع الاجتماعي (الجنس) قد تم رفضها والتي تقرض (وجود فروق فردية بين الوعي بمفهوم التتمية المستدامة والنوع الاجتماعي)، بينما تم قبول فرضية العدم لجميع الاقسام والتي تقرض (عدم وجود فروق فردية بين الوعي البيئي والنوع

$$
\text { الاجتماعي). }
$$

بينما يلاحظ من ان الفرضيات البديلة لجميع الاقسام فيما عدا قسم الجغرافية ضمن مناطق السكن قد نم رفضها والتي تقرض (وجود فروق فردية بين الوعي البيئي ومناطق السكن) وقبول فرضية العدم التي تفرض ( عدم وجود فروق فردية بين الوعي البيئي ومناطق السكن). 
في حين ان قسم الجغرافية فهو القسم الوحيد الذي تم قبول الفرضية البديلة لدية والتي تفرض (وجود فروق فردية بين الوعي بمفهوم التنمية المستدامة ومناطق السكن) أي ان مناطق السكن تؤثر على مستوى الوعي بمفهوم التتمية المستدامة ، ورفض فرضية العدم التي تفرض ( عدم وجود فروق فردية بين الوعي بمفهوم التتمية المستدامة ومناطق السكن).

الجدول (9) خلاصة تحليل التباين الاحادي

\begin{tabular}{|c|c|c|c|c|c|c|c|}
\hline \multicolumn{3}{|c|}{ مناطق السكن } & \multicolumn{3}{|c|}{ النوع الاجتماعي } & \multirow[b]{2}{*}{ القسم العلمي } & \\
\hline$\frac{E}{E}$ & $\frac{E^{*}}{E}$ & الفرضية & है & $\begin{array}{l}\text { E. } \\
\text { E. } \\
\text { E. } \\
\text { E. }\end{array}$ & الفرضية & & 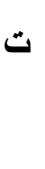 \\
\hline قبول & رفض & علم وجود فروق & قبول & رفض & عدم وجود فروق & العلوم النفسية & 1 \\
\hline قبول & رضض & علم وجود فروق & قبول & رفض & عدم وجود فروق & الإنكليزية & $r$ \\
\hline قبول & رفض & علم وجود فروق & قبول & رفض & عدم وجود فروق & التاريخ & $r$ \\
\hline رفض & قبول & وجود فروق فردية & قبول & رفض & عدم وجود فروق & الجغرافية & \{ \\
\hline قبول & رفض & عدم وجود فروق & قبول & رفض & عدم وجود فروق & اللغة العربية & 0 \\
\hline
\end{tabular}




\section{|الاستنتاجات:}

ا. إن طلاب قسم الجغرافية التطبيقية يمتلكون مستوى عالي من الوعيمفهوم

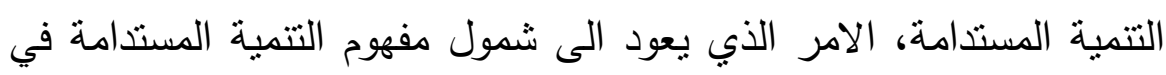
مقرراتهم الدراسية. r. إن طلاب قسم التاريخ هم الاقل مستوى من الوعي بمفهوم التتمية المستدامة وذللك بسبب ابتعاد اختصاصهم عن مفهوم التتمية المستدامة. r. عدم وجود فروق فردية لجميع الاقسام بين الوعي بمفهوم التتمية المستدامة والنوع الاجتماعي، الامر الذي يعني ان النوع الاجتماعي (الجنس) لا يؤثر على مستوى الوعي بمفهوم التتمية المستدامة وذللك يعود الى ان كلا النوعين يخضعون لنف البرامج التعليمية ونفس الظروف التي تؤدي الى اكسابهم مستوى معين من الوعي بمفهوم التتمية المستدامة. ع. عدم وجود فروق فردية لطلاب قسم العلوم النفسية، واللغة الانكليزية، والتأريخ، واللغة العربية بين الوعي البيئي ومناطق السكن، الامر الذي يعني انه يتعين زيادة اهتمام طلاب الريف بالبيئة كونهم الاكثر تعاملاً مع البيئة

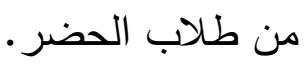
ه. وجود فروق فردية لطلاب قسم الجغرافية التطبيقية بين الوعي البيئي ومناطق السكن، الامر الذي يعني ان مناطق السكن تثؤثر على مستوى الوعي بمفهوم

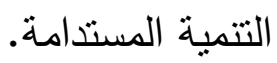




\section{التوصبات:}

ا • يتعين ادخال مقررات دراسية خاصه بمفهوم التتمية المستدامةلقسمالتاريخ من اجل زيادة وعي الطلاب بمفهوم التتمية المستدامة. r. يتعين تعزيز الوعي بمفهوم التتمية المستدامة لأقساماللغةالعربيةواللغةالإنكليزية والعلوم النفسية والجغرافية التطبيقية من خلال ادخال مقررات دراسية ومؤتمرات ومحاضرات علميه خاصه بمفهوم التنمية المستدامة . r. اقامة نشاطات علمية ومهرجانات خاصه بمفهوم التتمية المستدامة لتعريف الطلاب بالتتمية المستدامة وعلاقتها بالمحافظة على مستوى من الحياة التي لا تؤثر على البيئة وتحقق حاجات ورغبات الاجيال الحالية ولا تضر بقدرة الاجيال القادمة على تحقيق حاجاتها . ع. ضرورة تعريف طلاب الكلية بمفهوم التتمية المستدامة باعتبارهم في المستقبل سيصبحون مسؤولين عن تكوين وعي للطلاب بمفهوم التتمية المستدامة في المستقبل. 


\section{قائمة المصادر: - n}

ا ـ عدنان فرحان الجوارين ، التتمية المستدامة في العراق الواقع والتحديات ، شبكة الاقتصاديين العراقيين ، اوراق اقتصادية ، (بدون تاريخ) ، ص r.

Y. دوجالس موسشيت، مبادئ التتمية المستدامة، ترجمة بهاء شاهين، مصر، الدار الدولية للاستثمارات التقافية، الطبعة الأولى، . . . Y،صه 1. r. عبد القادر محمد عبد القادر، قضايا اقتصادية معاصرة، مصر، جامعة

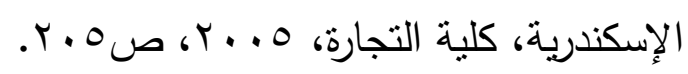

ع. البرنامج الإنمائي للأمم المتحدة، تقرير التتمية البشرية ع99 19 ،نيويورك،

$$
\text { . ะ. } 199 \leq
$$

هـ العايب عبد الرحمن ، التحكم في الاداء الثامل للمؤسسة الاقتصادية في الجزائر في ظل تحديات التتمية المستدامة ، اطروحة دكتوراه (منشوره) ، كلية العلوم الاقتصادية ، جامعة فرحات عباس ، الجزائر ، ، 1 . ب ، ص أ. 7. إبراهيم مطاوع، التربية البيئية في الوطن العربي. القاهرة ، دار الفكر العربي،

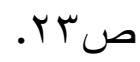
V. محمود أحمد حميد.، الثقافة البيئية مطلب حضاري للأسرة. دمشق: دار الرضا

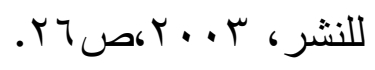

^. ناصر عبادي، السنيدي، دور القبائل في الحفاظ على الغطاء النباتي والمراعي في الجمهورية اليمنية. من وقائع وأبحاث المؤتمر العلمي الأول

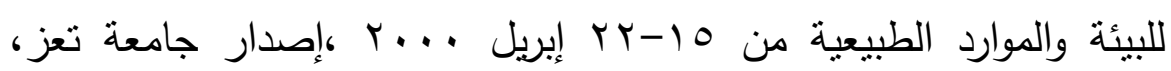

$$
\text { ص }
$$

9 ـ أسماء أبا حسين، مؤشرات مدى تحقيق المواطنة البيئة. مجلة العلوم

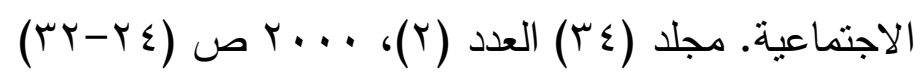




\section{م/ إستمارة|إستبانية}

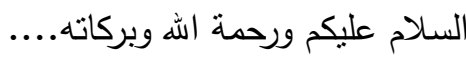
طلبتنا الأعزاء...

نضع بين أيديكم إستمارة إستبانة حول البحث الموسوم بـ ( قياس مستوى الوعي بمفهوم التنمية

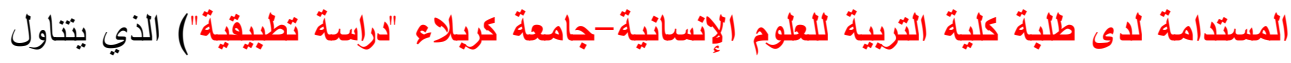
فيه قياس مدى معرفة واهتمام طلبة الجامعة بمفهوم التتمية المستدامة وأثر ذلك على إمكانية التحول كلئل نحو تحقيق برامج التتمية المستدامة في العراق والحفاظ على التوازن البيئي وديمومة الموارد الطبيعية

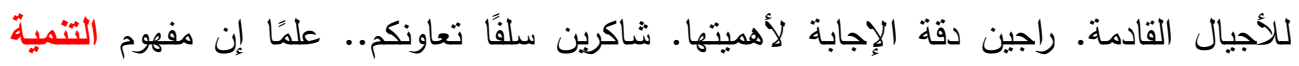

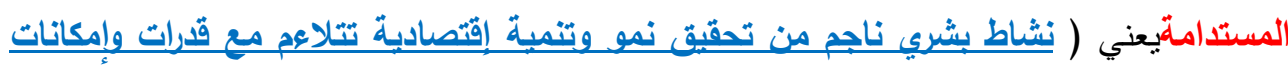
الباحثان: البيئة ضمن العيز المكاني (لحالي).

أ.د. رياض محمد علي عوده المسعودي والباحث مؤيد فضل حسين نجم الصكر.

أولًا: المطلومات الأساسية:

$$
\begin{aligned}
& \text { ا. ا. القسم العلمي: } \\
& \text { r. المرحلة: } \\
& \text { r. الجنس: }
\end{aligned}
$$

\begin{tabular}{|c|c|c|c|c|}
\hline 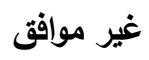 & 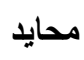 & 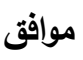 & 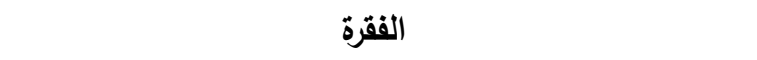 & $ت$ \\
\hline & & & التتمية الإقتصادية ضرورية لتحقيق التتمبة المستدامة & .1 \\
\hline & & & تحسين فرص الحياة للسكان صحياً بساهم في التتمية المستدامة & .4 \\
\hline & & & حماية البيئة ضرورة لتحقيق التتمية المستدامة. & 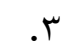 \\
\hline & & & ثقافة السلام وتسوية الصراعات سلمياً طريق نحو تحقيق التتمية المستدامة. & . \\
\hline & & & النشاطات والاعمال البشرية تساهم في احداث التغيرات المناخية. & .0 \\
\hline & & & التتمية المستدامة تتطلب من الافراد عملية ادارة النفايات بشكل سليم. & .7 \\
\hline & & & المواطنة الصالحة ضرورية لتحقيق التتمية المستدامة. &.$V$ \\
\hline & & & التتمية المستدامة لا تعتمد على المساواة بين الجنسين. &.$\wedge$ \\
\hline & & & القضاء على الفقر ضروري لتحقيق التتمية المستدامة. & .9 \\
\hline & & & التتمية المستدامة تتطلب الحصول على مستوى عال من التعليم الجيد للجميع. & .1 . \\
\hline
\end{tabular}$$
\text { ع. بيئة السكن: ريف ( ) ) حضر ( ) ). }
$$

ثانيًا: الاسئلة التخصصية. 


\begin{tabular}{|c|c|c|c|c|}
\hline & & & الحفاظ على المياه العذبة ضروري لتحقيق التتمية المستدامة. & .11 \\
\hline & & & الحفاظ على التتوع البيولوجي امر ضروري لتحقيق التنمية المستدامة. & $.1 \mathrm{r}$ \\
\hline & & & احترام التتوع الثقافي مهم لتحقيق التتمية الدستدامة. & .14 \\
\hline & & & تتطلب التتمية المستدامة احترام حقوق الانسان وتطلعاتهم المستقبلية. & $.1 \leq$ \\
\hline & & & تتطلب التتمية المستدامة التوجه نحو استخدام الموارد المتجددة. & .10 \\
\hline & & & السريعة. التنمية المستدامة من السكان مواكبة التطورات العلمية & .17 \\
\hline & & & بالموارد الحالية. & $.1 \mathrm{~V}$ \\
\hline & & & عن الجني تقاسم المهام المنزلية بالتساوي بين افراد الاسرة بغض النظر & .11 \\
\hline & & & الرتثاع اسعار السلع الصديقة للبيئة بساهم في تحقيق التنمية & .19 \\
\hline & & & الخدمات المقدمة للمواطنين تساعد في تحقيق التتمية المستدامة. &.$r$. \\
\hline & & & هناك علاقة بين منع التلوث البيئي وارتفاع الاسعار وعلاقتها بتحقيق &.$r^{\prime}$ \\
\hline & & & التقليل من شراء المواد الضارة بالبيئة يحقق التتمية المستدامة. & .r \\
\hline & & & توفير استهلاك الطاقة الكهربائية يساهم في تحقيق التتمية المستدامة. & Tr \\
\hline & & & اعادة تدوير النفايات بساهم في تحقيق التتمية المستدامة. &.$r \varepsilon$ \\
\hline & & & تتطلب التتمية المستدامة ان يفهم الناس كيف يعمل الاقتصاد. &. ro $_{0}$ \\
\hline & & & تتليملب التتمية المستدامة المشاركة الفعالة في دورات تدريبية ومناهج & . \\
\hline & & & تجاه موظفيها. &.$r V$ \\
\hline & & & بساهم التصحر في عرقلة تحقيق التنمية المستدامة. &.$r \wedge$ \\
\hline & & & تساهم طبيعة نظام الحكم للدولة في تحقيق التتمية المستدامة. & .19 \\
\hline & & & تحقيق حالتية الثنفافية والمشاركة الفعالة للسكان في اتخاذ القرار في & r. \\
\hline
\end{tabular}




\section{التقييم البيئي لنوعية هياه الشرب المحلاة في مدينة الغردقة}

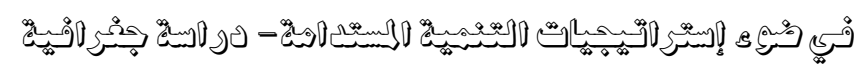

إعداد

د. محمدي شعبان محمدي

مدرس الجغرافية الطبيعية

كلية الآداب- جامعة المنوفية

r.IV 
تسببت الزيادة السكانية والتتمية الاقتصادية والاجتماعية، وكذلك التغيرات الهناخية، في زيادة

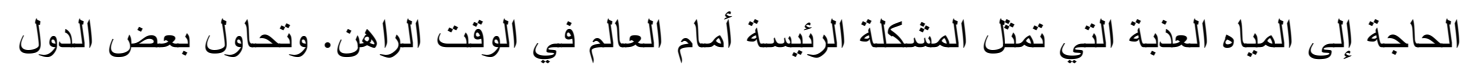

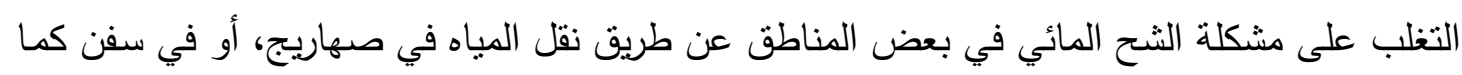
يحدث في جزر اليونان.

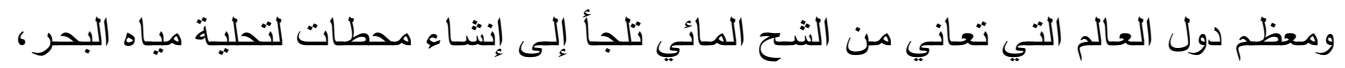

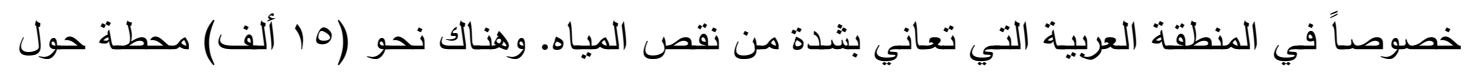

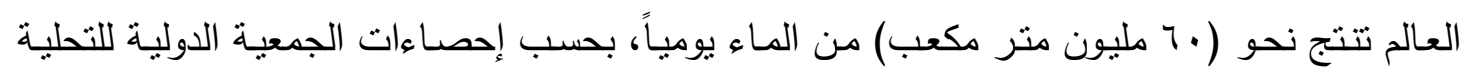

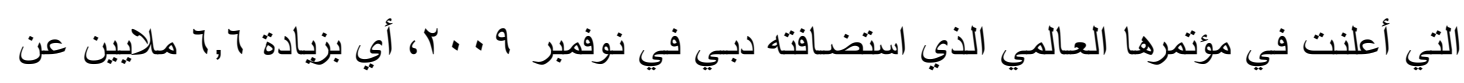

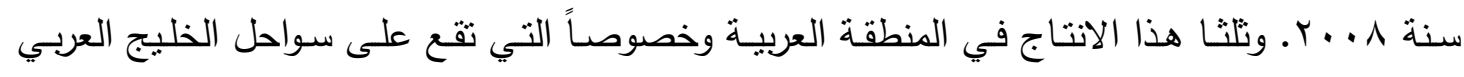

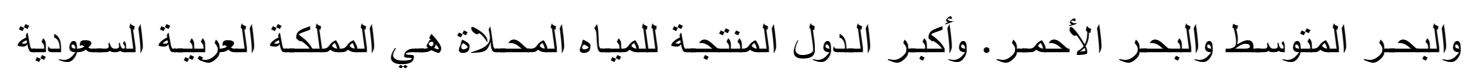

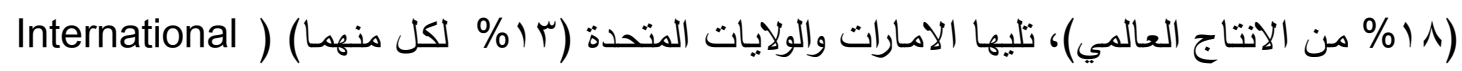

.(Desalination Association- IDA, 2009

وتعتبر تحلية المياه من المصادر غير الثقليدية للمياه العذبة، وتتتج عملية التحلية مياهاً ذات

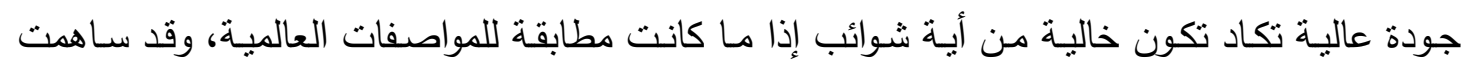

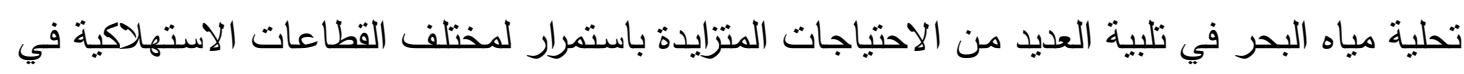

الكثير من دول العالم، خاصة تلك التي تقع في مناطق صحراوية الاحئ جافة منل منطقة الخليج العربي.

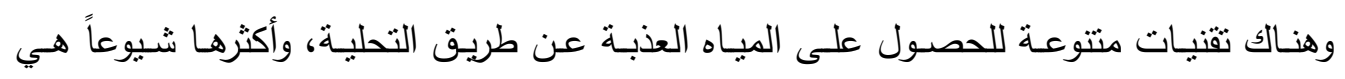

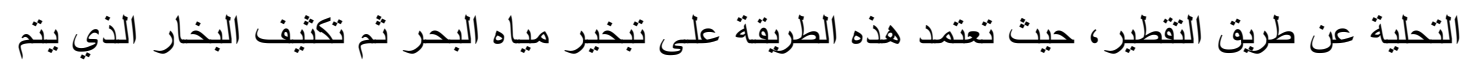

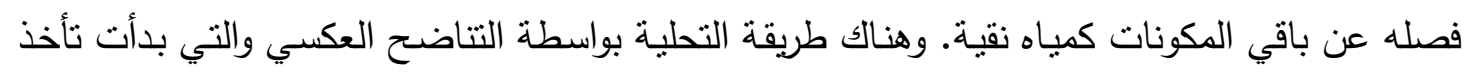

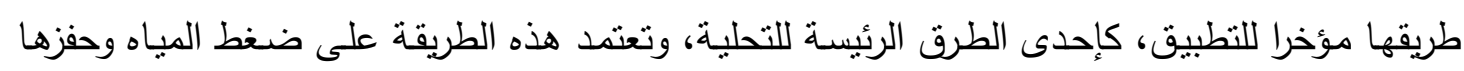

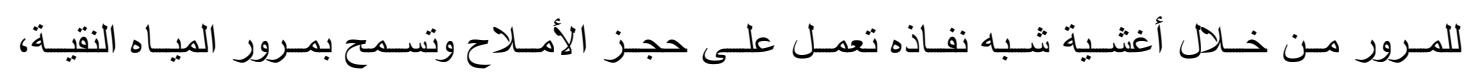

.(DOW",Water Solutions., Reverse Osmosis Membranes- Technical Manual) وأياً كانت التكنولوجيا المستخدمة في عملية النحلية، فإن المدخلات والمخرجات الرئيسة لعملية

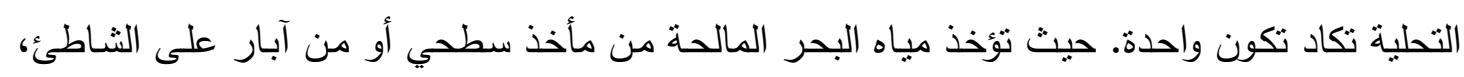

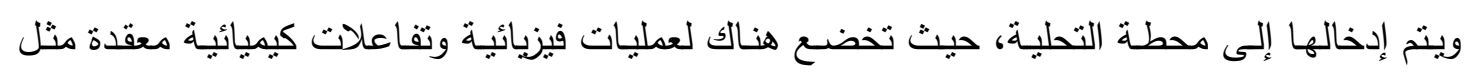

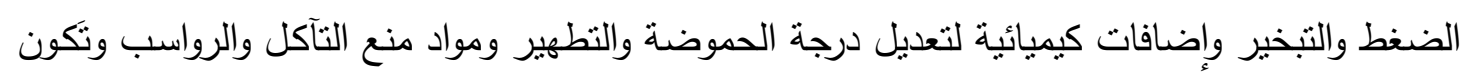

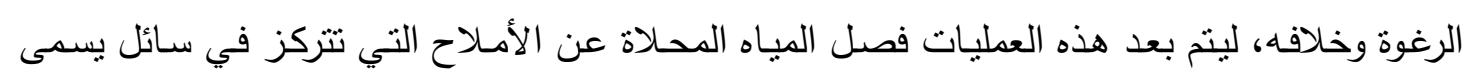

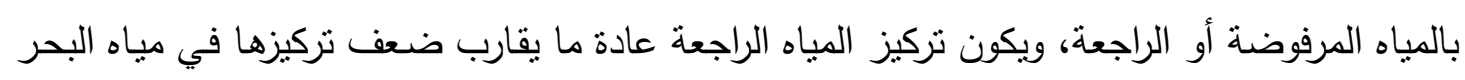

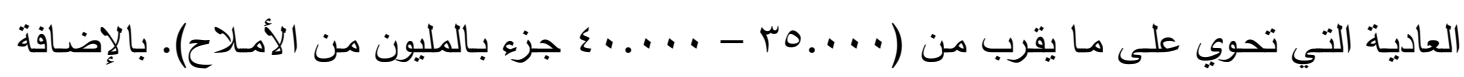

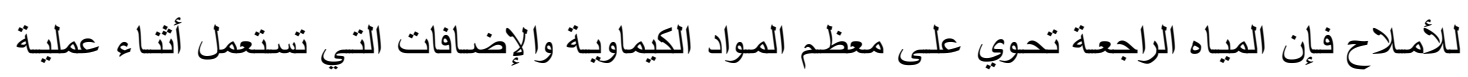

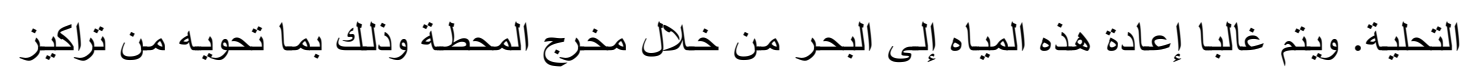
(1v9 1 \& $)$ 
عالية من الأمـلاح والكيماويات. أضف إلى ذلك درجة حرارة المياه الراجعة تكون عادة أعلى من درجة حرارة مياه البحر الطبيعية بحوالي (V- +1 درجات مئوية) وذلك في حالة التحلية عن طريق التقير

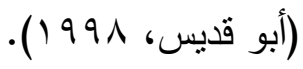

ومع دخول مصر منطقة الفقر المائي كما يقول الخبراء تسعى الحكومة المصرية للبحث عن مصادر بديلة لمياه الثرب النظيفة، زاد الاعتماد على تحلية مياه البحر خاصسة في المحافظات الساحلية والمناطق الحدودية التي يصعب مد مياه النيل إليها. وتعتمد مصر على مياه نهر النيل بنسبة (.9\%)

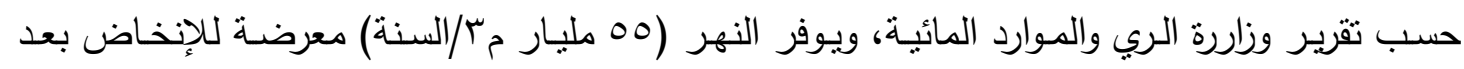
تششين سد النهضة الذي تننيه أثنيوبيا على فرع رئيسي من النهر •

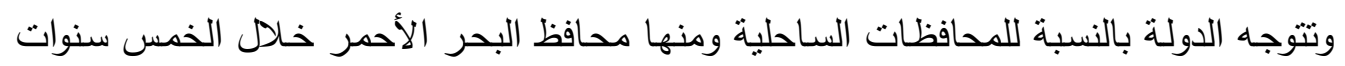

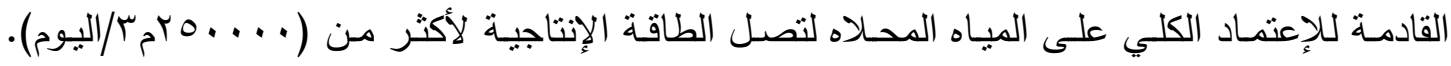
وييلغ إجمالي عدد محطات التحلية بمحافظة البحر الأحمر في عام ^1 ـ rام (1 (محطة تحلية) بإجمالي

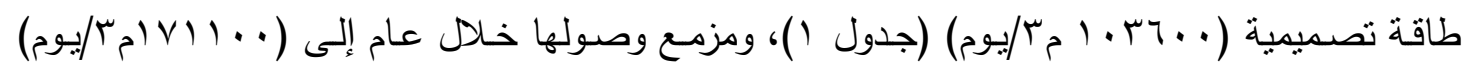

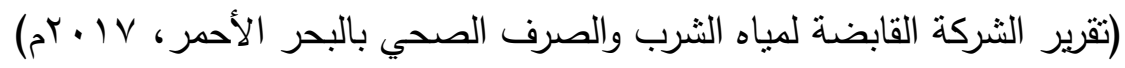

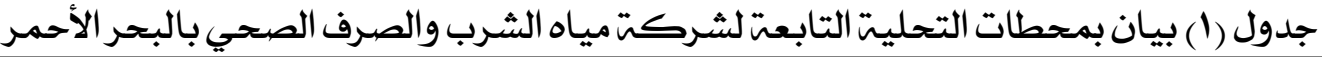

\begin{tabular}{|c|c|c|c|c|c|}
\hline مصدر التظذية & طاقة تصميمية لمحطات مخطط & الطاقة التصميمية & إسم المحطة & المدينة & b \\
\hline البحر مباشر & - & $\wedge \ldots$ & 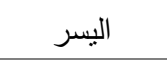 & 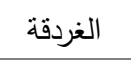 & 1 \\
\hline البحر مباشر & $r \ldots$ & $7 \ldots$ & سفاجا & سفاجا & r \\
\hline آبار شاطئية & $r \ldots$ & vo.. & القصير & القصير & $r$ \\
\hline آبار شاطئية & \multirow[t]{4}{*}{$1 \ldots$} & $10 \ldots$ & مرسى علم 1 & \multirow[t]{4}{*}{ مرسى علم } & $\varepsilon$ \\
\hline آبار شاطئية & & $7 \ldots$ & مرسى علم r & & 0 \\
\hline آبار شاطئية & & r... & مرسى علم r & & 7 \\
\hline البحر مباشر & & $r \ldots$ & حماطة & & V \\
\hline البحر مباشر & . . . . ستخخل بعد شهر & $1 \cdots$ & مرسى حميرة & \multirow[t]{2}{*}{ الثـلاتين } & $\wedge$ \\
\hline البحر مباشر & $1 \ldots$ & ro.. & التشلاتين & & 9 \\
\hline البحر مباشر & 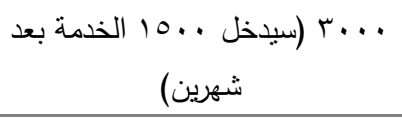 & $7 \ldots$ & أبو رماد & 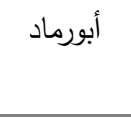 & 1. \\
\hline \multirow[t]{2}{*}{ البحر مباشر } & . . 10 ستخخل الخدمة بعد سنتين & 7. & حلايب - & 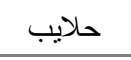 & 11 \\
\hline & TVO.. & $1 . .$. & \multicolumn{3}{|c|}{ المجموع } \\
\hline
\end{tabular}

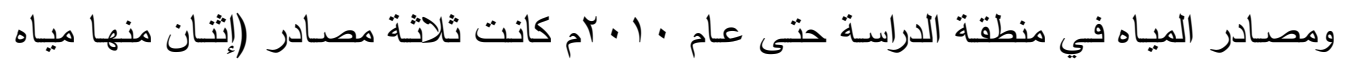

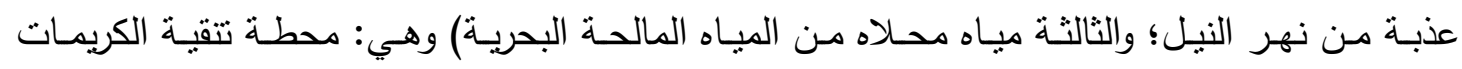

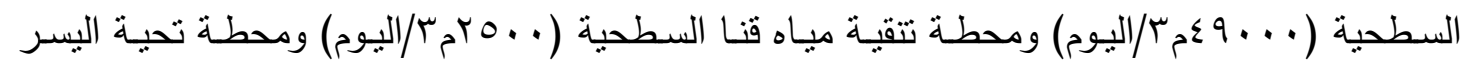

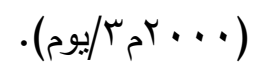


ولكن مصـادر عام 11 ـ بام هي محطة تحلية اليسر والتي وصلت الطاقة التصميمية لها إلى

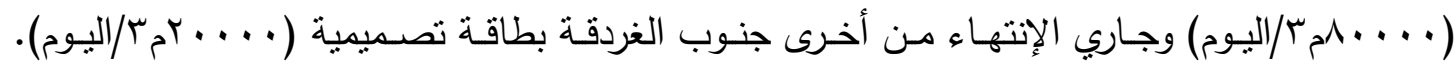
وتُوزع مياه المحطة إما عن طريق شبكة من المواسير الأرضية أو عربات نقل للمناطق غير المخدومة بشبكات مواسير أرضية والتي كانت تعتمد من قبل على مياه نهر النيل.

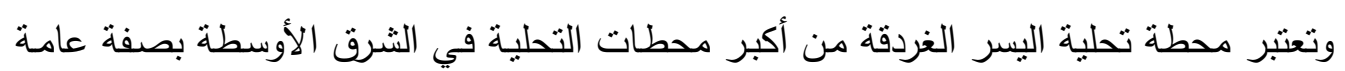
ومحافظة البحر الأحمر بصفة خاصـة، وقد تم تجديدها من عامين تقريباً على أحدث وسيائل التقنية العالمية المستخدمة في تحلية مياه البحر وفق معابير الجودة العالمية والتكنولوجيا اليابانية وهي تخلص

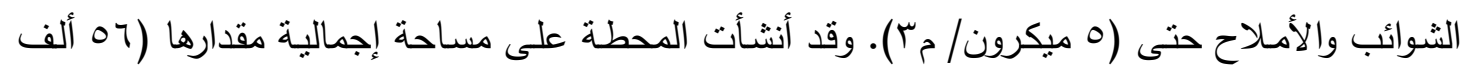

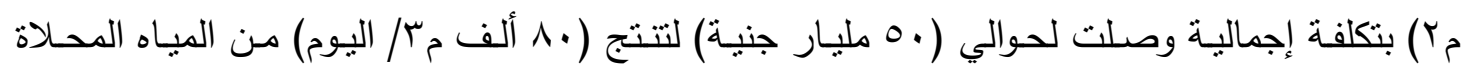
تخدم بها مدينـة الغردقـة وضـواحيها، (ثقرير الثـركة القابضــة لميـاه الثـرب والصـرف الصــي بـالبحر

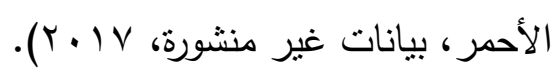

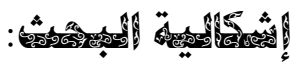

\section{يوجد عدة تساؤلات سوف تجيب عليها الدراسة وهي:}

1 - هل تم عمل دراسات لتقييم الأثر البيئي لمحطة تحلية المياه بالغردقة، لتقييم حالة المياه التي عدهي تغذي المحطة خصوصاً نركيز العناصر الثقيلة، وكذلك حالة مياه الصرف (الراجعة) وتأثنرها على البيئة البحرية، وكذلك الاشتراطات البيئية اللازمة ليكون الصرف في البحر آمناً؟

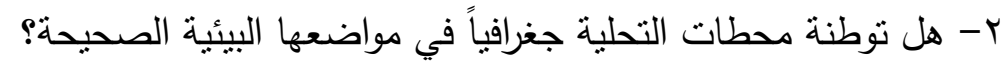
r- هل تتم المعالجة وفقاً للمعايير العالمية؟ وهل تمت الاستعانة بنماذج عالمية وإقليمية؟ هوبه ع - هل توجد أثار سلبية لمحطات التحلية على البيئة البحرية؟

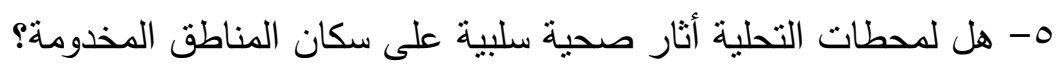

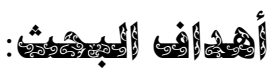

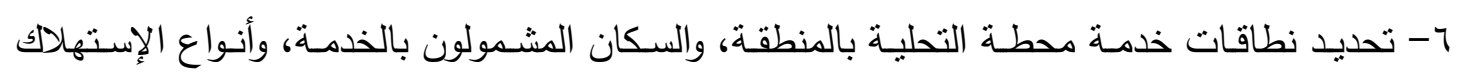

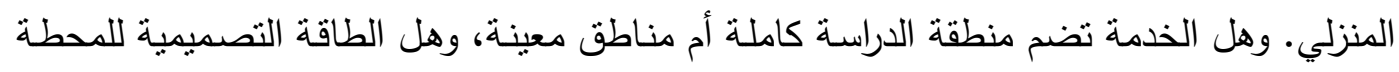

$$
\text { تكفي متطلبات المنتفعين. }
$$

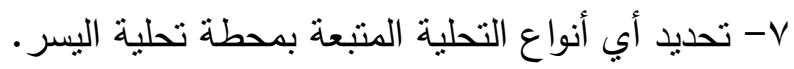

1- مراحل المعالجة بمحطة تحلية اليسر - مابل

9- التقييم الجغرافي لموقع محطة تحلية اليسر •

• 1-خصائص التمديدات الثبكية لمحطة التحلية من خلال معرفة أنواع المواسير المستخدمة وأنسبها

للخدمة.

11-دراسة الحالة النوعية لمياه التخذية والمياه المنتجة والمستهلكة.

r ا-دراسة الخصائص البيئية والصحية لمحطة التحلية من خلال دراسة الآثار البيئية على البيئة البحرية 
با-دراسـة التتمية المستدامة وسبل التعزيز بالمحطة من خلال إقتراح وسائل للحد من الآثار البيئية والصحية لتعظيم الطاقة الانتاجية للمحطة.

\section{:}

إعتمدت الدراسة على عدة مناهج هي:

区 المنهج الوصفي التحليلي ويهتم بتحليل الظاهرة وعناصرها والعوامل المؤثرة فيها سواء كانت طبيعية أو بشرية، وكذلك البحث عن أسباب الظاهرة من حيث تباينها وتغايرها. 邓 منهج النظم ويقوم برصد أبعاد الظاهرة من خلال المدخلات والعمليات والمخرجات.

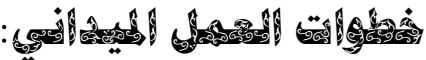

تم وضع خطة للعمل الميداني لتجيب على تساؤلات إثنكالية البحث كالثالي: 囚 قام الباحث بتصميم إستمارة إستيان نتتمل على مجموعة من الأسئلة كان أهمها مصادر مياه

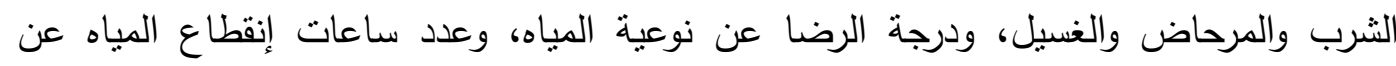
السكن، وهل توجد معاناة في الحصول على مياه نقية، ومقترحات المنتقعين من خدمة المياه المحلاة لتحسين جودتها.

囚 قام الباحث بجمع عينات من المياه الدحلاة (المحطة- المستهلكين) لتحليلها بيولوجياً وكيميائياً وبكتريولوجياً لنقيبم الحالة النوعية لها وبالتالي آثارها الصحية على الإنسان.

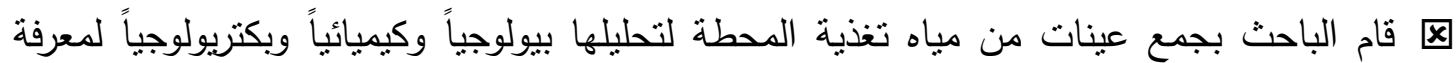
الحالة النوعية لها وهل مطابقة للمواصفات العالمية أم لا. 囚 قام الباحث بجمع عينات من أجاج (المياه المنصرفة) المحطة لتحليلها بيولوجياً وكيميائياً

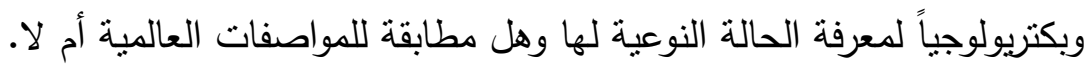

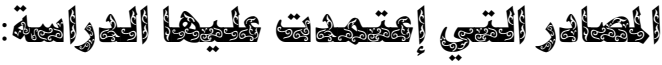

$$
\text { 1 }
$$

囚 التقرير الفني عن محطات التحلية بمحافظة البحر الأحمر ، قامت به وحدة التحلية بالثركة القابضة

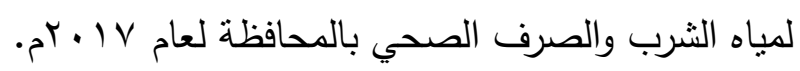

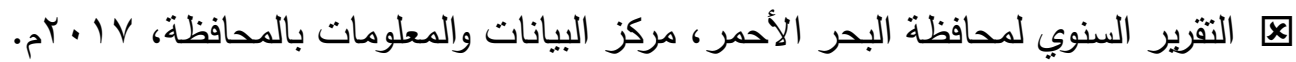

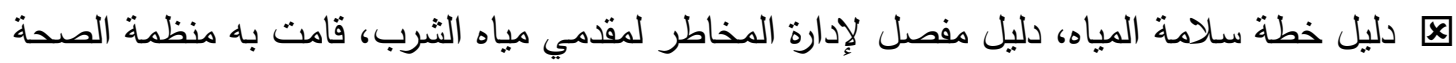

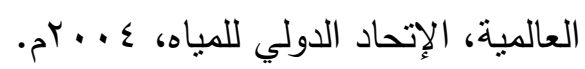

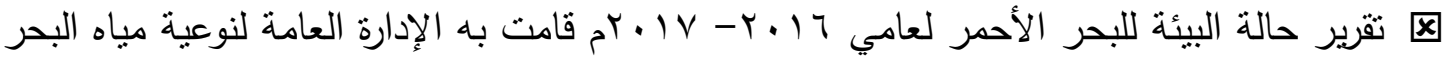
بوزارة الدولة لثئون البيئة.

邓 نتائج رصد نوعية الدياه الساحلية في البحر الأحمر وخليجي السويس والعقبة- خلال الرحلة الحقلية

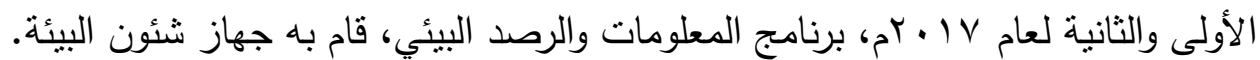

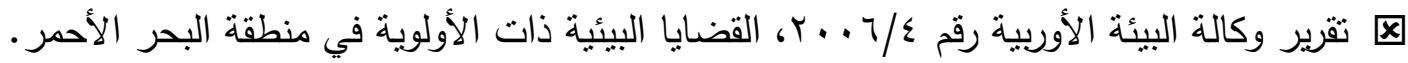

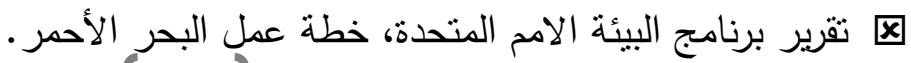
IV9v 


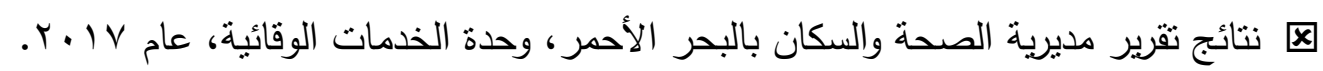
囚 تقارير المؤسسة العامة للتدريب التقني والمهني لمراقبة البيئة والتلوث (طرق تحلية المياه المالحةمعالجة المياه)، المملكة العربية السعودية، 9 بـ أهـ

区 تقرير إنجازات شركة مياه الثرب والصرف الصحي V V. Y، شركة مياه الثرب والصرف الصحي

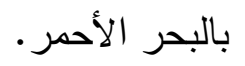

$$
\text { (1) }
$$

ه تم تحليل الخرائط الطبوغرافية مقياس (:... .0 الصادرة عن المساحة العسكرية عام ؟99 1. 囚 ت تمليل خريطة التكوينات الرسوبية السطحية مقياس ا:..... .0 الصادرة عن المساحة الجيولوجية

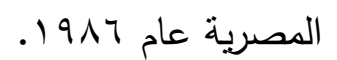

囚 مرئية فضائية حديثة وهي Land sat 8 (OLI) بدقة (•rم) لعام 0 • بrم، وعددها مرئية واحدة .(row, path)

\section{:}

أولاً: بعض الخصائص الجغرافية لمنطقة الدراسة.

ثانياً: طرق التحلية المتبعة بالمحطة. بولة

ثالثاً: خطوات معالجة المياه بالمحطة.

رابعاً: التقييم الجغرافي لموقع المحطة، وتمديداتها الثبكية.

خامساً: خصائص الحالة النوعية للمياه.

سادساً: الآثار البيئية والصحية للصحطة.

سابعاً: التتمية المستدامة وسبل تعزيز محطة التحلية بمنطقة الدراسة. ثامناً: النتائج والتوصيات.

\section{कै}

- 1

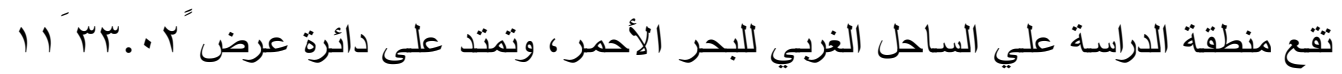

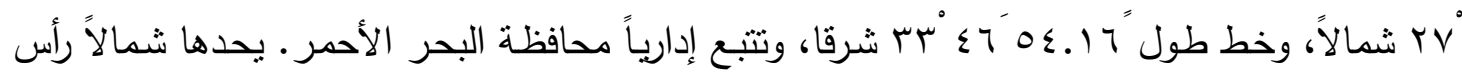

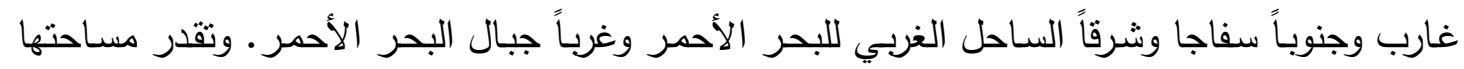

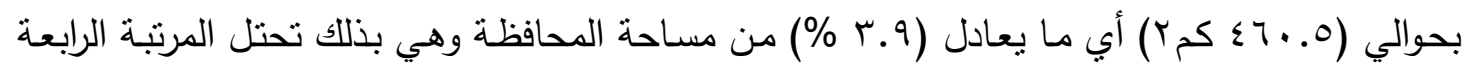

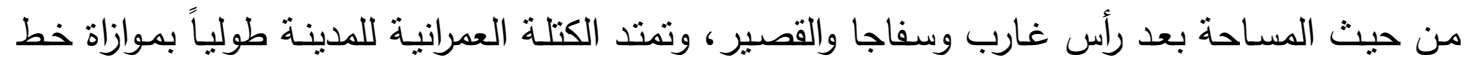
السـاحل لمسـافة تقدر بحوالي س بكم، بينمـا لا يزيد امتدادها للداخل عن 7. اكم. وتمتد مدينة الغردقة القديمة (الدهار ) في شريط طولي ينحصر بين هضبتنين جيريتين إحداهما في الثرق بين المدينة القديمة والساحل وتعرف بهضبة الضبعة والأخرى في الغرب. لذلك تقع مدينة الغردقة في سهل ساحلي يتباين

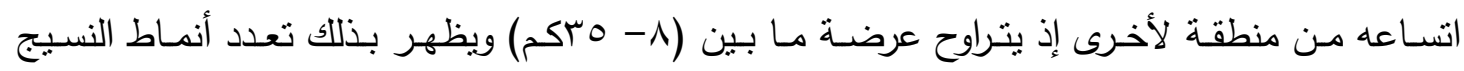
العمراني للمدينة، فيتركز النسيج التلقائي والثبكي في نواة المدينة حيث عشوائية العمران والذي يتسم ( $1 \vee 91)$ 
بالمباني الرديئة والمتوسطة المتلاحم معظمها، عـلاوة على ضيق وتعرج الطرق والثـوارع التي يتراوح عرضهها مـا بين (ب-7 بم تقريباً). أمـا النسيج الثبكي والثريطي المنظم فيسود في الامتدادات العمرانية

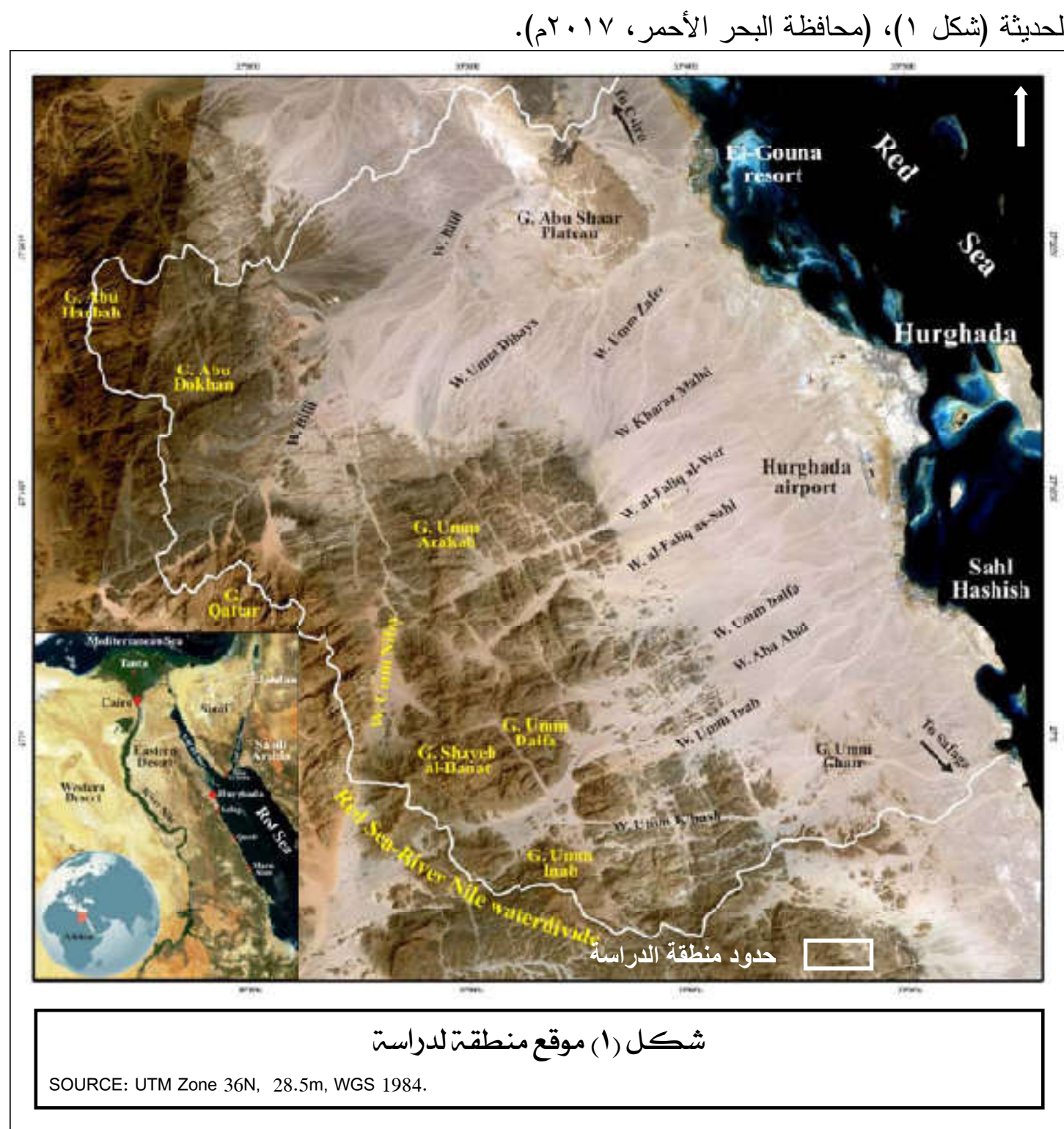

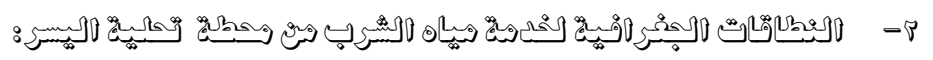

تخدم محطة اليسر أربعة نطاقات جغرافية عن طريق روافع (محطات تخزين أو محطات رفع

أو خزانات) تمهيداً لضخها في الثبكة، بالإضـافة إلى نطاق الضـخ المباشر من محطة التحلية (اليسر)

وذلك لمنطقتين قريبتنن من المحطة يمتدا على طول خط الساحل (شكل r)، وتتوزع نطاقات الخدمـة

لروافع مدينة الغردقة كالتالي (بيانات الثركة القابضة لمياه الثرب والصرف الصحي، VI ا • rم):

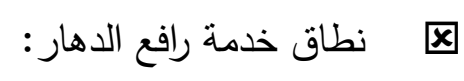

يعتبر حي الدهار هو المنطقة الثعبية بالمدينـة والمركز القديم، حيث يبرز الحياة المصرية

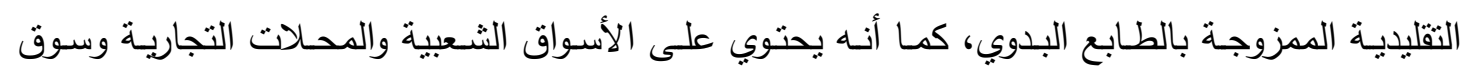


ويخدم رافع حي الدهار 10 منطقة هي (حي الأمل - والبداري- والزراعة- والزهراء- والسـلام

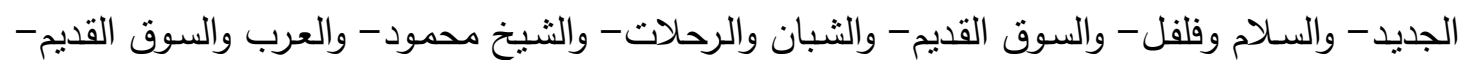

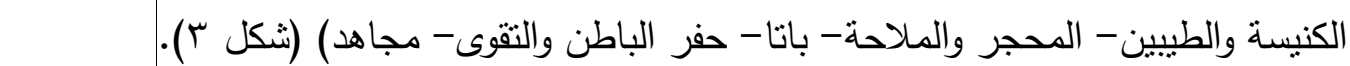

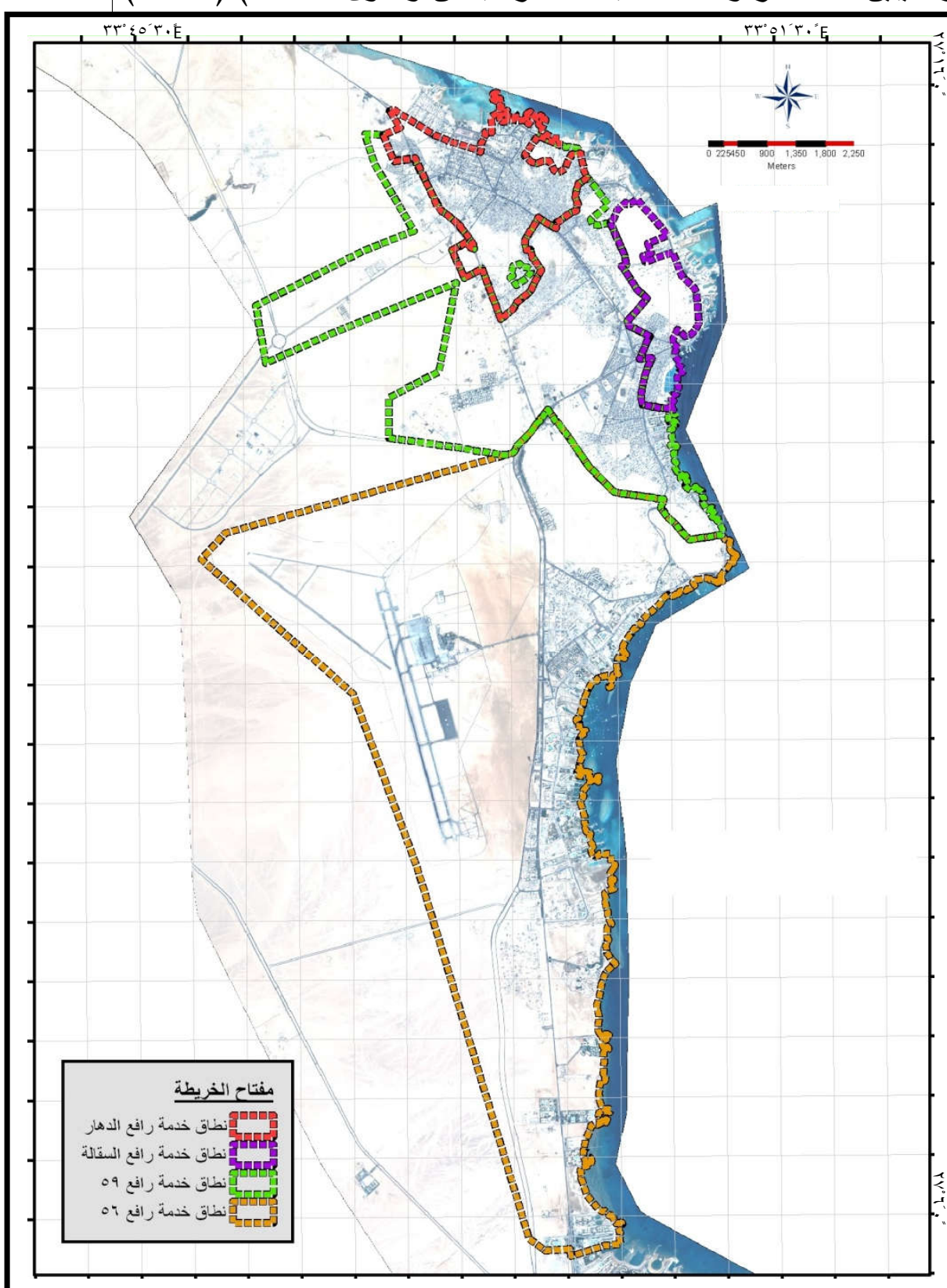

شكل (ז) نطاقات خدمت محطت اليسر لتحليت مياه البحرـ الغردقت

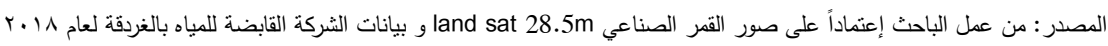

ه

يعتبر حي السقالة هو المنطقة السياحية بالمدينة، حيث يقع بـه العديد من الفنادق والمحلات

ومراكز التسويق والنوادي والمطاعم.

$(11 \ldots)$ 
ويخدم رافع حي السقالة أربعة مناطق هي ( الصيادين - الميناء السسباحي- منخفض التكاليف

وأبو نواس - منطقة الميناء) (شكل ع).

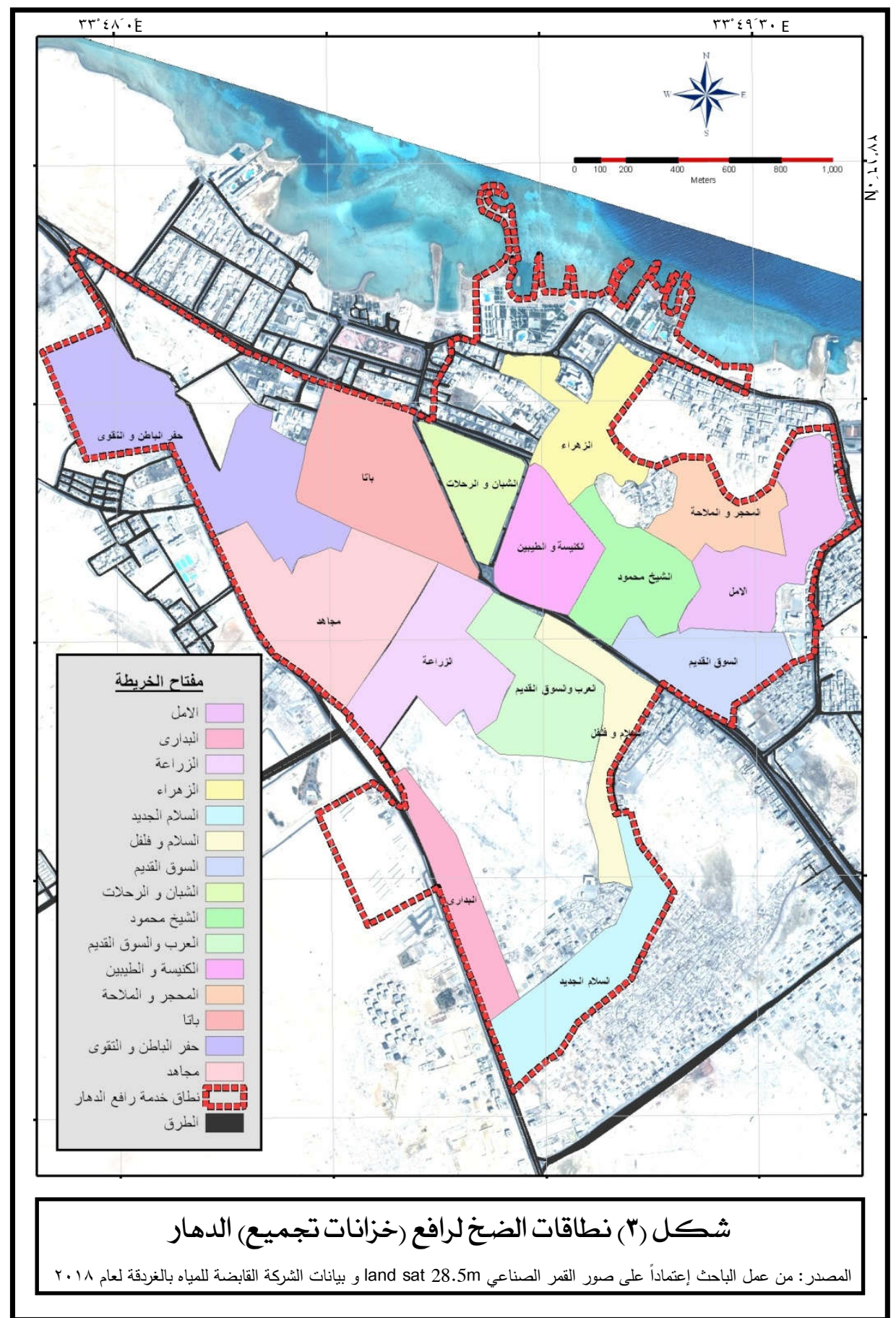

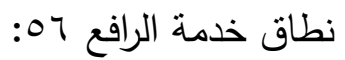


ويخدم عدة مناطق حديثة النشأة وجميعها سياحية عبارة عن فنادق وقرى ومنتجعات وفلل وشـاليها وإسكان فاخر وهي ( الهضبة- وتقسيم الكوثر والمطار - وسفير والماريوت- طريق القرى ومبارك r و ه مو ^) (نشكل 0).

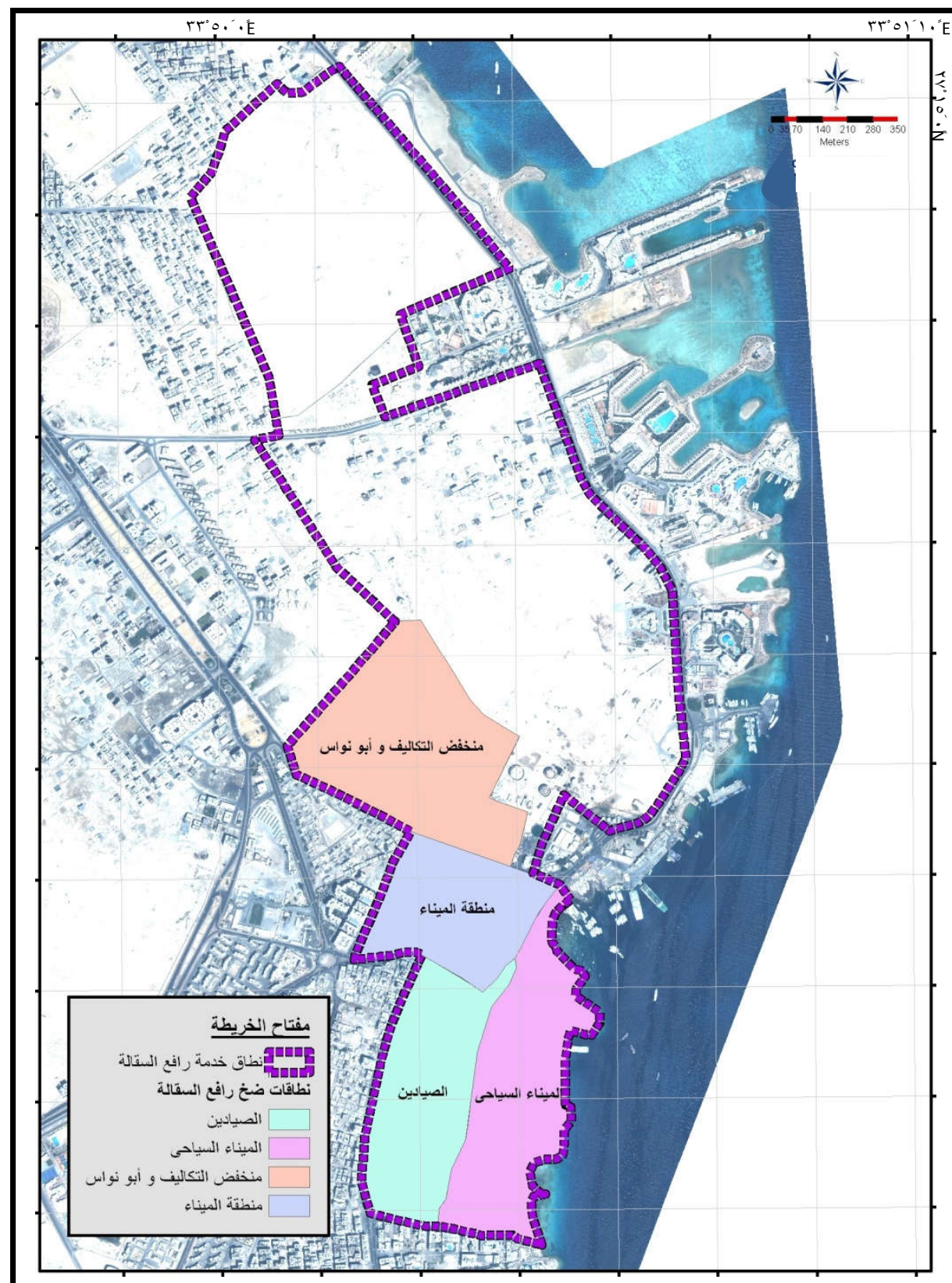

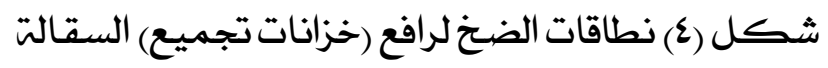

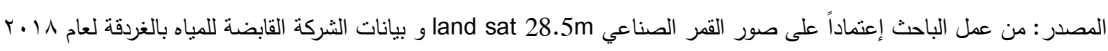




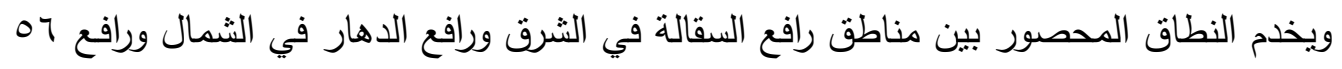

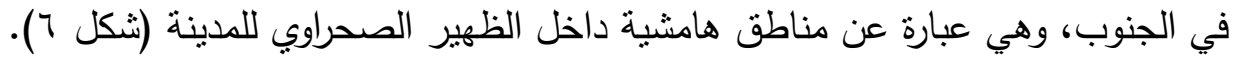

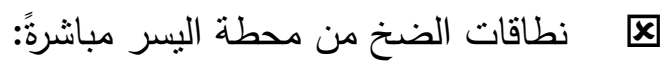

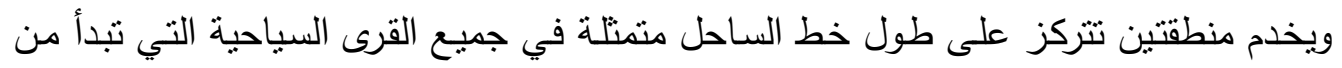

الثمال عند الثاطئ الاجتماعي حتى حضيض الهضبة في الجنوب. والمنطقتين هما ( الوفاء- طريق

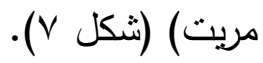
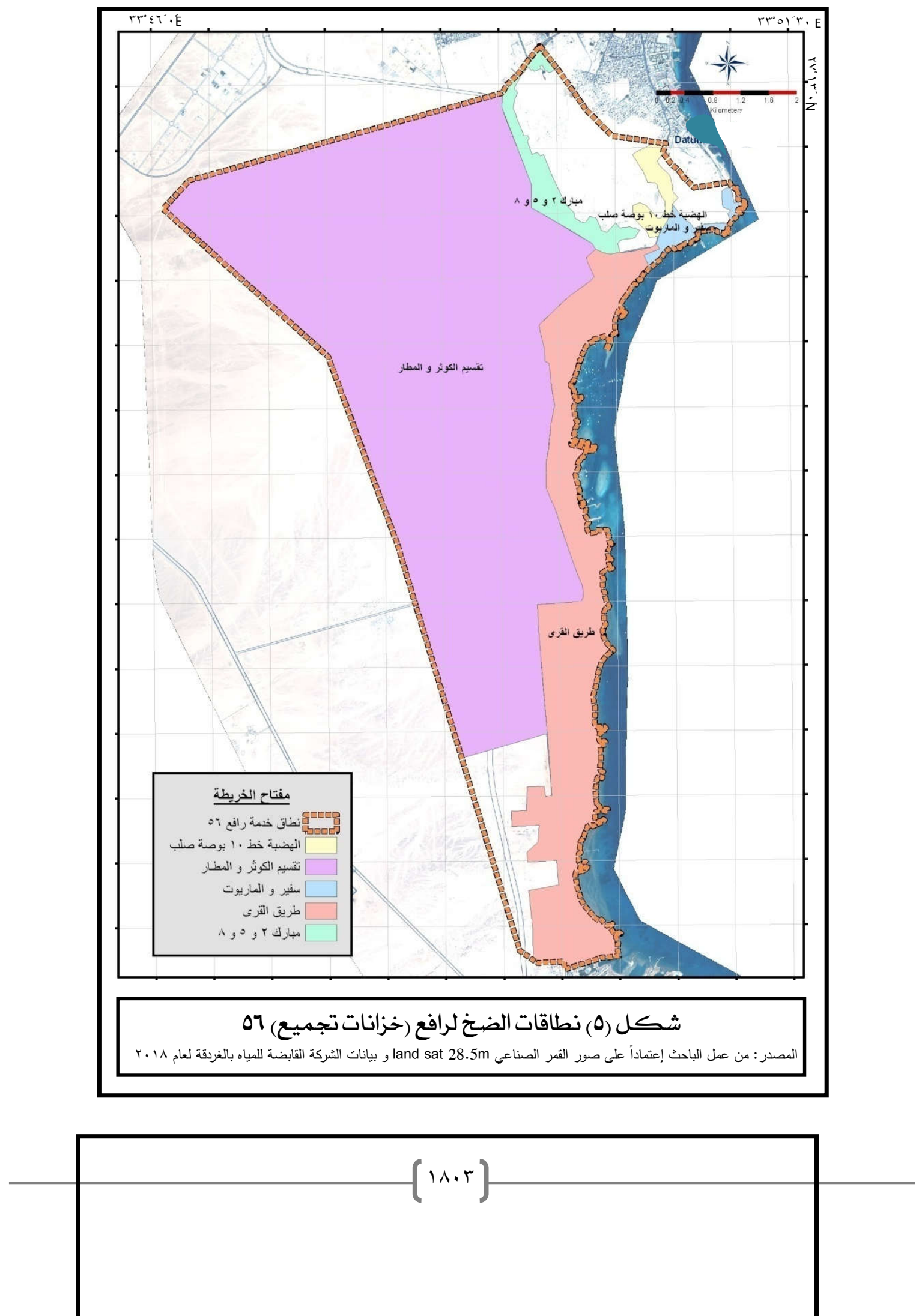


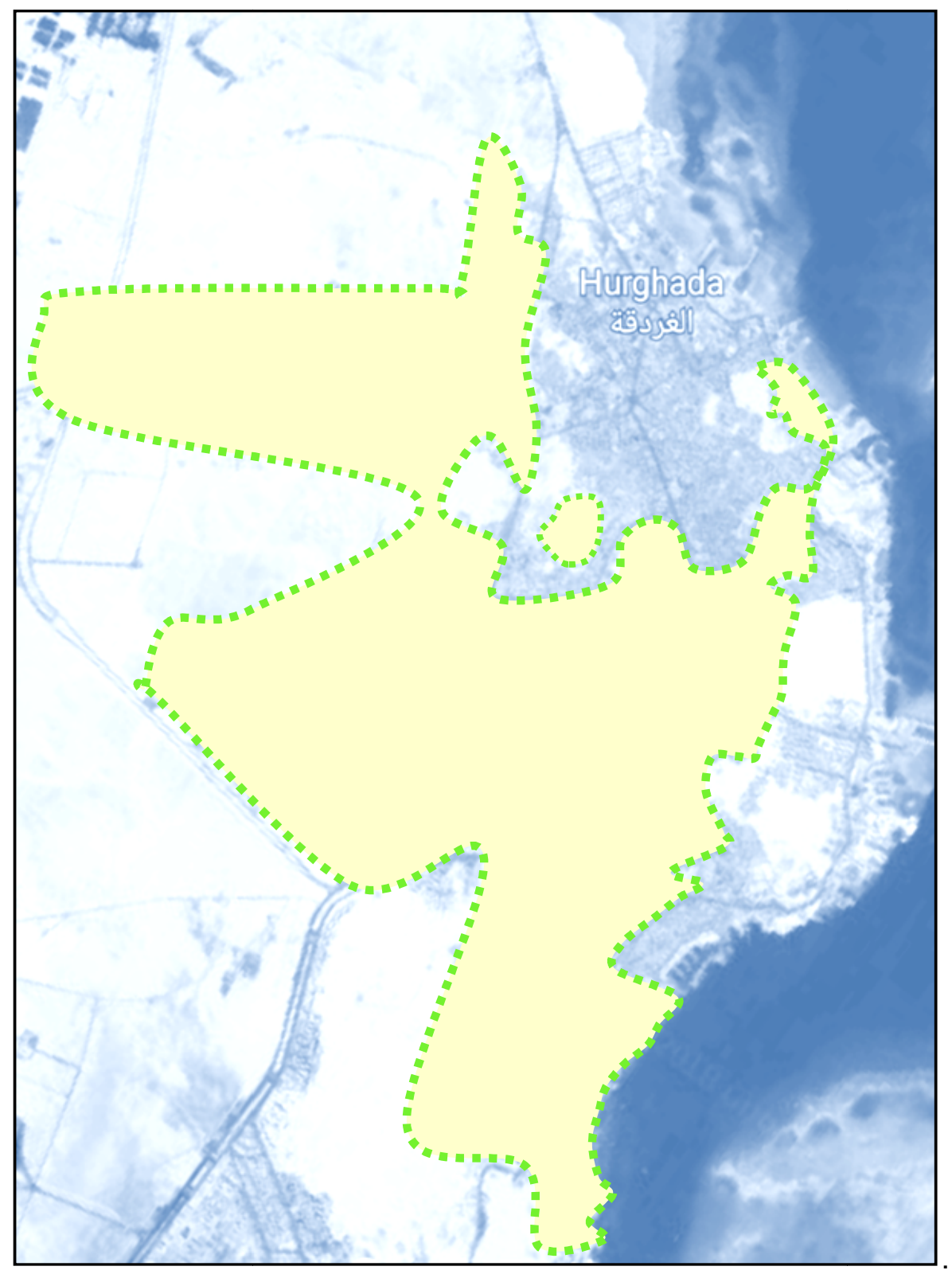

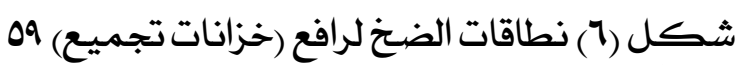

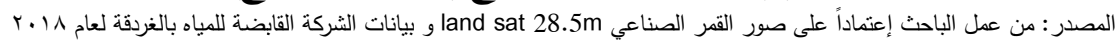

: -

تطور حجم الكتلة السكانية للغردقة خلال الفترة الأخيرة نتيجة للاستتمارات الكبيرة بالمحافظة،

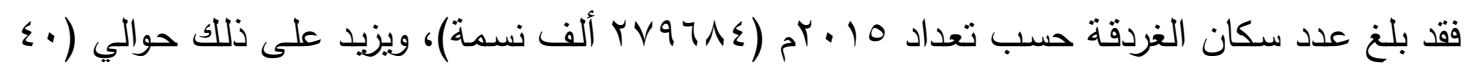
ألف نسمة) من العاملين القادمين من خارج المدينة للعمل بمجال السياحة. ويعود أصل سكان المدينة

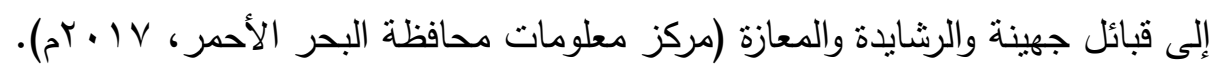




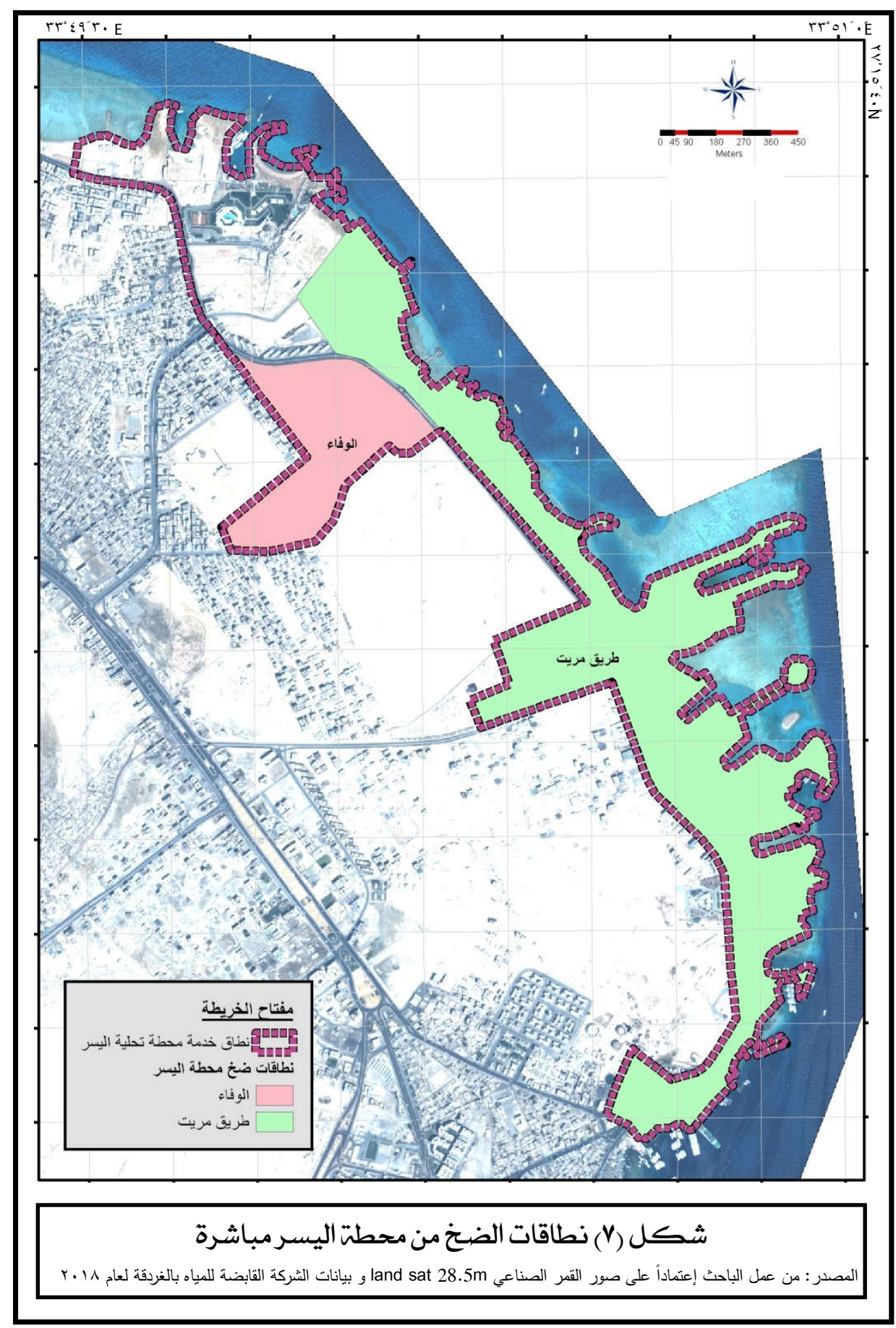

.

تجرى عمليات معالجة المياه لإزالة الملوحة بواسطة طرق مختلفة، بعضها معروف فكرته منذ

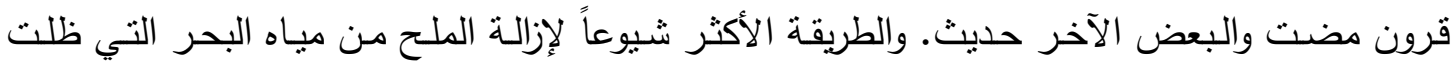

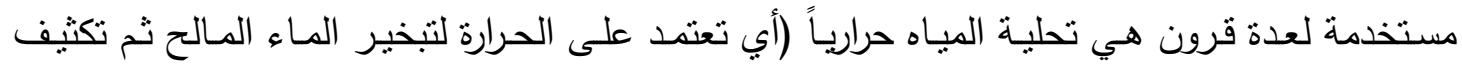
البخار إلى ماء عذب، كمحاكاة للدورة الهيدرولوجية الربانية). ومن الطرق المستخدمة في التحلية، طريقة التبخير الومضي، والتبخير متعدد التأثنير ، والتحلية

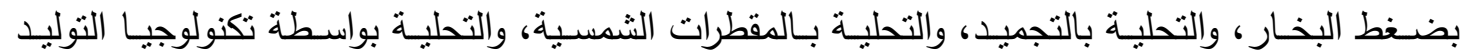
$(11.0)$ 
المشترك (توليد الكهرباء والماء)، والتحلية بالتتاضـح العكسي ( المؤسسة العامـة للتدريب التقني والمهني

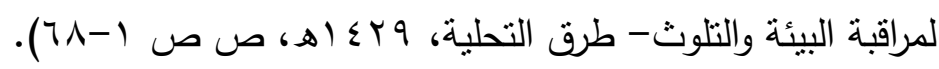
DOW, Water Solutions., ) وتعد التحليـة بالتناضـح العكسي (العليـة الأسـوزية) Reverse Osmosis Membranes- Technical Manual بمنطقة الدراسة. وعلى الرغم من أن العملية الأسموزية كانت معروفة للكثير من منذ أكثر من قرن، فإن تقنية إستخدام الأغشية لمعالجة المياه تعتبر حديثة. وكان أول إعلان لاستخدام التتاضـح العكسي هو أنس براءة إختراع بنفس الإسم لإزالة عسرة الماء (Softening) بإستخدام أغشية فيروسبانيد على مثثتات مسامية من البورسلين، وفي سنة 190 أنتج في جامعة فلوربدا أغشية من أسيتات السيليلوز لتحلية

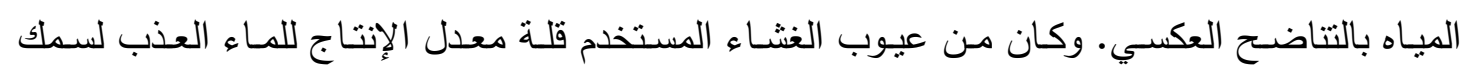
الغثـاء (وكان هذا تقريباً وقت ظهور تقنيـة الديلزة أو الفرز الكهربائي). وفي الخمسينيات تم تطوير

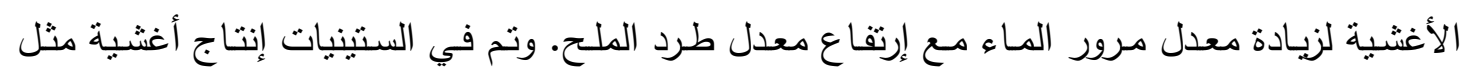
الملفوفة حلزونياً وعلى صورة أنابيب وغيرها ثم ظهرت في السبعينيات أغشية الشعيرات الدقيقة المجوفة من البوليميد مـع إستقرار إنتاج أغثية أسيتات السليلوز • وقد كان تطوير الأغشية لإستخدامها لإزالة ملوحة المياه قليلة الملوحة أما الآن (ومنذ نهاية السبعينيات) فقد تم تطوير الأغشية لتحلية المياه شديدة

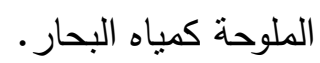

وتعد الطريقة الأسموزية هي أحدث طريقة سلكت الطريق في الوقت الراهن وهي الطريقة الوحيدة المستخدمة في جميـع محطـات التحليـة بمحافظـة البحر الأحمـر بصـفة عامـة ومحطـة الغردقـة (اليسر) بصفة خاصة. وتقوم فكرتها على أننا إذا وضعنا محلول ماء ملحي في جانب لغثاء شبه نفاذ والجانب الآخر ماء عذب فمن المعروف طبيعياً أن ينتقل الماء العذب (الأقل ثركيزاً) إلى المحلول الملحي (الأكثر تركيزاً)، وذلك لإحداث التوازن أو التعادل في عملية التركيز وهذه تعرف بعملية التتاضح (Osmosis Process) ويستمر نفاذ الماء العذب في هذا الإتجاه وعليه برتفع عمود المحلول الملي لأعلى نتيجة زيادة كمية الماء بالمحلول بإستمرار نفاذ الماء العذب. وبارتفاع عمود الماء يرتفع الضغط بجانب المحلول الملحي وتزداد لذلك مقاومة نفاذ ومرور المياه

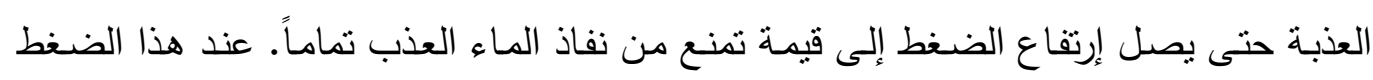
يحدث التوازن ويسمى هذا الضغط بالضغط الأسموزي. وقد إكتشف العلماء أنه يمكن عكس هذه العملية أي أنه إذا أثرنا على المحلول الملحي بضغط أعلى من الضغط الأسموزي فسينتقل الماء

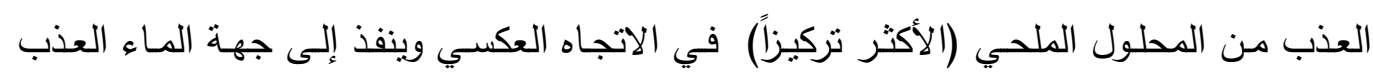
(الأقل تركيزاً) وتعرف هذه العملية بالتناضح العكسي (Reverse Osmosis) والتي يمكن بها الحصول على الماء العذب من الماء المالح. ومن ثم فعملية التتاضح العكسي هي عملية فصل فئل الماء العذب عن محلول ملحي من خلال غشاء نفاذ وذلك بضغط المحلول الملحي بضغط أعلى

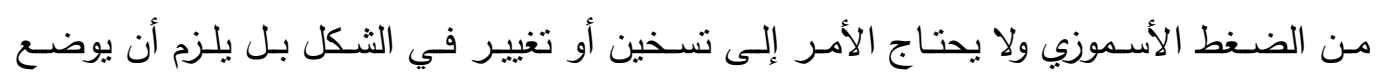


المحلول الملحي (الماء المالح) تحت ضغط أعلى من الضغط الأسموزي لكي تتم عملية التتاضح العكسي. وتعتمد قيمة الضغط الأسموزي على عوامل عدة منها تركيز الملوحة للماء المالح وعلى نوعية

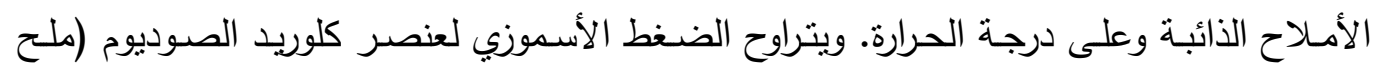

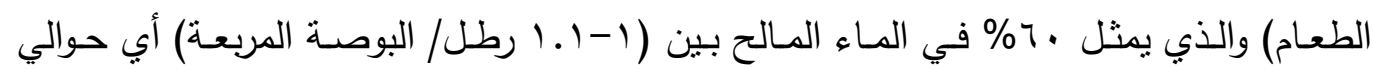

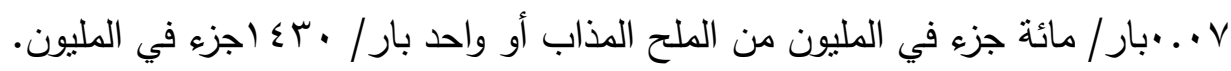

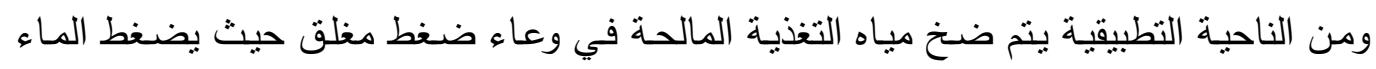

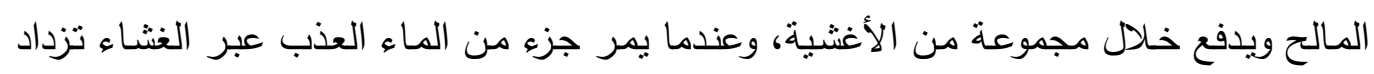

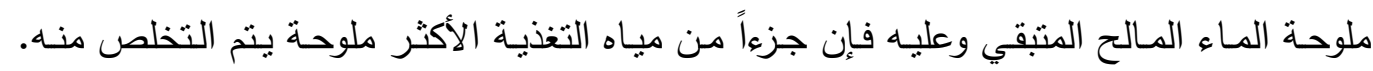
وبدون هذا التخلص فإن الازدياد المطرد لملوحة مياه التخذية سوف ينسبب في مشاكل كثيرة مثل

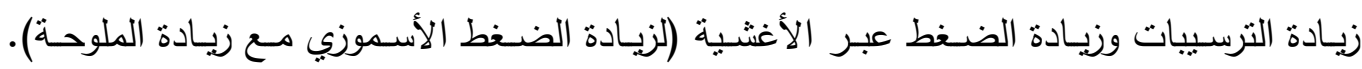

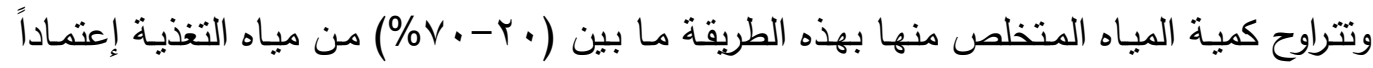

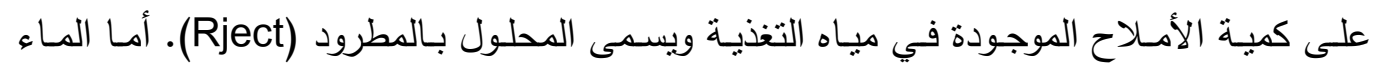
العذب والذي نفذ من الأغشية فيكون الماء المنتج (Permeat- OR Water Product).

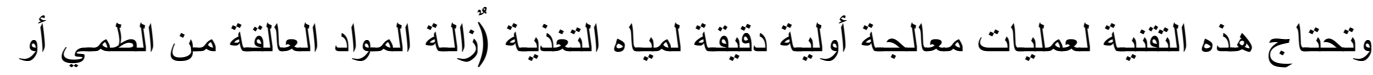

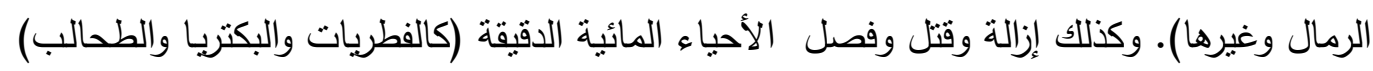

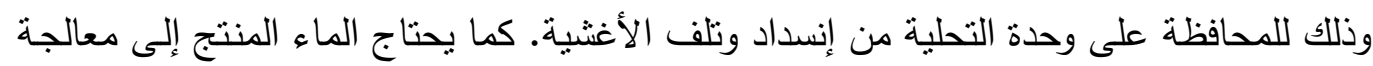

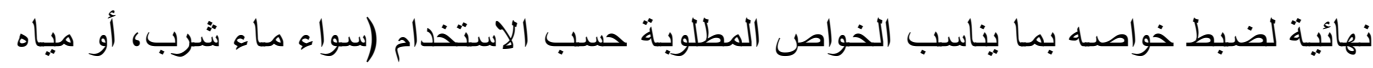

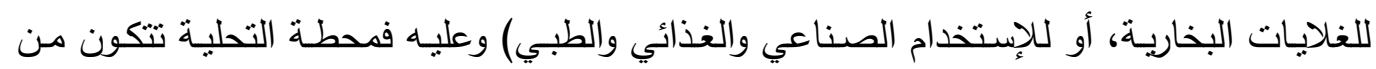

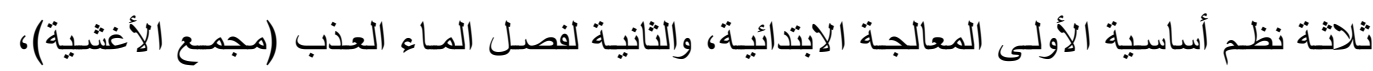

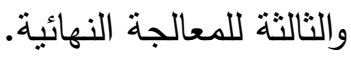

وأخيراً؛ كل من هذه الطرق مميزات وعيوب ويتم اختيار الأنسب منها حسب معايير كثيرة منها

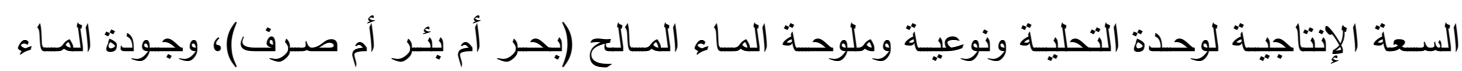

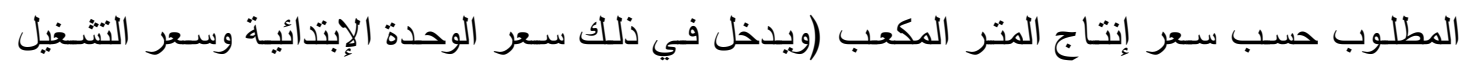
والصيانة وغيرها). ولا يوجد ما يسمى بأفضل طريقة للتحلية حيث تدخل هذه العوامل الكثيرة وغيرها

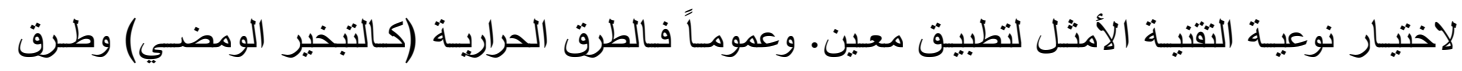

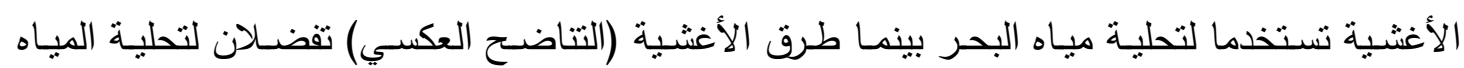
القليلة الملوحة مثل مياه الآبار.

وعلى كل فإختيار التقنية المناسبة يحتاج إلى دراسة شاملة ومعمقة وربما تلعب الظروف البيئية المحلية دوراً بارزاً في تحديد أفضل الطرق والتي تكون أكثر اقتصادية. كما يلزم أن يعمل النظام بكفاءة $(1 \mathrm{n} \cdot \mathrm{v})$ 
لتوفير كميات المياه العذبة المطلوبة بالنوعية والكمية والتكلفة المتوقعة طيلة عمر المحطة، (المؤسسة

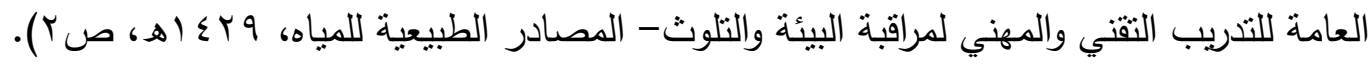
.

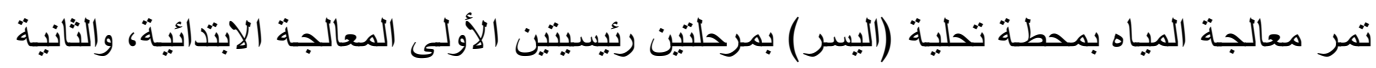

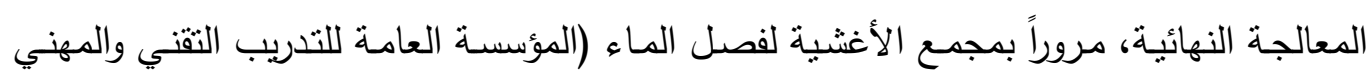

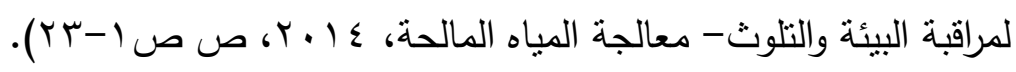
1

معالجة مياه التغذية الداخلية لوحدة التحلية feed treatment (سواء مياه البحار أو الآبار )

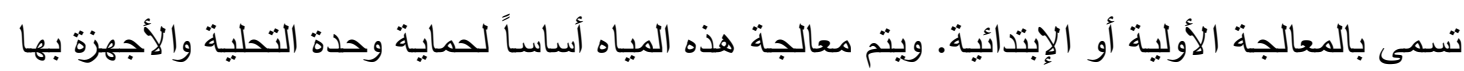

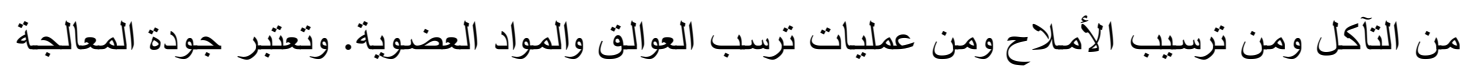

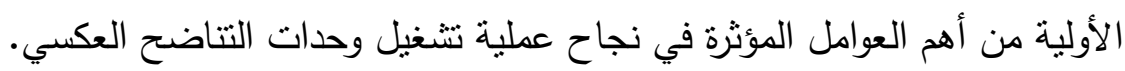

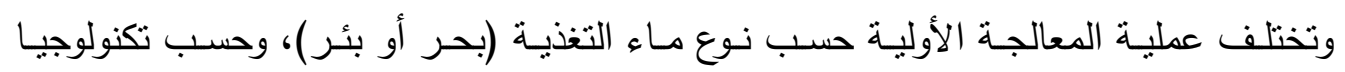

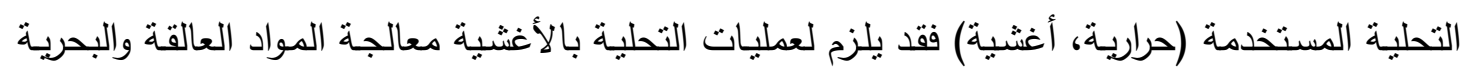

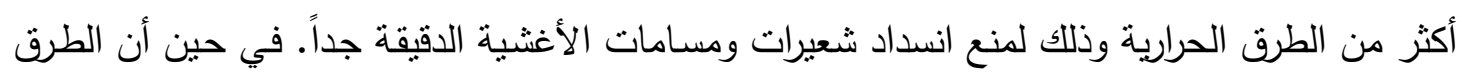

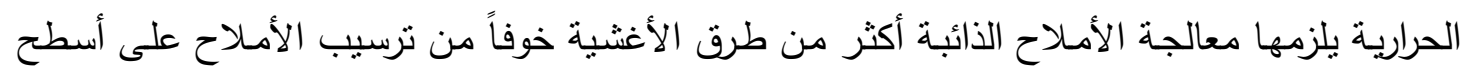
إنتقال الحرارة مع زيادة درجة الحرارة. وتمر عملية المعالجة الإبندائية لمحطة تحلية اليسر على المراحل التالية ( DOW, Water :(Solutions., Reverse Osmosis Membranes- Technical Manual ه ه 囚 إضافة المواد الكيميائية (لتجميع العوالق الدقيقة). 区 علية الترسيب. 囚 عمليات إزالة العوالق الدقيقة (التنشيح- الفلنرة). 囚 عمليات إزالة العوالق الدقيقة جداً (الفلترة الدقيقة جداً أو الميكرونية).

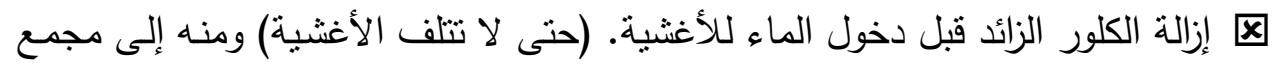
الأغشية. أما عن الكيمياويات المضافة لعملية التحلية في المعالجة الأولية، فهي كالتالي: هيبوكلوريد الصـوديوم (الهيبو) أو كبريتات النحاس، لتطهير ماء التغذيـة (أو المـاء المنتج). باي سلفات الصوديوم، لإزالة الكلور من ماء التغذية. هيكسا ميتا فوسفات الصوديوم، لمقاومة الترسيبات. حامض الكبرتيك، لضبط الرقم الهيدروجيني ومقاومة الترسييات. $(11.1)$ 


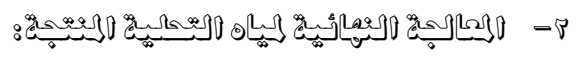

تعني المعالجة النهائية للمياه المنتجة، ضبط بعض الخواص عن طريق إضـافة بعض العناصر

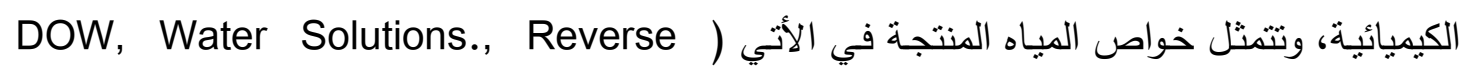
:(Osmosis Membranes- Technical Manual

X

区

ه

ه

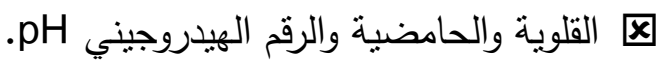

ه القدرة علة التآكل للمعادن.

ولكي يتم ما سبق لا بد من إضـافة عناصر كيميائية ليخرج المنتج النهائي للمياه في صورها

الحالية للمستهلك، وهذه العناصر هي:

• هيبوكلوريد الكالسيوم/ الصوديوم، لتطهير الماء المنتج.

• الجير ، لضبط الرقم الهيدروجيني.

• هيدروكسـيد الأمونيوم/ الصـوديوم وحسامض الهيـروكلوريك ويسـتخدوا لضـبط الـرقم

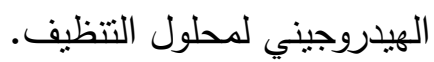

هامض الستريك/ الفسفوريك/ الاكسليك ويستخدموا إزالة الترسيبات الكربونية والأكسيد.

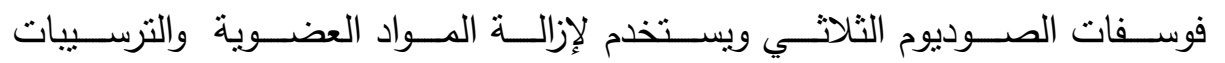

الميكروبيولوجية.

• الفورمالدهايد ويستخدم للتطهير والمحافظة على الأغشية.

يتضـح ممـا سـيق أن بمـرور محطات التحلبـة في أبــة منطقة في العـالم بمراحل المعالجـة

السابقة والدقيقة لا بـ من خرجج المنتج النهائي للمباه بكل تأكيد في أحسن صوره للمستهلك، ولكن

السيؤال.

هل المستهلك على دراية كاملة بتلك المراحل؟ وأن هناك ضوابط لتنفيذها، وأن المبياه المنتجـة

خرجت من محطة التحلية صـالحة للشرب بنسبة . . 1\%، وعلى المستهلك أن بعي ذلك ويحث عن سبب تلوث المياه؟ هل هو المسئول عن هذا التلوث من خلال (شبكة المواسير المنزلية، والخزانـات)؛

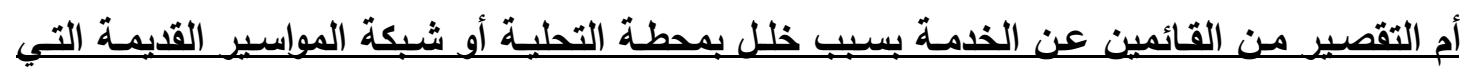
بحاجة للتجدي والإحلال بنوعية مناسبة لنوعية المياه وظروف البيئة. وتجيب الاراسة عن كل ذلك في

العناصر القادمة.

. - 
تبين مـن الدراسـة الميدانيـة وتحليل الصور الفضـائية (لمعرفة مصـادر الخطورة على محطة

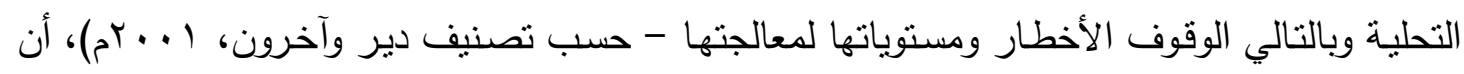

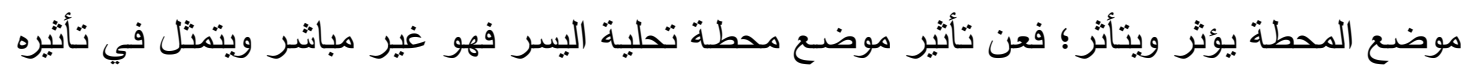

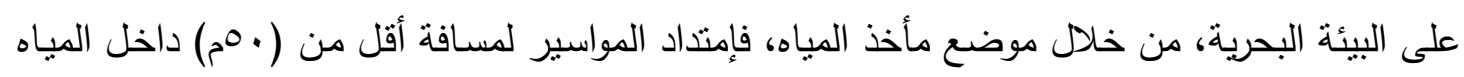

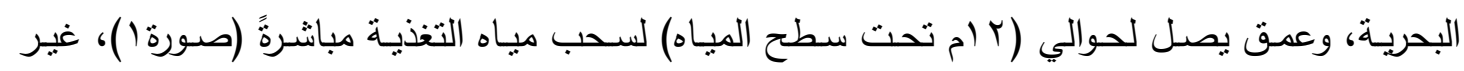

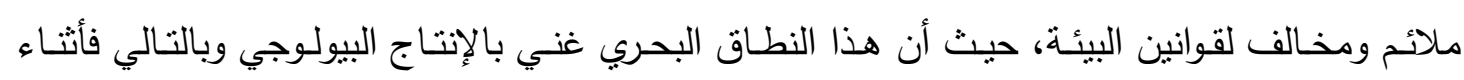

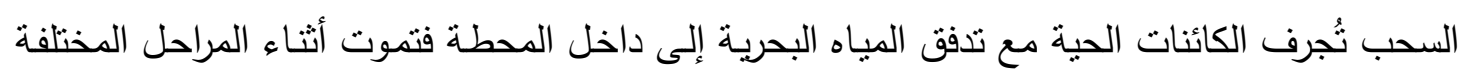

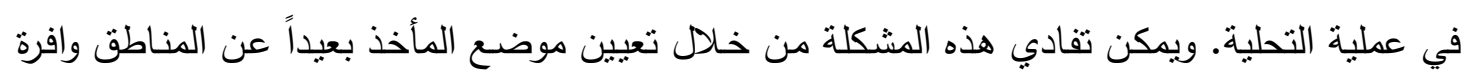

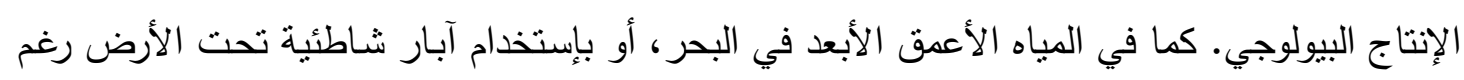

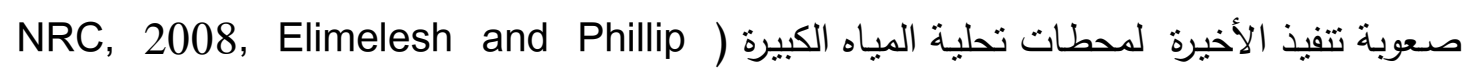

.(2011

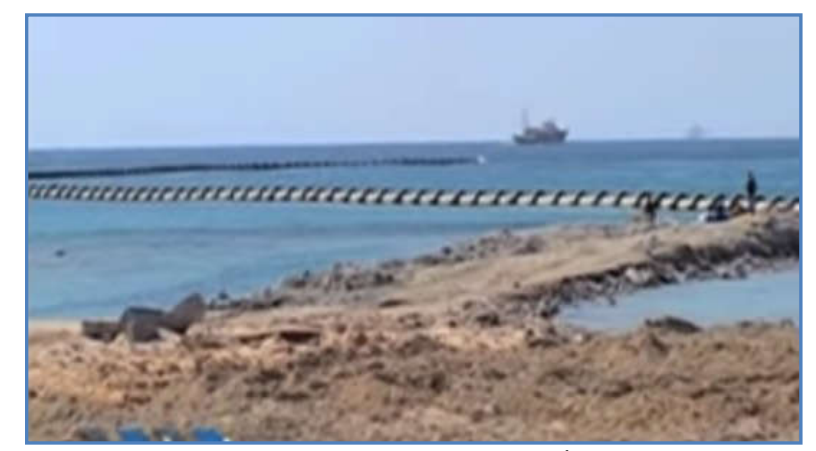

صورة (1) المأخذ البحري لمحطت اليسر- الغردقت

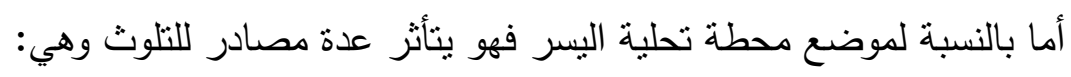

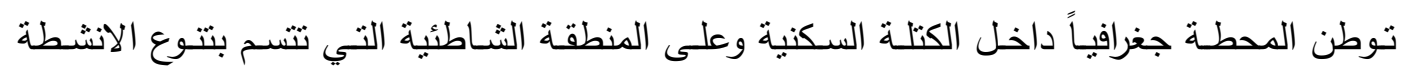

冈 الاقتصادية بداخلها.

囚 يقع داخل نطاق محطة اليسر عدة أنشطة بشرية تثثل مصادر خطورة للمحطة، أهمها محطة تخزين وتموين السفن ومواصلات النقل العام، وميناء الغردقة البحري السياحي، ومارينا اليخوت(مارينا الغردقة)، وميناء الصيد وحلقة السمك.

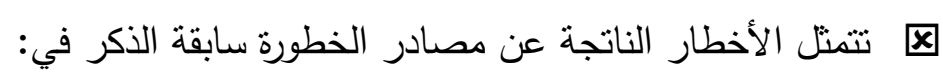

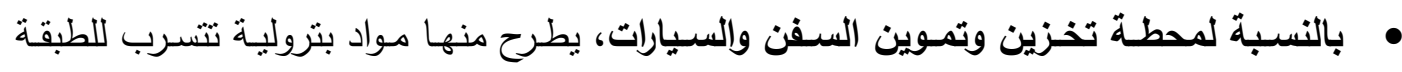

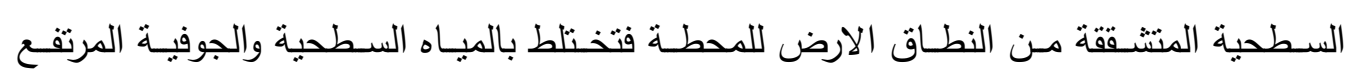

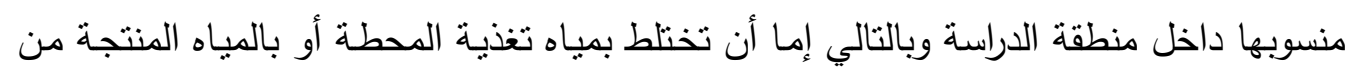
المحطة نتيجة التسريب من مواسير الثبكة القديمة المتهالكة.

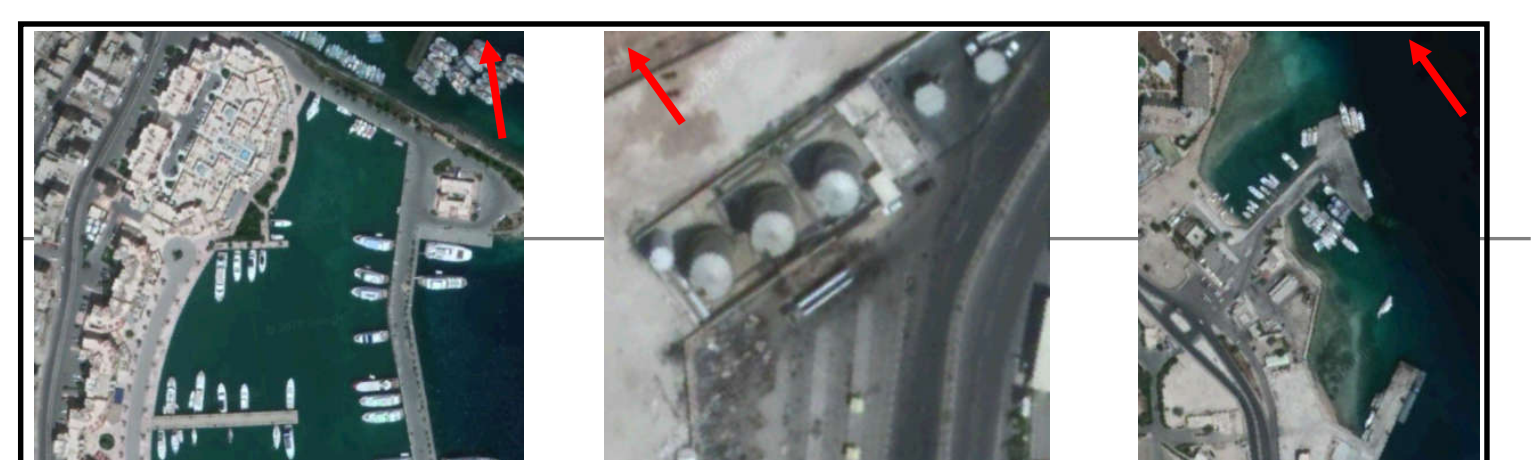


كود (0) مارينا الغردقت

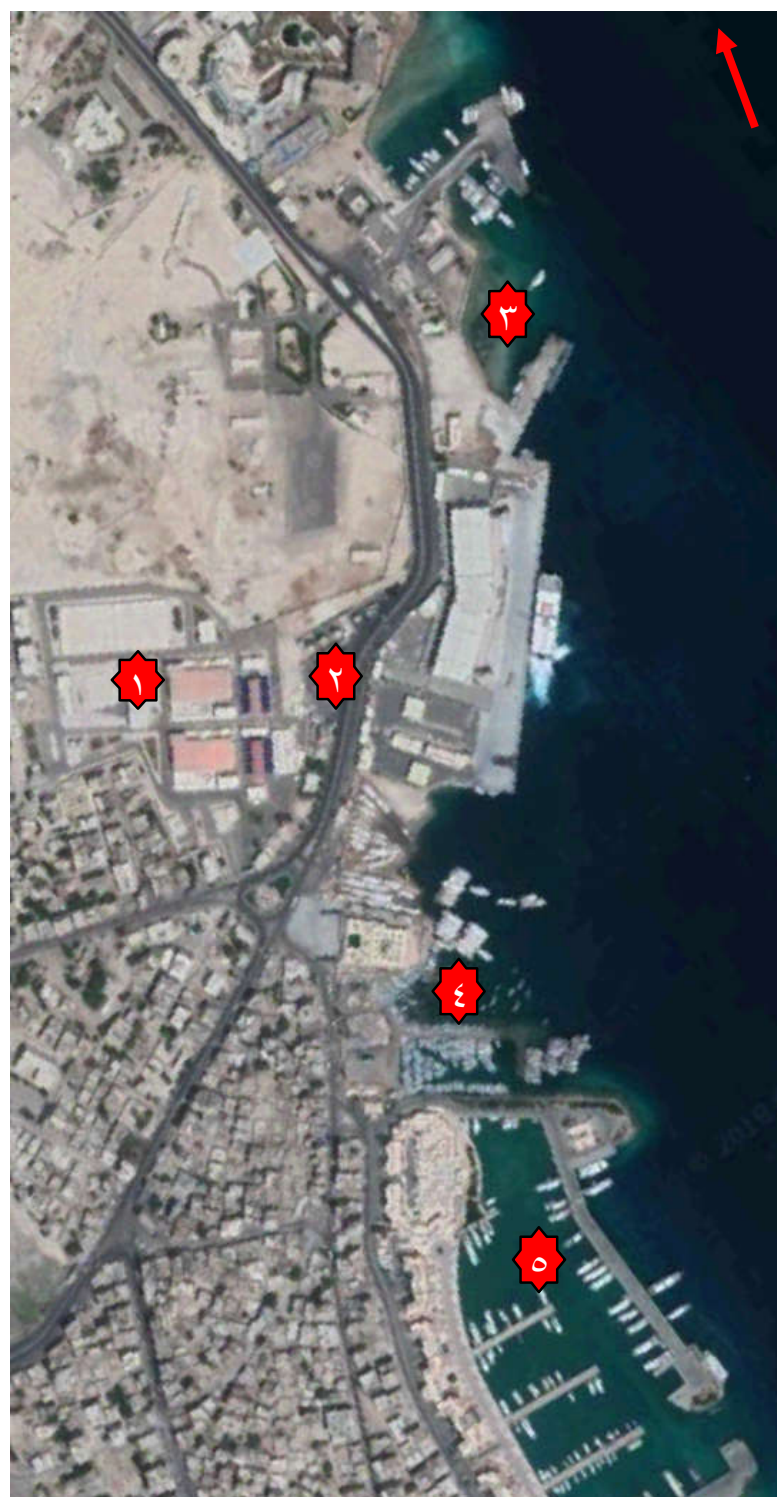

كود ("r) ميناء الغردقت البحري

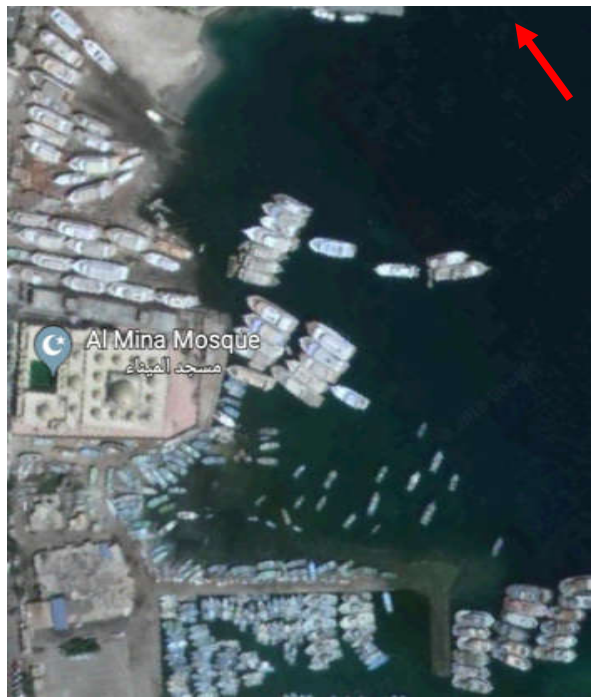

كود (ع) ميناء الصيد وحلقت

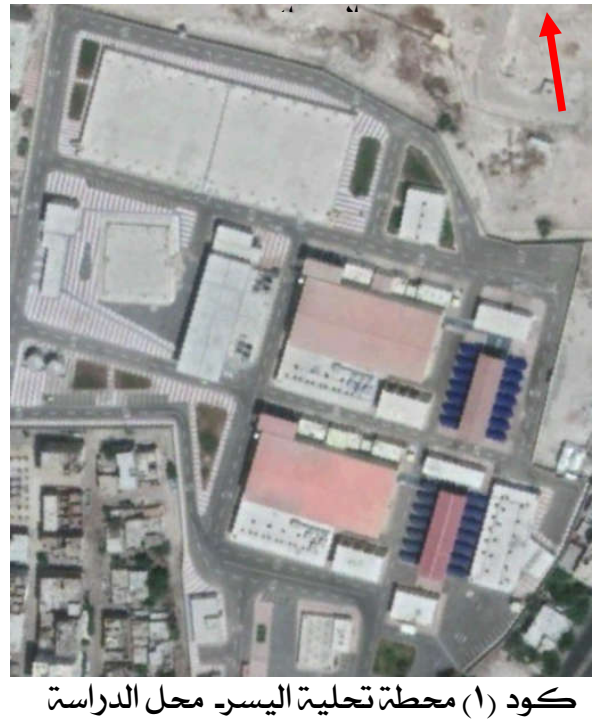

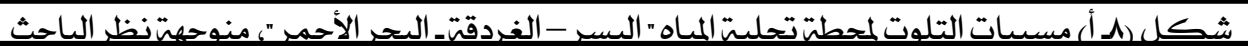

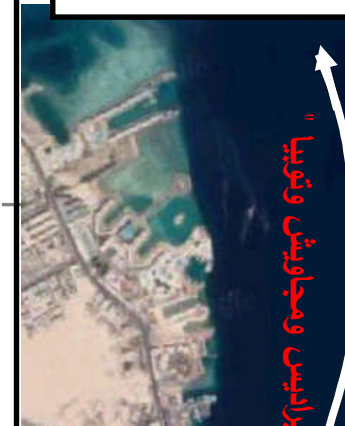




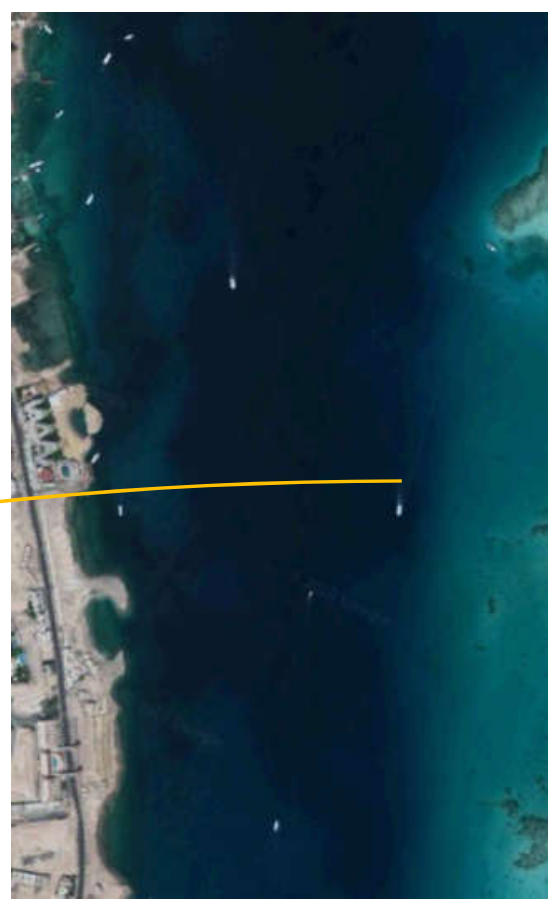

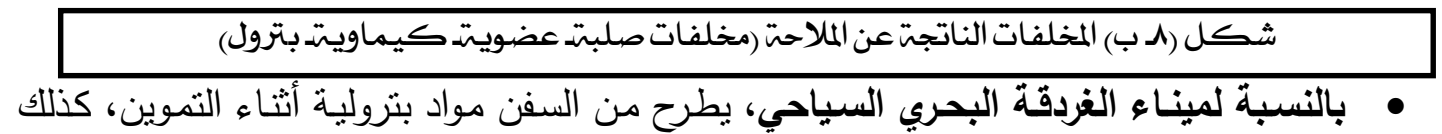

مخلفات صلبة وكيماوية أثناء القيام بالتتظيف، جميعها تتسرب في المياه البحرية بنطاق السحب المباشر لتغذية المحطة، وبالتالي تختلط المواد السامة بمياه التغدية التي ربما لا يمكن التخلص منها أو تكلف المحطة تكاليف إضافية للتخلص منها. • بالنسـبة لمينـاء الصـيل وحلقـة الســك، بطرح منهمـا مـواد بتروليـة ومخلفات حفظ وتصـنيع الاسماك، جميعها تتسرب في المياه البحريـة بنطاق السحب المباشر لتغذيـة المحطة. وبالتالي تختلط المواد السامة والعضوية بمياه التغذية والتي ربما بصعب التخلص منها. بالنسبة لمارينا الغردقة، بطرح من اليخوت مواد بترولية وعناصر كيميائية ومواد صلبة ناتجة عن عمليات النظافة، جميعها تتسرب في المياه البحرية بنطاق السحب المباشر لتغذية المحطة، ولئه وبالتالي تختلط المواد السامة بمياه التغدية التي ربما لا يمكن التخلص منها. ه وقوع محطـة التحليـة والنطـاق البحري لتغذيـة المحطـة على المـر الملاحـي للسـفن مـن الثــال والجنوب ومن القرى السياحية للجزر (الجفتون، براديس، أبو منقار ، ومجاويش، وتوبيا)، وينتج عن ون هذه السفن مـواد ببتروليـة ومـواد كيميائيسة ومخلفـات عضـوية وصلبة، جميعها تتسـرب في في الميـاه البحرية القريبة من نطاق السحب المباشر لتغذية المحطة. 䧑 $(1 N \mid r)$ 
ليس من المنطقي أن نُخلي أية مسئولية على عاتق المحطة والقائمين عليها، ونترك الأخطار

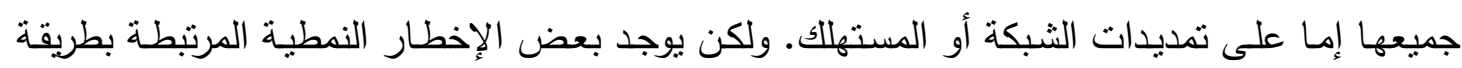

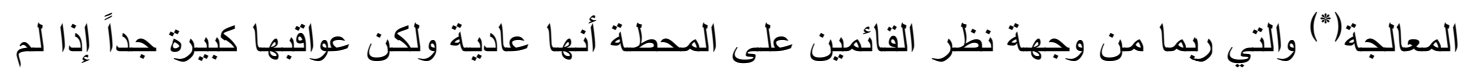

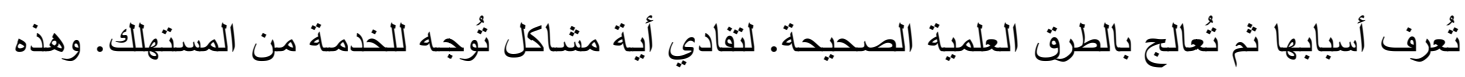

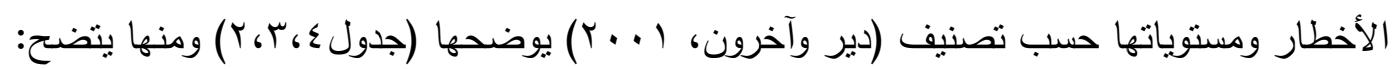

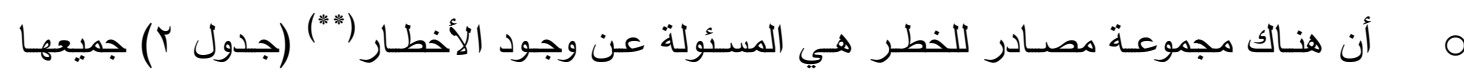

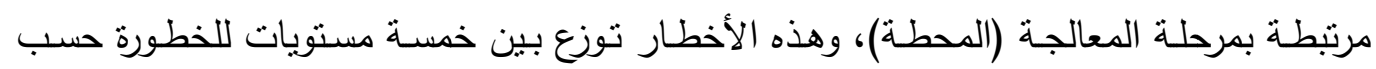
تصنيف (دير) (جدول r) ولمعرفة مستوى الخطورة لكل خطر لا بد من تحديد مصدر الخطر الخطر أولاً

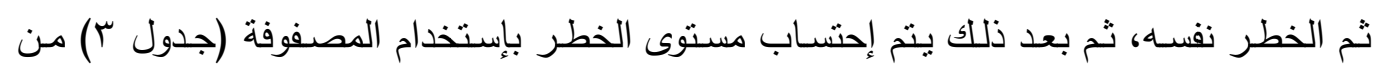
خلال عنصرين أحدهما افقي ممثلاً في صفوف المصفوفة وهي ولثي (مدي الخطورة أو الآثار) والثاني رأسي ممثلا في (درجة إحتمالية تكرار الحدث).

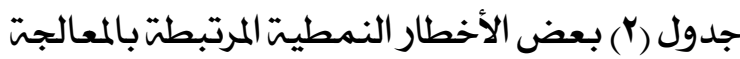

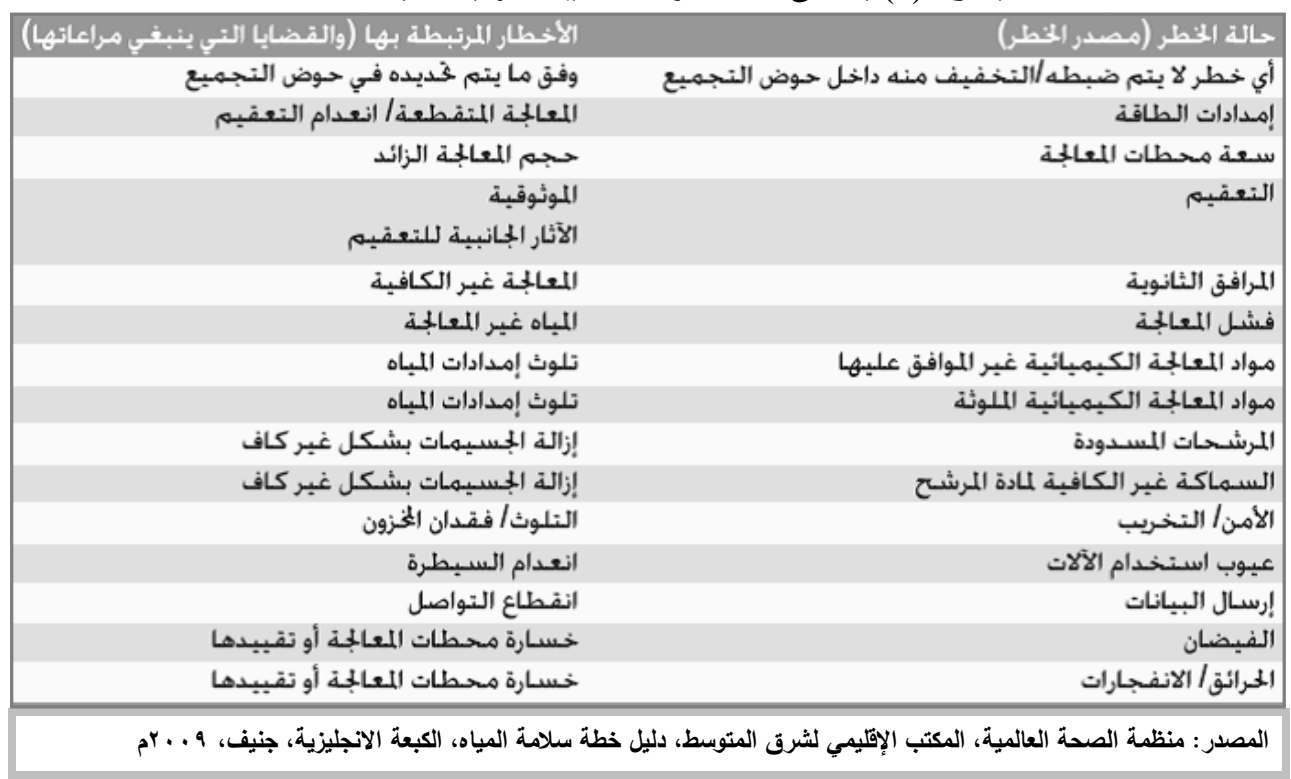

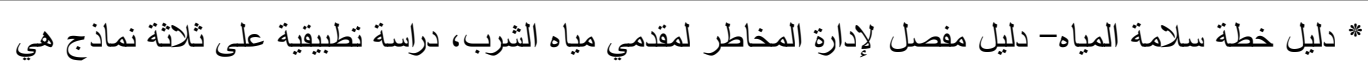

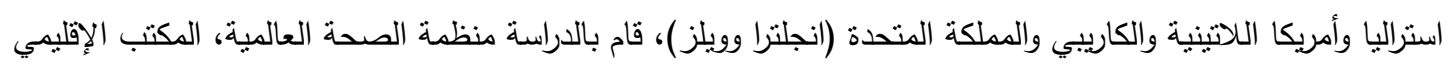

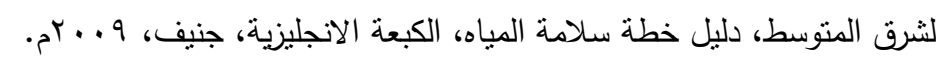

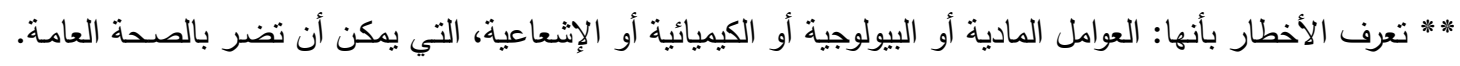

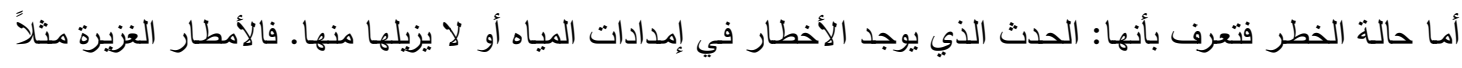

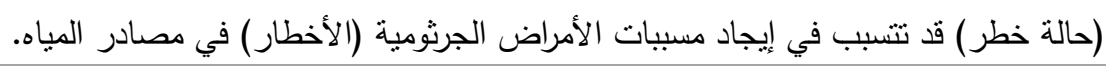


O أما عن الهدف من تحديد مستوى الخطوره للأخطار فهو لتقييم الأخطار والمخاطر بإتباع المنهج شبة الكمي ويوضـح (جدول ع) نتائج تقييم بعض الأخطار والمخاطر بإنباع المنهج شبه الكمي لمحطة تحلية اليسر بالغردقة.

\section{جدول (r) منهج مصفوفت المخاطر شبه الكمبي (مأخوذ عن دير وأخرين، ا.٪r)}

\begin{tabular}{|c|c|c|c|c|c|}
\hline \multicolumn{6}{|c|}{ 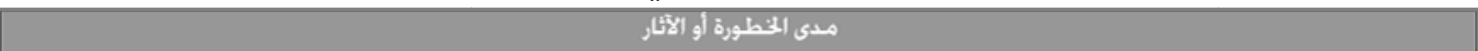 } \\
\hline نأثير كارثي على الصحة & تأثبر تنظبهي & نأثير جمالي متوسط & نأثير بسيط على & طفيف أو لا أثر له - & \\
\hline العامة - التصنيف: 5 & كبير- 4 & - التصنيف: 3 & الامتثال- التصنيف: 2 & التصنيف: 1 & \\
\hline 25 & 20 & 15 & 10 & 5 & الثبن مبوكد: مرة بومباً - \\
\hline 20 & 16 & 12 & 8 & 4 & 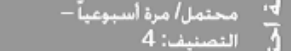 \\
\hline 15 & 12 & 9 & 6 & 3 & الثتوسط: مرة شهرياً - \\
\hline 10 & 8 & 6 & 4 & 2 & 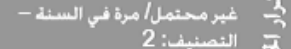 \\
\hline 5 & 4 & 3 & 2 & 1 & 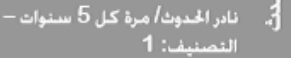 \\
\hline يمرتفع جداً 15 & & $\begin{array}{l}15-10 \\
\text { مرتفع }\end{array}$ & متوسط & مندئي & تصنيف المخطر \\
\hline
\end{tabular}

المصدر : منظمة الصحة العالمية، المكتب الإقليمي لثرق المتوسط، دليل خطة سلامة المياه، الكبعة الانجليزية، جنيف، 9 +. بم

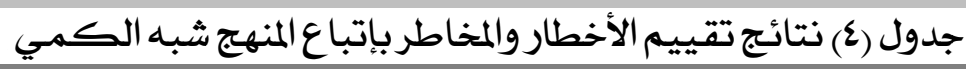

\begin{tabular}{|c|c|c|c|c|c|c|c|}
\hline الأساس & (قبل النظر الى الضوابط) & 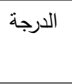 & 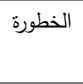 & الاحتمالية & الخطر & (مصدر الخطر) & خطوة العملية \\
\hline 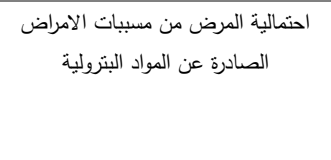 & مرتفع & 10 & 。 & $r$ & ورثيائي & 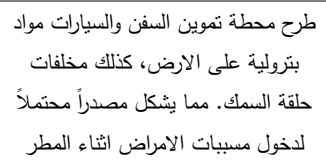 & (المياه الجوفية) \\
\hline 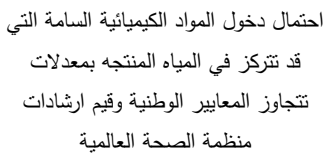 & مرتفع & 1. & 。 & r & كيميائي & طالميناء السياحي البحري وميناء الصيد النيد الثناء التموين & (المياه الجوفية) \\
\hline 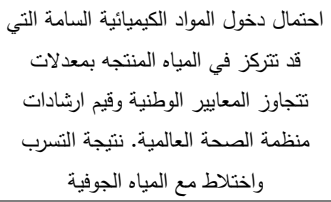 & متوسط & $\wedge$ & ؛ & r & كيمبائي & خليط من مبيدات الهوام المستخدمة في & (المياه الجوفية) \\
\hline 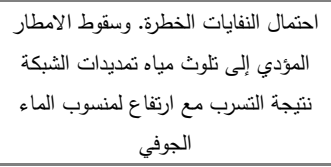 & متذني & 1 & 1 & 1 & وكمبائي & احتمال طرح الفضلات الصلبة بشكل & (المياه الجوفية) \\
\hline احتمال المرص من مسبات الامراض & 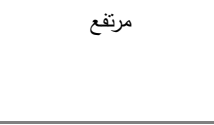 & 1. & 。 & r & جرثومي & 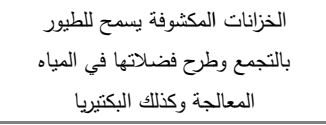 & المستهلك) \\
\hline احتمال فقدان المعالجة وصغط المضخات & 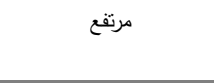 & 1. & 0 & r & و و ورثميائي & لا يوجد مصدر احتياطي للطاقة & المعالجة - المدر \\
\hline 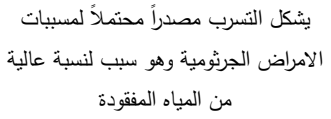 & 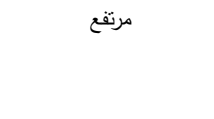 & 10 & $r$ & $\circ$ & جرثومي & التنسريب من الخط الرئيسي ونظام التززيع & (الثبكةر) \\
\hline
\end{tabular}

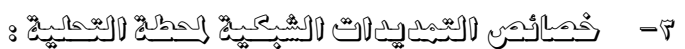

تستخدم عدة أنواع من المواسير في أعمـال ميـاه الثـرب بالغردقـة وتصنع المواسير بأقطسار

مختلفة ومواد مختلفة حسب الغرض منها وموضع إستعمالها، وتورد إلي مكان العمل بأطوال مختلفة مما بدعو إلى قطعها وثثيها ووصلها لنكون شبكات التغذية، ويجب أن تتوافر في المواسبر ثلاثة شروط وهي $(|\wedge| \leqslant)$ 
المتانة وطول فترة الإستخدام والإقتصاد في التكاليف ويجب أيضـاً الإهتمام بحمايـة أسطح المواسير

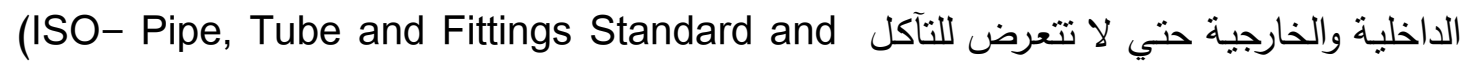
Specification)

\section{أ. أنواع هواسير الشبكة وأطوالها:}

تتكون الثبكة من عدة أنواع من المواسبر نتباين فيما بينها من حيث مادة الصنع وأطوالها،

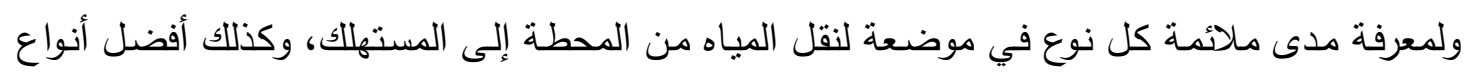

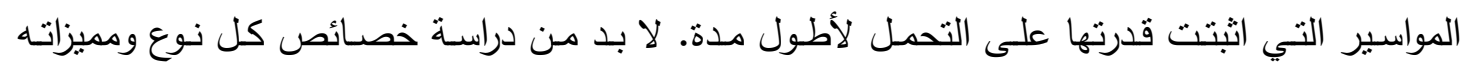

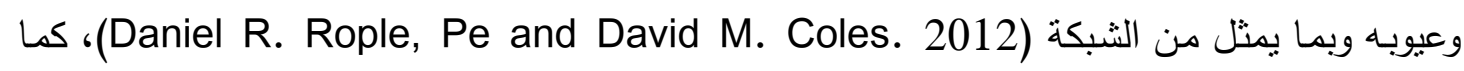

$$
\text { يلي: المهاسير اللزهر: }
$$

تتسم المواسير الزهر عن باقي أنواع المواسير بالعمر الطويل جدًا حيث أنه يوجد خط من التهن

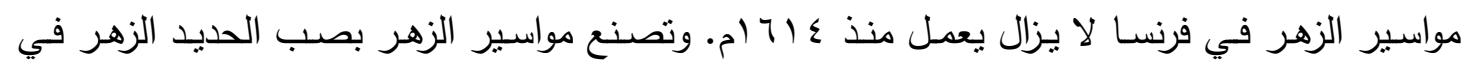

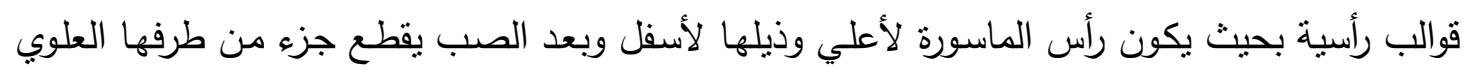

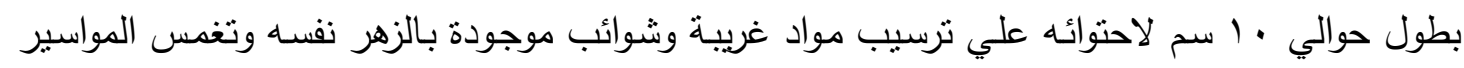

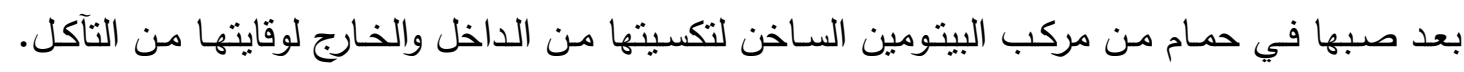

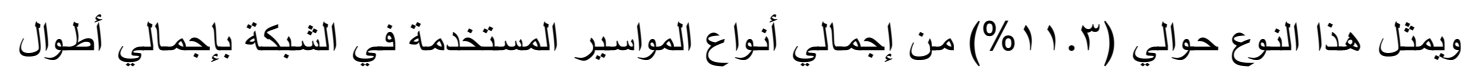

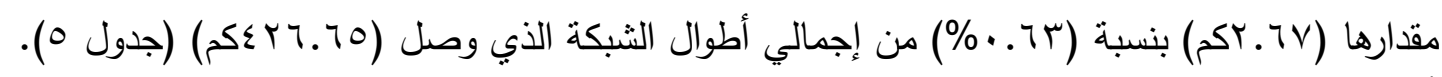

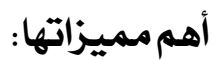

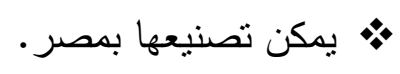
• م أسعارها مقبولة.

لا تلاتجاج الي عزل داخلي أو خارجي. • بهولة في التركيب.

•. مكن استخدامها في خطوط الطرد وشبكات الانحدار. • معيش عمراً طويلا.

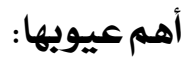

• • مهلة الكسر وتحتاج لحرص شديد في النقل والتركيب. • • ثقيلة الوزن.

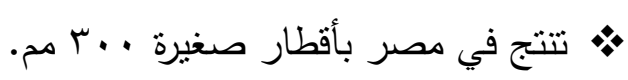

جدول (0) بعض خصائص شبكت التغذيتلمحطت تحليتً اليسر- الغردقت لعامA1.rم $(1110)$ 


\begin{tabular}{|c|c|c|c|c|c|c|c|}
\hline الطول (كم) & مادة الصنع (النوع) & |القطر (مم) & 5 & |الطول (كم) & مادة الصنع (النوع) & القطر (مم) & r \\
\hline$\leq \varepsilon . \Gamma$ & الأسبستوس الأسمنتية & \multirow{5}{*}{$r}$. & rᄉ & .11 & الأسبستوس الأسمنتية & $\wedge .$. & 1 \\
\hline..$r q$ & حديد ظهر & & rq & .1. & حديد & $\vee \cdots$ & r \\
\hline .ro & بولي ايثلين & & $r$. &. .21 & الأسبستوس الأسمنتية & \multirow{5}{*}{$\uparrow .}$. & $r$ \\
\hline V.os & بلاستيك (رمادي- اسود) & & $r$ &. .14 & حديد ظهر & & $\varepsilon$ \\
\hline..$\leqslant 7$ & حديد & & rr & r.\&૫ & بولي ايثيلين & & 。 \\
\hline$v 7.91$ & الأسبستوس الأسمنتية & \multirow{4}{*}{10.} & 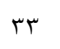 & .11 & حديد & & 7 \\
\hline$\{. .01$ & بلاستيك (رمادي- اسود) & & $r \varepsilon$ &. $.0 r$ & بلاستيك (رمادي- اسود) & & v \\
\hline $1 . v r$ & حديد & & ro &.$r$. & بلاستيك (رمادي- اسود) & so. & $\wedge$ \\
\hline$\cdots \wedge$ & استانلس عالي الضغط & & $\mu_{4}$ & 10.17 & الأسبستوس الأسمنتية & \multirow{5}{*}{$\varepsilon \ldots$} & 9 \\
\hline$\leqslant \wedge .99$ & الأسبستوس الأسمنتية & \multirow{4}{*}{$1 \ldots$} & re & 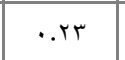 & حديد ظهر & & 1. \\
\hline$\ldots \varepsilon$ & بولي ايثيلين & & rᄉ & V.. I & بولي ايثيلين & & 11 \\
\hline TY.TA & بلاستيك (رمادي- اسود) & & rq & T.\&. & بلاستيك (رمادي- اسود) & & ir \\
\hline. .19 & حديد & & $\varepsilon \cdot$ &. .11 & حديد & & ir \\
\hline $1 . . r$ & أسمنت الأسبستوس & \multirow{5}{*}{ vo } & $\varepsilon$ & 纟.or & الأسبستوس الأسمنتية & \multirow{3}{*}{ ro. } & $1 \varepsilon$ \\
\hline r..v & بلاستيك (رمادي- اسود) & & $\varepsilon r$ & $.1 \varepsilon$ & حديد & & 10 \\
\hline 1.10 & حديد & & $\varepsilon \varepsilon$ & $\cdots 1$ & بلاستيك (رمادي- اسود) & & 17 \\
\hline$\ldots \varepsilon$ & استانلس عالي الضغط & & «o & N.vo & حديد & \multirow{5}{*}{$r .}$. & iv \\
\hline$\ldots \varepsilon$ & حديد ظهر & & $\varepsilon 7$ & $v .70$ & بلاستيك (رمادي- اسود) & & 11 \\
\hline$\cdots \leqslant 4$ & بلاستيك (رمادي- اسود) & 4 & $\varepsilon v$ & $9 . . \varepsilon$ & بولي ايثيلين & & 19 \\
\hline$\ldots 1$ & أسمنت الأسبستوس & \multirow{4}{*}{ o. } & $\varepsilon \wedge$ & $\ldots 1$ & حديد ظهر & & $r$. \\
\hline. .07 & حديد & & $\leqslant 9$ & ro.rv & الأسبستوس الأسمنتية & & r \\
\hline$\ldots r$ & استانلس عالي الضغط & & o. & 19.97 & الأسبستوس الأسمنتية & \multirow{4}{*}{ ro. } & rt \\
\hline $1 . r v$ & بلاستيك (رمادي- اسود) & & 01 & $1 . r \varepsilon$ & حديد ظهر مرن & & rr \\
\hline 1.01 & بولي ايثيلين & \multirow{2}{*}{ rv.o } & or & $\varepsilon . \wedge 1$ & حديد & & $r \varepsilon$ \\
\hline $1 . . \varepsilon$ & حديد & & or & 纟.r. & بلاستيك (رمادي- اسود) & & ro \\
\hline \multirow[t]{2}{*}{$\ldots 1$} & بالاتيك (رمادي- اسود) & ro & $0 \leq$ & 1.19 & بلاستيك (رمادي- اسود) & 17. & r \\
\hline & & & & r.91 & بلاستيك (رمادي- اسود) & 11. & rv \\
\hline EYr.7० & \multicolumn{7}{|c|}{ إجمالي طول الثبكة } \\
\hline
\end{tabular}

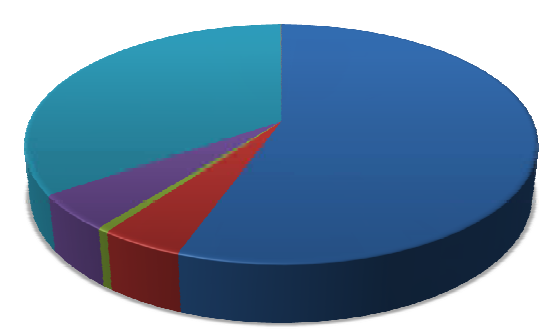

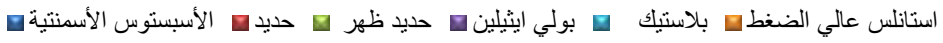

شكل (9) أنواع وأطوال المواسير المستخدمت في شبكت المياه بمدينت الغردقت 


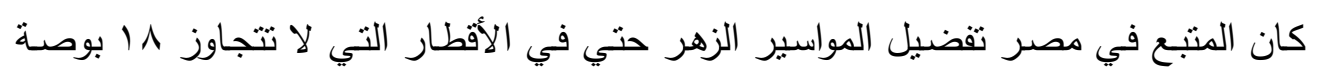
لقدرتها على مقاومة التآكل في التربة السبخية والكبريتية أو المردومة بينما مواسير الأسبستوس الأسمنتية دلت في الخارج علي مقاومتها لهذا التآكل لدرجة كبيرة مع تحملها للضغوط المطلوبة للتشغيل إحتمالاً مأموناً فضلاً عن مزاحمة أثنمانها للزهر والصلب في حدود هذه الأقطار وأكبر منها أحياناً في الضغوط المتوسطة. هذا بالإضافة إلى التيارات كهربائية الثـاردة في التربة بينما يكون التلف سريعاً في المواسير

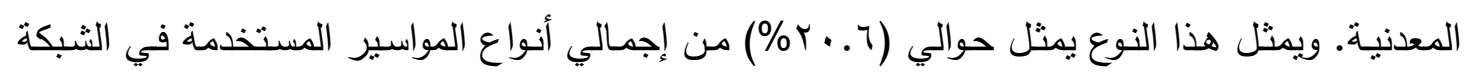

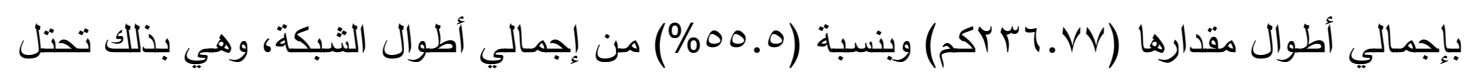
المرتبة الأولى من حيث تمثيلها للشبكة بالغردقة.

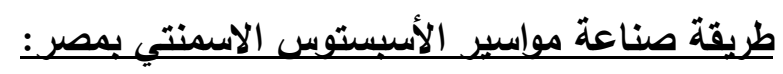
تصنع مواسير الأسبستوس الاسمنتي بمصـانع سيجوارت بالمعصرة بطريقة مانياتي الايطاليـة

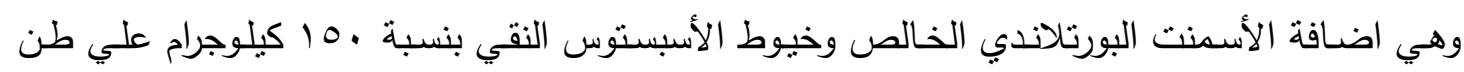
الاسمنت علي أربع درجات تجرب علي نفس الضغوط المقررة لمواسير الزهر .

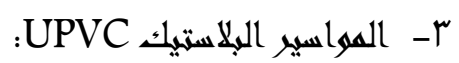
يتم تركيب مواسير البلاستيك بإستخدام حلقات مطاط أو بإستخدام المواد اللاصقة للحصول

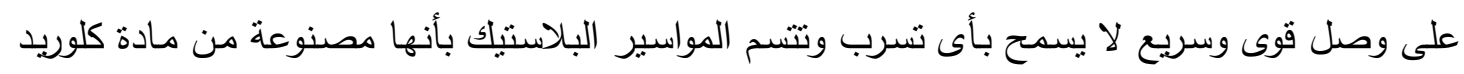
الفينيل غير الملدن بالنعومة الهيدروليكية نتيجة صغر معامل الاحتكاك للمواسبر مما يؤدي الي سرعة

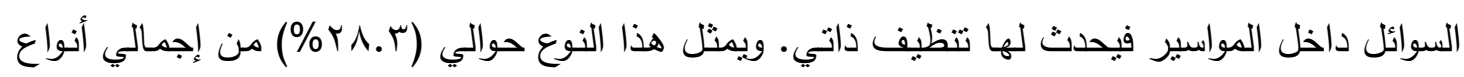

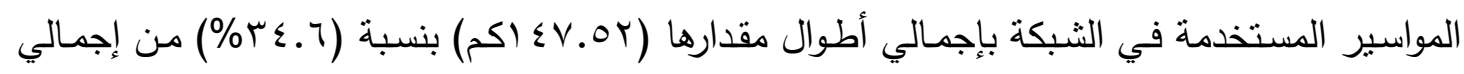
أطوال الشبكة، وهي بذلك تحتل المرتبة الثانية من حيث تمثبلها للشبكة بالغردقة.

أهم مميزاتها: • مهلة التركيب - سهلة النقل - سهلة الإصلاح وتتحمل الصدمات.

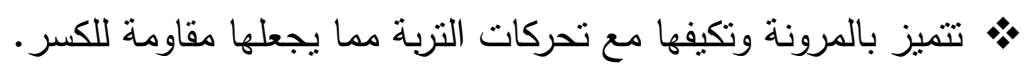

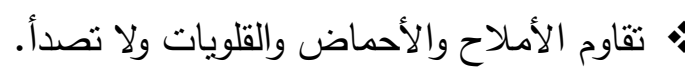
•• سطحها الداخلى يتميز بالنعومـة الهيدروليكية مدا يؤدى إلى سـرعة تدفق السوائل داخل المواسير

$$
\text { وعدم ترسيب الفطريات والاملاح وغيرها. }
$$

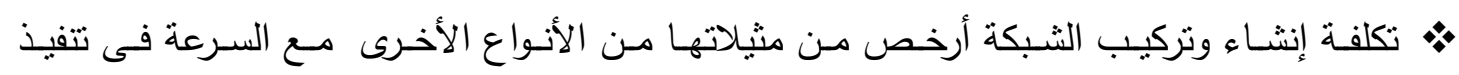
الثبكات. •. • العمر التصميمي الأفتراضى لهذة المواسير أكثر من خمسون عاماً. كثرة المصانع التي تتتجها في مصر . 


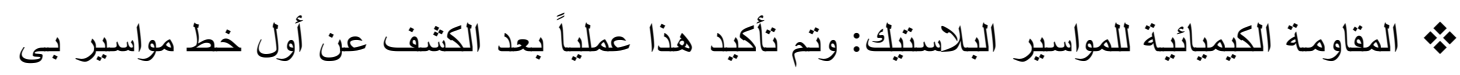

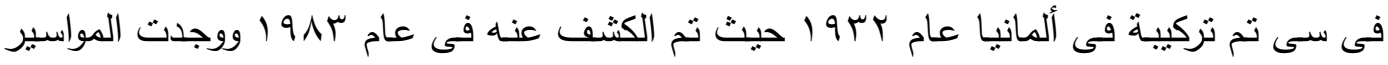
محتفظة بنفس خواصها كما أكدنها الإختبارات المعلية التى يتم إجراؤها بصفة دائمة.

ع- هواسير المبوليه إيثيلين:

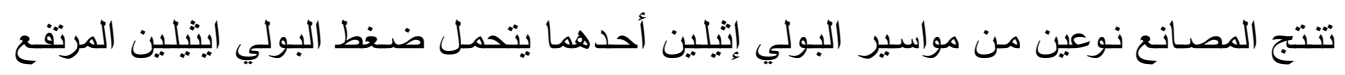
والآخر يتحمل الضغط المنخفض، وكلاهما بديل ممتاز للمواسير المعدنية لتوفير المياه ويمكن توصيله

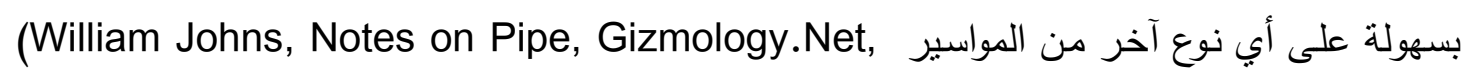

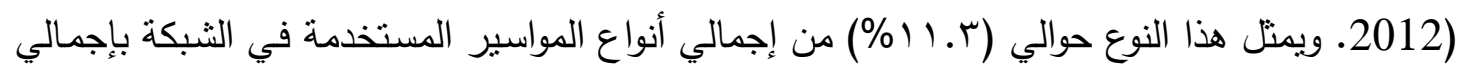

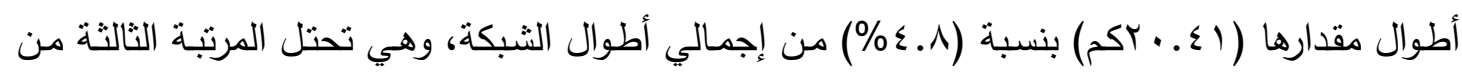
حيث تمثيلها للثبكة داخل منطقة الدراسة.

مميزاته: • • مقاومة لارجات الحرارة المنخفضة (أقل من · ب درجة مئوية).

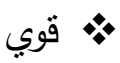
عيوبه:

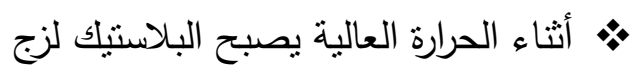

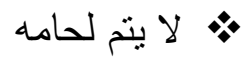

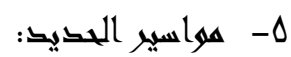

تعتبر المواسير الحديد أقدم مواسير التخذيـة، وتوجد حتى الآن، وتوجد في الأسواق بنوعين

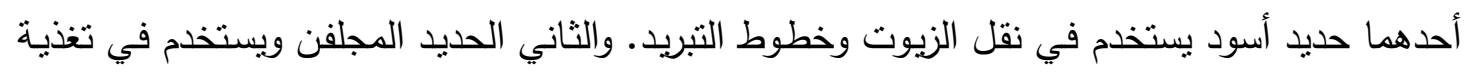

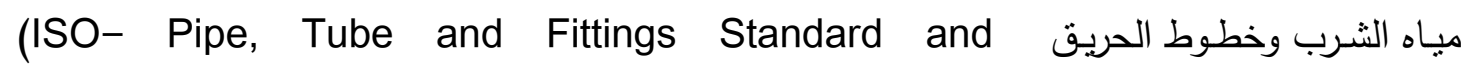
Specification)

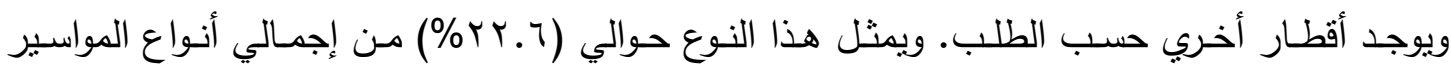

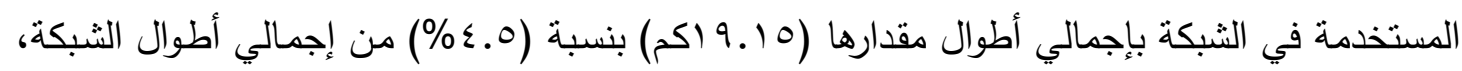
وهي تحتل المرتبة الرابعة من حيث تمثيلها للثبكة داخل منطقة الدراسة.

\section{الأطوال القياسية للمواسير وأفضلها نوعاً وتطبيق ذلك الكل على هنطقة الغردقة.}

يوجد أطوال قياسية للمواسير المستخدمة في شبكات المياه ومتوفرة في أي مكان بالعالم وتتطبق

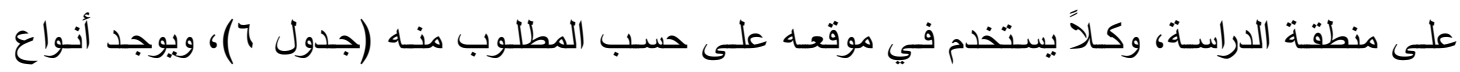

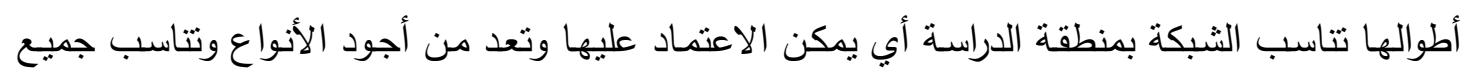

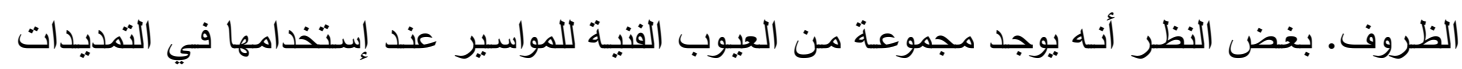

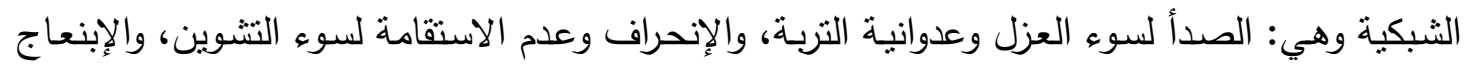

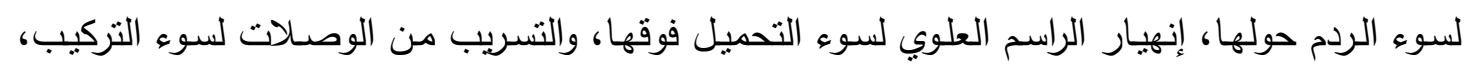

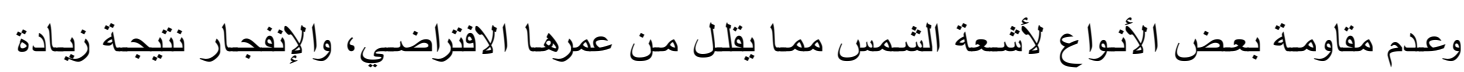

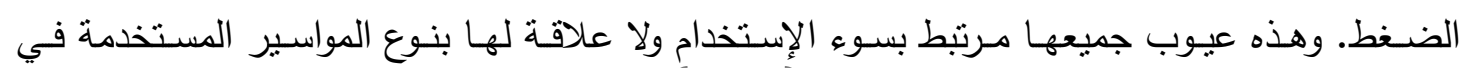
( 1111$)$ 
الثبكة. ولكن هنـاك دراسـات أثتبت أن المواسير البلاستيكية (PVC) هـي الأفضـل بين كل أنساع

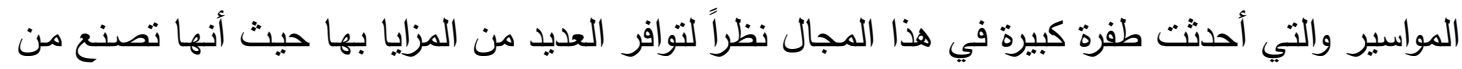

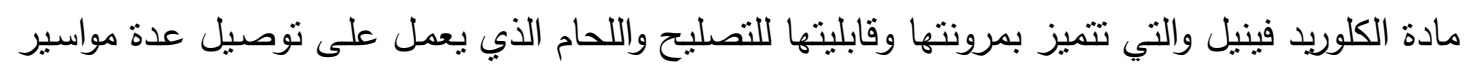

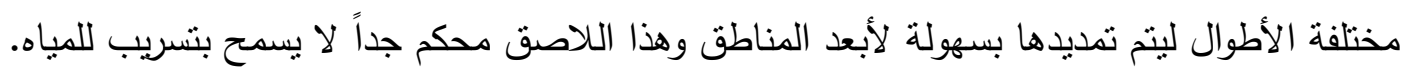

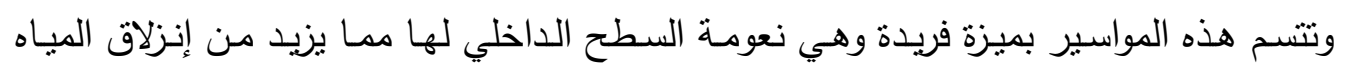

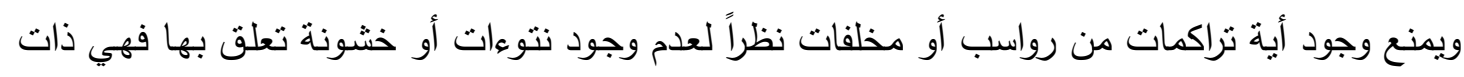

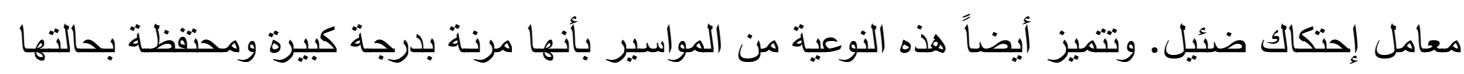

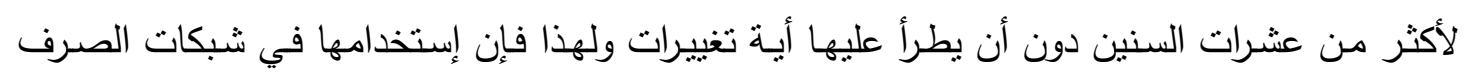

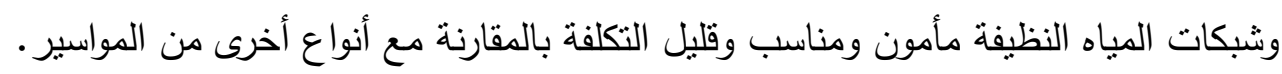
جدول (ا) الأطوال القياسيت المستخدمت في شبكات المات المياه

\begin{tabular}{|c|c|c|}
\hline مادة الصنع (النوع) & الطول (كم) & م \\
\hline فخار وخرسانة & $. r 0-. .10$ & 1 \\
\hline بولي بروبلين & $7-\varepsilon$ & r \\
\hline بلاستيك & \rceil$-\varepsilon$ & $r$ \\
\hline فايير & $\mid r-1$ & $\varepsilon$ \\
\hline خراطيم البولي ايثيلين & $1 \ldots-14$ & ○ \\
\hline
\end{tabular}

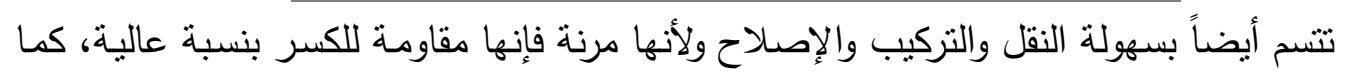

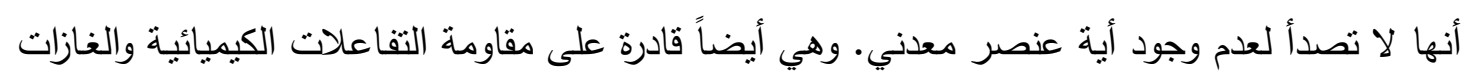

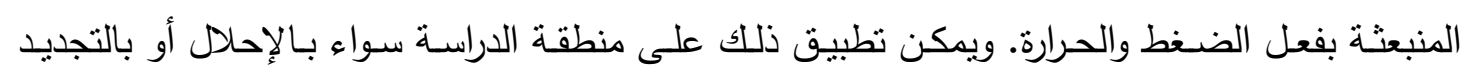

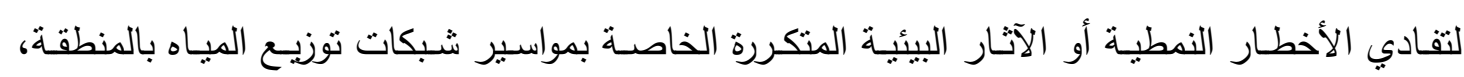

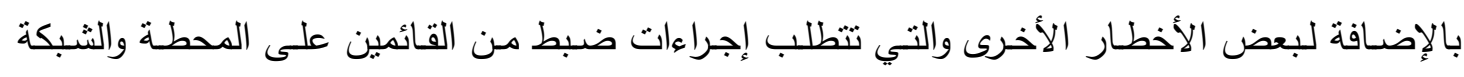

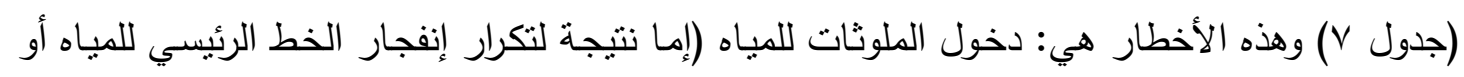

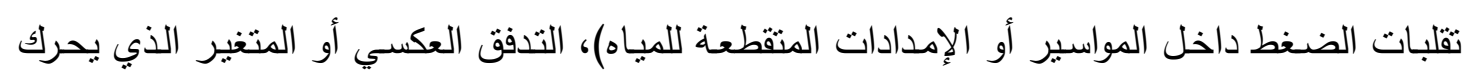

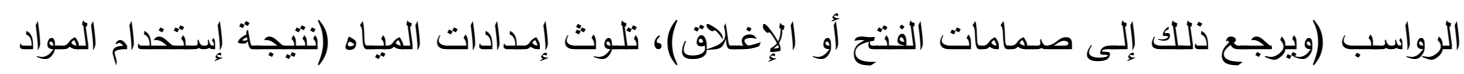

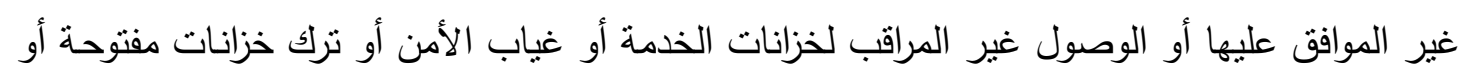

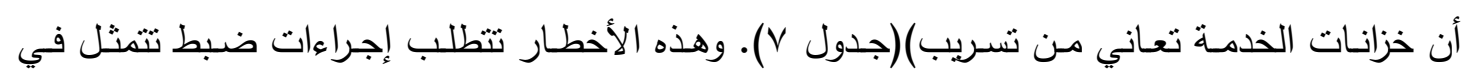
الآتي:

التفتيش المنتظم على الخزانات (الخارجية والداخلية). تغطية خزانات الخدمة المفتوحة. الخرائط الحيثة للشبكة. الحالة المعلومة للصمام. 
سياسة الثراء وإجراءاته.

إجراءات إصلاح الخط الرئيسي.

العاملون المؤهلون (كفاءة المشغل).

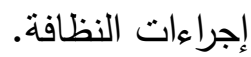

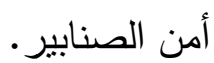

الصمامات المانعة لإرتداد المياه لمنع تحريك الرواسب.

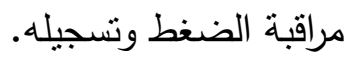

السياج والفتحات المغلقة والإنذار ضد الإنطفلين على خلى خزانات الخدمة وأبراجها.

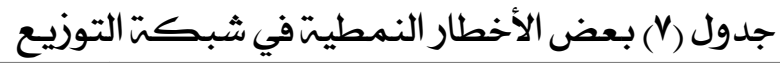

\begin{tabular}{|c|c|}
\hline الاخخطار المرتبطة بها (والفضابا التب ينبغي مراعاتها) & مالة الخطر (مصدر المخطر) \\
\hline وفق ما بتهم خدبده أثناء المعالجة & أي خطر لا بتهم ضبطه /التخفيف منه أثناء المعالجة \\
\hline دخول الملوئات & ن انفجار الأنبوب الرئيسي \\
\hline 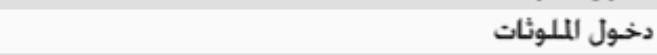 & قالبات الضغط \\
\hline دخول الملوئات & 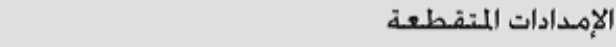 \\
\hline التدفق العكسي. أو المتغبر الذي بحرك الرواسب & 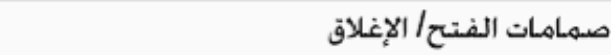 \\
\hline 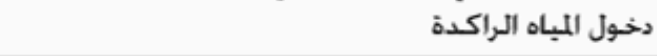 & \\
\hline تلوث إمدادات المباه & استخدام المواد غير الموافق عليها \\
\hline التلوث بالتدفق العكسي & وصول الآخرين إلى صنابير التحكم \\
\hline زيادة التدفق مما بحرك الرواسب & \\
\hline التلوث بالتدفق العكسي & 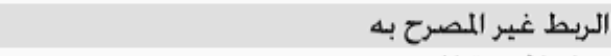 \\
\hline التلوث عن طريق الحبوانات البرية & 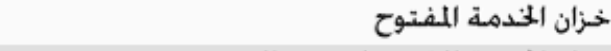 \\
\hline دخول الملوئات & 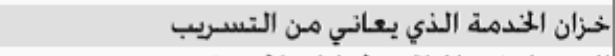 \\
\hline التلوث & الوصول غبر المراقب للخزانات الخذمة \\
\hline التلوث & 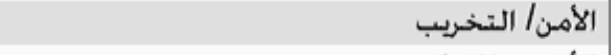 \\
\hline تلوث إمدادات المباه عن طريق الأنواع الخاطئة من الأنابيب & الأراضي الملوئة \\
\hline
\end{tabular}

ob

لقد حددت هيئة الصحة العالمية وغيرها من الهيئات القومية والعالمية مواصفات لمياه الثرب

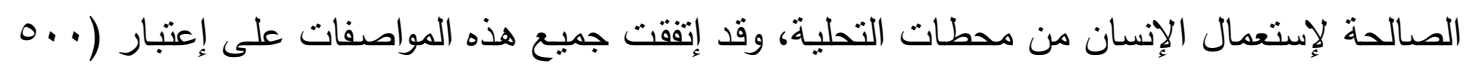

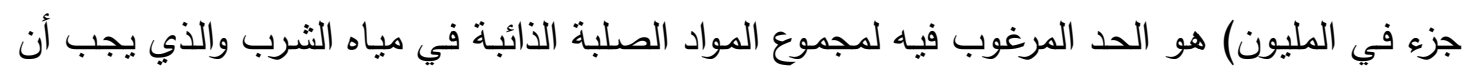

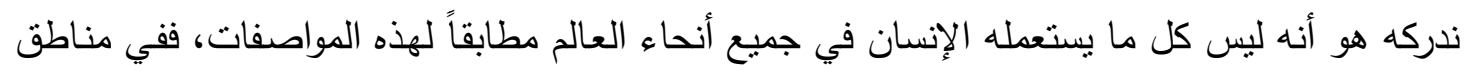

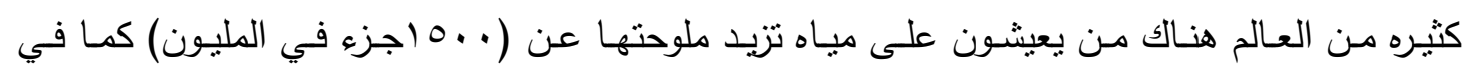
المكسيك والسنغال وأجزاء من استراليا.

وتختلف الأمساح الذائبة في نأثيرها على الإنسان أو خطورتها عليها، فكربونات الكالسيوم مثناًا

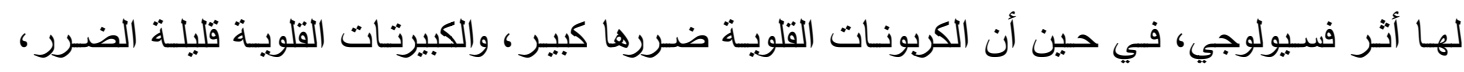

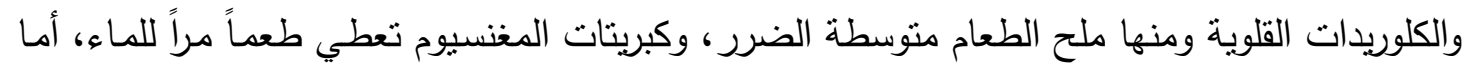

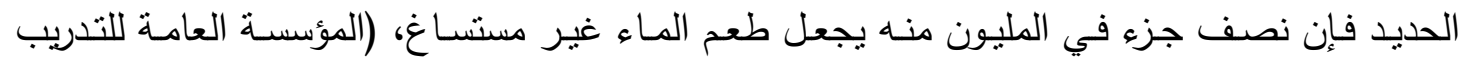

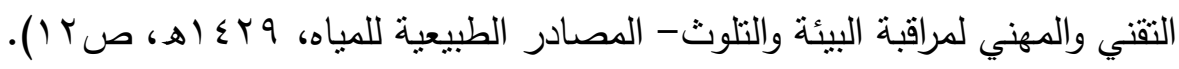


وتتلخص المواصـفات العالميـة لميـاه الثـرب مـن محطـات التحليـة فيمـا يلـي ( برنـامج الأمـم

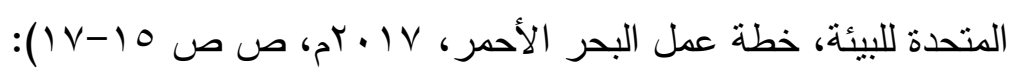

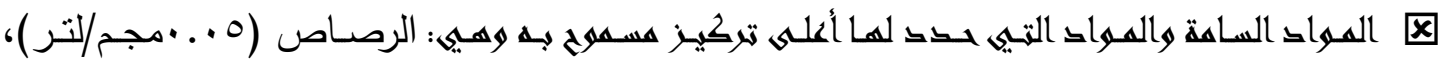
والسيلينيوم ( ا ...مجم/لتر)، والزرنيخ (0 . . •مجم/لتر)، والسيانيد ( ( . ..مجم/لتر)، والكادميوم

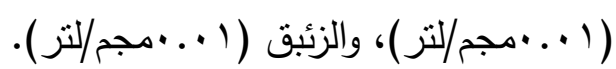

囚 المللهريدايت: وتتوقف الحدود المقترحة لتركيزها في الماء على الحرارة السائدة بالمنطقة (جدول ^):

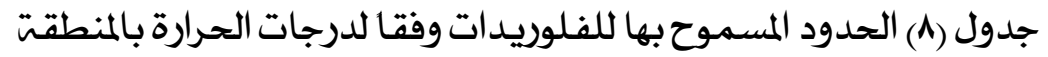

\begin{tabular}{|c|c|c|}
\hline \multicolumn{2}{|c|}{ الإستهالاك } & \multirow{2}{*}{ المنوسط السنوي لدرجة حرارة المنطقة } \\
\hline الحد الأقصى للفلور (مجم/لتر) & الحد الأدني للفلور (مجم/لتر) & \\
\hline 1.1 &. .9 & $1 r-1$. \\
\hline 1.0 &.$\wedge$ & $1 \leq .7-1 Y .1$ \\
\hline $1 . r$ &.$\wedge$ & $\mid V . T-1 \leqslant . V$ \\
\hline 1.4 & $\therefore v$ & YI.\&-IV.V \\
\hline 1 & $\because v$ & YY. $Y-Y 1.0$ \\
\hline.$\wedge$ & .7 & 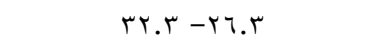 \\
\hline \multicolumn{3}{|c|}{ المصدر : برنامج البيئة،الأمم المتحدة، خطة عمل البحر الأحمر، VI.Yم. } \\
\hline
\end{tabular}

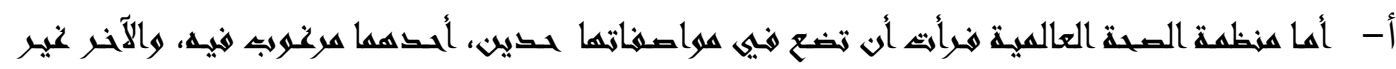

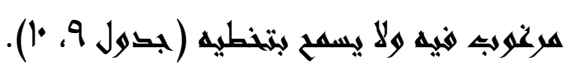

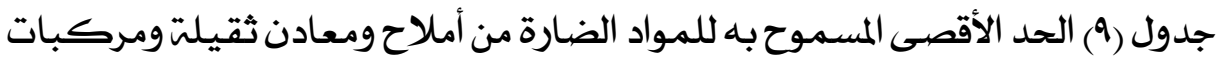

\begin{tabular}{|c|c|c|c|c|c|}
\hline \multicolumn{5}{|c|}{ المواصفات العالمية } & \multirow[t]{2}{*}{ العنصر } \\
\hline ل روسيا & امريكا & كندا ا & التحاد الاوروبي & هيئة الصحة العالمية & \\
\hline 1.0 & r & 1.0 & $1.0-. . V$ & 1.0 & فلوريد \\
\hline- & - & 0 & 1 & - & بورون \\
\hline. .1 & - & $\because r$ & - & .1 & سيانيد \\
\hline- & - & - &.$r$ &.$r$ & الومنيوم \\
\hline- & $\ldots 0$ & $\ldots .0$ & $\ldots 0$ & $\ldots 0$ & ارسنك \\
\hline- & 1 & 1 & $\because 1$ & - & باريوم \\
\hline$\ldots+1$ & $\ldots 1$ & $\ldots . .0$ & $\ldots \ldots$ & $\ldots \ldots$ & كادميوم \\
\hline$. .0-. .1$ & $\ldots 0$ & $\ldots 0$ & $\ldots \ldots$ & $\ldots 0$ & كروميوم \\
\hline .1 & - & - & - & - & كويلت \\
\hline 1 & 1 & 1 & .1 & 1 & نحاس \\
\hline .0 &.$r$ &.$r$ &.$r$ &.$r$ & حديد \\
\hline$\ldots r$ & $\ldots \circ$ & $\ldots 0$ & $\ldots 0$ & $\ldots 0$ & رصاص \\
\hline- & $\ldots 0$ & $\ldots 0$ & $\ldots .0$ &. .1 & منجنيز \\
\hline$\ldots \ldots$ & $\ldots r$ & $\cdots \cdots 1$ & $\cdots \cdots$ & $\cdots \cdots$ & زئبق \\
\hline- & - & - & $\ldots 0$ & - & بيكل \\
\hline- & $\cdots+1$ & $\ldots 1$ & $\because 1$ & $\ldots 1$ & سيانيوم \\
\hline 1 & o & o & $r-. .1$ & . & زنك \\
\hline \multicolumn{6}{|c|}{ المصدر : المؤسسة العامة للتنريب التقني والمهني لمراقبة البيئة والتلوث- المصادر الطبيعية للمياه، وبـ اهـ، ص 10.} \\
\hline
\end{tabular}

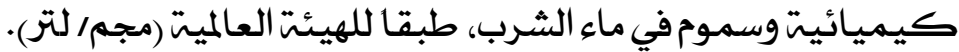

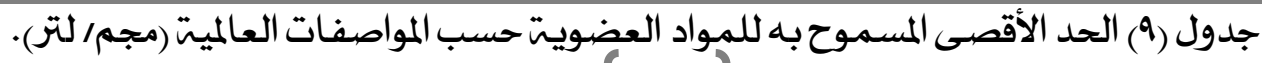
(|Nr|) 


\begin{tabular}{|c|c|c|c|c|c|}
\hline \multicolumn{5}{|c|}{ المواصفات العالمية } & \multirow[t]{2}{*}{ المنتجات العضوية } \\
\hline ل روسيا & امريكا & كندا & التحاد الاوروبي & هيئة الصحة العالمية & \\
\hline.$r$ & - & - & $\cdots 1$ & - & المنتجات البترولية \\
\hline- & - &. .1 &. .0 & - & المبيدات مجمعة \\
\hline- & - &. .1 &. .0 & - & المبيدات منفردة \\
\hline- & - & $\because v$ & - & $\ldots r$ & الدرين وديلزين \\
\hline- & - & $r$. & - & 1 & مادة ددني \\
\hline- & $\therefore \varepsilon$ & $\varepsilon$ & - & $r$ & الليندان \\
\hline- & $1 \ldots$ & $1 \ldots$ & - & $r$. & ميثوكثلدور \\
\hline- & 0 & - & - & 1. & البنزين \\
\hline- & - & - & - & $\cdots+1$ & الهيكساكلورو بنزين \\
\hline- & - & - & - & 1. & البنتاكلوروفينول \\
\hline 1 & - & r &. .0 & - & الفينول \\
\hline. .0 &. .0 & - &.$r$ & - & المنظفات \\
\hline
\end{tabular}

1 -

لمعرفة نوعية المياه الساحلية (مصدر تغذية الثبكة)، قام الباحث بجمع عينتين للمياه البحرية (من مكان معلوم أمسام الهضبة بجوار فندق صن رايز وقد حدده معهد علوم البحار في تقريره وأصر الباحث على نفس الموقع بهدف مقارنة نتائج التحاليل المعملية) في موسمين مختلفتين (صيف- شتاء)، بهدف إخضـاعها للتحليل المعملي بالمعمل المركزي لكلية العلوم جامعة المنوفيـة، وذلك لتحديد المواد الضارة الموجودة بالمياه البحرية (أملاح ومعادن ثقيلة ومركبات كيميائية وسموم) وتحديد مصادر التلوث التي تؤدي إلى تدهور البيئة البحرية، وإعتمدت الدراسة الحالية في تحليلها لنتائج التحليل المعلي على

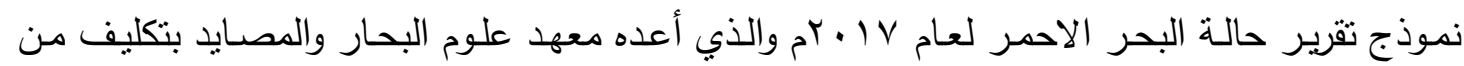

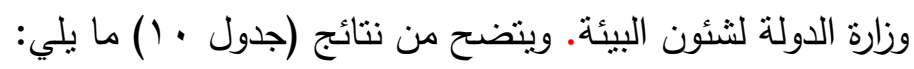

囚

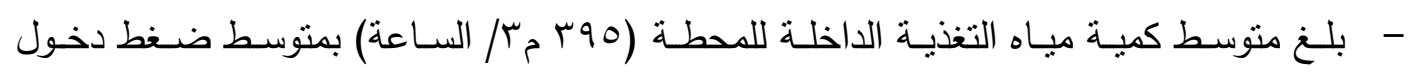
للمحطة وصل (عا بار) وبمعدل تحول وصل (rr\%\%)، ودرجة شفافية معتدلة (محطة تحلية

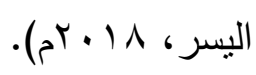

- - تبين من خلال نتيجة درجة حرارة المياه أنه لا توجد تقسيمات حرارية للمياه البحرية داخل منطقة

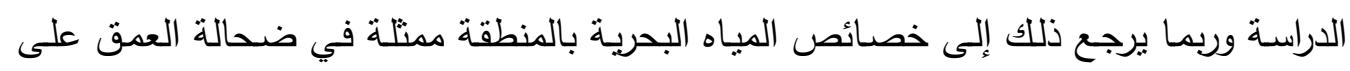

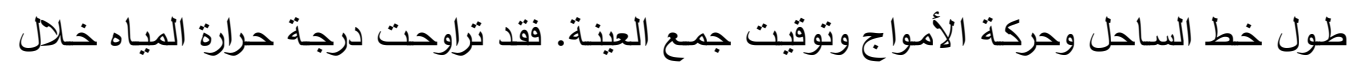
فصلي الثتاء والصيف بين (9 (1) آب) لكل منهما على التوالي.

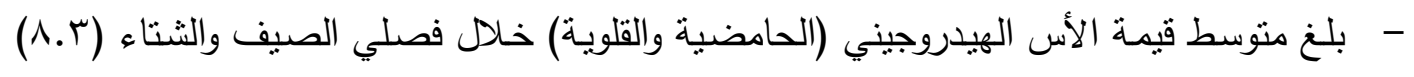
أي أنه دائما في الجانب القلوي الضعيف وهذه القيمة دائما مستقرة وثابتة.

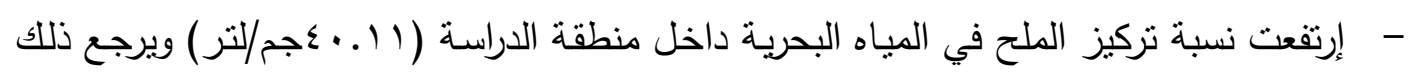

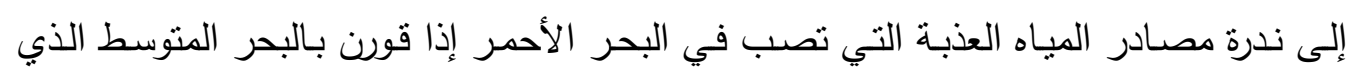


يصب فيه نهر النيل، ويؤكد على ذلك نسبة السيليكات النشطة في المياه البحرية بمنطقة الدراسة

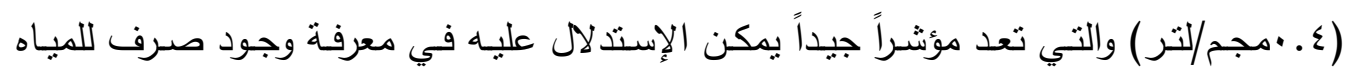

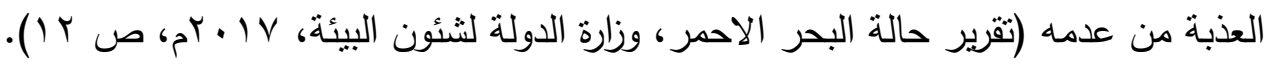

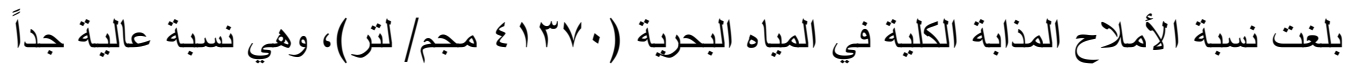
تعكس الضرر الكبير الواقع على التتوع البيولوجي بالمنطقة نتيجة تتوع الأثشطة الإقتصادية.

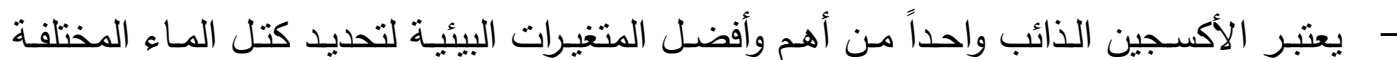

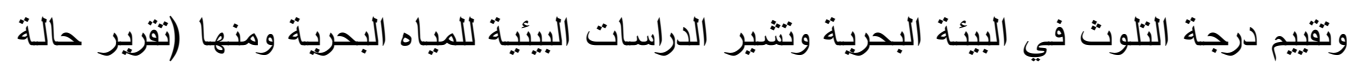

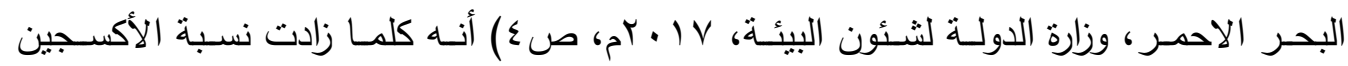
الذائب في اليباه البحرية عن (عمجم/لتر) دل ذلك على قلة معدلات التلوث في البيئة البحرية

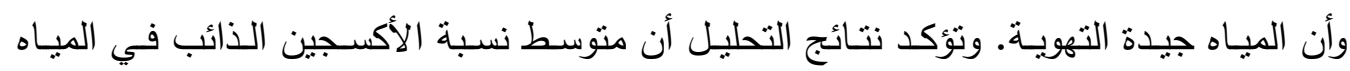

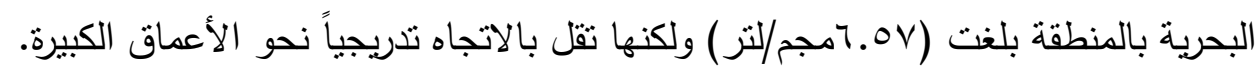

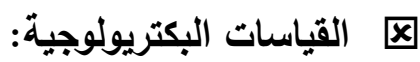

- - يتم عمل القياسـات البكتريولوجيـة (بكتريـا القولون الكليـة، وبكتريـا الايشـر شياكولاي، وبكتريـا

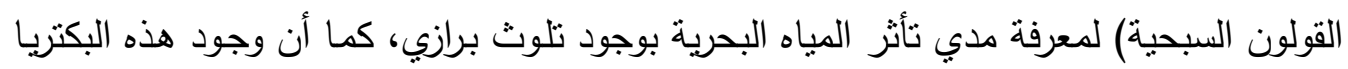

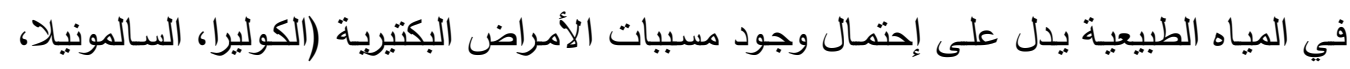
الثيجيلا)، والفيروسية (فيروسـات الإسـهال، والنزلات المعويـة وغيرها)، والطفيلية (البلهارسيا، الطيا،

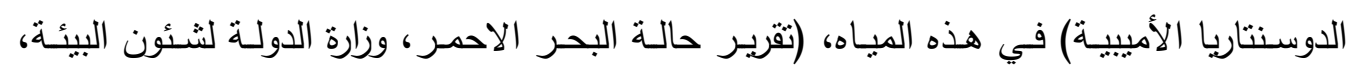

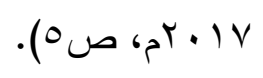

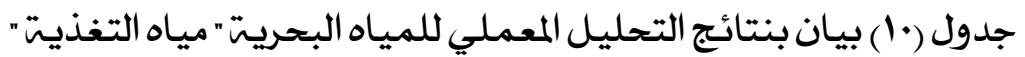

\begin{tabular}{|c|c|c|c|c|c|c|c|}
\hline الغردقة & الوحدة & العنصر & م & الغردةة & الوحدة & العنصر & 5 \\
\hline 0.25 & ملجم/لتر & الحديد & 21 & 8.30 & وحدة & الأس الهيدروجيني & 1 \\
\hline 0.4 & ملجم/لتز & السيليكا النشط & 22 & 59100.00 & ميكرو سيمنز/سم & التوصيلة الكهربائية & 2 \\
\hline 0.02 & ملجم/لتز & الأمونيا & 23 & NR & - & العكارة & 3 \\
\hline 0.1 & ملجم/لتر & النيتزوجين غير العضوي & 24 & NR & - & اللون & 4 \\
\hline 0.93 & ملجم/لتز & النيتروجين الكلي & 25 & NR & ملجم/لتر & النيتريت & 5 \\
\hline 0.004 & ملجم/لتر & الفوسفات الفعال & 26 & $<\mathrm{LOQ}$ & ملجم/لتر & الايرون & 6 \\
\hline 0.07 & ملجم/لتر & الفوسفور الكلي & 27 & $<\mathrm{LOQ}$ & ملجم/لتر & المنجنيز & 7 \\
\hline 5.5 & ملجم/لتر & البرون & 28 & 0.075 & ملجم/لتر & النترات & 8 \\
\hline 9.58 & ملجم/لتر & السترنشيوم & 29 & 1.99 & ملجم/لتر & الفلوريد & 9 \\
\hline 25 & درجة مئوية & الحرارة & 30 & 23950.50 & ملجم/لتر & الكلوريد & 10 \\
\hline 395 & مَ/لتر & كمية مياه التعذية & 31 & 2370.93 & ملجم/لتر & الكبريتات & 11 \\
\hline 37 & $\%$ & معدل التحول & 32 & 0.14 & ملجم/لتر & السيليكا & 12 \\
\hline$<\mathrm{LOQ}$ & ميكجر ام/لتر & النحاس & 33 & 13396.50 & ملجم/لتر & الصوديوم & 13 \\
\hline 0.09 & ملجم/لتز & الباريوم & 34 & 465.18 & ملجم/لتز & البوتاسيوم & 14 \\
\hline 54 & بار & ضغط دخول المياه & 35 & NR & ملجم/لتر & الأمونيوم & 15 \\
\hline$<\mathrm{LOQ}$ & ميكجر ام/لتز & الكادميوم & 36 & 512.70 & ملجم/لتر & الكالسيوم & 16 \\
\hline$<\mathrm{LOQ}$ & ميكجر ام/لتز & الكروم & 37 & 1577.52 & ملجم/لتر & المغنيسيوم & 17 \\
\hline 0.04 & ملجم/لتر & الألمونيوم & 38 & 7854.74 & ملجم/لتر & العسر الكلي & 18 \\
\hline \multirow[t]{2}{*}{$<\mathrm{LOQ}$} & ميكجر ام/لتز & الرصاص & 39 & 41370.00 & ملجم/لتز & الأملاح الذائبة الكلية & 19 \\
\hline & & & & 139.09 & ملجم/لتر & القلوية الكلية & 20 \\
\hline \multicolumn{8}{|c|}{ المصدر: نتائج التحليل المعملي للعينات، ثم التحليل بالمعمل المركزي بكلية العلوم جامعة المنوفية. } \\
\hline
\end{tabular}

- أظهرت نتيجة التحليل البكتريولوجية أن مستويات العد البكتيري (النلوث البكتيري) على سواحل منطقة الدراسة مقبول ولم يتعدى الحدود السسموح بها، فقد بلغ متوسط العد البكتيري لبكتيريا

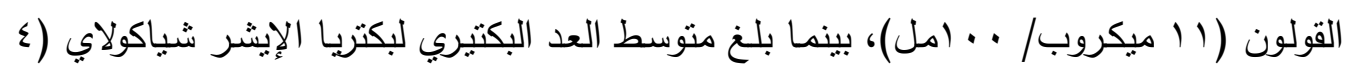
(INT) 
ميكروب/ . . (مل)، أما منوسط العد البكتيري لبكتريا القولون السبحية فقد بلغ (با ميكروب/

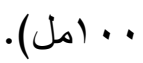

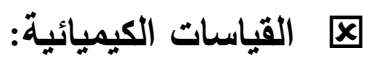
- - تهف التحليلات الكيميائية إلى معرفة نسبة كلاً من (الكلورفيل أ)، والأمونيا والنيتريت والنترات والنيتروجين الكلي والفسفور النشط والكلي والسيلكات الفعالة والكلوريدات والصوديوم والبوتاسيوم والكالسيوم والماغنسيوم والحديد والالمونيوم والفلوريدات والكبريتات الباريوم والاسترانثيوم.

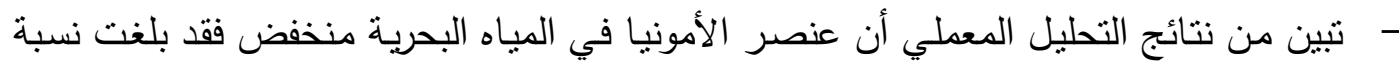

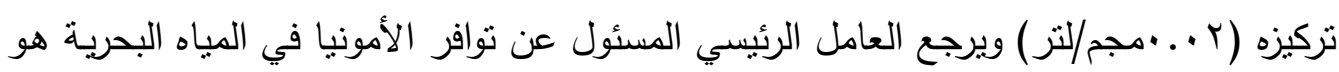

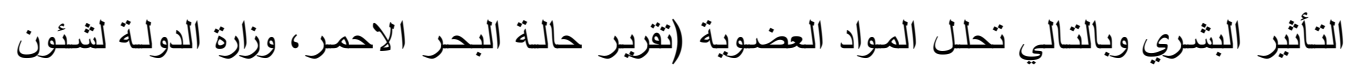

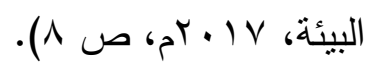

- - العضوي وهو في الغالب مركب غير مستقر بسبب موقعه المنوسط بين عمليات أكسدة الأمونيا وإخترال النترات الذي بلغ (V0 •. . •مجم/لنز ).

- - أوضحت النتائج إنخفاض نسبة النيتروجين غير العضوي (الذائب في المياه البحرية في المنطقة

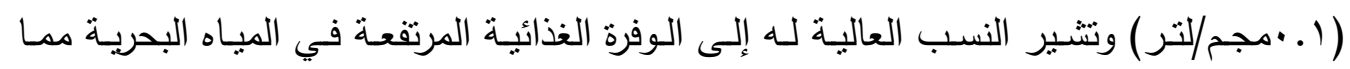

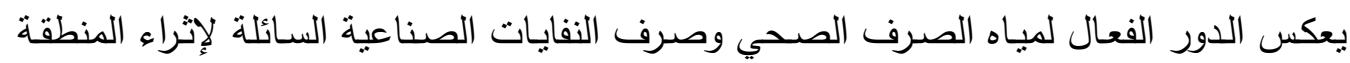
بالأملاح المغذية المختلفة.

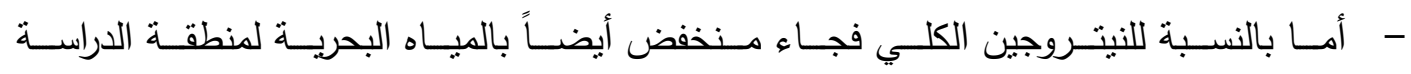

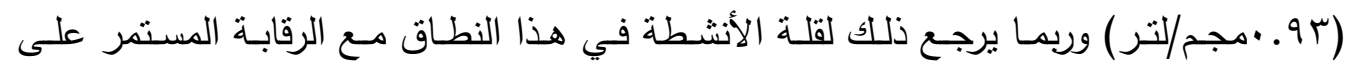

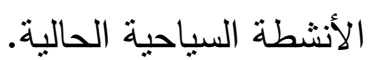
- - برجع الفارق بين النيتروجين غير العضوي والنيتروجين الكلي إلى زيادة النيتروجين في الصور

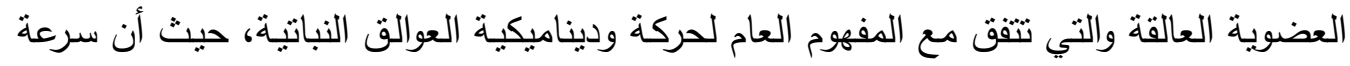

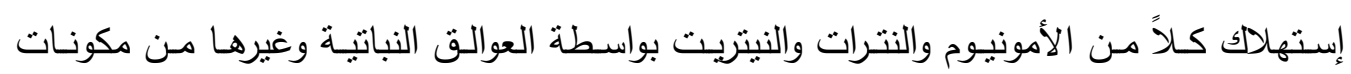
السلسلة الغذائية تكون كبيرة. وفي نفس الوقت فإن معدل إستهلالك صور النيتروجين العضوي

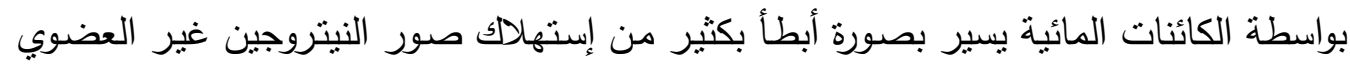

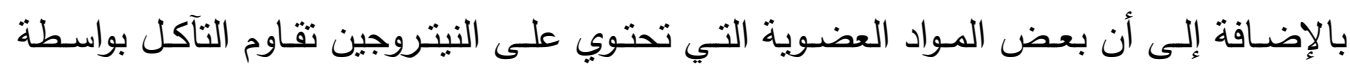

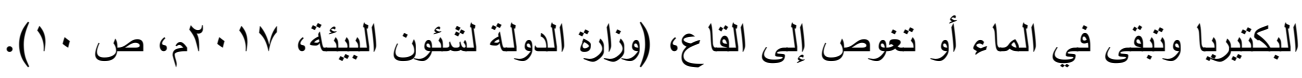

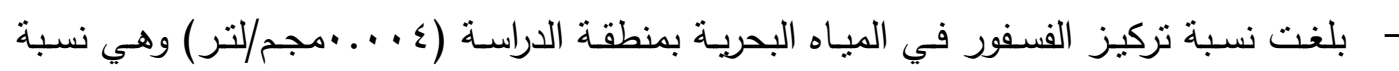

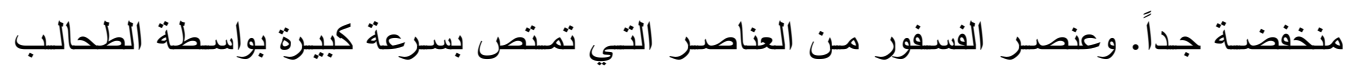

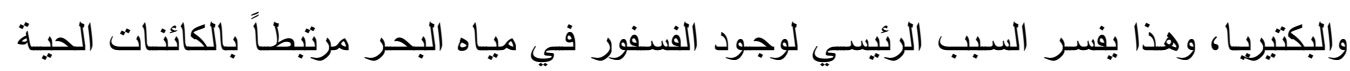

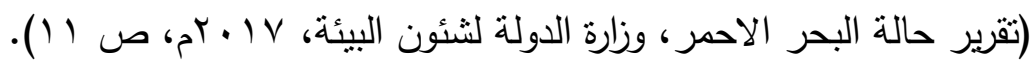


- - تثابهة تقربياً نتائج القياسات المعملية للاراسة الحالية مع نتائج تقرير حالة البيئة للبحر الأحمر

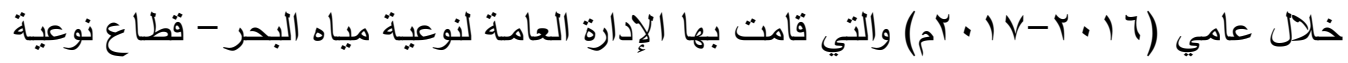
البيئة بوزارة الدولة لشئون البيئة في مصر ، وكلاهما مطابقين للمعايير العالمية.

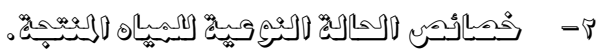

لمعرفة الحالة النوعية للمياه المنتجة من محطة اليسر - الغردقة، قام الباحث بجمـع عينة من مخرج المحطة، بهدف إخضاعها للتحليل المعملي بالمعمل المركزي لكلية العلوم جامعة المنوفية، وذلك لتأكيد صلاحيتها للإستخدام الآدمي من عدمة، وتبين من الخصائص الفيزيائية ونتائج التحليل الكيميائي والبيولوجي والبكتريولوجي. أن طعمها مستساغ، ولونها شبه معدوم ورائحتها معدومة وبها نسبة ضئيلة جداً من العكارة. وجاءت نتائج التحليل الكيميائي والبيولوجي والبكتريولوجي خالية من أية أخطار فيما عدا بعض الزيادات الطفيفة في بعض العناصر الكيميائية عن الحد المسموح بـه عالمياً مثل (الكوريدات والسيليكات والعسر المؤقت). وإرتفاعها في عناصر أخرى مثل (القلويات الكلية والتوصيلية الكهربائية

والبيكربونات) وجميعها ليس لها تأثثر سلبي على صحة الانسان (جدول (1). وجاءت نتائج تحليل العينة منقارب إلى حد كبير مع نتائج تحليل عينات الثركة القابضة لمياه

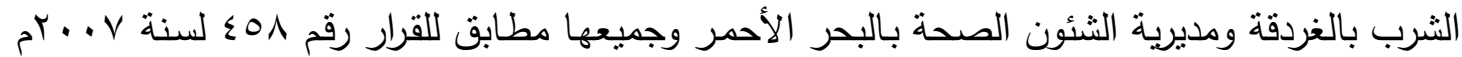
فيزيائياً وكيميائياً وبيولوجياً وبكتريولوجياً.

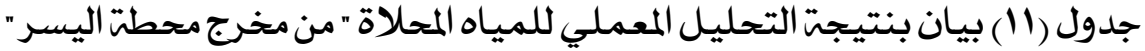

\begin{tabular}{|c|c|c|c|c|c|c|c|}
\hline الغردقة & Units & Analyte & $\mathbf{N}$ & الغردقة & الوحدة & العنصر & $\mathrm{N}$ \\
\hline NR & ملجم/لتز & الحديد & 26 & 7 & وحدة & الأس الهيدروجيني & 1 \\
\hline- & ملجم/لتر & السيليكا النشط & 27 & 820 & ميكروسيمنز/سم & التوصيلة الكهربائية & 2 \\
\hline- & ملجم/لتر & الأمونيا & 28 & 1 & - & العكارة & 3 \\
\hline- & ملجم/لتزر & النيتروجين غير العضوي & 29 & 2 & - & اللون & 4 \\
\hline- & ملجم/لتز & النيتزوجين الكلي & 30 & 0.02 & ملجم/لتر & النيتزيت & 5 \\
\hline- & ملجم/لتز & الفوسفات الفعال & 31 & - & ملجم/لتر & الايرون & 6 \\
\hline- & ملجم/لتز & الفوسفور الكلي & 32 & NR & ملجم/لتر & المنجنيز & 7 \\
\hline- & ملجم/لتز & البرون & 33 & NR & ملجم/لتر & النتر ات & 8 \\
\hline- & ملجم/لتز & السترنشيوم & 34 & 0.1 & ملجم/لتر & الفلوريد & 9 \\
\hline 80 & ملجم/لتر & العسر الكلي & 35 & 248 & ملجم/لتر & الكلوريد & 10 \\
\hline 80 & ملجم/لتز & العسر المؤقت & 36 & 0.5 & ملجم/لتر & الكبريتات & 11 \\
\hline NR & ملجم/لتزر & العسر الدائم & 37 & 0.2 & ملجم/لتر & السيليكا & 12 \\
\hline 40 & ملجم/لتزر & عسر الكالسيوم & 38 & NR & ملجم/لتر & الصوديوم & 13 \\
\hline 40 & ملجم/لتزر & عسر المغنسيوم & 39 & NR & ملجم/لتر & البوتاسيوم & 14 \\
\hline NR & ملجم/لتز & القلوية الكاوية & 40 & 0.08 & ملجم/لتر & الأمونيوم & 15 \\
\hline NR & \multicolumn{2}{|c|}{ العدد الاحتمالي للمجموعة القولونبة . . اسمץ } & 41 & 16 & ملجم/لتر & 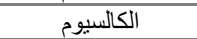 & 16 \\
\hline NR & \multicolumn{2}{|c|}{ العدد الاحتمالي لباسيل القولون النموذجي في · . اسمץ } & 42 & 9.6 & ملجم/لتر & المغنيسيوم & 17 \\
\hline LESS THAN 50 & \multicolumn{2}{|c|}{ العد البكتيري في (مل عند مب م } & 43 & - & ملجم/لتر & العسر الكلي & 18 \\
\hline- & \multicolumn{2}{|c|}{ العد البكتيري في امل عند بrم م } & 44 & 100 & ملجم/لتر & الأملاح الذائبة الكلية & 19 \\
\hline NR & \multicolumn{2}{|c|}{ مجاميع ستربتوفيكالس في · · اسمץ } & 45 & 100 & ملجم/لتر & القلوية الكلية & 20 \\
\hline NR & ملجم//تنز & قلوية الكربونات & 46 & - & ملجم/لتر & الألمونيوم & 21 \\
\hline 100 & ملجم/لتز & قلوية البيكربونات & 47 & - & ميكجر ام/لتر & الرصاص & 22 \\
\hline 120 & ملجم/لتز & الفحص لبيولوجي & 48 & - & ميكجر ام/لتر & الكادميوم & 23 \\
\hline 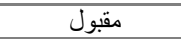 & - & الطعم & 49 & - & ميكجر ام/لتر & 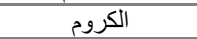 & 24 \\
\hline معدوم & - & الر ائحة و اللون & 50 & - & ميكجر ام/لتر & 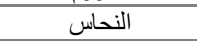 & 25 \\
\hline \multicolumn{8}{|c|}{ المصدر: نتائج التحليل المعملي للعينات، تم التحليل بالمعمل المركزي بكلية العلوم جامعة المنوفية. } \\
\hline
\end{tabular}

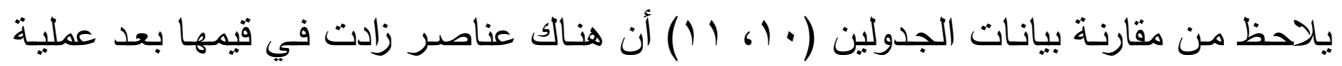
التحلية للمياه البحرية بمنطقة الدراسـة مع العلم أنها كانت زائدة عن الحد المسموح بـه قبل التحلية، مثل فئل (الأمونيا، والنيتريث، والنترات، والسيلكا). 
تبين من نتائج التحليل المعملي لعينة ضمن مجموعة عينات جمعها الباحث من صنابير منازل

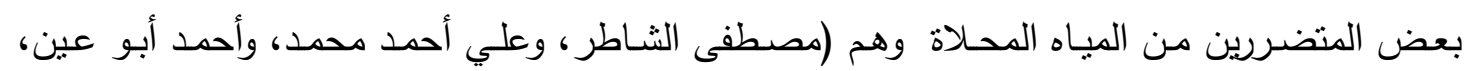

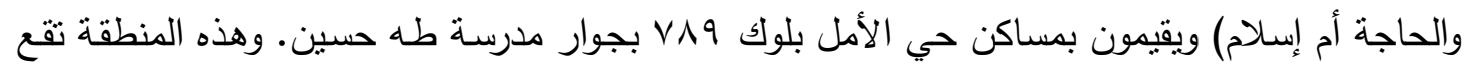

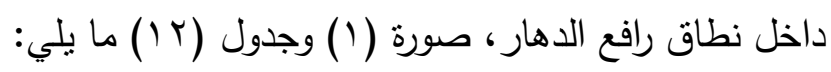

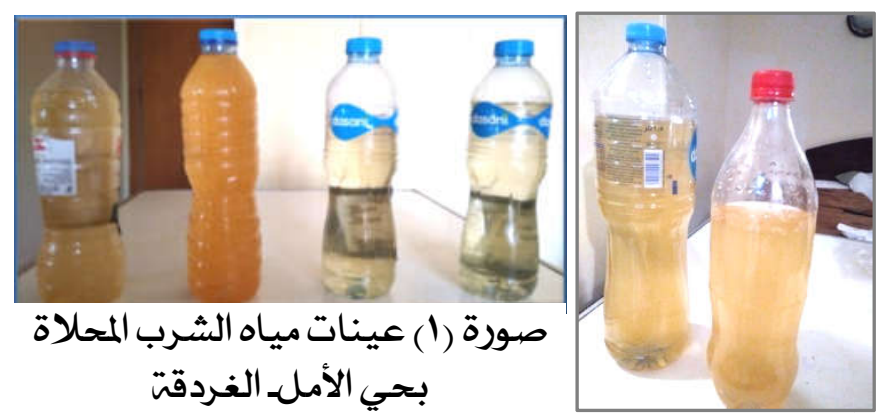

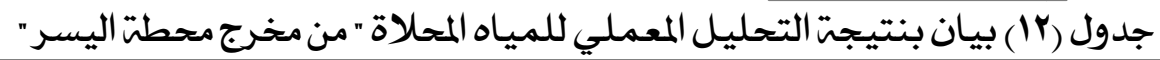

\begin{tabular}{|c|c|c|c|c|c|c|c|}
\hline الغردقة & الوحدة & العنصر & م & الغردقة & الوحدة & العنصر & 5 \\
\hline 12.64 & ملجم/لتر & الفوسفات & 16 & 7.85 & 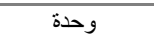 & الأس الهيدروجيني & 1 \\
\hline 4.02 & ملجم/لتز & تركيز الاكسجين الذائب & 17 & 614 & ميكروسيمنز/سم & التوصيلة الكهربائية & 2 \\
\hline 0.04 & ملجم/لتز & الكلور الحر & 18 & 85 & - & العكارة - ل العارة & 3 \\
\hline 70 & ملجم/لتز & العسر الكلي & 19 & clored & - & 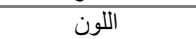 & 4 \\
\hline 50 & ملجم/لتز & عسر الكالسيوم & 20 & 360 & ملجم/لتر & الأملاح الذائبة الكلية & 5 \\
\hline 20 & ملجم/لتز & عسر المغنسيوم & 21 & 0.1 & $\mathrm{mg} / \mathrm{l}$ & المنجنيز & 6 \\
\hline 0.5 & ملجم/لتز & الحديد & 22 & 0 & $\mathrm{mg} / \mathrm{l}$ & $\mathrm{CO} 3$ & 7 \\
\hline 0.35 & ملجم/لتر & الزنك & 23 & 54.9 & $\mathrm{mg} / \mathrm{l}$ & $\mathrm{HCO} 3$ & 8 \\
\hline غير مقبول & - & الطعم & 24 & 0.11 & ملجم/لتر & 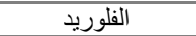 & 9 \\
\hline 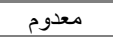 & - & الر ائحة & 25 & 147 & ملجم/تنر & الكلوريد & 10 \\
\hline موجود ل مود & - & بروتوزوه & 26 & 33 & ملجم/لتر & الكبريتات & 11 \\
\hline 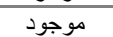 & - & ألجي & 16 & 16 & ملجم/لتز & الكالسيوم & 12 \\
\hline غير موجود & - & 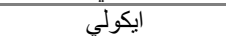 & 17 & 4.86 & ملجم/لتز & المغنبسيوم & 13 \\
\hline \multirow[b]{2}{*}{ موجود } & \multirow[b]{2}{*}{ - } & \multirow{2}{*}{ أنو المسبية للامر من البكتريا } & 18 & 9 & ملجم/لتز & النيتريت & 14 \\
\hline & & & 19 & 0 & ملجم/لتر & ال النترات & 15 \\
\hline & & مهن & & 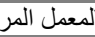 & م الس & التحليل المع & المص - المص \\
\hline
\end{tabular}

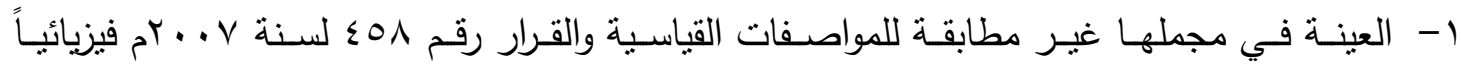
وكيميائياً وبيولوجياً وبكتريولوجياً.

r- التحليل الكيميائي لعينة المياه يدل على العديد من المشاكل على سبيل المثال:

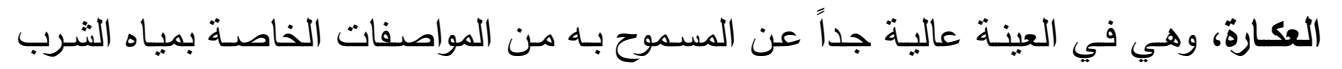
والمنصوص عليه في مواصفات مياه الثرب من قبل وزارة الصحة العالمية. اللون، وجودت المياه تثمثل في أنها عديمة اللون وهو ما لا يتوافر في العينة موضوع النقاش. الأملاح الكلية، وهي هنا زيادة عن ما هو مسموح بـه من العديد من وزارات الصحة العالمية

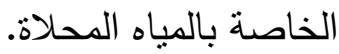
الفوسفات، وهو زيادة عن المسموح به وإرتفاعه يدل على أن العينـة غير مقبوله وغير صـالحة للثرب، وتثير دراسة أمريكية نشرتها جامعة هارفارد إلى أن إرتفاع نسبة الفوسفات في الجسم تؤدي حتماً إلى شيخوخة المبكرة أي ظهور علامات الثيخوخة على الثخص في سن صغير إنها

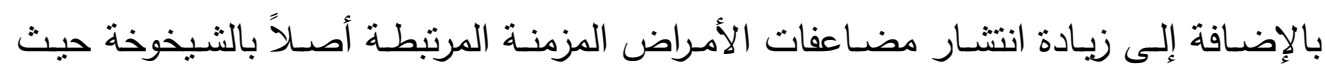
تزداد وتيرة أمراض الكلى المزمنة وتصلب الثرايين بلإضـافة إلى ضمور العضلات وتأثنيرات 
النيتريت وهو من المركبات الني لها مفعول سام فهي تتفاعل مـع الأكسجين في أنزيمات

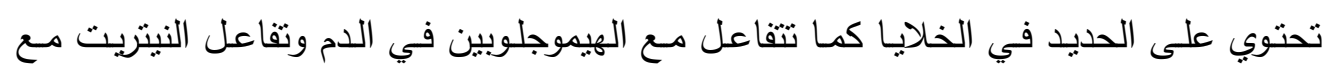

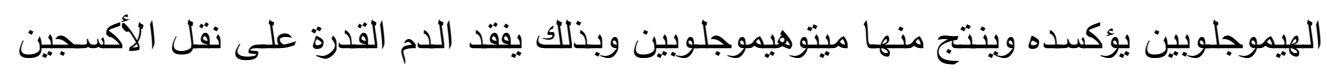

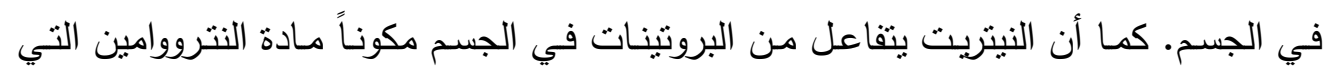
تتسبب في نثأة مرض السرطان.

الحديد والمنجنيز وهما من العناصر الغير مرغوب في وجودها بمياه الثرب والاستعمالات

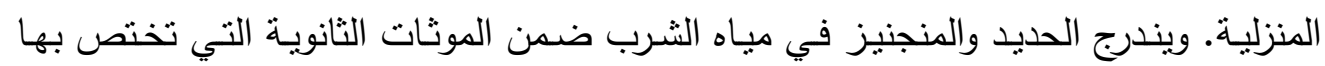

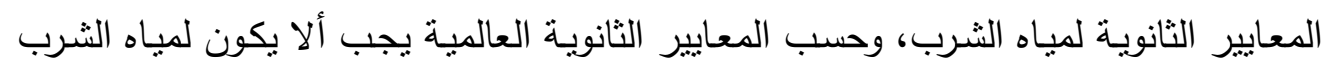

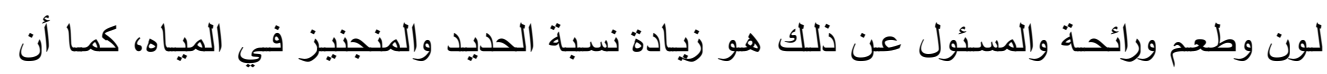

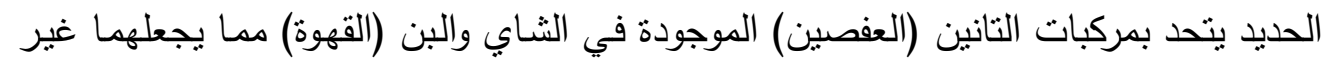

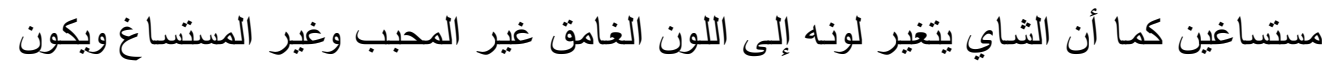

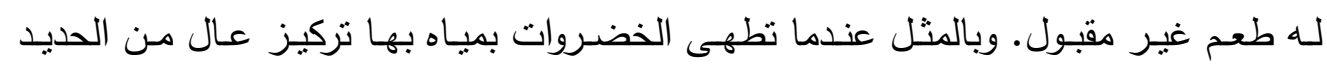

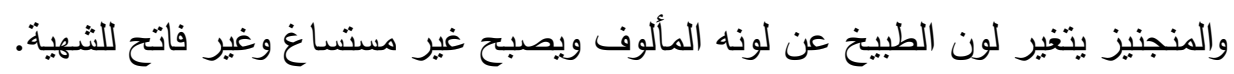

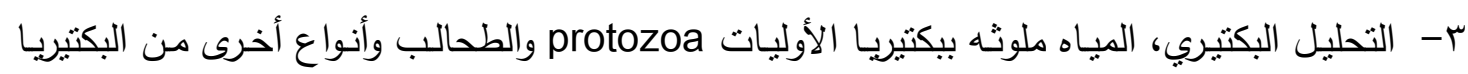

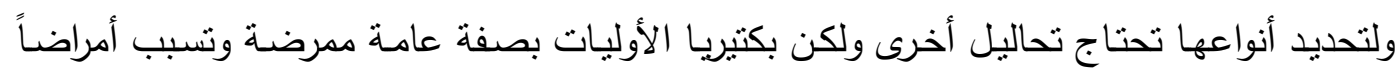

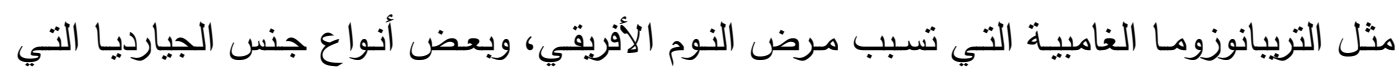

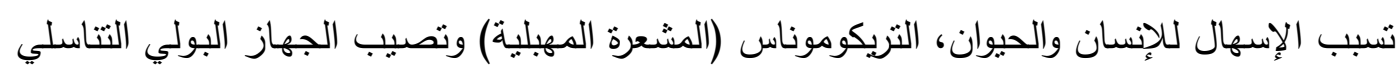

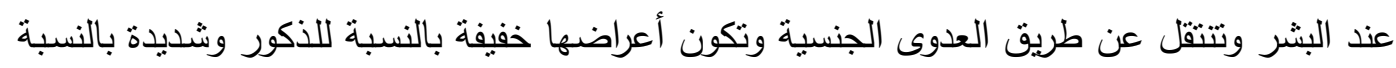

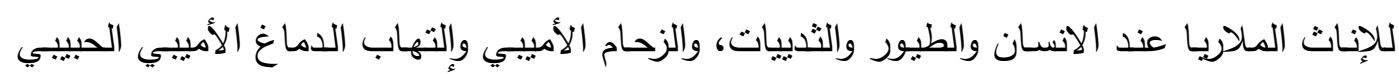
وإلتهاب القرنية. ع - - تثابهة نتائج تحليل العينة مع نتائج إستمارات الإستبيان (1/ إستمارة أجراها الباحث على عينة

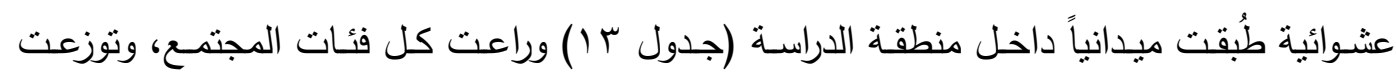

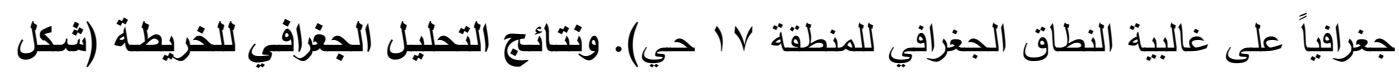

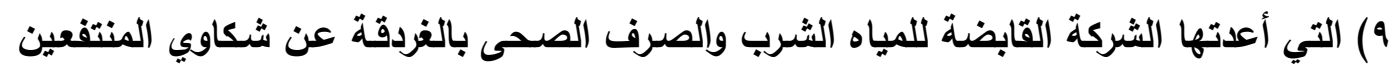

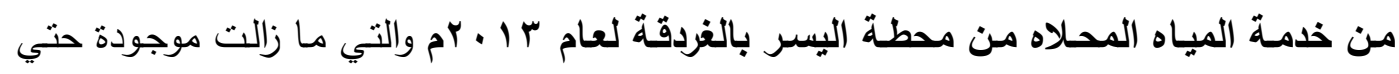
اليوم. وتبين منهما جميعاً عدة حقائق هي:

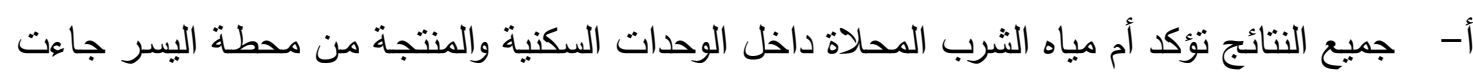
غير مطابقة للمواصفات القياسية العالمية وقرار وزارة الصحة المصرية. ب- أوضحت نتائج الإستبيان عدة حقائق كما يلي: لماصني

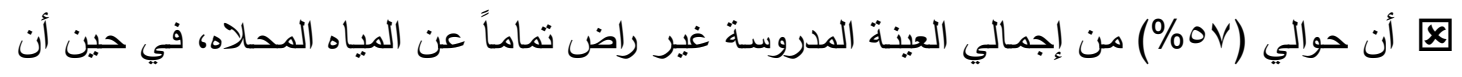

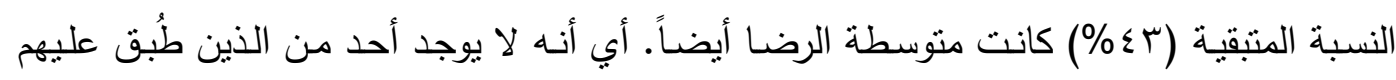
الإستنبيان راض عن الخدمة وغالبيتهم يطالب بتوفير مياه النيل. ( INYV) 
区 أن حوالي (^. (ا7\%) من إجمـالي العينـة المدروسـة هـ فقط الذين يستخدمون المياه المحـلاه في

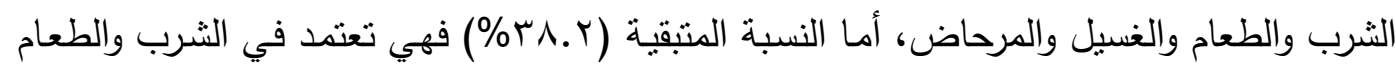

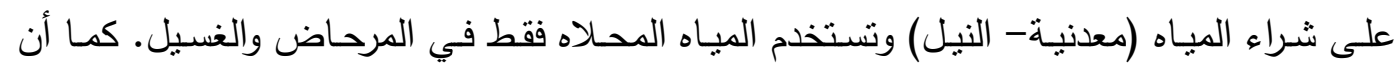
حوالي (. (1\%) من الذين يستخدمون المياه المحلاه، والذي لم يتيسر لهم الحال على شراء المياه المعدنية نتيجة لظروفهم الإجتماعية قاموا بتركيب فلاتر لتتقية المياه بالإضافة إلى غليها.

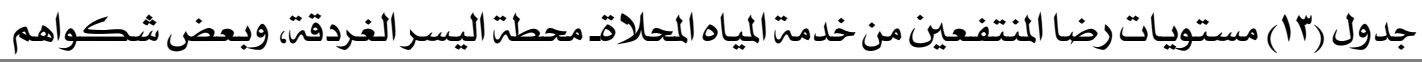

\begin{tabular}{|c|c|c|c|c|c|c|c|c|c|c|c|c|c|c|c|}
\hline \multicolumn{10}{|c|}{ شكاوب المنتفعين بالخدمة \% } & \multicolumn{3}{|c|}{ درجة الرضا \% } & \multicolumn{3}{|c|}{ مصدر مياه الثرب \% } \\
\hline متتوع & صدأ & شوائب & رواسب & مرتحع ملح & اصفر & عكرة & لا نصلح & الكلور & ذائحة & منخفض & متوسط & فرد & ومفلتره & المحطة & شراء \\
\hline q.६ & 7.1 & १.६ & $1 . .7$ & 9.1 & 9.1 & $1 . .7$ & r.^ & $1 \leq .0$ & $10 . r$ & or & $\varepsilon r$ & . & ri.o & $r . . r$ & rA.r \\
\hline
\end{tabular}

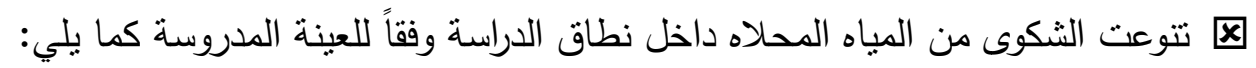
مياه ذات رائحة كريهة (صرف صحي) وكانت نسبتهم (דr\%) من إجمالي الثكاوي. • إرتفاع نسبة الكلور وكانت نسبتهم (9.0\%) من إجمالي شكاوي المنتفعين بالخدمة. • مياه عكرة (أصفر ، أسود) ونسبتهم (7 . ( \% ) من إجمالي شكاوي المنتفعين بالخدمة.

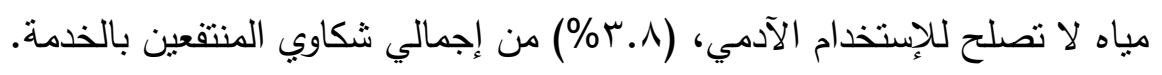
بها رواسب وشوائب، ( • r\%) من إجمالي شكاوي المنتفعين بالخدمة.

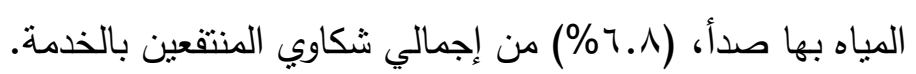

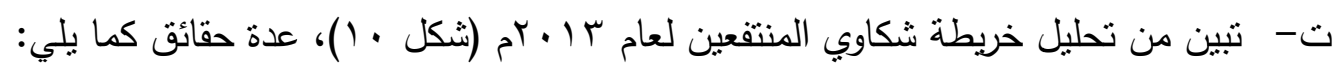

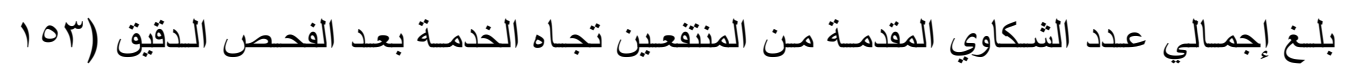
شكوى)، تتوعت بين ( شكاوي إختلاط بمياه الصرف الصحي، والمياه الجوفية، ووجود عكارة بالمياه). وتوزعت الشكاوي على منطقة الملاحة والأمسل ومسـاكن الإيواء ومنطقة ناصـر والمشروعات ومنطقة الميناء وقرية الصادين ومنطقة الجمعية الاستهلاكية والعمارات التي نوجد خلف الهاي جيت ومساكن أبو ومن ونهاء عشرة وشـارع السـلام ومنطقة حفر البـاطن. وتباينت كثافة الثـاوي بين هذه المنـاطق، فكانت منطقة وهنة الملاحة والأمل أكثرهم شكوى، تناها مسـاكن أبو عشرة ومسـاكن الإيواء ومنطقة ناصر والمشروعات. وجاءت جميع نتائج تحليل العينات من خلال الهيئة غير مطابقة للمواصفات ونتفق مع ما جاء بشكاوي المواطنين.

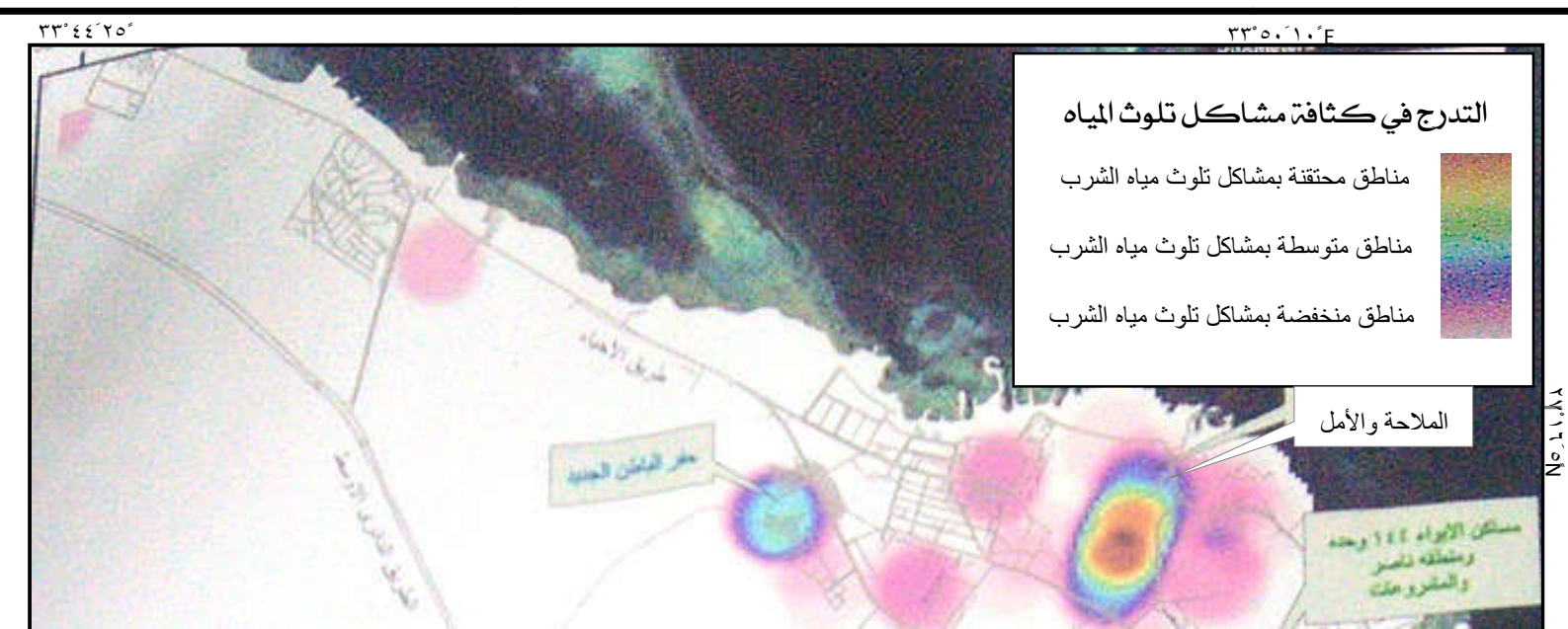




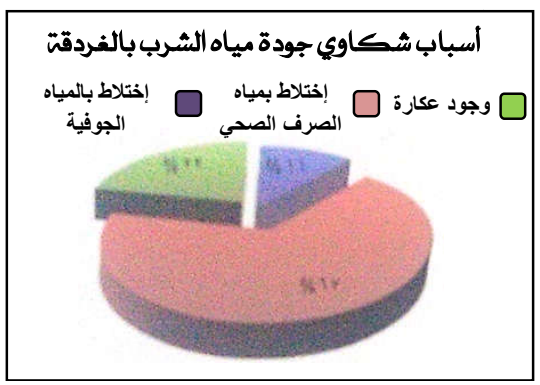

\begin{tabular}{|c|c|c|c|c|}
\hline 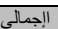 & أسباب فثل العينة & نتيجة تحليل العينات & عدد شاكوي الجودة & اسم المنطقة \\
\hline \multirow[t]{2}{*}{$r \varepsilon$} & إختّلاط بمياه الصرف الصحي & غير مطابق & $r$ & \multirow[t]{2}{*}{ الملاحة والامل } \\
\hline & ------- & مطابق & $\mathrm{T}$ & \\
\hline \multirow[t]{2}{*}{$\overline{1 \Lambda}$} & إختلاط بمياه الصرف الصحي & غير مطابق & $\overline{\text { IV }}$ & \multirow{4}{*}{ ومنطاكن الإيو اء ــ أمشرو وحدةت } \\
\hline & 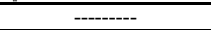 & مطابق & 1 & \\
\hline \multirow[t]{2}{*}{$r}$. & وجود عكارة & \multirow{2}{*}{ غير مطابق } & 1. & \\
\hline & إختلاط بالمياه الجوفية & & 1. & \\
\hline \multirow[t]{3}{*}{10} & وجود عكارة: & \multirow[t]{2}{*}{ غير مطابق } & \multirow[t]{2}{*}{$\overline{1 T}$} & \multirow{8}{*}{ عمار خلفة الجمعية الاستهلاكية بالسقالة } \\
\hline & إختّلاط بمياه الصرف الصحي & & & \\
\hline & 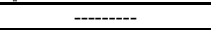 & مطابق & $r$ & \\
\hline \multirow[t]{2}{*}{$\mathrm{A}$} & إختّلاط بالمياه الجوفية & \multirow[t]{2}{*}{ غير مطابق } & $r$ & \\
\hline & إختلاط بمباه الصرف الصحي & & - & \\
\hline \multirow[t]{3}{*}{11} & إختّلاط بمباه الصرف الصحي & غير مطابق & o & \\
\hline & ------ & مطابق & 1 & \\
\hline & إختلاط بمياه الصرف الصحي & غير مطابق & o & \\
\hline$\Lambda$ & إختلاط بمياه الصرف الصحي & غير مطابق & $\lambda$ & \multirow{3}{*}{ شارع السلام } \\
\hline & وجود عكارة & & & \\
\hline & إرتفاع نسبة الاملاح & & & \\
\hline \multirow[t]{3}{*}{ rq } & إختلاط بمياه الصرف الصحي & غير مطابق & $r q$ & \multirow{3}{*}{ مناطق أخرى متفرقة } \\
\hline & إرتفاع نوبية عالارلاح & & & \\
\hline & $-\cdots$ & مطابق & $r$ & \\
\hline 10r & \multicolumn{4}{|c|}{ إجمالي عدد شكاوب جودة مياه الشُرب الناتجة عن التحلية بمدينة الغردقيًا } \\
\hline
\end{tabular}

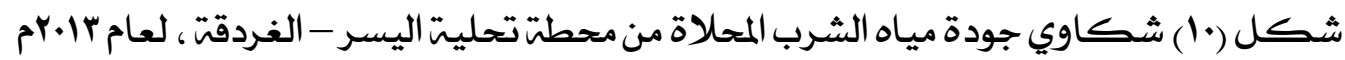

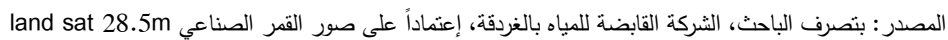

\section{F.}

وعلى الرغم من أن تحلية المياه لها الكثير من الآثار البيئية الإيجابية حيث أن إنتاج المياه

المحـلاة خاصـة في المنـاطق التي تعاني من شـح في مواردهـا المائية التقليديـة سَهل عمليـات التنميـة

الإقتصـادية والإجتماعيـة إلا أن لمحطات التحليـة آثارهـا السلبية على البيئة البحريـة، والصحية بمنطقة

$$
\begin{aligned}
& \text { الدراسة. ويمكن إيجازها في ما يلي :- إلي إلها }
\end{aligned}
$$

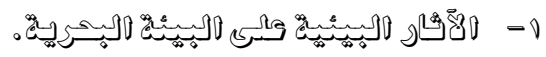


تظهر الآثار السلبية لمحطات التحلية منذ بداية عملية تشييد المحطة على الثـاطئ وبناء

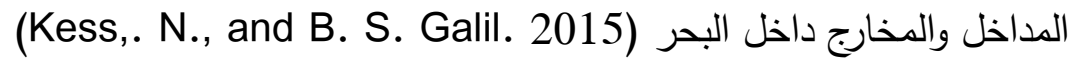
حيث يتم تغيير صفة إستعمال الإراضي في نلك المنطقة، وتقوم الآلات والمعدات بدمك الرمال الرال

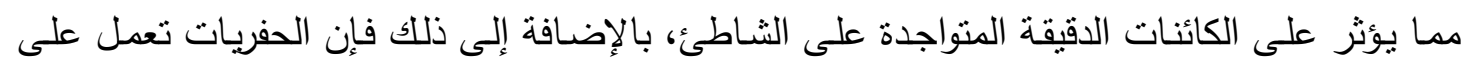

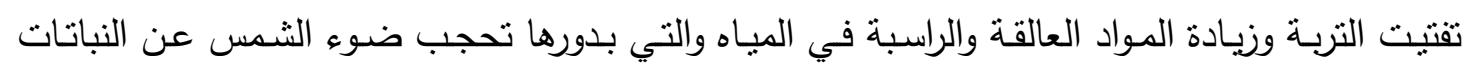

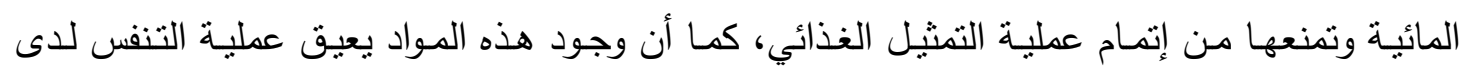

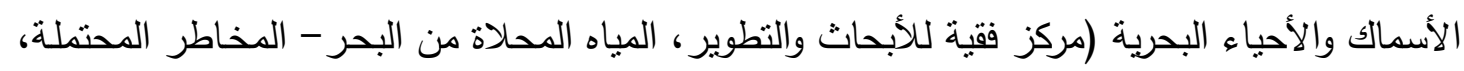

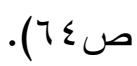

وتقترن الآثار البيئة لدحطة التحلية بمنطقة الدراسـة بمكونين هها: مأخذ ميـاه البحر (مياه

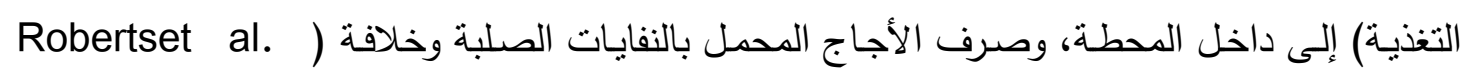

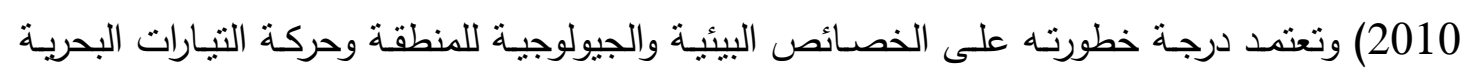

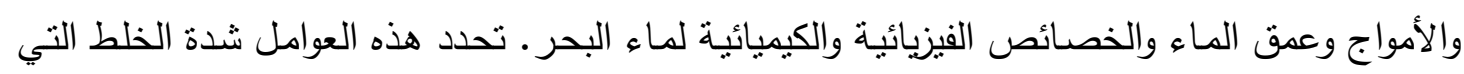

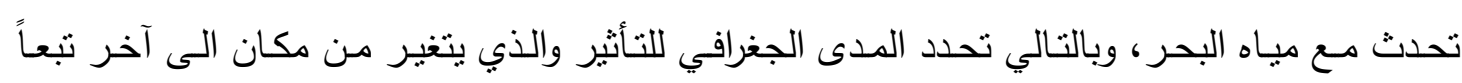

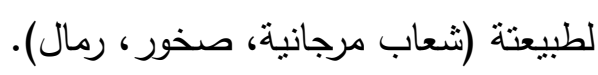

أ- مأخذ مياه البحر (مياة التغذية):

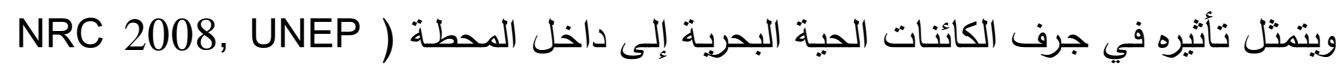

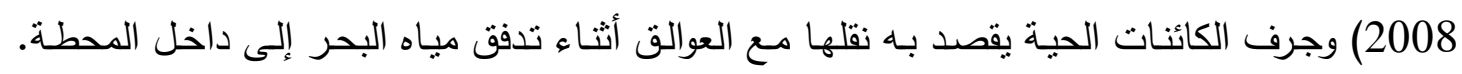

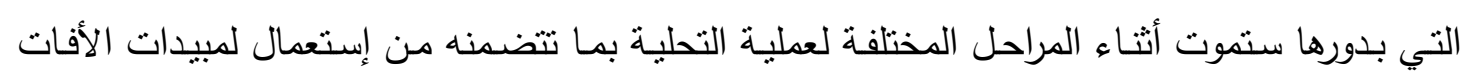
الإحيائية بالإضافة إلى مياه التبريد من محطات الطاقة (Mayhew et al. 2000). ب- برف الأجاج (طرد المحطة): يقصد بالأجاج الصرف شديد الملوحة والحرارة للمياه من محطة مستتدة إلى أغشية. وتتراوح

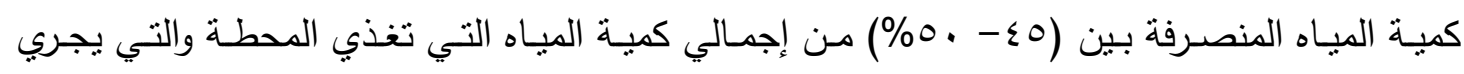

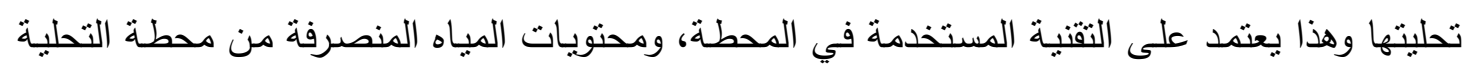

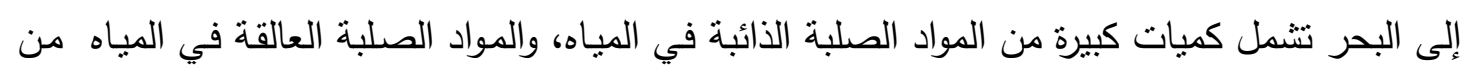

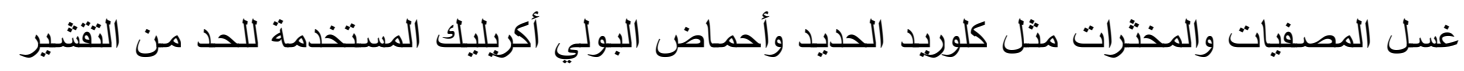

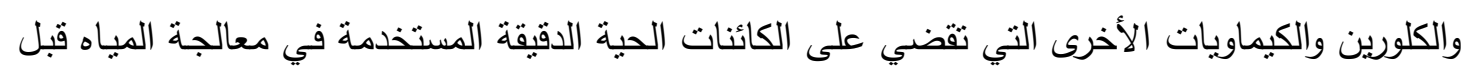

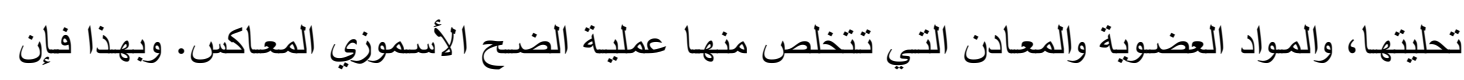

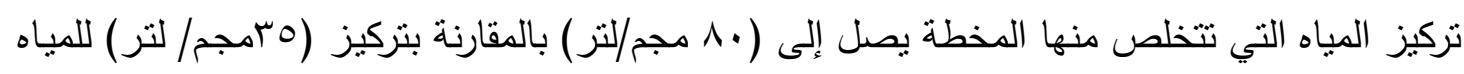

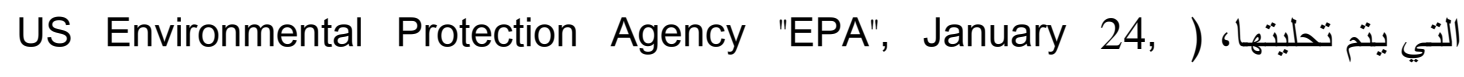

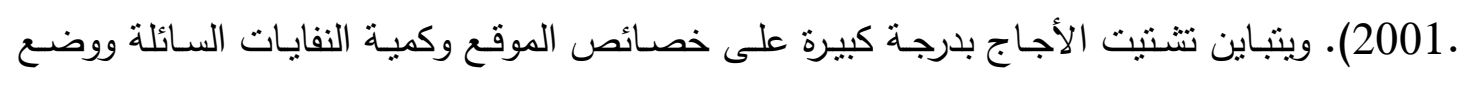

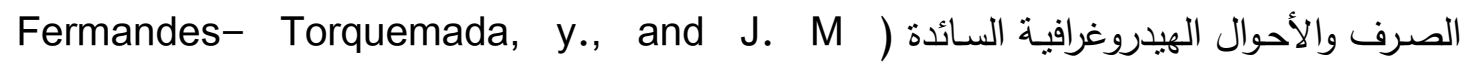
Gonzalez- correa, A Loya, L. M. Ferrero, M . Diaz- Valdes, and J. L. $(1 \wedge r \cdot)$ 
2009.

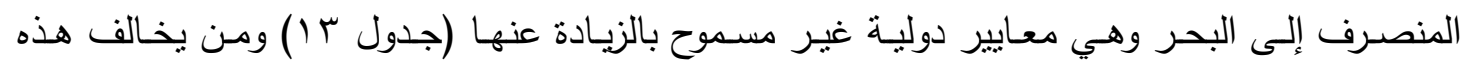
المعايير يعد مخالف للقوانين البيئية والصحية ويعتبر المنصرف غير دولئ مطابق للمواصفات العالميـة.

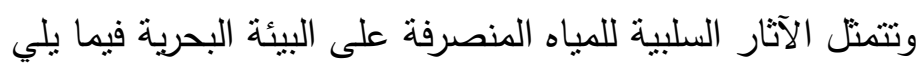

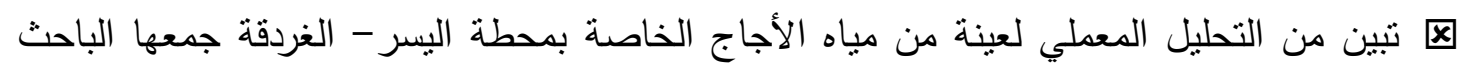

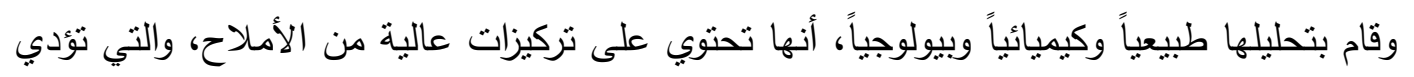

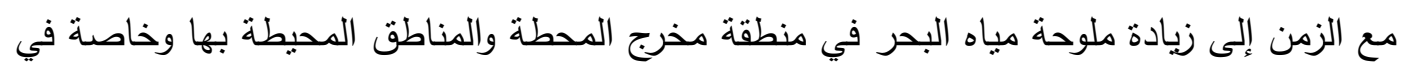

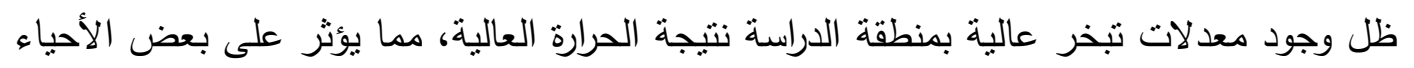
المائية التي لا تحتمل الملوحة الزائدة.

囚 ارتفاع لبعض المعادن النقيلة (حديد، نحاس، الألمونيوم) الناتجة عن التآكل في الاجزاء المعدنية

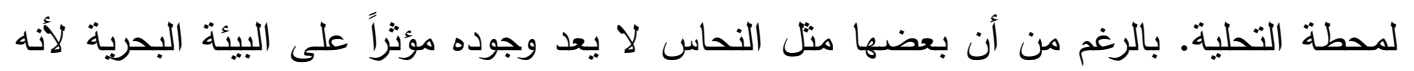

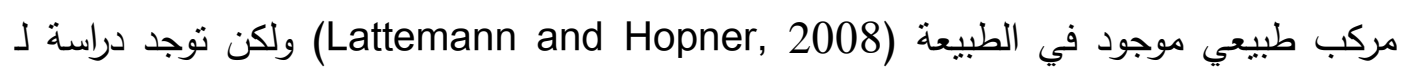
تذكر أن النحاس له أثر على أنواع بحرية معينة (chesher, 1971, Brand et al, 1986)

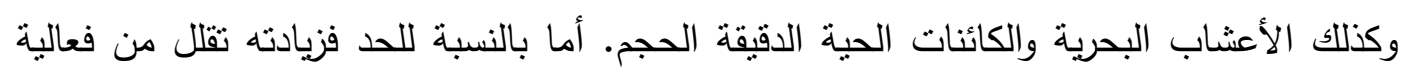

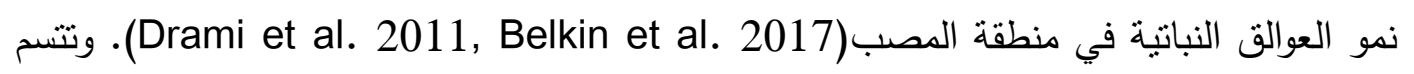

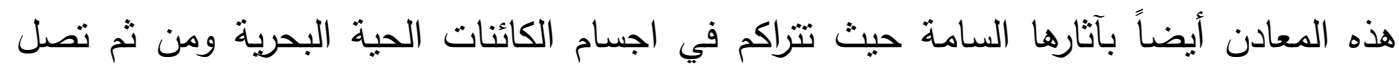
لـالإنسان من خلا السلسلة الغذائية. 囚 ارتفاع بعض المعادن النقيلة الأخرى مثل (منجنيز ، زنك، فوسفات، نيتريت) وجميعها له أثار سلبية على الكائنات الحية البحرية. 囚 تتوعت العناصر الكيميائية العضوية المنصرفة مع الأجاج وزادت نسبتها، مما يؤدي ذلك إلى الكية

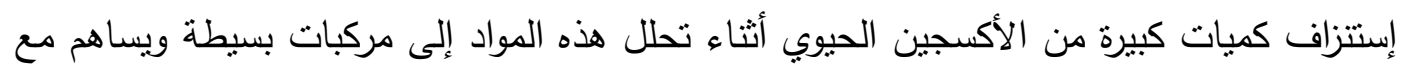

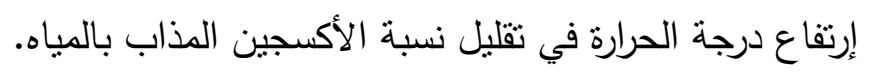

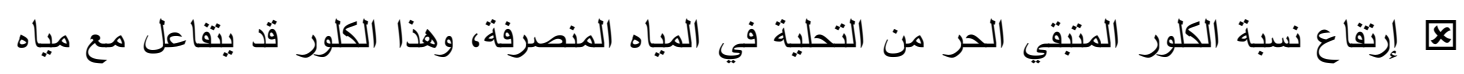

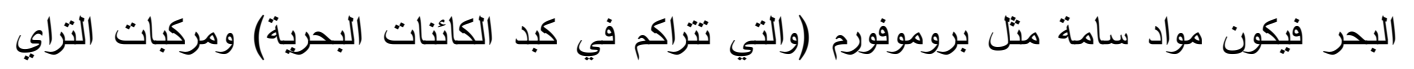

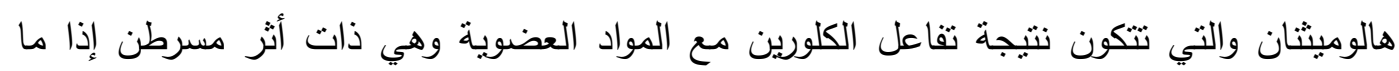
تواجدت بتراكيز معينة (Taylor, 2006). 囚 تستعمل الأحماض الكيميائية مثل (ميتا بيكبريتيت الصوديوم Na2S2O5) عادة لتتظيف الأغثية

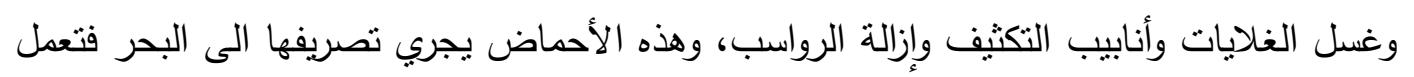

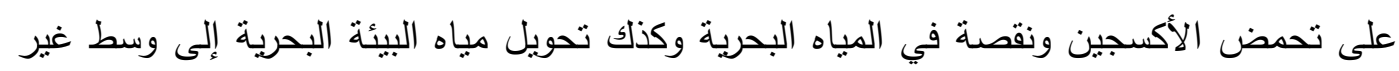
مناسب لنمو بعض الكائنات البحرية (Portillo et al, 2013). جدول (ع) المعايير والمواصفات لبعض البحنية (لعناصر المنصرفت من عمليات التحليت في المياه البحريتة

\begin{tabular}{|c|c|c|}
\hline نتايج تحليل عينة منطقة الدراسة "." & الحد الأقصى المسعوح به (مجم/تنز) & البيان - البيان \\
\hline- & لا تزيد عن · ل د درجات فوق المعدل السائد & درجة الحرارة \\
\hline
\end{tabular}




\begin{tabular}{|c|c|c|}
\hline$\wedge .1$ & $9-9$ & PH الرقم الهيدروجيني \\
\hline 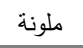 & خالية من الملوثات & ل لون \\
\hline- & 7. & الأكسجين الحيوي الممتص \\
\hline- & $1 \ldots$ & الأكسجين المستهلك كيماوياً \\
\hline \multirow[t]{2}{*}{-} & $r \ldots$ & مجموع المواد الصلبة الذائبة \\
\hline & 7. & المواد العالقة \\
\hline 11. & NTU 50 & 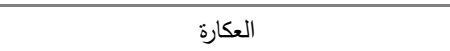 \\
\hline$r_{\Lambda}$ & 1 & الكبريتات \\
\hline iv & 10 & الزيوت والثحوم \\
\hline- &. .0 & الهيدروكربونات من أصل بترولي \\
\hline $1 \leqslant . \leqslant 0$ & $\circ$ & الفوسفات \\
\hline 11 & $\varepsilon$ & 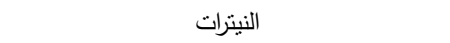 \\
\hline- & 1 & الفينولات \\
\hline 1.1 & 1 & الفلوريدات \\
\hline- & r & 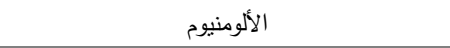 \\
\hline v & $r$ & الأمونيا (النيتروجين) \\
\hline- & $\ldots \ldots$ & الئبق \\
\hline- &. .0 & 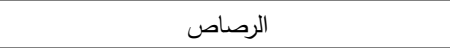 \\
\hline- & $\ldots 0$ & 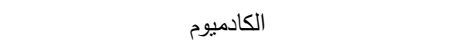 \\
\hline- & $\ldots \circ$ & الزرنيخ \\
\hline- & 1 & 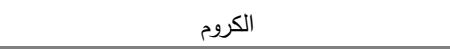 \\
\hline- & 1.0 & 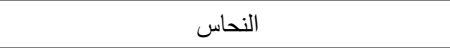 \\
\hline- &. .1 & 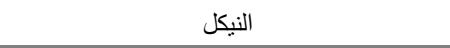 \\
\hline r.l & 1.0 & 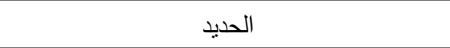 \\
\hline $1 . v$ & 1 & المنجنيز \\
\hline T.V & 0 & 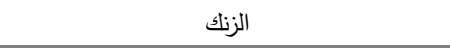 \\
\hline- &. .1 & الفضة \\
\hline- & r & 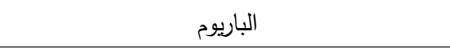 \\
\hline- & r & 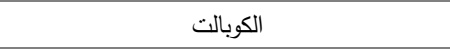 \\
\hline- &.$r$ & المبدات بأنواعها \\
\hline- &. .1 & السيانيد \\
\hline- & $0 \ldots$ & العدد الاحتمالي للمجموعة القولونية في .. اسمץ \\
\hline \multicolumn{3}{|c|}{ 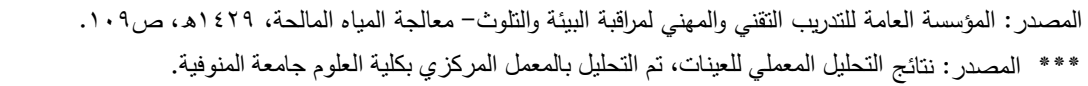 } \\
\hline
\end{tabular}

$$
\text { - }
$$

مما لا شك فيه أن طبيعة المياه المحلاة وخصائصها لا تضاهي تماماً طبيعة وخصائص المياه العذبة الطبيعية لأن المياه المحلاة تتنج بعمليات تتصف بالسرعة والقسر تحت ضغوط عالية بإستخدام

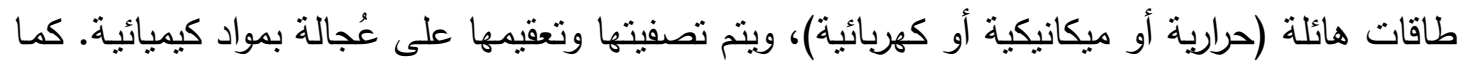
أنها خلال ذللك تفقد ما فيها من أكسجين وأملاح معدنية نافعة وتجري في أنابيب وتمر بأوعية معرضـة

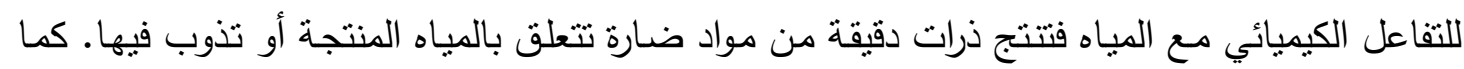
المياه المحلاة تجرف في طريقها للمستهلك كميات ضئيلة من المواد الضارة المخلفة عن عملية التحلية والتتقية والتعقيم إلى جانب ذلك فإن هذه المياه خالية تماماً من الأكسجين، أب أنها مياه ميتة تحتاج إلى منى سبل لإنعاثها (مركز فقيه للأبحاث والنطوير، المياه المحلاة من البحر - المخاطر المحتملة، ص ( ). $(1, k r)$ 
والمخاطر الصحية للمياه المحلاة على الإنسان، تتتج عموماً عن ما تحتويه مياه الثرب من عناصر عضوية أو غير عضوية تعرض صحة الإنسان للخطر سواء بطريق مباشر أو غير مباثر من

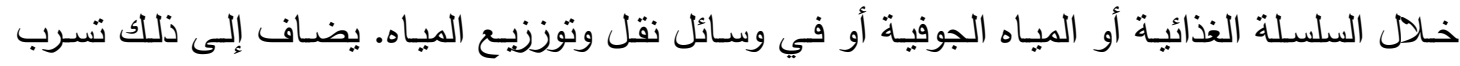
مركبات جديدة من المياه البحرية الخام إلى مياه الثرب ومنها البكتيريا التي تعيش في المياه المالحة والتي قد لا تتخلص منها عملية التحلية. كذلك المواد العضوية الخاصـة بالمياه البحريـة والمياه التقيلة التي تدخل مع مياه البحر الخام والتي قد تخرج مع المنتج النهائي للمياه المحلاه. وبنـاءً على ما سبق من دراسـة مستقيضـة للمياه المحلاة بمنطقة الدراسـة. يوجد إحتمالية وقوع أضرار على الإنسـان من المياه المحـلاة ومحطات التحلية معظمها يمكن تلافيها بإتخاذ الإحتياطـات اللازمة وإتباع المعايير والمواصفات العالمية للمياه المحلاة المنتجة التي تزودها المحطات للمستهلكين. هذا سواء كانت الأضرار بصورة مباشرة نتيجة شرب المياه المحلاة أو بصورة غير مباشرة لما ينجم عن محطات التحلية من مخاطر على البيئة قد تلحق الأذى بصحة السكان بالمنطقة.

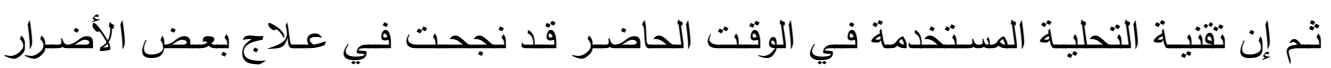
المتوقعة من شرب المياه المحلاة، وذلك بإضـافة الأملاح المعدنية التي تتزعها عملية التحلية من المياه والقيام بتهوية المياه لإنعاشها بالأكسجين. هذا وإن أغفلت مصالح المياه التلوث بالبكتريا الذي قد يعتري لبردي

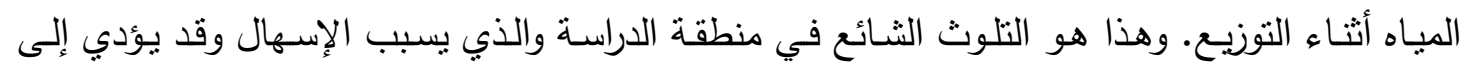

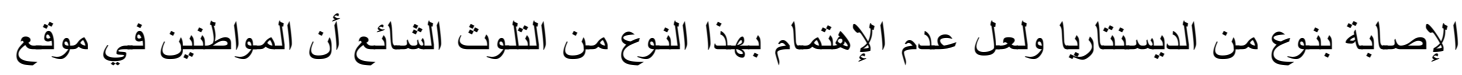
التوزيع يكتسبون مناعـة ضد نوع البكتريا أو الفلور المتواجد في مياه شربهم بعد أن تجد طريقها إلى إلى أمعائهم ثم أن المصالح المسئولة عن توزيع المياه تكثفي بوضع معايير لجودة المياه في مصدرها وتغفل بهل عن تحليل المياه في مراكز إستخدامها. أمـا الأضـرار الصـحية التي مـا زالت ثقتية التحليـة بمنطقة الدراسـة عـاجزة عن تفاديها والتي أكدتها نتائج الإجابة عن سؤال الإستبيان بالمنطقة (هل أصيب أحد من أفراد العائلة فعلياً بسبب المياه المحلاة). فتتمل التخلص من فلورا البحر الملحية القادرة على التعايش في درجات حرارة عالية، وفلورا

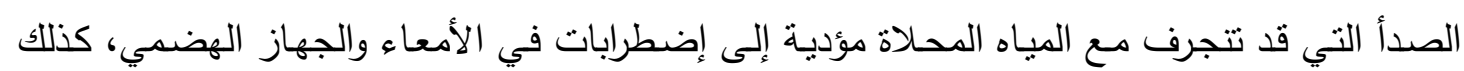
تلوث المياه المحلاة بكميات ضئيلة من المعادن الثقيلة المسئولة عن التسبب في الفثل الكلوي، وكميات محسوسـة من المياه التقبلة التي يصعب تحديد ضررها على الإنسان، والمواد السامة التي تسـامي في درجات الحرارة العالية والمسئولة عن أضـرار الجهاز التتاسلي والأجنـة. هذا بالإضـافة للتغير في بنية المياه التي تؤدي إلى الإصابة بأنواع مختلفة من الحساسية وإنتاج الثقوق الحرة المسئولة عن تكوين نواة الأورام الخبيثة (نتائج تطبيق الاستبيان بمنطقة الدراسـة، نتائج وحدة الخدمات الوقائية بمديريـة الصحة

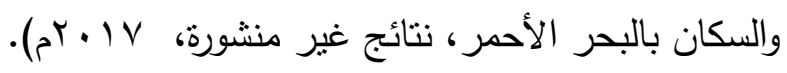

مثل هذه الأضرار التي لا تهنم بها تقنيات التحلية الحديثة مثلما تهتم بخفض تكاليف المحطات وزيادة كفاءة أدائها من الممكن إستخدام التقنيات الحديثة لفصل المياه التقيلة والمعادن التقيلة عن مياه الثـرب المحـلاة، وابتكار تقنيـات جديدة للحد من أضـرارها أو تلافيها نهائيـاً وحتى يمكن إيتكار تلك ألك 


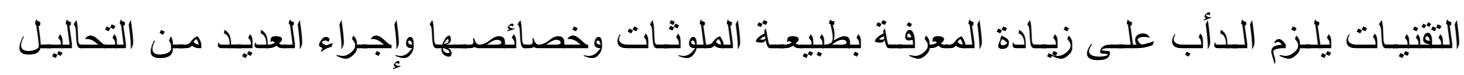
والتجارب إلا أن كل هذا له ثمنه.

\section{.}

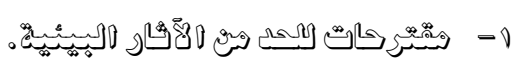

囚 إقامة محطات تحلية عائمة على مسافات بعيدة داخل البحر تقلل الآثار البيئية للتنبيد والتنتغيل والضوضـاء وتوفر الأراضي ذات الأهية الإقتصـادية وتمنع إعاقة حركة الملاحة، كذلك إبعادها عن مصادر التلوث البشري. 囚 صرف الأجاج في بحيرات سطحية أو خزانات لتبريدها وتهويتها ومعالجتها طبقاً للمواصفات ثم

$$
\text { صرفها بعد ذلك في المياه البحرية. }
$$

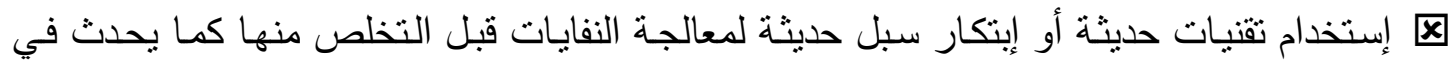
كثير من الصناعات وذلك لضمان أن المياه الني ستعود إلى الخليج لن تسبب أي أذى للبيئة.

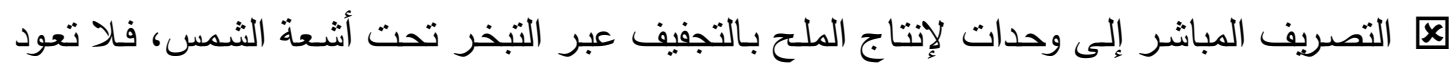

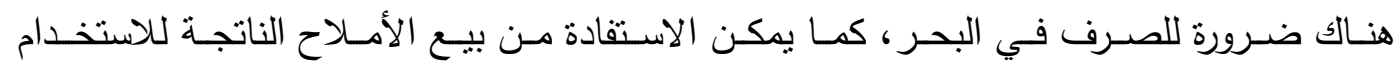
الصناعي، وهذا معمول به حالياً في بعض الدول الأوروبية مثل اليونان.

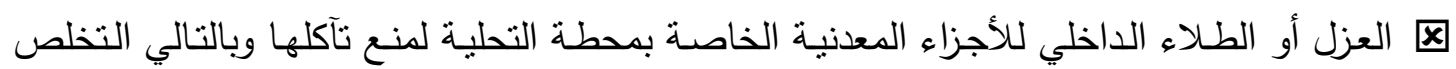
من العناصر الثقيله السامة التي تصرف بالمياه البحري.

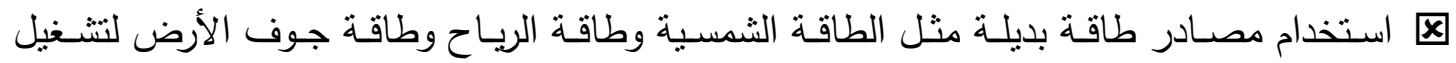
محطات الكهرباء الملحقة بمحطات التحلية، وهذا من التدابير البديلة التي يُعمل على جعلها مجدية التهاتية اقتصادياً.

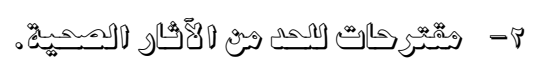

囚 إحـال وتجديد الثبكة القديمة بمواسير بلاستيكية ذات جودة عالية وأقطار مناسبة لضغط اليياه

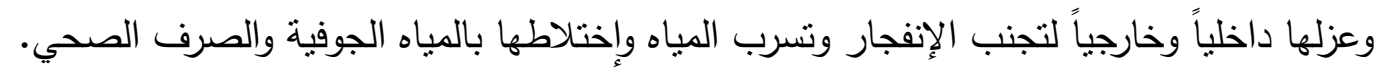

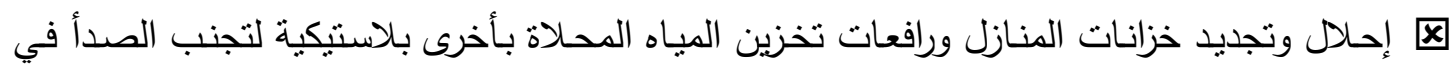
الخزانات الحديدية والتحلل والتسريب في الخزانات الأسمنتية. 囚 تركيب وحدات إضافة أملاح كربونات الكالسيوم التي تعيد للمياه نوازنها الأيونى والمعدني لتكون التئنة

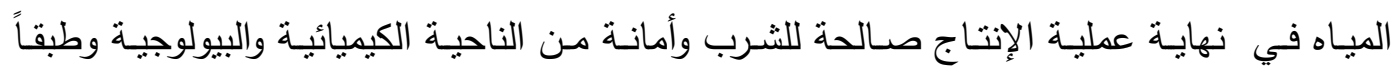
لمواصفات مياه الثرب التي حددتها وزارة الصحة الصصرية ومنظمة الصحة العالمية.

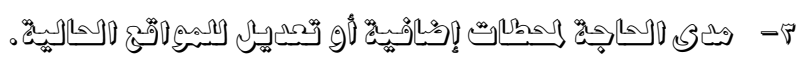

تم اعتماد جميع الموافقات من الجهات الرسمية على تخصيص ثلاثة مواقع جديدة داخل منطقة

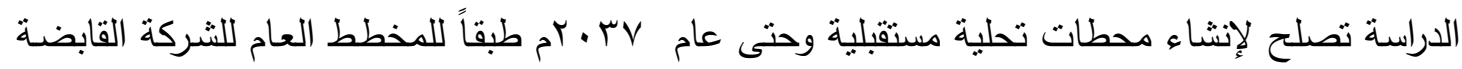

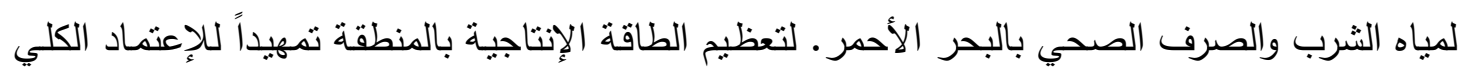

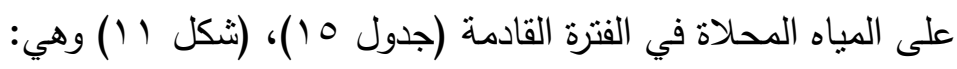
$(1 \wedge r \varepsilon)$ 


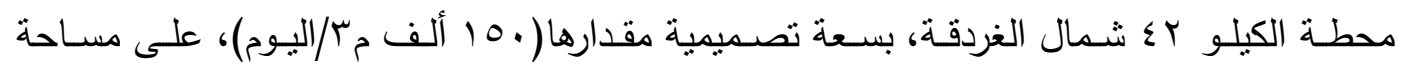

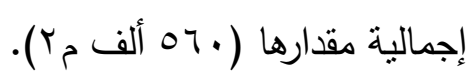

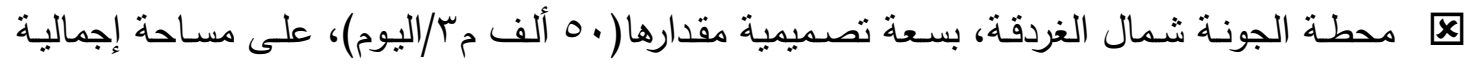

$$
\text { مقدارها (100 (ألف مبانه). }
$$

محطة الكيلو ری جنوب الغردقة، بسعة تصميمية مقدارها( •0 ألف مج/اليوم)، على مساحة إجمالية

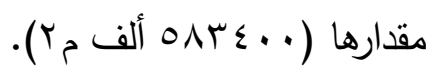

\begin{tabular}{|c|c|c|c|}
\hline المساحة & الطاقة & الإسم & الموقع الفلكي \\
\hline 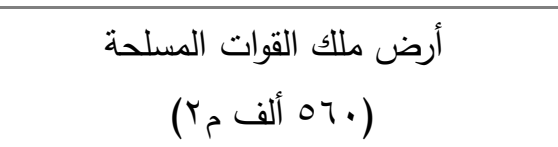 & ..... 10 مَّ/اليوم & شمال الغردقة & 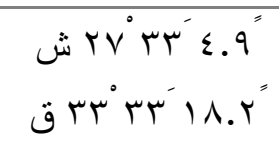 \\
\hline 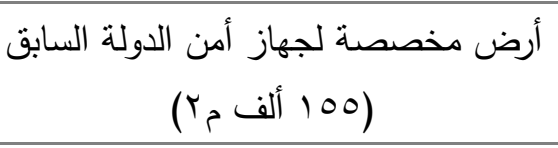 & .... ... م مr/اليوم & الجونة & 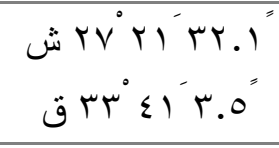 \\
\hline 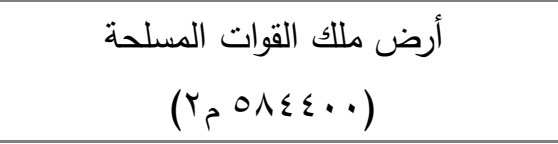 & ........ . זم ז/اليوم & جنوب الغردقة مبل & 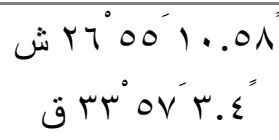 \\
\hline
\end{tabular}

جدول (10) المواقع المقترحت لإنشاء محطات تحمليت مياه البحر بالغردقت حتي عام rr.r.rم، طبقا لمخطط الشركت القابضت للمياه 


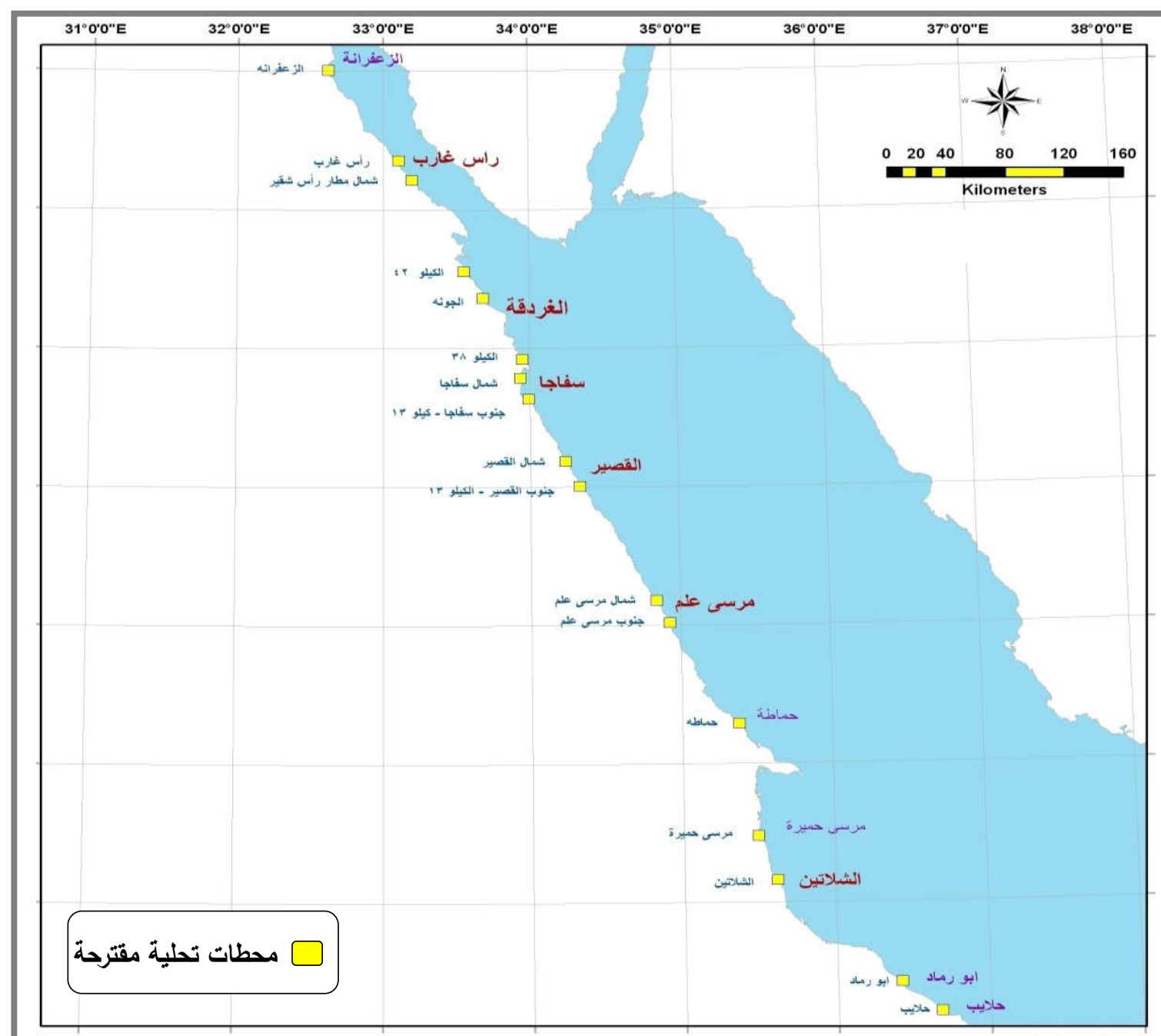

شكل (l) المواقع المقترحت لإنشاء محطات تحليت مياه البحر بالغردقت حتي عام rr.rم، طبقا لمخطط الشركت القابضت للمياه

المصدر : الثركة القابضة لمياه الثرب والصرف الصحي بالغردقة، بيانات غير منشورة، VI ل المباه.

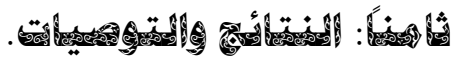

:

囚 تبين من الدراسة أن المنطقة يخدمها محطة تحلية واحدة هي (محطة اليسر) وتقع وسط المدينة بمنطقة الدهار (حي الميناء) على مساحة إجمالية بلغت (דه ألف مY)، وتعمل بطاقة تصميمية

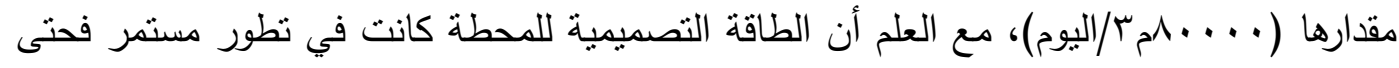

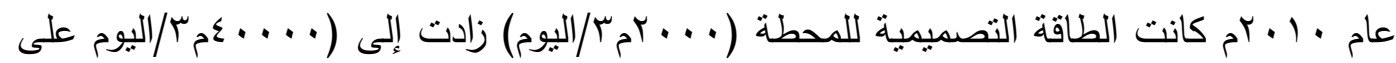
مرحلتين في الفترة • ( • - - ( • r م) حتى وصلت إلى ما هي عليه حالياً.

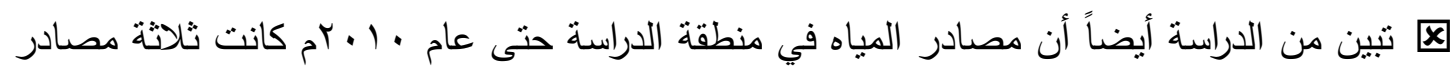
(إثثان منها مياه عذبة من نهر النيل؛ والثالثة مياه محلاه من المياه المالحة البحرية) وهي: محطة 


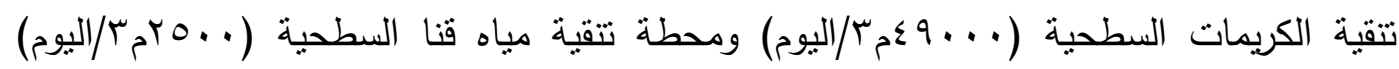

$$
\text { ومحطة تحية اليسر (.... بـمَ/يوم). }
$$

囚 أما عن مصادر المياه في منطقة الدراسة في عام 1 1 •rم فهي محطة تحلية اليسر والتي وصلت الطاقة التصميمية لها إلى (.....یمب/اليوم) وجاري الإنتهاء من أخرى جنوب الغردقة بطاقة تصميمية ( . . . .بمس//اليوم). وثُوزع مياه المحطة إما عن طريق شبكة من المواسير الأرضية أو عربات نقل للمناطق الغير مخدومة بشبكات مواسير أرضية والتي كانت تعتمد من قبل على مياه نهر النيل. وتسعى المحافظة حالياً إلى الإعتماد الكلي على المياه المحلاة البحرية كبديل للمياه العذبة المنقاه، فوضعت في خطتها حتى عام VTr r Tم إنشاء ثثلاثة محطات بإجمالي طاقة تصميمية

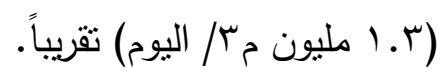

囚 تخدم محطة تحلية اليسر خمسة نطاقات جغرافية (قام الباحث بعمل خرائط نوزيعية لها) تخدمها أربعة خزانات تجميع رئيسة (رافعات) بالإضافة إلى الضخ المباشر للنطاق الخامس من المحطة مباشرةً. والنطاقات الجغرافية هي (نطاق خدمة رافع الدهار، نطاق خدمة رافع السقالة، نطاق خدمة رافع 09، ونطاق خدمة رافع 07، ونطاق الضخ المباشر من محطة تحلية اليسر)، وإجمالي عدد الثكان المشمولون بالخدمة حوالي ( • Y ألف نسمة في عام 10 • بام). 囚 تعد الطريقة الأسموزية (التتاضح العكسي) هي طريقة التحلية المتسخدة في منطقة الدراسة من بين طرق عدة للتحلية قامت بعرضها الدراسة الحالية للوقوف على مميزات وعيوب كل طريقة. 囚 تمر معالجة المياه بمحطة تحلية (اليسر) بمرحلتين رئيسيتين الأولى المعالجة الابتدائية لمياه التغذية، والثانية المعالجة النهائية للمياه المحلاة المنتجة، مروراً بمجمع الأغشية لفصل الماء. 囚 تنين من دراسة التقييم الجغرافي لموقع محطة اليسر أنه يؤثز ويتأثر؛ فعن تأثير الموضع فهو غير مباشر ويتمنل في تأثيره على البيئة البحرية، من خلال موضع مأخذ المياه، فإمتداد المواسير لمسافة أقل من (•0م) داخل المياه البحرية، وعمق يصل لحوالي (r ام تحت سطح المياه) لسحب مياه التغذية غير ملائم حيث أن هذا النطاق البحري غني بالانتاج البيولوجي وبالتالي فأثناء السحب تُجرف الكائنات الحية مع تدفق المياه البحرية إلى داخل المحطة فتموت أثناء المراحل المختلفة في عملية التحلية. أما بالنسبة لموضع محطة تحلية اليسر فهو يتأثر عدة مصادر للتلوث ومنها توطن المحطة جغرافياً داخل الكتلة السكنية وعلى المنطقة الثاطئية التي تتسم بتتوع الانشطة الاقتصادية بداخلها وبالتالي تمنل مصدراً للخطورة على المحطة وعن مصادر التلوث فهي محطة تخزين وتموين السفن 
ومواصلات النقل العام، وميناء الغردقة البحري السياحي، ومارينا اليخوت- (مارينا الغردقة)، وميناء الصيد وحلقة السمك. 囚 تبين من دراسة خصائص التمديدات الثبكية لمحطة اليسر، تتوع المادة المستخدمة في صناعة

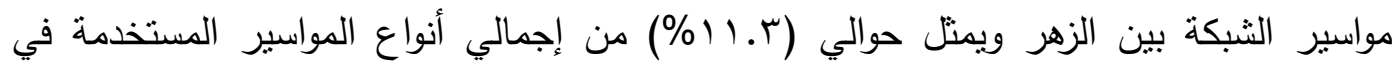

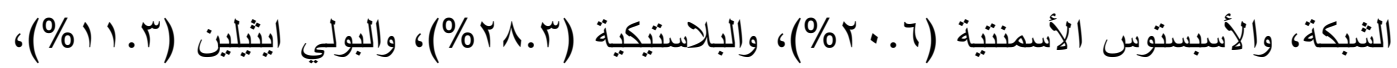
والحديد (T.7\%\%)، وعرضت الدراسة مميزات وعيوب كل نوع لتحديد أي الأنواع التي تصلح

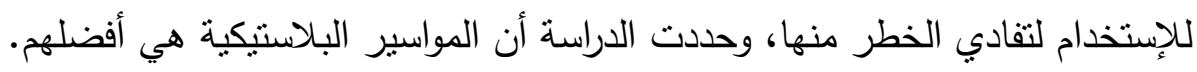
囚 أتضح من دراسة خصائص الحالة النوعية لمياه التغذية والمياه المنتجة والمياه المستهكة ومياه

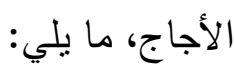
مطابقة القياسات الفيزيائية والكيميائية والبكتريولوجية لمياه تغذية الدحطة للمعايير العالمية ولكن بإرتفاع طفيف في بعض العناصر لم يتعدى الحد المسموح به مثل نسبة تركيز الملح والأملاح

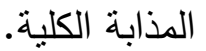
مطابقة الحالة النوعية للمياه المحلاة المنتجة للمعايير العالمية حيث تبين من نتائج التحليل إخفاق بعض العناصر الهامة من النحليل وعدم ورودها بالثقرير مثل العناصر النقلة وبعض لهض

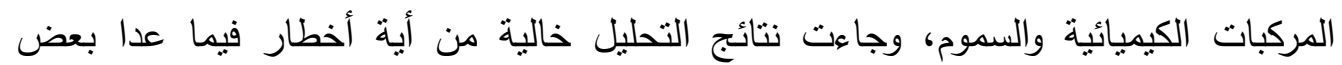
الزيادات الطفيفة في بعض العناصر الكيميائية عن الحد المسموح به عالمياً مثل (الكوريدات

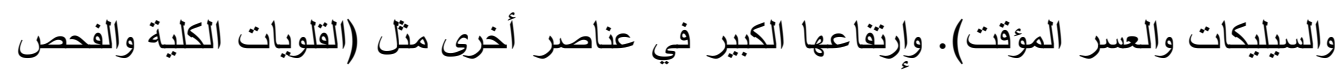
البيولوجي والتوصيلية الكهربائية والبيكربونات).

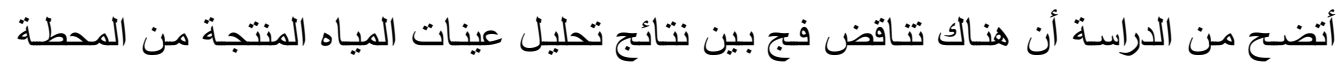

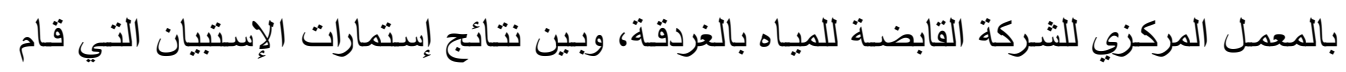

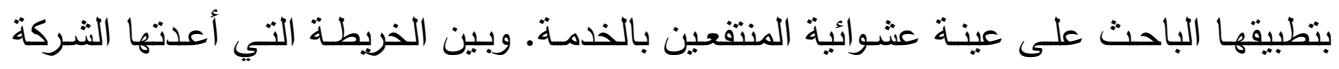

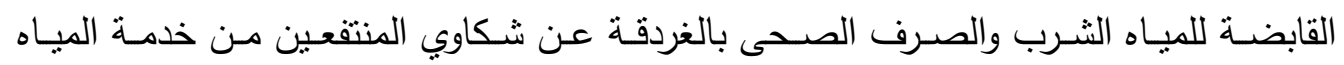

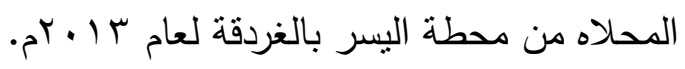
عدم مطابقة الحالة النوعية للمياه المحلاة المستهكة داخل المحلات العمرانية، للمعايير العالمية حيث تبين من نتائج التحليل ارتفاع في بعض العناصر الفيزيائية للمياه مثل (اللون والطعم والعكارة)، كذلك ارتفاع نسبة البيكربونات وبعض العناصر الثقيلة الخطيرة مثل (الحديد والزنكك والفوسفات والنيتريت). وإصابة المياه بالملوثات الأولية (protozoa) والطحالب وأنواع أخرى من البيكتريا الوتي تحتاج لاختبارات أخرى للفعرفة أنواعها. $(1 \wedge r \wedge)$ 
عدم مطابقة الحالة النوعية لمباه الأجاج المنصرفة إلى البحر فقد تبين من نتائج التحليل

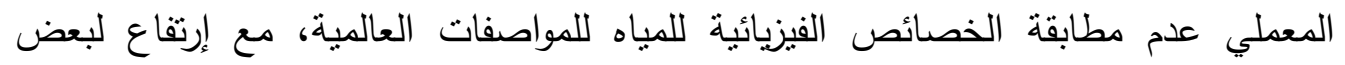

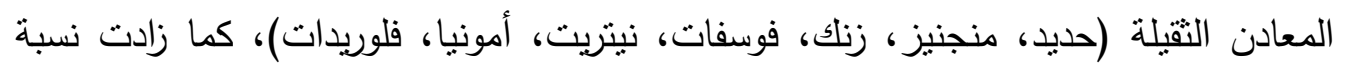

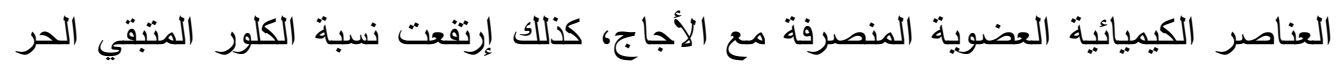
من التحلية في المياه المنصرفة.

囚 أظهرت دراسة الآثار البيئية والصحية لدحطة التحلية بمنطقة الدراسة أن هناك آثار على البيئة البحرية من مصدرين هما مأخذ مياه البحر وصرف الأجاج، وجاءت لهاءت نتائج القياسات الفيزيائية

والكيميائية والبكتريولوجية لعينة المياه غير مطابقة للمواصفات القياسية في أغلبية العناصر.

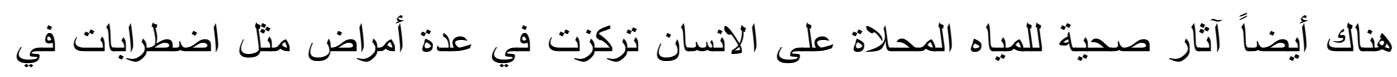

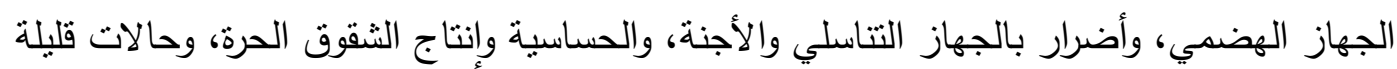
مصابه بالفشل الكلوي وحصاوي الكلى، والأمراض الناتجة من الذزانات المكثوفة مثل (حمى الهیى

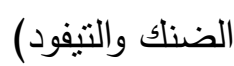
:

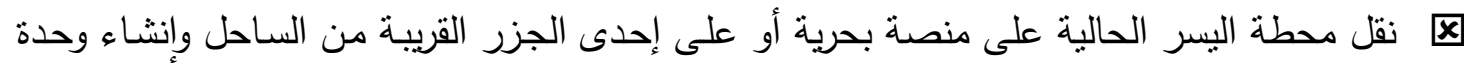
إضافية لإنتاج الملح بالتجفيف عبر التبخر تحت أنثعة الثمس.

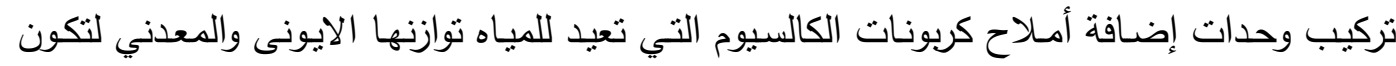
المياه في نهايـة عملية الإنتاج صـالحة للثـرب وأمانـة من الناحيـة الكيميائية والبيولوجيـة وطبقاً

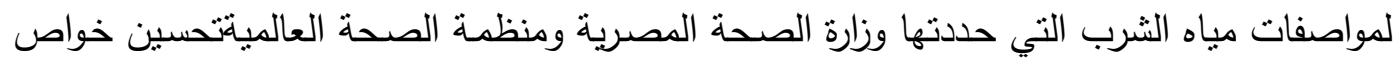
المياه

إستخدام التقنيات الحديثة لفصل الدياه الثقيلة والمعادن الثقيلة عن مياه الثرب الدحلاة، وابتكار تقنيات جديدة للحد من أضرارها أو تلافيها نهائياً 凤 الدأب على زيادة المعرفة بطيبعة الملوثات وخصائصها وإجراء العديد من التحاليل والتجارب مهما كانت التكلفة.

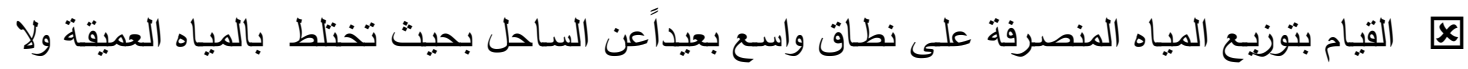
تسبب تغيرات محلية في مكان قلب النفايات على الساحل. هذا يقتضي مد مواسير لمسافات كبيرة تحت المياه بصورة لا تتعارض مع الملاحة. تثنديد الرقابة على العمالة بمحطة النحلية والرافعات ليقوم كلاً بعمله على أكمل وجه. 冈 الرقابة المستمرة على تتظيف وتطهير خزانات الرافعات الرئيسة. 区

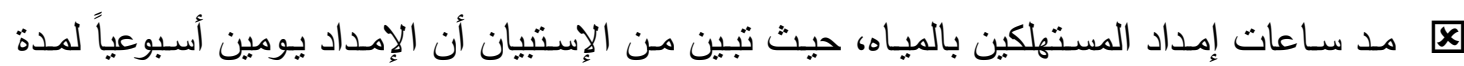
ساعنين في البوم الواحد. لف الرقابة على عربات نقل المياه من الثبكة للمواطنين وتتظيفها وتطهيرها بصفة مستمرة 
التحليل العشوائي لمياه الثرب المحلاة في مراكز الاستهلاك خاصة المنازل للتأكد من عدم تلوثها أثناء نقلها أو توزيعها.

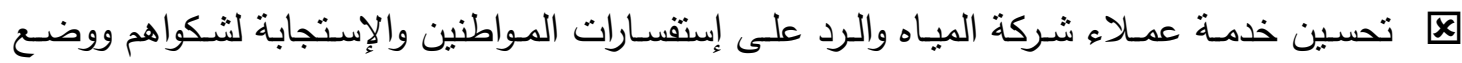
حلول لها، ليشعر المواطن بتحسن في الخدمة.

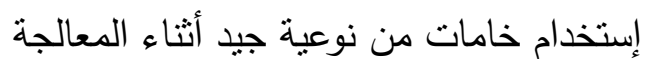

冈

区

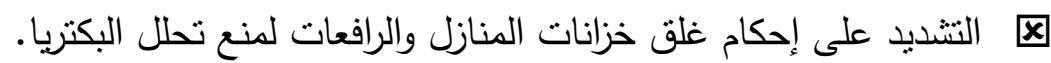

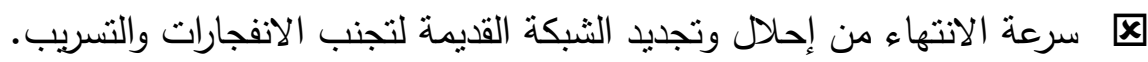
囚 إختيار مواسير ذات جودة عالية (إقترحة الدراسة المواسير البلاستيكية) لمنع تسرب المياه وإختلاطها

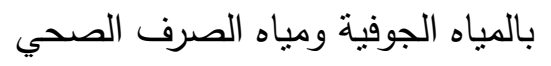

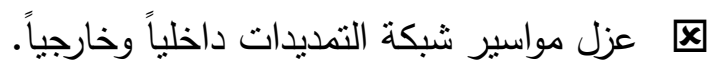
X تغيير شبكة مواسير المنازل المتهالكة واستبدالها بمواسير ذات جودة عالية 邓 النظافة الدورية والنطهير المستمر لخزانات المستهلكين، وفرض غرامات على من لا يقوم بالنظافة للخزان والمنطقة المجاورة له كل ثلاثة شهور كحد أقصى.

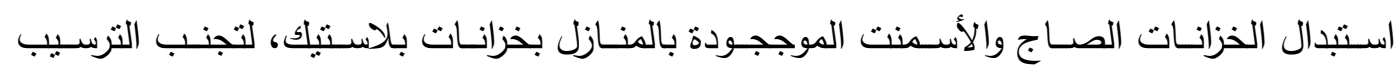

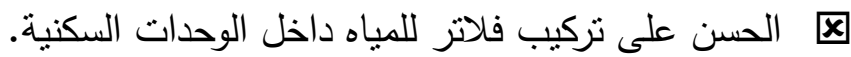

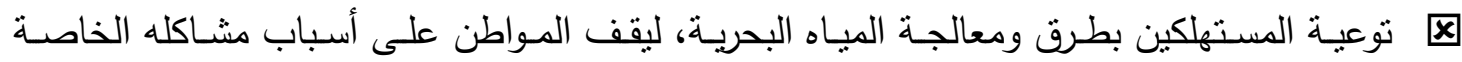
بالمياه المحلاة. نوعية المواطنين بأنواع الأمراض الناتجة عن المياه الدحلاة. 冈 (5)

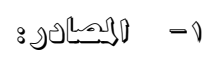
1- الثركة القابضة لمياه الثرب والصرف الصحي بالبحر الأحمر ، تقرير فني عن محطات التحلية

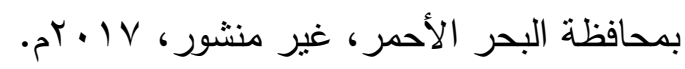

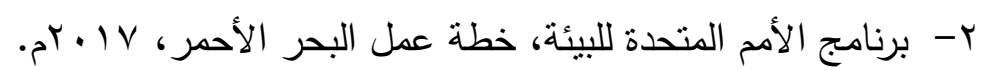

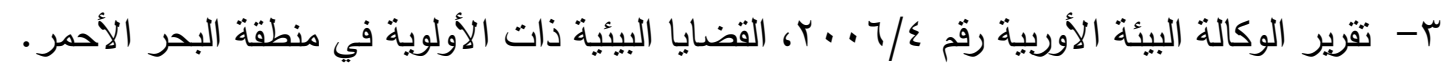
ع - جهاز شئون البيئة، برنامج المعلومات والرصد البيئي، نتائج رصد ونوعية المياه الساحلية في البحر

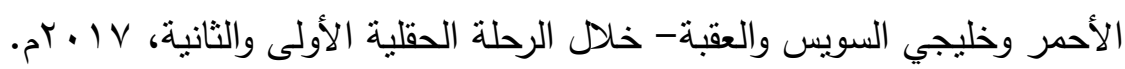

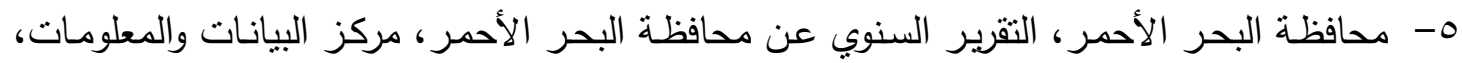
محافظة البحر الأحمر، VI Y. Y. צ- مديريـة الصـحة والسكان بـالبحر الأحمـر ، نتائج وحدة الخدمات الوقائية، بيانـات غير منشـورة، . $(1 \wedge \varepsilon \cdot$ 
V- منظمـة الصـحة العالميـة، المكتب الإقليمسي لثـرق المتوسط، دليل خطـة سـلامة الميـاه، الطبعـة

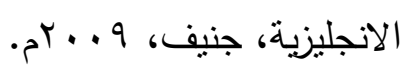

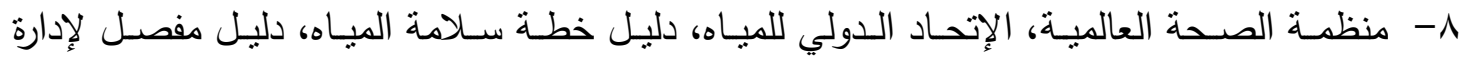

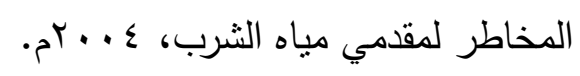

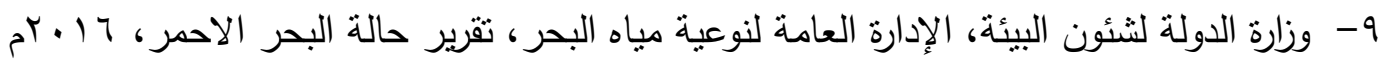

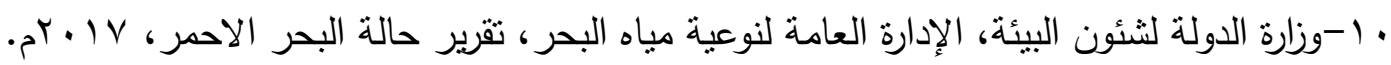

1- Desalination Association- IDA, 2009.

2- The Dow Chemical Company "DOW",Water Solutions., eRverse Osmosis Membranes- Technical Manual

3- ISO- Pipe, Tube and Fittings Standard and Specification.

4- Norwegian Refugee Council, 2008, Elimelesh and Phillip 2011.

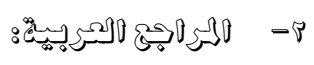

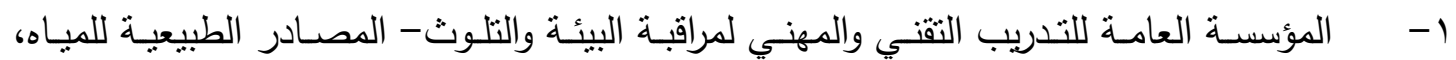
. $) \leqslant r q$

r- المؤسسـة العامة للتدريب التقني والمهني لمراقبـة البيئة والتلوث- طرق تحلية المياه المالحة،

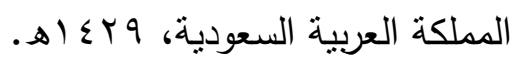

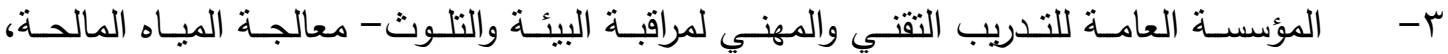
. $) \leqslant r q$

ع-مركز فقية للأبحاث والتطوير، المياه المحلاة من البحر - المخاطر المحتملة. 0 - هاني احمد أبو قديس، الآثار البيئية لمحطات تحلية المياه على البيئة البحرية، دكتوراه غير

$$
\begin{aligned}
& \text { منشورة، كلية الهنسسة، جامعة نيوكاسل، } 1991 \text { ا. } \\
& \text { W - }
\end{aligned}
$$

5- Daniel R. Rople, Pe and David M. Coles. " Potable Water Pipe Condition Assessment For a High Rise Condominium in The Pacific Northwest". GSG Groub Inc., Community Engineering services

6- William Johns, Notes on Pipe, Gizmology.Net, 2012.

7- Kess,. N., and B. S. Galil. 2015. Impact of seawater desalination by reverse osmosis on the marine environment. Pages 177-202 in s. Burn and S. Gray, editors. Efficient desalination by reverse IWA, London.

8- NRC. 2008. Desalination, a national perspective National Research Council of the National Academies. The National Academies press, Washington, D.C.

9- Mayhew, D. A., L. D. Jensen, D. F. Hanson, and P. H. Muessig. 2000. A comparative review

10- of entrainment survival studies at power plants in estuarine environments. Environmental Science \& Policy 3, Supplement 1:295-301.

11-US Environmental Protection Agency "EPA", January 24, 2001. Ocean Discharge Criteria Rregulation. 40CFR Parts 122, 123 and 125, Rin-204AD60

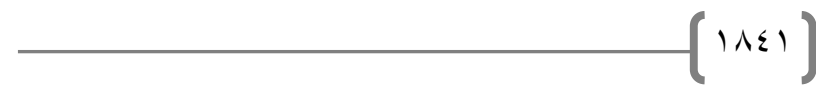


12- Fermandes- Torquemada, y., and J. M Gonzalez- correa, A Loya, L. M. Ferrero, M . Diaz- Valdes, and J. L. Sanchez- Lizaso. 2009. Dispresion of brine discharge from seawater reverse osmosis desalination plants. Desalination and Water Treatment5; 137-145.

13-Lattemann, S., and T. Hopner. 2008. Impacts of seawater desalination plants on the marine environment of the Gulf. Protecting the Gulf's Marine Ecosystems from Pollution. Ed A.H. Abuzinada, H.J. Barth, F. Krupp, B. Böer and T.Z. Al Abdessalaam Birkhäuser Verlag/Switzerland:191-205.

14-Chesher, R. 1971. Biological impact of a large-scale desalination plant at Key West, Florida. Elsevier Oceanography Series 2:99-164.

15- Brand, L. E., W. G. Sunda, and R. R. L. Guillard. 1986. Reduction of arine phytoplankton reproduction rates by copper and cadmium. Journal of Experimental Marine Biology and Ecology 96:225-250.

16- Drami, D., Y. Z. Yacobi, N. Stambler, and N. Kress. 2011. Seawater quality and microbial communities at a desalination plant marine outfall. A field study at the Israeli Mediterranean coast. Water Research 45:5449-5462.

17-Belkin, N., E. Rahav, H. Elifantz, N. Kress, and I. Berman-Frank. 2017. The effect of coagulants and antiscalants discharged with seawater desalination brines on coastal microbial communities: A laboratory and in situ study from the southeastern Mediterranean. Water Research 110:321331.

18- Taylor, C. J. L. 2006. The effects of biological fouling control at coastal and stuarine power stations. Marine Pollution Bulletin 53:30-48.

19- Portillo, E., G. Louzara, M. Ruiz de la Rosa, J. Quesada, J. C. Gonzalez, F. Roque, M. Antequera, and H. Mendoza. 2013. Venturi diffusers as enhancing devices forthe dilution process in desalination plant brine discharges. Desalination and Water Treatment 51: 525-542. 
مركز البحوث الجغرافية والكارتوجرافية - قسم الجغرافيا - كلية الآداب - جامعة المنوفية المؤتمر الجغرافي الدولي الثاني

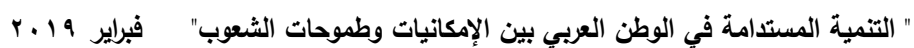

\title{
امكانيات تطوير الساحل الايمن
}

\section{لنهر الفرات في قضاء الكوفة كورنيش شط الكوفة}<smiles></smiles>

\author{
أ.م. منيرة محمد مكي \\ جامعة الكوفة/ كلية التربية للبنات \\ قسم الجغرافية
}




\section{المقدمة :- نبذة تاريخية عن مدينة الكوفة:-}

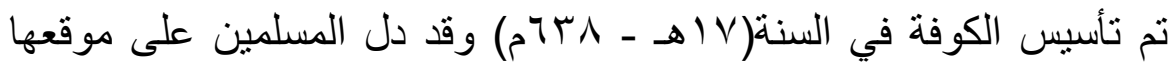

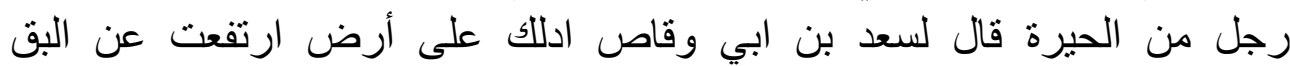

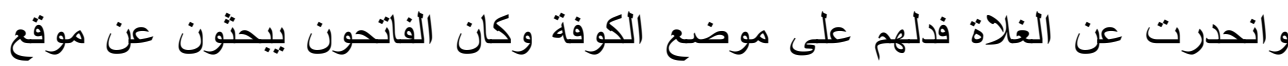

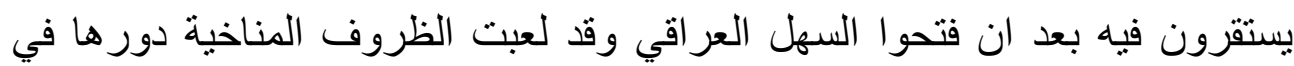

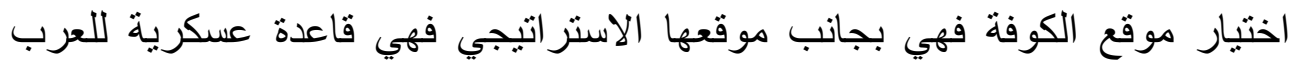

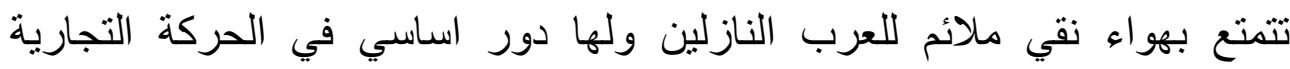

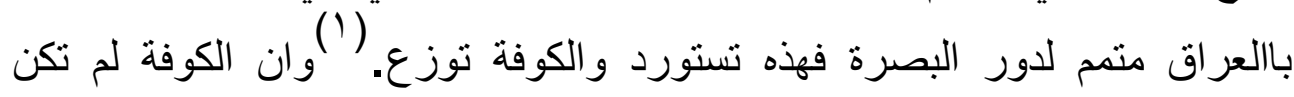

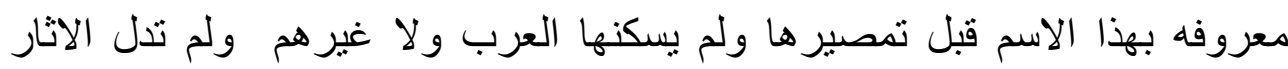

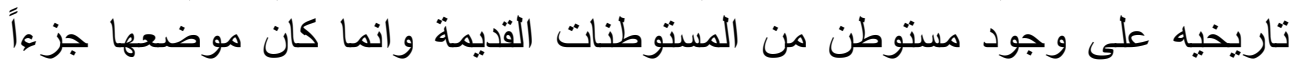

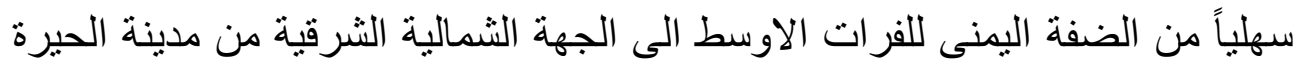

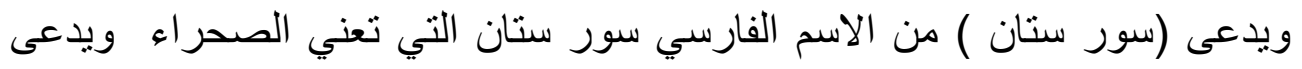

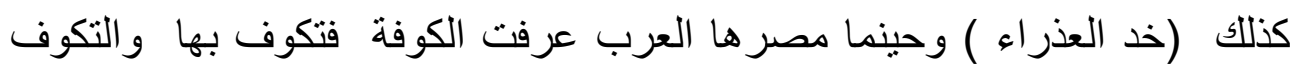

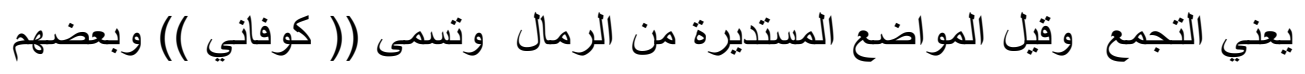

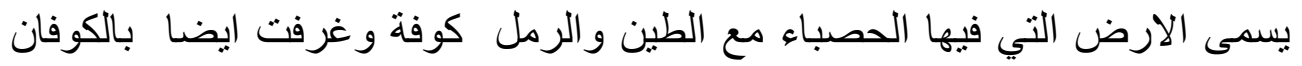

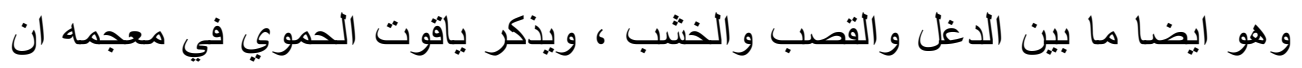

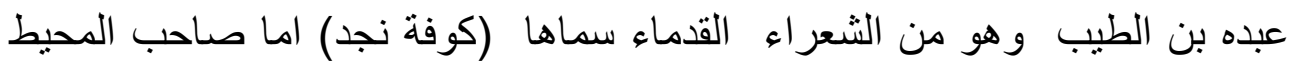

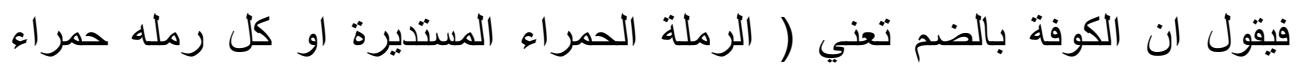

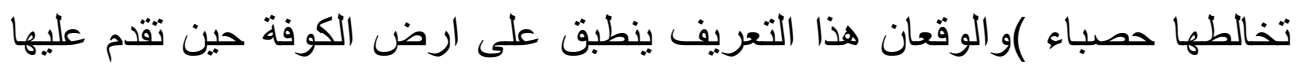

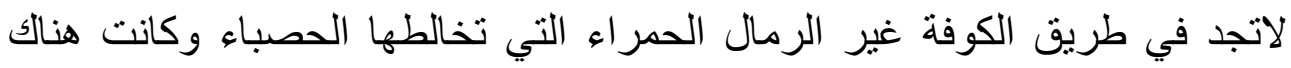

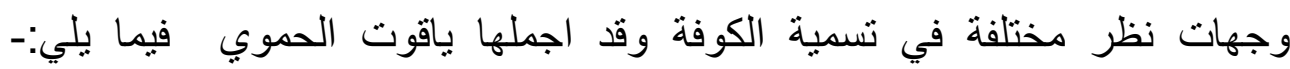

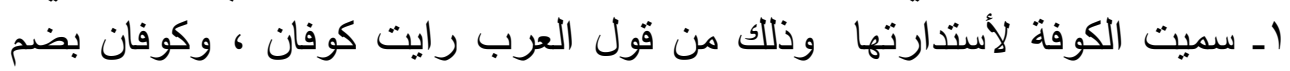

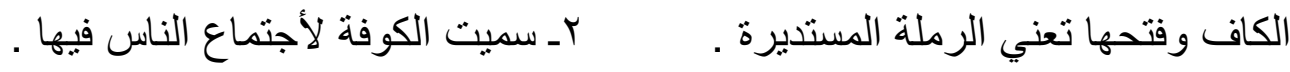
rـ يقال اخذت الكوفة من الكوفان وقيل سميت كوفة لانها قطعه من البلاد في قول

' ' ) محمد سعيد الطريحي ، العتبات المقدسة في الكوفة ، المجمع العلمي الفاطمي، اكادمية الكوفة ،

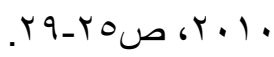


مركز البحوث الجغرافية والكارتوجرافية - قسم الجغرافيا - كلية الآداب - جامعة المنوفية المؤتمر الجغرافي الدولي الثاني

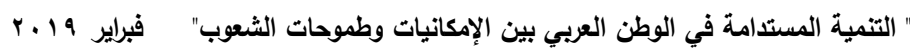

العرب ويقول لويس ماسينيون ان اسم الكوفة سرياني عرفت عن طائفه السريان

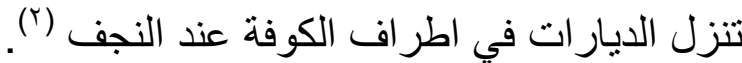
وشيدت الكوفة بدور ها على ثلاث مر احل الكل الهمها :-

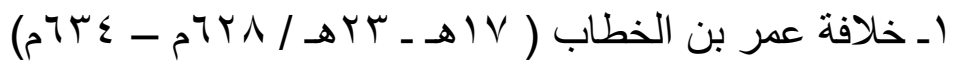

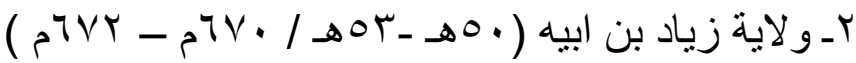

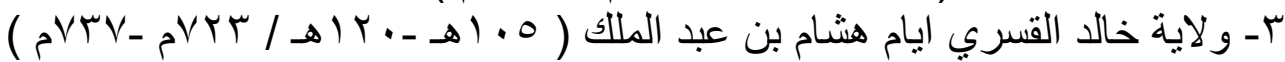

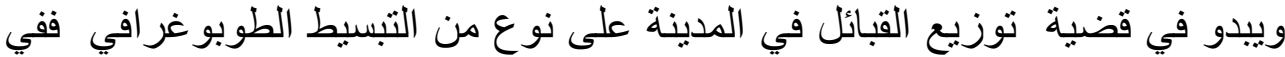

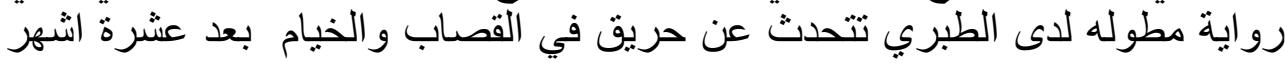

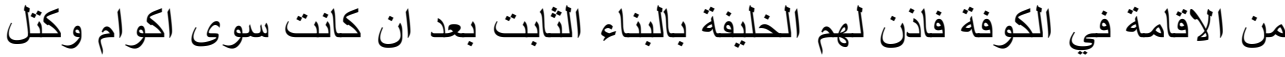

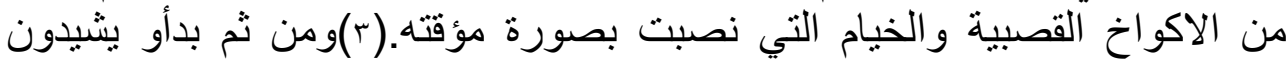

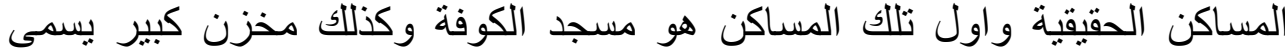

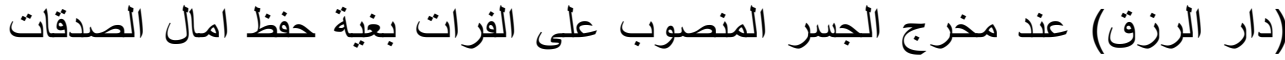

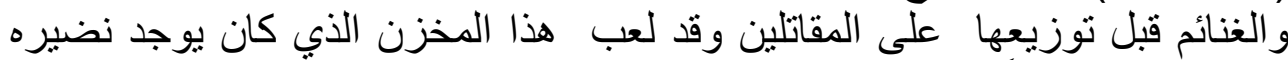

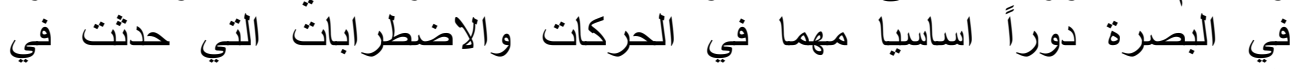

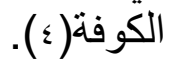

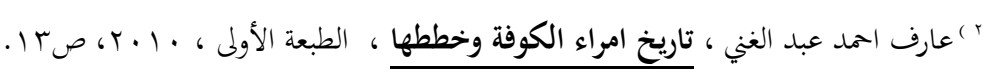

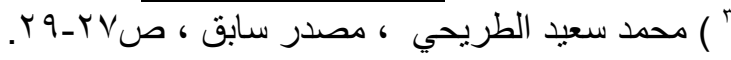

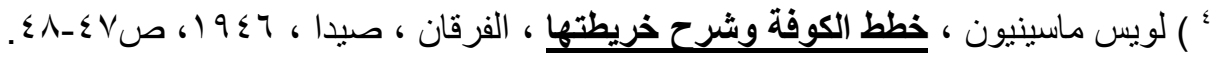




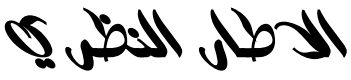

\section{مشك كلة الجحثة:-}

تندرج مشكلة البحث ضمن السؤال الأتي((هل توجد مقومات طبيعية وبشرية في منطقة الدر اسة يمكن استثمار ها في الميدان السياحي وكيف يمكن ذللك)).

خز ضيدة الجحد: يوجد في منطقة الدراسة عدد من المظاهر والمعالم الطبيعية المتمثلة بنهر الفرات الذي يمكن استثمارها في الجانب السياحي عن طريق تهذيبها وزيادة جماليته وتحسين خصائصه الطبيعية.

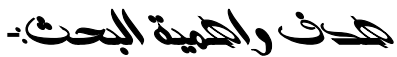

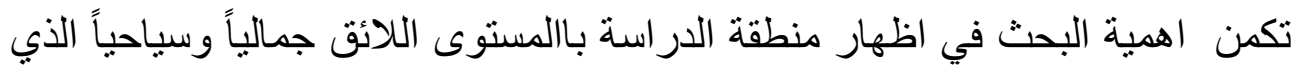

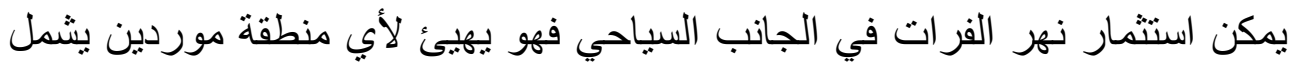

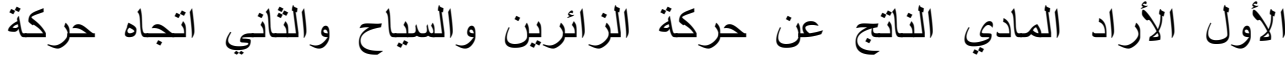

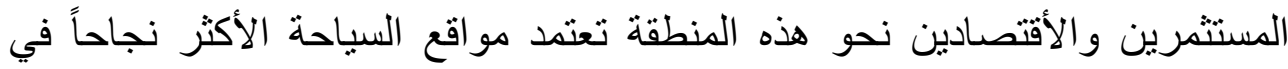

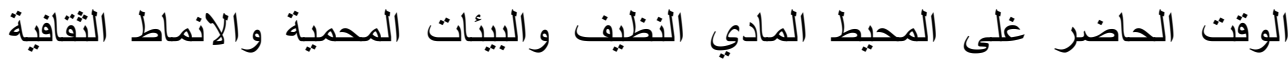

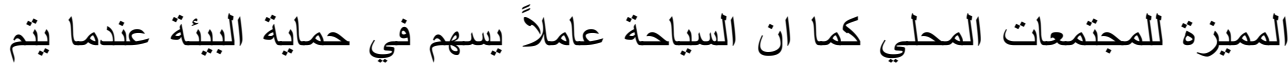

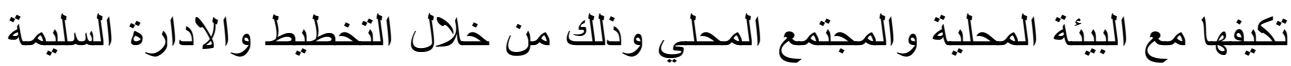
ويتوفر عند وجود بيئة ذات جمال طبيعي مما يساعد على اجتذاب السياح .

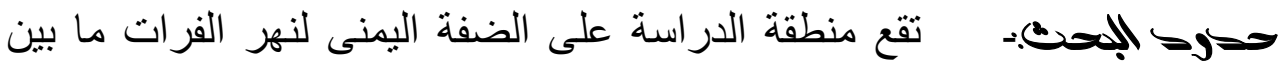

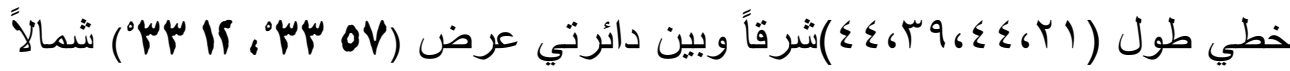
وقضاء الكوفة هو جزء من محافظة النجف وتتبعها ادارياً وتحد المدينة محافظة بابل

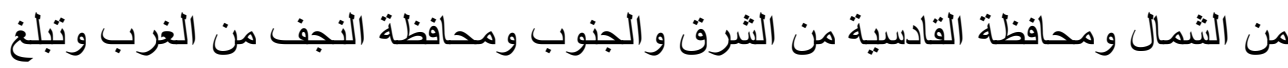


مركز البحوث الجغرافية والكارتوجرافية - قسم الجغرافيا - كلية الآداب - جامعة المنوفية المؤتمر الجغرافي الدولي الثاني

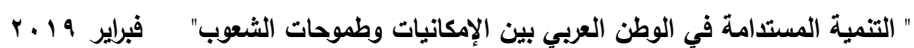

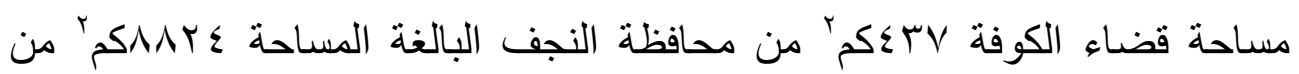

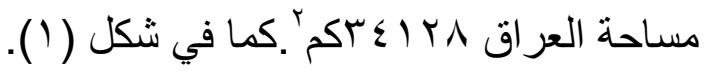

خريطة (1) (الإنة

الموقع القلكي والحدود الإدارية لمحافظة النجف الاشرف

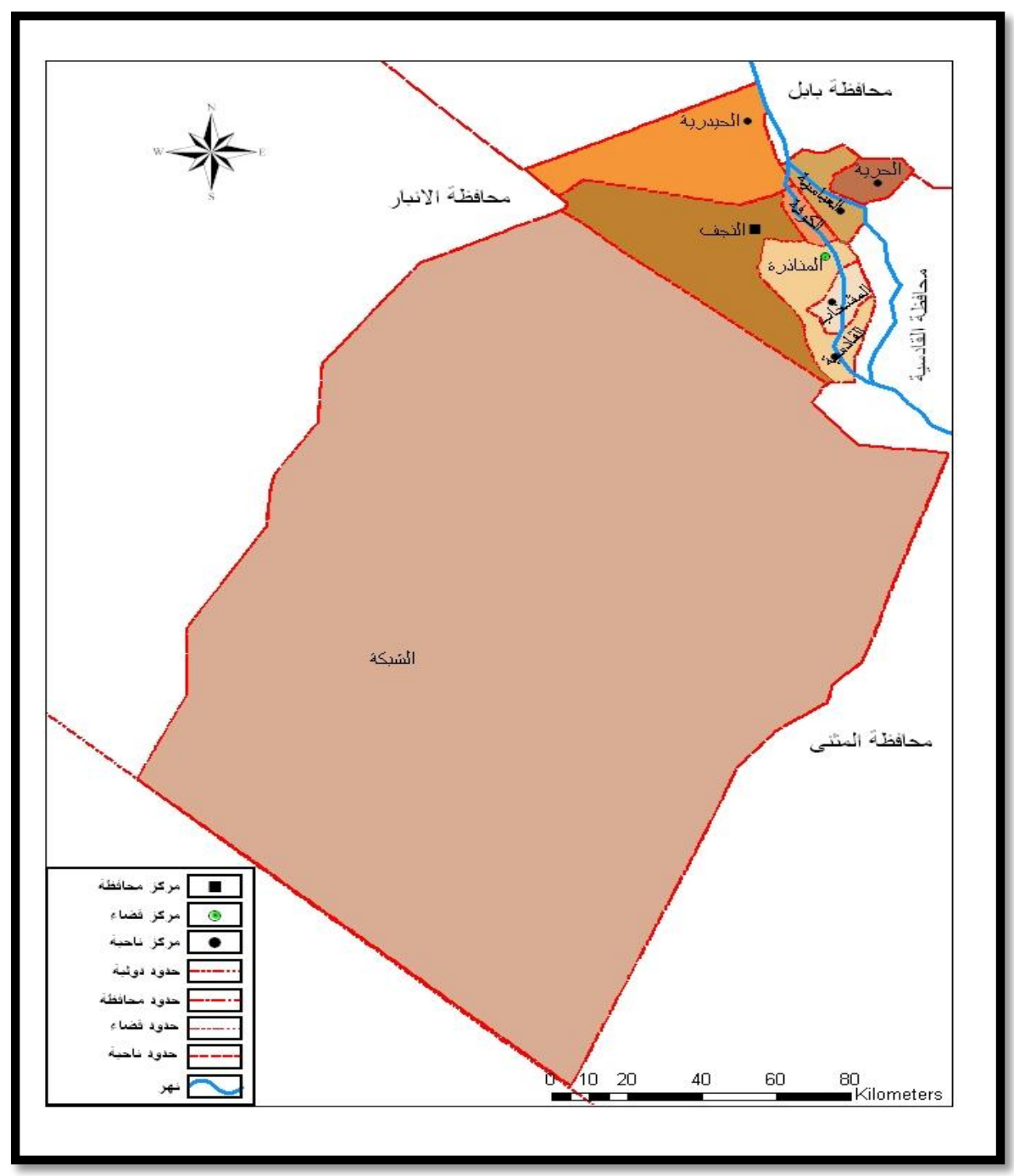

المصدر:جمهورية،الجهاز المركزي للاحصاء، الهيأة العامة للمساحة في محافظة النجف 


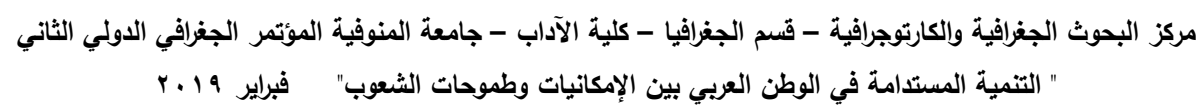

\section{((المبحث الثاني ())}

الخصائص الطبيعية لمنطقة الدراسة:-

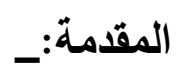

اولا:- الخصائص التركيب الجيولوجي.

تانياً:. الوضع الطبوغرافي لمنطقة الدراسة.

ثُالثاً:-- عناصر المناخ لمنطقة الاراسة.

1- الضوابط المناخية الثابتة .

ץ - الضوابط المناخية المتحركة .

رابعاً:. الخصائص المناخية .

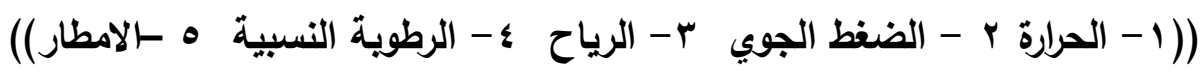

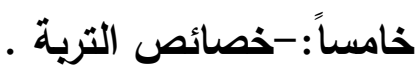

سادساً :- الموارد المائية والنبات الطبيعي . 


\section{الخصائص الطبيعية لمنطقة الدراسة:-}

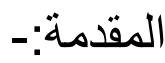

يتناول هذا الفصل تحليلا جغر افيا للخصائص الطبيعية في قضاء الكوفة ويتمثل اولا

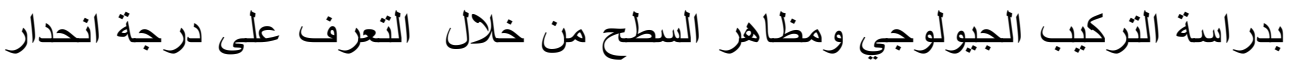

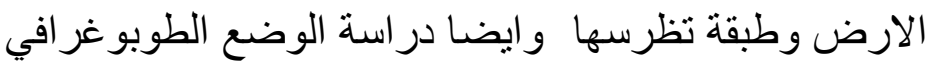

في منطقة الدراسة و الخصائص المناخية المنمثلة بدرجات الحر ارة و الضغط و الرياح

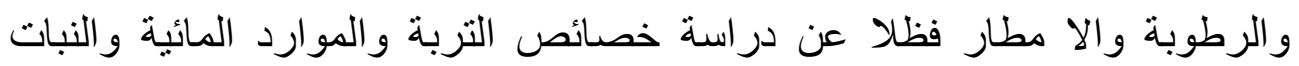

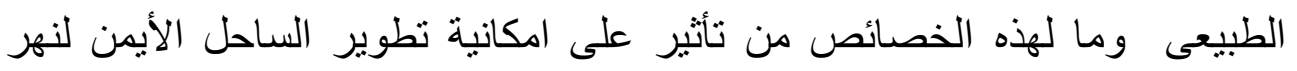
الفرات في قضاء الكوفة.

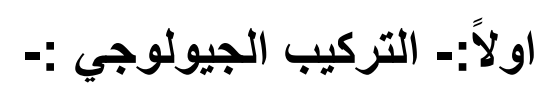

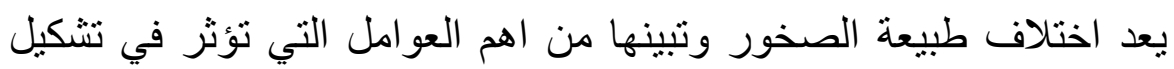

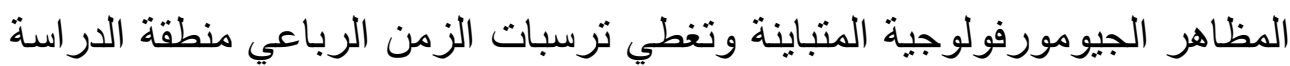

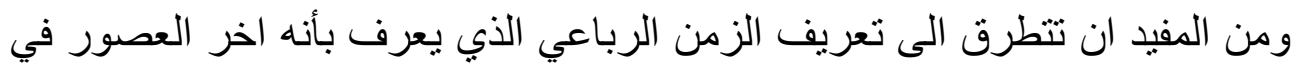

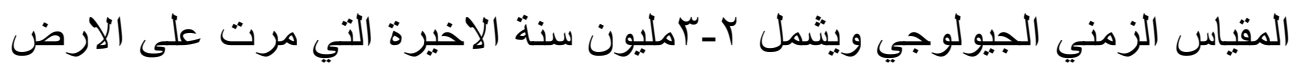

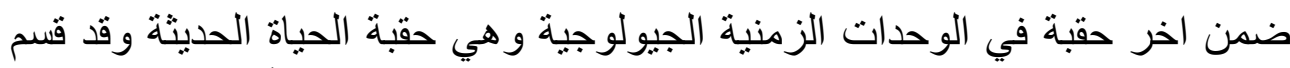

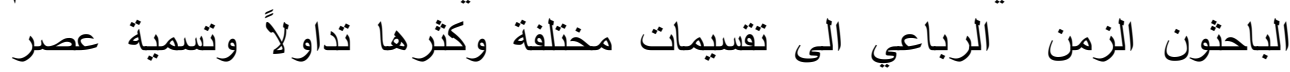

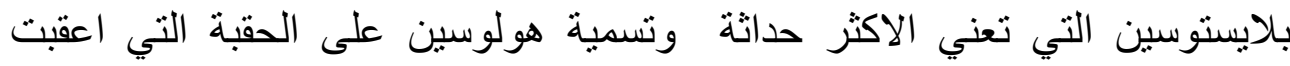

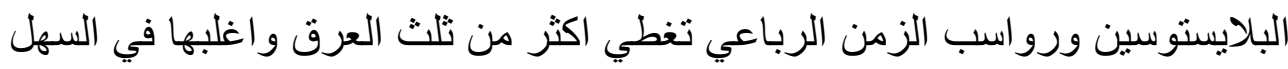

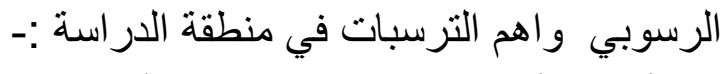
ا - القشرة الجبسية (بلايستوسين- هولوسين):-

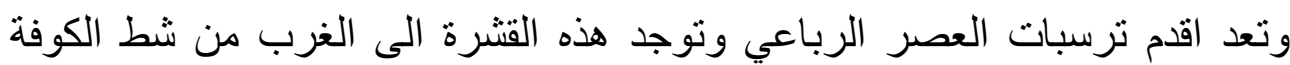

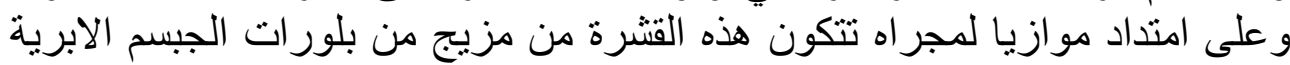

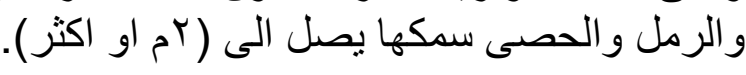
r- برسبات حشوة الو ادي (هولوسين):- 
مركز البحوث الجغرافية والكارتوجرافية - قسم الجغرافيا - كلية الآداب - جامعة المنوفية المؤتمر الجغرافي الدولي الثاني

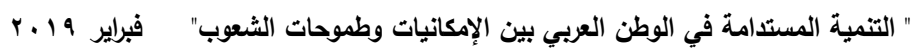

هذه الترسبات يمكن تميزها بوجود مقاطع كبيرة من الرمل الحصوي وبصورة عامة

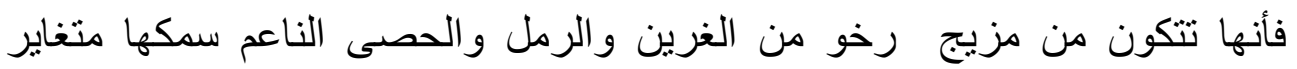

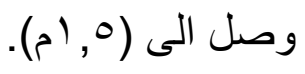

$$
\text { r- ترسبات السهل الفيضي (هولوسين):- }
$$

و هذه الترسبات نثأت نتيجة لتكر ار عملية فيضانات الانهار وطغيانها على الار اضي

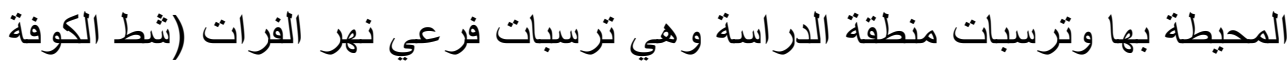

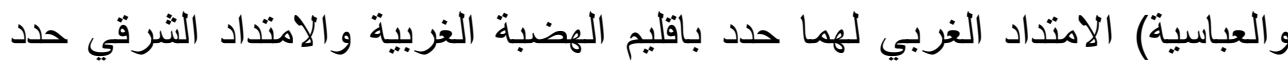

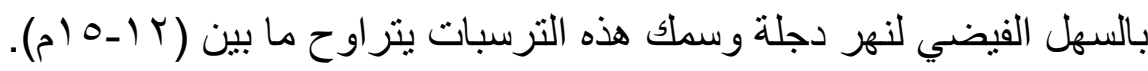

$$
\text { ع - ترسبات المنخفضات (هولوسين):- }
$$

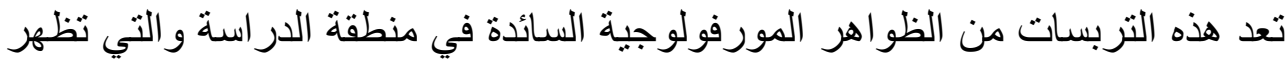

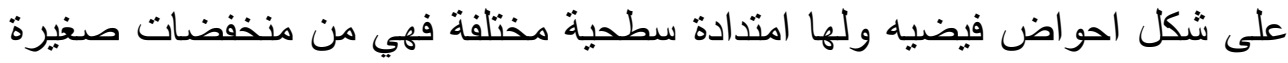

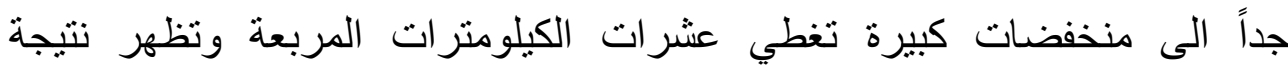

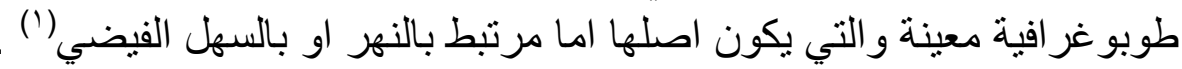

(') (اوسن محمد علي كاظم المكوطر الحسيني ، الخصائص الجيومورفولوجية لنهز الفرات وفرعية

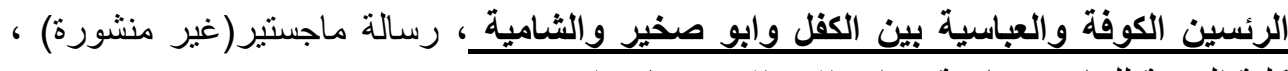

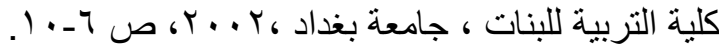


مركز البحوث الجغرافية والكارتوجرافية - قسم الجغرافيا - كلية الآداب - جامعة المنوفية المؤتمر الجغرافي الدولي الثاني

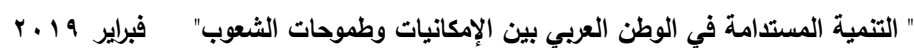

\section{خريطة(r).التركيب الجيولوجي في محافظة النجف}

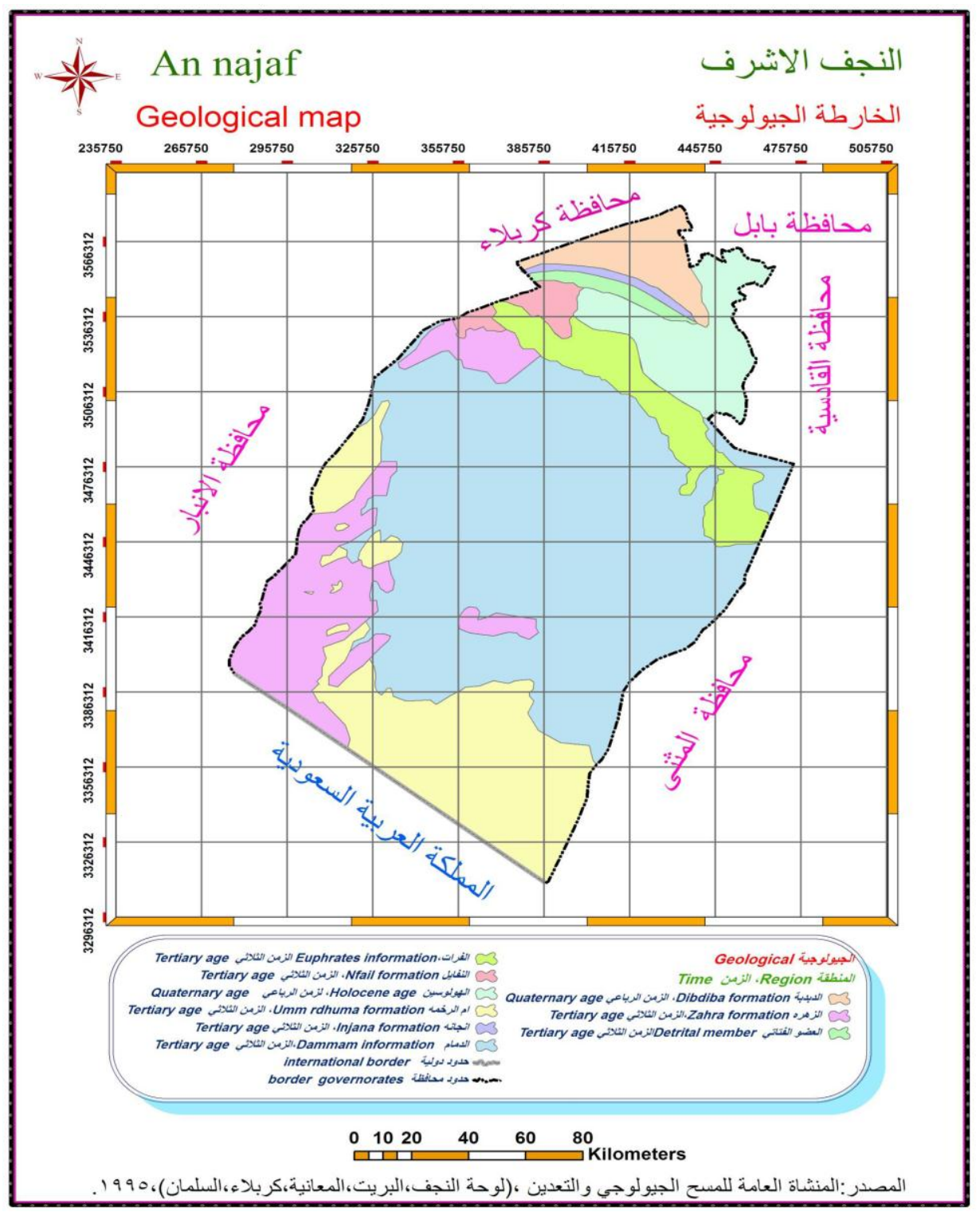




$$
\text { هـ نرسبات المستنقعات (هولوسين):- }
$$

معظم المكونات المهمة لترسبات المستنقع هي المواد العضوية وهي بأنثكال مختلفة

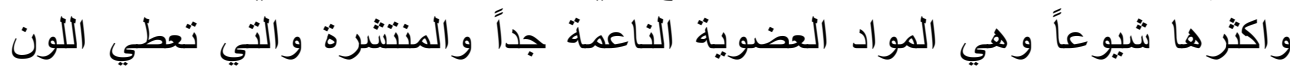

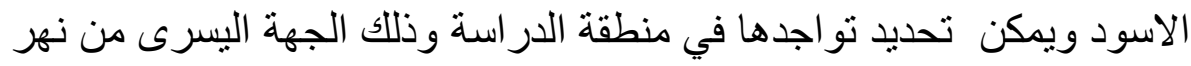

$$
\begin{aligned}
& \text { الفرات (شط العباسية ) والتي تسمى محليا بهور ابو نجم . } \\
& \text { 1- آ ترسبات من فعل الانسان : - }
\end{aligned}
$$

وهي الترسبات التي تتجمع نتيجة للنشاط الانسان وهي بقايا قتوات الري القديمة

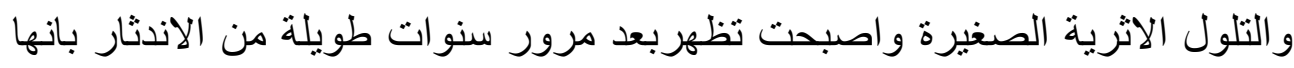

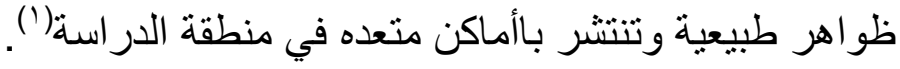

\section{ثانيا / الخصائص الطويوغرافية لمنطقة الدراسة :}

تعد التضاريس عاملاً جغر افياً مههاً في التصريف النهري عن طريق تحديد

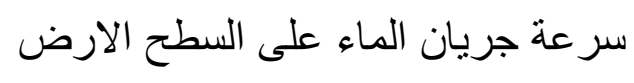

اذا تزداد سرعة جريانه السطحي في السطوح الثنديدة الانحدار مما يؤدي الى قصر التصر

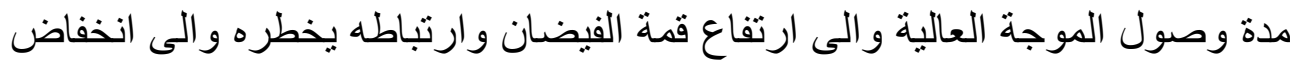

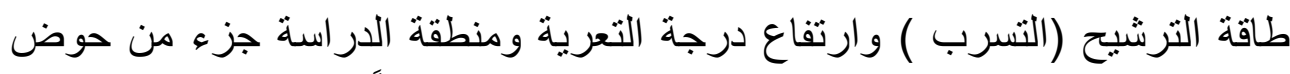

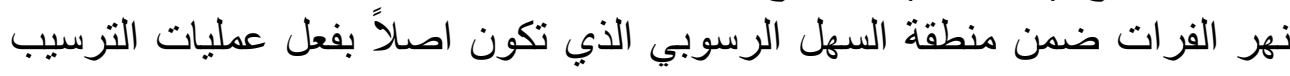

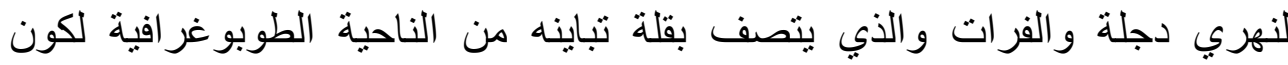

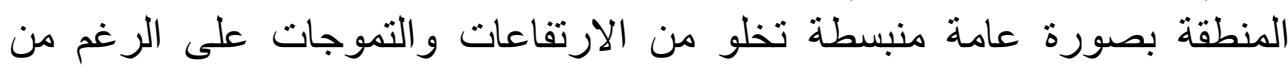

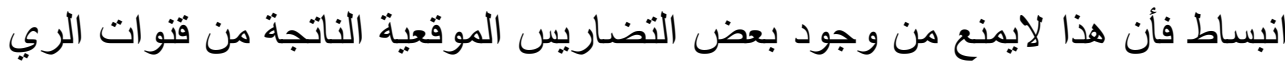

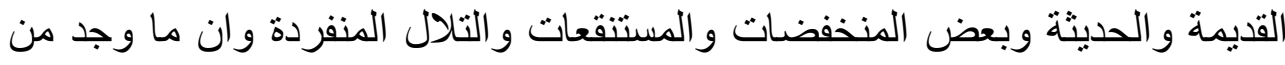

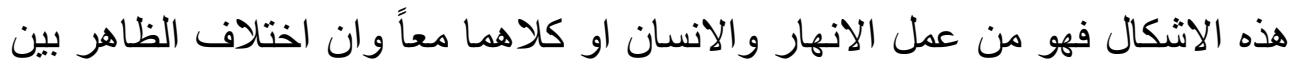

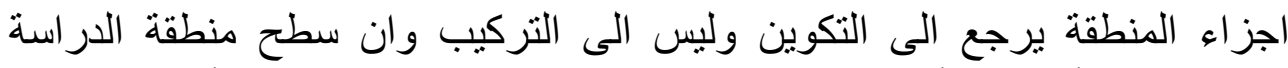

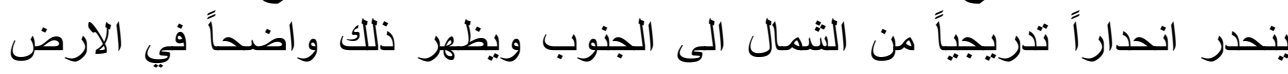

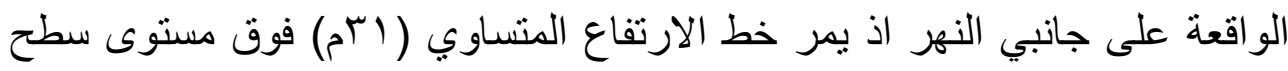

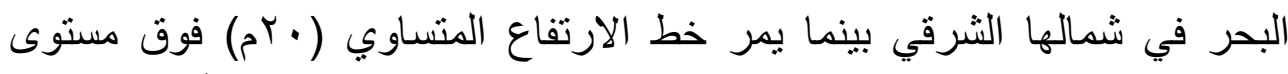

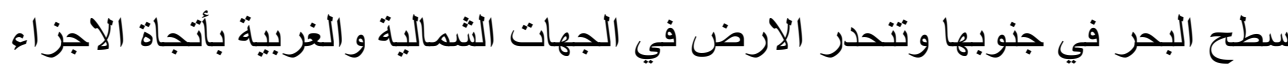


مركز البحوث الجغرافية والكارتوجرفية - قسم الجغرافيا - كلية الآداب - جامعة المنوفية الموتّمر الجغرفي الدولي الثاني

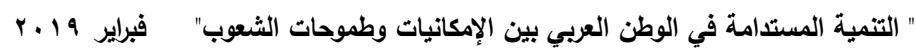

الثرقية والجنوبية الثرقية ولهذة الانحدارات واضحة مي جريان الكثير من القنوات

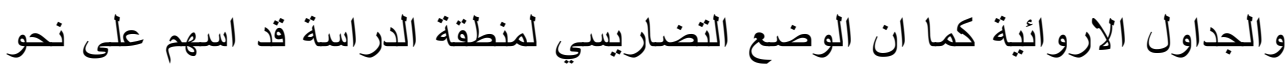

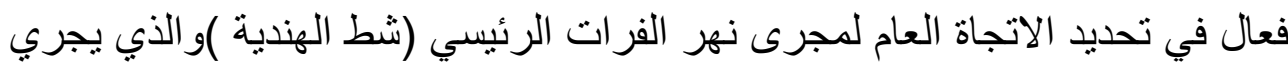

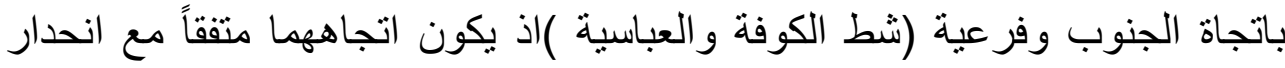

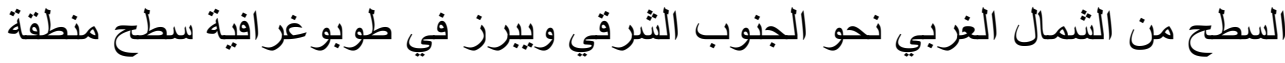

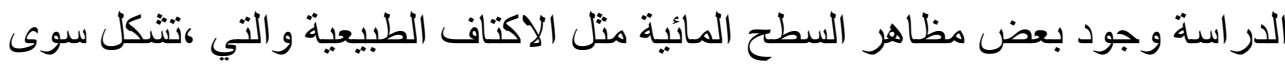

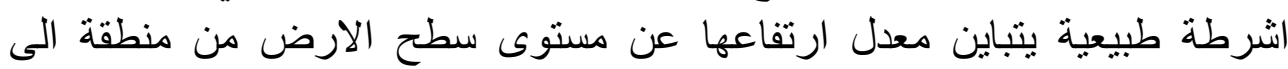

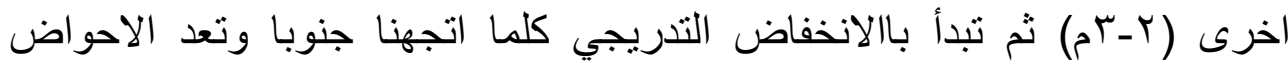

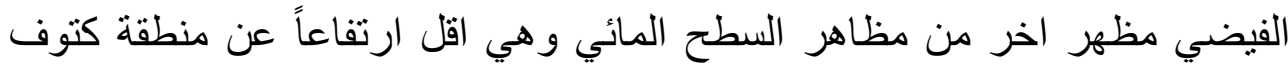

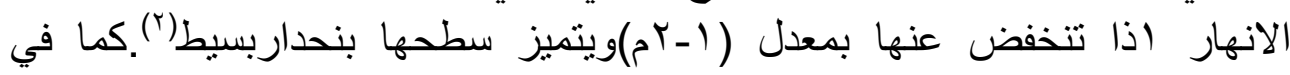
خريطة(r). (ذانهار) 
مركز البحوث الجغرافية والكارتوجرافية - قسم الجغرافيا - كلية الآداب - جامعة المنوفية المؤتمر الجغرافي الدولي الثاني

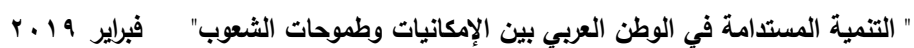

( (1)وسن محمد علي المكوطر الحسيني ، الخصائص الجيومورفولوجية لنهر الفرات وفرعية

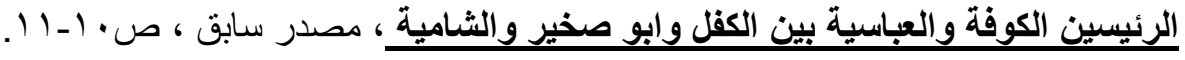

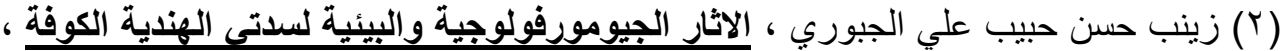

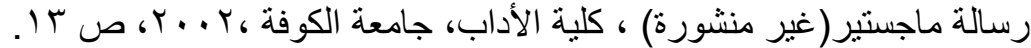

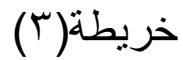

اقسام السطح في منطقة الدر اسة

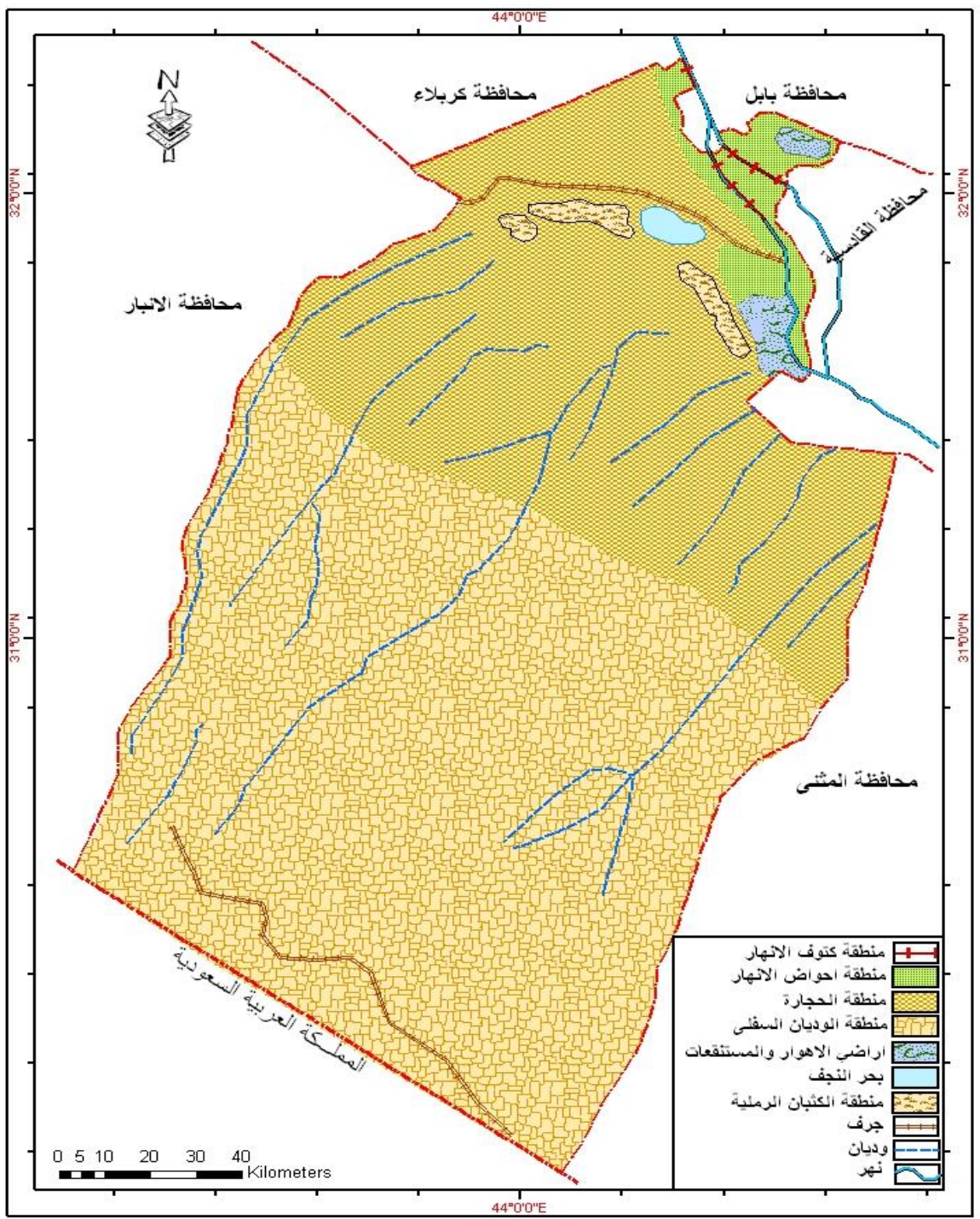

المصدر:- حمزية ميري كاظم الخزعلي ، مظاهر التصحر فى محافظة النجف وانعكاساتها على واقع

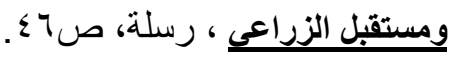




\section{ثالثاً/عناصر المناخ في منطقة الدراسة:-}

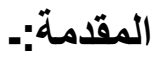

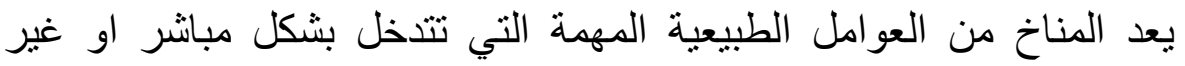

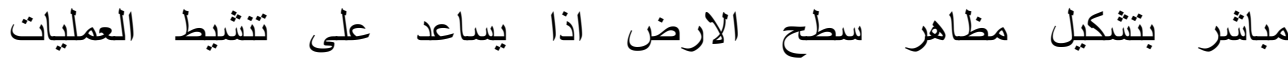

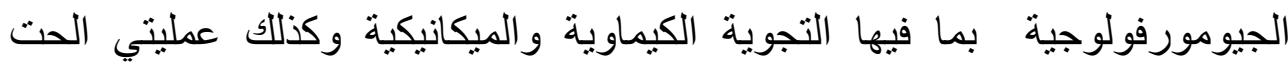

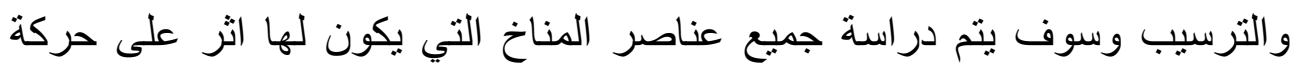
النهر و الاشكال الارضية التي توجد في منطقة الدراسة.

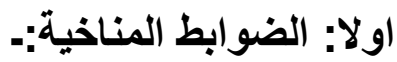

اــ الضوابط المناخية الثابتة :-

$$
\text { ا ـ الموقع الفلكي و الموقع الجغر افية :- }
$$

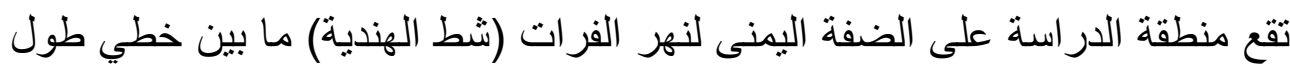

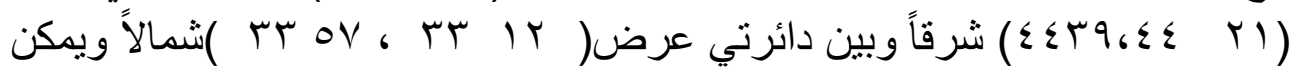

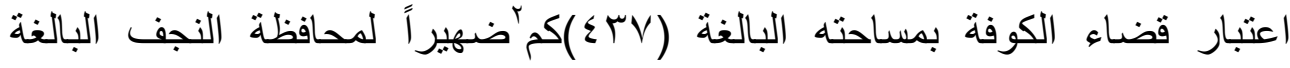

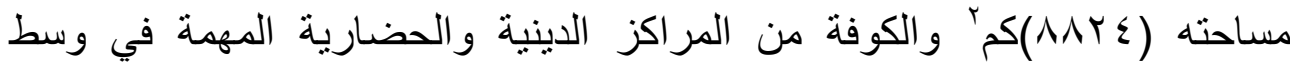

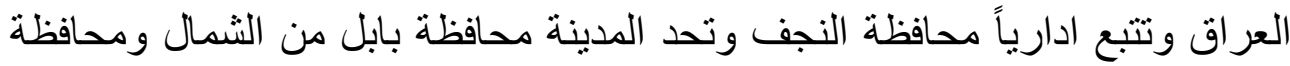

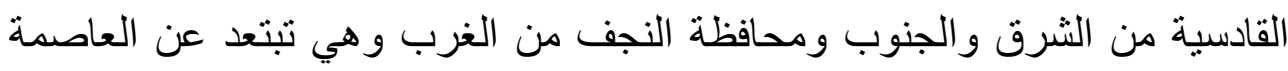

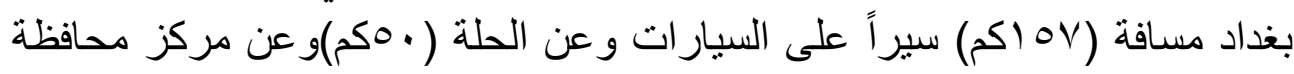

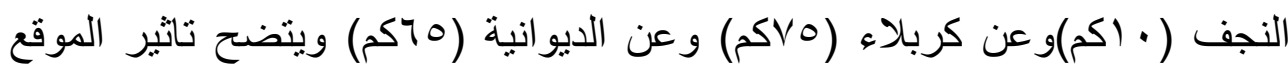

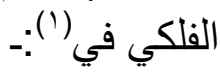

\section{solar Radiation}

الاشتعاع الشمسي وطول ساعات السطوع:-

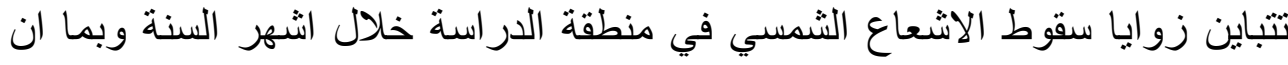

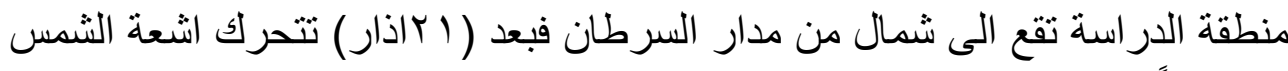

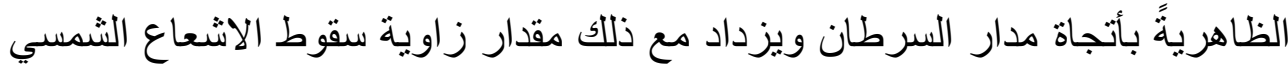

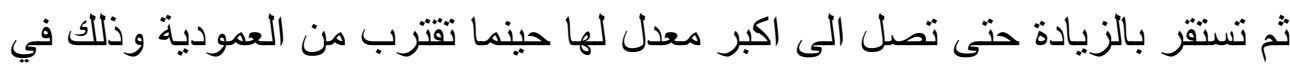

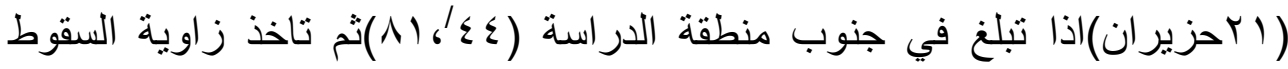

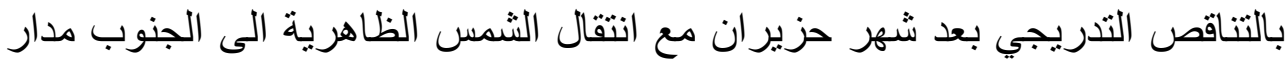


مركز البحوث الجغرافية والكارتوجرافية - قسم الجغرافيا - كلية الآداب - جامعة المنوفية المؤتمر الجغرافي الدولي الثاني

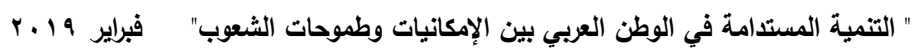

السرطان ويتحكم كبر وصغر زاوية سقوط الاشعاع الثمسي في عدد ساعات النهار

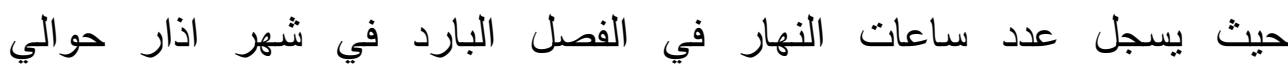

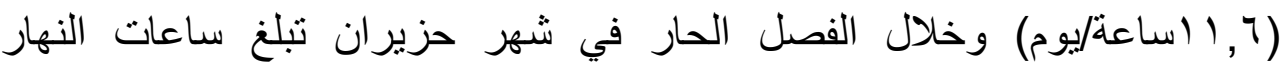

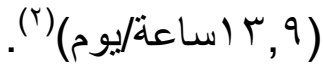

\section{ب ـ ـ الضوابط المناخية المتحركة:_}

تتميز هذه العو امل بانها ذات صفه متغيره و وتتأثر بحركة الثمس الظاهرية السنوية

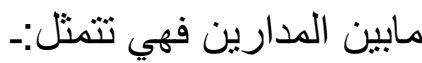
ا التوزيعات الضغطية.

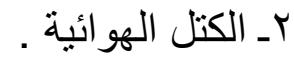

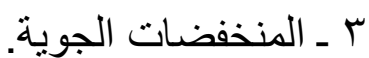

(1)سعدون شلال ،"خطة مدينة الكوفة وتطورها مورفولوجية مدينة الكوفة"، مجلة البحوث

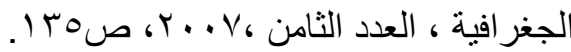

(r)علياء حسين سلمان البوراضي ، تقويم الوضع المائىـ الاروائي والاستغلال الامثل

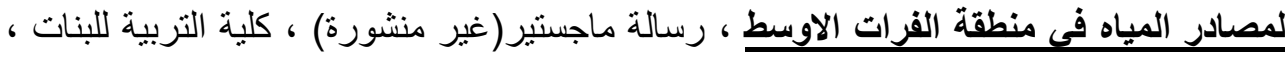

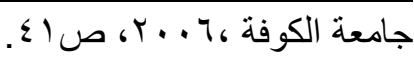

\section{رابعاً/ الخصائص المناخية:-}

يعد المناخ من العوامل الطبيعية التي لها اثرها الكبير على الانثطة الاقتصادية

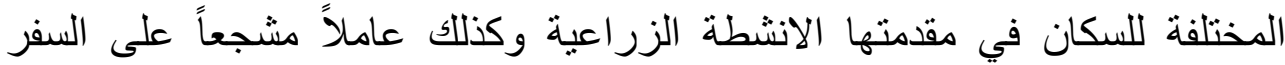
والسياحة وعلى امكانية تطوير الساحل الايمن لنهر الفرات ومن النه الهم عناصر المناخ كالأتي :- (n)

اــ درجة الحرارة:- ان السمات العامة لمناخ منطقة الدراسة هو حار جاف العاف صيفاً

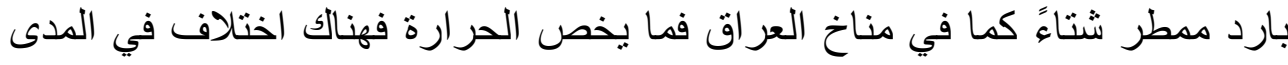


مركز البحوث الجغرافية وإكارتوجرافية - قسم الجغرافيا - كلية الآداب - جامعة المنوفية المؤتمر الجغرافي الدولي الثاني

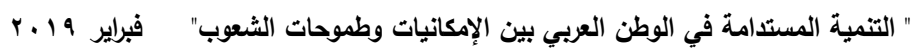

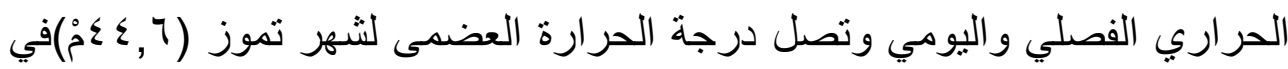

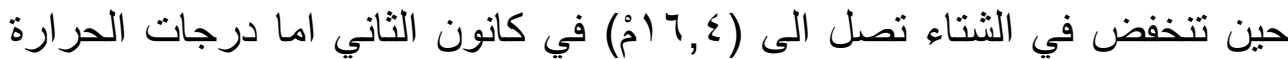

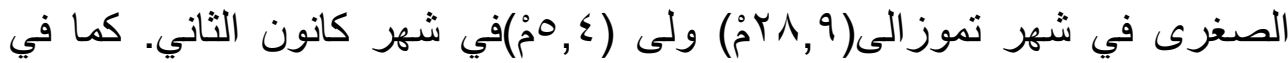

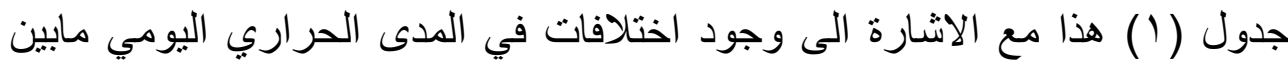
الليل والنهار ولكن ذللك لايمنع من ان تتمتع المناطق القريبة من النهر بجو معتدل التهائ ودرجات حرارة لطيفه خصوصا تللك التي تمند على ضفئة النهر.

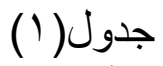

المعدلات الثهرية و السنوية لارجات الحرارة العظمى والصغرى و الددى لمحطة

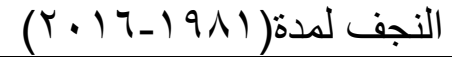

\begin{tabular}{|c|c|c|c|c|}
\hline المدى & المتوسط & معدلات درجة الصغرارة & الحرارة|العضمى درجى & الشهور \\
\hline 11 & $1 \cdot, 9$ & $0, \xi$ & 17,8 & كانون \\
\hline 11,1 & $1 \pi, 0$ & $V, 7$ & 19,8 & شباط \\
\hline$I r, \Lambda$ & $1 \Lambda, Y$ & 11,1 & $Y \leqslant, T$ & اذار \\
\hline $1 \pi, r$ & $r \leqslant, r_{0}$ & $I V, V$ & TI & نيسان \\
\hline $1 \leqslant, 7$ & $r \cdot \varepsilon$ & $r T_{1}$ & $r V, V$ & مايس \\
\hline 10,2 & $r \varepsilon, \tau$ & $r 7,9$ & $\varepsilon r, r$ & حزيران \\
\hline $10, V$ & r , Vo & $r \Lambda, q$ & $\varepsilon \varepsilon, 7$ & تموز \\
\hline 10,1 & $r q, r$ & $r \wedge, q$ & $\varepsilon \varepsilon, 1$ & اب \\
\hline 17 & Tr, & $r \leqslant, 7$ & $\varepsilon \cdot\rceil$, & ايلول \\
\hline $1 \leqslant, r$ & Y7,70 & 19,0 & $r r, \Lambda$ & تشرين \\
\hline$M, r$ & $1 \Lambda, r$ & $I Y, Y$ & $r \varepsilon, \varepsilon$ & تثنانين \\
\hline 11 & $I Y, Y$ & $V, r$ & $1 \Lambda, Y$ & كانون \\
\hline $1 T, V$ & $r \leqslant, 7$ & $I V, \Lambda$ & $r 1,0$ & المعدل \\
\hline
\end{tabular}

المصدر:- وزارة النقل و المواصلات ،الهيئة العامة للانواء الجوية و الرصد الزلز الي ،قسم المناخ ،بيانات غير منشورة 


\section{ب- بـ الضغط الجوي}

يعد الضغط الجوي عنصر مناخيا يتحكم في اتجاه الرياح وسرعنه الهيا كما ييرز

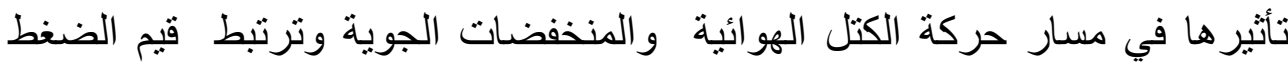

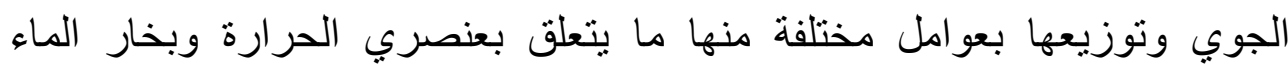

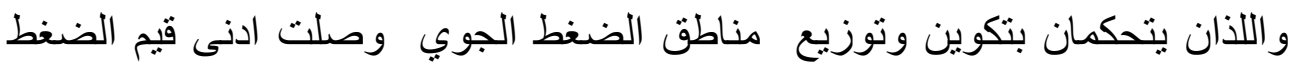

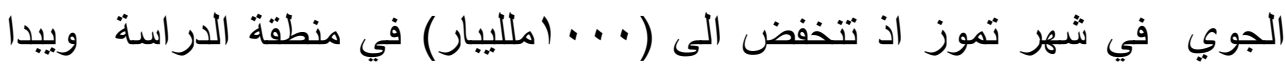

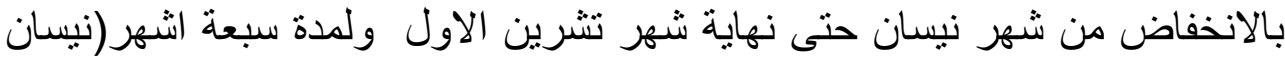

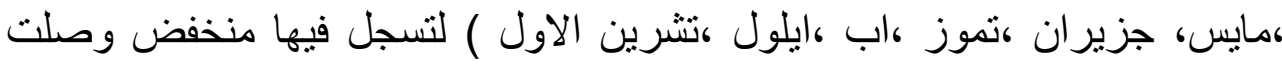

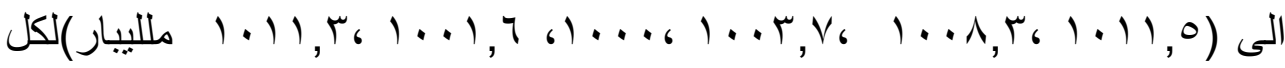

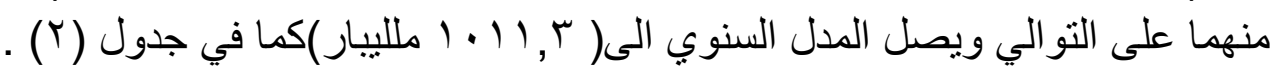

تعد الرياح من العناصر المناخية المهمة التي تلعب دورا مهما في زر اعة الئاح المحاصيل

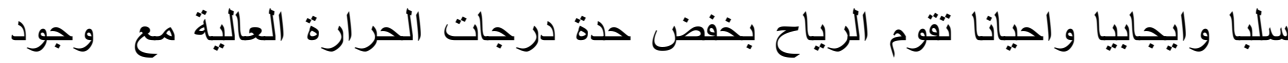

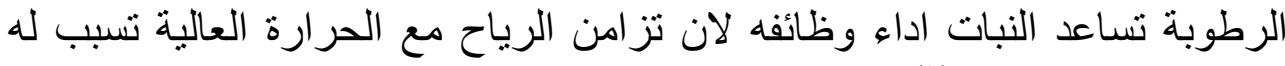

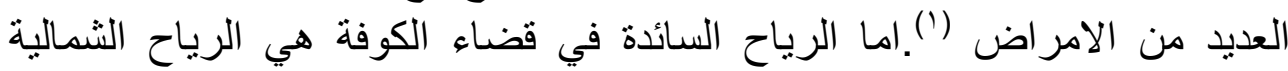

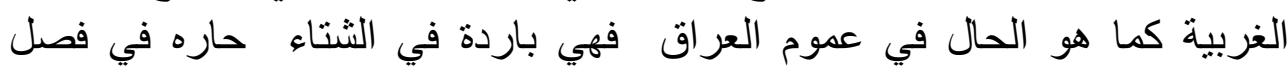

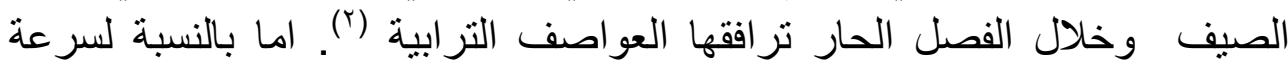

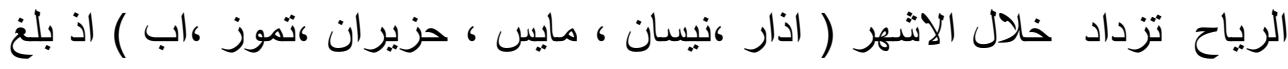

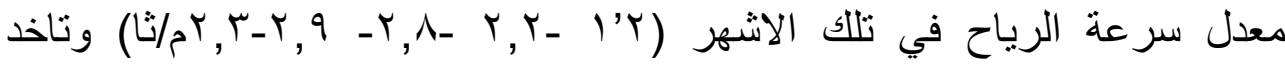

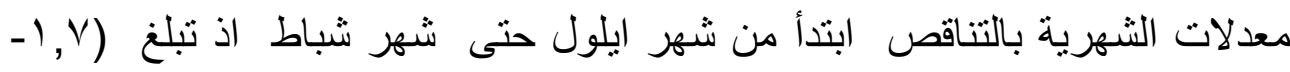

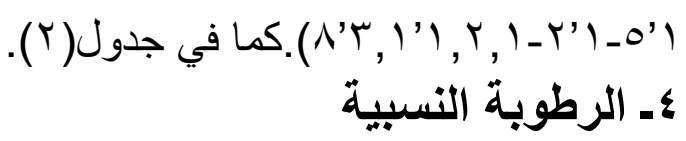

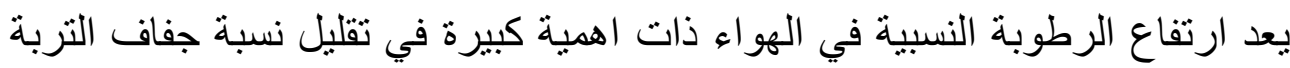

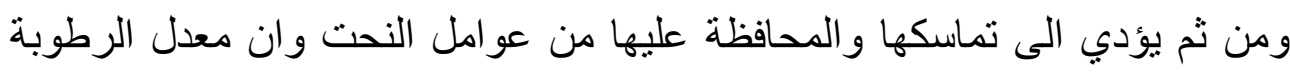

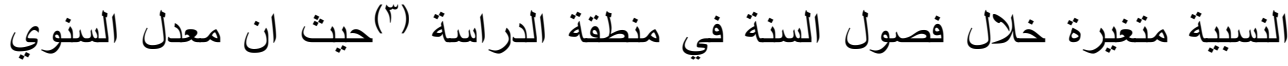

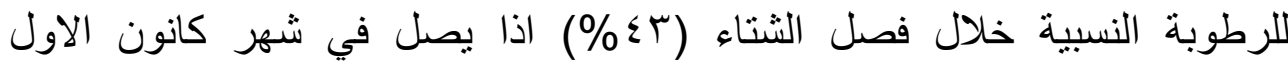

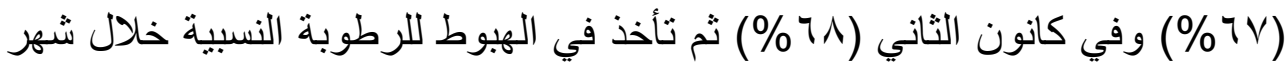

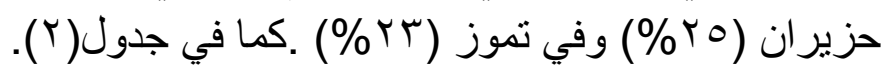


مركز البحوث الجغرافية والكارتوجرفية - قسم الجغرافيا - كلية الآداب - جامعة المنوفية الموتّمر الجغرفي الدولي الثاني

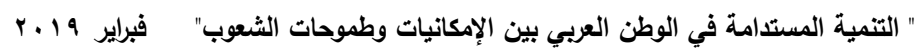

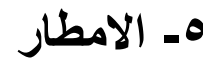

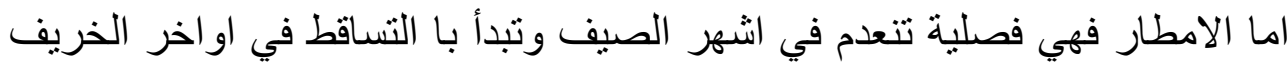

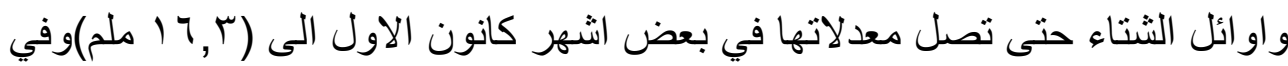

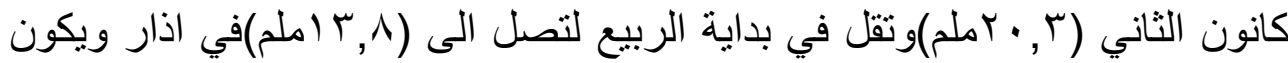

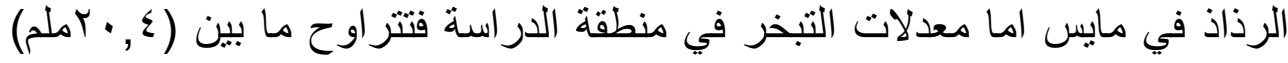

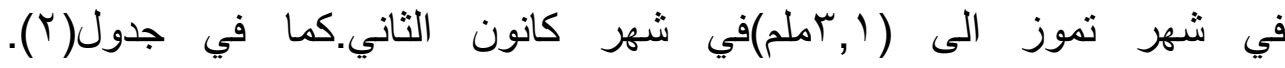

(1) (1) ريفاء نوري عيسى العنكوشي ،علاقة الخصائص المناخية بزراعة المحاصيل الزراعية في محافظة.

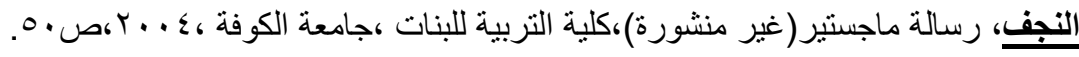

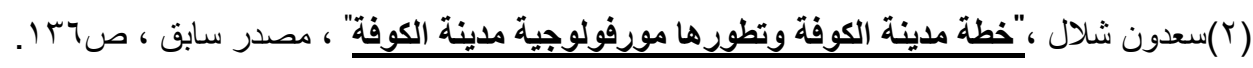

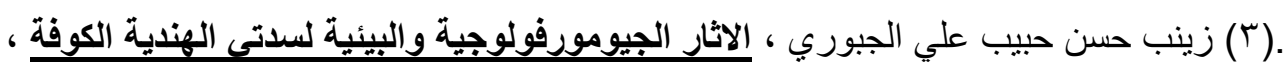

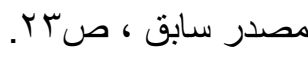


مركز البحوث الجغرافية والكارتوجرافية - قسم الجغرافيا - كلية الآداب - جامعة المنوفية المؤتمر الجغرافي الدولي الثاني

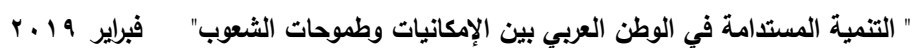

\section{جدول(r)}

المعدلات الثهرية والسنوية للضغط الجوي والرياح و الرطوبة النسبية والامطار

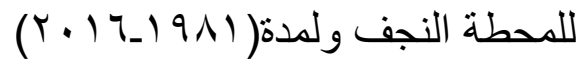

\begin{tabular}{|c|c|c|c|c|}
\hline قيم سقوط & الرطدلاث & سر الرياح(م/ثا) & 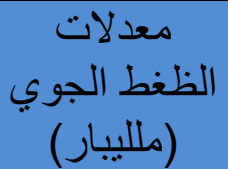 & الشهور \\
\hline$r \cdot, r$ & 71 & $1, r$ & $1.19,9$ & كانون الثاني \\
\hline $1 \leqslant, 9$ & 01 & 1,1 & $1.1 \mathrm{~V}, \mathrm{~A}$ & شباط \\
\hline $1 \pi, \Lambda$ & 0. & $1, r$ & $1 \cdot 1 \leq, 9$ & اذار \\
\hline $1 T, \mathrm{~V}$ & $\varepsilon r$ & $r, r$ & $1.11,0$ & نيسان \\
\hline$\varepsilon, \cdot 9$ & rT & $r, r$ & $\cdots \wedge, r$ & مايس \\
\hline - & ro & $r, \wedge$ & $1 \cdot r, v$ & حزير ان \\
\hline- & $r T$ & $r, q$ & $1 \ldots$ & تموز \\
\hline- & TE & $r, r$ & $1 \cdots 1,1$ & اب \\
\hline- & rq & $1, V$ & $1 \cdot V$ & ايلول \\
\hline$r, 7$ & $\varepsilon$. & 1,0 & $1.11,1$ & تشرين الاول \\
\hline 11,7 & $O V$ & $1, r$ & 1.11 & تشرين الثاني \\
\hline $17, r$ & $7 V$ & $1, r$ & $1 . r$. & كانون الثاني \\
\hline $9 \wedge, r$ & $\varepsilon r$ & 1,9 & $1.11, r$ & المعدل \\
\hline
\end{tabular}

المصدر :- وزارة النقل و المو اصلات ،الهيئة العامة للانو اء الجوية و الرصد الزلز الي ،قسم المناخ ،بيانات

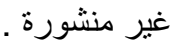




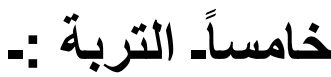

تعد التربة احد العناصر الطبيعية والتربة هي الطبقة العليا المفككة والهثة

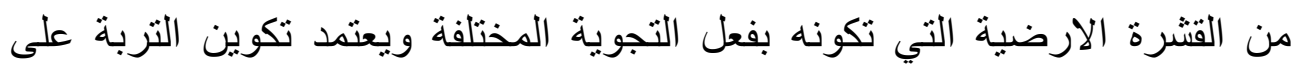
عو امل عديدة منها صخور الاساس والظروف المناخية و النبات الطبيعي و التباين في التضاريس الارضية فضلا عن عامل الزمن وتتصف تربة منطقة الدر اسة بانها تربة

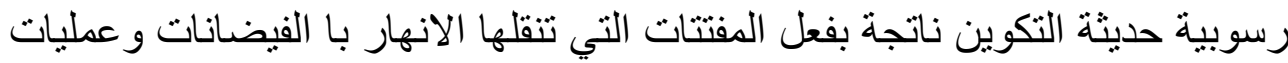

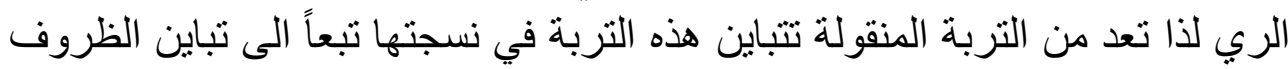

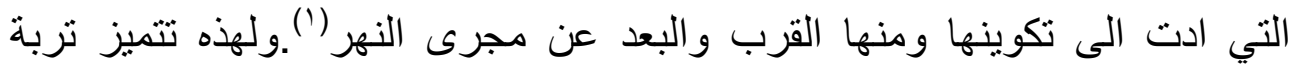

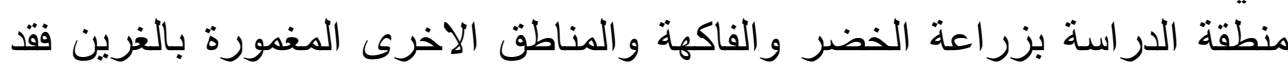

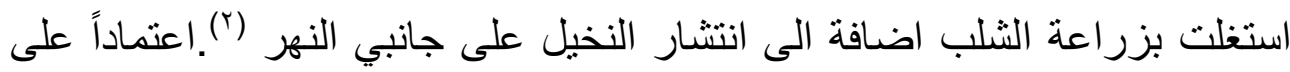
ذللك يمكن تقسيم التربة في منطقة الدراسة الى الانواع الاتية:-

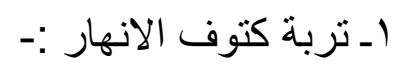

تغطي هذه التربة مساحات ضيقة ويتموج سطحها قليلاً او كثير اً حسب موقعها وهي

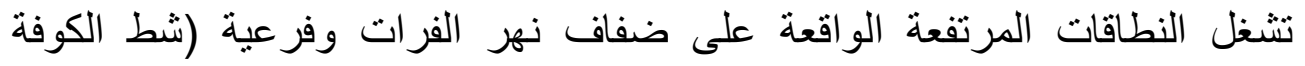

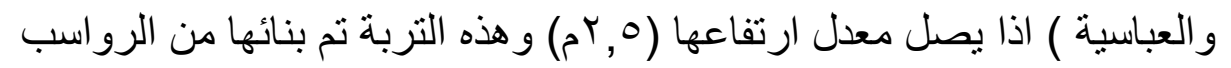
الحديثة التكوين المنقولة بو اسطة الفيضانات المتكررة لنهر الفرات وتتميز تربة تربة كتوف الانهار بجودة صرفها السطحي نظر اً لانحدار ها باتجاه النهر و انحدار ها ايضياً

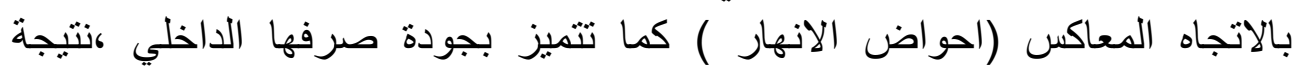
لخشونة مكوناتها فهي تربة ذات نسجه خشنة وتثمل النسجة المزيجية و النسجة

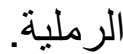

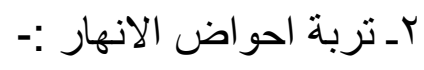

تغطي هذه التربة مساحات واسعة على جانبي فرعي نهر الفرات ( شط الكوفة

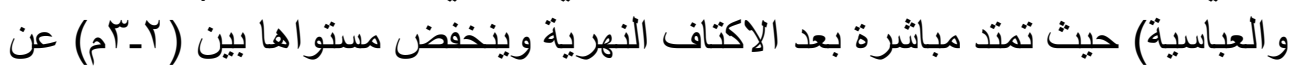
مستوى تربة كتوف الانهار وقد تكونت من تجمع الترسبات الناعمة التي نقلتها مياه

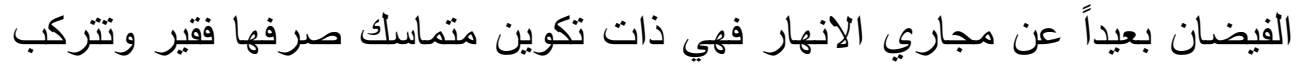


مركز البحوث الجغرافية والكارتوجرافية - قسم الجغرافيا - كلية الآداب - جامعة المنوفية المؤتمر الجغرافي الدولي الثاني

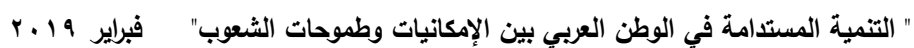

من الطين و المزيج الطيني الغريني تزداد نسبة الطين في نركيبها اذا يتراوح ما بين

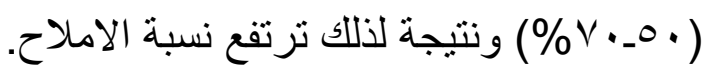
rـ تربة صحر اوية جبسية مختلطة:تسود منطقة الدراسة الو اقعة غرب شط الكوفة وتشكل المادة الاساسية لهذه التربة من

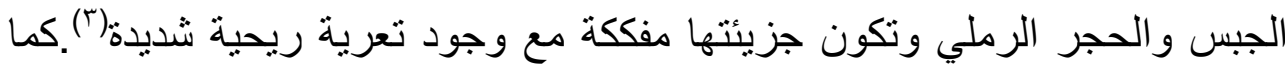
في خريطة (ع) الجنين

( ) زينب حسن حبيب علي الجبوري ،الاثار الجيومورفولوجية والبيئية لسدنى الهندية والكوفة ،

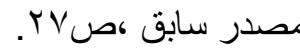

(r) سعدون شلال ،"خطة مدينة الكوفة وتطورها مورفولوجية مدينة الكوفة" ، مصدر سابق ،

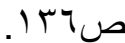

(r) وسن محمد علي الدكوطر الحسيني ،الخصائص الجيومورفولوجية لنهز الفرات وفرعية

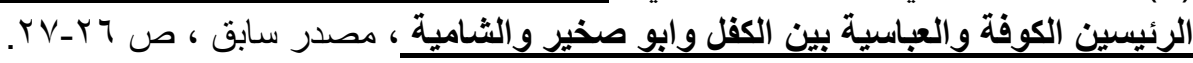


مركز البحوث الجغرافية والكارتوجرافية - قسم الجغرافيا - كلية الآداب - جامعة المنوفية المؤتمر الجغرافي الدولي الثاني

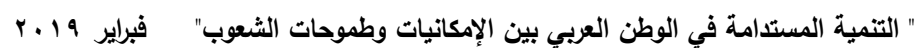

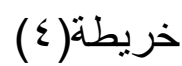

انو اع الترب في قضاء الكوفة

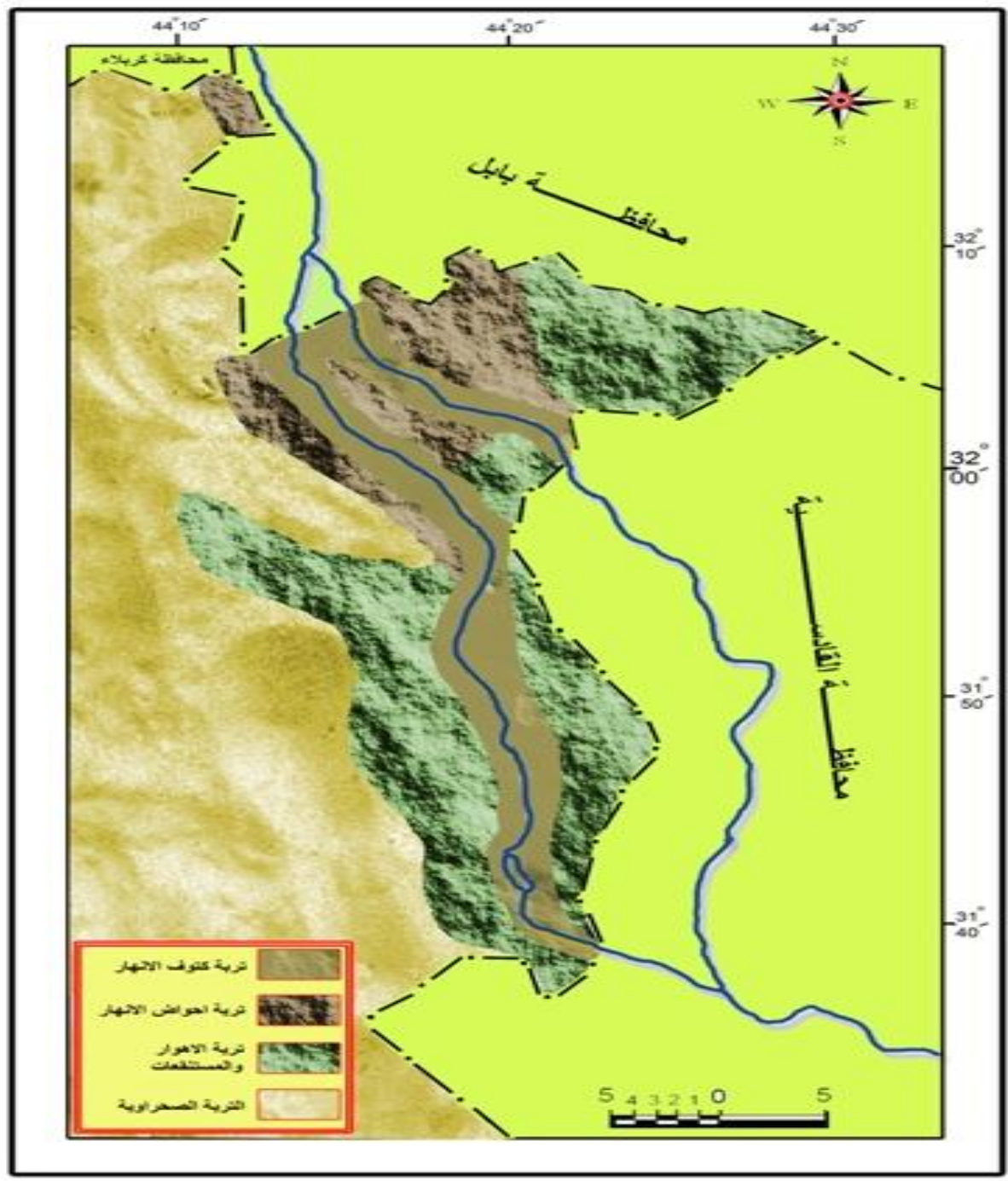

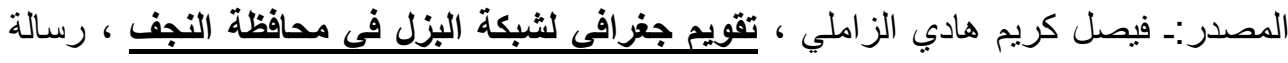

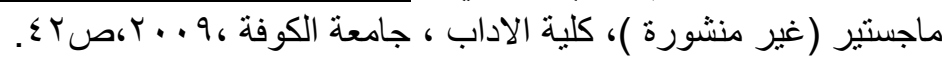




\section{سادساً/ ـ الموارد المائية والنبات الطبيعي:-}

تعد الموارد المائية في اي منطقة العمود الفقري الذي تعتمد علية الانشطة

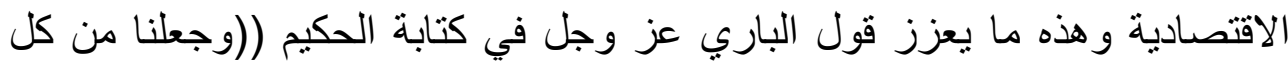

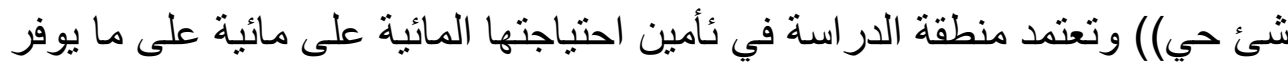

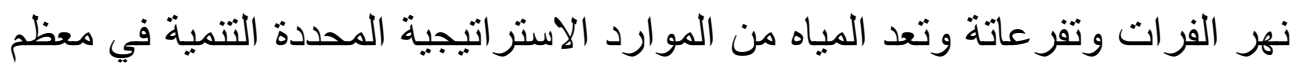

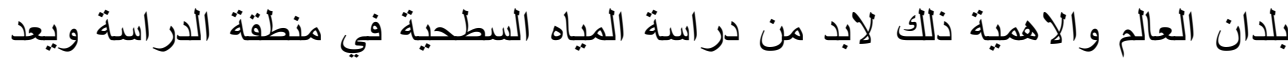

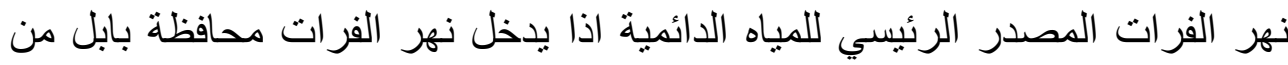

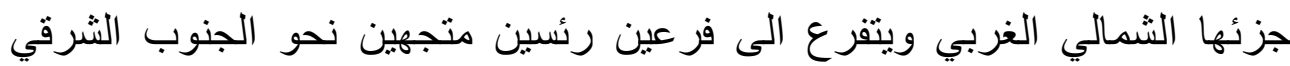

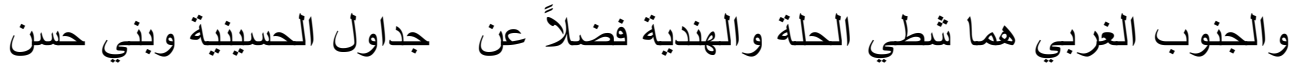

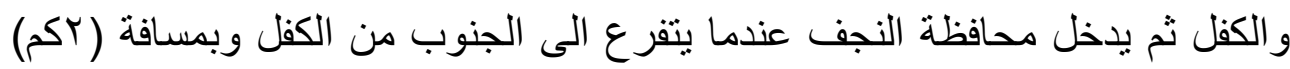

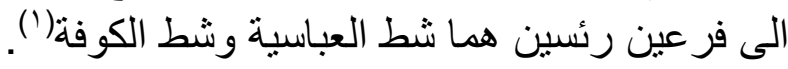

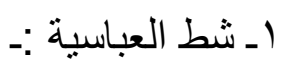

يجري شط العباسية في المحافظة بموازية شط الكوفة ويقطع مسافة اقصر مما يقطعة شط الكوفة ويتميز بقلة الجداول مقارنة مع شط الكوفة وتتحصر تفرعات الجانب الايمن ضمن الحدود الادارية لناحية العباسية فبعد اجتياز الثط مركز ناحية العباسية يخرج من جانبه الايمن جدول العياشي الذي يبلغ طوله (... (1) كم

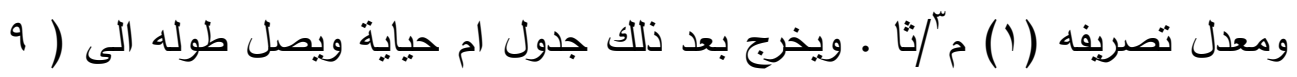

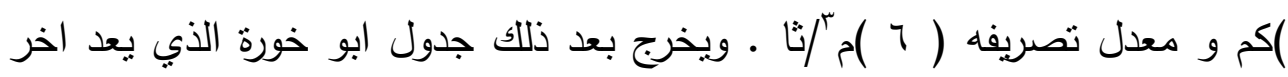
تفرعات هذا الجانب من الثط في المحافظة . وييلغ طوله ( م ) كم وبمعدل تصريف( ) م"ّاثا يخرج من الجانب الايسر شط العباسية مجموعة من الجداول اولها جداول (الحيدري والعدل ) ويصل طولهما (1/ ، ، ؛) كم على التوالي ومعدل

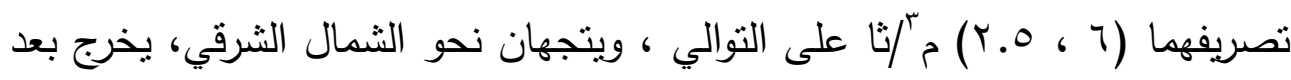
عدة كيلو مترات من سدة العباسية المقامة على المجرى الرئيس للثط ومن هذا

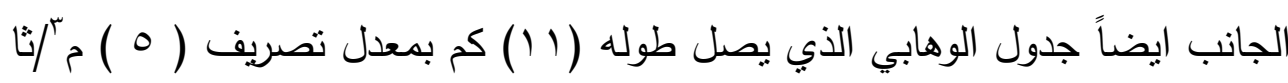


مركز البحوث الجغرافية والكارتوجرافية - قسم الجغرافيا - كلية الآداب - جامعة المنوفية المؤتمر الجغرافي الدولي الثاني

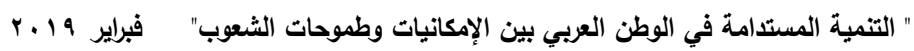

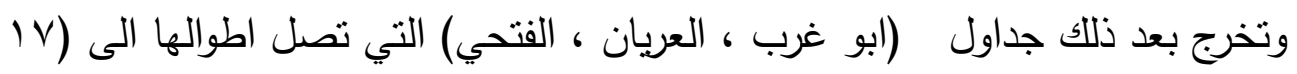

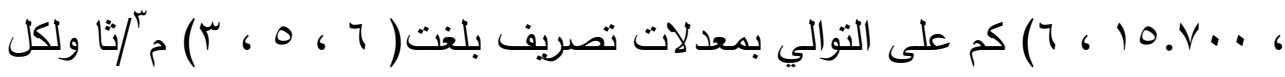
منها وعلى التوالي ، وتتنهي جميع تلاك الجداول بالاراضي الزراعية التي كان يشغلها هور ابن نجم الذي يعد الفاصل الطبيعي بين المحافظة ومحافظتي بابل والقادسية وقبل خروج شط العباسية من المحافظة يخرج منه الجدول الاخير جدول الخماسي بهي لهي الذي يعد اطول الجداول المتقرعة من الثط ، ويصل طوله( 11 (1 ) كم بمعدل

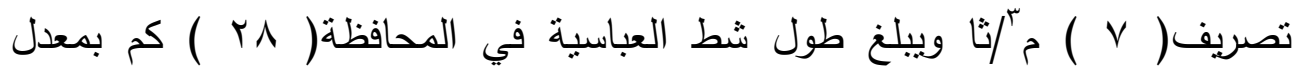

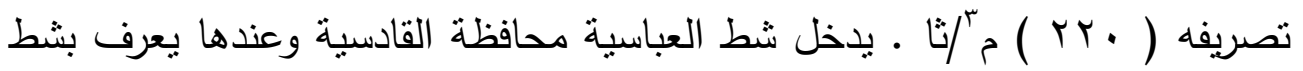

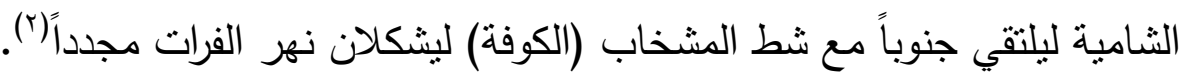

(1) منيرة محمد مكي ، الخصائص الجغرافية في منطقة الفرات الاوسط وعلاقتها المكاني بالتخصص الاقليمي ، رسالة ماجستير (غير منشورة)، كلية التربية للبنات ،جامعة الكوفة ، ، . r. ص D n (r) مثنى فاضل الوائلي ، المولزنة المائية المناخية في محافظة النجف ، دراسة في المناخ التطبيقي ، رسالة ماجستير (غير منشورة) ، كلية الاداب، جامعة الكوفة ، ع . . ، ، صـ00. 


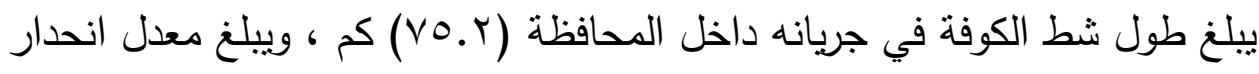
المياه بين الكفل والمناذرة (سو . . . . ) اما معدل التصريف المائي للشط فيتراوح بين

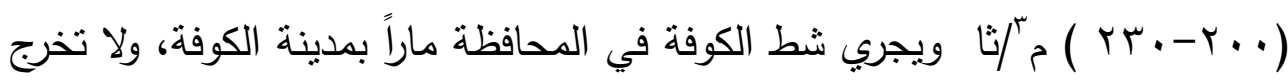
منه أي تفرعات حتى دخوله قضاء المناذرة (ابو صخير) ، اذ بطلق عليه عند المدينة الاخيرة وحتى خروجه منها بشط المشخاب وقد انثأ عليه فيها ناظم المشخاب . وتخرج عندها مجموعة من الجداول من ضفتي الثط اليمنى واليسرى ويعد جدول جحات اول تفرعات الجانب الايمن للشط ويصل طوله (ـ ا.0ب ) كم منها في قضاء

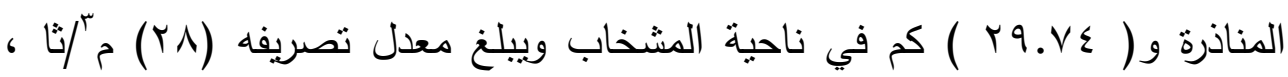
وتخرج من جدول جحات ومن ضفته اليمنى مجموعة من الجداول هي (السدير ، ؤابو جذوع ، البديرية ، الهاشمي ) على التوالي ويكتسب جدول السدير اهمية خاصة كونه الجدول الوحيد الذي تعتمد عليه الاراضي الزراعية في منخفض بحر النجف فضلاً عن الاراضي الزراعية شمال مدينة الحيرة ويمتد بأتجاه شمالي غربي ويصل طوله

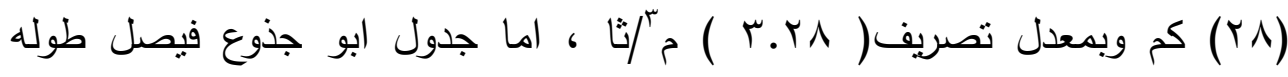

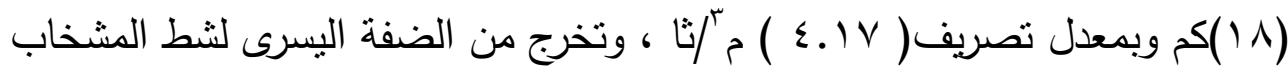
(الكوفة) مجموعة من الجداول ، تتميز بقصر اطوالها وقلة معدلات تصريفها مقارنة مع تقرعات الضفة اليمنى ، ويكون اول تلك التقرعات جداول (كثخيل ، العارفي ،

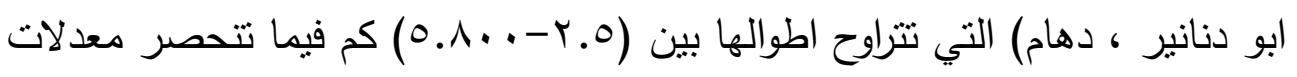

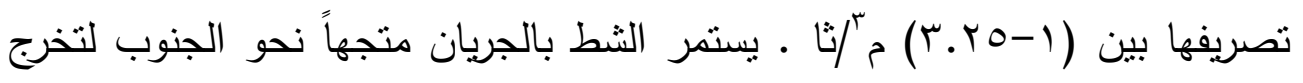
من ضفته هذه مجموعة اخرى من الجداول اهمها جدول الجنابية اليسرى الذي يجري 
مركز البحوث الجغرافية والكارتوجرافية - قسم الجغرافيا - كلية الآداب - جامعة المنوفية المؤتمر الجغرافي الدولي الثاني

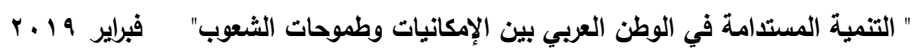

نحو الجنوب وبموازاة الثط ويبلغ طوله( . . (.7) كم وبمعدل تصريف ( . ( ) م"آزا(")كما في خريطة (V). ويجري شط الكوفة في ارض رسوبية قليلة الانحدار الامر الذي يؤدي الى زيادة الترسبات على قاع المجرى وهو عرضة للألتواء والتحول والزحف بسبب طبيعة المنطقة اذا ان ظاهرة المنعطفات النهرية تعتبر طبيعة اذا ان الانهار لاتتقى مستقيمة ان من جملة الاسباب المعروفة لحدوث ظاهرة المنعطفات النهرية في هذه المنطقة مايأتي:-

اــ ميل مجاري انهار المنطقة الى النحت الجانبي على حساب النحت الرأسي وتعميق النهر لمجراه بسبب قلة انحدار السطح الارضي الذي يبلغ (لسم/كم). r- تأثير مجرى نهر الفرات بانقسامه في هذه المنطقة الى فرعين من ذلك يؤدي وبشكل عام الى انخفاض طاقة النهر على حمل الرواسب حيث تتخفض سرعة وتتوزع طاقته وتتتتت فيميل الى تكوين المنعطفات .

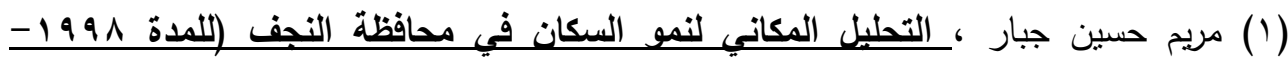

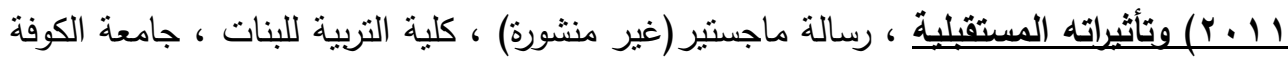
.00 D. T.1T، 
مركز البحوث الجغرافية والكارتوجرافية - قسم الجغرافيا - كلية الآداب - جامعة المنوفية المؤتمر الجغرافي الدولي الثاني

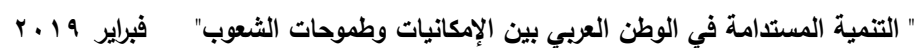

خريطة (0)

الموارد المائية في منطقة الدراسة

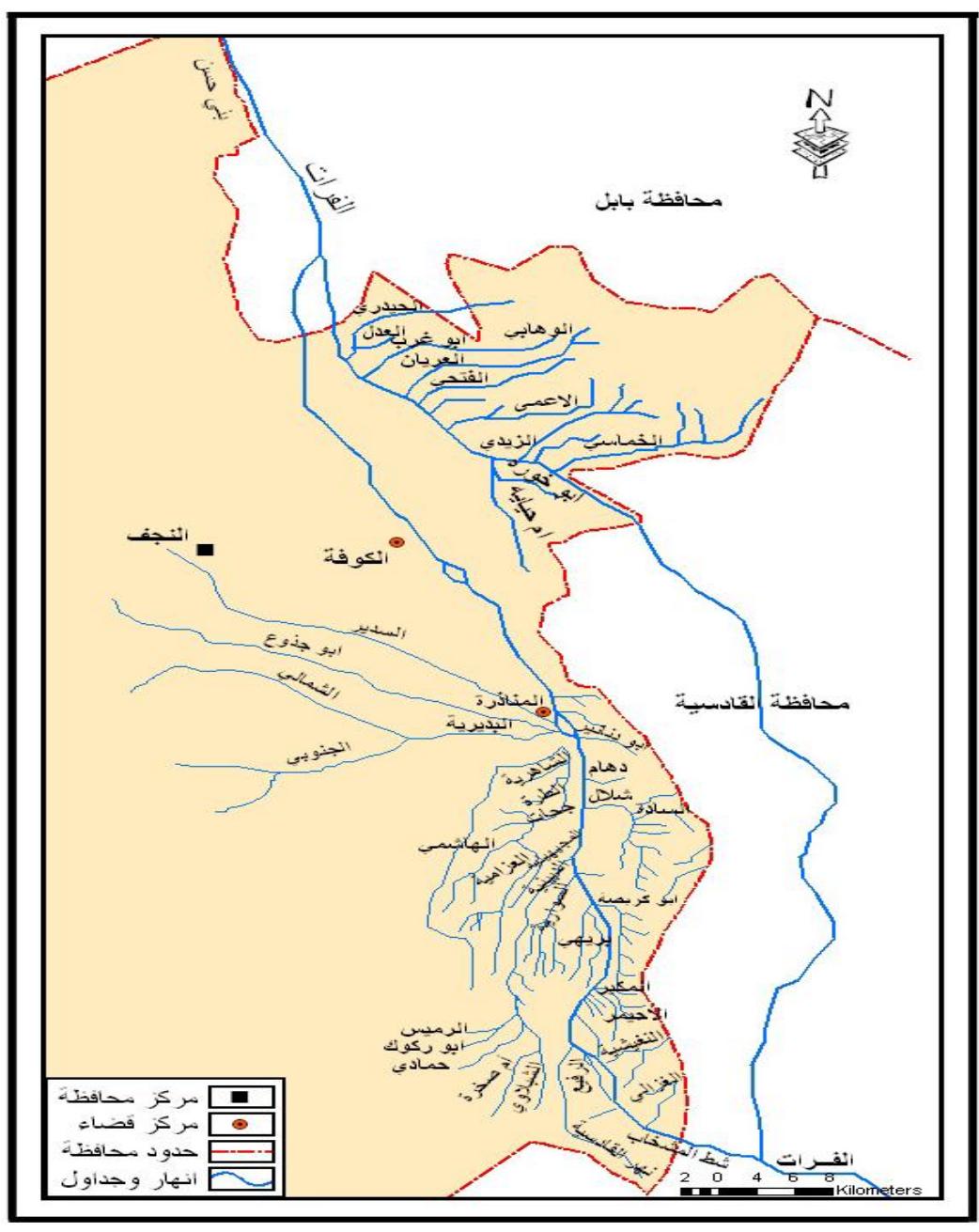

المصدر :- مريم حسين جبار ، التحليل المكاني لنمو السكان في محافظة النجف (للمدة 1991-

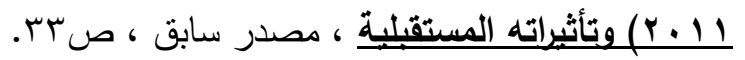


مركز البحوث الجغرافية والكارتوجرافية - قسم الجغرافيا - كلية الآداب - جامعة المنوفية المؤتمر الجغرافي الدولي الثاني

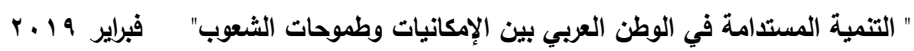

r- وجود مكاشف صخرية في قاع مجرى شط الكوفة في مناطق ابو صخير مما يؤدي الى ميل النهر في الانتقال نحو النحت الجانبي •

عـ تأثثر التركيب الجيولوجي في سير مجرى النهر وتقرعاته واتجاهاته وهو ما توضحه المنعطفات الحاده في مجاري انهار المنطقة مما يؤدي الى انحرافه عن الخط المستقيم النظري وبالتالي انحرافها الثديد وهو ما يحدث في بعض اجزاء مجاري هذه المنطقة خاصة في شط الكوفة المحاذي للهضبة الغربية عند منعطفات(ال ماضي-ال بو عجيل -علوة الفحل وحاج حمزة) في شط الكوفة . 0- حدوث انهيارات في جروف انهار هذه المنطقة وتتساقط نراكمات داخل المجرى النهري مما يؤدي الى اندفاع التيار لتعرية الجهة المقابلة وبالتالي بداية تكوين المنعطفات('). اما النبات الطبيعي فلة دور كبير في المحافظة على ضفاف الانهار من خلال جذورها التي تقوي وتزيد من تماسك التربة والقاع اضافة الى دورها في عرقلة سرعة حركة المياه الجارية وبالتالي تقليل فعالية الحت المائي وبصورة عامة ينركز النبات الطبيعي في منطقة الدراسة بصورة عامة في الجزر النهرية وعند ضفاف الانهار ويقل بالابتعاد عن اكتاف لجافي الانهار نحو ارض السهل الفيضي ومن اهم النباتات التي نتمو في المنطقة نبات القصب الذي يعد اكثر النباتات كثافة وانتشاراً حيث يشغل الجزر النهرية وجزءً من الضفاف النه وبليه نبات الطرفة والغرب والعوسج والصفصاف كل هذه النباتات تتواجد على ضفاف مجرى وجرى النهر اضافة الى العاقول والحلفا والطرطيع وهنالك نوع اخر من النباتات لا يمكن اهماله ينمو في مجرى النهر يطلق علية السكان المحليون اسم الشنبلان (؟).

(1) سرحان نعيم الخفاجي ، مراحل تظور المنعطفات النهرية لمجرى نهـ الفرات بين الكفل والثامية واثثها على الملكيات الزباعية، ، مجلة البحوث الجغرافية ، العدد التاسع ، ^... ؟،

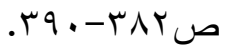

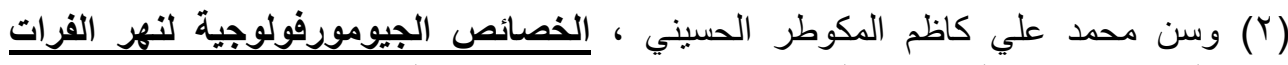

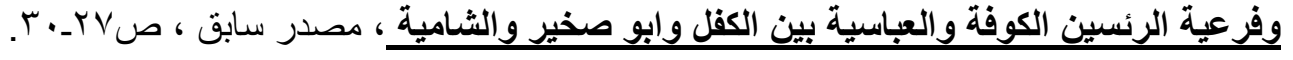




\section{(2) (2) (t) \\ أم \\ المفاهيم الاساسية في السباحة:-}

تعرف السياحة بأكثر من تعرف وكل منها يختلف عن الاخر بقر اختلاف

الزاوية التي ينظر منها الباحث الى السياحة بعظهم يعرف السياحة بأنها ظاهر اجتماعية والبعض الاخر بأنها ظاهر اقتصادية (اوانها رحلات ترفيهية وكل ما بتعلق بها من انشطة واشباع الحاجات والرغبات ) او (انها مجموعة العلاقات السلمية والرياضية الناتجة عن الاتصال بين الاشخاص الذين بزورون مكان ما وسكانه لأسباب اخرى غير الاسباب المتعلقة بالمهن ) ،ان تتوع الامكانات الطبيعية له تأثير تتشيط الحركة السياحية فكلما تتوعه الموارد الطبيعية تتوعت الانشطة السياحية التي يمارسها السياح ويلاحظ ان معظم الدول العربية ومنها العراق تعاني وبدرجات متفاوتة بشكل او بأخر من تدهور الموارد السياحية وارتفاع معدلات التلوث التي تؤثر على صحة المواطنين لذا يتطلب وضع الخطط والبرامج والاساليب السليمة لتحسين نوعيته البيئية وضمان الاستخدام الامتل للموارد بما يخفف الظروف الصحية والنفسية والمعيشية الملائمة للأنسان('). وقد اصبحت السياحة مجرد مظهر من مظاهر الانسحاب من الحياة اليومية الروتينية وقد تكون السياحة بصوره او اخرى سبيلا او اداة لتجديد الصحة النفسية والمعنوية للانسان واعادة بناء توازنه الفعلي والعاطفي ومن هنا نلمح مدى التطور في مفهوم السفر للسياحة فقد اصبح حاجه انسانيه ضرورية

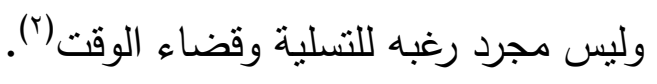


مركز البحوث الجغرافية والكارتوجرافية - قسم الجغرافيا - كلية الآداب - جامعة المنوفية المؤتمر الجغرافي الدولي الثاني

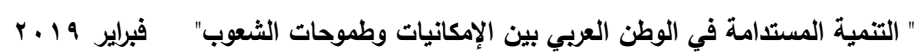

\section{الهم المناطق الترفيهة والسياحية واسباب عدم تنميتها المحور الاول / كورنيش شط الكوفة:-}

ان شط الكوفة الذي يمر بمدينة الكوفة هو الفرع الثاني من نهر الفرات الذي يعد جزءً من الموارد المائية وعلى الرغم من ذلك فهو بحتوب على امكانات جمالية تمثلت بمنظر الجميل فيقصده سكان منطقة الدراسة في فصل الصيف نتيجة لارتفاع درجات الحرارة فيلجأ الناس للمتعة والمشاهدة اذ ان وجود بعض القوارب النهرية التي تقدم المشروبات الغازية والعصائر والاطعمة للمنتزهين التي يبلغ عددها (جب) ما بين مطاعم واكثاك وهذا بدوره يساعد على جذب الوافدون من الاهلي وخصوصاً في ايام العطل والمناسبات اذ يكون ممراً لحفلات الزفاف وقد ساعدت طرق النقل التي تمر على كورنيش شط الكوفة في جذب الوافدين وقربة من المزارات الدينية اذ ان بعض الوافدون الذين يزورون المراقد المقدسة يتجهون الى مثاهدة المنظر الطبيعي المتمنل بشط الكوفة وتبدء اماكن الاكثاك بالارتفاع اسعار الايجار وخصوصاً في موسم العطل الصيفة اذ يكون الاعتماد على

(1) عايد جاسم الزاملي ومثنى فاضل علي ، المقومات الطيعية لمحافظة النجف الاشرف

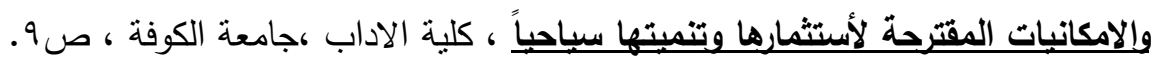

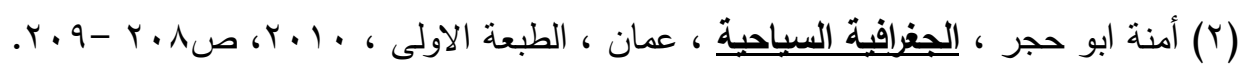


مركز البحوث الجغرافية والكارتوجرافية - قسم الجغرافيا - كلية الآداب - جامعة المنوفية المؤتمر الجغرافي الدولي الثاني

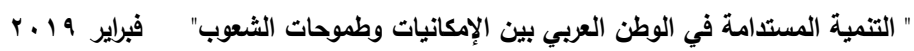

الاهلي سواء الساكنين في مدينتي النجف والكوفة وقد بلغ غدد العوائل الوافدة الى كورنيش

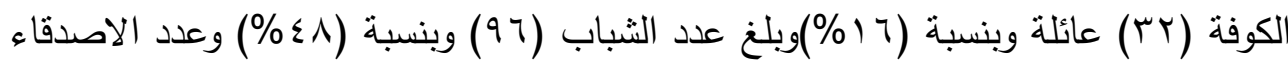

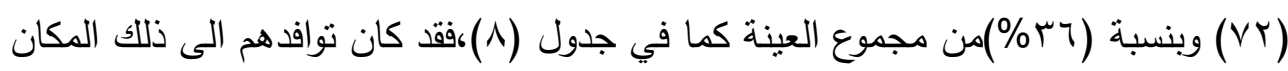

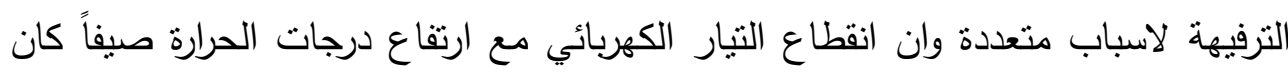

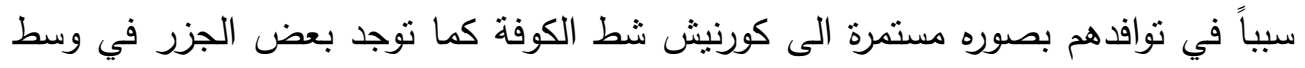

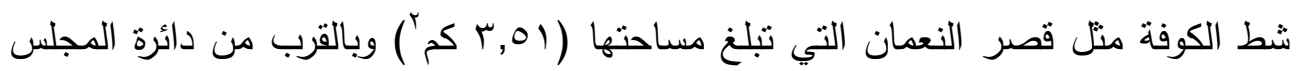

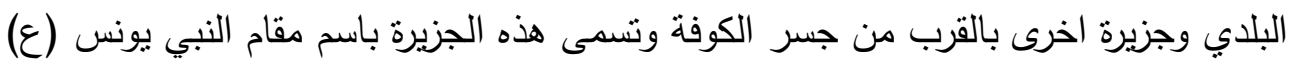

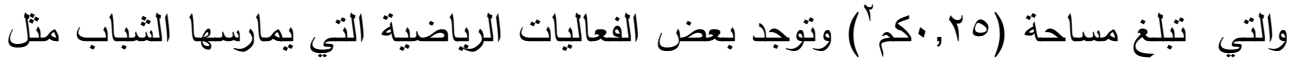

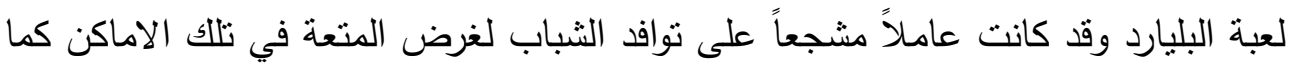

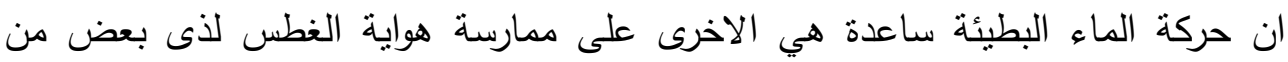

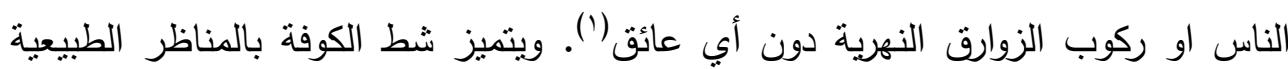

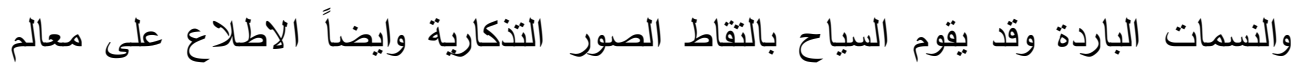
المكان وتناول العصائر والمنلجات من المحلات المطلة على النهر (؟).

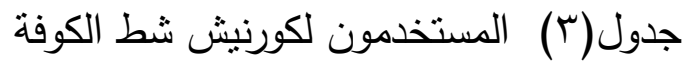

\begin{tabular}{|c|c|c|c|}
\hline النسبة المئوية\% & العدد & كورنيش شط الكوفة & $ت$ \\
\hline$\sum \wedge$ & 97 & الثباب & -1 \\
\hline 17 & rr & العوائل & $-r$ \\
\hline ז & VY & الاصدقاء & $-r$ \\
\hline $1 \ldots$ & r.. & المجموع & $-\varepsilon$ \\
\hline
\end{tabular}

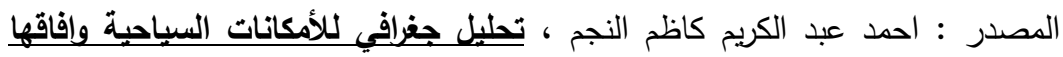

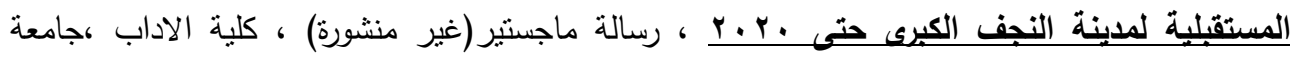

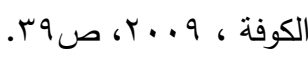

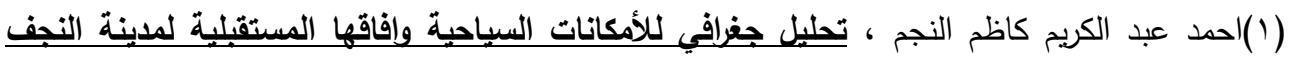

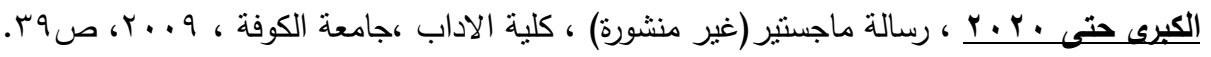

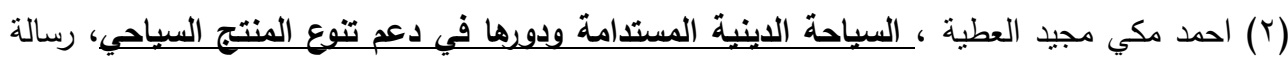

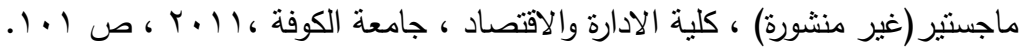


مركز البحوث الجغرافية والكارتوجرافية - قسم الجغرافيا - كلية الآداب - جامعة المنوفية المؤتمر الجغرافي الدولي الثاني

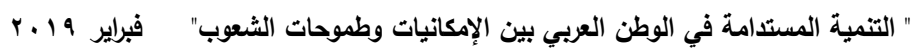

\section{هناك عدة امور يجب ان نذكرها قبل تطوير كورنيش شط الكوفة:-}

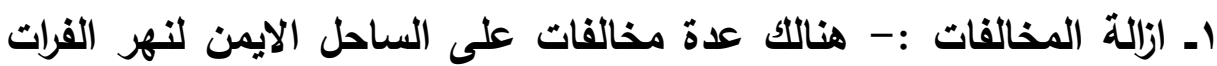

$$
\text { ومن هذه المخالفات هي :- }
$$

ا- انشاء الدقاهي والكازينوهات العشوائية وغير مجازه من قبل بلديه الكوفة حيث توضع الكراسي على ممر سير الزبائن كذلك تشوية ضفاف النهر بوضع الكراسي والمناضد الغير منضمة.

ب- هناللك بعض مراسي الزوارق العشوائية والغير نظاميه وتوجد بعض الاماكن الغير امانه للسياحة مما يؤدي الى غرق الكثير من السواح ·

ج- قيام بعض اصحاب المزارع من اخذ جزء من مزارعهم وجعلها اماكن للجلوس وهذا العمل غير نظامي.

r-طبيعة الناس المخالفين:-عند الدراسة للمنطقة تبين نوعين من المخالفين

ا- الناس البسطاء الذين يحاولون فقط كسب قوتهم اليومي همه كسب الرزق . ب- وعند الدراسة تبين هناك احد السؤولين قد تجاوزوا على صفة النهر وقام بتشيد بيت وتسيج المنطقة بسياج من الطابوق مما ادى الى عدم رؤية النهر والضفة ويكون

$$
\text { هذا با القرب من جسر الامام علي (ع). }
$$

r-تجاوز بعض الفلاحين على صفة النهر واستخدامها لزراعة الخضر كذلك نصب المضخات الزراعية المجازة وغير المجازة وهذه في بعض الاحيان 
مركز البحوث الجغرافية والكارتوجرفية - قسم الجغرافيا - كلية الآداب - جامعة المنوفية الموتّمر الجغرفي الدولي الثاني

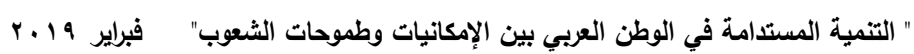

تؤثز على انشاء المشاريع السياحية وتؤدي الى مشاكل بين الفلاحين

$$
\text { والسلطات المسؤولة. }
$$

ع- دور البلدية في ازاله الدخالفات :- عند التجول في الدنطقة والاستفسار من

اصحاب المقاهي والكازينوهات عن كيفية قيام هذه المحلات وهل انها مجازه

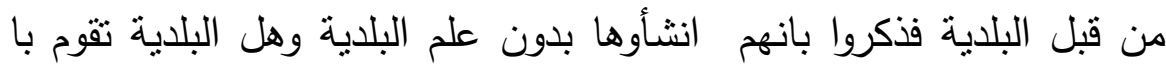

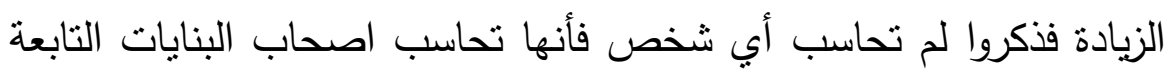
للبلدية فقط لغرض دفع الاجور ومن هذا نستتنج بان البلدية ليس لها أي دور في تطوير ومحاسبه المخالفين كذلك مشاهدة الحدائق التابعة الى البلدية في الجزرة الوسطية مهمله ومتروكة حتى العمال الذين يشتغلون فيها عددهم قليل وهم من كبار السن حيث هم مجرد موظف يؤدي يومه لغرض اجور

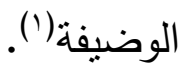


مركز البحوث الجغرافية والكارتوجرافية - قسم الجغرافيا - كلية الآداب - جامعة المنوفية المؤتمر الجغرافي الدولي الثاني

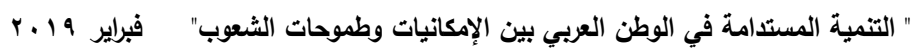

\section{تأثير المخالفات على المظهر الحضاري وطبيعة المنطقة :-} 1_ تأثير هذه المخالفات تأثير كبير على المنطقة لان مظهرها غير لائق لان بعضها ينكون من الخشب والصقيع والحصران التي لاتحمي الزبائن من الحر وكذللك البرد.

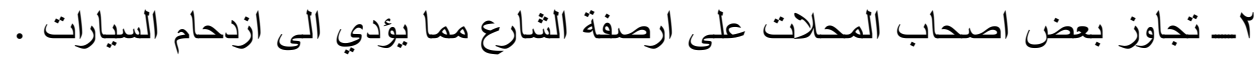
rـــ من الدخالفات الاخرى رمي النفايات على ضفة النهر وهذه مناظر غير لائقة. هناك امكانيات يمكن الاعتماد عليها في تطوير المناطق الترفيهية في منطقة

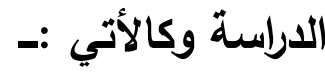
المحور الثاني/المشاريع السياحية/لمكن اقامتها على ضفة النهر وتكون كالاتي : ا- انثاء مراسي للزورق ويكون اكثر من مرسى نهري على الثناطئ وهنالك مقترح من شركة النقل النهري لتخصيص مراسي نهرية على نهر الفرات ضمن قضاء الكوفة وتم اقتراح ثلاث

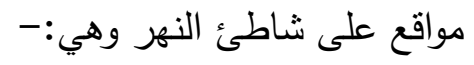

1- مرسى يقع بين جسر الامام علي (علية السلام ) والجسر الحديدي ويكون هذا بمسافة

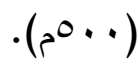
r- الموقع الثاني (المرسى الثاني ) على كورنيش شط الكوفة مقابل الكراج الداخلي بين الجسر الحديدي وجسر الكوفة القديم بمسافة (10 (1م).

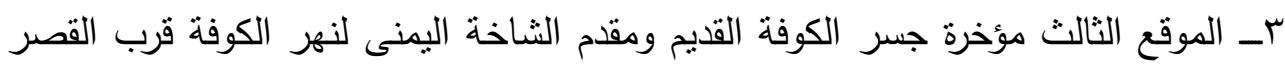

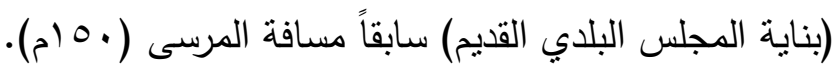
على ان لا تؤثر المشاريع المقترحة على عدة امور منها :-

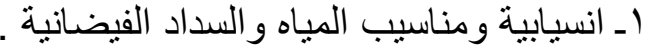

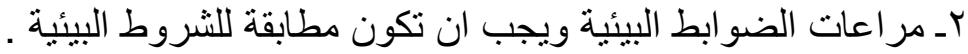

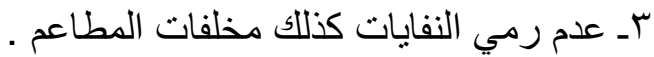

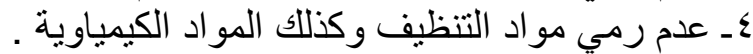

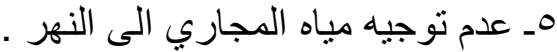
ب ـ انثاء منتز هات جميلة وحدائق و العاب وكازينو هات الثات عائلية.

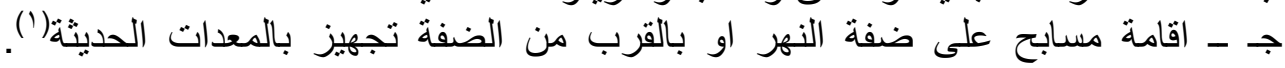
(1) - (1ائرة الموارد المائية ، قسم المساحة. 


\section{و هنالك شروط يجب ان تتوفر في المسابح:-

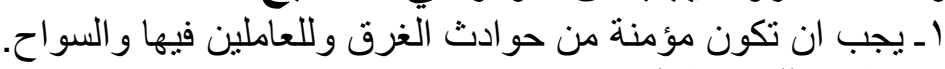

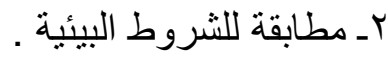 \\ بـ ـا لا تؤثر على انسيابية النهر ومناسيباه.}

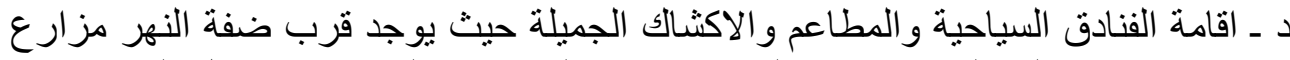

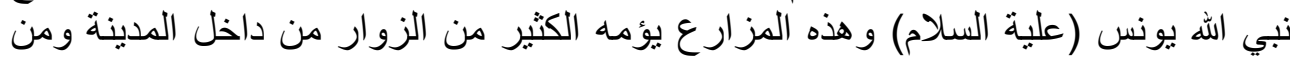

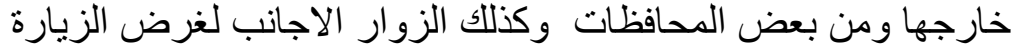

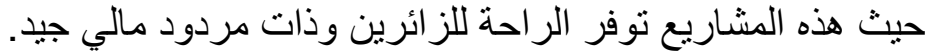

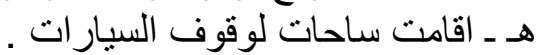

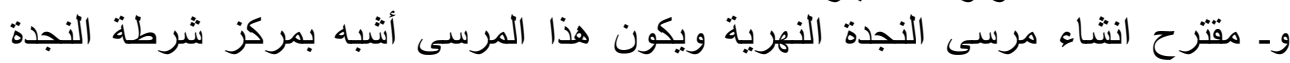

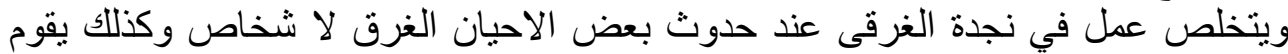
فض بعض الثجار الذي يحدث على الكونى الكورنيش . المشاكل التي تعيق أقامة المشاريع السياحية:-

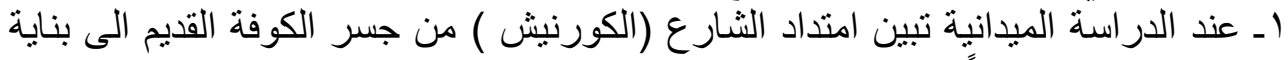

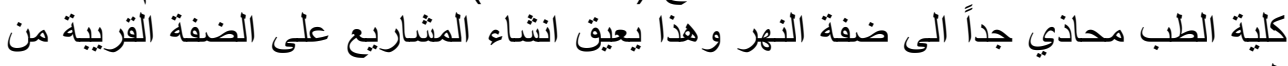

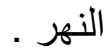
r ـ محاذاة البيوت السكنية من بناية مستثفى الكوفة سابقاً الى مشروع تصفية المياه وهذا

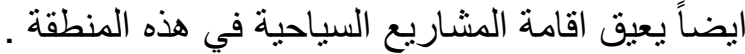

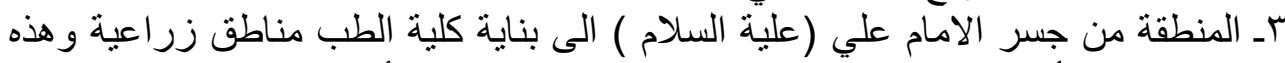

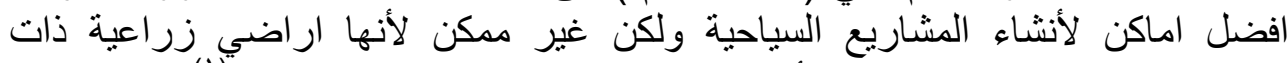

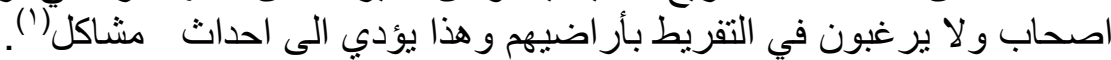

\section{تنمية الموارد المائية المتمثلة بشط الكوفة :-}

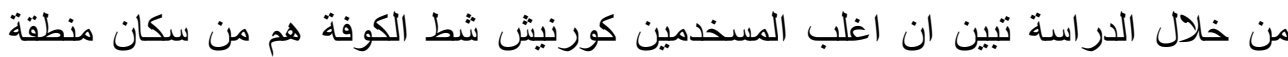

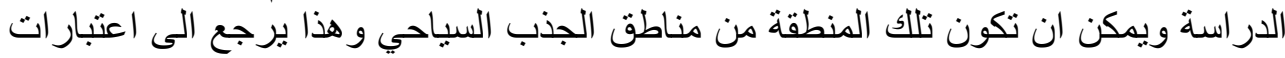

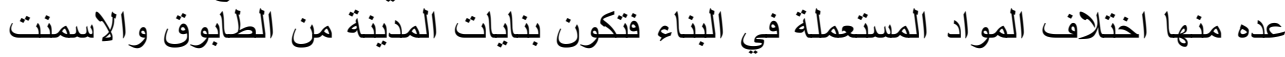

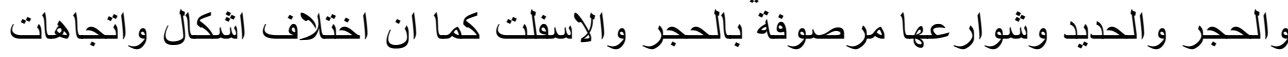

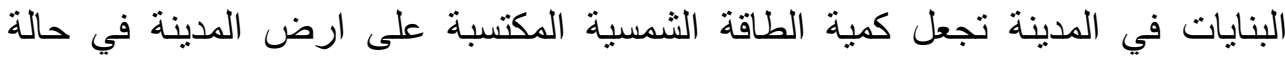

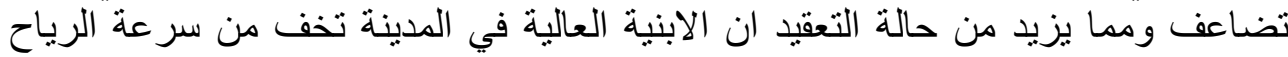
مما يعما على بطئ الطاقة المكنسبة في المدينة بسب الكثافة السكانية العالية في المدينة لذلك الكياح

(1) (1ائرة الموارد المائية ، قسم المساحة.

يلجأ سكان منطقة الدراسة الى شط الكوفة (شارع الكورنيش) وخصوصاً في العطلة

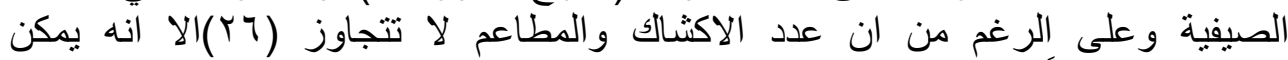

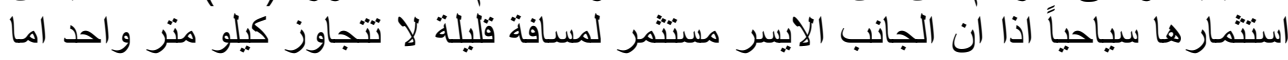


مركز البحوث الجغرافية والكارتوجرافية - قسم الجغرافيا - كلية الآداب - جامعة المنوفية المؤتمر الجغرافي الدولي الثاني

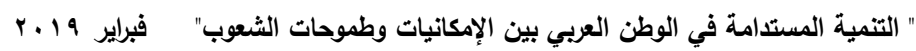

الجانب الايمن غير مستثمر ويعود سبب ذلك الى مورفولوجية المدينة القديمة اذا ان المدينة

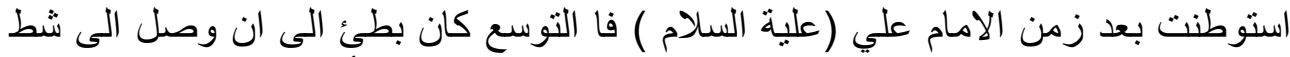

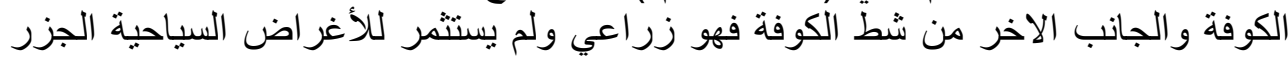

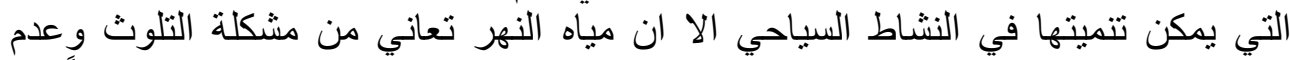

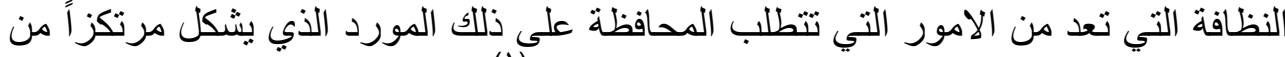

المرتكز ات السياحية التي يمكن استثمار ها في المستقبل (').

\section{امكانيات تطوير كورنيش شط الكوفة : الكرونة}

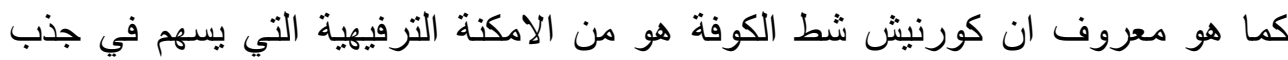

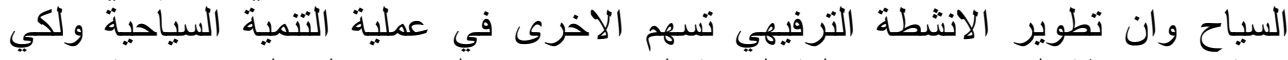

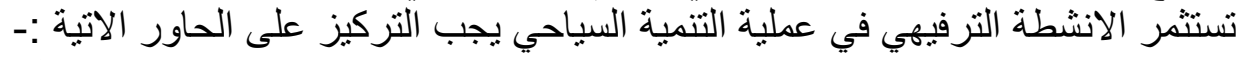

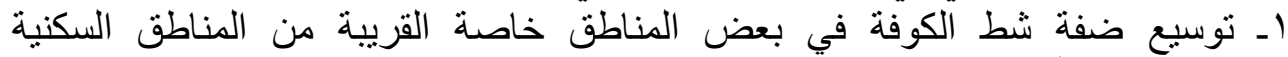

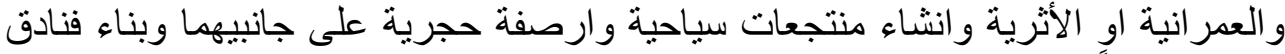

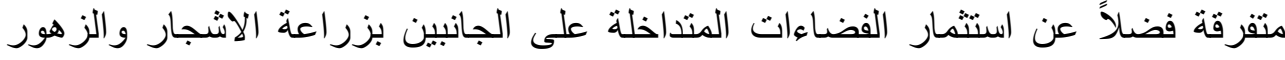
و اقامة الحدائق العامة و المنتز هات.

r ـ استثمار المياه والارض المحاذية للمناطق التي توجد فيها السداد لاسيما سدتي الكوفة

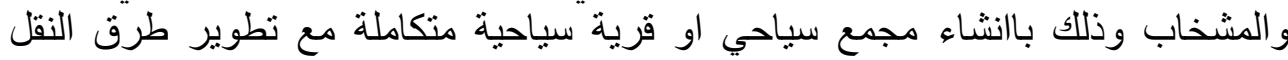

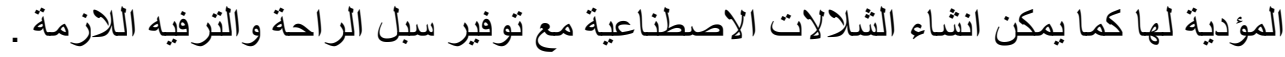

rـ شق قناة مائية تحيط بها منتز هات للسياح الو افدين ولم يقتصر على المنتز هات فقط ونما

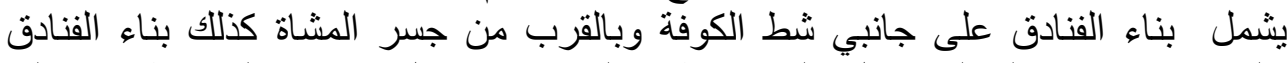

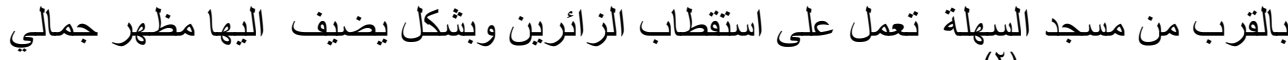

في ابنيتها وخدماتهاب( الكان.

دور الكازينوهات والمطاعم في تطوير كورنيش شط الكوفة :-

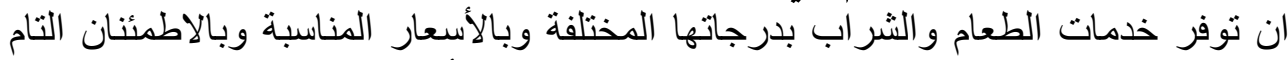

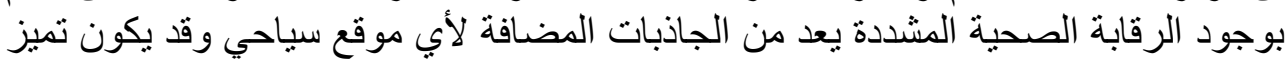

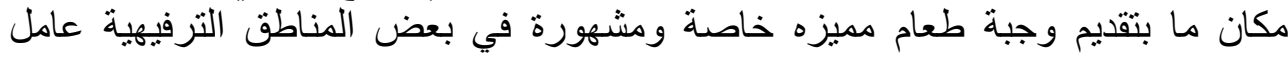

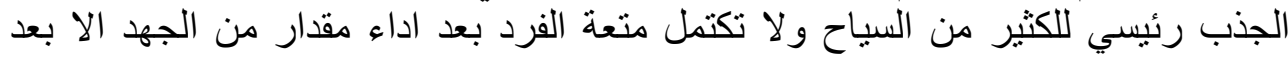

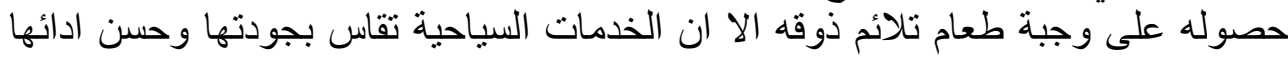

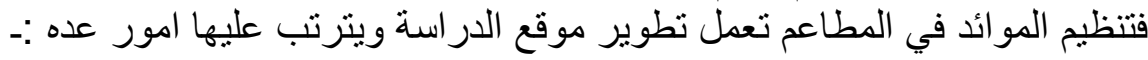

(1) احمد عبد الكريم كاظم النجم ، تحليل جغرافي للأمكانات السياحية وإقاقها المستقبلية لمدينة النجف

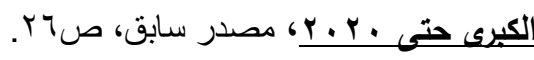

(r) (rايد جاسم الزاملي ومثنى فاضل علي ، المقومات الطيعية لمحافظة النجف الاشرف والامكانبيت

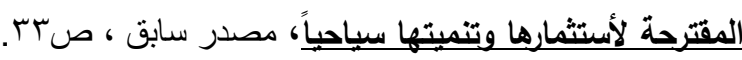


مركز البحوث الجغرافية والكارتوجرافية - قسم الجغرافيا - كلية الآداب - جامعة المنوفية المؤتمر الجغرافي الدولي الثاني

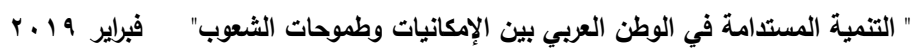

1 - يجب ان يكون المطعم اكثر من شكل وحجم للمو ائد (دائري ـ مربع ـ مستطيل ).

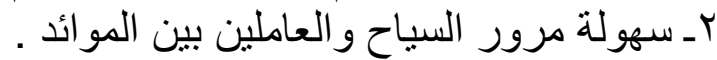

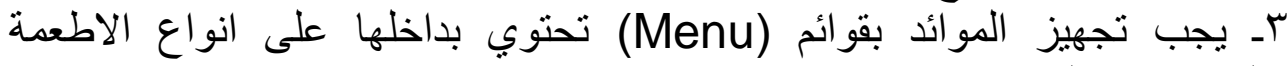

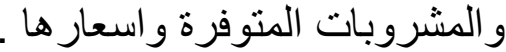

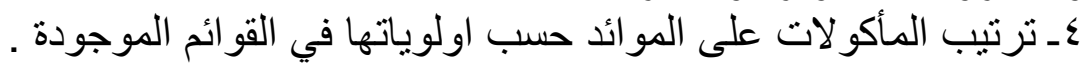
كل ذلك من شأنه يزيد من جودة الخدمة السياحية للمطعم وتكون حالة الألئ الاقبال مستمرة

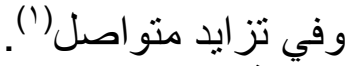

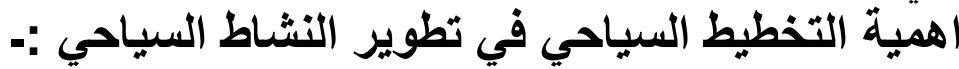

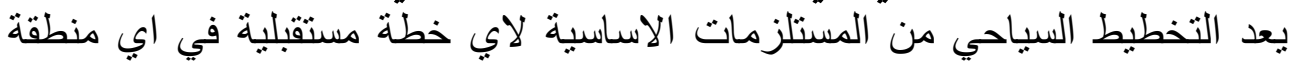

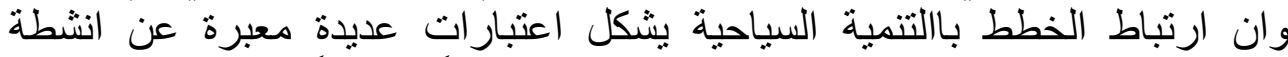

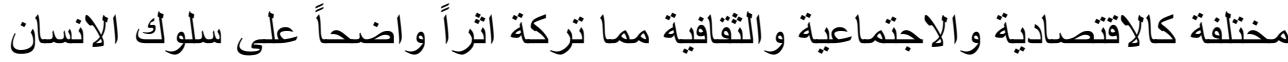

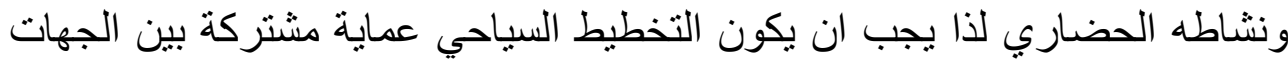

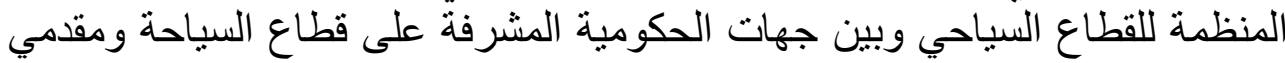

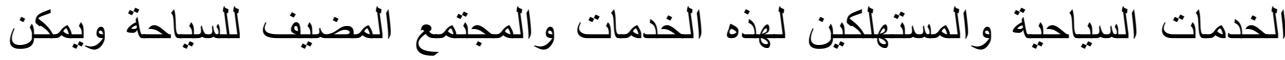
تحديد اهمية التخطيط السياحي في التطوير النشاط النيأ السياحي :اـ يساعد التخطيط السياحي في تحديد وصيانة الموارد السياحية والاستفادة منها

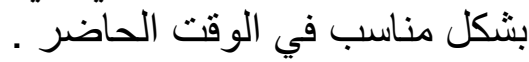
r- يكون التخطيط السياحي دور تكاملي نحو طريق ربط النشاط السياحي مع بقية

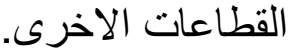

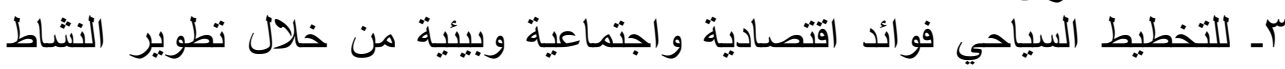

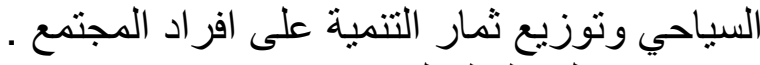

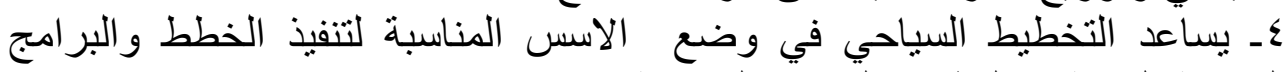

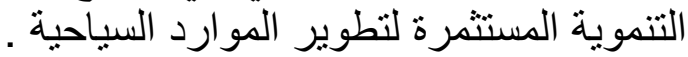

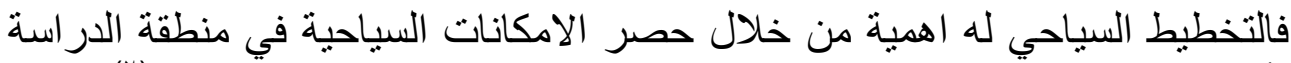

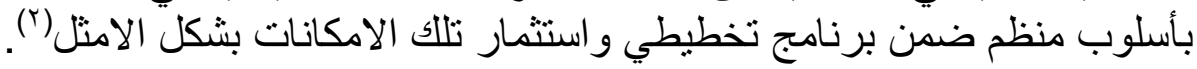

(1) سجاد محمد عطية الجنابي ، استراتيجيات مزيج الترويح السياحى ودور ها في جذب السائح

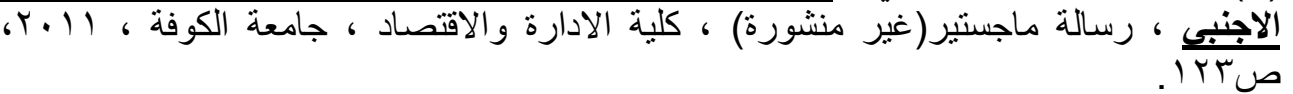
(r) احد عبد الكريم كاظم النجم ، تحليل جغرافي للأمكانات السياحية وافاقها المستقلية لمدينة

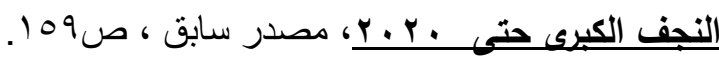




\section{الخاندة:}

وخلاصة ما توصل الية البحث نلاحظ ان تطوير المشاريع السياحية يتم

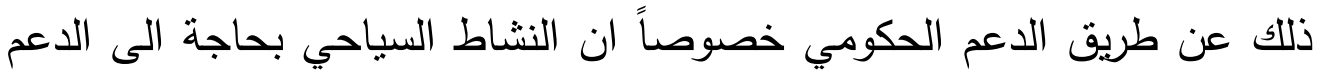

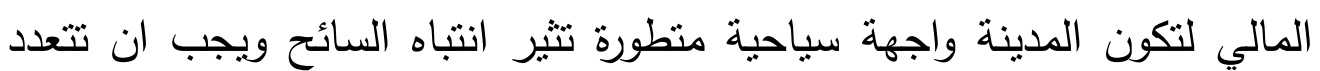
الفعاليات السياحية من انشطة ترفيهية ومناطق خضراء ومنتزهات والعاب تشهر في زيادة حجم الحركة السياحية وان تتظيم حجم الحركة السياحية مما يقلل

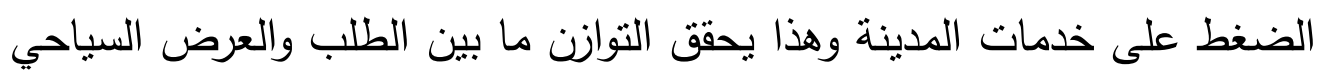

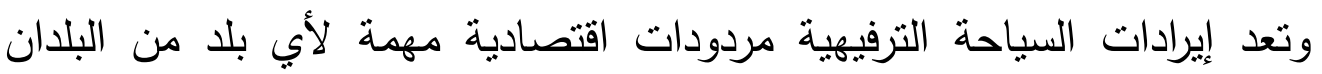
ويمكن الاستفادة منها ـ وتعاني السياحة الترفيهية في العراق من عدم وجود إعلام سياحي متخصص في هذه الأماكن يعمل على تعريف السواح بأهمية هذه

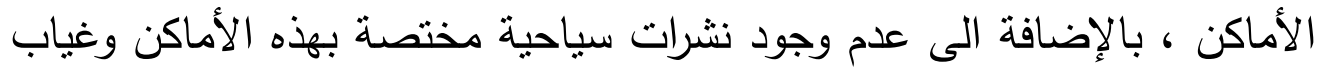

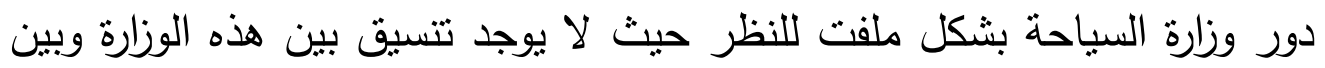

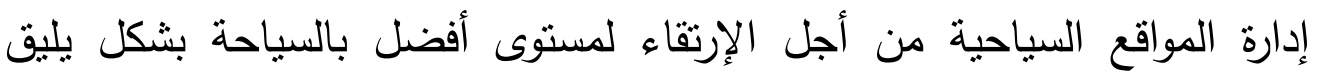
بمكانة هذه المواقع وايضاً ياتي دور جامعة الكوفة في تتمية المقومات السياحية وذلك من خلال المؤتمرات العلمية واعداد الدراسات اللازمة لتطوير البنى التحتية

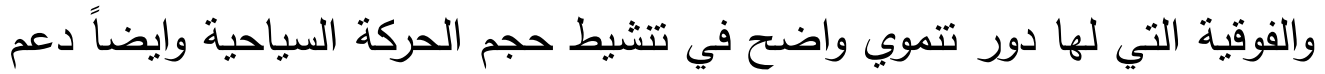
القطاع الخاص الذي يعمل في المجال السياحي من خلال إعطاء قروض طويلة الأجل وقليلة الفائدة من أجل تتمية السياحة التزفيهية في تلك الكي المدن والاهنمام بتوفير الأمن السياحي باعتباره أحد العناصر المهمة التي تسهم في تفعيل الحركة فئه 
مركز البحوث الجغرافية والكارتوجرافية - قسم الجغرافيا - كلية الآداب - جامعة المنوفية المؤتمر الجغرافي الدولي الثاني

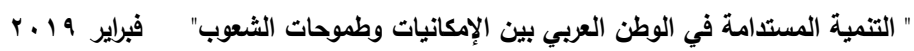

\begin{abstract}
$-j=0$ l

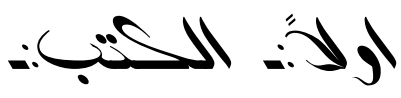

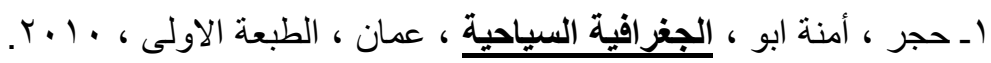
r ـ الطريحي ، محمد سعيد ، العتبات المقدة في الكوفة ، المجمع العلمي الفاطمي ، اكادمية

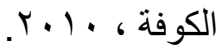

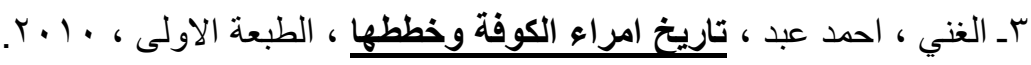

عـ ماسينيون ، لويس ، خطط الكوفة وشرح خريطتها ، الفرقان ، صيدا ، 19 1.

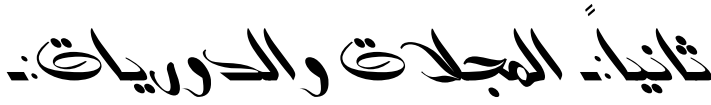

اـ الخفاجي ، سرحان نعيم ،"مراحل تطور المنعطفات النهرية لمجرى نهر الفرات بين الكفل

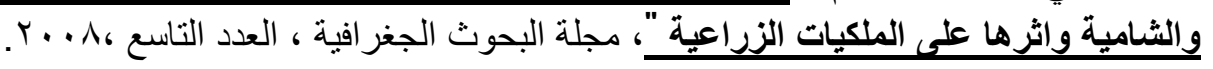
r ـ شلال ، سعدون ، "خطة مدينة الكوفة وتطور ها مورفولوجية مدينة الكوفة " ، مجلة البحوث

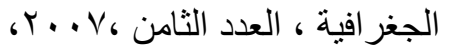




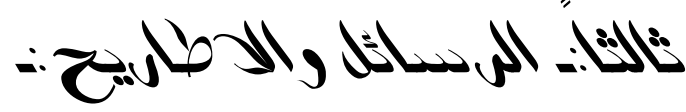

اـ البور اضي ، علياء حسين سلمان ، تقويم الوضع المائى ـ الأروائى والاستغلال الامثل لمصادر

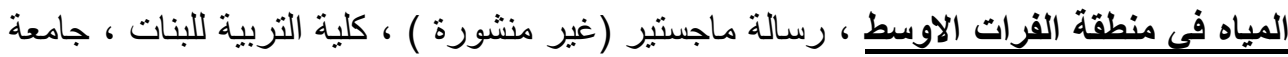

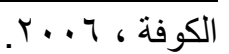

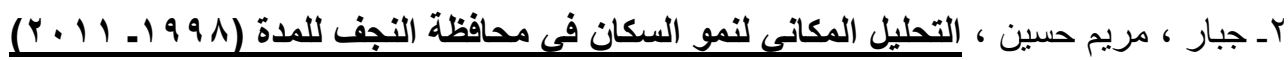

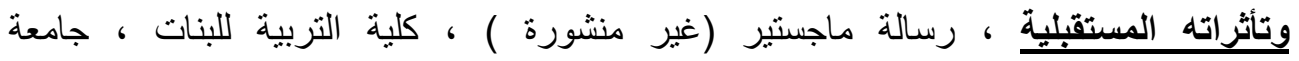

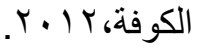

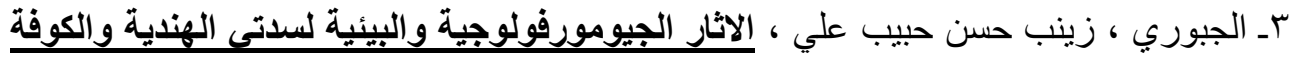

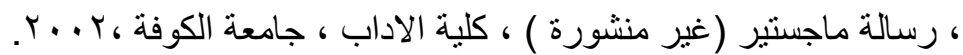

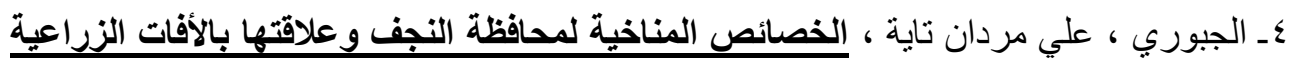

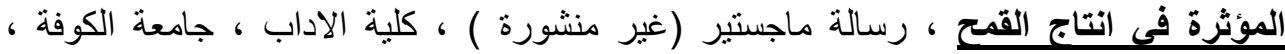
$r+11$

0ـ الجنابي ، سجاد محمد عطية ، استراتيجيات مزيج الترويح السياحى ودور ها فى جذب السائح

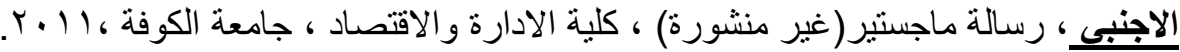

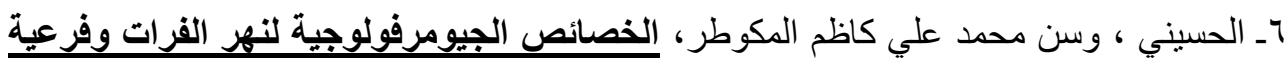

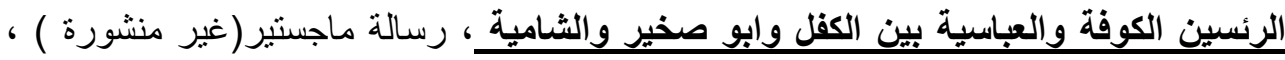

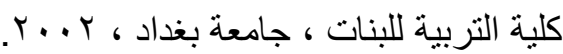

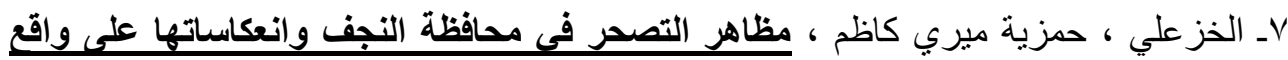
ومستقبل الوضع الزراعي ، رسالة ماجستير (غير منشورة) ، كلية التربية للبنات ، جامعة الكوفة $.1 \%$. A ـ الخفاف ، عبد علي ، جغرافية النجف ، عميد كلية الاداب ، جامعة الكوفة .

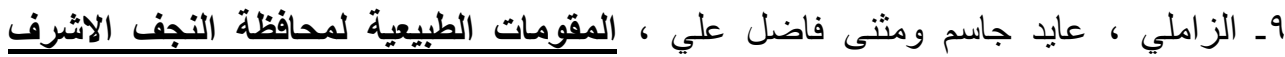
و الامكانيات المقترحة لاستثمارها وتنميتها سياحياً ، كلية الاداب ، جامعات الطيدة الكوفة .

• اـ الزاملي ، فيصل كريم هادي ، تقويم جغرافى لثبكة البزل في محافظة النجف ، هبل ، رسالة

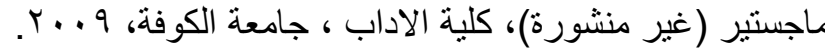


مركز البحوث الجغرافية والكارتوجرفية - قسم الجغرافيا - كلية الآداب - جامعة المنوفية الموتّمر الجغرفي الدولي الثاني

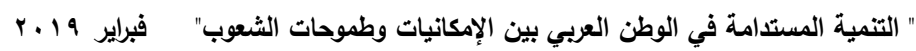

ا اـ العطية ، احمد مكي مجيد ، السياحة الدينية ودورها في دعم تنوع المنتج السياحي ،رسالة

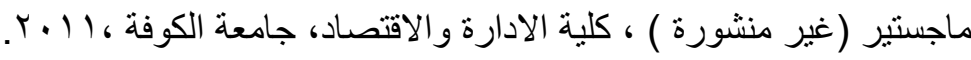

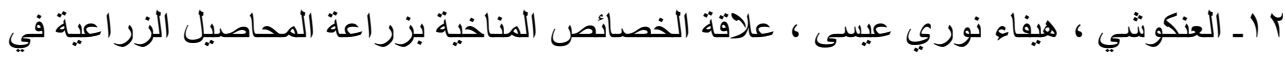

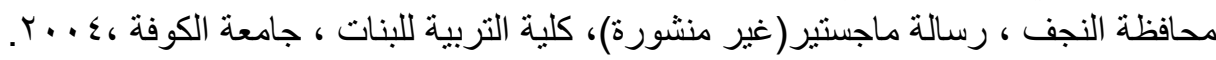

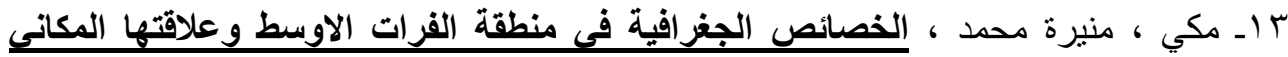

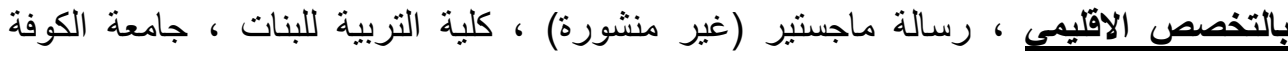
. Y...T،

ـ اـ النجم ، احمد عبد الكريم كاظم ، تحليل جغرلفي للأمكانات السباحبة وافاقها المستقبلية لمدبنة

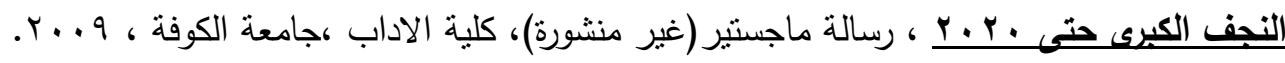
ه 1 ـ الوائلي ، مثنى فاضل ، الموازنة المائية المناخية في محافظة النجف، دراسة في المناخ التطبيقي، رسالة ماجستير (غير منشورة)، كلية الاداب، جامعة الكوفة ، ـ. . . .

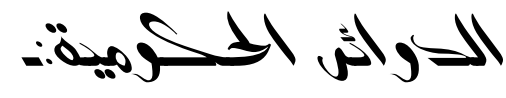

$$
\text { دائرة المو ارد المائية ، قسم المساحة. }
$$

(r)وزارة النقل والمواصلات ،الهيئة العامة للانواء الجوية والرصد الزلزالي ،قسم المناخ ،بيانات غير 
مركز البحوث الجغرافية والكارتوررافية - قسم الجغرافيا - كلية الآداب - جامعة الدنوفية المؤتمر الجغرافي الدولي الثاني

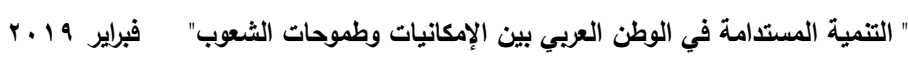

\section{مستقبل الأمن المائي لحوضي دجلة والفرات على ضوء السياسة المائية التركية}

$$
\text { د/ شفيعة حداد }
$$

أستاذة محاضرة أ، كلية الحقوق و العلوم السياسية

chafiaahaddad@gmail.com

د/ هاجر حميدة سليمان فرح

أستاذة مساعدة سابقا بجامعة الملك خالد فرالد

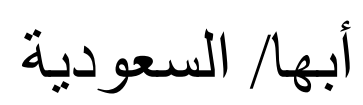

Drhager.2010@yahoo.com 
مركز البحوث الجغرافية والكارتوجرافية - قسم الجغرافيا - كلية الآداب - جامعة المنوفية المؤتمر الجغرافي الدولي الثاني

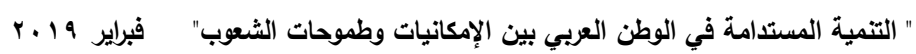

\section{ملخص}

من خلال هذه الورقة البحثية، تم التطرق إلى واحدة من أهم القضايا المتعلقة بالأمن المائي العربي. والتي تشكل محورا مثيرا لاهتمام الباحثين والدارسين في بحالات السياسة و الإستراتيجية والقانون، كما

$$
\text { في بحالات الري والزراعة والطاقات المتجددة. }
$$

لقد تمت إثارة تساؤل جوهري حول موضوع الأمن المائي في اثنين من أهم الأغار الدولية وهما دجلة والفرات. على ضوء تأثيرات السياسة المائية لتركيا، ومشاريعها وسدودها الكبرى. التي أقيمت وتقام على بجرى النهرين، وما يشكله ذلك من تداعيات سلبية على متطلبات الأمن المائي بالنسبة لجارتيها سوريا والعراق اللتان تشاطئاها هذين النهرين. وتم الخلوص إلى بحموعة من النتائج، لعل أهمها أن استمرار السياسة المائية لتركيا بهذا الشكل قد يحدث اختلالات كبيرة ستلحق أضرارا بالغة بالأمن المائي للنهرين ولسوريا والعراق. وأن مستقبل الأمن المائي لهذين النهرين مرهون باحتمالات التعاون أو الصراع بالسياسات التي ستنتهجها الدول المتشاطئة 
مركز البحوث الجغرافية والكارتوجرافية - قسم الجغرافيا - كلية الآداب - جامعة المنوفية المؤتمر الجغرافي الدولي الثاني

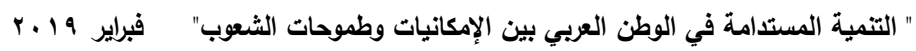

\section{Absract}

Through this paper, we have discussed one of the most important issues related to Arab water security. Which is an interesting focus for researchers and scholars in the fields of politics, strategy and law, as well as in the fields of irrigation, agriculture and renewable energies.

A fundamental question has been raised on water security in two of the most important international rivers, the Tigris and the Euphrates. In light of the effects of Turkey's water policy, its projects and its major dams. Which were established on the course of the two rivers, and the negative repercussions on the requirements of water security for its neighbors Syria and Iraq, which are crossing these two rivers.

The conclusion is that the continuation of Turkey's water policy in this way, could lead to major imbalances that would severely damage the water security of the two rivers, Syria and Iraq. And that the future of the water security of these two rivers depends on the prospects of cooperation or conflict, and the policies taken by the riparian States. 
مركز البحوث الجغرافية والكارتوجرافية - قسم الجغرافيا - كلية الآداب - جامعة المنوفية المؤتمر الجغرافي الدولي الثاني

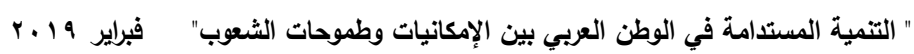

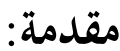

تبرز أهمية الأمن المائي بوصفه من الموضوعات الاستراتيجية ذات العلاقة بالأمن الوطني والأمن القومي

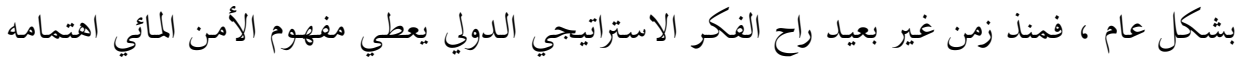

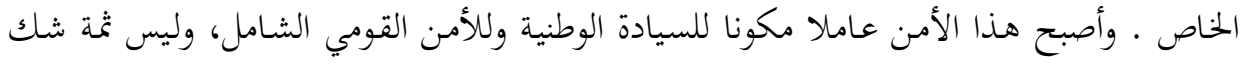

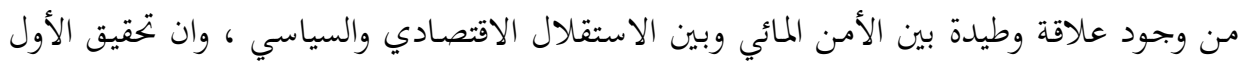

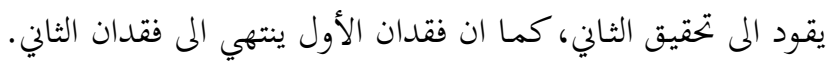

ويتعرض الأمن المائي في حوضي دجلة والفرات حاليا الى التحديات التي تمثل واحدة من ابرز القضايا

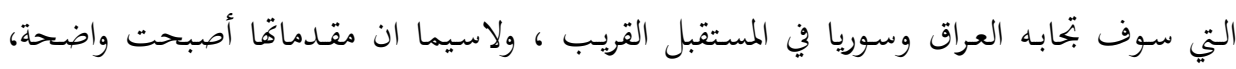

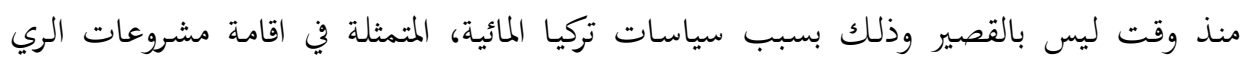
والسدود ، وهدفها من ذلك خفض تدفق منسوب مياه غري دجلة والفرات الم العراق وسوريا

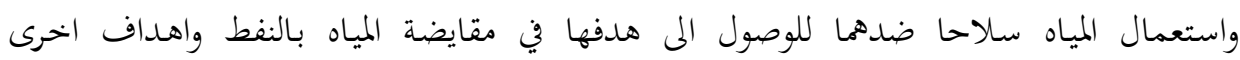
جيوسياسية واستراتيجية مهمة . لمانمان.

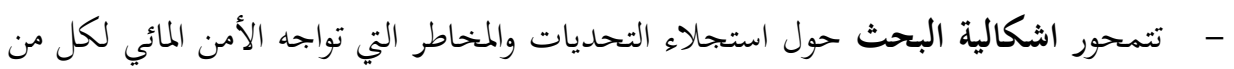

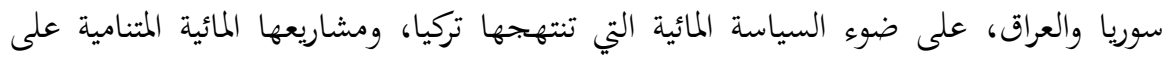
حوضي دجلة والفرات.

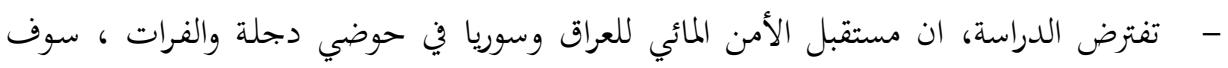

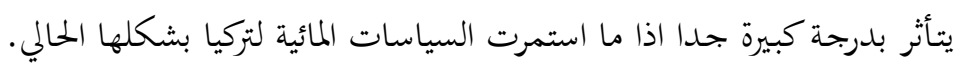

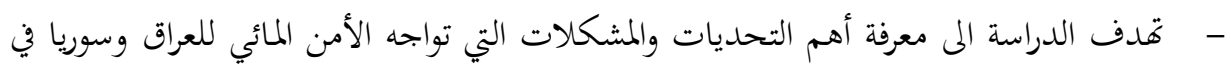

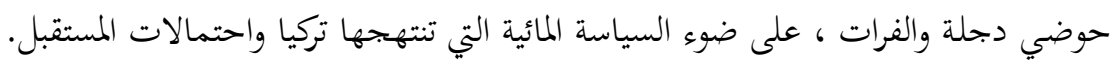


مركز البحوث الجغرافية والكارتوجرافية - قسم الجغرافيا - كلية الآداب - جامعة المنوفية المؤتمر الجغرافي الدولي الثاني

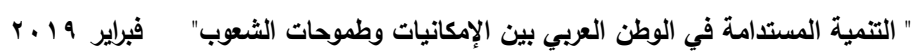

$$
\begin{aligned}
& \text { وعليه تم تقسيم الدراسة إلى أربعة محاور: } \\
& \text { المحور الأول: مفاهيم الدراسة } \\
& \text { المور الثاني؛ السياسة المائية لتركيا وأبعادها السياسية والاقتصادية } \\
& \text { المحور الثالث ؛ تأثير السياسة المائية لتركيا على الأمن المائي لسوريا والعراق. } \\
& \text { المور الرابع ؛ سيناريوهات مستقبل الأمن المائي للوضي دجلة والفرات (احتمالات الصراع أو } \\
& \text { التعاون) }
\end{aligned}
$$

\section{أولا: مفاهيم ومصطلحات البحث}

1-الأمن المائي : Water Security هو توفر الثروة المائية من حيث مخزوها وتنوع مصادرها، وطرق

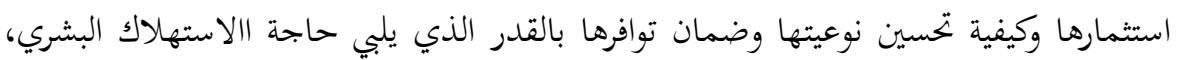

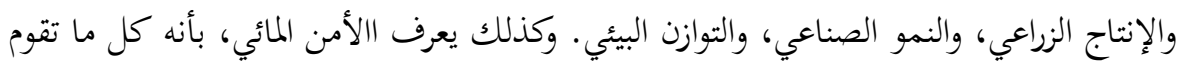
به الدولة للمحافظة على مصالحها المائية الحيوية، وبالتالي تحقيق أمنها المائي والغذائي . r- حوضي دجلة والفرات:

ينبع فري دجلة والفرات من ذوبان الثلوج بمرتفعات جنوب شرق هضبة الأناضول في تركيا، ويعبران

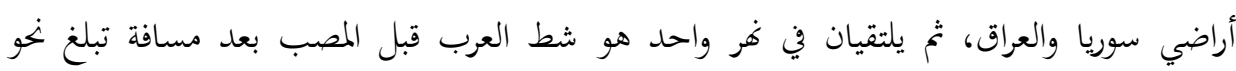
1VIN

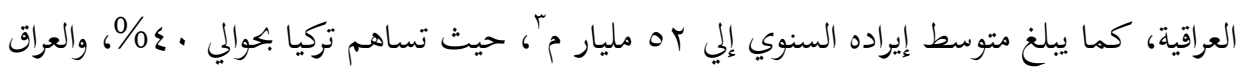

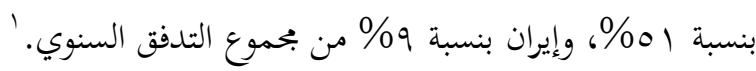

يمر غر الفرات بثلاث دول هي: تركيا، وسورية، والعراق، ويبلغ طوله من منبعه إلى مصبه أكثر من

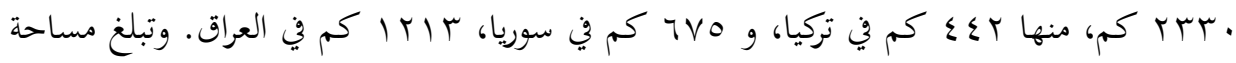


مركز البحوث الجغرافية والكارتوجرافية - قسم الجغرافيا - كلية الآداب - جامعة المنوفية المؤتمر الجغرافي الدولي الثاني

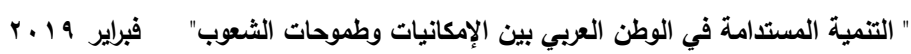

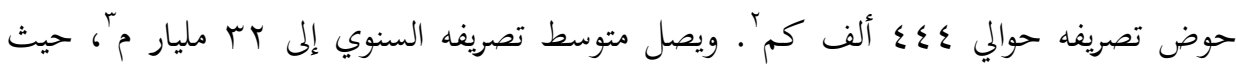

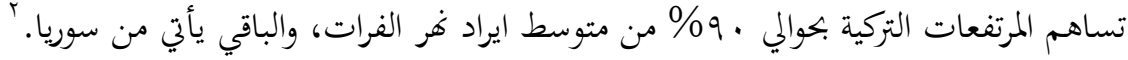

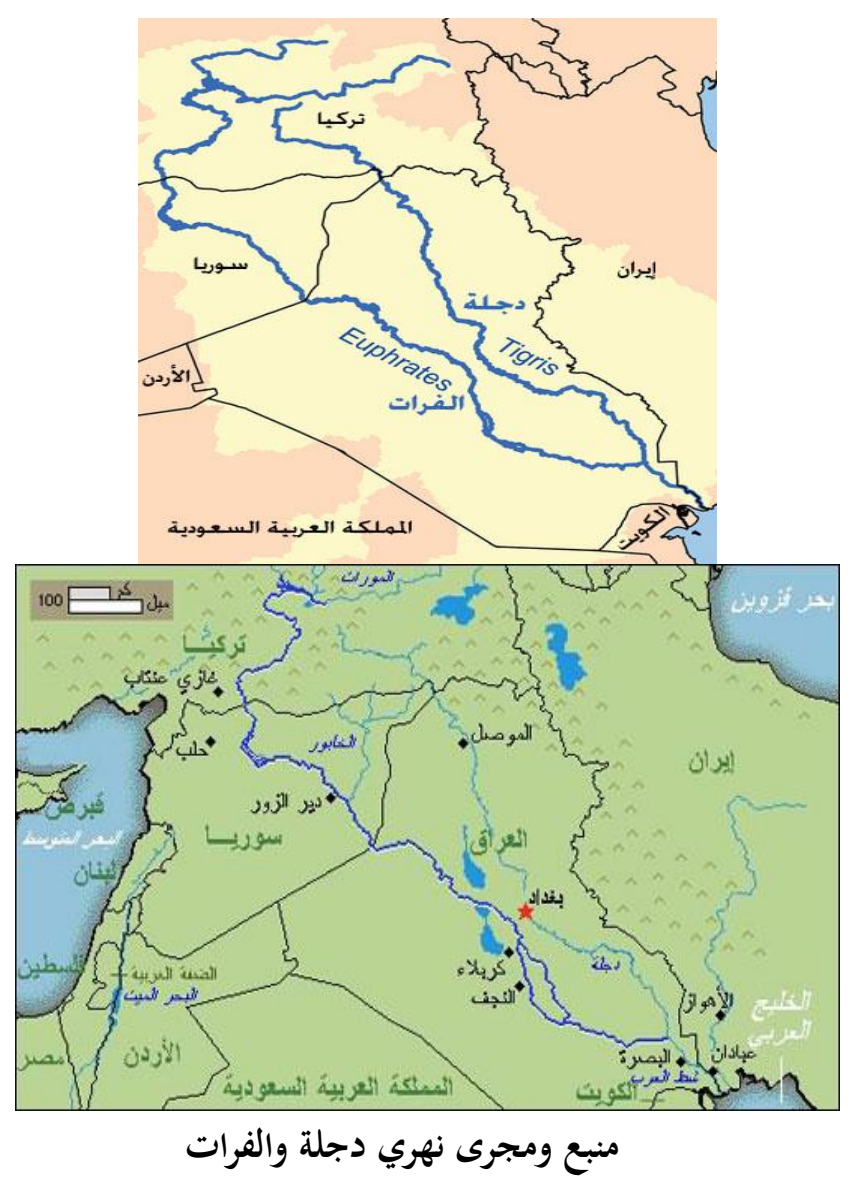

المصدر:http://maqalati.com/54.htm ، تم التصفح بتاريخ : r يناير 9 1. 
مركز البحوث الجغرافية والكارتوجرافية - قسم الجغرافيا - كلية الآداب - جامعة المنوفية المؤتمر الجغرافي الدولي الثاني

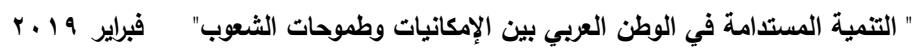

جدول (1): خصائص غري دجلة والفرات

\begin{tabular}{|c|c|c|c|c|}
\hline مساحة الحوض الفعلية & مساحة الحوض /كمَ' & الطول /كم & الدولة & حوض النهر \\
\hline OVTI & OVTI & ro. & تركيا & \multirow{5}{*}{ دجلة الرئيس } \\
\hline NTs & Ars & $\leqslant 9$ & سوريا & \\
\hline הTrV & $1100 \ldots$ & $1 \leqslant 19$ & العراق & \\
\hline$r \leq \varepsilon \ldots$ & $\leq 0 \ldots$ & - & إيران & \\
\hline 177.10 & r^q... & 1711 & الكلي & \\
\hline مساحة الحوض الفعلية & مساحة الحوض /كىז & الطول /كم & الدولة & \multirow{6}{*}{ الفرات الرئيس } \\
\hline $1 . \wedge \ldots$ & Iro... & $\varepsilon 00$ & تركيا & \\
\hline$r \ldots$ & vi... & TVO & سوريا & \\
\hline $1 \ldots$ & IVr... & Ir.. & العراق & \\
\hline- & $77 \ldots$ & - & السعودية & \\
\hline $\mid r \ldots$ & $\varepsilon \varepsilon \varepsilon \ldots$ & . זמז & الكلي & \\
\hline
\end{tabular}

المصدر: مثنى فاضل الوائلي، " التغيرات المناخية وتأثيراتها في الموارد المائية السطحية في العراق"، أطروحة دكتوراه، جامعة الكوفة، كلية الآداب،

ب- السياسة المائية لتركيا: تسعي تركيا من خلال سياستها المائية، إلي تعزيز سيادتا على مياه غري دجلة والفرات عن طريق إقامة العديد من المشروعات المائية (سدود ومحطات كهرباء) في الجنوب الشرقي من البلاد (المنطقة المحاذية للحدود السورية) علي غري دجلة والفرات لتحقيق توازن اقتصادي بين هذه المنطقة وباقي المناطق التركية. وخططت الدولة لتنميتها بإقامة سلسلة من

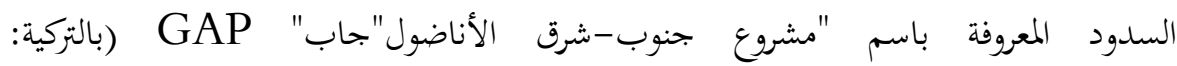
(Güneydoğu Anadolu Projesi)

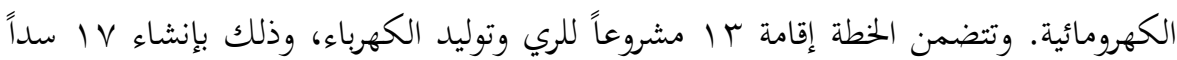
على غر الفرات، وأربعة سدود على غر دجلة، و V Vحطة لتوليد الطاقة الكهرومائية على 
مركز البحوث الجغرافية وإكارتوجرافية - قسم الجغرافيا - كلية الآداب - جامعة المنوفية المؤتمر الجغرافي الدولي الثاني

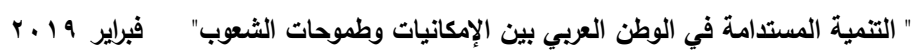

$$
\begin{aligned}
& \text { النهرين وروافدها، وذلك لري م, 1 مليون هكتار. وسيؤدي تنفيذ المشروعات التركية إلى وقوع } \\
& \text { الضرر على كل من سوريا والعراق، وتم عقد حوالي · ل اتفاقيات بين دول حوض دجلة والفرات } \\
& \text { لتنظيم تدفق المياه إلي سوريا والعراق، بدءً من معاهدة لوزان عام • بو ام إلي اتفاق سوريا } \\
& \text { والعراق عام . }
\end{aligned}
$$

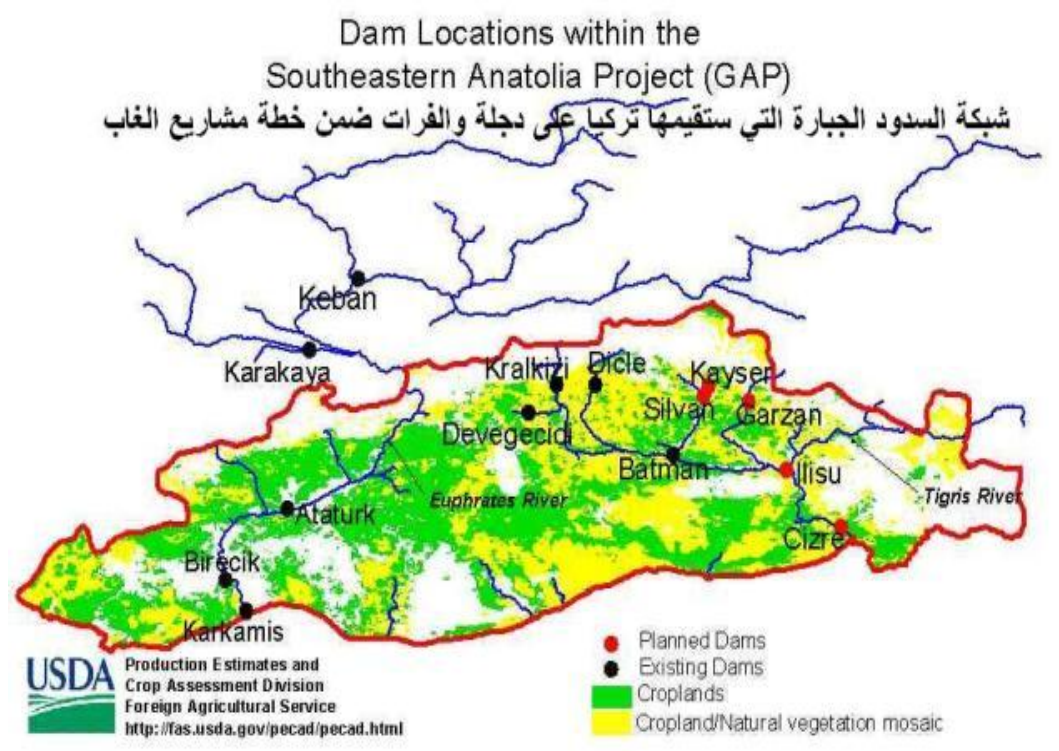


مركز البحوث الجغرافية والكارتوجرافية - قسم الجغرافيا - كلية الآداب - جامعة المنوفية المؤتمر الجغرافي الدولي الثاني

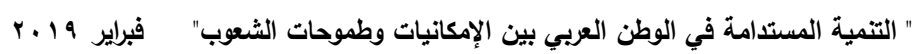

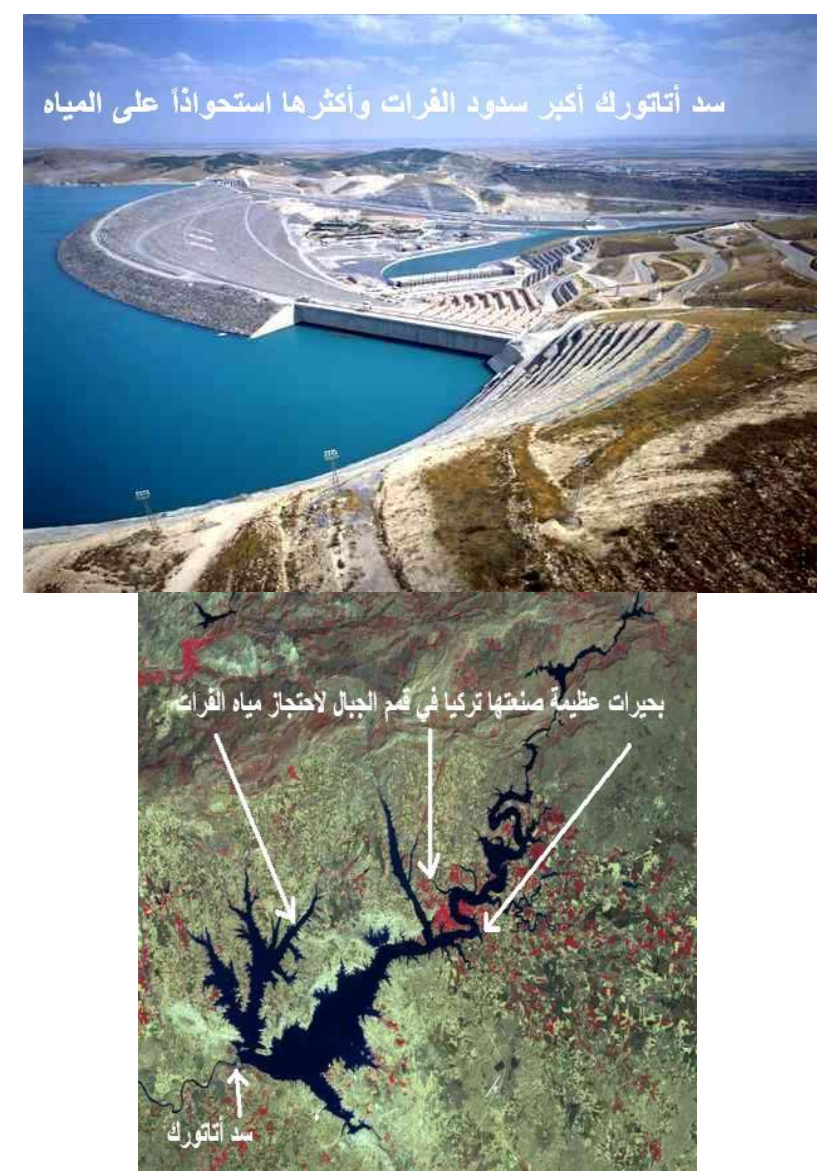

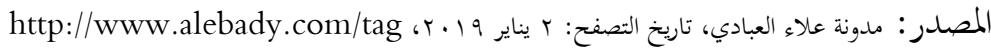

ثانيا : الأبعاد السياسية والاقتصادية للسياسة المائية التركية

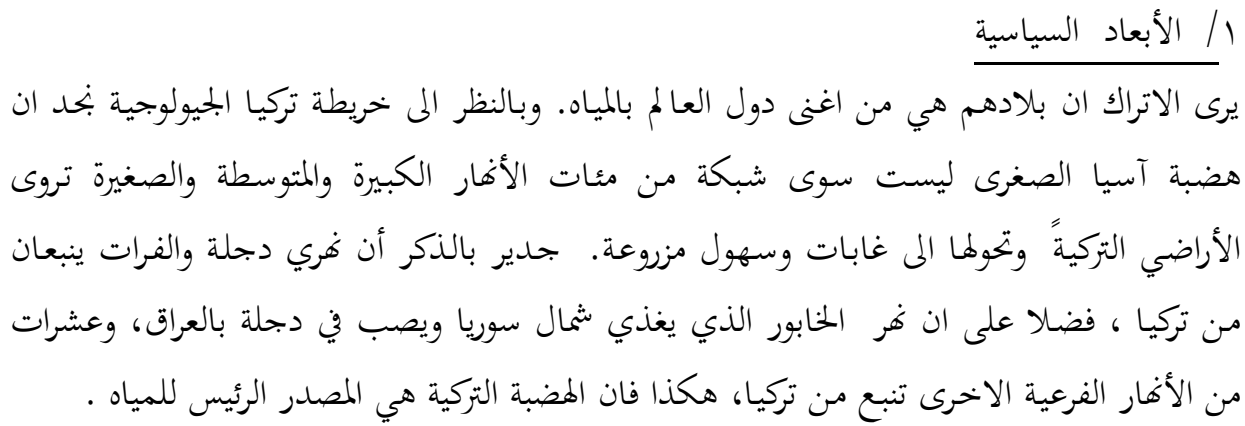


مركز البحوث الجغرافية والكارتوجرافية - قسم الجغرافيا - كلية الآداب - جامعة المنوفية المؤتمر الجغرافي الدولي الثاني

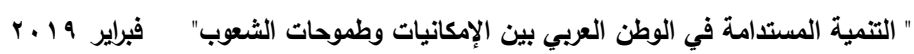

ولقد ادرك صانع القرار التركي - منذ وقت - أن مستقبل تركيا البعيد يقوم على تنمية دورهاً

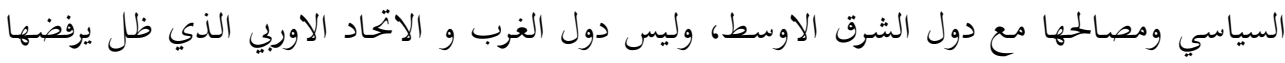

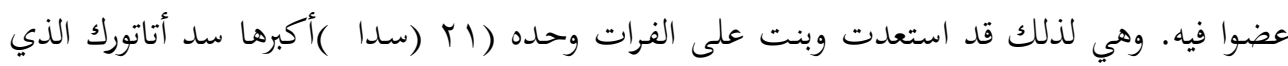
يعد من أكبر السدود في العالم، لتحكم بذلك سيطرتا على الفرات ، وتتحكمى في جريانه خارج أراضيها

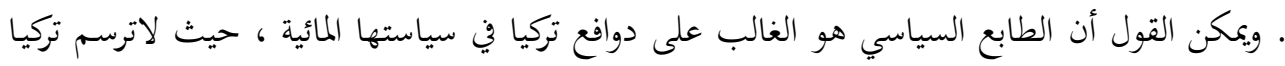

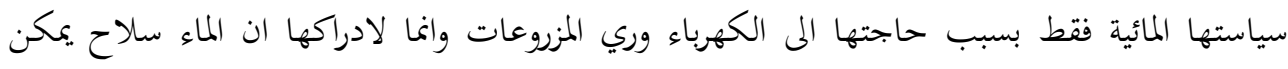
استخدامه في أي وقت ولديها منه الكثير ـ والحقيقة ان تركيا تبحث عن دور اقليمي يحقق لها قدر أكبر

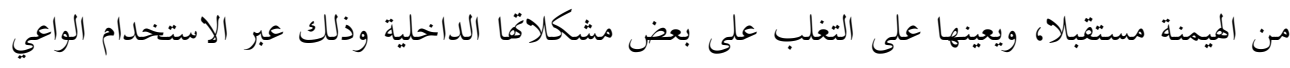
لالأداة المائية .

وبرزت ملامح وأبعاد السياسة المائية لتركيا، من خلال تعمد تركيا عدم التوصل الى اتفاق مائي

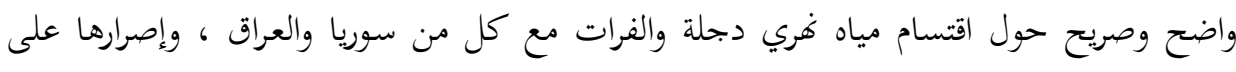
الاستمرار في تشييد السدود، وإقامة المشاريع المائية على النهرين بهدف تطوير منسير منطقة شرقي الاناضول ـ لذا فان سياسة تركيا المائية تسعى إلى تحقيق جملة أهداف ذات أبعاد سياسية واقتصادية

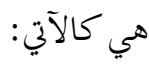
أ. تسييس المياه : لقد تم تسييس المياه من قبل تركيا ، والنزاع بشأها قد يتجه الى الصدام، مال لم يجصل تفاهم حقيقي بين الدول المشتركة في مياه الحوضين . وتسييس المياه يعني اضفاء الصفة

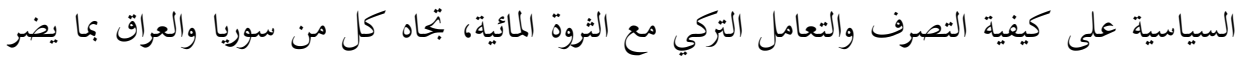

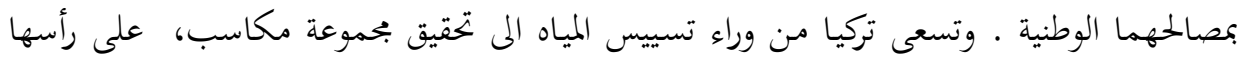

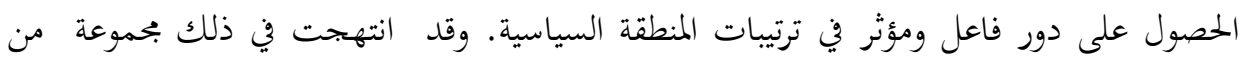
المرتكزات:

عـ- عدم الاعتراف بالصفة الدولية لنهري دجلة والفرات، ومازات تصر على أن الصفة الدولية لا تطلق الا

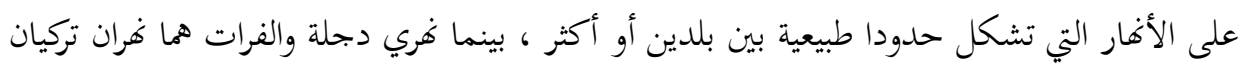

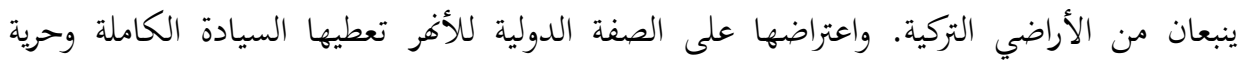
التصرف ،كما تعفيها من الاعتراف بحقوق سوريا والعراق الدولتان المتشاطئتان لها على النهرين، مما لماصيه 
مركز البحوث الجغرافية والكارتوجرافية - قسم الجغرافيا - كلية الآداب - جامعة المنوفية المؤتمر الجغرافي الدولي الثاني

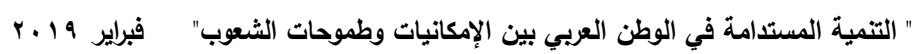

يعفيها من الالتزامات القانونية التي أقرها القانون الدولي بخصوص استغلال الاغار الدولية للأغراض

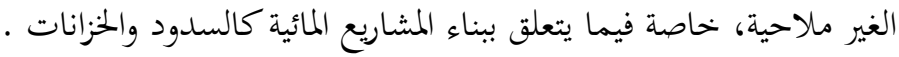

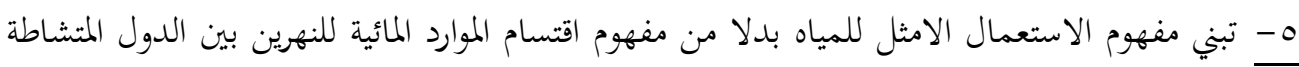

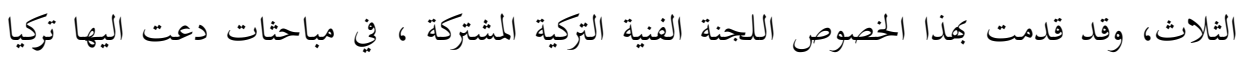
بخصوص تطبيق فكرة الاستعمال الامثل لمياه النهرين، قدمت مقترحا سنة ع 9 1، ولم يكظ بقبول سوريا والعراق، ثم أعادت تقديمه في الاجتماع الثلاثي سنة .99 19. ثمث قامت بتعميمة عن طريق وزارة خارجيتها سنة 1999 19، وضمنته خطة سميت بخطة المراحل الثلاث غرضها تفعيل وتنفيذ المشروع وفكرة الاستعمال الأمثل للمياه؛. 7- عدم الاعتراف بالحقوق المكتسبة للدول المتشاطئة، خاصة العراق باعتباره دولة المصب.

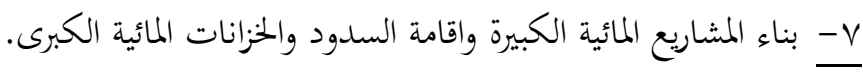
ب - استخدام المياه كورقة ضغط وابتزاز: ضد سوريا والعراق لاضعاف قدرهتما الاقتصادية،

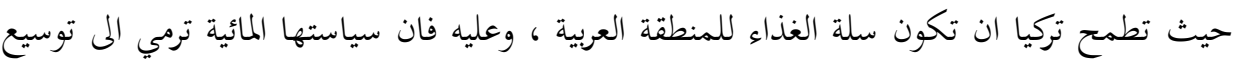
هيمنتها على دول الجوار وخاصة سوريا والعراق. ففي عام 1991 قامت تركيا باستخدام الورقة المائية في تحقيق اهداف سياسية، عندما أقدمت على حبس مياه الفرات بحجة ملء خزان أتاتورك، مستغلة ظروف العراق الصعبة آنذاك ( الحرب والحصار ) لتضغط عليه، مستخدمة تلك الورقة

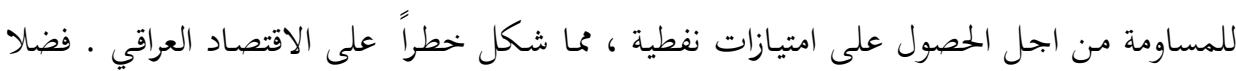

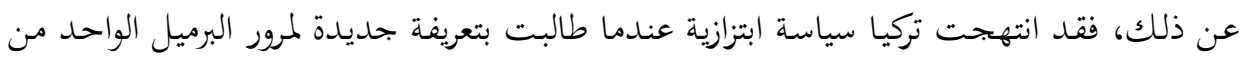

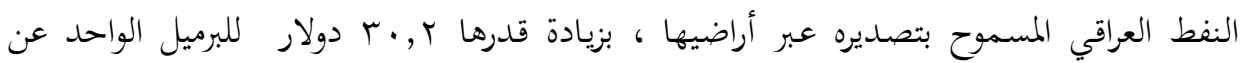

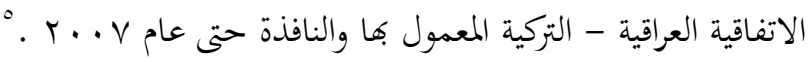
فيما يتعلق بسوريا، فان سياسة تركيا كانت تهدف إلى إضعاف سوريا أو الضغط عليها

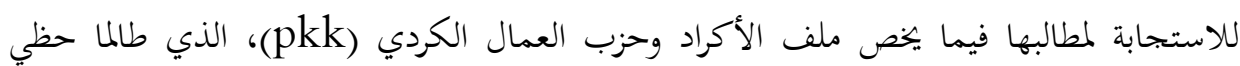
بدعم النظام السوري وبما يتلاءم مع مصالحها في المنطقة. 
مركز البحوث الجغرافية والكارتوجرافية - قسم الجغرافيا - كلية الآداب - جامعة المنوفية المؤتمر الجغرافي الدولي الثاني

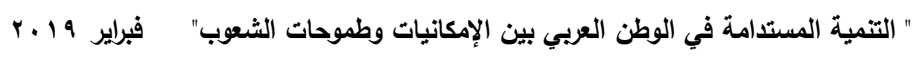

ج. تقوية الدور الاقليمي لتركيا: إن محاولة تركيا تسييس المياه، تعكس النهج التركي في زج عامل

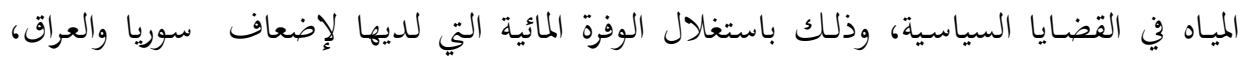
لغرض زيادة نفوذها والتمهيد للهيمنة الأقليمية في المنطقة.

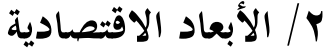

أ. مقايضة المياه بالنفط: منذ بداية التسعينيات من القرن الماضي، أصبحت أهمية المياه لاتقل

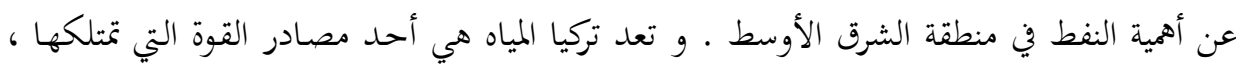

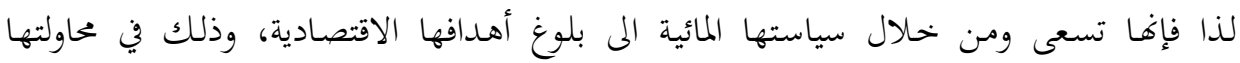
الاستحواذ على اكبر كمية من مياه غري دجلة والفرات، ومقايضتها بالنفط العربي ، كذلك فإنها

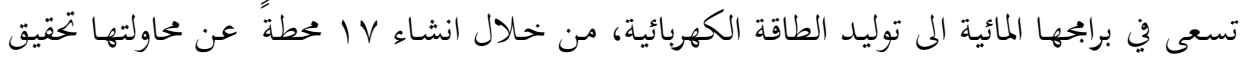
حلمها بجعلها سلة الغذاء في المنطقة ، فضلا عن ذلك يضعها بين الدول العشرة الكبرى المنتجة

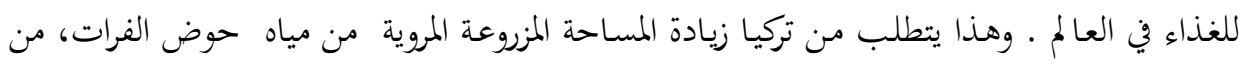

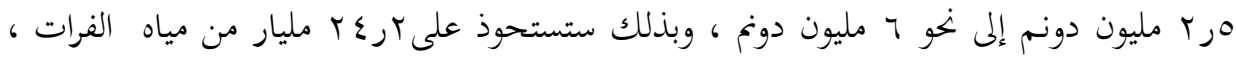

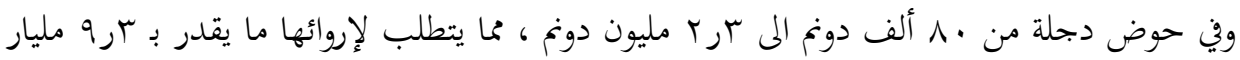

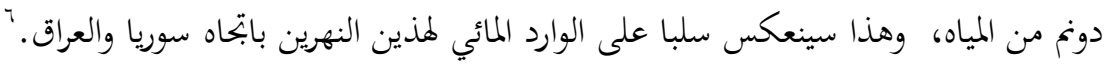
جدول (r ·) : مساحة حوض التغذية الفعلية والإيراد السنوي لنهري دجلة والفرات موزعة بحسب دول الحوضين

\begin{tabular}{|c|c|c|c|c|c|}
\hline إجمالي الإيراد السنوي (\%) & السنوي مليار (مץّ) & الحساحة إجمالي & مساحة حوض & 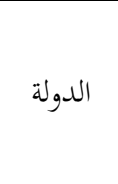 & النهر الن \\
\hline ז & r & $r \leqslant .79$ & OVTIE & تركيا & \multirow{5}{*}{ دجلة } \\
\hline$\cdot, .7$ & $\cdot, \cdot r$ & $\cdot, 0$ & גו & سوريا & \\
\hline $11 . \lambda \mathrm{V}$ & $\bullet, \cdot v$ & $1 \varepsilon, \gamma$. & $r \leqslant \varepsilon \cdot q$ & إيران & \\
\hline$r T, \varepsilon_{0}$ & $17, .0$ & $0 \cdot, v$. & Arrty & 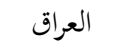 & \\
\hline$\%$ & $\varepsilon \wedge$ & $\%$ & $177.9 \varepsilon$ & المجموع & \\
\hline 91 & $r q$ & $9 \wedge, \uparrow \wedge$ & $1 \cdot \wedge \cdots$ & 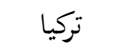 & حوض \\
\hline r & $\ldots 4$ & l,Ar & $r \ldots$ & سوريا & 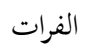 \\
\hline
\end{tabular}


مركز البحوث الجغرافية وإكارتوجرافية - قسم الجغرافيا - كلية الآداب - جامعة المنوفية المؤتمر الجغرافي الدولي الثاني

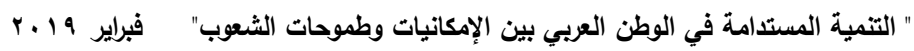

\begin{tabular}{|c|c|c|c|c|}
\hline - & - & - & - & السعودية \\
\hline - & - & - & - & العراق \\
\hline$\% 1 \ldots$ & $r$. & $\% 1 \ldots$ & $11 \ldots$ & المجموع \\
\hline- & VA & - & rVד, $9 \varepsilon$ & إجمالي \\
\hline
\end{tabular}

المصدر: محمد صالح العجيلي،" متغير المياه في العلاقات العربية التركية" ، بحلة آفاق عربية،( ايلول - تشرين الأول) ، بغداد، ، 1999

وبجد سياسة مقايضة المياه بالنفط بتسيدا لها ، وابتزاز النفط العراقي بشكل خاص، في تصريح

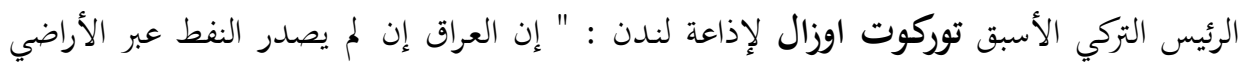

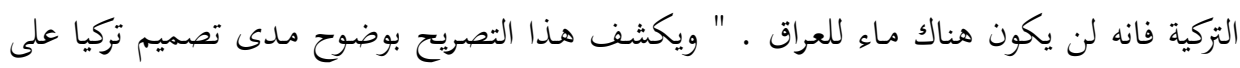

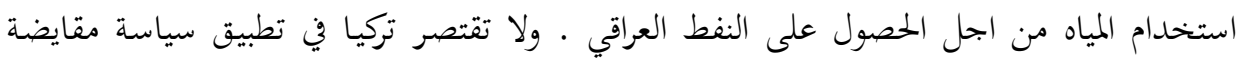

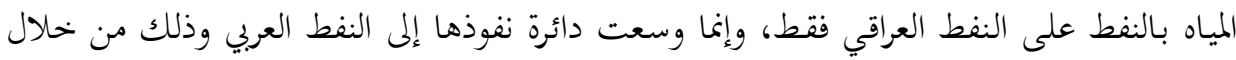
مشروع ( أنابيب السلام )، الذي يمتد أحد أنابيبه حتى أقطار الخليج العربي النفطية، من اجل

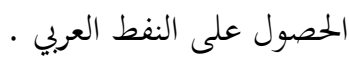

ب. وضع نظام جديد بشأن بيع المياه الى الدول الأخرى : عندما أصدر مسؤول تركي في بداية

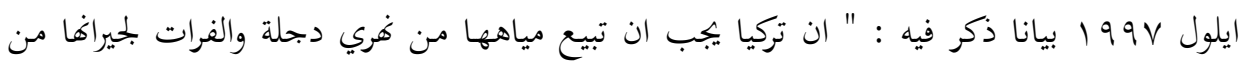

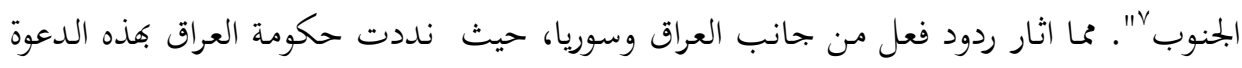

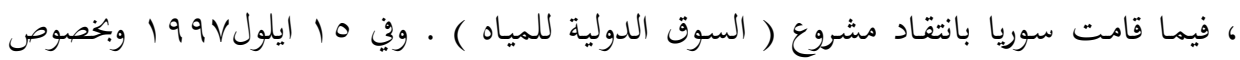
ماكان يتردد آنذاك عن( عقد مؤتمر في تركيا لوضع نظام جديد بشأن بيع المياه الى الدول الاخرى )

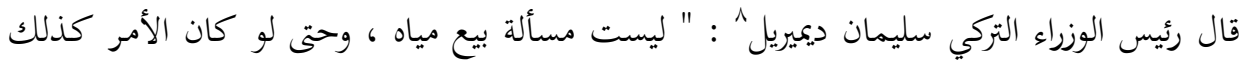

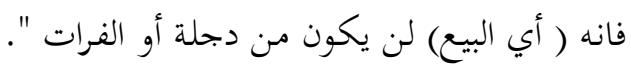

وعلى الرغم من النفي التركي لهذا الموضوع، فإنه يعد منحى جديدا يشكل تطورا

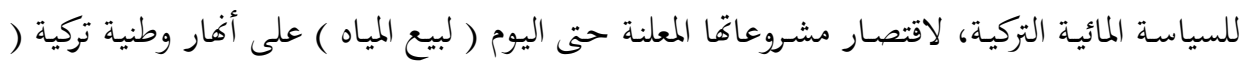
سيحون وجيحون ) في اطار مشروع مياه السلام، و غر ( مانوغات ) في اطار اتفاق المياه بينها 
مركز البحوث الجغرافية والكارتوجرافية - قسم الجغرافيا - كلية الآداب - جامعة المنوفية المؤتمر الجغرافي الدولي الثاني

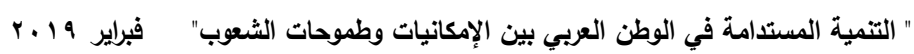

وبين اسرائيل، الذي يدور الحديث حوله منذ منتصف عام • 199 ـ. ان تركيا ومن خلال مشروع بيع المياه، تنظر الى المياه نظرة اقتصادية بوصفها ( سلعة استراتيجية بتحارية ) لها اسعار تباع وتشترى

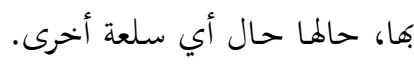

\section{ثالثا: تأثير السياسة المائية لتركيا على الأمن المائي لسوريا والعراق}

لقد تسببت سياسات تركيا المائية المخالفة للبروتوكولات والاتفاقيات والمعاهدات، التي وقعتها مع سوريا والعراق لضمان حقوقهما المائية في غري دجلة والفرات، مشكلات كثيرة على الموارد المائية في كل من سوريا والعراق وعلى خطط وبرامج التنمية الزراعية فيهما، هذه الحقوق لم تحترمها تركيا،

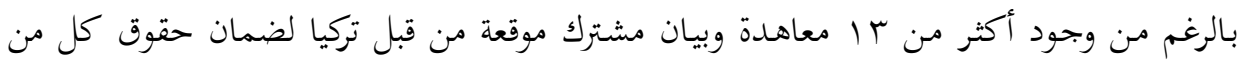

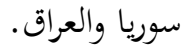

فضلا عن أن المشاريع التركية وتأثيرها في نقص كمية المياه الواردة الى العراق وسوريا، يتطلب من الجهات ذات العلاقة القيام بحث تركيا على ضرورة التوصل إلى إبرام اتفاقيات ملزمة بضمان الأمم

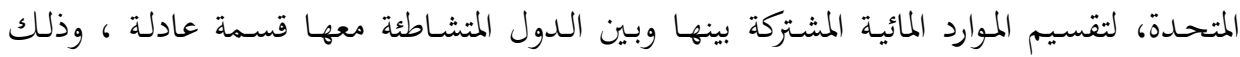

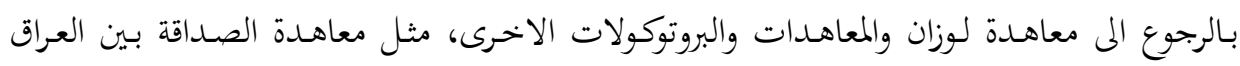

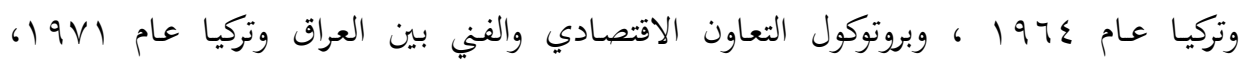

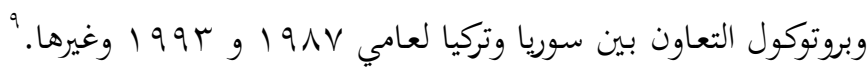

$$
\text { وتبرز أهم التحديات التي بحابه الأمن المائي للعراق وسوريا في: }
$$

1- مشكلة العجز المائي : بالنسبة للعراق يواجه أمنه المائي، اليوم أخطار اعتماده الكامل على مياه

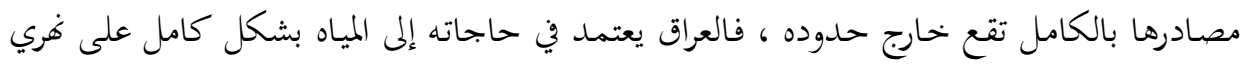

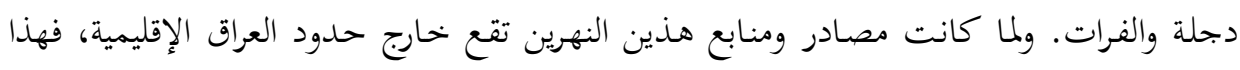

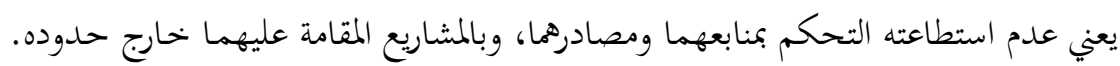
وتنحصر مشكلة مياه غر الفرات في طريقة توزيع المياه غير العادلة بين كل من تركيا وسوريا

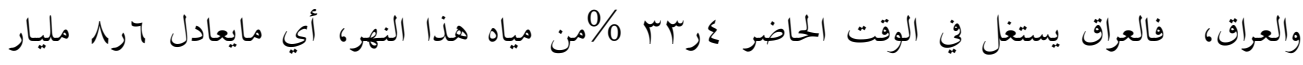


مركز البحوث الجغرافية والكارتوجرافية - قسم الجغرافيا - كلية الآداب - جامعة المنوفية المؤتمر الجغرافي الدولي الثاني

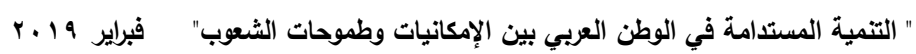

مكعب، على الرغم من أن هذا النهر الذي يبلغ طوله . بr كم يجري أطول مسافة في أراضي العراق،

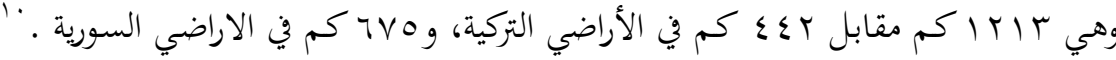

كما أن مساحة حوضه في العراق هي الأكبر سربـ \% \% ، وتبلغ حاجة العراق وحقه المشروع من

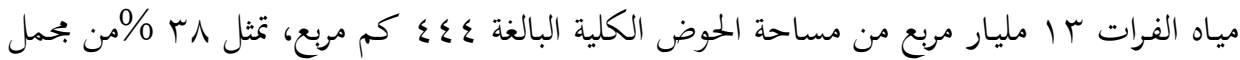
موارد العراق المائية .

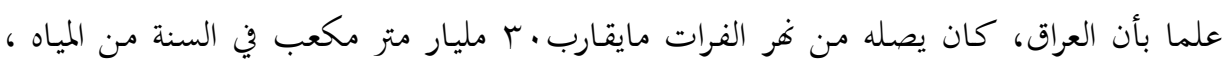

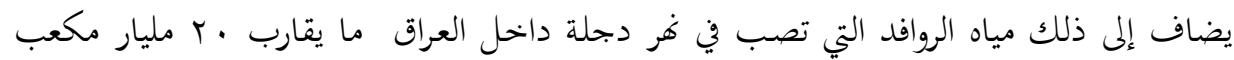

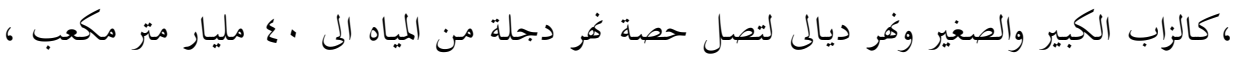
لكن خلال الخمس والعشرين سنة الأخيرة قلت هذه الكميات بشكل كبير، وبالأخص في غر

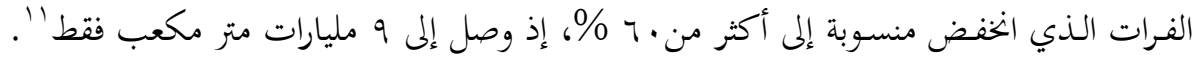

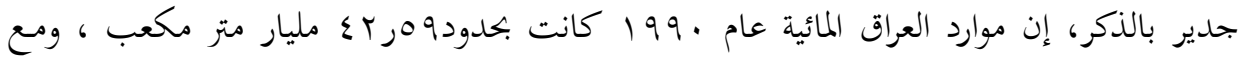
تزايد عدد السكان الى بr مليون نسمة في عام . ...r، فان الموارد المائية عجزت عن تلبية

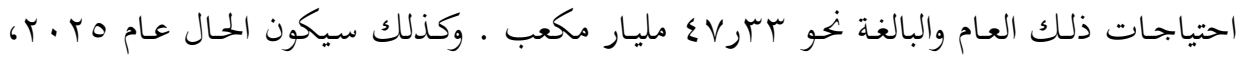

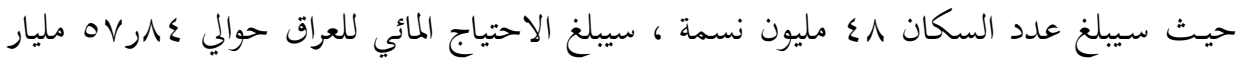

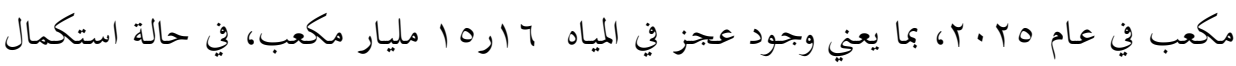
المشاريع التركية لاستثمار مياه النهرين من دون التوصل لاتفاقية تحدد قسمة عادلة لتلك المياه. متر

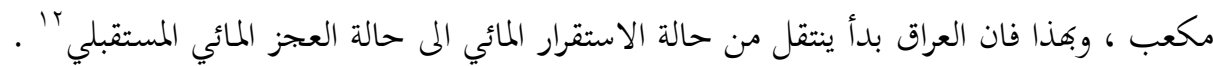
وبالنظر إلى الآثار السلبية التي لحقت بسوريا جراء مشروع (GAP) التركي، يتوقع الحبراء ان سوريا ستتحول تدريجيًا إلى بلد يعاني عجزًا دائمًا في انتاج الغذاء، وسوف تضطر إلى إسى استيراد كميات كبيرة

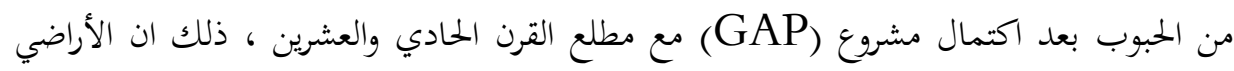

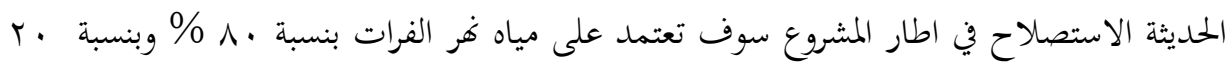
\% على غر دجلة.

كما تعتمد سوريا اعتماداً كبيراً على المحاصيل الزراعية المحدودة بسبب الجفاف النسبي الذي تعانيه، أما

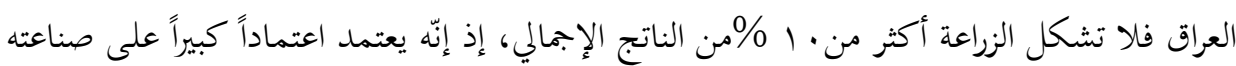


مركز البحوث الجغرافية والكارتوجرافية - قسم الجغرافيا - كلية الآداب - جامعة المنوفية المؤتمر الجغرافي الدولي الثاني

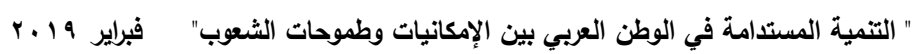

النفطية .وبالنتيجة تعد سوريا الدولة الأكثر تضرراً من الدول الثلاث من استغلال مياه الفرات.

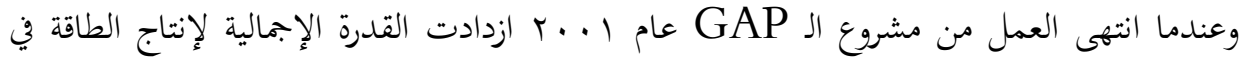
تركيا بنحو · V \%، وهذا ما جعل سوريا تنتبه إلى خطورة هذا المشروع الذي سيؤدي اكتمال برنامجه،

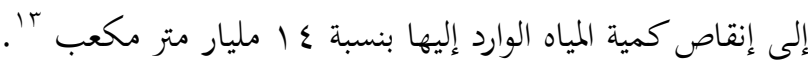

و بالإضافة إلى المشاريع السابقة الذكر التي أقامتها وتقيمها تركيا، هناك مشروع أنابيب السلام

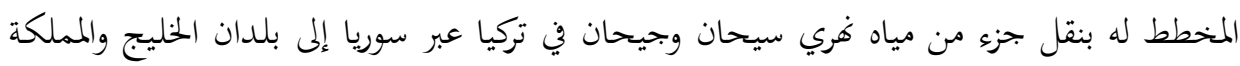

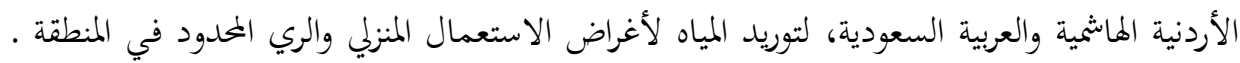

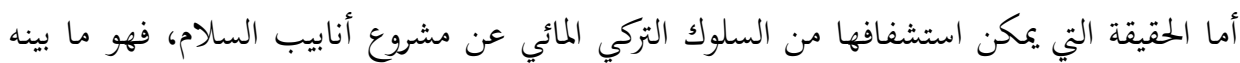
وزير الأشغال العامة والإسكان -جنكيز التن كايا- في حديث بثه التلفزيون التركي على قناته الثانية

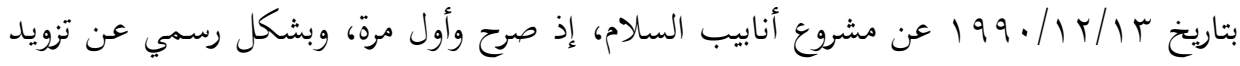

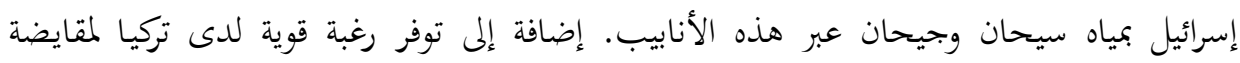
البترول بالمياه، وذلك كما ظهر من تصريح سليمان ديميريل الرئيس الأسبق لتركيا، لدى افتتاح سد سداه

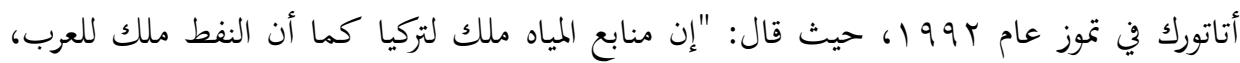

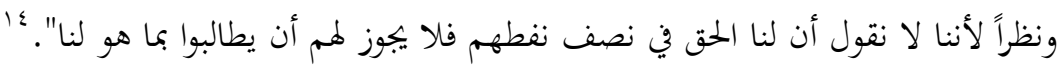

r- مشكلة التحكم التركي بمياه نهري دجلة والفرات : إن مشروعات تركيا المائية التي نفذها على

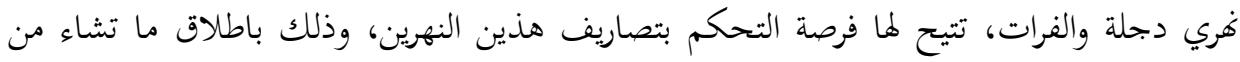

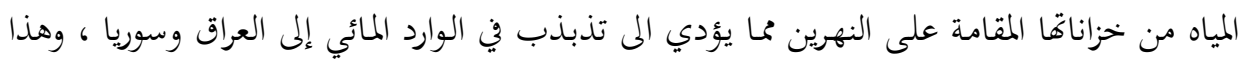
بدوره يؤدي إلى تعثر تنفيذ الخطط الزراعية ، حيث تشير الدراسات التي أعدةما وزارة الخارجية التركية

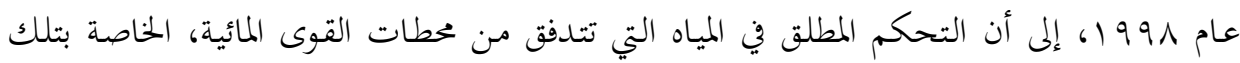
السدود، يكون على وفق الحاجة إلى الطاقة الكهربائية التي سيتم تشغيل وحدات التوليد فيها.

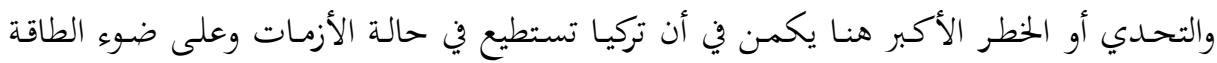

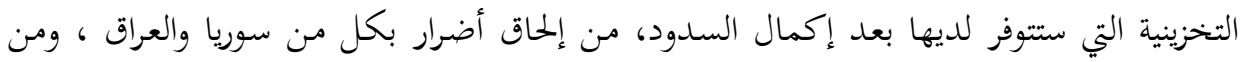
ذلك إمكانية إحداث فيضانات في النهر بإطلاق تصاريف عالية جدا تفوق استيعاب حوضه، كما

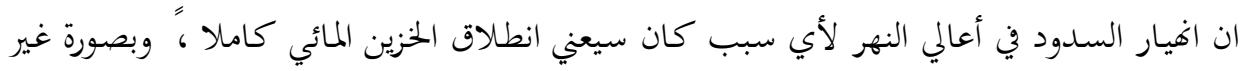


مركز البحوث الجغرافية والكارتوجرافية - قسم الجغرافيا - كلية الآداب - جامعة المنوفية المؤتمر الجغرافي الدولي الثاني

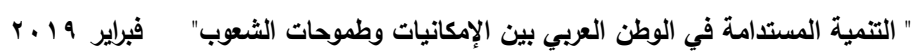

مسيطر عليها وخلال مدة قصيرةً وورود تصاريف عالية جدا في حوض النهر إلى سوريا والعراق ،

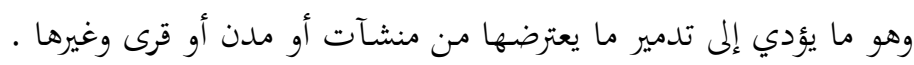

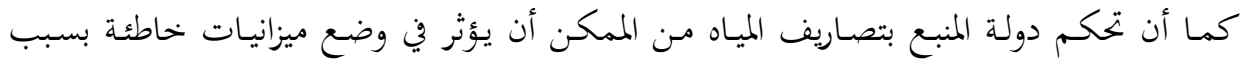
المعلومات غير الدقيقة ، وذلك كون العملية المتعلقة بالمياه متشعبة مـن النواحي الاقتصادية والاجتماعية والجغرافية.

r- مشكلة التأثير على إدارة الموارد المائية : إن التحكم التركي بتصاريف مياه غري دجلة والفرات سيؤثر على ادارة الموارد المائية في العراق وسوريا ، ولو توافرت الكميات المطلوبة من الموارد المائية في الوقت المناسب، لما كان هناك سبب لحاجة الإنسان إلى إدارة الموارد المائية ،

$$
\text { وتكمن المهام الأساسية لإدارة المياه في الآتي: }
$$

أ. تحقيق الموازنة المائية ، وهذه تعتمد على توقعات عرض المياه المتاحة والطلب عليها. ب. درء الأخطار الناجمة عن المياه الفائضة أثناء السنوات الرطبة ( المطيرة )، وتخزينها للاستفادة منها اثناء السنوات الجحافة . ج. المحافظة على نوعية المياه من التدهور والتلوث . وقد شهد عقد التسعينيات من القرن الماضي تحولا كبيرا في التوجه العراقي نحو إدارة الموارد المائية ،

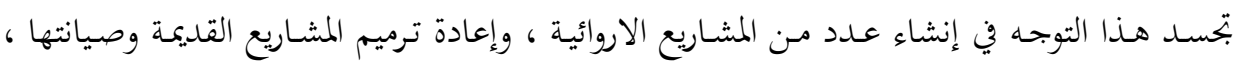
وتقليل الهدر في الموارد المائية ... الخخ ، من أجل تحقيق أفضل استثمار ممكن لمياه دجلة والفرات . ولغرض تأمين احتياجات العراق المائية، أقام العراق العديد مـ السـدود والمشاريع المائية في مقدمتها: سدود المندية والقادسية والرمادي ومشروع الحبانية وقناة الثرثار وسد الموصل ، التي تزود غر

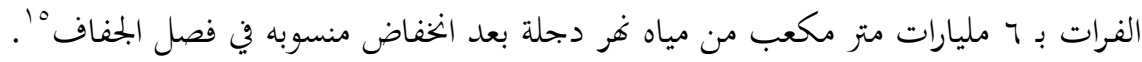

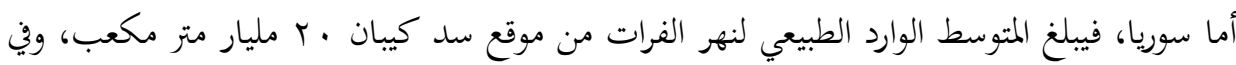

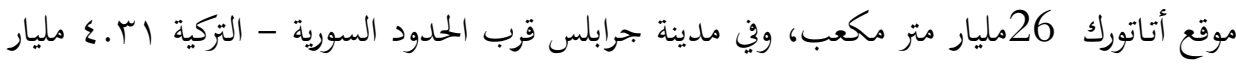

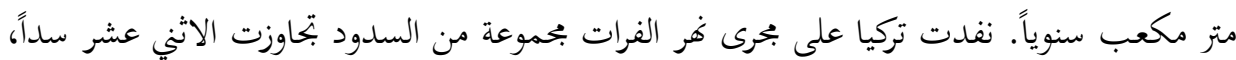

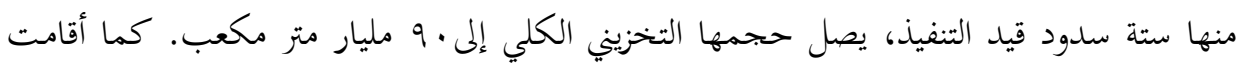

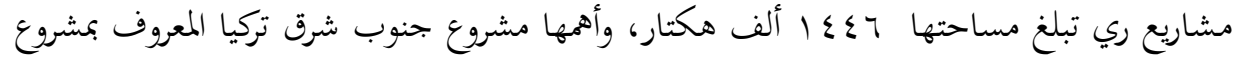


مركز البحوث الجغرافية والكارتوجرافية - قسم الجغرافيا - كلية الآداب - جامعة المنوفية المؤتمر الجغرافي الدولي الثاني

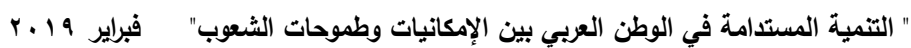

كما أقامت مشاريع توليد طاقة كهربائية استطاعتها (·• (مليون كيلو واط ساعي سنوياً"1 (GAP)

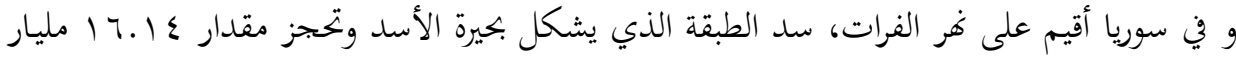

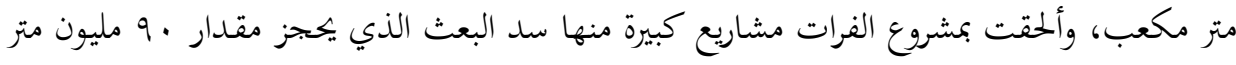

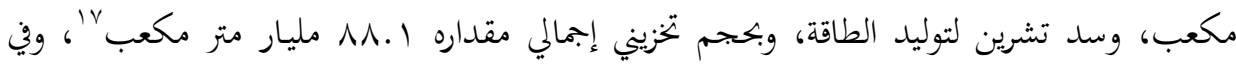

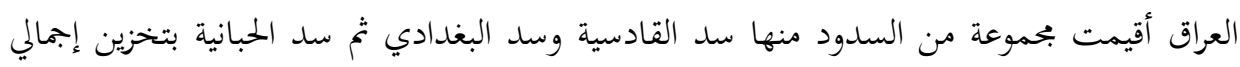

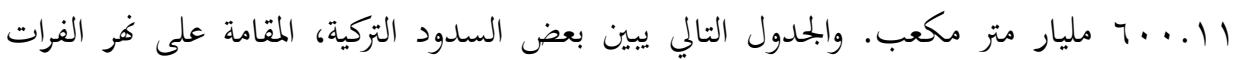
ومواصفاتما`' جدول رقم (ب): بعض السدود المقامة على نهر الفرات

\begin{tabular}{|c|c|c|c|c|c|c|c|c|c|}
\hline \multicolumn{8}{|c|}{ اسم السد } & \multirow{3}{*}{ القياس } & \multirow{3}{*}{ التصنيف } \\
\hline \multicolumn{2}{|c|}{ العراق } & \multicolumn{3}{|c|}{ سورية } & \multicolumn{3}{|c|}{ تركيا } & & \\
\hline الحبانية & حديثة & البعث & الطبقة & تشرين & أتاتورك & قرة قايا & كيبان & & \\
\hline - & r..人 & r..人 & r.. & r..人 & r.. & rT.o & $19 . \varepsilon$ & مكليار مكعب & السنوي \\
\hline$r .07$ & $11 . r$ & $\ldots 9$ & 11.7 & $1 . r$ & $\leqslant 9$ & $9.0 \leqslant$ & $r \cdot . \tau$ & مكليار مكعب & التخزينية \\
\hline- & 70. & TV & $7 \cdot\{$ & - & NIV & rฯ^ & TVO & مكيلو & سطح \\
\hline- & - & or & $\wedge \ldots$ & $\sum Y$. & $r \leq \ldots$ & $1 \wedge \ldots$ & $\mid r \varepsilon$. & ميغا & الكهربائية \\
\hline منفذ & منفذ & منفذ & منفذ & منفذ & منفذ & قالتفيذ & منفذ & & الوضع \\
\hline
\end{tabular}

المصدر: مثنى فاضل الوائلي، التغيرات المناخية وتأثيراتحا في الموارد المائية السطحية في العراق، أطروحة دكتوراه، جامعة الكوفة،

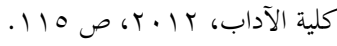


مركز البحوث الجغرافية والكارتوجرافية - قسم الجغرافيا - كلية الآداب - جامعة المنوفية المؤتمر الجغرافي الدولي الثاني

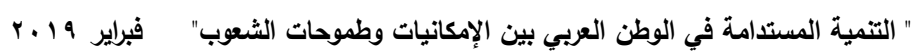

ع - المشاكل ذات الطابع القانوني: لم تستجب تركيا لاعتراضات كل من العراق وسوريا على

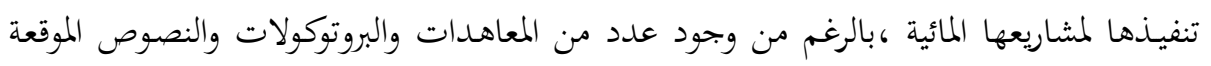

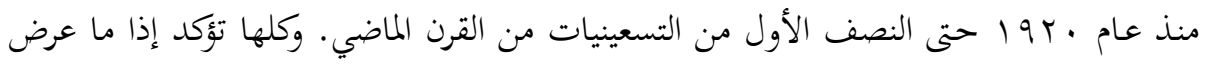

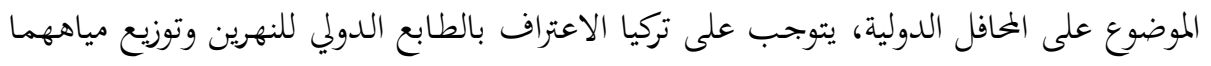

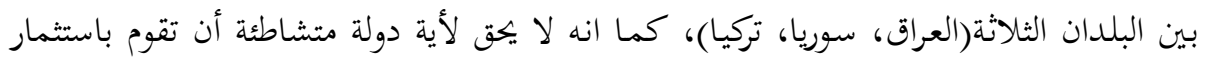

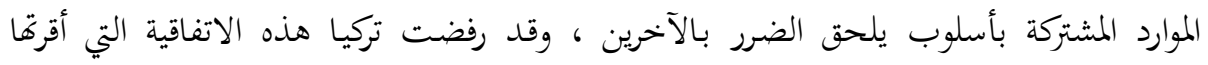

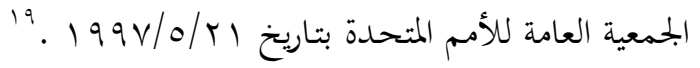

و ظلت تتمسك بحق السيادة المطلقة على مياه دجلة والفرات التي تنبع من أراضيها، وبأن ما تمرره من مياه إلى سوريا والعراق هو تضحيةً وليس واجبا، فهي ترفض مبدأ القسمة العادلة لتوزيع المياه

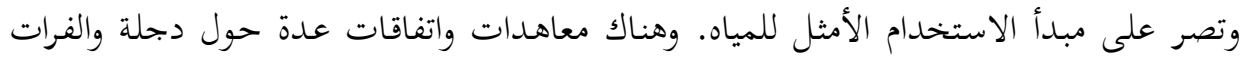

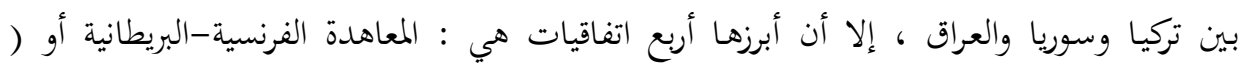

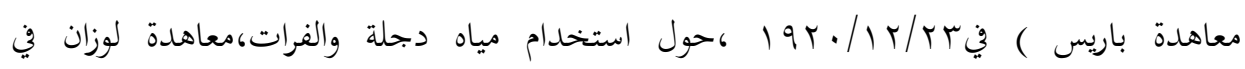

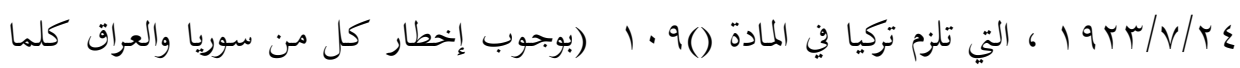

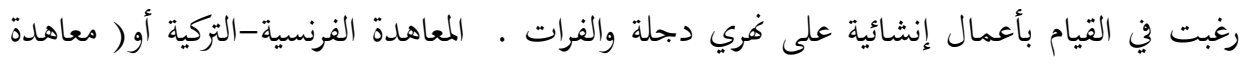

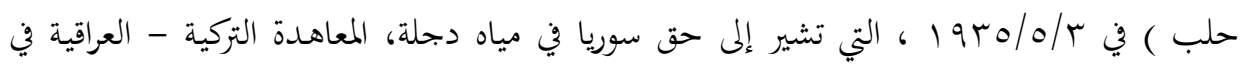

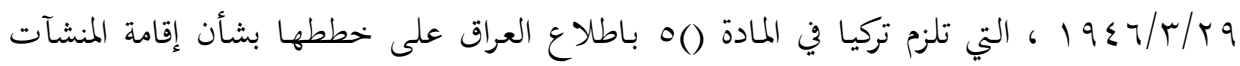
وصيانتها على غري دجلة والفرات ‘.

لقد سعى العراق منذ وقت مبكر مع الدول المتشاطئة ( تركيا وسوريا )، للدخول في مفاوضات

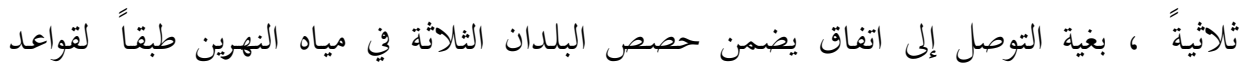

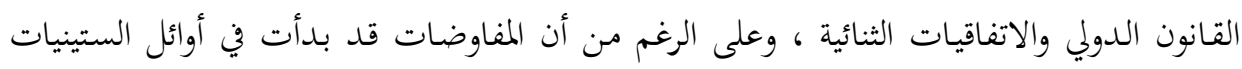

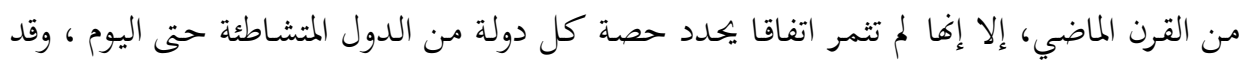

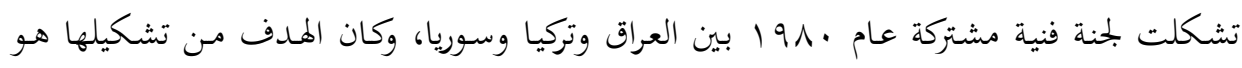

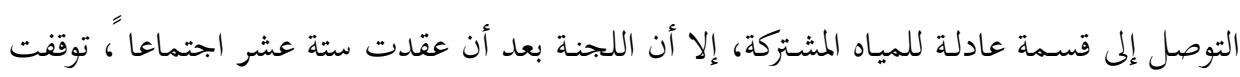

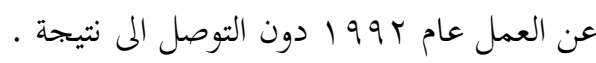


مركز البحوث الجغرافية والكارتوجرافية - قسم الجغرافيا - كلية الآداب - جامعة المنوفية المؤتمر الجغرافي الدولي الثاني

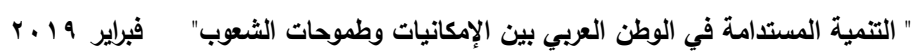

\section{ه - الاستخدامات التركية للمياه وأثرها على نوعية المياه وخصائصها}

اثر التطور الصناعي الذي عرفته تركيا في العقد الأخير، بدرجة كبيره على نوعية وكمية المياه الواصلة

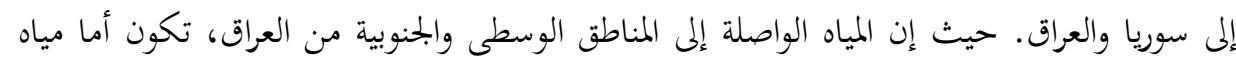
مالحة آو ملوثة آو نسبة الغرين والطمي فيها تكون عالية، وكما يأتي:

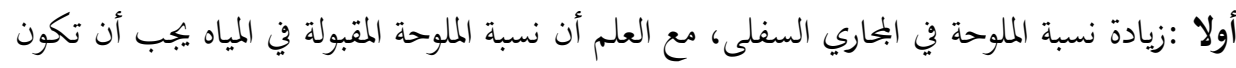
\% 1.5 (لأغراض الري الجيد، ولهذا سوف تتكون آثار سلبية متلاحقة على الأراضي والإنتاج الزراعي، مع ظهور بوادر السبخة والبور. ثانيا :قلة كميات الغرين - الطين الأحمر - التي ينقلها غري دجلة والفرات، وخاصة في موسرم

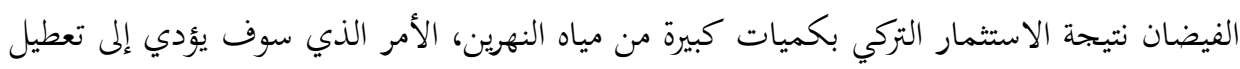
خصوبة التربة وظهور بوادر التصحر. ثالثا :التلوث بسبب مياه المرتفعات ، لان الفضلات ستعود إلى النهرين بدون معالجة مباشرة من

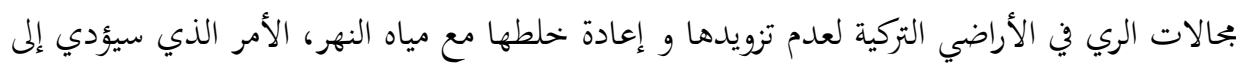

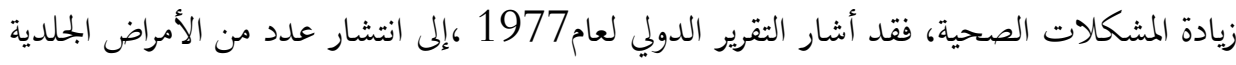

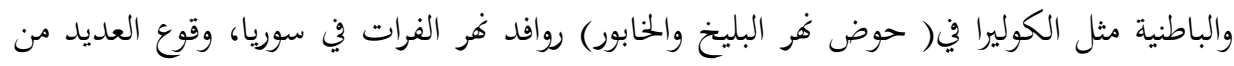

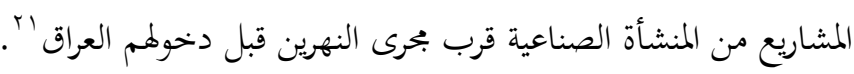


مركز البحوث الجغرافية وإكارتوجرافية - قسم الجغرافيا - كلية الآداب - جامعة المنوفية المؤتمر الجغرافي الدولي الثاني

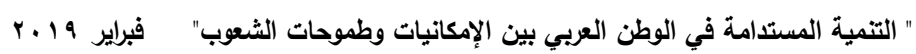

ه- تأثير المشاريع المائية التركية على متطلبات الأمن المائي للعراق وسوريا

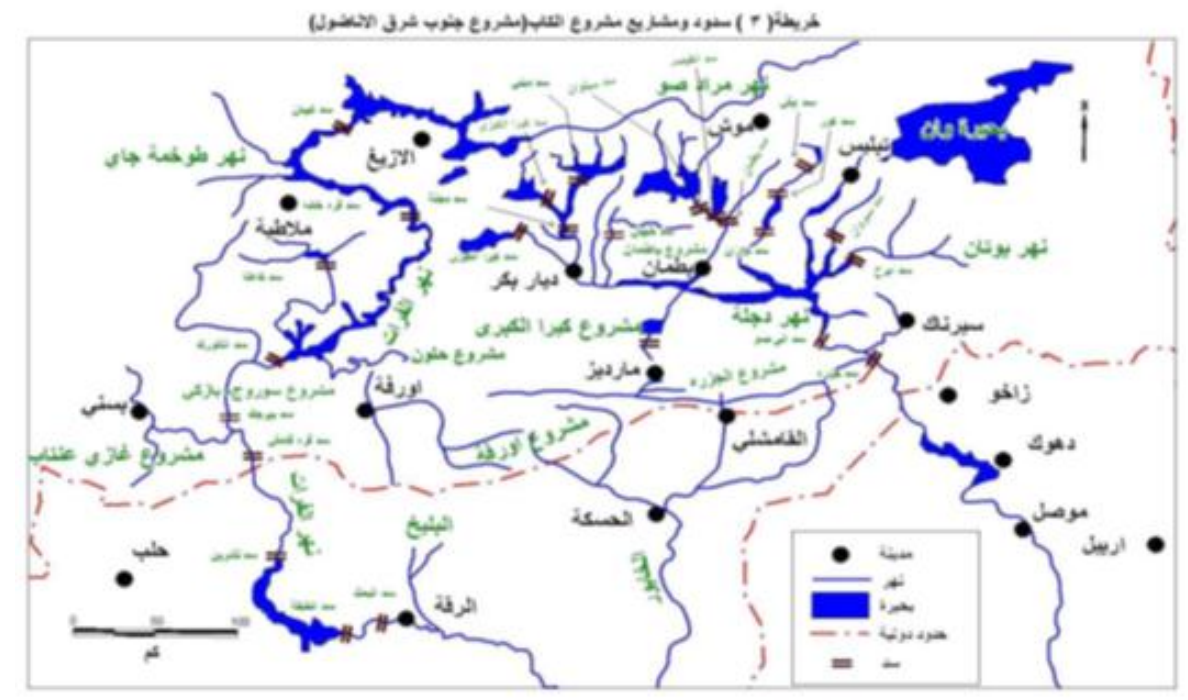

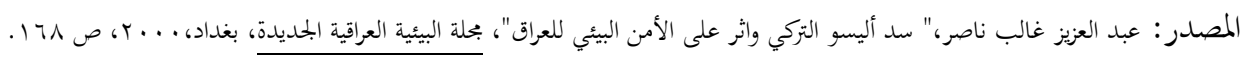

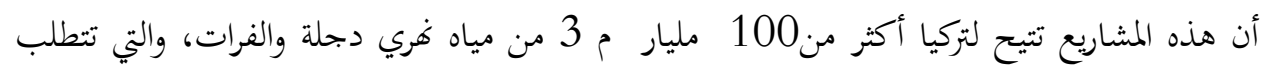

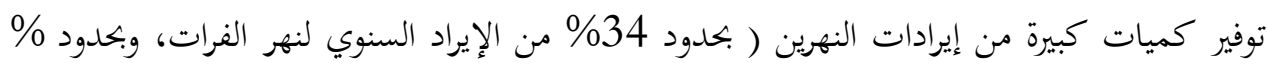
17.5من الإيراد المائي لنهر دجلة). ا - إن كمية المياه التي ستطلقها تركيا عبر النهرين بداية القرن القادم لا تزيد عن 27 مليار مإدم 3 سنويا، وهذا سوف ينعكس على الأوضاع الاجتماعية والاقتصادية لسوريا والعراق ويلقي ضررا فادحا في بجالات الري، الزراعة والصناعة. r- الإضرار بمشاريع توليد الطاقة الكهربائية، خاصة أنساعة أن سوريا والعراق تصنعان خططها بإقامة السدود لتوليد الطاقة على أساس المعدل السنوي لجريان المياه في النهرين.

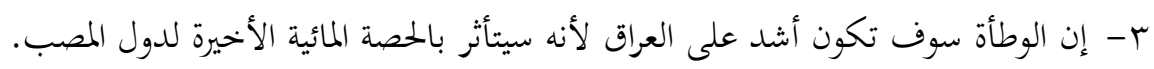

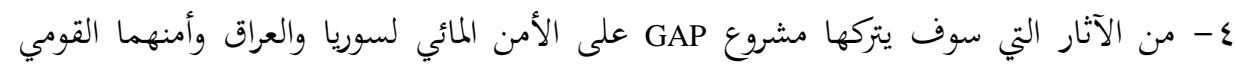

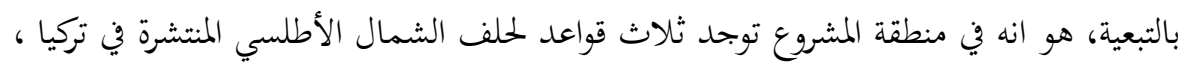

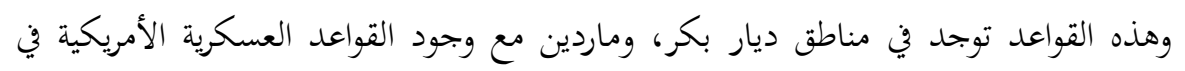

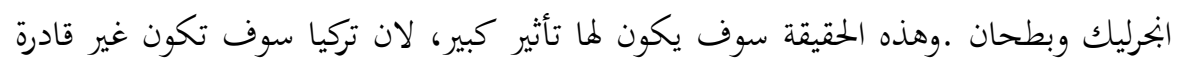
على التفاوض مع جيراها العرب في مسائلة المياه المشتركة. 
مركز البحوث الجغرافية والكارتوجرافية - قسم الجغرافيا - كلية الآداب - جامعة المنوفية المؤتمر الجغرافي الدولي الثاني

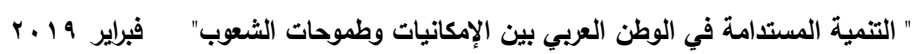

- - ان بحموعة الأراضي التي سوف يرويها المشروع ومن ضمتها المساحة المروية حاليا ، تقدر

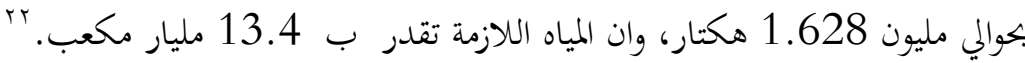

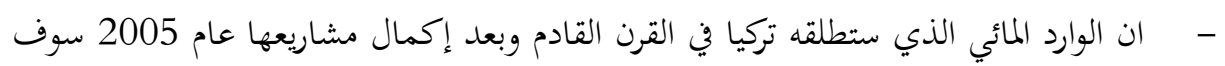

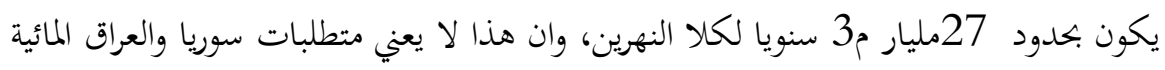

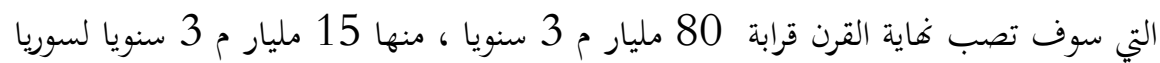

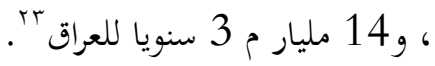
- - أن من التأثيرات السلبية للسدود والمشاريع الاروائية التي تقيمها تركيا، هو احتمالات تأثيرها المباشر على بحمل العلاقات السياسة بين البلدين خاصة اذا ما وضعنا في ما يأتي:

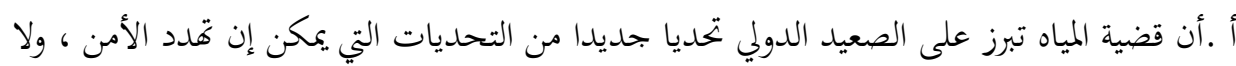
يجب ان تستعد له كل الأطراف إقليميا ودوليا والذي قد تصل إلى حيديد حالة الحرب.

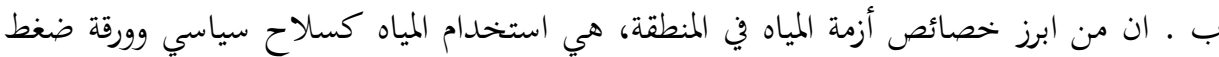
للمساومة على وضع حلول لمشكلات أخرى، وينطبق هذا المفهوم على مشكلة غري دجلة والفرات، اذا لا تخفى الدوافع السياسية للسياسة المائية التركية.

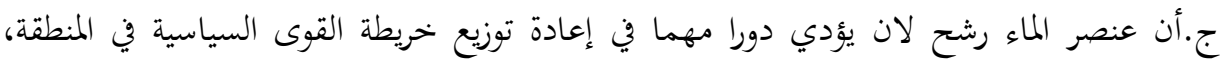
بحيث تصبح الدول ذات الوفرة لمصادر المياه هي القوة الإقليمية الجلديدة. رابعا: سيناريوهات مستقبل الأمن المائي لنهري دجلة والفرات لابد من القول أن عنصر المياه سيكون فعالا في إعادة توزيع خريطة القوى السياسية في المنطقة،

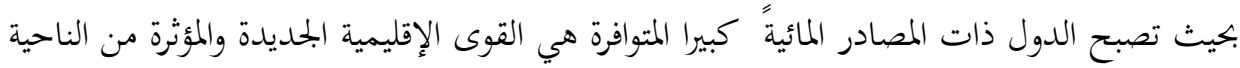
السياسية. وستشكل عامل صراع في المنطقة مستقبلا ، وذلك في الحقبة التي ستتبع سنوات العقد المقبل على الأكثر، إذ يقول تقرير وضعه" مركز الدراسات الإستراتيجية والدولية "في واشنطن، بعد دراسة فئس

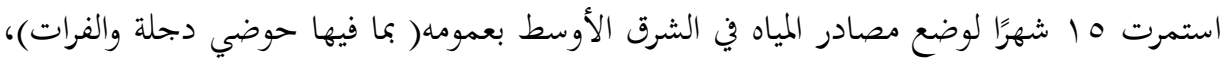
وشارك فيها العشرات من الخبراء والمسؤولين من عرب وغيرهم، يقول:" إن المياه - وليس النفط -

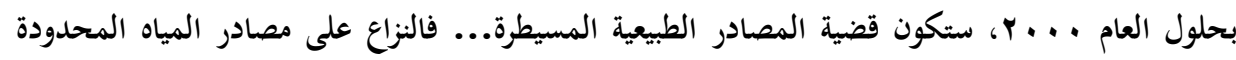


مركز البحوث الجغرافية والكارتوجرافية - قسم الجغرافيا - كلية الآداب - جامعة المنوفية المؤتمر الجغرافي الدولي الثاني

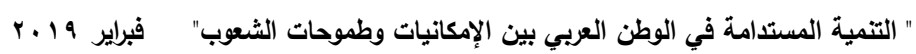

والمهددة، يمكن أن يؤثر على الروابط بين دول المنطقة، وربما يؤدي الى جيشان لم يعرف له مثيل من قبل...

ومن الناحية الاقتصادية، من المتوقع أن يصبح الماء سلعة تباع وتشترى مثل النفط، كما يتوقع ازدياد حدة الأزمة الغذائية، وعليه فان بإمكان العراق و سوريا إحالة القضية إلى محكمة العدل الدولية، نظرا لحجم التهديد الذي يتعرض لهما أمنهما المائي جراء السياسة المائية التي تتبعها تركيا. وبناءا على ما تقدم، فان مستقبل الأمن المائي لحوضي دجلة و الفرات يخضع للاحتمالات الآتية: 1- احتمال الصراع: تعود مشكلة مياه غري دجلة والفرات بين كل من سوريا والعراق تجاه تركيا، إلى تاريخ ليس بالحديث. فعلى الرغم من انه قد تم التباحث حول تقسيم المياه منذ أربعينيات القرن

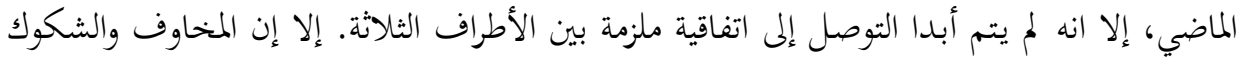

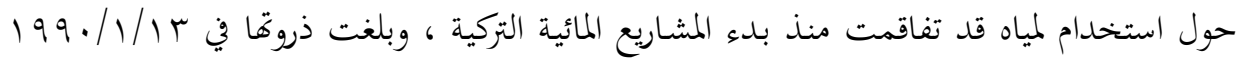

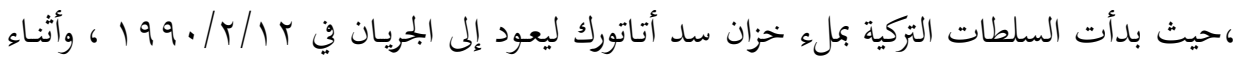

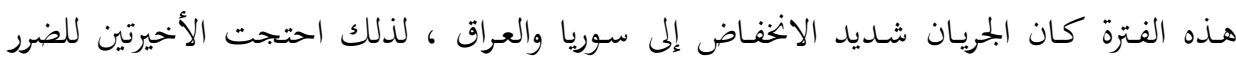
الذي أصاب اقتصادياقما. ro. وفي الوقت الذي عاد جريان المياه إلى وضعه الطبيعي، كانت قضية المياه تطرح كسبب محتمل لحرب

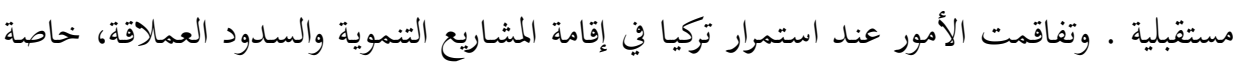
في مشروع جنوب شرق الاناضول (GAP)، والتي ستؤثر بشكل مباشر على كل من سوريا والعراق،

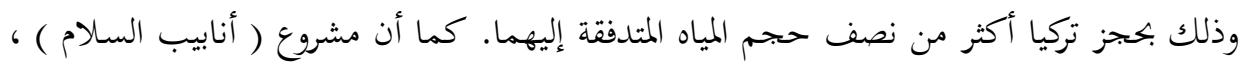
سيؤدي إلى إشعال فتيل الحرب في المنطقة لو قدر له النجاح ودخل حيز التنفيذ وإذا لم يتم حل الوضع القـائم، قد يتمخض عنه مضاعفات عدة ـ فربما تقوم تركيا وهي الدولة المتحكمة بمنابع غري دجلة والفرات بتغيير ميزان القوى في المنطقة لصالحها وتعزيز دورها في السياسات المائية ، وقد تتصاعد حدة الصراع على المياه بين العراق وسوريا. وقد تحدث تغييرات أساسية في البنى الاجتماعية والاقتصادية الناجمةً عن النشاط الزراعي للأقطار

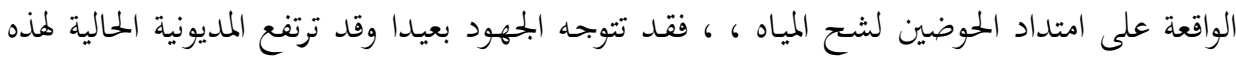
الدول ، وقد تؤدي أية بحموعة من تلك الأحداث إلى زعزعة الاستقرار بشكل خطير في الأقطار

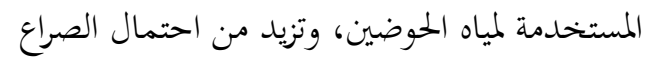


مركز البحوث الجغرافية والكارتوجرافية - قسم الجغرافيا - كلية الآداب - جامعة المنوفية المؤتمر الجغرافي الدولي الثاني

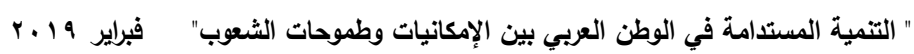

ومما تقدم يبدو ان احتمال الصراع في حوضي دجلة والفرات قائم ، وإذا ما كانت هناك حرب مائية مستقبلية فستكون كارثة اجتماعية وبيئية واقتصادية بالغة التكاليف.

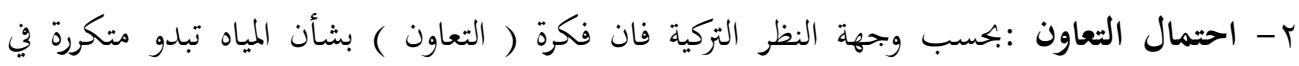

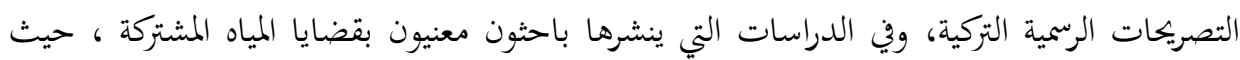

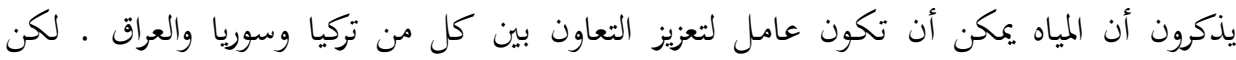
الأحداث تؤكد عمق التناقض بين تلك التصريحات، والممارسة العملية المتمثلة بتوجهين أساسيين هما : عرقلة الجهود الرامية لتحديد الحصص عبر اتفاق ثلاثي، والاستمرار في الوقت نفس بإقامة

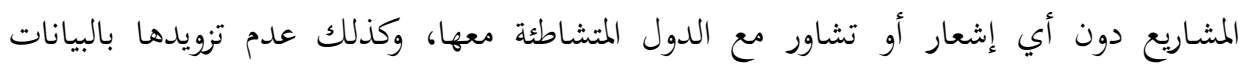
والمعلومات اللازمة ، الأمر الذي يؤكد عدم تطبيق تركيا لمفهوم التعاون في إدارة المياه الدولية المشتركة، وفق ما تقره قواعد القانون الدولي ـ لذا فان القضية الأهم لمشاريع التعاون التركي - العربي بشأن

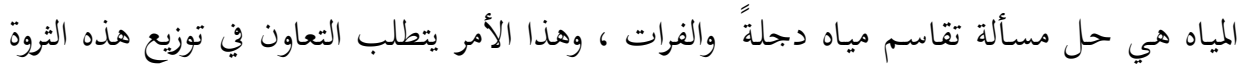
المائية ، لأن انعدام الثقة المتبادلة قد يولد توترا ونزاعا. كذلك إيجاد مشاريع مائية زراعية بين العراق وسوري وتركيا بهدف ضمان استمان استمرار تدفق المياه إلى

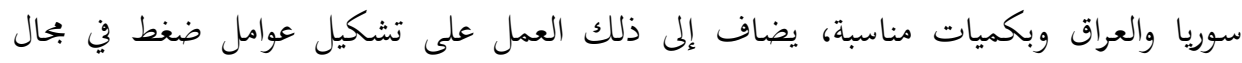

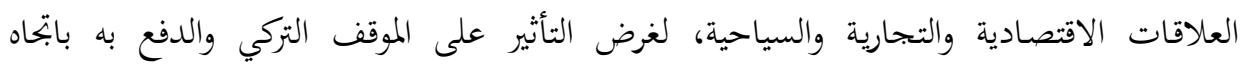

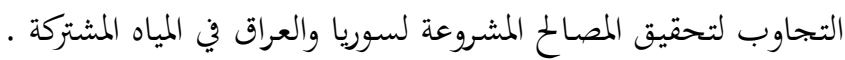
إن قضية المياه بين سوريا والعراق تعد قضية أساسية ليس لأغما دولتان عربيتان فحسب، بل لأهما تتخذان الموقف نفسه ازاء السياسة المائية التركية ، فهما يتأثران التأثر نفسه بالسياسة لتهية التركية ازاء المسألة المائية، ومن ثم فان التنسيق السوري العراقي هي مسألة مهمة وضرورية كوفما دولتي بحرى

مما تقدم يمكن القول، أن كل ما قامت به تركيا نابع من رؤية تتعلق بمصالحها الخاصة لتحقيق

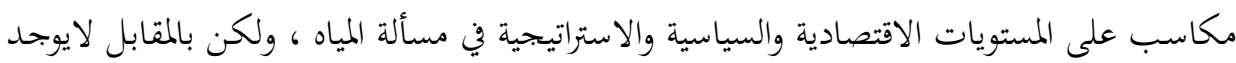
أي رد فعل سوري أو عراقي بهذا الابحاه يتناسب وحجم المخاطر المتحققة ، ولا توجد اجراءات

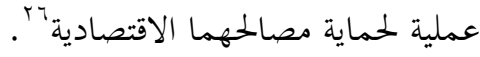


مركز البحوث الجغرافية والكارتوجرافية - قسم الجغرافيا - كلية الآداب - جامعة المنوفية المؤتمر الجغرافي الدولي الثاني

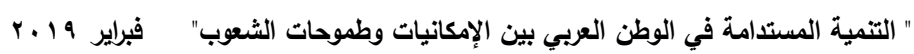

نتائج وتوصيات

- - تعد مشكلة تقاسم المياه بين الدول التي تتغذى أراضيها من مصادر مائية مشتركة، إحدى

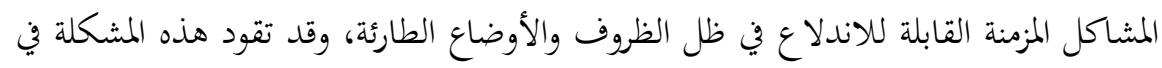
بعض الأحيان الى حروب محلية بين الأطراف المتنازعة، وهكذا كانت هذه المشكلة المكلة وماتزال مصدرا من مصادر التوتر الإقليمي. - يأتي التهديد الرئيس والتحدي الأكبر في حوضي دجلة والفرات من قبل تركيا بوصفها دولة

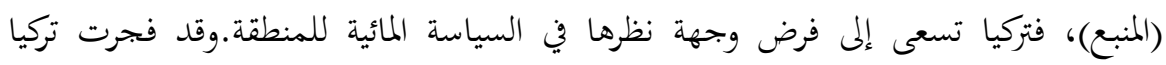

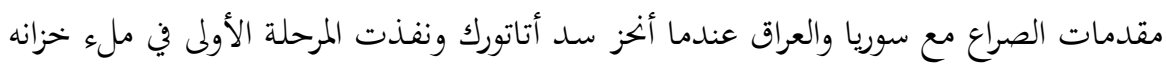

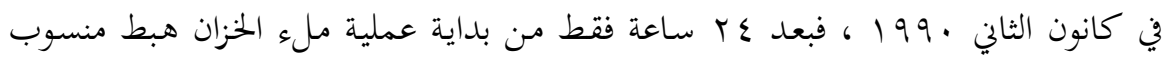

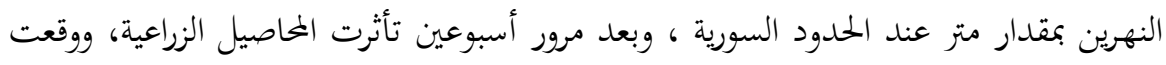

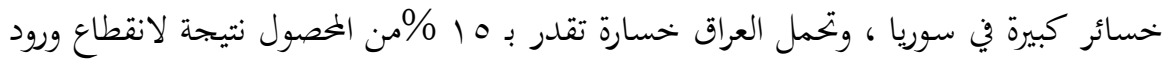
المياه .

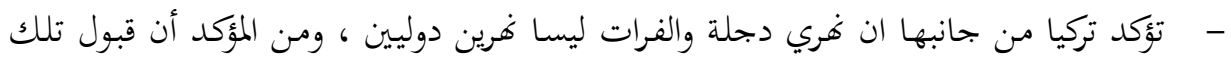

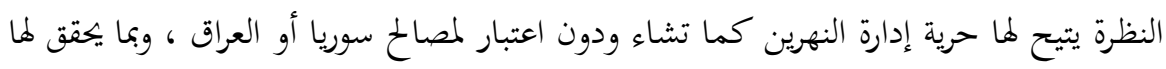
رغبة أن تصبح (سلة الغذاء) في الشرق الأوسط. - تحتفظ تركيا لنفسها باستخدام سلاح المياه كورقة ضغط ومساومة رغم النفي الرسمي لذلك ،

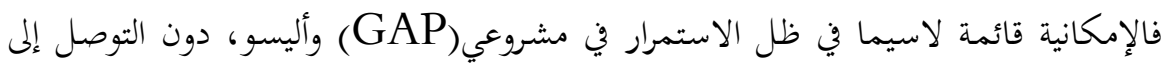

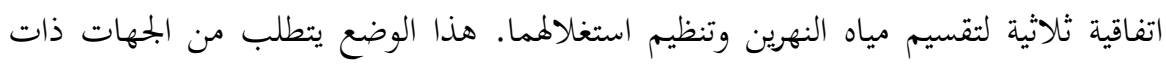
العلاقة ان تتحرك لمراقبة الوضع المائي، الذي ستؤول إليه الأوضاع في العراق وسوريا، وتدارسه العهاه

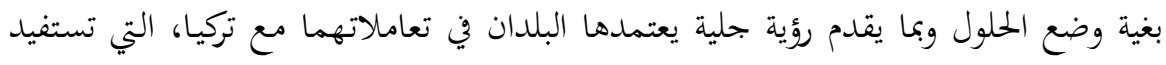

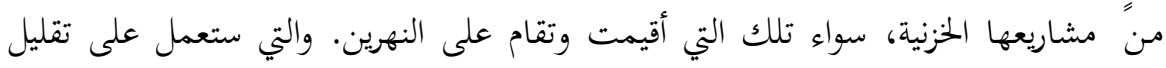

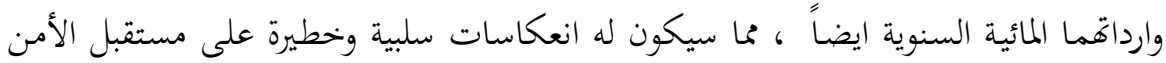
المائي فيهما ،وسينعكس بدوره على الأمن الغذائي والقومي.

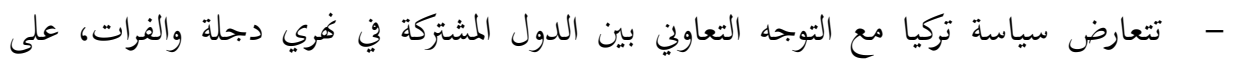

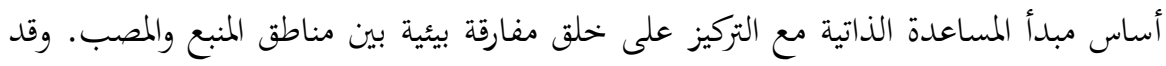


مركز البحوث الجغرافية والكارتوجرافية - قسم الجغرافيا - كلية الآداب - جامعة المنوفية المؤتمر الجغرافي الدولي الثاني

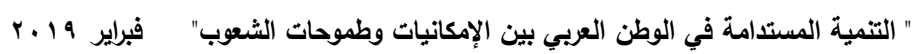

أدى هذا التوجه إلى انخفاض الدورة المائية، مع حدوث تأثيرات سلبية مثل اختلال الأمن الغذائي، والهجرة البيئية، وتدمير النظام الإيكولوجي في المنطقة .

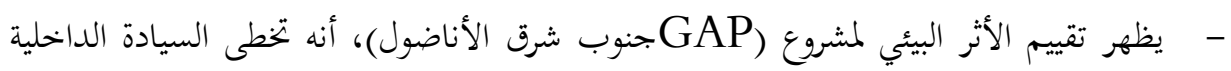

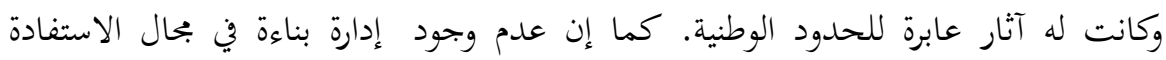

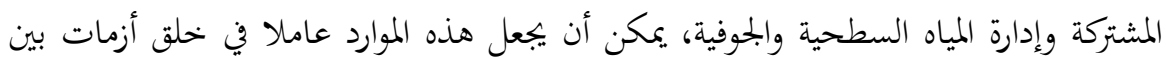
البلدان المتشاطئة لهذين النهرين. النتيجة هي أنه من أجل رصد موارد المياه العابرة للحدود لتحقيق نصيب عادل، من الضروري تعزيز

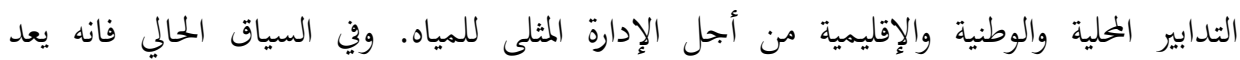
فها للتفاوض المائي والمشاركة البناءة. وبناءا على ما سبق، ومن أجل تحقيق متطلبات الأمن المائي لسوريا والعراق، يككن طرح التوصيات

- من الضروري التفاوض على اتفاقات لتقاسم المياه مع الدول المتشاطئة لنهري دجلة والفرات،

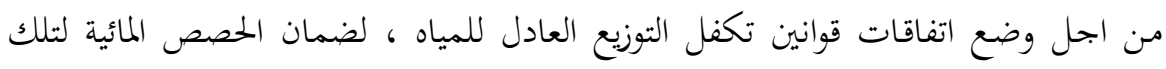
الدول، وفق ما تقرره الأعراف والقوانين الدولية

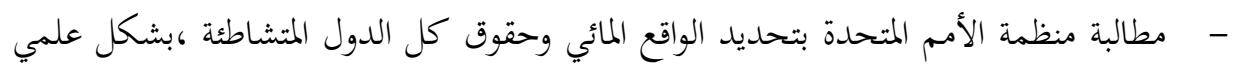
ودقيق من خلال دراسات علمية تحدد كميات المياه وحاجات الدول الآنية والمستقبلية، وتحدد

$$
\text { نوعياتا وهل هي متجددة من عدمها. }
$$

- - التعاون الدولي والإقليمي، و الاستفادة من المنظمات الدولية والإقليمية في بحال إدارة واستثمار الموارد المائية. - - تطبيق النهج التشاركي ومبادئ الإدارة المتكاملة للموارد المائية، واعتماد مقاربة التعاون في تقسيم المياه بين الدول المتشاطئة. - مارسة الضغط السياسي والدبلوماسي على تركيا ، من خلال الميئات والمنظمات الدولية

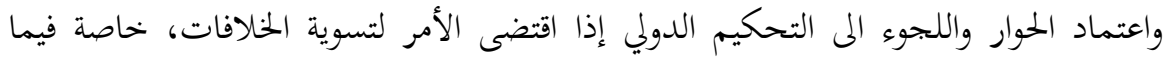

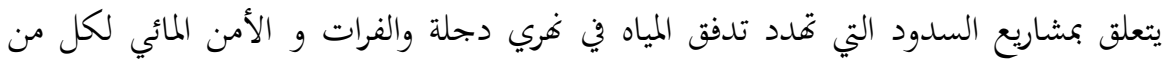
سوريا والعراق. 
مركز البحوث الجغرافية والكارتوجرافية - قسم الجغرافيا - كلية الآداب - جامعة المنوفية المؤتمر الجغرافي الدولي الثاني

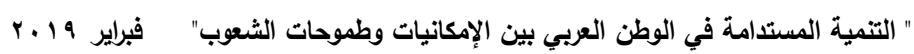

- - تبادل المعلومات وإنشاء منظومات إدارة الأحواض المائية، بعد التوصل إلى اتفاقيات تضمن التقاسم العادل للثروة المائية بين الدول المتشاطئة.

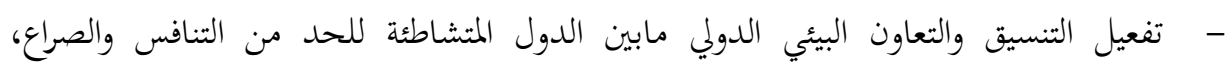
وتغليب لغة الحوار والتعاون في حل المشكلات الناجمة عن نقص المياه، والوصول إلى آليات الإدارة المتكاملة والمشتركة والمنصفة لكل الدول المتشاطئة. - - التأكيد على الربط العضوي بين الأمن المائي والأمن الغذائي، بوصفهما الوسئلة الوسيلة الفعالة في تحقيق التنمية الزراعية لمستدامة والتي تمدف إلى تحقيق أعلى مستوى في الاكتفاء الذاتي.

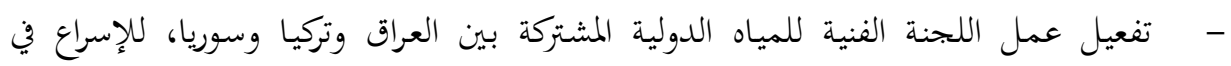

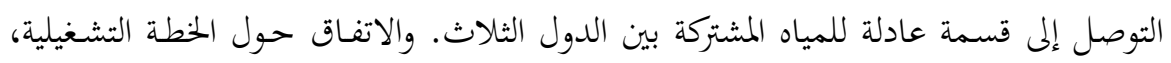
والتخزين في البحيرات المرتبطة مع السدود في تلك الدول.

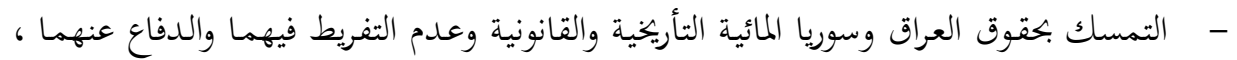
ورفض فكرة اعتبار المياه الدولية المشتركة سلعة اقتصادية لأن هذا مخالف لقواعد القانون الدولي.

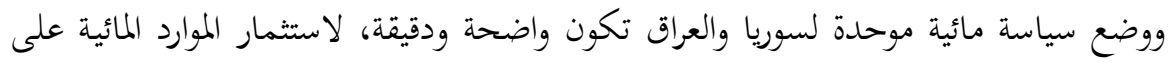

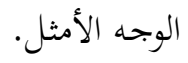
- ترشيد استهلاك الموارد المائية المتاحة، عن طريق رفع كفاءة شبكات نقل وتوزيع المياه وصيانتها

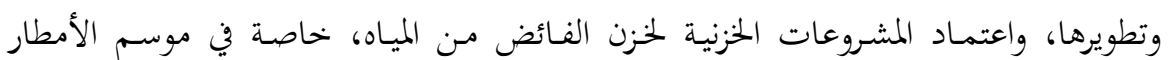

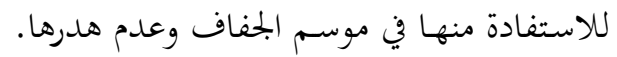
- تنمية الموارد المائية عن طريق مشروعات السدود والخزانات، وتقليل المفقود الناتج عن التبخر

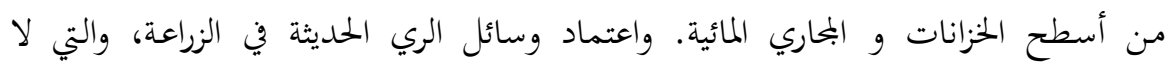

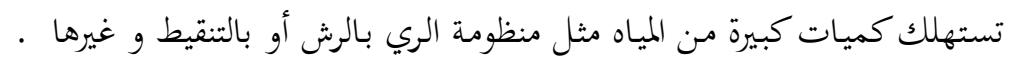

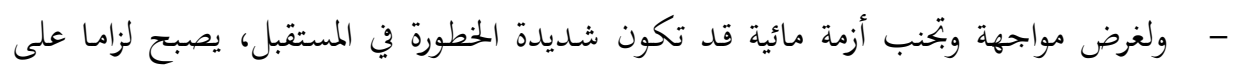
العراق وسوريا صياغة سياسة مائية شاملة تأخذ بعين الاعتبار حاجات البلدين إلى المياه في المستقبل ، وبناء المزيد من الخزانات والسدود ، واستغلال مياه الأمطار ، والمياه الجوفية ، وترشيد الاستهالك المائي بأنواعه الزراعي والصناعي والمنزلي. 
مركز البحوث الجغرافية والكارتوجرافية - قسم الجغرافيا - كلية الآداب - جامعة المنوفية المؤتمر الجغرافي الدولي الثاني

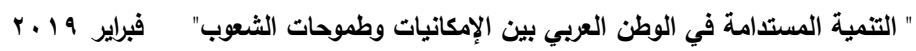

\section{الهوامش و الإحالات}

${ }^{1}$-www.worldatlas.com

2 -"Euphrates-Tigris River Basin", www.fao.org,

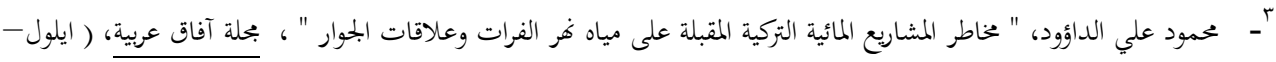

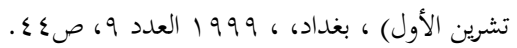

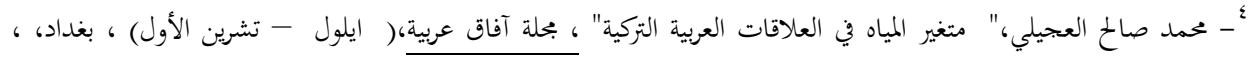

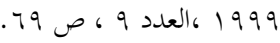

•- حامد عبيد حداد ، " دور تركيا في ازمة المياه في الشرق الاوسط : العراق انموذجاً " ، سلسلة دراسات استراتيجية ، مركز

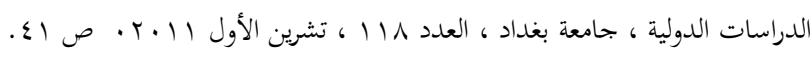

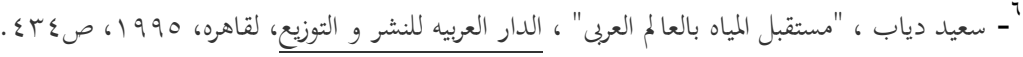

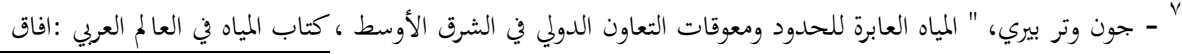

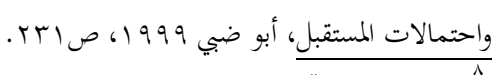

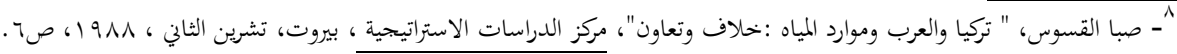

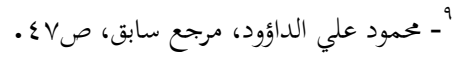

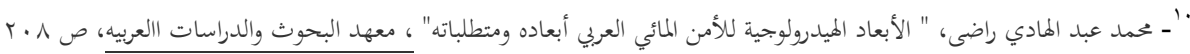

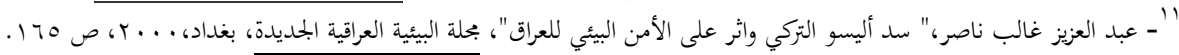

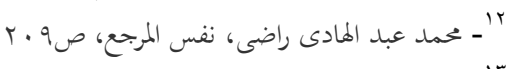

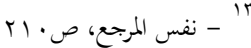

؛' - صبحي بحدي، " مشكلة المياه في المنطقة والمفاوضات متعددة الأطراف" ، مركز السياسات الإستراتيجية، القاهرة، ص 19.

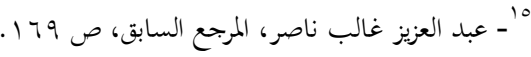

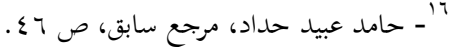

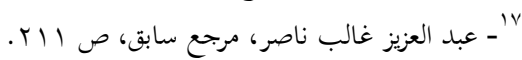

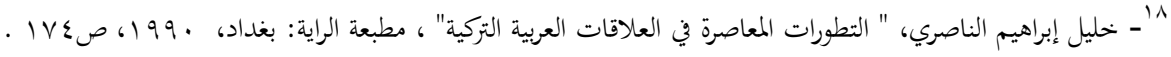

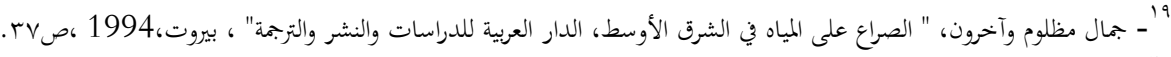

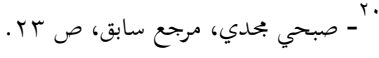

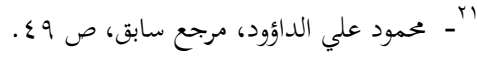

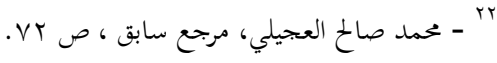

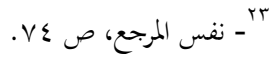

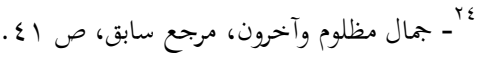

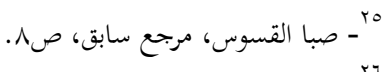

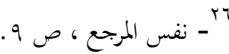

